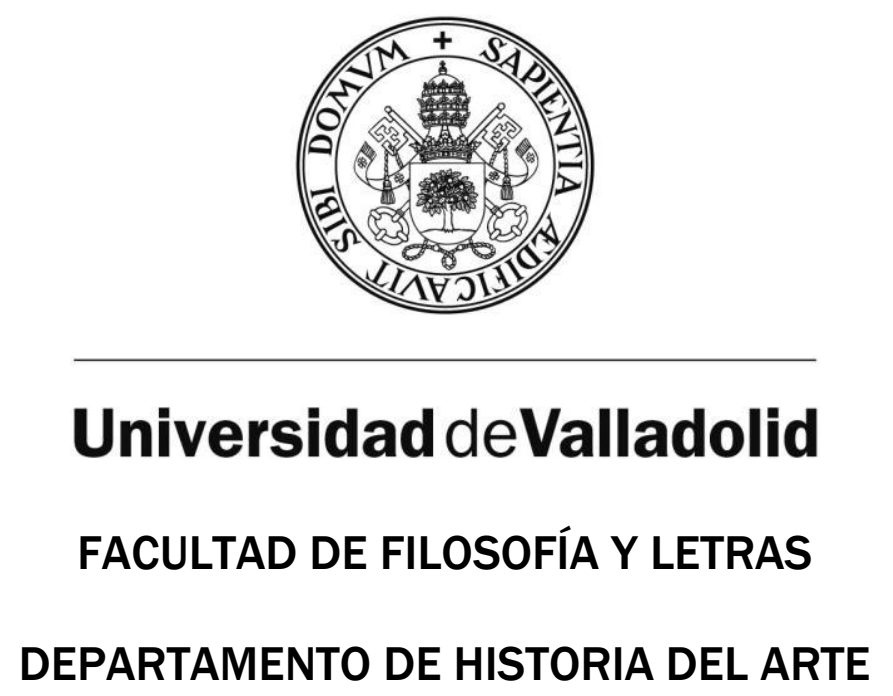

TESIS DOCTORAL:

\title{
EL ART DÉCO EN EL NORESTE DE MÉXICO
}
Presentada por Rodrigo Daniel Gustavo Ledesma Gómez para optar al grado de doctor por la Universidad de Valladolid

Dirigida por:

Dra. Da. Lourdes Cerrillo Rubio 


\section{ÍNDICE}

\begin{tabular}{|c|c|}
\hline INTRODUCCIÓN & 11 \\
\hline 1. El Art Déco & 17 \\
\hline $\begin{array}{l}\text { 1.1. París 1925: Exposition Internationale des Arts Décoratifs et Industriels } \\
\text { Modernes }\end{array}$ & 19 \\
\hline 1.2. El triunfo de lo decorativo, consecuencia de la Exposición del 25 & 28 \\
\hline 1.3. Más allá de la Exposición del 25 & 45 \\
\hline 1.4. El mundo artístico y cultural de los años del Art Déco & 49 \\
\hline 1.4.1. Art Nouveau & 49 \\
\hline 1.4.2. Escuela de Glasgow & 67 \\
\hline 1.4.3. Secesión del Viena & 68 \\
\hline a. Taller Vienés & 73 \\
\hline 1.4.4. Cubismo & 80 \\
\hline a. Cubismo Órfico y la Section d'Or & 88 \\
\hline b. Cubismo en la escultura y en la arquitectura & 91 \\
\hline 1.4.5. Abstraccionismo Ruso & 95 \\
\hline a. Suprematismo & 98 \\
\hline b. Constructivismo & 102 \\
\hline 1.4.6. Deutscher Werkbund & 112 \\
\hline 1.4.7. De Stijl & 118 \\
\hline 1.4.8. Bauhaus & 131 \\
\hline 1.4.9. Compagnie des Arts Francaise & 142 \\
\hline 1.4.10. De Rusia a París. Los espectáculos de los Ballets Rusos & 147 \\
\hline 1.5. Aproximación a las características estilísticas del Art Déco & 161 \\
\hline 1.5.1. Cómo distinguir al Art Déco y sus variantes estilísticas & 161 \\
\hline $\begin{array}{l}\text { 1.5.2. El Art Déco a través de la arquitectura, su manifestación más } \\
\text { visible }\end{array}$ & 179 \\
\hline
\end{tabular}




\begin{tabular}{|c|c|}
\hline 2. Presencia del Art Déco en México & 211 \\
\hline 2.1. Los estudios del Art Déco en México & 213 \\
\hline 2.2. México en los años del arribo del Art Déco & 242 \\
\hline 2.3. El cemento, material moderno para el Art Déco & 249 \\
\hline 2.4. El prehispanismo como fuente de inspiración & 255 \\
\hline 2.5. Características del Art Déco en México & 281 \\
\hline 2.5.1. Arquitectura en México estilo Art Déco & 281 \\
\hline 2.5.2. Escultura mexicana y el Art Déco & 337 \\
\hline 2.5.3. Pintores mexicanos dentro del Art Déco & 362 \\
\hline 2.6. El Nacionalismo en la época del Art Déco & 385 \\
\hline 3. El Art Déco en el Noreste de México & 401 \\
\hline 3.1. El Noreste de México: Nuevo León y Coahuila & 403 \\
\hline 3.2. El Art Déco en Nuevo León & 404 \\
\hline $\begin{array}{l}\text { 3.2.1. Monterrey, capital industrial de México y sus producciones Art } \\
\text { Déco }\end{array}$ & 405 \\
\hline 3.2.1.1. Arquitectura Escolar & 411 \\
\hline a. Escuela Fernández de Lizardi & 411 \\
\hline b. Escuela Industrial Álvaro Obregón & 421 \\
\hline c. Escuela Nuevo León & 455 \\
\hline d. Escuela Monterrey & 460 \\
\hline e. Escuela Presidente Calles & 466 \\
\hline 3.2. 1.2. Arquitectura Gubernamental & 485 \\
\hline a. Palacio Federal & 485 \\
\hline 3.2.1.3. Arquitectura de Servicios & 504 \\
\hline a. Mercado del Norte & 504 \\
\hline b. Edificio La Nacional & 510 \\
\hline 3.2.1.4. Arquitectura Asistencial & 517 \\
\hline a. Hospital Civil & 517 \\
\hline 3.2.1.5. Arquitectura del Ocio & 527 \\
\hline a. Cine Lírico & 527 \\
\hline
\end{tabular}




\begin{tabular}{|c|c|}
\hline b. Cine Encanto & 530 \\
\hline c. Cine Monterrey & 535 \\
\hline d. Cine Reforma & 543 \\
\hline e. Sociedad Recreativa Acero & 549 \\
\hline 3.2.1.6. Arquitectura Religiosa & 557 \\
\hline a. Iglesia de Cristo Rey & 557 \\
\hline 3.2.1.7. Arquitectura Comercial & 563 \\
\hline a. La Esquina Famosa & 563 \\
\hline 3.2.1.8. Urbanismo y Renovación & 568 \\
\hline a. Plaza General Treviño o del Chorro & 568 \\
\hline 3.2.1.9. Las Artes Plásticas y las Artes Decorativas & 576 \\
\hline a. Murales de la Catedral de Monterrey de Ángel Zárraga & 576 \\
\hline $\begin{array}{l}\text { b. Mural de la Casa del Campesino de Crescenciano Garza } \\
\text { Rivera }\end{array}$ & 592 \\
\hline c. Mural Alegoría de la Producción de Fermín Revueltas & 602 \\
\hline $\begin{array}{l}\text { d. Esculturas de Adolf Laubner: la Virgen de la Purísima y los } \\
\text { Ángeles }\end{array}$ & 613 \\
\hline e. Monumento a Mariano Escobedo de Guillermo Ruiz & 621 \\
\hline $\begin{array}{l}\text { f. Vitrales de la Aula Magna del Colegio Civil de Roberto } \\
\text { Montenegro }\end{array}$ & 626 \\
\hline 3.2.1.10. Arquitectura en cuatro Municipios de Nuevo León & 646 \\
\hline a. Anáhuac & 646 \\
\hline a.1. Arquitectura Gubernamental & 647 \\
\hline a.1.1. Palacio Municipal & 647 \\
\hline a.1.2. Edificio Agrario & 650 \\
\hline a.2. Arquitectura Escolar & 652 \\
\hline a.2.1. Escuela Cuauhtémoc & 652 \\
\hline a.3. Urbanismo y Renovación & 654 \\
\hline a.3.1. Fuente Obelisco & 654 \\
\hline b. Linares & 656 \\
\hline b.1. Arquitectura Comercial & 657 \\
\hline b.1.1. Gasolinería & 657 \\
\hline b.1.2. Casa-Comercio Melesio Elizondo & 660 \\
\hline
\end{tabular}




\begin{tabular}{|c|c|}
\hline b.1.3. Botica Morelos & 663 \\
\hline b.2. Arquitectura del Ocio & 681 \\
\hline b.2.1. Teatro Benítez & 681 \\
\hline c. Sabinas Hidalgo & 685 \\
\hline c.1. Arquitectura del Ocio & 686 \\
\hline c.1.1. Cine Olimpia & 686 \\
\hline d. Salinas Victoria & 689 \\
\hline d.1. Arquitectura Escolar & 689 \\
\hline d.1.1. Colegio Dr. Lucas Lazcano & 689 \\
\hline 3.3. El Art Déco en Coahuila & 695 \\
\hline 3.3.1. El desarrollo urbano de Saltillo y su arquitectura Art Déco & 695 \\
\hline 3.3.1.1. Arquitectura Escolar & 699 \\
\hline a. Escuela Coahuila & 699 \\
\hline b. Ateneo Fuente & 709 \\
\hline c. Escuela Álvaro Obregón & 733 \\
\hline d. Escuela Margarita Maza de Juárez & 743 \\
\hline e. Escuela Constituyentes de 1917 & 751 \\
\hline 3.3.1.2. Arquitectura del Ocio & 756 \\
\hline a. Cine Palacio & 756 \\
\hline 3.3.1.3. Arquitectura Comercial & 763 \\
\hline a. Casa Joch & 763 \\
\hline 3.3.1.4. Arquitectura Religiosa & 766 \\
\hline a. Seminario Diocesano del Sagrado Corazón & 766 \\
\hline 3.3.2. Torreón, una ciudad del siglo XX y sus manifestaciones Art Déco & 775 \\
\hline 3.3.2.1. Arquitectura de Servicios & 778 \\
\hline a. Mercado Juárez & 778 \\
\hline b. Edifico Eléctrico & 788 \\
\hline c. Hotel Galicia & 797 \\
\hline 3.3.2.2. Arquitectura del Ocio & 804 \\
\hline a. Estadio de la Revolución & 804 \\
\hline
\end{tabular}




\begin{tabular}{|c|c|}
\hline b. Parque del Estadio de la Revolución & 816 \\
\hline 3.3.3. Nueva Rosita & 820 \\
\hline 3.3.3.1. Arquitectura Escolar & 820 \\
\hline a. Escuela Fortunato Gutiérrez Cruz & 820 \\
\hline CONCLUSIONES & \\
\hline BIBLIOGRAFÍA & 827 \\
\hline Publicaciones Periódicas & 845 \\
\hline Webgrafía de Textos & 865 \\
\hline Webgrafía de Imágenes & 871 \\
\hline $\begin{array}{l}\text { CENTROS DE DOCUMENTACIÓN ESPECIALIZADOS } \\
\text { CONSULTADOS }\end{array}$ & 875 \\
\hline
\end{tabular}




\section{INTRODUCCIÓN}

Los estudios del Art Déco fuera de la ciudad de México son pocos y esto debido a que ahí se ubican los principales centros de investigación en relación con los temas del arte y poco se valora lo que se haga en otras partes del país, a pesar de la riqueza patrimonial que, como ocurre en el caso del que vamos a ocuparnos, poseen otros importantes escenarios de los Estados de la república mexicana.

Conscientes de esta deficiencia, el origen de nuestra tesis doctoral surgió por nuestro interés particular de estudiar el Art Déco en Nuevo León, parte de la Región Noreste de México, pero que al haber obra arquitectónica en el vecino estado Coahuila que no se ha estudiado bajo esta perspectiva artística, propusimos llevar a cabo esta investigación en esta zona geográfica del país.

De los ejemplos escogidos la mayoría son de arquitectura, ya que es lo más representativo del Art Déco en México y en la Región Noreste, sin embargo sólo seleccionamos lo más digno de estudiar, pues hay casos que aunque lleven la estética del Déco, consideramos que no tenían la suficiente calidad artística como para incluirlos, como sucede con la arquitectura doméstica, que debido al paso del tiempo, el deterioro y sobre todo el mal estado de conservación de las escasas edificaciones, discurrimos que no merecía la pena tratarlas aquí.

Para el caso de Nuevo León, además de la arquitectura, incluimos esculturas, murales y vitrales, dentro de las artes plásticas y decorativas, pero no incluimos mobiliario, vidrio, textiles, cerámica, joyas u otro tipo de estas artes, por las dificultades de acceso a este tipo de piezas, ya que pertenecen a colecciones privadas y aunque en un principio fue nuestro interés dedicar un capítulo específico a este campo tan significativo del Art Déco, no hay museos de arte decorativas que resguarden producción local y lo escaso que tienen algunos anticuarios, así como las colecciones privadas, no se sabe su procedencia, talleres, mucho menos autores y además son piezas mercadas en el extranjero, especialmente en Estados Unidos, por lo que no son obras hechas en el país, ni mucho menos en la Región Noreste. Para Coahuila además de algunos ejemplos aislados, analizamos especialmente bajo el lenguaje del Art Déco la obra arquitectónica de Zeferino Domínguez Villarreal (1894 - f.?), de quien ya se hizo y publicó una monografía, pero mínimamente se dice que los edificios que aquí incluimos son Déco, pues no se dan sus características compositivas y es un constructor del que hay que rescatar el gran valor de sus obras Art Déco. 
El presente trabajo está organizado en tres capítulos. El primero tiene un carácter eminentemente teórico, dedicado a analizar la trayectoria de este importante movimiento artístico. Para ello, partimos de la descripción de la gran exposición de París de 1925, planteamos sus principales consecuencias y, paralelamente, repasamos los distintos movimientos y fenómenos artísticos que influyeron en la formación del Art Déco. En este sentido hemos considerado necesario valorar la importancia que para la gestación y desenvolvimiento del Art Déco tuvieron el Art Nouveau y las demás vanguardias artísticas de Austria, Alemania, Holanda, Rusia, mencionando la importancia de su aportación al Déco de Les Ballets Russes. Para cerrar este capítulo hacemos una aproximación a las características distintivas del estilo, exponiendo cómo lo explican diversos autores tanto extranjeros como nacionales y finalmente cómo se manifiesta el Art Déco a través de la arquitectura, ya que para nuestro punto de vista es donde más podemos conocer y analizar a este estilo.

El segundo capítulo trata sobre el Art Déco en México. Iniciamos con una referencia de los estudios que se han hecho a partir de 1977, prosiguiendo con la situación política y social del país en los años en que se desarrolló el estilo en la nación. Un pequeño subcapítulo lo dedicamos al cemento, el material moderno del Art Déco, ya que en México fue sumamente importante por el tipo de materiales que antes se utilizaban y que en los años del Déco fueron substituidos por el cemento y el concreto armado. El siguiente subcapítulo está dedicado al prehispanismo y al indigenismo, temas bastante valorados después de la Revolución, justo cuando el Art Déco estaba de moda y los motivos decorativos del mundo indígena alimentaron la estética del Déco, tanto en Estados Unidos como en México. Luego de todo esto, exponemos las características del Art Déco en México y como éstas están dadas a través de la arquitectura, ejemplificando con edificaciones de la ciudad de México y de otras urbes del país como Mérida, Durango, Morelia y Puebla. Como de la escultura Déco casi nada se ha dicho, teorizamos sobre la misma y ponemos casos, además de esculturas monumentales en la ciudad México, de lugares como Acapulco, Janitzio, Morelia, Silao y tallas de pequeño formato. De la pintura Art Déco que se ha escrito más, la explicamos con trabajos del Muralismo, pintura de caballete y gráfica.

Como ya señalábamos, el objetivo de estos dos capítulos ha sido plantearnos un panorama teórico del Art Déco, de un estilo que se inspira en la cultura visual y que tiene un componente integrador de las vanguardias y movimientos artísticos de la época, para de esta manera mejor entender y valorar su producción, tanto a nivel internacional 
como en México, y así equipáralo con las grandes manifestaciones de la Historia del Arte.

El tercer capítulo dedicado al Art Déco en la región Noreste de México inicia con una breve explicación de qué es el Noreste de México y de la inclusión en este trabajo de los estados de Nuevo León y Coahuila. Iniciamos con Nuevo León y debido a que Monterrey es una importante metrópoli industrial, presentamos una historia del desarrollo de la ciudad en los años del Art Déco, para luego analizar por tipologías sus ejemplos arquitectónicos: arquitectura escolar, gubernamental, de servicios, asistencial, del ocio, religiosa, comercial, más urbanismo y renovación. En el subcapítulo dedicado a las artes plásticas y decorativas, tratamos murales, esculturas y vitrales.

De los municipios de Nuevo León hallamos en su gran mayoría ejemplos de arquitectura en Anáhuac, Linares, Sabinas Hidalgo y Salinas Victoria, de los cuales hacemos una breve relación de su origen y desarrollo hasta los años del Déco, para luego exponer los casos de Art Déco, también bajo tipologías arquitectónicas.

En Coahuila principiamos con la capital del estado, Saltillo, de la cual hacemos una descripción de su situación urbana y económica en los años veinte, treinta y cuarenta del siglo XX, cuando la ciudad tuvo la edificación de varios inmuebles Art Déco. Iniciamos con las escuelas en la tipología arquitectura escolar construidas por Zeferino Domínguez Villarreal, para continuar con la arquitectura del ocio, la arquitectura comercial y finalizar con la arquitectura religiosa, estas dos últimas con obra de Domínguez, que como dijimos arriba, hacemos una relectura de su obra bajo la perspectiva del Art Déco.

Torreón, ciudad que alcanzó su desarrollo urbano en la primera mitad del siglo XX, tiene algunas manifestaciones Déco muy interesantes. Después de dar una introducción sobre la localidad, analizamos algunas edificaciones en la tipología de arquitectura de servicios y luego del ocio, nuevamente con trabajos de Zeferino Domínguez.

Por último, presentamos bajo la arquitectura escolar un plantel educativo en el lejano poblado de Nueva Rosita.

Los tres capítulos están ilustrados con fotografías que tomamos de libros y bajadas de internet, especialmente para el 1 y el 2 y en menor medida para el 3. Están señaladas con números, así como con notas de pie de página de dónde fueron obtenidas. Cuando no vienen señaladas con números y notas es que son fotografías tomadas por nosotros: en el capítulo 1 hay imágenes de París, Reims, Madrid, Barcelona, Buenos 
Aires, La Plata, La Habana y ciudad de México. En el capítulo 2 aparecen de la ciudad de México, Monterrey, Acapulco, Janitzio, Morelia, Puebla y Mérida. En el capítulo 3, la gran mayoría son imágenes de nuestra autoría y hay unas pocas fotografías en que vienen señaladas sus autores.

Para el capítulo 3 hay algunas imágenes que fueron difíciles de captar por el tráfico vehicular, peatonal, más anuncios públicos publicitarios, como sucedió en el Mercado del Norte en Monterrey (págs. 596 y ss.) y el Mercado Juárez de Torreón (págs. 784 y ss.). Las fotografías de los inmuebles no fueron maquilladas, ni arregladas y demuestran las condiciones actuales en que se conservan, que en muchos casos son deplorables. También en este capítulo en algunos casos incluimos planos arquitectónicos de pocos edificios que conseguimos en el Catálogo de Monumentos Históricos del Instituto Nacional de Antropología e Historia y en una publicación del periódico Excélsior de la época.

A continuación del tercer capítulo siguen las Conclusiones encaminadas a exponer los alcances y aportaciones de esta tesis doctoral sobre las producciones Art Déco de los Estados de Nuevo León y Coahuila, que si de alguna manera algunos de los casos analizados ya habían sido estudiados, no se hizo bajo la perspectiva de la estética del Déco, muchos más son hallazgos nuestros, por lo que damos a conocer obras para enriquecer el acervo del Art Déco en México.

Posteriormente presentamos la Bibliografía, la cual está acomodada de la siguiente forma: primero lo que son libros, en segunda instancia Publicaciones Periódicas de revistas y periódicos, después Webgrafía de páginas de internet de textos y finalmente reseñamos la Webgrafía de Imágenes, las cuales fueron obtenidas de páginas de internet y utilizadas para ilustrar los tres capítulos, acomodadas por orden de capítulo y subcapítulos.

En centros de Documentación Consultados Especializados nos referimos a secciones o salas con colecciones especiales sobre Arte e Historia de bibliotecas, a hemerotecas u otro tipo de centros culturales con documentación útil para este trabajo.

Como se verá a lo largo de todo el trabajo el término Art Déco en ocasiones y para evitar la redundancia lo substituimos solamente por la palabra Déco, como se hace en muchas acepciones de términos artísticos. Respetamos la ortografía de títulos de publicaciones y en citas textuales de los diversos autores, tal y como la escriben, pues hay veces que aparecerá como "Art Deco", sin acento, “Art Decó" con acento al final 
como si fuera palabra aguda, o bien, "Art-Déco", "Art- Decó” o "Art-Deco", las tres denominaciones pero con guión intermedio.

Queremos agradecer primeramente a mi familia, a Laura mi esposa quien nos apoyó fuertemente para ir a estudiar a Valladolid en tiempos de crisis de nuestro país y luego ya con ella y los hijos Meritxell y Rodrigo, por los felices meses que pasamos por España.

A mi papá, el maestro Felipe Ledesma Guillén, fallecido en enero de este año, un fortísimo agradecimiento, a quien ya no le dimos la satisfacción de vernos titulados como doctor, siempre recibimos su apoyo de todo tipo y estuvo al pie de la letra pendiente de la realización de esta tesis.

Por parte de la Universidad de Valladolid, queremos agradecer a la profesora, lamentablemente ya fallecida, Dra. Guadalupe Ramos de Castro, las gestiones, ayuda y apoyo para ingresar a realizar los cursos de doctorado, con quien tuvimos una buena relación en la Universidad de Valladolid.

Un especial y muy grande reconocimiento y agradecimiento a la Dra. Lourdes Cerrillo Rubio, quien amablemente aceptó dirigirnos este trabajo de tesis doctoral, primeramente en la solicitud inicial y luego ya en la elaboración ininterrumpida desde hace cuatro años. Siempre recibimos su amable consejo, orientación, dirección y sobre todo, las finísimas atenciones cuando fuimos a las cinco asesorías a Soria. ¡Gracias Lourdes!

Y de parte de la Universidad de Monterrey, nuestro centro de trabajo desde hace veinticinco años, nuestra más amplia gratitud a las autoridades correspondientes que nos apoyaron con la beca para ir a estudiar a Valladolid, y a nuestros jefes inmediatos tanto de cuando reiniciamos esta tesis hace cuatro años, como a los que ahora nos han apoyado para concluirla.

San Nicolás de los Garza, Nuevo León, MÉXICO, septiembre de 2014. 


\section{EL ART DÉCO}




\subsection{PARIS 1925: EXPOSITION INTERNATIONALE DES ARTS DECORATIFS ET INDUSTRIELS MODERNES}

En Francia, desde 1912, se había planeado una exposición internacional que se iniciara en 1915 con el fin de exponer los productos franceses salidos de las casas de diseño, así como invitar a los países europeos a que mostrasen sus adelantos en materia de diseño y decoración. Sin embargo, el advenimiento de los conflictos que desataron la I Guerra Mundial impidieron que esta exposición se llevara a cabo.

Una vez terminada la guerra, en 1918, se anunció que dicha exposición se celebraría en 1922, mas los problemas financieros y la reconstrucción económica hicieron que la exposición no se celebrara hasta 1925.

Para ubicar esta magna muestra se pensó que el Grand Palais sería el lugar ideal para su exhibición dada su amplitud de 33.000 metros cuadrados, pero realmente fueron 220.000 metros cuadrados los que se necesitaron para el conjunto de la exposición, en donde participaron 21 países, incluyendo colonias francesas.

El director arquitectónico fue Charles Plumet (1861-1928) y para la arquitectura de paisaje Louis Bonnier (1856-1946), mientras que para acondicionar el Grand Palais estuvo al frente Charles Letrosne (1868-1939). Varias puertas de acceso había en el recinto de la magna exposición, pero a juicio de Xavier Esqueda "las más sobresalientes fueron la Puerta de la Concordia, diseñada por el arquitecto Pierre Patout, con una estatua en el centro realizada por Déjean y con bajo relieves de Joel y Jean Martel. La puerta de Orsay diseñada por Louis Boileau con un enorme panel a manera de cartel de gran efectivismo pintado por Louis Voguet. La puerta de honor fue diseñada por Henry Favier y A. Ventre; las rejas siguieron los diseños de Edgar Brandt con el consabido motivo de una fuente estilizada".

La Puerta de Honor, o la Porte d'Honneur, fue la entrada principal, en donde destacaban en especial dos elementos: las fuentes congeladas trabajadas en vidrio por René Lalique (1860-1945) en forma piramidal, dando más bien la idea de una gran columna con capitel, y el gran arco triunfal de la reja de Edgar Brandt (1880-1960) compuesta por líneas curvas de diversos grosores que mostraban elementos vegetales. Esta puerta, incluía

\footnotetext{
${ }^{1}$ Xavier Esqueda, El Art Déco. Retrato de una época, México, UNAM, 1986, p. 64.
} 
diseños téctonicos y geométricos de paneles, esculturas, rejerías y fuentes que darían un sello característico al Art Déco.
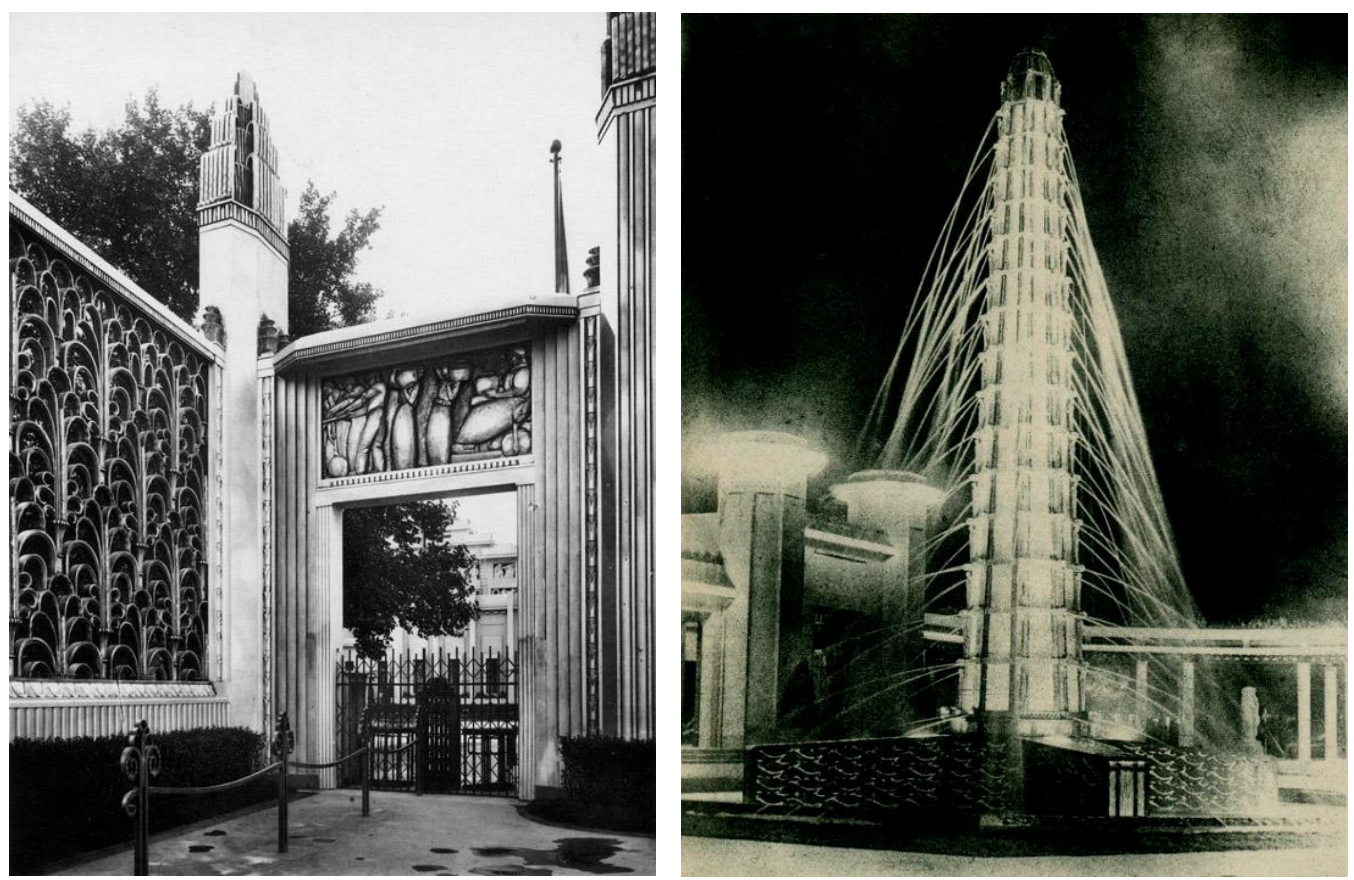

Puerta de Honor de Edgard Brandt, Henri Favier y André Ventre ${ }^{2}$ y Fuente de René Lalique en la exposición de $1925 .^{3}$

Para conectar el pabellón con el otro lado del río Sena, el puente Alejandro III, que había sido inaugurado en la exposición de 1900, fue investido de nuevos diseños hechos por Maurice Dufrene (1876-1955) para boutiques individuales, entre las que destacaban las de Sonia Delaunay-Terk (1885-1979), René Lalique y Jacques Heim (1899-1967). El puente parecía salido de una fantasía o de un cuento de hadas, pues la iluminación que recibía en diversos colores asemejaba piedras preciosas de gran tamaño.

A los lados del puente pequeñas embarcaciones flotantes funcionaban como elegantes restaurantes, mientras que Paul Poiret (1879-1944) en tres barcos montó su Atelier Martine, con atractivos y lujosos interiores.

\footnotetext{
${ }^{2}$ Alastair Duncan, The Encyclopedia of Art Deco, London, Quantum Books, 1988, p. 154.

${ }^{3}$ Rossana Bossaglia, L'Art Déco, Roma, Laterza, 1984, p. 53.
} 
Y no podía faltar el símbolo de la ciudad de París, la torre Eiffel, en la cual se montaron juegos de luces que formaban círculos, formas geométricas, estrellas, cometas y hasta un zodiaco, publicitando la marca de automóviles Citroën.

La invitación hecha a la magna exposición llevaba como fin que se mostraran los adelantos en materia de artículos de decoración como de productos industriales, pero ante la incompatibilidad de presentar trabajos en conjunto entre industrias y talleres de decoración, muchos productos expuestos, así como el diseño y construcción de pabellones dio como resultado la exaltación de artistas que se coronaron como grandes exponentes del Art Déco.

Los cuatro almacenes más importantes de París hicieron gala con sus pabellones colocados en cada esquina del pabellón general: Studium del Louvre, Primavera de Au Printemps, La Maitrise de Galerías Lafayette y Pomone de Au Bon Marché. Estos pabellones exhibieron "lo más depurado del diseño art deco, que aunque en arquitectura no aportaron ninguna novedad, la suntuosidad de su decoración y el uso de nuevos materiales fue un punto clave para lo que ahí en adelante sería la base para la creación de este particular estilo". 4

Debido a la importancia de estos pabellones en su toque distintivo considerado ya como Art Déco, como lo señala Xavier Esqueda, y a la fuerte influencia que provocaron sus diseños, haremos una breve descripción de cada uno de ellos.

El pabellón Studium de los almacenes Louvre fue un diseño de Albert Laprade (1883-1978) con planta poligonal de ocho lados. Compuesto por dos alturas, en la primera, tanto la puerta de acceso como los vanos de las ventanas, presentan estrías lineales que se van conformando hacia dentro, dando un efecto de movimiento; obviamente los diseños son geométricos. En la segunda planta se abre una terraza con jardineras, que entre columnas cuadradas y pareadas resguardan grandes macetones. El conjunto se remata por una linternilla octagonal en cuyo tambor y en cada cara aparecen tres ventanas cuadradas. Tanto en la terraza como en la linternilla, aleros salientes recubren las techumbres.

El pabellón de $A u$ Printemps llevó el nombre de Primavera y su diseño fue concebido por Henri Sauvage (1873-1932) y Georges Wybo (1880-1943). La planta era circular cubierta con una cúpula, la cual estaba decorada en su exterior con una simulación de piedras incrustadas y líneas que formaban una especie de caminos ascendentes que

\footnotetext{
${ }^{4}$ Xavier Esqueda, Op. Cit., p. 65.
} 
desembocaban en pequeños vanos elípticos. En la entrada dos enormes columnas estriadas remataban con una especie de capitel que funcionaba a la vez como jardinera circular, y entre las dos columnas, una techumbre circular a manera de celosía permitía el paso de la luz. Un efecto de fuerza dinámica fue concebido en este pabellón.

La Maitrise fue el nombre que recibió el pabellón de los almacenes Lafayette, el cual se hizo merecedor del primer lugar entre los cuatro pabellones de las tiendas. Diseñado en su arquitectura por Joseph Hiriart (1888-1946), Georges Tribout (1890-1970) y George Beau, el interior fue decorado por el director de la tienda Maurice Dufrene (18761955). También de planta poligonal, destacaba la parte central por tener más altura. Pero la decoración a base de estrías en cuatro tectónicas columnas circulares y en las jambas de la entrada, así como el enorme vitral que daba la idea de luz irradiada y que conectaba a la escalinata con el interior, le dio a este pabellón un denso sentido decorativo geométrico, aunado a la disposición de rectángulo, cuadrado, círculo en su construcción.

Los almacenes $A u$ Bon Marché presentaron su pabellón Pomone con el diseño arquitectónico de Louis-Hippolyte Boileau (1898-1948) y el interior de Paul Follot (18771941). Una intersección de tres cubos forma el primer cuerpo del edificio. En la fachada, la puerta de acceso está realizada como un gran vitral que se dispone con formas curvas, líneas oblicuas y vidrios de diversos colores, asemejando un gran caleidoscopio; a los lados de la puerta había tres prismas en forma empinada y con decorados ascendentes dentro de un rectángulo. Las escaleras presentan líneas verticales y horizontales. En el friso del remate del primer cuerpo caen unos pequeños triángulos dobles con un sentido de armonía que se contraponen a la decoración arrítmica de la superficie de todo el primer cuerpo. El segundo cuerpo es un poliedro octagonal de menor tamaño que emerge espontáneamente del resto del edificio; las caras ochavadas se oponen a las esquinas angulosas del primer edificio, dando así un efecto de movilidad.

Todo el pabellón Pomone es un conjunto de armonías geométricas y asimetrías decorativas, que en su totalidad conciertan un compendio del Art Déco de la exposición, de Francia y del estilo en general.

La exposición del 25 fue una apoteosis de la muestra de productos y pabellones; entre estos últimos hubo algunos que resaltaron los elementos constitutivos que contribuyeron a la formación del Art Déco. 


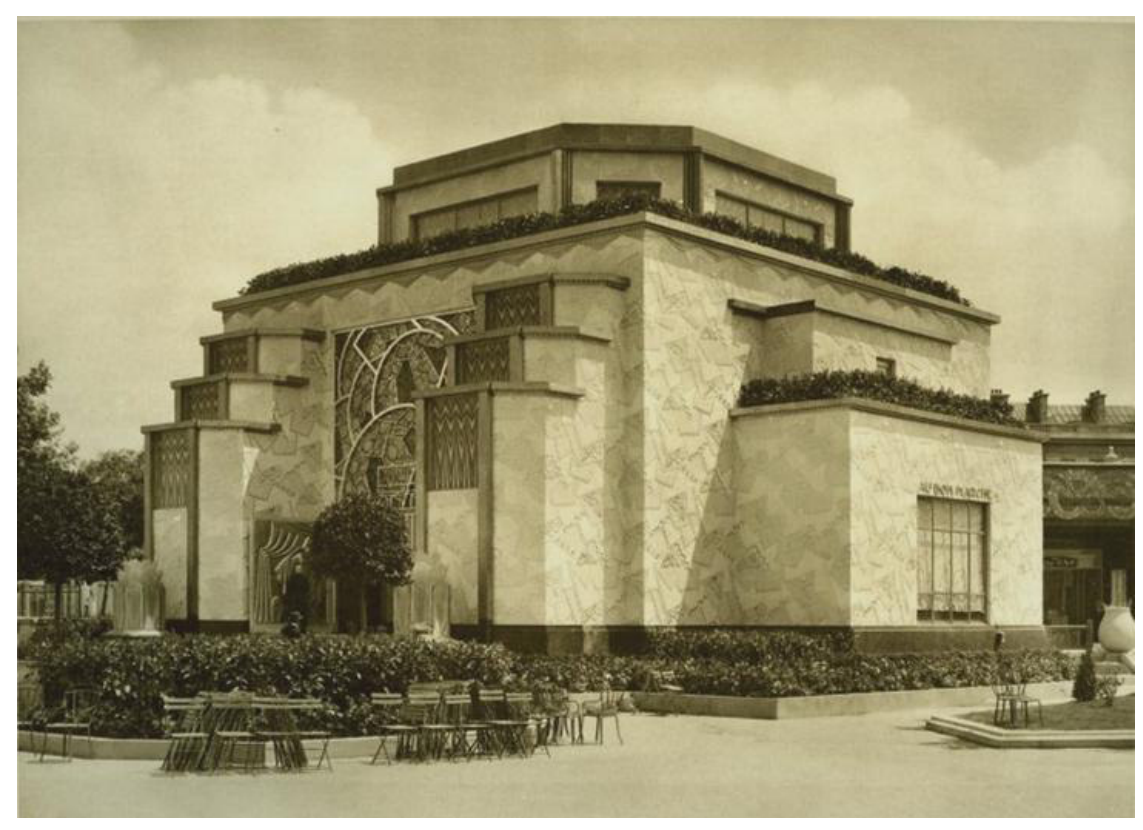

Pabellón Pomone con el diseño de Louis-Hippolyte Boileau, $1925 .^{5}$

El Pavillon du Turisme era un centro de información y bancario que se encontraba enfrente a la Puerta de Honor. Fue diseñado por el arquitecto Robert Mallet-Stevens (18861945) y se caracterizó por tener poca decoración y resaltar la funcionalidad de la arquitectura. Contaba con un reloj en forma de cruz y con unos paneles con relieves obra de los hermanos mellizos Jean (1896-1966) y Jöel Martel (1896-1966) ${ }^{6}$; un diseño cubista en las ventanas afirmaba la contemporaneidad de la glamurosa exposición.

Para mostrar el camino conservador, pero a la vez la finura, distinción y donaire del gusto francés Émile-Jacques Ruhlmann (1879-1933) organizó el pabellón L'Hotel du Collectionneur, en el cual también incluyó su mobiliario, que consistió en la fantasía extrema de las piezas que un coleccionista pudiera tener. El diseño como tal se debió a Pierre Patout (1879-1965) y “contenía esculturas de Joseph Bernard, Antoine Bourdelle, Le Bourgeois, Temporal, Poisson, Hairon, Janiot, Déjean, Foucault, Despiau y Pompon, la decoración del mismo Ruhlmann con la colaboración de Francis Jourdain, Léon Jallot y Henri Rapin, plata de Jean Puiforcat, herrería por Edgar Brandt, cerámicas por Lenoble, Mayodon y Decour, lacas por Dunand, cristal y vidrio por Décorchemont y pintura de

\footnotetext{
${ }_{6}^{5}$ Jean-Paul Bouillon, Diario del Art Déco 1903-1940, Barcelona, Destino, 1988, p. 187.

${ }^{6}$ Los hermanos mellizos Martel formaron un mismo taller y desde 1926 hasta su muerte, que fue en el mismo año con seis meses de diferencia, laboraron en su famosa casa construida por Robert Mallet Stevens.
} 
artistas como Jean Dupas, Robert Bonfils y Gustave Jaulmes". 7 Aunque todos estos artistas trabajaban sus propios diseños, en este pabellón se unen para conjuntar no un estilo, sino la idea de lo que podría ser una mansión casi exótica, pero de "buen gusto". Los objetos salidos de los "ateliers", únicos y exclusivos ahí presentados se convirtieron como tales en obras de Art Déco. En la arquitectura del pabellón un medio cilindro con vanos rectangulares está acompañado de tres niveles ascensionales lo cual remite ya sea a la arquitectura mesopotámica de los zigurats o bien, a la arquitectura mesoamericana. Escaso de decoración exterior, en el remate del medio cilindro tres paneles en bajo relieve de Joseph Bernard (1866-1931) representan escenas de mujeres en movimiento donde hay una fuerte referencia a la plástica helénica. Al frente un grupo escultórico de tres mujeres semidesnudas de anatomías robustas, las cuales descansan en una base cuadrada, es obra de Alfred Auguste Janniot (1889-1969) y también refiere al mundo mediterráneo. El profundo impacto de este pabellón provocó que "los críticos coincidieran en señalar el palacio del Coleccionista, de Ruhlmann, como el acontecimiento más espectacular de la Exposición". 8

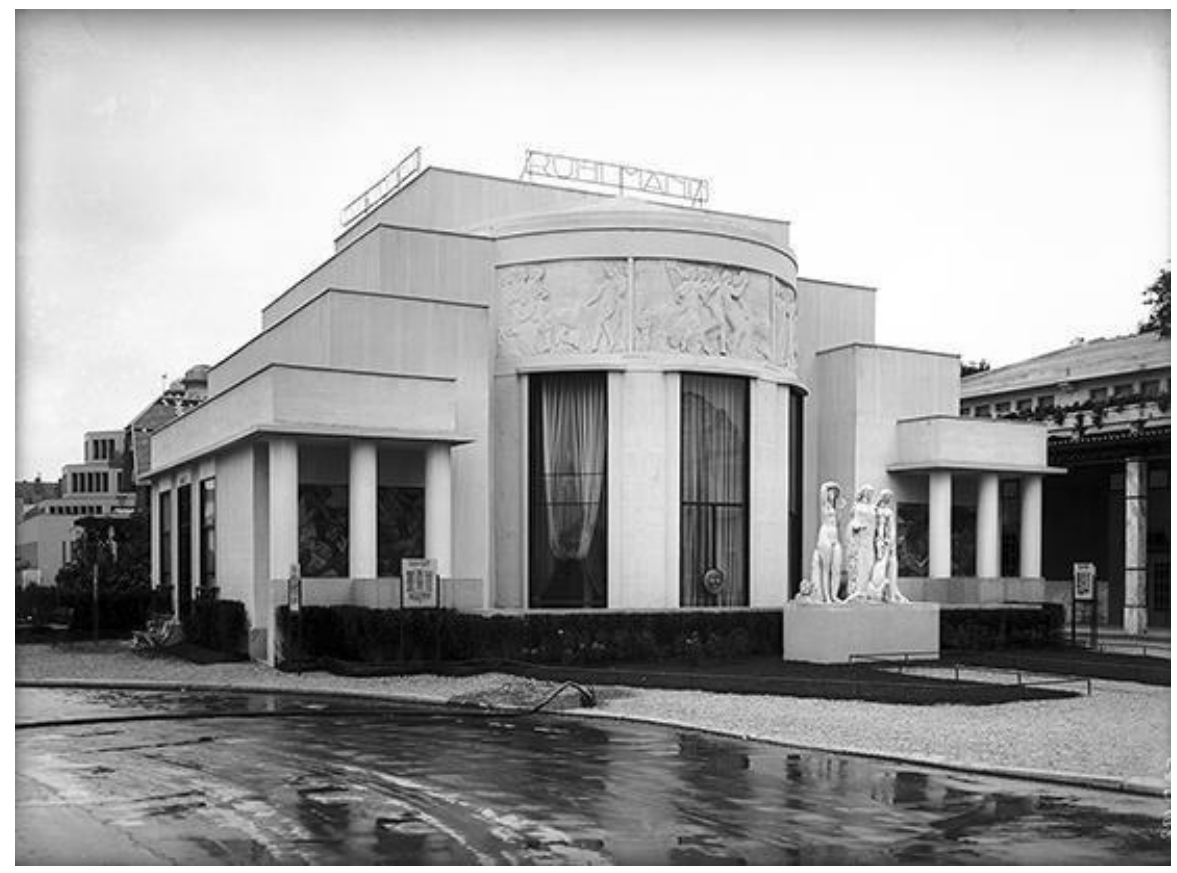

Pabellón de L'Hotel du Collectionneur, organizado por Emile-Jacques Ruhlmann, $1925 .{ }^{9}$

\footnotetext{
${ }^{7}$ Xavier Esqueda, Op. Cit., p. 66.

${ }^{8}$ Alastair Duncan, Muebles Art Déco, Londres, Quantum Books, 1988, p. 14.

${ }^{9}$ Victor Arwas, Art Deco, New York, Abrams, 2000, p. 35.
} 
Como la gran exposición se presentó en París era obvio que los franceses quisieran exponer un pabellón que sirviera de modelo de una sede diplomática del galo país, más aún siendo una nación con un fuerte colonialismo. La Societé des Artistes Décorateurs fue la encargada de trabajar la Ambassade Francaise, en la cual artistas tanto de la sociedad como ajenos participaron en todos los campos del diseño para la decoración del interior. Veinticinco habitaciones fueron engalanadas por grandes maestros de la época, que se convertirán de la misma manera en renombrados artistas del Déco: Maurice Dufrene (18761955), Jean Dunand (1877-1942), André Groult (1884-1967), Pierre Chareau (1883-1959), Paul Follot (1877-1941).

En todos los pabellones franceses se exhibía con lujo y exaltación los diseños tanto de talleres como de tiendas, muchas de ellas relacionadas con la elite de la Belle Epoque. El pabellón de René Lalique, además de mostrar sus objetos, presumía su iluminada fuente de cristal, mientras que el pabellón de La Elégance, refinado como su nombre, se ennoblecía aún más con los textiles de la destacada casa Bianchini-Férier y con los exóticos muebles de Armand-Albert Rateau (1882-1938). "Los pabellones de fabricantes eminentes como Baccarat, Christofle, Luce y Sevres expusieron también lo último en diseño moderno". ${ }^{10}$

Muchos países ofrecieron sus muestras a través de sus pabellones. Bélgica, Holanda, Inglaterra, Italia, España, Austria, Suecia, Dinamarca, Checoslovaquia. Uno de los que llamó la atención de los franceses, entre otros, fue el pabellón de Polonia titulado Republique Polonaise, cuya arquitectura fue hecha por Joseph Czajkowski (1872-1947). La reja de entrada la componían formas vegetales geométricas. En el dintel de la puerta letras estilizadas titulaban el pabellón y un tímpano triangular se encontraba decorado con relieves geométricos y angulosos que daban la idea de un medio sol irradiando vibrantes rayos luminosos. En el friso que recorre el remate de la barda, un zigzag en relieve daba la idea de movimiento. Entre la puerta de acceso y el interior se ubicaba un pequeño patio en el cual se situaba una escultura de una mujer desnuda, parecida a las mujeres de Janniot del pabellón de Émile-Jacques Ruhlmann. Una torre en hierro se elevaba escalonadamente en ritmo con las decoraciones de la puerta de acceso.

El pabellón soviético de Konstantin Melnikov (1890-1974) causó revuelo, pues carente de decoración alguna, era una verdadera muestra de los anhelos de vanguardia y

\footnotetext{
${ }^{10}$ Eva Weber, Art Decó, Madrid, Lisba, 1993, p. 9.
} 
modernidad de la recién formada U.R.S.S. Grandes ventanales cuadriculados en una edificación geométrica y una escalera al aire libre colocada en la parte lateral, equilibraba el peso con unas estructuras entrecruzadas en forma de equis. La aventura técnica de este pabellón, además de obtener un Grand Prix, iba en avanzada a los tiempos venideros del estilo internacional. Vittorio De Feo en su libro La arquitectura en la U.R.S.S. 1917-1936 comenta sobre el pabellón soviético: "Obra de Mélnikov, del grupo Asnova, la pequeña construcción provisional evita toda retórica. Resulta perfectamente conseguida la intención de transformar en movimiento la estaticidad espacial y romper el volumen en perspectivas inesperadas; a ello contribuyen el juego de las escaleras, la ligera estructura de madera, puesta sinceramente de manifiesto, y los colores puros". 11

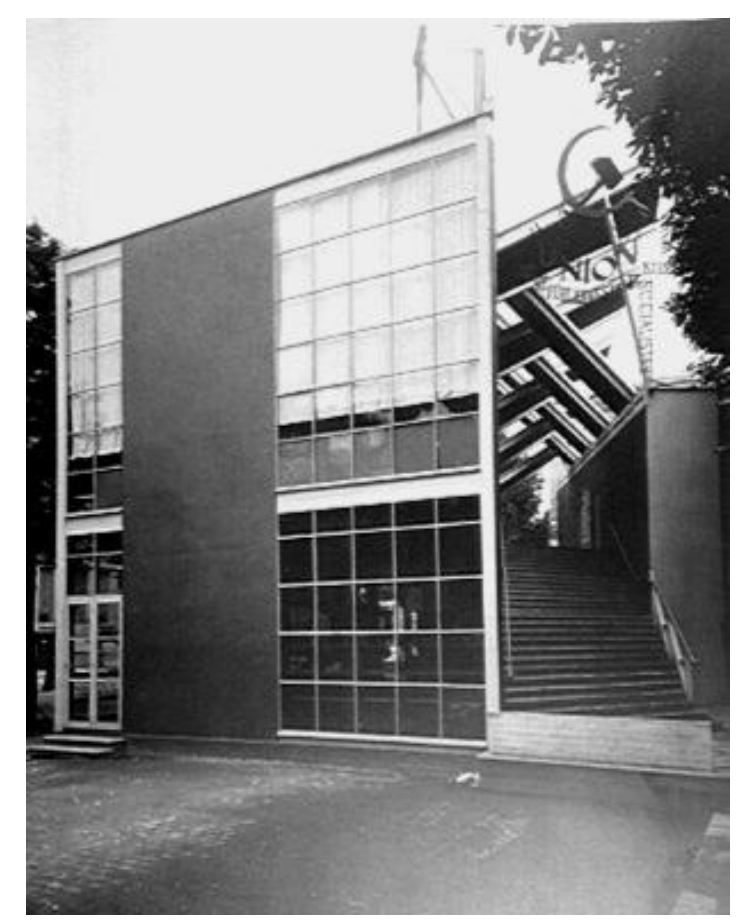

Pabellón Soviético de Konstantin Melnikov, $1925 .{ }^{12}$

El pabellón del Esprit Nouveau de Le Corbusier (1887-1965) y Amédée Ozenfant (1886-1966) sería la antítesis de los resultados de la Exposición: la decoración. Yendo más lejos que el pabellón soviético, el de Le Corbusier proponía explícitamente la negación a utilizar cualquier adorno superfluo, proponiendo sus “máquinas para vivir" en un sentido de

\footnotetext{
${ }^{11}$ Vittorio De Feo, La arquitectura en la U.R.S.S., 1917-1936. Madrid, Alianza Editorial, 1979, p. 53.

${ }^{12}$ Peter Gössel y Gabriele Leuthäuser, Arquitectura del Siglo XX, Köln, Taschen, 2012, p. 197.
} 
poder construir casas en serie, con los avances tecnológicos de la época y a la manera de los nuevos productos industriales en serie. El purismo y la desnudez decorativa son las proposiciones de Le Corbusier con su pabellón. En sus propias palabras afirmó. "Nuestro pabellón contendrá solamente casas estandarizadas creadas por la máquina en fábricas y producidas en serie; objetos verdaderamente del estilo de hoy día". ${ }^{13}$ Y debido a que su pabellón era para Le Corbusier el símbolo de la más alta modernidad declaró: "Hoy mismo una cosa es segura, 1925 marca un decisivo punto de partida en la batalla entre lo viejo y lo nuevo. Después de 1925 los amantes de las antigüedades virtualmente habrán terminado sus vidas y el esfuerzo productivo industrial estará basado en lo 'nuevo'," ${ }^{14}$

Si bien los pabellones de Melnikov y el de Le Corbusier no contribuyeron al Déco con las propuestas decorativas, sí lo hicieron con el acentuado geometrismo.

La exposición del 25 marcó el punto de arranque para la efervescencia del Art Déco; es decir, que es a partir de dicha exposición cuando la convergencia de casas, tiendas, movimientos, diseñadores, arquitectos y países, mostraron lo que para ellos era lo más avanzado en artes decorativas, que en su conjunto tendieron hacia algunos elementos, que sin ser comunes entre sí, tenían ciertas coincidencias o similitudes en su origen o aplicación y dieron por resultado lo que más tarde se llamaría como Art Déco.

Para Paul Maenz hubo tres caminos que se dieron como consecuencia de la Exposition Internationales des Arts Décoratifs et Industriels Modernes. Él escribe: “Tres tendencias se disputan la primacía del escenario de las artes ornamentales en <Annés 25>: una clásica y elegante interpretación de la Compagnie de Arts Francais, que representan nombres como Ruhlmann, Lalique o Dufrene; otra, la de los <románticos exotizantes>, sus arabescos y su zigzagueante cubismo de salón, lo representan Poiret, Erté, Rateau; por último, los <románticos modernizantes>: Puiforcat, Herbst o Dunand. Ellos rinden culto a una estética constructivista, sin extremarla por supuesto hasta las últimas consecuencias, como hicieran un Ozenfant o un Le Corbusier, pues no indagan su plástica a partir de las condiciones de producción del maquinismo, sino en lo que es su mera apariencia formal". ${ }^{15}$

\footnotetext{
${ }^{13}$ Xavier Esqueda, Op. Cit., p. 68.

${ }^{14}$ Ídem.

${ }^{15}$ Paul Maenz, Art Déco: 1920-1940, Barcelona, Gustavo Gili, pp. 140-141.
} 


\subsection{EL TRIUNFO DE LO DECORATIVO, CONSECUENCIA DE LA EXPOSICIÓN DEL 25}

Uno de los resultados, por decirlo así, de la exposición del 25 fue la victoria de la decoración. Las "artes decorativas" del título de la exposición estuvieron reflejadas en los trabajos de las más exclusivas firmas de "ateliers": vidrio, metal, muebles, esculturas, objetos domésticos, tejidos, tapices, cerámicas se apropiaron de la decoración exhibida en la soberbia muestra parisina.

Es la decoración que gana el terreno de ser primero y ante todo sobre la función. Es el objeto diseñado para deleitar al consumidor dentro de una estética ornamental de encanto y seducción, pero que a la vez está en concordia con las manifestaciones modernas de los años de entreguerras. Pero es el laurel de lo decorativo surgido de los talleres franceses lo que impera en la resplandeciente exposición parisina, porque Francia presume con galanura sus diseños, pues aún es el imperio de la elegancia, del refinamiento y del buen gusto.

La añoranza por el decorativismo versallesco e imperial de las cortes borbónica y napoleónica, es la razón de por qué Francia tenía que arrollar en la lúcida Exposición Internacional, pues era la sede y no podía perder la oportunidad de mostrarle nuevamente al mundo que en los tiempos modernos también cada objeto, cada diseño eran concebidos y producidos con los más exigentes postulados estéticos, donde cada producto emanado de un "atelier" sería una verdadera obra de arte decorativa.

René Lalique es uno de los más citados artistas del vidrio de la época del Art Déco. Sus motivos ornamentales humanos combinaban la figura humana clásica en posturas serpentinas, con sus exclusivas y exuberantes cabelleras femeninas, hasta la geometrización del cuerpo. También animales, flores y formas míticas y humanas de la antigüedad clásica formaron parte de su creatividad decorativa.

Lalique, que el mismo se consideraba un escultor de vidrio, produjo relojes, marcos, vasos, vajillas, juegos para baño, espejos, frascos para perfumes, esculturas, accesorios arquitectónicos y hasta las novedosas mascotas para coches, entre los muy variados productos emanados de su taller, los cuales fueron producidos consiguiendo matices que simulaban joyas como la esmeralda o el rubí, o bien adquirir el efecto de vidrio antiguo y ahumado, así como su característico vidrio opalescente. 
Además de participar en la mencionada fuente de la Porte d'Honneur en la exposición del 25, tuvo su propio pabellón, diseñó una mesa de vidrio de comedor para el pabellón de la casa cerámica de Sevres y como trabajaba los envases de perfumes de la firmas Coty, D'Orsay y Worth, entre otras, "sus frascos dominaron la espectacular fuente de perfumes en la sección de perfumería". ${ }^{16}$ A manera de chorros de agua, tres niveles de forma ascendente configuraron un armazón de curvas, cuya base son los escaparates de los frascos de las selectas fragancias.

También colaboró con el ya mencionado pabellón Primavera, cuyas incrustaciones de piedras traslúcidas en el domo, no eran otra cosa que sus propios diseños.

Lalique es por lo tanto considerado como el máximo ejemplo de los maestros vidrieros del Déco, ya que sus influencias posteriores a la exposición del 25 fueron definitivas en muchos autores.
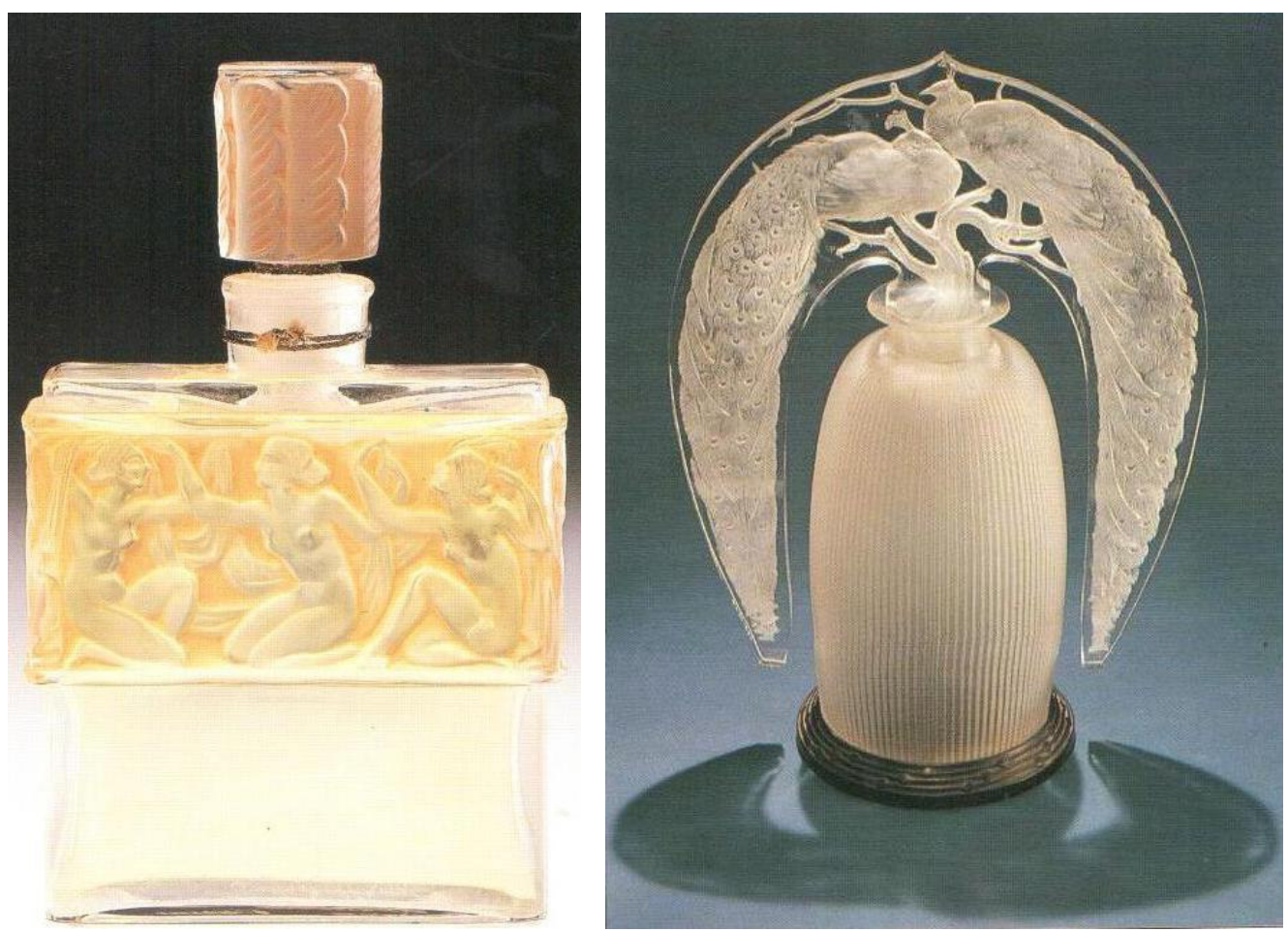

Dos obras de René Lalique. Frasco para perfume de la fragancia Iles d'Or de 192917 y frasco con figura de pavos reales de1925 en el Victoria \& Albert Museum, Londres. ${ }^{18}$

\footnotetext{
${ }^{16}$ Alastair Duncan, The Encyclopedia of Art Deco, London, Quantum Books, 1988, p. 100.

${ }^{17}$ Patricia Beyer, Art Deco, Barcelona, Oceano, 199, p. 79.

${ }^{18}$ Rosemary Lambert, El siglo XX, Barcelona, Gustavo Gili, 1989, $3^{\text {a }}$, edición, p. 59.
} 
El trabajo en plata de la exposición del 25 tuvo como máximo ejemplo a Jean Puiforcat (1897-1945). Presentó sus trabajos en el Salon d'Autonome de 1921 donde fue altamente reconocido. Su manera de concebir sus diseños estaba basada en la filosofía de Platón, ya que de él "aprendió el significado de la aritmética, la armonía y la geometría y el Número de Oro". ${ }^{19}$ Sus juegos de té o de cubertería son de un acentuado geometrismo sin elementos ornamentales, ya que el diseño en sí está demostrando la concepción basada en la estética platónica. Además de manejar la plata de la manera tradicional con marcas, incluyó en sus obras piedras preciosas como lapislázuli o jade, marfil y madera de ébano materiales que completaban los objetos concebidos en el argento metal, en muchas ocasiones del tipo dorado, y completado con incrustaciones de cristal.

Meramente decorativos o de uso doméstico, relojes, picaportes, cerraduras, cálices, custodias, jarras, charolas, juegos de té, vajillas, cubertería, piezas de ajedrez, todos ellos envueltos dentro de la máxima de Puiforcat "Le beau dans l'utile" (la belleza de lo útil), denotaban la armonía matemática aplicada al objeto. En la exposición del 25 sus diseños fueron apreciados en el pabellón del Groupe Rouards des Artisans Francais Contemporains y más diseños suyos estuvieron expuestos en la Embajada Francesa.

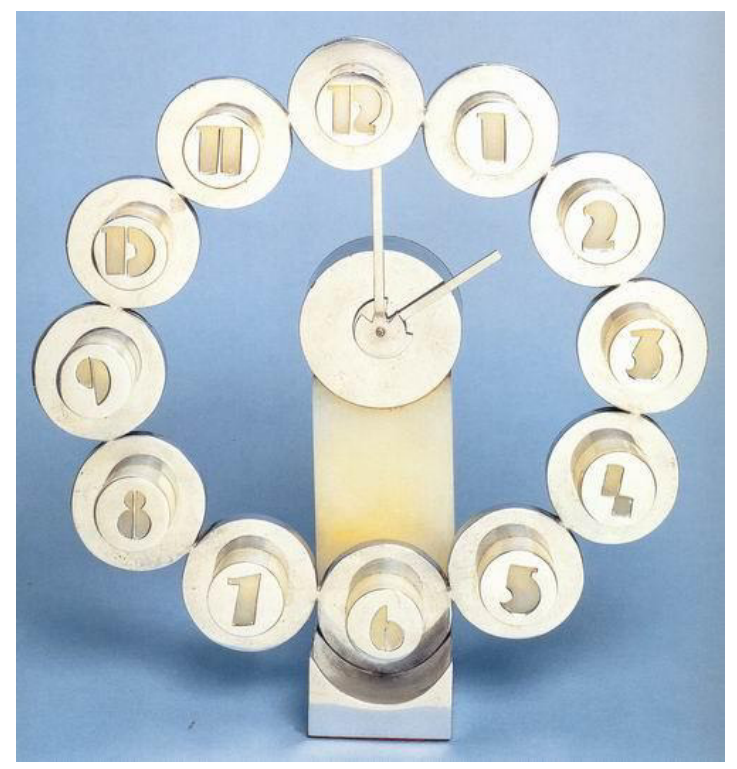

Reloj de Jean Puiforcart en ónix y metal bañado en plata s/f. ${ }^{20}$

\footnotetext{
${ }^{19}$ Victor Arwas, Art Deco, New York, Abradale Press, 2000, p. 95.

${ }^{20}$ Patricia Bayer, Op. Cit., p. 39.
} 
En metal los trabajos de Edgar Brandt (1880-1960) ya eran reconocidos antes del exposición del 25, pero fue ahí donde despegó su fama. Ganador de premios en la Société des Artistes Francais y jurado del Salon d'Automme así como de la Société des Artistes Décorateurs, Brandt trabajaba desde la decoración de un edificio hasta la más fina joyería.

$\mathrm{Su}$ relación de trabajo con los arquitectos André Ventre (1874-1951) y Henry Favier (1888-f.?) lo llevó a realizar juntos muchos proyectos y obras, con quienes trabajó en la monumental Port d'Honneur de la gran exposición del $25 .{ }^{21}$ Columnas estriadas en remate piramidal, las cuales protegen por una parte galerías que resguardan figuras humanas de influencia clasicista y por otra, rejas a manera de celosías con motivos florales geometrizados, todo el conjunto formando un zigzag en su disposición se ha convertido en uno de los más destacados motivos del Art Déco.

En su propio pabellón Brandt presentó un biombo de cinco piezas trabajado en hierro forjado y latón, cuyo panel central es una fuente con caídas de agua estilizadas en forma de elipses y las otras cuatro son una amalgama de formas florales y follajes geometrizados, combinando lo monumental con la delicadeza de las formas.

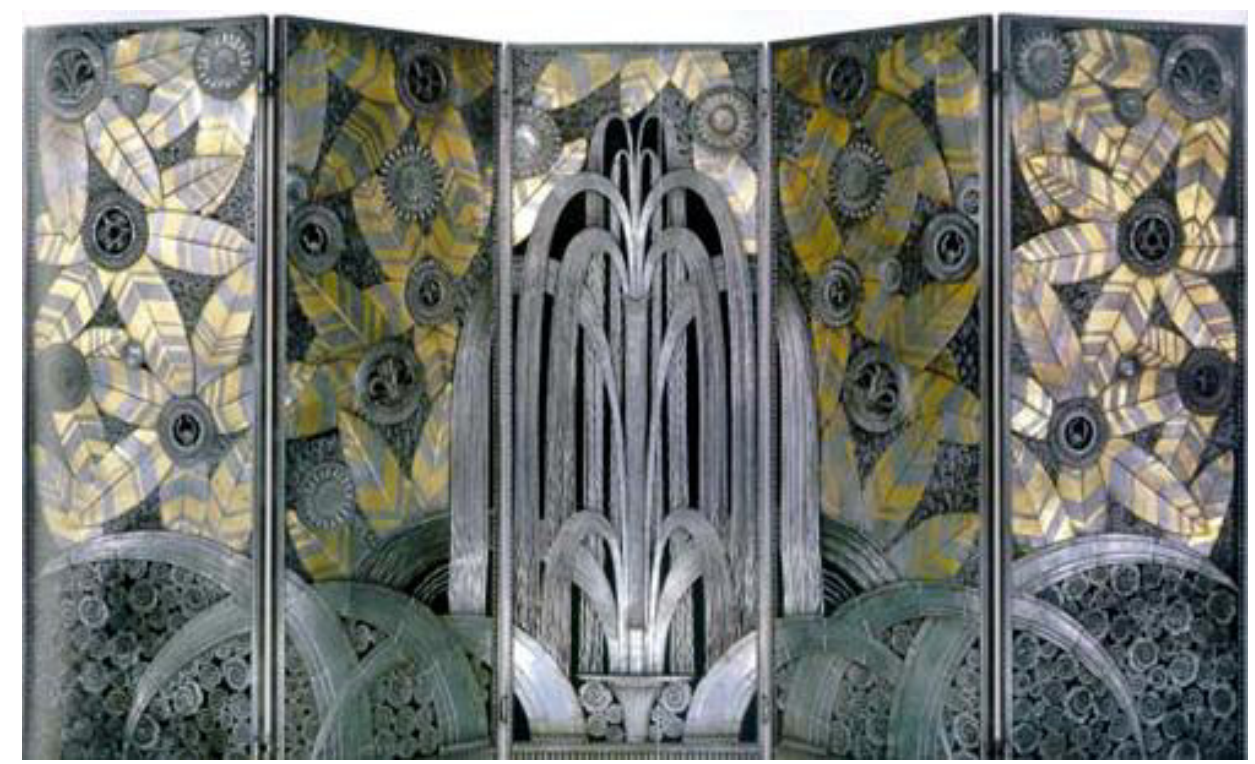

El Oasis, biombo de Edgar Brandt en la exposición de 1925.22

\footnotetext{
${ }^{21}$ Victor Arwas, Op. Cit., p. 87.

${ }^{22}$ Lynn Byrne, 2DESIGNER WHO'S WHO: Edgar Brandt", Décor Arts, Now, http://www.decorartsnow.com/2013/11/08/designer-whos-who-edgar-brandt/
} 
Una de las más entrañables tradiciones decorativas de lo francés es el mobiliario cortesano. Los estilos Luis XV y XVI, Imperio y Louis Philippe fueron retomados y de ellos se entresacaron los elementos que pudieran ser útiles para algunos diseñadores. Podríamos decir que fue en el mueble en donde más se destacó el decorativismo de la magna exposición de 1925, pues los pabellones en sus interiores eran precisamente acondicionados con los modernos diseños de muebles.

El binomio Louis Süe (1875-1968) y André Mare (1887-1932) fue la significación de una firma donde se desarrolló el diseño de variados objetos que van desde el papel pintado para pared, pasando por las alfombras, tapices, cerámicas, platería, cristales, hasta los muebles, enseres en los que fueron más reconocidos.Mare con una formación encaminada hacia las artes decorativas y la pintura y Süe con las Bellas Artes y la arquitectura, conjugaron genios y talentos en una mixtura de elementos compositivos de lo geométrico y sensual, de lo concreto y abstracto, de lo real y lo fantástico. Con la intención de unirse en un Atelier, el advenimiento de la conflagración de 1914 hizo que este proyecto se hiciera realidad hasta 1919: La Compagnie des Arts Francais.

Como otros diseñadores de la época, la admiración por el glamuroso siglo XVIII de los luises no les era ajena: el barroco sería una época de inspiración para la firma. Pasando por la época de la Restauración, para ambos fue la fase de Louis-Philippe la más legítima en cuanto a mobiliario por su adecuada austeridad de la mano con el confort. Los 18 años del soberano que se distinguió por su política de reestablecer el régimen monárquico que era reconocido como la mejor opción de gobierno por las demás naciones europeas, fueron los años de la austeridad de la mano con la comodidad, porque esos diseños eran retrotraídos por sus concepciones racionales que aplicaban a los proyectos de la Compañía, que siempre buscaron agradar y satisfacer, pues claramente Süe y Mare externaban su compromiso con lo humano.

Para conformar sus muebles utilizaron como otros tantos artistas de la época, maderas finas como el ébano de Macasar, el palisandro, la caoba, pero también integraron maderas claras que permitían conseguir diseños curvos como son el abedul y la muy europea haya.

La exposición del 25 dejó atrás al Atelier de La Compagnie, pues los objetos expuestos en el pabellón del Musée d'art Contemporain, en donde colaboraron diferentes 
diseñadores, ostentaron el lujo, lo deleitoso, lo refinado e inclusive lo histórico, a través de una propuesta decorativa distintiva de los dos artistas que buscaba crear algo muy francés, es decir, productos decorativos que estuvieran ligados con el pasado de Francia, pero insertos en las necesidades modernas. Y no sólo eso, sino que también dieron muestra de su maestría decorativa en los pabellones de Fontaine et Cie, Parfums d'Orsay, Salle des Fétes, y la Ambassade Francais.

En el año de la exposición parisina del 25 el rumano Jean Badovici (189-1956) en su revista L'Architectura Vivante escribió sobre las propuestas de los fundadores de La Compagnie des Arts Francais: "Süe y Mare reaccionan vigorosamente a la vez contra el diletantismo de algunos y contra el rígido utilitarismo de los demás... Aún reconociendo la necesidad de someter la nueva arquitectura a los cánones clásicos, quieren conservarle los ritmos vivientes, la poesía y la sensibilidad". 23

La empresa dejó de existir en 1928 y cada quien por su cuenta siguió trabajando con sus propios diseños.

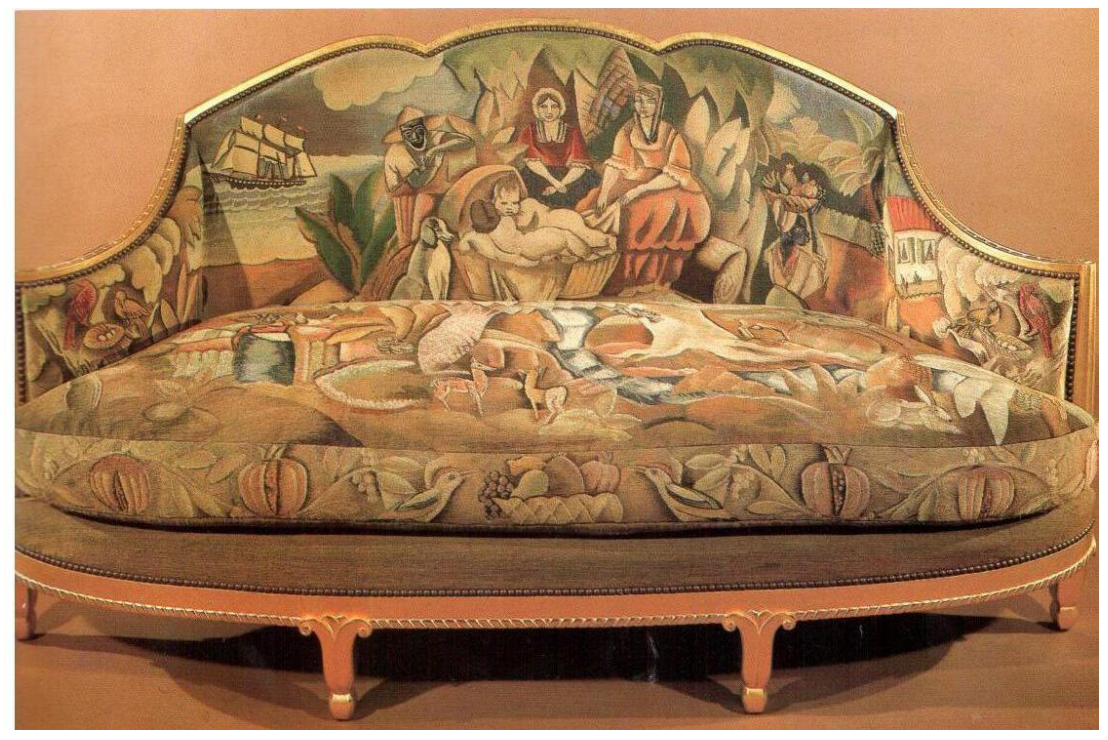

Süe y Mare. Sofá en madera dorada tapizado con Aubusson. Grand Salon del Musée d'art Contemporain de la exposición de $1925 .^{24}$

Una gran figura del mobiliario fue Maurice Dufrène (1876-1955), quien resaltó por sus diseños variados, los cuales sin tener una línea decorativa definida ensaya con una

\footnotetext{
${ }^{23}$ Jean Paul Bouillon, Op. Cit., p. 173.

${ }^{24}$ Alastair Duncan, Muebles Art Déco, Barcelona, Stylos, 1986, imagen 67.
} 
refinada modalidad sus trabajos, entre los que destaca la utilización de volutas talladas y los medallones de flores en boj, ébano y marfil. Durante más de treinta años expuso sus muebles en el Salon Des Artistes Décorateurs, del cual fue cofundador en 1904.

Transitando de lo femenino a lo clásico y de un naturalismo orgánico hacia lo floral y simétrico, Dufrène de la misma manera afanó la madera para también experimentar con el vidrio y el metal, consiguiendo un lenguaje propio. En 1921 fue nombrado Director de La Maitrise, casa de muebles que buscaba producir de manera industrial y en serie muebles a precios cómodos, que para Dufrène no era causa para descuidar la calidad estética, por lo cual afirmaba que: "Lo importante es adaptar el mueble a los medios, pero también subordinar los medios al mueble y no esperar el mismo resultado de enfoques distintos". ${ }^{25}$

La participación de Dufrène en la exposición del 25 dejó constancia de su gran capacidad creativa, porque si bien trabajó en la decoración del puente Alejandro III con las tiendas que se colocaron a lo largo del monumento, donde la curva suave y lo floral se integra en lo geométrico, dirigió el pabellón de La Maitrise de Galerías Lafayette, cuyo "hall” exhibe la línea recta y atenta a componer los ángulos de lo cúbico; a la vez participó en la decoración del Petit Salon de la Embajada Francesa y una boutique de peletería para la firma Jungmann et Cie. Es decir, su presencia variada en propuestas significó convertirse en un descriptor de las directrices de la decoración del Art Déco.

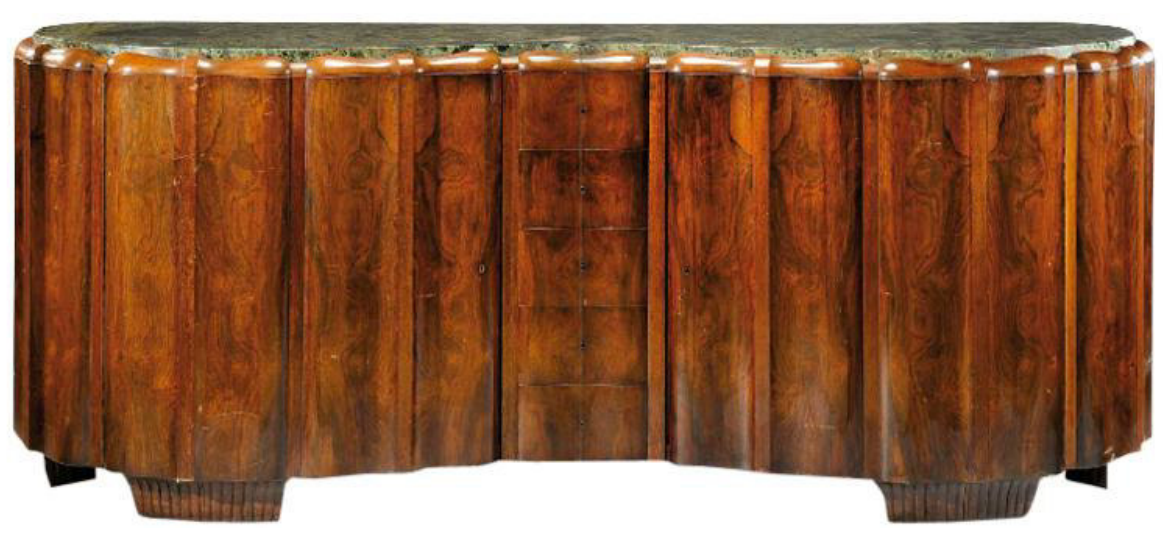

Maurice Dufréne, Aparador en caoba tallada y mármol, $1930 .{ }^{26}$

\footnotetext{
${ }^{25}$ Alastair Duncan, Op. Cit., p. 48.

${ }^{26} 1$ stdibs, "MAURICE DUFRENE documented exceptional buffet in carved mahogany with a marble top", http://www.1stdibs.com/furniture/storage-case-pieces/buffets/maurice-dufrene-documented-exceptionalbuffet-carved-mahogany/id-f_725364/
} 
El suizo avecindado en Francia, Jean Dunand (1887-1942) inicialmente tuvo el oficio de metalistero, trabajando con el martilleo objetos en peltre, cobre, zinc, plomo, níquel, entre otros. Posteriormente aprendió el laqueado con unos artífices japoneses y tiempo más tarde incluirá la cáscara de huevo en sus muebles para lograr tonalidades blanquecinas. Ese contacto con los asiáticos lo conminó a trabajar sus famosos biombos laqueados con figuras de animales en movimiento. Un renacer del barniz "vernis Martin" dieciochesco fue lo que concretó Dunand, que lo convirtió en el máximo maestro de la laca de los años del Déco. ${ }^{27}$ Partiendo de bocetos florales de tipo Art Nouveau sus diseños decorativos se irán geometrizando. Con un buen número de colaboradores logró crear un importante taller, mismo que tendrá que cerrar con el advenimiento de la II Guerra. La flamante vida marítima de los grandes trasatlánticos como el Ile-de-France, Atlantique y el Normandie dan cuenta de las lujosas decoraciones elaboradas por Dunand y su equipo.

$\mathrm{Su}$ espectro decorativo abarcó figuras tanto africanas como orientales, diseños geométricos abstractos como animales fantásticos, todos ellos plasmados en sus lacas de diferentes tonalidades.

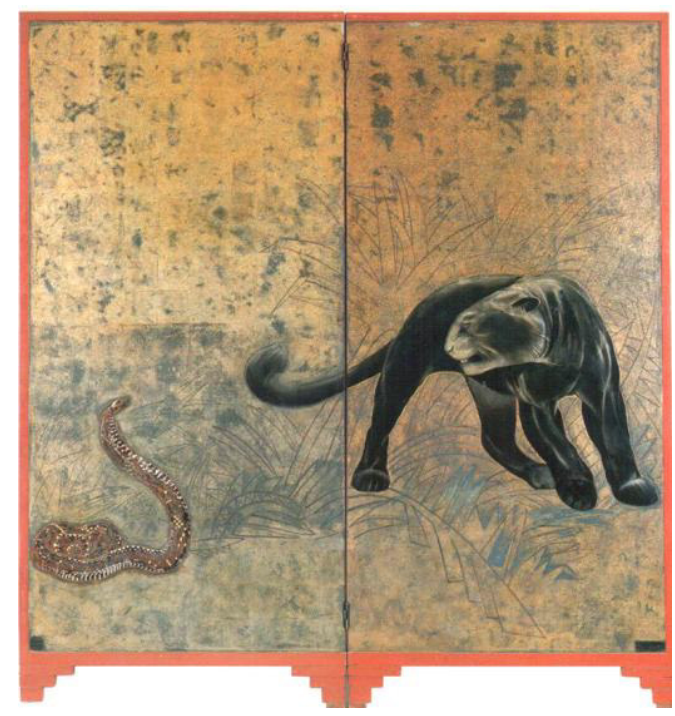

Biombo de Jean Dunand con hojas lacadas e incrustracionesde marfil bajo un diseño de Paul Jouve, ha. $1925 .^{28}$

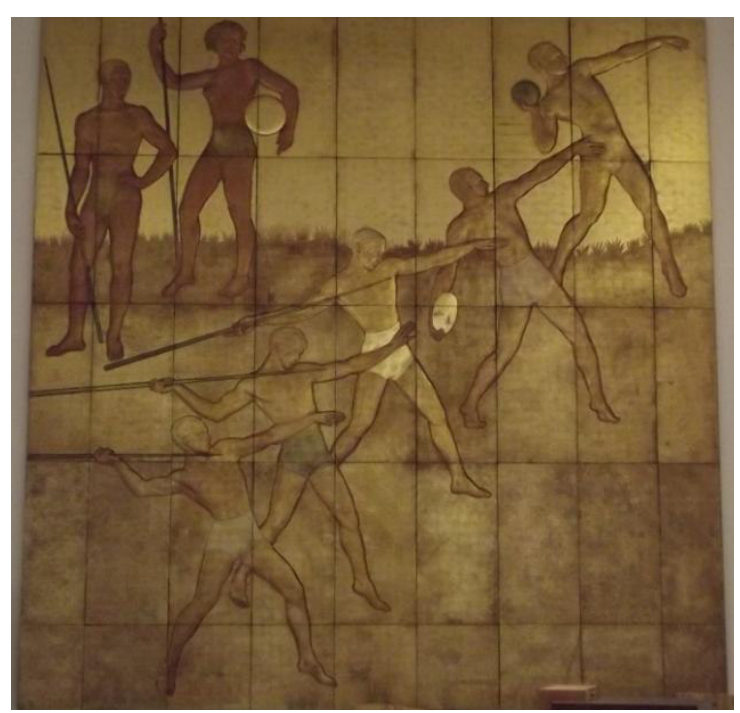

Los deportes. Panel en laca y pan de oro de Jean Dunand, 1935.

Musée d' Art Moderne de la ville de Paris.

\footnotetext{
${ }^{27}$ S/A, El mueble del siglo XX. Art Déco, Barcelona, Planeta-Agostini, 1989, p.42.

${ }^{28}$ S/A, Art Déco, Mobiliario y Metalistería, Madrid, Edimat, 1999, p. 26.
} 
André Groult (1884-1967) como otros tantos abrió su camino en las propuestas de Art Nouveau como decorador, para más adelante convertirse en un innovador diseñador de muebles bajo las influencias de los estilos Luis XV y Luis XVI pero con la premisa de la modernización, suavizando las líneas y llevándolas hacia una delicada geometrización. Si bien su fuerte pasión por los estilos del siglo XVIII fue una constante, en la mayoría de sus diseños mobiliarios dentro de su taller, en el cual colaboraban artesanos y artistas, otro elemento de esa época estuvo presente: el galuchat, aquella innovación de Jean Claude Galluchat (f.?-1774) con las pieles de pescados como el tiburón o la raya para las exigencias de Madame de Pompadour en los tiempos de Luis XV. El palisandro, ébano, marfil, carey fueron algunos de los materiales utilizados por Groult para componer y ornar sus diseños.

El dormitorio femenil de la Embajada de Francia en la excelsa exposición del 25 le da fama y reconocimiento. ${ }^{29}$ La cómoda "bombé" en galuchat, visiblemente muestra la predilección del estilo Luis XV, refinado, suavizado, rasurado del adorno abusivo, en pro de la limpidez del ornato. Si sus diseños eran para ambientes masculinos, sus formas vigorosas invitaban a la formalidad del convite, de la comida; si se trataba de lo femenino, la confortabilidad del encanto se desenvolvía en la sutileza de lo curvilíneo.

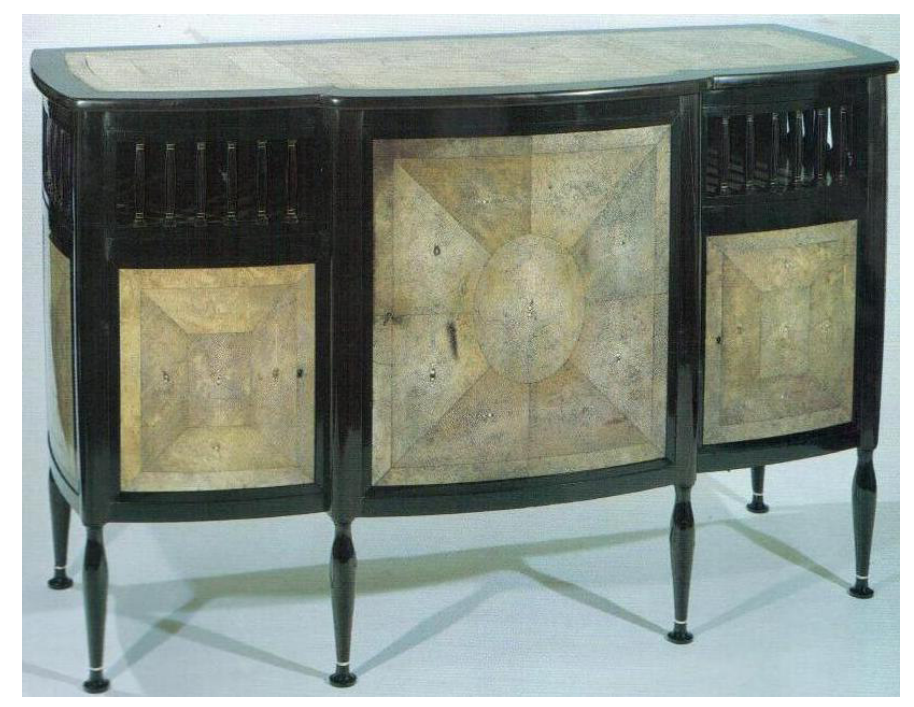

André Groult, Aparador realizado en ébano con cuarterones de galuchat, palisandro e incrutaciones de marfil, s/f. ${ }^{30}$

\footnotetext{
${ }^{29}$ Jean Paul Bouillon, Op. Cit., p. 175.

${ }^{30}$ Alastair Duncan, Op. Cit., imagen 31.
} 
La lógica de lo lineal como búsqueda de lo decorativo es lo que consiguió el arquitecto Pierre Chareau (1883-1950) en el diseño de muebles, es decir, elementos básicos se articulaban para conseguir diversos usos y/o funciones. El dejar abiertamente visible la composición de la madera y el metal, permitía conformar parte de la decoración geométrica y lineal de sus diseños, como las mismas vetas de las maderas que colocadas vertical u horizontalmente dan un ritmo decorativo. Jugar con el palisandro, el amourette, el sicomoro o con el amaranto y combinarlo con la piel de la marta o el terciopelo, Chareau lograba muebles elegantes y finos que convergían en la elegancia de la geometricidad, como sus mesas en forma de abanico, con perfiles metálicos y el uso de charnelas visibles.

En la exposición de París de 1925, Chareau tuvo dos participaciones: en la Embajada Francesa asumió la originalidad de presentar muebles para un estudio-biblioteca elaborados con madera de palma, cuyo escritorio en ébano de Macasar se ubica en el centro dentro de un espacio circular, logrando una decoración intrínseca constructivista; la otra, fue una galería para muebles en la que él mismo expuso sus diseños geométricos para selectos maceteros en hierro forjado. ${ }^{31}$

Cofundador de la Union des Artistes Modernes en 1930, posteriormente se dedicó a la decoración de interiores y a la arquitectura en los Estados Unidos.

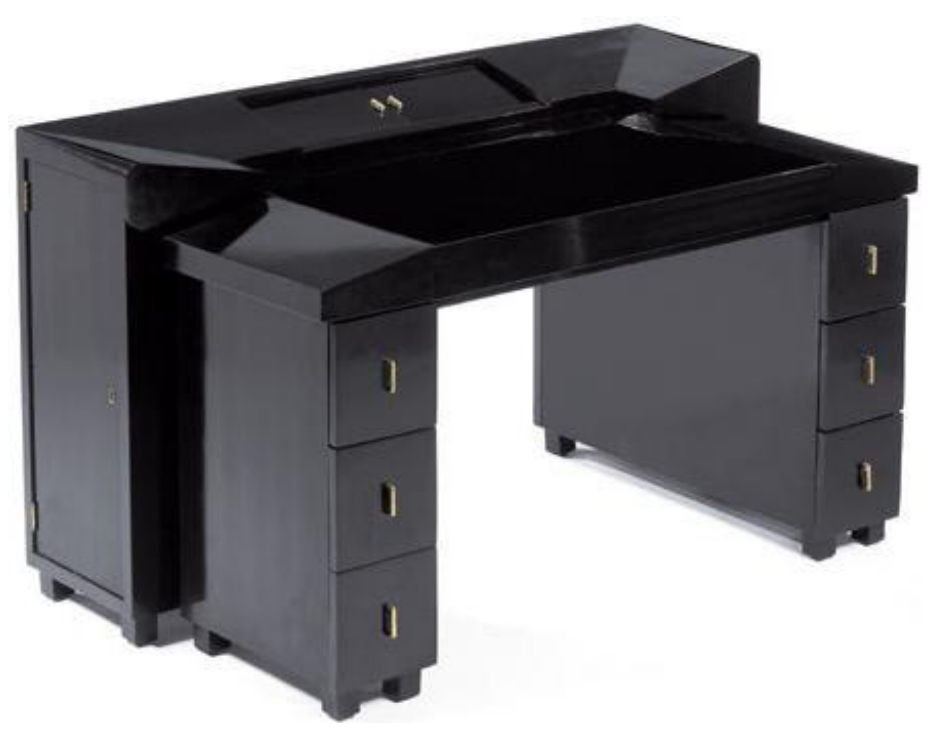

Pierre Chareau, Escritorio para la Ambassade Francais en la exposición de 1925 confecionado con ébano de Macasar. ${ }^{32}$

\footnotetext{
${ }^{31}$ Alastair Duncan, Op. Cit., p. 42.

${ }^{32}$ S/A, El mueble del siglo XX. Art Déco, Op. Cit., pp. 56-57.
} 
Paul Follot (1877-1941) es el significado de apego y tradición al siglo XVIII. Durante su trayectoria nunca dejará su neoclasicismo abundante de adorno, pero sometido a las directrices modernizantes de estilización, especialmente lo floral. Director de Pomone desde 1923, el centro de diseño de los almacenes Au Bon Marché, trabajó con maderas de lugares lejanos como era la madera de coral o de sicomoro, integrando en sus diseños animales cuadrúpedos o pájaros exóticos, lo que confluía en ambientes sumamente refinados. En el pabellón de Pomone, junto con su equipo de colaboradores, consiguió uno de los ambientes que mejor recibió las críticas en la Exposición del 25. Con una profusa participación destacó su Gran Salón con vitrinas en madera oscura con incrustaciones de marfil; conformadas circularamente, al frente un panel verticalmente veteado, resguarda los adornos florales con hojas que se distribuyen alternadamente, ya sea de manera ascendente o descendente, ${ }^{33}$ símbolos arquetípicos de la decoración Art Déco.

A contracorriente con los defensores de la producción en serie y con los promotores de los purificadores del adorno, Follot y su equipo lograron crear una línea mobiliaria y decorativa emanada de la tradición, pero al servicio de los ambientes de la galanura modernizante de los años 20.

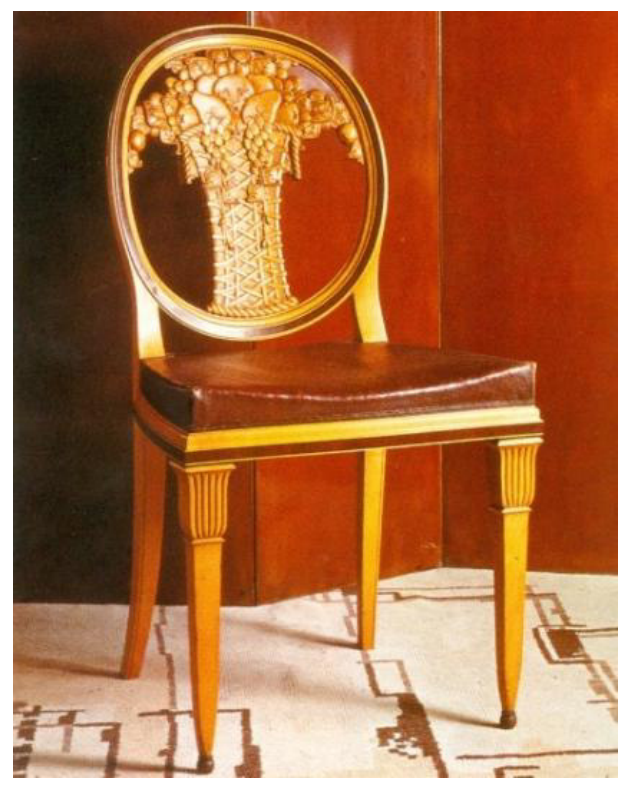

Silla de Paul Follot, 1913.

Musée des Art Décoratifs, París. 34

\footnotetext{
${ }^{33}$ Alastair Duncan, Op. Cit., p. 84.

${ }^{34}$ S/A, El mueble del siglo XX. Art Déco, p. 60.
} 
El ambiente neoclásico es trasladado al siglo XX por Armand-Albert Rateau (18821938). Fuertemente impactado por las ruinas romanas de Pompeya desarrollará un decorativismo en el cual integrará faisanes, gacelas, loros, mariposas, peces acompañados de florestas, entre las que destaca las hojas de acanto y también incluyendo decoraciones orgánicas del lejano Oriente. Su taller recibió encargos de acaudaladas familias y prestigiosas firmas. De la misma manera, Rateau participó en la decoración del Palacio de la Lira en Madrid, residencia de los Duques de Alba.

Elegancia, refinamiento, glamour, sofisticación es lo que significan los muebles de Rateau trabajados en roble y en bronce, el cual es tratado con verde patinoso para remitir a lo antiguo. Tal es el caso del tocador de la casa de la estilista y diseñadora de moda Jeanne Lanvin (1967-1946) con patas a manera de colgaduras alargadas y espejo sostenido por loros recargados en líneas serpentinas. ${ }^{35}$

Su participación en la Exposición parisina del 25 expuso sus muebles en el puesto de la Maison Callot Soeurs, en el Pavillon de L'Elegance y en la Renaissance de l'Art Francais et des Industries de Luxe. Los mismos nombres de los espacios nos hablan de la dirección de la producción de Rateau. No abandonó su directriz clasicista y orientalista en sus decoraciones durante toda su carrera artística.

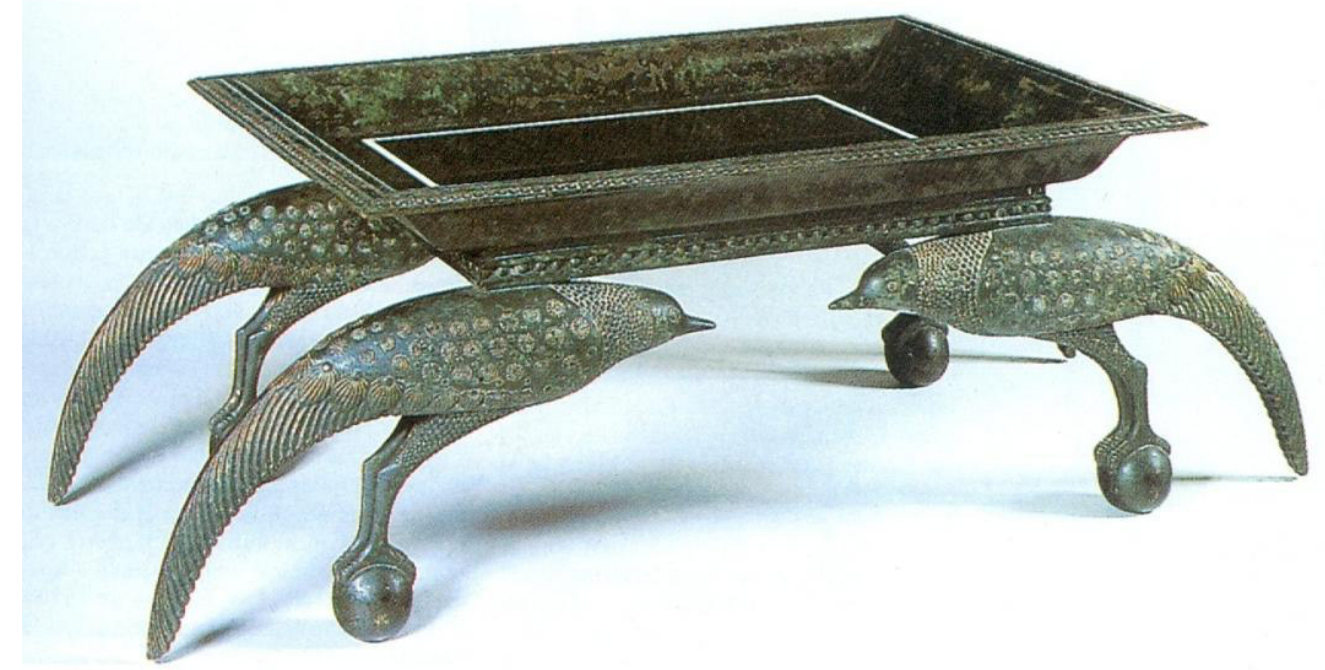

Armand-Albert Rateau, mesa en bronce y mármol para la residencia Lanvin, hacia $1924 .{ }^{36}$

\footnotetext{
${ }^{35}$ S/A, El Mueble del siglo XX. Art Deco, Op. Cit., p. 48.

${ }^{36}$ S/A, Art Déco, Mobiliario y Metalistería, Madrid, Edimat, 1999, p. 31.
} 
A Emile-Jacques Ruhlmann (1879-1933) se le ha considerado como uno de los máximos exponentes del diseño del Art Déco. Iniciado en el negocio paterno, pronto se interesó en el diseño de muebles. Para 1919 se asocia con Pierre Laurent, taller que le diera muchísima clientela acaudalada y un crecimiento vertiginoso. Como era la moda de la época, el uso de materiales finos y exóticos era un gran atractivo, Ruhlmann utilizó las maderas de palo de violeta, el amaranto, la amboina, el ébano de Macasar con las que experimentaba la taracea y las incrustaciones de marfil y nácar. Su famosa rinconera de 1916 en tres y cuatro patas cuya decoración floral abarca la mayoría de la puerta es un clásico del Art Déco que reúne los postulados de Ruhlmann.

El metal repujado colocado en el centro de sus muebles, fue una de las constantes de sus diseños muchos de ellos laqueados por la maestría de Jean Dunand; las patas estilizadas, troncopiramidales y airosas, estaban protegidas por "zapatos" en metal que si conseguían un efecto decorativo, a la vez cumplían la función de protección. Otras de las propuestas de Ruhlmann son los juegos de pesantez al sostener los muebles en bases cerradas remetidas para resaltar el diseño del objeto: un cubo de mayor tamaño sostenido livianamente por una base menor, un verdadero homenaje al cuerpo geométrico cubotizado.

El efecto decorativo de Ruhlmann se consigue a través de delicadas líneas punteadas con incrustaciones de marfil en los contornos, formando cuadros, o con los rombos sobre la piel de galuchat o conformados con el mismo marfil, que en algunos casos son completados con los tiradores en forma de flecos trabajados en bronce, mismo material para las cerraduras centrales.

Admirador de los estilos de Luis XIV, XV, Imperio y Louis Philippe, pero especialmente del Imperio, estas tendencias transitaron a sus diseños modernos de sus refinados muebles con los cuales no buscaba conseguir una funcionalidad, sino una verdadera obra de arte envuelta a la vez del confort, como sucedía con sus almohadillados con las que averiguaba deleitar según el uso para el que fue diseñado: "Un sillón para una estancia no debe ser concebido como un sillón para una oficina, el cual a su vez debe ser muy distinto al sillón de un fumoir. El primero debe ser acogedor, el segundo cómodo, el tercero voluptuoso. Cada uno ha de tener su propia forma: la primera tarea de un artífice es la de determinarla", ${ }^{37}$ decía Ruhlmann para diferenciar el destino de cada creación.

\footnotetext{
${ }^{37}$ S/A, El mueble del siglo XX. Art Deco, Op. Cit., p. 34.
} 
La participación de Ruhlmann en la Exposición del 25 fue su lanzamiento al estrellato, pues antes era conocido por una clientela exclusiva y reducida, mientras que en el Pabellón de L'Hotel du Collectionneur los miles de asistentes quedaban maravillados al encontrarse con un mobiliario exquisito, moderno, lujoso, acogedor que reivindicaba el mueble cortesano que tanta identidad ha dado a los franceses.
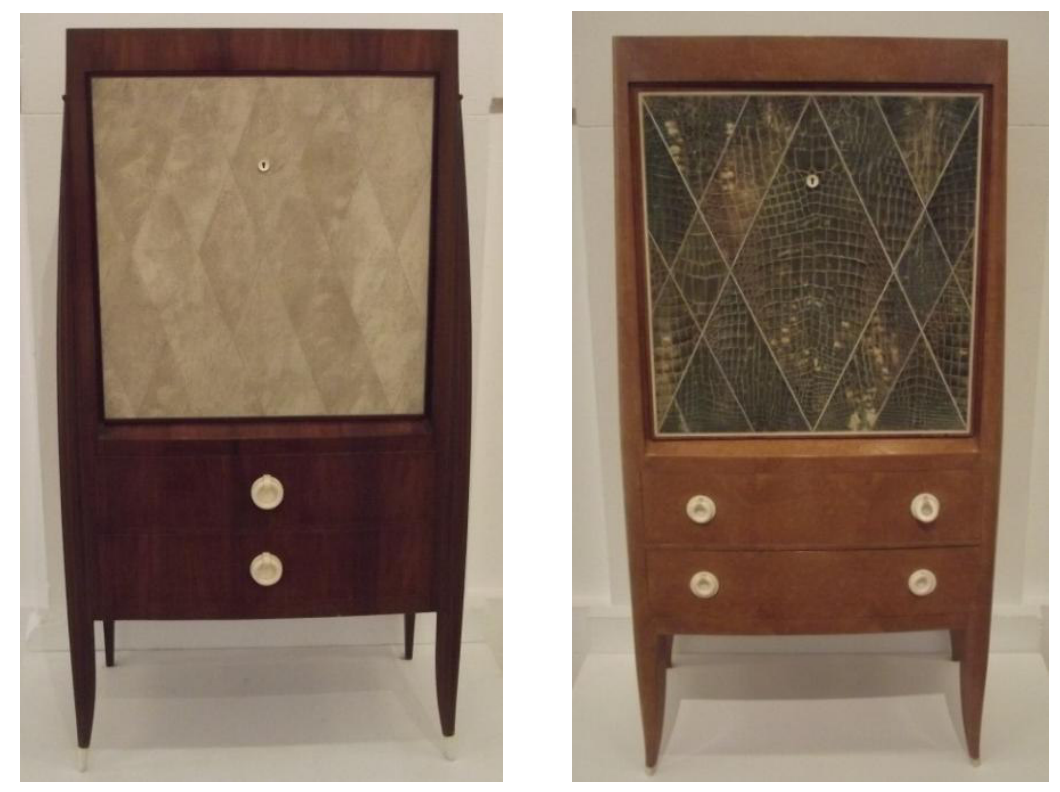

Emile-Jacques Ruhlmann, Dos Secreter tipo egicio. El de lado izquierdo en amaranta, galuchat y manijas de marfil, 1926. Del lado derecho, ambonia de Birmania, piel de cocodrilo y agarraderas de marfil, 1933.

Musée d' Art Moderne de la ville de Paris.

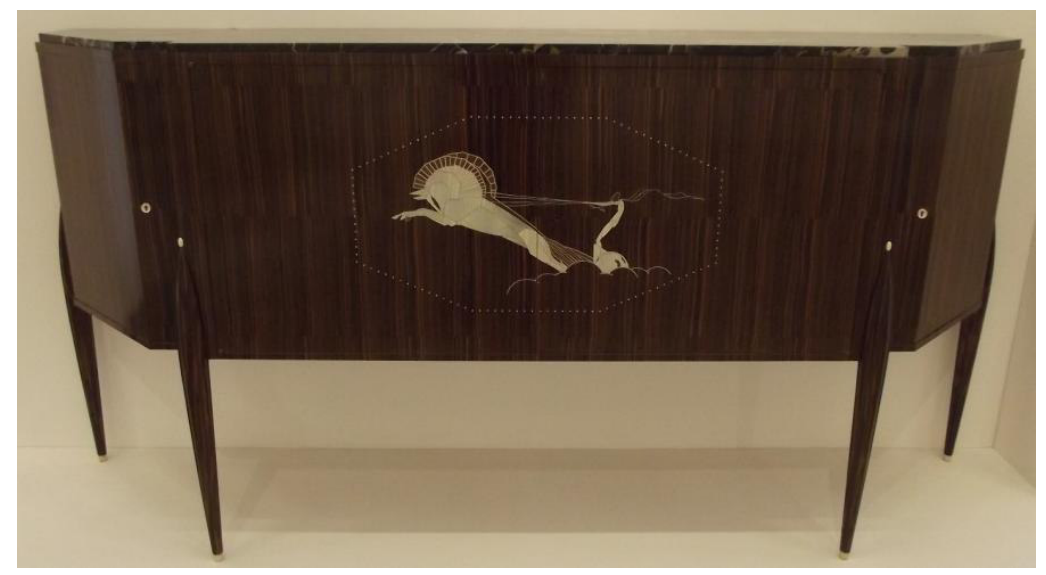

Emile-Jacques Ruhlmann, Argentier, mueble para guardar plata, en ébano de Macasar e incrsutaciones de marfil, 1921.

Musée d' Art Moderne de la ville de Paris 
Dentro del mundo de la moda, una de las figuras más emblemáticas de la época del Déco fue el modisto Paul Poiret (1879-1944). Extravagante y atrevido, fundó el Atelier y la Ecole Martine, en la cual jóvenes alumnas internas recogían imágenes en vivo a través de dibujos que posteriormente eran utilizados por Poiret para sus diseños. En sociedad con el pintor Raoul Dufy (1877-1953) trabajaron muchos años creando diversos diseños de tipo floral, hasta que Dufy trabaja para la firma textil Bianchini-Férier, lo que provocó la enemistad y el rompimiento de la sociedad, así como los proyectos del Atelier Martine.

Cada diseñador tenía sus propias creaciones y experimentos plásticos decorativos. Los pocos comunes diseños florales, imbuidos de color y sin dejar de lado las claras influencias de las decoraciones de los ballets rusos de Alexandre Benois (1870-1960) y de Léon Bakst (1866-1924) con su fuerte orientalismo, ${ }^{38}$ tan en boga en París antes de la I Guerra, fueron una constante en los trabajos de Poiret y su Ecole, que a la vez abarcaron el diseños de muebles, lámparas y alfombras, como fue el caso de la decoración del camarote Chantilly en el refinado trasatlántico Ile-de-France.

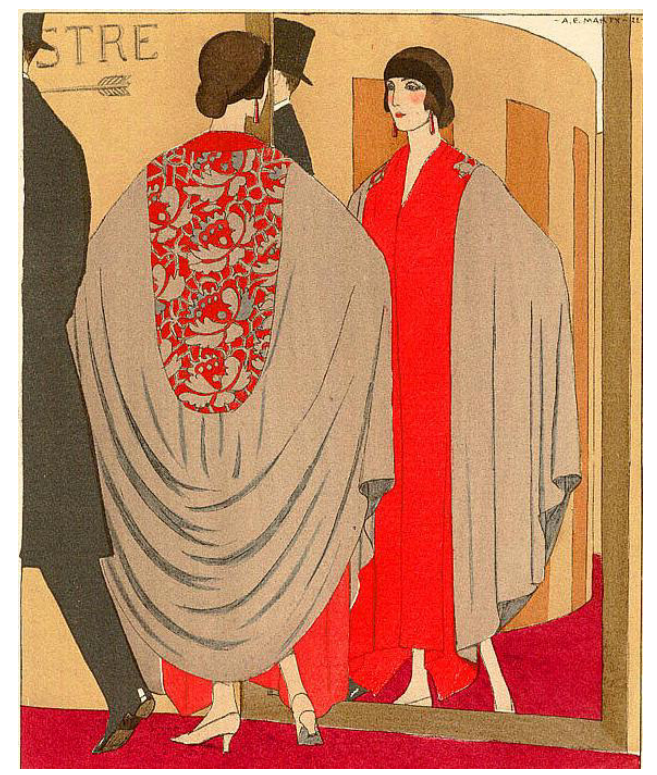

Paul Poiret, Abrigo de Noche, 1922.

The Metropolitan Museum of Art, New York. 39

\footnotetext{
38 "Sobre este contexto, se llama orientalismo a una mezcla ecléctica de influencias de lo más variado, las cuales son indias o egipcias, bizantinas, árabes o chinas, e inclusive originarias de la Rusia oriental. Los motivos principales son colores intensos, lujuriosos y un mínimo de carácter exótico". Gertrud Lehnert, Histoire de la mode au XXe siécle”, Paris, Konemann, 2000, pp. 15-16.

${ }^{39}$ Susan A. Sternau, Art Deco. Flights of Artistic Fancy, New York, SMITHMARK, p. 70.
} 
El exotismo de Poiret dio cuenta de ello en la exposición del 25 con sus barcas sensualmente decoradas que trabajó en colaboración con Dufy: Amours, Délices y Orgues, verdaderas casas flotantes, llenas del glamour decorativo de formas orgánicas, vívidos colores y exquisitos diseños originales.

En los años del Déco la gran personalidad de la moda sin equivocaciones fue Gabrielle "Coco" Chanel (1883-1971). La revolución que causó en el ámbito del diseño femenino no tenía antecedente alguno. Al quedar huérfana de madre, fue internada en un orfanatorio de monjas, donde aprendió la costura y el bordado. No cabe duda que al coser la ropa de los militares y ver los hábitos de las mojas concibió sus ideales de una ropa fresca, suelta y de colores obscuros. Sin formación de diseño ni de ningún campo de las artes, ella se inspira en el guardarropa masculino para concebir inclusiones en sus osados diseños para los sacos, gorras, pantalones y blusas para las mujeres, buscando una ropa cómoda, ligera, fresca, con novedosas telas, pero al mismo tiempo elegante.

Su relación con Demetrio Pávlovich Románov, conocido con el Duque Dimitri (1891-1942), mucho le impactó para la confección de sus chaquetas rectas, con las botonaduras en oro, pues los uniformes militares del noble ruso eran de su fascinación. El hecho de que Coco Chanel se involucrara en sus idilios sentimentales con gente de una sociedad elitista y elegante que acostumbraba deambular por los cafés, bares, teatros, así como lugares de prácticas deportivas y balnearios, le permitió relacionarse para alcanzar una alta proyección con sus invenciones de la moda.

Al mismo tiempo, la amistad que cultivó con Misia Sert (1872-1950), la pianista de origen ruso que convivía con las personalidades del mundo del arte y la música, le abrió las puertas para que sus diseños fueran símbolo también de la modernidad artística. Misia se había casado por tercera vez con el pintor español José María Sert (1874-1945), matrimonio que la invita a un viaje por Italia, coincidiendo con Serguéi Diáguilev (1872-1929), el director y propietario de Les Ballets Russes, nada menos que en Venecia, quien invita a Chanel para que diseñe los trajes de algunos ballets, imbuyéndose del ambiente artístico de vanguardia de esos años, por lo que Lourdes Cerrillo señala: "Chanel, de manera similar a Rietveld, Mondrian, Le Corbusier o Mis van der Rohe, consagraba la belleza de las formas simples y prácticas creando una prenda cuyos cortes se acomodaban a la figura femenina, 
sirviéndose de la elasticidad de los materiales para integrar la estructura del cuerpo en la definición de los diseños."

Su revolución a través de blusas sueltas de manga corta, de tirantes, vestidos sin el uso de corsé, por abajo de la rodilla, sueltos, con escote redondo, cinturón holgado debajo de la cintura, adornados por bisuterías sencillas poco costosas, y su novedad del traje en tres piezas, así como el trascendente "petite robe noire" de 1926, publicado en New York en la revista Vogue, corto, negro, color reservado para el luto y seriedad, ahora convertido en elegancia para toda ocasión, se aplica a una máxima donde dentro de la sencillez está la elegancia.

Por eso se decía sobre Coco Chanel: "siempre, ella misma cose su ropa, de una gran simplicidad y de una sobriedad extrema". ${ }^{41}$
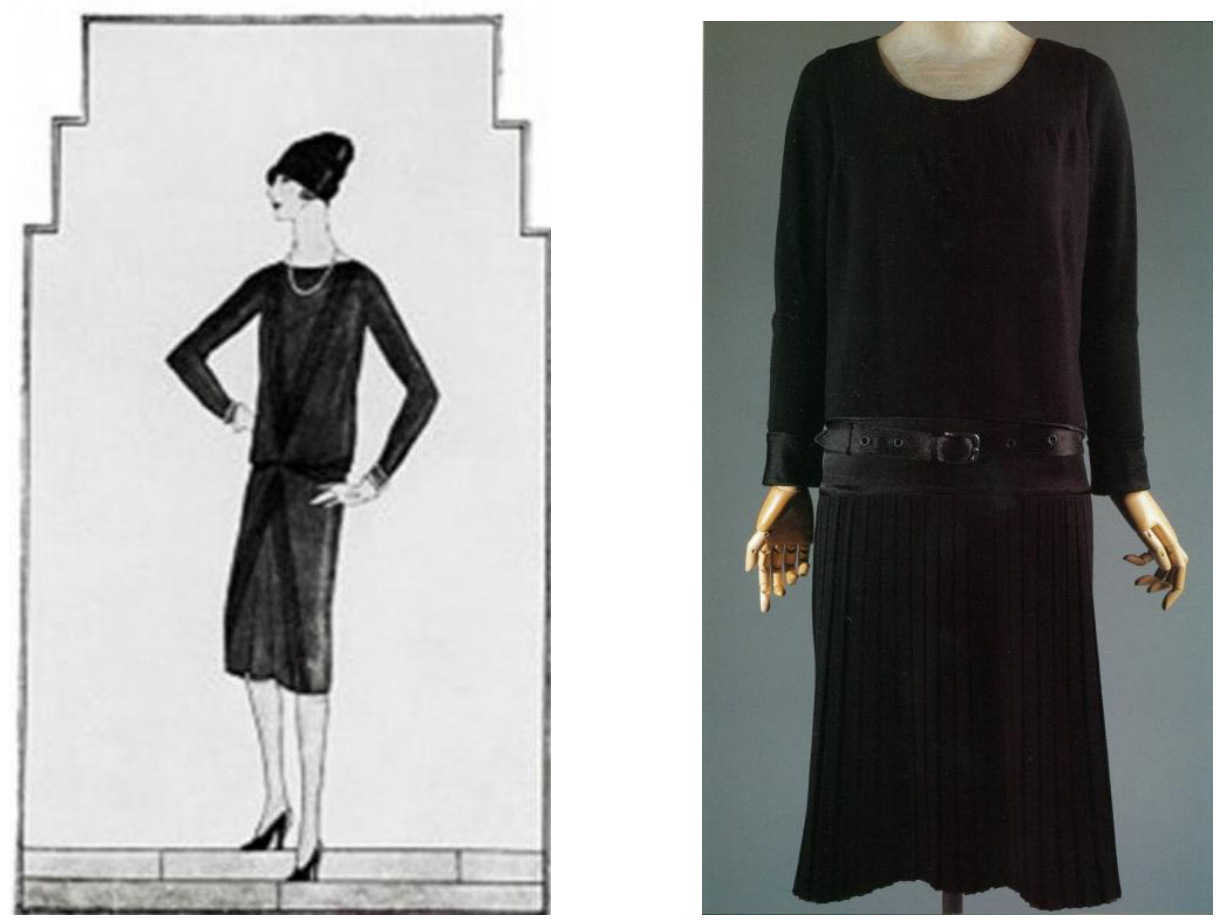

Coco Chanel, Petite robe noire, $1926^{42}$ y Conjunto de día en negro, Metropolitan Museum of Art, Ney York. $1926 .{ }^{43}$

\footnotetext{
${ }^{40}$ Lourdes Cerrillo Rubio, La moda moderna. Génesis de un arte nuevo, Madrid, Siruela, 2010, p. 129.

${ }^{41}$ Gertrud Lehnert, Op. Cit., p. 22.

${ }^{42}$ Ídem.

${ }^{43}$ Suzanne Lussier, Art Deco fashion, London, Bulfinch Press, 2003, p. 39.
} 


\subsection{MÁS ALLÁ DE LA EXPOSICIÓN DEL 25}

Después de la magna exhibición del 25, los productos y diseños siguieron una ruta itinerante durante 1926 y dos exposiciones en París continuarán con las propuestas decorativas Art Déco propuestas por Maenz: la Exposition Coloniale Internationale de 1931 y la Exposition Internationale des Arts et Techniques de 1937.

La primera mostró objetos de las culturas de los países africanos, asiáticos y del Caribe que pertenecían a Francia. Los pabellones se diseñaron con ornamentos y objetos de los remotos lugares, los que influenciarán al Art Déco con motivos y materiales de la Indochina, África, el Pacífico y América. Exóticos, "primitivos", tribales o autóctonos diseños, conceptos franceses hacia dichas culturas, afectaron las creaciones de los artistas participantes en la exposición, por lo que el Art Déco se verá nutrido de esos objetos. El gran cactus de los arquitectos André Granet (1871-1974) y Roger-Henri Expert (18821955) hecho de metal e iluminación interior en las bandas curvas que se conectan con el cilindro central que pareciera el tronco de una palmera, más las fuentes de luz que asemejan chorros de agua, conmocionó al espectador y se convierte en un icono del Art Déco.

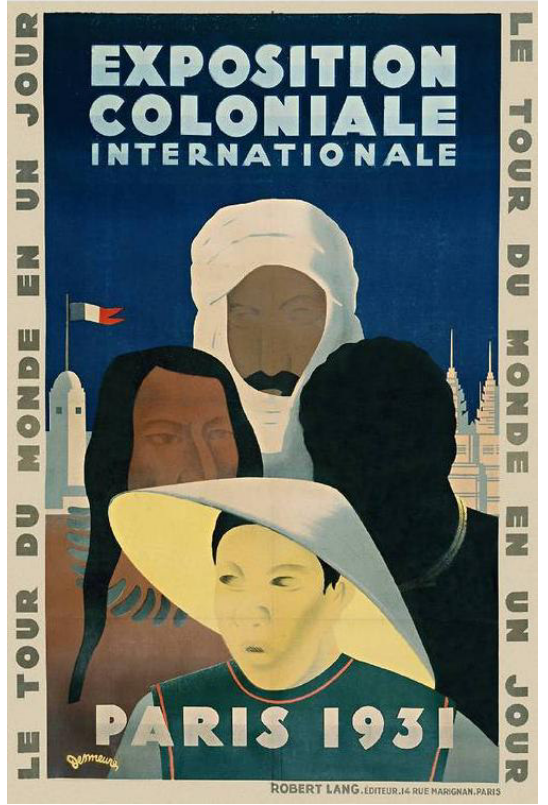

Cartel de la exposición de $1931 .^{44}$

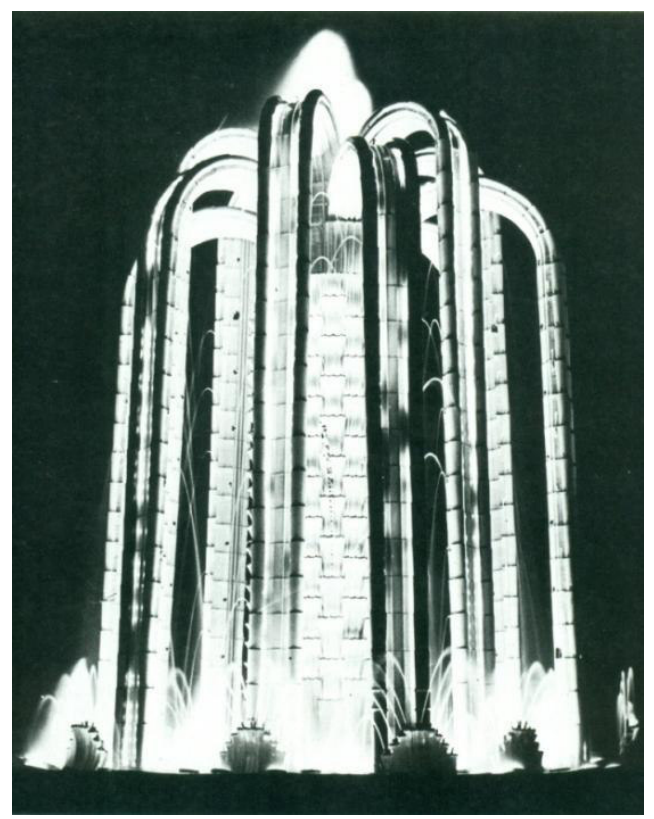

Le Cactus de Granet y Expert, $1931 .^{45}$

\footnotetext{
${ }^{44}$ Bevis Hillier; Stephen Escritt, Art Deco Style, London, Phaidon Press Ltd, 1977, p. 111.

${ }^{45}$ Jean-Paul Boullion, Op. Cit., p. 232.
} 
La segunda fue nuevamente una muestra de los avances decorativos y técnicos, en donde la relación entre arte y productos industriales seguía el camino ascendente que decaerá con la llegada de la otra gran guerra. El Palais de Chaillot, con su apacible arquitectura de toques neoclásicos geometrizados, gran tributo al Art Déco, fue construido para esta magna muestra, donde se ubicó el Palais de Trócadero, por los arquitectos Léon Azéma (1888-1978), Jacques Carlu (1890-1976) y Louis-Hippolyte Boileau (1878-1948) con esa majestuosidad que aún presume frente a la Torrre Eiffel.

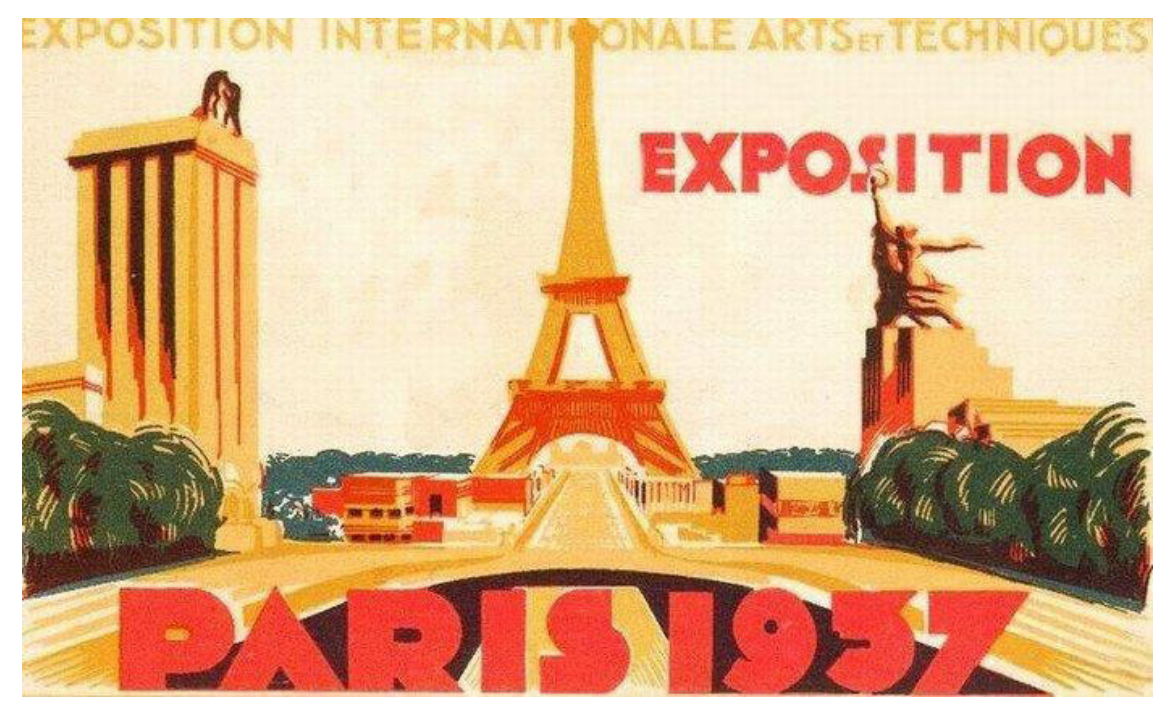

Cartel de la exposición de París de 1937.46

Los pabellones, más gigantescos esta vez, continuaban con las influencias del Art Déco y lo aerodinámico hizo su aparición en el macro Palais de l'Air que presagiaba los triunfos técnicos de la aviación militar y comercial, que contrastaba con el pabellón español donde se exhibía el Guernica de Picasso, muestra de la devastación franquista y nazi.

El pabellón de Alemania con su altura y rectilínea composición ensaltando el águila germana y la swástika nazi, obra de Albert Speer (1905-1981), quien fuera arquitecto jefe de Hitler, competía frente a frente con el pabellón de la Unión Soviética con su gigantesca escultura de 24.5 m., en acero inoxidable, obra de Vera Mújina (1889-1953), representando al Obrero y la koljozina, la nueva figura de la campesino rusa.

\footnotetext{
46 "L’Exposition Internationale Arts et Techniques á Paris 1937”, http://lartnouveau.com/art_deco/expo_internationale_1937.htm
} 


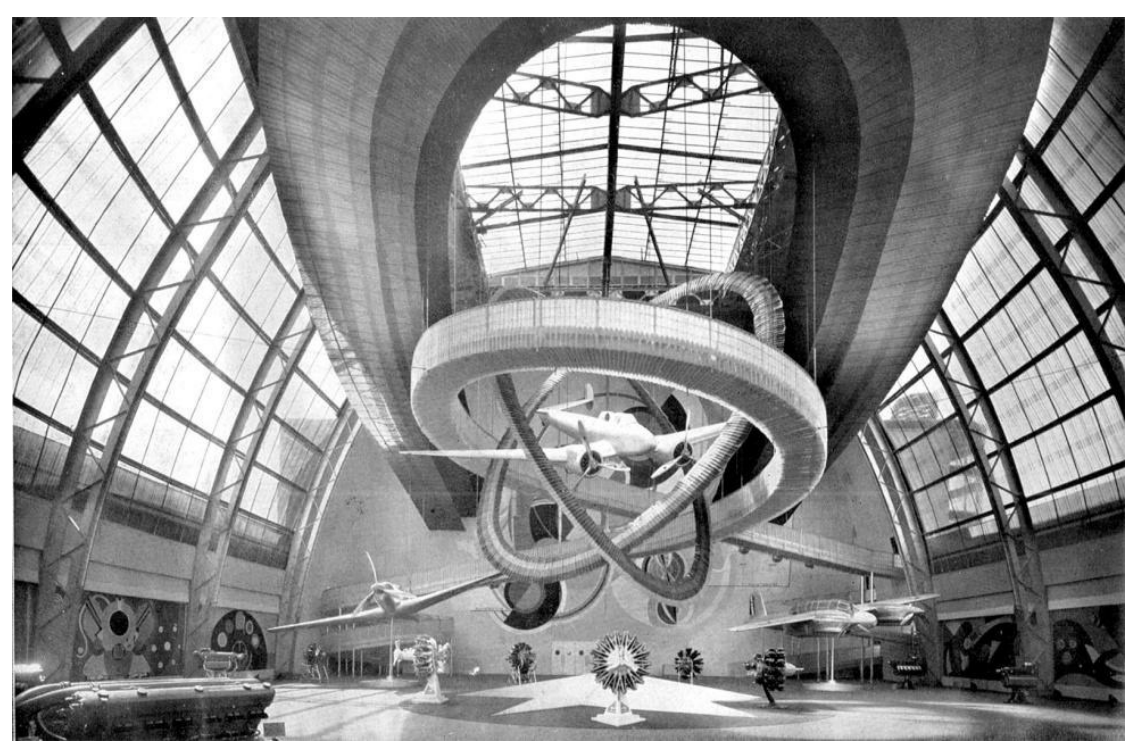

Palais de l'Air, en la exposición de París de $1937 .{ }^{47}$

Por su parte, en el otro lado del Atlántico, la emergente y poderosa nación de los Estados Unidos recibirá las influencias de la muestra del 25 en algunas exposiciones: Century of Progress Exposition, celebrada en Chicago en el año de 1933, Golden Gate International Exposition de 1939 en San Francisco y la de New York World's Fair de 1939 en Nueva York.

En la de Chicago, por ejemplo, los elementos geométricos y la fuerza solar estuvieron claramente vistos en el Travel and Transport Building, obra de los arquitectos Daniel Burnham Jr. (1886-1961), Hubert Burnham (1889-1968), John A. Holabird (18861945) y Edward H. Bennett (1874-1954), entre otros, quienes formaron parte de la comisión de la exposición. ${ }^{48}$

En la del puerto de San Francisco se presumía el Golden Gate Brige con sus 1.300 $\mathrm{m}$., de longirtud, mientras las culturas orientales se hicieron presentes en los diseños, pues precisamente de San Francisco salían las embarcaciones hacia el lejano oriente. Y la de Nueva York, que consagró el estilo aerodinámico o Streamline, visualizaba el mundo del mañana, en el año en el cual se iniciaba la II Guerra Mundial, cautivando a los miles de

\footnotetext{
${ }^{47}$ Playin in the Wolrd Game, "Hall the Aeronautic-Paris 1937", https://playingintheworldgame.wordpress.com/tag/1937/

${ }^{48}$ Eva Weber, Op. Cit., p. 13.
} 
asistente con la Cápsula del Tiempo, con todo el adelanto tecnológico de la época y que se vería posteriormente nutrido por los científicos e intelectuales inmigrantes europeos. ${ }^{49}$

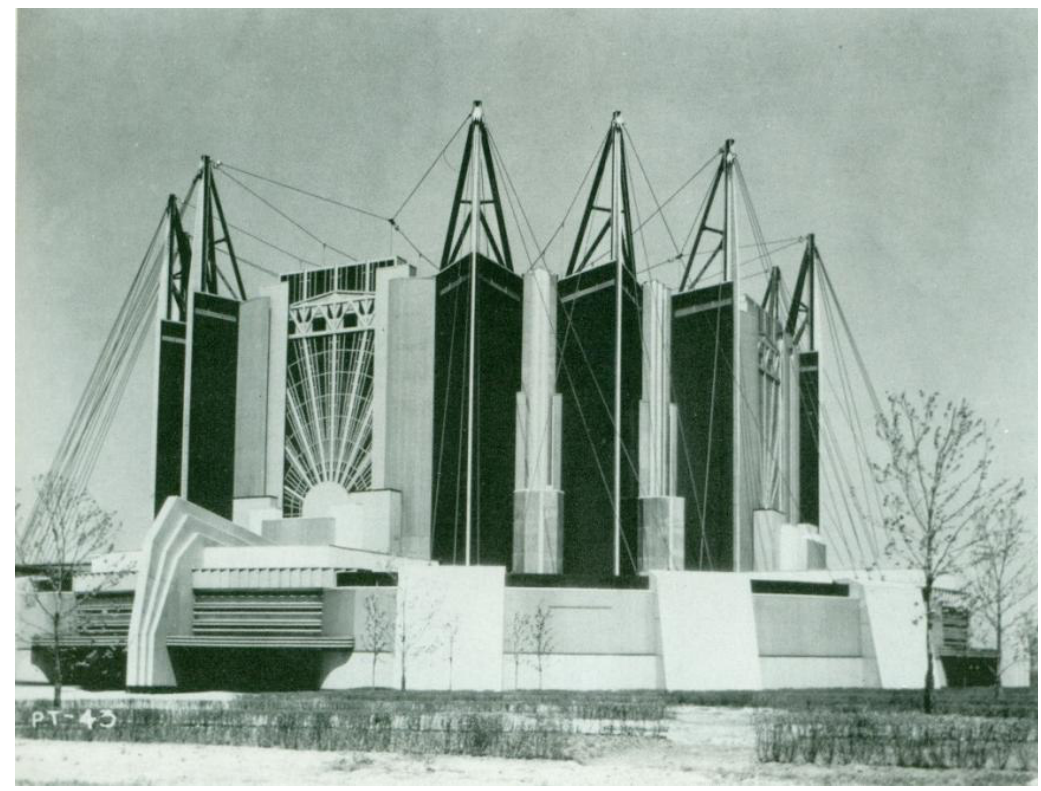

Travel and Transport Building en la exposición de Chicago, 1933. ${ }^{50}$

Nosotros consideramos que las exposiciones internacionales fueron el mejor escaparate para lucir y revelar los nuevos productos artísticos, artesanales e industriales que herederos de vanguardias, talleres y centros de producción tanto artística como industrial conformaron aquellos objetos y diseños que le dieron vida al Art Déco.

\footnotetext{
${ }^{49}$ Paul Maenz, Op. Cit., pp. 204-205.

${ }^{50}$ Eva Weber, Op. Cit., p. 13.
} 


\subsection{EL MUNDO CULTURAL Y ARTÍSTICO DE LOS AÑOS DEL ART DÉCO}

\subsubsection{Art Nouveau}

A fines del siglo XIX surge en Europa occidental un fenómeno artístico de reacción en contra del eclecticismo reinante y el clasicismo academicista anquilosado. Manifestado en forma individual y sin ser una escuela o movimiento de tipo agrupación, este arte buscaba imbuir, por primera vez en la historia, los ambientes tanto exteriores como interiores del hábitat humano.

Producto de una mezcla de influencias artísticas salidas del movimiento Arts and Crafts (Artes y Oficios, del cual hablaremos más adelante), de los Prerrafaelitas, del arte oriental y celta, así como de ideas estéticas, este fenómeno artístico conocido como Art Nouveau tenía fines netamente decorativistas, además de estar en contra de la producción industrial de objetos en serie y de la máquina, por lo que revalora la elaboración de productos en forma artesanal y faculta nuevamente a la herramienta manual.

Las ideas estéticas que conforman en sí al Art Nouveau vienen de las propuestas de dos británicos: John Ruskin y William Morris.

John Ruskin (1810-1900), poeta y tratadista, fue propulsor de los Prerrafaelitas a quienes defendió en un folleto publicado en 1851, en su afán por mantener la fidelidad del arte con la naturaleza. En 1843 apareció su obra Pintores Modernos, en cuyo contenido ya había aconsejado a los jóvenes artistas la relación entre arte y naturaleza, y en 1846 Las Siete Lámparas de la Arquitectura, obra donde preconiza nuevamente la relación íntima que debe haber entre el artista y la naturaleza para imitar a esta última. Sin embargo, la obra que más influyó en los jóvenes estudiantes de las escuelas de arte fue Las Piedras de Venecia, publicada en 1851, trabajo en el cual hace una revalorización de la arquitectura gótica, diciendo que en el arte medieval el hombre se realizaba placenteramente en el trabajo, pues la artesanía del medioevo conformaba la homogeneidad de la sociedad productora. Esto último hace pensar a Ruskin que al obrero, en su labor mecanizada, se le impide tener una relación estrecha y afectiva con su trabajo, lo cual provoca la decadencia del arte, pues el producto final es un objeto desespiritualizado. ${ }^{51}$

\footnotetext{
${ }^{51}$ Philip B. Meggs; Alston W. Purvis, Historia del diseño gráfico, Barcelona, RM VERLAG, 2009, p. 167.
} 


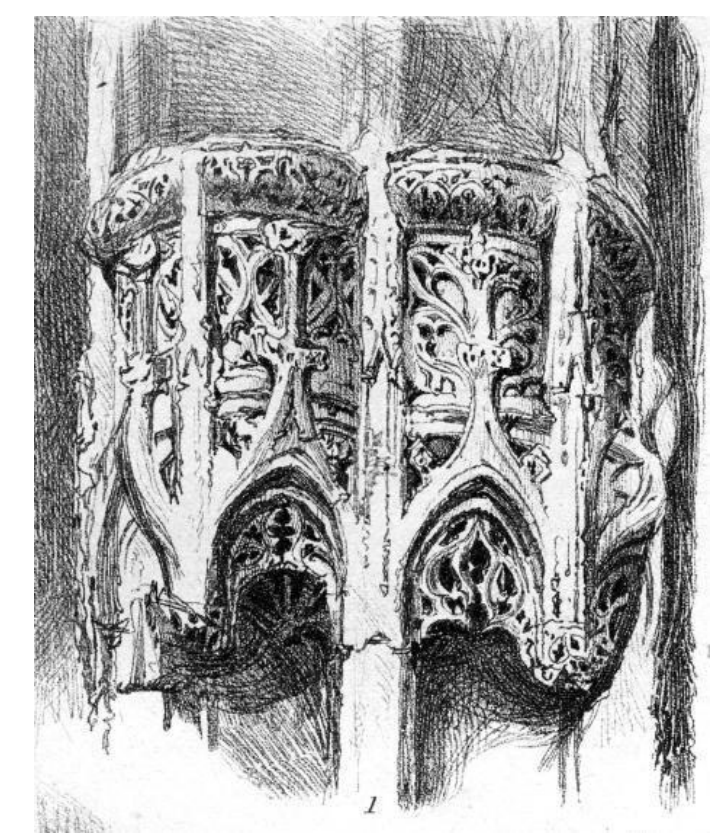

Nicho de la puerta central de la Catedral de Rouen dibujo de Ruskin para las Siete Lámparas de la Arquitectura, 1846.52

A partir de 1853, Ruskin cambia su ideología estética por una social, convirtiéndose en un defensor de los derechos del obrero y las clases sociales menos favorecidas económicamente.

William Morris (1834-1896) se formó con los prerrafaelitas Dante Gabriel Rossetti (1828-1882) y Edward Coley Burne-Jones (1833-1898), con quien después formará una sección del movimiento rafaelita en Oxford. Pintor, artesano y diseñador, Morris fue un apasionado seguidor de las enseñanzas de Ruskin, por lo tanto un revalorizador de la naturaleza y del arte de las catedrales góticas inglesas y francesas. El gótico le llamaba más la atención por la organización del trabajo de los gremios constructores del medioevo que por los monumentos en sí. Igual que su pretor Ruskin, William Morris odiaba a la máquina, pues decía que ésta hacía que el hombre se subyugara a realizar trabajos en serie, sin arte y destinados a cumplir con un gusto decadente de las nuevas clases sociales, como era la obrera; sin embargo, Morris, al igual que Ruskin, fue un enardecido defensor de los derechos sociales de los trabajadores.

Las creaciones de Morris se componían de flores y pájaros; de las primeras, la margarita, la madreselva, la tulipa, la violeta y la aguileña; de los segundos, en especial el

${ }^{52}$ George P. Landow, “Ruskin”, http://www.victorianweb.org/espanol/autores/ruskin/pm/intro.html 
pavo real. Inspirado fuertemente en la Gramática de la Ornamentación (publicada en 1856) del arquitecto Owen Jones (1809-1874), Morris se inclina por los dibujos planos, geométricos, florales que recuerdan los entrelazados celtas, los manuscritos y miniaturas medievales, así como los tejidos de esa época. Formador del gusto del público, Morris influye fuertemente con sus diseños en Inglaterra en la década de los años setenta del siglo XIX. Defensor de la unión entre arte y oficio y de las mejoras sociales de los trabajadores, Morris consolidará sus ideales con la fundación de Arts and Crafts (Artes y Oficios) en 1881, asociación que busca que los objetos utilitarios tuvieran una semántica más artística.

Hubo otras razones por las cuales Morris influyó en el gusto inglés de la época: además de sus conferencias que a partir de 1877 dictaba, la fundación en 1890 de su empresa editorial, la Kelmscott Press, difundió los diseños elaborados por él mismo para la elaboración de libros, lo cual se expandió a nivel internacional. ${ }^{53}$ Así pues, si Morris no es el fundador en sí del Art Nouveau, sí fue el progenitor de la pesquisa de encontrar una nueva alternativa estética.

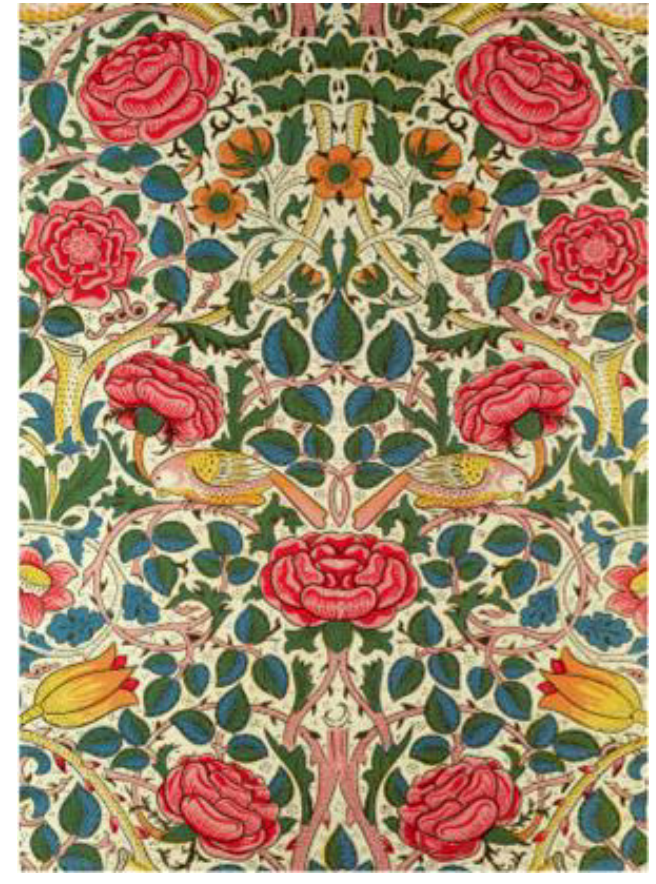

William Morris, Diseño textil rosa, $1883 .^{54}$

\footnotetext{
${ }^{53}$ Aurora Fernández Polanco, Fin de siglo: Simbolismo y Art Nouveau, Madrid, Historia 16, 1989, p. 64.

${ }^{54}$ Philip B. Meggs; Alston W. Purvis, Historia del diseño gráfico, Barcelona, RM VERLAG, 2009, p. 169.
} 
Gran Bretaña tuvo un importante protagonismo en la creación del Art Nouveau. Uno de los iniciadores fue Christopher Dresser (1834-1904), quien en su obra Art of Decorative Design (Diseño del Arte Decorativo) de 1862, enarbola las propiedades decorativas de la línea curva, cualidad propia del Art Nouveau, al decir: "Una sección del dibujo de una elipse es una curva más bella que la de un arco, ya que su origen es menos evidente, al ser trazada ésta desde dos centros". 55 Dresser visitó Japón como representante del gobierno británico en 1876, quedando impregnado de los diseños nipones que utilizará en sus trabajos en metal y vidrio.

Sin embargo, uno de los primeros diseños que se ha considerado que como tal muestra al Art Nouveau, es la portada del libro Wren's City Churches (Las Iglesias de la Ciudad de Wren) de 1883, escrito y diseñado por Arthur Heygate Mackmurdo (1851-1942). El dibujo se compone de líneas curvas que naciendo del centro de la base, se elevan en forma de zarcillos, distribuidos asimétricamente, que sostiene en móviles cartelas el título de la obra. La sinuosidad, lo serpenteante, lo inestable y lo ondulante de la línea curva del diseño de Mackmurdo, lo convierten en el sello distintivo del Art Nouveau.

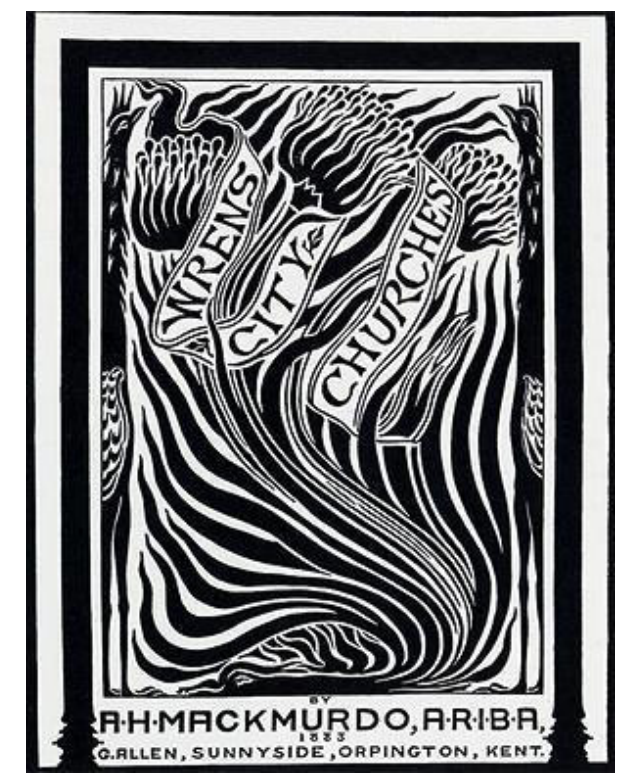

Arthur Heygate Mackmurdo, Wren's City Churches, 1883.

Victoria \& Albert Museum, Londres. 56

\footnotetext{
${ }^{55}$ Lucy Peel, Polly Powell, Alexander Garrett, Introducción a la Arquitectura del siglo XX, Barcelona, CEAC, 1990 p. 12.

${ }^{56}$ Aurora Fernández Polanco, Fin de siglo: Simbolismo y Art Nouveau, Madrid, Historia 16, 1989, p. 151.
} 
Los trabajos de los dibujantes Walter Crane y Kate Greenaway también favorecerán decisivamente en los diseños del Art Nouveau. Walter Crane (1845-1915) fue dibujante de libros para niños. Influido por los Prerrafaelitas, por John Ruskin, el arte japonés y la pintura italiana del siglo XV, cristaliza en sus dibujos una nueva manera de tratar a la línea recta para pasar a la ondulante y arqueada. De sus primeras ediciones está el abecedario Absurd A.B.C., de 1874, con figuras de animales inegradas con letras de gran tamaño. Sus trabajos que presentaba en los periódicos Justice y The Commonwealth fueron publicados en un libro bajo el título de Cartoons for the Cause (Caricaturas para la Causa) en 1896. Entre otras de sus actividades fue fundador y presidente del Art Worker's Guild (Gremio de Trabajadores del Arte). ${ }^{57}$

Kate Greenaway (1846-1901), conocida también como Catherine, se hizo famosa por sus encantadoras ilustraciones de libros para niños, que fueron aclamados por John Ruskin, además de tener una circulación internacional y que aún se siguen editando. Sus imaginarios diseños mucho influyeron en los trazos y planteamientos del Art Nouveau, utilizados en cerámica, papel y azulejos decorativos para interiores.

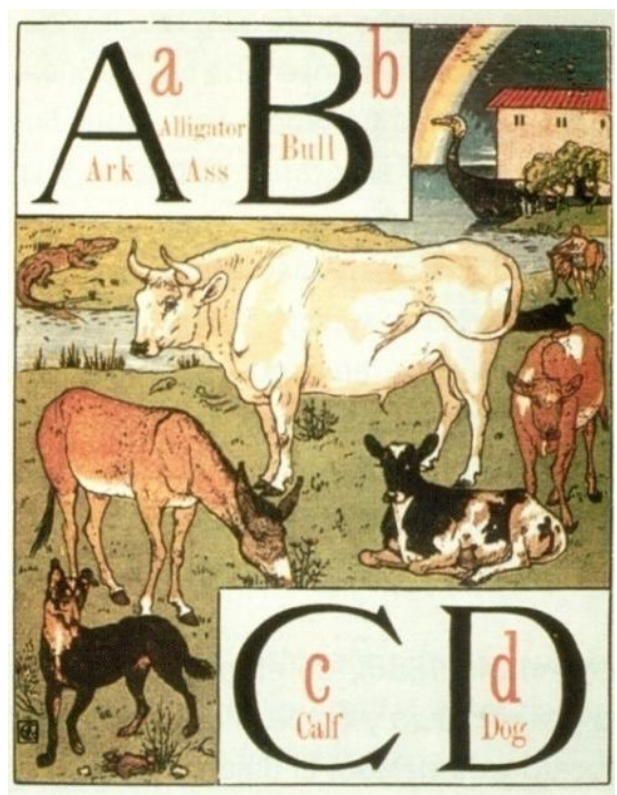

Walter Crane Absurd A.B.C., $1874 .{ }^{58}$

\footnotetext{
${ }^{57}$ Organización de constructores fundada en 1884 en Inglaterra por Walter Crane, Edward Schroeder Prior (1852-1932) y William Lethaby (1857-1931), entre otros. Este gremio sirvió como foro para difundir las propuestas del movimiento Arts and Crafts.

${ }_{58}$ Philip B. Meggs; Alston W. Purvis, Op. Cit., p. 159.
} 
El Art Nouveau, que tuvo una existencia de aproximadamente treinta años, de 1880 a 1910, tiene como característica principal la línea curva, ondulante, serpentina que junto con los motivos florales y en una distribución arrítmica, busca un encuentro íntimo entre naturaleza y el mundo social. El objeto y su ornamentación son una misma unidad orgánica, donde la forma es inestable, mutable y trasciende a lo fantástico.

El ornamento en el Art Nouveau tiene dos propiedades: "Su curso variable de la forma, del que continuamente pueden surgir nuevas transformaciones, especialmente agrupaciones mixtas de motivos abstractos e indicios objetivos, y su dinámica extendida, que rebasa los límites de la realidad, y reúne los distintos objetos en un conjunto totalizador". 59

Con una búsqueda de liberarse de los estilos históricos, el Art Nouveau lo mismo imbuyó a la arquitectura que a las artes decorativas; tanto se trabajaba una lámpara, un tocador, muebles de oficina, comedores, cocinas, recámaras, baños e inclusive textiles, como puertas, barandales o fachadas arquitectónicas. También abarcó el diseño de libros y la fotografía. Los artistas y los diseñadores trabajaban en una relación creadora, buscando así la obra de arte total.

El estilo recibió diferentes nombres en los países donde se desarrolló, además de tener sus propias directrices. En Inglaterra, país donde, en buena medida, se gestó y expandió, se le bautizó como "Modern Style"; en Bélgica, el país más industrializado a fines del siglo XIX y por lo tanto muy afín con Inglaterra, se le conoció como "Coup de Fouet" (latigazo), por la forma ondulante que se produce por un látigo en el aire. En Francia se le nombró “Art Nouveau”, por la tienda del alemán Samuel Bing, L’Art Nouveau, abierta en 1895 , donde se vendían objetos producidos bajo los cánones de dicho estilo; también se le conoció como “Style Guimard”, por Hector Guimard (1867-1942), quien diseñó las entradas del metro de París; pero fue el término de "Art Nouveau" el que más se manejó y el que ha pasado a la Historia del Arte. En Alemania, "Jugendstil”, por la revista Jugend; en Austria como "Sezessionstil", el cual trataremos en un punto aparte, por su estrecha influencia en la conformación del Art Déco. En Holanda lo denominaron "Niewe Kunst”. En Italia lo llamaron "Stile Florale” y en España "Modernismo". A Estados Unidos llegó como "Modern Style" y a México como "Art Nouveau".

\footnotetext{
${ }^{59}$ Ursula Hatje, Historia de los Estilos Artísticos, Madrid, Istmo, 1971, vol. II, p. 207.
} 
Cabe mencionar que aunque fue en Inglaterra donde se gestó y conformó el Art Nouveau, no tuvo este estilo tanta acogida, pues los británicos prefirieron seguir su propio camino con un estilo sencillo e influenciado por las propuestas de Arts and Crafts y del Domestic Revival inglés, que intentaba revivir la casa de campo, principalmente del siglo XVIII. Sin embargo, fue en Francia donde más se extendió el Art Nouveau, pues fue bien aceptado por los artistas franceses de la época y además ofrecía una alternativa en contra del academicismo de la Escuela de Bellas Artes francesa (École des Beaux-Arts). ${ }^{60}$

En la arquitectura el Art Nouveau promovía como nueva opción el ornamento dinámico, orgánico y ahistórico, que queda plasmado en el Hotel Tassel en Bruselas, edificio que se considera como el primer ejemplo de este estilo, levantada por Victor Horta (1861-1947) entre 1892-1893. En la escalera podemos apreciar el movimiento de las líneas curvas como latigazos en el aire y los afanes decorativistas florales que brotan de la columna, los cuales se prolongan hasta la techumbre, conformando una entidad orgánica.

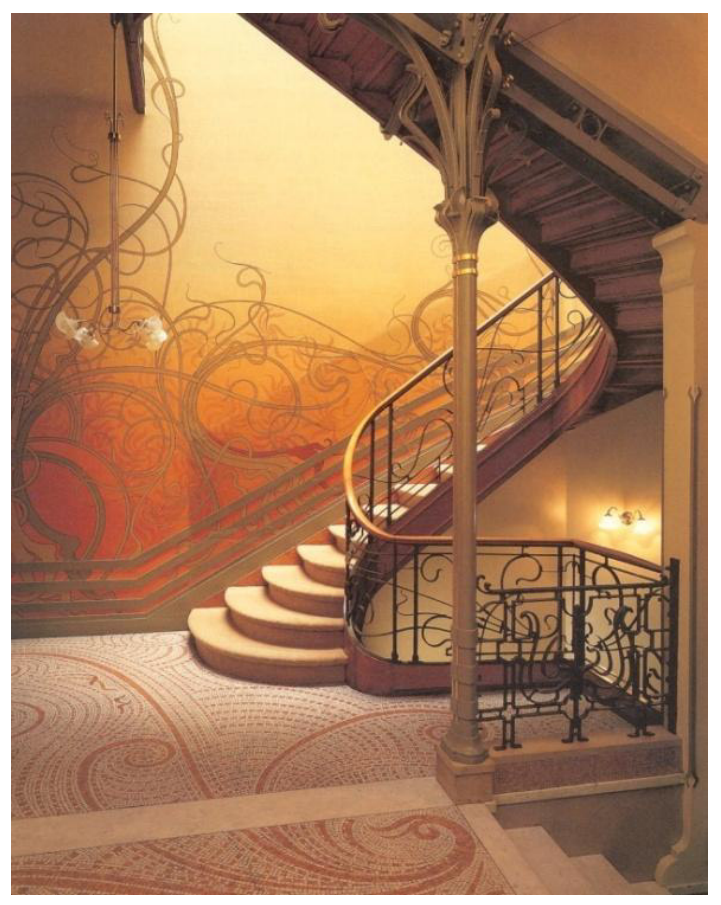

Victor Horta, escalera del Hotel Tassel, Bruselas, 1892-1893. ${ }^{61}$

\footnotetext{
${ }^{60}$ Francisco de la Maza, Del neoclásico al art nouveau y Primer viaje a Europa, México, Secretaría de Educación Publibica, 1974, p. 76.

${ }^{61}$ María Costantino, Art Nouveau, Madrid, LISBA, 1993, p. 60.
} 
Hay dos arquitectos más, que por su contribución al Art Nouveau belga son dignos de mencionarse: Hankar y Van de Velde. Paul Hankar (1859-1901) estuvo más orientado hacia lo geométrico y lineal, como lo demuestran sus casas edificadas en la calle Defacqz en Bruselas.

Henri Clemens Van de Velde (1863-1957) inicialmente trabajó con el estilo Art Nouveau en tipografía y encargos editoriales, para luego consolidarlo en la arquitectura. En 1895 construye su propia casa en Bloemenwert, Uccle, cerca de Bruselas, logrando un todo orgánico ondulante, donde los muebles, vajillas, alfombras y demás mobiliario interior, conciertan con la construcción que denota una fuerte influencia de la vivienda rural inglesa.

En el mismo año de 1895, el alemán Samuel Bing (1838-1905) marchante de arte, le encarga la decoración de cuatro habitaciones de su tienda parisina L'Art Nouveau, lugar en el cual Van de Velde expone abiertamente sus diseños naturales, florales, curvos, arrítmicos y coloristas. Deja su natal Bélgica en 1899, para trasladarse a Alemania, donde trabajará en Weimar y más tarde formará parte de la Bauhaus.

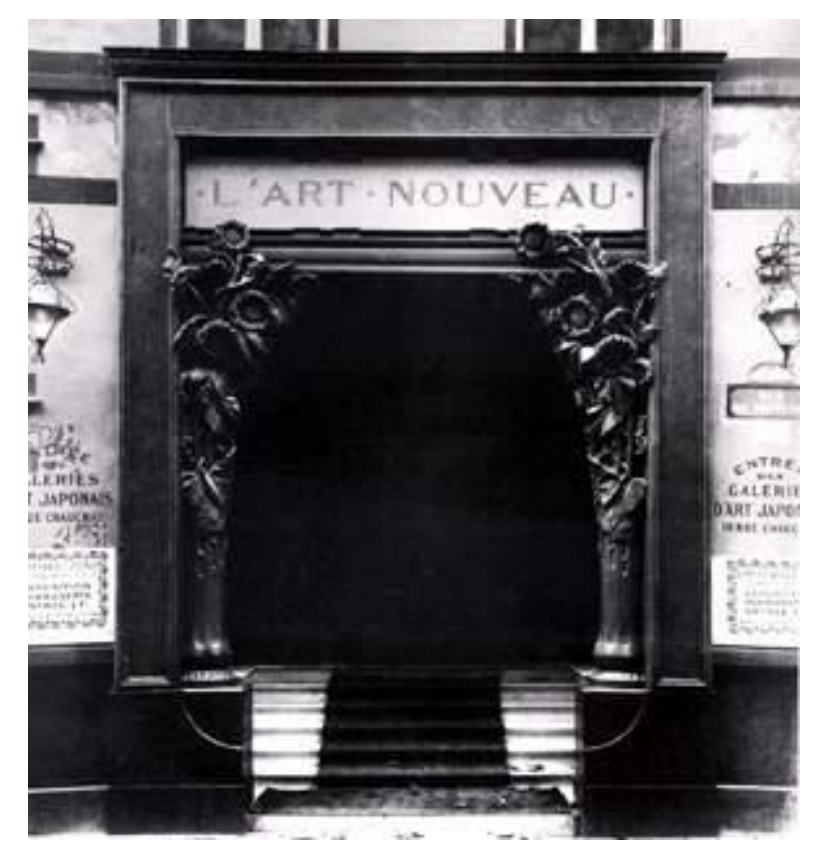

Henri Clemens Van de Velde, tienda L'Art Nouveau, París, 1895.62

62 L'ART NOUVEAU, "Boutique de Siegfried ("Samuel") Bing (1839-1905) 22, rue Chauchat Paris ouverture en décembre 1895", http://lartnouveau.com/documents/boutique_bing_art_nouveau.htm 
En Francia el máximo exponente del Art Nouveau fue Hector Guimard (1867-1942). Famoso por sus entradas al Metro de París, construyó dos obras significativas: el Castel Béranger, de 1898, donde con motivos florales y líneas sinuosas, conforma un todo orgánico que recordaba a los trabajos de Víctor Horta, y la sala de conciertos Humbert de Romans, también de 1898, pero destruida en 1905, cuya techumbre abovedada y cúpula perforada le daban un ambiente iluminado y exótico. Pero lo más conocido de Guimar son las entradas al sistema de transporte metropolitano de París, el Metro. Trabajadas en hierro forjado, pintadas en color verde, bellamente iliminadas, los barandales con líneas sinuosas sostienen medallones que representan formas florales; las farolas y los letreros parecieran enredaderas o seres fantásticos que resguardan apaciblemente las aberturas de entradas al mundo subterráneo del nuevo transporte citadino. Fascinante creación que daba -y da- a la ciudad de París un toque de distinción a su inmobiliario urbano.

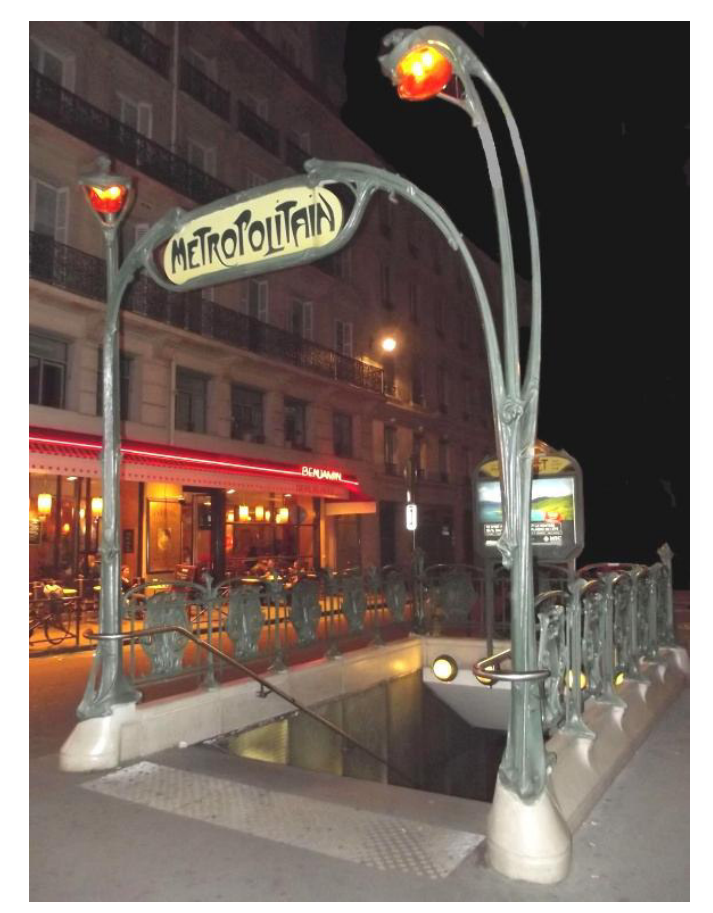

Héctor Guimard, Metro de París, estación Chatelet, 1900.

Otro ejemplo del Art Nouveau en Francia fue la École de Nancy, escuela de arquitectos que era dirigida por el vidriero Émille Gallé (1846-1904). Conocido más por sus objetos decorativos, Gallé trabajó en la Villa Majorelle, en Nancy, hacia 1898-1900, construcción diseñada por Frédéric-Henri Sauvage (1873-1932). 
Alemania tuvo como gran aportación arquitectónica al Art Nouveau el desaparecido estudio fotográfico Elvira, en Munich, levantado entre 1897-1898. Su autor, August Endell (1871-1925), decoró la portada, que se protege con una marquesina rectangular, con un diseño de tipo oriental que posee una gran fuerza expresiva en el uso de la línea serpentina, el cual asemeja un choque violento de olas con todo y la espuma del mar, que invade la superificie, salpica por arriba del vano de entrada y una ventana y que a la vez recuerdan nuevamente a la escalera del Hotel Tassel de Horta. La puerta y las ventanas con los recortes curvos en la parte superior también remiten a decorados asiáticos y sus rejerías llevan formas vegetales de líneas ondulantes, como ramas de árboles secos sacadas de la tradición medieval de los ambientes boscosos de los druidas. En el interior, la línea curva se apoderaba arrolladoramente de los espacios, consiguiendo el efecto de una elegante, así como táctil fantasía.

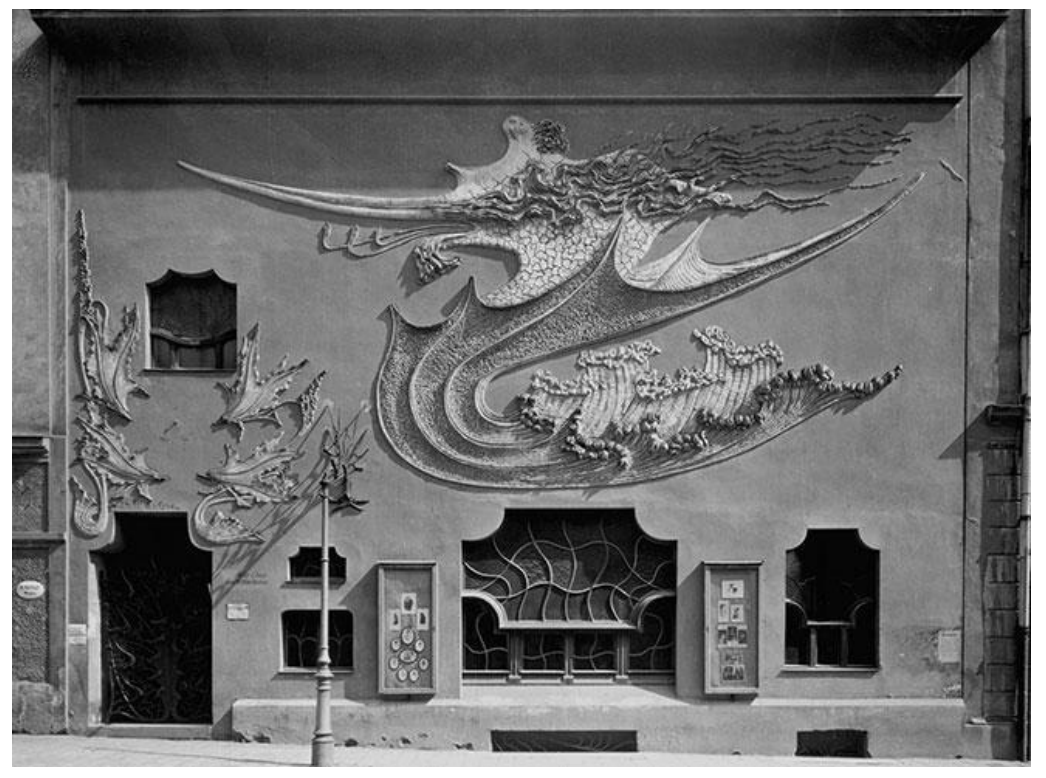

August Endel, Estudio Elvira, Munich, 1897-1898. ${ }^{63}$

Austria tiene como representante del Art Nouveau a Otto Wagner (1841-1918), aunque no toda su obra está dentro de dicho estilo. Fundador de la Wiener Schule der Architektur (Escuela Vienesa de Arquitectura) a fines del siglo XIX, con sus alumnos más destacados, Joseph-María Olbrich (1867-1908), Adolf Loos (1870-1933) y Joseph

\footnotetext{
${ }^{63}$ Gabriele Sterner, Modernismos, Barcelona, Labor, 1982, $1^{\text {a }}$., reimpresión, p. 114.
} 
Hoffmann (1870-1956), Wagner se proclama como defensor de lo moderno en la arquitectura, lo cual debe buscarse en las formas que así lo expresen.

Estas ideas las dio a conocer en su Moderne Architektur en 1895, conferencia inaugural dictada en la Akademie der Bildenden Künste (Academia de Educación Artística); es en esta época cuando en su etapa de 1894 a 1901, se apega al Racionalismo ${ }^{64}$ y al Art Nouveau. Encargado del proyecto de reestructurar el centro de Viena, construye la Karlsplatz, estación de ferrocarril levantada en 1888 y 1889. Concebida con líneas rectas y con soportes de acero, Wagner acoge elementos del Art Nouveau que se logran en la decoración floral, la cubierta curvilínea y en las ondulantes protecciones de las puertas, las cuales rematan en delicadas espirales.

Sin embargo, en Austria el Art Nouveau fue más bien conocido como el Sezessionstil, mismo que abordaremos en otro apartado, pues es ahí donde se crea como tal, la primera obra arquitectónica considerada como Art Déco.

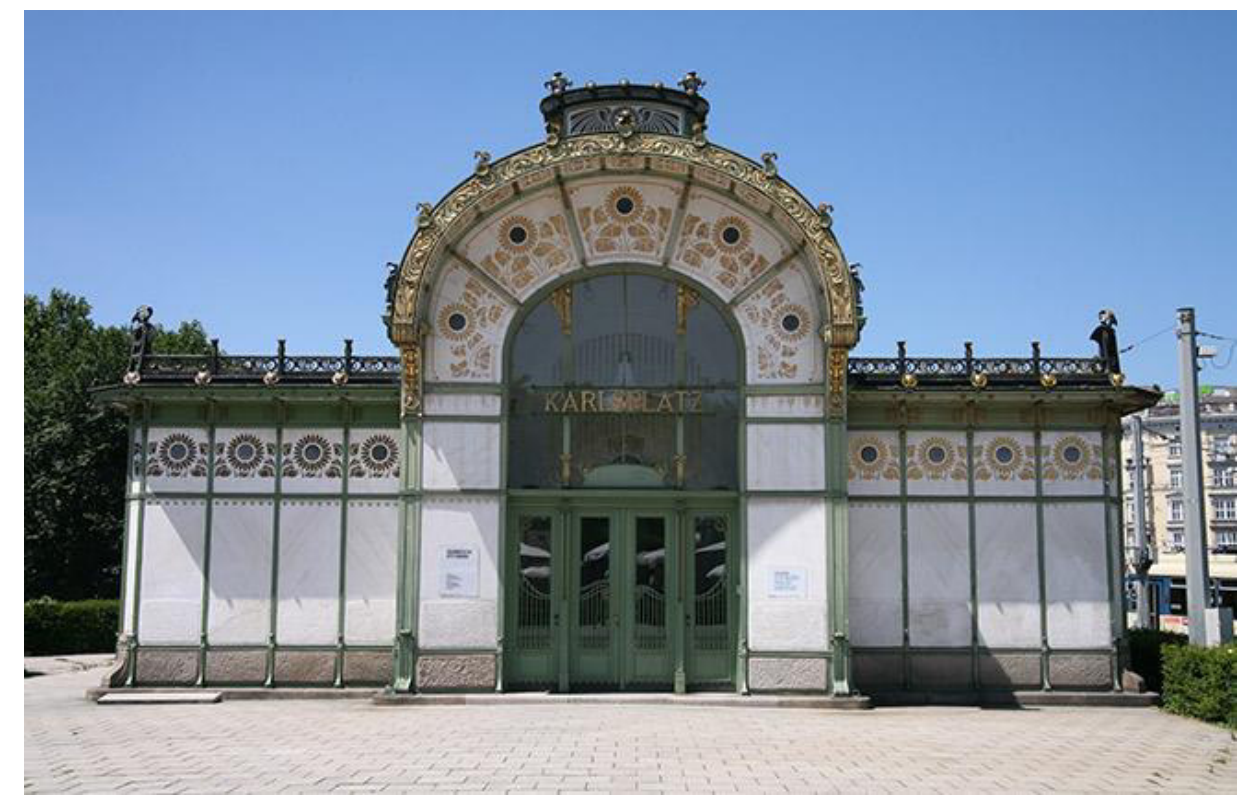

Otto Wagner, Karlsplatz , Viena, 1888-1889.65

\footnotetext{
${ }^{64} \mathrm{Al}$ referirnos que Wagner estuvo dentro del Racionalismo, no es que haya estado inmerso dentro de este movimiento, sino que él trabajó en dicha época con una idea de utilizar la razón, ser más racional para solucionar los problemas de la urbanización de Viena, con un estilo más puro, limpio, sencillo y sin una ornamentación exagerada.

65“'Otto Wagner Pavilion, Karlsplatz”, http://www.aviewoncities.com/gallery/showpicture.htm?key=kveat0358
} 
En España, es en la región de Cataluña donde destaca como máximo exponente del Art Nouveau, Antoni Gaudí i Cornet (1852-1926). Originalísimo e individualista, constituye un caso excepcional dentro de la arquitectura modernista. Concibió un arte fuera del eclecticismo y el historicismo reinante, logrando una arquitectura de fuerte concepción original, además de buscar con sus obras una identificación con la comarca catalana. "La fascinación que Gaudí despierta incluso en nuestros días se basa, con toda seguridad, en la libertad que él reclamó para sí mismo como artista y arquitecto". 66

Gaudí tuvo como principal cliente y mecenas, al señor Eusebi Güell i Bacigalupi (1846-1918), para quien construyó el Palau Güel de Barcelona, 1885-1889, la Iglesia de la Colonia Güell en Santa Coloma de Cervelló (Barcelona) en 1898 y Park Güell de Barcelona, levantando entre 1900 y 1914 con la sala de cien columnas con techos abovedados y muros decorados con trecadís, sus particulares mosaicos realizados con fragmentos cerámicos; pasillos con columnas inclinadas acabadas en piedra agreste y serpentinos bancos policromos, trabajados con la ayuda de su discípulo y colaborador, el arquitecto Josep María Jujol i Gilbert (1879-1949).

Con todo, las obras más reconocidas de Gaudí dentro del Modernismo son la Casa Batlló y la Casa Milá, ambas en Barcelona e iniciadas en 1906. La Casa Batlló fue reformada por Gaudí, convirtiendo su fachada en un conjunto de quimeras; forrada de mosaicos, su superficie ondulante y policroma, alterna con columnas óseas, ventanas bucales y balcones enmascarados mortuoriamente. La Pedrera, como es conocida la Casa Milá, fue erigida de 1906 a 1910; de planta trazada con líneas curvas y rompiendo con los ángulos y esquinas en las prominentes y enérgicas fachadas, pues son tres debido a que abarca dos calles y hace frente en el entrecruce, muestra ventanas y balcones enmarcados por sinuosas salientes sostenidas por caprichosas columnas y balcones, realizados por Jujol, que forjados en hierro, asemejan una hoja seca y marchita; la casa remata en un alabeado piñón formado de mosaicos con ventanillas distribuidas siguiendo la curvatura, el cual protege las titánicas chimeneas. Todo esto fragua una arquitectura orgánica, en cuyo interior las paredes se desbordan, rompiendo con lo plano y anguloso. Así pues, Antoni Gaudí demuestra que el Modernismo no sólo era un estilo meramente decorativo, sino también constructivo.

\footnotetext{
${ }^{66}$ Klaus-Jürgen Sembach, Modernismo, Köln, Taschen, 2007, p. 78.
} 


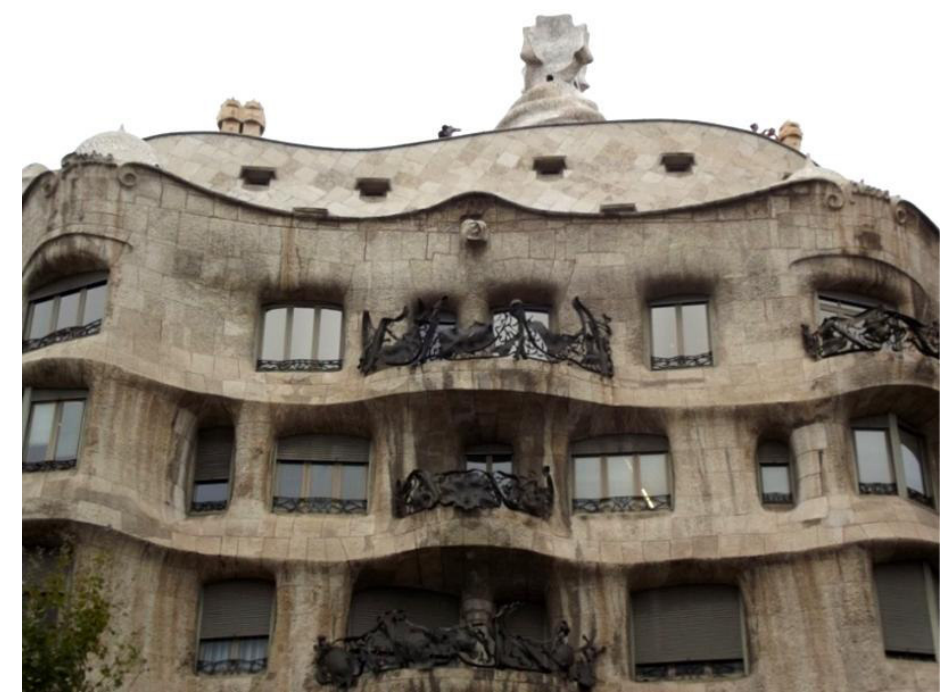

Antonio Gaudí, Casa Milá “La Pedrera”, detalle, Barcelona, 1906-1910.

El otro representante significativo del Modernismo en España es el también catalán Lluís Domenech i Montaner (1849-1923), autor del Palau de la Música Catalana, levantado entre 1905-1908. Palacio no sólo de música, sino también de cristal y de la decoración floral, presume mosaicos que cubren columnas y techumbres, así como grupos escultóricos, todos envolviendo al espectador en un escenario dinámico y ondulante. ${ }^{67}$

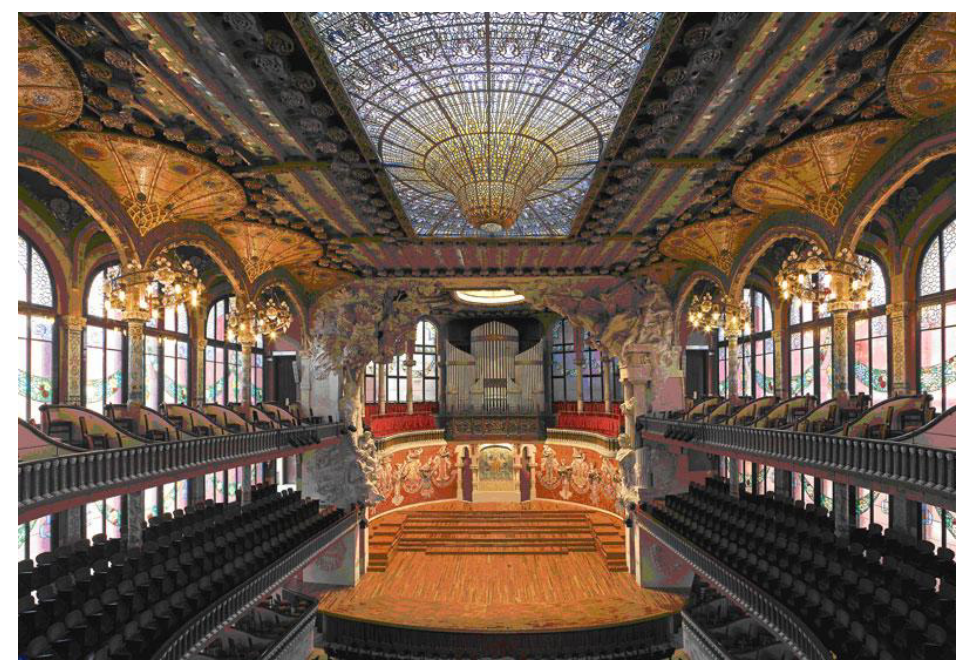

Luis Doménech, Palacio de la Música Catalana, Barcelona, 1905-1906.68

\footnotetext{
${ }^{67}$ Alexandre Cirici, "Modernismo", Historia del Arte, México, Salvat Mexicana de Ediciones, 1979, Tomo 10, p. 146.

${ }^{68}$ arquiscopio“El Palau de la Música Catalana”, http://arquiscopio.com/el-palau-de-la-musica-masarquitectura-del-momento/
} 
El caso de Inglaterra con respecto al Modern Style en la arquitectura es un tanto diferente. Sus posturas pronto se apartaron de la línea curva y ondulante y del ornamento retorcido y serpentino, para seguir la línea recta y la composición cuadrangular. Dos ejemplos son notables de mencionarse: Charles Rennie Mackintosh (1868-1928) y Charles Francis Annesley Voysey (1857-1941). Del primero hablaremos en el punto dedicado a la Escuela de Glasgow. El segundo, quien perteneció al Art Workers Guild, se hizo famoso por las casas que diseñó entre 1889 y 1910. Sus construcciones las proyectó dentro del estilo rural de las casas inglesas, pero sin incluirles elementos historicistas. Utilizó por lo general la planta cerrada o en forma de L, muros de ladrillo enlucidos, cañones de chimeneas rectangulares y pronunciados tejados. Los interiores son espacios, iluminados, funcionales y con una distribución armónica.

El ejemplo más connotado de las casas de Voysey es The Orchard, en Chorleywood, Hertfordshire, de 1899. Tendida horizontalmente, ventanas rectangulares, tejados elevados y chimeneas visibles, componen un conjunto acompasado de cuerpos poliédricos. El interior, funcionalmente distribuido, fue mesuradamente decorado por el propio Vosley. El efecto geométrico de Charles Annesley Voysey tendrá fuerte impacto en Joseph Hoffmann y Joseph-María Olbrich, miembros del Sezessionstil.

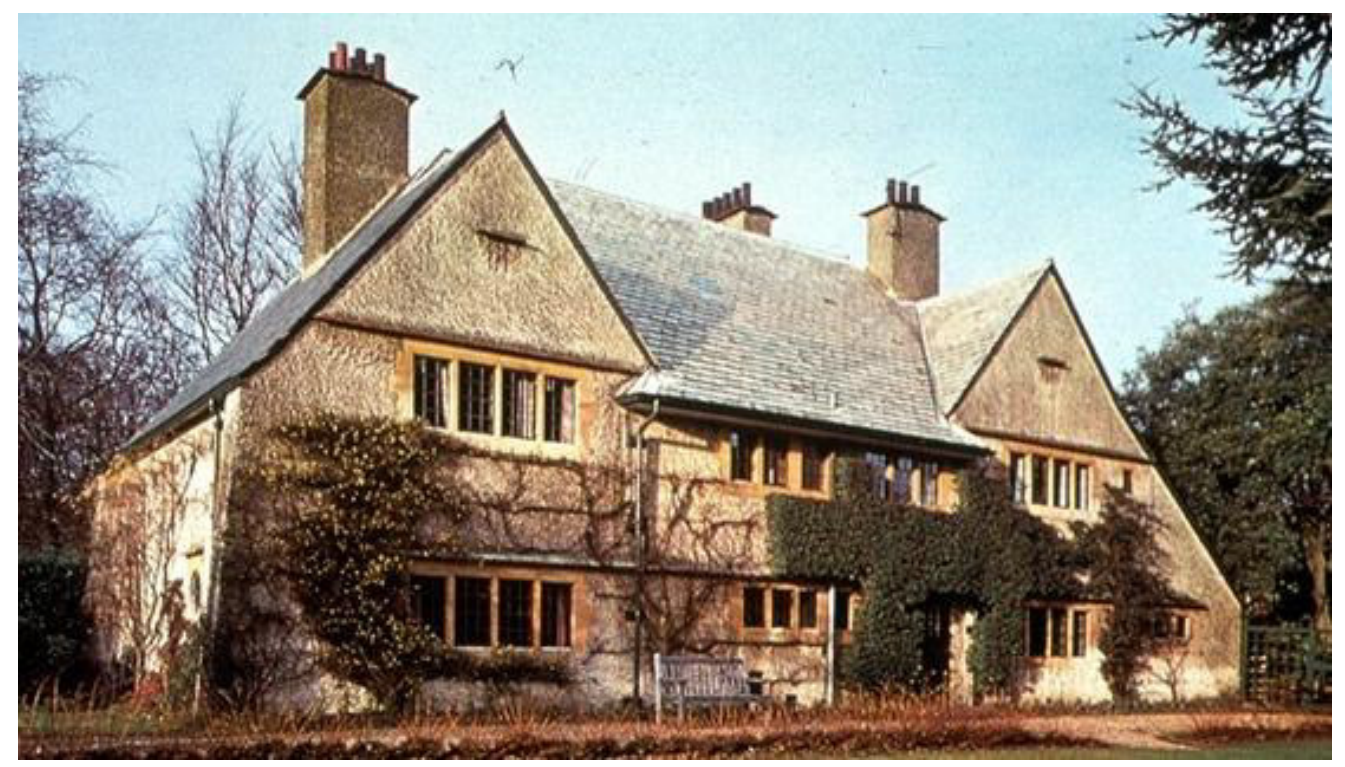

Charles Annesler Vosey, The Ochard, Chorleywood, Hertfordshire, 1899.69

\footnotetext{
${ }^{69}$ Lucy Peel, Polly Powell, Alexander Garrett, Op. Cit., p. 29.
} 
Holanda tomará una dirección más bien rectilínea que ondulante dentro del Art Nouveau. Destaca la figura de Petrus Hendrik Berlage (1856-1934). Defensor de la sinceridad de los materiales como el ladrillo, aboga por el trabajo artesanal en las construcciones. En 1897 Berlage gana un concurso convocado para levantar la Bolsa de Amsterdam, enorme edificio fuertemente influenciado por el arte románico. El exterior está trabajado en ladrillo y sin ornamento, y en el interior, una enorme bóveda es sostenida por hierro y cubierta con cristal. El trabajo de Berlage se verá encaminado hacia el movimiento De Stijl.

El Art Nouveau cruzó el Atlántico y llegó a Estados Unidos, país que se industrializaba fuertemente a finales del siglo XIX. Sus máximos exponentes fueron Louis Comfort Tiffany (1848-1933), quien se distinguió como vidriero. Incorporó a sus diseños formas islámicas, japonesas y plumas de pavo real, además de innovar la forma de producción del vidrio a la que llamó "Favrile" (del latín "faber", artesano), logrando hacer de cada pieza, una obra de arte y Louis Henry Sullivan (1856-1924) con algunas aportaciones al Art Nouveau como el Auditorium Building en Chicago, erigido en 1899 en colaboración con el ingeniero Dankmar Adler (1844-1900), con arcos de medio punto en diferentes dimensiones, acomdados dentro de una estructura cúbica.

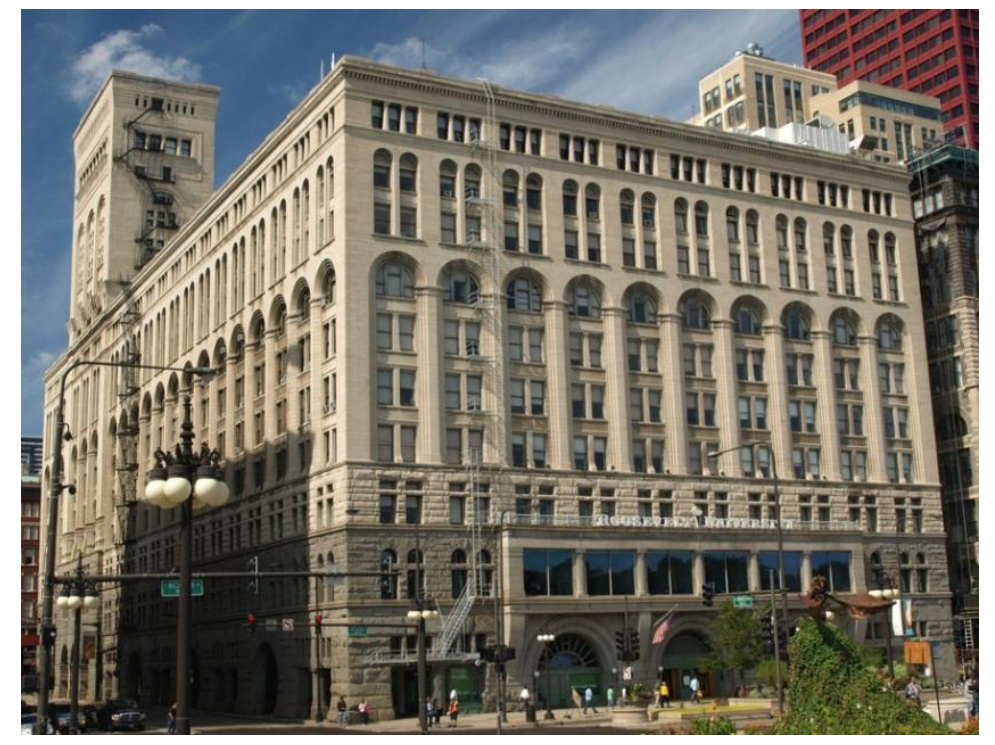

Louis Sullivan, Auditorium Building, Chicago, $1899 .{ }^{70}$

\footnotetext{
${ }^{70}$ Alargos, Arte e Historia, "La escuela de Chicago. El origen de los Rascacielos", http://algargosarte.lacoctelera.net/post/2011/06/01/la-escuela-chicago-origen-los-rascacielos
} 
A México el Art Nouveau llegó vía Francia bajo el gobierno de Porfirio Díaz (18301915), quien, además, tenía un gusto personal por todo lo francés. ${ }^{71}$ Mucho se hizo bajo los cánones del Art Nouveau, principalmente en la ciudad de México, pero poco se ha conservado.

El ejemplo más significativo es el Palacio de Bellas Artes. Originalmente concebido como el nuevo Teatro Nacional, para hacerse cargo del diseño y construcción del majestuoso edificio fue invitado el arquitecto italiano Adamo Boari (1863-1928), quien inició las obras en 1904, inspirado en el Teatro de Dresde y en la Ópera de París ${ }^{72}$. Con una intersección de un cuadrado y un rectángulo en la traza de la planta y una cúpula que coronaba el gran vestíbulo, el exterior realizado con mármol blanco de Carrara contó con los trabajos escultóricos del húngaro Géza Maróti (1874-1945), Leonardo Bistolfi (18591933) Gianetti Fiorenzo y uno más de apellido Boni.

El pórtico de entrada con columnas acomodadas en semicírculo cargan un amplio balcón en el segundo piso, donde el tímpano de una arquivolta abocinada de la puerta, resguarda a sensuales personajes desnudos: al centro una voluptuosa mujer representa a la armonía y los demás protagonistas a las pasiones de la naturaleza, es un grupo escultórico realizado por Leonardo Bistolfi que denota la influencia de Auguste Rodin (1840-1917). Los adornos ornamentales de los vanos laterales de la portada principal con motivos florales, así como máscaras y decoraciones de tipo indigenista mexica (azteca), como cabezas de caballeros águila y serpientes simbolizando al dios Quetzalcóatl, fueron obra de Gianetti Fiorenzo y el grupo en bronce con el águila nacional en la cúpula fue ejecutado por Géza Mároti. Los pórticos de las fachadas laterales en el primer piso llevan la misma composición de columnas de la fachada principal, acomodadas en forma de hemiciclo, con lo que le dan al edificio sensualidad y emotividad constructiva.

Elegancia desmedida muy a la europea, la construcción del magnánimo palacio se interrumpió por el estallido de la Revolución, para posteriormente no ser concluido hasta 1934. Sólo se terminó el exterior en 1910, ostentando un elegantísimo Art Nouveau francés,

\footnotetext{
${ }^{71}$ Para una visión de la arquitectura del Art Nouveau en México, véase: Francisco de la Maza. Op. Cit., pp. 74-106. Justino Fernández. El Arte del siglo XIX en México. México, UNAM., 1983, segunda edición, pp. 173-181.

72 Óscar Olivo, "Las Bellas artes del palacio", Artes Plásticas, Nos. 1 y 2, octubre 1984 - enero 1985, p. 25.
} 
con la combinación de un Sezessionstil vienés y un Stile Florale italinano, con formas rectilíneas, curvas, abombadas, sensuales, para culminar con su interior en un esplendoroso Art Déco.

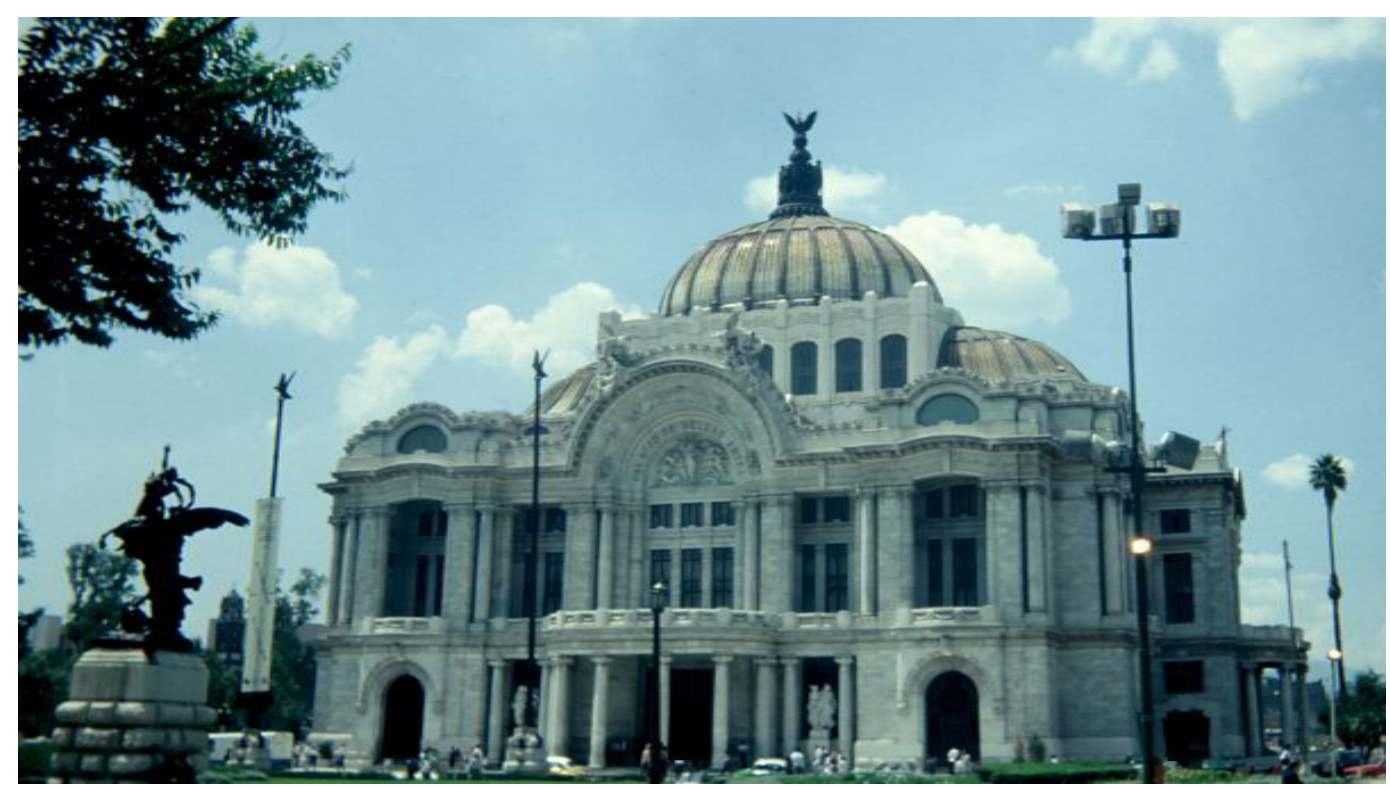

Adamo Boari, Palacio de Bellas Artes, México, D.F., 1904-1910.

En Monterrey como ejemplo de Art Nouveau se encuentra el Hotel Ancira, ubicado en el centro de la ciudad. Fue edificado con cantera entre 1909 y 1912, siguiendo el modelo de los elegantes hoteles parisinos, bajo un diseño del arquitecto francés Henrí Sauvage (1873-1932) y su socio el arquitecto Charles Sarazin (1873-1950), quienes contratados por el empresario Fernando Ancira, habían establecido una agencia de su despacho en Monterrey, la cual cerraron debido al advenimiento de la Revolución. ${ }^{73}$

Bajo un lenguaje académico en su diseño constructivo y con una decoración exterior de tipo Art Nouveau, Sauvage deja para Monterrey y México un gran ejemplar de arquitectura finisecular decimonónica, pero levantada a principios del siglo $\mathrm{XX}$, de tipo palaciego, dirigida a una elite social que se componía de la burguesía porfiriana.

De cinco niveles, con fachada en ochavo, su ornato es un conjunto de la naturaleza, de tallos con flores sustituidos por telares de un verdadero "Estilo Floral" que da galanura al edificio y distinción en su atavío. La disposición de la fachada principal es curva

\footnotetext{
${ }^{73}$ Jean-Baptiste Minnaert, Henri Sauvage oul'exercice du renouvellement, París, Norma, 2002, p. 153.
} 
convexa, hacia delante, donde se resaltan más sus elementos decorativos y ofrece una singularidad, porque lo curvo imprime el sentido de movimiento, de vitalidad naturalista, de conexión con el espectador.

La fachada remata en un encumbrado piñón que se eleva por encima del límite superior del edificio, engalanado con un gran mascarón femenino.

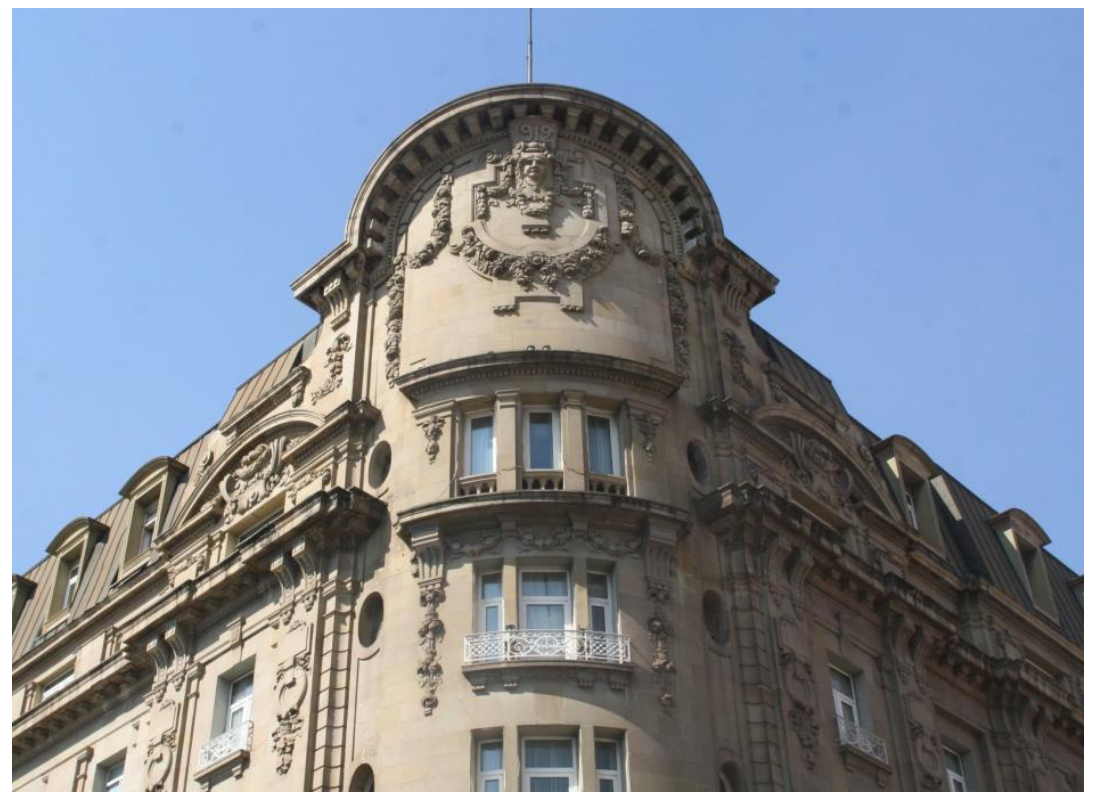

Henri Sauvage, Hotel Ancira, Monterrey, detalle, 1909-1912.

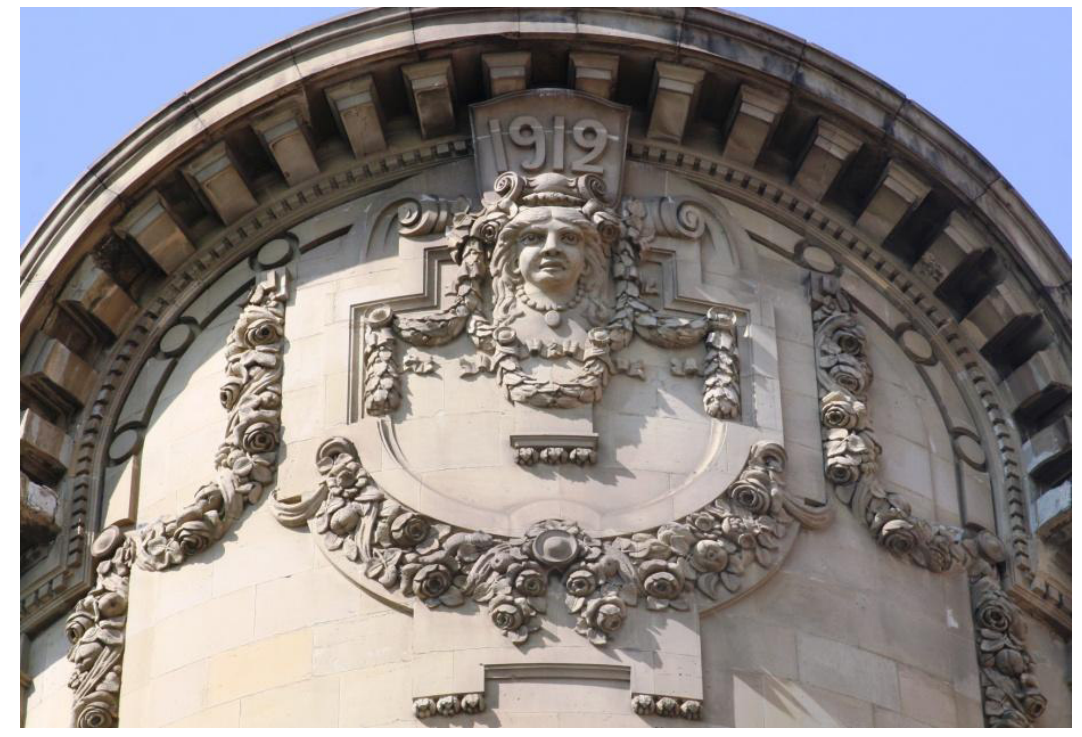

Hotel Ancira, Mascarón. 


\subsubsection{Escuela de Glasgow}

En Glasgow, Escocia, Charles Rennie Mackintosh (1868-1928), su esposa Margaret Macdonald (1864-1933) y el arquitecto James Herbert Mcnair (1868-1955), casado con Frances Macdonald (1873-1921), hermana de Margaret, formaron una comunidad de artistas-diseñadores que buscaban un nuevo estilo para las artes aplicadas, libre de las influencias Prerrafaelitas y las teorías sociales como las de Morris y Ruskin. Bajo en nombre de The Four y con Mackintosh a la cabeza, el grupo buscaba, desde 1890, alternativas decorativas en el diseño artístico dentro del Art Nouveau.

Mackintosh egresado de la Escuela de Artes y Oficios de Glasgow y máximo representante de la misma, participa en 1895 en la exposición inaugural del Art Nouveau en París. Muestra unos carteles, los cuales con estilo lineal y simbólico dan a conocer la ruta estilística de la Escuela de Glasgow. Alterna su labor como decorador de interiores y diseñador de muebles con los proyectos arquitectónicos. En el mobiliario, la línea recta y la perpendicularidad se mezclan con la limpieza formal, que combinado todo esto con colores claros como el marfil, da por resultado una sencillez innovadora. Se conocen estas propuestas en la Europa continental, cuando Mackintosh participa en la exposición de Munich de 1898 y la anual de la Secesión en 1900 celebrada en Viena. Pero "¿Tenía conciencia de lo que estaba haciendo o era tan solo un malabarista apurando sus últimos recursos?”, se pregunta Klaus-Jürgen Sembach sobre Mackintosh, del que dice que tal vez "sea el más enigmático artistas de fines de siglo". 74

Su fama arquitectónica se proyecta cuando Mackintosh gana en 1897 el concurso para construir el nuevo edificio de la School of Arts de Glasgow, edificado entre 1898 y 1909 utilizando la cantera, cuyo resultado de diseño es el conjunto de espacios abiertos y cerrados en una síntesis de geometrización. En la fachada, las formas curvas aparecen sutilmente en especial en los zócalos y rejería que limitan con la banqueta, para dejar la fuerza a las líneas rectas, a los cuadrados, a los cubos y a los poliedros, dentro de un conjunto asimétrico, pero que a la vez guarda integridad estilística en su composición. De 1907 a 1909 se añade la biblioteca, que es la asimilación de la línea recta con la funcionalidad, creando un ambiente espacial con fuerte acentuación geométrica.

\footnotetext{
${ }^{74}$ Klaus-Jürgen Sembach, Op. Cit., p. 175.
} 


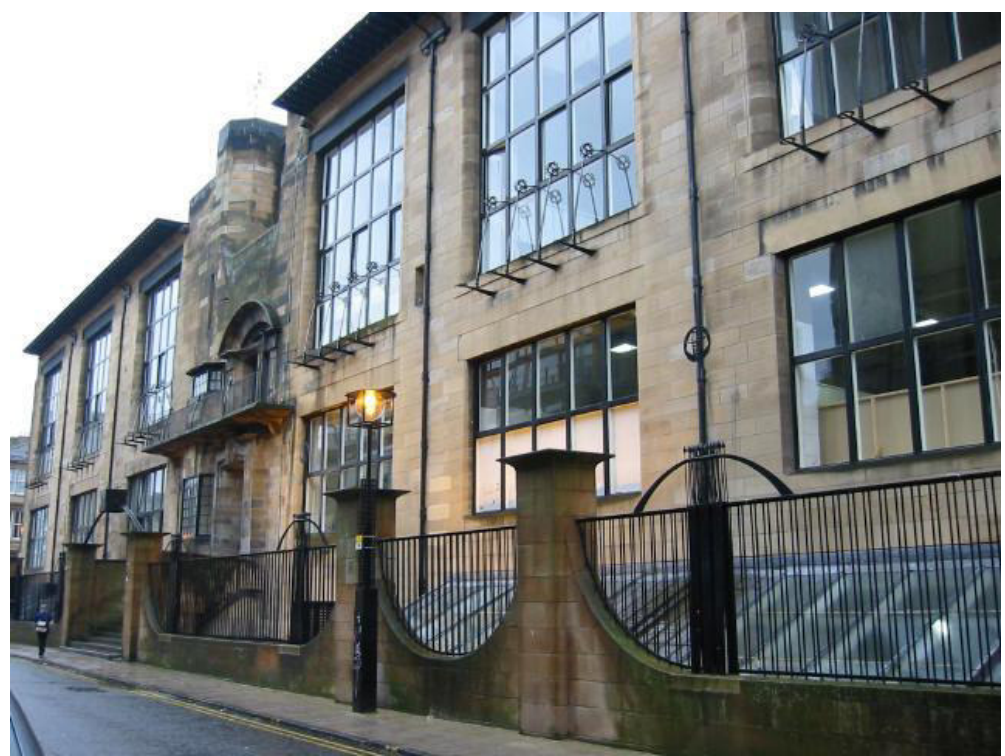

Charles Rennie Mackintosh, School of Arts, Glasgow. ${ }^{75}$

Otro ejemplo de la proyección lineal-geométrica del Art Nouveau plasmado por Mackintosh, es la puerta doble de la sala de lujo de los salones de té Willow, la Room de Luxe también en Glasgow diseñados entre 1902 y 1904, donde la sinuosidad de la línea ha cambiado para ser rectilínea, dentro de una distribución más simétrica.

En estas propuestas de geometrización de Mackintosh, encontramos un antecedente para el Art Déco. ${ }^{76}$

\subsubsection{Secesión de Viena}

Un grupo de artistas que buscaban separarse de los dictados académicos, promover exposiciones, suscitar un arte para todos, un arte nuevo que no se inspirara en ideas ya obsoletas, que estuviera en interacción con la vida y deseosos de buscar una actitud experimental en la pintura, fundan en mayo de 1897 la Secesión de Viena. Entre los iniciadores están Joseph María Olbrich (1867-1908), Gustav Klimt (1862-1918), Koloman Moser (1868-1918), Josef Hoffmann (1870-1956) y más tarde se afilió al grupo Otto

\footnotetext{
${ }^{75}$ michellegoetz, "Innovation-Art Nouveau”, http://michellegoetz.wordpress.com/2011/08/22/innovation-artnouveau/

${ }^{76}$ Xavier Esqueda, Op. Cit., p. 26.
} 
Wagner (1841-1918). Considerada como la manifestación del Art Nouveau austríaco, la Secesión de Viena buscaba más armonía entre los objetos de arte y sus ambientes interiores.

La Secesión tuvo su propia revista. La primera vez que se publicó fue en el año de 1898. Tuvo el nombre de Ver Sacrum (Primavera Sagrada) nombre que conservó hasta la última edición en 1903. En el primer número es donde se publica el manifiesto de la Secesión, escrito por el periodista y escritor austríaco Hermann Bahr (1863-1934). En una parte del manifiesto dice: “... Nosotros no peleamos por la tradición o en su contra, porque no la tenemos. No peleamos por un arte nuevo o por un arte viejo, ya que este último no existe. No peleamos por un desarrollo o por una modificación del arte, sino por el arte mismo, por el derecho a la creación artística", 77

Así como la Secesión tuvo su propia publicación, también tuvo un edificio. Levantado entre 1897-1898, fue primeramente bosquejado por Gustav Klimt, pero la construcción se debe a Joseph María Olbrich, quien ayudado por Josef Hoffman, ambos decoran el edificio con ornamentos estéticos que presentan formas vegetales y animales. En el dintel una sentencia reza:

\section{DER ZEIT IHRE KUNST \\ DER KUNST IHRE FREIHEIT}

(A cada tiempo su arte, a cada arte su libertad), indicaba las ideas redentoras de los secesionistas).

En el monumento construido con formas cúbicas y esféricas y simetría axial, rematado con una estructura esférica, perforada y decorada con laureles y resguardada por cuatro pilones, se convirtió en el símbolo de la agrupación. Digno palacio para el arte de los secesionistas vieneses.

La Vereinigung Bildender Künstler Österreichs-Sezession (Asociación de Artistas Plásticos de Austria), nombre completo de la Secesión, tenían entre sus miembros a personas que por una parte estaban atentos a las nuevas orientaciones del arte elaborado fuera de su país y por otra, abiertos a enaltecer las producciones artísticas modernas. Debido a sus ideales internacionalistas, la Secesión tuvo el fuerte apoyo del gobierno, quien le comisionó edificios y encargos gráficos como fue el caso de los sellos postales. También

\footnotetext{
77 S/A. “La Secesión de Viena”, Saber Ver, México, Fundación Cultural Televisa, No. 7, noviembrediciembre de 1992, pp. 30-31.
} 
los banqueros y empresarios apoyaron fuertemente a la Secesión, pues el movimiento iba de acuerdo con las ideas expansionistas del Imperio Austro-Húngaro.

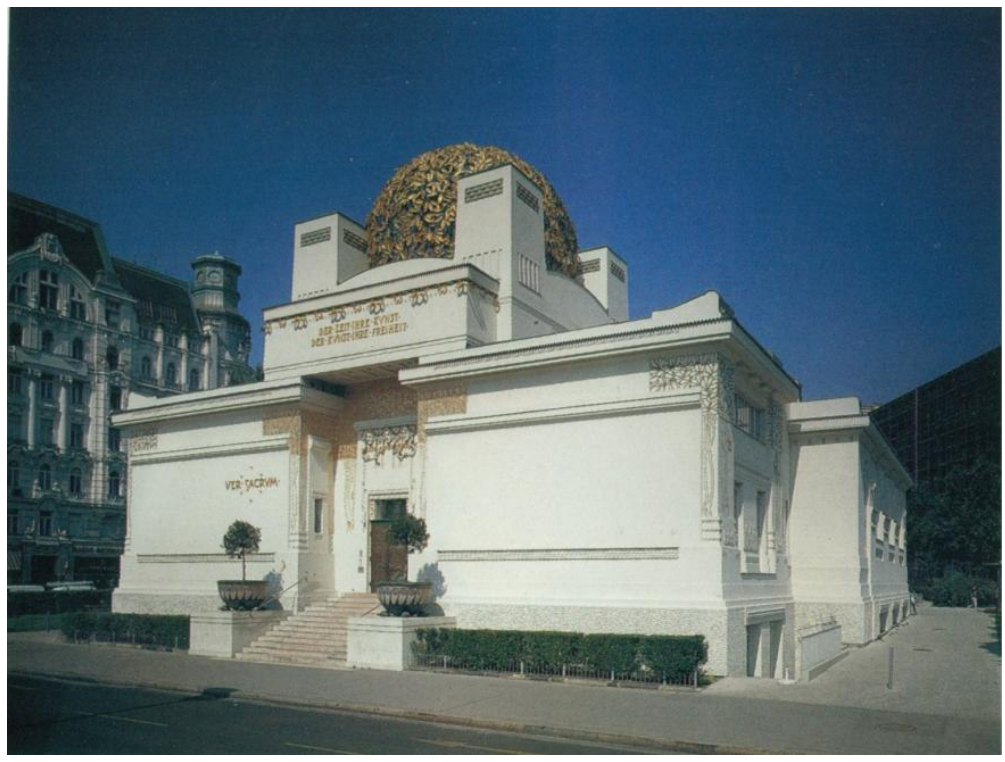

Joseph María Olbrich, Edificio de la Secesión de Viena, 1897-1898.78

De 1898 que fue la primera exposición, hasta la última en 1905, hubo veintitrés exposiciones de la Secesión, todas ellas organizadas por el pintor y decorador Carl Moll (1861-1945). En 1905 con la salida de Klimt y de otros artistas de la Secesión, provocará que ésta se desintegre paulatinamente y que varios de sus miembros se dirijan al Wiener Werkstätte (Taller Vienés) fundado por Josef Hoffmann en 1903.

La Secesión de Viena con sus avanzadas propuestas artísticas, hizo de la capital austriaca, el centro más moderno de Europa. La Secesión vienesa buscaba, al igual que el Art Nouveau, un arte que estuviera en interacción con la vida y con significación para el público en general y que su referente estético no se inspirara en el pasado.

Por lo que respecta a la arquitectura, la Secesión tuvo sus orientaciones hacia una geometrización de los elementos constructivos y decorativos. Influidos por la fuerte corrientes del Art Nouveau, el camino seguido por los secesionistas estuvo más acorde con los presupuestos estéticos de la Escuela de Glasgow de Mackintosh y las soluciones de Charles Voysey: la línea recta, el cuadrado, formas compactas, superficies lisas y

\footnotetext{
${ }^{78}$ Ibídem, p. 61.
} 
ornamentación geometrizada. Esto quedó exhibido en el ya mencionado edificio de la Secesión construido por Olbrich.

Joseph María Olbrich trabajó cinco años con Otto Wagner decorando las estaciones de la Stadtbahn (el Metro) de la capital austriaca. En 1899 es invitado a trabajar en Darmstadt, Alemania, país en donde permanecerá hasta su muerte. Su presencia en la Secesión, de la cual fue fundador, aunque fue breve dejó significativa huella, pues como dijo Benévolo que "el trabajo de Olbrich no se limitó a un número de determinados materiales y combinaciones típicas, ya que lograba una gran gama de efectos cromáticos". 79

Otto Wagner, a quien ya mencionamos en el Art Nouveau austriaco, será uno de los pilares de la Secesión, a la cual se afilia en 1899. Después de pasar por una etapa de transición y estar contagiado por modelos del Art Nouveau, su búsqueda de una nueva concepción del espacio contribuye para formar las bases de la arquitectura del siglo XX. Para Wagner "el arte debe nacer de la vida moderna... sus formas deben armonizarse con las exigencias del tiempo... lo que no es práctico no puede ser bello". ${ }^{80}$

Dos obras de Otto Wagner son importantes de considerar por su influencia en la Secesión: Primero la Majolikahaus, de 1899, cuya fachada está compuesta por un paramento con ventanas rectangulares y decoraciones florales en rojo. Segundo, la Österreichische Postsparkasse de Viena (La Caja Postal de Ahorros), de 1904 a 1906, en donde Wagner utiliza los materiales modernos. La planta es trapezoidal y el espacio interno simétrico y sin ornamentación. La fachada presenta un cuerpo delantero y dos alas laterales, que con una composición lineal, el edificio remata con dos rígidas esculturas que están acompañadas por un zócalo que desciende en forma de escalera. Finalmente, un ático de formas geométricas cierra el edificio. En el interior, el espacio se cubre con una gran techumbre en hierro y vidrio. Las columnas de la calefacción recuerdan unas columnas clásicas, donde la base, fuste y capitel son perfectamente distinguibles. Y contra lo que pareciera estar en desacuerdo, el maestro de la "Sezession" respeta el referente histórico y lo adecua a un nuevo lenguaje arquitectónico.

\footnotetext{
${ }^{79}$ Leonardo Benévolo, Historia de la Arquitectura Moderna, Barcelona, Gustavo Gili, 1982, $2^{\text {a }}$., ed, p. 332.

${ }^{80}$ Citado en: Bruno Zevi, Historia de la Arquitectura Moderna, Barcelona, Poseidón, 1980, p. 72.
} 


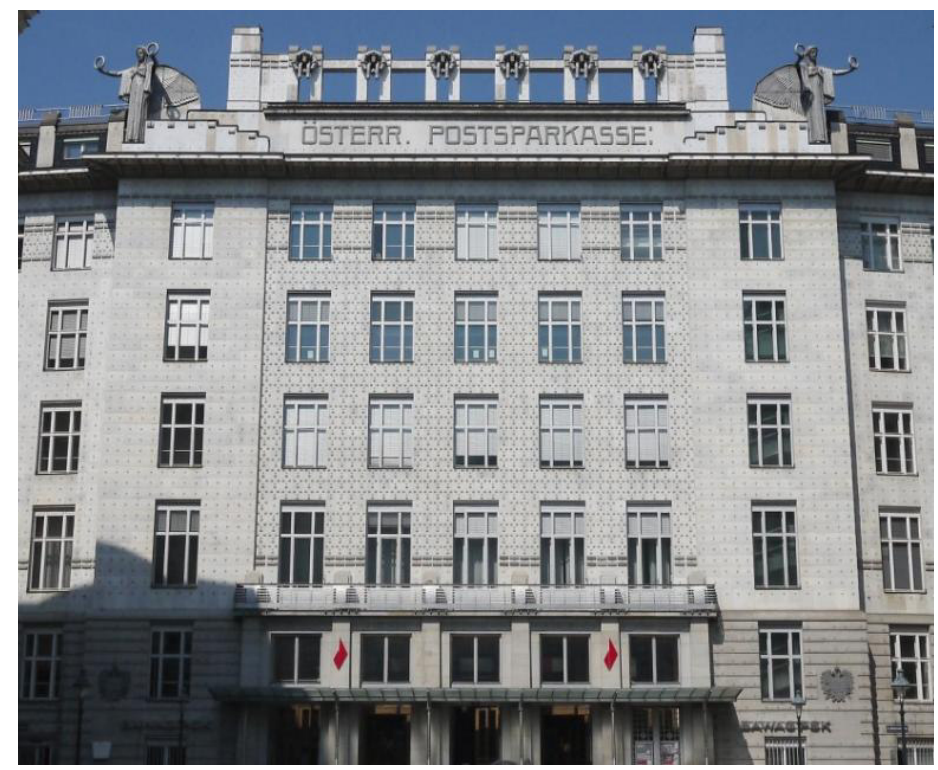

Otto Wagner, Österreichische Postsparkasse en Viena, 1904-1906. ${ }^{81}$

La importante figura pictórica de la Secesión fue Gustav Klimt, fundador y presidente de 1897 a 1899, quien junto con su hermano Ernst (1864-1892) y con Franz Matsch (1861-1942) funda el taller Maler Compagnie que se dedica a la decoración de telones para teatro.

Después de su viaje a Rávena efectuado en 1903, queda impresionado por el arte de los mosaicos bizantinos especialmente por los de San Vitale, por lo que Klimt entra en lo que se ha llamado su Etapa Dorada que dura hasta 1910, de la que destacan dos obras: Bildnis Fritza Riedler (Retrato de Fritza Riedler), 1906 y Der KuSS (El Beso), 1907-1908.

En el primero destaca la composición rectilínea de los paneles rectangulares del fondo en tonalidades oro, ocre y negro; en los dos últimos, aparecen mosaicos a la manera bizantina, de los cuales dos son de mayor tamaño y forma curvilínea y en uno de ellos la cabeza de Fritza Riedler se fusiona con los mosaicos para remitirnos a las composiciones de Diego Velázquez (1599-1660), como en el afamado retrato de La Infanta María Teresa de España de 1652-1653, que se encuentra en el Museo de Historia del Arte de Viena.

En El Beso, la pareja se viste de dorados colores para descansar en una jardínea alfombra con flores moradas, y un fondo dorado obscuro a la vez contrasta y resalta la escena central. Él lleva hojas de laurel en la cabeza, como condecorado a la usanza romana,

${ }^{81}$ Lucy Peel, Polly Powell, Alexander Garrett, Op. Cit., p. 18. 
y ella con flores de colores para resaltar su feminidad. Los dorados claros de diversas tonalidades se diferencian por las incrustaciones de rectángulos y círculos.
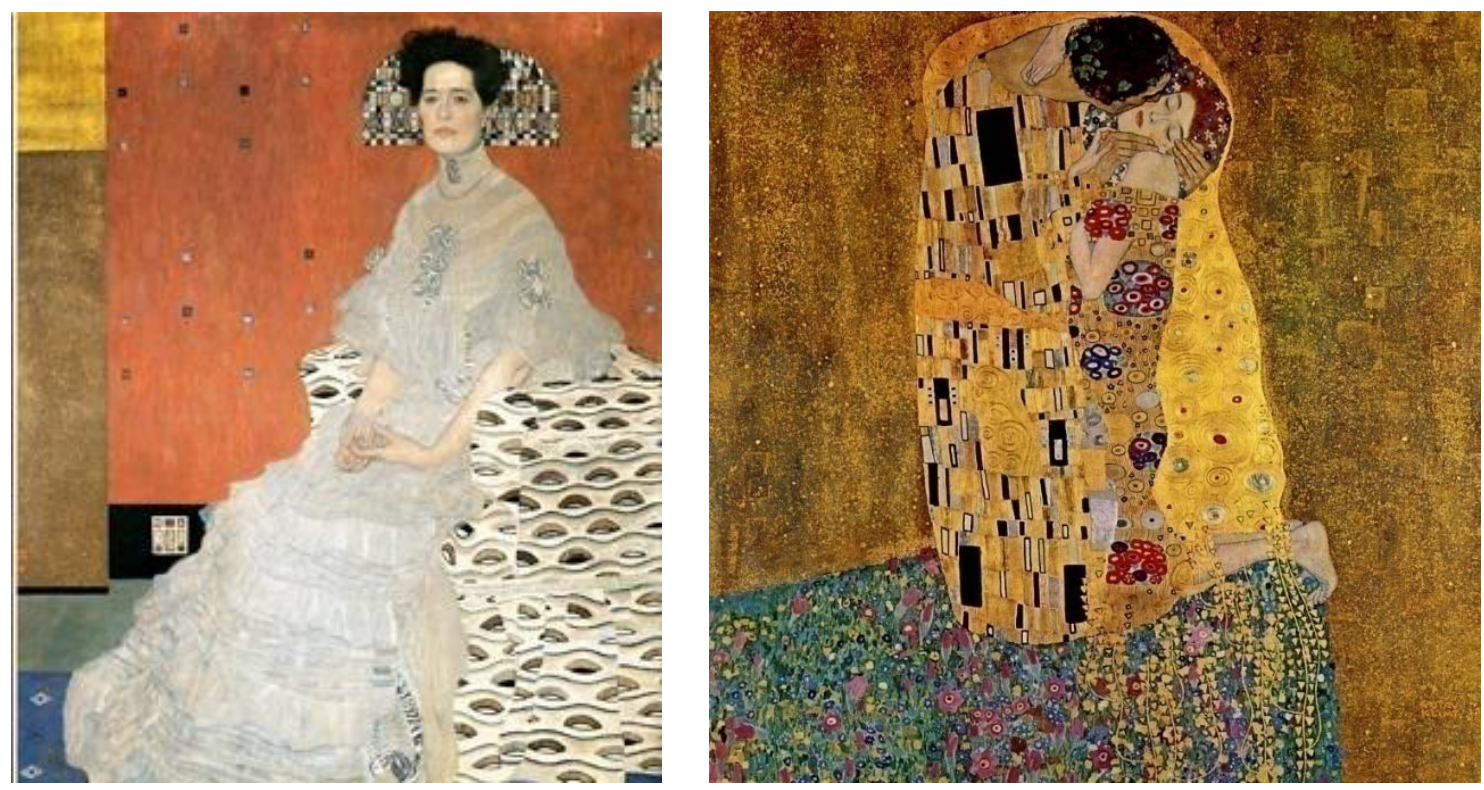

Retrato de Fritza Riedler, 1906, y El Beso 1907-1908, Österreichische Galerie, Viena. ${ }^{82}$

En 1905 Gustav Klimt rompe con la Secesión, pues su postura no encaja ni con los realistas, ni con los naturalistas del grupo. Abandonó las formas orgánicas de influencia oriental y el Art Nouveau para concebir una composición estática, ornamentada y tendiente a la inclusión de elementos geométricos. Veremos más adelante la participación de Klimt en la decoración del primer monumento arquitectónico del Art Déco: el Palais Stoclet de Hoffmann.

\section{a. Taller Vienés (Wiener Werkstätte)}

Como una derivación de la Secesión vienesa se forma en 1903 un taller que buscaba la producción de objetos únicos, dando primacía a la artesanía y a las artes ornamentales aplicadas. Sus fundadores fueron Kolo Moser (1868-1918), el arquitecto Joseph Hoffmann (1870-1956) y el empresario Fritz Wärndorfer (1868-1939). El acto tuvo lugar en el café Henrichshoft, ubicado enfrente de la ópera de Viena.

\footnotetext{
${ }^{82}$ Gilles Néret, Klimt. K, Köln, Taschen, 1993, pp. 61 y 63.
} 
El Wiener Werkstätte (Taller Vienés) recurre a los trabajos del Arts and Crafts de William Morris (1834-1928), pero con el lenguaje de Charles Rennie Mackintosh (18681928), quien había estado en Viena invitado por los secesionistas. De él, los vieneses valoraron la depuración de las formas, la reducción del volumen, para dar lugar a lo plano, además de la eliminación de la línea curva, el color y las composiciones naturalistas, en favor de la cuadrícula en blanco y negro, pues: "La geometría es uno de los instrumentos de liberación, especialmente el cuadrado". ${ }^{83}$

Los miembros del Wiener Werkstätte buscaban un arte que, además de bello y funcional, fuera accesible a todo público, aunque realmente sus productos estuvieran dirigidos a grupos elitistas. Enarbolaron el trabajo del artesano por encima de la máquina y afirmaron que había que darle la misma importancia a la artesanía, como la que se da a la pintura y escultura, con el fin de eliminar los obstáculos existentes entre arte y artesanía y así producir objetos del uso diario, funcionales, de formas geométricas, pero con lujo y elegancia artesanal, para conseguir una verdadera “obra de arte total” (Gesamtkunstwerk).

Sin un manifiesto como otros movimientos, pero sí con un Programa de Trabajo (Arbeitsprogram) dado a conocer en 1905, Joseph Hoffmann declaraba:

"Es imposible contentarse con adquirir cuadros, por magníficos que sean mientras nuestras ciudades, nuestras casas, nuestras habitaciones, nuestros armarios, nuestras herramientas, nuestros vestidos y nuestros adornos, mientras nuestra lengua y nuestros sentimientos no simbolicen de manera bella y simple el espíritu de nuestro tiempo, nos veremos relegados a una distancia infinita de nuestros antepasados y ninguna mentira podrá jamás disimular esas debilidades". 84

El Wiener Werkstätte se caracterizó por el uso de la geometría como elemento constitutivo de composiciones carentes de decoración innecesaria, con lo que el Taller consigue "un estilo en cuya discreta erudición hallaba cabida a un tiempo la más exquisita sensibilidad y las más inteligentes inquietudes, inspirándose en la rectilínea pulcritud y rítmica precisión de un Charles Rennie Mackintosh, que logra una combinación casi racional de los módulos ornamentales". ${ }^{85}$ Pero también está la posterior reivindicación de la decoración que junto con el movimiento vigilado de las curvas intercaladas con las líneas

\footnotetext{
83 Jean-Paul Bouillon, Op. Cit., p. 26.

${ }^{84}$ Ibídem, p. 28.

${ }^{85}$ Paul Maenz, Op. Cit., p. 34.
} 
rectas y el adorno de guirnaldas y festones estilizados, se sumaban, a la vez, referencias clásicas y folklóricas para conformar, como tal, otra manera de hacer objetos.

El Taller Vienés tuvo una duración desde su fundación en 1903, hasta 1932 cuando se desintegró; hubo una interrupción de un año entre 1913 y 1914. Trabajó en colaboración con la Wiener Kunstgewerbeschule (Escuela de Artes y Oficios) y con la Secesión, abarcando diversas áreas: arquitectura, joyería, trabajo en metal, artes gráficas, ebanistería. Poseyó su sala de exposición-tienda instalada en la Neustiftgasse en Viena, a partir de 1904, levantada por Josef Hoffmann (1870-1956) y decorada por Kolo Moser (1868-1918), donde las propuestas geometrizantes aparecen en todos los diseños: las puertas rectangulares con diagonales entrecruzadas, el abocinamiento de enmarques en la pared; los mosaicos del piso conjugan sus octágonos blancos con los cuadrados negros, conformando así un ritmo simétrico; y los muebles conjugan sus formas poliédricas para enaltecer en armonía el anagrama del Taller con sus dos "W" realzadas en el dintel de la puerta.

La primera exposición del Taller Vienés se llevó a cabo en Berlín en 1904, ${ }^{86}$ donde el triunfo de la geometría se visualizó en el dintel quebrado -por líneas oblicuas- de una puerta, o bien por un arco quebrado. Y la primera muestra dentro de Austria tuvo lugar en Viena en 1905, en la vanguardista galería Miethke, la cual estuvo dedicada a portadas de libros y encuadernaciones, mismos que ostentaron diseños lineales y geométricos.

En la arquitectura el Wiener Werkstätte obtuvo su máxima expresión con Joseph Hoffmann y Gustav Klimt en el Palais Stoclet. El encargo, con un suntuoso presupuesto, fue hecho a los artistas por el industrial belga del carbón, Adolphe Stoclet (1841-1949), quien vivía en Viena y deseaba levantar una mansión-palacio en Bruselas. La construcción tardó seis años, de 1905 a 1911. Concebido el palacio bajo los lineamientos del espíritu del Wiener Werkstätte, "Se trataba”, en palabras del propio Hoffmann, "de sustituir con ayuda de su arquitectura, los viejos elementos estilísticos por nuevos... y dar con la forma adecuada y la utilidad reducida a las más exactas proporciones". ${ }^{87}$

Hoffmann utiliza en la casa Stoclet una planta asimétrica, para levantar asimismo un edificio con fachada asimétrica: del lado izquierdo, un gran rectángulo alberga tres hileras de ventanales geométricas y una saliente ochavada; y del lado derecho se abre el espacio a

\footnotetext{
${ }^{86}$ Jean-Paul Bouillon, Op. Cit., p. 27.

${ }^{87}$ Joseph Hoffmann, Kultur und Architektur, 1930, en: Gillés Néret, Op. Cit., p. 55.
} 
través de un ensamblaje de planos cuadrados y rectangulares que cargan una galería abierta en forma de "L". Al centro, la triunfante torre de la escalera que a manera de zigurat remata con motivos florales y cuatro severas esculturas; al frente y en la parte baja, dos lineales relieves femeninos que sostienen una cesta de flores, se ajustan al cuadrado que las enmarca.

Hacia el jardín, la curvatura central cóncava se equilibra con los poliedros salientes de los extremos que apuntan hacia una fuente rectangular, la cual eleva al centro una columna octagonal, acompañada de otras cuatro pequeñas con la misma composición. Puntos dorados en sucesión que forman líneas de cobre, remarcan todos los contornos del edificio conformado por placas de mármol blanco.

Gustav Klimt participó en la decoración interior del Palais Stoclet, cuando se encontraba en su "Etapa Dorada", realizando nueve tablas de dos metros de alto trabajadas en mosaicos dorados y con incrustaciones de joyas semipreciosas, ambos elaborados por gente del Taller Vienés. El comedor del Palacio se alumbra con dorados paneles abstractos como la composición del Lebensbaum (Árbol de la Vida) y el Friso, así como con los paneles figurativos Die Erwartung (La Expectación) y Die Erfüllung (La Satisfacción), en el cual la pareja abrazada, consumada y fundida entre los círculos, triángulos y cuadrados de sus coloridas prendas lleva como fondo roleos dorados sobre una superficie también dorada, matizando así los planos por contraste de tonalidad.

El ambiente creado por Klimt buscaba la adecuada decoración para acompañar las colecciones de arte hindú y budista del Sr. Stoclet y su esposa Suzane Stevens.

El Palais Stoclet se convierte en el triunfo plástico del Wiener Werkstätte, fuera de Viena, pero dentro de sus lineamientos estilísticos: lo lineal y lo geométrico. Rechazando lo curvo y delicado del Art Nouveau, el Palais Stoclet vence exitoso con la línea recta, el cuadrado y el rectángulo, tanto en el plano como en el volumen, plasmándose a partir de entonces en el símbolo inicial del Art Déco. ${ }^{88}$

\footnotetext{
${ }^{88}$ Jean-Paul Bouillon, Op. Cit., p. 17.
} 


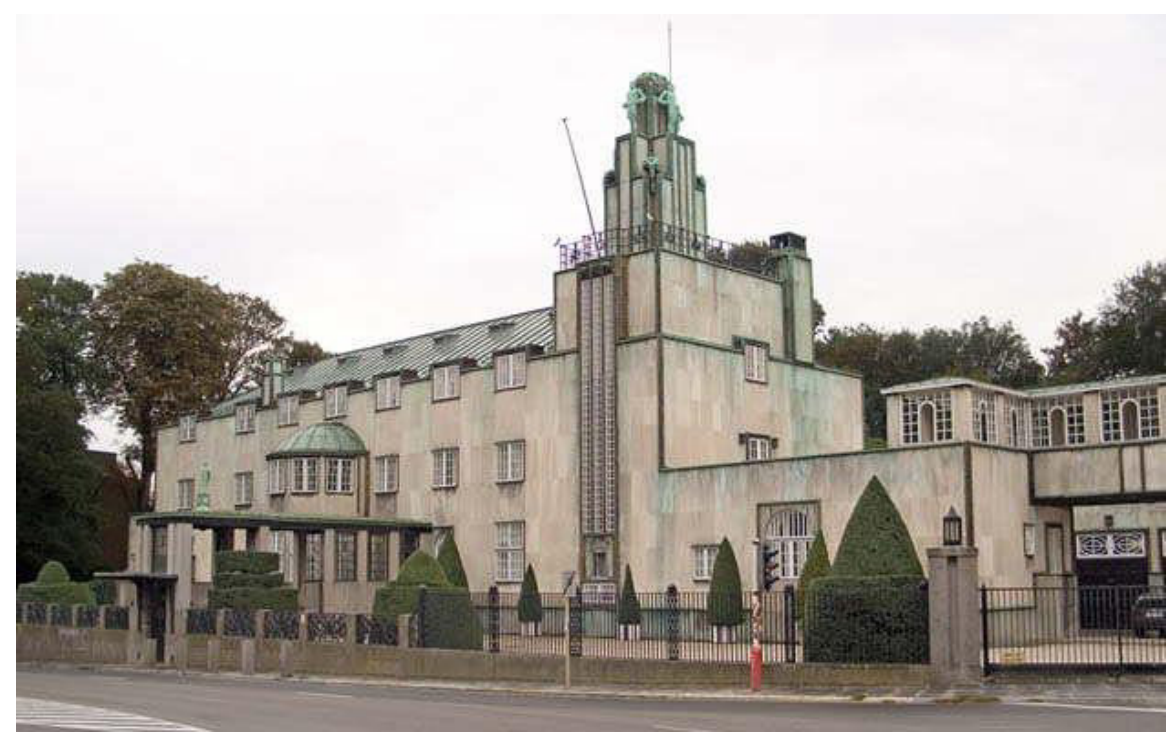

Joseph Hoffmann, Palais Stoclet, Bruselas, 1905-1911. ${ }^{89}$

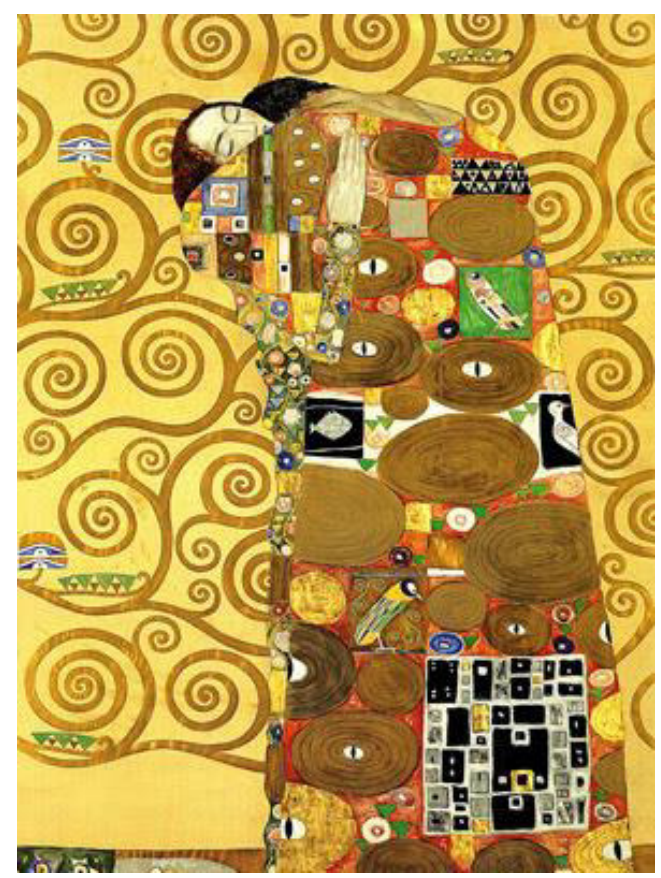

Gustav Klimt La Satisfacción de, 1905-1909, modelo para el Palais Stoclet.

Österreichisches Museum fur Angewandte Kunst, Viena ${ }^{90}$

${ }^{89}$ Lucy Peel, Polly Powell, Alexander Garrett, Op. Cit., p. 28.

${ }^{90}$ Gilles Néret, Klimt, Op. Cit. p. 56. 
Hoffmann se convertirá en el líder arquitectónico del Wiener Werkstätte, ya que además del Palais Stoclet, concebirá diversas obras, que pugnaron por la defensa de sus nuevos lineamientos estéticos: el edificio de la Kunstschau, el Fledermaus (Cabaret Murciélago), las casas Primavesi, Eduard Asto y Skywa-Primavesi y los pabellones austriacos de Roma y Colonia.

En 1905 la ruptura de la Secesión en dos grupos obliga a los "Estilistas" del “Klimt-Gruppe”, Wagner, Moser, Hoffmann y Klimt, a buscar otro espacio para la puesta de sus obras: el creador del Palais Stoclet se encargará del proyecto. Así pues, en 1908 Hoffmann levanta el pabellón de la Kunstschau para que los disidentes de la Secesión, pero integrantes del Taller Vienés, pudieran exponer sus trabajos.

En el pabellón austriaco para el Werkbund de Colonia de 1914, Hoffmann proyecta un cuerpo simétrico con pilastras nuevamente acanaladas, mismas que son la base para dos tímpanos también triangulares basados en tres plataformas escalonadas, las cuales remembrando al edificio de la Secesión de Olbrich llevan inscripciones con sentencias estéticas. Límpida construcción que pareciera inspirada en el templo de Apolo de Pompeya.

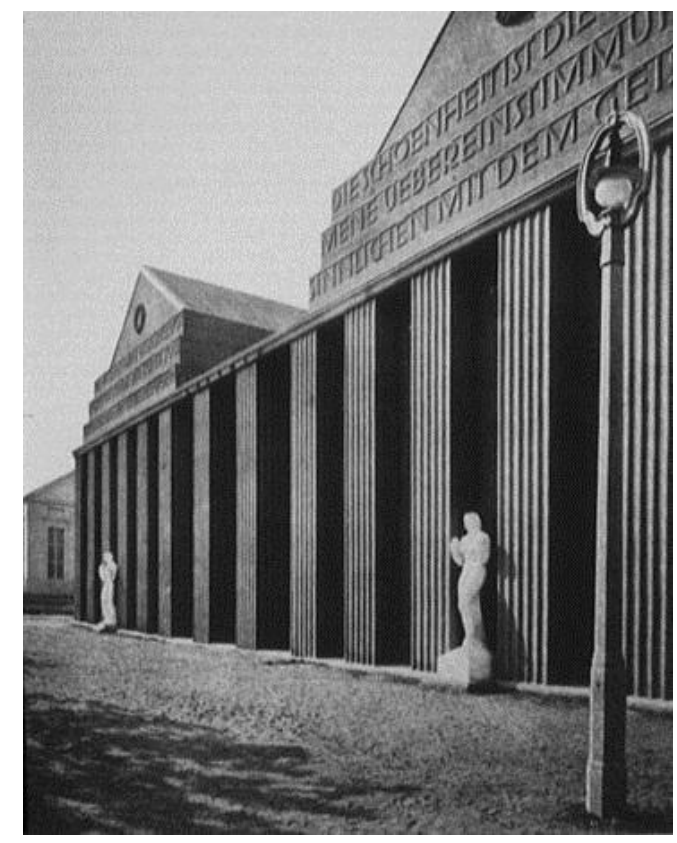

Joseph Hoffmann, Pabellón austriaco en el Werkbund de Colonia, 1914. ${ }^{91}$

\footnotetext{
${ }^{91}$ Jean-Paul Bouillon, Op. Cit, p. 39.
} 
Pero Joseph Hoffmann no sólo se dedicó a la arquitectura, sino que fiel al principio de abarcar diversos ámbitos de la vida cotidiana, diseñó enseres tanto utilitarios como decorativos. Así como en sus construcciones, dos vertientes estéticas hay en sus objetos: los que obedecen al purismo geométrico y los que aceptan, en parte, las decoraciones curvilíneas.

De los primeros están los argentarios Servicios de Té de 1904, con sus composiciones robustas y briosas, y el Escritorio en madera de roble de 1905, estilizado, sobrio y elegante, cuyas incisiones pareciera el antecedente del enmarque exterior de la escalera del Palais Stoclet. De los segundos objetos, además de sus cristalerías, están los artículos domésticos, como el Frutero en Latón, de 1924 compuesto a través de gajos unidos y con orejas serpenteantes.
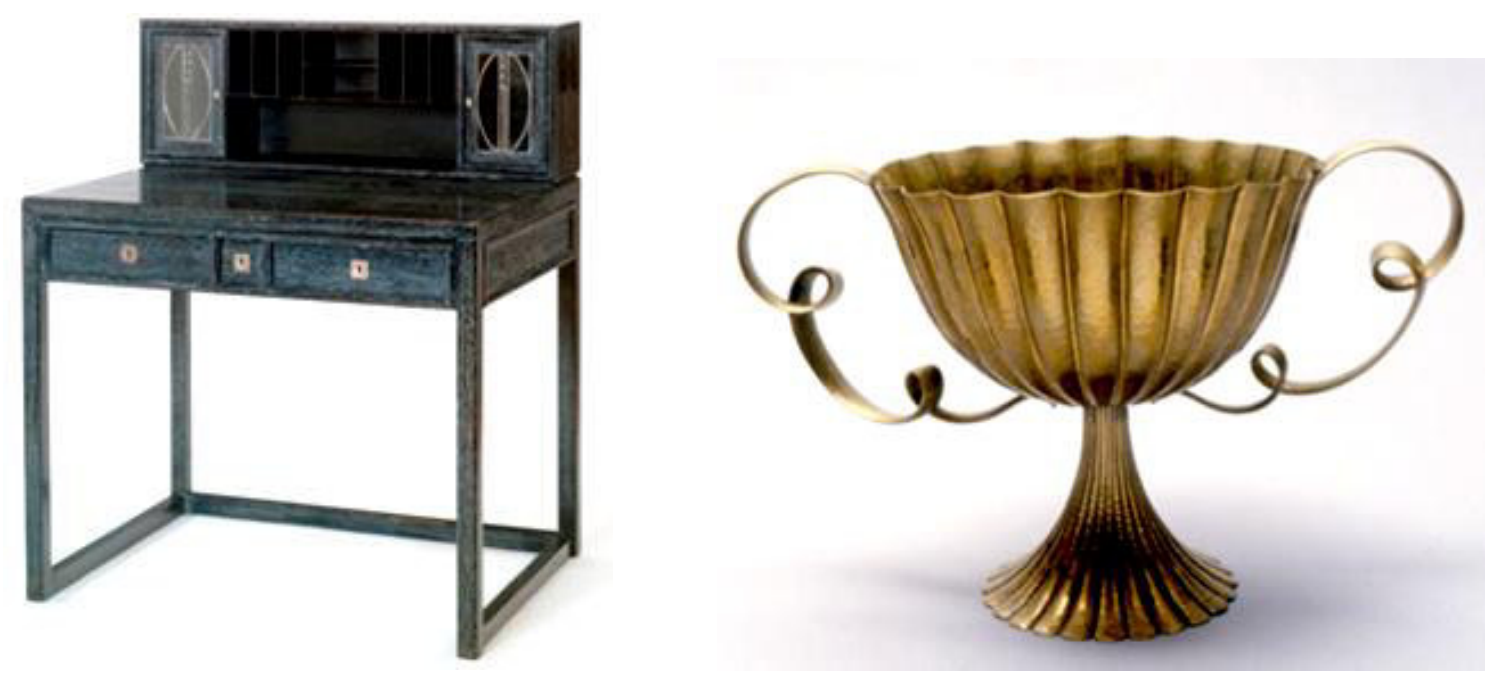

Joseph Hoffmann, Escritorio, 1905, Österreichisches Museum für Angewandte Kunst, Viena ${ }^{92}$ y Frutero en latón, $1925 .{ }^{93}$

Miembros como Kolo Moser (1868-1918), Otto Prutscher (1880-1949), Carl Otto Czeschka (1878-1960), Michael Powolny (1871-1954), Dagobert Peche (1886-1923), trabajaron ilustraciones, orfebrería, joyería, cerámica, efectos decorativos, para un público generalizado, aunque los productos se convirtieron en artículos de lujo para unas minorías.

\footnotetext{
92 Klaus-Jürgen Sembach, Op. Cit., p. 221.

${ }^{93}$ Charlotte \& Peter Fiell, Diseño del siglo XX, Köln, Taschen, 2012, p. 335.
} 


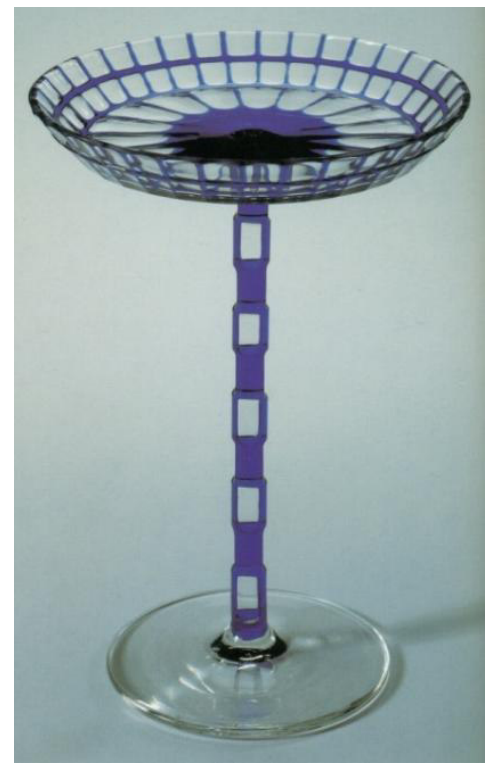

Copa de champagne, Otto Prutscher, 1907.

Colección particular. ${ }^{94}$

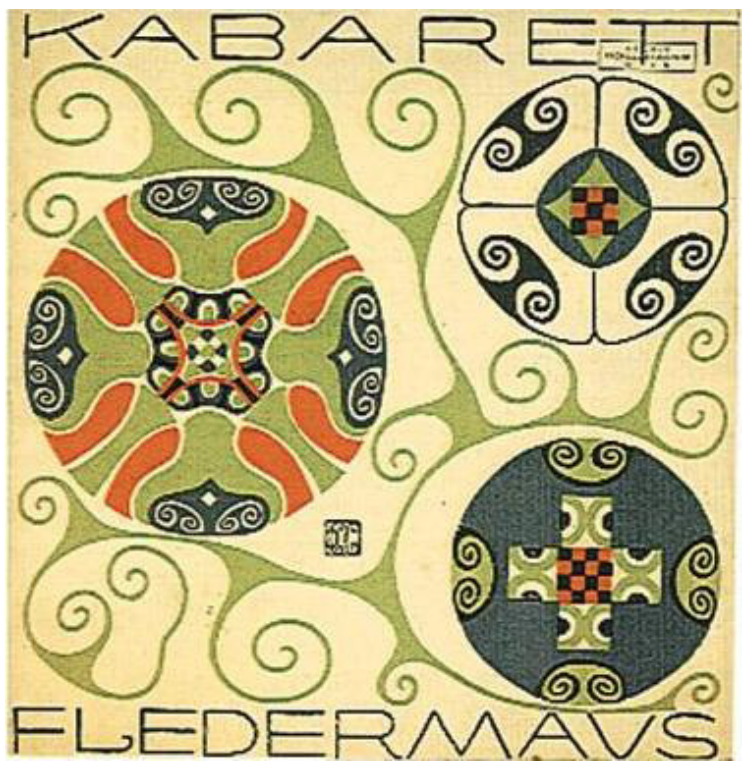

Carl Otto Czeschka, Portada del programa para el Cabaret "Fledermaus", 1907, Viena. Los Angeles County Museum of Art. ${ }^{95}$

Si el Taller Vienés no es exclusivamente Art Déco, sí se le consideran a la mayoría de sus obras como tales y son un referente visual directo de la estética del Déco, aunque hayan sido realizadas tiempo atrás a la exposición de París de 1925, por lo que se le puede tomar como uno de los más directos y principales antecedentes del Art Déco

\subsubsection{Cubismo}

"El señor Braque es un muchacho muy audaz. El ejemplo desconcertante de Picasso y de Derain lo ha envalentonado. Quizás también el estilo de Cézanne y las remembranzas del arte estático de los egipcios lo obsesionan desmesuradamente. Braque construye hombrotes metálicos y deformes que son de una simplificación terrible. Desprecia la forma, reduce todo: sitios, figuras y casas, a esquemas geométricos y a cubos. No nos burlemos de él, puesto que es de buena fe. Y esperemos". 96

\footnotetext{
${ }^{94}$ Torsten Bröhan; Thomas Berg, Avantgarde Design 1880-1930, Köln, Benedikt Taschen, 1994, p. 52.

${ }^{95}$ Klaus-Jürgen Sembach, Op. Cit., p. 225.

${ }^{96}$ S/A., “Cubismo ¿Cómo nació?”, Saber Ver, México, Fundación Cultural Televisa, septiembre-octubre 1992, No. 6, p. 39.
} 
Precisamente, esquemas geométricos y cubos. Así se expresó Vauxcelles (18701945) en el periódico Gil Blas de París, el 14 de noviembre de 1908, sobre la obra de George Braque (1882-1963) expuesta en la galería de Daniel Henri Kahnweiler (18841979). Pero con este comentario, sin querer, el crítico bautizó a uno de los movimientos más trascendentes del arte del siglo XX: el Cubismo.

Desde las propuestas de George Seurat (1859-1891) se puede hablar de los antecedentes del Cubismo. Seurat proponía que a base de yuxtaponer colores complementarios pero sin mezclarlos y de contrastar tono, color, línea, luz y sombra se lograría que el ojo humano sintetizara lo visto en el cuadro. A esta manera de pintar se le conoció como Divisionismo, en la cual el artista pintaba con pequeños puntos con el fin de lograr mayor luminosidad; además, en la composición se destacaban las formas conseguidas a través de figuras recostadas y colocadas en disposición de planos superpuestos.

Ahora bien, por sus investigaciones plásticas e influencias en ellos, los pintores cubistas mucho le debieron al maestro de Aix-en-Provence, Paul Cézanne (1839-1906). Para él un cuadro tenía vida y guardaba su autonomía sólo por la fuerza de la obra pictórica y haciendo a un lado lo anecdótico; de esta manera consiguió una renovación técnica a través de una ejecución facetada de paisajes y figuras, de planos y volúmenes, con pinceladas secas, es decir, una pintura constructiva con una principal preocupación: la colocación de los objetos en el espacio. Para esto trata de llevar los objetos hacia adelante, borrando el límite entre las cosas. Y un recurso más: lo cristalino, lo cual según el criterio de Cézanne era la manera de acercarse a las propiedades objetivas de la naturaleza.

Utiliza una técnica, el passage, la cual consiste en ir aislando pinceladas a manera de mosaicos, pero con la particularidad de que entre ellos se funden objetos, dejando espacios que permiten ver la tela; como todo está modelado por oposición de tonos fríos, la suma total de esto hace que retroceda lo pintado y el resultado obtenido es el equilibrio natural en la percepción entre lo captado por el ojo y la mente humana.

Las influencias cezannianas sobre los cubistas estarán plasmadas en dos líneas. La primera cuando Cézanne se refiere a la simplificación de las formas. Y la segunda, cuando la propuesta sobre la perspectiva que hace Cézanne permite ver al objeto desde diferentes 
puntos de vista al abrirlo en diversas facetas, alcanza así una nueva manera de ver y hacer pintura.

En 1907 se lleva a cabo en París una muestra retrospectiva de Paul Cézanne en el Salón de Otoño, exposición que dejó una buena referencia de innovación técnica en muchos artistas, en especial en dos, quienes se habían conocido ese mismo año gracias al poeta Guillaume Apollinaire (1880-1918): George Braque y Pablo Picasso (1881-1973). El primero llega a París en 1900. Durante 1907 y 1908 pasa algunos días en L'Estaque pintando marinas y algunos paisajes, telas con composiciones donde los objetos aparecen con formas geométricas. El segundo, un malagueño que después de pasar por Barcelona se establece definitivamente en París, en donde en 1905 conoce a Matisse, quien le acerca a estudiar y apreciar figuras procedentes del África negra tribal. Lo que inició como un mero pasatiempo, se convirtió en verdadera devoción. Hubo otro hecho que acercó a Picasso a la admiración por las piezas de "arte primitivo"97: la exposición en el Louvre de piezas prerromanas ibéricas. De ambas experiencias Picasso tomará la manera de construir objetos, con otra estética, con otra composición.

En el año que conoció a Braque, Picasso pintó un cuadro que dejó impresionado al artista francés: Las Señoritas de Aviñón, que representa a cinco mujeres desnudas trabajadas con composiciones angulosas y llevadas hacia el frente. La composición deshacía la perspectiva tradicional, escandalizó a muchos, tanto por el tema como por su hechura y dejó admirado a George Braque, quien se propone seguir una misma línea de invención y cambio como lo hizo en sus casas y paisajes de L'Estaque.

De esta manera, lo que más tarde se llamó Cubismo estaba naciendo como un movimiento pictórico de talla internacional que revolucionó la estética de la época. Y como dijo en el año de 1912 el crítico francés André Salmón (1881-1969) que con Las Señoritas de Aviñón -obra que él bautizó así recordando un prostíbulo de la calle de Avinyó en Barcelona- se iniciaba el arte de Vanguardia. ${ }^{98}$

Así pues, Braque y Picasso ofrecían una propuesta en la cual se rompía con la estética y perspectiva tradicional, eliminando la idea de profundidad, además de incluir la

\footnotetext{
${ }^{97}$ Con este término nos referimos a las piezas, que admiradas por los europeos, pertenecían a sociedades tribales africanas o de periodos prehistóricos. Aquí se incluyen también los objetos de culturas asiáticas y americanas previas al contacto con Occidente, o bien, de grupos étnicos poco desarrollados en su cultura material en comparación con Europa.

98 Javier Arnaldo, Las vanguardias históricas (1), Madrid, Historia 16, 1993, p. 30.
} 
técnica del facetado, es decir todavía bajo el influjo de Cézanne, y trabajar los objetos desde varios puntos de vista.

En 1908 con la ya mencionada exposición de Braque en la cual Vauxcelles bautizó al Cubismo, con las proposiciones técnicas tanto de Braque como de Picasso y con el “escandalizante" cuadro de Las Señoritas de Aviñón se inaugura el movimiento cubista que denominó la escena del arte plástico durante las décadas segunda y la tercera del siglo XX.

De 1907 a 1909, bajo la influencia cezanniana aún, Braque pinta sus paisajes de $L^{\prime} E s t a q u e$ con trazos geométricos y poco uso de colores vivos, mientras que Picasso atravesaba un "Periodo Negro" cuyo tratamiento geometrizante de las figuras, lo combinaba con la influencia de las máscaras africanas. A esta fase en la que se desenvolvieron ambos pintores se le conoce como Protocubismo o Cubismo Primitivo.

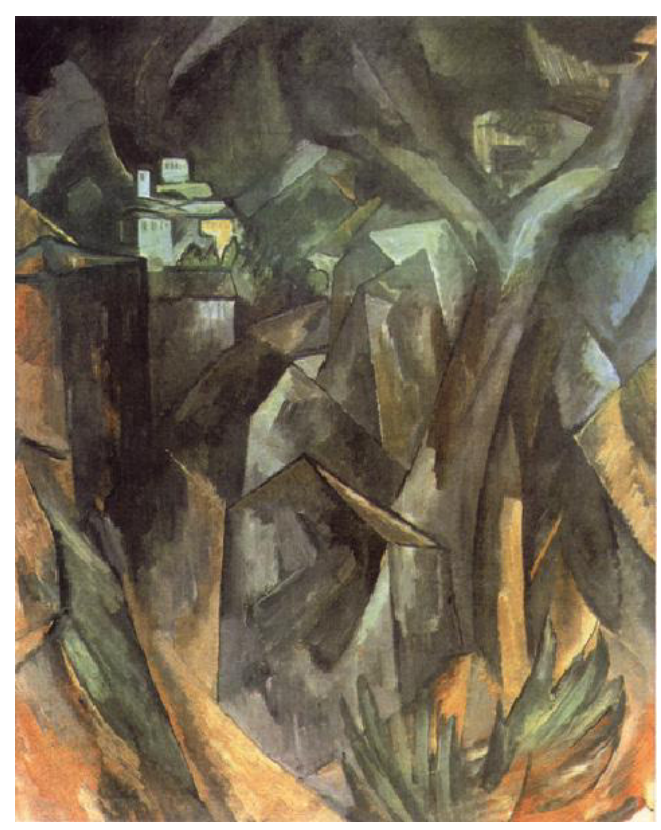

George Braque, Paisaje de L'Estaque, 1908. Kunstmuseum, Basilea. ${ }^{99}$

Los experimentos de Braque y Picasso van a desembocar en lo que se llamó Cubismo Analítico, cuya duración oscila entre los años 1909 a 1912. Si el análisis consiste en la descomposición de una unidad en sus partes, de esta manera el Cubismo Analítico dejó en un nivel inferior al tema para ser más importante la técnica, la cual consistía en

\footnotetext{
${ }^{99}$ Jean-Luc Chalumeau, Cubismo, Barcelona, Poligrafía, 1996, p. 2.
} 
tratar al cuadro en facetas de aspecto cristalino con un juego de formas fundidas entre sí; por lo tanto, planos geometrizantes independientes y superpuestos logran una representación que rompe con la perspectiva tradicional. Luego entonces, la “descomposición” en partes permite observar al tema desde varios lados y para su entendimiento se ha pasado ya por el proceso analítico.

La ausencia de colores vivos en el Cubismo Analítico es un reclamo contra los excesos cromáticos de los impresionistas y de los fauves -según los cubistas-, por lo que los ocres, marrones, grises, negros y verdes obscuros, perfilan un cubismo escueto y sabio. Y si observamos Violín y candelabro, 1910, de Braque o Paisaje de Céret , 1911, de Picasso, veremos cómo el planteamiento del Cubismo Analítico se explica más aún con las palabras de Mario De Micheli : “El cubismo analítico comienza hacia finales de 1909: los planos simples y anchos se quiebran aún más en facetas apretadas y continuas que rompen el objeto, lo desmembran en todas sus partes y, en suma, lo analizan, fijándolo a la superficie de la tela, donde el relieve queda reducido al mínimo. ${ }^{100}$

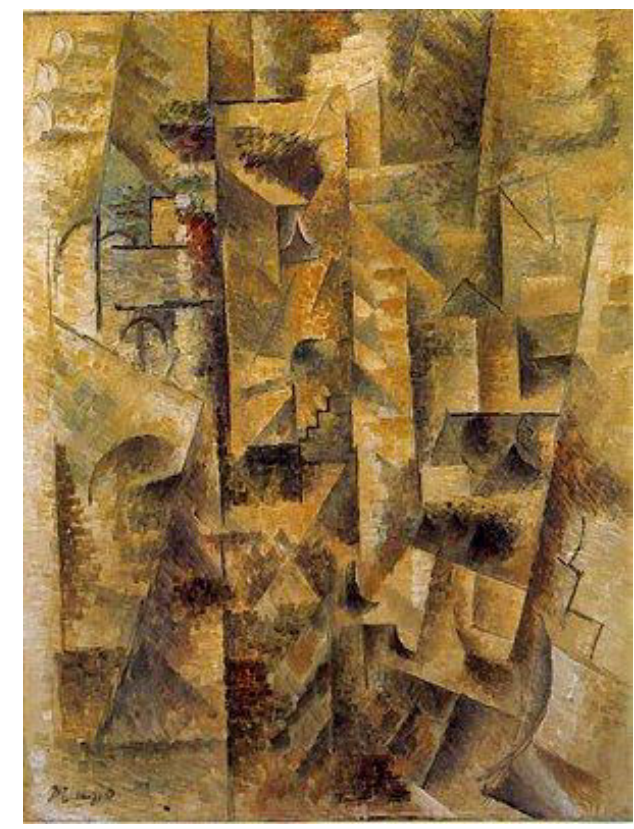

Pablo Picasso, Paisaje de Céret, 1911. Musée Picasso, París. ${ }^{101}$

\footnotetext{
${ }^{100}$ Mario de Micheli, Op. Cit., p. 210.

101 Jean-Luc Chalumeau, Op. Cit., p. 14.
} 
Cuando en 1911 Picasso y Braque empiezan a incluir letras en sus composiciones, como el ya mencionado Naturaleza muerta con botella de ron de Picasso o Naturaleza muerta con banderillas de Braque se abre la búsqueda plástica hacia encontrar significaciones de realidad, no en una mera evolución, sino en una continua indagación. Así pues, Picasso y Braque entran en lo que se ha llamado Cubismo Sintético.

Síntesis, lo contrario a Análisis, es el proceso por medio del cual un todo se compone por la reunión de sus partes. Es decir, ya no es ver en facetas al objeto, sino tomando todas o algunas partes de éste, se aprecia en una relación de sus componentes, consiguiendo una significación del objeto mismo reconstruido, pero sin imitarlo. Este proceso plástico tiene lugar a partir de una obra de Picasso titulada Naturaleza muerta con rejilla, de 1912, cuando el malagueño en una composición oval incluye un hule que pega sobre el lienzo, mismo que simula una rejilla de asiento, y le incluye sobre él las letras JOU; en lugar de un marco usual, lo substituye por una cuerda gruesa de cáñamo: el resultado, un montaje, un papier collé, un nuevo enfoque plástico que transforma por completo la historia de la pintura, pues ya no sólo son los instrumentos y la técnica tradicional de tela, colores y pincel, sino que el collage abre un camino nuevo de experimentación pictórica nunca antes utilizado.

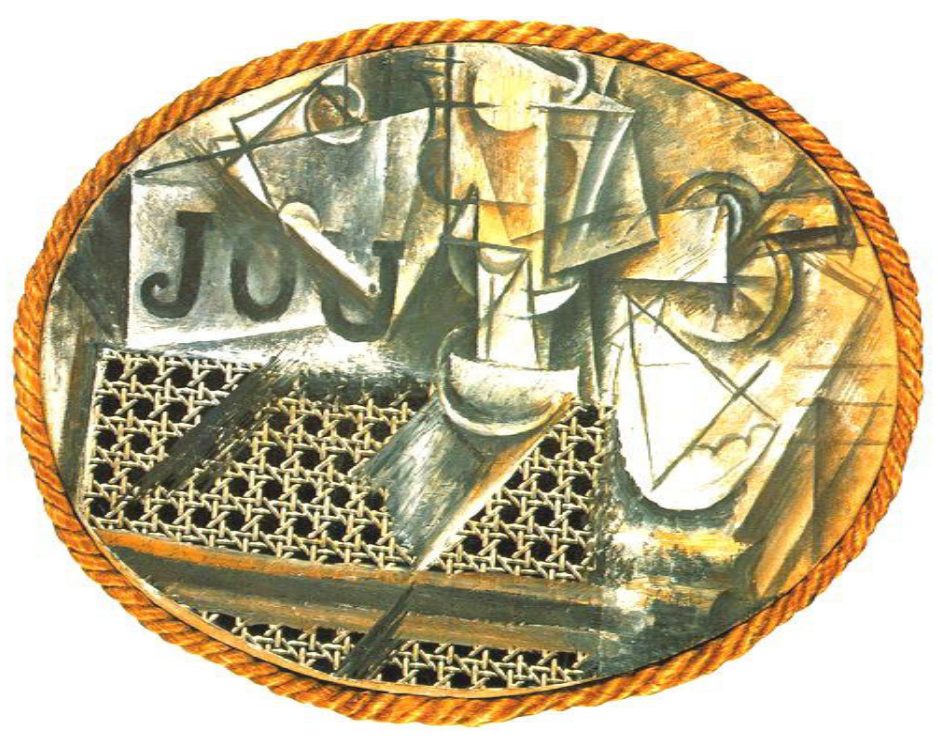

Pablo Picasso, Naturaleza muerta con rejilla, 1912. Musée Picasso, París. ${ }^{102}$

$\overline{102}$ Jean-Luc Chalumeau, Op. Cit., p. 19. 
El periodo de Cubismo Sintético oscila entre los años 1912-1914. Mientras en el Cubismo Analítico el tema se colocaba en un término inferior, en el Sintético el tema cobra un aspecto de más reconocimiento debido a los papier collé. Esto logra que las texturas se vuelvan más sensuales, ya que simulan vetas marmóreas y de maderas o porque se incluyen papeles con imitaciones de estos materiales; se alcanzan rugosidades y granulados con materiales como la arena y el serrín, además de la inclusión de pedazos de papel periódico. Y algo más. El Cubismo Sintético recobra el valor del color y la luminosidad, mas sin caer en el excesivo uso que le dieron los fauvistas.

Entre los mismos años de 1912 a 1914 Picasso experimentó con materiales como la madera, el alambre, el cartón, cuyo efecto fueron ensamblajes tridimensionales con una frontalidad que estaba de acorde con el Cubismo Sintético, porque los objetos conseguidos, como sus famosas guitarras, acusan la visión de lo escultórico geométrico junto con la materialidad sensitiva de la pieza.

En 1914 el Cubismo Sintético en Braque y Picasso llegará a su término. En junio de ese año es asesinado en Sarajevo el Archiduque Francisco José, heredero del Imperio Austro-Húngaro. Estalla la I Guerra Mundial. Francia se une a la Triple Entente y sus ciudadanos son movilizados al frente de batalla; tal es el caso de Braque y del poeta Apollinaire. La relación entre Picasso y Braque ha terminado.

Mientras Braque está en el combate, Picasso continuará con su experimentación cubista al ampliar sus planos y cambiar sus temas de bodegones por figuras humanas y a la vez lleva diferente tipo de búsquedas plásticas que más tarde desembocarán en otros lenguajes pictóricos. Podríamos decir que la continuación y finalización de su obra cubista está en Los Tres Músicos, de 1921, en sus dos versiones: una en el Museum of Modern Art en New York y la otra en The Philadelphia Museum of Art. Cuando Braque regresa a su trabajo artístico en 1917, después de recuperarse de una herida de guerra, el lenguaje utilizado por él será el mismo que había dejado en 1914. Su evolución por el Cubismo será paulatina, para luego abordar otras temáticas y modos técnicos hacia 1920.

Una figura clave del Cubismo Sintético fue el madrileño Victoriano González, conocido como Juan Gris (1887-1927). Ubicado en París en 1906, Gris se instala a un lado del taller de su compatriota Picasso y es así como conoce cercanamente la propuesta cubista. Ganándose la vida con dibujos humorísticos hasta 1910, cambia su giro por los 
bodegones y es en ese año cuando en un lenguaje cubista pinta su óleo Retrato de Pablo Picasso (Homenaje a Pablo Picasso). Al año siguiente, durante la estancia de Picasso y Braque en Céret, Francia, Gris acompaña en ese viaje a los creadores del Cubismo, donde aprende y toma la técnica cubista que será la que trabaje hasta sus últimos días.

En 1912 Gris participa en el Salón de los Independientes y en la Section d'Or, pero todavía trabajando con una pintura parca en el color y monocroma como lo era el Cubismo Analítico. Para el año siguiente, interesado por las sensaciones de las texturas, irrumpe con juegos de color, para después desembocar, a finales de 1914, en los papiers collés. En el bienio 1914-1915 Gris trabajará el Cubismo dentro de una línea doctrinal de los postulados cubistas, manejando principalmente los temas de bodegones y paisajes, mismos que pintará con mayor fecundidad después de 1916.

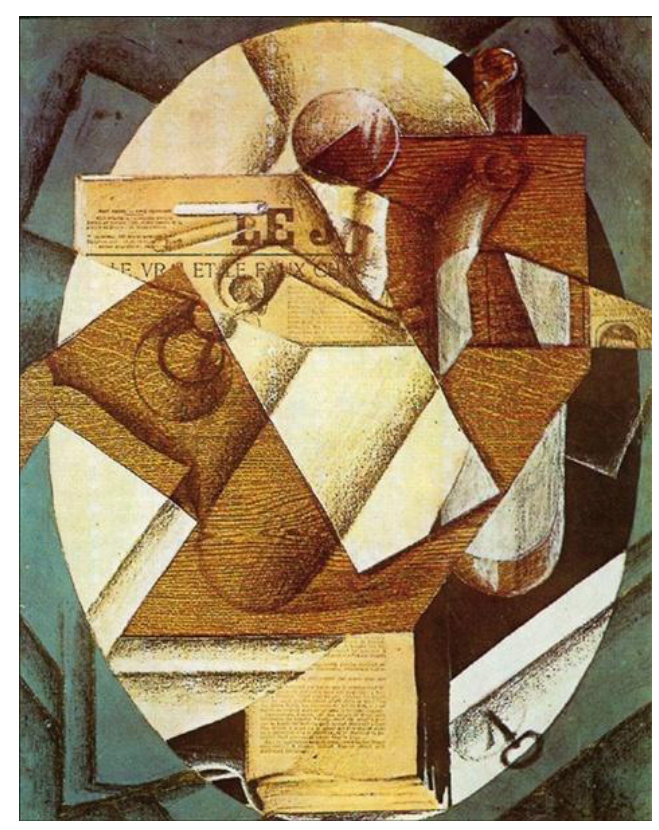

Juan Gris, La Mesa, 1914.

Philadelphia Museum of Art. 103

Los pierrots y arlequines los iniciará a partir de 1917 en adelante, y ya para 1918 Gris será amo y señor del Cubismo Sintético, con un dominio de los colores brillantes y composiciones planas, además de utilizar un método que él mismo clasificó de deductivo,

${ }^{103}$ Guy Habasque, “Cubismo”. Historia del Arte. México, Salvat Mexicana de Ediciones, 1979, Tomo 11, p. 29. 
de lo general a lo particular, que se puede interpretar con las siguientes palabras del propio artista: "Cézanne de una botella hace un cilindro, yo parto del cilindro para crear un individuo de un tipo especial; de un cilindro yo hago una botella. (L'Esprit Nouveau, París, No. 5, febrero 1921)",. 104

La severidad constructiva plástica de Gris, así como su pudorosa expresión fueron factores fundamentales para los arquitectos Charles-Edouard Jeanneret (1887-1965), mejor conocido como Le Corbusier, y Amédée Ozenfant (1886-1966), quienes en su revista L'Esprit Nouveau estarán en contra de la ornamentación y proclamarán un purismo geométrico vinculado a la producción industrial moderna de los años veinte.

\section{a. Cubismos Órfico y la Section d'Or}

El término de Cubismo Órfico fue propuesto por Apollinaire para los trabajos de Robert Delaunay (1885-1941) y para otros tres pintores que estuvieron en la línea de Delaunay, Francis Picabia (1879-1953), Fernand Léger (1881-1955) y Marcel Duchamp (1887-1968), aunque ni el mismo Apollinaire, parece ser, supo exactamente qué quiso decir con dicho nombre. Lo que sí es identificable como Cubismo Órfico es la obra del propio Robert Delaunay y de su esposa Sonia Delaunay-Terk (1885-1979).

Delaunay fue un pintor que iniciado en el lenguaje fauve acogerá el Cubismo Sintético, recurriendo a la yuxtaposición de imágenes simultáneas, aparte de darle a las formas una diáfana visión. Persuadido de la herencia clásica de la línea, paulainamente la irá desvaneciendo, para terminar rompiéndola por completo, commo sucederá más adelante en en uno de sus periodos. Después de pasar por una etapa en la cual pintó varias veces la Iglesia de Saint Séverin en 1910, entre los años 1911 y 1912 trabajó series con los temas de La ciudad, La Torre Eiffel, Las ventanas simultáneas, Las torres de Laon, en las cuales, precisamente, la simultaneidad de los colores logran a su vez independencia sobre la retina. Las diversas tonalidades de los colores será una de las constantes en toda su obra y una diferencia con los otros tipos de Cubismos. El mismo Delaunay nombró a su propuesta Simultaneísmo.

\footnotetext{
${ }^{104}$ Juan Gris en Michel Laclotte, Diccionario Larousse de la Pintura, Barcelona, Planeta de Agostini, 1987, vol. II, p. 865 .
} 
Una de las series más significativas de Delaunay es la de La Torre Eiffel, en la cual podemos apreciar su Cubismo Órfico, donde la torre se desbarata en medio de edificios y geométricas composiciones cristalinas, con lo cual consigue un efecto de dinamismo, sumado a la fuerza del color. A esta época el propio pintor le llamó "Periodo Destructivo".

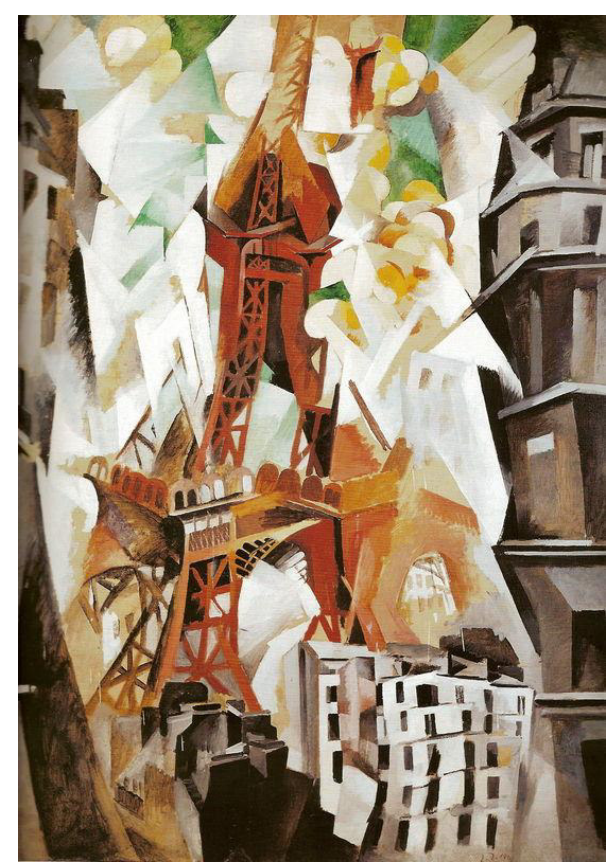

Robert Delaunay, La torre Eiffel roja, 1911. The Art Institute of Chicago. 105

En el otoño de 1912, en la galería La Boëtie de París, un grupo de pintores comandados por los hermanos Jacques Villon (Gastón Duchamp, 1875-1963), Raymond Duchamp-Villon (1876-1918) y Marcel Duchamp (1887-1968) presentaron una ambiciosa exposición titulada La Section d'Or, en la que participaron artistas quienes se alineaban en la tendencia cubista, aunque claro está, ni Picasso ni Braque colaboraron en esta muestra.

El nombre de Section d'Or fue utilizado ya que algunos de los militantes tenían intereses en la relación matemática entre el Cubismo y la pintura, mas hay que mencionar que una de las contribuciones de este apartado del Cubismo fue el cinetismo que impregnaron a sus obras Marcel y Gastón Duchamp.

Marcel Duchamp, especialmente, contrapunteó con las ideas originales del Cubismo, para formar después parte del Dadá -pero no del todo- y luego orientar su carrera

\footnotetext{
${ }^{105}$ Francesc Vicens, Arte Abstracto Arte Figurativo, Barcelona, Salvat, 1979, p. 6.
} 
a la especulación teórica, dejando de lado la pintura. Sin embargo, Duchamp dentro de la Section d'Or trabajó influenciado por la cromofotografía, consiguiendo, como lo hicieran también los futuristas, una pintura cinética cuyo movimiento lo logra con la técnica de la angulación abundante y los esquemas múltiples; tal es el caso de las tres versiones de Desnudo bajando una escalera, 1912, en donde el viraje hacia la vanguardia futurista y del complejo camino del arte moderno está dado en Duchamp.

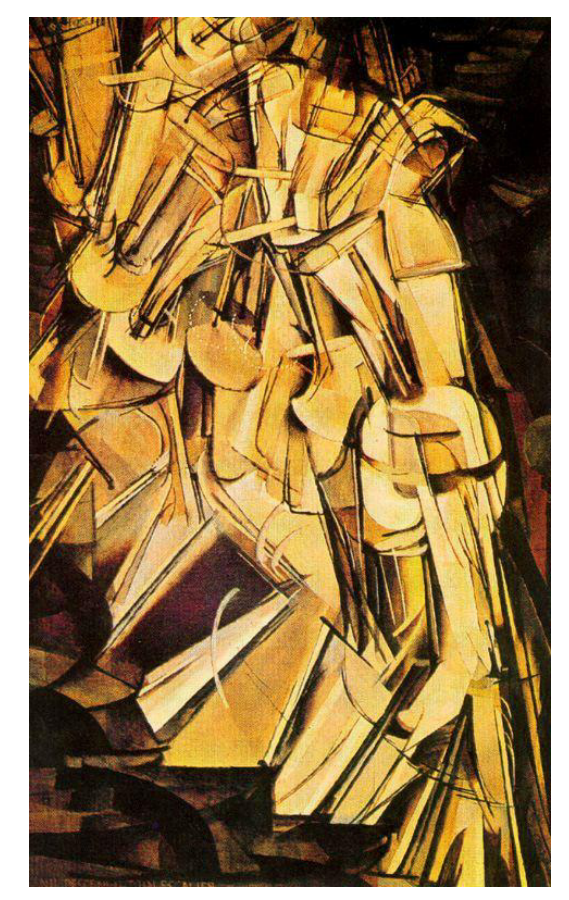

Marcel Duchamp, Desnudo bajando una Escalera, 1912.

Philadelphia Museum of Art. 106

Por lo que respecta a los manifiestos, aunque es bien sabido que a Braque y Picasso se les atribuye el haber iniciado el Cubismo, también son conocidos los hechos de que ellos no asistían a tertulias ni reuniones ni exposiciones colectivas que en "pro" del Cubismo se hicieron entre 1912 y 1914, ni tampoco escribieron o dictaron algún manifiesto.

Dos pintores Albert Gleizes (1881-1953) y Jean Metzinger (1883-1956), quienes más que verdaderos creadores cubistas sólo rondaron en las composiciones geométricas y en las técnicas del Cubismo, escribieron el manifiesto Du Cubisme en 1912, el cual tuvo subsecuentes ediciones en ese año y en 1913. Pero fue Guillaume Apollinaire quien

${ }^{106}$ Guy Habasque, Op. Cit., p. 35. 
constituye lo que se ha considerado como el Manifiesto Cubista en su libro Méditations Esthétiques y más concretamente en el capítulo Les peintres cubistes.

Hay algunas partes del Manifiesto Cubista en las cuales se reflejan las aportaciones que contribuyeron e influyeron, desde nuestro punto de vista, a conformar parte de las pretensiones del pensamiento artístico innovador y geometrizante llamado Art Déco al hablar precisamente de la geometría, o bien, de la audacia técnica de un arte que hace las cosas de manera diferente. En la parte III dice:

"A los nuevos artistas-pintores se le han reprochado vivamente sus preocupaciones geométricas.

Sin embargo, las figuras de la geometría son la base del dibujo.

La geometría, ciencia que tiene por objeto el espacio, su medida y sus relaciones, fue en todo tiempo la regla misma de la pintura.

...Ciertamente, los nuevos pintores no se proponen, en mayor medida que los antiguos, ser geómetras.

Pero se puede decir que la geometría es a las artes plásticas lo que la gramática es al arte del escritor."107

\section{b. Cubismo en la escultura y en la arquitectura}

La importancia del Cubismo para el arte del siglo XX fue tan crucial, como lo mencionamos en páginas anteriores, que sus influjos también alcanzaron a la escultura. Además de los ensamblajes que hizo Pablo Picasso, cuyo producto fueron las guitarras, desde tiempos tempranos del Cubismo Analítico trabajó la famosa Cabeza de mujer, de 1909, la cual le condujo a sus primeras experiencias escultóricas cubistas, mismas que continuó hasta la década de los veinte, época de cambio hacia otras temáticas y técnicas.

Uno de los importantes escultores que estuvieron inmiscuidos dentro del Cubismo fue Jakoff Lipchitz (1891-1973). Amigo de Juan Gris, desde 1914 se inició en las formas cubistas, las que continuó inclusive hasta la década de los veinte para luego continuar en el mundo del Surrealismo. Gustoso de apreciar las figurillas africanas o de otra procedencia

${ }^{107}$ Mario de Micheli, Op. Cit., pp. 360 y 361. 
étnica "primitiva", trabajó temas con músicos, payasos y arlequines, tal como la había hecho también Picasso en la pintura.

Sin embargo, a quien se le considera como el máximo representante de la escultura cubista es al francés Henri Laurens (1885-1954). Iniciado con la madera exclusivamente, después la combinó con el metal y el color, logrando esculturas cubistas con formas geométricas puras; mas el papier collé, así como las terracotas y las piedras policromadas, también fueron de su incumbencia técnica. En sus obras Botella y vaso, de 1917, y El frutero con uvas, 1922, podemos ver cómo en la primera el ensamblaje de madera y metal policromados se apilan para componer una pieza del Cubismo Sintético, lo mismo que la segunda, no es otra cosa sino un papier collé traspasado a la terracota, armando verdaderas “esculto-pinturas". 108

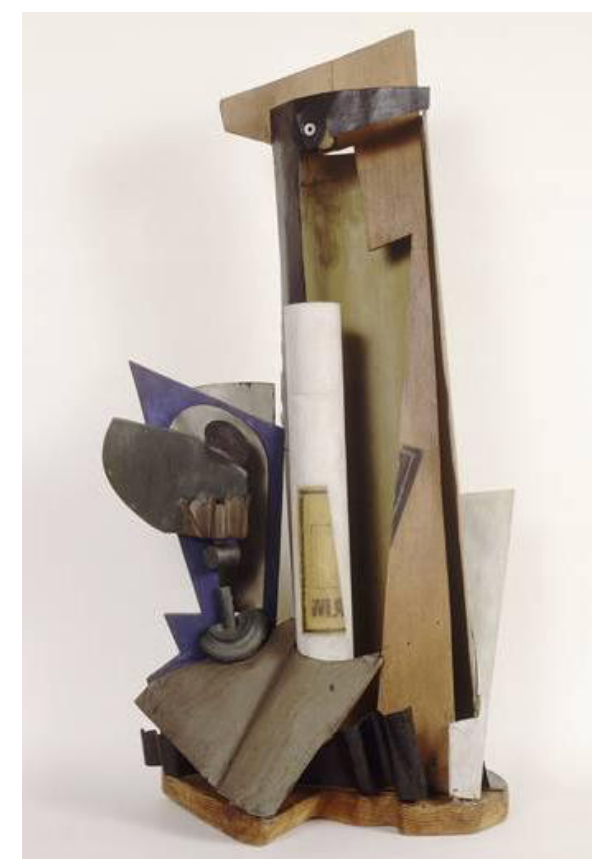

Henri Laurens, Botella y vaso, 1917.

Musée National d' Art Moderne, París. 109

Los temas de Laurens fueron diversos, aunque el bodegón ocupó un lugar predominante, hasta que la mujer se convirtió en su único y exclusivo tema en la década de

\footnotetext{
${ }^{108}$ Término propuesto por el artista ucraniano Alexander Archipenko (1887-1964) en el año de 1914, producto de sus ensamblajes escultóricos.

${ }^{109}$ Jean-Luc Chalumeau, Op. Cit., p. 48.
} 
los veinte. Desafortunadamente nada se sabe de sus trabajos anteriores a 1915, ya que él mismo los destruyó, por lo tanto, su obra conocida presenta ya una madurez consolidada. Debido a que su trayectoria escultórica estuvo siempre dentro del Cubismo, aunque también caminó en las indagaciones surrealistas, Henri Kahnweiler denominó al arte de Laurens como "La fine fleur du cubisme". 110

La aplicación del Cubismo a la arquitectura apenas si se vislumbró en la propuesta de los participantes de la Section d'Or, en especial con Raymond Duchamp-Villon, Jacques Villon y André Mare (1885-1932), quienes en el Salón de Otoño de 1912 lanzaron el proyecto de su Villa Cubista, que tiempo después se realizó en Checoslovaquia, específicamente en Praga, pero más que todo como una aplicación escultórica decorativa y no tanto arquitectónica, ya que se trataba de una casa neoclásica con decoraciones prismáticas, angulares y de algunos cubos en las cornisas.

Otro intento de arquitectura cubista fue el de Robert Mallet-Stevens (1886-1945) en la Exposición Internacional de Industrias y Artes Decorativas celebrada en París en 1925, en la que expuso su Jardín Cubista, con el cual consiguió un conjunto escultórico más que constructivo.

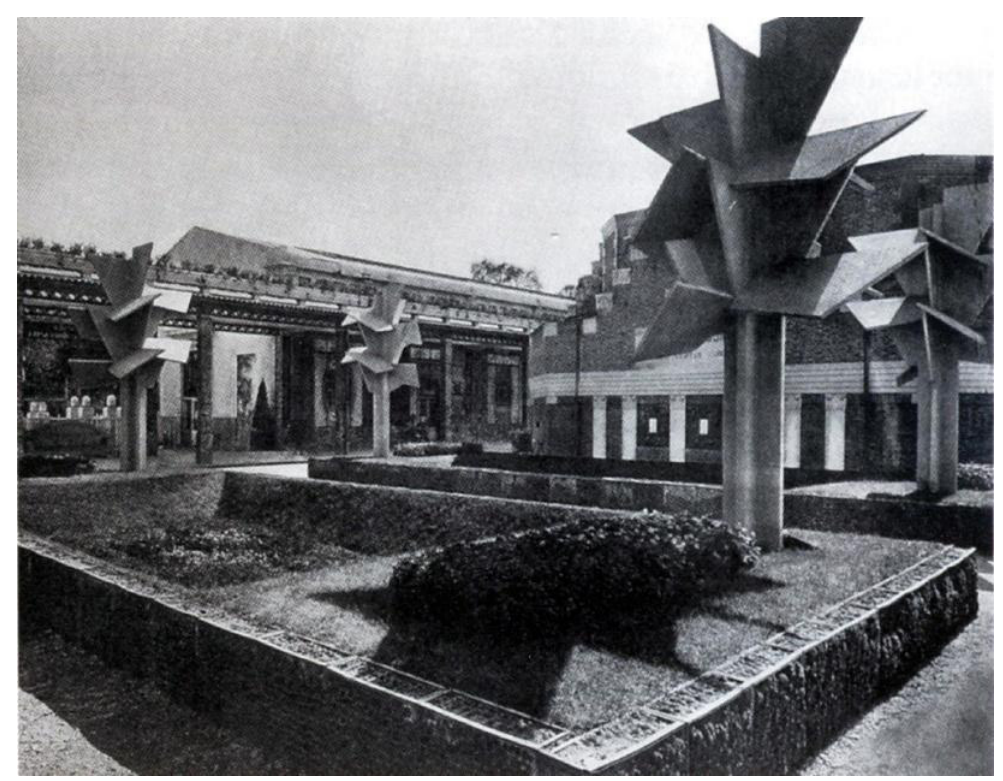

Robert Mallet-Stevens, Jardín Cubista, $1925 .^{111}$

\footnotetext{
${ }^{110}$ Javier Arnaldo, Op. Cit., p. 92.

${ }^{111}$ Delfín Rodríguez, La arquietctura del siglo XX, Madrid, Historia 16, 1989, p. 52.
} 
Dos arquitectos que habían admirado el Cubismo, en especial a Juan Gris, posteriormente refutarán a dicho movimiento. Nos referimos a los ya citados CharlesÉdouard Jeanneret, conocido como Le Corbusier y a Amédée Ozenfant, mismos que publicaron en 1918 su libro Aprés le Cubisme, en donde se declaran absolutamente contra las proposiciones de dicho movimiento y en el cual Le Corbusier fundamentó las máximas del Purismo arquitectónico. Juntos, Le Corbusier y Ozenfant editarán de 1920 a 1925 la revista L'Esprit Nouveau, titulada así por recomendación de Apollinaire, publicación periódica en la que manifestarán su postura a favor de la estética industrial.

En el libro nominado Vers une Architecture, 1923, Le Corbusier alude que el cilindro, la pirámide, el cubo, el prisma y la esfera son nada menos que extraídos de la arquitectura romana antigua. Él dijo que: "Los cubos, los conos, las esferas, los cilindros o las pirámides son las grandes formas primarias que la luz revela bien... Es la condición esencial de las artes plásticas". ${ }^{112}$ Nada menos que los objetos geométricos usados en el Protocubismo y también, algunos de ellos, indicados por Cézanne.

En una de las construcciones de Le Corbusier, la Villa Savoye, en Poissy, de 1929 a 1931, sin ser una obra cubista, utilizó tres elementos básicos: el cubo, el cilindro y la esfera, cuerpos geométricos que, como mencionábamos anteriormente, fueron la base del movimiento Cubista.
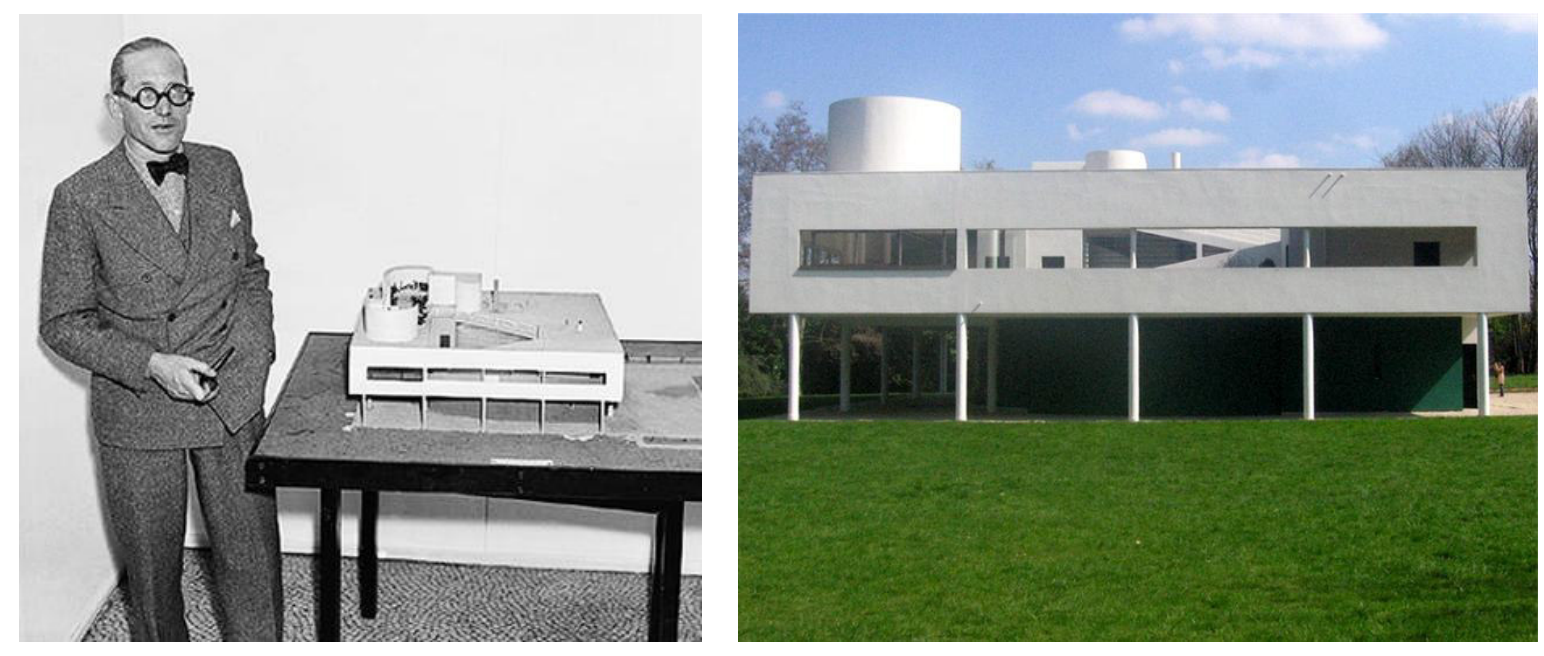

Le Corbusier con la maqueta de la Villa Savoye en el Museum of Modern Art de New York en 1935 y vista general, edificada entre 1919-1931. ${ }^{113}$

\footnotetext{
${ }^{112}$ Le Corbusier en Delfín Rodríguez, Op.Cit., p. 88.

113 Jean-Louis Cohen, Le Corbusier, Köln, Taschen, 2013, p. 43.
} 


\subsubsection{Abstraccionismo Ruso}

Después de 1905, ante el fallido intento del derrocamiento del Zar, el desencanto hace presa a los artistas e intelectuales quienes después del triunfo de la Revolución Bolchevique de 1917, algunos tomaran partido en las esferas oficiales de la nueva U.R.S.S., y otros seguirán con sus rutas de manera independiente o en grupos alternos.

Sin embargo, pese a los acontecimientos entre 1905 y 1914, los rusos no estaban ajenos al conocimiento de las Vanguardias europeas, además de que ellos mismos contribuirán al desarrollo de los movimientos artísticos e intelectuales transformadores de principios del siglo $\mathrm{XX}$. Tal es el caso de los estudios literarios y lingüísticos que en la Rusia anterior a 1914 se encontraban estancados en la historia literaria positivista y en la crítica anquilosada que carecía de seriedad y metodología; esto provocará que unos alumnos de la Universidad de Moscú fundaran entre 1914 y 1915 un grupo al que llamaron Círculo Lingüístico de Moscú, entre cuyos integrantes se encontraba Roman Jakobson (1896-1982). Y en la Ciudad de Petrogrado (San Petersburgo) en 1916, se conforma otra agrupación con intereses en la literatura conocida como el Opojaz, que significaba Sociedad para el Estudio del Lenguaje Poético, donde militaba el teórico Viktor Shklovsky (1893-1984). A ambas agrupaciones se les conoce como el Formalismo Ruso, movimiento que influyó en Europa y que se encontraba fuertemente vinculado con los futuristas y cubistas de Moscú. ¿Qué tenía en relación un movimiento lingüístico con las vanguardias artísticas? Pues la estrecha ligazón en búsqueda de nuevas alternativas para el arte y la literatura, rompiendo con el pasado histórico academicista. Por ejemplo, para el Formalismo Ruso la literariedad no estaba en el alma o en la persona, sino en el poema mismo; es decir, quitaron toda la subjetividad del hecho literario, lo cual se relaciona con los presupuestos ideológicos del Suprematismo.

Las vanguardias hacían eco en Rusia y especialmente el Cubismo. Pese a la distancia territorial y de lenguaje, los rusos estaban al día de los acontecimientos culturales de Europa Occidental y ante las intenciones de buscar un arte nuevo que estuviera de la mano con la transformación del nuevo Estado Soviético, el camino a tomar por los artistas rusos fue la abstracción de tipo geométrico, la cual iba de la mano con la utopía socialista 
de romper con el pasado histórico y contribuir con un nuevo arte, así como una nueva realidad social.

Una vez concluida la revolución e instaurado el nuevo régimen soviético, la idea de transformación total de la sociedad rusa contagia a los diversos sectores de la cultura artística, lo cual se ve concretado en los apoyos que el Comisario de Instrucción, Anatoli Lunacharski (1875-1933), dio a las artes, fundando escuelas y repartiendo encargos oficiales a los artistas. Tal fue el caso de los Vkhotemas (Talleres Superiores de Educación Artística del Estado), fundados en 1920 en Moscú con la intención de crear artistas y técnicos que estuvieran vinculados entre sí y que produjeran aquellos objetos cotidianos indispensables, con diseños innovadores y a bajo costo para la población soviética Los Vkhotemas fueron unas de las primeras instancias por desarrollar y unir el arte con la producción industrial, por lo que fueron la base para el diseño industrial en Rusia. Estos talleres, que estuvieron en contacto con la Bauhaus alemana, tuvieron su final en 1926 con el advenimiento del dictador Stalin (1879-1953) y cambiaron nombre por el de Vkoutein (Instituto Superior Artístico y Técnico) que perduró hasta finales del año de 1930.

Otro de los establecimientos educativos creados por el Estado fue el Inchuk (Instituto de Cultura Artística), que se fundó en 1920 bajo la dirección de Wassily Kandinsky (1866-1944). En el Inchuk los estudiantes se podrían especializar en arquitectura, pintura, escultura, artes gráficas y textiles, cerámica, además de estética industrial que podría ser ya como el diseño industrial, pues ésta se desenvolvió en los talleres en los cuales se laboraba con materiales como la madera, el metal y que recibieron el nombre de Dermetfak. Estos talleres significaron un gran adelanto en la producción de enseres que se requerían para la nueva sociedad socialista, lo que llevó a dichos planteles a consolidar proyectos que abarcaran el diseño y la ejecución de toda una comunidad. Con la exposición de 1925 de los resultados de los Dermetfak, el pueblo en general quedó gustoso de las innovaciones que se hacían sobre el diseño de los objetos.

Desde 1917, con el triunfo de la Revolución Soviética, hasta principios de los años treinta, el arte y la política social, la vanguardia y la utopía rusa se convirtieron en atrayentes modelos a seguir por muchos artistas europeos. Mientras la transformación de la sociedad rusa se gestaba, el arte contribuía a afianzar esa nueva forma de vida y de ver los objetos artísticos con la lupa de la abstracción pura. Y la cultura proletaria promovida por el 
nuevo Estado, estará muy de la mano con las proposiciones de los movimientos de vanguardia rusos, cuyos artistas fueron apoyados por el mismo Lenin (1870-1924) siempre y cuando contribuyeran con la nueva causa socialista.

Ya para 1932, con Stalin en el poder, el arte entrará en una alienación partidista donde cualquier intento de primicia era sofocado. La vanguardia rusa, simplemente, perece.

La abstracción rusa se dio en tres movimientos: el Rayonismo, el Suprematismo y el Constructivismo. El primero lo explicaremos de manera breve y los otros dos los trataremos más detenidamente, ya que su contribución al Art Déco es sustancial.

El Rayonismo fue un movimiento que emparentado con el Cubismo, el Futurismo y el Orfismo de Delaunay, buscaba la luz cristalina radiada a través de rayos que lograban un efecto de movimiento y motricidad, que con líneas oblicuas y angulosidades obtenía una abstracción figurativa con formas espaciales. Este movimiento nació con los pintores Mikhail Feodorovich Larionov (1881-1964) y Natalia Goncharova (1881-1962), en 1909. En 1913 Larionov publica el Manifiesto del Rayonismo, pero un año después el artista sale de Rusia y con ese suceso el movimiento llega a su fin.

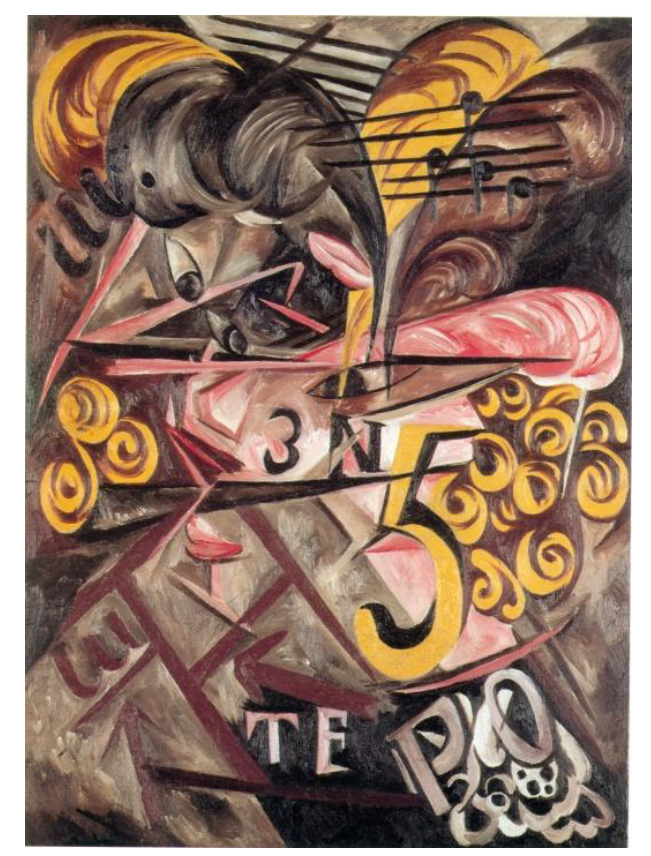

Natalia Goncharova, Dama con sombrero, 1912. Musée National d'Art Moderne, París. 114

\footnotetext{
${ }^{114}$ Jean-Luc Chalumeau, Op. Cit., p. 45.
} 
Una expresión significativa sobre el Rayonismo dice: “iViva el espíritu nacional! Nosotros marchamos al lado de los artistas rusos. ¡Viva nuestro estilo rayonista en pintura, independiente de las formas reales, que vive y se desarrolla según las reglas de la pintura! El rayonismo es una síntesis de cubismo, futurismo y orfismo." 115

El Rayonismo, entonces, finalizó en el año del inicio de la Revolución Rusa. Larionov y Goncharova partirán en 1917 a París para trabajar como escenógrafos y modistos con Les Ballets Russes.

\section{a. Suprematismo}

El pintor Kazimir Severinovich Malevich (1878-1935) denominó así a su arte abstracto que con formas estereométricas de colores sobre fondo blanco están limitadas al cuadrado, rectángulo, círculo, triángulo y la cruz, o bien a un solo cuadrado negro, rojo o blanco sobre fondo blanco.

Para Malevich el arte no debería ser objetivo, ya que la sensibilidad pura se basaba precisamente en la no objetividad, para así obtener un arte liberado de las ataduras del pasado. De esta manera, la esencia del arte tomada de las representaciones objetivas es inexistente en la obra de Malevich.

Por lo anterior, Malevich decía que el artista moderno debería desprenderse de las escenas que estaban al servicio de la Iglesia o del Estado, para poder conseguir la libertad del arte, el cual tendría que estar desligado completamente de la vida práctica, por lo tanto, se pintaría o esculpiría bajo los dictados de una nueva sensibilidad plástica pura. Esa sensibilidad pura en las bellas artes, para Malevich, estaba en una "supremacía" sobre cualquier propuesta artística; de ahí, entonces, se derivó el término de Suprematismo.

Las primeras obras consideradas como abstracciones suprematistas fueron presentadas en la exposición titulada 0.10 en Petrogrado en diciembre de 1915, que constó de treinta y cinco obras en cuyo catálogo no aparece la palabra Suprematismo ni en el Manifiesto de la misma exposición, lo que hace suponer que el término fue utilizado por el propio Malevich en una conferencia-debate que se realizó posteriormente a dicha exposición y de ahí en adelante se empleó la denominación en los artículos periodísticos. El

\footnotetext{
${ }^{115}$ Mario de Micheli, Op. Cit., p. 383.
} 
propio Malevich dio la fecha de 1913 como inicio del Suprematismo, pues de ese año se supone que es su lienzo Cuadrado negro sobre fondo blanco obra con la cual se considera a este artista ruso como el iniciador de la abstracción. El propio Malevich lo explica así:

"Cuando en 1913 a lo largo de mis esfuerzos desesperados por liberar al arte del lastre de la objetividad, me refugié en la forma del cuadrado y expuse una pintura que no representaba más que un cuadrado negro sobre un fondo blanco, los críticos y el público se quejaron: <<Se perdió todo lo que habíamos amado. Estamos en un desierto. ¡Lo que tenemos ante nosotros no es más que un cuadrado negro sobre fondo blanco!>>". 116

Ahora bien, el Manifiesto Suprematista, en el cual Malevich contó con la ayuda del poeta Vladimir Maiakovsky (1894-1930), fue publicado en 1915, fecha también de la exposición 0.10 , por lo que sí hay conciencia en la relación de que esas obras expuestas hayan sido las primeras ya como suprematistas. Hay que considerar que el propio Malevich afirmaba que su obra había pasado por dos periodos de Suprematismo: el "mecánico", el cual revelaba la vida interior de la máquina y esto incumbía a su etapa cubofuturista, y el "cósmico" que es el que se conoce en general como Suprematismo, cuya duración oscilará entre 1915 y 1922, ya que después Malevich continuará con temáticas que trataban el aspecto social campesino.

Además del Manifiesto Suprematista, Malevich escribió, entre otras cosas, el ensayo Del Cubismo y del Futurismo al Suprematismo en 1916; en 1920 El Suprematismo como modelo de la no representación; y en 1927 en Berlín -en la Bauhaus- parte de sus teorías suprematistas fueron publicadas con el título Die gegenstandslos Welt (El Mundo sin Objeto), lo cual habla de la fuerza intelectual de este artista.

Malevich explicaba que su obra suprematista tuvo tres fases: el periodo negro, el periodo de color y el periodo blanco; en éste último, en diciembre de 1918, en el X Salón Estatal de Moscú expuso la obra Cuadrado blanco sobre fondo blanco en la que llegaba al clímax de la abstracción de la sensibilidad pura.

Kasimir Malevich ocupó diversos puestos directivos. De 1917 a 1918 fue nombrado profesor de los Talleres Superiores de Educación Artística y Técnica del Estado en Moscú (Vkhotemas), en donde se encuentra con los artistas Wassily Kandinsky (1866-1944),

\footnotetext{
${ }^{116}$ Malevich en Mario de Micheli, Op. Cit., p. 386.
} 
Vladimir Tatlin (1885-1953), Anton Pevsner (1884-1962) y Naum Gabo (1890-1977). En 1918 Marc Chagall (1887-1985) lo llama a la academia de Vitebsk. Durante 1919 imparte la cátedra de pintura en la Escuela Nacional de Artes Aplicadas de Moscú y en 1924 es Director de Instituto para el Estudio de la Cultura Artística de Leningrado.

Las propuestas abstractas de Malevich serán conocidas en el extranjero gracias a la participación del pintor en una exposición de arte ruso en Berlín, pero más difusión tuvieron durante su estancia de tres meses en 1926, que con motivo de una exposición retrospectiva en Varsovia y en Berlín, viajó por los países de Polonia y Alemania; en éste último visitó la Bauhaus y pudo intercambiar ideas y programas artísticos con los maestros de Dessau. Es tanto lo que aporta Malevich a los alemanes, que como resultado le publicaron sus teorías, como ya lo hemos mencionado.

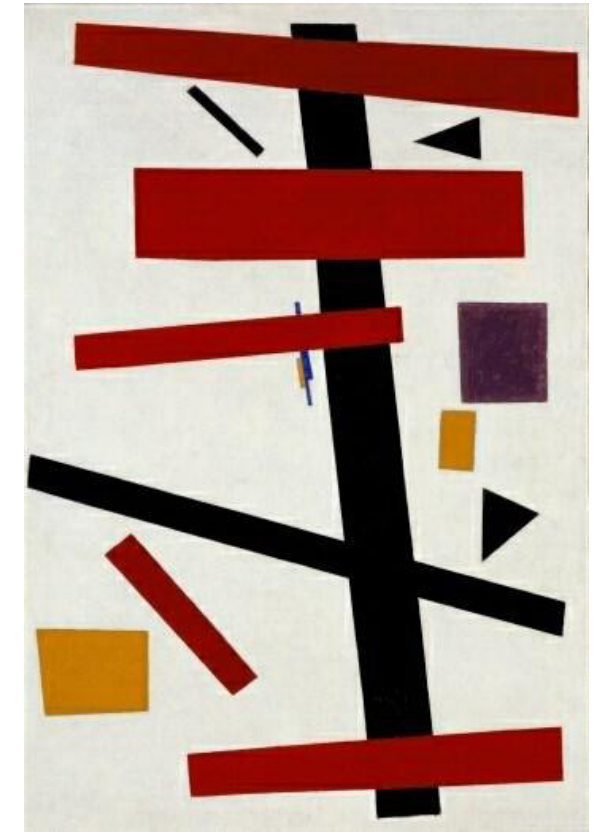

Kasimir Malevich, Suprematismo 417, 1915.

Stedelijk Museum, Amsterdam. ${ }^{117}$

La pintura de Malevich se hilvanaría con la arquitectura a través de las Architektone, maquetas de los años veinte que el autor las nombraba con letras y que consistían en la

${ }^{117}$ L.C Jaffé, “Abstracción geométrica”, Historia del Arte, México, Salvat Mexicana de Ediciones, 1979, Tomo 11, p. 78. 
proyección de planos y volúmenes en el espacio. Para dicha década el Suprematismo alcanza con objetos prácticos a las esferas oficiales, como fueron las cerámicas de Malevich manufacturas en los hornos del Estado en Leningrado.

Además de las Architektone, Malevich construye los Planita, que eran estructuras concebidas como las casas del futuro, diseñadas en madera y que junto con las Architektone construían un lenguaje abstracto tanto en lo arquitectónico como en lo escultórico. Malevich explicaba así sus casas del futuro: "Para el nuevo arte de la construcción (...) pienso en el cristal blanco opaco, en el hormigón armado y en el cartón embreado como los materiales más adecuados de las $<<$ planita $>>$; la calefacción será eléctrica, ya que las $<<$ planita $>>$ no deben tener chimeneas. Los colores predominantes en una $<<$ planita $>>$ de viviendas son el blanco y el negro; el rojo en casos excepcionales."118

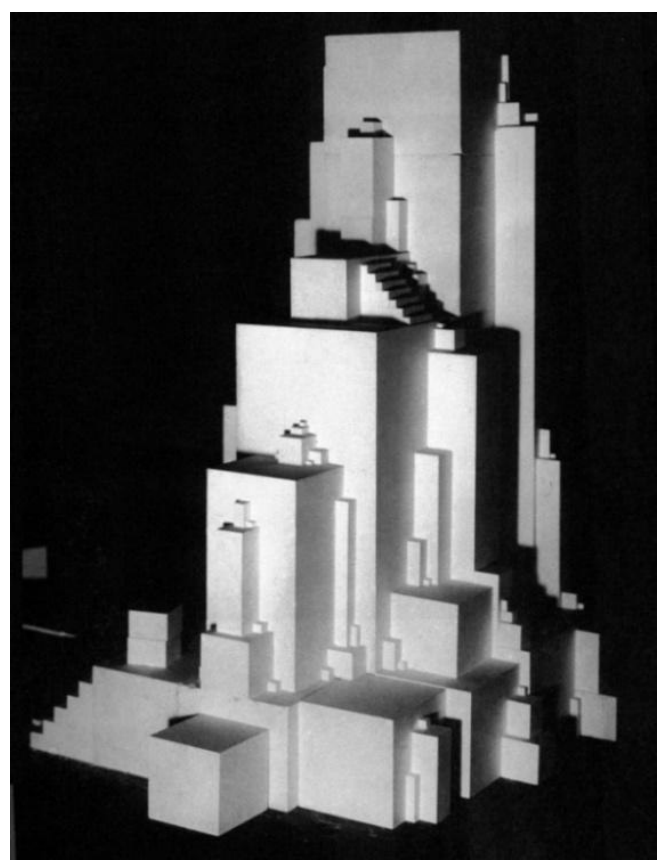

Kasimir Malevich, Architektone Zeta, década de $1920 .{ }^{119}$

La fuerte influencia que el Suprematismo tuvo en Europa, llevó a concretar algunas de las ideas de Malevich, como fue la construcción de una casa bajo los postulados de los

\footnotetext{
${ }^{118}$ Malevich en Vittorio De Feo. La arquitectura en la U.R.S.S. 1917-1936, Madrid, Alianza, 1979, p. 54.

119 The Charnel House. From Bahaus to Beinhaus, "Architektons", http://thecharnelhouse.org/tag/architektons/
} 
Planita que Piet Mondrian (1872-1944) y Theo Van Doesburg (1883-1931) realizarán en Holanda, entre 1924 y 1925.

Además la presencia de El Lissitsky (1890-1941), de quien hablaremos más adelante, en la Bauhaus y la estancia de Malevich en la misma escuela harán que el Suprematismo junto con otras corrientes de abstracciones rusas, se pongan de moda y se admiren las propuestas del abstraccionismo geométrico de la U.R.S.S.

Algunas partes del Manifiesto del Suprematismo de Malevich destacan sus ideas contra la objetividad y la proclama por un nuevo arte, mismo que también ensalza la geometrización y la construcción de una nueva manera de transportar las ideas en el lienzo y en el espacio, lo cual fue importante influencia en el Art Déco: "El cuadrado de los suprematistas y las formas derivadas de él se pueden comparar a los $<<$ signos $>>$ del hombre primitivo, que en su conjunto no quieran ilustrar, si no representar la sensibilidad del $<<$ ritmo $>$ >...El cuadrado se modifica para formar figuras nuevas cuyos elementos se componen de una u otra manera según las normas de la sensibilidad inspiradora...". ${ }^{120}$

\section{b. Constructivismo}

Otra de las manifestaciones del Abstraccionismo Ruso fue el Constructivismo, término que empezó a ser utilizado después de 1920 y que también se aplica de manera extensiva al Abstraccionismo geométrico ruso en general. Sin embargo, con el término Constructivismo nos referimos a la abstracción geométrica del pintor Vladimir Yevgrafovich Tatlin (1885-1953) y su grupo de artistas.

Entre los años 1911 y 1913, Tatlin caminó por el Cubismo y el Futurismo, además de estar influido por los iconos ortodoxos. Durante 1912, tras una estancia de quince días en París, Tatlin conoce los experimentos picassianos, lo que le induce a realizar sus cuadros relieves. Todo esto lo conducirá en 1914 a buscar composiciones con formas puramente geométricas y sin figuración alguna, que se compondrán, a través de un concepto nuevo, en construcciones abstractas en relieve, pintadas y con formas geométricas, mutuamente ensambladas, utilizando materiales de desecho tal y como lo proponía en su Manifiesto de

\footnotetext{
${ }^{120}$ Malevich en Mario de Micheli, Op. Cit., p. 389.
} 
la Escuela Futurista de 1912 Umberto Boccioni (1882-1916). De esta manera, Tatlin inicia y funda el Constructivismo.

Todavía para 1915, en las exposiciones de Petrogrado tituladas Tranvía V y 0.10, Tatlin utiliza una técnica futurista, pero en ese mismo año hubo dos acontecimientos trascendentes para la cimentación del Constructivismo: por una parte, las dos exposiciones celebradas el Petrogrado, la de febrero y la de diciembre, en las cuales participó Tatlin junto con Malevich; en la primera cada uno participó con sus obras, en la segunda, los maestros junto con sus adeptos se presentaron en salas separadas: la escisión entre Malevich y Tatlin estaba dada. El otro suceso fue la elaboración de sus construcciones denominadas Relieves de Rincón, piezas que trabajadas con metales y alambres se amalgaman en una proyección tridimensional que se inyectan hacia el espacio, buscando la intersección del espacio real y del espacio ilusionista; desafortunadamente estas piezas se han perdido y sólo se conocen por las reconstrucciones realizadas a través de fotografías. Con este último episodio, Tatlin forja el preludio del Constructivismo.

Al terminar la revolución del 1917, Tatlin será el Presidente de la Federación de Izquierda de los Pintores en Moscú y un año más tarde estará a la cabeza del Departamento de Bellas Artes como Comisionado para la Educación del Pueblo.

En 1919 Tatlin imparte clases en los Vkhotemas y más tarde es llamado a Petrogrado para dirigir los Estudios Libres Estatales de Arte, centro educativo que venía a sustituir a la antigua Academia decimonónica. En dicho centro Tatlin experimenta, impulsa y perfecciona sus teorías constructivistas, trabajando el volumen, los materiales y la construcción de sus composiciones.

Y en el mismo año de 1919, un proyecto tatliano concretará y expandirá el Constructivismo: el Monumento a la III Internacional, presentado a través de una maqueta de madera en Petrogrado en diciembre de 1920, en la exposición del VIII Congreso de los Soviets. Este diseño fue promovido por el IZO (Departamento de Artes Plásticas) del NARKOMPROS (Comisariado de Cultura), cuya jefatura estaba en manos de Lunacharsky. El monumento estaría realizado con materiales como el acero y el cristal, tendría una altura de trescientos metros y se compondría de un cilindro, una pirámide, un segundo cilindro y una media esfera, todos envueltos por una gran estructura de acero. 
El monumento, cuya maqueta desapareció y sólo se conoce a través de tres reconstrucciones (Estocolmo, Moderna Museet; Moscú, Museo de Arquitectura; París, Musée National d'Art Moderne), además de fotografías, era una gran utopía, como el mismo comunismo soviético. Magnánima construcción que utilizaría la nobleza de los nuevos materiales, símbolo del progreso, como el acero inoxidable y el cristal, de la misma manera como lo fue el mármol para la antigüedad clásica. Obra de "arte total" que se proyectaba a través de las formas geométricas del cilindro, la pirámide, la esfera más el helicoide y que se identificaba con la construcción de la nueva sociedad soviética.

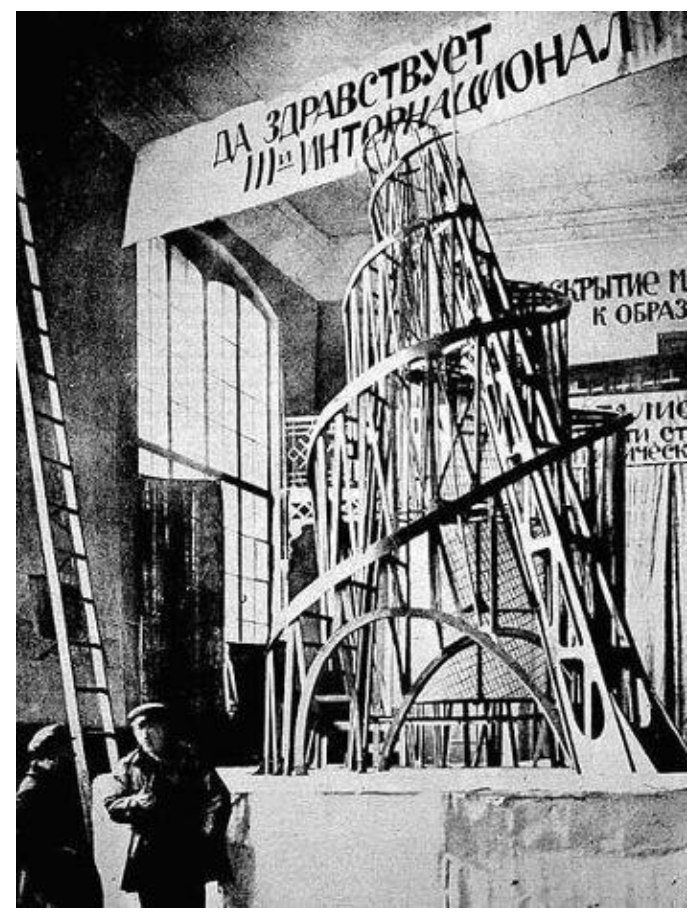

Vladimir Tatlin, Maqueta del Monumento a la Tercera Internacional, 1919. ${ }^{121}$

El Constructivismo buscaba crear un arte que estuviera en vinculación con la vida, por lo que los trabajos de publicidad, la tipografía, la arquitectura y la producción industrial -como antelación al diseño industrial-, serían unas de las premisas difundidas por Tatlin, además de buscar un arte objetivo, utilitario, limpio de banalidades decorativas, individual y que produjera cosas nuevas. En sí, el arte y el artista serán productores de objetos para la nueva cultura proletaria, dejando de ser propios de una cultura de élite burguesa.

${ }^{121}$ Charlotte \& Peter Fiell, Op. Cit., p. 684. 
Además de buscar esa pureza de las formas, el Constructivismo tuvo también una finalidad pedagógica con el arte, pues se tenía que encontrar un método en el cual se estableciera una adecuada relación entre los artistas y el Estado. Podríamos decir que este programa de hecho se llevó a cabo, ya que a los constructivistas les fueron asignados monumentos efímeros para las grandes conmemoraciones oficiales y además por el apoyo estatal a través de varios organismos, por ejemplo, el Instituto de Cultura Artística de Moscú, la Facultad de Arquitectura y el impulso dado por el ministro Lunacharsky, lo cual hizo que se diera una férrea relación y se asociara al Constructivismo en la década de los veinte, como el arte del nuevo Estado Soviético.

Pese a que el Constructivismo se conformó como un grupo cuyo líder era Tatlin, las discrepancias entre sus miembros pronto salieron a relucir: por un lado, el beneplácito de Tatlin y sus seguidores por las teorías marxistas no fue bien recibido por algunos miembros; y por otro, aquéllos que estaban en armonía con las "estructuras inútiles”, que avalaban la no objetividad del arte como lo proponía Malevich, que pugnaban por un arte de formas reales y se contraponían con el productivismo de Tatlin. A éstos últimos se les conoció como "Realistas", quienes utilizaron este término para identificar a su abstraccionismo. El grupo estaba encabezado por los hermanos Anton Pevsner (1884-1962) y Naum Pevsner (1890-1947) -conocido como Naum Gabo-, quienes el 5 de agosto de 1920 lanzaron su Manifiesto Realista.

El grupo del Realismo estaba en contra del Futurismo y el Cubismo, al afirmar que no habían cumplido lo que ofrecían pese a que, según ellos, sólo dichos movimientos eran lo único interesante del pasado reciente. El color, la línea descriptiva y el volumen no son elementos constitutivos del arte para los realistas, lo mismo que la escultura como masa y los ritmos estáticos. El arte será aquel que se construya con el espacio y el tiempo, libertado de la belleza y de los sentimientos. La nueva realidad en estrecha relación con la tecnología moderna y dentro del tiempo presente, será para los realistas la entidad donde se procree el arte, mismo que atenderá las actividades de la vida diaria.

Para apoyar lo anterior citaremos algunas partes del Manifiesto Realista:

“1. ...en la pintura renunciamos al color como elemento pictórico... la tonalidad de la sustancia, es decir, su cuerpo material que absorbe la luz, es la única realidad pictórica. 
2. Renunciamos a la línea como valor descriptivo: en la vida no existen líneas descriptivas;...

3. Renunciamos al volumen como forma espacial pictórica y plástica... Afirmamos el valor de la profundidad como única forma espacial pictórica y plástica.l

4. Renunciamos a la escultura en cuanto masa entendida como elemento escultural...

5. Renunciamos al desencanto artístico enraizado desde hace siglos, según el cual los ritmos estáticos son los únicos elementos de las artes plásticas". ${ }^{22}$

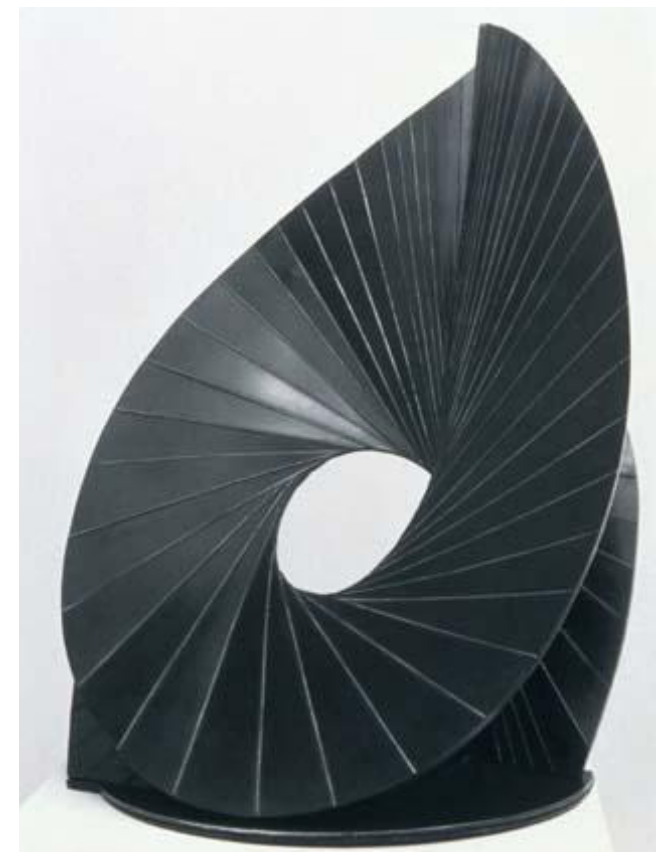

Anton Pevsner, Construcción superficie desarrollable, ha. 1920.

Kunstmuseum, Basilea. ${ }^{123}$

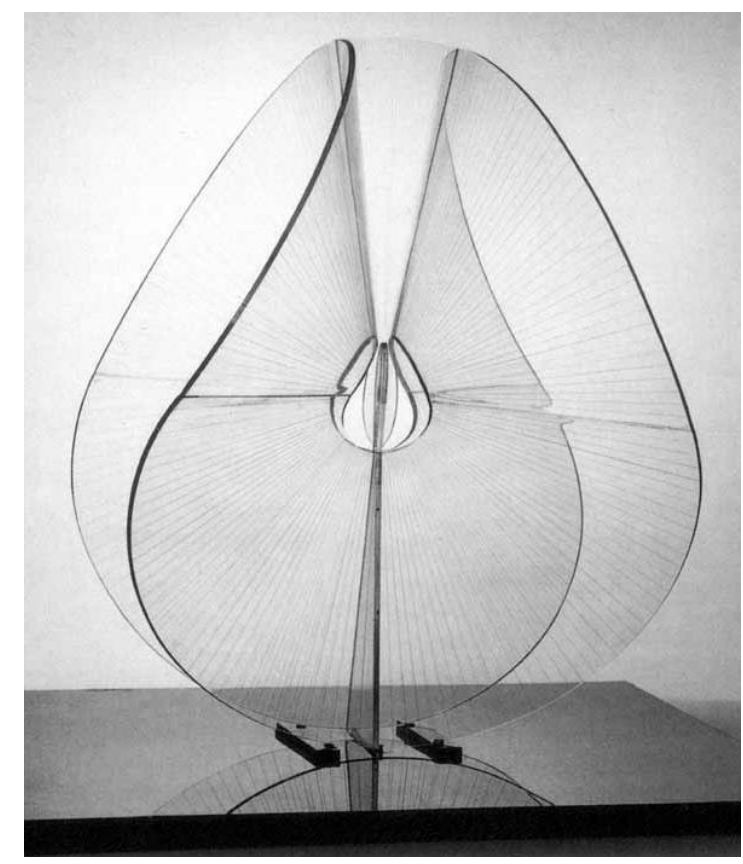

Naum Gabo, Variación translúcida sobre un tema esférico, 1937.

Guggenheim Museum, New York. ${ }^{124}$

Ante el Manifiesto del Realismo los seguidores de Tatlin prontamente reaccionaron con la publicación de un Programa del Grupo Productivista, redactado por Aleksander Mikhailovich Rodchenko (1891-1956) y Bárbara Stepanova (1894-1954), en el cual defienden un arte colectivo, basado en la elaboración de productos industriales como en la

\footnotetext{
${ }^{122}$ Mario de Micheli, Op. Cit., pp. 400-401.

${ }^{123}$ Francesc Vicens, Op. Cit. p.77.

${ }^{124}$ Ibídem, p. 81.
} 
construcción de edificios, todo esto en íntima relación con la vida que el comunismo soviético ofrece al pueblo.

Alexander Rodchenko en 1917 trabajó al lado de Tatlin en la decoración del Café Pintoresco de Moscú. Tiempo después elaboró estructuras tridimensionales tales como Construcción Espacial No. 12, obra en la que anillos de madera chapeada con pintura de aluminio se intercalan e interponen para formar una composición ágil y arrítmica. Además de los trabajos en fotografía, la tipografía fue manejada por Rodchenko, quien diseñó la portada de la revista $L E F$, que fungió como portavoz de las ideologías constructivistas.
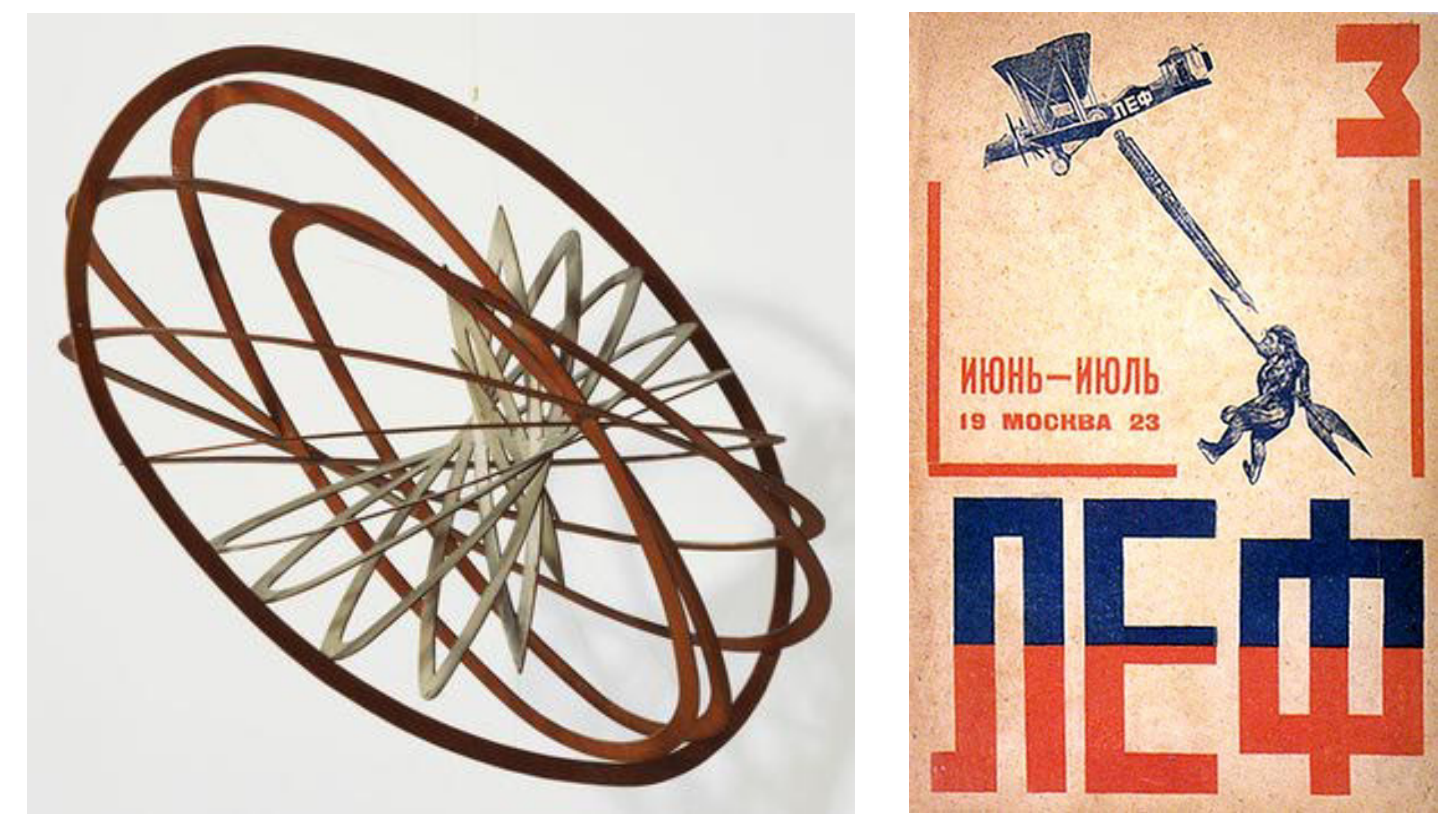

Alexander Rodchenko, Construcción Espacial No. 12, 1920, Museum of Modern Art, New York, 125 y portada del LEF, no. $3,1923.126$

Aparte de Rodchenko hubo un artista que contribuyó fuertemente en el Constructivismo, Lazar Markovich Lissitsky, conocido como El Lissitsky (1890-1941), uno de los promotores al exterior de este movimiento. Estudió en Darmstadt, Alemania, obteniendo el diploma de Ingeniero-Arquitecto en 1915. Regresa a su país natal y milita en el IZO (Departamento de Artes Plásticas) y en el NARKOMPROS (Comisariado de Cultura), comprometiéndose así con la nueva sociedad soviética.

\footnotetext{
${ }^{125}$ MoMA, "The Collection. Alexander Rodchenko", http://www.moma.org/collection/object.php?object_id=81043

${ }^{126}$ Philip B. Meggs; Alston W. Purvis, Op. Cit., p. 295.
} 
Marc Chagall (1887-1985), quien ocupaba la dirección de la Academia de Vitebsk, invita a Lissitzky en 1919 a trabajar a esa ciudad, lo mismo que había hecho un año antes como Malevich; Lissitzky se convertirá en un cercano colaborador de Malevich y formará parte del UNOVIS (Proyecto para una Afirmación de lo Nuevo), agrupación de artistas que dirigió el líder del Suprematismo.

En el mismo año de 1919 Lissitzky empieza a trabajar sus PROUN, término derivado de "Pro Unovis", que son proyecciones espaciales tridimensionales entre la pintura y la arquitectura, con lo que buscaba la renovación del arte a través de la creación de objetivos y la libertad del artista frente a la fuerza aplastante de la ciencia. Los PROUN eran espacios abstractos, geométricos, sin ritmo, aperspectivos, sin simetría, multidimensionales y cromáticos.

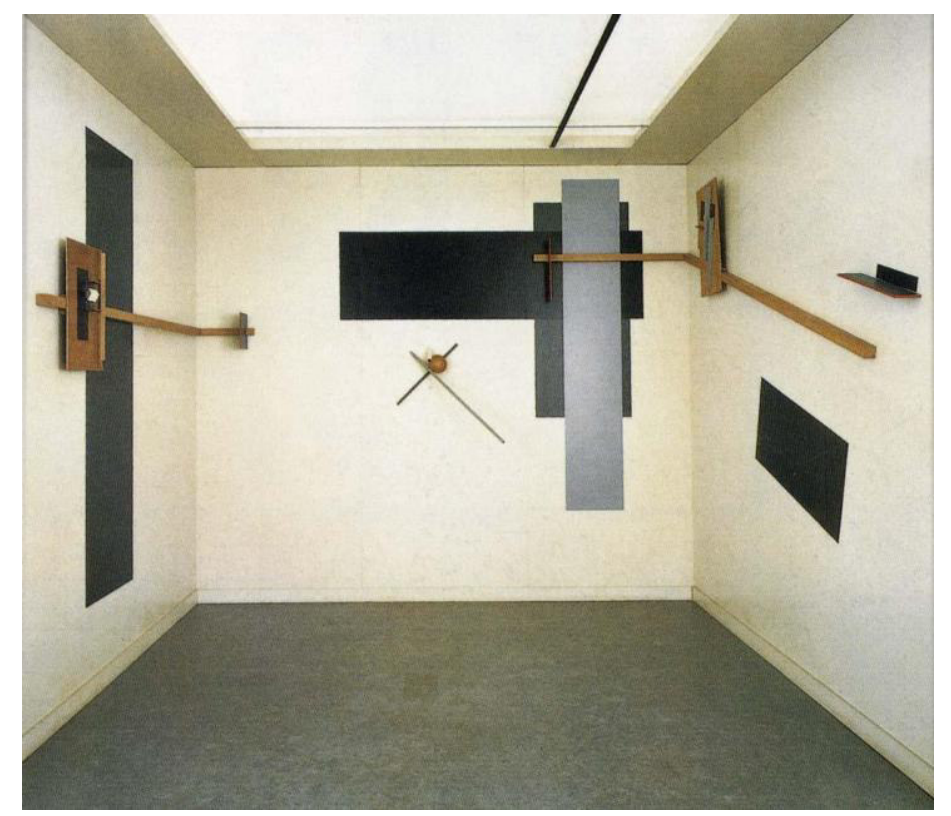

El Lissitzky, reconstrucción de Instalación Proun, creada para la Gran Exposición de Arte de Berlín, 1923.

Stedelejik Van Abbe Museum, Eindhoven. 127

Después de la publicación del Programa de los Productivistas y hacia finales de los años veinte, Tatlin y sus seguidores habían traspasado los límites de la nueva U.R.S.S., y sus proclamas eran ampliamente conocidas por Europa Occidental. Por su parte Tatlin dará un giro a su trabajo pintoescultórico para desarrollar decorados de teatros, carteles,

${ }^{127}$ Carsten-Peter Warncke, De Stijl 1917-1932, Köln, Taschen, 1993, p. 159. 
cerámicas, obras que fueron expuestas en 1933 en el Museo de Artes Decorativas de Moscú, muestra en la que congruentemente plasmó el enunciado de que el arte y los artistas deberían abarcar todos los ámbitos de la vida social. En ese mismo año y hasta su muerte, casi veinte años, Tatlin trabajará en el diseño de una máquina de hombre volador conocida como Letatlin, quimera sobre el hombre-artista-constructor para una nueva vida presente y futura.

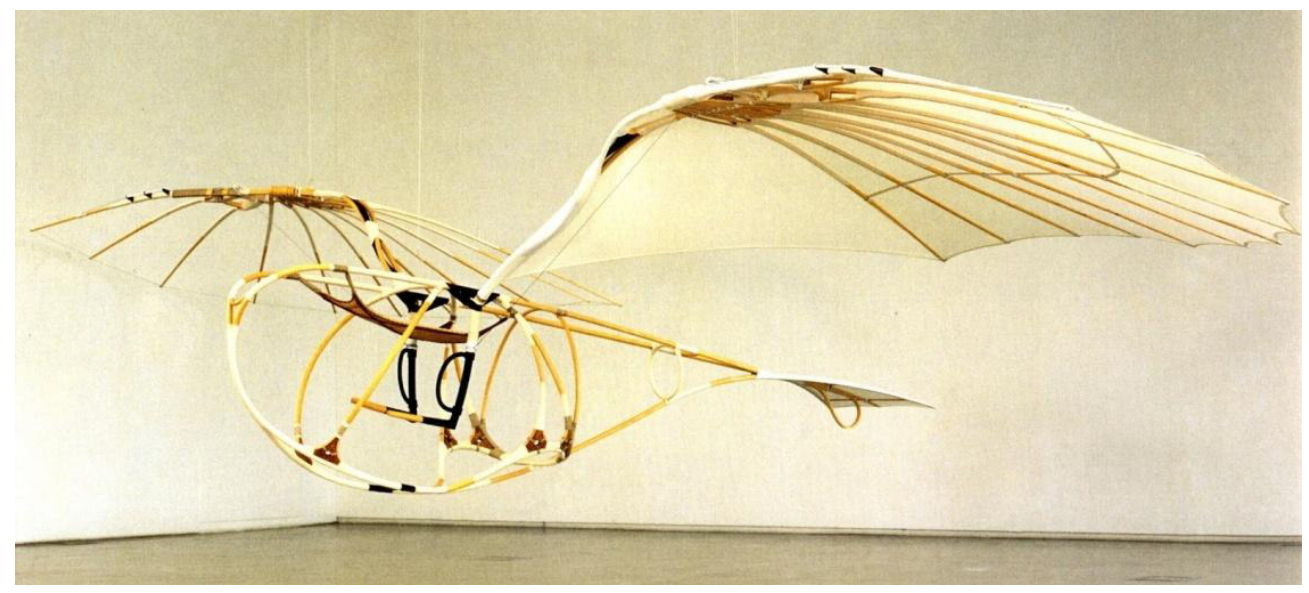

Vladilmir Tatlin, Letatlin, 1932, reconstrucción de Jürgen Steger en 1991. Lufthistoriche Gesellschaft am Flughafen, Frankfurt am Main. ${ }^{128}$

Con el advenimiento del estalinismo, Tatlin abandonará sus pasiones constructivistas para dedicarse a partir de 1940, a una pintura realista que capta la condición social campesina.

Uno de los esquemas notables de los constructivistas fue la mitificación y alabanza de la máquina, que como símbolo del progreso y del triunfo de la revolución socialista, expandieron la idea de utilizarla por todo el amplio territorio soviético como panacea para remediar las carencias tecnológicas. La autonomía del arte sería condenada por los constructivistas quienes clamarían más que por un arte, por la producción de objetos utilitarios, circunstancia que les valió para denominarse a sí mismos como productivistas para diferenciarse del grupo de los realistas, como ya lo habíamos expuesto anteriormente.

La relación entre el Constructivismo y la arquitectura se consolida cuando organizaciones de arquitectos como la OSA (Unión de Arquitectos Contemporáneos), la

\footnotetext{
128 José Jiménez, "Exposición Vladimir Tatlin”, Cuerpo y Tiempo, lunes 9 de julio de 2012, http://josejimenezcuerpoytiempo.blogspot.mx/2012/07/exposicion-vladimir-tatlin.html
} 
VOPRA (Unión de Arquitectos Proletarios), se sintieron atraídos por los presupuestos ideológicos socialistas de los constructivistas, principalmente por aquella premisa de que la arquitectura era el mejor campo para llevar a cabo los ideales de Tatlin y sus adeptos. Arquitectos como los hermanos Vesnin, Leonid Aleksandrovich (1880-1933), Viktor Alexandrovich (1882-1950) y Aleksandr Aleksandrovich (1883-1959), otros profesionales de la construcción como Ilya Alexandrovich Golosov (1883-1945) con su Club de los trabajadores comunales de Moscú de 1928, Konstantin Melnikov (1890-1974) con su seductor Pabellón de la U.R.S.S., para la Exposición Internacional de Artes e Industrias Decorativas de París en 1925 (ya ilustrado en ese tema), o bien Nikolai Aleksandrovich Ladovski (1881-1941) y su ASNOVA (Asociación de Nuevos Arquitectos) con la pureza formal del Proyecto de Rascacielos de Moscú, 1923, o del Instituto Lenin de Moscú de 1927, todos coparticipan con las proposiciones de los constructivistas al realizar sus trabajos con un geometrismo aséptico, impío con la estética académica, pero de acorde con los nuevos menesteres socialistas.

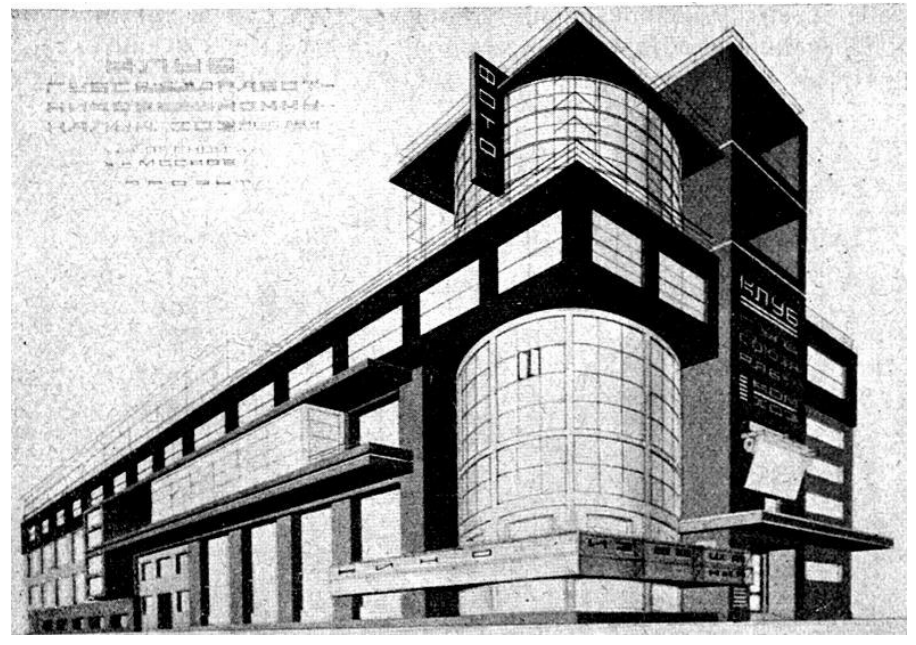

Ilya Golosov, Club de los trabajdores comunales de Moscú, $1928^{129}$.

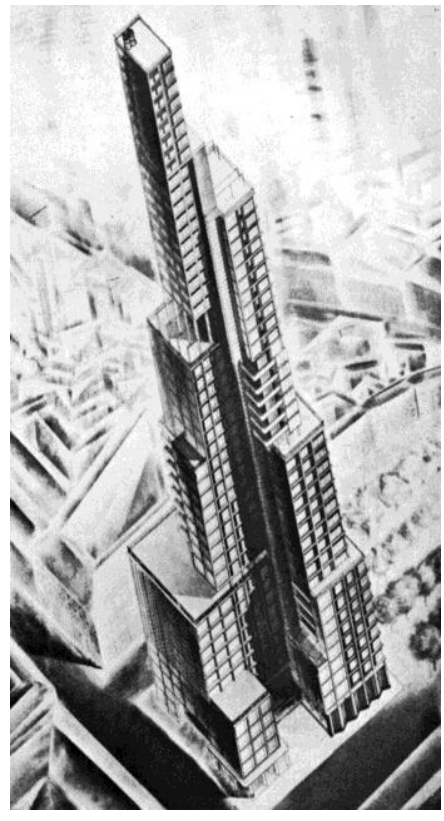

Nikolai Ladovski, Proyecto de Rascacielos de Moscú, 1923. ${ }^{130}$

\footnotetext{
${ }^{129}$ Vittorio De Feo, Op. Cit., p. 145.

${ }^{130}$ Ibídem, p. 130.
} 
El Constructivismo tuvo una forma de manifestarse y ésta fue a través del Frente de Izquierda de las Artes, conocido como el LEF, que a partir de 1923 y hasta 1925 el movimiento publica una revista con el mismo nombre dirigida por el poeta Vladimir Maiakovski (1893-1930). En el LEF convergieron desde futuristas y suprematistas, hasta cineastas y dramaturgos como fueron: Serguei Eisenstein (1898-1948), Usevolod Emilievich Meyerhold (1874-1942) o Boris Leonidovich Pasternak (1890-1960). Los miembros del $L E F$ buscaban un arte que se diluyera dentro de la vida social, que produjera objetos utilitarios necesarios, además de originar una literatura actual basada en documentos que tratara acontecimientos verdaderos y contribuyera con el quehacer periodístico.

Pero para poder desarrollar las intenciones del $L E F$ era consabido que no podían retroceder ni estancarse en las propuestas artísticas decimonónicas prerrevolucionarias; era necesario permanecer dentro del contexto de la revolución socialista y del arte moderno, el cual propulsaría las innovadoras ideas. En el primer número de la revista del $L E F$, en cuyo diseño participaron Alexander Rodchenko y su esposa Barbara Stepanova, Maiakovski publicó el manifiesto titulado Por qué combate el $L E F$, en el cual explica cómo el Futurismo se convirtió en el frente de izquierda de las artes, mismo que estaba fuertemente vinculado con la revolución de octubre, las ideas socialistas y los grupos obreros. Propone una nueva estética, una nueva cultura que rompa con el pasado, para resolver a través de su propio grupo los problemas del arte.

Fuertes afinidades se dan entre el LEF y el Programa de los Productivistas, ya que al final de cuentas ambos luchaban por un nuevo concepto y realidad del arte vinculado al naciente Estado soviético. Maiakovski escribe al respecto del nuevo arte: "El Lef debe reunir a las fuerzas de izquierda. El Lef debe pasar de revista a sus filas repudiando el pasado. El Lef debe unificar el frente para minar lo viejo, para marchar a la conquista de una nueva cultura." 131

Aunque el Constructivismo como movimiento único no logró consolidarse y tuvo divergencias con los suprematistas y realistas, sin embargo tuvieron entre sí la coincidencia de luchar por un nuevo arte que sirviera a las emergentes clases sociales a través del aparato

${ }^{131}$ Mario de Micheli, Op. Cit., p. 411. 
estatal y que estuviera en avanzada hacia el futuro, cortando toda reminiscencia del pasado. Mas la unanimidad en una teoría marxista es la principal concomitancia entre los diversos grupos, los cuales se apoyaron en el ideario de Alexander Alexandrovich Malinovki Bogdanov (1873-1928), quien reprobaba la cultura burguesa afirmando que habría que suplantarla por la del proletariado; además profesaba que si en el socialismo la conciencia colectiva es la que tiene la voluntad general del pueblo, el arte como manifestación individual estaba condenado a desaparecer, pues sería absorbido por el naciente arte colectivo. Estos enunciados tenían una severa relación con los de la Asociación para la Cultura Popular, el Proletkult, de existencia previa a la Revolución de Octubre.

Para 1923 el Constructivismo vino en decadencia, a pesar que en ese año se funda el $L E F$. Sin embargo, la expansión del movimiento por Europa Occidental se da con la salida de Kandinsky y de los hermanos Pevsner de la U.R.S.S., o bien con los trabajos en Alemania de El Lissisky y sus contactos con la Bauhaus. Pero con la publicación del Manifiesto de la Internacional Constructivista en Holanda en la revista De Stijl, el Constructivismo había alcanzado a influenciar a los europeos occidentales. Por esta razón el poeta Maiakovski exclamó: "Por vez primera, una palabra nueva en el arte, el constructivismo, no ha venido de Francia sino de Rusia. Incluso produce asombro que este término se encuentre en el léxico francés." 132

\subsubsection{Deutscher Werkbund}

El escritor, crítico y arquitecto Hermann Muthesius (1861-1927), el arquitecto Fritz Schumacher (1869-1947) y el pintor-arquitecto Peter Behrens (1868-1940) el 9 de octubre de 1907 fundan en Munich una asociación, que además de arquitectos, unió a industriales, artesanos, maestros, comerciantes, diseñadores y publicistas con la finalidad de ennoblecer el trabajo alemán, en una defensa por vincular lo artístico con lo industrial. Esta asociación entre industria, máquina, arte y artesanía la veían como la única solución para conseguir una estética de alta calidad, la Qualitätsarbeit, en los objetos producidos en serie. Entonces la máquina podía producir trabajos de alta calidad de tipo artesanal y artístico,

\footnotetext{
${ }^{132}$ Vittorio De Feo, Op. Cit., p. 41.
} 
desacreditando así las iniciativas de William Morris y su Arts and Crafts, que apelaban por la primacía de la artesanía.

El nombre de esta asociación fue Deustcher Werkbund (Liga Alemana de Talleres), agrupación que no defendía la artesanía, pero tampoco iba en contra del trabajo en serie. La Werkbund tuvo entre sus miembros a Josef Hoffmann (1870-1956), Joseph Maria Olbrich (1867-1908), Heinri Clemens Van de Velde (1863-1957), Hans Poelzig (1869-1936), Richard Riemerschmid (1868-1957), Bruno Taut (1889-1938), Walter Gropius (18831969), Henrich Tessenow (1876-1950), Paul Michael Nikolaus Bonatz (1877-1956), Fritz Schumacher (1869-1947), Bruno Paul (1874-1968), Theodor Fischer (1862-1938), Adelbert Niemeyer (1867-1932), Max Läuger (1864-1952), Paul Schultze-Naumburg (1869-1949), Jacob Julius Schraivogel (1854- ¿?).

Hermann Muthesius, quien había estado en Inglaterra durante seis años como agregado de la embajada alemana, estudió el diseño y la casa inglesa. Al regresar a su país difundió la idea de que para conseguir un equilibrio entre la vida diaria y el mundo exterior, habría que basar la experiencia en lo doméstico y en la sencillez. Muthesius proponía también un inmobiliario libre de adornos, con pulcritud en sus formas, lo mismo que para las construcciones arquitectónicas y los productos industriales, resaltando fuertemente la sobriedad de la composición.

Por su parte, Fritz Schumacher pensaba que para lograr la economía en la producción industrial había que vincular lo estético con lo ético, pues de esta manera se obtendría la calidad buscada y necesaria en los productos industriales. Otra de sus propuestas fue la de romper con lo enajenante que era el trabajo, mismo que debería estar en fuerte vinculación con las clases populares.

La Werkbund se convirtió en un centro de debates en el que los intelectuales hablaban sobre la imperiosa necesidad de entablar comunicación con la ciudad, la metrópoli, que con sus avances tecnológicos abrazaba toda la vida social. Dicha comunicación se convertiría en un instrumento purista con claridad de formas que aunadas a la "voluntad artística" (kunstwollen), entrarían en el capital económico en expansión, ideas de las cuales hablaba Schumacher. En sí, el Werkbund propugnaba por una correspondencia entre el artista y la industria. 
Para 1910, la asociación tenía setecientos treinta y un miembros: trescientos setenta artistas, doscientos setenta y seis industriales y noventa y cinco técnicos. En ese mismo año se expandía hacia Austria, fundándose así la Werkbund austriaca. En 1912 la Deutscher Werkbund sacó a la luz el primer catálogo, en el cual más de mil diseños publicados se conocieron, lo que provocó que se instituyeran organizaciones similares en Suiza, 1913; Suecia, entre 1910 y 1917; El Reino Unido, 1915, en donde se llamará Design and Industries Association (Asociación de Diseño e Industrias).

Desde 1912, año con año, la asociación organizaba su Jahrbücher, exposición donde se presentaban sus propios trabajos. El éxito de estas muestras alcanzó niveles de visita inesperados. Y apoyados en la base de sus propuestas, la relación entre artesanía, industria, arte, trabajos de orfebrería, vidriería, escultura, diseño industrial e inclusive pintura, se exhibieron con gran éxito. ${ }^{133}$

La magna exposición de 1914 en Colonia, dejó ver las grandes divergencias que se daban al interior de la Werkbund. Van de Velde estaba a favor de la individualidad creadora, de lo artístico, por lo tanto desacreditaba la unificación de formas, es decir, su bandera estaba en la autonomía del arte, mientras Muthesius apologizaba por la estandarización y tipificación de los objetos, por la uniformidad en el gusto, rechazando lo individual. Lo que parecía que podía caer en una escisión no se dio, pues el estallido de la I Guerra Mundial hizo que se suspendieran las actividades por cuatro años, para reanudarse en 1918, con el aplastante triunfo de los seguidores de Van de Velde: ganó lo artesanal.

En la arquitectura, la Werkbund contribuye desde un principio con un insólito caso: la fábrica de hormas de zapatos Fagus, en Alfeld an der Leine, cerca de Hannover, construida por Walter Gropius en 1911, con la colaboración de Adolf Meyer (1881-1929). El edificio tiene en su fachada una pared acristalada que abarca incluso las esquinas, sin necesidad de soporte alguno. Es el primer inmueble que utilizara una pared cortina que permite mirar hacia en interior. Una arquitectura abierta y novedosa acorde con la ideología de crear una estética germana que dominara el ámbito de las artes.

133 LAMPUGNANI, Vittorio Magnano. (ed.) Enciclopedia $G G$ de la arquitectura del siglo XX. Barcelona, Gustavo Gili, 1989, pp. 88-89. 


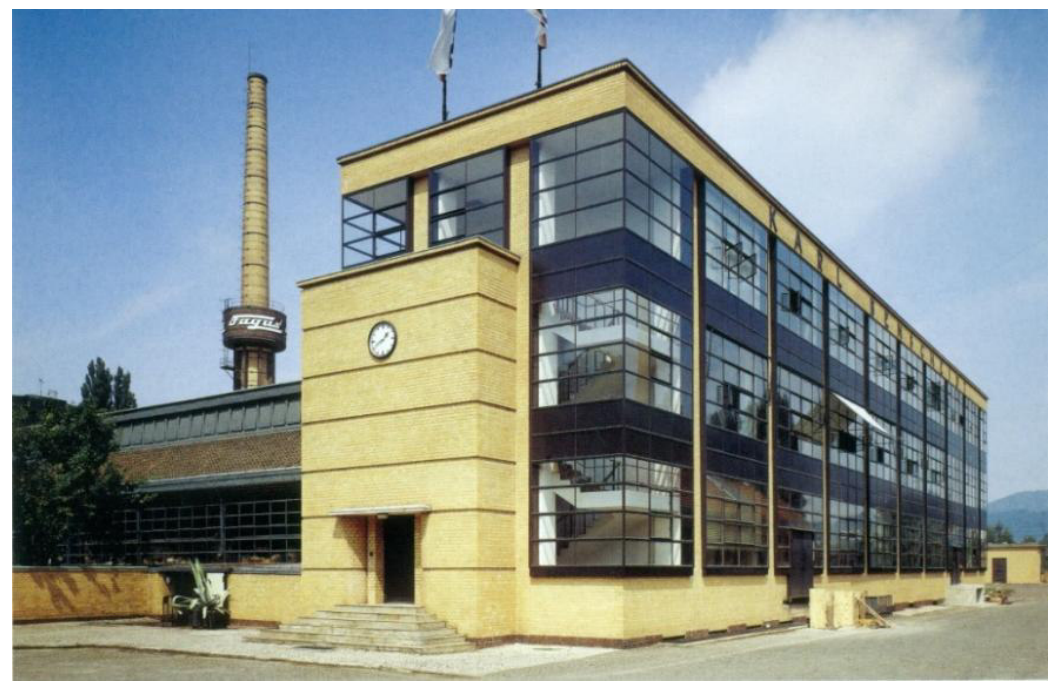

Walter Gropius y Adolf Meyer Fábrica Fagus, Alfeld an der Leine, 1911.134

El mismo Gropius, con la asociación de Meyer, participó en la exposición de Colonia de 1914 con el Modelo de Fábrica y Bruno Taut levantó su Glashaus (Casa de Vidrio), conformada por una gran cúpula compuesta con prismas, descansando sobre un tambor; las mismas escaleras eran también de vidrio, uno de los materiales incorporados a las construcciones modernas.

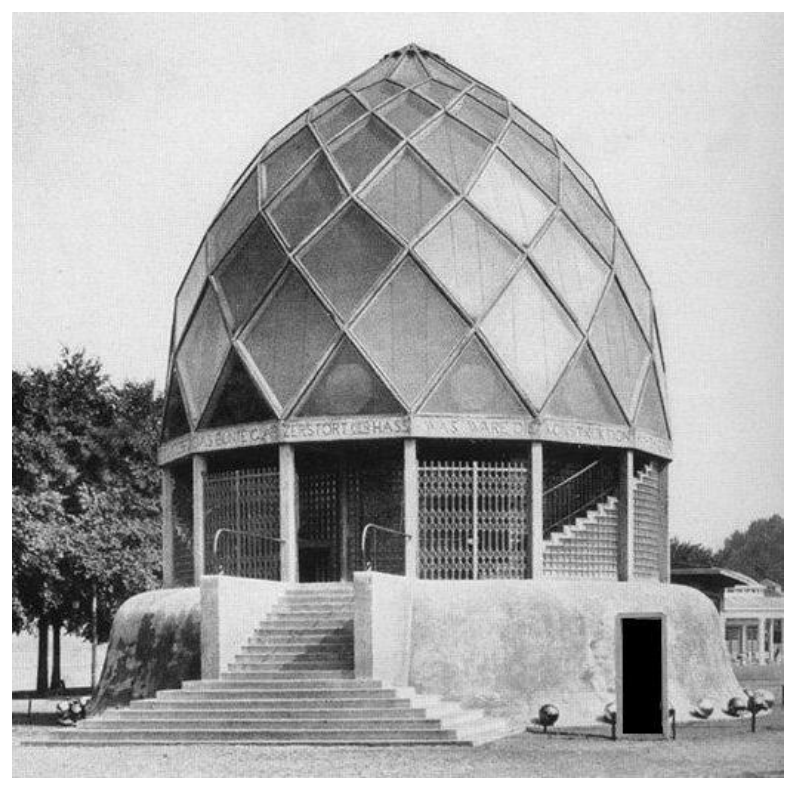

Bruno Taut, Glashaus, Colonia, $1914 .^{135}$

\footnotetext{
${ }^{134}$ Peter Grössel; Gabirele Leuthäuser, Arquitectura del siglo XX, Köln, Taschen, 2012, p. 140.

${ }^{135}$ Ibidem, Op. Cit., p. 167.
} 
Henri van de Velde presentó para la misma exposición el Teatro Werkbund, construcción más bien vinculada con el Art Nouveau por sus líneas curvas y adornos florales en la fachada, pero tratado con formas geométricas, lo que le ha valido ser considerado también como uno de los primeros edificios Art Déco. Una volada marquesina curvilínea hace juego con las escaleras en la puerta de recepción al teatro. Todo el inmueble, hoy destruido, fue tratado con elegante sencillez de formas.

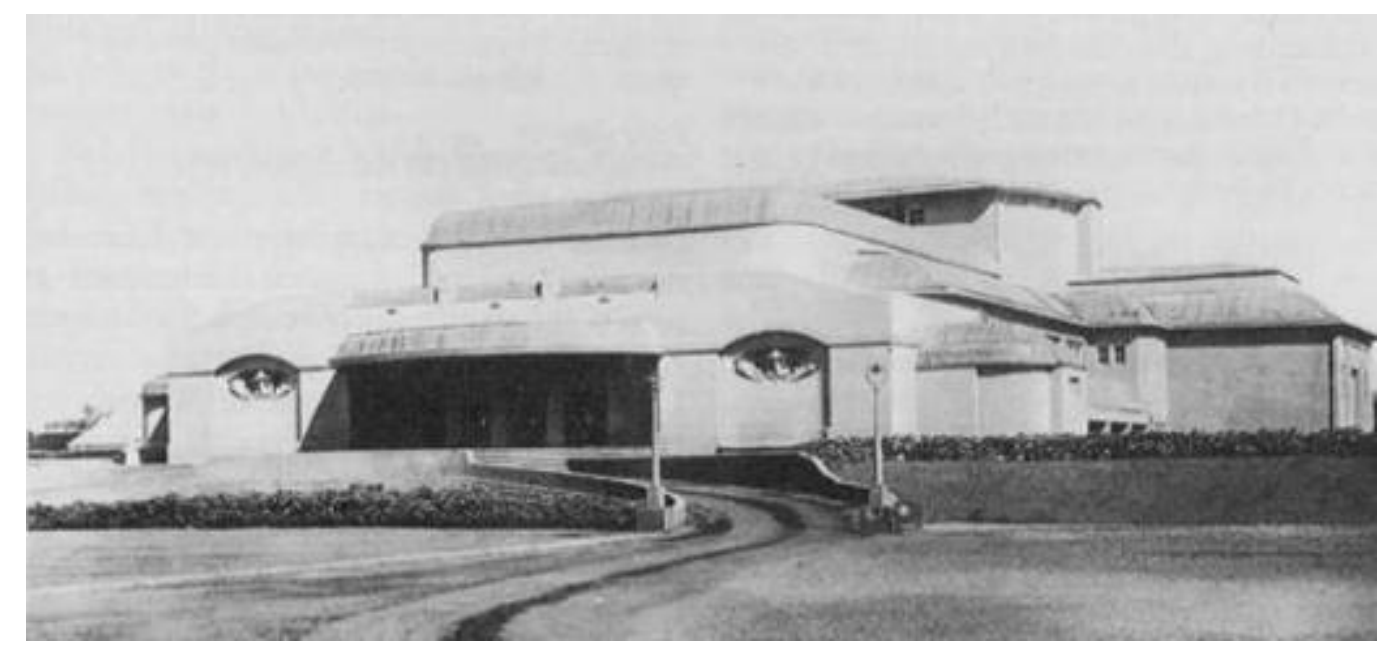

Henri van de Velde, Teatro Werkbund, Colonia, $1914 .^{136}$

Peter Behrens, uno de los más importantes miembros de la Deutscher Werkbund, estuvo en Glasgow, pues quería conocer la obra de Mackintosh, a quien rinde homenaje en Düsseldorf en la exposición Kunst und Gartenbau de 1904, al levantar el restaurante Jungbrunnen, en donde además de incluir un diseño de Gustav Klimt, los respaldos de las sillas fueron concebidos en forma de escaleras y los pisos trabajados con decoraciones al estilo Hoffmann. A partir de aquí la geometría y el cuadrado serán parte de Behrens.

Dentro de la Werkbund, Behrens trabaja para la AEG (Allgemeine ElektricitätsGesellschaft), Compañía Eléctrica General, a la cual fue invitado por el empresario industrial Emil Moritz Rathenau (1838-1915) en 1907, año, precisamente, de la fundación del Deutscher Werkbund. La tarea de Behrens en la $A E G$ incluía el diseño de aparatos electrodomésticos tales como: lámparas, calentadores, teteras, cafeteras, ventiladores, tostadores de pan, o bien objetos como relojes, rizadores y secadoras de pelo, voltímetros,

136 Vittorio Magnano Lampugnani, Op. Cit., p. 376. 
interruptores y motores; a la vez diseñaba los carteles, catálogos y publicidad en general de la empresa. Y hasta la construcción de las mismas fábricas fueron obra de Behrens, por lo que le ha valido ser considerado como el primer diseñador industrial de la historia. En sí, la labor de Behrens consistió en un proceso de humanizar la producción industrial.

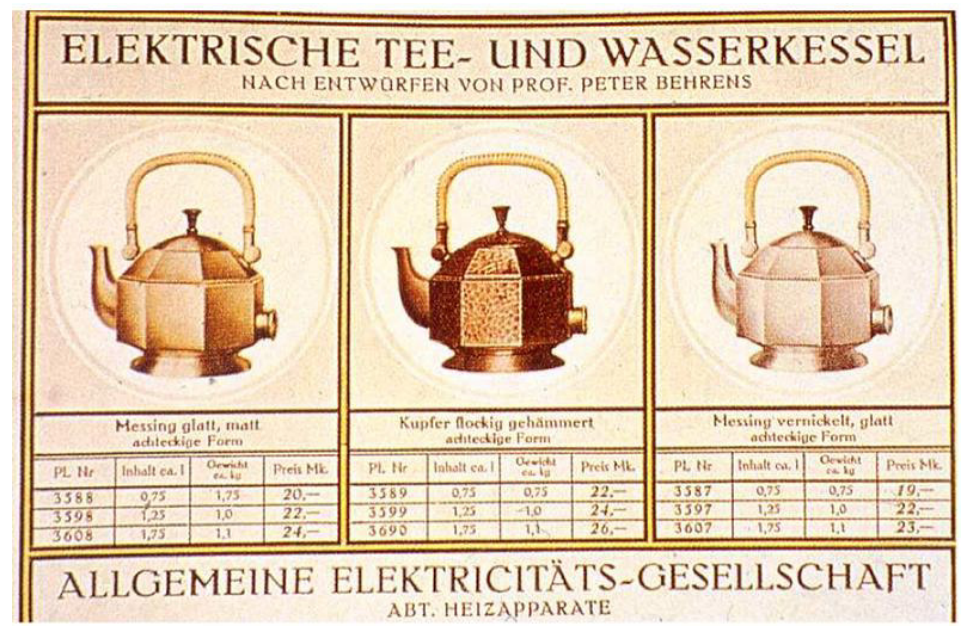

Peter Behrens, Folleto publicitario de teteras AEG, ha. 1910.137

La Fábrica de Turbinas de la AEG de 1909, Behrens la concibe como un templo de la industria berlinesa: los materiales como el acero y el vidrio engalanan la fachada que remata con un tímpano de ocho lados en donde luce el emblema de la compañía dentro de un hexágono. En el mismo Berlín otro edificio para la AEG, la Central de Alta Tensión de 1910, es un palacio con doble pórtico clásico geometrizado. Todo el edificio es una magnánima exaltación a lo geométrico, ya que se encuentra rodeado de ventanales cuadrados y rectangulares.

La Deutscher Werkbund contribuyó fuertemente a la apertura del Estilo Internacional, además de asentar las estructuras de lo que se desarrollará más adelante en la Bauhaus. A través de la pulcritud en los diseños, de la búsqueda de caminos para elevar la calidad de los productos industrializados, de la conexión entre vida urbana, arte, artesanía, industria y con la geometrización de sus construcciones y objetos terminados, nosotros inferimos que el Deutscher Werkbund es uno de los cimientos del Art Déco.

${ }^{137}$ Charlotte \& Peter Fiell, Op. Cit., p. 22. 


\subsubsection{De Stijl}

Pieter Cornelis Mondrian (1872-1944) conocido como PietMondrian, pintor holandés que atraído por el Cubismo se va a residir a París en 1911, regresará a su natal país en 1914. Más tarde conocerá a dos artistas: Bart van der Leck (1876-1958) y Theo van Doesburg (1883-1931). Afinidades y coincidencias con éste último desembocarán en la fundación de un estilo nuevo difundido a través de una revista en la cual sus colaboradores expresaban sus ideas sobre "el camino que el arte moderno iba a seguir". ${ }^{138}$

Esta revista se publicó de 1917 a 1931 y llevaba por título De Stijl. La nominación no fue una mera casualidad, ya que el término que significa "El Estilo", estaba muy en boga desde que Alois Riegl (1858-1905) con su escrito Problemas de Estilo (1893) y su doctrina del "Kunstwollen", la "voluntad artística", proponía el estudio de la historia del arte a través de estilos y decoración, entendiendo a la palabra estilo como un lenguaje formal para determinadas épocas y regiones. Más aún, el maestro arquitecto holandés Hendrikus Peter Berlage (1656-1934) creador del edificio de la Bolsa de Amsterdam, también había planteado en 1905 en su trabajo Reflexiones sobre el Estilo ideas al respecto de este tema. Entonces Mondrian y Van Doesburg buscaban crear el estilo no sólo para el arte holandés, sino para el arte universal.

De Stijl tuvo entre sus colaboradores, además de los ya mencionados, al flamenco Georges Vantongerloo (1886-1965), al diseñador Vilmos Huszár (1884-1960) de origen húngaro, al constructivista ruso El Lissitzky (1890-1941), al futurista italiano Gino Severini (1883-1966); a los dadaístas Kurt Schwitters (1887-1948), de origen alemán, al francés Hans Arp (1886-1966) y su esposa la alemana Sophie Taeuber-Arp (1899-1942); a los arquitectos y diseñadores holandeses Jacobus Johannes Pieter Oud (1890-1963), a Jan Wils (1891-1972), a Robert van't Hoff (1887-1979), a Cornelis van Eesteren (1897-1988) y al diseñador de muebles Gerrit Rietveld (1888-1964). Además, dentro del grupo estuvieron participando el pintor holandés César Domela (1900), la decoradora de interiores Truus Schröder-Schräder (1889-1985) también holandesa, el cineasta alemán Hans Richter

\footnotetext{
${ }^{138}$ Carsten-Peter Warncke, De Stijl. 1917-1931, Colonia, Taschen, 1993, pp. 9-10.
} 
(1888-1976), los diseñadores alemanes Karl Peter Röhl (1890-1975) y Werner Graeff (1901-1978), y el poeta holandés Antony Kok (1882-1969).

Las diferentes nacionalidades de los miembros de De Stijl muestra cómo se conformaba esta agrupación con un carácter verdaderamente universal, lo cual se verá reflejado en la filosofía del grupo, la cual se basaba en la forma y el color, la superficie y la línea, en una expresión artística que renuncia a la individualidad del proceso creativo para producir un arte universal, el cual estaba fundamentado en la abstracción a través de lo geométrico y matemático, desacreditando todo lo anecdótico, lo figurativo, así como el mundo de los objetos. Se apoyó, en un principio, en la línea recta, el cuadrado y el rectángulo y los tres colores primarios: rojo, amarillo y azul, además de una escala de tonalidades grises. Todos estos elementos entran en oposición concordante entre espacio y tiempo, reposo y movimiento, que para Mondrian era "lo verdadero" en donde se encontraba precisamente "lo bello".

Fue el artista Piet Mondrian quien elaboró la doctrina que dio sostén teórico al grupo De Stijl. Influido, al igual que Doesburg, por las ideas del matemático y teósofo el Dr. Mathieu Hubertus Josephus Schoenmaker (1875-1944), por la tradición del Idealismo en Europa, desde Platón (¿428 ó 427? a. C. - 347 a. C.), pasando por el Idealismo místico del "separarse del todo" de Plotino (¿203 - 269 ó 270?) hasta llegar a George W. Friedrich Hegel (1770-1831); orientado por el calvinismo holandés y además de integrar a su pensamiento, lo mismo que Vantongerloo, la ética de Baruch Spinoza (1632-1677) ${ }^{139}$ conocida a través de la famosa obra Ética demostrada en un orden geométrico, publicada en el año de su muerte, Mondrian creyó que el arte podría ser una guía para la humanidad. Trabajó, junto con algunos miembros del grupo, un estilo abstracto encaminado a buscar leyes de armonía y equilibrio tanto para la vida como para el arte, las cuales desembocaran en una concepción universal, espiritual y armoniosa del universo.

Mondrian proponía que con la eliminación de efectos causales de apariencia o del mundo de los objetos, así como de la arbitraria perspectiva de lo individual, se conseguiría un arte librado de la percepción visual momentánea y del temperamento individual del artista, con lo que se llegaría, entonces, a crear una visión pura, acompañada del espíritu, la conciencia y la vida interior. Así pues, visualizó liberar al arte de sistemas extraños de

\footnotetext{
${ }^{139}$ Carsten-Peter Warncke, Op. Cit., p. 73.
} 
valor, para otorgarle la libertad y de esta manera poder crear sus propias leyes. Por la ya mencionada influencia del calvinismo holandés, Mondrian afanosamente inquirió en plasmar una pureza en el arte que estuviera más allá de lo meramente representativo, concepto que proviene de la palabra en holandés schoon, la cual significa pureza y belleza, que el artista consolidó en sus composiciones abstractas a través de líneas, cuadrados, rectángulos, los colores elementales azul, rojo y amarillo, además de incluir como soportes de composición el blanco, el negro y el gris.

Lo subjetivo y lo emocional deberían ser eliminados del arte, por lo que la depuración de las formas sólo se conseguiría a través de lo geométrico. "La única ley indiscutida debía ser la del color unido, compacto, plano, puro, alejado de cualquier aproximación emotiva". ${ }^{140}$ A esta teoría de Mondrian se le conoció con el nombre de Neoplasticismo, el "nieuwe beelding” que significa "la nueva manera de configurar" que representó como tal la filosofía del grupo De Stijl. Las famosas "Composiciones”, como Composición I con rojo, amarillo y azul, 1921 o Contra-composición VIII, 1924, o bien, los cuadros Composición XXII, 1920-1922, y Contra-composición con disonantes XVI, 1925 de Van Doesburg, pueden servir como ejemplificaciones de las propuestas neoplasticistas, obras en que lo negro de las líneas y el blanco del fondo equilibran los cuadros de colores.

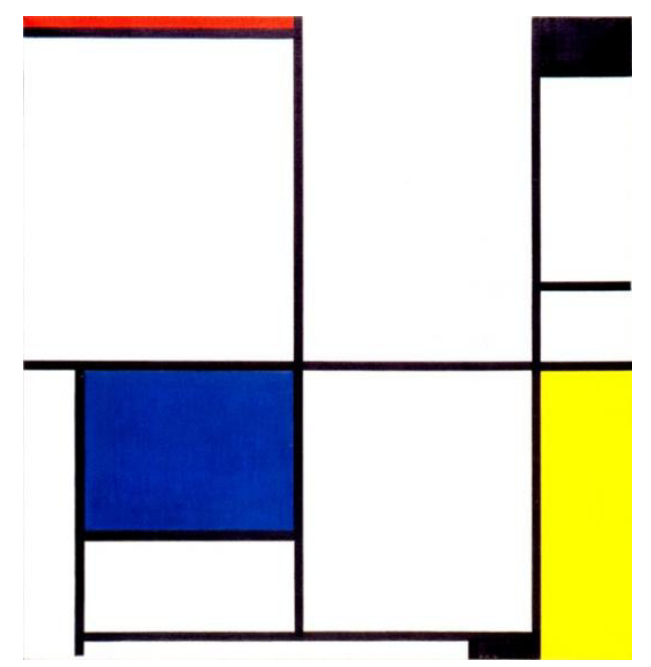

Piet Mondrian, Composición I con rojo, amarillo y azul, 1921.

Gemeentemuseum, La Haya. ${ }^{141}$

140 Mario de Micheli, Op. Cit., p. 282.

${ }^{141}$ Carsten-Peter Warncke, Op. Cit., p. 62. 


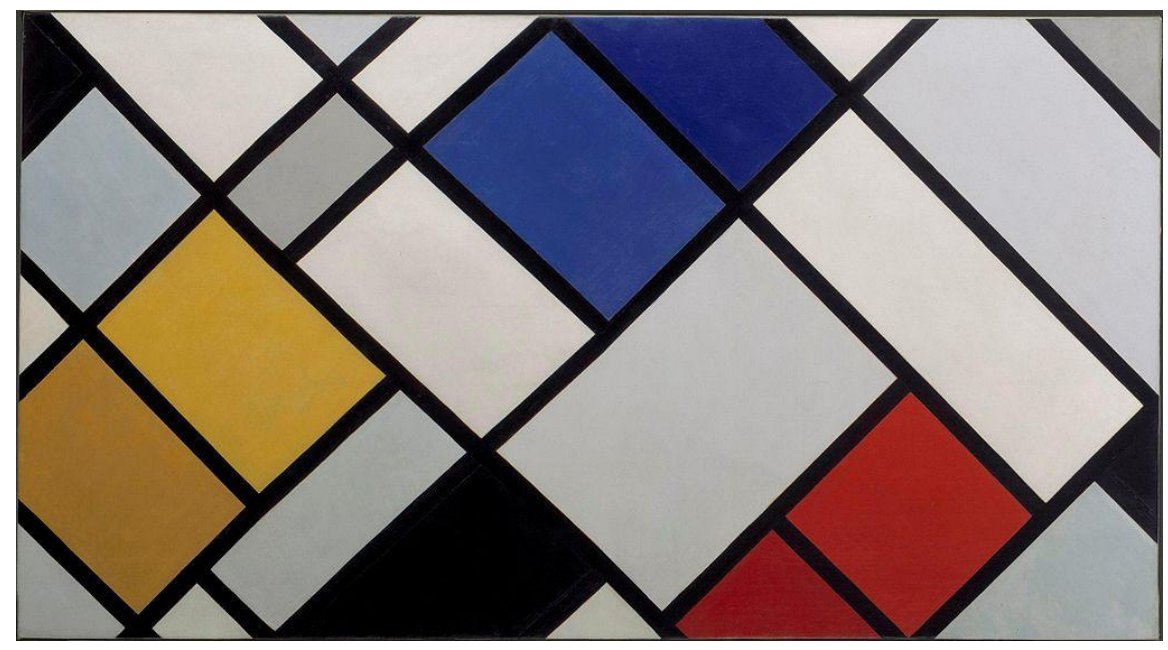

Theo van Doesburg, Contra-composición con disonantes XVI, 1925. Gemeentemuseum, La Haya. ${ }^{142}$

En los Prefacios y Manifiestos del grupo, quienes los escriben disertan, además de lo ya expuesto, sobre la necesidad de una comunidad espiritual para expresar lo bello, de un reciente y original espíritu, así como de una nueva Europa que rompa con las tradiciones del pasado:

"Primer Manifiesto de la Revista <De Stijl>, 1918.

1. Hay una vieja conciencia del tiempo, y hay otra nueva.

La primera tiende al individualismo.

La nueva tiende hacia lo universal.

3. El arte nuevo ha puesto en evidencia el contenido de la nueva conciencia del tiempo: proporciones equilibradas entre lo universal y lo individual.

Manifiesto III: hacia la formación de un mundo nuevo.

...Una nueva Europa está naciendo en nosotros. Sólo junto a ellos será posible modelar el cuerpo espiritual del nuevo mundo. ¡Actuad!”. 143

En 1918, Bart van der Leck incluye en una de sus obras las líneas diagonales, como en su obra Composición, lo cual crea una discusión entre los miembros del grupo, pues con la inclusión de esas líneas se podría crear la ilusión de la espacialidad y eso era algo contra lo que estaba, precisamente, De Stijl. Theo van Doesburg rechazó la idea, pero Mondrian ve la posibilidad de incluir las diagonales; sin embargo, para no ir en contra de lo que él

\footnotetext{
${ }^{142}$ Ibídem, p. 77.

${ }^{143}$ Ibídem, pp. 416, 418-419.
} 
defendía, Mondrian pinta con diagonales, pero el cuadro lo cuelga de una de sus esquinas, convirtiéndose así las líneas en rectas verticales y horizontales, tal es el caso de Rombo: superficies claras con contornos grises, 1919.

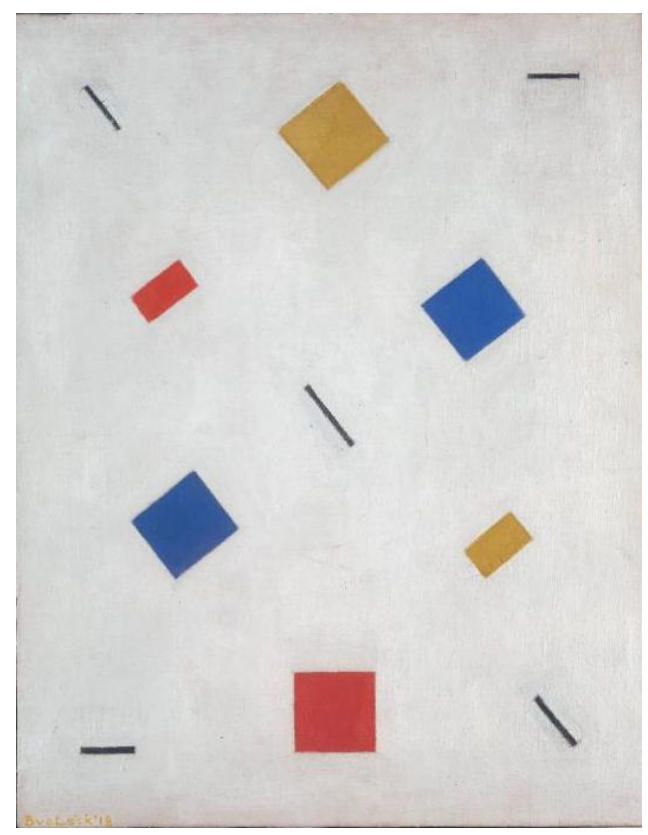

Bart van der Leck, Composición, 1918.

Tate Gallery, Londres. ${ }^{144}$

Esta diferencia de criterios provoca que Van Doesburg acoja una actitud en contraposición con Mondrian y cree su propia teoría a la cual llama Elementarismo, misma que explicó de la siguiente manera:

"La composición rectangular, en la que quedaron neutralizadas tensiones extremas líneas horizontales y verticales -, presentaba una cierta homogeneidad con el estatismo de la arquitectura, lo que debía considerarse como un relicto de la tradición clásica. La contracomposición (o composición anti-estática) se ha liberado de tal homogeneidad. Su relación con la arquitectura, de signo contrario (y que se produce a otro nivel) puede compararse con el contraste entre la arquitectura blanca y plana y la gris y sinuosa naturaleza. El Elementarismo ha liberado por fin a la pintura de la convención". ${ }^{145}$

\footnotetext{
144 TATE, "Bart van der Leck. Composition 1918”, http://www.tate.org.uk/art/artworks/leck-compositiont00896

${ }^{145}$ Mondrian en Carsten-Peter Warncke, Op. Cit., p. 81.
} 
Además de las divergencias mencionadas, Van Doesburg estaba a favor de un arte en constante cambio, con un desarrollo permanente e inmiscuido en el desarrollo social, mientras que Mondrian favorecía la conservación de ideas invariables dentro de un progreso lineal. Aunado a lo anterior Mondrian se oponía a la inclusión de la curva en la escultura como lo había hecho Vantongerloo, pues con esto se conseguían las tres dimensiones espaciales y esto para Mondrian era regresar a los arcaísmos estéticos contra los cuales tanto él había luchado.

Para 1924 Mondrian, líder ideológico y espiritual de De Stijl, se separa del grupo y seguirá con su propia filosofía y quehacer artístico de manera individual.

La difusión del movimiento se debió definitivamente a Theo van Doesburg, quien a partir de 1920 viaja dando conferencias por Francia, Europa Central y Alemania, país en el cual las influencias dejadas en la Bauhaus harán eco en el arquitecto Mies van der Rohe. En Francia, aunque la influencia de De Stijl fue menor, se presentó una exposición del movimiento en el año de 1923 en la galería L'Effort Moderne de París, propiedad de Léonce Rosenberg (1879-1947), el marchante de arte que al lado de su hábil hermano Paul (1881-1959) descubría nuevas figuras artísticas y quien además le publica a Piet Mondrian su tratado sobre el Neoplasticismo en 1920. En dicha exposición convergieron las tendencias que habían formado el desarrollo del movimiento y que hicieron que aquélla fuera como una retrospectiva, además de que con esta muestra el De Stijl tuvo una amplia propalación.

En el campo de la escultura, es la personalidad de Gerrit Rietveld la que simboliza al De Stijl. Hijo de un ebanista de Utrecht, es ahí, en el taller de su padre, donde aprende sus primeros rudimentos de carpintería. Desde 1906 escucha los cursos del arquitecto Pieter Jan Christopher Klaarhamer (1874-1954), pero es hasta 1908-1911 y 1915 cuando realmente se vuelve su alumno, al mismo tiempo de que colaboró con él construyéndole algunos muebles. Además del contacto con Klaarhamer, Rietveld también estuvo en relación con Van der Leck, lo cual hizo que Rietveld tuviera ya influencias del movimiento De Stijl. El contacto de Rietveld con Theo van Doesburg se dará hasta 1919, fecha en la cual se integra tanto al grupo como a la publicación de la revista, cuando ya es reconocido tanto como arquitecto como maestro carpintero. 
La obra que elabora Rietveld dentro de los principios De Stijl y que es considerada como su punto de arranque dentro de este movimiento es la notable Silla Rojiazul, 19181923. Aunque iniciada desde 1918, la silla tendría su configuración total hasta 1923, que Rietveid experimentó con diferentes versiones en las cuales había cambios, ya fueran de material o de medidas, pero la silla definitiva hecha en madera mide ochenta y ocho centímetros de altura y está armada por trece piezas, mismas que se encuentran unidas y ensambladas con tarugos y agujeros perforados, salvo en el asiento y respaldo, pues el peso lo obligó a atornillar esas partes. Esta silla estaba formada y construida "por dos tablas y un cierto número de listones de madera, con el fin de mostrar que la belleza y un objeto espacial pueden obtenerse sin otra cosa que simples materiales y elementos industrializados", ${ }^{146}$ tal como lo expresara el propio Rietveld años después de su conclusión.

La silla es un conjunto de piezas que llevan la idea de no ensamblarse, como si cada elemento solamente estuviera yuxtapuesto. El caso del respaldo y el asiento no llegan a tocarse, pues cada uno está apoyado en su respectivo armazón. Los colores utilizados son los propuestos en los principios De Stijl: amarillo en los cortes de los soportes los cuales están pintados de negro, rojo en el respaldo y azul en el asiento; esto consigue un efecto de anular cualquier referencia con el mundo natural o con algún tipo de decoración, es decir, obtener un verdadero proceso de desnaturalización. El resultado, una utopía hecha realidad que le valió ser considerada por Theo van Doesburg como una obra "tipo" del movimiento De Stijl, además de convertirse en una articulación entre la pintura abstracta y los conceptos arquitectónicos-espaciales del grupo.

La técnica y la estética en la Silla Rojiazul es una composición aparentemente sencilla, aunque en realidad es compleja, es un objeto de análisis y a la vez útil (pues no es cierto que no sirva para sentarse), porque es un mueble de piezas que conforman un conjunto ortogonal, cuya composición plástica en la que se resalta la geometría en un mueble como nunca antes se había hecho, la hacen ser una primicia y referencia del diseño moderno y contemporáneo.

\footnotetext{
${ }^{146}$ Rietveld en S/A. El mueble del siglo XX. Art Deco, Barcelona, Planeta-Agostini, 1989, p. 74.
} 


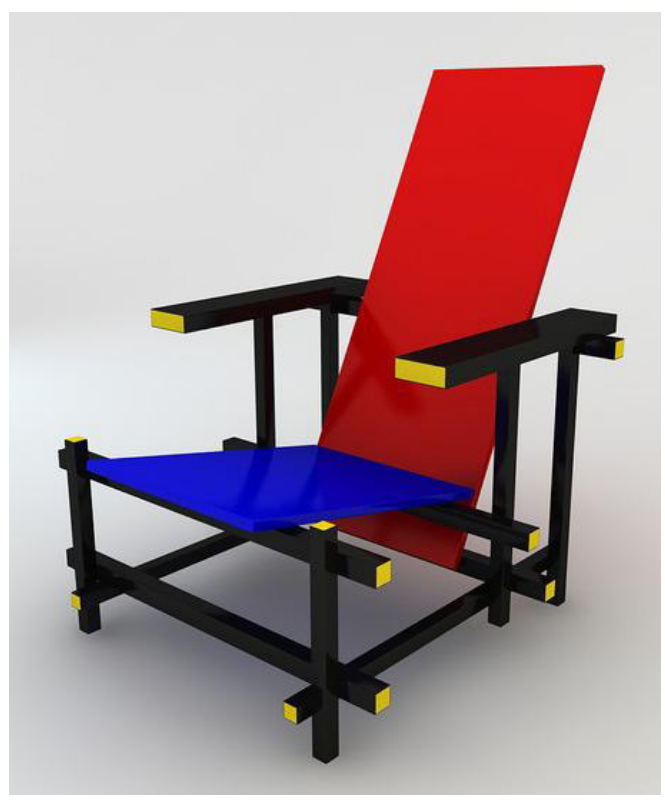

Gerrit Reitvel, Silla rojiazul, 1918-1923.

Stedelijk Museum, Amsterdam. ${ }^{147}$

Rietveld continuará con el grupo De Stijl en el ascenso de su carrera como carpintero y diseñador al elaborar más muebles con la experiencia lograda de la yuxtaposición de partes; tal es el caso del Aparador de 1919, pintado de color blanco, o la Mesa auxiliar de 1923, copia de la firma Cassina di Meda, en la que los colores primarios se aúnan al negro y blanco, o bien, la Silla Berlín también de 1923, en donde los grises van descendiendo de tonalidades, combinados con lo blanco de los soportes.

Mas hay una relación entre el diseño de muebles y la arquitectura en la obra de Rietveld que es la Casa Rietveld-Schröder, proyectada y construida en 1924 en Utrecht. La dueña, la señora Truus Schröder-Schräder (1889-1985), era decoradora de interiores por lo que participó con algunos diseños para el atavío de la casa. Un año más tarde la Sra. Schröder-Schräder se afiliaría al De Stijl. "La Casa Rietveld-Schröder puede considerarse como el ejemplo más logrado de una aplicación resuelta y consecuente de los principios estéticos de Stijl”, ${ }^{148}$ afirma Carsten-Peter Warncke. Utilizando los colores primarios azul, amarillo y rojo, además del negro, gris y blanco, la construcción es una superposición de elementos, tanto en el exterior como en el interior, en cuyo espacio se consigue una relación geométrica de sus partes, pero sin necesidad de la simetría.

\footnotetext{
${ }^{147}$ Cartens-Peter Warnke, Op. Cit., p. 121.

148 Ibídem, Op. Cit., p. 134.
} 
Las superficies que comprenden el conjunto están dispuestas vertical y horizontalmente; por su disposición pareciera como si estuvieran montadas y desmontadas a la vez. Las tres fachadas del exterior pueden cualesquiera de ellas ser la principal; los muros están pintados de blanco y son recortados por los soportes, balcones y maineles de las ventanas que van en los colores amarillo, rojo, azul y negro. En el interior, con mobiliario del propio Rietveld, la concepción de la abstracción geométrica, límpida de referencias naturales, le da un sentido de arritmia espacial moderna, como sucede en la planta alta donde las paredes móviles permiten que se pueda crear un solo espacio.

La Casa Rietveld-Schröeder fue la tesis de las ideas de De Stijl, pues se convirtió en realidad la utopía y la teoría; y aunque se considera como la aportación plástica de conjunto más reveladora del movimiento, sin embargo hay otras significativas aportaciones a la arquitectura.
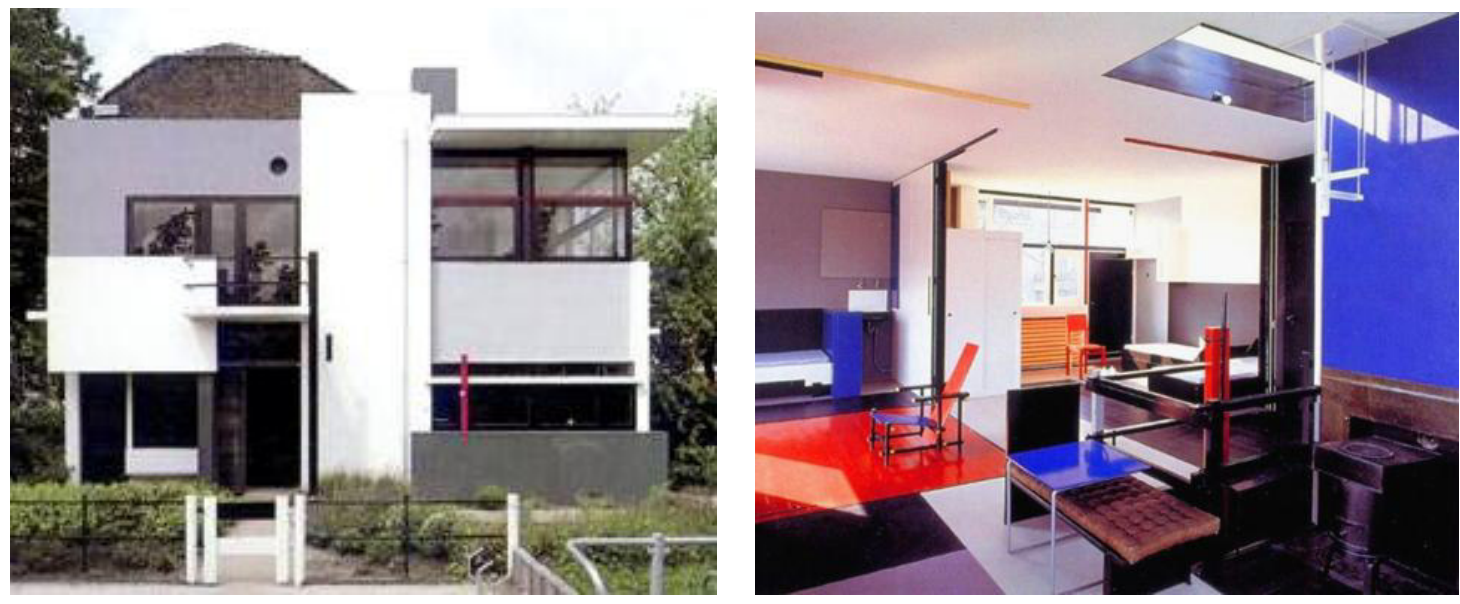

Gerrit Rietvel, Casa Rietveld-Schröder, vista lateral ${ }^{149}$ e interior ${ }^{150}$, 1923, Utrech.

En 1985, a raíz del fallecimiento de la Sra. Schröder-Schräder, la casa fue restaurada y actualmente está abierta al público en calidad de museo, bajo la administración del Museo Central de la Ciudad.

Antes de la construcción de la Casa Rietveld-Schröeder, en el año 1922, Theo van Doesburg y Cornelis van Eesteren publicaron en el revista De Stijl un manifiesto en el cual hablan de la correspondencia única entre pintura-escultura-arquitectura; también mencionan

\footnotetext{
${ }^{149}$ Peter Gössel y Gabriele Leuthäuser, Op. Cit., p. 195.

${ }^{150}$ Cartens-Peter Warnke, Op. Cit., p. 141.
} 
la relación de un nuevo espacio interior, el cual se logra a través de la exclusión de muros. Una parte del Manifiesto dice así: "Eliminando los elementos de limitación (muros, etc.) hemos eliminado la dualidad entre el interior y el exterior. Hemos dado al color en la arquitectura el lugar que le corresponde legítimamente y afirmamos que la pintura separada de la construcción arquitectónica (es decir, la pintura de caballete) no tiene razón de existir". 151

Van Doesburg y Van Eesteren tuvieron un proyecto nunca realizado denominado la Maison particuliere, 1923, que consiste en un gran núcleo de cubos ordenados que conforman tres plantas, cuyas paredes pintadas con los colores primarios, además del negro y el blanco, dan la idea de espacialidad tridimensional, como si un cuadro de caballete se transformara en volúmenes acoplados entre sí. Aún se conservan los famosos dibujos axonométricos (es decir, la proyección de un cuerpo desde un plano) desde diferentes vistas en el Rijksdienst Beeldende Kunst de La Haya.
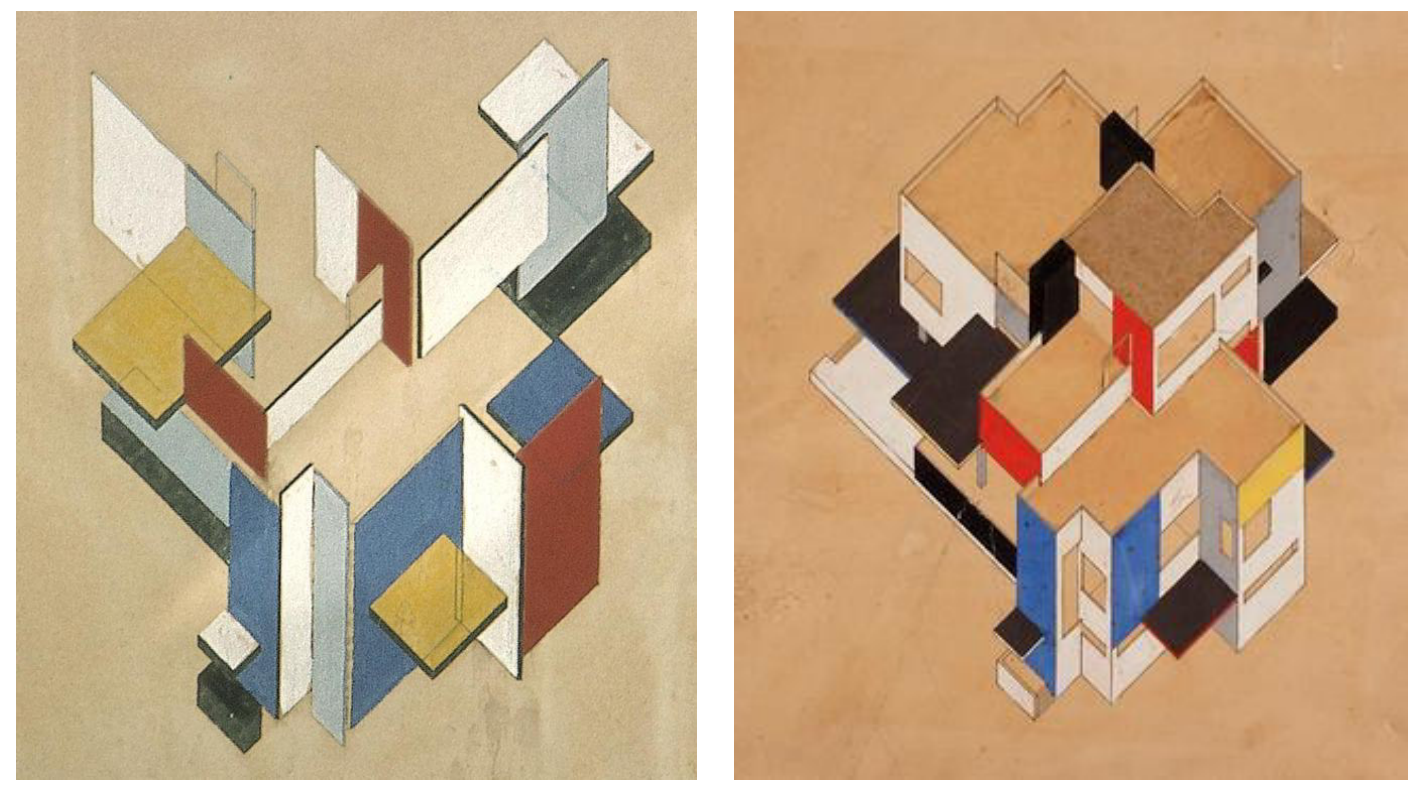

Theo van Doesburg, Contra-contrucción y Dibujo axonométrico de la Maison particuliére, 1923. Rijksdienst Beeldende Kunst, La Haya. 152

Pese a que a Mondrian no le interesaban los problemas arquitectónicos es importante mencionar la escenografía que diseñó para la obra de teatro L'Ephémére est

\footnotetext{
151 Theo van Doesburg en Delfín Rodríguez Ruiz, Op. Cit., p. 60.

${ }^{152}$ Cartens-Peter Warnke, Op. Cit., pp. 168 y 165.
} 
éternel del pintor abstracto y poeta Michel Seuphor (1901-1999), empeñoso propagador del arte abstracto y en gran medida biógrafo de Mondrian, pues publicó la monografía Piet Mondrian, su vida, su obra en 1956. La puesta en escena no se pudo llevar a cabo por complicaciones económicas; sin embargo, hoy podemos conocer las maquetas gracias a unas reconstrucciones hechas en 1964, las cuales se conservan en el Stedelijk Van Abbemuseum en Eindhoven. En una puerta rectangular los colores azul y rojo están en los extremos del soporte izquierdo sobre fondo blanco y en el otro extremo de la puerta el ancho es más amplio y está trabajado con dos tonalidades grises divididas por una línea negra horizontal; en el travesaño blanco, cargado hacia la derecha y uniéndose a las tonalidades grisáceas, el amarillo descansa sobre una línea blanca horizontal, pero se divide del resto por una línea vertical negra; la portería es como un indiviso unificado que se proyecta hacia el frente de espectador. El fondo está compuesto por cuadros y rectángulos, que en los tres modelos reconstruidos varían en sus coloraciones primarias separadas por líneas negras, todo descansando sobre fondo blanco. El piso blanco separado por líneas negras sólo aparece acompañado por el color gris. Una pequeña pilastra cuadrangular en color negro es recortada en su remate, a manera de un capitel por el color blanco. El conjunto asemeja una de las múltiples composiciones de caballete de Mondrian, pero proyectada hacia atrás, como un rehundido geométrico, cúbico. Piet Mondrian, pese a su aferrada defensa de lo plano, cae en la tridimensionalidad arquitectónica.
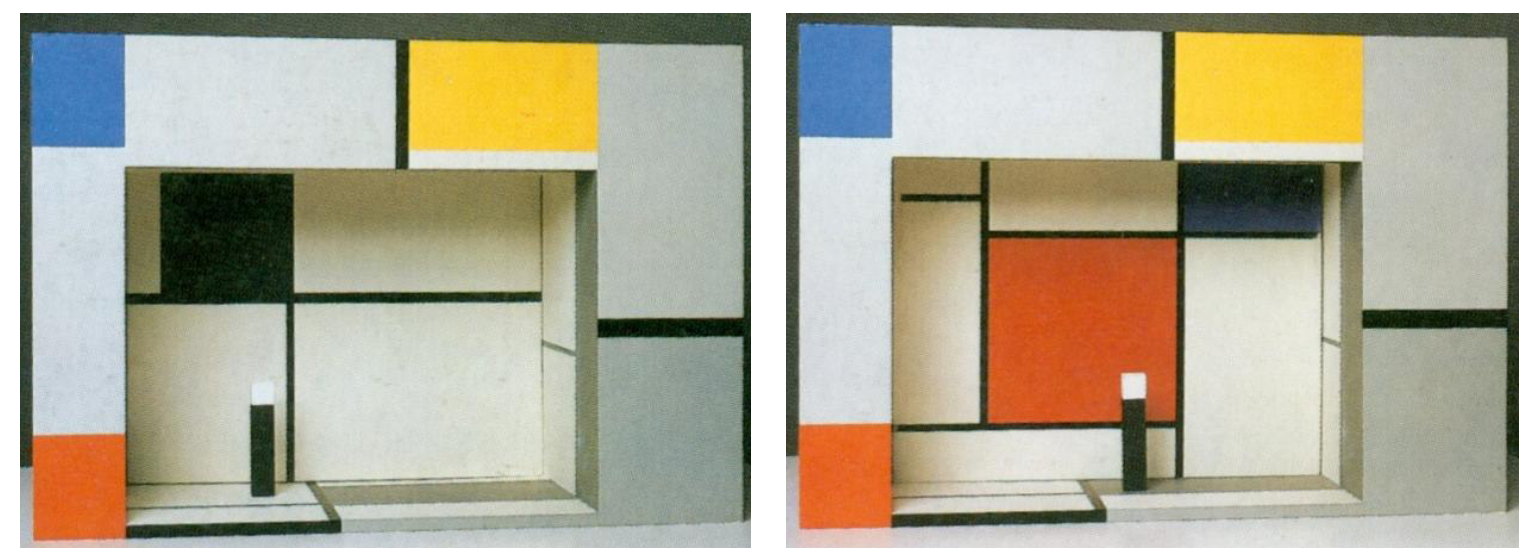

Piet Mondrian, Reconstrucciones de la escenografía para la obra L'Ephémére est éternel, 1926. Stedelijk Van Abbe Museum, Eindhoven. ${ }^{153}$

${ }^{153}$ Ibídem, p. 176. 
Otro de los edificios capitales del De Stijl dentro del campo de la arquitectura fue la remodelación del Café Bal Aubette en la ciudad de Estrasburgo. Dentro ya de una fase de expansión del movimiento, la aportación de Van Doesburg cobra doble importancia, pues el trabajo que realiza en este establecimiento es fuera de su país, por lo que la propagación del De Stijl, como ya lo habíamos mencionado, mucho se debió a este artista. Aunque el plan de modernizar la decoración del local fue dado a Hans Arp y a su esposa Sophie TaeuberArp, ellos invitaron a Van Doesburg, quien prontamente se convirtió en el director del proyecto, el cual duró de 1926 a 1928.

Dentro de los múltiples espacios esparcidos por cuatro pisos del edificio, Van Doesburg se encargó de la planta baja, en la que se encontraban la cafetería y la cervecería, y del primer piso donde aderezó los grandes salones, a excepción del "bar-foyer". En estos espacios Van Doesburg aplicará sus proposiciones "elementaristas" al incluir líneas diagonales en las decoraciones de techos y paredes, además de introducir el verde y otras tonalidades leves del azul. A esto se aúna la iluminación natural y artificial que en conjunto con el color, el artista obtuvo una composición verdaderamente abstracta con movimiento.

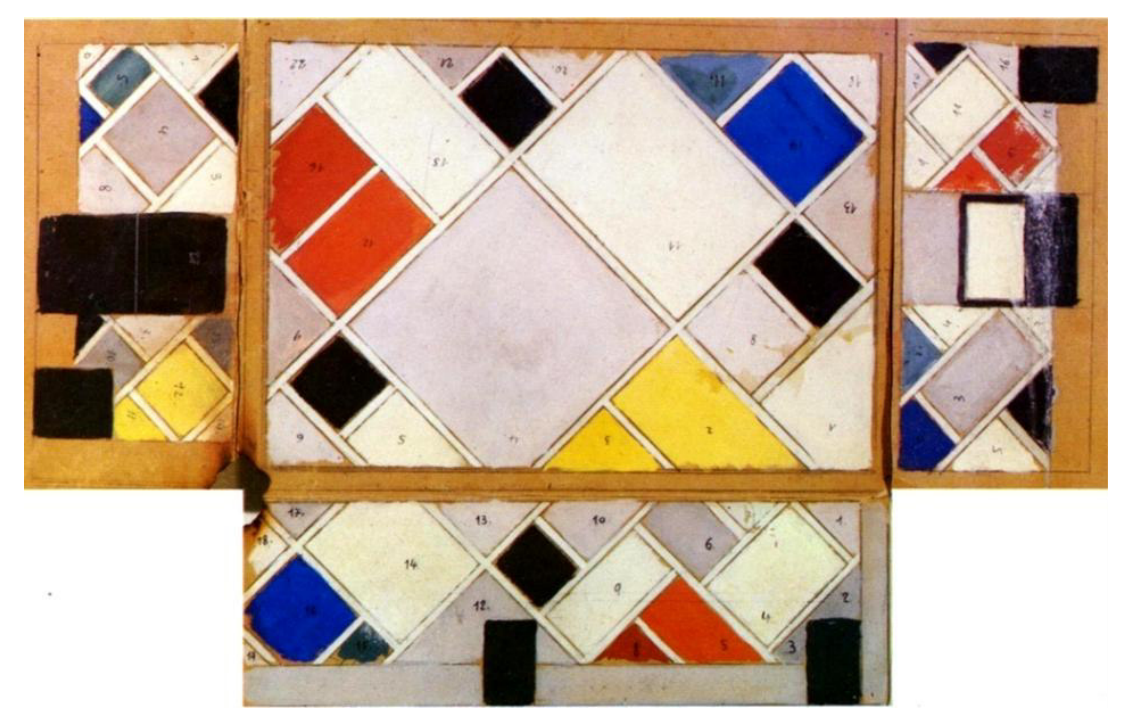

Theo van Doesburg, Disposición de los colores para el gran salón de fiestas en el Café Bal Aubette, Strasburgo. 1927. ${ }^{154}$

Jacobus Johannes Pieter Oud como aportación a la arquitectura dentro del De Stijl, levantó entre 1927-1930 un conjunto de viviendas en Rotterdam conocido como Kiefhoek,

\footnotetext{
${ }^{154}$ Ibídem, pp. 188-189.
} 
pero es otro grupo de casas ubicadas en el Hoek van Holland, construidas entre 1924-1927 el más conocido. Aquí con sencillez de formas geométricas en puertas y ventanas, así como en las divisiones del exterior de la segunda planta, las cuales están trabajadas en retículos cuadrados ligeramente curveados en las esquinas, lo blanco de las paredes conjuga con las jardineras frontales trabajadas en ladrillo. Como un todo armónico, la parte final del conjunto termina en una forma curva. Esta edificación predice su entrada al Estilo Internacional.

En la Exposición Internacional de Arquitectura en 1927 llevada a cabo en Stuttgard, Oud presentó un proyecto de casas adosadas, mismo que se levantó en la Weissenhofsiedlung: cinco casas que se componen de un conjunto de cubos, tanto por el frente como por atrás, con formas abiertas en ventanas y puertas y formas cerradas en las paredes. Los balcones son un conjunto de líneas horizontales, lo mismo que las rejerías que dividen los jardines delanteros.

Si bien ya las casas de Hoek van Holland tenían un lenguaje que apuntaba hacia lo internacional de la arquitectura, con las casas de Stuttgard el De Stijl se difunde al exterior de Holanda, con el beneplácito de arquitectos tales como Mies van der Rohe y Le Corbusier.

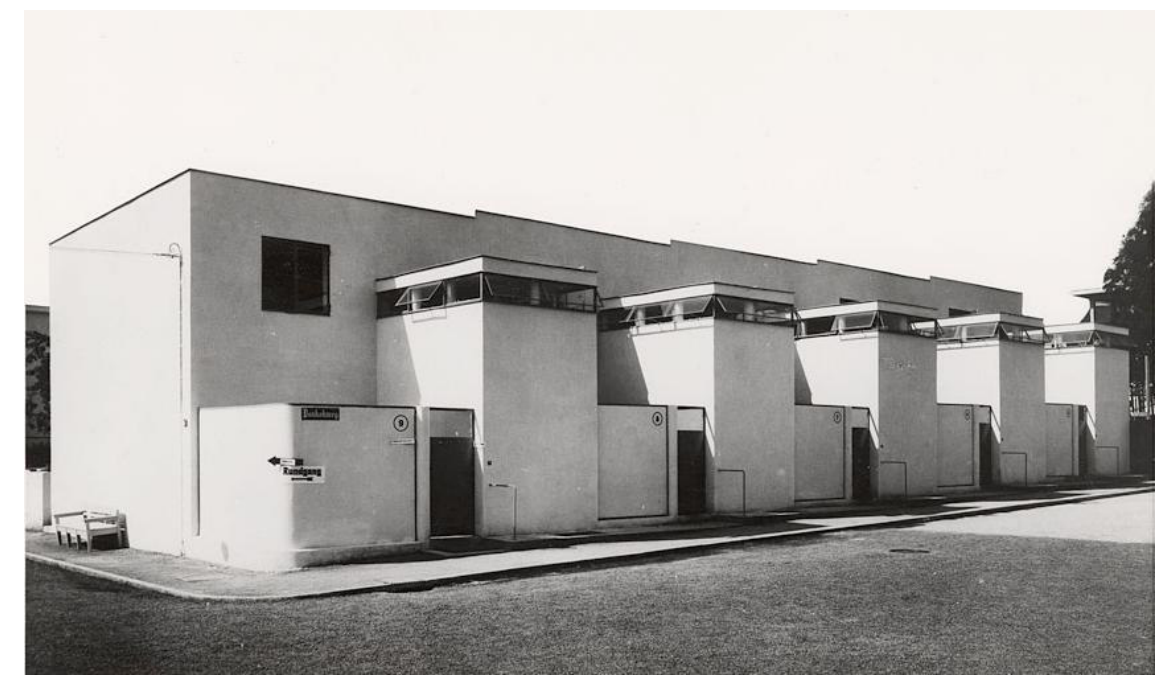

Jacobus Johannes Pieter Oud, Imagen de la época de la vista trasera de las casas en la Weissenhofsiedlung, Stuttgart, 1927.155

\footnotetext{
${ }^{155}$ Ibídem, p. 194.
} 
Es muy significativa la aportación del De Stijl al Art Déco, pues las propuestas geométricas, así como la sencillez de sus composiciones se verán aplicadas en las formas Déco.

\subsubsection{Bauhaus}

En 1903 el holandés Henry Clemens Van de Velde fundó en Weimar la Kunstgewerbeschule, (Escuela de Artes y Oficios), pero en esta ciudad también existió la Hochschule für Bildende Kunst (Escuela de Bellas Artes). Un año después de terminada la I Guerra Mundial, se pensó en fusionar ambas escuelas y para dirigirlas la decisión de Van de Velde y de algunos profesores de la Escuela de Bellas Artes fue la de considerar al arquitecto Walter Gropius. Tomemos en cuenta que ya desde 1914 Van de Velde fue obligado a dejar el puesto de la escuela de Artes y Oficios y le sugirió al Duque de Sajonia a Gropius para la dirección, quien ya se había hecho famoso a raíz de la construcción, en colaboración con Adolf Meyer de la fábrica Fagus.

De 1914 a 1918 Walter Gropius ve sus actividades interrumpidas al alistarse en el ejército alemán, pero en abril de 1919 la Escuela de Bellas Artes y la de Artes y Oficios serán una misma entidad dirigida por Gropius que recibió el nombre de Das Staatliche Bauhaus Weimar, conocida comúnmente como la Bauhaus.

En un principio la Bauhaus le da una vital importancia a la artesanía y a la fusión de las diversas manifestaciones artísticas dentro del mundo industrial, pues no hay diferencia entre el artista y el artesano, ya que el primero es un artesano especializado y el segundo un verdadero trabajador industrial especializado. Estas ideas se expresan en el Manifiesto inaugural de Gropius de 1919: "Forjemos, pues, un nuevo futuro de artesanos más allá de la petulancia que quiere separar las clases creando una altiva barrera entre el artesano y el artista. Querramos, pensemos y creemos comúnmente las nuevas construcciones del futuro que lo convertirán todo en una sola figura: la arquitectura y el arte plástico y la pintura, unidos por millones en manos de artesanos ascenderán así hacia el cielo como símbolo cristalino de un nuevo credo futuro". 156

${ }^{156}$ Gropius en Gert Selle, Ideología y utopía del diseño, Barcelona, Gustavo Gili, 1975, pp. 112. 
Como podemos ver, en un principio no hay mención de la máquina, pues se le dio más importancia a la artesanía y ésta es la razón por la cual Gropius acentuaba la formación artesanal de sus alumnos, con el objetivo que se familiarizaran con los materiales utilizados en la construcción de edificios.

El programa de la Bauhaus comprendía un curso preliminar de seis meses que impartían los pintores suizos Johannes Itten (1888-1967), y posteriormente Paul Klee (1879-1940). Ahí la forma, el color, el volumen, los materiales en bruto eran conocidos por los estudiantes para que ellos pudieran manejar un lenguaje que descartara todas aquellas ideas ya establecidas, lo que dio por resultado que el alumno trabajara el material sin regla alguna. Después el programa se dividía en dos ramas: una específica, dedicada al manejo del material con auxilio de la máquina, es decir, el oficio de aprendiz, y otra que revisaba la teoría avanzada de la forma, el dibujo y de los colores. Los dos ciclos comprendían tres años de estudio y el alumno se convertía en un oficial al estilo medieval que le permitía trabajar en la artesanía dominada, o bien, presentar un examen de grado para obtener el título de Oficial de la Bauhaus. Con este grado el estudiante podría acceder al último peldaño de la Bauhaus y que era el de la construcción, el cual consistía en un trabajo común con maestros tanto en una obra, como en el taller.

Durante los primeros años de la Bauhaus la unión de arte-oficio se hace una realidad, pues los Formmeistern (Maestros de la Forma o el Diseño) y los Werkmeistern (Maestros del Taller) trabajaban en conjunto en talleres de escultura, escenografía teatral, vidriería, fotografía, forja, ebanistería, cerámica, diseño de tipografía, exposiciones, pintura mural y tapicería, para que los alumnos dominaran alguna de estas áreas y así pudieran ganar algún dinero con sus oficios. La unión de arte-artesanía se consolidaba. Con esto se buscaba que los estudiantes de cursos preliminares manufacturaran objetos de acuerdo a su función, en los cuales ellos mismos pudieran aportar sus propias ideas y de esta forma estar preparados para los cursos siguientes.

Pero la transformación conceptual escolar, por un centro artístico y cultural, como lo fue la Bauhaus, se debió al tipo de maestros contratados. Los pintores: Johannes Itten, el norteamericano Lyonel Feininger (1871-1956), Paul Klee, el ruso Wassily Kandinsky (1866-1944), el húngaro László Moholy-Nagy (1895-1946), el pintor y grafista Georg Muche (1895-1987) y el escultor Gerhard Marcks (1889-1981). 
Fueron miembros de la Bauhaus, además de los ya mencionados: el pintor y maestro Josef Albers (1888-1976), el arquitecto Alfred Arndt (1898-1976), el pintor y diseñador gráfico Herbert Bayer (1900-1985), la diseñadora en metal Marianne Liebe, conocida por su nombre de casada como Marianne Brandt (1893-1983), el arquitecto de origen húngaro Marcel Breuer (1902-1981); la profesora de música quien impartía la cátedra de armonía Gertrud Grunow (1870-1944), los arquitectos y urbanistas Ludwig Hilberseimer (1885-1967) y el suizo Hannes Meyer (1889-1954), el fotógrafo Walter Peterhans (1897-1960), la arquitecta de interiores Lilly Reich (1885-1947); el pintor y conservador de monumentos Hinnerk Scheper (1897-1957), el pintor Oskar Schlemmer (1888-1943), el tipógrafo y escultor Joost Schmidt (1893-1948), el escritor, dramaturgo y pintor Lothar Schreyer (1886-1966) y la tejedora Gunta Stölzl (1897-1983).

Johannes Itten, de origen suizo, durante su formación se siente atraído por el Cubismo y los movimientos expresionistas; sus primeras pinturas son de tipo abstracto, donde busca el color y el ritmo en la composición. En 1919 expone en Viena, conoce a Gropius y es invitado por éste para formar parte del cuerpo académico de la Bauhaus.

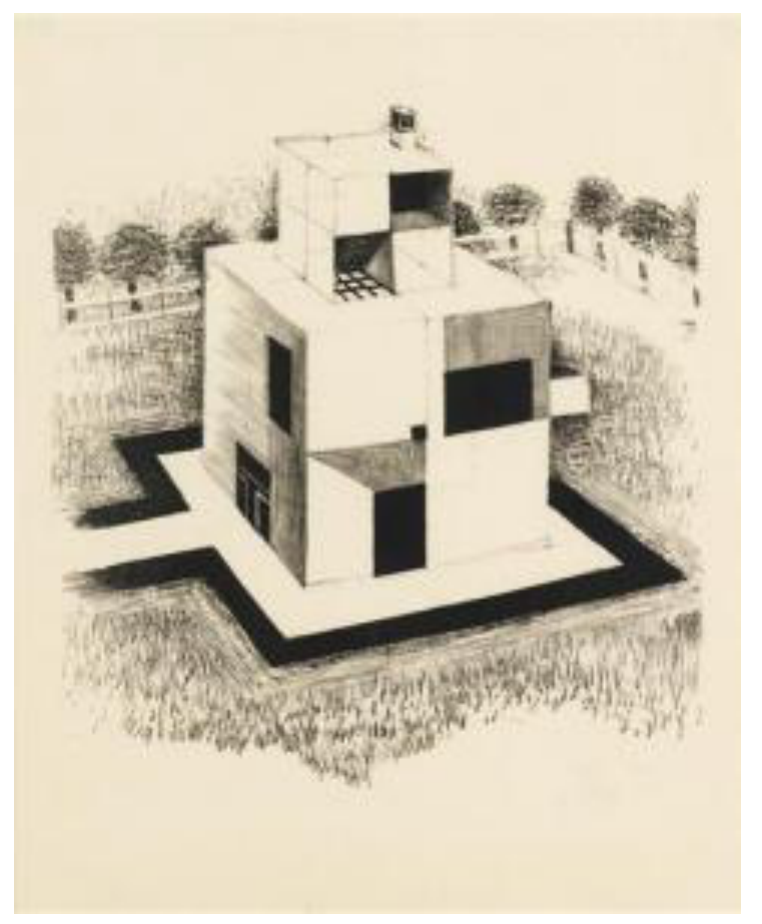

Johannes Itten, Casa del hombre blanco, $1920 .^{157}$

\footnotetext{
${ }^{157}$ Magdalena Droste, Bauhaus, 1919-1933. Köln, Taschen, 1993, p. 32.
} 
Lyonel Feininger, nacido en Estados Unidos, llega a Alemania a los 16 años para estudiar música, la que abandona por la pintura. Conoce a los pintores de Die Brückey posteriormente participa con los del Blaue Reiter. Además de ser profesor de la Bauhaus, es el director del taller de grabado. Maestro de pintura y teoría de la forma, sus influencias cubistas lo hacen transmitir una técnica racionalista de planos arquitectónicos.

Klee, de origen suizo, había transitado por el Cubismo y el Dadaísmo. Para él el arte era una "trans-formación", es decir, una metáfora de la naturaleza, por lo que a partir de aquí Klee enseña que un punto puesto en movimiento hace aparecer la línea activa y móvil que revela la "superficie activa" y sus efectos se combinan en un espacio llamado "zona medial". A través de la relación de líneas y colores para conseguir un equilibrio, Klee descubre que las formas y toda composición surgen por sí mismas. Debido a su interés por la ciencia, pudo combinar las ideas con la práctica haciéndose un profesor muy demandado por los alumnos de la Bauhaus.

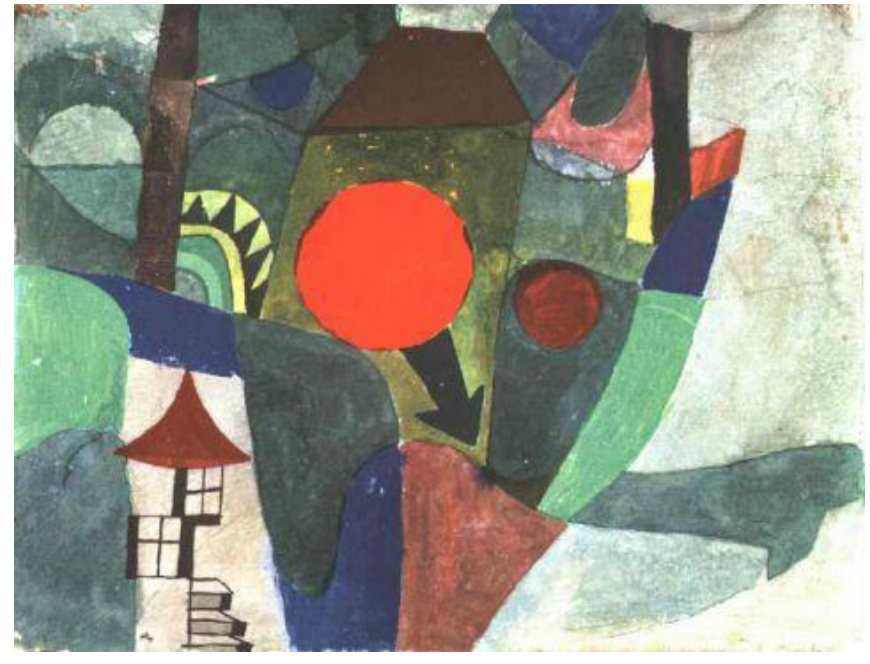

Paul Klee, Con la caída del sol, 1919. 158

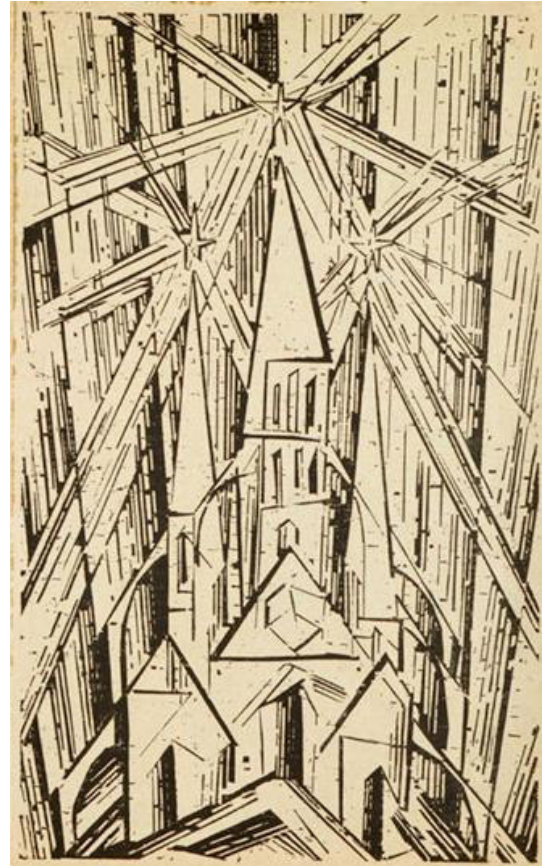

Lyonel Feininger, Grabado en madera para el Manifiesto y Programa de Walter Gropius 1919.159

\footnotetext{
158 José Riello, "Paul Klee en la Bauhaus”, Descubrir el Arte, Madrid, Año XIV, nº 169, marzo 2013, p. 79.

${ }^{159}$ Magdalena Droste, Op. Cit., p. 18.
} 
El pintor Wassily Kandinsky, tuvo su formación tanto en Alemania como en Francia, pero nunca dejó al olvido su natal Moscú. Habiendo expuesto con el grupo Die Brücke, formará con Franz Marc (1880-1916) el movimiento Die Blaue Reiter. Se incorpora a la Bauhaus hasta 1922, cuando se encontraba en una etapa que él mismo llamó “Geometrismo Lírico". Él prefería llamar a su trabajo "concreto" en lugar de "abstracto", pues relacionaba la teoría con la práctica, pero donde se hacía el análisis final de este paralelismo era en la forma ya acabada.

Kandisnky enseñaba que si se partía de un punto se formaba una línea; el agrupamiento de líneas formaba el plano y espacios planos y más líneas se usaban para construir formas tridimensionales. De esta manera, los alumnos aprendían a observar un objeto con precisión para saber representar sus elementos constructivos y sus leyes de tensión.

Tanto a Klee como a Kandinsky les interesaba lo infantil, ya que a través de un cuadro hecho por un niño se expresa la realidad más allá de lo visible.

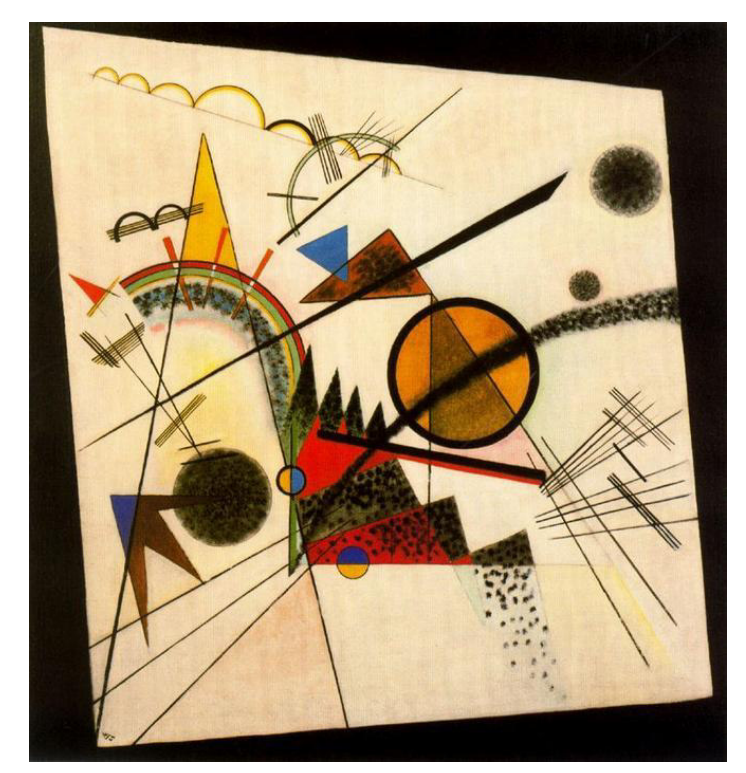

Wassily Kandinsky, En el cuadrado negro, 1923. Guggenheim Museum, New York. ${ }^{160}$

El húngaro Moholy-Nagy se integra a la Bauhaus en 1923. Imparte los cursos de grabado en metal y en materiales sintéticos, así como fotografía. Sus cuadros de esa época

\footnotetext{
${ }^{160}$ Peter Anselm Riedl, "Wassily Kandinsky”, Cinco Grandes de la Pintura Moderna, México, PROMEXA, 1980, p. 32.
} 
presentan composiciones geométricas dentro de espacios tridimensionales. Sin embargo, uno de los aportes más significativos de László Moholy-Nagy fue el introducir las concepciones del Constructivismo ruso dentro de la Bauhaus.

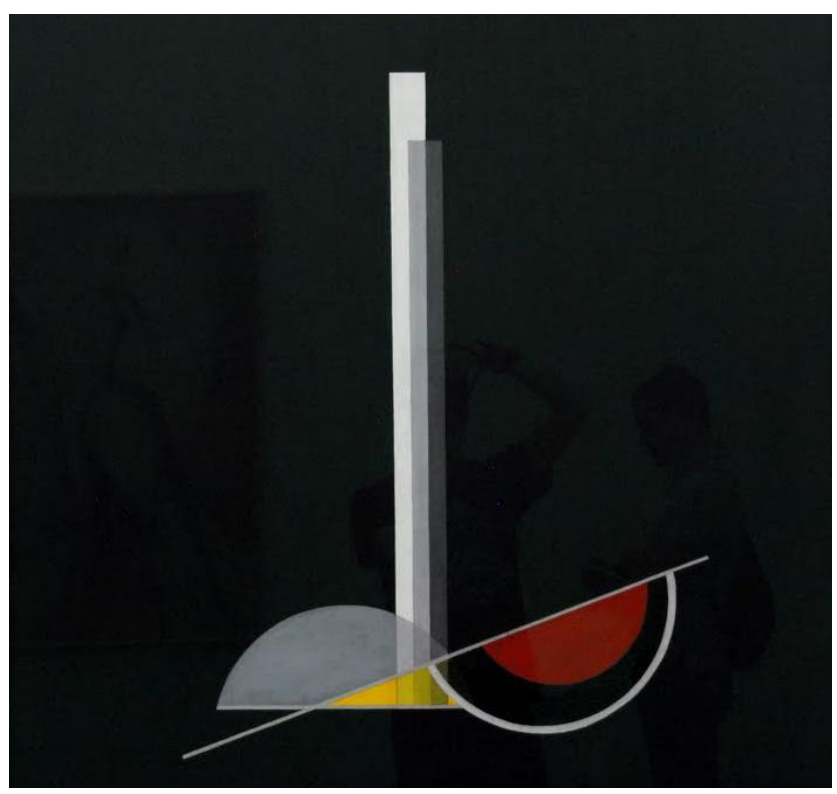

Lazslo Moholy-Nagy, Composición K. IV, 1922.

Staatsgalerie Moderner Kunts, Munich. ${ }^{161}$

Con la llegada a la Bauhaus de Theo Van Doesburg (1883-1931), aunque todo se quedó en el intento de ser contratado como profesor en 1922 y solo dicta conferencias para difundiar los preceptos del De Stijl, y de Jacobus Johannes Pieter Oud (1890-1963) quien participa en la semana de la Bauhaus en Weimar en 1923, las ideas del De Stijl influirán fuertemente en las concepciones teóricas de la escuela de Weimar. Junto con el Constructivismo ruso de Moholy-Nagy, los holandeses cambiarán el programa romántico de la Bauhaus por uno más práctico en relación con el entorno que exigía una valoración de las necesidades de la sociedad industrial de la época.

Entonces, la Bauhaus reconoce a la máquina como el medio moderno para el diseño que Gropius con su lema de "Arte y Técnica, una nueva unidad”, aún seguía considerando que los oficios eran importantes como preámbulo al conocimiento de lo industrial.

${ }^{161}$ L.C. Jaffé, Op. Cit., p. 91. 


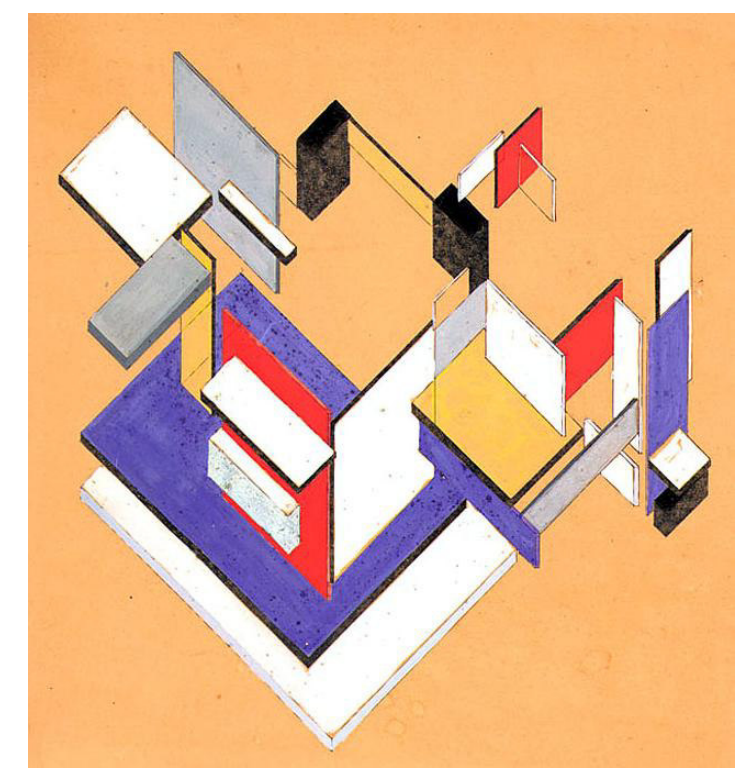

Theo van Doesburg, Construcción de los colores en La cuarta dimensión del espacio-tiempo, 1924. Stedelijk Museum, Amsterdam. 162

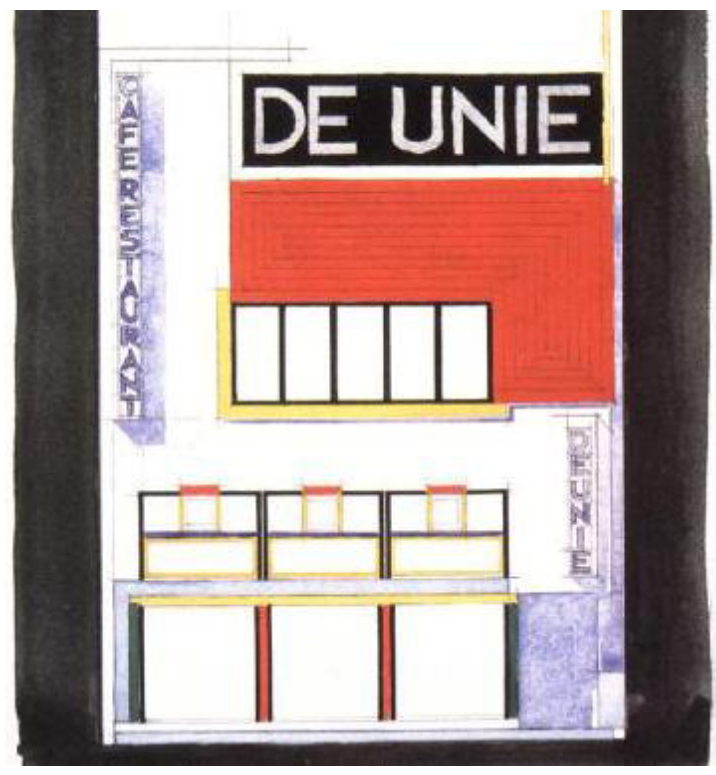

Jacobus Johannes Pieter Oud, Dibujo para la decoración del café De Unie, Rotterdam, 1924. Nederlands Documentatiecentrum voor de Bouwkunst, Amsterdam. ${ }^{163}$

El más joven de los maestros George Muche, se integra en 1919 por invitación de Gropius. Impartió clases de tejidos y el curso preliminar. Miembro del grupo Sturm, su obra era abstracta, teniendo fuertes influjos de Paul Klee y Marc Chagall, pero ya en la Bahaus giró hacia la figuración y obras con elementos orgánicos. En 1923 organizó la muestra de la Bauhaus y diseño la Haus am Horn, obra donde se aplicaba toda la nueva teoría de la construcción de la escuela que buscaba producir en serie con materiales como el hormigón y el acero y con fuerte sentido de funcionalidad. La casa aún sigue en pie en el Parque An der Ilm en Weimar.

Gerhard Marcks fue uno de los primeros profesores invitados por Gropius, pues lo había cnocido en la muestra del Werkund de Colinia en 1914. Dirigió el taller de cerámica, en el cual se pudo lleva a cabo de la mejor manera la fórmula del "maestro de forma" y el "maestro de taller", ya que instaló el taller en las caballerizas del castillo de Dornburg del Saale, situado a $30 \mathrm{~km}$ de la escuela de Weimar, por lo cual trabajo con absoluta independencia. Su obra buscaba el estudio de la figura humana como modelo para la

\footnotetext{
${ }^{162}$ Carsten-Peter Warncke, Op. Cit., p. 170.

${ }^{163}$ Ibídem, p. 108.
} 
creación artística. Su famosa cafetera Sintrax de 1925 con vidrio de alta resistencia al calor, ha sido una de las más reconocidas contribuciones a la Bauhaus.

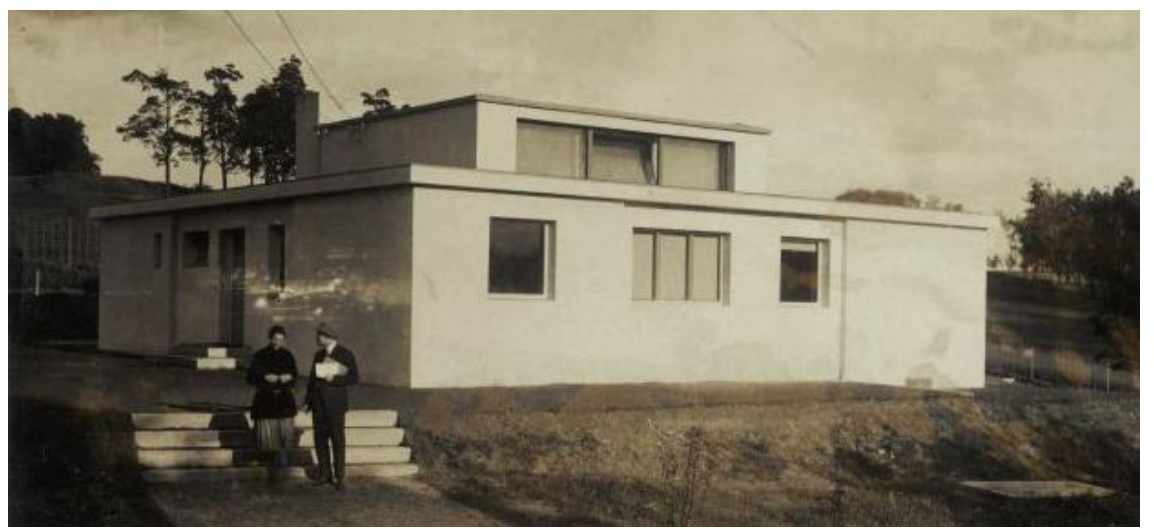

Geroge Muche, Haus am Horm, Weimar en 1923. En la foto aparecen Alma Buscher y Lazlo Moholy-Nagy. 164

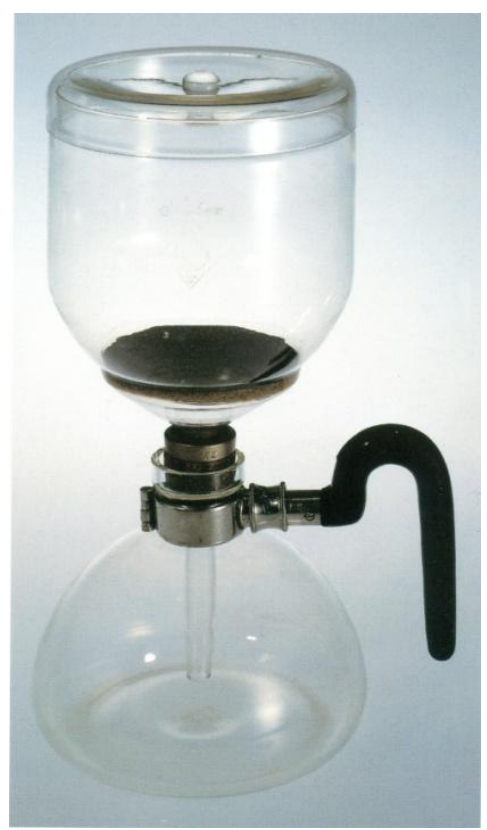

Gerhard Marcks, Cafetera Sintrax, 1925.

Schott \& Gen., Jena. 165

Con estas influencias, se gira dentro de la Bauhaus del trabajo artesanal hacia el diseño industrial. Las formas y estructuras elegidas configuraban ya para 1924 un estilo Bauhaus, pese a la oposición de Gropius de crear un estilo como tal. En ese mismo año la

\footnotetext{
${ }^{164}$ Magdalena Droste, Op. Cit., p. 106.

165 Torster Bröhan y Thomas Berg, Op. Cit., p. 111.
} 
escuela dejará Weimar para trasladarse a Dessau, ciudad industrial en la cual consiguen préstamos financieros para construir el nuevo edificio sede, además de un conjunto habitacional para los profesores y estudiantes.

La obra fue concebida y edificada por Walter Gropius en 1925 e inaugurada en 1926. De tres plantas altas más la baja, dos de ellas se unen por medio de un puente y salvan el paso de la calle; salones de clase, teatro, gimnasio, estudios tanto para estudiantes como para Gropius y Meyer, además del comedor y las habitaciones, constituyeron una arquitectura cuyo esqueleto fue realizado con hormigón armado y la techumbre cubierta con un nuevo material antihumedad. La gran cortina de cristal de uno de los muros y las formas simples, geométricas y límpidas, hacen que la Bauhaus consolide su estilo arquitectónico. Al respecto de este edificio, en 1927 Rudolf Arnheim escribió: "La voluntad de limpieza, claridad y generosidad ha alcanzado aquí una victoria. A través de los grandes ventanales se puede ver, ya desde fuera, a la gente trabajando y al que descansa en privado. Cada casa muestra su construcción, no se oculta ningún tornillo, ningún arte de cincelaje esconde la materia prima". ${ }^{166}$

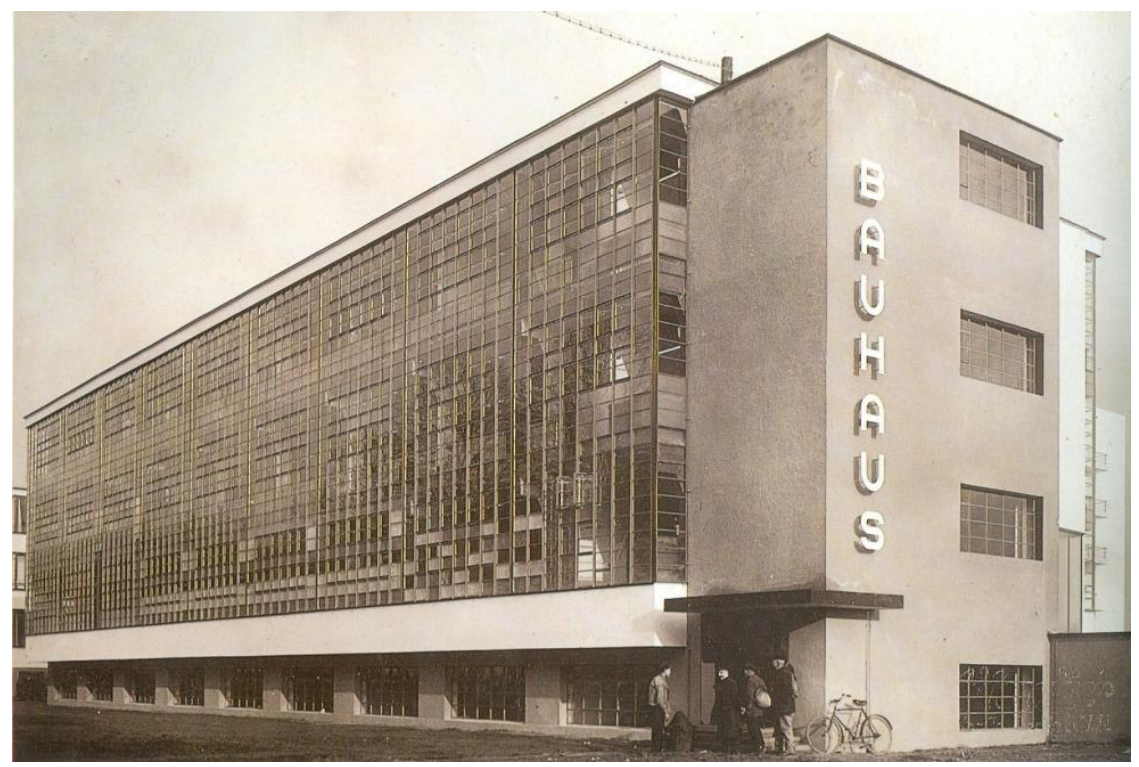

Walter Gropius, Edificio de la Bahaus, en Dessau, foto de 1927.167

\footnotetext{
${ }^{166}$ Rudolf Arnheim en Magdalena Troste, Op. Cit., p. 122, pie de fotografía.

${ }^{167}$ Ibídem, p. 122.
} 
Marcel Breuer, quien había diseña la cocina en la Haus am Horn creó el diseño de sillas elaboradas con acero cromado y doblado, de formas y peso ligeros. El resultado fue la Silla Wassily, en honor a Kandinsky, de 1925 y fabricada en 1926 por la Standar-Möbel Lengyel \& Co., para las habitaciones de los profesores de la Bauhaus; los tubos para los bastidores sostienen las telas o pieles fuertemente tensados, creando un estilo espacial inédito. Otro ejemplo de muebles tubulares fueron la Serie de mesas der 1925-1926, que consisten en cuatro mesas de menor a mayor y que se acomodan dentro de un mismo espacio.
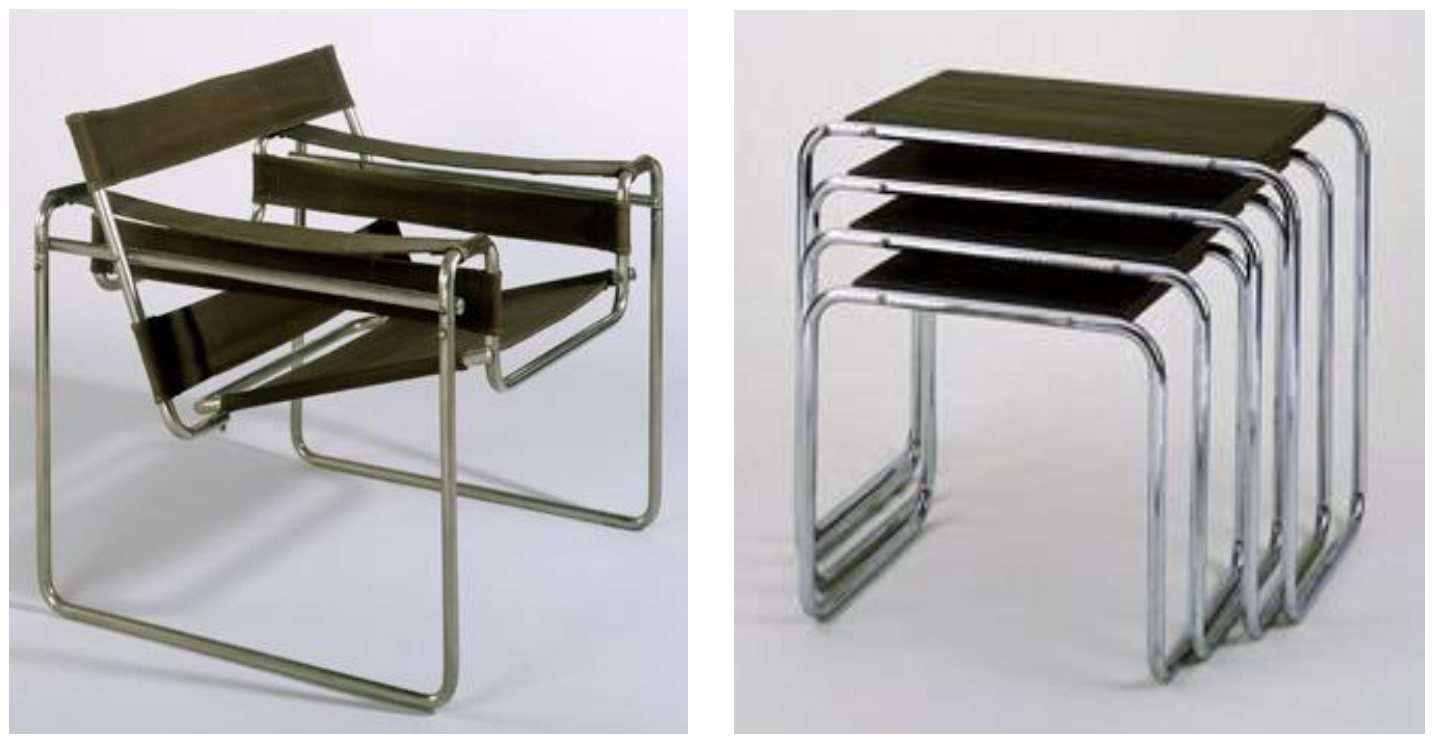

Marcel Breuer, Silla Wassily Club B3 y Serie de mesas B9-B 9c, ambas de 1925-1926. ${ }^{168}$

Sin embargo, a pesar de los ya mencionados ejemplos, el departamento de arquitectura de la Bauhaus fue creado hasta 1927 por el suizo Hannes Meyer, quien trabajó al lado de Gropius en la construcción de las viviendas en el distrito Törten, en Dessau: un proyecto experimental hecho en paneles de hormigón, trabajado in situ.

En 1928 Gropius deja la dirección de la Bauhaus, quedándose al frente Hannes Meyer. La bonanza económica se dio bajo la dirección de Meyer, pues el desarrollo de diseños en serie, en lugar de los que se proponían de gusto ecléctico, fueron de fácil acceso para un amplio sector social.

${ }^{168}$ Torster Bröhan y Thomas Berg, Op. Cit., pp. 88 y 91. 
Por presiones políticas Meyer tiene que dejar la Bauhaus en 1930 y en su lugar fue designado Ludwig Mies van der Rohe (1889-1969). Con una carrera ampliamente reconocida, el férreo arquitecto llevará a la Bauhaus por un camino de creación de diseños exclusivos y a reforzar la arquitectura, principalmente, en su parte teórica. Justamente en el periodo en que estuvo como director, edifica dos obras significativas para la arquitectura moderna: el Pabellón de Alemania para la Feria Internacional de Barcelona de 1928 a 1929 y la casa Tugendhat, en Brno, Checoslovaquia de 1928 a 1930.

En la primera, una gran placa de hormigón sostenida por pilares de acero cromado, componen la techumbre, que es rebasada por paredes acristaladas. La distribución asimétrica, pero funcional, ordenan el espacio interior. El mobiliario, también diseñado por Van der Rohe, presentaba la famosa Silla Barcelona, con pies en forma de tijera, tubos cromados y ausencia de decoración, que se convertiría en pieza clave del diseño industrial. La casa del Pabellón de Alemania en Barcelona fue reconstruida en la misma ciudad entre 1984 y 1986 por Ignasi Solà-Morales, Fernando Ramos y Cristian Cirici. ${ }^{169}$

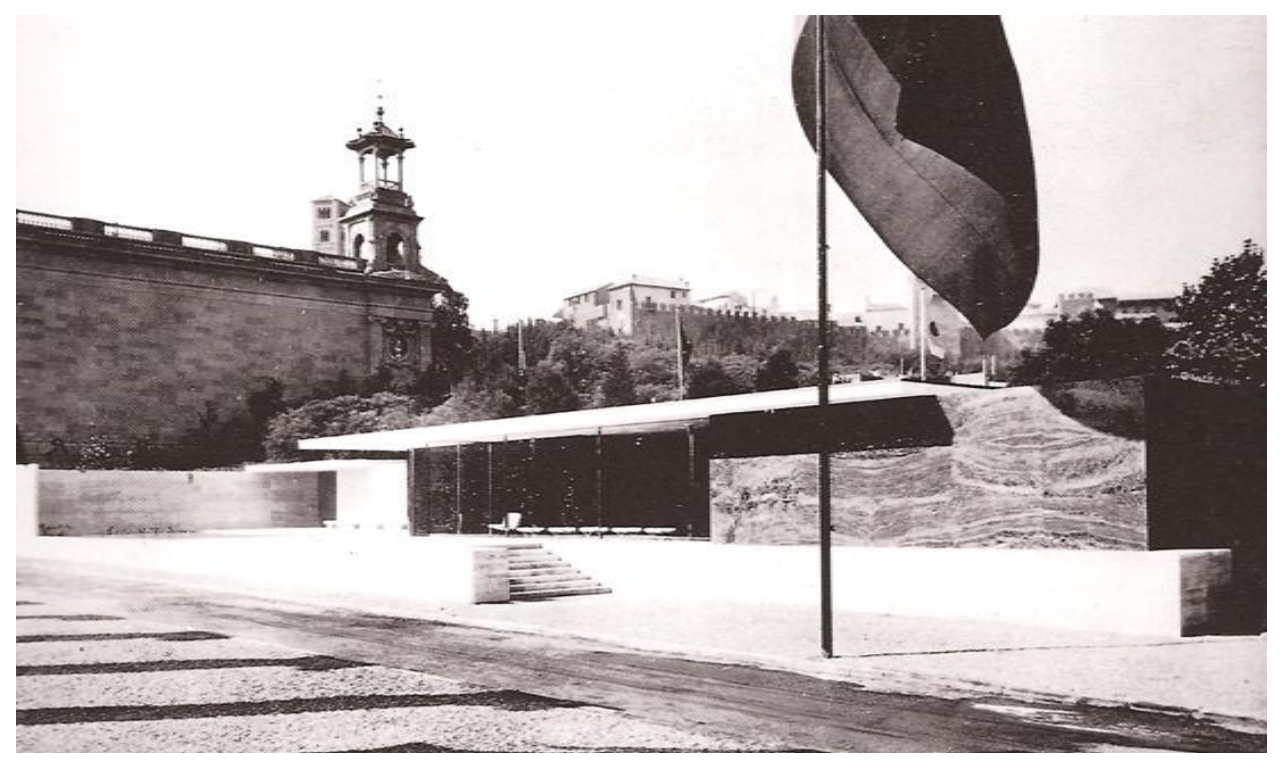

Mies van der Rohe, Pabellón de Alemania, Exposición Universal de Barcelona, 1929.170

La segunda, levantada sobre una ligera prominencia, se compone de un gran bloque acristalado que invade las esquinas de la planta baja y otro más pequeño; ambos con formas

\footnotetext{
${ }^{169}$ Vittorio Magnano Lampugnani (ed), Op. Cit., pp. 250-251.

${ }^{170}$ Claire Zimmermann, Mies van der Rohe, Köln, Taschen, 2009, p. 40.
} 
cúbicas, le dan una elegancia delicada que remite necesariamente al Pabellón de la feria de Barcelona, pues los enseres también salieron de la mano de Mies van der Rohe.

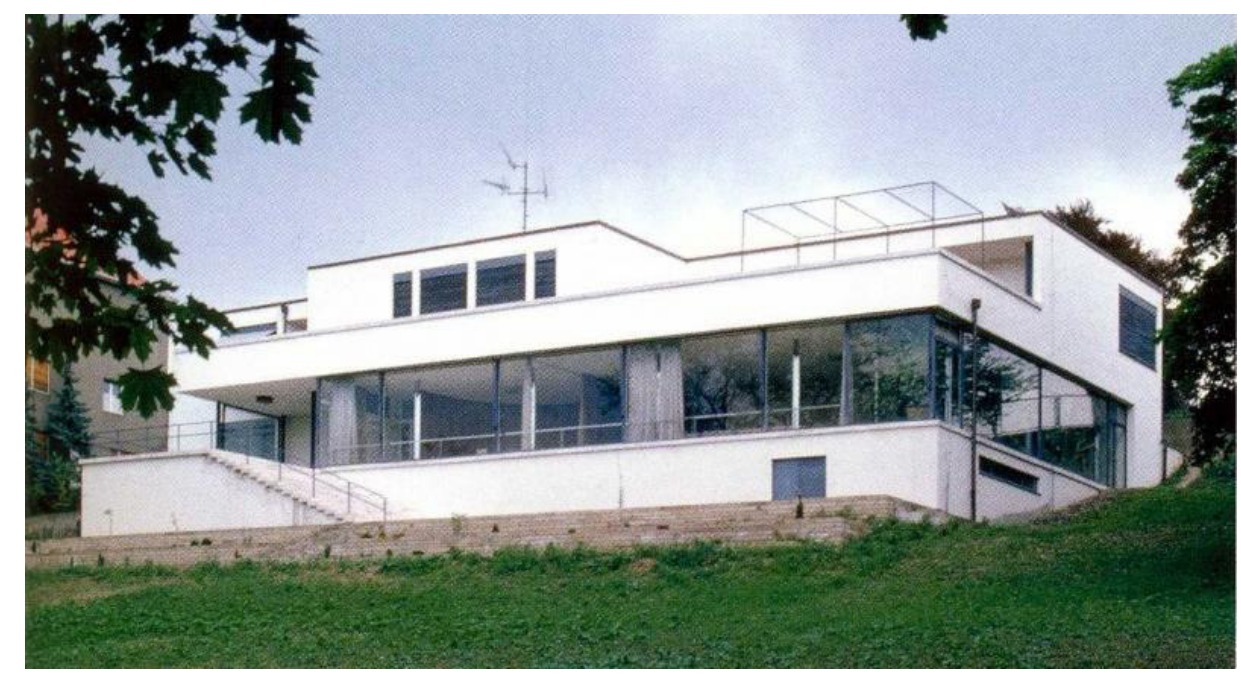

Mies van der Rohe, Casa Tugendhat, en Brno, 1928-1930. ${ }^{171}$

En 1938 Mies van der Rohe es invitado a Chicago para trabajar en el Instituto de Tecnología de Illinois, donde se establecerá hasta su muerte.

La Bauhaus termina con la suspensión de la misma por el Nacional Socialismo alemán. Un gran número de los profesores emigran a los Estados Unidos, donde continuarán de manera aislada con las enseñanzas de la gran escuela germana. Y aunque la Bauhaus, como una de las primeras escuelas de diseño industrial, además de sus enseñanzas no compartía la idea de un decorativismo aplicado, es una de las corrientes estéticas que influirá fuertemente en los diseños del Art Déco.

\subsubsection{Compagnie des Arts Francaise}

A principios del siglo XX el Art Nouveau en Francia dominaba, por decirlo así, la totalidad de los ambientes de la decoración. La línea curva seguía hechizando con los diseños sensuales de tapices, cristales, muebles y rejería, tanto los ambientes interiores como exteriores.

\footnotetext{
${ }^{171}$ Ibídem, p. 45.
} 
En 1901 se fundan la Societé des Artistes Décorateurs y un poco después el Musée des Arts Décoratifs en Le Pavillon Marsan del Museo del Louvre. A su vez, el Salón de Otoño servía como escenario para presentar todas aquellas expresiones artísticas novedosas, o bien, de carácter independiente, pero que a la vez incluían a las artes decorativas.

Sin embargo, las vanguardias hacían su aparición unas tras otras en los países occidentales, mientras que en el campo de la decoración Francia seguía con el influjo de los modelos del esplendor de los Luises XIV y XV, o bien de Louis-Philippe.

Durante los años de la I Guerra Mundial, 1914-1918, las actividades artísticas en Francia se verán disminuidas debido a su participación en el conflicto. Una vez terminado el combate, en 1919 el pintor y arquitecto Louis Süe (1875-1968) y el pintor André Mare (1887-1932) fundan la Compagnie des Arts Francaise, asociación con la participación de pintores, escultores y decoradores que buscaban una renovación del gusto francés.

Aunque en el punto “1.2. El triunfo de lo decorativo, consecuencia de la Exposición del 25", hablamos de la compañía formada por Süe y Mare, la enfocamos hacia sus propuestas en la decoración de muebles, pero en este apartado el tema es resaltar su importancia como uno de los movimientos que conformaron la estética del Art Déco.

En contraposición con los objetos de moda, la idea de la compañía era crear trabajos serios y acogedores a los que los mismos miembros de la Compagnie llamaban "revolucionarios". Basados en la tradición del trabajo artesanal francés de la cerámica, la ebanistería, la arquitectura y el diseño textil, en sí todos los aspectos del diseño de interiores además de la arquitectura, buscaban un estilo nacional francés sin influencias exteriores y basado en una reinterpretación del Neoclasicismo y que en palabras de Paul Maenz la compañía "parece haber adoptado por emblema su gout de la fleur petrifié". ${ }^{172} \mathrm{Al}$ respecto de lo anterior, André Véra, quien colaboraba en la compañía además de ser amigo tanto de Mare como Süe, declaró: "para los muebles no aceptaremos consejos de los ingleses, ni de los holandeses, sino que seguiremos la tradición francesa, asegurando que el nuevo estilo sea una continuación del último estilo internacional que hemos tenido: el Luis Felipe". 173

\footnotetext{
${ }^{172}$ Paul Maenz. Op. Cit., p. 139.

${ }^{173}$ S/a. El mueble del siglo XX. Art Deco, Op. Cit., p. 41.
} 
Los nombres de Süe y Mare no eran extraños, pues Süe había creado en 1911 un antecedente de la compañía que fue el Atelier Francaise, el cual tuvo que cerrar por el inicio de la I Guerra Mundial. Mare había participado en el Salón de Otoño de 1912, donde propuso con otros artistas la Villa Cubista, como ya lo hemos mencionado en el tema sobre el Cubismo.

Creadores de un tipo de diseños, éstos se caracterizaban por ser de formas voluminosas, con decorados sobresalientes y con una fuerte influencia geométrica; lo que buscaban era recrear ambientes seductores, cuyos moradores se embelesaran con los diseños de los artistas además de emparentar el trabajo artesanal, todo esto con el fin de obtener productos para el uso cotidiano y no sólo para la élite, pero que en la práctica fue exactamente al revés.

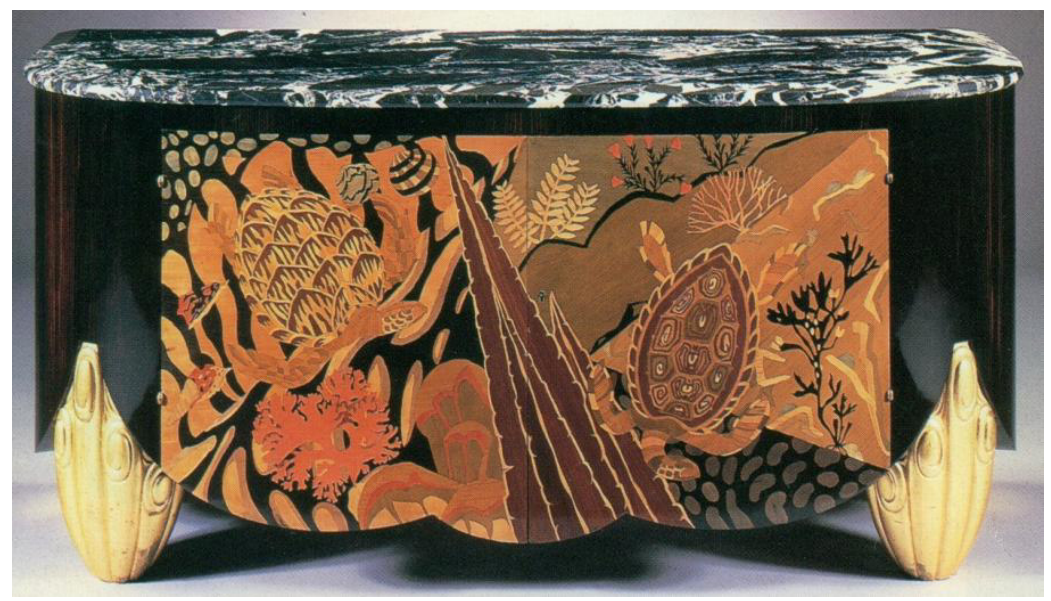

Süe y Mare, Cómoda en ébano de Macasar, marquetería y mármol, ha. 1913. ${ }^{174}$

Süe y Mare transmitieron su ideario sobre los diseños que realizaban en unas obras que podríamos llamar manifiestos: Architectures e Intérieurs. La primera fue publicada en 1921, con una presentación de Paul Valéry (1871-1945) titulada Eupalinos y la portada hecha por Paul Véra (1882-1958) expresa la iniciativa geometrizante de las figuras femeninas y los frutos que aparecen en ella. Intérieurs data de 1924 y lleva un prefacio de Jean Badovici que dice: "Mira en todas partes, en todas las obras decorativas, esta sobriedad muy natural de las líneas. El alma de esta geometría es precisamente lo que debe hablarle al hombre moderno. ¿No te parece? Esas aristas bruscas, esos ángulos apenas

\footnotetext{
${ }^{174}$ Patricia Bayer, Op. Cit., p. 30.
} 
redondeados, encierran unos volúmenes estrictamente definidos, marcan la negativa a transigir, la voluntad de encerrarse en sí mismo, de determinarse en sí mismo". ${ }^{175}$

La Compañía renovó el gusto francés, hizo gala del uso de la geometría o de la "flor petrificada", esto lo revelan, entre muchos diseños de muebles y objetos decorativos, pero también en la arquitectura como fue el caso de las perfumerías parisinas edificadas en 1923: Robert Linzeler, con una portada cuadrada, aparador en forma de punta de diamante, un marco de cuatro molduras de mayor a menor dando el sentido de abocinamiento y pequeños casetones en la base al lado de la puerta y Parfums d'Orsay, con diseños florales de marcadas "flores petrificadas" en relieves rehundidos colocados por arriba de dos vanos arcados.
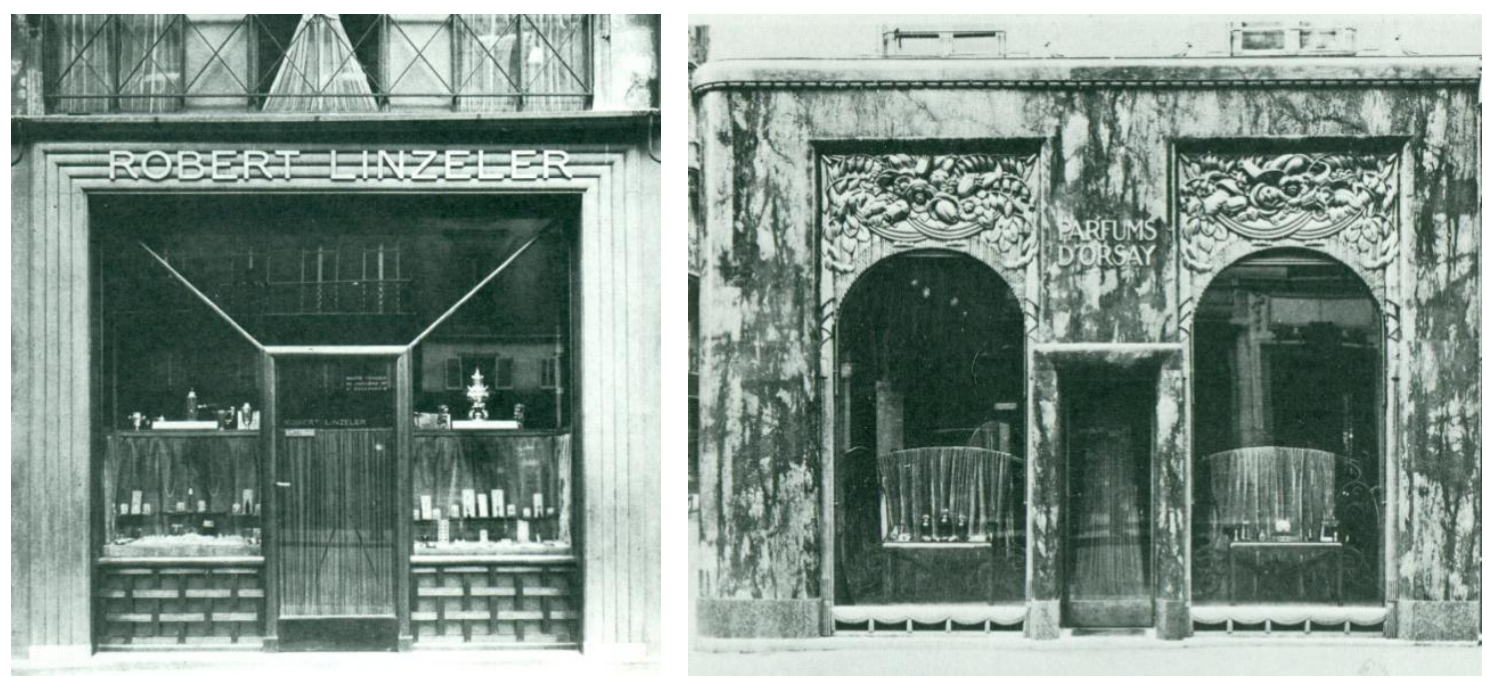

Süe y Mare, Perfumerias Robert Linzeler y D’Orsay en 1923, París. ${ }^{176}$

Este estilo tendrá su apogeo en la década de los veinte, ya que además de participar en la Exposición de Artes Decorativas del 25 -donde presentaron el pabellón Un Musée d'Art Contemporain, mismo que por su elegancia y exotismo rivalizaba con otros como la Ambassade Francaise y Parfums d'Orsay- significó un estilo que halagaba el sentimiento del parisino y del viajero francés de la época, pues los diseños salían de la creatividad de maestros de los grandes almacenes de la "ciudad luz"; sin embargo, debido a la depresión

\footnotetext{
175 Jean Badovici en Jean Paul Bouillon, Op. Cit., p. 105.

${ }^{176}$ Ibídem, p. 153.
} 
económica del 29, los encargos vinieron a menos y las influencias del exterior invadieron en gran medida el gusto galo, por lo que Süe y Mare desarticularán la compañía para luego desaparecerla definitivamente, aunque Süe siguió trabajando por su cuenta en los años treinta.

El efecto obtenido se aplicó en casas de magnates y en embajadas francesas, pero especialmente serán los transoceánicos S.S. Normadie, París y el Ile-de-France los que llevarán en sus salones de fiesta y en los camarotes de lujo los diseños seductores y exóticos de la Compagnie des Arts Francaise y que los consolidarán como un estilo muy orgullosamente francés, que el mismo gobierno de Francia publicitaba ampliamente y que a diferencia de las propuestas racionalistas del Bauhaus y del De Stijl, tendría el encanto y la dulzura de la tradición francesa, combinada con la estética de la época moderna y que recibió el nombre de Bon Gout Francaise, el cual reformó lo que el Art Nouveau había impuesto como el único lenguaje estético.

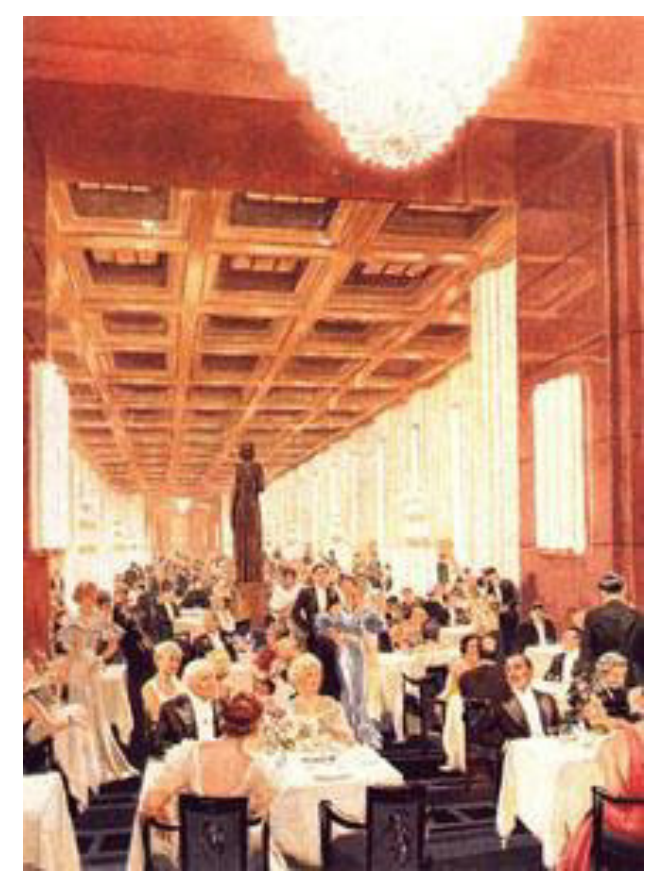

Süe y Mare, Gran Comedor del S.S. Normadie, en L'Illustration, 1935. ${ }^{177}$

Si la Compagnie des Arts Francaise no fue el Art Déco como tal, en Francia sí fue una de las conformadoras y difusoras de dicho estilo, especialmente recalcando la elegancia

\footnotetext{
${ }^{177}$ Bevis Hillier; Stephen Escritt, Op. Cit., p. 115.
} 
y el glamour para una clase acomodada, cosmopolita, de intelectuales y, sobre todo, con un fuerte presencia y participación femenina.

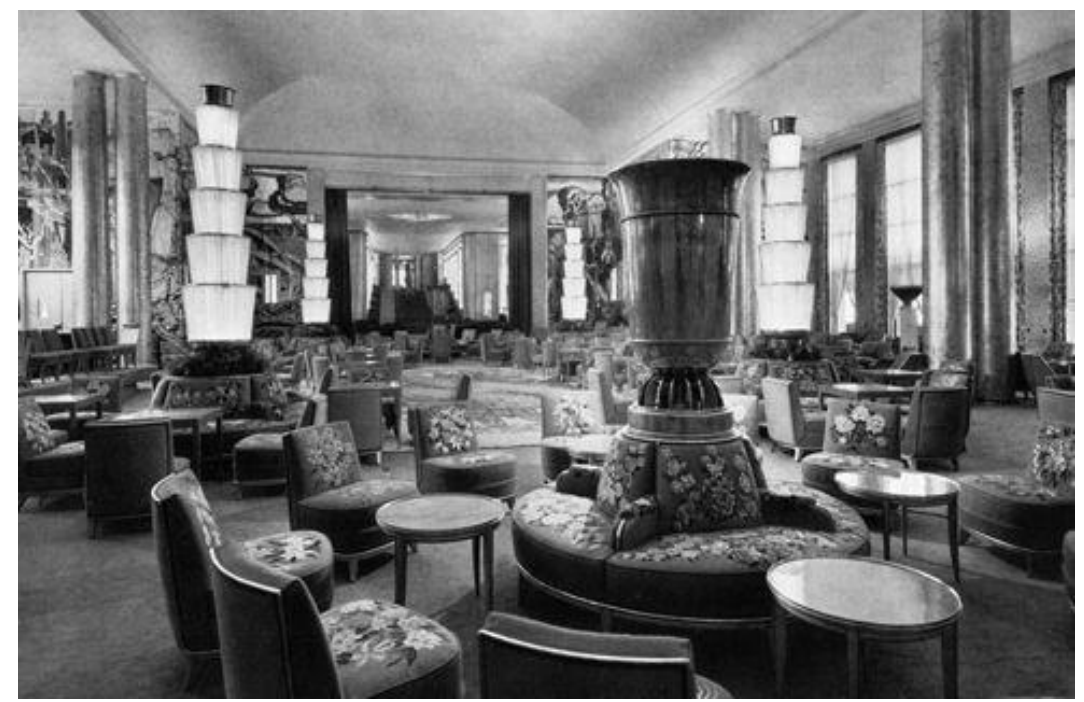

Compagnie des Arts Francaise, Salón en el S.S. Normadie, 1935.178

\subsubsection{De Rusia a París. Los espectáculos de los Ballets Rusos}

En la ciudad de San Petersburgo el letrado, pintor y escritor Alexandre Nikoláyevich Benois (1870-1960) toma conciencia de que la Rusia de finales del siglo XIX debía transformar su apreciación del arte y sacarla del romanticismo en la que estaba estacionada. Así pues, reúne a varios intelectuales para discutir el tema propuesto, pero principalmente ven la necesidad de que los pintores se empapen de los movimientos artísticos de la Europa Occidental, con lo que consigue fondos para visitar Italia, Alemania y especialmente la capital francesa.

El viaje realizado en 1897 llevó entre sus objetivos principales que en París los pintores visitaran las academias del norteamericano James Abbott Macneill Whistler (18341903), del italiano Filippo Colarossi (141-1906) y del francés Rodolphe Julian (1839-1907) para imbuirse en las nuevas tendencias. La obligada excursión a Versalles provocó en Benois tal fascinación que trabajó unas acuarelas a las que tituló Les dernierés promenades

178 Alstair Duncan (ed.), Op. Cit., p. 173. 
de Louis XIV que fueron exhibidas por el mecenas Pável Tretiakov (1832-1898) y causaron la admiración de Sergéi Diaghilev y Léon Bakst. No era de extrañar que Benois viniendo de familia de arquitectos y con una fuerte tradición en la formación artística quedara extasiado con la belleza monumental de la Ciudad Luz, donde morirá muchos años después.

Sergéi Diaghilev (1872-1929) aunque de formación abogado, igual que Benois, se interesó desde temprana edad por las artes y se movía en los ambientes intelectuales y culturales de San Petersburgo gracias a su herencia familiar. Pronto incursionó como empresario, promotor cultural y corredor de arte. En 1891 viaja por primera vez a Europa, casi a la manera del Gran Tour dieciochesco, para conocer entre otras ciudades, París, Roma, Venecia, siendo ésta última la que lo cautivará de por vida. Volverá en 1893-94 esta vez con el fin de conseguir obras para una galería que abrirá en San Petersburgo.

A partir de 1897 Diaghilev se dedicará a abrir exposiciones de artistas alemanes, ingleses, finlandeses, franceses, rusos e inclusive norteamericanos. Sin embargo, había la agravante de que mucha gente poco entendía de las nuevas propuestas pictóricas, por lo que Diaghilev es un convencido que había que producir un órgano de difusión donde se explicara lo que sucedía con las entonces recientes creaciones de los jóvenes artistas rusos, así como manejar temas del arte de corte internacional. De aquí surgirá la revista El mundo del Arte en 1898, pero tendrá sólo una duración de cinco años, pues para 1904 se editará el último número. Con la colaboración del pintor Léon Bakst (1866-1924) ${ }^{179}$ es que Diaghilev formará la revista y ésta iba a la par con las exposiciones organizadas por él mismo que buscaban una renovación artística.

Bakst quien ya había convivido con Diaghilev y Benois al formar el movimiento artístico Mir Iskustva (El Mundo del Arte) desde 1890, había estado en la academia Julian en París, ciudad donde también morirá. En uno de los últimos números de la revista, Bakst concibe para la portada un dibujo en tinta china de una casa del siglo XVIII de Moscú. La concepción novedosa deja de lado las sinuosidades del Art Nouveau para dar cabida a una proposición lineal y geométrica, modernizando los cánones clásicos dentro de una abstracción de columnas y dintel, así como la transparencia de la rejería. Un anuncio de la decoración que vendrá a imponerse en varias de las vanguardias y que más tarde

\footnotetext{
${ }^{179}$ El verdadero nombre de Léon Bakst era Lev Rosenberg, pero cambió su apellido tomado del de su abuela materna Baxter.
} 
desembocará en el Art Déco. Y por eso Bouillon se pregunta: “¿Es una casualidad que Bakst y Diaghilev estuviesen en París unos años más tarde, entre los principales inspiradores del Arte decorativo internacional?"180

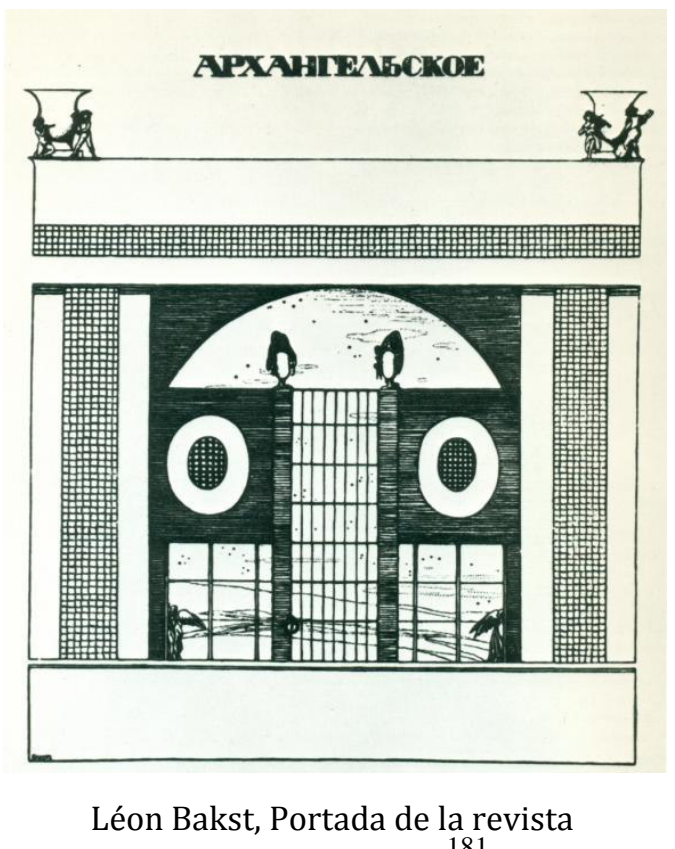

Mir Iskustva, 1904. ${ }^{181}$

Sin embargo el espíritu de renovación de Mir Iskustva no detendrá a Diaghilev en su continua búsqueda de indagar en lo novedoso. Nombrado administrador de los teatros imperiales, continuará con las exposiciones pictóricas. En 1905 en el Palacio Tauride de San Petersburgo exhibirá una muestra de doscientos años (1705-1905) de "Retratos Históricos Rusos" y un año más tarde en París abrirá la muestra poco exitosa de arte ruso en el Salón de Otoño. El estar en contacto directo con la ópera y el ballet en los teatros rusos y el regresar a París le permitieron a Diaghilev vislumbrar que lo que podía darle ganancias eran la música y el ballet, por lo que estos espectáculos serán sus nuevos derroteros que lo llevarán a verdaderamente transformar el arte ruso y europeo.

Con el antecedente de Savra Mamontov (1841-1918) y su ópera privada inaugurada 1885, el rico industrial y desarrollador de los ferrocarriles encarga a pintores como el paisajista Vasily Polenov (1844-1927), Konstantin Korovin (1861-1939) y a Alexandre

\footnotetext{
${ }^{180}$ Jean Paul Bouillon, Op. Cit. p. 11.

${ }^{181}$ Ibídem, p. 10.
} 
Golovine (1863-1930) los decorados para las representaciones, lo que viene a darle un giro a la visión de la decoración para los espectáculos, pues son ahora los pintores quienes sustituirán a los tradicionales decoradores. De esta manera Diaghilev visualiza una integración de las diversas partes que comprenden el mundo del espectáculo, especialmente de los ballets, en los cuales innovará la manera de llevarlos a cabo, dándoles a cada quien el mismo valor e importancia. "Con Diaghilev el ballet se concibe de otra manera; música, danza, decorado adquieren la misma importancia, cuentan con idéntica significación a la hora de componer el ballet". ${ }^{182}$

Esta integración de Diaghilev para los ballets es una consolidación de la Gesamtkunstwerk del revolucionario Richard Wagner (1813-1883), quien además de músico, cultivó la poesía, la filosofía y también ejecutó la dirección escénica, ya que en su búsqueda "reúne todos los elementos del arte -palabra, música, imagen, gesto, acción- bajo la supremacía del drama". ${ }^{183}$

Así pues, Mamontov y Wagner en la mente de Diaghilev, la reforma de la escenografía y vestuario, en sí del decorado, la unificación de los elementos del ballet, todos al servicio de todos y la exploración del color en los decorados, hacen que los ballets rusos como tales descubran el color para sorprender al público.

Les Ballets Russes tendrán dos grandes etapas en lo que se refiere al decorado que es realizado por pintores: Antes y durante la Primera Guerra Mundial de 1909 a 1916 y de 1916 hasta la muerte de Diaghilev en 1929. En la primera, los pintores son todos rusos y la mayoría proviene del grupo Mir Iskustva, cuyas propuestas son de una pintura figurativa, cargada de imaginación y de la fuerza del color, un neoimpresionismo ruso que crea un verdadero estilo para los decorados de los ballets. Los nombres de Nikolai Roerich (18741947), Léon Bakst, Alexandre Benois, Alexandre Golovin (1863-1930), Boris Anisfeld (1879-1973), Sergéi Sudeikin (1882-1946), Mstislav Doboujinsky (1875-1957), Natalia Goncharova (1881-1962), Mikhail Larionov (1881-1964) formaron el equipo artístico de la primera época.

La segunda etapa es cuando diversos artistas radicados en París o en relación con las vanguardias de la época entran en contacto con Diaghilev, tales como: los españoles José

\footnotetext{
${ }^{182}$ Lourdes Cerrillo Rubio, “El nuevo decorado en los ballets rusos de Serge Diaghilev", Revista de Investigación, Colegio Universitario de Soria, Tomo VI, No. 1-2, 1982, p. 40.

${ }^{183}$ Marie-Claire Beltrando-Patier, Historia de la Música, Madrid, Espsa, 2001, p. 574.
} 
María Sert (1874-1945), que ya había participado con Léon Bakst en “La Leyenda de José” de 1914, Pablo Picasso (1881-1973), Pedro Pruna (1904-1977), Juan Gris (1887-1927); los italianos Carlo Socrate (1889-1967), Giacomo Balla (1874-1958) y Giorgio de Chirico (1888-1978); los franceses André Derain (1880-1954), Henri Matisse (1869-1954), Marie Laurencin (1883-1956), Georges Braque (1882-1963), Henri Laurens (1885-1954), Maurice Utrillo (1883-1955), Georges Rouault (1871-1958), Coco Chanel (1883-1971) y el francés de origen finlandés Leopold Survage (1874-1968), así como los rusos avecindados en París, Naum Gabo (1890-1977), Antoine Pevsner (1888-1962) y George Yaculov (18841928). Un caso aparte es el escenógrafo norteamericano Robert E. Jones (1887-1954) creador de la escenografía para Till Eulenspiegel de Strauss que la compañía de Diaghilev presentó en New York en 1916.

Estos artistas eran revolucionarios del arte con sus novedosas propuestas, buscando nuevas tendencias desde la figuración, hasta la abstracción y sobre todo en el color. Integrantes de las vanguardias renovadoras del arte tales como el Cubismo, el Futurismo, el Fauvismo el Rayonismo, el Realismo soviético plasmaron en sus diseños de vestuarios y escenografías un novedoso repertorio cromático que inyectaba una enérgica visión espectacular. La imaginación creativa de cada uno se emparentaba con las propuestas coreográficas y musicales para dar impulso a la concepción del espectáculo, composiciones llenas de intelectualidad vanguardista para una nueva clase social formada por una incipiente burguesía que degusta con desenfado las innovadoras propuestas escenográficas de los ballets.

Por lo que respecta a la coreografía los Ballets Rusos tendrán una continuidad dentro de la escuela rusa. Desde sus inicios Michel Fokine (1880-1942) estará al frente ininterrumpidamente de 1909 hasta 1912 con diecisiete puestas en escena que van desde las Danzas polovetsianas del Príncipe Igor, hasta Thamar, para luego alternar con el genial Vátslav Nijinski (1890-1950) y Boris Románov (1891-1957), consiguiendo un total de veintidós coreografías, siendo Midas la última en 1914.

Nijinski participó sólo con cuatro coreografías entre 1912 y 1916, realizando creaciones espectaculares como su primer obra L'aprés-midi d'un faune (1862-1918) y la portentosa y pasmosa Le Sacre du Printemps en 1913. Por su parte, Románov sólo trabajó en dos coreografías, entre ellas Le Rossignol en 1914. 
Después vendrá la figura de Léonide Massine (1896-1979) quien sustituirá a Nijinski cuando éste se retira por su enfermedad mental. Veinte coreografías saldrán de la creatividad de Massine, bailarín y coreógrafo que trabajó para Diaghilev desde 1915 hasta 1928. Soleil de Nuit fue la primera coreografía de Massine, pero trabajó para importantes creaciones como Las Meninas, estrenada en 1916 en San Sebastián, Parade del año 1917, el Sombrero de tres picos de 1919 o la segunda puesta de La Consagración de la Primavera en 1920. Cinco años continuados que como sucedió con Fokine, después fueron alternados con otras personalidades hasta 1928 cuando llevó a escena su última coreografía que fue Ode, pasando por Pas d'acier de 1927.

Una sola contribución coreográfica de Mikhail Larionov fue el ballet Chout en 1921, la única obra en la que participó el líder del Rayonismo. Un año más tarde vendrá a dirigir las coreografías la hermana de Nijinki, Bronislava Nijinska (1891-1972); después de alternar con Nicolás Sergueiev en La boda de la bella Durmiente, Nijinska se iniciará con la coreografía de Renard en 1922 y concluir en 1924 con la opereta Le train bleu, consiguiendo en total nueve coreografías para los ballets de Diaghilev.

El último de los coreógrafos que trabajará para Diaghilev será George Balanchine (1904-1982) a quien conoció en París en 1924 cuando el bailarín huía de la Rusia soviética. Su primera creación coreográfica para Les Ballets Russes fue en 1925: Le Chant du rossignol. Nueve serán sus coreografías hasta el fallecimiento de Diaghilev ocurrido en 1929, cuando trabaja Le fils prodigue, lo que significó a la vez la muerte de la gran compañía de Les Ballets Russes. Entre 1927 y 1928 Balanchine alternó con Léonide Massine y con Serge Lifar (1904-1986) quien reinterpreta Renard en 1929.

Bailarines y coreógrafos, geniales en ambas actividades, algunos alumnos del gran maestro y su "método" Enrico Cecchetti (1850-1928), como el propio Diaghilev Nijinski, Massine y Lifar, dieron a los ballets rusos esa contundencia dancística de la mano con la música y la escenografía que posteriormente expandieron por Europa y Estados Unidos, influencias en el ballet que hasta la fecha siguen dejando huella.

Así como los escenógrafos en un primer momento fueron los pintores rusos invitados por Diaghilev, en el caso de la música la mayoría de los que participaron en un principio con los Ballets Rusos fueron compositores de su país natal, pero así como la vision estética de renovación de Diaghilev hizo que conectara a los principales artistas 
vanguardistas, con los compositores hizo algo similar, llamando a los principales músicos rusos de su tiempo.

El estreno de la compañía de Les Ballets Russes en París fue en 1909 con las Danzas polovetsianas del Príncipe Igor con la música de Alexander Borodin (1833-1887) que si bien era ruso, ya no estaba en vida. La escenografía fue de Nikolai Roerich. Pero fue en el mismo año cuando Diaghilev muestra al mundo parisino que la escuela musical rusa tiene de lo más destacado en cuanto a creación, basándose tanto en los músicos deñ siglo XIX, como los que estaban activos en principios del XX. Tal fue el caso del ballet Cléopatre obra de Anton Arenski (1861-1906), Sergei Tanéyev (1856-1915) RimskiKorsakov (1844-1908), Modest Músorgski (1839-1881), Mikhail Glinka (1804-1857), con coreografía de Michel Fokine y escenografía de Léon Bakst, quien muestra en el telón una arquitectura con enormes esculturas y columnas egipcias, composiciones que tienden hacia la geometrización de lo Déco.

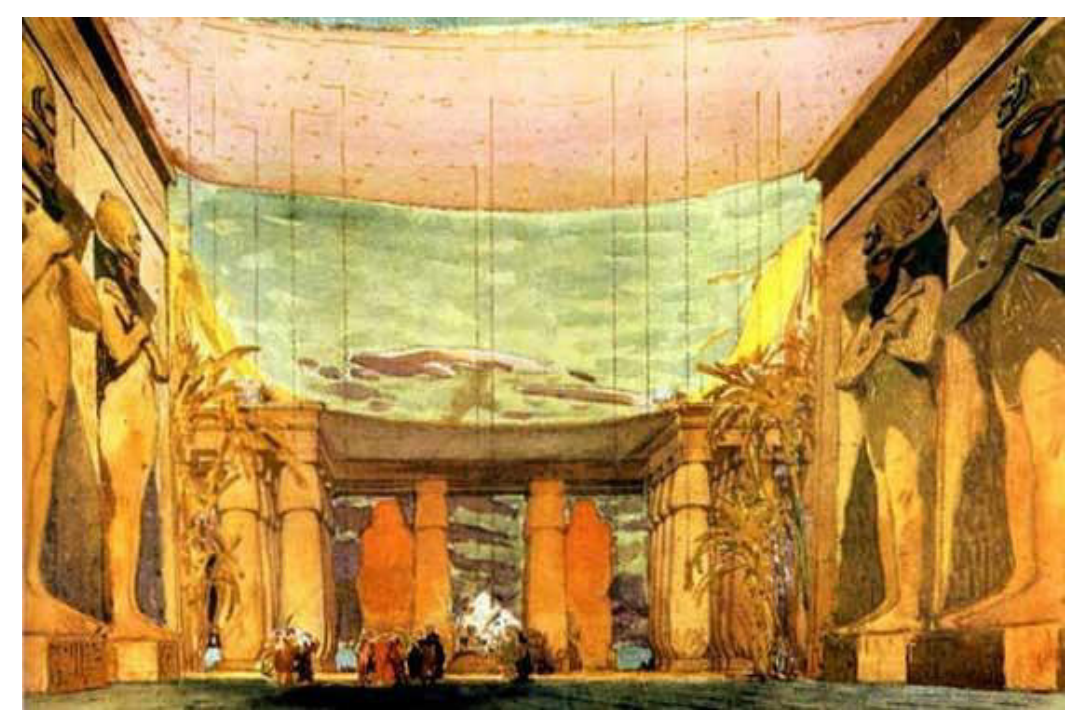

Léon Bask, Diseño para Cléopatre, 1909.184

Cabe destacar que Rimski-Korsakov quien falleció un año antes del inicio del primer ballet en París, varias de sus obras fueron puestas en escena, algunas con sus colaboradores y otras individuales como fueron Schérérazade en 1910, Sadko au royaume sous-marin en 1911 y Le Coq d'or en 1914y Soleil de Nuit en 1915, con la escenografía de

\footnotetext{
184 “Cléopatre 1909”, http://theatrex.net/Ida/cleopatra.htm
} 
Mihkail Larionov, en cuya cortina de fondo con intensos y vivos colores plasma el follaje de los arboles con luminosas formas de estrellas geométricas, en un abigarrado bosque que pareciera un trabajo infantil.

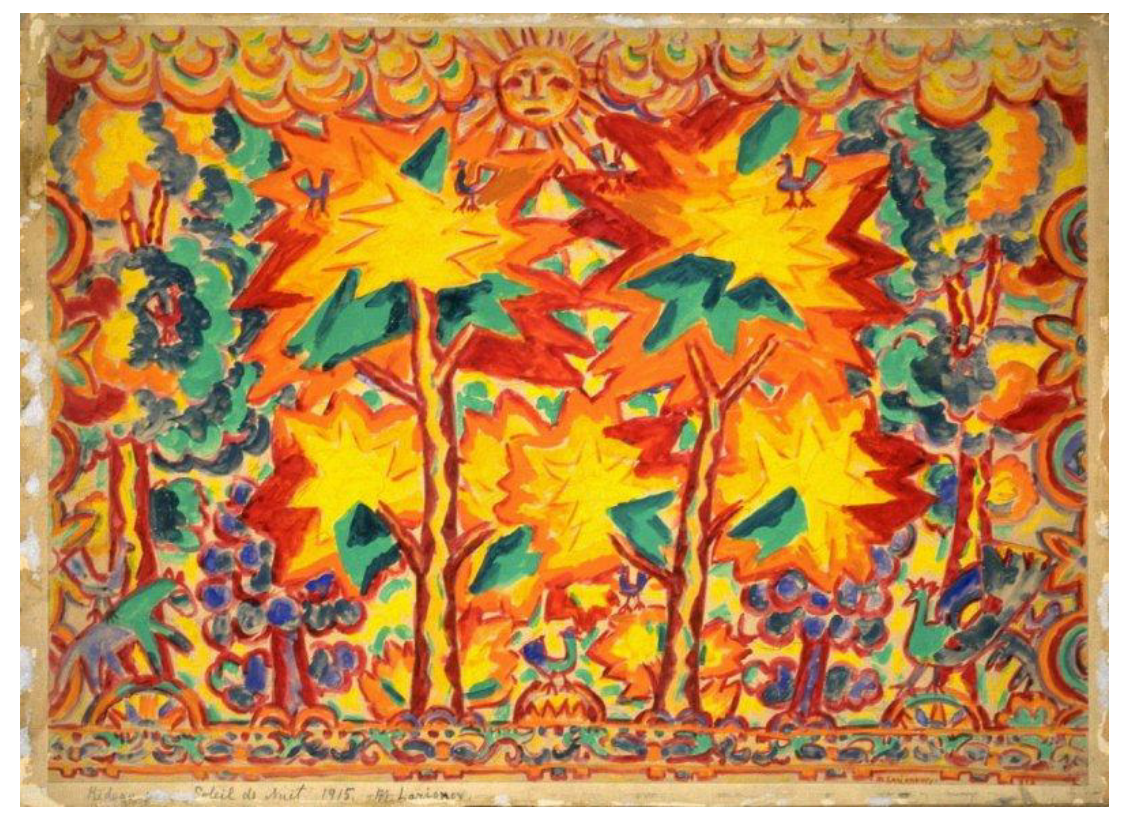

Mihkail Larionov, escenografía para Soleil de Nuit, 1915. ${ }^{185}$

Otro miembro del Grupo de los Cinco, Mili Balákirev (1837-1910), sólo tuvo una participación póstuma cuando la compañía puso la obra Thamar en 1912.

Nikolái Tcherepnin (1873-1945), un exalumno de Rimski-Korsakov, también participó en el estreno de los ballets en 1909 con Le Pavillon d'Armide obra que él mismo dirigió, para luego trabajar con otros colegas en 1910 y en 1911 componer su segunda y última obra para la compañía que fue Narcise, pues en 1914 sólo orquestará Papillons de Schumann (1810-1856) y retirarse del equipo de Diaghilev. Un discípulo más de RimskiKorsakov fue Maximilien Steinberg (1883-1946), quien además de tener una buena relación con su maestro, se casó con su hija en 1908. Un solo trabajo realizó para la compañía de Diaghilev y ésta fue Midas en el año de 1914.

\footnotetext{
${ }^{185}$ De Young/ Legion of Honor Fines Arts Museums of San Francisco, "Mikhail Feodorovich Larionov, Courtain deisgn for the dance performance, Le Soleil de Nuit", http://art.famsf.org/mikhail-feodorovichlarionov/curtain-design-dance-performance-le-soleil-de-nuit-midnight-sun
} 
Anatoli Liadov (1855-1914) y Sergéi Tanéyev (1856-1915) fueron dos miembros participantes de los ballets rusos con orquestaciones y composiciones grupales entre 1909 y 1910. Póstumamente fueron puestas dos obras de Liadov: en 1916 Kikimora. Cuento de hadas ruso y Les contes russes en 1917.

La figura del mundo musical ruso que más participaciones tuvo con Diaghilev fue Ígor Stravinski (1882-1971). Iniciándose en la orquestación de Les Sylphides de Chopin (1810-1849) en 1909 junto con Aleksandr Glazunov (1865-1936), Liadov y Tanéyev, para 1910 con L'Oiseau de feu emprenderá una larga carrera musical al lado de la compañía, obra con la coreografía de Fokine y la participación de Golovin y Bakst en la escenografía. En 1911, Petrushka tendrá a Fokine en la coreografía y a Benois en la escenografía y en 1913 su sensacional Le sacre du Printemps, para muchos su mejor composición, tendrá a Roerich en la escenografía y al ya citado Nijinski en la coreografía y como bailarín principal.

En una segunda puesta en escena en 1920 de Le sacre du Printemps, el mismo Roerich se encargo de la escenografía y Massine de la coreografía, pues Nijinski ya se encontraba internado en Suiza para el tratamiento de su esquizofrenia.

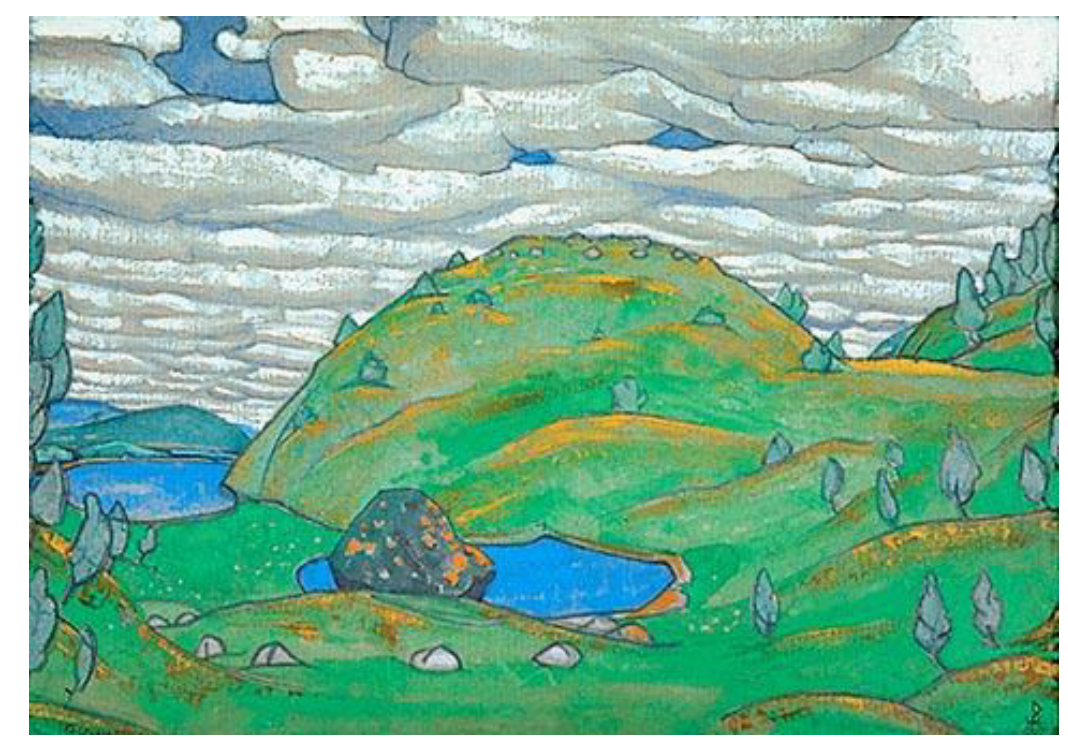

Nikolai Roerich, El beso de la tierra, para Le Sacre du Printemps, 1913.186

\footnotetext{
${ }^{186}$ Matthew McDonald, 'Forever Young? 'The Rite of Spring' approaches 100, Boston Syphony Orchesta, http://www.bso.org/brands/bso/features/forever-young.aspx
} 
El músico italiano Alfredo Casella (1883-1947), quien cultivó la amistad de Stravinski, presenció el estreno y cuatro puestas más de esta obra y afirmó: "La Consagración representa, sin duda, una de las más inauditas aventuras del arte encaminada hacia lo ignoto espantable; pero constituye también una de las más clamorosas victorias que haya alcanzado jamás el genio del hombre en el dominio de la adivinación y del sentido de lo 'posible latente'. No hay en toda esta prodigiosa partitura una sola nota que no contenga en sí, en su férrea lógica, el secreto de lo logrado y la propia justificación total". ${ }^{187}$

Ya que este trabajo es sobre el Art Déco en México, es oportuno comentar que el escritor, intelectual y político mexicano José Vasconcelos (1882-1959) se encontraba en París en una misión diplomática cuando fue estrenada Le sacre du Printemps en el Nouveau Théatre des Champs Elisées, del cual alabó su estilo modernista que constrataba según él con el mal gusto de la decoración de la Ópera, y sobre la música dijo: "La obra de Stravinsky, silbada por unos cuantos, fue recibida por la mayoría como el mensaje de los tiempos nuevos. Todo arte inseguro de su contenido y de su intención adopta desde entonces la etiqueta de la novedad. Se trataba de un pseudopaganismo de estepa rusa, que es cristiana. Las pisadas de los bailarines sobre tierra matriz, evocaban el ritmo de los elementos que colaboraban la faena de la primavera. Las disonancias, fruición de los nuevos, sombolizaban las resistencias del caos". ${ }^{188}$

Bien vale la pena citar los otros trabajos que Stravinski realizó para la compañía de Diaghilev, ya que debido a la fuerte relación de trabajo entre ambos personajes, las obras de Stravinski causaban éntre los miembros del ballet gran expectación. En 1914 fue Le Rossignol con la coreografía de Romanov y la escenografía de Benois y debido a la I Guerra Mundial fue hasta 1917 que compuso Feu d'artifice, contando con la coreografía de Massine y la escenografía de Giacomo Balla. En 1920 El Ruiseñor, bajo la versión de Le Chant du rossignol y Pulcinella, tuvieron la coreografía de Massine y el vestuario y coreografía de Matisse para el primero y de Picasso para el segundo, ambos con sus vanguardistas y geométricos diseños.

\footnotetext{
${ }^{187}$ Alfredo Casella en Guillermo Orta Velázquez, 100 Biografías en la Historia de la Música, México, Olimpo, 1970, p. 185.

188 José Vasconcelos, La Tormenta, México, Jus, 1958, p. 34.
} 


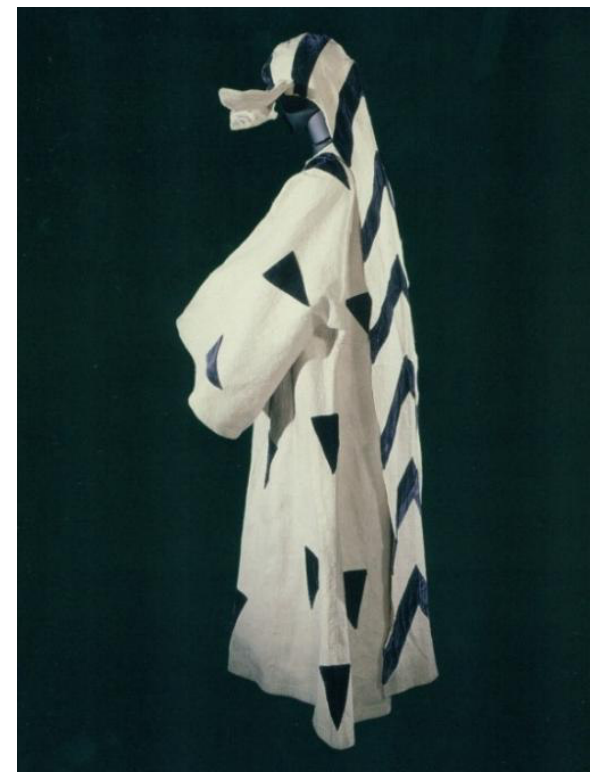

Henri Matisse, traje de un Doliente para Le Chant du rossignol, 1920.

Victoria \& Albert Museum, Londres. 190

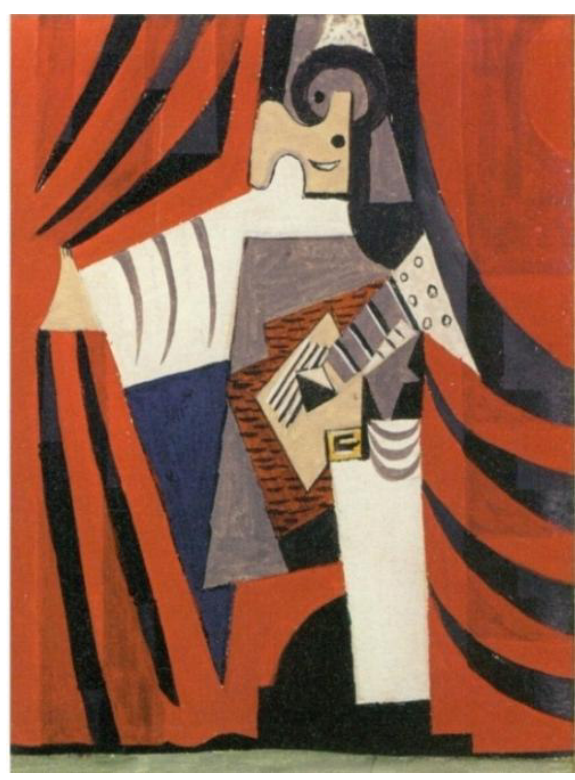

Pablo Picasso, telón para Pulcinella, 1920. Colección particular. ${ }^{189}$

En 1922 Stravinski estrena Mavra y Renard (compuesta desde 1916), ambas obras con la coreografía de Nijinska y escenografía de Survage y Larionov respectivamente. Un año más tarde en 1923 nuevamente Nijinska colabora con la escenografía para Les Noces, mientras la coreografía fue de Goncharova. En 1928 compuso Apollon Musagéte, encargándose de la coreografía Balanchine y los franceses Coco Chanel del vestuario y André Bauschant (1873-1958) de la escenografía. En el último año de la compañía, 1929, Stravinski estrena Renard, penúltimo ballet en el que particparon Lifar como coreógrafo y Larionov como escenógrafo. Una gran relación de trabajo y amistad unieron a Diaghilev y a Stravinski, ya que juntos construyeron una época de gran desarrollo para el espectáculo. Sus restos descansan uno cerca del otro en el panteón de San Michele en Venecia.

Escasa, pero decisiva fue la participación de Sergéi Prokofiev (1891-1953) con los ballets rusos, componiendo solamente tres obras: Chout en 1921, Pas d'acier de 1927 y la penúlitma presentación del ballet con Diaghilev al frente de la compañía que fue el 21 de mayo de 1929, donde se incluyó Le fils prodigue de Prokofiev.Esta participación de Prokofiev con Les Ballets Russes se dio mientras el músico vivía por Europa, especialmente

\footnotetext{
189 FUNDACIÓN "LA CAIXA", Catálogo de la exposición Los Ballets Rusos de Diaguilev 1909/1929 cuando el arte baile con la música, Barcelona, Fundación "la Caixa"/TURNER, 2011, p. 137.

${ }^{190}$ Ibídem, p. 183.
} 
en París entre los años 1918-1933, y daba cuenta del compositor ruso más destacado, por aquel entonces, después de Stravinski.

Vladimir Dukelsky (1903-1969) fue invitado por Diaghilev cuando el músico se encontraba en París huyendo de la represión soviética; compuso Zephyr et Flore que fue estrenada en 1925. Cuando se instala en los Estados Unidos tomó el nombre de Vernon Duke que es con el que más popularmente se le conoce.

Otro de los músicos que habían salido de la Rusia stalinista y que formó parte del grupo de emigrados rusos en París fue Nicolás Nabokov (1903-1978), a quien Diaghilev le propone la música para un ballet y es así como compuso Ode, estrenada en 1928.

Dentro de las obras musicales para los ballets de Diaghilev que no fueron compuestas por rusos están, entre otras, las siguientes: Parade en 1917, un poema de Jean Cocteau (1889-1963), música de Erick Satie (1866-1925), coreografía de Massine y escenografía y vestuario de Picasso. Con el mismo coreógrafo e igual escenógrafo y la música de Manuel de Falla (1876-1946), El sombrero de tres picos se estrenó en 1919. Otra opereta de Cocteau fue Le train bleu de 1924, con la música de Darius Milhaud (18921974), la coreografía de Nijinska, escenografía de Henri Laurens y Picasso, más el vestuario de Coco Chanel. Y el ballet La chatte de 1927 fue musicalizado por Henri Sauguet (1901-1989), contando con la escenografía de Balanchine y la escenografía de los constructivistas rusos avencindados en París, Naum Gabo y Antoine Pevsner.

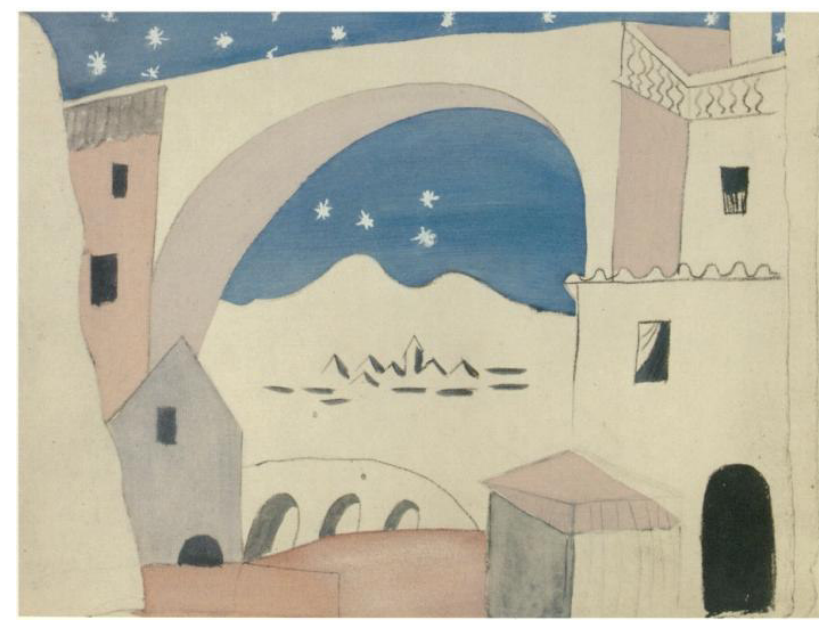

Picasso, Pueblo español, para El sombrero de tres picos, 1919. Victoria \& Albert Museum, Londres. ${ }^{191}$

${ }^{191}$ Ibídem, p. 101. 


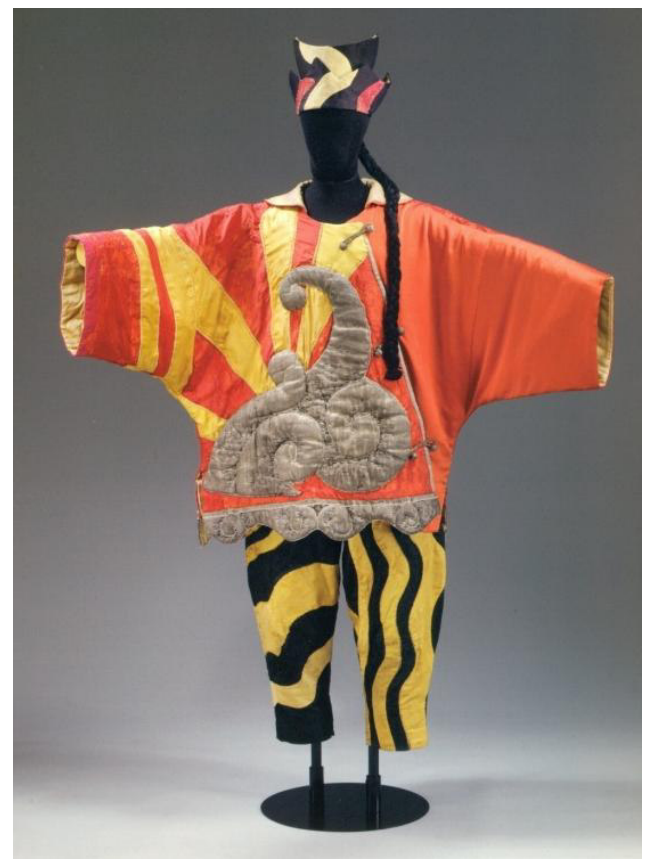

Picasso, traje del Prestidigitador Chino para Parade,1917.

Victoria \& Albert Museum, Londres. ${ }^{192}$

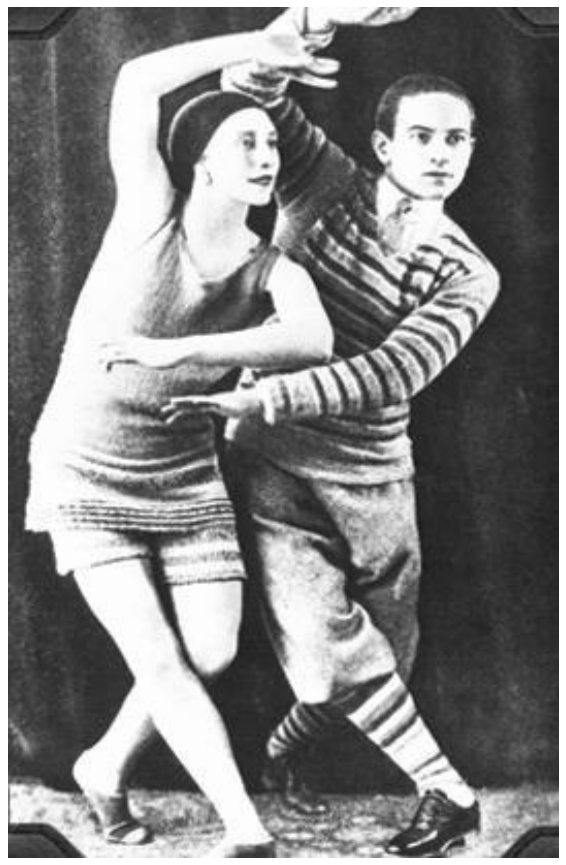

Coco Chanel, vestuario para Le train blue, 1924.

Victoria \& Albert Museum, Londres. ${ }^{193}$

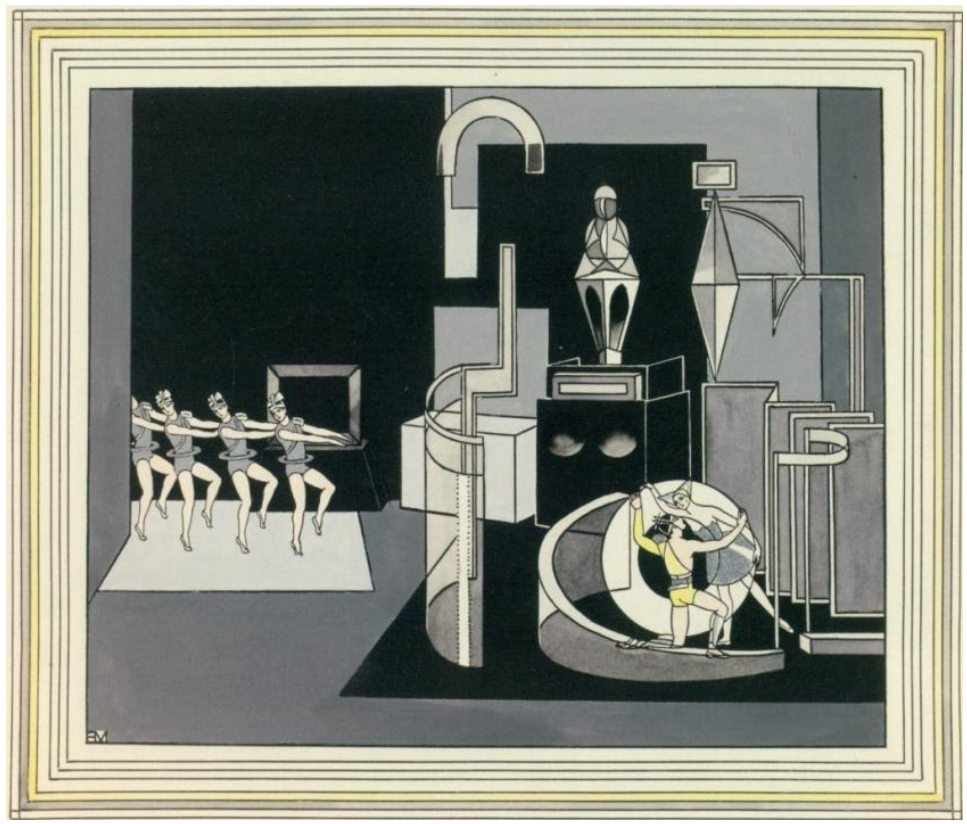

Naum Gabo y Antoine Pevsner, diseño para La chatte, 1927.

Victoria \& Albert Museum, Londres 194

\footnotetext{
${ }^{192}$ Ibídem, p. 103.

${ }^{193}$ Suzanne Lussier, Art Deco Fashion, London, Bulfinch Press, 2003, p. 36.

${ }^{194}$ Catálogo de la exposición, Los Ballets Rusos de Diaguilev 1909/1929 cuando el arte baile con la música, Op. Cit., p. 101.
} 
Así como mencionamos que los coréografos y bailarines rusos de la compañía de Diaghilev salieron de Rusia para nunca regresar, lo mismo sucedió con la mayoría de los músicos rusos que participaron con los ballets.

Duante los diez años de Les Ballets Russes de Diaghilev, la aportación cultural que dejaron en Europa, especialmente en París, no se ha repetido, pues el intenso y amplio repertorio de los ballets, con la coreografía, música, escenografía y vesturaio, contribuyeron a la conformación de una estética que influyó en los movimientos artísticos de la vanguardia y que coincidió con los "Años Locos" y la época del Art Déco, con la particularidad de que esta empresa con Diaguilev a la cabeza, reunió a lo más connotado del mundo del arte. 


\subsection{APROXIMACIÓN A LAS CARACTERÍSTICAS REPRESENTATIVAS DEL ART DÉCO}

\subsubsection{Cómo distinguir al Art Déco y sus variantes estilísticas}

Cuando se trata el término o estilo Art Déco como tal es necesario explicar un conjunto de diferentes manifestaciones estéticas que se dieron cita en la ya mencionada Exposition Internationale de Arts Décoratifs et Industriels Modernes de 1925 y que fueron conmemoradas en la retrospectiva titulada, Les Annés 25, llevada a cabo en París en el Musée des Arts Décoratifs del 3 de marzo al 16 de mayo de 1966. Además, dichas manifestaciones constituyeron una época de la decoración que inundó todos los ámbitos de la vida cotidiana, desde una lámpara hasta un edificio completo y que alternó con los movimientos de vanguardia. Esa época son los años de entreguerras, los veinte y los treinta, los "Años Locos", que quedaron insertos en la historia del siglo XX y de la decoración como los años del Art Déco.

Mientras que el Art Nouveau se investía con sus sinuosas y serpentinas líneas, en la primera década del siglo XX se empezará a trabajar en el diseño de muebles, aparatos domésticos, transportes y medios de comunicación masiva, como serán los cines y más tarde la radio, utilizando líneas rectas, formas geométricas y compactas. Así, el ya mencionado Palais Stoclet de Hoffmann, proyectado en 1905 y terminado en 1911, inauguraría una estilización geométrica en la arquitectura, como más tarde también serían los Ballets Russes de Sergei de Diaghilev que llenan los teatros parisinos a partir de 1909, con sus inauditas y coloridas coreografías trabajadas bajo los diseños geométricos y exóticos de León Bakst.

Así pues, si los primeros catorce años del siglo XX europeo transitaron del Art Nouveau hacia nuevas formas de concebir los diseños, lo cual se vio interrumpido por la I Guerra Mundial, una vez terminada la beligerancia entre las naciones, algunas vanguardias y movimientos artísticos, los talleres artesanales y casas de diseño, las industrias y los productos emanados de ellas, buscarán invadir todos los ámbitos de la vida cotidiana, desde un cubierto de mesa, hasta la edificación de un inmueble. 
Caros y extraños, nuevos materiales serían utilizados en los productos que salen de los ateliers para cumplir con los deseos de una élite caprichosa: el cromo, metal de color argentino y cristalino, la baquelita, resina sintética y moldeable, y el plástico que por su nobleza matérica podía aplicarse de múltiples maneras. También estaban las exóticas maderas y otros elementos naturales traídos de tierras lejanas que se utilizaban en los muebles y en la confección de atuendos de vestimenta: la madera de amboina traída de las Islas Molucas y que recibió dicho nombre por provenir de la capital Ambon o el ébano del estrecho de Macasar en Indonesia; la piel áspera del pez zapa, la concha de tortuga conocida como carey, la piel de serpiente o de tiburón. Todo esto reflejaba las excentricidades a las cuales se acostumbraba esa clase acomodada que a través de objetos lujosos de decoración mostraban su estatus social.

Sin embargo, un sector social más amplio de la población desea consumir también esos nuevos objetos de diseños exclusivos; esa es la razón por la cual la industria produce gran cantidad de productos, copiados o inspirados en los originales que se vendían en los selectos almacenes y finas boutiques.

Época de consumo que provoca que los grandes almacenes comerciales sean decorados atractivamente para atraer la atención de los consumidores. Todo esto se esparce y se da a conocer a través de la publicidad, en donde el cartel toma gran importancia.

Y toda esa nueva gama de productos y diseños se verán contagiados por lo geométrico, lo cual se proponía y trabajaba en algunos movimientos artísticos de vanguardia o estaba en relación con las máquinas de la industria. Pero lo geométrico también será tomado por la colección de piezas africanas que tanto Braque como Picasso usaran en el Cubismo, o también de lo egipcio, pues en 1922 Howard Carter (1874-1939) exhuma la tumba de Tutankamón y cobra fuerza la maldición de los faraones por la repentina muerte del descubridor y los motivos decorativos del antiguo Egipto se ponen de moda; además, las ruinas teotihuacanas, mayas y objetos de la cultura mexica se vuelven a revalorar sobre todo después del extravío del coronel Percy Fawcett (1867-¿1925?) en 1925 en las tierras peruanas de Machu-Pichu y posteriormente la expedición al mando de Peter Fleming (1907-1971) en su búsqueda: las culturas prehispánicas sudamericanas y mesoamericanas cobran importancia, así como también los indios Pueblo de los Estados Unidos, inundando los ambientes de la decoración e inclusive de la moda: zigzags, soles 
radiantes, cactus hieráticos, figuras de perfil, mujeres cleopatrizadas, templos escalonados, atuendos indígenas mesoamericanos e incas, se ritualizan junto con los zigurats mesopotámicos y bailarinas hindúes o balinesas que se rescatan del olvido occidental en un intento de voltear hacia culturas exóticas y encantadamente fantásticas.

La era de la máquina y de un mundo industrial provoca la producción a gran escala que da por consecuencia los intercambios comerciales mundiales y los negocios internacionales que se desplazan a la velocidad del ferrocarril o en la comodidad y lujo de los monumentales trasatlánticos. O bien, los recorridos en automóviles descapotados y en aeroplanos que desafían las alturas y más aún después de que el Atlántico fue atravesado sin escalas en 1927 por Charles Lindbergh (1902-1974), consagran el triunfo de la aplastante motorización. Surge la visión "poética" de la máquina, del mundo moderno, mecanizado donde el mito del robot algún día tomará el mando de la civilización.

Los “Años Locos” europeos se hermanan con los años del Fox-Trot, del Charleston, de la música negra del Jazz, de la crisis del 29, del New Deal de los Estados Unidos. Paraninfos de bailes, salas de espectáculos, iluminados con líneas de luz geométricas, ritman con las grandes bandas y orquestas de nuevas cadencias, rápidas, sincopadas e improvisadas que desgarran las enraizadas piezas de vals y hacen vibrar los cuerpos en inéditos bailoteos.

Y mientras Fritz Lang (1890-1976) exhibe un mundo mecanizado y robotizado en Metropolis, 1927, Alan Crosland (1894-1936) en The Jazz Singer hace cantar al cine cuando Al Jolson (1886-1950), quien se maquilla como un afroamericano, entona una pieza de jazz.

Tiempos de los veinte y treinta, donde el hombre, el "dandy" de bigote recortado, pelo engomado, vestido con esmoquin, que merodea en clubes y cócteles, frivoliza con cierta naturalidad y pose ante las mujeres de boca menuda, peinadas a la garçonne, con sombreros encasquetados, que ya no usan corsés ni hombreras, engalanadas con telas ligeras, de vestidos cortos que muestran las piernas, alcanzando así una expresión de mujer dinámica y flexible, que al igual que el hombre fuma y bebe en la nueva vida social.

Todos esto se incorporará con las emisiones del diseño, del arte, la artesanía y la industria europea de la época de entreguerras y es lo que se conocerá más tarde como Art Déco. 
Para Paul Maenz, uno de los primeros tratadistas sobre este tema, afirma:

"El estilo $<$ Art Déco>, como tal, jamás existió. El término aparece por primera vez en 1966 con ocasión de la muestra retrospectiva <Les Annés 25> celebrada en el Musée des Art Décoratifs de París, y que conmemora la última y más alta cota jamás alcanzada por la artesanía modernista: la <Exposition Internationale des Arts Décoratifs Modernes> de 1925.

Desde aquella Exposición de 1966, cuantas manifestaciones artísticas se produjeron entre las dos guerras mundiales, o sea, entre 1920 y 1940, quedaron englobadas bajo el común patronímico de $<$ Art Déco $>$. Desde el $<$ Bon Gout $>$ de la Compagnies des Arts Francais, pasando por el $<$ Esprit Nouveau $>$ de Le Corbusier, hasta llegar al $<$ Stream-Line Camp > de Chicago. Tan art déco han acabado siendo el hechizo coreográfico del ballet ruso de Diaghilev de principios de los años veinte, como la fascinación constructivista del cubismo de finales de siglo o la exaltación arcaizante de los años treinta. Doctrinas estéticas que se confrontaron con fervor casi religioso, se ven ahora condenadas desaprensivamente a compartir un mismo rasero". 195

Esta cita del libro de Maenz nos deja en claro qué es lo que se considera Art Déco; sin embargo, hace falta mencionar las características distintivas, para lo cual citaremos a varios autores que explican lo que es el Art Déco.

Xavier Esqueda en su libro Art Déco. Retrato de una época lo explica así:

"El empleo de la línea recta es la principal característica de este estilo, en diferentes combinaciones y principalmente en la de zig-zag, líenas que por sí solas son un símbolo elcuente del Deco. Las curvas aparecen frecuentemente, y el círculo en especial, pero estas líneas se emplean con un sentido geométrico, sin sensualidad como lo había empleado el art nouveau. La geometría impera en los diseños desde la arquitectura hasta todo aquello diseñable, y notablemente se hace uso de la simetría incluso cuando se estiliza la figura humana.". 196

Como rasgos distintivos del Art Déco, Eva Weber cita lo siguiente:

"Una de las características más reconocibles del estilo Art Decó fue la riqueza ornamental de las superficies en el exterior de los edificios, repetida en sus instalaciones en

\footnotetext{
${ }^{195}$ Paul Maenz, Op. Cit., pp. 10-11.

${ }^{196}$ Xavier Esqueda, El Art Déco. Retrato de una época. México, UNAM, Centro de Investigación y Servicios Museológicos, 1986, p. 14.
} 
el interior. Los motivos con formas precisas comprendían zigzags, triángulos, rayas, círculos segmentados y espirales, mientras entre los motivos naturalistas se encontraban flores, árboles, frondas, fuentes, gacelas, pájaros, nubes y amaneceres estilizados... Fueron representativos de la era de la máquina su dinamismo los rayos, los aeroplanos, las locomotoras, los trasatlánticos, los automóviles, los rascacielos y los puentes. La imaginería de la era de la máquina se extendió también a las cúspides de los edificios, que con frecuencia estaban coronadas con mástiles futuristas o pretiles con aletas". ${ }^{197}$

Dentro del Art Déco hay dos periodos que corresponden a dos líneas estéticas del estilo: el Zigzag y el Streamline, aunque también se habla de un Neoclásico Moderno o Neoclásico Déco que es el antecendente.

El Neoclásico Moderno aunque se da más en la arquitectura y lo explicaremos en ese apartado, se puede aplicar a aquellas producciónes que toman elementos de la cultura clásica, como son los órdenes arquitectónicos, los diseños influidos de la época antigua renacentista y neoclásica, los cuales se geometrizan y adaptan a las vanguardias. Este tipo de Déco se desarrolla desde antes de la gran exposición del 25 y durantes los años veinte.

El Zigzag va aproximadamente de 1920 a 1930, se dio mayormente en Europa y fue el que se basó en las referencias de las culturas pasadas que se pusieron de moda por descubrimientos arqueológicos de Egipto, Mesopotamia, Mesoamérica, la cultura Inca, o que se rescataron del olvido y del desinterés occidental, tal como sucedió con las piezas africanas y algunas mismas culturas europeas antiguas, o bien las extrañas y lejanas sociedades orientales. Resalta en su decoración los triángulos encadenados y superpuestos y líneas y composiciones geométricas en movimiento.

El Streamline tuvo su auge de 1930 a 1939 y se le denomina tanto Stream Line cuando se refiere a la línea aerodinámica o Streamline como la variante estilística. Se desarrolló más en Estados Unidos y representa la era de la recuperación económica después del “crack" bursátil del 29. Hombres fuertes y desnudos, quienes controlan máquinas de diversa índole y vislumbran un futuro prometedor tecnológico, adornan paneles y los principales motivos decorativos son las líneas curvas aerodinámicas, de aquí su nombre, líneas horizontales aplicadas o también abstracciones de la velocidad.

${ }^{197}$ Eva Weber, Art Deco. Madrid, Lisba, 1993., pp. 28-29. 


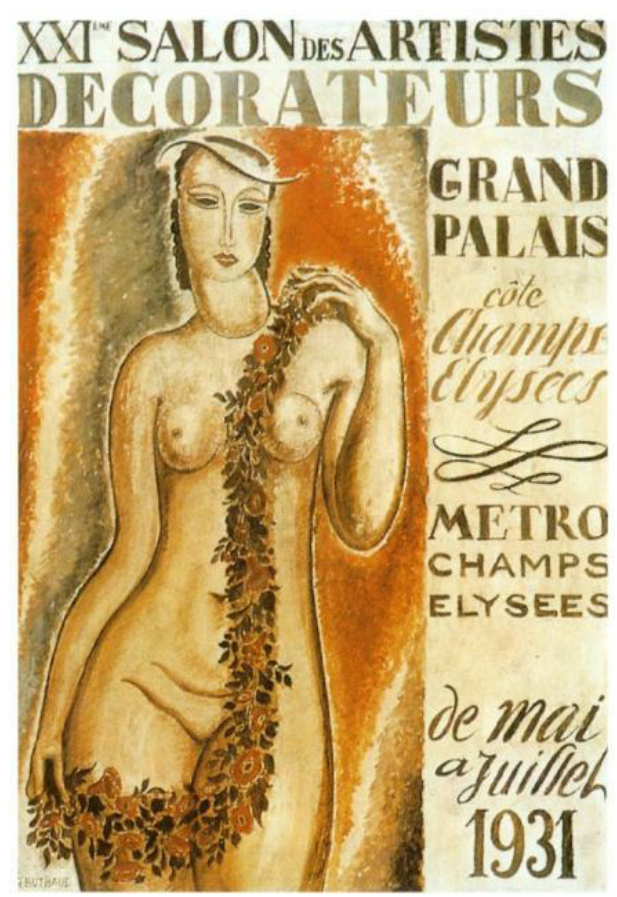

René Buthardt, Neoclásico Déco. Cartel del XXI Salón des Artistes Decorateurs, 1931.198

Enrique de Anda explica las características de ambos periodos. El Zigzag:

"Del tiempo del Zigzag son, dentro del género de los trabajos de pequeño formato: la joyería, el mobiliario y los diseños textiles, las composiciones cuyo principio estructural se apoya en las seriaciones lineales, siempre dispuestas en un solo plano y en las cuales, como ya quedó señalado, se trabaja con el principio de inducir ópticamente la idea de movimiento".

Y el Streamline:

“...la temática antropomorfa de la Stream Line se orienta hacia la representación del hombre vigoroso, con el torso desnudo, dominando a la máquina, cuya imagen aparece en murales policromos y en relieves adosados a la arquitectura...Por eso las composicones arquitectónicas de la época...parecerían haberse adaptado a geometrías que remiten a la sensación de estar frente a una máquina;...”. ${ }^{199}$

\footnotetext{
${ }^{198}$ S/A, Art Déco Pintura y Diseño, Madrid, Edimat, 1999, p. 43.

199 Enrique X. De Anda Alanís, "El Art Déco: Formas y Razones", Catálogo de la exposición Art Déco. Un país nacionalista, un México cosmopolita. México, Instituto Nacional de Bellas Artes, 1997 1ª., edición, 1998 $1^{\text {a }}$., reimpresión, pp. 54-55.
} 


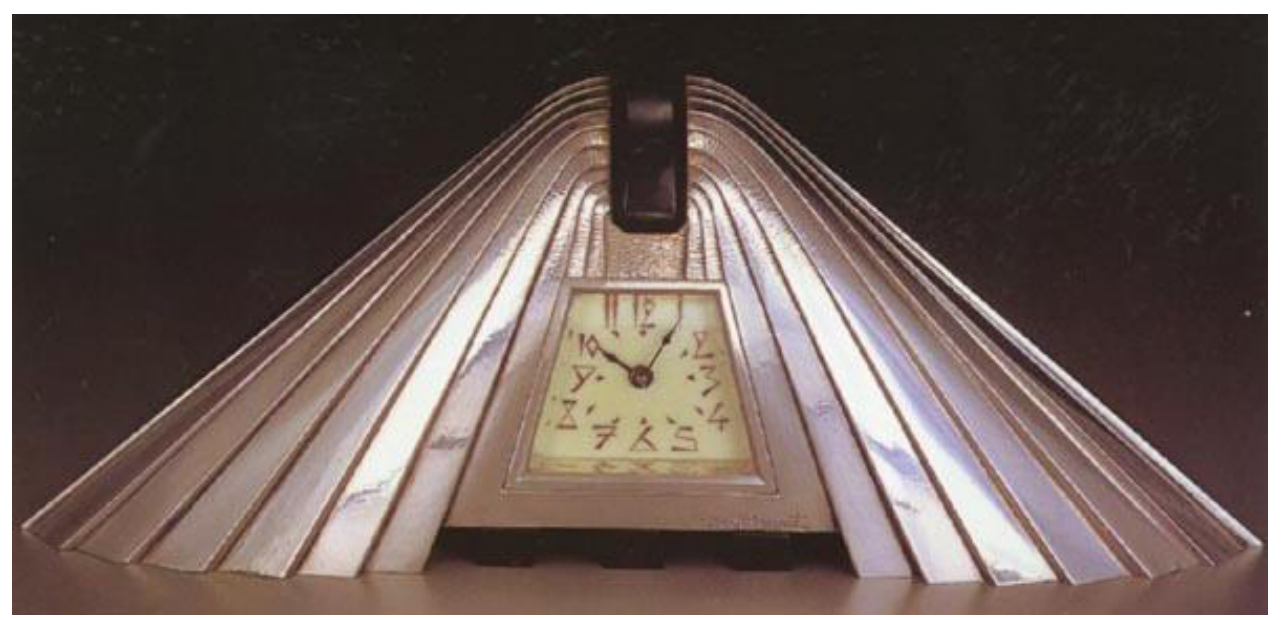

Zigzag. Alber Cheuret (1884-1996). Reloj en bronce plateado y ónix de inluencia egipcia y números estilizados en base a líneas rectas, ha. 1930.

Virginia Museum of Fine Arts, Richmond. ${ }^{200}$

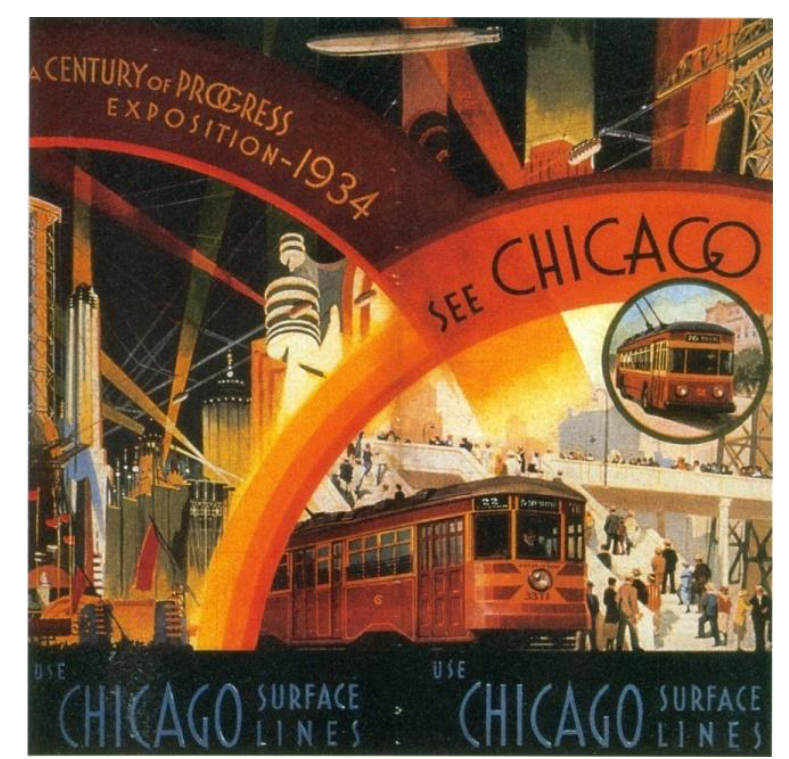

Streamline. Cartel de la exposición Century of Progress, Chicago,1933-1934. ${ }^{201}$

Además de las variantes del Neoclásico Déco, Zigzag y el Streamline, en Estados Unidos hubo dos tipos más del Art Déco que queremos mencionar debido al influjo que tuvieron en México. Una es el Pueblo Deco que se dio en los estados de Arizona, Nuevo México y el occidente de Texas, lugares donde habitan los grupos étnicos amerindios conocidos como Indios Pueblo. Referencias artesanales de los Hopi y Navajos, así como los

\footnotetext{
${ }^{200}$ Patricia Bayer, Op. Cit., p. 42.

${ }^{201}$ Bevis Hillier; Stephen Escritt, Op. Cit., p. 93.
} 
vaqueros y los cactus desérticos de Texas, se mezclan en las decoraciones aplicadas en la arquitectura neocolonial de tipo californiano. La otra es el Tropical Deco, la cual tuvo su desarrollo en la Florida y en algunas playas de California; principalmente, fue en el distrito de Old Miami Beach donde más se consolidó. Con alusiones marítimas e interpretaciones naturalistas, quebradizos zigzags y colores suaves, se edificaron hoteles y apartamentos que constituyeron esta variante del Déco. Estas varianets estilísticas las explicaremos con más detalle en el siguiente punto sobre la arquitectura Déco, pues tuvieron sus manifestaciones en casas y edificios.

Entonces, para una síntesis distintiva del Art Déco, el mismo Xavier Esqueda en el libro Una puerta al Art Deco compendia claramente los elementos formales de este estilo:

"Las líneas sueltas y ondulantes del Art Nouveau se convierten en rectas y curvas rígidas con sentido puramente geométrico y muchas veces simétrico: los torcidos lirios y pavorreales dejan su lugar a formas de un exotismo más remoto, como las garzas, las palmeras y los cactus. El humo que parece salir de una pipa de opio es ahora el humo de las fábricas, de las locomotoras, de los trasatlánticos, de los aviones, de los automóviles y, en general, el humo devastador del progreso técnico.

La energía se transforma en el motivo principal del ART DECO. El Sol, con sus rayos geométricos es el centro decorativo entre una gama de colores con sentido étnico, como en las culturas arcaicas era el centro de adoración religiosa. Las líneas rectas en zig zag son un elemento no solamente decorativo, sino simbólico del rayo o la energía. Las repetidas curvas geométricas ondulantes representan el agua que vierten las fuentes estilizadas, incorporadas a la arquitectura o que simplemente se plasma como bajo relieve en paredes, lámparas, vitrales, etc.

Los cactus se reproducen en metales o en piedra y al natural forman parte principal de la decoración. La figura humana es de vital importancia en la simbología, especialmente el hombre representado por titanes, obreros, atletas y demás pretendidos exponentes de la fuerza de nuestro siglo. La figura femenina aparece, ya no con la fragilidad de la mujer del Art Nouveau, sino con una fuerza que hace pensar en la emancipación de la mujer del Siglo XX. 
Los materiales de que se vale son de gran solidez y pureza: concreto, mármoles de diferentes colores y procedencias, vidrio, cristal y metales como el acero, aluminio y bronce". 202

Como un sumario, daremos una serie de características generales que nos describen al Art Déco y que fueron utilizadas tanto en decoración, como en arquitectura, escultura y hasta en la pintura, las cuales nos ayudan a identificar este estilo, además de que las aplicaremos en las descripciones de los edificios y obejtos de artes pláticas y decorativas propuestos a estudiar.

En primer lugar diremos que el Art Déco se basa principalmente en la geometría imperante del cubo, la esfera y la línea recta, además de los imprescindibles zigzags; conjuntos horizontales y verticales de líneas rectas, o bien perpendiculares combinadas con medias circunferencias y circunferencias enteras, además de los hexágonos y los octágonos.

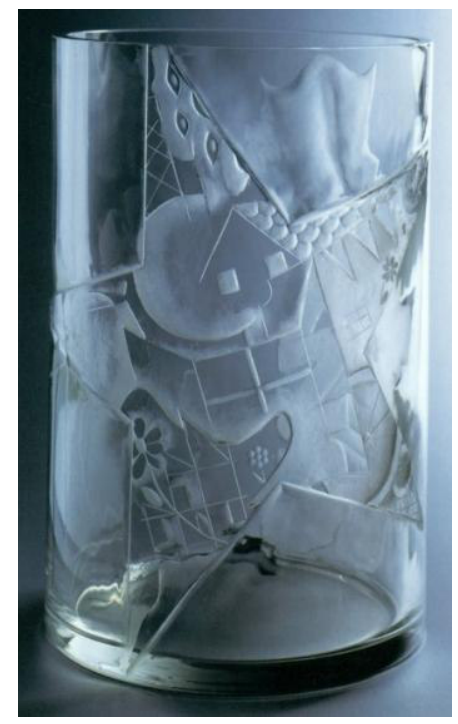

Zdenek Juna, Vaso, 1921.203

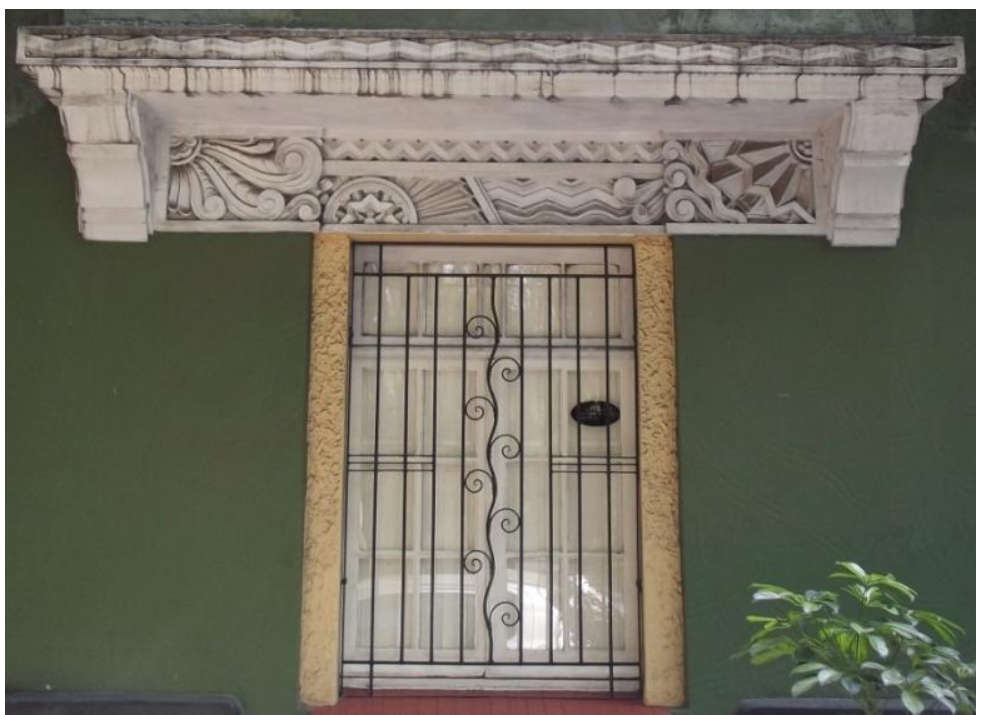

Decoraciones en una casa de la avenida México, ha. 1930. colonia Hipódromo Condesa, México, D.F.,

Soles con rayos luminosos radiantes, nubes trazadas rígidamente, ondulaciones que buscan representar fluidos acuáticos son algunas de las abstracciones que se hacen de la naturaleza.

202 Xavier Esqueda, Una puerta al Art Deco, México, U.N.A.M., Centro de Investigación y Servicios Museológicos, 1980, pp. 11 y 13.

${ }^{203}$ Torsten Bröham; Thomas Berg, Op. Cit., p. 148. 


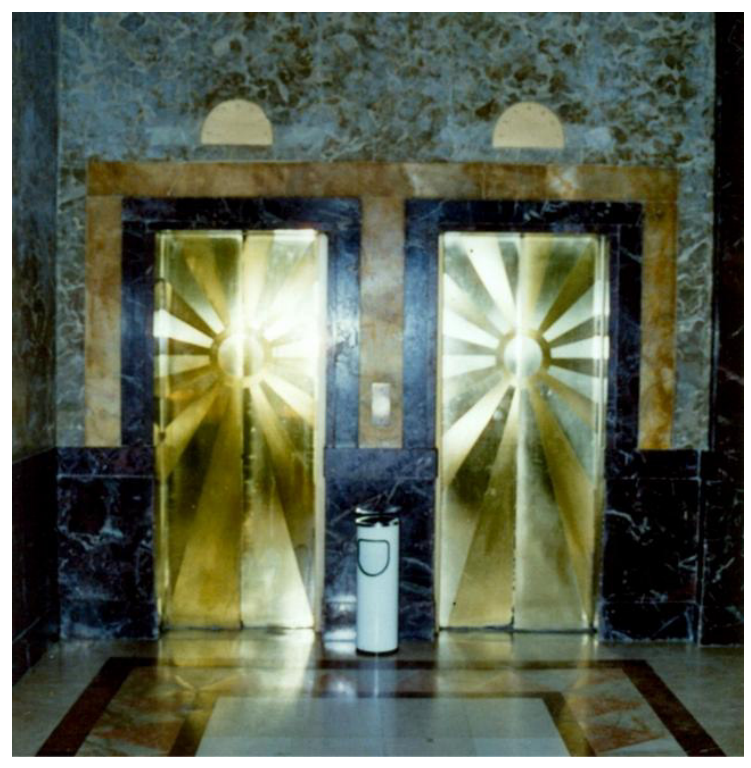

Esteban Rodríguez Castells, Elevadores del Edificio Bacardí, La Habana, 1930.

Animales como gacelas, galgos, leopardos y panteras son utilizados junto con aves como águilas, palomas y garzas por su referencia con la velocidad.

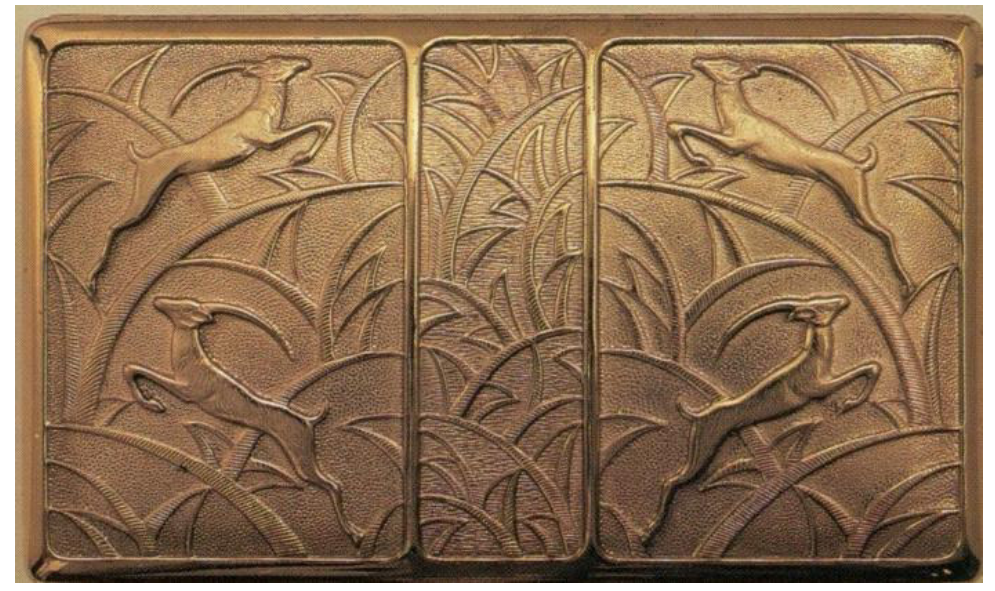

Cigarrera y polvera en metal de la Elgin American, Illionis, ha. $1930 .{ }^{204}$

Dentro de los elementos fitomorfos más utilizados están las flores, frutas y plantas enmarcadas, trabajadas con delineaciones geométricas, creando el concepto de "flores petrificadas", así como los cactus y las palmeras.

${ }^{204}$ Patricia Bayer, Op. Cit., p. 43. 


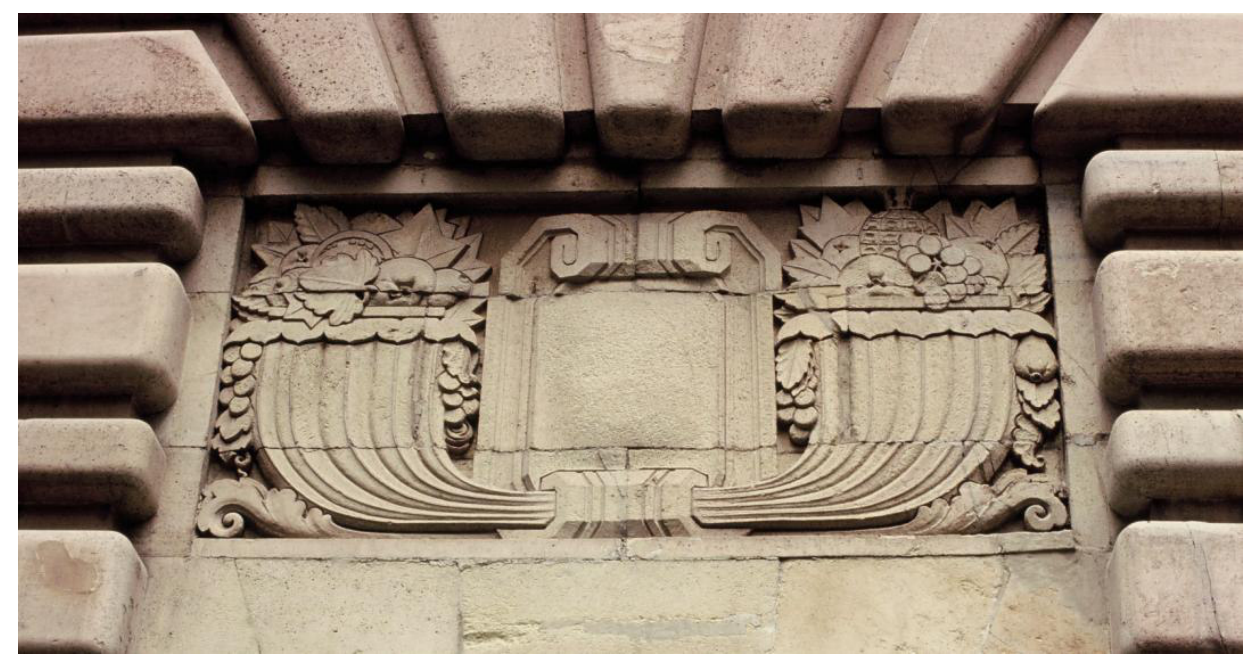

Manuel Centurión, relieve en el Banco de México, México, D.F., 1927

Imágenes de fuentes congeladas y en forma ascendente son una constante del Déco que tanto se utilizarán en objetos de decoración, como en la arquitectura.

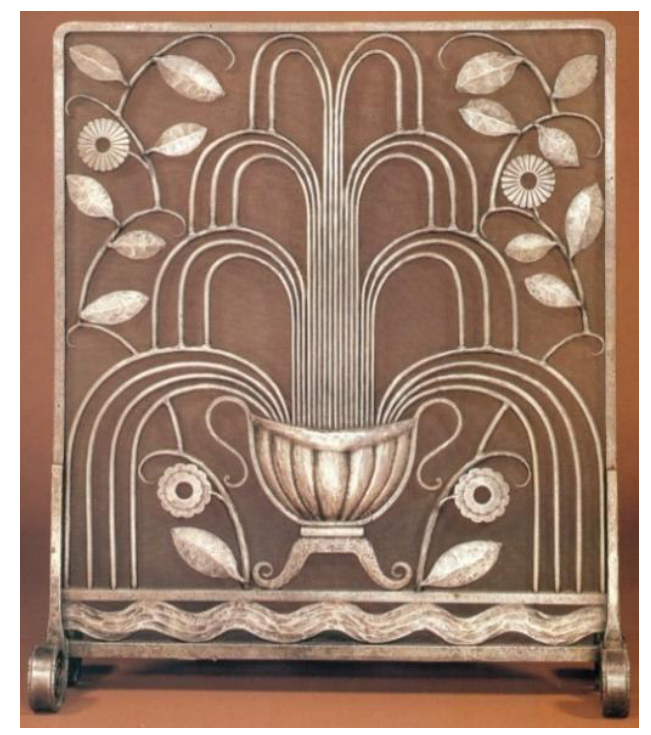

Egard Brand, Fuente, 1924.

The Metropolitan Museum of New York. 205

Nuevos materiales industriales se ponen de moda: el cromo, la baquelita y el plástico; naturales, piel de zapa, de tiburón y el carey; maderas traídas de lejanas tierras como el ambón, el ébano y el palisandro

\footnotetext{
${ }^{205}$ Susan A. Sternau, Op. Cit., p. 34.
} 


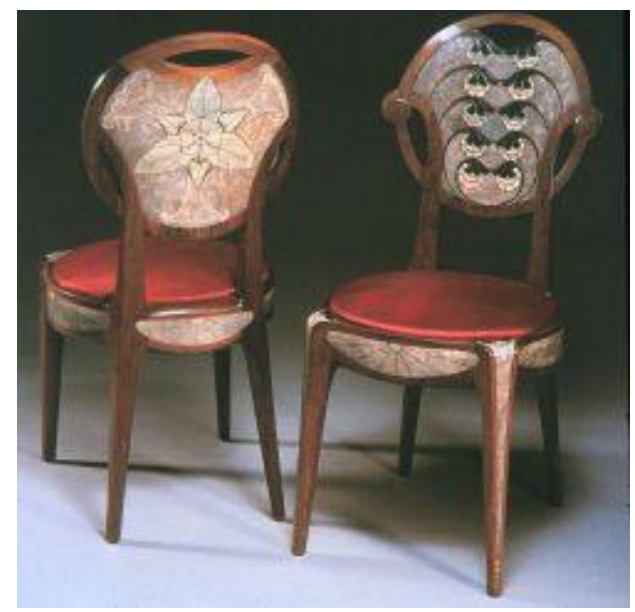

Clément Rousseau, Sillas con estructura de palisandro y piel de tiburón, 1925.

Virginia Museum of Fine Arts, Richmond. 207

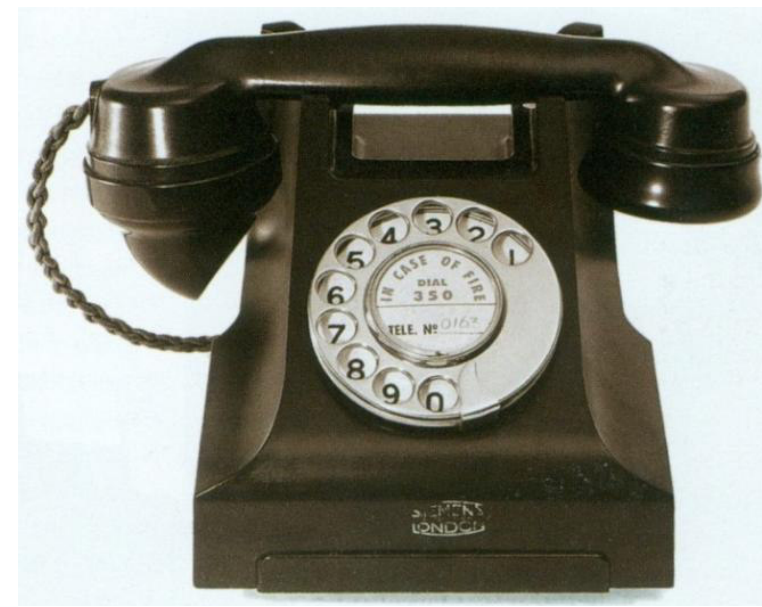

Jean Heiberg, Teléfono en baquelita DHB 1001, para la marca Siemens, 1932. ${ }^{206}$

Los motivos de las culturas prehispánicas americanas como lo mexica o azteca, lo maya, lo inca sirven de inspiración tanto a decoradores como a arquitectos; lo mismo sucedió con los descubrimientos arqueológicos de lo egipcio y lo mesopotámico, así como con los objetos africanos, vikingos, hindúes y de los indios Pueblo.

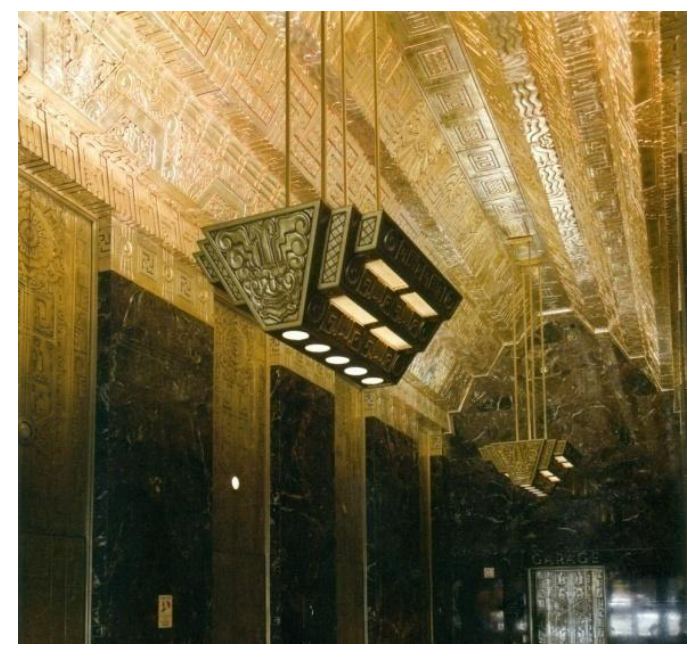

James Rupert Miller y Timothy Pflueger,

detalle del techo y lámparas con motivos mayas del Medico-Dental Building, San Francisco, CA., ha. 1930.208

\footnotetext{
${ }^{206}$ Charlote \& Peter Fiel, Op. Cit., p. 319.

207 “Durniture Desingns of 1920's and 1930's”, Clément Rousseau, http://core.ecu.edu/art/duffym/49706911/4970materials/artdeco2.html

208 Therese Poletti, Art Deco San Francisco. The Architecture of Timothy Pflueger, New York, Princenton Architectural Press, 2008, p. 78.
} 
La máquina simboliza una nueva era de la mecanización: automóviles, locomotoras, barcos, aviones, representan el triunfo del dominio de la locomoción y la velocidad.

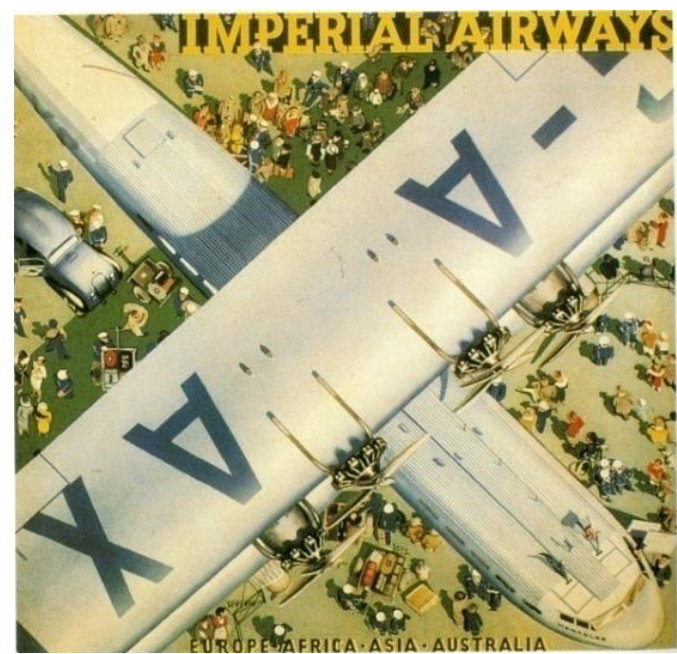

Cartel de la aerolínea británica Imperial Airways, 1930.209

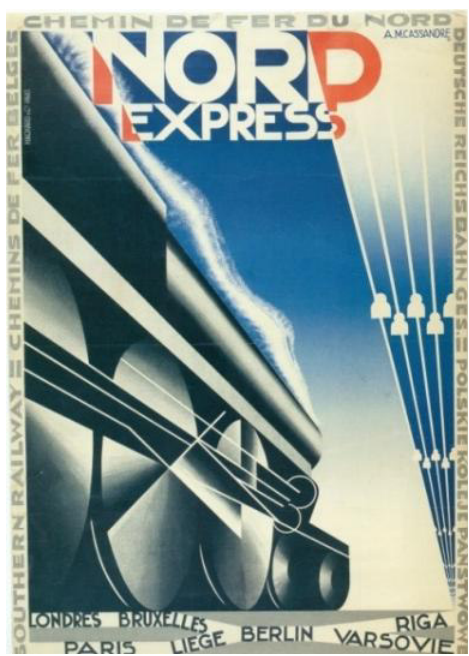

A. M. Cassandre, Expreso del Norte. 1927.210

Los aparatos electrodomésticos que facilitan las labores hogareñas son diseñados bajo los mismos ideales mecánicos y de progreso, a través de figuras geométricas.

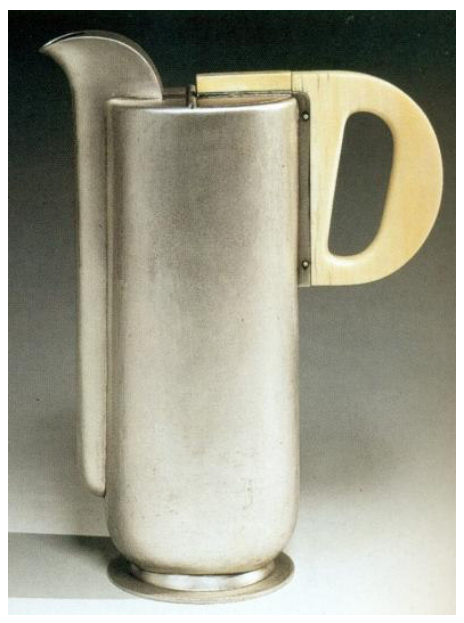

Christian Dell, Cafetera, ha. 1930.211

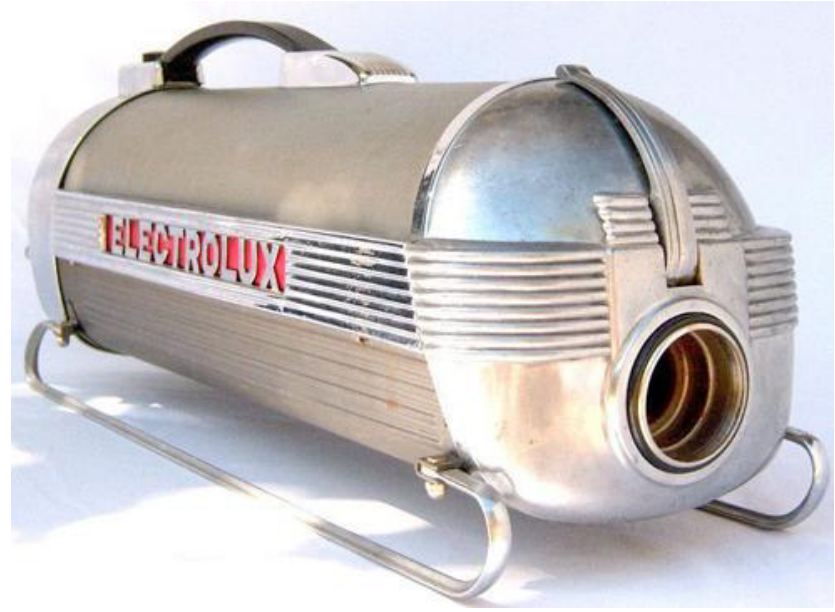

Aspiradora sueca Electrolux, ha. 1930.212

\footnotetext{
${ }^{209}$ S/A, Art Déco. Pintura y Diseño, Madrid, EDIMAT, 1999, p. 36.

${ }^{210}$ Philip B. Meggs; Alston W, Op. Cit., 281.

${ }^{211}$ Charlotte \& Peter Fiell, Op. Cit., p. 476.

212 Ignacio Urbina Polo, "Vacuum_electrolux_1930”, di-conexiones, http://www.di-conexiones.com/navibots-aspiradoras-inteligentes-o-mascotas-electronicas/vacuum_electrolux_1930/
} 
Y la avasalladora energía eléctrica, así como la transmisión de las comunicaciones son interpretadas con líneas resquebrajadas, rayos, luces radiales que se expanden desde su centro productor, simbolizandso la intensidad de su expansión, todo representado en la publicidad de carteles, que se enmarcan en paneles o bien en las herrerías de puertas, ventanas y rejas.

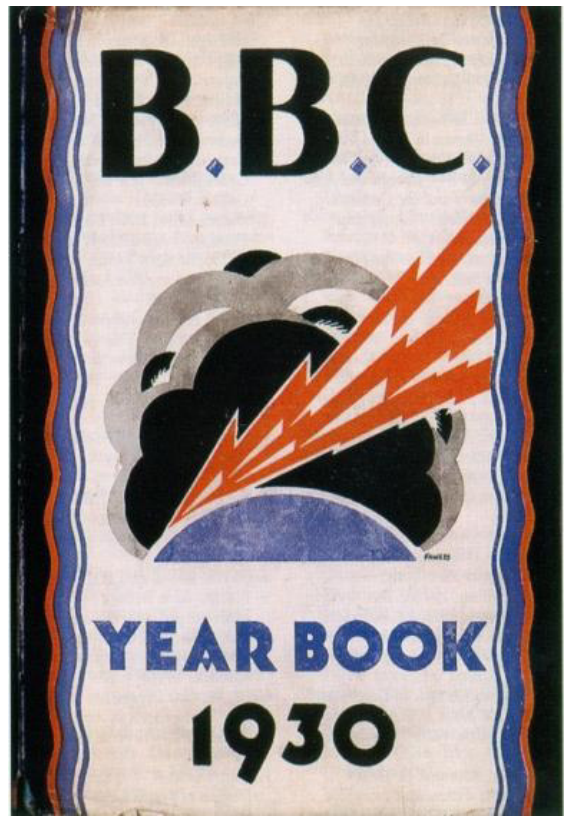

Cartel de la B.B.C., Londres. ${ }^{213}$

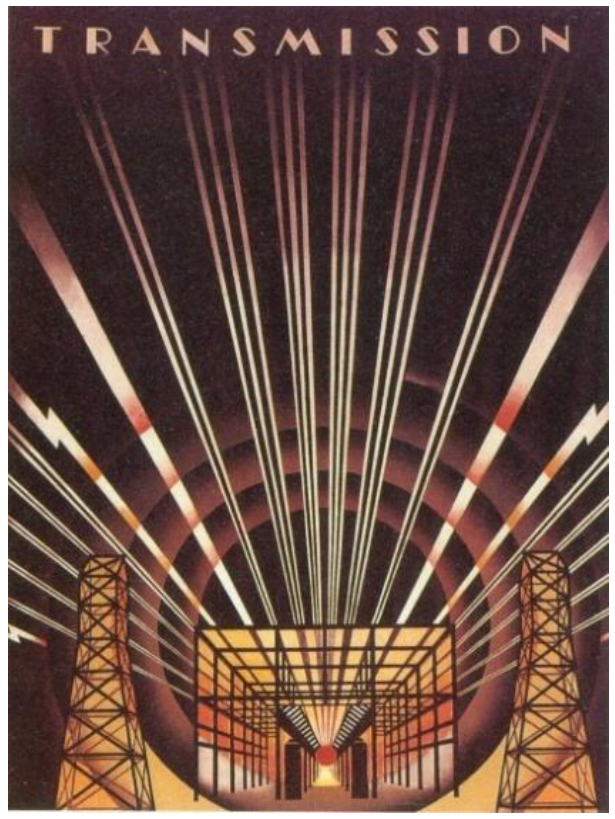

Panel en vitrolite de la Niagara Mohawak Power Corporation Building, West Syracuse, New YorK, 1932. ${ }^{214}$

Finalmente, la figura humana de hombres gimnastas, atlantes, obreros, con posturas rígidas, habitantes de las urbes, con traje y pelo engomado, que someten al mundo moderno mecanizado, se emparejan con mujeres resueltas que participan en la producción económica, vistiendo una moda más atrevida, con el pelo corto a la garçonne, que fuman y participan en cócteles, denotando su liberación. Ambos también aparecen en traje de baño, en modernos centros deportivos con piscinas, o bien en ciertas ocasiones con el torso desnudo o desvestidos completamente, con hercúleos cuerpos, en posturas circulares y vertiginosos saltos, los cuales connotan la impetuosidad del siglo XX. Los humanos alados

\footnotetext{
${ }^{213}$ Patricia Bayer, Op. Cit., p. 185.

${ }^{214}$ Bevis Hillier; Stephen Escritt, Op. Cit., p. 85.
} 
se recrean en los ambientes aéreos en franca competencia con la paulatina conquista del espacio.

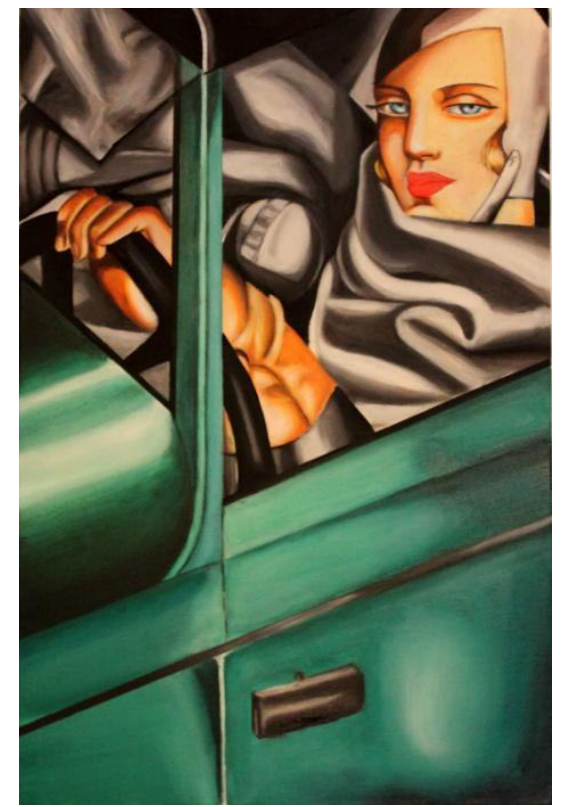

Tamara de Lempika, Autorretrato,1925. Colección privada. ${ }^{215}$

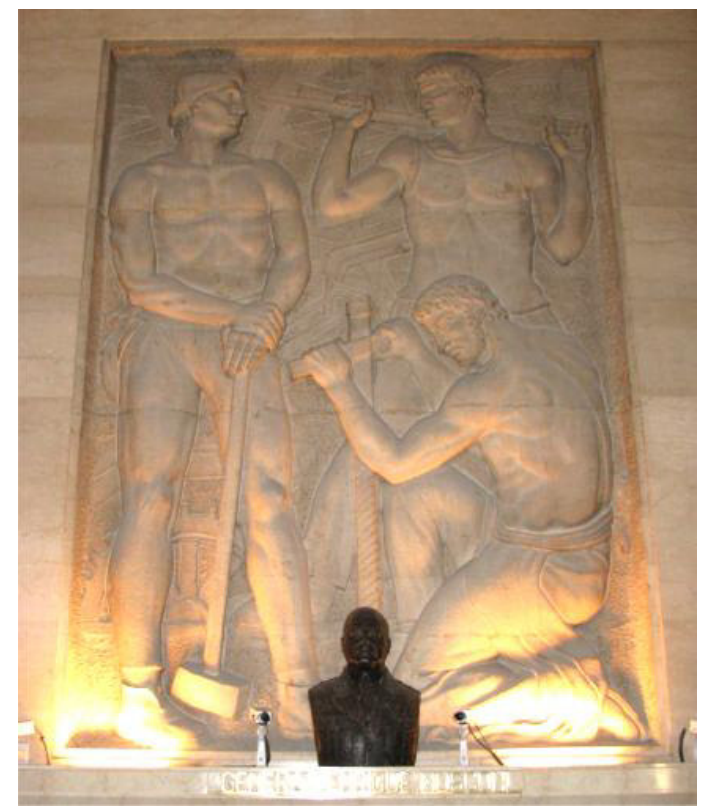

Alfredo Lagos, Relieve el trabajo petrolero, 1938. Antiguas oficinas de Yacimientos Petrolíferos Fiscales, Buenos Aires.

Dentro de la arquitectura (que la explicaremos más detalladamente en el siguiente punto), además de las formas geométricas que ya mencionamos, se recurre a remates terminados escalonadamente y con proas marítimas que sostienen mástiles que sirven como astas; arcos y puertas ochavadas y lujosos materiales como el mármol, el granito y el aluminio consuman el aparato decorativo.

Todos estos elementos descritos nos hablan de manifestaciones que buscaban ante todo la decoración, por lo cual es importante aclarar que no sólo se produjo Art Déco en los años de entreguerras, pues hubo diferentes caminos y búsquedas artísticas a la par y que algunas de ellas influenciaron o tomaron parte del Déco. Por lo tanto, el Art Déco ante todo buscó la decoración por encima de la funcionalidad.

Pero si nos preguntamos: ¿qué es el Art Déco?, ¿cómo lo podríamos definir? Veamos lo que han dicho algunos de los especialistas sobre el tema, además de los ya expuestos, la forma en cómo se acercan al concepto.

${ }^{215}$ Gilles Néret, Lempicka, Köln, Taschen, 1993, p. 6. 
Alastair Duncan, en la Enciclopedia of Art Deco lo explica así:

"No es fácil definir las principales características del Art Deco, porque el estilo atrajo una multitud de diversas y, con frecuencia, contradictorias influencias. Muchas de ellas vinieron de los estilos pictóricos de vanguardia de los tempranos años del siglo, como el Cubismo, el Constructivismo Ruso y el Futurismo Italiano -abstracción, distorsión y simplificación- todos evidentes en las artes vernáculas decorativas Art Deco. Pero estos no fueron todos: una examen del repertorio de motivos estandarizados del estilo tales como racimos de flores estilizadas, jóvenes doncellas, geometrícos y ubicuos frutos- revelan influencias del mundo de la alta moda, de Egipto, el Oriente, la África tribal y de los Ballets Rusos de Diaghilev. A partir de 1925 el creciente impacto de la máquina puede ser discernido en repetidas y superpuestas imágenes, o más tarde, en los treinta, por formas modernizadas derivadas de principios aerodinámicos. Todo esto resultó en una elevada amalgama de complejas influencias artísticas, descritas desafiantemente por una simple frase, el término 'Art Déco'. 216

En el libro ART DECO. Flights of Artistic Fancy, Susan Sternau describe al Art Déco del subsiguiente modo:

"Desarrollado en París y más tarde fomentado en Hollywood como el estilo de las estrellas, el Art Deco hizo la transición, en unos pocos años, de un primario estilo francés a un universalmente entendido símbolo del glamour. Art Deco, es un conveniente término usado para describir arte decorativo en el periodo entre las dos guerras mundiales, y refiere a un estilo que es clásico, simétrico y rectilíneo. Como movimiento se desarrolló durante los años 1908 a 1912 y alcanzó un alto punto de 1925 a 1935. Este estilo fue el producto de influencias tan diversas como el Art Nouveau, Cubismo, el Bauhaus y el arte de Egipto, el Oriente, África y las Américas". ${ }^{217}$

Sobre una ubicación en la época en que se desarrolló, pero sin dar las características que lo distinguen, ya que lo hace en varias páginas, Sara Morgan en Art Deco the European Style manifiesta:

"Art Deco es un movimiento no definido claramente: el término cubre un periodo en la historia de las artes decorativas (incluyendo una parte de las bellas artes), como un

\footnotetext{
${ }^{216}$ Alastair Duncan, Encyclopedia of Art Deco, Londres, Quantum Books, 1988, p. 6.

${ }^{217}$ Susan Sternau, ART DECO. Flights of Artistic, Nueva York, Smithmark, 1997, p. 4.
} 
estilo el cual se desarrolló justamente antes de la I Guerra Mundial y que terminó en la década de los treinta, aunque no exactamente en la misma forma.

El Art Deco empezó específicamente como una creación francesa e inclusive parisina y esencialmente permaneciendo como un estilo francés. Inclusive muchos diseñadores esparcidos por Europa fueron influenciados por el diseño francés y trabajaron en el mismo, o un similar, idioma... Importantes variantes del Art Deco fueron producidas en otros países además de Francia, aunque algunos creadores basaron sus diseños con menos influencia del estilo francés, produjeron trabajos que captaron el mismo espíritu". ${ }^{218}$

Ante la dificultad de definir al Art Déco, Bevis Hillier y Stephen Escritt en Art Deco Style lanzan una pregunta para introducirse al tema: Art Déco: ¿Un estilo total?, y para responderla advierten que:

"Un libro acerca de un estilo debería empezar con una definición, desafortunadamente las definiciones sobre Art Deco tienden a ser demasiado simplistas o desconcertantemente complejas", por lo que para allegarse al concepto lo explican a través de prototipos: "El Art Deco nunca tuvo un conjunto de reglas que sirvan como un banco de marcas para su interpretación, así es que de muchas maneras la mejor ruta para definir es a través de ejemplos”. Continúan comentado que para apreciar el estilo, se referirán a “...los objetos que son los iconos del Art Deco. En arquitectura se podría citar ya sea el Edificio Chrysler en Manhattan o la fábrica Hoover en el oeste de Londres; en términos de mobiliario, quizás un lujoso armario aconchado del taller del fabricante francés EmileJacques Ruhlmann, o una aerodinámica silla del diseñador californiano Kem Weber; en la casa un radio de baquelita producido en serie, o un juego de té Vogue de Shelley; en la calle, un cartel del ferrocarril hecho por Cassandre. Cada uno de estos objetos en su momento pueden ser vistos como la encarnación del Art Deco: los siete son decorativos y modernos, empleando un amplio vocabulario de angulosas ves [de la letra v] invertidas o curvas refinadas, estilizadas representaciones y patrones cubistas o futuristas formas aerodinámicas". 219

Debido a la complejidad por puntualizar más certeramente lo qué es el Art Déco, Teresa Ortega-Coca en su libro Eduardo García Benito y el Art-Déco, además de ubicar en

\footnotetext{
${ }^{218}$ Sara Morgan, Art Deco the Eurepean Style, Greenwich, CT, Dorset Press, 1990, p. 8.

${ }^{219}$ Bevis Hillier y Stephen Escritt, Op. Cit., p. 19.
} 
el siglo XX, como otros autores, al estilo en cuestión, da un juicio aproximativo para tratar de delimitar lo que es:

“En su acercamiento no definitivo, sino aproximado a la definición de art-déco, diremos que alude principalmente más a un aspecto histórico-testimonial, que a unos rasgos determinados en formas. Sería el arte que de por sí es capaz de evocar el carácter del periodo en el que aparece, que fue llamado de entreguerras (la primera y la segunda mundial)...

Intentando una definición, que exponemos únicamente con carácter provisional, se podría decir que el art-déco es el arte que con sentido testimonial tuvo lugar en Europa durante el decenio 1920-1930, que empalmó con los motivos decorativos del modernismo anterior a la primera Guerra Europea, desnaturalizándolos, y que después de congelar y estirar, enfáticamente, pero con intención funcional las curvas húmedas y la raíces del modernismo en rectas racionalistas, registrará su mayor apogeo".220

Entonces, como podemos apreciar al menos en estos tratadistas definir al Art Déco no es una solución sencilla, ya que no conformó un grupo de asociados que bajo un ideal o propuesta estética se hayan reunido para procrear un cierto estilo, sino que fueron una serie de movimientos, corrientes, talleres y que desembocaron en una cierta época, conllevando elementos compositivos que los distinguen dentro de un tratamiento estilístico.

Así pues, por nuestra parte, si queremos aproximarnos al término Art Déco, proponemos interpretarlo de la siguiente manera:

Art Déco es un conjunto de diversos manifestaciones artísticas que convergieron entre las décadas de los años veinte y treinta en Europa Occidental, algunos países de las colonias francesas e inglesas y Estados Unidos, principalmente, así como con una fuerte presencia en América Latina, exaltando el gusto por la decoración, a través de diseños, en muchas ocasiones exóticos, que subliman lo geométrico, lo cúbico, lo lineal y lo aerodinámico, en contraposición de la delicadeza curvilínea y serpenteante de Art Nouveau y sus diferentes acepciones.

220 Teresa Ortega-Coca, Eduardo García Benito y el Art-Déco, Valladolid, Ayuntamiento de Valladolid, Fundación Municipal de Cultura y Diputación de Valladolid, 1999, pp. 62, 66 y 68. 


\subsection{El Art Déco a través de la Arquitectura, su manifestación más visible}

Debido a que en México donde más expresamente se desarrollaron las características estilísticas del Art Déco fue en la arquitectura, ésta es la razón por la cual incluimos un subcapítulo dedicado a este tema, que como veremos en el siguiente capítulo, México estaba viviendo su reconstrucción nacional después de la Revolución y mucho de esto se dio a través de la construcción de nuevos edificios que llevaron el signo estilístico del Déco.

Si el Palais Stoclet en Bruselas de 1905 a 1911, obra del austriaco Joseph Hofmann ya descrita en el subcapítulo sobre el Taller Vienés, se considera como el primer monumento del Art Déco, hay algunos antecedentes en la arquitectura que nos hablan de las búsquedas geométricas y que serían como una transición entre el Art Nouveau y los lenguajes del Art Déco.

Auguste Perret (1874-1954), de tradición neoclasicista, trabaja en un edificio de departamentos del 25 Bis Rue Franklin, en París, bajo un nuevo concepto: el uso de hormigón sin que éste se vea, en una verticalidad y horizontalidad que envuelve al inmueble. Además, la frontalidad y planimetría se transforman al ser movidas hacia dentro para conformar cinco caras. Udo Kultermann dice sobre esta construcción: "Los edifcios de Perret en París, especialmente la casa de la calle Franklin número 25, realizada en 1903, se valen del hormigón armado en foma de esqueleto que hace las veces de soporte estructural del edifcio y libera las paredes de toda función sustentante." ${ }^{221}$ La geometrización de puertas, ventanas, balcones, estructuras, se acompañan por las estilizaciones también geométricas de flores diseñadas por Alexandre Bigot (1862-1927), las cuales se insertan en paneles rectangulares; molduraciones recorren verticalmente los ángulos de ensamble de las paredes, y en el penúltimo piso, decoraciones que remiten a las techumbres emplomadas de las iglesias medievales y, más aún, los cuadros moteados de los balcones. Sin renunciar a la decoración, la nueva tecnología del concreto sirve de estructura a la continuidad del Art Nouveau, podríamos decir un "tardío Nouveau" que busca nuevas alternativas que desembocarán en un esprit géométrie que será el triunfo del Art Déco francés.

\footnotetext{
${ }^{221}$ Udo Kultermann, "Arquitectura del siglo XX”, Historia del Arte, México, Salvat Mexicana de Ediciones, 1979, Tomo 12, p. 13.
} 
Tan sólo estamos a principios del siglo XX, cuando es levantado el edificio de la Rue Franklin. Perret, quien había nacido en Bruselas, pareciera que estaba en franca oposición de su coterráneo Victor Horta o del parisino Hector Guimard, significativas figuras del serpenteante y curvilíneo Art Nouveau.
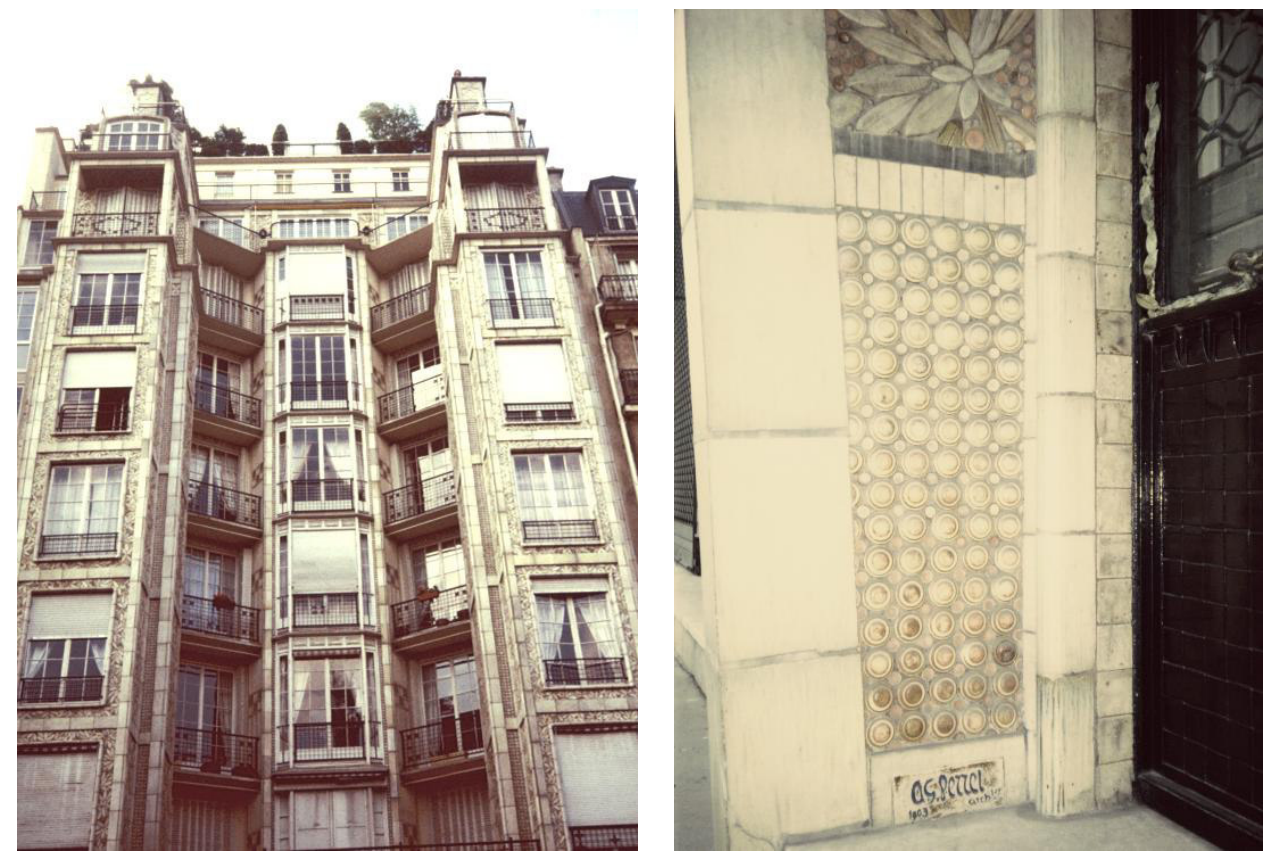

August Perret, apartamentos de la25 Bis Rue Franklyn. En la imagen de la derecha, detalle de la puerta de entrada y firma de Perret en la parte baja. París, 1903.

Sin embargo, en 1907 Adolf Loos (1870-1933) había levantado el Bar Kärntner en Viena, en el cual su abierta contraposición con el historicismo y el Art Nouveau es expuesta en la composición total del lugar, ya que el piso es un ajedrezado, el techo un conjunto de casetones rectangulares abocinados, las mesas con forma octagonal: todo es un triunfo de la geometría que sin buscar el ornato da por resultado, precisamente, la decoración geométrica. Tomemos en cuenta que Loos una año más tarde publica su trabajo Ornamentación y Crimen, en el cual expone su ideario sobre la necesidad de crear una arquitectura libre de cualquier atavío. Sin ser una obra Art Déco, el Bar Kärntner es igualmente uno de los antecedentes de este estilo. 


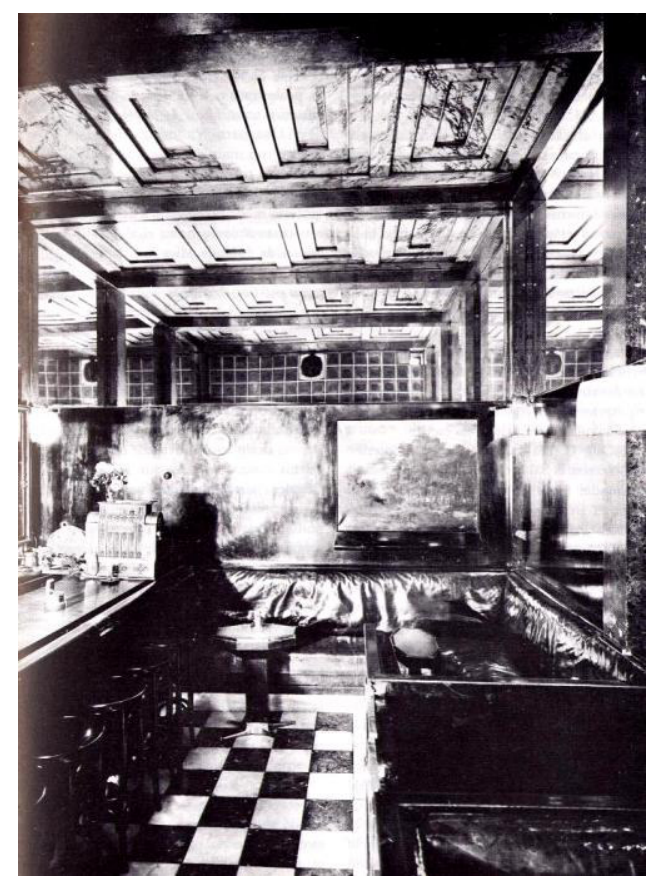

Adolf Loos, Bar Kärtner, Viena.

Foto de 1907.222

En Madrid sorprende enfrente de la Plaza de la Cibeles el esplendoroso Palacio de las Comunicaciones, erigido de 1904 a 1918 por los arquitectos Antonio Palacios Ramilo (1874-1945) y Joaquín Otamendi Manchimbarrena (1875-1960), inaugurado hasta 1919. Con el uso del hormigón y el hierro, los autores toman el influjo de la arquitectura española del Renacimiento, pero integran esas reminiscencias dentro de un lenguaje moderno en el que combinan los elementos clásicos con la rectitud de elementos geométricos. Un gran pórtico con arco de medio punto, por ejemplo, se mezcla con las pilastras de los ventanales laterales y de la galería superior, y la torre ochavada coronada presume el reloj dentro de un marco escalonado. Algunos adornos emanados del Modernismo se integran con los ornatos geométricos, anunciando el advenimiento del Art Déco. En el interior, el espacio central magistralmente iluminado que se eleva en tres niveles, permite apreciar de mejor manera las pilastras cuadradas y las colmunas octagonales que se funden con las trabes de hierro que le dan solidez visual. "Sin embargo, en la obra finalizada, las formas geométricas simples y los volúmenes lisos de las escaleras y balustradas exteriores -fachada de Cibelesson de una fuerza y rotundidad poco modernista. El sentido de la fastuosidad de los

\footnotetext{
${ }^{222}$ Vittorio Magnano Lampignani (ed)., Op. Cit., p. 226.
} 
materiales, la retórica, la megalomanía, el porte majestuoso del edificio y su tendencia monumental, están mucho más cerca del déco", 223 afirma Javier Pérez Rojas sobre el Palacio de las Comunicaciones.
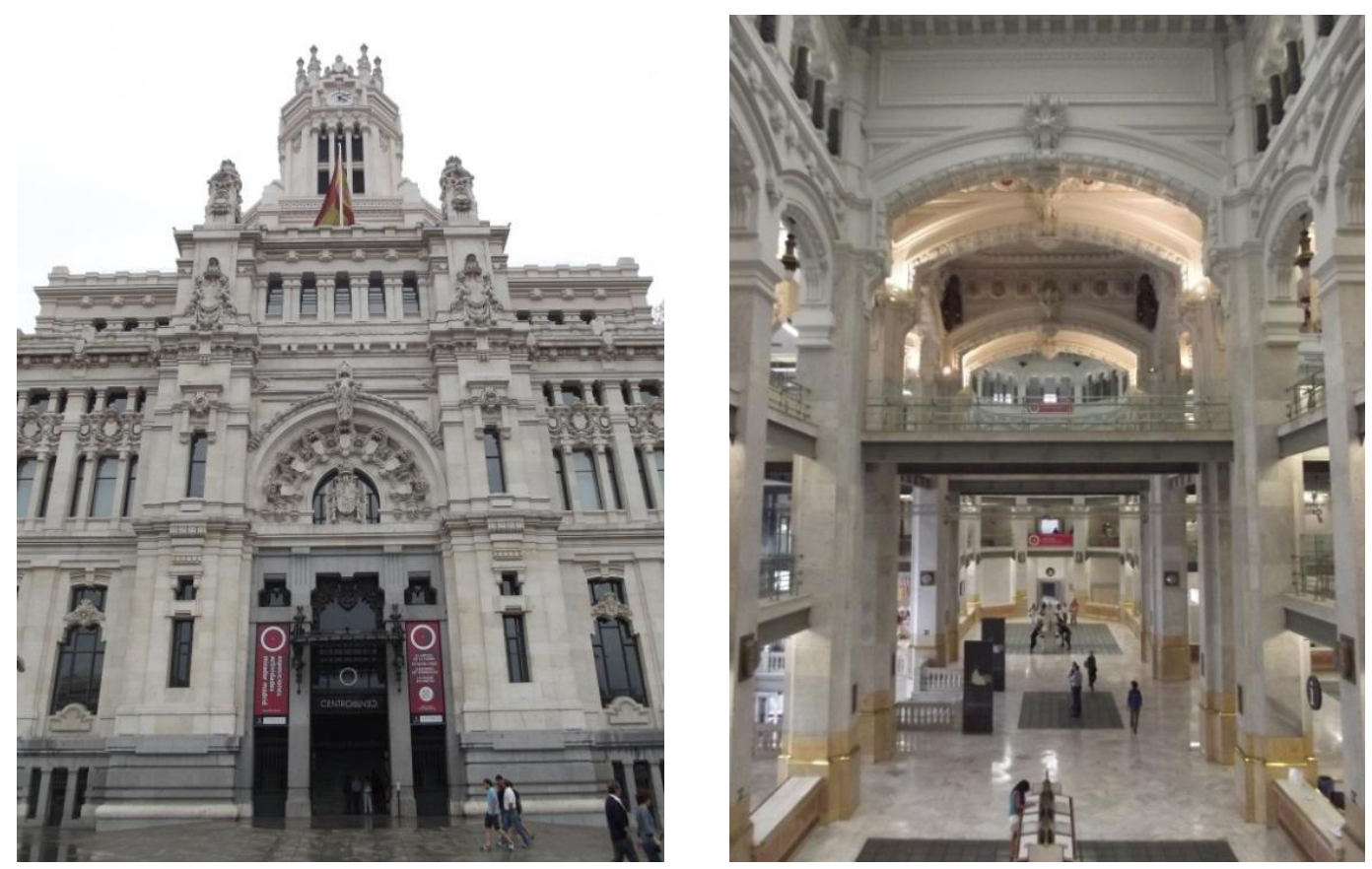

Antonio Palacios y Joaquín Otamendi, Palacio de las Comunicaciones, Madrid, 1918.

Mientras Hoffmann, Perret, Loos, Palacios y Otamendi, entre otros, en Europa marcan el camino hacia la geometrización, Frank Lloyd Wrigth (1867-1959) lo hace en Estados Unidos. Habiendo trabajado en el despacho de Louis Henry Sullivan (1856-1924) y su socio el alemán Dankmar Adler (1844-1900) en Chicago, Wrigth busca una arquitectura orgánica que se desprendiera de la tradición académica clásica y europea. No es nuestra intención hacer una descripción de la obra completa de este arquitecto, sino solamente mencionar que dentro de los antecedentes de la geometrización, en el otro lado del Atlántico, en el emergente titán de Norteamérica, entre las obras de Wright hay tres que caben mencionar por su relación con el Art Déco: el Unity Temple (Templo de la Unidad), en Oak Park, Chicago de 1906; la Robie House de 1907-1909, también en Chicago; o la Walter Dodge House, de 1915-1916. Pero es en la primera donde la cuadrícula impera por todo el edificio en su interior, techos, ventanas y el mobiliario, se conjugan con las

\footnotetext{
${ }^{223}$ Javier Pérez Rojas, Art Deco en España, Madrid, Cátedra, 1990, p. 304.
} 
verticales líneas decorativas dentro de un ambiente ámbar conseguido por la luz que penetra a través de los cristales. "El plan de Wright para el Unity Temple está cercanamente relacionado con las centralizadas iglesias del Renacimiento, basadas en formas geométricas puras del cuadrado y el cubo, lo cual Wright retoma por las mismas razones como los arquitectos del Renacimiento: ellos fueron perfectamente geométricos, 'divinos' como (Walt) Whitman dijo, y ellos hicieron la perfección presente en el espacio cuando cinstruyeron un apropiado espacio en el cual se venera a Dios". ${ }^{224}$ Cubos acomodados en orden simétrico forman el exterior y una decoración de origen prehispánico exorna el conjunto. Una cualidad más, el uso del concreto emparenta al Unity Temple con los edificios de Perret y Hoffmann.

Es importante comentar que el viaje realizado por Wrigth a Viena en 1910 le deja un toque de impresión al admirar las obras arquitectónicas de Wagner y Olbrich, así como las pinturas de Gustav Klimt.
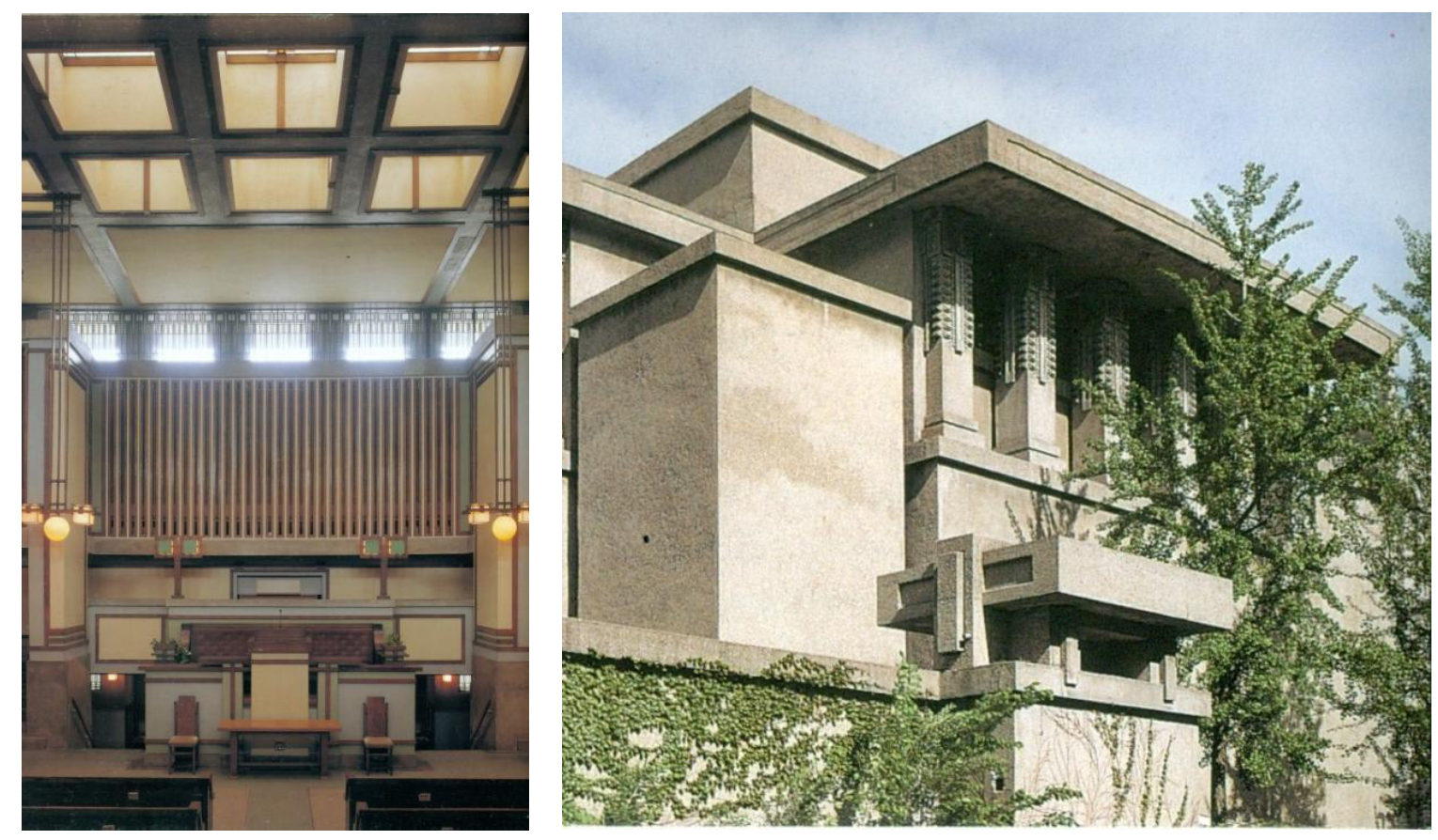

Frank Lloyd Wrigth interior y exterior del Unity Temple, Oak Park, Chicago, Illinois, 1906.225

\footnotetext{
${ }^{224}$ Robert McCArter, Fran Lloyd Wright, London, Phaidon, 1999, p. 81.

${ }^{225}$ Ibídem, pp. 76 y 80.
} 
El Palais Stoclet de Bruselas, la Rue Franklin 25 Bis, el Théatre des Champs Elysées, los apartamentos de Sauvage de la Rue Vavin y de la Rue des Amiraux en París, el Bar Kärtner en Viena, el Unity Temple en Chicago; Hoffmann, Perret, Sauvage, Loos y Wright, entre otros autores, anteceden a la formalidad compositiva geométrica de la arquitectura Art Déco. El cubo, la recta, la verticalidad y la horizontalidad, la geometría más la decoración, están dando el paso constitutivo hacia la expresión triunfante de la exposición parisina del 25.

Y como ya lo expusimos en el punto 1 de este capítulo, la magna exposición de 1925 es la que marca la consolidación del Art Déco a través de los pabellones tanto franceses como de otros países, -de los cuales describimos los de los cuatro almacenes más importantes de París: Studium del Louvre, Primavera de Au Printemps, La Maitrise de Galerías Lafayette y Pomone de Au Bon Marché, así como el Pabellón du Tourisme o L'Hotel du Collectionneur - o bien, por medio de las puertas de acceso como la Porte de la Concorde y la Porte d'Honneur, e indudablemente, por los objetos expuestos en la exhibición.

Con la exposición del 25 se consolida el estilo que es conocido como Zigzag que se desarrolló más en la década de los veinte. Más tarde vendría el Streamline que caracterizó a la década de los años treinta y que tuvo su expansión hacia Estados Unidos, como ya fue expuesto también en el punto anterior de este mismo capítulo.

Entonces, podríamos hablar de tres momentos de la arquitectura Art Déco: un proto Art Déco llamado Necolásico Moderno o Neoclásico Déco que se distingue por las geometrizaciones de elementos clasicistas y del Art Nouveau, que va de principios de siglo hasta 1914, fecha del estallido de la primera gran guerra; el Zigzag que enarbola las composiciones geométricas triangulares, cúbicas, escalonadas, hexagonales, el cual tiene su vida en la década de los veinte y el Streamline que con la adaptación de formas aerodinámicas, verticales y lineales inunda la década de los treinta. Sin embargo, esta propuesta no puede ser aplicada estrictamente a los períodos mencionados, sino que nos servirá de una manera general para ubicar a los edificios Art Déco, ya que puede haber algún inmueble construido que rebase las fechas propuestas y que lleva los estilos de otra etapa. 
Queremos incluir la clasificación que para la arquitectura hace Eva Weber en su libro Art Decó, que aunque hecha para las obra levantadas en Estados Unidos, incluye algunas europeas; además, por la influencia que ejerció Estados Unidos para que se desarrollara el estilo de la modernidad de esa época en México, será de utilidad para el estudio de los edificios de este trabajo en la región noreste. Weber propone tres estilos en la arquitectura Déco: Neoclásico Moderno, Zigzag Moderno y Estilo Aerodinámico.

El primero, el Neoclásico Moderno se dio tanto en la década de los veinte como en los treinta y "se caracterizó por sus masas equilibradas al modo clásico y por una acentuación de la simetría y la horizontalidad. Las columnas exteriores habituales de los estilos clásicos históricos fueron reemplazadas por pilares alisados que a veces eran estriados, pero generalmente no tenían capiteles o bases. La monumentalidad de los edificios se resaltó con paredes lisas, simplificadas, que casi siempre eran, o estaban revestidas, de piedra, granito, mármol o terrazo. Algunos relieves estilizados y esculturas adornaban con frecuencia el exterior, aunque en un grado menor que en el estilo zigzag. Era usual que las entradas se embellecieran mientras las demás paredes permanecían sin adornos. A veces los interiores eran sorprendentemente vistosos, con profusión de murales, esculturas en relieve, mosaicos, metalistería ornamentada, atractivas iluminaciones modernistas, y con las paredes y los suelos recubiertos por una gran variedad de maderas exóticas, a menudos haciendo contrastes. La imaginería solía ser simbólica de la función de edificio o de su región y la historia local de la zona".226

Como edificios del Neoclásico Moderno está el Palais de Tokyo en donde participaron los arquitectos Jean-Claude Dondel (1904-1989), André Aubert (1905-1987), Paul Viard (1880-f.?), Marcel Dastugue (1881-1970) y relieves de Alfred Janniot (18891969); obra construida entre 1934 a 1937, se hizo para ser sede del Museo de Bellas Artes como parte de las construcciones para la Exposition Internationales des Arts et Techiques celebrada en París en 1937. Un pórtico a manera de un gran propileo y dos pabellones rectangulares unidos en forma de "U" cuadrada, con paredes lisas más columnas y pilastras sin capitel, miran hacia una plazoleta que baja hacia unas terrazas, en donde se van anexando las otras partes del edificio, formando una conexión de cubos. En las paredes que

\footnotetext{
${ }^{226}$ Eva Weber, Op. Cit., p. 23.
} 
miran hacia el Sena los relives escultóricos de Janniot hacen alusión a las nueves musas, representadas con sus atributos artísticos o científicos.

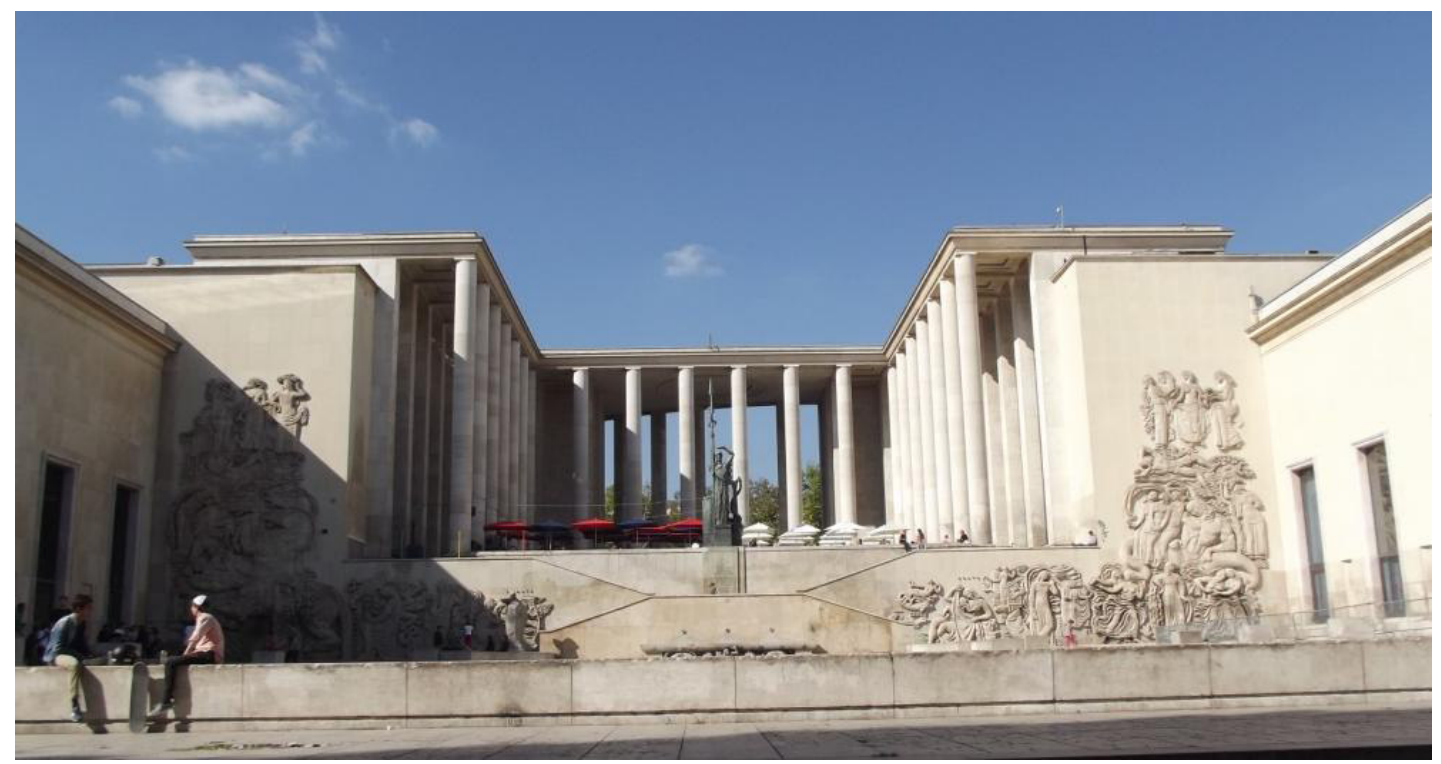

Jean-Claude Dondel, André Aubert, Paul Viard, Marcel Dastugue, Palais de Tokyo, París, 1937.

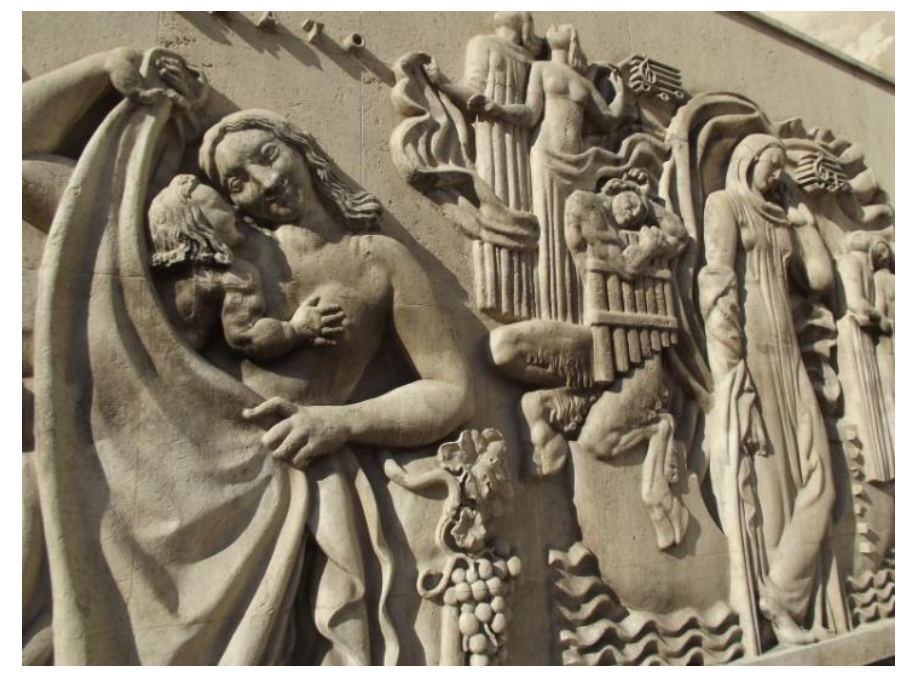

Alfred Janniot, Erato y Euterpe, Palais de Tokyo, París, 1937.

En Inglaterra la BBC Broadcasting House en Londres, obra del arquitecto Val Myers (1883-1959), es otro digno ejemplo del Neoclásico Moderno. Del año 1931 este robusto edificio de paredes sin decoración, se ilumina por ventanas rectangulares colocadas simétricamente. El conjunto armoniza la frontalidad cuadrada con la delicada sinuosidad de 
un piso superior remetido. Esculturas de Eric Gill (1882-1940) adornan el exterior, el cual en su fachada principal termina con un reloj enmarcado dentro de un cuadrado con ornamentos laterales en forma de rejilla $\mathrm{y}$ todo sostenido por unas alas estilizadas geométricamente.

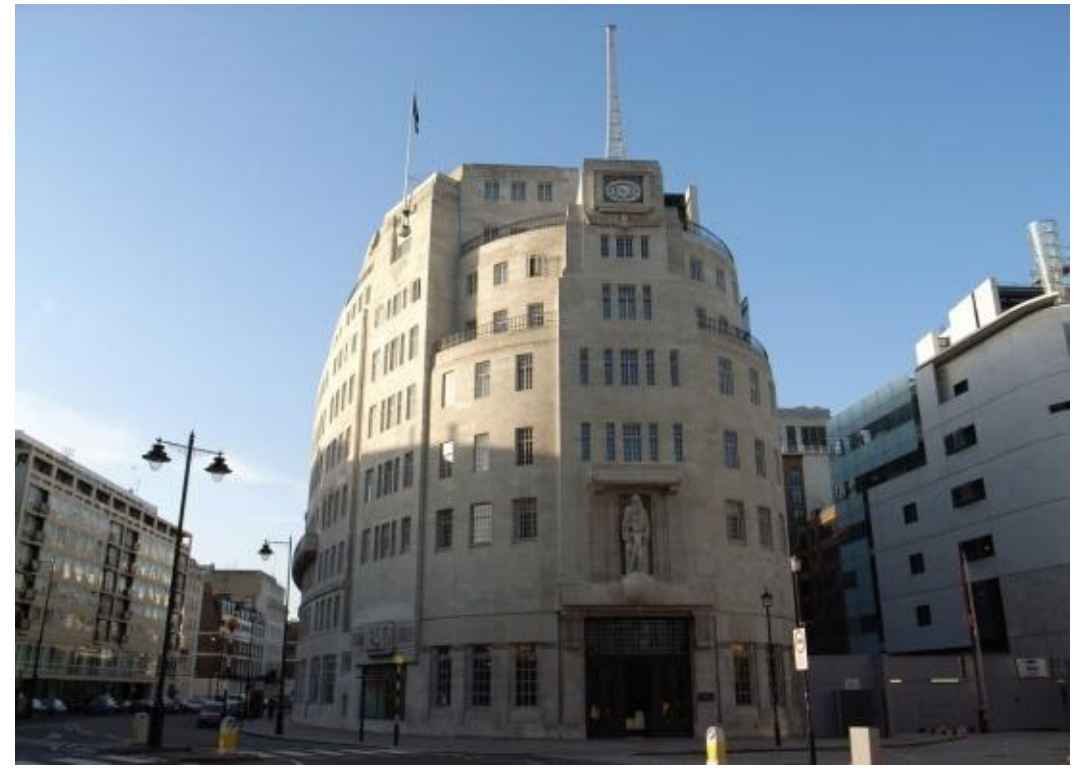

Val Myers, la BBC Broadcasting House Londres, 1931. ${ }^{227}$

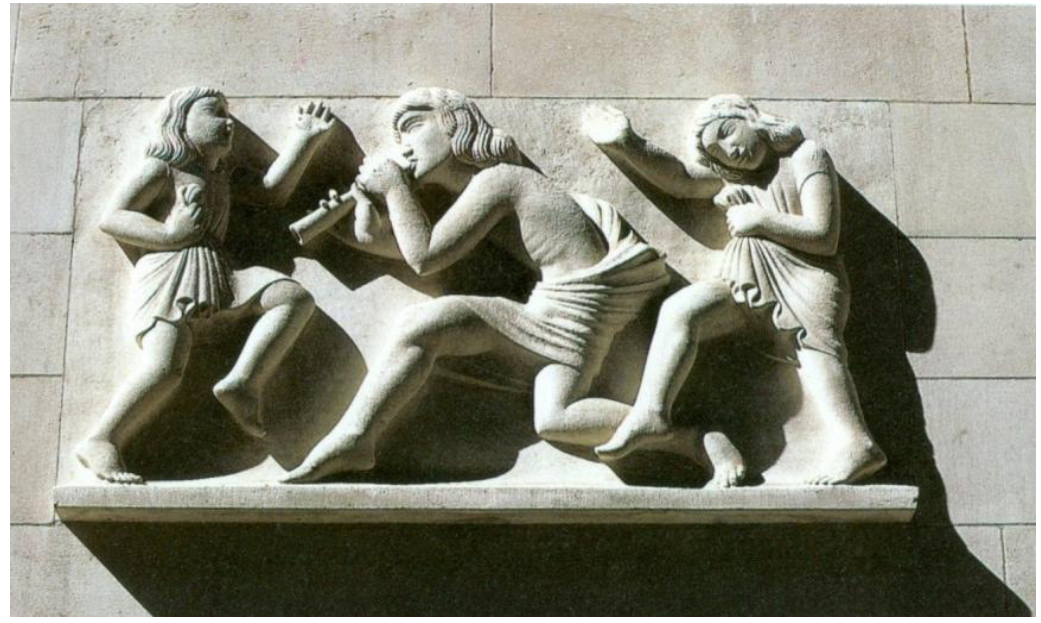

Eric Gill, escultura en la BBC Broadcasting House Londres, $1931 .^{228}$

\footnotetext{
${ }^{227}$ Movehut, "BBC Staff Complain About Noise at New Broadcasting House", http:www.movehut.co.uk/news/bbc-staff-complain-about-noise-at-new-broadcasting-house-10915/
}

${ }^{228}$ Bevis Hillier; Stephen Escritt, Op. Cit., p 171. 
En Estados Unidos está el Nebraska State Capitol en Lincoln, proyectado y dirigido por Bertram Goodhue (1869-1924) entre 1922 y 1932; las decoraciones estuvieron a cargo de Lee Lawrie (1877-1963), Hildreth Meier (1892-1961) y murales pintados por Augustus Vincent Tack (1870-1949). En enomre edificio se componen por una gran estructura cúbica de dos altos pisos y paredes lisas, y al centro la enorme torre destaca por su Déco Neoclásico Moderno. En la torre se ubica la puerta del acceso principal, la cual se compone de un arco de medio punto que está acompañado por robustas pilastras cuadradas; un segundo cuerpo cúbico se alarga con afables líneas verticales que forman los ventanales y luego un alargado cuerpo ochavado sirve de base para un tambor circular decorado con mosaicos con figuras de pájaros, el cual sostiene una cúpula forrada de mosaicos dorados que a su vez remata con una escultura dedicada al campesino sembrador. Formas cúbicas y clásicas se arman ascendentemente para conseguir el efecto de modernidad.

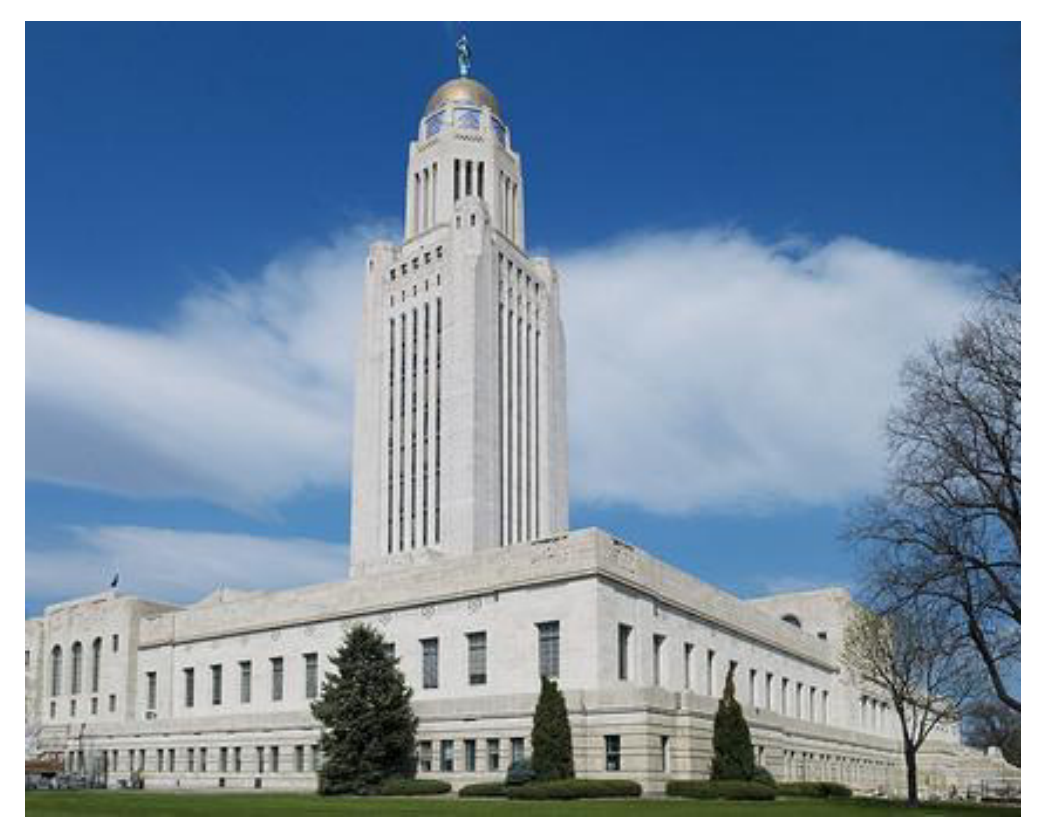

Bertram Goodhue, Nebraska State Capitol, Lincoln, 1932.229

Sobre el estilo Zigzag la autora Eva Weber explica:

"Una de las características más reconocibles del estilo Art Decó fue la riqueza ornamental de las superficies en el exterior de los edificios, repetida en sus instalaciones en

\footnotetext{
${ }^{229}$ OpenBuildings, "Nebraska Sate Capitol", http://openbuildings.com/buildings/nebraska-state-capitolprofile-2839\#
} 
el interior. Los motivos con formas precisas comprendían zigzags, triángulos, rayas, círculos segmentados y espirales, mientras entre los motivos naturalistas se encontraban flores, árboles, frondas, fuentes, gacelas, pájaros, nubes y amaneceres estilizados. La imaginería astrológica, junto con personificaciones idealizadas de fuerzas naturales y tecnológicas, era también usual". ${ }^{230}$ El Zigzag se dio en la década de los veinte, principalmente del año 25 al 30, aunque se siguió produciendo en los primeros años de la década de los treinta.

De los cuatro pabellones ya descritos de la exposición del 25, el de Au Bon Marché llamado Pomone del arquitecto Boileau y el Maitrise de Galerías Lafayette de Iriart, Tribout y Beau ostentan las características del Zigzag: triángulos, circunferencias sesgadas, soles radiantes.

Hay un edificio en París que podría ser como la exaltación de las propuestas de los pabellones del 25 y que al mismo tiempo se convirtió en una referencia del Zigzag. Son los almacenes de La Samaritaine, obra de Franz Jourdain (1847-1935) erigida en 1905 con estructura de acero y remodelada en 1926 por Henri Sauvage (1873-1932). En la fachada que da hacia el Sena y el Pont Neuf, así como en la que mira hacia la Rue du Pont Neuf, el edificio tiene una armazón con pilastras rectangulares, ventanales cuadrados y una composición escalonada en los últimos tres niveles, en donde en el antepenúltimo piso resaltan balcones de medios círculos que se enlazan con pilastras estriadas. En los extremos cinco ventanales están enmarcados por largas pilastras con ligeras molduras sobrepuestas que rematan en forma de un gran rectángulo adornado geométricamente con cinco prismas colgantes que forman un escalonamiento invertido. Las esquinas que se curvean, en el penúltimo piso cinco arcos ochavados exhornan al inmueble y la parte final como si fuera la cubierta de un barco mostrando un Style Paquebot, exhiben junto con todos los demás componentes del edificio las propuestas geométricas del Déco Zigzag, razón por la cual Rossana Bosaglia dice de Sauvage y el Art Déco: "Su contribución en la Exposición de París del 25 es una de las más geniales y brillantes caracterizaciones déco...El trabajo que está más visiblemente ligado a su nombre es la expansión de la tienda La Samaritaine en París". 231

\footnotetext{
${ }^{230}$ Ibídem, pp. 28-29.

${ }^{231}$ Rossana Bossaglia, L'Art Déco, Roma, Laterza, 1984, p. 137.
} 


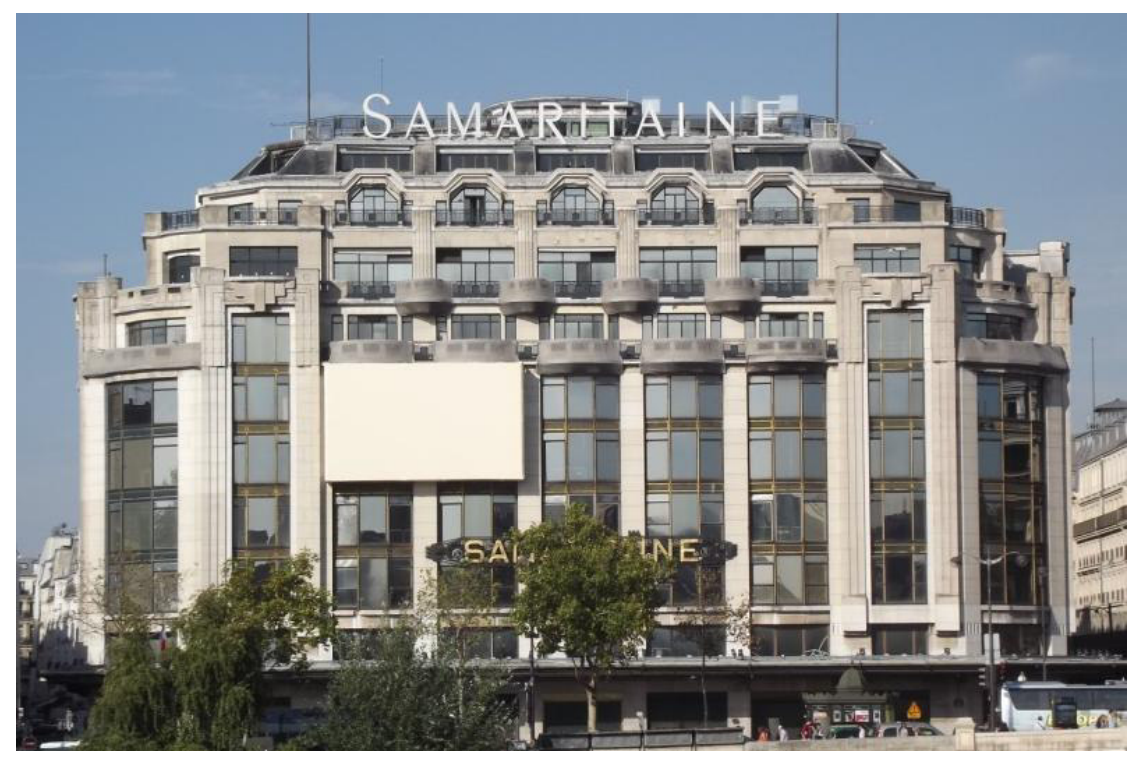

Henri Sauvage, La Samaritaine, París, 1926.

La Biblioteca Carnegie en Reims, se construyó entre 1921 y 1927, obra del arquitecto Max Sainsaulieu (1870-1953). La biblioteca debe su nombre al filántropo de origen escocés Andrew Carnegie (1835-1919), cuya fundación otorgó un fuerte donativo para la construcción de la biblioteca de la ciudad después de la I Guerra Mundial. Inmueble de una planta, el pórtico de entrada podría más bien mostrar un Art Déco Neoclásico Moderno con sus dos columnas ochavadas y el frontón triangular sin cornisa; sin embargo, las decoraciones de los escudos que están en la parte superior de las jambas, protegidos por cornisas decoradas con motivos zigzags en la parte interior, las flores esgrafiadas que están en el tímpano por arriba de las columnas y el nártex ricamente decorado con motivos zigzgas en vivos colores, hacen que su exterior sea uno de los más connotados casos del Déco Zigzag, así como su interior, opulentamente ornado con motivos geométricos y ventanales zigzags.

Los escudos mencionados representan del lazo izquierdo a los Estados Unidos protegidos por el águila, ya que el señor Carnigie se nacionalizó estadounidense, y el del lado derecho es el de la ciudad de Reims, acompañado de bajorelieves planos de flores petrificadas y líneas abiertas a manera de luces solares. En la parte interior de las cornisas, motivos ondulantes, pero ya con la geometría del zigzag, acompañdos de un cuadrado con un punto, refieren el triunfo del decorativismo del Art Déco Zigzag. 


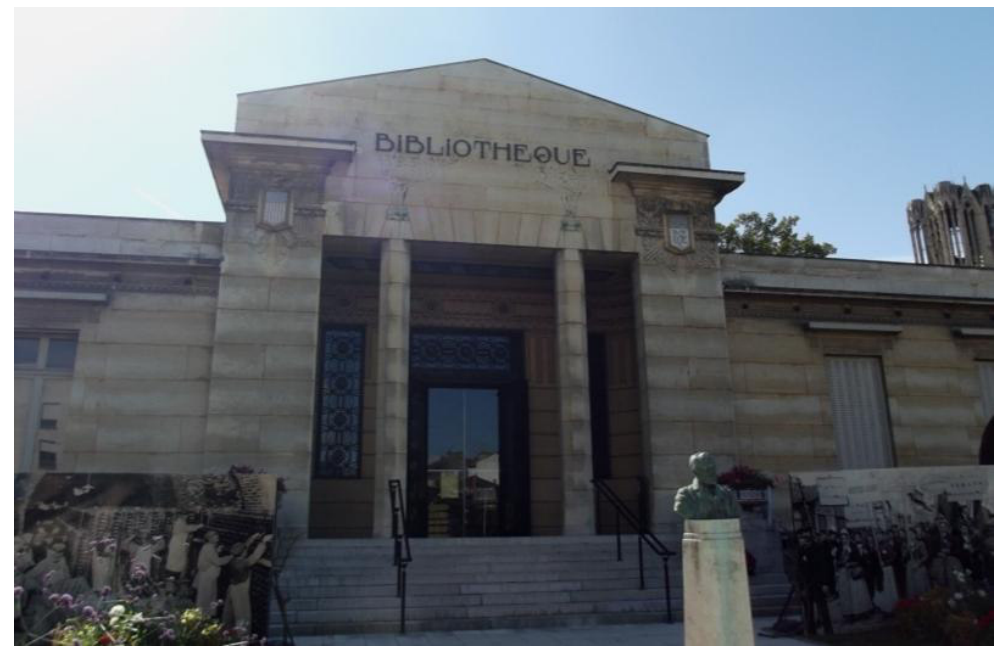

Max Sainsaulieu, Biblioteca Carnigie, Reims, 1927.

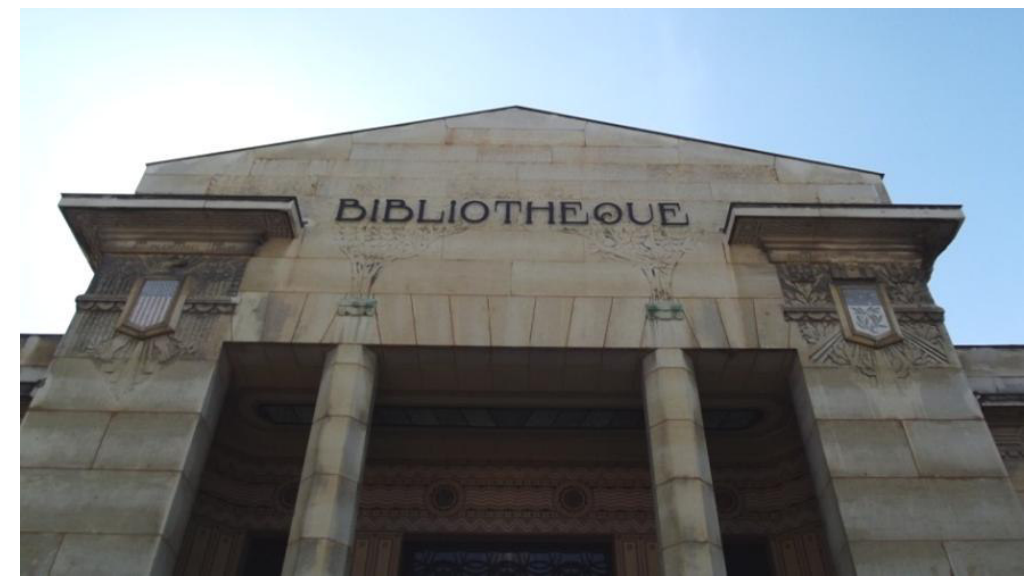

Biblioteca Carnigie, detalle del pórtico.

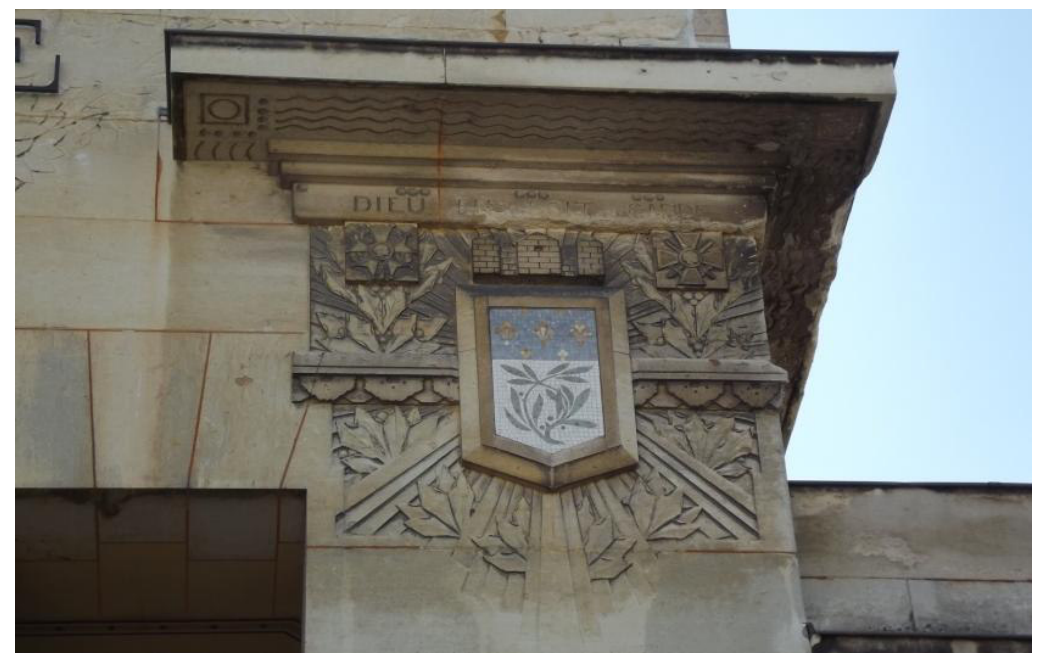

Biblioteca Carnigie, detalle del escudo de Reims e interior de la cornisa. 
En la ciudad de La Plata en Argentina, existen varias construcciones Art Déco, debido a que la ciudad tuvo un fuerte desarrollo urbano en las primeras décadas del siglo XX. Tal es el caso de un pequeño comercio llamado El Mundo Limpio ubicado en el cruce de la Diagonal 80 con la Avenida 47. Posiblemente edificado a finales de la década de los veinte, es obra del ingeniero civil S. Danieri (hijo) y los construcores J. y C. Pierini, nombres obtenidos gracias a las placas que se encuentran en el inmueble. De un solo piso y con planta en forma de pirámide truncada, la construcción está forrada con cantera rosa, pero lo que resalta es la abundante decoración de tipo Déco Zigzag. En las fachadas laterales un gran ventanal para exhibición está protegido por una cornisa formada por tres molduras que van callendo sobrespuetas una encima de otra y de menor a mayor. Más arriba otra cornisa dentada en la parte superior sirve de base para unas estrías gruesas que van creciendo paulatinamente a media que se acercan hacia el centro. A los lados del vano, un enmarcamiento triple rehundido que abarca todo el muro, remata con una decoración con formas de recuadros. En la fachada principal donde se inserta el letrero lleva una geométrica cornisa que cae escalonadamente y en lo que es el entablamento, los ornatos son zigzas con medios círculos. A continuación dentro de un marco recrtangular estriado, tres triángulos se superponen ascendentemente. Un piñón cubre el remate con poliedros cúbicos que se van engarzando de manera escalonada, para finalizar con un prisma triangular que sirve de astabandera. Magnífica construcción con toda la geometría del Déco Zizgag.

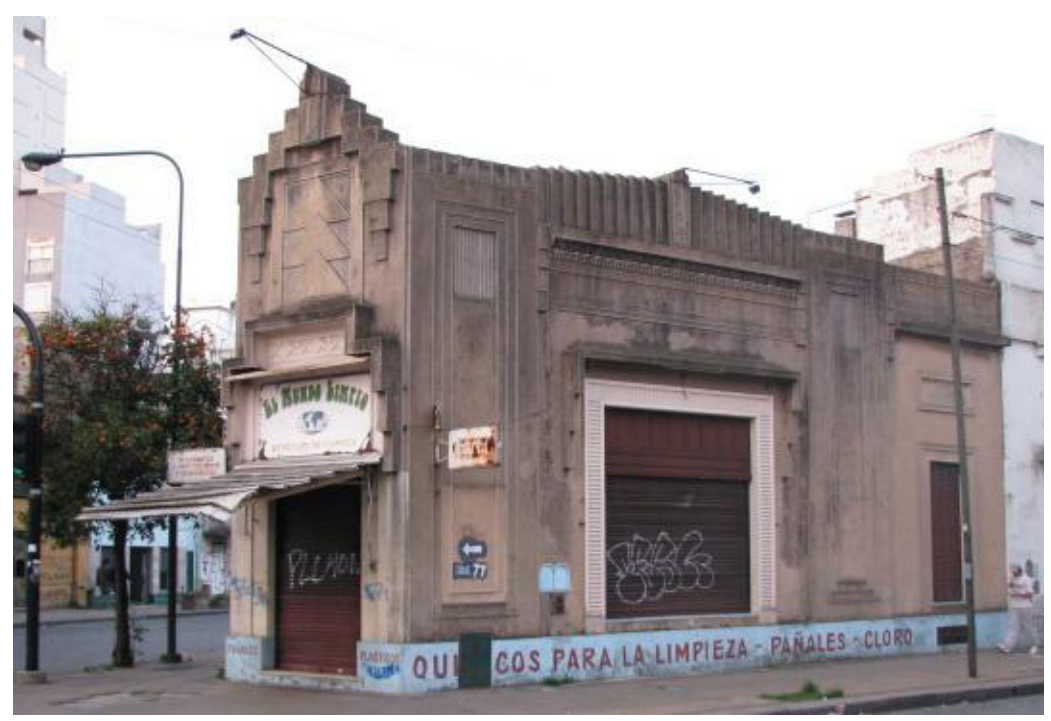

S. Danieri y J. y C Pierini, comercio en el cruce de Diagonal 80 con Avenida 47. La Plata, ha., finales 1920. 


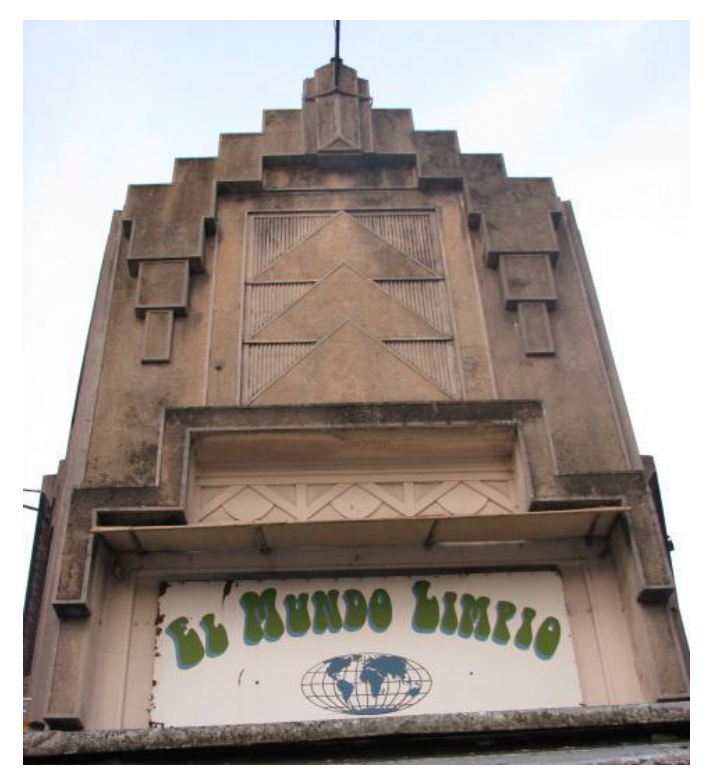

Detalle de la parte superior del comercio en el cruce de Diagonal 80 con Avenida 47, La Plata.

Sin embargo, dentro del Zigzag hubo un alto desarrollo de esta variante al otro lado del Atlántico: en Estados Unidos.

En San Francisco, California, donde hubo mucha reconstrucción después del temblor de 1906, la Pacific Telephone \& Telegraph Company mandó edificiar un nuevo edificio, para lo cual contrató los servicios de los arquitectos James Rupert Miller (18691946) y Timothy Plfueger (1892-1946). Las obras que iniciaron en el corazón de la ciudad en 1923, terminaron en 1925, convirtiéndose en el primer rascacielos de la urbe con sus 135.5 m., de altura y 26 pisos. Está construido con un aramazón de hierro y cubierto con placas de terracota, terminando en la parte superior con tres elevaciones escalonadas y una torre central. Con decoración a base de columnillas adosadas en la entrada, rectángulos en los entrepaños, líneas que caen a manera de listones colgantes, en el coronamiento del edificio están colocadas unas esculturas tipo Art Déco de águilas que miran hacia el horizonte, símbolo de la universalidad del servicio telefónico. El impacto de su altura, modernidad y belleza cuando fue concluido, hizo que se dijeran frases tales como. "Un iluminado, destellante monumento para hablar", "Una oración en piedra y acero". ${ }^{232}$

\footnotetext{
${ }^{232}$ Therese Poletti, Art Deco San Francisco. The Architectura of Timothy Pflueger, New York, Princenton Architectural Press, 2008, p. 69.
} 

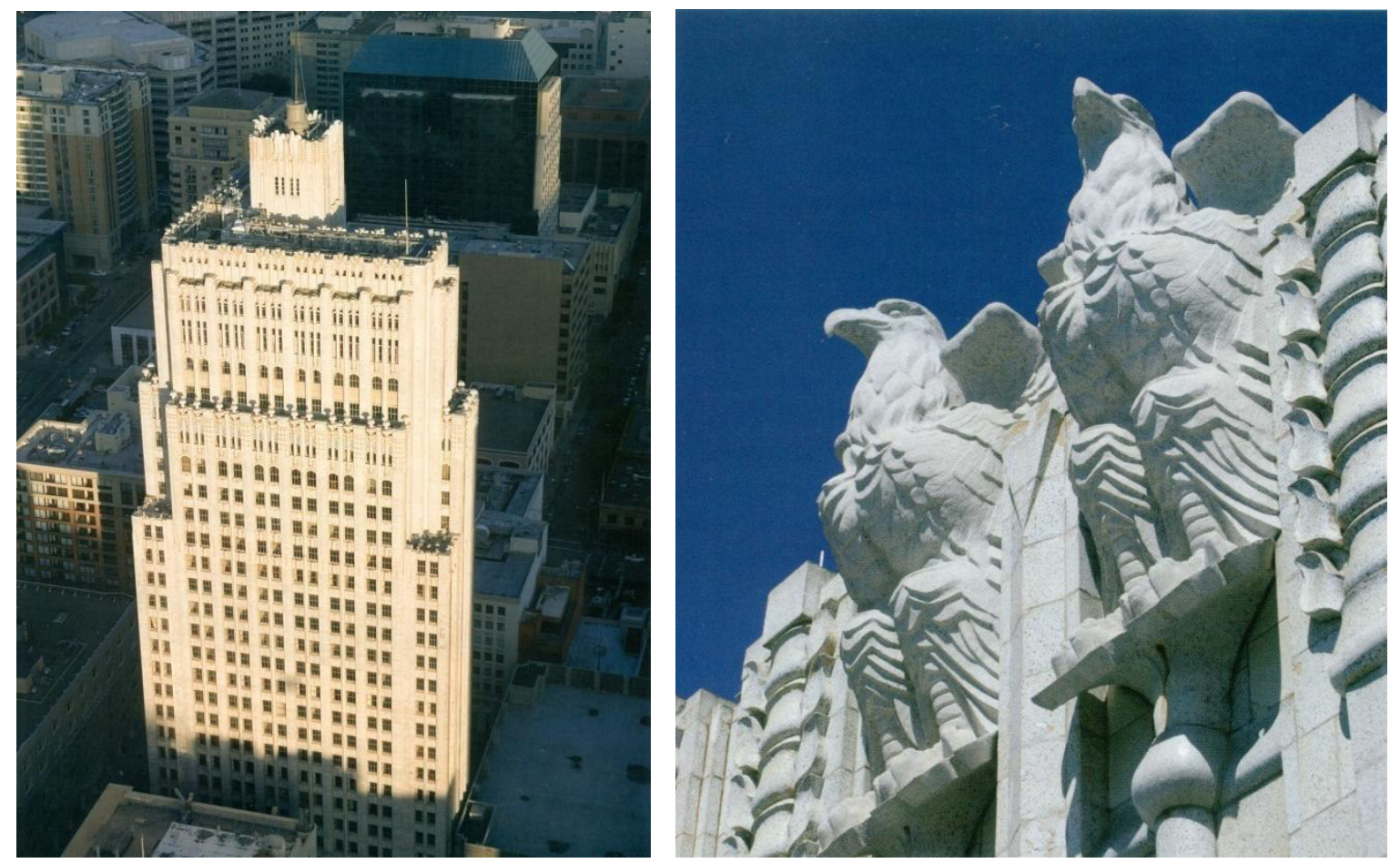

James Rupert Miller y Timothy Pflueger, Pacific Telephone \& Telegraph Building, San Francisco, 1925.233

Es la etapa de los grandes rascacielos de Nueva York, como es el Chrysler Building diseñado y dirigida su construcción por William Van Allen (1882-1854) entre 1928-1930. Elevado como una gran vitrina cuadrada, gárgolas adornan la división donde arrancan curvas radiantes que representan rayos solares que sostienen la enorme aguja de níquel y acero, buscando la altura y el punto de referencia más álgido, como antes lo eran las catedrales góticas.

Otro de los ejemplos es el Empire State Building que fue levantado entre 1931 y 1932 por Shreve, Lamb \& Harmon -nombres de una compañía compuesta por: Richmond Harold Shreve (1877-1946), William Frederick Lamb (1893-1952) y Arthur Loomis Harmon (1878 -1958)- presenta una estructura como si fuera un gran zigurat, reflejando el estilo muy en boga de esa época: el Art Déco de la época del jazz. En algún tiempo el edificio más alto del mundo, con sus 381 m., de altura, remata también con una gran flecha, la cual funcionaba como mástil para dirigibles.

Y el Rockefeller Center, obra de varios arquitectos e ingenieros entre los cuales destacó el proyecto de Raymond Hood (1881-1934). La construcción se realizó entre 1931

${ }^{233}$ Therese Poletti, Op. Cit., p. 59 y 70. 
y 1939, con 19 edifcios, el más alto con 270 pisos y una alltura de 266 m., y podríamos decir que este edificio cierra el ciclo de los grandes rascacielos neoyorkinos, los cuales abiertamente expresaban -y expresan- un rito de admiración a la tecnología y al poder económico que los financió. Con muchas obras de Art Déco, aunque ya estarían más bien dentro de la iconografía del Streamline y como una transición hacia esa variante del Déco, sobresalen la fuente en bronce dorado de Prometheus de Pual Manship (1885-1966) del año 1934, en la que el personaje, atrapado dentro de un anillo, en una postura volátil detiene el fuego con una mano; de Lee Lawrie (1877-1963) el panel en tearrocta de la entrada al edificio central, Wisdom, "La Sabiduría", es representada a través de un hombre barbado entre nubes que apunta con dos agujas sobrepuestas en la cita de Isaías 33,6:

\section{"WISDOM AND KNPWLEDGE SHALL BE THE \\ SATABILITY OF THE TIMES" \\ (Sabiduría y conocimiento reinarán en sus tiempos).}

Debajo de la cita hay una decoración floral entre líneas curvas y en las entradas laterales sobre las arquitrabes, mujer y hombre nacen en un nuevo mundo. Otra obra de Lawrie es el poderoso Atlas en bronce de 1937 que carga el mundo confeccionado a través de anillos.

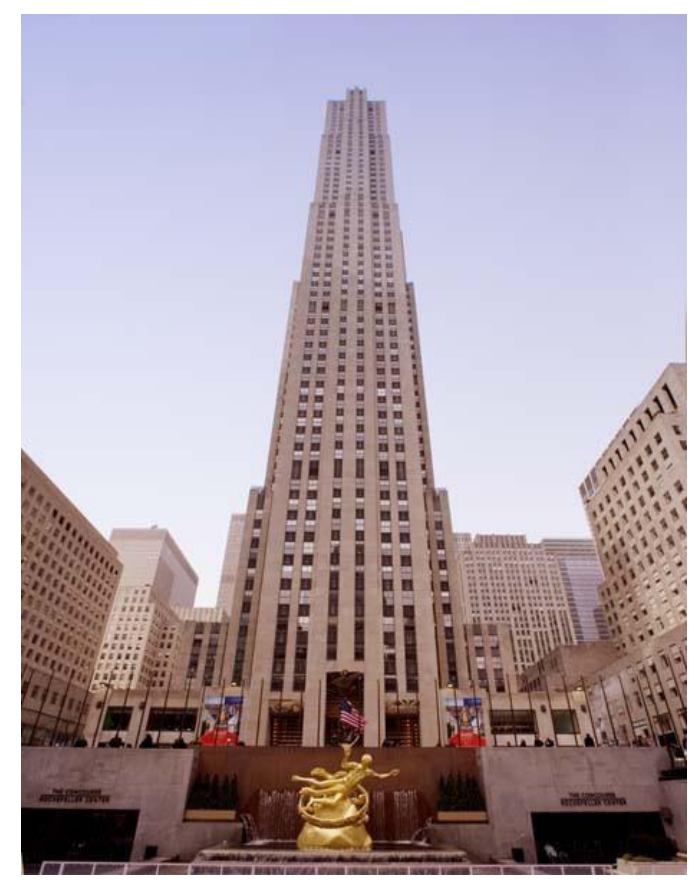

Raymond Hood, Rocekefeller Center, New York, 1939.234

234 “Rockefeller Center”, http://diegomolinasobradillo.blogspot.mx/2010/10/new-yorkd.html 


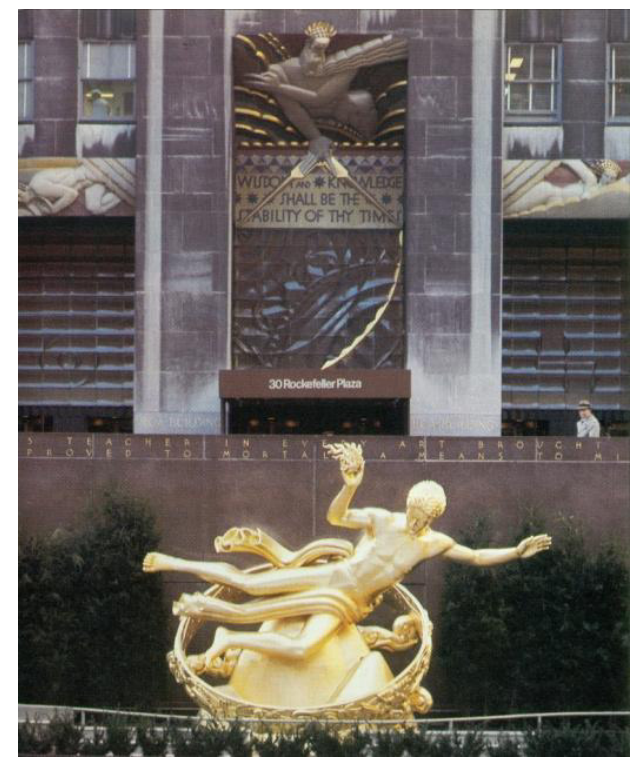

Paul Manship, Prometheus, 1934, Lee Lawrie, Wisdom, 1933, Rocekefeller Center. ${ }^{235}$

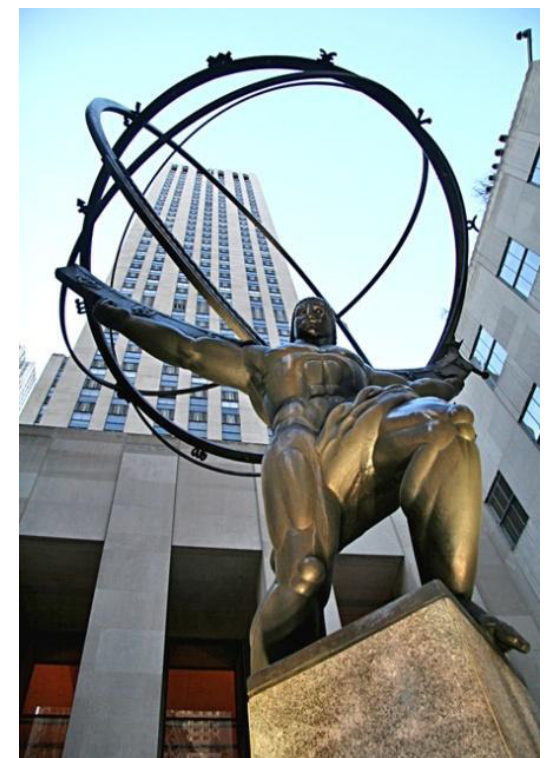

Lee Lawrie, Atlas, 1937, Rockefeller Center. ${ }^{236}$

En el edifcio de la Associated Press dentro del mismo compejo Rockefeller, está el gran panel en acero inoxidable de Isamu Noguchi (1904-1988), realizado entre 1930 a 1940, que representa a los periodistas en busca de la noticia, colocados en un escorzo que les imprime velocidad y movimiento, lo que se refuerza con las líneas oblicuas que denotan la celeridad de la información. Una de las más sobresalientes obras del Art Déco.

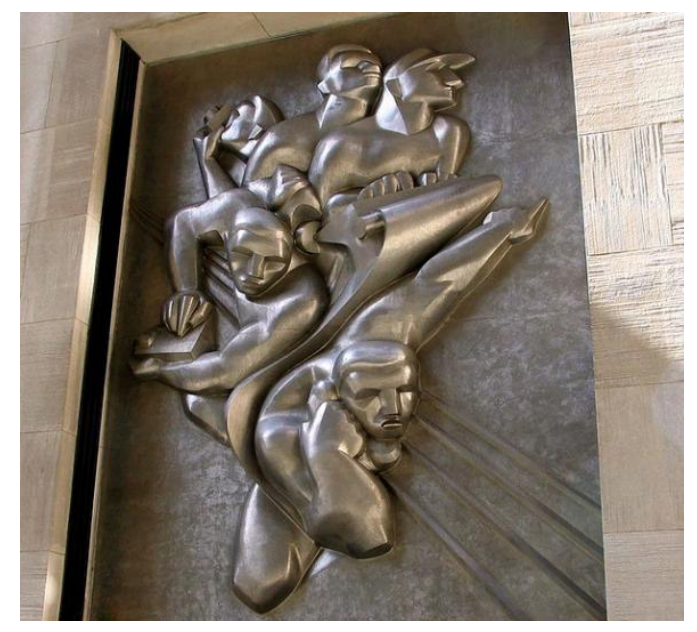

Isamu Noguchi, News, 1940 Rockefeller Center. ${ }^{237}$

\footnotetext{
${ }^{235}$ Patricia Bayer, Op. Cit., p. 155.

${ }^{236}$ New York Daily Photo, “Atlas”, http://newyorkdailyphoto.com/nydppress/?p=266

237 "Noguchi-Associated Pres bas-relief,1938-1940, https://www.flickr.com/photos/raimist/318310011/
} 
La tercera variante del Art Déco es la conocida como Streamline o Aerodinámico; la misma Weber lo describe así:

"Orientado a la horizontalidad en las curvas aerodinámicas, los techos planos, el ladrillo vidriado, las ventanas en forma de franja, las barandillas de acero tubular, las superficies de las paredes alisadas mecánicamente y las consecuencias de la fabricación en serie, el estilo aerodinámico en arquitectura igualaba al utilizado por los diseñadores industriales de aeroplanos, locomotoras, automóviles y aparatos electrodomésticos. Era una adaptación romántica de los cubos blancos, de techos planos, de los arquitectos funcionalistas europeos como Adolf Loos, Le Corbusier y otros...Con sus barandillas tubulares ajustadas horizontalmente, sus elegantes curvas, sus ventanas de portilla y sus detalles decorativos modernistas, el estilo se utilizó con frecuencia en lugares de descanso o en las casas de campo de los potentados, los vanguardistas o los intelectuales". ${ }^{238}$ Fue en la década de los treinta cuando se levantaron edificios dentro de esta variante estilística del Déco, principalmente en Estados Unidos, ya que el alto desarrollo industrial alcanzado por este país influyó en la realización de construcciones de este estilo.

En Inglaterra se encuentran varias edificaciones que caen dentro del estilo Aerodinámico o Streamline, como sería el caso del cine Dreamland del año 1935, ubicado en el parque de diversiones de Margate, Kent, y mandado construir por el propietario del lugar, John Henry Iles (1871-1951). El cine se cerró en 2007, pero en 2012 se inició un proyecto para abrirlo nuevamente. La obra fue hecha por los arquitectos John Bird Illes, Julian Rudolph Leathart (1891-1967) y W.F., Grainger, tomando en cuenta que el primero era hijo del empresario y poco se sabe de su carrera posterior como arquitecto. ${ }^{239}$ Una barda central forrada con ladrillos y como si fuera un gran alero en el que se colocan letras luminosas verticalmente, dos composiciones cúbicas descendentes se adosan por el lado izquierdo, cuyas aristas se curvean y líneas horizontales enmarcan letras que anuncian los servicios del lugar; del lado derecho un espacio traslúcido y cúbico completa el grupo asimétrico que se sostiene por el piso bajo. En síntesis, es un bello conjunto de poliedros iluminados con mínima decoración lograda por las líneas horizontales que lo exornan.

\footnotetext{
${ }^{238}$ Ibídem, pp. 34-35.

239 Margate Renewal Partnership, “The Prince's Regenation Trus”, Margate, March 2009, p. 41, http://www.dreamlandmargate.com/downloads/5_Dreamland_Margate_SC_Conservation_Statement_final_c omp.pdf
} 


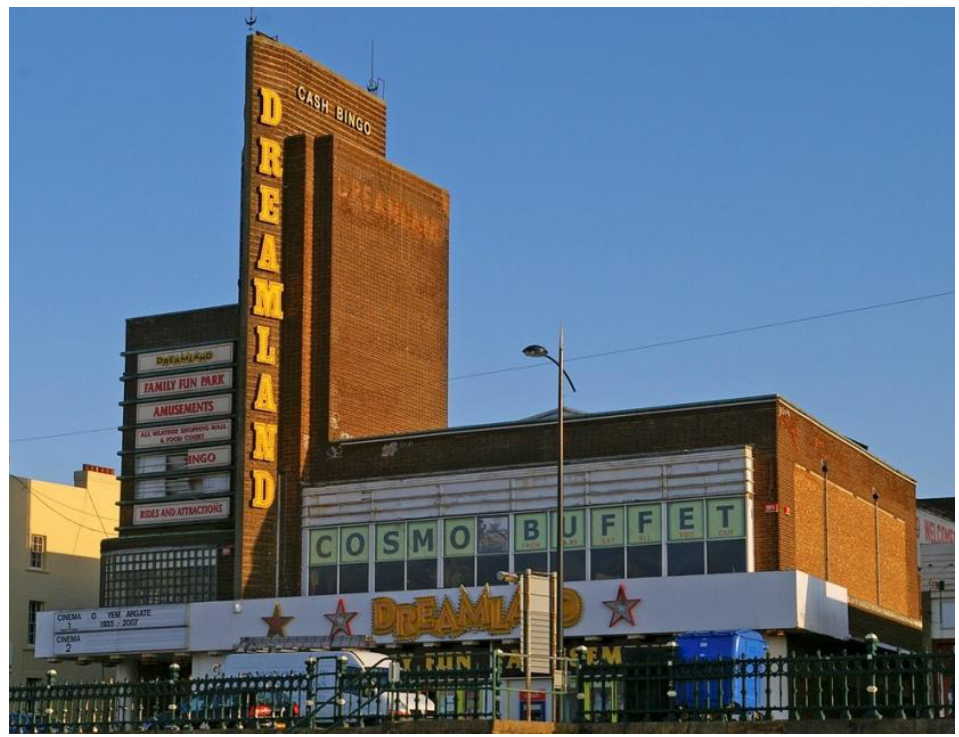

Illes, Leathart y Grainger, Dreamland Cinema, Margate, Kent, 1935.240

Algunas de las estaciones del metro londinense fueron trabajadas bajo el estilo Art Déco Streamline, como fue la estación Arnos Grove, de 1932 a 1934, o bien la Osterley de 1935, ambas diseñadas por Charles Holden (1875-1960), en la más absoluta sencillez, trabajadas con ladrillo rojo y ventanales rectangulares pintados de blanco.

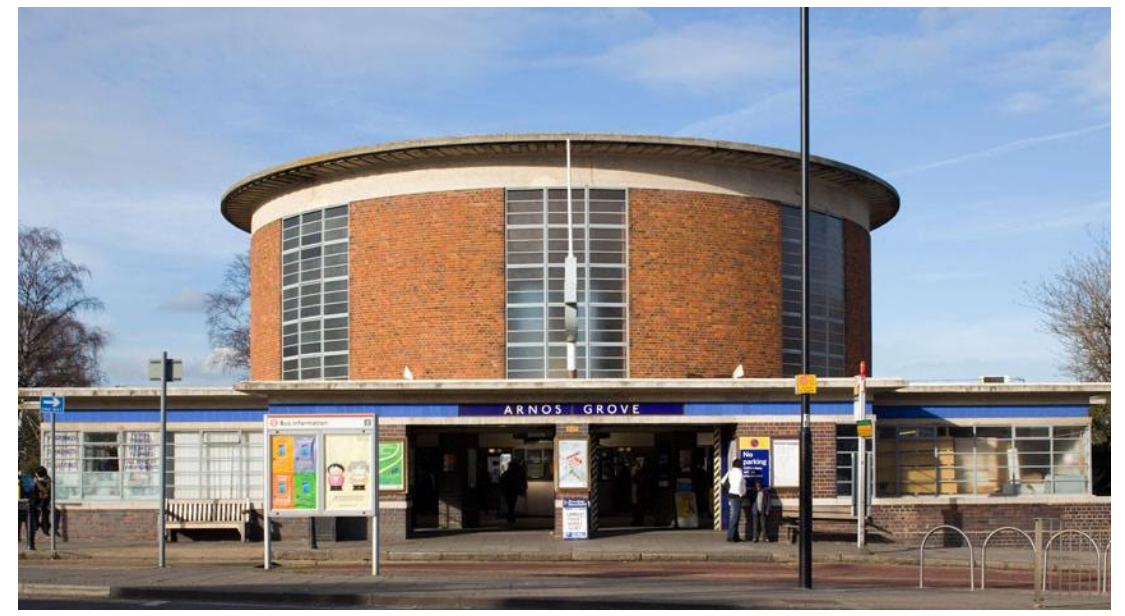

Charles Holdes, Arnos Grove Station, Londres, 1935.241

\footnotetext{
${ }^{240}$ Picture Ville, "Margate's Dreamland revival is on the move", Wednesday, 22 August 2012, http://www.pictureville.net/2012/08/margates-dreamland-revival-is-on-move.html

${ }^{241}$ Ian Jones, "The London Underground's most beautiful stations", The Telegraph, Tuesday 15 July 2014, http://www.telegraph.co.uk/travel/picturegalleries/9778235/The-London-Undergrounds-most-beautifulstations.html
} 
Pero es evidente que en Estados Unidos de Norteamérica el estilo Streamline cogió más fuerza que en ninguna parte, por la galopante expansión industrial y por las proyecciones de las ya mencionadas ferias de Chicago, Century of Progress de 1933, la de San Francisco, Golden Gate International Exposition de 1939 y del mismo año la New York World's Fair que mostraron con gran orgullo los impresionantes avances tecnológicos del potente industrial estadounidense.

En Inglewood, Los Ángeles, Charles Lee (1899-1990) construyó el fantástico Academy Theatre en 1938. El frente con líneas curvas se ensambla con una gran columna estriada envuelta en una espiral, para rematar con una bola incrustada de agujas, como si fuera un homenaje a la energía que se irradia. La elevada columna pareciera un instrumento mecánico de los conocidos como "sinfín", utilizados en la industria automotriz.

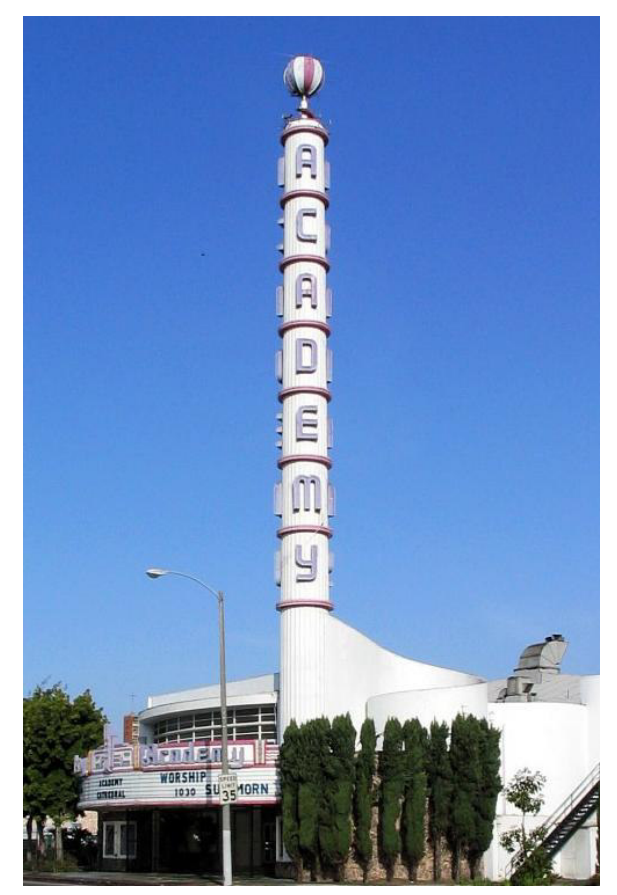

Charles Lee, Academy Theatre, Inglewood, Los Angeles, 1938.242

Esta variante Streamline fue utilizada en estaciones de autobuses, de servicio, restaurantes de comida rápida, por todo el territorio norteamericano, con formas que representaban barcos o aeroplanos, utilizando materiales laminados y luminosos, con la intención de tener alguna alusión a la velocidad.

242 “Academy Theatre 1938 by architect S. Charlee Lee”, http://www.you-are-here.com/theatre/academy.html 
Es importante mencionar dos variantes más que se dieron en la arquitectura Art Déco de Estados Unidos, mismas que tendrán una fuerte influencia en México y una de ellas, en especial, en la zona norte. Son los estilos Pueblo Déco y Tropical Déco.

El Pueblo Déco, que ya lo habíamos mencionado en el punto sobre las características generales del Art Déco, se desarrolló en el suroeste donde habitan los llamados indios Pueblo; de sus objetos artesanales se tomaron motivos decorativos para aplicarlos a la arquitectura, relacionados con los cactus del desierto y la arquitectura vernácula colonial que había quedado de las misiones tanto franciscanas como jesuitas, sobre todo en California. "La ornamentación se basaba en motivos simbólicos y ceremoniales de la cerámica, la cestería, la joyería y la artesanía textil de los indios Navajo, Hopi y Pueblo. Los símbolos del sol, de vaqueros y de cactus eran motivos relacionados con ella". ${ }^{243}$ Uno de los ejemplos más representativos fue el KiMo Theatre de los años 1926-1927, ubicado en Alburquerque, Nuevo México, realizado por Carl Henrich Boller (1868-1946) de la firma Boller Brothers Architecs, especializada en la construcción de teatros y cines. El KiMo Theatre resume en la entrada a través de gruesas columnas, en la fachada con escudos colocados en la parte superior, así como en el interior, los elementos decorativos tanto de los indios Navajos como de los Pueblo de Arizona y Nuevo México.

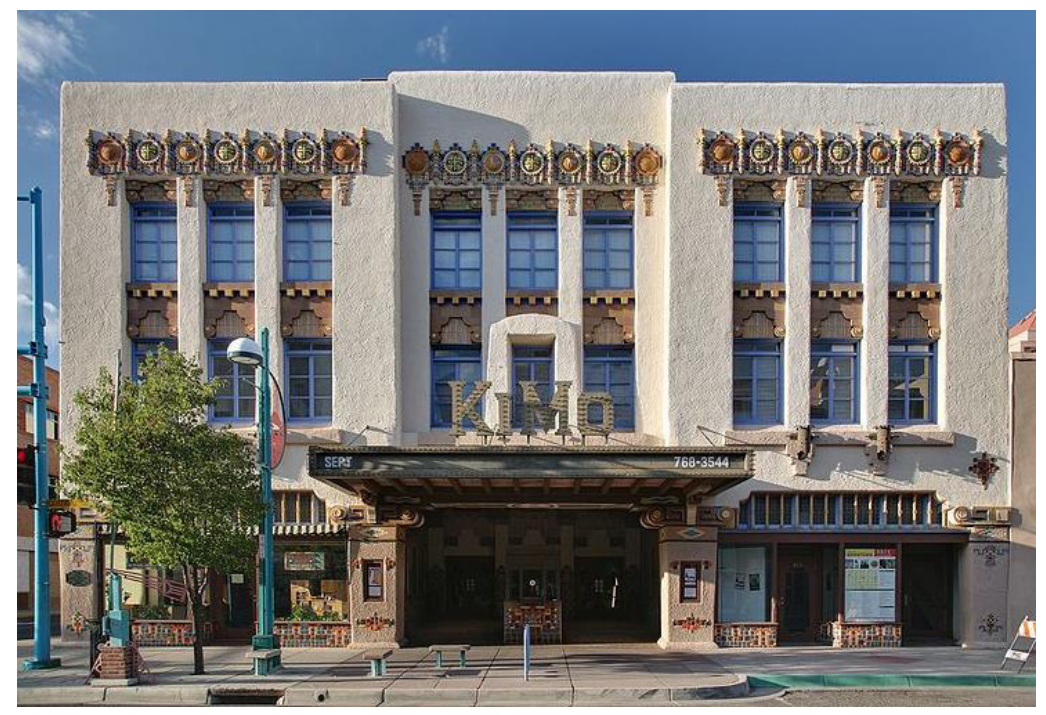

Carl Henrich Boller, KiMo Theatre, Alburquerque, Nuevo Mexico, 1927.244

\footnotetext{
${ }^{243}$ Eva Weber, Op. Cit., p. 33.

244 "KiMo Alburquerque", http://commons.wikimedia.org/wiki/File:KiMo_Albuquerque.jpg
} 


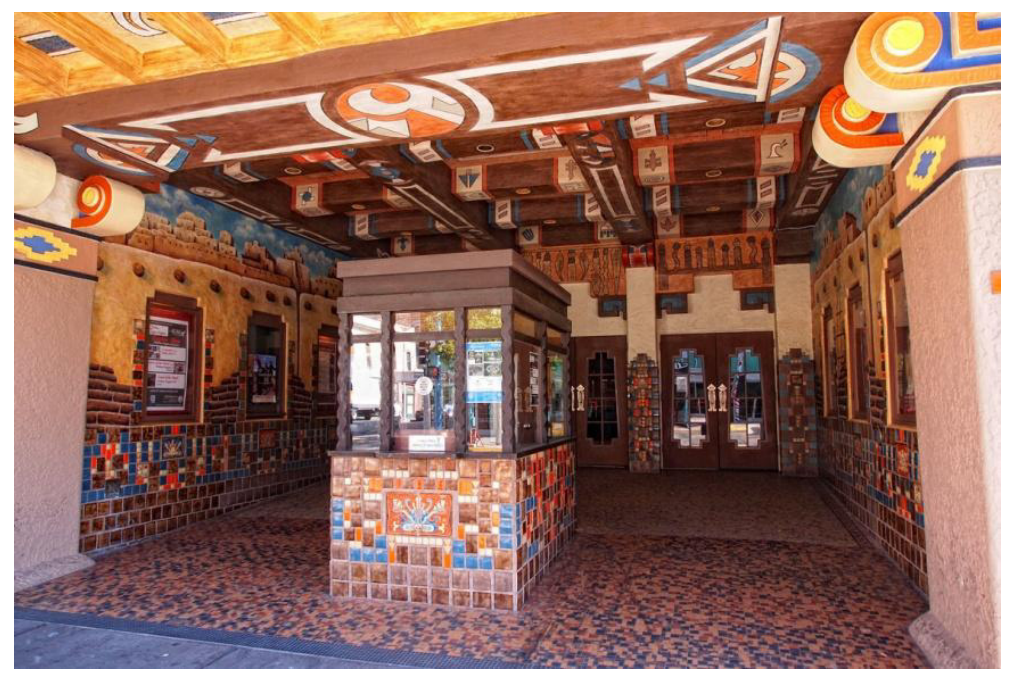

Vestíbulo del KiMo Theatre. ${ }^{245}$

El Tropical Déco es la variante que en La Florida tuvo su máxima expresión. En Miami, el distrito conocido como Old Miami Beach durante la década de los veinte y treinta se convirtió en un lugar de vacaciones veraniegas; por lo tanto, hoteles, restaurantes y residencias de descanso se construyeron bajo los esquemas del Art Déco, aunque también se hicieron en otras partes con playas como fue en California, pero resaltando elementos decorativos marinos, colores suaves en los muros, marquesinas en las ventanas que imitan aleros y como un elemento muy distintivo serían las portadas principales en las que las esquinas curveadas y adornadas por líneas horizontales asemejaban a proas de barcos, mismas que se coronaban con astas a manera de mástiles. Eva Weber lo describe así: "Como regla, los edificios tropicales déco se construían sin grandes gastos, en hormigón estucado. Templaban la esbeltez del estilo aerodinámico con retranqueos estilo zigzag, policromía y una estilizada ornamentación orgánica y abstracta". 246

Por su parte, Rossana Bossaglia cincunscribe al Tropical Déco a un cierta época en los inicios de los años cuarenta y lo ubica en las zonas de playas, especialmente en el Old Miami Beach, dando las siguientes características distintivas: "Las peculiaridades Deco se basan principalmente en los dispositivos de adorno, frisos y dinteles de hormigón, barandillas, puertas de hierro y metales blandos, enyesando el exterior de las casas con colores marinos como el azul, el verde agua, el amarillo solar, predominantemente (pero no

\footnotetext{
245 "KiMo Theatre", http://www.mu-43.com/showthread.php?t=24326\&page=10

${ }^{246}$ Eva Weber, Op. Cit., p. 36.
} 
en todos los casos son las escayolas originales); en otros casos se pintaba con unos colores más sutiles, utilizando los temas decorativos de fórmula internacional (desde la fuente hasta, la lluvia de flores de color rosa), a menudo jugando con ingenio el repertorio clásico (el capitel jónico, la secuencia de las columnas, el vaso conrintio) junto con evocaciones estilizadas de flora y fauna tropical". 247

Entre los muchos ejemplos está el hotel The Carlyle, del año 1941, obra de Kichnell y Elliott: ${ }^{248}$ los colores pastel como el amarillo, rosa y verde limón hacen juego con la frescura del blanco y los aleros de las ventanas que están trabajados con ligeras curvas. Otro caso es The Marlin Hotel, construido en 1939 por Lawrence Murray Dixon (19011949). En el exterior pinturas con temas acuáticos (seguramente no son originales, ya que el edifico se nota que ha tenido restauración) le dan más el ambiente de playa, así como unas estilizaciones de olas dispuestas en una franja en el tercer piso. Los colores suaves como el azul claro y la rejería que da a la calle simulando olas geometrizadas casi como un Déco Zigzag, parodian el mar. El remate central escalonado sostiene un asta. Por su puesto, dentro de la variante Streamline, los aleros curvos resguardan las ventanas de todo el edificio.

El arquitecto Henry Hohauser (1895-1963) construyó algunos hoteles en la zona de Miami Beach como fue The Essex House, 1938, y el Century Hotel, 1939, pequeño establecimiento de dos plantas que lleva un rodapié con círculos rehundidos, la puerta de acceso con decoraciones de medios círculos y líneas onduladas, para continuar a los lados con gruesas estrías. Influido por Gropius, en las esquinas están colocados amplios ventanales. Una marquesina cubre el perimer piso que al centro se prolonga a manera de alero, el cual sostiene el nombre del hotel con amplias grafías geométricas. Al centro del segundo nivel un ventanal de tijera está cubierto por un alero y arriba de éste una prolongación semielíptica con anillos rebasa la altura del techo. A los lados franjas rehundidas cierran la parte central del segundo nivel. En los extremos los vanos de las ventanas están cubiertas por aleros que en la parte superior llevan una decoración a base de tres líneas horizontales y tres círculos. La combinación de blanco con el verde acentúan la

\footnotetext{
${ }^{247}$ Rossana Bossaglia, Op. Cit., pp. 119-120.

${ }^{248}$ Susan Sternau, Op. Cit., p. 113, sólo da en el pie de fotografía del edificio los apellidos de los arquitectos.
} 
idea del mar y el diseño del edificio es una parodia de un buque, al mismo tiempo que combina su composición de Tropical Déco con el Streamline.

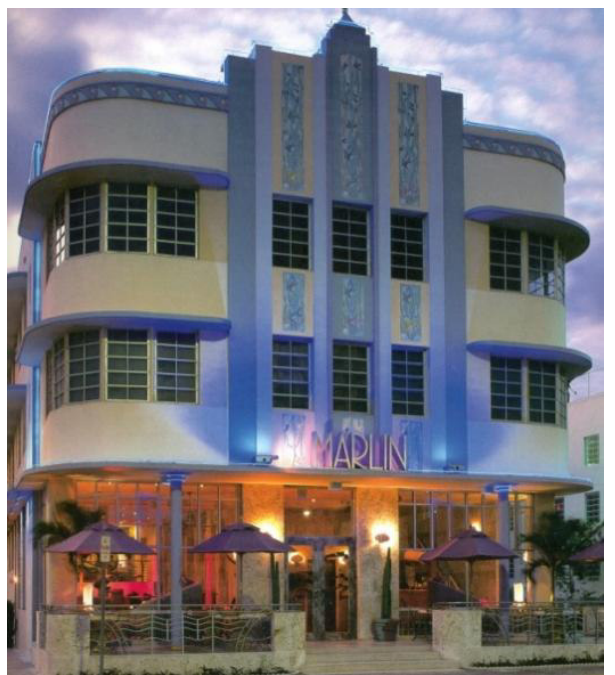

Lawrence Murray Dixon, The Marlin Hotel, Miami Beach, 1939. 250

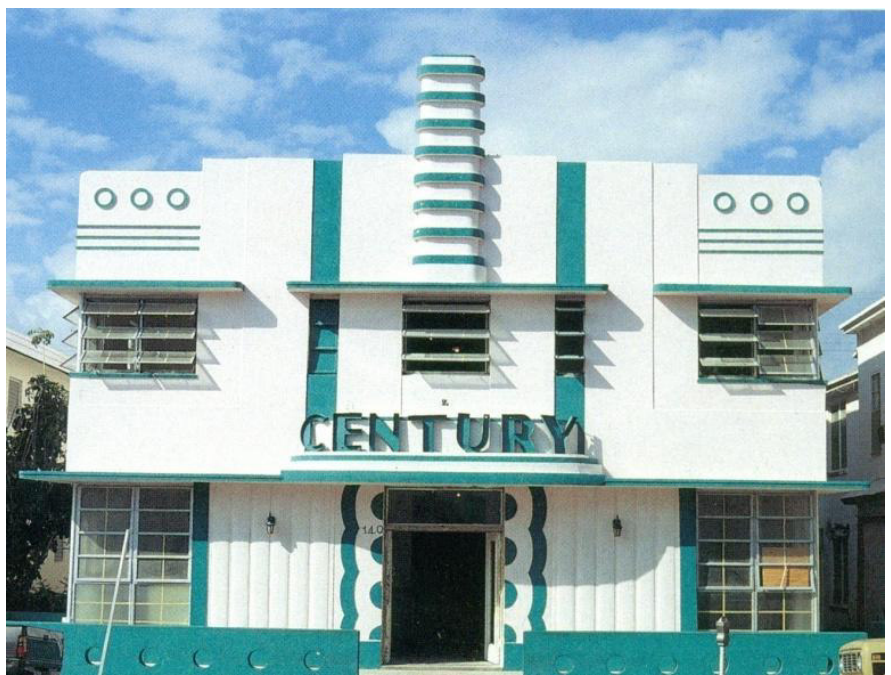

Henry Hohauser, Century Hotel, Miami Beach, 1939.249

Debido a su cercanía con La Florida y por ser una ciudad junto al mar, el caso de La Habana es muy singular porque además de darse especialmente el Art Déco Zigzag, hay varios edificios de tipo Tropical Déco. Como sabemos, por la situación política del gobierno cubano y su cierre hacia el exterior, los edificios en su mayoría están en malas o pésimas condiciones, pero es una ciudad que tiene mucho Art Déco de magnífica calidad en la zona centro, así como en la zona de El Vedado y que gracias al trabajo de investigación y fotografía del italiano Martino Fagiuoli es que podemos apreciar muchos de esos monumentos.

Un caso de Trópical Déco en La Habana que se encuentra en buenas condiciones de conservación y uso, es el Teatro Fausto de 1938, obra del arquitecto Saturnino Parajón, mencionado por Leopoldo Fornés Bonavía como un hecho de trascendencia del año 1938 dentro de la historia cubana, en su libro Cuba, cronología: cinco siglos de historia, política y cultura. ${ }^{251}$ En la planta baja lleva portales con vanos rectangulares como es el requisito de

\footnotetext{
${ }^{249}$ Peter Gössel y Gabriele Leuthäuser, Op. Cit., p. 282.

${ }^{250}$ Bevis Hillier y Stephen Escritt, Op. Cit., p. 220, mencionan que el interior fue rediseñado en 1989 por Barbara Hulanicki. La foto es del mismo libro y página.

${ }^{251}$ Leopoldo Fonrnés Bonavía, Cuba, cronología: cinco siglos de historia, política y cultura, Madrid, Verbum, 2003, p. 170.
} 
los edificios de la ciudad. En la parte frontal tres aleros curvos en las esquinas inician el ritmo de más aleros que dividen ocho entrepaños, la mayoría de ellos cerrados, mientras que el uno y el siete tienen ventanas y el ocho enmarca unas bellas decoraciones de flores geometrizadas. Al centro se elevan unas estilizadas columnas geométricas y remata con dos celosías que nos recuerdan una cara del dios maya de la lluvia Chaac, lo que se combina con el coronamiento de los lados que son de menor altura que el remate central y que están decorados a través de un pretil dentado. La suavidad de los lienzos laterales y sus aleros que se retranquean en relación con la fachada le dan movimiento al conjunto. Fagiuoli comenta sobre la modernidad de este edifcio cuando fue puesto en uso: "Ventajas técnicas y comodidades hicieron de esta construcción algo de muy especial interés. Por ejemplo, fue el primero que tuvo aire acondicionado en la ciudad; sus muros disponían de una separación interna para impedir que el ruido exterior molestara; y el frente, tras los tubos metálicos que aun conserva, ocultaba fuentes de luz neón que producían efectos cromáticos; tales avances, merecían justamente una fachada que en términos nuevos, comunicara su función". 252

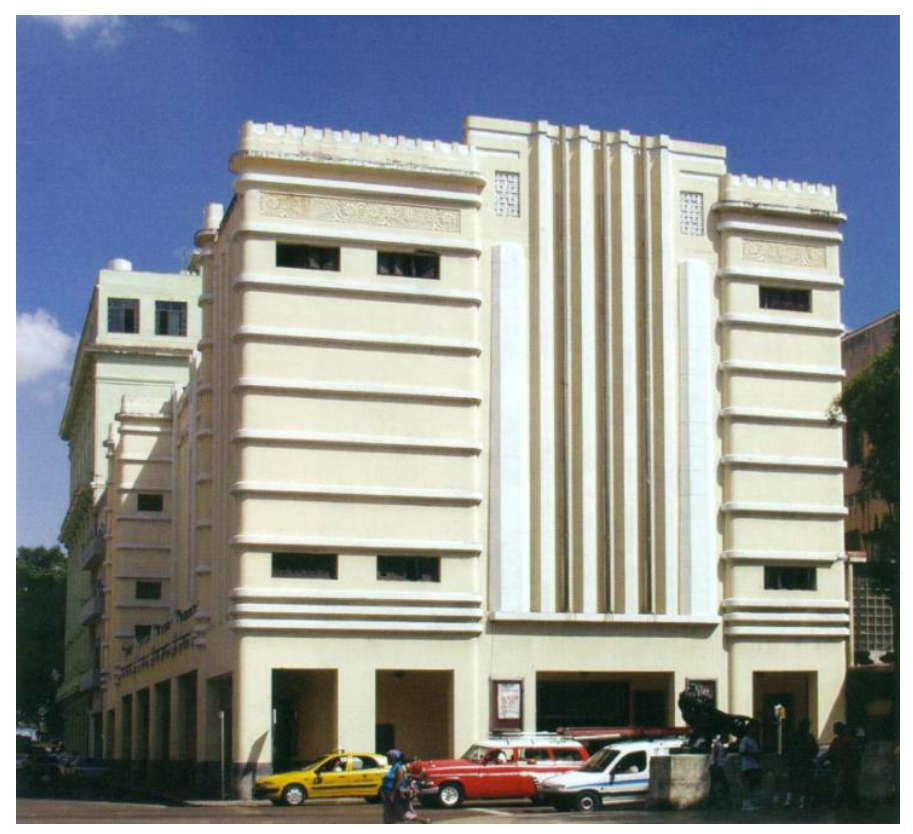

Saturnino Parajón, Teatro Fausto, La Habana, 1938.253

\footnotetext{
${ }^{252}$ Martino Fagiuoli, La Hababa Deco, Bolonia, CV Export, 2003, pp. 59-60.

${ }^{253}$ Ibidem, p. 60.
} 
Con estas especificaciones de Eva Weber y con la cita de algunos ejemplos nos damos una idea general de las variantes estilísticas del Art Déco en la arquitectura; sin embargo, queremos trascribir una relación de características que dan Alicia Suárez y Mercé Vidal, con lo cual nos aclara aún más cómo distinguir la arquitectura Déco.

"Por lo que a arquitectos se refiere, las fachadas presentan las siguientes características dominantes: muros de cerramiento movidos con profusión de formas angulares; distribución regular de los huecos y simetría muy acusada, que en muchos casos queda subrayada por dos cuerpos laterales salientes; ventanas geminadas que destacan así la horizontalidad; mansardas geometrizadas de tipo francés que coronan los edificios; bandas paralelas horizontales o escalonadas que se repiten en toda la fachada o aparecen en los huecos de ventanas y puertas; utilización de estilos históricos (columnas, capiteles, volutas de forma plana y esquemática; uso de balaústres de cemento cilíndricos o prismáticos de bastante grosor; aparición de bajorrelieves en placas que se hallan generalmente sobre la puerta (los más significativos son los que toman como tema la velocidad: barcos, trenes, aviones). Pero quizá sea en las rejas de balcones y puertas donde los caracteres del estilo pueden captarse de forma más inmediata: las formas geométricas simples, paralelas, ondas, zig-zags, espirales, surtidores de agua, temas florales simplificados o siluetas de cactus y palmeras, aparecen constantemente. Entre las tiendas, es muy característica la rotulación de diseño simple, geométrico, de gran tamaño y de atractivo grosor, y la utilización de espejos, de cristales esmerilados en bandas o con los característicos temas estilizados y cubistas de la ornamentación déco". 254

Como ejemplos de estas características está el edificio de apartamentos del 11 Avenue Frederic Le Play en París, obra de 1927 realizada por el arquitecto A. Filder 255 dentro de la variante Déco Zigzag. Las formas angulares resaltan en los balcones dobles y triples, la distribución regular de huecos se da por medio de las ventanas, de las cuales las geminadas son las que destacan, dándose al inmueble horizontalidad, al mismo tiempo que presenta las mansardas geometrizadas de tipo francés que rematan en la parte superior.

\footnotetext{
${ }^{254}$ Alicia Suárez y Mercé Vidal, “Prólogo” del libro de Paul Maenz, Op. Cit., pp. VI-VII.

${ }^{255}$ El nombre está inscrito en una placa en la parte derecha de la entrada.
} 


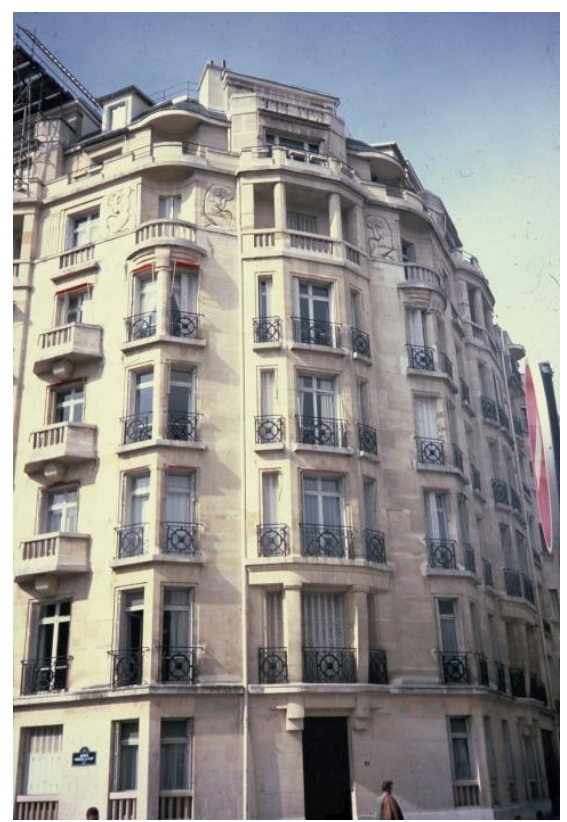

A.Fildler, Apartamentos 11 Avenue Frederic Le Play, París, 1927.

Otro caso donde se pueden aplicar las características de Suárez y Vidal y que es un modelo de Art Déco Zigzag tanto para su país como para el mundo, es el excepcional Edificio Bacardí que se encuentra en La Habana Vieja. Construido para las oficinas de la famosa compañía ronera del mismo nombre, reúne tanto los lineamientos constructivos como decorativos del Art Déco. Fue en el año de 1930 cuando se inauguró el majestuso inmueble, diseñado por el arquitecto Esteban Rodríguez Castells, con la asistencia del arquitecto Rafael Fernández Ruenes y el ingeniero José Menéndez, ${ }^{256}$ convirtiéndose en la construcción más alta del centro de la ciudad en su tiempo. Con rodapié y peldaños de la entrada en mármol negro, los vanos rectangulares de la entrada y los octagonales de las ventanas de la planta baja, llevan placas de terracota en color obscuro, para contrastar con las placas del mismo material, pero en colores claros, del resto de la construcción. Composición escalonada que se eleva al centro con un amplio balcón y torre con balcones, presume almenas decoradas, así como dos relieves femeninos colocados en el séptimo piso del cuerpo central, elaborados en terracota esmaltada por la casa parisina Maxfiel. Simetría y distribución regular en las ventanas, horizontalidad marcada en todos los pisos, diseño escalonado tanto en la parte superior como en la posición de los cuerpos que se unen para

\footnotetext{
${ }^{256}$ Martino Fagiuoli, Op. Cit., p. 18.
} 
darle forma al edificio, pero sobre todo bandas escalonadas adornan todas la ventanas en la parte superior. Y los estilos históricos los vemos en las pilastras estriadas y capiteles corintios de las decoraciones del interior. "Babilonia y París se abrazan", dice Martino Fagiuoli, pues para él las influencias en el Edificio Bacardí de los pabellones de la exposición de París de 1925, más la mesopotámica Puerta de Istar no es casualidad. ${ }^{257}$
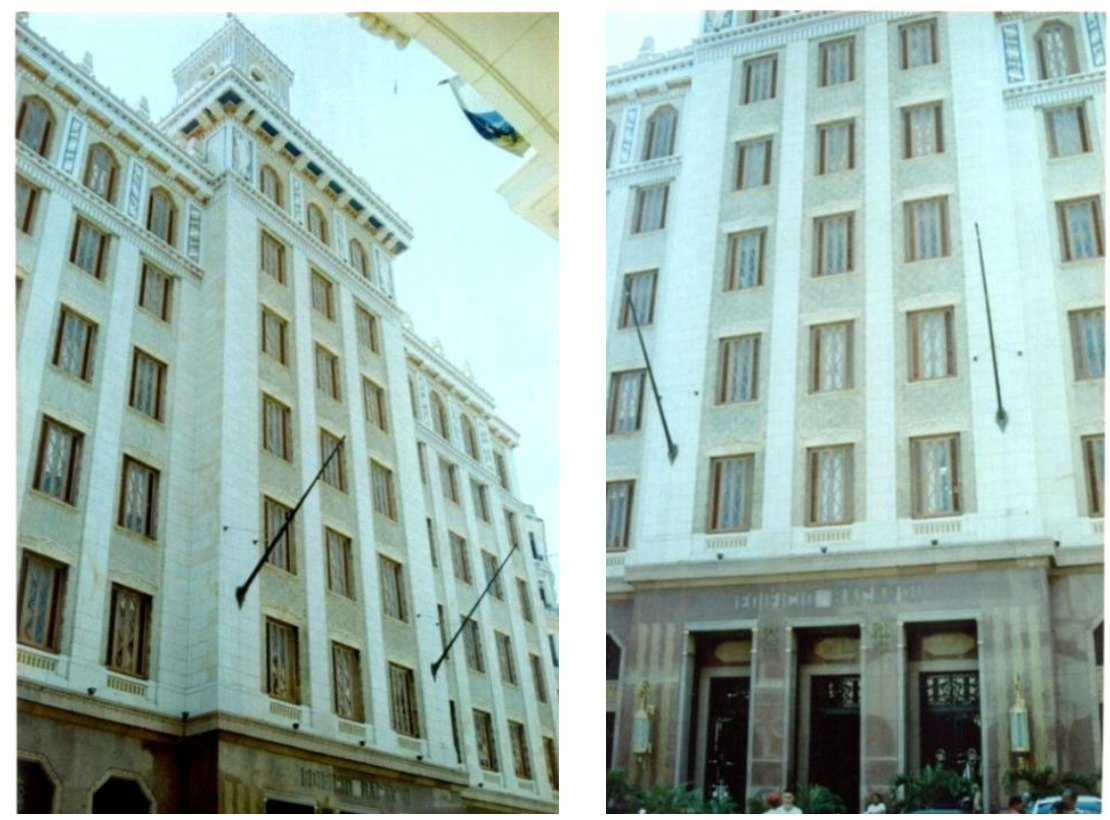

Esteban Rodríguez Castells, Edificio Bacardí, La Habana, 1930. Vista de conjunto y detalle de las puertas del acceso principal.

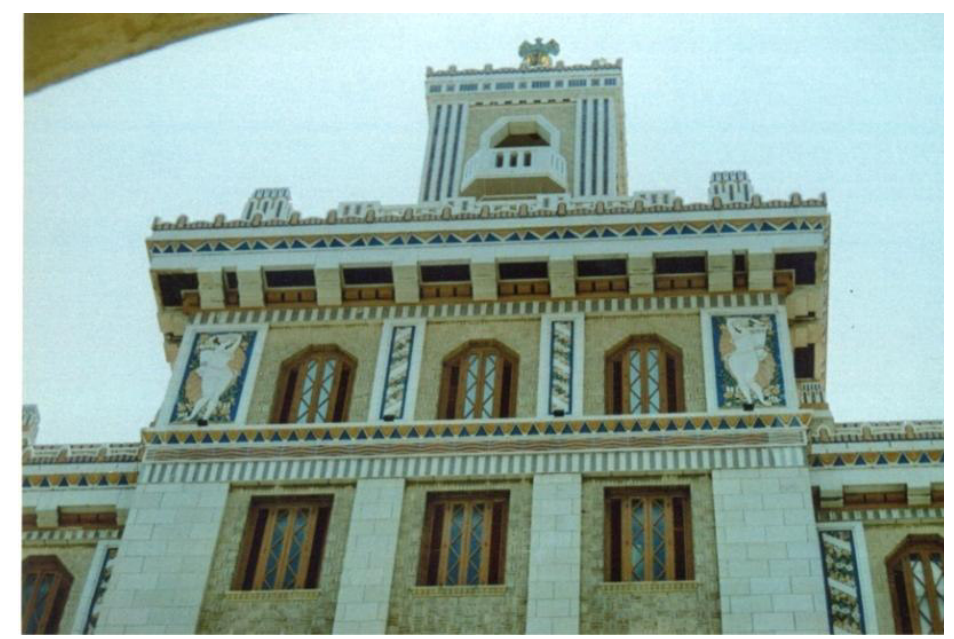

Edificio Bacardí, detalle del último piso del cuerpo central con ventanas ochavadas y relieves femeninos, más el coronamiento con la torre.

${ }^{257}$ Ibídem. 


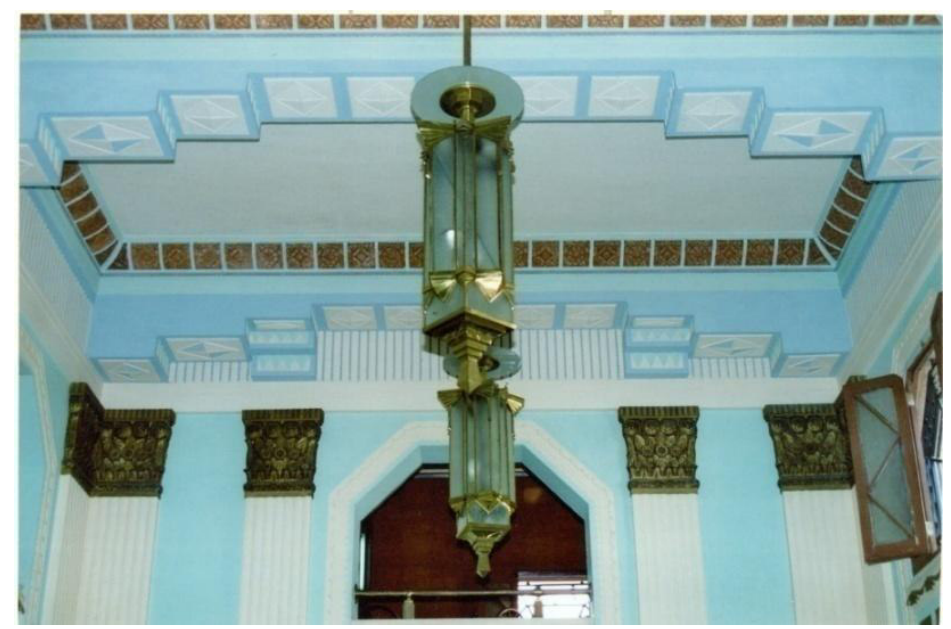

Edificio Bacardí, interior. Al fondo pilastras estriadas con capiteles corintios. Al frente y atrás trabes escalonados con decoraciones de puntas de diamante y las magníficas lámparas Déco Zigzag.

Finalmente, para ejemplificar lo concerniente a las rejas de puertas y balcones, en La Plata, Argentina, en la Avenida 51 entre Avenidas 3 y 4 hay dos casas Déco de principios de los años treinta con los números 769 y 773 que comparten la estética geométrica del Zigzag; en la primera casa destaca el remate escalonado y triangular por arriba del nivel de la techumbre y en la segunda las ventanas ochavadas de la primera planta, así como el remate decorado y retranqueado.

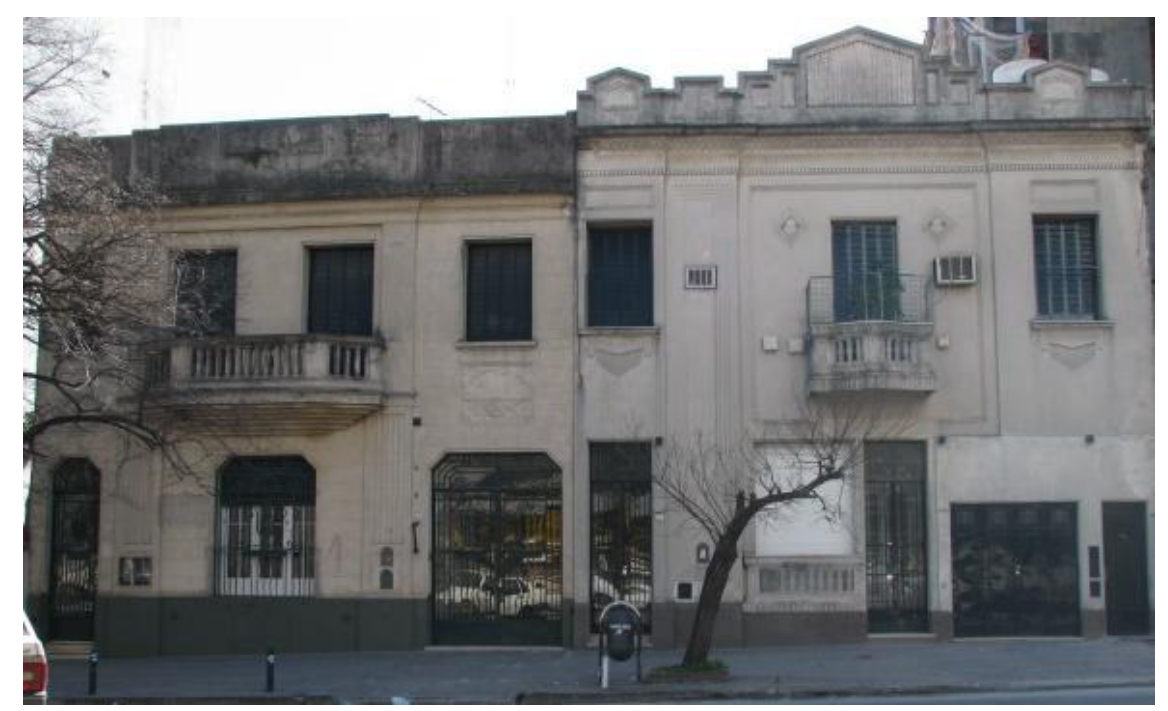

Casas en la Avenida 51, nos. 773 y 769, entre Avenidas 3 y 4, La Plata, ha. 1930. 
Ambas casas comparten el uso de balaustres prismáticos en balcones, pero principamente es en las puertas de entrada donde las rejerías llevan formas geométrcias como dos "V" cruzadas al derecho y al revés, tal como es la traza de la ciudad, más zigzags y rígidas ondulaciones en la casa 769 enmarcada rectangularmente, y de flores simples sueltas y en floreros, con líneas quebradas y ondulaciones, todo dentro de un marco ochavado, como sucede en la casa número 773.
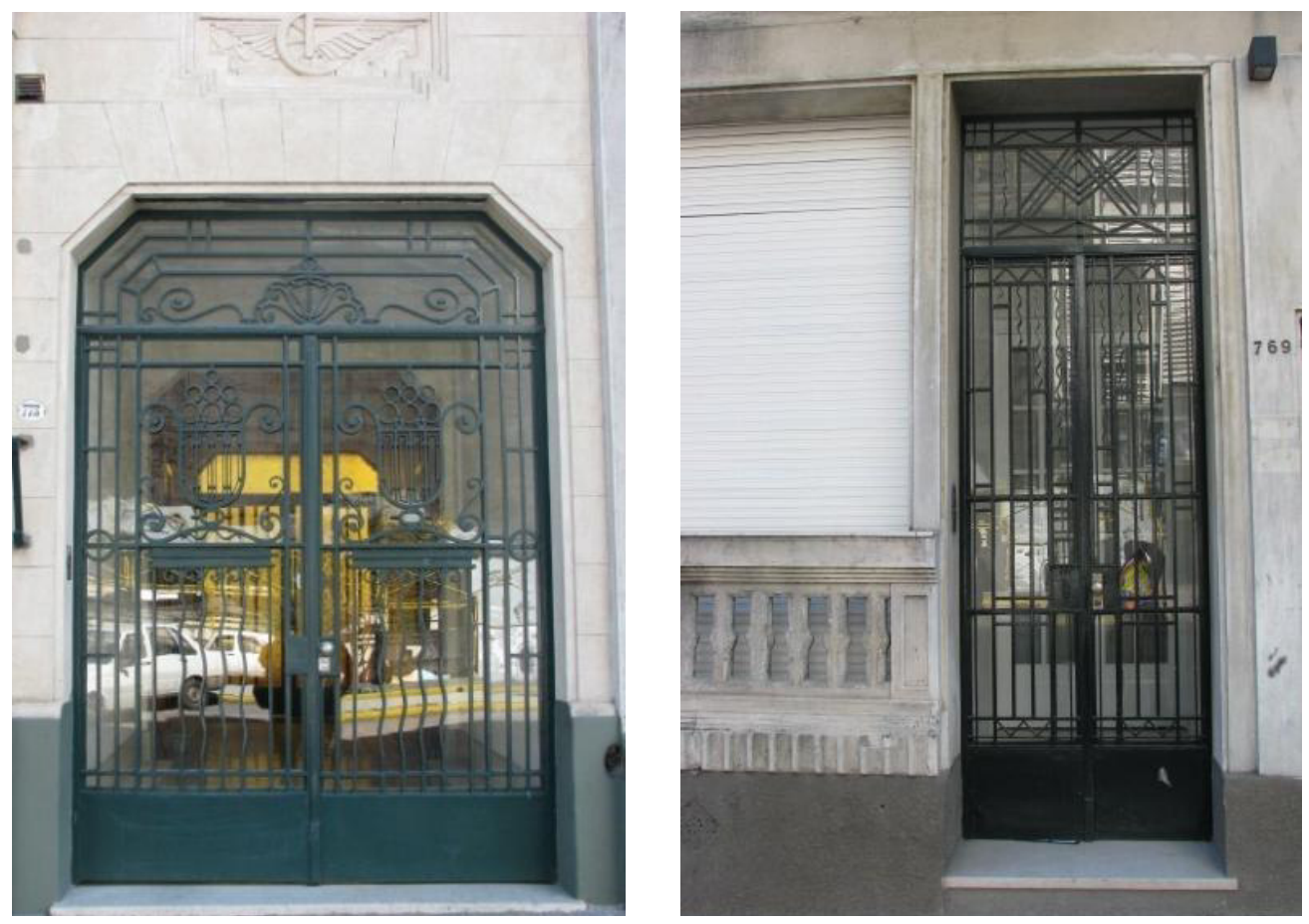

Rejerías de las casas no. 773 y 769 de la Avenida 51, entre Avenidas 3 y 4. En la segunda a la vez se ven los balaustres prismáticos del balcón. La Plata, ha. 1930. 
2. PRESENCIA DEL ART DÉCOEN MÉXICO 


\subsection{LOS ESTUDIOS DEL ART DÉCO EN MÉXICO}

En septiembre de 1977 Felipe García Beraza (1924-1997), hombre dedicado a la cultura, fundador del Centro Mexicano de Escritores (CME) y de la Sociedad Defensora del Tesoro Artístico de México, organizó una exposición fotográfica en el Instituto Mexicano Norteamericano de Relaciones Culturales titulada Art Déco en México, con un folleto en el cual se incluyeron textos del propio Felipe García, Luis Ortiz Macedo (1933), Carlos Flores Marini, Antonio Luque, Salvador Moreno (1916-1999), Jaime Cuadriello, Alberto Yarza y Xavier Esqueda (1943). Con el objetivo de valorar la importancia artística y arquitectónica de varios edificios de la ciudad de México, así como objetos decorativos y artes gráficas, esta muestra fue el inicio del estudio del Art Déco en el país.

En su texto A propósito de esta exposición, Felipe García resalta la importancia de la presencia de lo prehispánico, enfatizando que el Palacio de Bellas Artes es el ejemplo más logrado dentro del Art Déco mexicano y afirma el autor que estilo se ubicó en México un poco después de su desarrollo en París. Por haber sido el primer evento realizado con este contenido en el país, García Beraza declara: "Al presentar esta exposición del ArtDecó -sic- (la primera en México, la cuarta en América, incluyendo las dos en los Estados Unidos), el Instituto Mexicano Norteamericano de Relaciones Culturales, A.C.; espera despertar el interés por este estilo ya difunto o, por lo menos, ofrecerle un velorio digno de su breve y esplendorosa vida". ${ }^{1}$ Una aportación lingüística ofrece García al utilizar la palabra "art-decoízadas" al referirse a las casas de la colonia Hipódromo Condesa de la ciudad de México, otra aportación además de la exposición misma.

El destacado arquitecto e historiador del arte y de la arquitectura Luis Ortiz Macedo (1933), colaboró con dos escritos. En el primero titulado Sobre el Art-Deco diserta sobre que si se intenta tratar con este término a una unidad estilística daría como resultado desencuentros teóricos. Explica que el Art Déco se desarrolla cuando el caos imperaba sobre el orden en una época en que la industrialización proporcionaba nuevos materiales que serían incorporados en este arte, donde la inestabilidad de las entreguerras en Europa y la postrevolución en México, llevaron a los artistas a buscar otros elementos plásticos y

\footnotetext{
${ }^{1}$ Felipe García Beraza, “A propósito de esta exposición”, catálogo de la exposición El Art Deco en México, México, Instituto Mexicano Norteamericano de Relaciones Culturales, 1977, p. 6.
} 
decorativos basados en la tradición histórica, como fue el caso de nuestro país con las artes populares y hace mención de las huellas del Déco en construcciones de la colonia Hipódromo, en el Palacio de Bellas Artes y el Banco de México. En su conclusión agradece a Felipe García la iniciativa de efectuar la muestra en la cual se pudo estimar “otra más de las prolijas y dilatadas estancias de nuestro arte, el cual se nos escapa irremisiblemente entre los aires...sin que se eleve una firme acción pública tendiente a conservar los vestigios materiales de nuestra historia...".

El otro artículo de Ortiz Macedo, La Plaza de la República y el Monumento a la Revolución, es un panegírico a éste último. Inicia y concluye con una opinión del escultor de origen alemán Mathías Goeritz (1915-1990), quien en 1975 indicó que el Monumento había mejorado con el tiempo, ya que hasta la fecha y desde su edificación en $1933^{3}$ ha sido objeto de duras críticas, por lo que Ortiz Macedo señala que los propios autores y hasta Diego Rivera (1886-1957) lo habían defendido en su momento. Elogiando a "el arquitecto", Carlos Obregón Santacilia (1896-1961), como le llamaban en esos años a quien modificó la estructura de lo que iba a ser el Palacio Legislativo para lograr el monumento, además cita a jóvenes arquitectos contemporáneos que en esos años supieron incluir con rigor metodológico las nuevas técnicas y la estética arquitectónica, tales como Manuel Ortiz Monasterio (1887-1967), Orvañanos, José Villagrán García (1901-1982), Vicente Mendiola (1899-1986), Juan Segura (1898-1989), Manuel Cortina García (1877-1847), Ernesto Ignacio Buenrostro, Federico Mariscal (1881-1971). El monumento concebido y realizado por Obregón Santacilia y por el joven escultor Oliverio Martínez (1901-1938) es una de las grandes expresiones del Art Déco mexicano. "En suma. Lo que buscó Obregón por encima de todo, fue el de realizar una concepción de tal fuerza, que impusiera a la ciudad un nuevo carácter y le imprimiera una distinta escala". 4

Como era de suponerse, un texto del catálogo está dedicado al interior del Palacio de Bellas Artes. ${ }^{5}$ Lo escribe el arquitecto Carlos Flores Marini (1937), connotado

\footnotetext{
${ }^{2}$ Luis Ortiz Macedo, "Sobre el Art-Deco”, Ibídem, p. 11.

${ }^{3}$ El Monumento a la Revolución fue realizado entre 1933 a 1938. Aquí Ortiz Macedo da el año de 1933 como fecha de conclusión. Más adelante en el punto 4. CARACTERÍSTICAS DEL ARTE DÉCO EN MÉXICO, hacemos una descripción del monumento.

${ }^{4}$ Luis Ortiz Macedo, "La Plaza de la República y el Monumento a la Revolución”, Catálogo de la exposición El Art Deco en México, Op. Cit., p. 21.

${ }^{5}$ El nombre del edifico es Palacio de Bellas Artes, tal y como aparece en el tímpano de la entrada, sin embargo Flores Marini le llama Palacio de las Bellas Artes.
} 
conservador y restaurador de obras arquitectónicas. Titulado El Art-Deco en el Palacio de Bellas Artes, el contenido versa sobre los elementos decorativos del suntuoso edificio que le dan esa lozanía decorativa, en donde se integran las grecas prehispánicas, con los zigzag, los mascarones mayas de Chaac con las lámparas en forma de cactus o los brillantes metales con los mármoles negros y rojos, en un hall de amplias dimensiones nunca antes visto en México. La iluminación hecha por la casa Tiffany de París logra con estupendo acierto conseguir la luminosidad del elegante recinto, lo que Flores Marini pondera: “Aquí podemos observar claramente una de las grandes preocupaciones y retos que inquietaron a los decoradores y arquitectos del Art-Deco. Integrar de manera armónica y estética los nuevos y revolucionarios sistemas de alumbrado eléctrico, a la estructura general del edificio". 6 Si el Art Déco no es un movimiento artístico con unicidad estilística, sino un combinado de diversas manifestaciones, concluye Carlos Flores que como han dicho varios críticos, justamente eso se refleja en el Palacio de Bellas Artes.

Antonio Luque en el artículo El Banco de México ejemplo del Art-Deco afirma que lo mejor del Art Déco en el país son el Palacio de Bellas Artes y el Banco de México. Explica que el edificio fue en un principio de La Mutua, oficina de seguros y que fue remodelado por el arquitecto Carlos Obregón Santacilia, inaugurándose en sus nuevas funciones el 12 de octubre de 1927 por el Presidente Plutarco Elías Calles. La fachada no fue intervenida para que armonizara con los edificios del entorno, sin embargo "A diferencia del exterior, su interior fue remodelado totalmente con un bello decorado del más clásico Art-Deco, logrando en el conjunto de detalles una armonía única, ya que pertenecen en sus elementos fundamentales los lineamientos paradigmáticos de dicho estilo. Desde la entrada se puede apreciar la sobria elegancia dada por los acabados y los ricos materiales que se utilizaron". 7 Una sustanciosa descripción de los materiales y decorados es lo que ofrece Luque, destacando el techo del vestíbulo, en el cual las figuras humanas que están insertas, muestran la moda de la época. Demás detalles como los elementos zoomorfos y fitomorfos, más los lujosos mármoles de Italia y Bélgica, armonizan con la escalera y la

\footnotetext{
${ }^{6}$ Carlos Flores Marini, "El Art-Deco en el Palacio de las Bellas Artes", Catálogo de la exposición El Art Deco en México, Op. Cit., p. 17

${ }^{7}$ Antonio Luque, "El Banco de México ejemplo del Art-Deco", Ibídem, p. 26.
} 
gran linterna de bronce, la cual completa la iluminación tenue del glamoroso edificio, símbolo del más puro Art Déco.

Un breve trabajo es el escrito efectuado por Salvador Moreno que lleva por título $\mathrm{La}$ Estatuaria Art-Deco en México. De gran significación y trascendencia es la afirmación que hace al referirse sobre los tratados e investigaciones del Déco en la nación mexicana: "Su estudio serio aún no ha comenzado, o mejor dicho comienza ahora, y resulta oportuno, porque existen en nuestro país ejemplos suficientes para hacer posible su comprensión. Algunos de sus autores viven aún, y los nombres de muchos otros podrían recuperarse en ese injusto olvido". ${ }^{8}$ Era el año 1977 y nadie todavía había abordado el tema; sólo habían pasado once años de la exposición de 1966 donde se había bautizado al estilo y en México se lleva a cabo la exposición organizada por García Baeza, que con la edición del catálogo y los textos escritos por expertos suponen el comienzo de los estudios formales del Art Déco en México. Al hacer una diferenciación entre estatua y estatuaria, Moreno expresa que la única pretensión de la segunda es "estar" por lo tanto lo que busca es adornar espacios abiertos como monumentos, plazas y jardines, o balaustradas y nichos en inmuebles cerrados. Para él, las piedras que forman las figuras humanas del Monumento a la Revolución esculpidas por Oliverio Martínez, la frondosa mujer de la fuente del Parque México con su simetría tanto en los cántaros que carga como en su anatomía y los geométricos relieves fitomorfos y femeninos del Banco de México, son iconos de la estatuaria decorativa Art Déco en el país.

En aquel año de 1977, el todavía muy joven investigador Jaime Cuadriello escribió para el catálogo un apartado titulado De Diseño y las Artes Decorativas, en donde primeramente relata el desarrollo de las artesanías y la industria, pasando por la Arts and Crafts de Morris, el Art Nouveau y sus diferentes acepciones para llegar a la exposición parisina de 1925 y el surgimiento del Art Déco, el cual, explica Cuadriello, se regionaliza por país y en una renuncia de la curva por la atracción a la recta, la geometría triunfa con la beldad de la maquinaria. Nuevos y antes innecesarios productos de lujo forman parte de los diseños del Art Déco, entre los cuales las telas y los tapices exornan la atmósfera interior, pero son los espejos y los vitrales los que provocan espléndidas irradiaciones de luz. Mas una de las grandes aportaciones de Cuadriello es la descripción de la "estrella fatal", en esa

\footnotetext{
${ }^{8}$ Salvador Moreno, "La Estatuaria Art-Deco en México" Ibídem, p. 32.
} 
época de liberación femenina: “La 'estrella art-decoizada' debió espigarse, tornarse frágil en su constitución, con un corte de pelo mínimo, de flecos y rizos simétricos, pintura de rasgos agudos y felinos en las cejas y pestañas, boca pequeña en rojo carmesí, algún lunar discreto a la deriva, brazaletes, pulseras y cintillas, uñas largas, vestidos de escote y sin mangas, interceptado por un cinto caído a las caderas, modelos de lentejuelas y escamas fulgureantes, largos al tobillo incluyendo los flecos al ribete, tacones con broche o moño, boas al cuello y boquillas largas en las manos afiladas, la vista siempre dirigida al hombro izquierdo". 9 Esto obliga a que el tocador de mujer se convierta en un mueble con muchos recovecos y cajones, donde se guardaban las esencias en envases de Lalique o Baccarat y la moda se compraba en los grandes almacenes, algunos en activo todavía, como El Palacio de Hierro, El Puerto de Liverpool o Highlife. Estas marcas se publicitaban en las revistas ilustradas como Jueves de Excélsior, Revista de Revistas, Fantoche, en las que se anunciaban los cosméticos europeos como Myrurgia o Soir de París y las casas mexicanas utilizaban en sus publicidades diseños de inspiración maya o azteca. Para finalizar, Cuadriello destaca el trabajo de los caricaturistas como fue Ernesto García Cabral, quienes ilustraban las portadas de aquellas revistas geometrizando los temas en boga. Jaime Cuadriello concluye encomiando la exposición, la primera, pero no definitiva de Art Déco, para que se tome conciencia y se valore el pasado reciente de nuestro país.

El arquitecto Alberto Yarza escribe Explicación del cuadro evolucionario de paralelismos Art-Deco entre Europa y México. Con una inicial aclaración sobre que el Art Déco es un conjunto de relaciones de diverso tipo que inclusive en algunos casos es difícil concordarlos, posteriormente hace un expeditivo recorrido desde 1900 con el Art Nouveau, el Liberty Art, la Sociedad de Artistas Decoradores Franceses y la mención del Expresionismo a través de la pintura y la fotografía como fundamento del Art Déco, al que lo sitúa entre la Revolución Rusa, los conflictos económicos y los regímenes totalizadores, así como de los movimientos del Funcionalismo, el Constructivismo Ruso hasta llegar a la línea futurista de los grandes rascacielos. Importante comentario sobre el decorativismo geométrico y esquemático, Yarza lo coordina con las culturas mexica o azteca, egipcia, hindú y de Oriente como nutrientes de la estilística del Déco, consumida por una nueva burguesía urbana e industrial. Sustancioso como breve, el texto culmina con la siguiente

\footnotetext{
9 Jaime Cuadriello, "Del Diseño y las Artes Decorativas", Ibídem, p. 40.
} 
conjetura: "Toda esta complejidad de influencias era el mundo de información que llegaba a México, y los arquitectos representativos de esta época las amalgamaron con todo un soporte nacionalista dando como resultado una arquitectura peculiar". ${ }^{10}$ Un siguiente artículo del mismo autor nombrado Invariables tipologías de las obras arquitectónicas ArtDeco en México lo incluiremos en el punto "2.5. Características del Art Déco en México" de este capítulo. Finalmente, Yarza inserta en el catálogo un CUADRO EVOLUCIONARIO DE PARALELISMOS ART-DÉCO EUROPA-MÉXICO, que va de 1900 a 1970, colocando los diferentes movimientos artísticos, sociales, políticos, así como a los principales arquitectos tanto de Europa como de México. Destaca en el cuadro el desarrollo del Art Déco en Europa entre la década de 1920 y 1930, mientras que en México lo coloca entre los lapsos de 1930 e incluso a principios de 1950

Cierra el catálogo con las Observaciones sobre el Art-Deco de Xavier Esqueda (1943), uno de los grandes estudiosos del estilo en México. Lo que años después publicará en lo que es hasta la fecha el estudio más completo de Art Déco en el país, Esqueda ofrece un resumen de las características estilísticas, aportando a diferencia de los demás autores los elementos compositivos del Déco tales como: las exóticas garzas, palmeras, cactus, el humo industrial y mecánico, así como las figuras latinas del cine; la energía y los soles con rayos geométricos, los descubrimientos arqueológicos tanto de Egipto como de Mesoamérica, especialmente lo maya y lo azteca, son nutrientes para las creaciones del Art Déco. El arquitecto austriaco Joseph Olbrich (18867-1908), los artistas holandeses Jan Toorop (1858-1928) y Hildo Corp, los arquitectos norteamericanos Frank Lloy Wright (1867-1959) y Walter Burley Griffin (1876-1937), el arquitecto inglés Alfred Charles Bossom (1881-1965), todos son personajes imbuidos en esta nueva estética, donde la preeminencia por los lejanos y extravagantes mundos de Java, Bali, el antiguo Egipto, la prehispánica Mesoamérica, así como las artesanías mexicanas, ofrecen una gama inmensa de motivos decorativos para incorporarlos a sus modernos diseños. Sobre la arquitectura de la época y cuestión social Esqueda manifiesta que: "Hacia mediados de la década de los treinta, la arquitectura cambia de curso hacia un estilo funcional y se empieza a crear

\footnotetext{
${ }^{10}$ Alberto Yarza, "Explicación del cuadro evolucionario de paralelismos Art-Déco entre Europa y México", Ibídem, p. 45.
} 
verdaderamente la clase media, y para esta clase va dirigida la arquitectura y las artes: razón por la cual en México la mayoría del Art-Deco se encuentra en el corazón de las colonias de las clase media y los edificios públicos y gubernamentales de esa época son de un depurado Art-Deco. Se adopta con gusto esta medida, y así vemos que en aún modestas construcciones, el diseño brilla por doquier, sin duda ayudado por el dominio artesanal que en México es un privilegio".11 Finalmente Esqueda destaca la importante labor del norteamericano William Spratling (1900-1967) quien avecindado en Taxco, Guerrero, con sus diseños en joyería de plata expande el nombre de México, lo mismo que los escritores Somerset Maugham (1874-1965), francés, y los ingleses Aldous Huxley (1894-1963) y David Herbert Lawrence (1885-1930), quienes entre los años 20 y 30 del siglo XX incluyen a México en sus novelas y narraciones de viajes.

La primera exposición, el primer catálogo, por lo tanto el primer acercamiento al Art Déco en México. Eso fue la exposición de 1977 y sus textos.

La segunda ocasión en que se trataba en México el tema del Art Déco no fue en la capital de la República como se podría esperar. Fue en la ciudad de Monclova, Coahuila, en el Noreste mexicano donde se llevó a cabo una exposición de objetos, esculturas, diseños y fotografías en el Museo Biblioteca Pape de marzo 29 a junio 28 de 1980, titulada Art Nouveau. Art Deco, cuando estaba como Director Jenaro Martínez y como Directora de Colecciones y Exhibiciones Sylvia Pandolfi, quien escribió el texto del catálogo. Pandolfi dilucida sobre la terminología, las características y la historia de los dos estilos de la muestra, el Nouveau y el Déco, así como una relación de hechos relevantes para el desarrollo de ambas corrientes. En la introducción anota: "En México, aunque cada vez menos, todavía forman parte del ambiente cotidiano, ciertos rastros de los estilos Art Nouveau y Art Deco; los podemos encontrar en algunas construcciones, entre las pertenencias de nuestros abuelos y en las casas de antigüedades... Como en otras partes del mundo, en nuestro país están desapareciendo estas aportaciones artísticas como consecuencia de la destrucción y el olvido. En éste como en otros casos, los conocedores y estudiosos, las universidades y algunas instituciones de gobierno luchan por conservar los pocos ejemplos de arquitectura que aún se conservan. Los objetos domésticos o decorativos

\footnotetext{
${ }^{11}$ Xavier Esqueda, “Observaciones sobre el Art-Deco”, Ibídem, p. 56.
} 
de ese periodo son buscados y conservados por su valor artístico". ${ }^{12} \mathrm{Y}$ en la parte final del texto expresa: "El Museo Pape - como otros museos - participa en la actual revalorización y ubicación, dentro de la historia del arte, de estos dos movimientos; y dada la situación actual de las artes aplicadas, es oportuno destacar el aspecto más importante en estos intentos de "estilo total", la postura clara y decidida del artista frente a los medios de producción, en una búsqueda por interrelacionar armónicamente el arte con la vida". ${ }^{13}$

Siendo una muestra sobre los dos estilos mencionados, una brevísima reseña sobre La mujer y el Art Nouveau, escrita por Jaime Chávez se inserta en el catálogo, además de incluirse al final unos Datos relacionados al desarrollo del Art Nouveau y el Art Deco. Las piezas de la exposición se consiguieron con coleccionistas locales y nacionales y con la colaboración de Felipe García Beraza del Instituto Mexicano Norteamericano de Relaciones Culturales, de Javier Ezqueda (escrito así en el catálogo) y de Jaime Chávez.

En el mismo año de 1980 de agosto a octubre en la Galería Universitaria Aristos de la UNAM de la ciudad de México se presentó la exposición Una puerta al Art Deco, en la cual se mostró con fotografías, construcciones de cinco colonias de la ciudad de México. El catálogo fue escrito por Xavier Esqueda y la investigación la realizaron académicos del Centro de Investigación y Servicios Museológicos de la UNAM, quienes llevaron a cabo “el análisis inicial de este estilo, que predominó en México entre 1918 y 1938. El deterioro progresivo de inmuebles y monumentos del estilo Déco generó la inquietud por realizar la investigación sobre el tema". ${ }^{14}$

Esqueda ofrece un panorama del origen y desarrollo del Art Déco, para luego entrar con el tema en México y explica que el trabajo presentado es un análisis de edificaciones de ciertos sectores de la ciudad de México, mencionado los nombres de los principales arquitectos y describiendo las características constructivas, así como decorativas de los inmuebles. Concluye diciendo: "Esta es una revisión del estilo ART DECO y su integración en México (estilo que hoy es valorado y preservado en varias partes del mundo como legado artístico), con el propósito de invitar a reflexionar sobre su valor estético. El

\footnotetext{
${ }^{12}$ Sylvia Pandolfi, Catálogo de la exposición ART NOUVEAU. ART DECO, Monclova, Coahuila, Museo Pape, 1980, p. 1.

Agradezco a Betina Villarreal de Luna el haberme conseguido este catálogo.

${ }^{13}$ Ibídem, p. 17.

${ }^{14}$ Rodolfo Rivera, "Introducción", en Xavier Esqueda, Catálogo de la exposición Una puerta al Art Deco. México, UNAM, Centro de Investigación y Servicios Museológicos, 1980, p. 6
} 
ART DECO es representativo de una época que deja sentir cierta nostalgia cuando se vuelve la cabeza y se nota que se ha ido". ${ }^{15}$

El catálogo contiene un buen número de fotografías en blanco y negro de los edificios estudiados, los cuales están ubicados en un perímetro de $7 \mathrm{~km}$., entre las avenidas Chapultepec, Cuauhtémoc, Viaducto, Miguel Alemán, Martí, Revolución y Tacubaya (hoy Vasconcelos) y que al final están nombres de calles y los números de las construcciones y en algunos casos los nombres de las firmas de las constructoras o de los arquitectos. Este catálogo era la tercera aproximación al tema y Esqueda se convertiría en el máximo experto en el país, pues había participado en las tres muestras llevadas a cabo hasta entonces, por lo que ratifica: "En México, no es sino hasta 1977 que se presenta la primera exhibición con el título de, “Art Decó en México”, en el Instituto Norteamericano de Relaciones Culturales, A.C. El gran interés que levantó, se acrecentó con la exposición del Museo-Biblioteca Pape, de Monclova, Coah., titulada "Art Nouveau y Art Decó” en febrero de 1980". ${ }^{16}$

Después de estas tres exposiciones y sus catálogos, vendrá en 1986 la publicación del único libro que como tal y hasta ahora se ha realizado con el tema del Art Déco en México. El autor fue Xavier Esqueda y fue publicado por la UNAM a través del Centro de Investigación y Servicios Museológicos. El título fue El Art Deco. Retrato de una época. No pretendemos hacer aquí una larga reseña del contenido, pero sí mencionar las partes que lo componen.

En un amplio prólogo el autor da una cercamiento a cuáles fueron las condiciones sociales, políticas y económicas que desencadenaron la época de los años veinte en Europa y Estados Unidos, los llamados "Años Locos". Ya en el primer capítulo "El Estilo Art Deco", inicia con la "Terminología" sobre el significado del término Art Déco y luego describe las "Características". El siguiente capítulo "Antecedentes e Influencias" es un amplio recorrido por diversas escuelas, movimientos, vanguardias que confluyeron para formar el estilo: el Art Nouveau, el Jugendstill, La Escuela de Glasgow, La Secesión Vienesa, el Deutscher Werkbund, la Arquitectura Expresionista, el Cine Alemán Expresionista, el Futurismo, la Escuela de Ámsterdam, De Stijl, la Bauhaus, el

\footnotetext{
${ }^{15}$ Xavier Esqueda, Op. Cit., p. 18.

${ }^{16}$ Ibídem., p. 22. Como ya anotamos la exposición de Monclova fue entre marzo y abril y no en febrero.
} 
Constructivismo. Por nuestra parte también hemos seguido este esquema interpretativo a través del análisis pormenorizado del panorama cultural artístico del periodo.

Un capítulo está dedicado a "París: el siglo $X X$ ”. Iniciándose con las actividades de la Exposición Universal de 1900 y las actividades culturales que se desarrollaban como con los Ballets Rusos, llega al subcapítulo "La Exposición Internacional de Artes Decorativas e Industriales Modernas", la cual es una amena descripción de la magna exposición de 1925, de los artistas y decoradores franceses que participaron, además de los pabellones tanto franceses como de otros países. Después analiza el capítulo dedicado a los "Estados Unidos”, país que recibió un año más tarde la muestra itinerante de lo más destacado de la exposición parisina de 1925. Por su puesto, el edificio Chrysler, el Empire State y el Rockefeller Center, el edificio de la RCA, con los murales de Diego Rivera, son señalados, lo mismo que los neogóticos The Tribune Tower de Chicago o el General Electric en New York; la influencia de lo maya en Teatro Maya y en el Cine Castro y los azteca en Paramont Theather, todos ellos en San Francisco, junto con el Niagara Hundson (Mohawk) en Syracusa NY y sus influencias decorativas con motivos de los nativos mohawks son ejemplos de la adaptación al Déco de elementos de las culturas indígenas. No podía faltar la alusión a Hollywood con sus súper producciones cinematográficas y sus palacios de proyecciones que eran adornados con los motivos egipcios, mayas y aztecas, entre otros.

Finalmente se centra en el capítulo "México en el Art Deco", donde Esqueda diserta sobre las influencias de las culturas mesoamericanas como la maya, azteca, zapoteca, olmeca, tolteca en los edificios que se construían en los años 30 y 40 del siglo XX en varias partes de los Estados Unidos, destacándose las áreas de California, Nuevo Mexico, Arizona, Oregon y Texas. Es curioso que en este capítulo el autor hable de los sarapes de Saltillo y sus diseños geométricos y que no los incluya en las artesanías mexicanas. Los ya mencionados escritores Maugham, Huxley, Lawrence en el catálogo de 1977, más Lawrey, junto con el artista Spratlin completan este apartado para pasar al subcapítulo "El Art Deco en México", el cual abarca la mitad del contenido del libro.

"Nos llega aquí el momento, después de lo tratado, de revisar el art deco en México, que ocurrió en fechas gloriosos del país; tiempo histórico en el que el Arte Nacional Mexicano ha sido el más ambicioso y el más grandilocuente de la producción artística en lo que va de este siglo. Su grandiosidad reside, además de sus producciones en sí, (aunque no 
siempre los resultados estéticos estuvieran a la altura de sus intenciones), en el hecho de haber creado un verdadero arte nacional con alcances internacionales, historia del arte universal <El Renacimiento Mexicano>". ${ }^{17}$ De esta manera Esqueda empieza a tratar el tema en el subcapítulo junto con el nacionalismo mexicano que se despliega desde el aparato estatal y con la férrea personalidad de José Vasconcelos al frente de la rectoría de la Universidad Nacional y luego de la Secretaría de Educación Pública. Los antecedentes del nacionalismo indigenista y los años de la postrevolución es la época en que se cultivan los elementos para el desarrollo del Art Déco en México.

Se detendrá en una serie de apartados dentro del subcapítulo señalado, iniciando con "La Pintura". David Alfaro Siqueiros y su época de colaboración en las revistas El Universal Ilustrado, Revistas de revistas, Album salón y Roberto Montenegro (1885-1968) con los murales en la Secretaría de Educación Pública y en el Colegio de San Pedro y San Pablo, entre otros, son artistas que destacaron en algunos años los elementos Art Déco en sus obras, remarcando que Montenegro es el pintor que más Déco realizó. Otros pintores más son incluidos como Jorge González Camarena (1008-1980), Manuel Rodríguez Lozano (1896-1971), Jean Charlot (1898-1979), Fermín Revueltas (1901-1935), Máximo Pacheco, Pablo O’Higgins (1904-1983), Santos Baltimore, Ramón Alva de la Canal (18921985), Adolfo Best Maugard (1891-1964) e inclusive Frida Kahlo (1907-1954). En “La Gráfica” señala Esqueda a través de una cita de Raquel Tibol (1923) que fue Jean Charlot quien inició a Francisco Díaz de León (1897-1975), Gabriel Fernández Ledesma (19001983), Fernando Leal (1896-1964), Ramón Alva de la Canal (1892-1985) y Emilio Amero (1901-1976). En la parte dedicada a "La Escultura" vienen los nombres de Guillermo Ruiz (1894-1965) con su monumental Morelos en la isla de Janitzio, Ignacio Asúnsolo (18901965) autor del grupo escultórico del Monumento a Álvaro Obregón, el neoleonés Fidias Elizondo (1891-1979) de quien sólo menciona sus influencias clasicistas; Manuel Centurión (1883-1952) que ejecutó las esculturas del edificio de la Secretaría de Salubridad, el colombiano Rómulo Rozo (1899-1964) creador de la escultura El pensamiento del campesino sentado debajo de un cactus que le ha dado la vuelta al mundo

\footnotetext{
${ }^{17}$ Xavier Esqueda, Art Deco. Retrato de un época, México, UNAM, Centro de Investigación y Servicios Museológicos, 1986, p. 90.
} 
como icono de lo mexicano y Oliverio Martínez el imaginero del Monumento a la Revolución.

El apartado de "La Arquitectura" ocupa prácticamente una tercera parte de las 150 páginas del libro. Esqueda esclarece que la gran mayoría de los ejemplos que analiza están en la ciudad de México, porque "Hay pocas ciudades en el mundo donde puedan encontrarse tantos ejemplos de arquitectura art deco, o mejor dicho elementos art deco en arquitectura, como en la ciudad de México, hablando de lo que hoy resta para no mencionar lo que ha sido destruido o transformado". ${ }^{18}$ Continúa Esqueda mencionado el indigenismo y su presencia en algunas edificaciones como el Pabellón de Sevilla de 1929, el Palacio de Bellas Artes y algunos otros edificios de la ciudad de tipo Déco para entonces ofrecer las características de la arquitectura Art Déco de la ciudad de México, mismas que describiremos más adelante en el punto “4. Características del Art Déco en México” de este mismo capítulo y que nos servirán para el análisis de los monumentos del Noreste mexicano.

En este apartado, el autor inserta a los principales arquitectos que realizaron obras Art Déco. Juan Segura quien erigió el Edificio Ermita en la colonia Hipódromo y se hace la única mención de un inmueble fuera de la ciudad de México el Asilo para Ancianos F. Mier y Pesado en Orizaba, Veracruz. Carlos Obregón Santacilia y su monumental edificio de la Secretaría de Salud, el elegante interior del Banco de México, más su famoso Monumento a la Revolución. Federico Mariscal, el artífice de convertir el interior del Palacio de Bellas Artes en un verdadero éxtasis de glamur decorativo. Francisco Serrano con sus muchas construcciones en la colonia Hipódromo Condesa y el Edificio Basurto; Ernesto y José María Buenrostro quienes trabajaron en la colonia Hipódromo Condesa, sobresaliendo el Edificio San Martín. José Gómez Echeverría, inmortalizado por ser el autor de la Estación del Ferrocarril Infantil del Bosque de Chapultepec. Manuel Cortina García construyó uno de los primeros edificios Art Déco que fue el Orfanatorio San Antonio y Santa Isabel. Joaquín Capilla es el constructor del Frontón México; Vicente Mendiola y Guillermo Zárraga edificaron la Estación de Policía y Bomberos, hoy Museo de Artes Populares. José Villagrán García quien integró algunos elementos Art Déco en el Instituto de Higiene o

\footnotetext{
${ }^{18}$ Ibídem, p. 109.
} 
Granja Sanitaria. Los arquitectos Manuel Ortiz Monasterio, Bernardo Calderón y Luis Ávila participaron en la construcción del llamado primer rascacielos mexicano, La Nacional. Con lamento por la pérdida del Art Déco por la llegada e invasión del Funcionalismo es como Esqueda termina con este apartado sobre la arquitectura.

En un apartado sobre "Las Artesanías", Esqueda incluye "El mobiliario", explicando que aún quedan muebles de tipo Art Déco con toques indigenistas. La "Platería", que prácticamente es la relación de la obra del norteamericano William Spratling (1900-1967). En “Otras manifestaciones” Xavier Esqueda vuelve a citar al colombiano Rómulo Rozo con la escultura El pensamiento y a los objetos industrializados con motivos decorativos geométricos e indigenistas que llegaron al diario vivir de los mexicanos.

"La Literatura" es comentada a través del Estridentismo, el cual tuvo una vida entre 1921 a 1928. Un texto de Germán List Arzubide (1898-1998) y poemas de Miguel Aguillón Guzmán (1898-1995), Arqueles Vela (1899-1977) y Alfonso Muñoz Orozco, ilustran lo que fue este movimiento de vanguardia. Y "La Música" es explicada a través de los compositores que crearon piezas con carácter nacionalista como fueron Manuel M. Ponce (1882-1948), Julián Carrillo (1875-1965), Candelario Guisar (1888-1970), Carlos Chávez (1899-1978), el genial Silvestre Revueltas (1899-1940), José Pablo Moncayo (1912-1958), Miguel Bernal Jiménez (1910-1956), Eduardo Hernández Moncada (1889-1995), Blas Galindo (1910-1993) e inclusive el norteamericano Aaron Copland (1900-1990), admirador de la música mexicana. Aclara Esqueda que no se puede hablar de una literatura ni de una música Art Déco, sino que son los años en que estas vertientes del arte iban en el camino de la vanguardia y la internacionalización.

Con un "Epilógo" sobre "El Revival” del Art Déco finaliza Esqueda sus textos, para cerrar el libro con la amplia lista de las 209 ilustraciones entre fotografías en blanco y negro y reproducciones de grabados, así como la bibliografía.

Hasta ahora no se ha vuelto a escribir un tratado sobre el Art Déco en México como éste. Prácticamente es la "Biblia" para el estudio del tema en el país, pues paso a paso, precisamente como una elevación geométrica, como unas líneas energéticas o como un aderezo decorativo, es como Xavier Esqueda lleva al lector a introducirse en el gallardo, fino, elegante y airoso Art Déco en México. 
En 1990, el arquitecto e investigador Enrique X., de Anda publicó el libro La Arquitectura de la Revolución Mexicana. Corrientes y estilos de la década de los veintes. La edición fue a través del Instituto de Investigaciones Estéticas de la UNAN. El libro consta de ocho capítulos y el "VI. La arquitectura del Déco" está dedicado al desarrollo de dicho estilo en la ciudad de México. Inicia con "La Exposición de Artes Decorativas de París en 1925", para continuar con "La difusión en México de las imágenes de la Exposición de París", las cuales llegaron en el mismo año del 25 por medio de la revista Cemento, así pues se pudieron conocer los grandes pabellones de la exposición, destacándose los de los almacenes Galerías Lafayette, Bon Marché, De Louvre. En "La producción Déco en México" el autor da un gran aporte para el estudio de la arquitectura Art Déco en el país, al proponer que a través del estudio de los elementos característicos de un conjunto de edificios analizados, planeta cuatro tendencias: "la primera denominada geometrista, aludía a un propósito purista que buscaba caminos de expresión en el lenguaje lineal y abstracto; la segunda, ecléctico-mayista se emparentó vivamente con los postulados "clásicos" del Déco europeo, que en caso de México, presentó proporcionalmente pocos ejemplos; la tercera, la tendencia plasticista ofreció casos muy interesantes de coherencia plástica...; finalmente, el cuarto apartado, el decorativista, contemplaba en los edificios la presencia de la vasta colección de recursos y aplicaciones formales que llegaron a ser característica inconfundible del discurso ornamental de la tendencia". ${ }^{19}$ Justamente estas tendencias son las que utilizaremos para el análisis de los edificios de la Región Noreste y las describiremos en el siguiente punto dedicado a las características distintivas del Déco en México. Concluye el capítulo con "El edificio de La Nacional: una síntesis arquitectónica del Estilo Deco", el primer rascacielos mexicano terminado en 1932, con estructura de acero y apariencia en cemento y con los más modernos sistemas de distribución de agua, ventilación y ascensión por medio de elevadores: para esos años, el edificio más novedoso del país se concibió dentro del estilo Art Déco. Los apéndices están compuestos por 16 cuadros que son relaciones de los edificios correspondientes de los años 1920 a 1934 y uno sobre edificios sin fecha identificada. Se incluyen algunas construcciones en Monterrey, de lo cual hablaremos al momento de estudiar los inmuebles en el capítulo 3.

\footnotetext{
${ }^{19}$ Enrique X., de Anda Alanís, La Arquitectura de la Revolución Mexicana. Corrientes y estilos de la década de los veintes, México, IIE, UNAM, 1990, p. 134.
} 
La Arquitectura de la Revolución Mexicana. Corrientes y estilos de la década de los veintes fue presentado en el Museo Nacional de Arte el jueves 4 de marzo de 1993, con la participación de Rita Eder, Teresa del Conde (1938), Ramón Vargas Salguero, Carlos González Lobo y Jorge Alberto Manrique (1936). El autor mencionó en dicha presentación que "muchas de la edificaciones de tipo deco [sic] están en estado lamentable y a punto de caerse. En México no existe una cultura de evaluación. Hay que comprender a la arquitectura, no sólo construir". ${ }^{20}$

Veinte años después de la exposición en el IMNRC, el Museo Nacional de Arte organizó la más extraordinaria muestra sobre Art Déco que se haya hecho en México. No había un mejor escenario para llevarse a cabo que el Palacio de Bellas Artes, sin embargo se realizó en el propio museo. De noviembre de 1997 a abril de 1998 se llevó a cabo Art Déco. Un país nacionalista. Un México cosmopolita, una exhibición de objetos, electrodomésticos, gráficos, pinturas, esculturas, fotografías de edificios, todo de lo más sobresaliente del Déco. Como una retrospectiva y a la vez una nostalgia por aquellos años en que la modernidad postrevolucionaria quedó plasmada, entre otras, en la estética del Déco. Glamurosos como la exposición, los textos del catálogo fueron escritos por Enrique X., de Anda Alanís, quien además fungió como asesor curatorial, lo mismo Jaime Cuadriello Aguilar, mientras que Xavier Esqueda Aceves fue asesor académico. Un sinnúmero de personas e instituciones aparecen al principio en los "Agradecimientos", pues fueron quienes prestaron las piezas o dieron facilidades para la toma de fotografías.

El primer texto "Preámbulo a las cinco de la tarde..." es una remembranza del arquitecto Juan Segura desde su departamento en la colonia Hipódromo-Condesa de la ciudad de México en el año de 1934, recordando una portada de Revista de Revistas de 1925 con una sensual mujer o cuando en 1924 y 1925 asistió a aquellos teatros de variedades musicales a degustar bailes de charlestón; mientras fuma un cigarro Chesterfield escucha en la radio la canción "Azul”, a la vez que rememora cuando en 1931 en París, Antonieta Rivas Mercado se suicidaba por el amor de José Vasconcelos en la gótica catedral de Notre Dame. O bien, la evocación del año 1932 y la invitación por parte de su maestro, el arquitecto Manuel Ortiz Monasterio, a la inauguración del majestuoso edificio

\footnotetext{
${ }^{20}$ Merry Mac Masters, "Enrique X., de Anda presentó su libro. Desprotegida, la arquitectura mexicana moderna". El Nacional, México, D.F., sábado 6 de marzo de 1993, secc. Cultura, p. 20.
} 
de La Nacional. Segura revive el asesinato del General Álvaro Obregón en julio de 1928, un años después de que él había llegado a vivir a la Hipódromo-Condesa y que para 1931 el ingeniero Ernesto Buenrostro ya había terminado el Edificio San Martín. La frialdad de la casa de Diego Rivera en San Ángel Inn le venía a la mente, inaugurada en 1932 y que su autor, el joven arquitecto de 27 años Juan O'Gorman (1905-1982), la había concebido bajo los dictámenes del Funcionalismo. Otra revista, ahora es El Arquitecto de noviembre de 1933, contiene anuncios de El Palacio de Hierro que lo remiten a los sets de la película La noche del pecado de ese mismo año. Juan Segura deja sus meditaciones y regresa a sus planos entre siluetas de aviones y carros descapotados. Eran los años del Déco.

"Referencias Obligadas" (el siguiente subcapítulo) se abre con la justificación del uso de la palabra aroma; porque el aroma permanece en la mente y viene su recuerdo cuando las condiciones son las propicias. Así pues, el Déco es el aroma de los años de entreguerras. Dice De Anda que mientras esto escribe, enfrente de él tiene la foto de la bailarina Josephine Baker (1909-1975) a sus 25 años, uno de los iconos femeninos del Déco. La aclaración del surgimiento del término Art Déco en 1966 para un conjunto de manifestaciones artísticas dadas principalmente en las artes decorativas, las artes aplicadas y la arquitectura, fueron desarrolladas entre los años de entreguerras y se desplegaron principalmente en Francia, Inglaterra y Estados Unidos, para llegar a otros países como a México, que buscaba su integridad de modernidad después de la Revolución. La moda, la liberación femenina, la pobreza, el desasosiego son las formas de vida de esos años convulsos que rematan en 1929 con la caída de la bolsa en New York en la época del desarrollo del diseño industrial. La vida urbana crecía y el consumo de productos inexistentes, pero necesarios, se logra gracias a la publicidad a través de la radio y de las imágenes en periódicos y revistas. La liberación femenina es una novedad en la sociedad, así como las vanguardias artísticas que debaten con lo establecido, para exaltar la inconsistencia de una sociedad sin rumbo; tal es el caso de los dadaístas como Duchamp (1887-1968), Tzara (1896-1963) y Picabia (1879-1953). La máquina y su triunfo productivo desplazan a la artesanía manual, entonces fue la hora de armonizar la mano artesanal de un producto y su elaboración en serie bajo los estatutos estéticos de su creación individual, ganando terrenos el diseño industrial y el objeto artístico tendría que tener también un fin utilitario. 
En "La Modernidad a Salvo de la Vanguardia", De Anda habla de las "tensiones culturales" que se dieron en los años de entreguerras para distinguir los productos que se reconocen como Déco, aclarando que el Art Déco no es un estilo ni se concibió como tal dentro del campo de las bellas artes en los años 20 del siglo pasado. Lo que se le conoce ahora como Déco, fueron objetos que llevaban una utilidad práctica, además de su estética, y que muchos de ellos sobreviven en el uso cotidiano, mientras que otros pasaron a ser piezas de museo como un objeto artístico. Su producción se dio entre los años 1920 a 1940 y en algunas ocasiones fueron elaborados en serie y ante la problemática de si el Déco es un estilo de Anda esclarece: “Cabría hablar del déco como un estilo amplio con peculiaridades cronológicas y regionales, que presenta una plataforma plástica conceptual que, aun con variantes, se mantiene en escena con elementos compositivos e iconográficos propuestos para satisfacer lo que he llamado: esquemas de significación". ${ }^{21}$ Otra imprescindible aclaración es la que hace alusión a la exposición parisina de 1925 que muchos han querido tomar como punto de partida para el Déco, porque ese evento más bien fue una sinopsis y no una exaltación del estilo, como lo explica Paul Maenz. El traslado del Déco de París a New York alrededor del año 1928 hizo que se aplicara de manera más amplia en la arquitectura, como no hizo en Europa. En esos años veinte al lenguaje del Art Déco se le conoce como el Zigzag, cuyos autores dentro de la vanguardia "modernos y funcionales", siguieron conservado la tradición Por otra parte, en los años treinta se desarrolló la modalidad del Streamline principalmente en Estados Unidos, donde la máquina y lo aerodinámico se insertan en los diseños y la arquitectura alcanza proporciones desmesuradas en los rascacielos, cines y hoteles. Así pues, en las principales metrópolis latinoamericanas, el Déco tuvo su propio desarrollo como símbolo de renovación venido de Europa y principalmente de Estados Unidos, por lo que México, Buenos Aires, Montevideo, Río de Janeiro y Santiago de Chile se modernizaban con edificios Art Déco. ${ }^{22}$

\footnotetext{
${ }^{21}$ Enrique X., de Anda Alanís, "La Modernidad a Salvo de la Vanguardia”, Catálogo de la exposición Art Déco. Un país nacionalista, un México cosmopolita. México, Instituto Nacional de Bellas Artes, 1997, $1^{\mathrm{a}}$ edición, $19981^{\text {a }}$ reimpresión, p. 32.

${ }^{22}$ He tenido la oportunidad de estar dos veces en La Habana, en 2005 y 2007, donde pude apreciar la gran cantidad de edificios Art Déco en sus tipologías de oficinas, cines, departamentos, casas-habitación, la gran mayoría en condiciones deplorables, pero de una muy buena calidad. Véase el libro: Martino Fagiuoli, La Habana Deco, Bolonia, CV Export, 2003.
} 
Del 1 de diciembre de 1920 cuando Álvaro Obregón asume el poder, hasta el 22 de mayo de 1942 cuando Manuel Ávila Camacho declara la guerra a Alemania, es la cronología para ubicar los años del Déco en el país a través de "México: el Debate de la Modernidad”. Aquí Enrique X., de Anda comenta los triunfos de la Revolución, entre ellos los de la naciente clase media urbana y sus nuevos usos y costumbres, como los de la adopción de comportamientos sociales venidos de Estados Unidos, dejando los estereotipos del campo en las películas como Allá en el Rancho Grande. Pero lo interesante son las tres posiciones que surgen con los postulados postrevolucionarios en el campo de la cultura: el primero, la búsqueda de un nacionalismo, el segundo las vanguardias y tercero, el indigenismo. Dentro de los primeros el autor comenta cómo dentro del proyecto vasconcelista del muralismo, Diego Rivera tuvo que pasar por un proceso de mexicanización para luego dejar su legado en los murales de la Secretaría de Educación Pública. Y del tercero, las propuestas de reivindicación del indio prehispánico y del presente a través de sus producciones artesanales van desde el método de dibujo de Adolfo Best Maugard (1891-1964) basado en los diseños de la cerámica prehispánica, pasando por las Escuelas al Aire Libre para culminar con los estudios del doctor Manuel Gamio (18831960) en el Valle de Teotihuacán. Sin embargo, la visión nacionalista se bifurcó en dos orientaciones: una, los que buscaban una verdadera vanguardia, como el Funcionalismo de Juan O’Gorman, el movimiento poético de los Estridentistas o el periodo cubista de Diego Rivera; la otra, aquellos que fueron vanguardias pero moderados, como José Villagrán y sus teorías arquitectónicas con los "principios de sinceridad y coherencia", los pintores que integraban la vida moderna y mecanicista o los Contemporáneos y su poesía que respetaba la métrica. Sin embargo, De Anda habla de un tercer camino dentro de ese nacionalismo que fue ecléctico y tanto abordó las artes plásticas, especialmente la arquitectura, y las artes decorativas, que entendió a las nuevas exigencias sociales de la clase media e insertó lo extranjero dentro de lo nacional; ese camino fue el Art Déco mexicano, que convivió con las nuevas prácticas sociales de las clases medias y el maquinismo, tales como el papel de emancipación que tomaba la mujer, el deporte que servía también como práctica de esparcimiento y bienestar, la vida cotidiana que se conducía mejor con los productos electrodomésticos, la música extranjera y nacional que se escuchaba en la radio y en el 
fonógrafo, con la capacidad de repetirla cuantas veces se quisiera, y el avión que atravesaba los cielos mexicanos denotando la rapidez de los cambios de la vida.

Con un cuestionamiento hacia los que han estudiado el siglo XX y han sido selectivos, es como inicia el apartado "El Art Déco: Formas y Razones”. Y esto porque algunos estudiosos han eliminado al Art Déco de la historia del arte, sin tomar en cuenta que acopló las novedades técnicas con la creatividad de los artistas. Para los veinte años de proceso de producción del Déco ya existe una historiografía, pero salvo Paul Maenz y Juan Pedro Margenat ${ }^{23}$, los demás trabajos han sido meros catálogos de obras, sin conectar la cultura moderna occidental con la producción artística y el diseño industrial como sucedió con el Art Nouveau, el Art Déco y la Bauhaus. William Morris (1834-1896) y sus Arts and Crafts, Henry van de Velde (1863-1957) con la Escuela de Artes y Oficios del Gran Ducado de Sajonia, Walter Gropius (1883-1969) en la Bauhaus, los Ballets Russes de Sergei Diaghilev (1872-1929), así como el Cubismo y De Stijl estuvieron en inmediación con lo que se produjo como Art Déco. Así pues, Enrique X., de Anda propone para explicar el desarrollo del Déco cuatro "tensiones culturales":

I. El problema de la naturaleza, donde De Anda propone tres "esquemas de significación": el primero, cuando el ornato vegetal del Nouveau se convierte en la geometría del Déco; segundo, el horror vacui tanto en el Nouveau como en el Déco, este último con sus dos variantes, el Zigzag y sus líneas entrelazadas geométricamente, y el Streamline con la diversidad de acoplamiento de cuadrángulos; el tercero, cuando la estructura del objeto es la misma con cual se diseñó.

II. Otro rostro para la realidad es la explicación del antagonismo del Nouveau con la tradición académica y de la inserción de algunas de las vanguardias así como de culturas antiguas dentro del Déco, situación que proyecta hacia dos “esquemas de significación”: el primero, en el cual se explica que mientras el Nouveau incorpora "lo místico y lo irracional como sustitutos del naturalismo", el Déco lo "transforma en geometría y abstracción"; el segundo esquema es "El simbolismo como forma de codificación para eliminar todo vestigio de la apariencia externa de las cosas", ${ }^{24}$ porque si en el Nouveau se estructuraban las partes de un objeto para significar conceptos abstractos, en el Déco los objetos

\footnotetext{
${ }^{23}$ Juan Pedro Margenat, Arquitectura art déco en Montevideo (1925-1950). Cuando no todas las catedrales eran blancas. Montevideo, Dardo Sanzberro, 1994.

${ }^{24}$ Enrique X., de Anda Alanís, “El Art Déco: Formas y Razones”, Op. Cit., p. 51.
} 
encuentran su identidad de modernidad. Como uno de los aportes a las artes del siglo XX, De Anda concluye este apartado aseverando que lo dinámico no en partes, sino como un todo dentro de las producciones del Déco, es una característica distintiva que utiliza tres recursos: "uno, el alejamiento de los límites de un plano respecto a su centroide; dos, una deformación controlada de la forma original buscando, generalmente, la elongación vertical; tres, el encadenamiento de varias figuras iguales en series verticales y horizontales". 25

III. La mujer símbolo de seducción y amenaza, dos calificativos para la representación del sexo femenino que en el Nouveau y en el Déco son unas constantes con las cuales representan el papel que asume en la anquilosada sociedad. Sin embargo, en el caso de México, en plenos años de la modernidad del Déco, muchos artistas insisten en seguir representando a la mujer en su condición indígena de sumisión. Las bellas y sensuales mujeres del Nouveau son seductoras por su candidez, en el Déco son cautivadores por su solícito erotismo, como las damas del artista Ernesto García Cabral, osadas, llamativas en su poses y sus modas de pelo corto, sombrero encasquetado, bailando con pasos atrevidos.

IV. La asunción de la historia se define en dos "esquemas de significación". El primero es "la revisión visual del pasado", que mientras en los años del Nouveau fue el encuentro con los "primitivos" africanos y la valoración estética de sus producciones tribales, en el Déco se incorporaron los diseños decorativos de las civilizaciones antiguas como la egipcia, la mesopotámica, la maya, o bien las culturas aborígenes europeas como la vikinga, la celta y la ibera que la arqueología ponía a la luz del siglo XX; las grecas o las líneas rectas en directrices diversas de las culturas antiguas, pasaron a formar parte del decorativismo del Déco de su variante Zigzag en producciones de la joyería, el mobiliario o los textiles, la herrería de puertas, ventanas y barandales, así como el arco falso maya utilizado en el rascacielos neoyorkino de la compañía Chrysler. La "sobrevaloración del futuro trasladado al presente" es el segundo esquema, el cual tiene que ver con el triunfo y dominio de la máquina para hacer al hombre más feliz y entrever un futuro prometedor, sobre todo en los Estados Unidos, país que después de la depresión de 1929, cultiva el culto al maquinismo en edificios, electrodomésticos, la industria automotriz y en las poderosas

\footnotetext{
${ }^{25}$ Ibídem, p. 52.
} 
locomotoras; época del Streamline, de hombres briosos, atléticos, dominadores de la tecnología, en armoniosa relación con la máquina, que en México se denotó en la década de los años treinta en las construcciones con "tabletas horizontales seriadas que rematan con placas verticales, los revestimientos metálicos en las columnas y el clásico capitel de la época, consistente en un enorme plato que no alcanza a tocar la cubierta, pero que deja que la luz que emana de su interior se desborde sobre el plafón". 26

Uno de los capítulos más amplios del catálogo de la exposición del MUNAL es "La Identidad del Art Déco en México”. Enrique X., de Anda inicia afirmando que el Déco en la mayoría de los países del continente americano tuvo presencia con sus rasgos particulares más por ciudad que por país. Para el caso de México su fuerte tradición artesanal le permitió abarcar en esos años a las artes aplicadas y el uso de diversos materiales locales; como los objetos artesanales tenían un fin práctico, de uso, los nuevos objetos producidos bajo la estética del Déco, también llevan un fin utilitarios y se podían conseguir ahora en tiendas departamentales. Artículos Déco de importación de Inglaterra, Francia, Estados Unidos, se consumían a la par del desarrollo de una arquitectura local, de las ilustraciones para periódicos y revistas, de la producción de cerámica y en el caso de las artes plásticas, de influencias más en la pintura que en la escultura. Para explicar esta “identidad" el autor encuentra cuatro temas:

I. Folklor y prehispanismo es un tema que el Déco lo manejó de diferente manera que el Muralismo. El Déco indagó el mundo indígena y produjo modelos con la indumentaria femenina, plumajes, pectorales, dioses feroces y por supuesto, con la anatomía del indígena corpóreo, en posiciones de sumisión ante las divinidades o los poderosos, teniendo una gama amplísima de posibilidades creativas, basadas en el pasado prehispánico. Otra vertiente de inspiración para el Déco fue el mundo rural, pues dentro del folklorismo estaba el charro y la china poblana o el pueblo colonial. Sin embargo, fue lo indígena en su acepción prehispánica lo que más se le representó, como al indio de perfil con poca movilidad, la cerámica con monotemas indígenas o la incorporación de las grecas arqueológicas en los edificios. Así pues folklor e indigenismo se representaron en cuatro disciplinas:

\footnotetext{
${ }^{26}$ Ibídem, p. 55.
} 
- "Joyería de Plata", siendo sus máximos representantes Frederick Davis (18771961), con su propia tienda en los años veinte en la ciudad de México en el Antiguo Palacio de Iturbide, cuyos productos se caracterizaron por el uso de caritas de obsidiana con formas teotihuacanas, y William Spratling quien se instaló en Taxco, creando una joyería inspirada en los modelos prehispánicos, dándoles una sublime estilización.

- "Ilustración" en periódicos, revistas, publicidad impresa realizada por pintores y dibujantes, como en la caso de la tipografía donde la inserción de diseños de pirámides y grecas prehispánicas quedaron en consonancia con la abstracción geométrica del Déco, aunque lo más representado fueron el indio y el medio rural.

- "Pintura" en la que algunos artistas se contagiaron de la corriente Déco como Diego Rivera que abordó la "imaginería maquinista" internacional; Jorge González Camarena, con sus ilustraciones de la revista Cemento, así como de sus pinturas, combinando la figura humana y el paisaje dentro de un ambiente maquinista y con la técnica que De Anda ha denominado "volumetría facetada", donde se alcanza la corporeidad de un objeto en tercera dimensión; Fermín Revueltas quien manejó la técnica de "marco rebasado" dando la idea de movilidad en el cuadro. Roberto Montenegro, artista que se movió en dos caminos, en el folklorismo nacional y en exotismo de fantasías orientales.

- "Cerámica” que se caracterizó por una decoración con grecas, lacerías geométricas, en algunos casos indígenas en posición de perfil y con un gusto por horror vacui.

II. Lo casual es una propuesta de Enrique X., de Anda para la obra de Ernesto García Cabral, entendiéndose por el concepto la efímera continuidad del tiempo o de dos momentos específicos, situación en la que a través de las ilustraciones semanales de revistas, García Cabral dibujaba a mujeres, de cuerpos delgados, en poses sensuales y provocativas, bailando, leyendo, acosada por hombres, pero destacándose el movimiento y su interacción con lo que le rodea.

III. Maquinismo y fuerza de trabajo es un tema que se refiere a que las representaciones de los nuevos productos emanados de las fábricas y las máquinas, significaban para el Déco más por su capacidad transformadora del hábitat que por su novedad, lo mismo que la fuerzas masculina. Así pues, en el subtema de "Pintura e ilustración" se refiere a que en las 
portadas de la revista Cemento de Jorge González Camarena manejan la cuestión del maquinismo, con operarios con el torso al descubierto y fondos fabriles o bien del paisaje del campo mexicano "faceteado" y coloreado. Fermín Revueltas, quien innova con sus contenidos de la modernización tecnológica de México, ya que los cables de la electricidad y del telégrafo pendientes de los postes y los pabellones industriales son temáticas de la exaltación del mundo de la máquina. Y el mismo Diego Rivera incluyó también en algunos de sus grandes murales los tópicos maquinistas y fabriles, con los obreros en la faena industrial o el hombre y el uso de la máquina para el control del cosmos.

$I V$. Deporte y baile, actividades que son simbólicas de la transformación de las costumbres de la emergente clase media. Ahí está el caso del edificio de la Young Women Christian Association que en año de 1927 abrió sus puertas a las feligresas para la práctica del deporte, el cual está representado en los paneles exteriores. Poca representación tuvieron las imágenes impresas del juego deportivo y del baile, porque más bien se difundieron a través de la fotografía; sin embargo, está el caso del artista Miguel Covarrubias (1904-1957) quien entre los años 1923 a 1942 radicó en los Estados Unidos y trabajó su libro Negro Drawings de 1927, donde sus caricaturas son exaltaciones de los movimientos y contorsiones al ritmo del charlestón y del fox-trot.

La geometría es como un epílogo del capítulo "La Identidad del Art Déco en México”. Enrique X., de Anda especifica que el tema principal del Art Déco es precisamente la geometría, por lo que no quiere dejar de lado la tipografía con sus letras y números gruesos y geométricos, así como las herrerías con líneas en búsqueda de composiciones y combinaciones geométricas, como también se hicieron con los pavimentos en diversos materiales, todo esto encontrando el gusto en la forma y en la libertad creadora.

El capítulo titulado "La Arquitectura Déco en la ciudad de México" es el más extenso del catálogo e inicia con la ya dada referencia de que en las ciudades latinoamericanas como Santiago de Chile, Río de Janeiro, Buenos Aires, Montevideo y México ${ }^{27}$, tuvieron una abundante arquitectura Déco, que el caso de México fue más mesurada. En los Estados Unidos se dieron las variantes del rascacielos elevado a manera

27 Como mencionamos arriba, en caso de la ciudad de La Habana que tiene mucha arquitectura Art Déco. Ver nota 22 . 
de pirámide y el Tropical Déco ${ }^{28}$ de Miami, que tuvo definitiva influencia en el Caribe. En México la arquitectura Déco se inició en la capital en la segunda mitad de los años veinte con los edificios de la Alianza de Ferrocarrileros Mexicanos en 1926 y el Orfanatorio San Antonio y Santa Isabel de 1927 e inmediatamente después se levantaron cuantiosas edificaciones en el lenguaje del Déco, ya que ofrecía novedades arquitectónicas, claridad en el tratamiento arquitectónico, el aporte de artistas y artesanos reconocidos, incluyó el diseño geométrico y la construyó con firmeza de sus estructuras. El Déco en México se convirtió en un símbolo de identidad de la nueva clase media postrevolucionaria que buscaba vivir mejor tanto en la ciudad como en la intimidad de su nueva casa, fenómeno que se dio en las principales ciudades del país como Monterrey, Puebla, Torreón o Mérida. Luego de establecer una crítica contra los fracasos del Funcionalismo en México, De Anda reitera que hay que valorar en su justa aportación al Art Déco, ya que cuando llegó a su fin, aceptó su tiempo y salió de la escena arquitectónica.

Un subcapítulo está dedicado a "Los fraccionamientos habitacionales de los años veinte", siendo el principal la colonia Hipódromo-Condesa que inició en 1927 bajo el proyecto del arquitecto José Luis Cuevas Pietrasanta (1881-1952) y los diseños de casas del arquitecto Juan Segura y del ingeniero y arquitecto Francisco J. Serrano (1900-1982) en una nueva zona fuera del Centro Histórico, como lo fueron la mayoría de las nuevos fraccionamientos que construían bajo la estética del Déco; sin embargo, muchos edificios de la administración pública y de oficinas se levantaron el centro de la ciudad, salvo el de la Secretaría de Salud. Como una nueva arquitectura de la época, el Déco ofrecía un ambiente de distinción con sus fachadas amplias, de ventanas rectangulares, pisos con formas geométricas, luz eléctrica y vistosos mobiliarios con materiales antes no utilizados. En La composición arquitectónica De Anda propone tres elementos para el discernimiento de la arquitectura Déco de la ciudad de México, pero antes de explicarlos nos dice que no fueron las imágenes de la exposición parisina de 1925 las que sirvieron únicamente de modelo para la arquitectura Déco mexicana, sino que se dieron tres situaciones: la primera, que en la Escuela de Arquitectura se conocían imágenes de la Secesión de Viena y de Otto Wagner, tal como De Anda lo comprobó en la biblioteca de la Facultad de Arquitectura de

\footnotetext{
${ }^{28}$ De Anda cita a Juan Pedro Margenat como el creador del término Tropical Déco, pero quien lo propone fue Eva Weber en su libro Art Deco in America de 1985, traducido en España por editorial Lisba en 1993, véase pp. 36-37.
} 
la UNAM; la segunda, que a través de publicaciones europeas se apreciaba la imprescindible necesidad de una nueva estilización; y la última, que la renovación arquitectónica no era factible a partir de lo neocolonial. Los tres elementos planteados son:

- La mercadotecnia del cemento que a través de la revista Cemento, que tan sólo en 1925 editó 8.000 ejemplares, buscaba vender este material, resaltando las bondades para construir una arquitectura sólida y a la vez con posibilidad de ornamentación. Además, dicha revista ofreció las primeras imágenes de la gran muestra de 1925 con textos explicativos, que en uno de los primeros se exaltan los ideales de la rapidez, la función y la eliminación de lo antiguamente aparatoso, lo cual se convierten en indicadores a seguir en la arquitectura Déco de México.

- Plantas y manejos de espacios novedosos de la arquitectura del siglo XX como los usaron los arquitectos del Funcionalismo y el Racionalismo, era buscar la fórmula para vivir modernamente en sociedad. Sin embargo, el Déco "no propuso espacios polivalentes, sino que prefirió trabajar con modelos de compartimentación, es decir, con habitaciones relativamente autónomas, vinculadas unas con otras mediante vanos". ${ }^{29}$ Las plantas del Déco que se utilizaron en los edificios de oficinas tenían un espacio central y alrededor de éste se distribuyen los espacios. En lo concerniente a la casa-habitación se modificaron los espacios porfirianos por un mejor confort con cochera, baño en planta alta en correspondencia con las recámaras, cocina con electrodomésticos, relación entre desayunador, ${ }^{30}$ comedor y éste con la sala; además, el confort que ofrecía la vida moderna de esos años se denotaba con la sustitución de nuevos artefactos, electrodomésticos y servicios que hacían la vida precisamente más confortable, como fue la integración del espacio del closet que suplía al ropero. De la misma manera, las lámparas de pedestal o con pantalla suspendidas desde el centro del techo y las vitrinas con objetos decorativos de la época contribuían a darle ese toque de modernidad a la decoración.

Enrique X., de Anda plantea en este apartado repasar las tipologías arquitectónicas donde más representación tuvo el Déco. La primera es los edificios departamentales

\footnotetext{
${ }^{29}$ Enrique X., de Anda Alanís, "La Arquitectura Déco en la Ciudad de México", Catálogo de la exposición Art Déco. Un país nacionalista, un México cosmopolita, Op. Cit., p. 77.

${ }^{30}$ Espacio acoplado en la cocina que se utiliza para desayunar.
} 
que fueron de tres plantas, eliminando el patio central y substituyendo la planta baja de comercios por departamentos; ya para los años treinta los balcones extensivos y redondeados en las esquinas fueron una constante. La segunda tipología son los edificios de oficinas, los cuales tuvieron más altura y se inspiraban en el rascacielos norteamericano, ya fuera de tipo piramidal o de masa rectangular, cuyas decoraciones interiores se dieron en pisos y muros. La tercera son los grandes cines que tuvieron una fuerte relación con el Streamline de los años treinta, con sus dinámicas líneas y placas tanto en posición vertical como horizontal; pero uno de los principales recursos de los cines fue la iluminación artificial, periférica, circular, salida de plafones conformados por márgenes redondeados. Por último, de los postes, bancas, fuentes, paradas del transporte, letreros que constituyen el mobiliario urbano que iba en estrecha analogía con la estética Déco de los edificios.

- La composición de las fachadas del Art Déco es donde más se aprecian sus elementos simbólicos. Las características más distintivas son: "fachada simétrica y segmentada en lienzos verticales, acceso al centro, vocación vertical con sobreposición de planos de perímetro rectangular y en sucesión de mayor a menor a partir del muro de respaldo ...fachada compuesta en lienzos como superficies continuas con estructura decorativa". 31 Sobre esta cuestión del ornato, la arquitectura Déco fue de las primeras en despojar a las fachadas de la decoración, ya que ésta se colocaba, en muchas ocasiones, en el frontispicio; sin embargo, la geometría expresada a través del conjunto de líneas rectas, entremetidas con ángulos rectos y rectángulos, todos ellos en sentido dinámico, daban el efecto de movimiento. Otra manera más de acentuar el sentido de geometricidad fue ornando las fachadas con la integración de placas, las cuales contenían relieves, de variados temas, ejecutados con cemento.

Otro breve subcapítulo, "Las artes aplicadas en la arquitectura déco" es una advertencia al clarificar que si la arquitectura Art Déco es fácil de identificar, a la vez pudo resolver la relación entre la postura racionalista en la que imperaba la negación al ornato, con la de la aplicación de los motivos decorativos provenientes de las artesanías que no

\footnotetext{
${ }^{31}$ Ibídem, p. 82.
} 
tenían limitaciones en cuanto a su creatividad. Aparte, cuando se diseñaba un edificio Déco era todo un conjunto de arquitectura en el que se integraban desde un principio las herrerías, vitrales, placas estructuradas con cemento, lámparas y hasta mascarones, entre otros. Concluye el capítulo con "Singularidades del déco en México", es decir, de la ciudad de México, tales como: Arco mixtilíneo y abocinado, donde en el primero se substituye el medio punto por líneas rectas, consiguiéndose un efecto de movimiento y en el segundo, el arco se compone de placas que van disminuyendo hasta tocar la puerta de acceso; Marquesina de concreto es un elemento que se manejó principalmente en los edificios de departamentos al incrustarse en la puerta de acceso y muchas veces siguió el ritmo del arco mixtilíneo; Torreta con remate, la cual se colocaba en las esquinas del inmueble con la finalidad de prolongar la altura; Sucesión de placas en fachada con lo que se buscaba eliminar la decoración y a la vez conseguir el efecto de movimiento; Ornamentación neocolonial e iconografía prehispánica, consistiendo en el primer caso en la utilización del ladrillo de barro en rodapiés y las placas de azulejos y en el segundo, las representación de deidades prehispánicas a través de mascarones, relieves con motivos indigenista o bien, las grecas y antifaces de las herrerías.

“El edificio de la Secretaría de Salud. La Modernidad frente al castillo” es todo un panegírico al primer edificio para la administración pública construido por el gobierno postrevolucionario. Iniciado en 1925 por el joven arquitecto Carlos Obregón Santacilia, bajo el mandato presidencial del Gral. Plutarco Elías Calles, su ubicación en el Paseo de la Reforma, un tiempo la avenida virreinal del Castillo de Chapultepec al Palacio del Poder, luego la ruta rumbo a Palacio de los 30 años del gobierno del Gral. Porfirio Díaz, para después convertirse en la moderna avenida por donde circulaban los coches presidenciales de los caudillos revolucionarios para llegar al despacho del Jefe del Ejecutivo, fue desde un principio un inmueble que se disponía desde un espacio central y abierto, para unir las partes laterales. Dos diseños se realizaron previamente, para llegar al definitivo, donde la influencia de Otto Wagner se expresa en la volumetría. Hubo una solución que llama la atención y es la unidad de laboratorios que se dispuso en el fondo del terreno, solucionada modernamente con losas voladizas y estructuras lineales logrando el efecto de claroscuro. Continúa De Anda dentro de este capítulo con El Déco instalado en el eje del poder, oración con la cual explica que el edificio se ubicó en el Paseo de la Reforma y que fue 
construido modernamente en el lenguaje del Art Déco, tal como lo preferían los nuevos gobernantes, porque Obregón Santacilia tomó al Déco en su amplia concepción de integrar a artistas como fue Diego Rivera con los vitrales y murales y Manuel Centurión con esculturas y relieves; los dos esquemas de significación que imperan en el edificio son la geometría expresada a través de la eliminación de decoraciones y con la estructura misma y la simbología de las cuatro edades del hombre personificadas en cantera por Manuel Centurión, los cuatro elementos representados en modernos vitrales bajo el diseño de Diego Rivera, quien a su vez pintó los murales de la sala de laboratorios con alusiones al dominio científico y los conceptos de vida, salud, continencia, pureza, fortaleza y ciencia. Para concluir este capítulo el autor comenta que las herrerías del edificio están dentro de la tendencia del Streamline y que las lámparas de los plafones resueltas a través de un "saque cuadrangular en las esquinas" son de la mejor calidad Déco del inmueble. Enrique X., de Anda cierra el elogio del soberbio edificio con Los esquemas de significación de la arquitectura, al ponderar el uso del corte diagonal para evitar el ángulo recto y encomiar la distribución vertical sobrepuesta de placas, ya que así se transforma el efecto de luz y sombra.

El magno catálogo, como la exposición misma, concluye con "Epílogo: a las cinco de otra tarde..." donde De Anda dice que ya no hay quien se asome en el edificio San Martín, pues en esos años de la muestra estaba abandonado y que la calle llena de autos, la plaza con árboles crecidos, niños jugando en el parque que hasta ha cambiado su nombre, deja lentamente un sabor a añoranza de la arquitectura Art Déco.

Todo el catálogo va acompañado de fotografías en color, un índice de ilustraciones y el catálogo de los objetos expuestos organizados por rubros: I. Artes Plásticas, II. Impresos, III. Material Cinematográfico, IV. Arquitectura, V. Artes Aplicadas e Industriales; posteriormente ya al final, referencias arquitectónicas con los datos de algunos de los arquitectos identificados de edificios de la ciudad de México.

Más que un catálogo de la exposición, Art Déco. Un País Nacionalista. Un México Cosmopolita es un verdadero tratado de las características del Déco en el país, que junto con el libro de Xavier Esqueda Art Déco. Retrato de una Época constituyen los trabajos que más y mejor han estudiado el tema. 
Xavier Esqueda y Enrique X. de Anda son los pioneros en el estudio del Art Déco en México, lo cual se demuestra cuando fueron llamados por el Museo Nacional de Arte para fungir como asesores de la exposición ya mencionada. Sus obras citadas serán la fuente principal del apoyo teórico que utilizaremos para explicar las características del Art Déco en México y, aunque sus trabajos se refieren en la gran mayoría a la ciudad de México, los elementos compositivos característicos de los edificios que ellos analizan nos servirán de marco de referencia para nuestro estudio en el Noreste de México.

Como podemos apreciar en estas reseñas, el estudio del Art Déco en México prácticamente es una referencia de ejemplos de la ciudad de México, ya que lo que hasta ahora se ha publicado sobre este tema está anclado en citar casi exclusivamente lo producido en la capital de la República, destacando que las dos obras más importantes que se han realizado para analizar formalmente el estilo, como ya lo mencionamos, exponen lo facturado en México, D.F., porque el catálogo de la exposición del Museo Pape de Monclova mostró objetos de colecciones privadas.

Así pues vemos cómo los años del Art Déco en México van a la par de transformación postrevolucionaria del México moderno. 


\subsection{MÉXICO EN LOS AÑOS DEL ARRIBO DEL ART DÉCO}

Cuando el caudillo revolucionario Álvaro Obregón (1880-1928) se convierte en el hombre fuerte de la revolución triunfante al gobernar como Presidente de 1920-1924, busca darle al país una imagen diferente a la que había dejado el porfiriato; por lo tanto, los campos de la cultura y la educación eran unas de las vertientes que podían ayudar a consolidar ese ideal. Así pues, invita al licenciado José Vasconcelos (1882-1959) para que se hiciera cargo de la entonces creada Secretaría de Educación Pública en octubre de 1921. Desde esta dependencia, Vasconcelos creó, entre otras cosas, el Departamento de Bellas Artes y fue un férreo patrocinador del naciente movimiento pictórico conocido como el "Muralismo".

El esquema vasconcelista se inspiró en el programa que el Ministro de Instrucción de la naciente Unión Soviética, Anatoli Lunatcharsky (1875-1933), había implantado para desarrollar la actividad cultural. Sobre este punto Carlos Monsiváis (1938-2010) comenta: "Un año axial: 1921. Un común denominador el impulso de José Vasconcelos quien, ya habiendo sido rector de la Universidad, al reinstalar la Secretaría de Educación Pública suprimida por el gobierno de Carranza, estudia admirativamente el programa de Lunatcharsky como Ministro de Instrucción en la URSS y elabora un plan de salvación/regeneración de México por medio de la cultura (el Espíritu)". ${ }^{32}$

Más tarde, durante el gobierno de Plutarco Elías Calles (1877-1945), de 1924 a 1928, se continuaron con algunos de los programas iniciados por Vasconcelos y tanto el sector oficial como el privado emprendieron una fuerte inversión en edificación de obras públicas, tales como oficinas para la administración gubernamental y privadas, hospitales, escuelas, casas-habitación, plazas, edificios de departamentos, cines, teatros, entre otros, con lo cual coadyuvaba a fortalecer la apariencia del "México Moderno" que quería crear Elías Calles, ya que si Rusia había cambiado de ser una sociedad agraria a una industrial, no era extraño que México quisiera ser algo parecido, tomando en cuenta que en ambos casos habían salido de una revolución. Mas la cimentación del "México Moderno" continuó

\footnotetext{
${ }^{32}$ Carlos Monsiváis, "Notas sobre la cultura mexicana en el siglo XX", Historia General de México. Tomo 2, El Colegio de México, México, 1981, p. 1417.
} 
después de Elías Calles, pese al asesinato de Obregón en julio de 1928, quien había movido toda la maquinaria electoral para reelegirse como Presidente para el periodo 1928-1932.

Los sucesores de los caudillos sonorenses, Emilio Portes Gil (1890-1978), [19281930], Pascual Ortiz Rubio (1877-1963), [1930-1932] y Abelardo Rodríguez (1889-1967), [1932-1934] dieron, a su manera, seguimiento al proyecto de transformación de la nación, especialmente de la capital, ya que si se "modernizaba" la ciudad de México, también el país sufriría ese efecto. En los seis años que gobernaron los “peleles”, como se les conoció a estos tres Presidentes, -por ser manipulados por el "Hombre Fuerte de la Revolución", Plutarco Elías Calles- la construcción de obras públicas de acuerdo al programa postrevolucionario se siguió dando, más aún, pues en 1929 se funda el Partido Nacional Revolucionario que enarbolaba todos los ideales triunfantes de la revolución y se prosiguió con ello durante el sexenio de Lázaro Cárdenas (1895-1970), [1934-1940].

Esa época de "tiempos modernos mexicanos" tiene dos hechos que desde el aparato estatal controlan la economía del país y que coincide con los tiempos de desarrollo del Art Déco en México: la fundación del Banco de México en 1924 bajo el gobierno de Calles, con la finalidad de emitir la moneda y más tarde en 1935 como única casa bancaria que controlaría a todas las demás entidades financieras, y la Expropiación Petrolera del 18 de marzo de 1938 declarada por Cárdenas, unificando todas las empresas petroleras tanto extranjeras como mexicanas en un gigante paraestatal: PETROMEX. Son las décadas de los veinte y los treinta, los años de las entreguerras, como los llama Paul Maenz.

Esta situación de cambio ideológico sobre las actividades culturales postrevolucionarias se relaciona con el Art Déco, ya que éste venía a ser un estilo coherente con la modernidad y, como ya lo habíamos mencionado, era eso lo que buscaba reflejar el gobierno caudillista triunfante, ya que, en palabras de Enrique X., de Anda, el Déco "refleja una imagen social caracterizada por el optimismo ante la abundancia de recursos y la confianza absoluta en que la tecnología por sí misma habrá de revolucionar el mundo"33 y México empieza a transformarse en un estado industrializado, moderno y que confía en que la abundancia de tierras, mares, minas y petróleo lo harían un país de progreso tanto económico como tecnológico.

\footnotetext{
${ }^{33}$ Enrique X., de Anda, "La influencia estética del decó", Historia de la arquitectura mexicana, México, Gustavo Gili, 2013, $3^{\text {a }}$, edición, p. 177.
} 
Para Enrique X., de Anda la difusión del Déco en México llegó más por vía de Estados Unidos que de París, pues la influencia de aquel país fue más importante en México, especialmente la ciudad de los rascacielos, Nueva York, que para nuestra nación era el nuevo símbolo e ideal del progreso urbano, esto "debido a dos circunstancias: su aproximación a la clase media a través de mobiliario, vestido, maquillajes, además de la arquitectura, y por la paulatina desviación de los polos culturales occidentales que sufrieron un desplazamiento hacia el nuevo mundo; París perdió importancia como la capital artística mundial y Nueva York se preparaba para asumir el papel preponderante de los nuevos gustos,... ${ }^{34}$ Otra de las razones que da De Anda por la cual se conoció el Déco en nuestro país es que la magna exposición de 1925 celebrada en París se dio a conocer vía la revista Cemento, en un artículo que incluía fotografías y firmado por Derisanty, posiblemente un pseudónimo, quien a su vez tomó la información de un artículo de W. Francklyn Paris publicado en la revista norteamericana The Architectural Record. ${ }^{35}$ Además, si tomamos en cuenta que después de la Revolución, México por su cercanía geográfica con Estados Unidos se inspira más en el norte que en Europa y que ese país se vuelve el modelo a seguir, es entendible que las influencias del Déco hayan llegado más por ahí y no tanto por el Atlántico.

Esqueda, por su parte, comenta cómo la llegada del Déco a México coincide con la reconstrucción de la nación a través de los ideales revolucionarios -ungidos en las figuras de los caudillos triunfantes en el poder- que, entre otras cosas, buscaban enaltecer la cultura del país, combinando lo moderno de ese tiempo con elementos "mexicanistas" que reforzaran la identidad nacional, porque "la creación del art deco en México corresponde al momento cultural nacional en que más que nunca urgía encontrar las bases donde levantar una cultura y arte propios, de acuerdo con los cambios y los avances que proponía la Revolución Mexicana y que crearan un nuevo sistema para el país... ${ }^{36}$ Más adelante al referirse ya en sí a la arquitectura Déco en México, Esqueda interpreta que por las consecuencias revolucionarias una gran masa poblacional educada escolarmente y con un naciente sistema de vida, necesitaba nuevos servicios urbanos, académicos y artísticos y

\footnotetext{
${ }^{34}$ Enrique X., de Anda, "La arquitectura del Déco", La arquitectura de la Revolución Mexicana. Corrientes y estilos de la década de los veintes, México, UNAM, p. 130.

${ }^{35}$ Ídem.

${ }^{36}$ Xavier Esqueda, Art Déco. Retrato de una época, Op. Cit., p. 90.
} 
que con las influencias extranjeras europeas y norteamericanas de educación y cultura surgió la necesidad de inquirir una arquitectura que reflejara mexicanidad y el Déco fue uno de esos caminos, de lo que resultó la proliferación de construcciones en este estilo. ${ }^{37}$

El mismo Esqueda en su trabajo Una puerta al Art Deco expone que las dos guerras mundiales, las dos revoluciones del siglo XX de esa época, la rusa y la mexicana, los hechos políticos, económicos y sociales que se dieron en los años veinte y treinta y que fueron determinantes para el Art Déco, también contribuyeron para que en México adviniera ese estilo, pero especialmente al darse por terminada la Revolución Mexicana en 1920, pues "sus consecuencias coinciden con la creación del estilo DECO en este país. Empieza a crecer la clase media en México y a ella van dirigidas las nuevas construcciones modernas... así mismo colonias masivas de la clase media en sus distintas categorías... que en conjunto son la representación más profusa y homogénea del ART DECO...". 38

En un artículo titulado "El Art Déco. Una nueva alternativa cultural”, Rocío Guerrero y Cecilia Delgado explican que hubieron tres factores que ayudaron a que el Déco se introdujera y desenvolviera en México: "La importación de artículos de uso cotidiano", pues películas, revistas y enseres reflejaban un nuevo estilo de vida moderno; "Interés por la transformación fisonómica del país”, ya que era necesario dar una nueva imagen al México Moderno a través de edificaciones públicas estatales y privadas; "Recuperación económica" que se reflejó en el despegue industrial y en las inversiones tanto del Estado como de empresarios privados. ${ }^{39}$ Cabe aclarar que este artículo fue escrito como una pequeña introducción temática para la exposición Art Déco. Un país nacionalista. Un México cosmopolita, en donde las autoras -quienes aparecen en el catálogo de dicha muestra como "Asistencia Curatorial, Investigación, Documentación y Catalogación de la Obra"- mencionan que "es una excelente oportunidad para hacer un vasto recorrido por esta etapa poco conocida y estudiada de la historia del arte mexicano". ${ }^{40}$ Precisamente, nuestro trabajo va encaminado a conocer, estudiar y divulgar dicha etapa.

Sobre el punto citado por Guerrero y Delgado "La importación de artículos de uso cotidiano", De Anda en el capítulo titulado "La identidad del Art Déco en México", del

\footnotetext{
${ }^{37}$ Ibídem, p. 109.

${ }^{38}$ Xavier Esqueda, Una puerta al Art Deco, Op. Cit., p. 15.

${ }^{39}$ Rocío Guerrero y Cecilia Delgado, "El Art Déco. Una nueva alternativa cultural", México en el Tiempo, México D.F., No. 23, marzo-abril 1998, pp. 27 y 29.

${ }^{40}$ Ibídem, p. 29.
} 
libro ART DÉCO. Un país nacionalista. Un México cosmopolita, hace una minuciosa explicación al respecto de los enseres. Nos dice que la fuerte tradición y producción artesanal de México, que en esos tiempos era más demandada, tanto de objetos de uso doméstico diario como de adornos, fue paulatinamente substituida por productos de importación, los cuales se vendían en tiendas que significaban, como ahora, un estatus social diferente y adecuado a la moda de la vida moderna y que connotaban estar al día de las nuevas formas de vida europeas y estadounidenses. "La vidriería, la joyería, la cerámica, el mobiliario elaborado con maderas preciosas, los objetos de bronce, latón y marfil se trajeron de Bélgica, Francia e Inglaterra. En Estados Unidos se compraron los aparatos electrodomésticos, los objetos de baquelita y en menor medida joyería y mobiliario, para ser vendidos en México por grandes almacenes como El Puerto de Liverpool, El Palacio de Hierro y el Centro Mercantil. Frente a esa ola de importaciones, México fue un gran productor de arquitectura déco con identidad local". ${ }^{4}$

"Herencia Decó por los rumbos de La Villa" es un artículo de Edgar Anaya Rodríguez publicado en la revista MÉXICO en el tiempo, en donde el autor hace una relatoría del origen y del estilo Déco del edificio Fundación Mier y Pesado y para explicar el concepto del Art Déco y de su arribo al país describe que: “En México, se considera a los primeros años de la década de los treinta como la madurez plena del art déco, aunque hay magníficas obras realizadas antes y después. La aparición de este estilo europeo coincidió con el resurgimiento económico que planteó el régimen del presidente Calles". ${ }^{4}$

Arquitectura mexicana. El arte de los espacios, artículo de Patricia Urías y Andrés Ruiz, hacen un recorrido desde principios del siglo veinte hasta las manifestaciones de los ochenta, donde muy brevemente comentan sobre el Art Déco: "Llegó también, hacia los años treinta, el art déco que influyó en la arquitectura mexicana, como se puede ver en las obras de los arquitectos Francisco José Serrano y Juan Segura, dos de sus principales exponentes. Un ejemplo de ello es el edificio Ermita en la avenida Revolución". 43

\footnotetext{
${ }^{41}$ Enrique X., de Anda, "La identidad del Art Déco en México", Catálogo de la exposición Art Déco. Un país nacionalista, un México cosmopolita, Op. Cit., p. 57.

${ }^{42}$ Edgar Anaya Rodríguez, "Herencia Decó por los rumbos de la Villa", México en el Tiempo, No. 18, mayojunio de 1997, p. 36.

${ }_{43}$ Patricia Urías y Andrés Ruiz, “Arquitectura mexicana. El arte de los espacios”, Memoria de Papel, Año 3, No. 6, junio de 1993, p.55.
} 
En la popular revista México Desconocido se publicó un breve artículo titulado Decó. La geométrica ciudad escrito por Mauricio Lavista y con un buen número de imágenes fotográficas de Jorge Pablo de Aguinaco. El texto inicia valorando una construcción religiosa que se ha considerado por varias opiniones, según comenta autor, como "uno de los edificios más 'feos de nuestra ciudad" [México D.F.]; se refiere a la Parroquia del Purísimo Corazón de María, obra de 1922 considerada como Art Déco, cuya autoría se debe al arquitecto Antonio Muñoz García (1896-1965) y al ingeniero Miguel Rebolledo (1868-1962), por cierto el introductor del concreto armado en México en 1902. ${ }^{44}$ Lavista enumera a los ejemplos más distintivos del Déco en la ciudad de México, tales como el Edificio de Bomberos [sic], la Asociación Cristiana Femenina, el Palacio de Bellas Artes, el Frontón México y el Monumento a la Revolución, estos dos últimos ubicados en la Plaza de la República, además de mencionar colonias donde se desarrolló este estilo.

Sin embargo, el autor enuncia algo que enarbola al Déco en relación con la capital de la República al expresar: "Hay pocas ciudades en el mundo donde pueda encontrarse una arquitectura genuina Art Decó. Una de ellas es, indudablemente, la ciudad de México". ${ }^{4}$

Como indicamos al inicio de este capítulo que la generalidad de los estudios realizados o que las publicaciones sobre el Art Déco se centran en su gran mayoría en la capital de la República, la afirmación de Lavista expuesta en el párrafo anterior se relaciona con lo que asienta Víctor Jiménez en el artículo El siglo del México Contemporáneo en la Arquitectura, en donde explica que la arquitectura mexicana después de la Revolución tomará un lenguaje propio y hecho por arquitectos mexicanos, como fue el caso de "Carlos Obregón Santacilia, autor de obras historicistas: la Escuela Benito Juárez de 1927 y cosmopolitas: interior del Banco de México de 1927 (primer ejemplo art déco en México), quien consigue en el edificio de la Secretaría de Salud (1928) una síntesis original de este camino". ${ }^{46} \mathrm{Y}$ en el mismo trabajo, aunque Jiménez afirme que "las ciudades mexicanas adaptan a la arquitectura doméstica un art déco menos espectacular que el de los grandes

\footnotetext{
${ }^{44}$ Humberto Musacchio, Diccionario Enciclopédico de México, México, Andrés León Editor, 1995, $1^{a}$ edición, $10^{\mathrm{a}}$ reimpresión, p. 1700.

${ }^{45}$ Mauricio Lavista, "Decó. "La geométrica ciudad”, México Desconocido, No. 140, octubre de 1988, pp. 2425.

${ }^{46}$ Víctor Jiménez, "El Siglo del México Contemporáneo en la arquitectura", México en el Tiempo, México, D.F., No. 33, noviembre-diciembre de 1999, p. 36.
} 
edificios públicos (interior del palacio de Bellas Artes, de Federico Mariscal, 1934), apareciendo colonias como la Hipódromo Condesa, a partir de 1925, o edificios como el Ermita, de Juan Segura en 1930 y el Basurto, de Francisco Serrano de 1942”, sólo son citados, como vemos, casos de la ciudad de México, D.F. ${ }^{47}$

La revista capitalina CENTRO. Guía para caminantes, en el número 15 se publicó un reportaje sobre edificios Art Déco en el centro histórico escrito por Concha Cue, Inés Noriega y Daniel Rodríguez Barrón titulado "El Centro Histórico: origen, esplendor y gloria del ART DÉCO mexicano". En este trabajo bastante ilustrado se describen espléndidas construcciones como el Palacio de Bellas Artes, la Antigua Estación de Policía y Bomberos, hoy sede del Museo de Artes Populares, el edificio La Nacional, la Central Telefónica Victoria, el Edificio de la Asociación Cristiana Femenina (YWCA), inmuebles que describiremos en el apartado 2.5.1., de este capítulo “Arquitectura en México estilo Art Déco", además de edificios de oficinas como el ubicado en las calles de Victoria y Revillagigedo o el de apartamentos en la esquina de Victoria y López. Sobre la importancia de los edificios de la ciudad de México, los autores manifiestan: "El Art Déco, un movimiento internacional de corta vida, pero de gran impacto, encontró en nuestro país una de las interpretaciones más originales y más ampliamente adoptadas. En el centro histórico, que siempre ha sido del laboratorio de la cultura nacional, se crearon algunas de sus manifestaciones más relevantes, bastante ignoradas el día de hoy, a la espera del aprecio y rescate que se merecen". 48

Si la fuerte corriente de personas interesadas en el patrimonio Art Déco de la ciudad de México, representado principalmente a través de la arquitectura, proponen su rescate y aprecio, en nuestro trabajo es lo que pretendemos lograr, un conocimiento, salvamento, conservación y difusión del Art Déco del Noreste de México.

\footnotetext{
${ }^{47}$ Ibídem, p. 38.

${ }^{48}$ Concha Cué, Inés Noriega y Daniel Rodríguez Barrón, "El Centro Histórico: origen, esplendor y gloria del ART DÉCO mexicano", CENTRO. Guía para caminantes, México, D.F., No. 15, febrero de 2005, p. 30.
} 


\subsection{EL CEMENTO, MATERIAL MODERNO PARA EL ART DÉCO}

Como anotamos en el capítulo 1, además de los nuevos materiales que se pusieron en boga con los decorativismos del Déco, el cemento viene a significar también el progreso. Una construcción que se realizara con este material, estaba acorde con la vida moderna, con lo urbano, ya que substituía a viejos elementos como la piedra, el adobe, la madera o la teja, lo que se asociaba con lo rural o con el concepto de lo vetusto y anticuado. Los nuevos edificios levantados en los tiempos de la postrevolución deberían reflectar todo ese ideal de modernidad del que hemos hablado anteriormente, así como la perdurabilidad; al mismo tiempo, la nueva visión matérica y tecnológica que daba el cemento, congraciaba tanto al nuevo poder estatal, a los constructores privados y a la naciente clase media.

A la vez el cemento daba una alternativa que no se había experimentado en México: la posibilidad de construir edificios de varios pisos, en forma ascendente, con lo cual se imitaba al rascacielos neoyorquino. Y, entre otras cosas, en 1924 se rememoraba un siglo de la creación del cemento Portland, por lo que este material era el "último grito de la moda" para los arquitectos que sentían estar al día; además, se daba una doble valoración al uso del cemento: por una parte, los constructores estaban al corriente de las nuevas técnicas, y por otra, quienes adquirían las lozanas construcciones reflejaban tener un poder adquisitivo en relación con las emergentes formas de vida. Con esto no queremos decir que haya sido a partir de 1924 cuando se empezó a utilizar el cemento en México, pues ya se usaba años antes, sino lo que queremos es recalcar la importancia de este material en el periodo de nuestro estudio.

En el ensayo titulado "Las condiciones materiales de realización de la arquitectura del art-déco" de Jorge H. Jiménez, al hablar del cemento dice: "El art-déco no es imaginable sin la incorporación de los sistemas constructivos derivados del cemento, el concreto y el concreto armado... cuando se inició aquí la promoción extensiva de este producto, y para tal efecto se creó un comité impulsor, el art-déco se encontraba dando sus primeros pasos y no con malos resultados". ${ }^{49}$

\footnotetext{
${ }^{49}$ Jorge H. Jiménez, "Las condiciones materiales de realización de la arquitectura del art-déco", en: Fernando González Gortázar (editor), La arquitectura mexicana del siglo XX, México, CONACULTA, 1996, p. 122.
} 
Pero es Enrique X., de Anda quien hace una completa descripción del uso del cemento en México desde principios de siglo, hasta finales de los años veinte, en el capítulo II "El concreto armado: la técnica constructiva del siglo" de su libro La Arquitectura de la Revolución Mexicana. Corrientes y Estilos de la década de los veinte. Ahí nos menciona cómo en el año de 1925 se inició la publicación de la revista Cemento, la cual tuvo una duración de cinco años, ya que terminó en noviembre de 1930. Esa revista fue un medio de divulgación de las propiedades del cemento, así como de la edición de artículos traducidos del inglés, provenientes de revistas norteamericanas, y noticias de países de Europa occidental sobre las novedades en materia de construcción. Ya citamos anteriormente cómo el autor en el mismo libro, en el capítulo dedicado a la arquitectura Déco, nos habla de que fue en la revista Cemento donde se dieron a conocer imágenes y textos sobre la exposición del 25 en París.

Además, la publicación enarbolaba los parabienes del uso de la moderna sustancia para la ingeniería y la arquitectura, de sus logros inauditos, de la existencia imperecedera y futura de las construcciones realizadas con ese material, aunando a los plácemes para los arquitectos que trabajaban con el novedoso conglomerante: "En la revista Cemento se felicitaba al genial arquitecto que empleaba concreto en los edificios así como a los felices propietarios porque poseían bienes a prueba de terremoto y huracanes". ${ }^{50}$

Es interesante cómo De Anda hace una relación, en el capítulo citado, entre la edición de la revista y el arte de esa época al especificar los trabajos del pintor Jorge González Camarena (1908-1980), quien inició las portadas de la revista para más tarde también trabajar las páginas interiores, con edificios trazados preponderantemente con la fuerza de la geometría y la línea recta. Habla de la afinidad que hay en el procedimiento de plasmar la figura humana como lo hacía en ese mismo tiempo el caricaturista Ernesto "Chango" García Cabral (1890-1968), pero a la vez aclara que González Camarena presenta al obrero de la construcción "bajo una concepción titánica, como queriendo representar idealmente la vital importancia que tiene la edificación en el mundo moderno", 51 tomando en cuenta que los albañiles u obreros de la construcción venían de estratos sociales humildes o eran campesinos migrados a la ciudad y eran representados con

\footnotetext{
${ }^{50}$ Israel Katzman, Arquitectura Contemporánea Mexicana, México, INAH, 1964, p. 109.

${ }^{51}$ Enrique X., de Anda, "El concreto armado: la técnica constructiva del siglo", La arquitectura de la Revolución Mexicana. Corrientes y estilos de la década de los veintes, México, UNAM, 1990, p. 47.
} 
el torso desnudo, con cuerpos musculosos, lo cual estaba muy lejos de la realidad, pero que a la vez dichas representaciones servían para enaltecer el trabajo de la construcción.

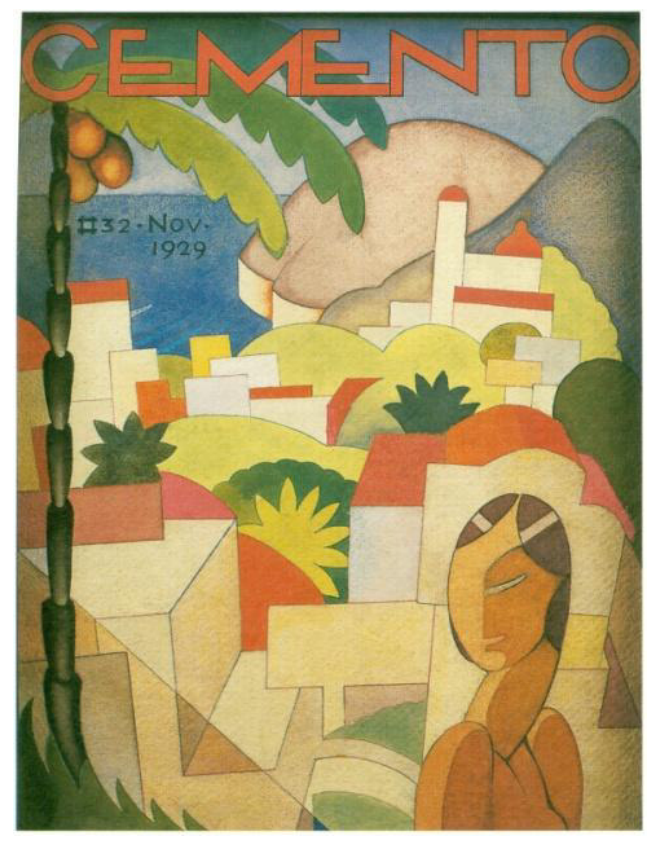

Jorge González Camarena, revista Cemento \# 32,

Nov. 1929.52

Por la manera similar como González Camarena concebía los dibujos de sus edificios, De Anda también hace un enlace del dibujante de la revista Cemento con los artistas Jean Charlot (1898-1979) y Ramón Alva de la Canal (1898-1985), quienes colaboraron con el movimiento del Estridentismo ${ }^{53}$ ilustrando sus poemas o las portadas de la revista Horizonte, la cual fue el órgano de difusión y tuvo una corta vida entre 1926 y 1927, pues en sendos casos las líneas quebradas, zigzagueantes y geométricas están en íntima relación con las propuestas del Déco.

\footnotetext{
${ }^{52}$ Enrique X., de Anda, Catálogo de la exposición Art Déco. Un país nacionalista, un México cosmopolita, p. Cit., p. 40.

${ }^{53}$ El Estridentismo fue un movimiento literario con una duración de casi siete años que se desarrolló entre 1921 a 1928, influido por los movimientos de vanguardias europeos como el Ultraísmo español, el Dadaísmo y el Futurismo italiano. Como era usual en esa época, los estridentistas dieron a conocer su manifiesto en la revista Actual, donde publicaron hasta cuatro manifiestos. Desafiaban la tradición artística y en búsqueda de un nuevo arte, se portaban irreverentes con lo establecido en cualquier ámbito. Algunos de los principales miembros fueron: Manuel Maples Arce, Germán Liszt Arzubide, Arqueles Vela, Salvador Gallardo y Luis Quintanilla. Para un estudio completo sobre el movimiento, véase: Luis Mario Schneider, El Estridentismo. México 1921-1927, México, U.N.A.M., 1985. Este trabajo incluye algunas láminas de los artistas mencionados.
} 
Además de los mencionados, otros artistas que participaron con los estridentistas, siguiendo el modelo del zigzag o del rayo eléctrico y las formas cubistas, fueron el pintor Fermín Revueltas (1903-1935), el grabador Leopoldo Méndez (1902-1969) y los escultores Germán Cueto (1893-1975) y Guillermo Ruiz (1896-1965), entre otros.
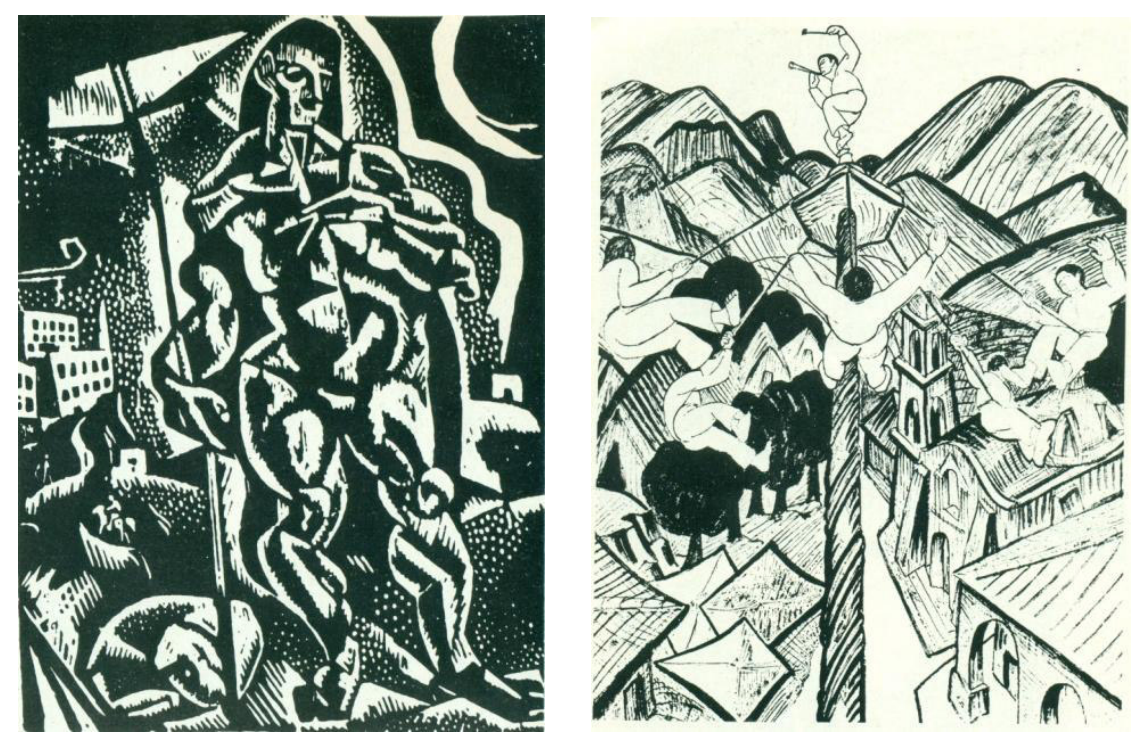

Ilustraciones Estridentistas de Jean Charlot sobre el hombre moderno en la ciudad y de Leopoldo Méndez mostrando el ritual de los Voladores de Papantla, Veracruz, ambas ha. 1926.54

Antonio Toca Fernández en su trabajo "Evolución de la crítica de la arquitectura en México: 1900-1990”, en el apartado 'Nacionalismo revolucionario’, sólo da una breve cita sobre la revista Cemento al decir "que promovió activamente la introducción del concreto armado en las edificaciones". 55

Otra de las publicaciones de aquél tiempo fue la revista Tolteca, que era el órgano de difusión de la compañía cementera Tolteca. La dirección de la publicación quedó en manos de Federico Sánchez Fogarty (1901-1976), el publicista que trabajó en Cemento y que se llevó a Jorge González Camarena para seguir colaborando con las viñetas. Más tarde Sánchez Fogarty se convertiría en jefe de Relaciones Públicas de la empresa.

Tolteca fue una impulsora de la corriente arquitectónica del Racionalismo, ya que reproducía imágenes y comentaba artículos relacionados con lo que se consideraba como lo

\footnotetext{
${ }_{55}^{54}$ Luis Mario Schneider, Op. Cit., ilustraciones 10 y 21.

${ }^{55}$ Antonio Toca Fernández, "Evolución de la crítica de la arquitectura en México: 1900-1990”, en: Fernando González Gortázar (editor), Op. Cit., p. 471.
} 
más moderno; sin embargo, tomemos en cuenta que si el Déco logra su más amplio desarrollo en México en la década de los treinta y el cemento era unos de los materiales principales a usar, la publicación seguía siendo un marco de consulta y referencia.

La importancia del cemento y la publicidad de la fábrica Tolteca se vieron conjugadas en la Estación del Ferrocarril Infantil de Chapultepec, obra del arquitecto José Gómez Echeverría ${ }^{56}$, pues en una placa de azulejos reza la siguiente leyenda que "Hasta los niños tenían que leer": 57

"Niño:

Fíjate bien que esta estación es de una sola pieza. Aquí no hay juntas porque no fue construida piedra sobre piedra, sino moldeada en concreto. Esta estación durará muchos siglos porque el concreto se hace con cemento. Cuando seas grande, tus palacios los harás de concreto.

\section{LA TOLTECA}

Cia. de Cemento Pórtland SA

Av. Independencia no $8 . " 58$

El cemento, ya fuera a través de la publicación del mismo nombre o de la revista Tolteca tenía una amplia difusión y era la intención de sus fabricantes el convencer que el material constructivo moderno y del futuro ya se estaba produciendo en el país. La edificación de los nuevos edificios para la administración pública, de la salud, del esparcimiento y sobre todo para la vivienda, se hacían con cemento y acero, por lo que “existía una campaña para impulsar el concreto como el material 'moderno' por excelencia, como la tecnología constructiva que conduciría a una arquitectura más racional, más audaz y más libre...Y las formas geométricas eran perfectas para trabajar ese material". 59

\footnotetext{
${ }^{56}$ El único dato que hemos encontrado sobre este arquitecto es el que da Katzman al citar a los profesores de la Facultad de Arquitectura de los años treinta del siglo XX: "Como profesor de presupuestos estaba Manuel Gómez Echeverría”, Op. Cit., p. 112.

${ }^{57}$ Israel Katzman, Op. Cit., p. 109.

${ }^{58}$ Enrique X., de Anda, Op. Cit., p. 144 y foto 19 de dicho capítulo.

${ }^{59}$ Concha Cué, Inés Noriega y Daniel Rodríguez Barrón, Op. Cit., p. 32.
} 
El Art Déco se constituye principalmente de composiciones geométricas, así pues a través de la arquitectura que fue la más significativa representación del Déco en México, ésta se realizaba con cemento. 


\subsection{EL PREHISPANISMO COMO FUENTE DE INSPIRACIÓN}

Así como en Europa se justipreciaron las culturas tribales negras africanas, lo celta, los vikingos, los iberos, más todo lo que para el europeo era exótico como la cultura egipcia faraónica o las culturas americanas prehispánicas, en México el amplio y extenso, temporal y geográficamente mundo prehispánico fue altamente revalorado en las épocas en que se desarrolló el Art Déco en nuestro país. Desde nuestro punto de vista hubo dos veredas por donde llegaron las influencias prehispánicas: una interna, es decir, a través del territorio nacional y otra externa, vía Europa y Estados Unidos.

La interna se inicia con la revaloración del mundo indígena prehispánico que tuvo mucho eco en el México del siglo XIX, cuando a mediados de esa centuria en la Academia de San Carlos se realizaron varias obras pictóricas con temas indigenistas, tal es el caso de Netzahualcóyotl escondido, 1865, de Luis Coto (1830-1891), El ofrecimiento del pulque, 1869, de José Obregón (1832-1902), La deliberación del senado de Tlaxcala después de la embajada de Hernán Cortés, 1875, de Rodrigo Gutiérrez (1848-1903); las pinturas del paisajista José María Velasco (1840-1912) sobre Teotihuacán Pirámides del Sol y de la Luna y Pirámide del Sol, ambas de 1878; La fundación de Tenochtitlán de 1879, 1889 y 1891 de Luis Coto, José María Jara (1866-1939) y Joaquín Ramírez (1834-1886), respectivamente.

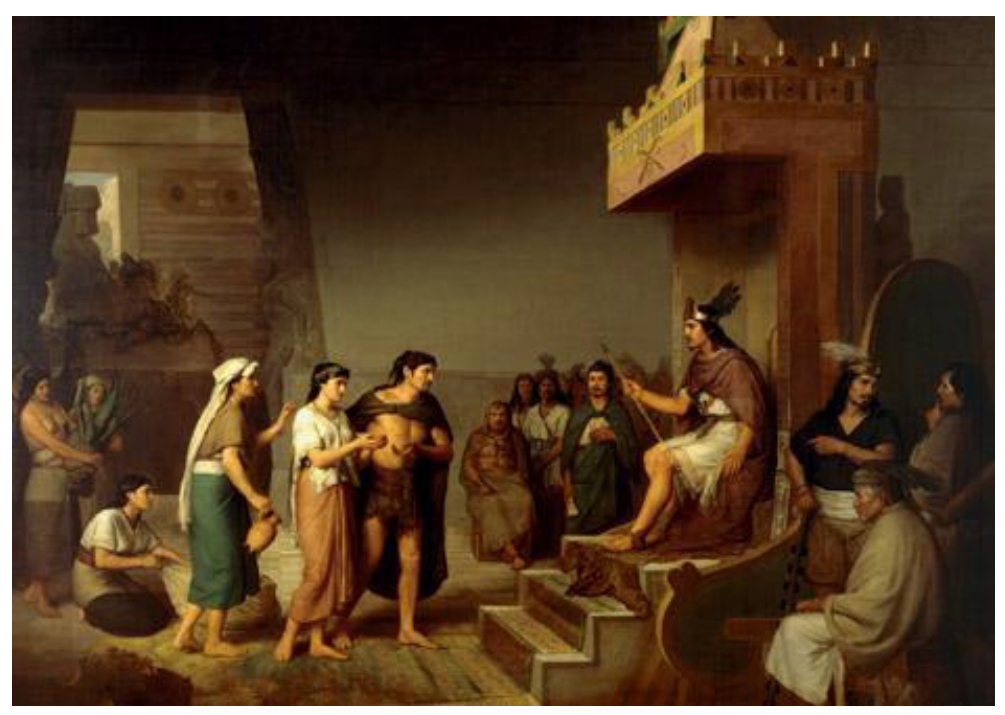

Gonzalo Obregón, El descubrimiento del pulque, 1869, Museo Nacional de Arte, México, D.F. 
Y la apoteósica pintura de Leandro Izaguirre (1867-1941) El suplicio de Cuauhtémoc, 1893, obra con la que los mexicanos conocieron a Cuauhtémoc y a la recreación del acontecimiento que conformó todo un icono con la escena sobre la legendaria tortura del último "tlatoani" mexica, se había presentado primero en una feria internacional en Philadelphia, para luego venir a México a cerrar el ciclo de la pintura académica histórico- indigenista.

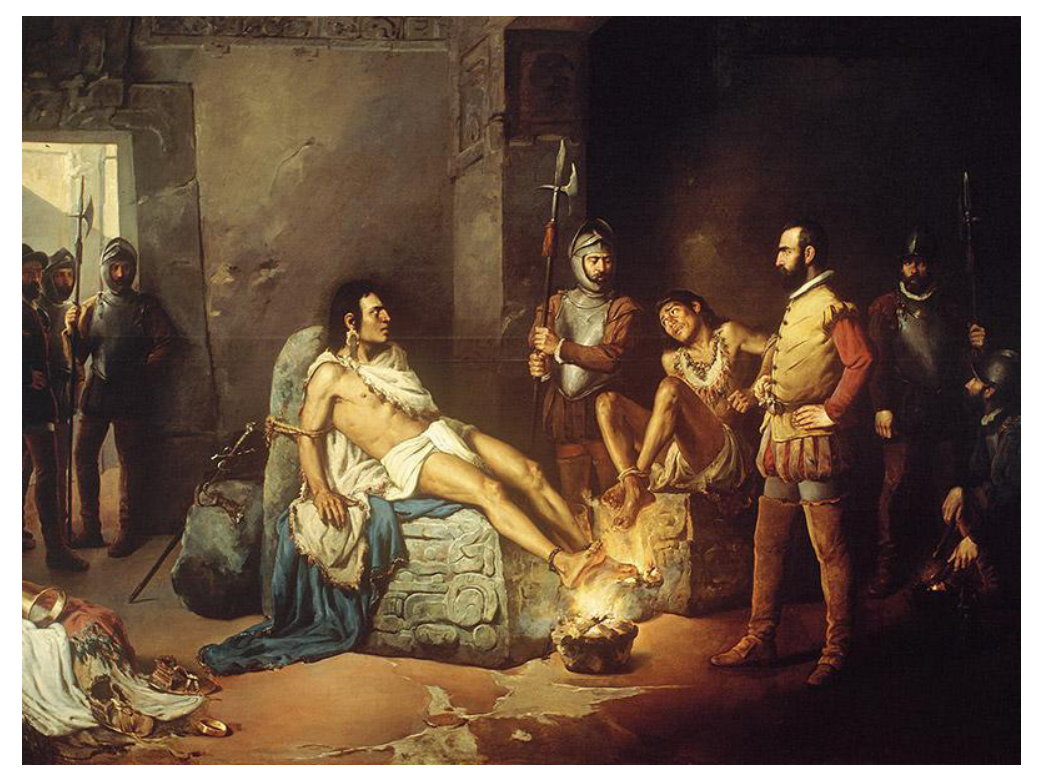

Leandro Izaguirre, El sacrificio de Cuauhtémoc, 1893, Museo Nacional de Arte, México, D.F.

En el campo de la escultura el maestro de la Academia de San Carlos, el español Manuel Vilar (1812-1860), trabajó, aunque a la manera clásica en la manufactura, en el año de 1851 a La Malinche y al jefe tlaxcalteca Tlahuicole, obra de la cual Justino Fernández opina: "Su monumental estatua Tlahuicole tiene fuerza y dramatismo, está tratada en la mejor tradición de la escultura clásica y es de gran calidad artística y estética". ${ }^{60}$ Estas obras, ambas ubicadas también en el Museo Nacional de Arte, son el antecedente de otros grupos escultóricos que trataron temas prehispánicos por algunos de los alumnos de Vilar, que a su vez se hicieron maestros de una segunda generación.

\footnotetext{
${ }^{60}$ Justino Fernández, El Arte del siglo XIX en México, México, UNAM, 1967, p. 118.
} 

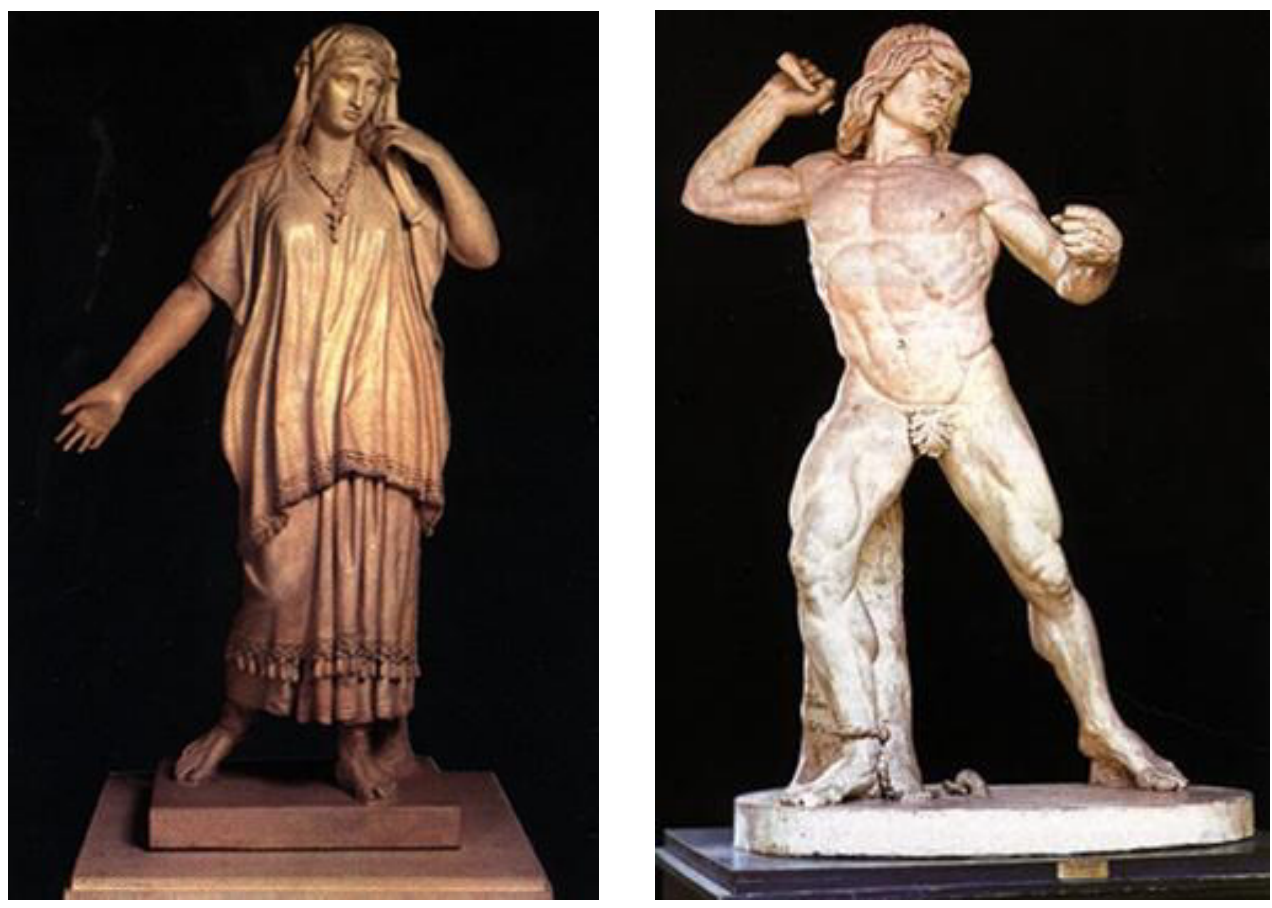

Manuel Vilar, La Malinche y Tlahuicole, 1851, Museo Nacional de Arte, México, D.F. 61

Uno de esos grupos escultóricos es el Monumento a Cuauhtémoc en la ciudad de México. Mandado erigir mediante un decreto presidencial de Porfirio Díaz (1830-1915) en 1877, se iniciaron las obras en 1878y se concluyeron hasta 1887: el proyecto de la gran base fue del ingeniero Francisco M. Jiménez y Arias (1844-1884) y el de la escultura de un alumno de Manuel Vilar, Miguel Noreña (1843-1894). En la soberbia base de tres cuerpos, Jiménez se inspira en las culturas prehispánicas al insertar los tableros de doble escapulario de Monte Albán y las grecas de Mitla en el primer cuerpo, donde también hay dos relieves: uno, hecho por el propio Noreña que narra el enfrentamiento entre Cuauhtémoc y Cortés, y otro realizado por un alumno de Noreña, Gabriel Guerra (1847-1893), que escenifica el tormento de Cuauhtémoc. El segundo cuerpo arranca con cuatro taludes en los cuales se insertaron nombres de gobernantes de los señoríos aliados de los mexicas en el momento de la conquista: Cuitláhuac, de Iztapalapa; Cacama y su sucesor Coanacoch, ambos de Texcoco; y Tetepanquetzal, de Tlacopan; hatos de columnas toltecas sostienen un entablamento con decoraciones mayas. En el tercer cuerpo, una primera base presenta decoraciones en zigzag, para luego continuar con un zócalo cuadricular que se decora con

\footnotetext{
${ }^{61}$ Eloísa Uribe, "Los ciudadanos labran su historia. Escultura 1843-1877”, Historia del Arte Mexicano,
} México, SEP, Salvat, 1986, 2a ., edición, vol. 10, pp. 1437 y 1440. 
formas serpentinas que caen y se combinan con motivos geométricos. Finalmente, la escultura del último "tlatoani” mexica, Cuauhtémoc, obra de Miguel Noreña.
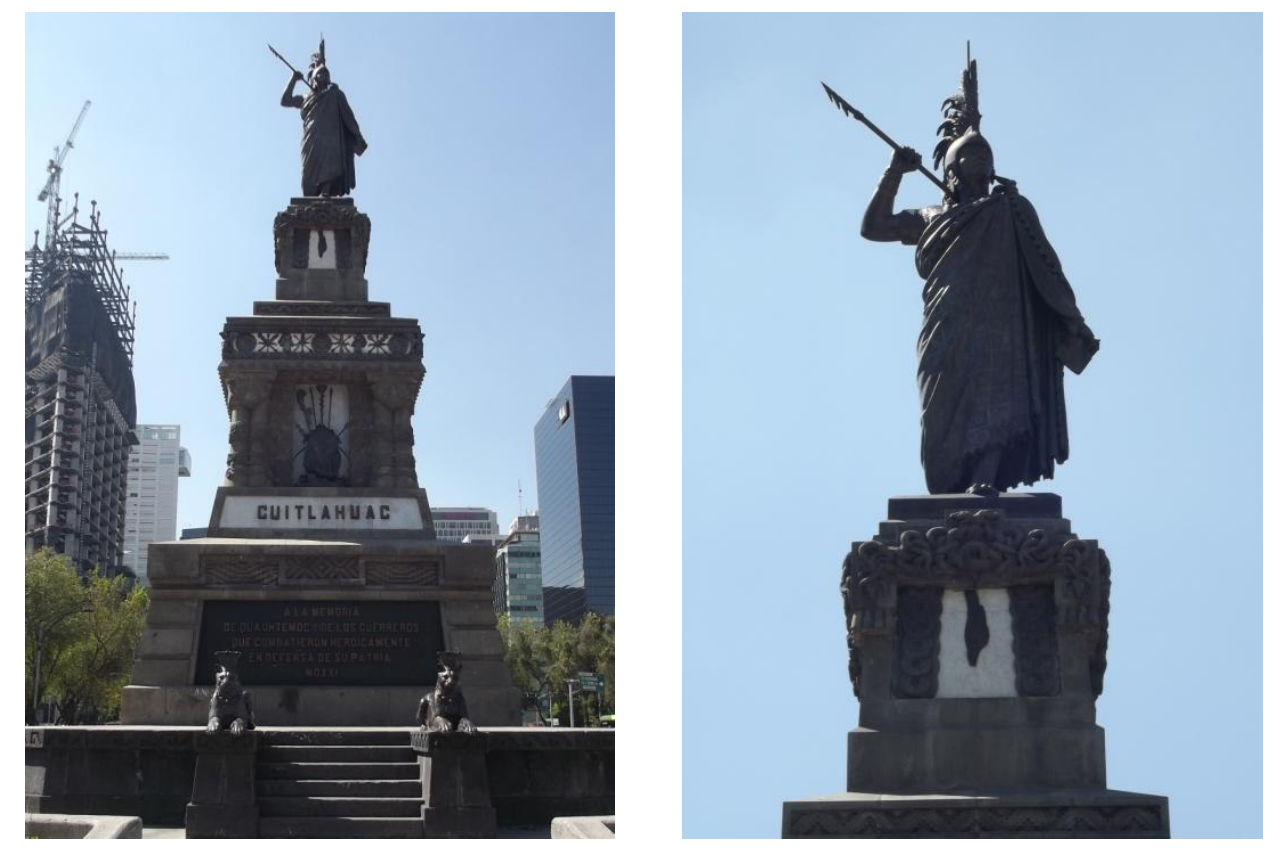

Francisco M. Jiménez y Arias, estructura y Miguel Noreña escultura, Monumento a Cuauhtémoc, 1887, México, D.F.

Este magno monumento es una verdadera obra neoindígena de gran calidad artística, en especial la base, pues con su acentuado geometrismo es un antecedente de las tendencias que más tarde imperarán en las primeras décadas del siglo XX y que alimentaron al Déco, además de convertirse en un fuerte ejemplo de representatividad del mundo indígena, con el cual se identificaban (y aún se identifican) los mexicanos de esa época. Por su composición, tal pareciera que fue hecha en años posteriores.

Otro caso podría ser las esculturas conocidas como Los Indios Verdes, de Alejandro Casarín (h.1840-1907), erigidas en 1891. También sobre un pedestal geométrico que trata de representar una abstracción de una pirámide prehispánica, se levantan dos esculturas individuales de los "tlatoanis" mexicas Izcóatl y Ahuízotl. Aunque desde que fueron develados causaron crítica adversa y han sido movidos de lugar varias veces, sin embargo, para muchos habitantes de la ciudad de México conformaron un icono sobre los tipos indígenas. 
Al citar estos ejemplos no queremos decir que hayan sido las únicas influencias que sobre el mundo prehispánico se tomaron para el Art Déco en México, sino que ya había un fuerte referente indigenista para esos años y algunas de esas imágenes pudieron servir de inspiración. Más adelante explicaremos las características decorativas de tipo prehispánico aplicadas a la arquitectura y que a la vez nos servirán para otro tipo de manifestaciones del Déco.

Los trabajos de campo en las zonas arqueológicas fue otra de las vertientes de influencias de lo prehispánico, pues con la llegada de expedicionarios extranjeros a nuestro país, durante el porfiriato y más tarde en los años postrevolucionarios se hicieron estudios y exploraciones por parte de antropólogos mexicanos.

Durante el porfiriato fue la figura de Leopoldo Batres (1852-1926) la que destacó la iniciativa de la arqueología en México. Después de estudiar en París, a su regreso fue comisionado por el Presidente Porfirio Díaz (1830-1915) para explorar Teotihuacán entre 1884-1888 y más tarde en 1905 y 1910. También exploró Monte Albán y Mitla en Oaxaca, La Quemada en Zacatecas, la Isla de Sacrificios en Veracruz y Xochicalco en Morelos. Sus más distintivas investigaciones fueron las de Teotihuacán, Estado de México, donde reconstruyó la Pirámide del Sol, cambiándole su composición original; sin embargo, en Teotihuacán construyó el primer museo de sitio y un buen número de los objetos excavados fueron trasladados a la ciudad de México y depositados en el Museo Nacional, mediante un ferrocarril tendido desde la zona arqueológica. Producto de sus trabajos arqueológicos publicó los libros Cuadro arqueológico y etnográfico de la República Mexicana, 1885, Exploraciones de Monte Albán, 1902, Teotihuacán, 1906, entre otros.

Más tarde, en los años de la fase armada de la Revolución Mexicana, Manuel Gamio (1883-1960) fue una figura central para el desarrollo de la arqueología en el país. Entre muchas de sus importantes actividades, dirigió una investigación sobre la población del valle de Teotihuacán entre 1917 a 1922, para lo cual contrató como dibujante para hacer los retratos de los pobladores al pintor Francisco Goitia (1882-1960). Entre esos mismos años intervino en el edificio conocido como La Ciudadela y en el Templo de Quetzalcóatl, con lo que contribuyó a dar más luz sobre dicha cultura. 


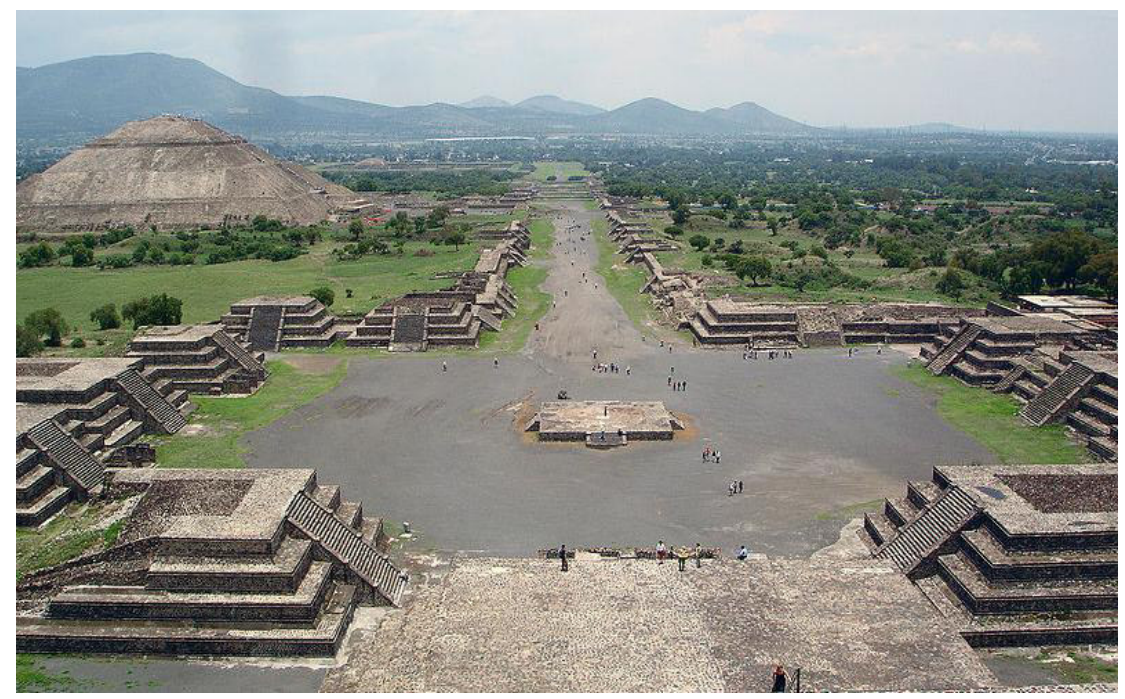

Teotihuacán, Estado de México. ${ }^{62}$

Pero hay una aportación más de Gamio que lo consagra en el campo de la arqueología y fueron sus trabajos en las ruinas del Templo Mayor de México-Tenochtitlan, pues a raíz de obras de drenaje que se realizaban entre las calles de Tacuba y Guatemala, allá por el año de 1900, se encontraron restos arqueológicos que trece años más tarde fueron excavados por Gamio. Desenterró, además de piezas, una escalinata perteneciente al templo de Huitzilopochtli y cabezas de serpiente del muro llamado el Coatepantli. Este hallazgo contribuyó a que el interés por lo mexica o azteca se pusiera de moda tanto en México como en el extranjero, aparte que años atrás exploradores extranjeros ya habían trabajado en el país. ${ }^{63}$

A Gamio se le debe también una gran revaloración del arte prehispánico, al cual consideraba como una fuente de identidad y patriotismo, además de que visualizaba que ese arte había sido creado por los nativos de estas tierras y era una manifestación no importada de Europa, ideas que manifestó en su obra Forjando Patria. En relación con estas ideas, Rita Eder puntualiza que “... aún para 1916, Manuel Gamio intentaba desembarazarse del peso de la tradición estética modelada por los cánones clásicos europeos, y tenía la inquietud de pensar en otros parámetros estéticos para evaluar la producción artística de las

\footnotetext{
62 "Teotihuacán", http://www.historiacultural.com/2010/10/cultura-teotihuacana.html

${ }^{63}$ Los datos sobre los exploradores que trabajaron en diversos sitios arqueológicos de México fueron obtenidos de Roberto García Moll y Jaime Bali Wuest, México Arqueológico, México, Salvat, 1988.
} 
culturas prehispánicas. Se trata de una nueva valorización teórica, de una nueva aproximación al arte de un pueblo de tradición no-occidental". ${ }^{4}$

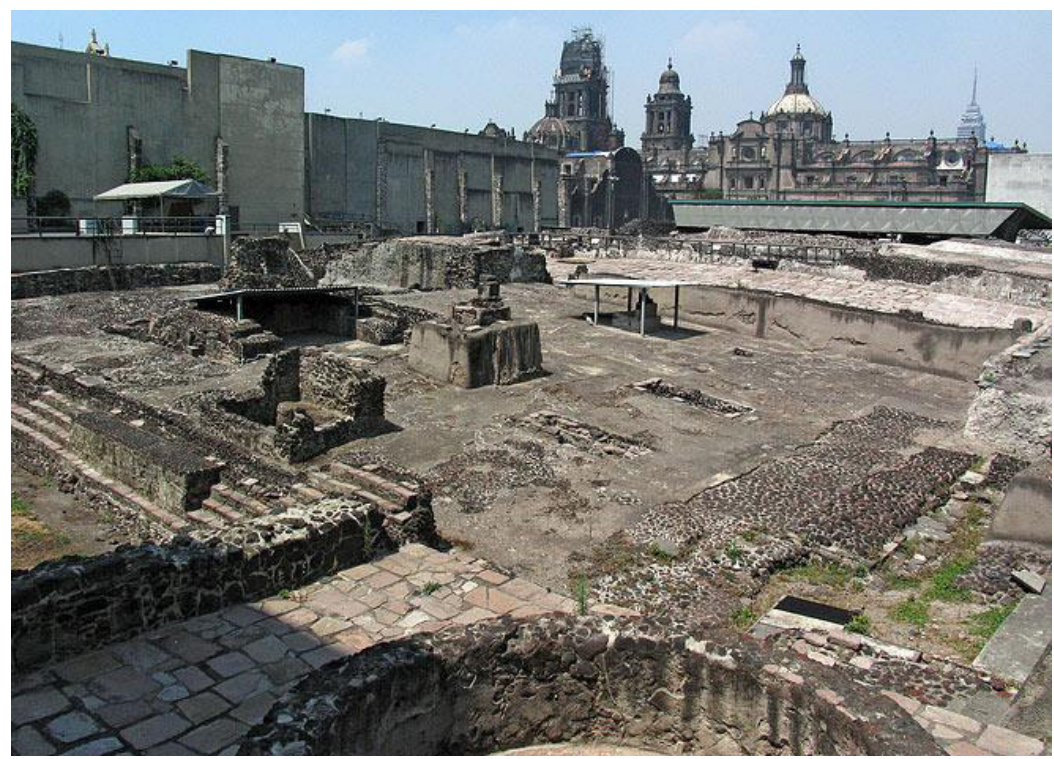

El Templo Mayor, México, D.F.65

Dentro de los mexicanos que en los años de la postrevolución trabajaron en zonas arqueológicas están Eduardo Martínez Cantón, que hacia 1926 estuvo en Chichén-Itzá, Yucatán; Eduardo Noguera Auza (1896-1977) y Miguel Ángel Fernández (1890-1945), ambos estuvieron en Palenque, Chiapas: el primero en 1926 y el segundo entre 1934 a 1945.

La figura de Noguera es muy importante para el desarrollo del estudio de las culturas mesoamericanas, pues entre los años de nuestro estudio publicó Ruinas de Tizatlán, 1927, Ruinas arqueológicas del norte de México: Casas Grandes, La Quemada, Chalchihuites, 1930, El altar de los cráneos esculpidos de Cholula, 1937, Cultura tarasca, 1939, entre otras. En Tulum, Quintana Roo, trabajaron en 1937 el mismo Miguel Ángel Fernández y el escultor colombiano Rómulo Rozo (1899-1964).

\footnotetext{
${ }^{64}$ Rita Eder, "Las imágenes de lo prehispánico y su significación en el debate del nacionalismo cultural”, en: El nacionalismo y el arte mexicano (IX Coloquio de Historia del Arte), México, UNAM, Instituto de Investigaciones Estéticas, 1986, p. 73.

${ }^{65}$ Universes in Universi, "México Art Destinations. Mexico/Culturas Antiguas/Templo Mayor/http://universes-in-universe.org/esp/art_destinations/mexico/tour/templo_mayor/01
} 


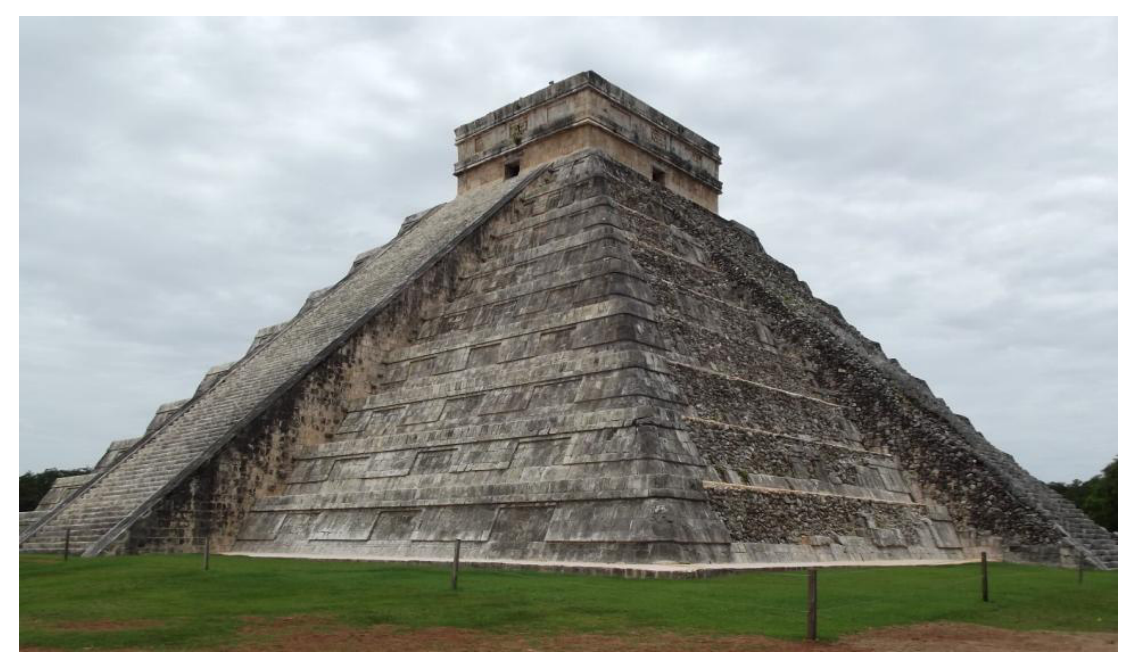

El Castillo, Chichen-Itzá, Yucatán.

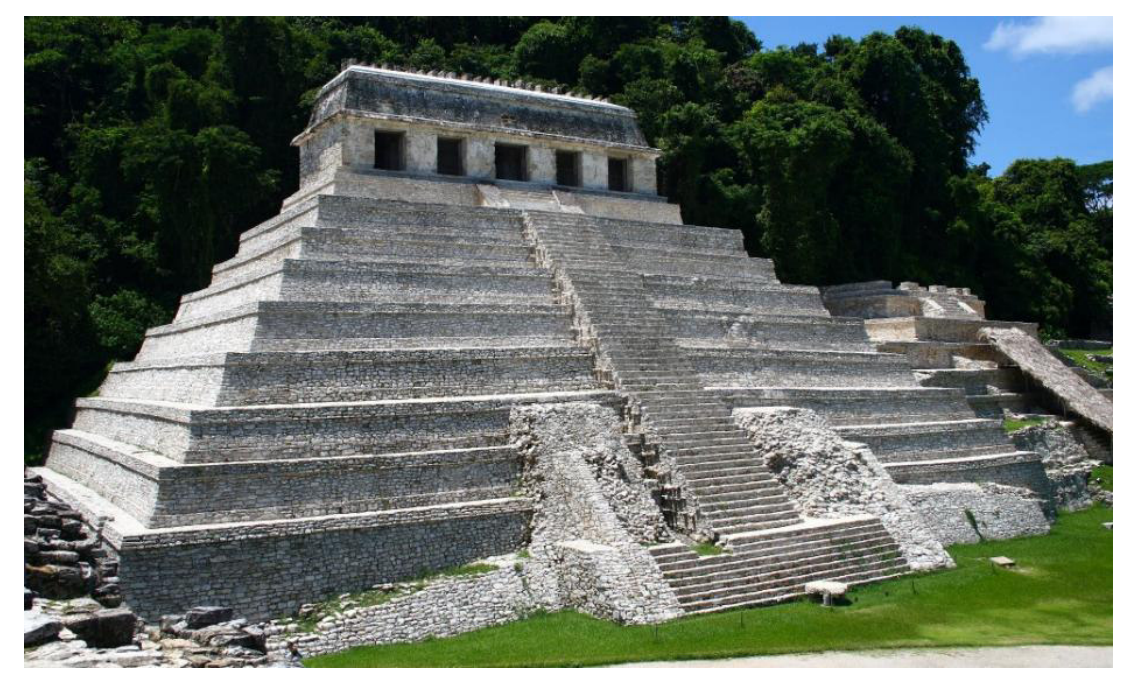

Templo de las Inscrpciones, Palenque, Chiapas. ${ }^{66}$

En Monte Albán, Oaxaca, serán de gran importancia las excavaciones iniciadas en 1931 por Alfonso Caso (1896-1970), lugar donde laboraría por doce años, dando a conocer importantes hallazgos de la cultura zapoteca como fue el tesoro de la Tumba 7 en 1932, así como la reconstrucción de la gran ciudad; cabe mencionar que Caso estuvo al frente del Museo Nacional de Arqueología, Historia y Etnografía de 1933 a 1934, entre muchos otros cargos. Es importante señalar que Ignacio Bernal (1910-1991) estuvo en las primeras exploraciones de Monte Albán, lo mismo que Jorge R. Acosta (1904 ó 1908-1975).

\footnotetext{
${ }^{66}$ Destinos Turísticos de México, "Palenque, Chiapas", http://www.mexplora.com/destinos_mexico/destino.php?id=2600
} 


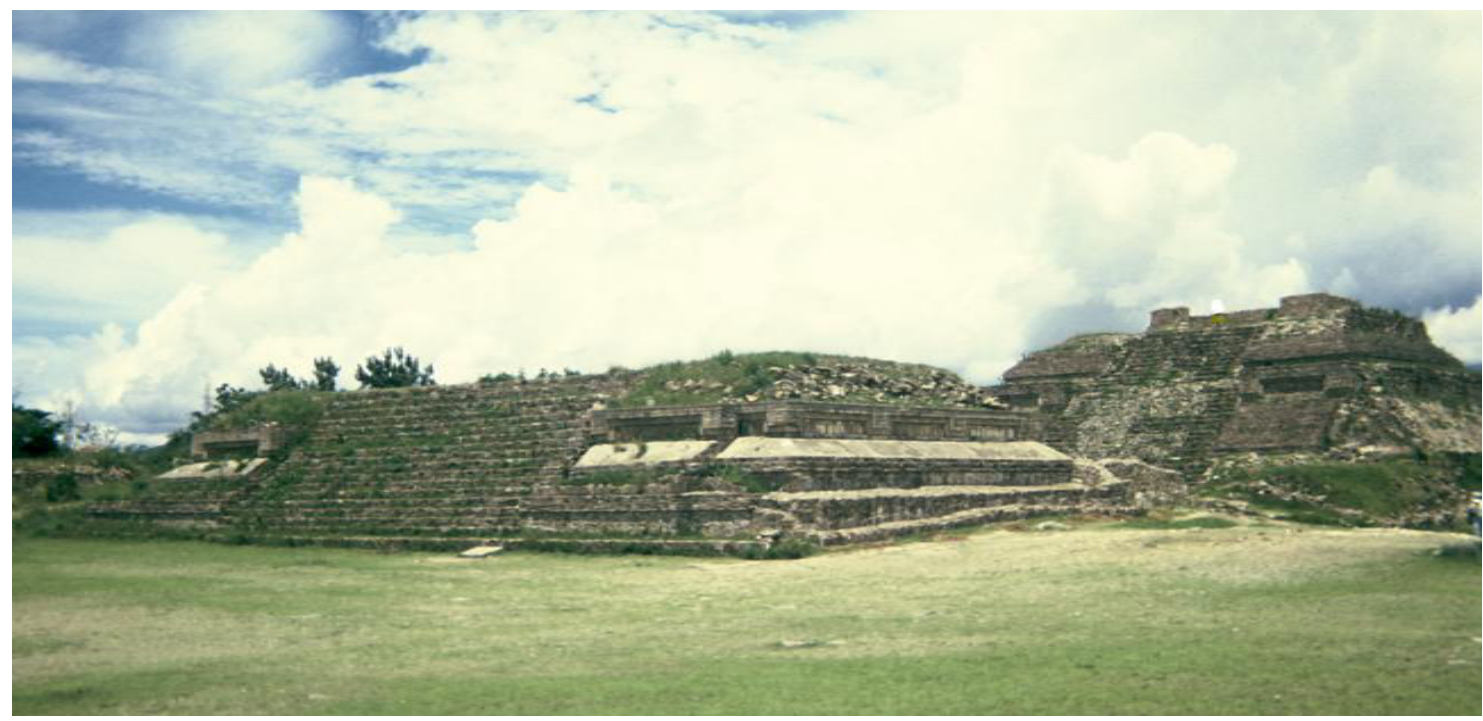

Estructura IV, Monte Albán, Oaxaca. El tablero doble escapulario tendrá mucha influencia en el Art Déco.

Otra de las culturas prehispánicas estudiadas en los tiempos del Déco fue la Tolteca por medio de Wigberto Jiménez Moreno (1909-1985), pues en 1934 fue comisionado para reunir material en la zona arqueológica de Tula, en el estado de Hidalgo, de donde surgió su libro Tula y los toltecas, de 1941.

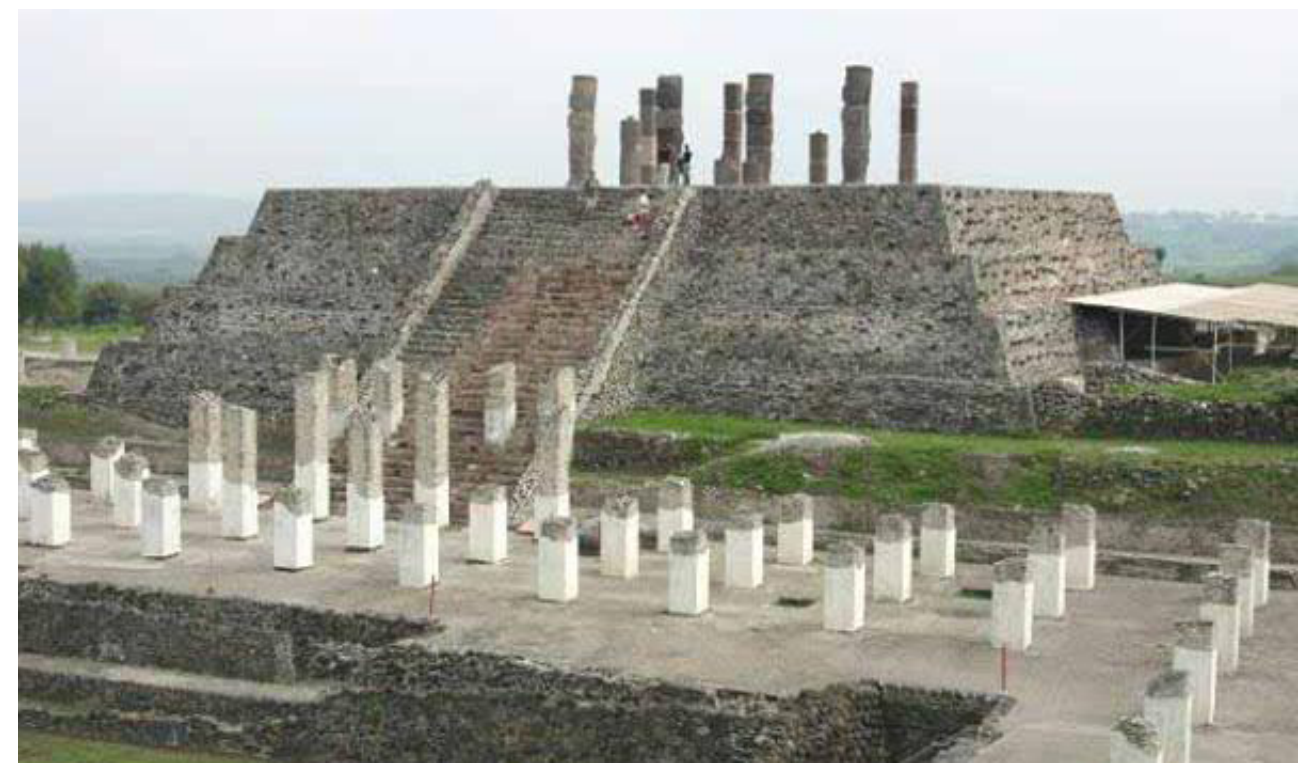

Templo de Tlahuizcalpantecuhtli, Tula, Hidalgo. ${ }^{67}$

\footnotetext{
${ }^{67}$ Maravillas Arquitectónicas, "México”, http://perso.wanadoo.es/berethor07/mexico.htm
} 
Con los aludidos exploradores y arqueólogos mexicanos y con las obras artísticas que se desarrollaron en el siglo XIX, queremos recalcar que para los años del Art Déco en México, ya había bastante información arqueológica, especialmente de los mayas, así como de los mexicas o aztecas; por lo tanto, uno de los caminos de la búsqueda de la identidad nacional de la postrevolución fue el mundo indígena prehispánico, pues éste se puso de moda, combinándose con la modernidad del Déco.

La otra vereda de influencias prehispánicas, la externa, se abrió por medio de exploradores extranjeros que se sintieron atraídos principalmente por dos civilizaciones mesoamericanas que mucho sirvieron como modelo y de las cuales se tomaron elementos para aplicarlos al Art Déco tanto de México como de Estados Unidos: el mundo maya y el mexica, bajo la nominación de azteca.

Sobre el mundo maya tan sólo tomemos en cuenta que desde la publicación de Incidents of Travel in Central America, Chiapas and Yucatán del año 1841, con las memorias del norteamericano John L. Stephens (1805-1852) y los insuperables e inigualables dibujos del inglés Frederick Catherwood (1799-1854) plasmados en litografías, despertó en Estados Unidos y Europa un fuerte interés por la cultura maya, tanto así que ese mismo trabajo sirvió de guía para viajeros extranjeros posteriores y para mismos mexicanos que incursionaban en la zona.

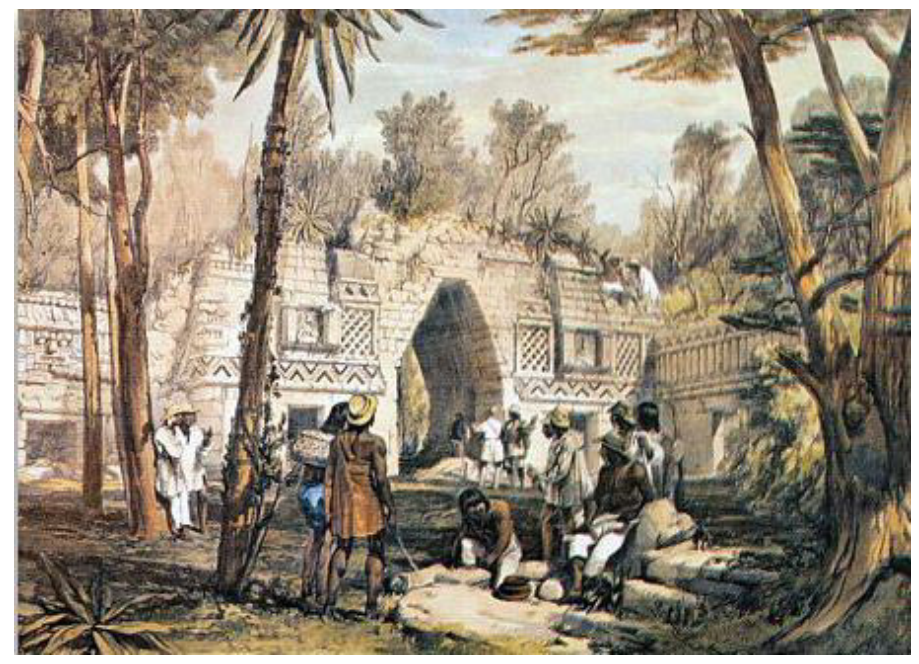

Frederick Catherwood, Arco de Labná, $1841 .{ }^{68}$

\footnotetext{
${ }^{68}$ Fausto Ramírez, "La visión europea de la América Tropical: los artistas viajeros", Historia del Arte Mexicano, México, SEP, Salvat, 1986, 2ª ., edición, vol. 10, p.1390.
} 
Algunas de las importantes personalidades que a finales del siglo XIX exploraron la zona maya fue el francés Desiré Charnay (1828-1915), quien hizo varias visitas a nuestro país entre 1857 y 1886, recorriendo diversos sitios arqueológicos de México. Libros suyos que tuvieron un gran impacto en Europa fueron Les anciennes villes du Nouveau Monde, 1885, y Ma dernier voyage, 1881, que narra sus experiencias en su viaje por Yucatán, trabajos que se convirtieron en su época como importantes documentos sobre los mayas de México. Otro de esos intrépidos viajeros fue el inglés Alfred Percival Maudslay (18501931), quien estuvo por México, Guatemala y Honduras entre los años 1881 a 1895 y compartió algunos recorridos con Charnay; las descripciones de los sitios mayas que él realizó tanto de México como de los otros países, se dieron a conocer en la Biología Centrali-Americana, 1879-1915, en los cinco últimos volúmenes. Uno más de los exploradores fue el alemán, aunque nacido en Italia y más tarde naturalizado austriaco, Teobert Maler (1842-1917), quien llegó a México como soldado en 1865, pero con la caída del Imperio de Maximiliano se quedará a residir en el país; desde 1895 y hasta 1911 expediciona por las tierras mayas, cuyos informes, de gran calidad y actualidad hasta la fecha, fueron publicados por el Peabody Museum en la serie de Memories. ${ }^{69}$

Otros de los importantes exploradores fueron el estadounidense Sylvanus Griswold Morley (1883-1948) y el inglés John Eric Sidney Thompson (1898-1975); este último desde 1926 está trabajando con el equipo de arqueólogos en Chichén-Itzá, auspiciados por el Instituto Carnegie de Washington. De los tiempos que corresponden al Art Déco está su obra The Civilation of the Mayas de $1927 .^{70}$

Hubo muchos más exploradores que trabajaron en diversas zonas del país, especialmente en el área maya. Entre algunos de ellos estuvieron William Henry Holmes (1846-1933), norteamericano quien en 1895 exploró Chichén-Itzá, Uxmal y Palenque y en 1897 al describir los sitios arqueológicos que él visitó hace mención de Monte Albán en Oaxaca y de la zona de Teotihuacan. El danés Frans Blom (1893-1963) quien fue

\footnotetext{
69 "Viajeros en el Usumacinta", Arqueología Mexicana, vol. IV, No. 22, noviembre-diciembre de 1996, pp. 30-35. En este artículo indican que los datos fueron obtenidos del libro de Roberto García Moll y Daniel Juárez Cossío, Yaxchilán: antología de su descubrimiento y estudios, México, INAH, 1990 (Colección Científica, 152).

${ }^{70}$ Adriana Velázquez, "Eric Thompson: “¿Quién soy entre el pueblo de los putunes?”, Arqueología Mexicana, vol. II, No. 11, enero-febrero de 1995, pp. 50-54.
} 
contratado en 1923 por el gobierno mexicano para trabajar en Palenque y entre 1929 y 1930 en Uxmal. Samuel Kirkland Lothrop (1893-1965), también norteamericano, estuvo entre 1916 y 1922 al lado de Morley en las excavaciones de Tulum. Eduard George Seler (18491922), de origen alemán, realizó algunos estudios de Uxmal a principios del siglo XX. En Teotihuacan, en 1924, laboró el arqueólogo sueco Sigvald Linné. El ya mencionado Desiré Charnay, quien además de estar en la zona maya, también trabajó en Tula, Hidalgo, hacia 1888. Y el ya citado Alfred Maudslay colaboró con Leopoldo Batres en la ubicación del Templo Mayor de Tenochtitlán.

Además, los años revolucionarios de la Fase Armada y luego los del Caudillaje hicieron que México fuera foco de atención en Europa, especialmente en Francia, y en los Estados Unidos, ya que en el país de América que se había distinguido por su estabilidad política por más de 30 años y cuyo gobierno progresista había importando de su vecino del Norte y Francia tecnología, educación, modas y en sí, estilos de vida para las elites, tenía una vastísimo patrimonio prehispánico prácticamente desconocido por sus propios habitantes y altamente valorado por los foráneos. Así pues, en palabras de Felipe García Beraza: "resulta sorprendente que la Revolución Mexicana tuvo una floración artísticas en el París de los veintes. Es decir, que en última instancia Pancho Villa y Emiliano Zapata, entre otros adalides de la Revolución Armada, hicieron que el nombre de México repercutiera de tal modo en Europa y durante tan largo tiempo, que al fin lograron despertar interés por este misterioso y lejano país donde los generales tenían descomunales bigotes y donde siglos antes habían surgido civilizaciones de grandes y exquisitos refinamientos. Si esto es verdad, habría que convenir que el Arte Prehispánico cautivó las mentes europeas y norteamericanas. ¿Fue mera coincidencia el hecho de que el Art-Decó utilizara la abstracciones geométricas tal como lo hicieron nuestros antepasados indígenas? o, ¿fue el interés tan hondo y tan profundo del europeo y del norteamericano por nuestro país, en aquellos años fulgurantes de este siglo, que se dedicaron a estudiar y a sentir el pasado artístico de México?". ${ }^{71}$ Si bien, ya el interés por el país y su gran legado prehispánico venía dándose desde mediados del siglo XIX, la Revolución alentó todavía más a los extranjeros a conocer las grandes herencias indígenas y el hecho de incorporar los

\footnotetext{
${ }^{71}$ Felipe García Beraza, “A propósito de esta exposición”, Catálogo de la exposición El Art Deco en México, Op. Cit., pp. 5-6.
} 
elementos decorativos de las grandes culturas mesoamericanas como la teotihuacana, la zapoteca, la totonaca, la maya, la tolteca o la mexica fue porque su geometrismo y exotismo quedaba en estrecha relación con los postulados estéticos que se valoraban en esos años del Déco de culturas pasadas y autóctonas.

Aunque hubo exploradores y estudiosos tanto europeos como norteamericanos en el país, fue principalmente en Estados Unidos, dada la cercanía geográfica, donde la pasión por el exotismo de las zonas arqueológicas de México se volcó en las decoraciones de edificios y diseños en los años del desarrollo del Déco. A pesar de ser mexicana, tal fuerza tuvo esta tendencia que vía Estados Unidos llegó la influencia a nuestro país de lo maya y lo "azteca" aplicado a la arquitectura y que es parte lo que consideramos como la vereda externa por donde llegaron las imágenes prehispánicas.

En relación con lo anterior Jorge $\mathrm{H}$. Jiménez en el ya referido trabajo Las condiciones materiales de realización de la arquitectura del art-déco, esclarece que en el Déco lo prehispánico tuvo mucha utilización en los decorados, pues éstos fueron dedicados en múltiples construcciones de esa época en Estados Unidos: "El prehispánico encontró en el Art Déco su expresión más refinada, ya que en Estados Unidos, con el estilo Pradera, se había experimentado la integración de los avances tecnológicos con detalles artesanales. Dentro de estos detalles artesanales escogidos por los arquitectos de aquel país se encontraba el rescate de los decorados prehispánicos". ${ }^{72}$

Xavier Esqueda en su antedicho libro Art Deco. Retrato de una época, nos da importantísimas relaciones bibliográficas y de edificios sobre las construcciones Déco en Estados Unidos que fueron trabajadas con referencias prehispánicas. Al respecto del cine nos dice que en Hollywood hubo escenografías que utilizaron "hasta los palacios mismos que fueron construidos para la proyección de las películas a manera de palacios barrocos, templos egipcios, mayas, aztecas". 73

En el subcapítulo "México en el Art Deco”, Esqueda alude a que: "En todos los libros escritos sobre art deco siempre se menciona la influencia del maya y el azteca sobre

\footnotetext{
${ }^{72}$ Jorge H. Jiménez, Op. Cit., p. 121.

${ }^{73}$ Xavier Esqueda, Art Déco. Retrato de una época, México, Op. Cit., p. 78.
} 
el estilo, pero en especial sobresalen los libros de Bevis Hillier". ${ }^{74}$ Más adelante advierte que en Estados Unidos hay una fuerte influencia azteca en el edificio de la McGraw-Hill Building de New York, ahora Group Health Inc., ${ }^{75}$ obra de Raymond Hood (1881-1934) en colaboración con el arquitecto francés André Fouilhoux (1879-1945), construido de 1930 a 1931, con 34 pisos. Sobre Hood y este edificio, Alastair Duncan dice que: "Ningún otro arquitecto contemporáneo mostró tal versatilidad, o bravura". ${ }^{76}$

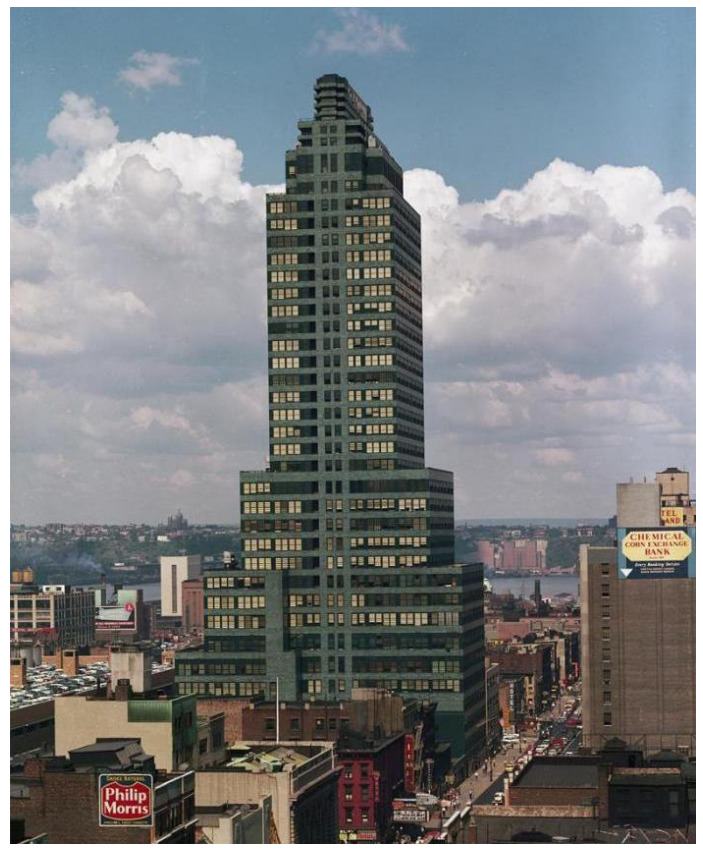

Raymon Hood y André Fouilhoux, McGraw-Hill Building New, York, 1931.77

Uno de los que mucho contribuyeron con la expansión de los motivos prehispánicos, especialmente los mayas, fue Frank Lloyd Wrigth (1867-1959), quien en la zona de Los Angeles, edificó algunas casas a las que integró motivos decorativos prehispánicos: la casa Barnsdall (Hollyhock), 1917-1920, con elementos mayas y zapotecas colocados a manera de una serie de pináculos o acróteras en cornisas que rodeaban los

\footnotetext{
${ }^{74}$ Ídem. Esqueda cita los libros de Bevis Hillier, Art Deco, Londres, Studio Vista, 1968 y The World of Art Deco, catálogo para la exposición en The Minneapolis Institute of Arts, New York, E.P. Dut Ton and Co., Inc., New York, 1971.

${ }^{75}$ Ídem.

${ }^{76}$ Alastair Duncan (Ed.), The Encyclopedia of ART DECO, Londres, Quantum Books, 1988, p. 16, al hablar del edificio y su constructor, curiosamente no da las fechas de construcción.

${ }^{77}$ Docomo_us, "McGraw-Hill Building", http://www.docomomo-us.org/register/fiche/mcgrawhill_building
} 
límpidos muros, aunque Judith Dunham, sólo habla de motivos precolombinos, sin especificar su procedencia: "Evocación de Wright de la monumentalidad e imaginería precolombina". ${ }^{78}$ la casa Millard en Pasadena, 1921-1923, conocida popularmente como “La Miniatura” fue levantada con estructuras prefabricadas llamadas por el propio Wright como "textile block" ${ }^{79}$, con cuadros que encierran espirales geométricas rememorando el estilo Puиc de Yucatán; la casa Storer de 1923, donde también utilizó las estructuras prefabricadas con decorados mayas, lo mismo que en la monumental Ennis, 1924, con vista panorámica hacia la ciudad de Los Angeles, con la cual finaliza su serie de casas con influencias mayas.

Sobre estas casas construidas con "textile block", Kenneth Frampton dice: "Todas estas residencias están ahora, pero la Casa Storer es única en el cuidado excepcional con el que ha sido restaurada en su condición original por su propietario actual". ${ }^{80}$

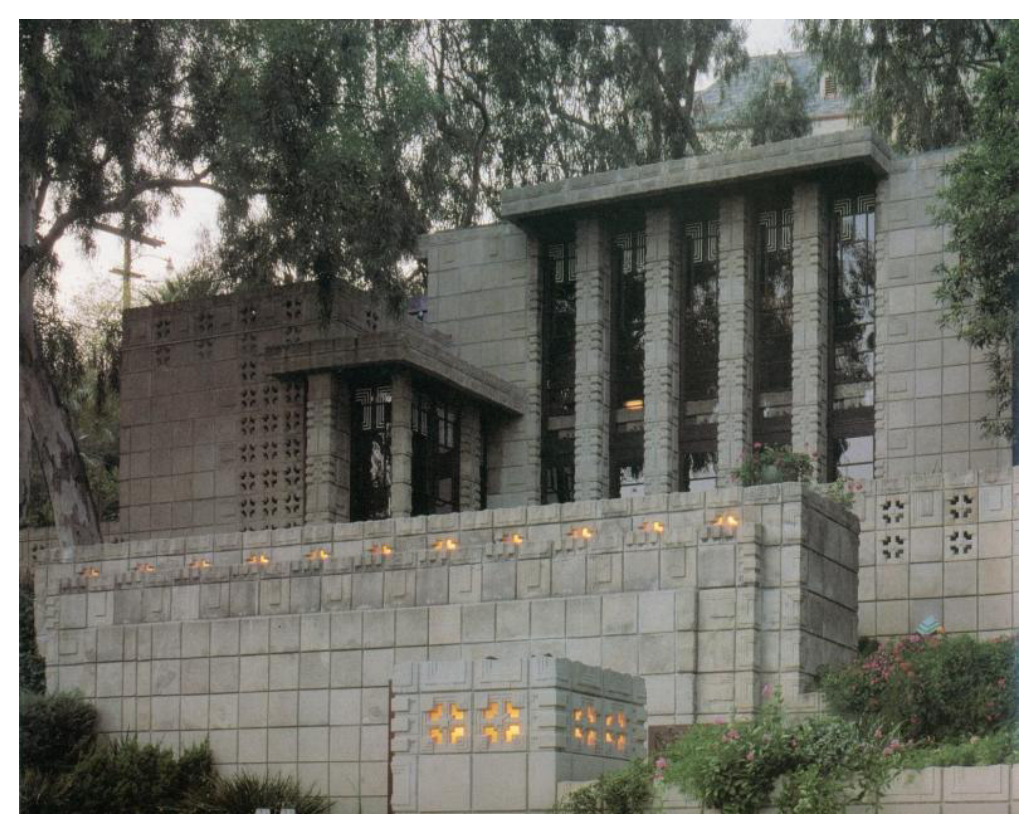

Frank Lloyd Wright, Storer House, Hollywood, $1923 .{ }^{81}$

\footnotetext{
${ }^{78}$ Judith Dunham, Details of Frank Lloyd Wright. The California Work, 1909-1974, San Francisco, Chronicle Book, 1994, p. 26.

${ }^{79}$ Robert McCarter, Frank Lloyd Wright, London, Phaidon, 1999, p. 163.

${ }^{80}$ Kenneth Frampton, American Masterworks, New York, Rizzoli, 1995, p. 36.

${ }^{81}$ Ibídem, p. 34.
} 
En San Francisco, California, destacó el arquitecto Timothy Ludwig Pflueger (1892-1946) quien pertenecía a la firma J.R. Miller (James Rupert Miller ,1869-1946) \& T. L. Pflueger. Más conocido por el Oakland Paramount Theatre, 1931, Pflueger diseñó un soberbio edificio con abundantes motivos mayas en el Medico-Dental Building de 1930, ubicado en el 450 Sutter Street. Therese Poletti explica la razón de por qué Pflueger escogió ese tipo de diseños para su edificio: "Pfueger escogió un inusual tema para 450 Sutter, la antigua cultura Maya. Él posiblemente estaba familiarizado con el Aztec Hotel de 1925 diseñado por Robert Stacy-Judd cerca de Los Angeles. Como Stacy-Judd, Pflueger usó formas parecidas a los jeroglíficos mayas. Stacy-Judd y unos pocos arquitectos habían tratado de evangelizar con diseños mayas o precolombinos como una única fuente para la arquitectura moderna norteamericana, otro camino para refutar la clasicista relación con los diseños europeos. Los mayas fueron conocidos por sus estupendas características arquitectónicas de palacios y tumbas. Sus templos de plataformas de piedra fueron los rascacielos del mundo antiguo. Entre la promoción del tema mesoamericano del hotel y los descubrimientos de ruinas mayas en la península de Yucatán en 1926, Pflueger estaba pleno en la búsqueda exótica de influencias no europeas para su próximo rascacielos". ${ }^{82}$

Desde la entrada al lujoso centro médico dental, los motivos mayas en placas de terracota se hacen aparecer en un verdadero hórror vacui. Una marquesina de cuatro partes y apuntando hacia fuera resguarda la entrada; sin embargo, por encima de la entrada, una celosía conlleva motivos pero mexicas o aztecas, lo mismo que en la parte interna de la trabe, donde en un relieve octagonal, el adorno es el universo mexica de los cuatro soles y una grande espinal de maguey. Todo el rascacielos está adornado con motivos indigenistas: el exterior en los entrepaños, la entrada, el "lobby", lámparas, techos, puertas de elevadores, aunque dentro de la inspiración maya encontramos los decorados mexicas. Esto sucedió, seguramente, a que aún no había una clara definición de los decorados en los aficionados extranjeros a los ornatos mesoamericanos y mezclaban unos con otros con el fin de darle a sus diseños un toque de exoticidad prehispánica.

Pflueger fue un arquitecto que estuvo imbuido dentro del Déco, aunque no fue su única vertiente, y fue notable su participación como asesor del Comité en la Golden Gate

\footnotetext{
${ }^{82}$ Therese Polleti, Art Deco San Francisco. The Architecture of Timothy Pflueger, New York, Princeton Architectural Press, 2008, pp. 79-80.
} 
International Exposition de San Francisco en 1939, una de las últimas manifestaciones feriales del Art Déco.
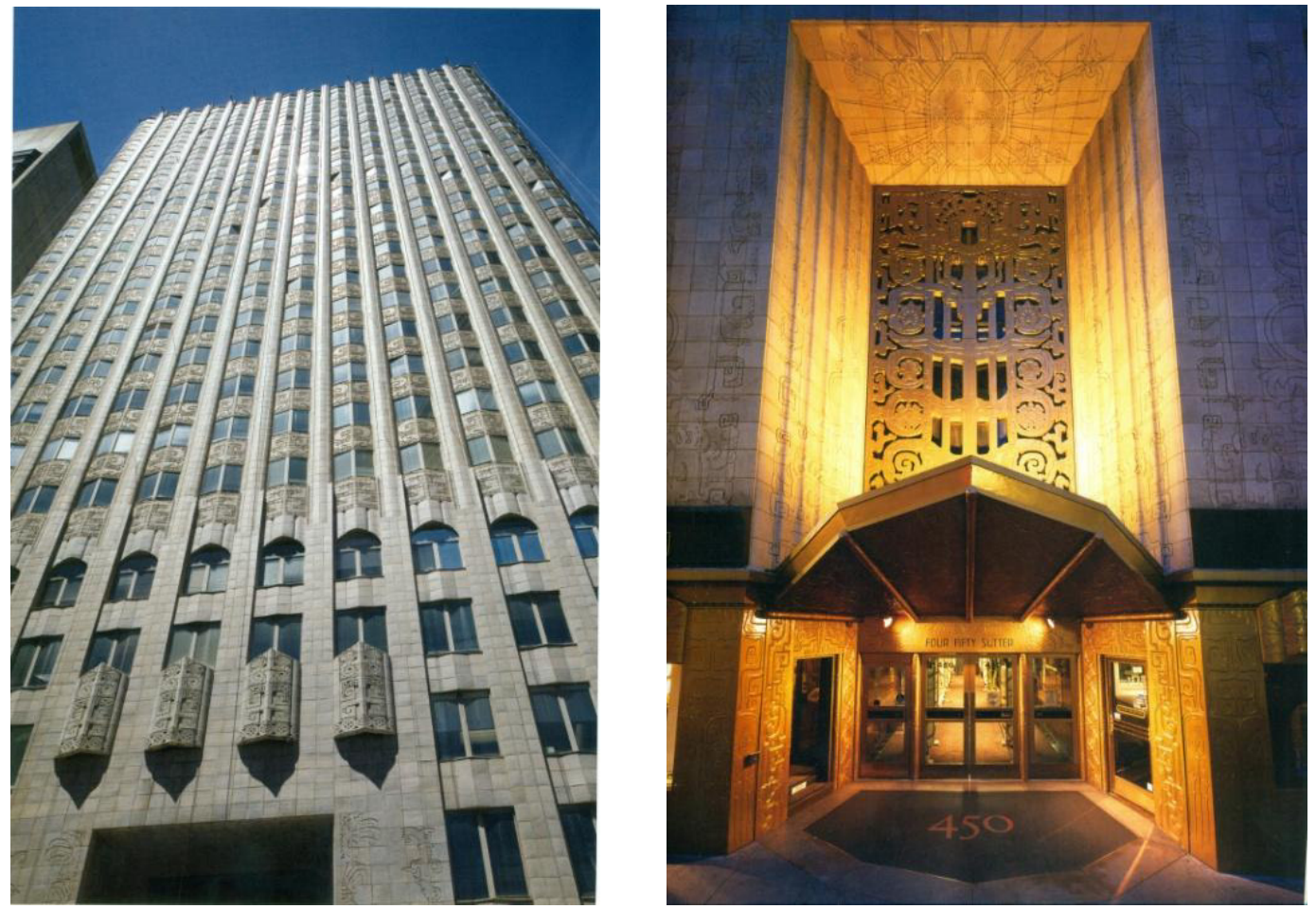

Timothy Pflueger, Medico-Dental Building, San Francisco, Cal., 1930. En la segunda imagen, en la parte interior de la trabe es donde lleva un adorno mexica y no maya. ${ }^{83}$

Por su parte, en el sur de California se desarrolló fuertemente el Déco con influencias mesoamericanas, pero especialmente lo maya y azteca. Fue el ya mencionado arquitecto de origen inglés Robert Benjamin Stacey-Judd (1884-1975) uno de los principales impulsores con obras tales como el Aztec Hotel de 1925 en Monrovia, un edificio de una planta, ricamente adorando con motivos mayas y mexicas, elaborados con cemento, en donde hasta las letras de la entrada fueron diseñadas inspirándose en la floresta de las culturas mesoamericanas. El color de todo el exterior trata de asemejar a la piedra clara utilizada en las construcciones mayas.

En la esquina del boulevard West Foothill y la avenida Magnolia, donde se localiza el Aztec Hotel, Stacy-Judd parodia una plataforma prehispánica con una galería de balaustres prismáticos, que pueden ser de cualquier cultura mesoamericana del periodo postclásico, pero que en aquella época todo podría ser maya o mexica.

\footnotetext{
${ }^{83}$ Ibídem, pp. 75 y 77.
} 


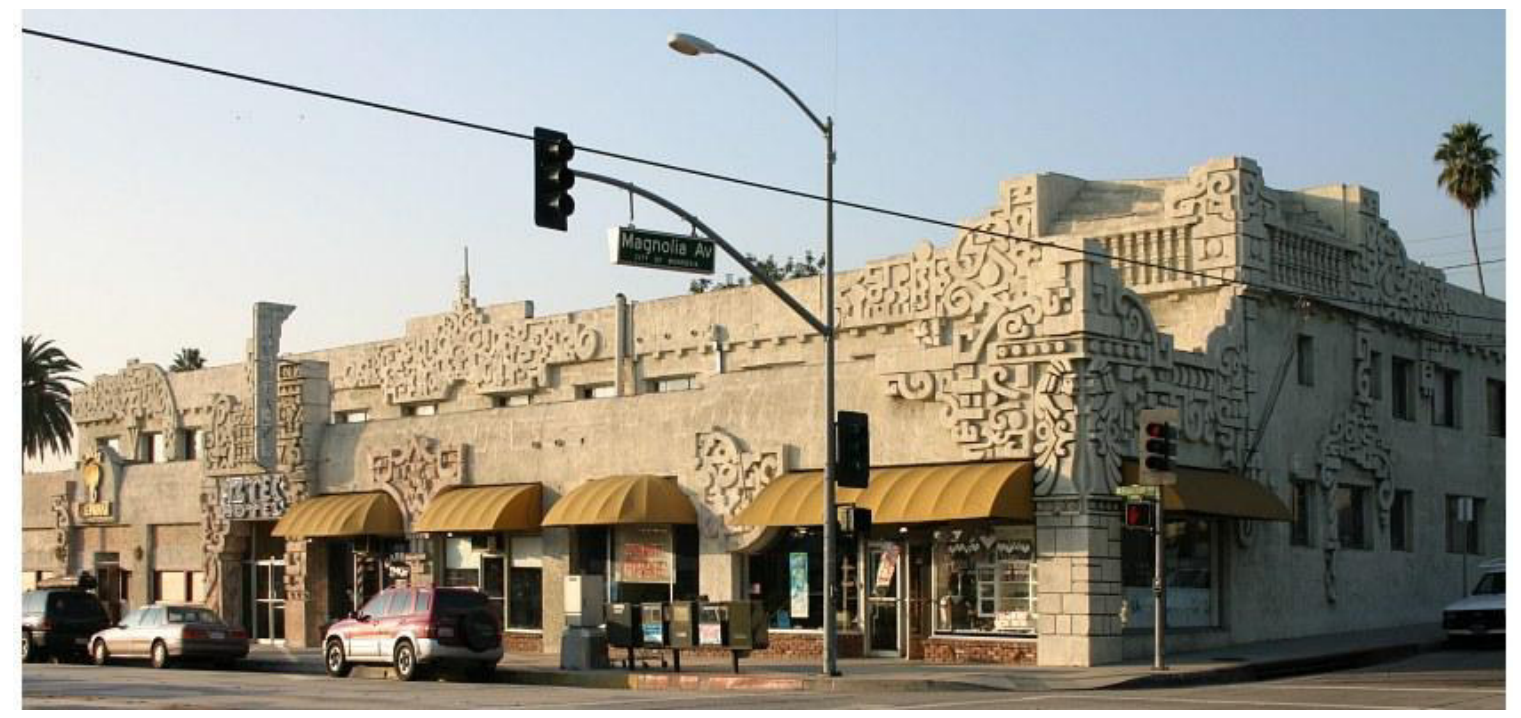

Robert Sacy-Judd, Aztec Hotel, Morovia, Cal., 1925. ${ }^{84}$

Una combinación entre lo gótico y lo maya Satcy-Judd lo consiguió en la First Baptist Church en Ventura, obra de 1926 que fue redecorada en 1932, de la cual Enrique de Anda al referir su propuesta de la "Tendencia Ecléctico-Mayista" para el Déco en la ciudad de México en su libro de La Arquitectura de la Revolución Mexicana, comenta como una hipótesis que tal vez este edificio pudo ser una de las influencias del neomaya californiano que llegaron a México; al respecto de la construcción apunta: “...la figura triangular más que hacer referencia a la silueta piramidal, alude a la forma peculiar del "arco falso maya" con sus características paredes inclinadas la una frente a la otra y cerramiento adintelado... Otros hechos sobresalientes dentro de la geometría del edificio son: los recortes dentellonados tanto del pilón como de uno de los volúmenes inferiores, circunstancia que alude a una marcada intención de rescatar la silueta de la pirámide maya del Castillo de Kukulkán en Chichén-Itzá”. ${ }^{85}$ En la entrada en donde más se aprecia el uso de la figura triangular a la que hace referencia De Anda, pues esa intención de reproducir el arco maya, se repite en varias superposiciones y el mismo tipo de arco se repite en una capilla lateral.

\footnotetext{
84 “Aztec Hotel 1924 architect Robert Stacy-Judd, http://www.you-are-here.com/building/aztec_hotel.html

${ }^{85}$ Enrique X., de Anda, La arquitectura de la Revolución Mexicana. Corrientes y estilos de la década de los veintes, Op. Cit., p. 141.
} 
Cuando Stacy-Judd termina esta construcción, el había hecho un viaje por Yucatán en 1930 del cual regresará fascinado.

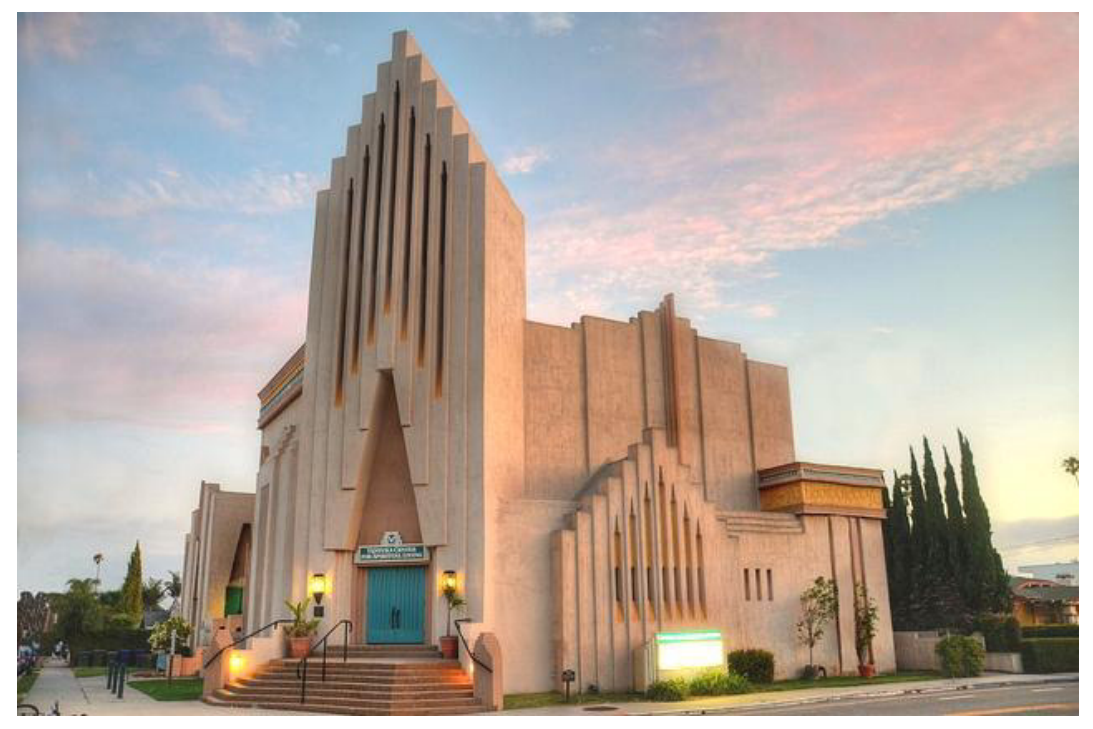

Robert Stacyy-Judd, First Baptist Church, Ventura, Cal., $1932 .{ }^{86}$

Otro caso en la misma región fue el de los arquitectos Octavius Morgan, John A. Walls y Stiles Oliver Clements (1883-1966), quienes fundaron una firma constructora con sus apellidos, Morgan, Walls \& Clements, e hicieron varias obras Art Déco en Estados Unidos con decoraciones de influencias prehispánicas, entre las cuales realizaron en 1927 una fastuosa obra en Los Angeles llamada Mayan Theatre bajo el diseño de Clemens y la fachada e interior decorados por el artista mexicano Francisco Cornejo (1892-1963). ${ }^{87}$ En el libro Movie Palaces, $1980,{ }^{88}$ realizado por Ave Pildas con textos de Lucinda Smith y prefacio del cineasta King Vidor (1894-1982) se dice de este teatro: “...caracteriza lo maya de Los Angeles con una inmensa fachada en terracota, la cual fue pintada para parecerse a una ruina de Yucatán. El innovador uso de pinturas utilizadas le dan una apariencia de antiguo, lo cual da la impresión de que el Mayan Theatre ha sido excavado por los arqueólogos. El piso embaldosado del lobby, remite a una madera esculpida de un templo

\footnotetext{
86 “Art Deco Church”, https://www.flickr.com/photos/intherough/9467036691/

${ }^{87}$ Escasa información hay sobre este artista mexicano quien trabajo la escultura y la pintura. Nació en La Paz, Baja California. Estudio en la ciudad de México hasta 1911 y luego se trasladó a Los Ángeles. En la década de los 30 se regresa a México, donde habita hasta su muerte.

${ }^{88}$ La edición de 1980 fue publicada en New York, por Clarkson N. Potter, Inc.; hay una segunda edición en 2001 realizada en New York por Hennessey \& Ungalls.
} 
antiguo de Guatemala. Cubren las paredes escenas de la mitología como dioses de la lluvia y el sol, pájaros de fuego y mayas adoradores mezclados con los símbolos del colorido azteca. Adicionalmente, el voladizo del techo parece una ilustración colosal de un calendario maya centrado sobre una araña de luces". ${ }^{89}$ Eva Weber sólo dice al respecto de este edificio: "el llamativo, vistoso Mayan Theatre de Los Angeles". 90 De Anda únicamente lo menciona dando la fecha de 1927, junto con uno de igual nombre en Denver, Colorado. ${ }^{91}$ Este último fue construido entre 1929 y 1930 por el arquitecto Montana Fallis (1864-1938); hacia 1980 se encontraba abandonado y fue rescatado para ser remodelado y volver a sus actividades cinematográficas en 1986.

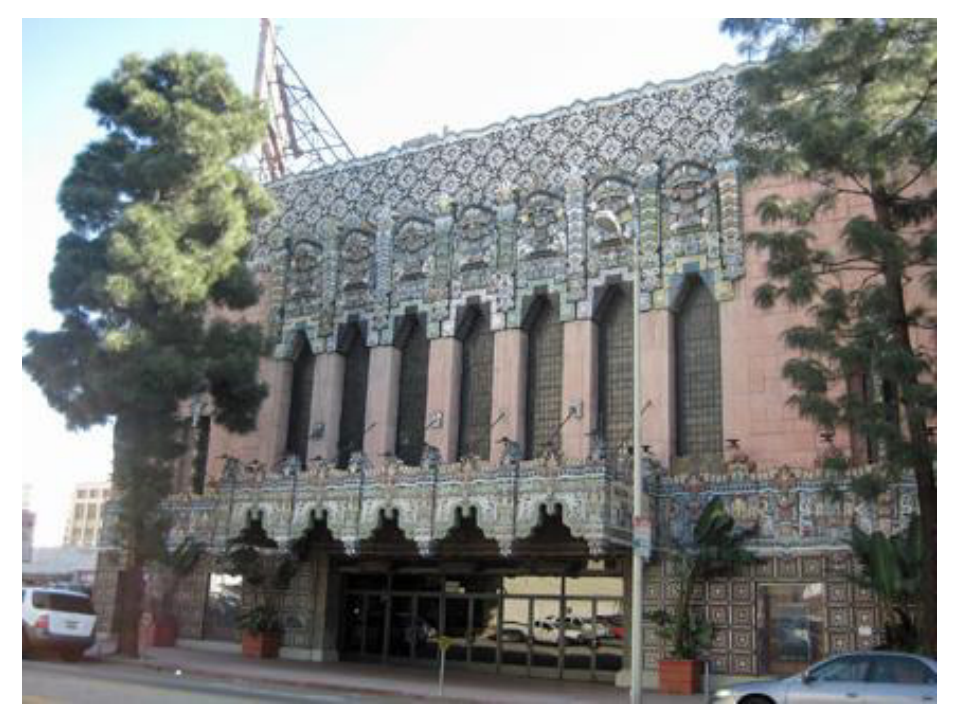

Morgan, Walls \& Clements, Mayan Theatre, Los Angeles, Cal., 1927.92

Ante todos estos ejemplos, la fuente iluminadora del mundo maya y mexica en los Estados Unidos fue un manantial del cual bebieron muchos arquitectos y artistas que plasmaron en sus obras los motivos prehispánicos de las culturas antiguas desarrolladas en México, por eso en el libro An Architectural Pilgrimage in Old Mexico el arquitecto de origen inglés Alfred Charles Bossom (1881-1965) afirmaba: “¡Mexico! No visitar México es no conocer el Hemisferio de Occidente. No haber visto el significado profundo de la

\footnotetext{
${ }^{89}$ Ave Pildas, Movie Palaces, New York, Clarkson N. Potter, Inc., 1980, p. 21.

${ }^{90}$ Weber, Op. Cit., p. 33.

${ }^{91}$ De Anda, Op. Cit., p. 140.

92 "Mayan Theatre", http://www.publicartinla.com/art_buildings/mayan1.html
} 
tradición americana, ni totalmente abarcar el desarrollo del pueblo americano". ${ }^{93}$ En el Petroleum Building de Houston terminado en 1927 (ahora Great Soutwest Life Building), Bossom integra elementos decorativos de tipo mexica en el segundo piso dentro de una galería de arcos de medio punto como máscaras, caras del dios Quetzalcóatl, representaciones del cuerpo de la Serpiente Emplumada y la elevación de los últimos pisos es una inspiración de la arquitectura maya.
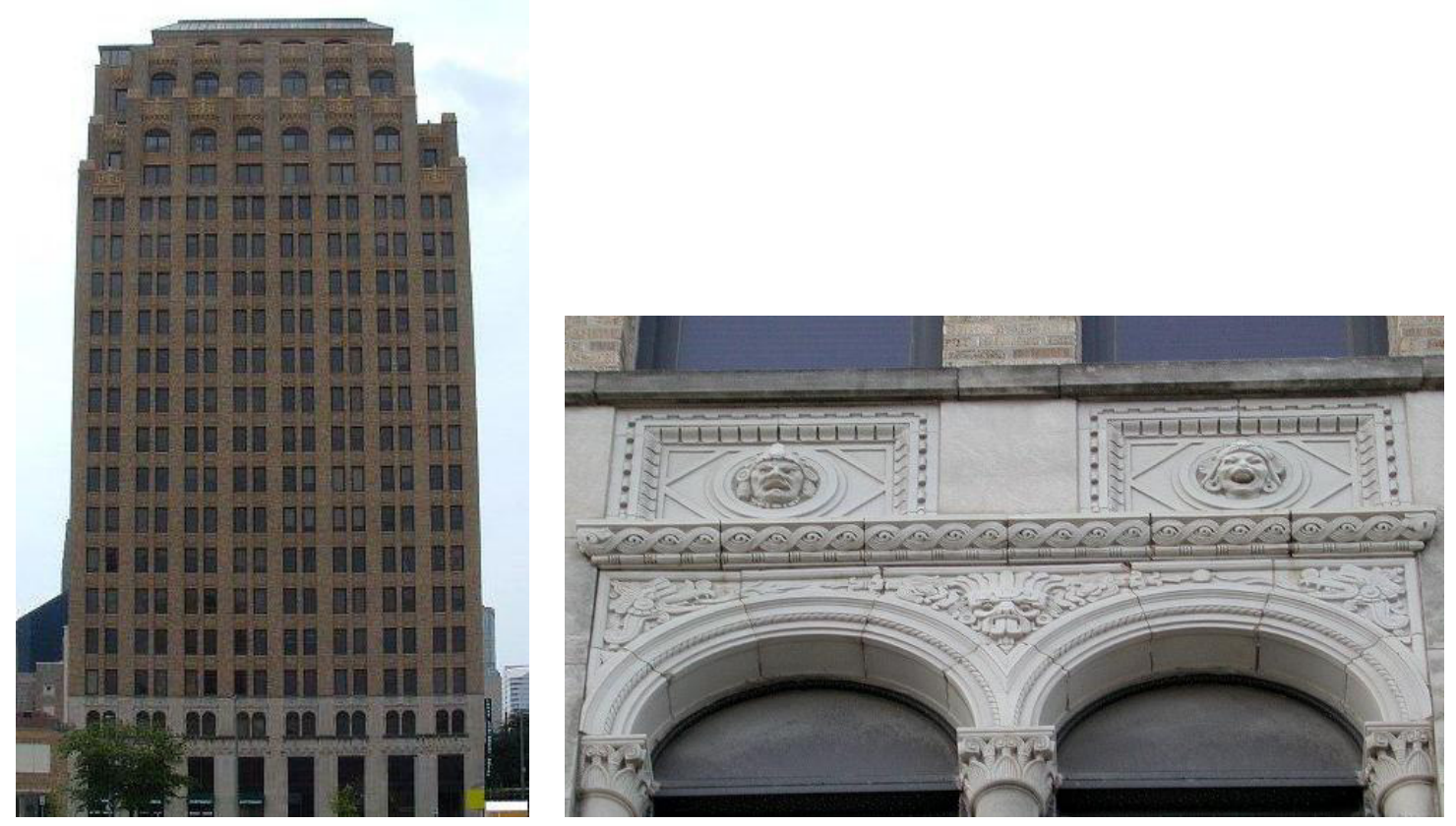

Alfred Charles Bossom, Petroleum Building, Houston, Texas, 1927. En la imagen de la derecha, detalles de los decorados de tipo mexica en el segundo piso. ${ }^{94}$

Tomemos en cuenta que desde 1889, en la Exposición Internacional de París que conmemoraba los 100 años de la Revolución Francesa con la Torre Eiffel, México mandó su pabellón bajo idea de mostrar un palacio azteca, una propuesta neoindigenista, aunque afrancesada por ser terminada por un contratista francés, obra de Antonio M. Anza (18471925), la asesoría de Antonio Peñafiel Barranco (1830-1922) y con esculturas de Jesús Contreras Chávez (1866-1902), trataban de emular los antiguos dioses y personajes del pasado indígena. En los años veinte México participó en la Feria Internacional de Sevilla en 1929 con un pabellón neo-maya, realizado por el yucateco Manuel Amábilis (1886-1966),

\footnotetext{
${ }^{93}$ Alfred Charles Bossom en Xavier Esqueda, "Observaciones sobre el Art-Deco", Catálogo de la exposición El Art Déco en México, Op. Cit., p. 54.

${ }^{94}$ Arch-ive.com, "Great Southwest Life Building", http://arch-ive.org/archive/great-southwest/
} 
con la ayuda del escultor y arquitecto Leopoldo Tommasi López (1899-1976) y del pintor y arquitecto Víctor M. Reyes, quien quiso difundir lo maya en esa muestra internacional, tal como estaba sucediendo en Estados Unidos y en el mismo México y aunque fue hecho por un mexicano, la proyección de lo prehispánico como símbolo de mexicanidad de dicho pabellón fue en el extranjero. ${ }^{95}$ Lo interesante de los tres autores es que eran meridenses y apasionados de la cultura maya y tolteca, de esta última especialmente Reyes, ya que la gran metrópoli del Post-Clásico, Chichen-Itzá, es una urbe con influencias toltecas dentro del mundo maya.

El Pabellón de México en la Feria Iberoamericana de Sevilla, aún se encuentra en dicha ciudad en la Plaza María Luisa y actualmente están instaladas oficinas de la rectoría de la Universidad de Sevilla. Sobre esa presencia de lo maya como elemento distintivo de lo mexicano y que dio elementos decorativos para el Art Déco en México, podemos percibir la importancia que tuvo dicho pabellón ante los ojos de los extranjeros en aquellos años: “En el mismo tiempo, el cambio de énfasis de lo maya 'civilizado' al asertivo estilo imperial azteca estuvo manifestado en Manuel Amábilis en el comprometido diseño para el pabellón mexicano de la Feria Iberoamericana de Sevilla en 1929. El pabellón fue realizado en la nueva moda de un estilo maya-tolteca e incorporando conscientemente modernos elementos constructivos, apuntando a crear una síntesis de lo maya-mexicano, pasado y presente, que podía representar los valores del nuevo México revolucionario. El estilo maya-tolteca ofrecía un modelo prehispánico en un camino en la cual formas híbridas de arquitectura podrían estar unificadas, reflejando los intereses de diseños contemporáneos dentro de una homogénea y antigua tradición mexicana". 96

Como una relación de la inserción de los elementos indigenistas dentro del Art Déco en México y la incorporación de los mismos vía Estados Unidos, la profesora Amparo Graciano García de la Universidad de Sevilla al describir el pabellón mexicano de la Feria de 1929 y analizar los adornos en formas de grecas que envuelve al escudo nacional de la

\footnotetext{
${ }^{95}$ Xavier Esqueda en Art Déco. Retrato de una época, p. 109 da la fecha de 1926 para el Pabellón, lo cual suponemos que fue un error de imprenta. Para más información véase: Manuel Amábils, El pabellón de México en la exposición ibero-americana de Sevilla, México, Talleres Gráficos de la Nación, 1929; Mauricio Tenorio Trillo, Artilugio de la Nación Moderna. México en las exposiciones universales, 1880-1930, México, F.C.E., 1998.

${ }^{96}$ Carlotte Benton, Tim Benton and Ghislaine Word (eds.), Art Deco 1910-1939, London, V\&A Publications, 2003, p. 64.
} 
fachada explica: "Conscientes de que pueda parecer aventurada la afirmación de que son grecas Art Decó, cuando el zig-zag era motivo propiamente indígena, nos vemos obligados a señalar el hecho de que el empleo del zigzag se venía extendiendo sobre todo desde 1926 (por tanto coincidiendo con la realización del proyecto) a raíz del éxito del Art Decó en México. Las críticas que hicieron a la Exposición de París los enviados norteamericanos introdujeron el nuevo estilo que retomaba ciertos elementos prehispánicos, como una opción modernizadora y cosmopolita de la arquitectura. Según esto, el empleo de la greca en zigzag era el fruto de un doble proceso de ida y vuelta. En cualquier caso, su presencia no tiene por qué suponer una relación obligada con el Art Decó; por ejemplo, elementos decorativos de grecas prehispánicas fueron empleados por el arquitecto ingeniero José Ramón Ibarrola en los remates del pabellón de México que, en estilo mozárabe, construyera en 1884-1885 ${ }^{97}$ para la exposición de Nueva Orleáns". ${ }^{98}$

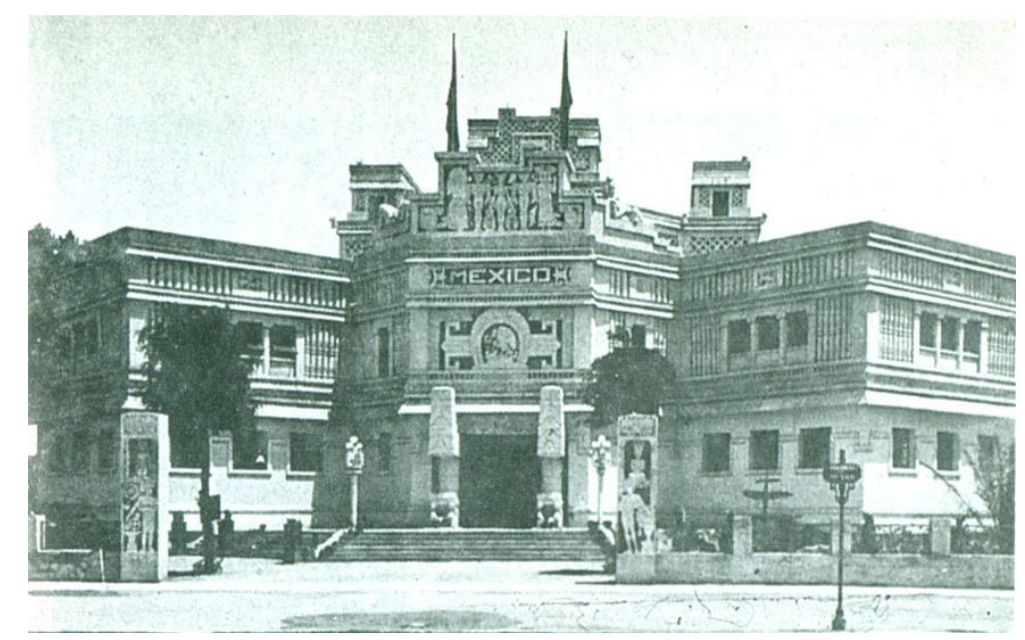

Manuel Amábilis, Pabellón de México, Feria Iberoamericana de Sevilla, imagen de 1929.99

Podemos apreciar, entonces, cómo tanto de adentro del país como de afuera hubo una amplísima gama de información sobre lo prehispánico y a la vez, una moda decorativa en construcciones modernas venida de Estados Unidos, que para los nacientes tiempos

\footnotetext{
${ }^{97}$ El pabellón se conserva en muy buen estado en el parque de la colonia Santa María la Ribera. Después de la exposición fue traído a la ciudad de México e instalado en la Alameda Central, hasta el año de 1910 que fue trasladado a su ubicación actual.

98 Alfonso Braojos Garrido y Amparo Graciano García, El pabellón de México en la Sevilla de 1929: evocaciones históricas y analíticas, Sevilla, Universidad de Sevilla, 1998, p. 111.

${ }^{99}$ Mauricio Tenorio Trillo, Op. Cit., figura 50.
} 
mexicanos postrevolucionarios significaban la vanguardia arquitectónica del rascacielos norteamericano y la identidad de "los verdaderos" orígenes del pueblo de México, descartando casi por completo todo lo virreinal que se asociaba con el imperio opresor español.

Así como citamos inmuebles con los estilos neomaya y neoazteca en los Estados Unidos que reivindican lo prehispánico dentro de lo Déco, en el siguiente punto mencionaremos algunos edificios, la mayoría en la ciudad de México, que ostentaban dichas influencias.

Mucho ayudó a esa difusión de lo prehispánico la obra pictórica de los muralistas, los Tres Grandes, pero especialmente Diego Rivera (1886-1957) quien en sus frescos de la Secretaría de Educación Pública, por ejemplo, pinta a la diosa náhuatl de la danza, el juego, las flores y el amor bajo el título Xochipilli y Adoradoras, trabajo de 1928 ubicado en las escaleras del edificio. Vemos a la Xochipilli en un paisaje tropical y dos mujeres morenas desnudas que son las Adoradoras.

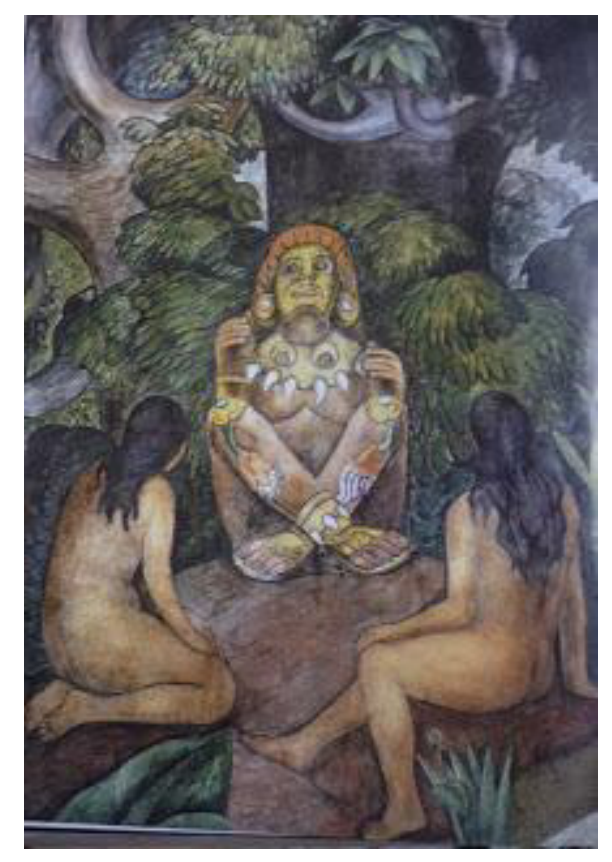

Diego Rivera, Xochipilli y las Adoradoras, SEP, escaleras, México, D.F., 1928. ${ }^{100}$

\footnotetext{
${ }^{100}$ Xochipilli, “Xochipilli”, http://ojosdesconocidos.blogspot.mx/2010/12/dinamica-expansiva-oo.html
} 278 
Otro caso de los muchos que realizó Rivera con este tema fue en la escalera de Palacio Nacional, donde narra la historia de México entre 1929 y 1935. En el muro de la derecha donde inicia con el mundo indígena, Rivera pinta a un Quetzalcóatl tanto como dios astro solar, pero también como el héroe divino del cosmos prehispánico. La civilización prehispánica con sus gobernantes, artistas del arte plumario y "tlacuilos" hacedores de códices, mujeres trabajando el algodón, campesino que siembran el frijol y el maíz, todo ese afable mundo es destruido con la conquista española.

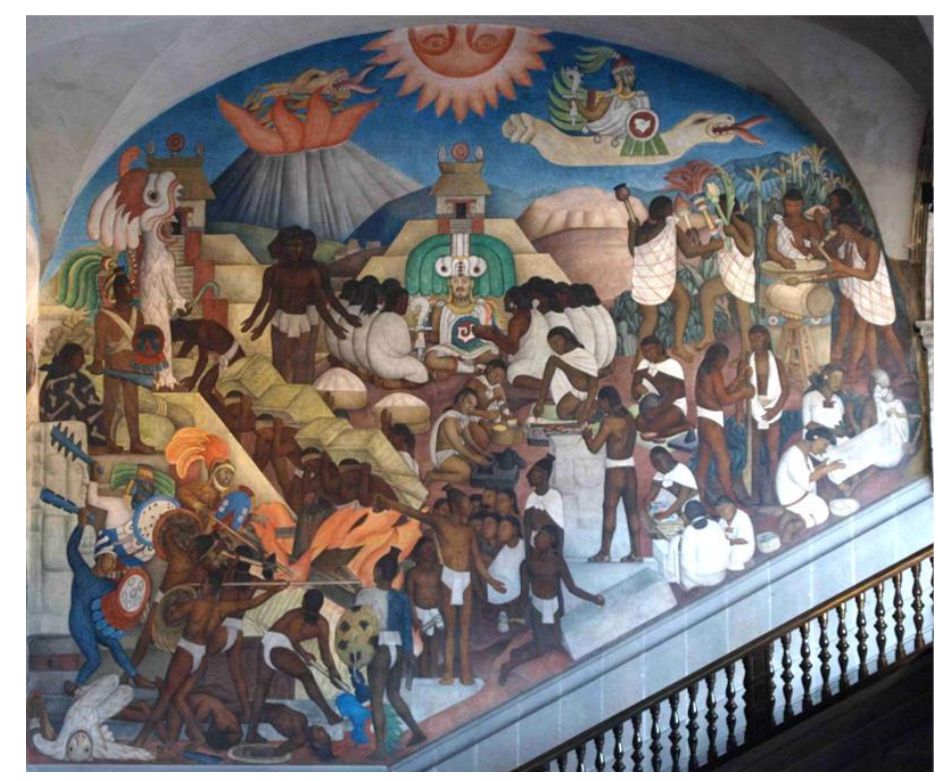

Diego Rivera, México prehispánico, Palacio Nacional, México, D.F., 1929. 101

Ya fuera de los años del desarrollo del Déco, en los muros del primer piso del mismo palacio de 1941 a 1945, Rivera hizo una apoteósica reivindicación del glorioso y aniquilado pueblo indígena, cuya lectura hasta la fecha exalta los ánimos de los apasionados proindigenistas mexicanos.

Y pese que a muchas de estas referencias indígenas prehispánicas que se utilizaron en varios de los edificios de la postrevolución dentro del estilo Art Déco fueron tomadas del exterior, los mexicanos de esos años consumían una estética nacional, pero importada del extranjero, por eso Enrique de Anda dice que: "La ciudad de México dejó penetrar

\footnotetext{
${ }^{101}$ Brenton LeMesurier, "Diego Rivera Murals, Palacio Nacional”, http://brentonlemesurier.wordpress.com/2012/10/27/diego-river-murals-palacio-nacional/
} 
libremente todos estos nuevos caracteres plásticos, sin reparar jamás en que se habían originado en su propio territorio geográfico". ${ }^{102}$

Queremos terminar este punto con una síntesis de Xavier Esqueda que aúna lo geométrico con lo indígena del Déco en México, entre eso lo maya y lo azteca que viniendo de Estados Unidos se adopta para enaltecer el mundo prehispánico como un elemento de identidad nacional postrevolucionaria y moderna: "El hecho es que los diseños aztecas, mayas, zapotecas, toltecas y olmecas ofrecieron un gran número de motivos ornamentales al art deco que por su geometría cayeron como 'anillo al dedo' ". ${ }^{103}$

\footnotetext{
${ }^{102}$ Enrique X., de Anda, Op. Cit., p. 141.
}

${ }^{103}$ Xavier Esqueda, Op. Cit, p. 79. 


\subsection{CARACTERÍSTICAS DEL ART DÉCO EN MÉXICO}

\subsubsection{Arquitectura en México Art Déco}

Para hablar de las características del Art Déco en México, como ya lo habíamos mencionado anteriormente, nos basaremos primero en las que da desde la perspectiva arquitectónica por Xavier Esqueda y luego en las de Enrique X., de Anda, ya que han sido los dos grandes estudiosos del Art Déco en México; asimismo, como es obvio, el Déco en nuestro país tuvo algunas variantes "nacionales" a diferencia de Europa y Estados Unidos.

Sin embargo, por orden cronológico queremos incluir antes las características que proporciona Israel Katzman en su ya citado libro Arquitectura Contemporánea Mexicana, que por ser publicado en 1964 aún no se daba el término Art Déco. Considerado como el pionero de los estudios de lo moderno y contemporáneo en México en el campo de la arquitectura, en el capítulo IV llamado “TRANSICIÓN”, explica cómo se va modernizando la arquitectura mexicana después de la Revolución Mexicana a través de nuevos elementos que innovan los diseños y a la vez buscan evitar una arquitectura fría y sin decoración.

Los edificios con los que Katzman ilustra e incluiremos en las citas de su texto, son algunos de los que más adelante describiremos como ejemplos del Art Déco. Así pues para explicar el uso del arco ochavado dice: "pero el cerramiento de transición más típico es el de tres lados u ochavado que constituye no solamente el símbolo de esa indecisión entre arco y dintel, sino también expresión de tres estilos arquitectónicos que tal vez se quiso integrar: el cerramiento ochavado existe en la arquitectura prehispánica (cuadrángulo de las Monjas en Uxmal); en la arquitectura Virreinal (Basílica de Guadalupe, campanario de la Catedral de Morelia, edificio de la Inquisición) y en la arquitectura de transición europea (cine de Richard Acke en París). Encontramos cerramientos ochavados en las siguientes obras:...puerta principal del Departamento de Salubridad (1926);...Edificio Ermita de Juan segura (1930);...en muchas casas de la Colonia Hipódromo, del arquitecto Segura y el Ingeniero Dantán; en cines de Francisco Serrano, etc...” 104

El dejar una construcción solamente con aplanados sin aderezos ni color, tal como se concebía en la modernidad vanguardista de algunas tendencias arquitectónicas, permitió

${ }^{104}$ Israel Katzman, Op. Cit., pp. 103-104. 
la incorporación de los elementos que son parte del Art Déco y que Katzman expone así: "El temor que existía de emplear escuetamente el ángulo recto y la gran superficie plana, se trasluce también en el ochavado de otros elementos, además de los vanos y en la simulación de pilastras adosadas y de sección escalonada...En la fuente central del Edificio de Salubridad y los faroles del monumento a la Revolución (1933) de Carlos Obregón Santacilia...así como en los escalones y perímetro del edificio de la Avenida Revolución, de Juan Segura, y en los aleros exteriores del Edificio Ermita, del mismo arquitecto (1930), hallamos también el perfil ochavado". ${ }^{105}$

Para demostrar el uso de los remetimientos angulosos a manera de perfiles enumera las siguientes construcciones: "Las salientes de sección escalonada existen en muchos edificios de varios pisos: el de la Alianza de Ferrocarrileros, de Vicente Mendiola, Carlos Greenham y Luis Alvarado (1926);...el frontón México; el Orfanatorio de San Antonio y Santa Isabel que construyó para la fundación Mier y Pesado el arquitecto Manuel Cortina García (1827);...el de Policía y Bomberos de Mendiola y Zárraga; ...el edificio La Nacional de Manuel Ortiz Monasterio, Bernardo Calderón y Luis Ávila (1939)”. ${ }^{106}$ Como podemos ver, casos que son estudiados posteriormente como edificios representativos del Art Déco de la ciudad de México.

Y para explicar los ascendientes que llegaron a México de la Exposición Internacional de Artes Decorativas e Industrias Modernas de 1925 y que se prolongaron hasta la década de los cuarenta del pasado siglo, Katzman sólo se concreta a referir algunos casos, sin discurrir por los elementos compositivos: "Esa exposición tuvo influencia directa en México: los bocetos que Vicente Mendiola hacía en 1925 para la revista Cemento (cine, hangar, banca, garage, etc.); la Estación del Ferrocarril Infantil de Chapultepec, de José Gómez Echeverría (1928); muchas obras de Francisco J. Serrano de la cuarta década, como los departamento de Querétaro 109". ${ }^{107}$

En el catálogo de la exposición El Art-Deco en México del Instituto Mexicano Norteamericano de Relaciones Culturales, presentada en 1977, el arquitecto Alberto Yarza ofrece las Invariables tipologías de las obras arquitectónicas del Art-Deco en México, explicando que: "Conociendo con anterioridad a los principales exponentes del ART-

\footnotetext{
${ }^{105}$ Ibídem, pp. 104-105.

106 Ibídem, p. 105.

${ }^{107}$ Ibídem, pp. 105-106.
} 
DECO en México, como son los arquitectos Carlos Obregón Santacilia, Federico Mariscal, Juan segura, el Ing. J.J. Serrano, así como los arquitectos Víctor Suárez, José María Buenrostro, José Gómez Echeverría y muchos otras más, intentaré encontrar unas serie de características que permitan analizar una obra arquitectónica y ubicarla en el momento histórico de su creación, que en este caso sería la arquitectura con influencia Art-Deco en México". 108

Las características dadas por Yarza se convierten en las primeras ofrecidas dentro del estudio del Art Déco en México y éstas son:

Formas geométricas tales como círculos, triángulos, cuadrados, líneas paralelas, onduladas, en zig-zag y espirales que se podían hacer en materiales como la Talavera.

Utilización de ventanas cuadradas, unidas por una línea que compone grupos de ventanas realzadas con motivos decorativos.

Abocinamiento de las puertas de acceso principal con arcos continuos que algunas veces puede ir acompañado de un alero, el cual también puede ser utilizado como placa.

El uso del arco fragmentado en seis partes rectas lo que conlleva a una evocación de lo maya.

La pérgola-terraza cubierta es común en el último piso de los edificios.

La texturización se conseguía a través de aplanados con cemento que podían ser lisos, estriados, salpicados, radiales y mezclados con rosetones decorativos.

Dentro de los materiales el granito es utilizado en rodapiés, escaleras, jardineras y pisos.

El vidrio block en combinación con cristales esmerilados produce un efecto de iluminación extraordinario.

Para la protección del agua eran utilizados los azulejos importados muchos de ellos con una amplia variedad de motivos decorativos de tipo Art Nouveau, destacándose los colores negro, blanco, azul marino y café tabaco.

En la herrería de puertas y ventanas se utilizaban los diseños geométricos de círculos y líneas diagonales, obteniéndose en ocasiones resultados inusitados.

\footnotetext{
108 Alberto Yarza, "Invariables tipologías de las obras arquitectónicas del Art-Deco en México", Catálogo de la exposición El Art Deco en México, Op. Cit., p. 46.

Haremos una paráfrasis de las características que propone el arquitecto Yarza.
} 
Los colores utilizados en los interiores eran principalmente el negro y el blanco, tal vez porque ante la escasez de revistas ilustradas a color, quienes veían los ejemplos que venían del extranjero sólo podían apreciarlas en dichas coloraciones.

Las escaleras con sus pasamanos, arranques y los remates de barandales fueron trabajados con delicadez y buen gusto, utilizando el hierro cromado.

Las letras y los números para la nomenclatura de calles y edificios se realizaban con delineaciones geométricas, de amplio grosor y tamaño grande.

La integración al entorno urbano de los edificios Art Déco es la última característica que incluye Yarza, es decir, se respeta la morfología del medio donde se construyen los nuevos inmuebles.

Acompaña a las "Invariables tipologías" una tabla de "Arquitectos y obras más representativas del periodo Art-Deco en México (enlistados sin orden cronológico ni de importancia)", refiriéndose exclusivamente a obras de la ciudad de México.

Por su parte, Esqueda en su libro Art Déco. Retrato de una época de 1986 inicia la descripción de características aclarando que los azulejos son un toque de mexicanidad y que éstos se aplican "en formas cuadradas o rectangulares, decorados o en secciones diagonales, en dos colores que forman líneas geométricas en zig-zag. ${ }^{109}$ Continúa declarando:

En las puertas de entrada se logra un abocinamiento a través de arcos superpuestos y en muchas ocasiones los aleros siguen el ritmo de las arcadas, en donde se coloca la iluminación eléctrica, o bien, pequeños blocks de vidrio para lograr luz natural.

El rodapié trabajado en granito es una característica del Déco en México; en ocasiones se le incluyeron jardineras con la idea de sembrar plantas del desierto mexicano, especialmente cactus, aunque hoy muchas de ellas ya no se conserven.

El vitral se pone de moda al ser utilizado en escaleras y en vestíbulos; los diseños pueden ser geométricos o paisajes estilizados, ya sean en juegos policromos o simplemente en blanco y negro.

Con cemento se lograron aplanados de heterogéneas formas decorativas, tales como composiciones geométricas, líneas radiales o curvas. Y con el mismo material se hicieron

\footnotetext{
${ }^{109}$ Xavier Esqueda, Op. Cit., p. 114.
} 
relieves de muy variadas contexturas, que también se trabajaron con piedra, logrando ornamentaciones, en algunas ocasiones exuberantes, de diseños geométricos, prehispánicos o florales.

La herrería fue un elemento con el cual se completó la decoración Déco, pues puertas y ventanas, barandales exteriores e interiores, se engalanaron con líneas quebradizas a manera de rayos eléctricos, círculos conectados con líneas oblicuas o curvas. En la forja se dieron rienda suelta a muchas creaciones de tipo Art Déco, desde las suntuosas edificaciones, hasta las casas habitación de clase media.

En zonas habitacionales urbanas se levantaban fuentes de cemento ornadas con azulejos, o bien, iluminadas desde su interior a través de vidrios para reflectar más iluminación.

En lo concerniente a materiales, Esqueda explica que de acuerdo al tipo de construcción se utilizaban más sencillos u ostentosos, ya que si eran de mucho lujo éstos "hablan por sí solos: Bronces, latón, aluminio, mármoles en diferentes colores y de diversas procedencias, cristales esmerilados, acidulados o biselados; de procedencia nacional o importados", 110

Los colores manejados en los exteriores, aparte del blanco, fueron los tonos cálidos. En los interiores era muy habitual el blanco y negro, sin embargo los baños se engalanaban con azulejos importados de tonos intensos; además, en el interior fue común que en los techos se hicieron relieves en yesos, principalmente alrededor de las instalaciones para la luz eléctrica.

Los números de las casas y los nombres de los edificios cobraron importancia al hacerlos en relieves o rehundidos con el diseño geométrico que se puso de moda y que en ocasiones se forjaron en metal. También los nombres, ya sean de la constructora o del arquitecto, se incluyen en alguna pequeña placa, muchas veces trabajada en azulejos. ${ }^{111}$

Enrique de Anda en su obra La arquitectura de la Revolución Mexicana. Corrientes y Estilos de la década de los veintes, publicado en 1990, en el apartado dedicado a la arquitectura Art Déco, propone cuatro tendencias para el desarrollo de dicho estilo en

\footnotetext{
${ }^{110}$ Ibídem, p. 117.

${ }^{111}$ Hemos parafraseado e incluido algunos breves comentarios a las características dadas para la arquitectura por Xavier Esqueda en el capítulo "El Art Deco en México" del libro citado Art Déco. Retrato de una época, Op. Cit., pp. 114-117.
} 
México: "la primera denominada geometrista...; la segunda, ecléctico-mayista...; la tercera, la tendencia plasticista...; finalmente el cuarto apartado, el decorativista”. 112

La Tendencia Geometrista utilizó la línea como elemento de definición, la constante presencia del ángulo recto y los recuadros elaborados en cantera o algún material parecido que guardan motivos fitomorfos. En lo que respecta a los planos, éstos se trabajaron de manera vertical y lineal, consiguiendo el efecto de mayor altura. Además con un juego de relieves rectangulares verticales superpuestos y ascendentes, así como con la elevación de la parte central del edificio, originaba un efecto de juegos de planos hacia fuera que combinado con el ritmo de estrías verticales con líneas horizontales daba el triunfo a la geometrización. Para la ejecución de la fachada, la elevación de la entrecalle central y el pintarla con otro color ayuda a contrastar con el resto del edificio, a más de colocarle en muchos casos en el acceso principal una marquesina de forma mixtilínea.

La segunda, la Tendencia Ecléctico-mayista, se refiere a las inspiraciones de los decorados mayas que se tomaron de dos fuentes: una, venida de la arquitectura californiana en la que se emplean cilíndricas estrías gruesas y abultadas con el fin de provocar la verticalización de las paredes y el uso del marco mixtilíneo, el cual remite al arco falso maya. La otra, se toma directamente de las ciudades mayas, especialmente de la Península de Yucatán, como fue el caso del estilo Puиc, primordialmente de la ciudad de Uxmal; aquí aparecerá el conjunto de columnillas de pequeño tamaño y grueso fuste, acomodadas en rectángulos rematados por las cornisas biseladas de afuera hacia adentro al estilo Puuc.

La Tendencia Plasticista es la que expone un fuerte ornamentalismo decorativista, pero que al aplicarse da por resultado planos cerrados, mas sin absorber la masividad del edificio. Esta tendencia tiene cierto ascendente de la arquitectura expresionista de Erich Mendelsohn (1887-1953), aunque como aclara De Anda, no con esto quiere decir que los arquitectos mexicanos conocieran la obra del alemán, o al menos no hay documentos para comprobarlo, pero sí que hubo un sincretismo cultural que relaciona ambas obras.

\footnotetext{
${ }^{112}$ Enrique X., de Anda, Op. Cit., p. 134. De la misma manera que lo hicimos con las características proporcionadas por Esqueda, parafrasearemos las cuatro tendencias propuestas por Enrique de Anda, incluyendo en la Tendencia Decorativista los ocho Elementos exteriores: Relieves adosados, Las marquesinas, Vanos de acceso, Herrería de puertas de acceso y en otros elementos, Rodapiés y jardineras, Letreros y lámparas, Astabanderas y esculturas, Ménsulas, así como los cuatro Elementos interiores: Directorios y buzones, Fuentes y bancas, Pavimentos y lambrines, Vitarles y mascarones.
} 
La última y cuarta es la Tendencia Decorativista, que como su nombre lo indica se refiere a elementos decorativos que complementan la composición geométrica de las edificaciones. Esta inserción de aditivos plásticos, como los llama De Anda, se hizo a través de "la manufactura de herrerías, labrado de cantera, granito y otros materiales pétreos, modelado de relieves a base de pastas suaves, combinación de metales y uso de azulejos y mosaicos". ${ }^{113}$ Enrique X., de Anda clasifica los elementos que comprenden esta Tendencia Decorativista en Exteriores e Interiores, los cuales expondremos a continuación.

\section{Los Elementos Exteriores son:}

1. Relieves adosados. Éstos se facturan por medio de pastas suaves o en directo en el material que los comprende dentro de placas cuadradas o rectangulares. Manejan tres temáticas: la primera recurre a elementos fitomorfos, abstracciones de flores o frutos petrificados en los que se aprecian "generalmente ramilletes de hojas estilizadas con

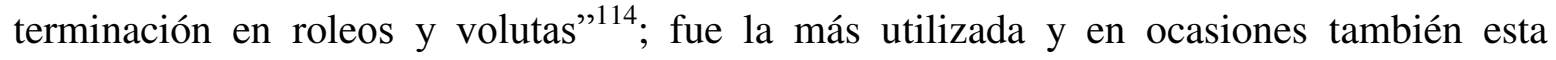
temática aparece dentro de frisos rectangulares. La segunda se conforma de composiciones planimétricas, cuyo objetivo es articular libremente partes sombreadas en contraposición con otras iluminadas, aunque también se usaron en "series geométricas tanto en forma de cenefas y bandas verticales, como en forma de recuadros y tableros" ${ }^{\text {"115; }}$; la tercera temática, que fue la menos trabajada, es la que emplea elementos antropomorfos y zoomorfos.

2. Marquesinas. Se refiere al uso de una placa de concreto proyectada hacia el frente del acceso principal del edificio que puede ser plana o ligeramente curvada.

3. Vanos de acceso. Éstos se produjeron de forma abocinada; es decir, que los perfiles se van reduciendo de manera rítmica. Hubo tres tipos de vanos: de arco mixtilíneo, el cual por su factura geométrica fue el más común; de arco de medio punto; y el adintelado, que fue el menos usual.

4. Herrerías de puertas de acceso y en otros elementos. El trabajo de la herrería se produjo en dos directrices de composición: la primera, por la diferencia de materiales, lo cual se da por la textura, por la apariencia ya sea de suavidad o de dureza y por el color, pues el contraste de un plateado brillante del acero inoxidable, el amarillo del latón, o el

\footnotetext{
${ }^{113}$ Ibídem, p. 146.

${ }^{114}$ Ibídem, p. 147.

115 Ídem.
} 
negro del fierro, daba un nuevo juego cromático hermanado con la modernidad de la tecnología maquinaria. La segunda, con la aplicación de la línea curva o en forma de latigazo, o bien, con un acopio de barras asimétricas se conseguía provocar un efecto cinético.

5. Rodapiés y jardinerías. El rodapié se identifica por resaltar no más de un metro de altura desde el piso; normalmente se trabaja en granito o con algún tipo de aplicación rugosa y contrasta con el resto de la fachada por utilizar otro tipo de color o de textura.

Las jardineras, por su parte, responden a los elementos geométricos compositivos del edificio y son colocadas a la altura de la marquesina, aunque esto no sea necesariamente una constante encontrarlas en todos los edificios Déco.

6. Letreros y lámparas. Para los letreros de los edificios y de los números se utilizó una tipografía de fuertes líneas rectas con ángulos pronunciados en los que aparece la línea curva dilatada; su aplicación podía ser en dos formas: con metal, o bien, labrados en el mismo edificio en bajorrelieve o en rehundido.

Las lámparas se ejecutaban en forma de prismas triangulares y se instalaban de forma vertical, en ambos lados de los vanos de acceso; en ocasiones se emplazaban de forma asimétrica y en algunas más con el fin de alumbrar el letrero del edificio. La luz irradiada por esta modalidad de las lámparas, denotaba el alto grado de desarrollo y progreso tecnológico que se quería imprimir a los edificios modernos en México.

7. Astabanderas y esculturas. La astabandera fue una característica del Art Déco proveniente de Europa y que se aplicó a la arquitectura mexicana de este estilo. Su origen viene de la representación de nacionalismos, religión y linajes; sin embargo, queremos anotar que también tiene un origen náutico, pues al ser utilizada por los grandes trasatlánticos, más tarde fue acoplada a la arquitectura conocida como Tropical Déco de Miami, íntimamente vinculada a lo marítimo.

Las esculturas de bulto fueron escasas de manera aislada, pues más bien iban adosadas a un edificio o monumento escultórico. Como ya se había mencionado, fue más frecuente utilizar placas con bajorrelieves.

8. Ménsulas. En el Déco sirvieron para sostener bandas superpuestas que nacen del primer nivel del edificio y se prolongan verticalmente por la fachada; en la parte donde 
emergen y donde finalizan en el segmento más alto del edificio, se curvan a manera de envolver el paramento y penetrar en él.

\section{Elementos Interiores.}

1. Directorios y buzones, y puertas de elevadores. Las líneas verticales, horizontales y curvas en los rectangulares directorios y buzones siguieron el estilo geométrico del Déco, además de utilizar el latón y el acero inoxidable como materiales típicos.

Los elevadores en la mayoría de las veces también conformaron un elemento plástico más, ya que las puertas presumían su propia decoración y no sólo eran una extensión de la composición general del edificio.

2. Fuentes y bancas. En algunas construcciones Déco de tipo habitacional multifamiliar, se incluyeron estos elementos en los vestíbulos para conseguir dentro del espacio interior áreas de descanso y/o de encuentro comunitario. Se trabajaron en concreto o en mampostería de tabique.

3. Pavimentos y lambrines. En los vestíbulos de edificios tanto públicos como privados, los pavimentos normalmente se realizaron en granito o mármol de variados colores, respondiendo a la geometrización en sus diseños al mostrar "grecas, recuadros, cenefas y formas planas y anguladas a que dio lugar la imaginación Déco, motivada por la aparente prisa por asimilar los conceptos del maquinismo futurista"116. Los lambrines eran trabajados con algún material similar al utilizado en el pavimento, pero conservando una sola tonalidad. En ciertos casos, también fueron cubiertos ambos elementos con maderas ensambladas, proyectando la misma geometrización.

De Anda explica que bastantes ejemplos de puertas de acceso a espacios interiores, pasamanos y barandales de escaleras fueron manufacturados en madera. Como una variante pone a las puertas y ventanas de hoja abatible, las cuales se forman de barrotes cilíndricos superpuestos de madera, creando la sensación de una celosía; este ejemplo proviene de imágenes cinematográficas en las que se intentaba recrear un pasado rural mexicano inexistente.

4. Vitrales y mascarones. Los vitrales que se originaron en la Europa medieval del gótico, fueron retomados a finales del siglo XIX y nuevamente utilizados en el Déco. Los

\footnotetext{
${ }^{116}$ Ibídem, p. 152.
} 
temas abordados en nuestro país estaban relacionados con paisajes que resaltaban un sentido de mexicanidad, o bien trataban la tecnología con algún tipo de alegoría, pero siempre inmersos dentro del geometrismo y la policromía.

Los mascarones fueron elementos, que tomados de las culturas aborígenes mesoamericanas, alimentaron la iconografía europea de lo exótico y antiacadémico y luego regresaron a México como una importación plástica occidental, para incorporarse al lenguaje Déco.

Dentro de este apartado de Vitrales y Mascarones y a manera de cierre sobre la tendencia Decorativista, De Anda plantea tres tipos de elementos iconográficos inspirados en el arte prehispánico: el primero son personajes ataviados con indumentaria indígena en posiciones de sumisión, o bien, retratados como seres pertenecientes a sociedades ingenuas; en el segundo se agrupan ornatos tomados de la arquitectura mesoamericana, tales como grecas o cualquier otro tipo de decorados geométricos; el tercer tipo es el que retoma de manera precisa o sintetizada mascarones mayas y teotihuacanos.

El mismo Enrique de Anda en 1998 en el catálogo ART DÉCO. Un país nacionalista. Un México cosmopolita, en el capítulo "La arquitectura déco en la ciudad de México" tiene un subtema titulado "Singularidades del déco en México", en donde da también características, algunas de las cuales ya han sido explicadas:

- El Arco mixtilíneo y abocinado y la Marquesina de concreto están explicados en la Tendencia Decorativista, Elementos Exteriores: Vanos de acceso.

- La Sucesión de placas en fachada fue descrita en la Tendencia Geometrista.

-La Ornamentación neocolonial e Iconografía prehispánica en parte fue desarrollada en la Tendencia Ecléctico-mayista y en la Tendencia Decorativista, Elementos Interiores al explicar los Mascarones; sin embargo, no hay mención de lo neocolonial, lo cual explica De Anda que a pesar del uso de las referencias coloniales de los años veinte, hubo decoraciones Déco que evocaban hacia la herencia virreinal, como fue el caso de algunas residencias de la colonia Hipódromo-Condesa, obras de Juan Segura (1898-1989), aunque aclara el autor que no fue el único arquitecto que haya utilizado este recurso.

- De las características no dadas anteriormente sólo está Torreta con remate, la cual fue un acoplamiento del sentido de verticalización del rascacielos neoyorquino. Consistente 
en un prisma piramidal, se ubica en las esquinas con el objetivo de proyectar altura y en ocasiones puede ir acompañado de contrafuertes, lo que le da vigor constructivo. ${ }^{117}$

Para ejemplificar dichas características, iremos mencionando algunos edificios Art Déco. Como podemos observar, hay elementos compositivos que se repiten en ambos autores, no obstante, nosotros tomaremos cualesquiera de ellos que nos sean útiles para hacer la descripción estilística de los monumentos a estudiar en la región Noreste.

Hay edificios en la ciudad de México que son distintivos del Art Déco y que son reconocidos como tales. Citaremos algunos de ellos sin el afán de describirlos minuciosamente, pues han sido ampliamente estudiados tanto por Xavier Esqueda como por Enrique X., de Anda en sus obras ya mencionadas y también por Carolina Magaña en su tesis doctoral sobre la arquitectura Art Déco en la ciudad de México. Los enumeraremos en orden cronológico, dando algunas particularidades estilísticas.

La Alianza de Ferrocarrileros (Ponciano Arriaga No. 20, Col. Tabacalera) tal vez sea el primero de estos edificios públicos estatales Art Déco, ya que para 1926 estaba terminado. Obra de los arquitectos Carlos Greenham, Luis Alvarado y Vicente Mendiola Quezada (1899-1986), nombres que aún se conservan en un placa casi ilegible del lado izquierdo de la puerta, denota en su composición geométrica de planos entremetidos un fuerte sentido verticalista que se refuerza con los ventanales rectangulares abocinados, unos pareados en los extremos y los demás individuales, y con la elevación de la calle central, la cual está elaborada con piedra de otro color lo que le da una volumetría aparente hacia el exterior. Como elementos decorativos están unos paneles horizontales a los lados del remate de la calle central que resguardan decoraciones abstractas tipo biombo zigzagueantes y el emblema de la alianza ubicado en el interior de la calle central. El vano de acceso es un arco de medio punto coronado por una marquesina que se proyecta como un arco mixtilíneo. A los lados un enmarcamiento rectangular escalonado se remarca con líneas rectas estriadas, resaltando el sentido geométrico de la fachada. Por la pureza y juego de sus planos esta obra entra en la Tendencia Geometrista, y por el uso de pilastras alargadas y perfiladas hacia adentro en el Neoclásico Moderno. El edifico se encuentra en desuso y por lo tanto el abandono ha producido que pierda mucho de su lozanía.

\footnotetext{
${ }^{117}$ Enrique X., de Anda, "La arquitectura Déco en la ciudad de México", Catálogo de la exposición Art Déco. Un país nacionalista, un México cosmopolita, Op. Cit., pp. 84-85.
} 

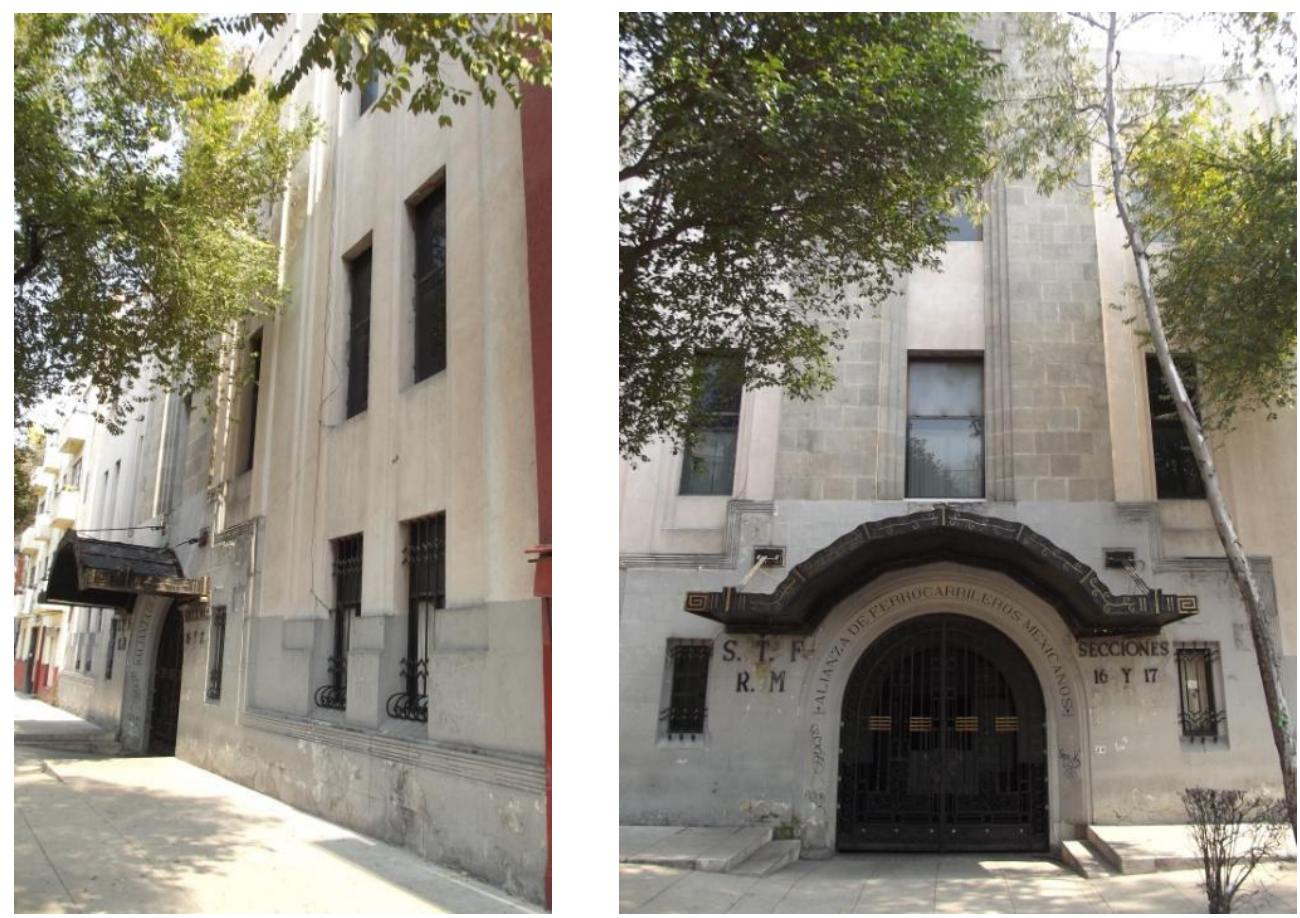

Vicente Mendiola, Carlos Greenham y Luis Alvarado, Alianza de Ferrocarrileros, México, D.F., 1926.

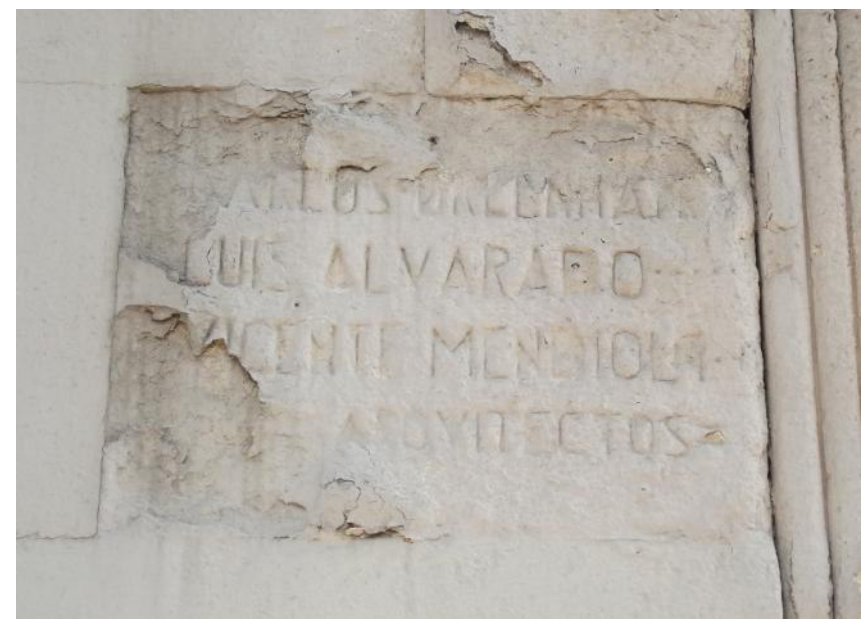

Alianza de Ferrocarrileros, placa con los nombres de los arquitectos Carlos Greenham, Luis Alvarado y Vicente Mendiola.

El Orfanatorio San Antonio y Santa Isabel (Calzada de Guadalupe), del arquitecto Manuel Cortina García (1877-1947), data del año $1927 .{ }^{118}$ Este magno y lujoso edificio de planta radial, en toda su decoración, tanto arquitectónica como de herrería, impera la geometría: en la fachada principal, diez vanos rectangulares se protegen con herrerías que

${ }^{118}$ Edgar Anaya Rodríguez, Op. Cit., p. 41, da la fecha de 1932. 
forman caprichosos dibujos abstractos y en cuatro límpidas pilastras se colocan candiles octagonales. El letrero es toda una lección del tratamiento de las letras geometrizadas tipo Art Déco.

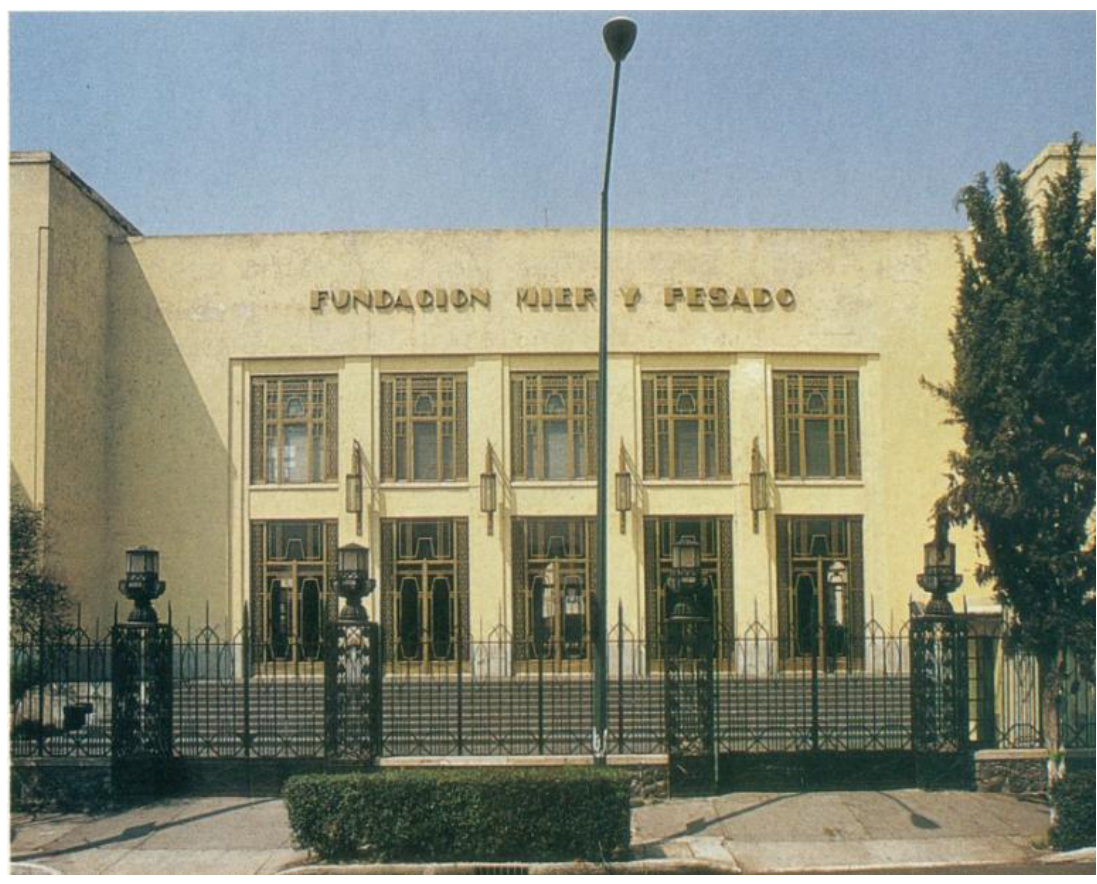

Manuel Cortina García, Orfanatorio San Antonio y Santa Isabel, México, D.F., 1927.119

En el interior todo es un paraíso decorativo de la línea, el ángulo, el rectángulo y las estrías decorativas que están aplicadas en pilastras así como en techumbres. El rodapié grisáceo se entremete por todo el edificio, tanto en interiores como en exteriores, dando así un equilibrio de claroscuro.

En el patio la escalera central que conduce a los salones es una combinación de la línea curva integrada con un trapecio a profundidad, donde los barandales también van al ritmo de ascenso a través de pequeñas placas horizontales y el reloj inserto dentro de un marco ochavado culmina con la composición cúbica del edificio. La cabal integración plástica hace que el orfanato esté dentro de la Tendencia Geometrista, así como también del Neoclásico Moderno.

\footnotetext{
${ }^{119}$ Ibídem, p. 37.
} 


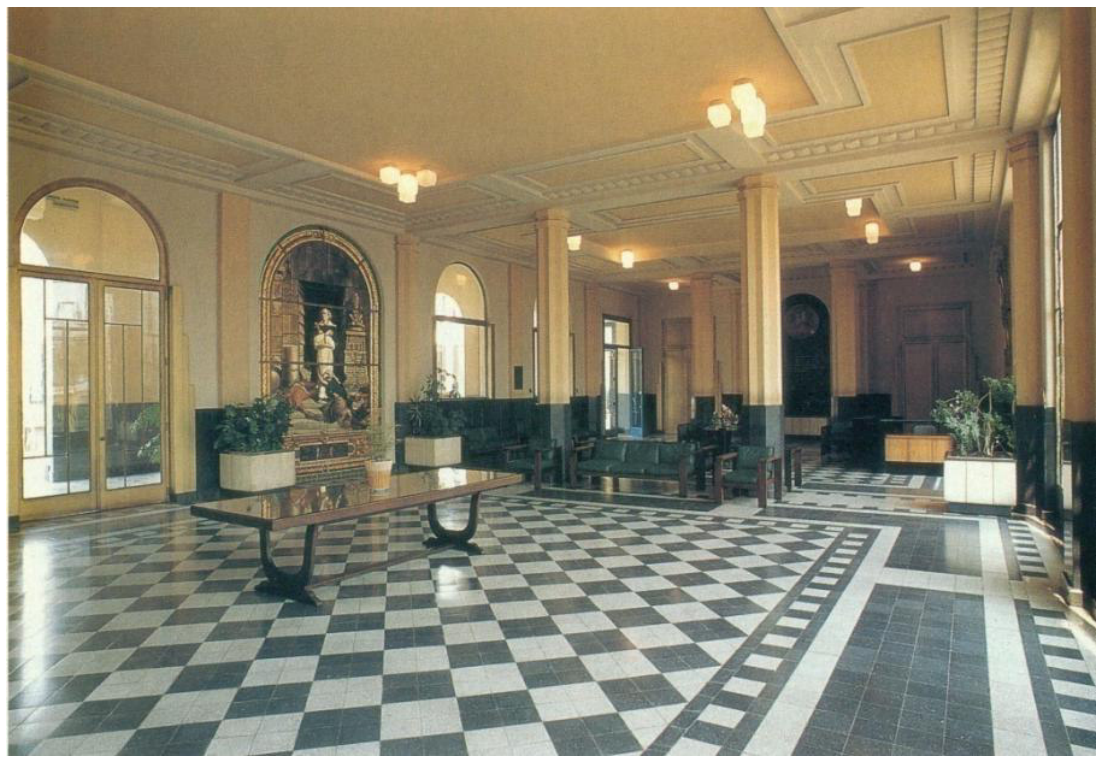

Orfanatorio San Antonio y Santa Isabel, interior, México, D.F., 1927.120
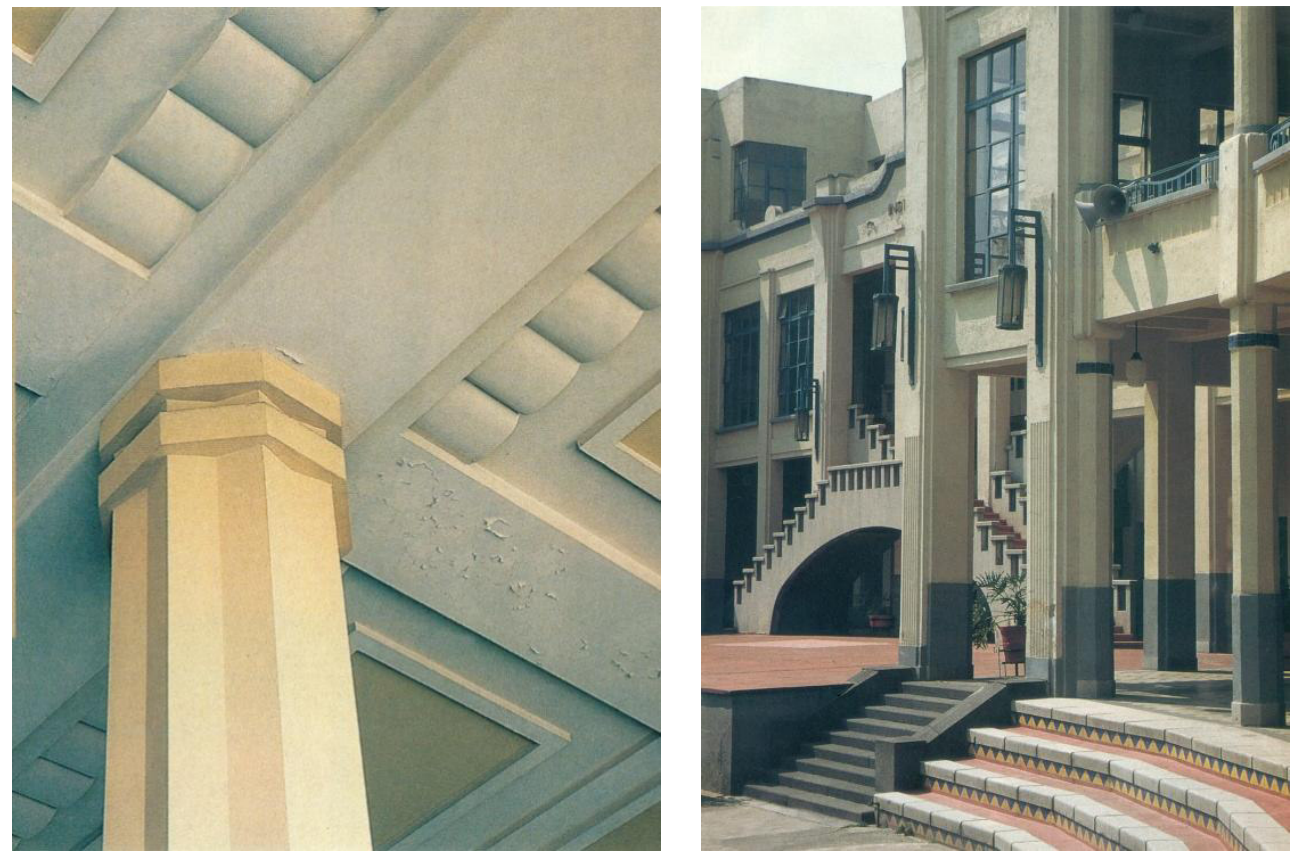

Orfanatorio San Antonio y Santa Isabel. Del lado izquierdo, interior con columna en forma de estrella de ocho picos y estrías gruesas en la techumbre; ${ }^{121}$ del lado derecho escalera y corredores con vista hacia el patio, ${ }^{122}$ México, D.F., 1927.

\footnotetext{
${ }^{120}$ Ibídem, p. 38.

${ }^{121}$ Ibídem, p. 36

${ }^{122}$ Ibídem, p. 39.
} 
En la colonia Hipódromo-Condesa se encuentra el Parque General San Martín y en el centro de éste se ubica como afirmó Israel Katzman "el primer teatro al aire libre"123 Coronel Lindbergh, ambas obras realizadas por el arquitecto Leonardo Noriega en 1927, aunque Katzman y Esqueda atribuyen el teatro al ingeniero Javier Stávoli ${ }^{124}$; el foro está exornado con cinco pilares unidos por un semicírculo en la parte baja y por una marquesina, lo que le da un fuerte sentido clásico y a cada lado del escenario se encuentra el relieve de una mujer, realizados en piedra en 1927 por Roberto Montenegro (1885-1968) y titulados Alegoría del Teatro. En ellos se acentúa la verticalidad en los pliegues del vestido y en las sinuosas líneas en las que se recargan las figuras. Julieta Ortiz Gaitán especialista en la obra de Montenegro diserta: "ambos relieves son trabajos muy interesantes y con un gran sentido decorativo, enmarcados en los lineamientos del Art-Déco, plenamente representativos de la época. En los muros laterales se ven motivos realizados en la misma técnica, que representan el sol, la luna y las estrellas". ${ }^{25}$

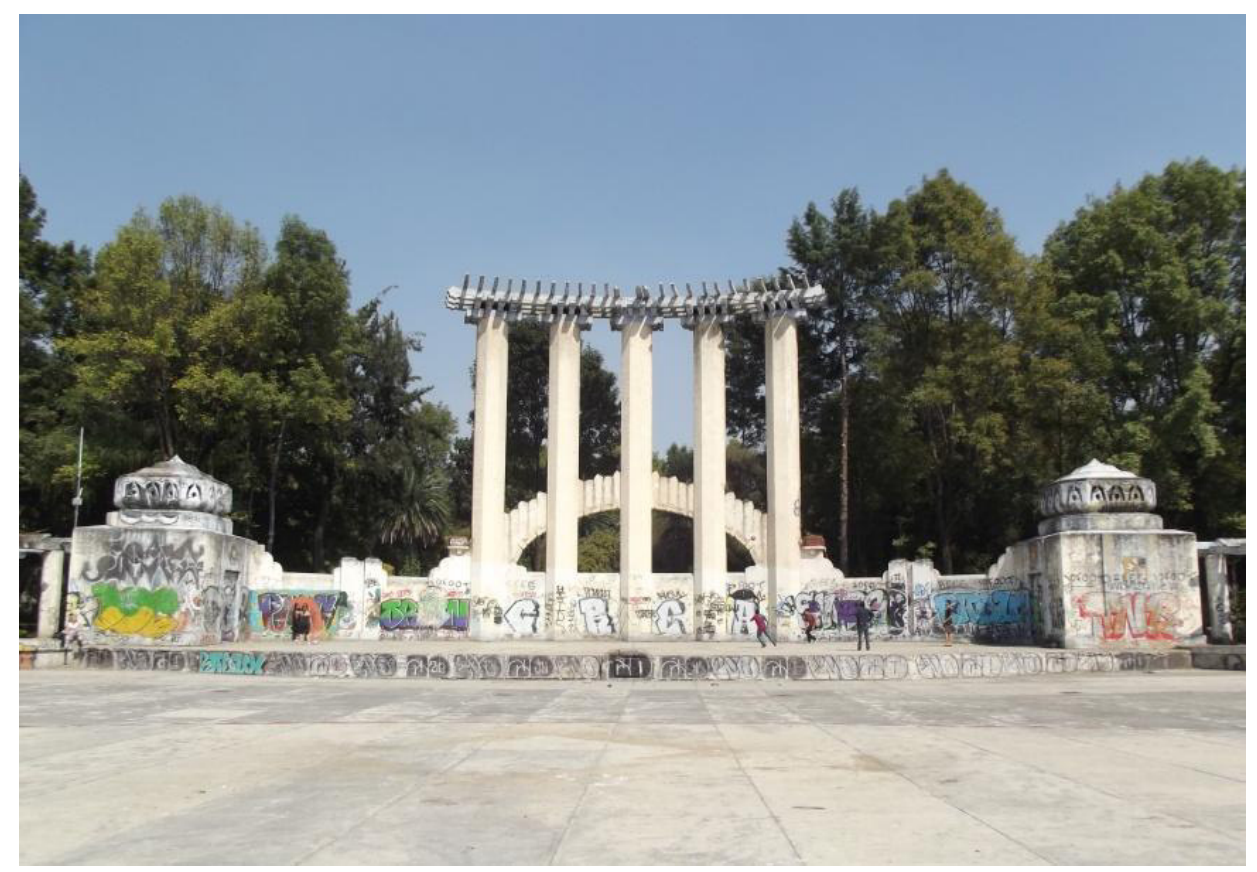

Leonardo Noriega y Javier Stávoli, Teatro Coronel Lindbergh en el Parque Gral. San Martín, México, D.F., 1927.

\footnotetext{
${ }^{123}$ Israel Katzman, Op. Cit., p. 105.

${ }^{124}$ Israel Katzman, Ídem y Xavier Esqueda, Op. Cit., p. 112, quien seguramente se basa en el dato dado por Katzman.

${ }^{125}$ Julieta Ortiz Gaitán, Entre dos mundos: los murales de Roberto Montenegro, México, UNAM, 1994, p. 137.
} 

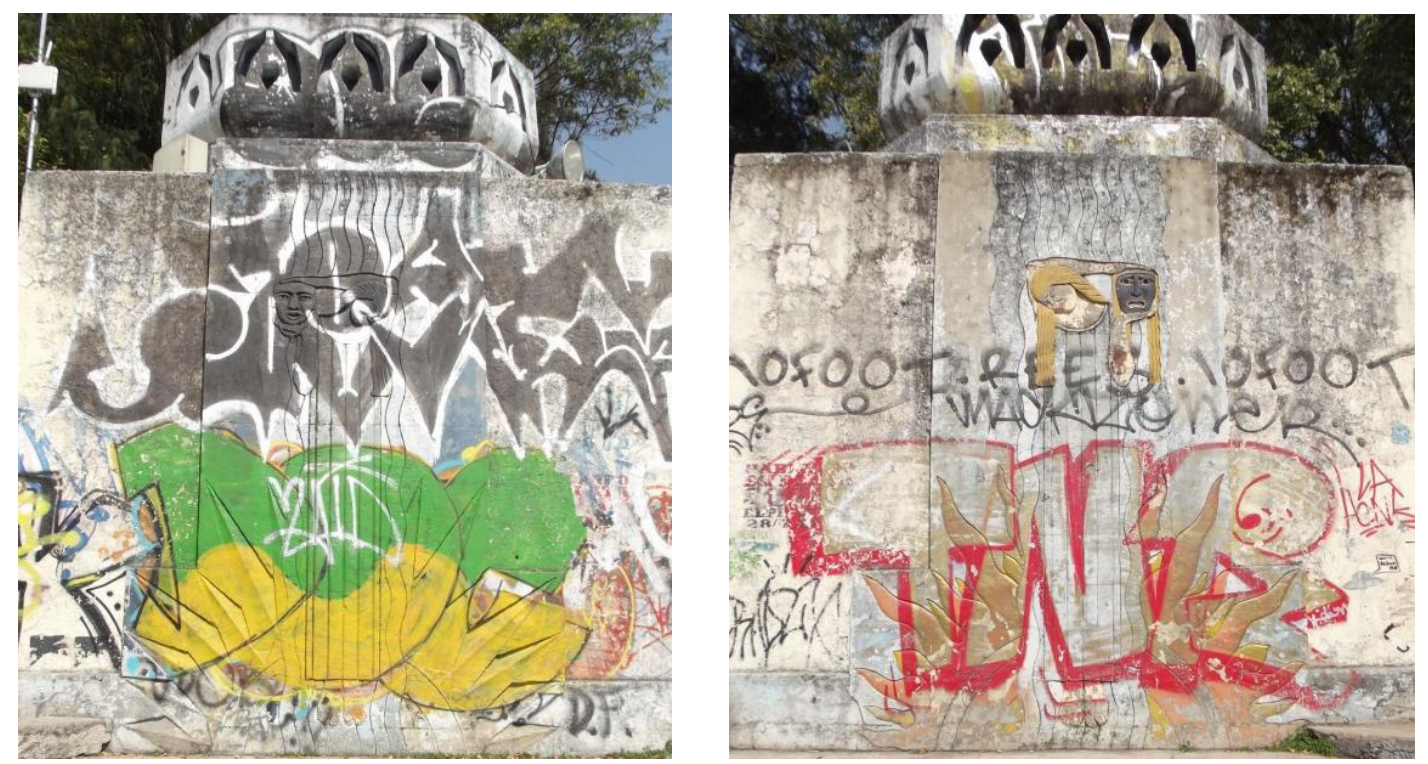

Roberto Montenegro, Relieves (casi invisibles) alusivos al Teatro, en el Foro del Teatro Coronel Lindbergh del Parque Gral. San Martín, México, D.F., 1927.

Rodea al parque un conjunto de columnas que forman una pérgola y una bella fuente con una tectónica figura femenina desnuda, que sostiene dos cántaros de los cuales brota el agua. La pila se recorta en ochavo y la pared es triangular con recortes de acodamientos donde están insertos unos caracoles en color verde.

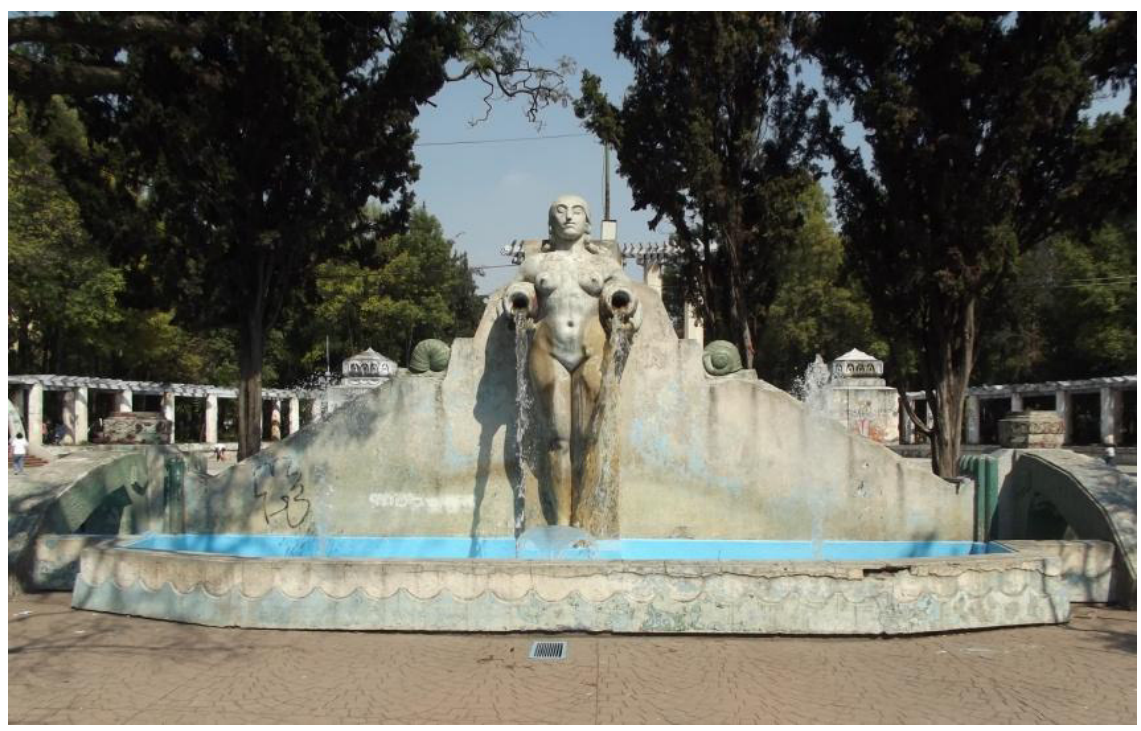

Fuente en el Parque Gral. San Martín, México, D.F., 1927. 
Otro espacio acuático es La Fuente del Reloj, obra del arquitecto José Gómez Echeverría. "De especial relevancia para este parque, es su diseño arquitectónico, mismo que estuvo a cargo del Arq. Leonardo Noriega y del Ing. Javier Stávoli, quienes aprovecharon la monumentalidad y el cuidado en los detalles propios del Art Decó para dar realce a los diferentes espacios". ${ }^{126}$

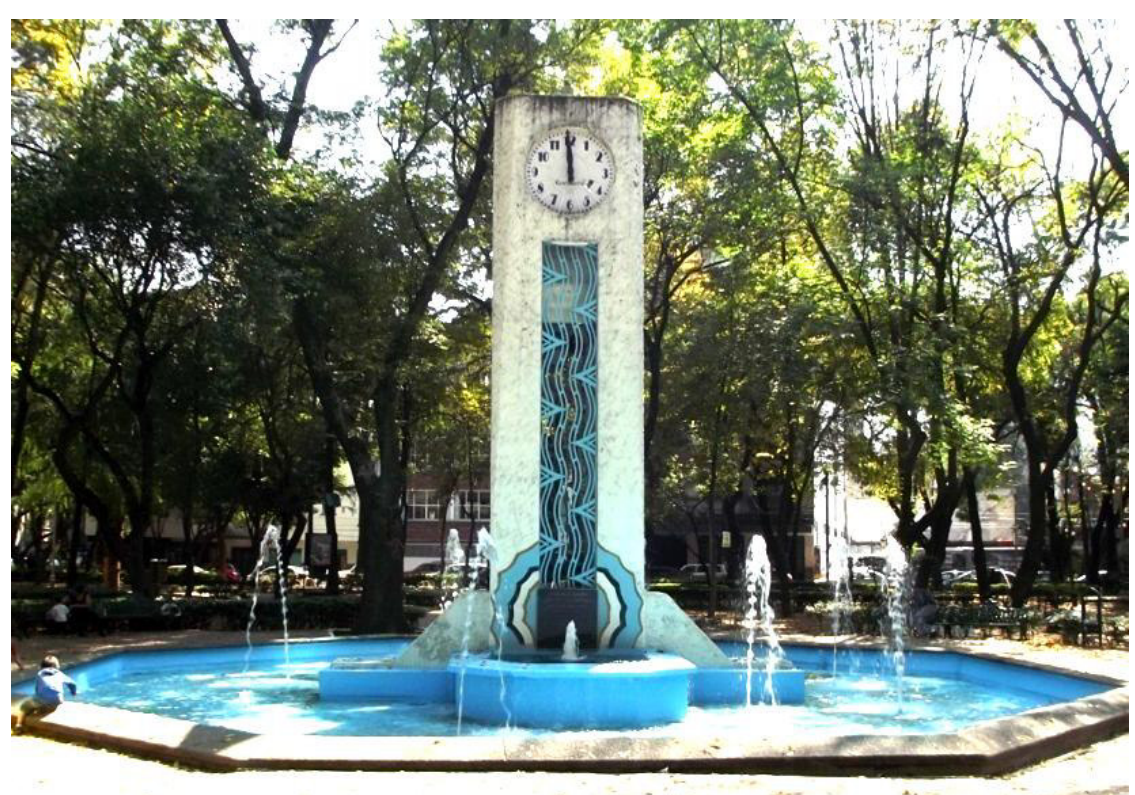

José Gómez Echeverría, La Fuente del reloj, en el Parque Gral. San Martín, México, D.F., 1927.

Por sus características decorativas el Parque General San Martín, entra en las Tendencias Plasticista y Decorativista, y en el Déco tanto del Neoclásico Moderno como del Zigzag. El descuido, el pandillerismo y el grafiti impiden prácticamente apreciar los relieves de Montenegro, como se puede ver en las imágenes.

El Banco de México (5 de Mayo y Eje Central Lázaro Cárdenas, Centro), obra proyectada en 1902 por la constructora de los arquitectos norteamericanos Theodor de Lemos \& Cordes, llevada a cabo a partir de 1904 por el contratista también norteamericano A. R. Whitney Jr., y bajo la dirección del ingeniero mexicano Gonzalo Garita, originalmente fue el edificio de la compañía de seguros La Mutua inaugurado en 1905. Al

\footnotetext{
${ }^{126}$ Victoria Mallet, "Parque San Martín”, México, D.F., 1 de septiembre de 2011, Art Decó México, http://www.artdecomexico.com/parquesanmartin/
} 
crearse el Banco de México en 1925, el edificio fue transformado: en el exterior, en el acceso principal, un ábaco con las figuras desnudas de un hombre y una mujer, obras de Manuel Centurión (1883-1948), acompañan al letrero de la institución bancaria estatal. Ambas cargan unas franelas con pliegues en zigzag y en el cuerpo del hombre está marcadas toda la musculatura. Detrás del letrero, brotan manojos de flores y frutas aprisionados, muy a la manera Déco.

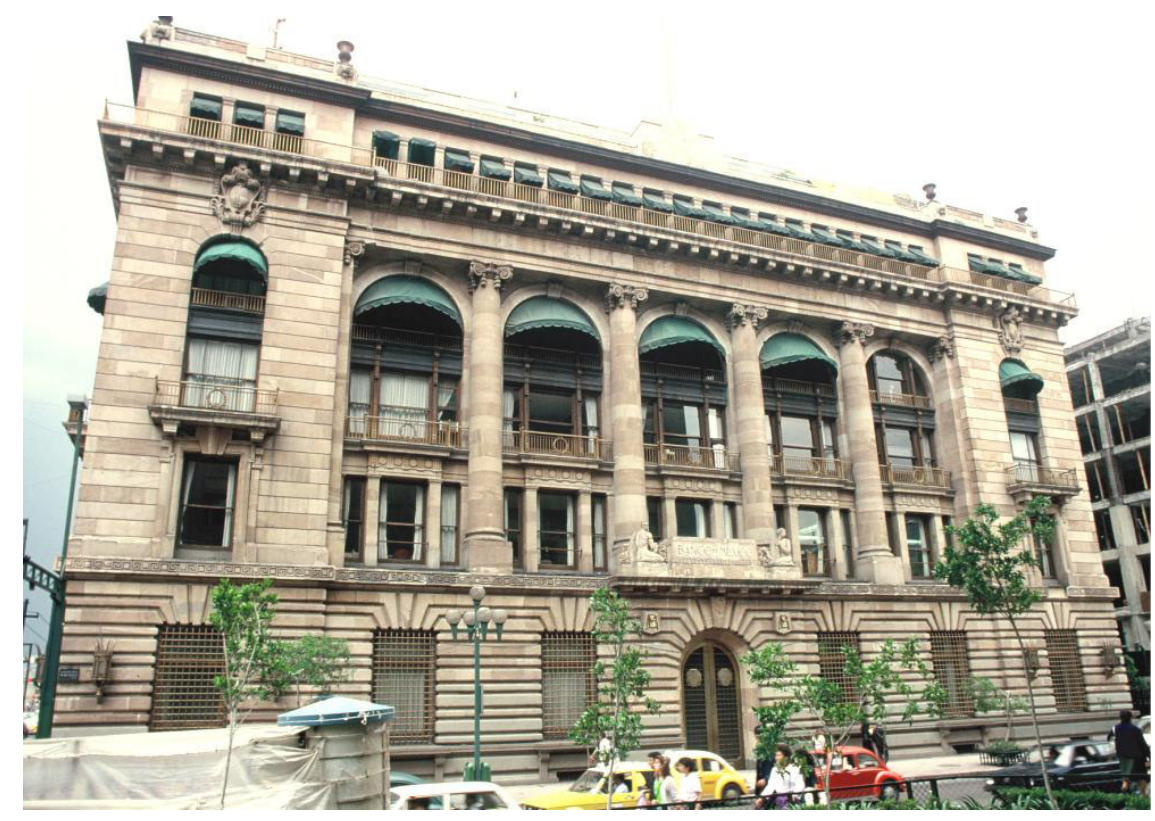

Theodor de Lemos \& Corde, Banco de México, 1905 y 1925.

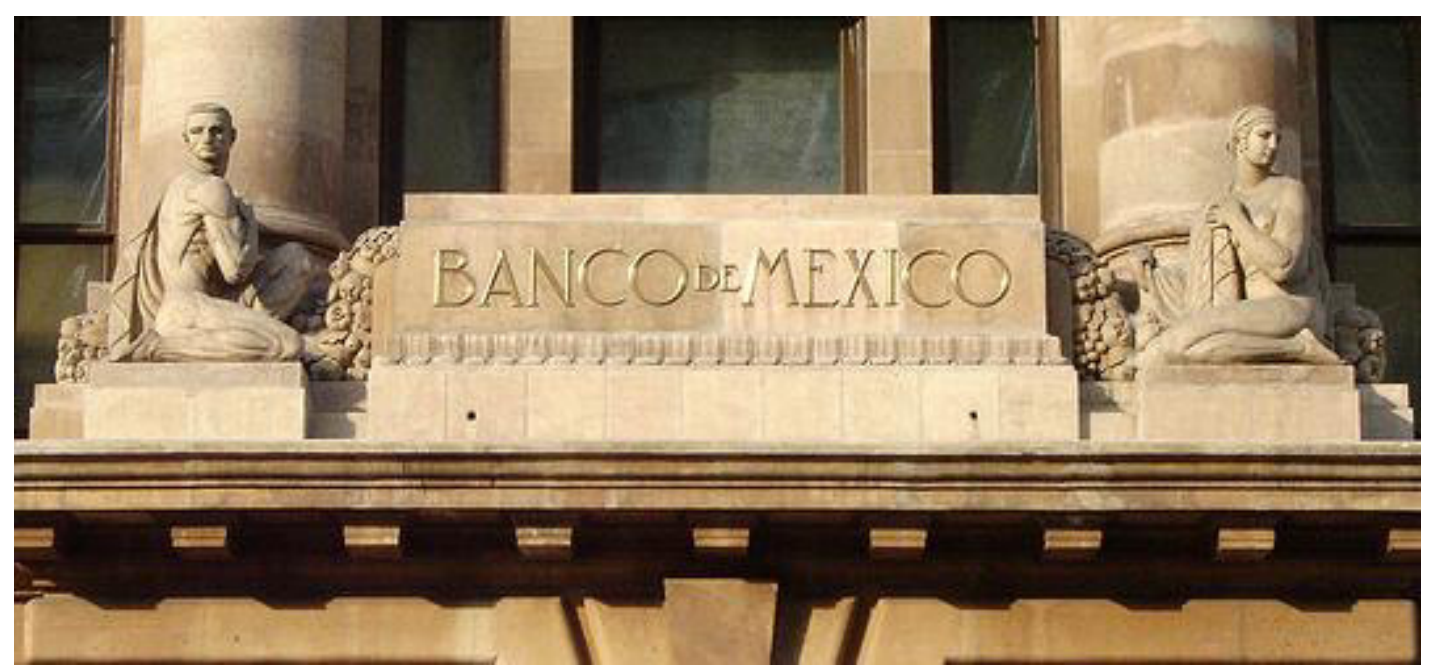

Manuel Centurión, Esculturas en el Banco de México, México, D.F., 1927. 
El interior del Banco de México ${ }^{127}$ fue decorado por el arquitecto Carlos Obregón Santacilia (1896-1961) entre 1926 y 1927. Louise Noelle y Carlos Tejeda comentan: "En el gran espacio central encontramos toda una lección de arquitectura "art déco", con obras de calidad y ricos materiales que van de acuerdo con su relevante giro bancario". ${ }^{128}$ Placas alusivas al escudo nacional, a hombres trabajando la maquinaria y el campo, a corpulentas mujeres desnudas acompañadas de frutos, atribuidas a Manuel Centurión, más geométricos vitrales y lujosos mármoles italianos y belgas cortados en los talleres de las vetas. Antonio Luque hace la siguiente descripción: "El techo del vestíbulo es el elemento más bello y característico Art-Deco de todo el edificio. Seis grandes pilares prismáticos de mármol negro lo sostienen. Se compone de un hermoso plafón (de cristal) al centro, también de color ámbar, cuyos motivos principales son una serie de espigas de trigo en forma quebrada, que rodean un espacio color blanco y ocho paneles de colores neutros que representan cuatro de ellas figuras masculinas y femeninas desnudas reclinadas, que adornan cornucopias que ellas mismas sostienen". ${ }^{129}$ Reinaugurado el inmueble el 12 de octubre de 1927, "a partir de entonces ha sido no sólo un referente importante en la vida económica del país, sino también en la historia de la arquitectura mexicana -ícono del Centro Histórico de la Ciudad de México-, al convertirse en uno de los ejemplos más finos y acabados del estilo art déco reflejado en su maravilloso interior". ${ }^{130}$ Un magnífico ejemplo de la Tendencia Plasticista y Decorativista, a la vez que del Zigzag Moderno por las líneas quebradas continuas que lo ornan.

Vicente Mendiola y Guillermo Zárraga (1920-1988) son los autores del elegante edificio de la antigua Estación de Policía y Bomberos (Revillagigedo No. 11 esquina con Independencia, Centro) del año 1928. Aunque ha sufrido varias remodelaciones en su interior, además de haber ocupado diferentes dependencias gubernamentales, desde 2006 es sede del Museo de Arte Popular Mexicano. La composición estructural geométrica de

\footnotetext{
${ }^{127}$ Debido a que es donde se guarda el tesoro de la nación, no está permitido tomar fotografías ni están publicadas en internet.

${ }^{128}$ Louise Noelle y Carlos Tejeda, Catálogo Guía de Arquitectura Contemporánea. Ciudad de México, México, Fomento Cultural Banamex, 1993, p. 25.

${ }^{129}$ Antonio Luque, "El Banco de México ejemplo del Art-Deco", Catálogo de la exposición Art Deco en México, Op. Cit., p 28.

${ }^{130}$ Edgar Tavares López, "El edificio de la Compañía de Seguros La Mutua", Relatos e historias de México, México, Editorial Raíces, Año III, No. 32, abril 2011, p. 10.
} 
planos superpuestos, alterna con las ventanas escalonadas del cubo de la torre, la cual remata con una torreta.
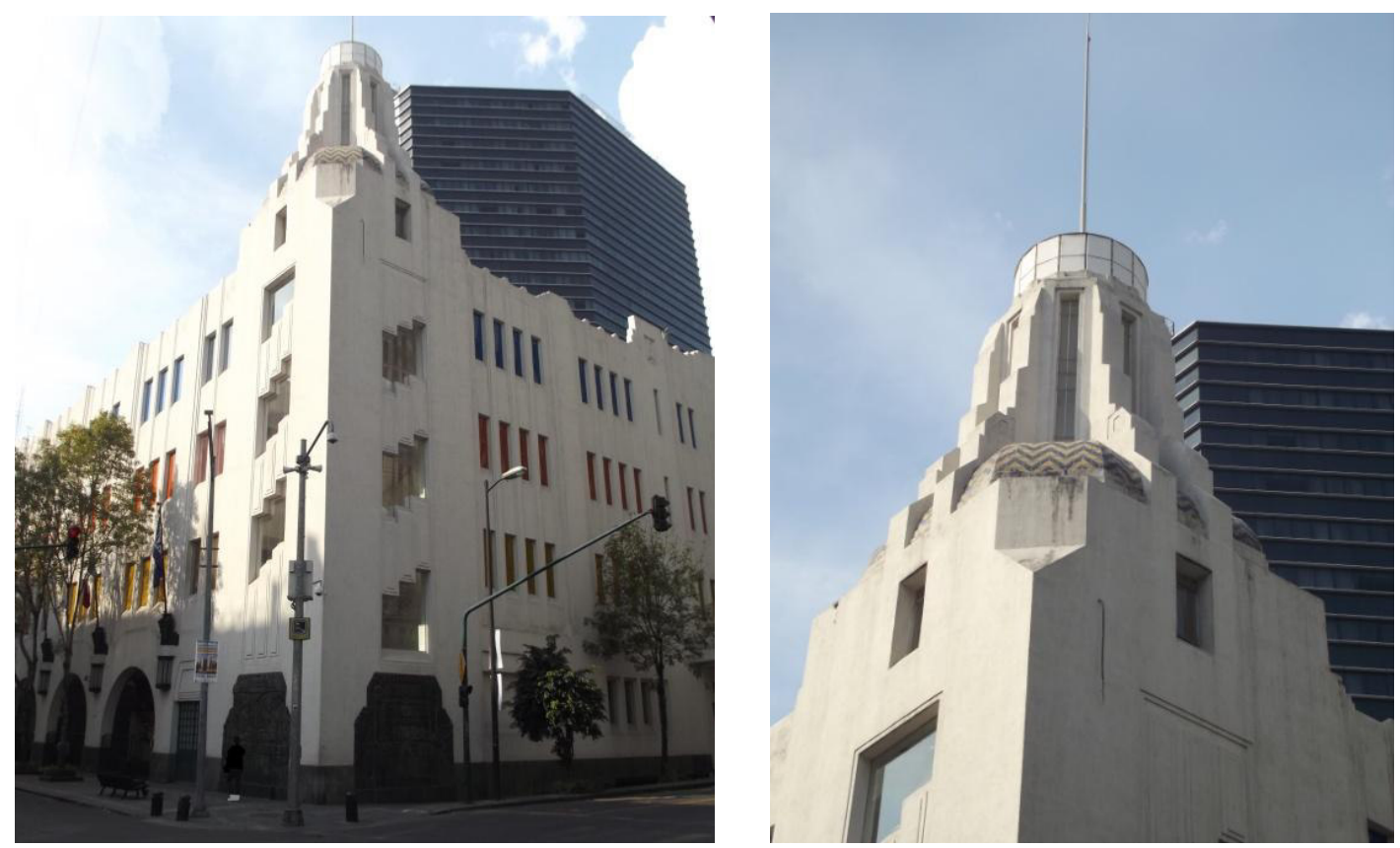

Vicente Mendiola y Guillermo Zárraga, Antigua Estación de Policía y Bomberos, México, D. F., 1928.

El edificio conserva la mayoría de su diseño original y decoraciones exteriores, entre ellas dos placas con motivos prehispánicos que embellecen el exterior, obras del escultor Manuel Centurión, quien inspirado en la cultura olmeca presenta a unos personajes con amplias fosas nasales, colmillos salientes, lengua bífida y rodeado por plumas flamígeras, lo que enlaza la cosmovisión del dios-hombre-jaguar-serpiente emplumada; estos relieves son un buen ejemplo de la integración de lo prehispánico en la modernidad del Déco.

Cuatro lámparas prismáticas de los $\operatorname{arcos}$ de la entrada principal fueron acertadamente restauradas, ya que muchas estaban destruidas casi en su totalidad, y encima de ellas unas ménsulas sostienen astabanderas. La composición estructural geométrica de planos superpuestos, alterna con las ventanas escalonadas del cubo de la torre, la cual remata con una torreta. Digno ejemplar del Art Déco en México, la Antigua Estación de Policía y Bomberos está dentro de la Tendencia Geometrista, Plasticista, y de la 
Decorativista, así como del Zigzag por el juego de las líneas geométricas que aparecen por varias partes de la construcción.

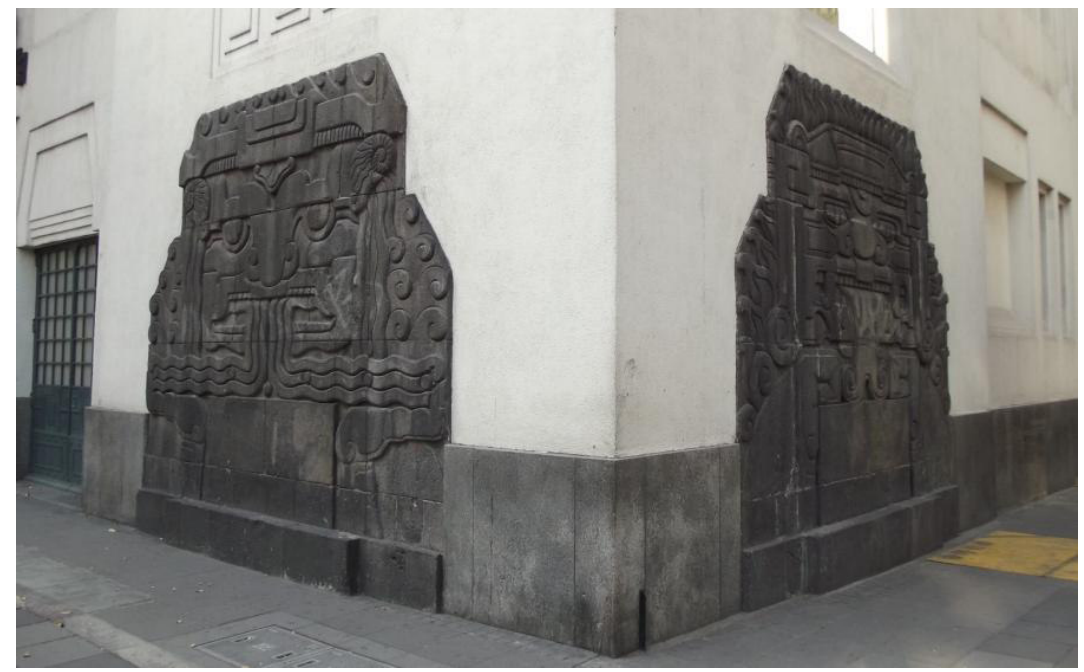

Manuel Centurión, Relieves con motivos olmecas, Antigua Estación de Policía y Bomberos, México, D.F., 1928.
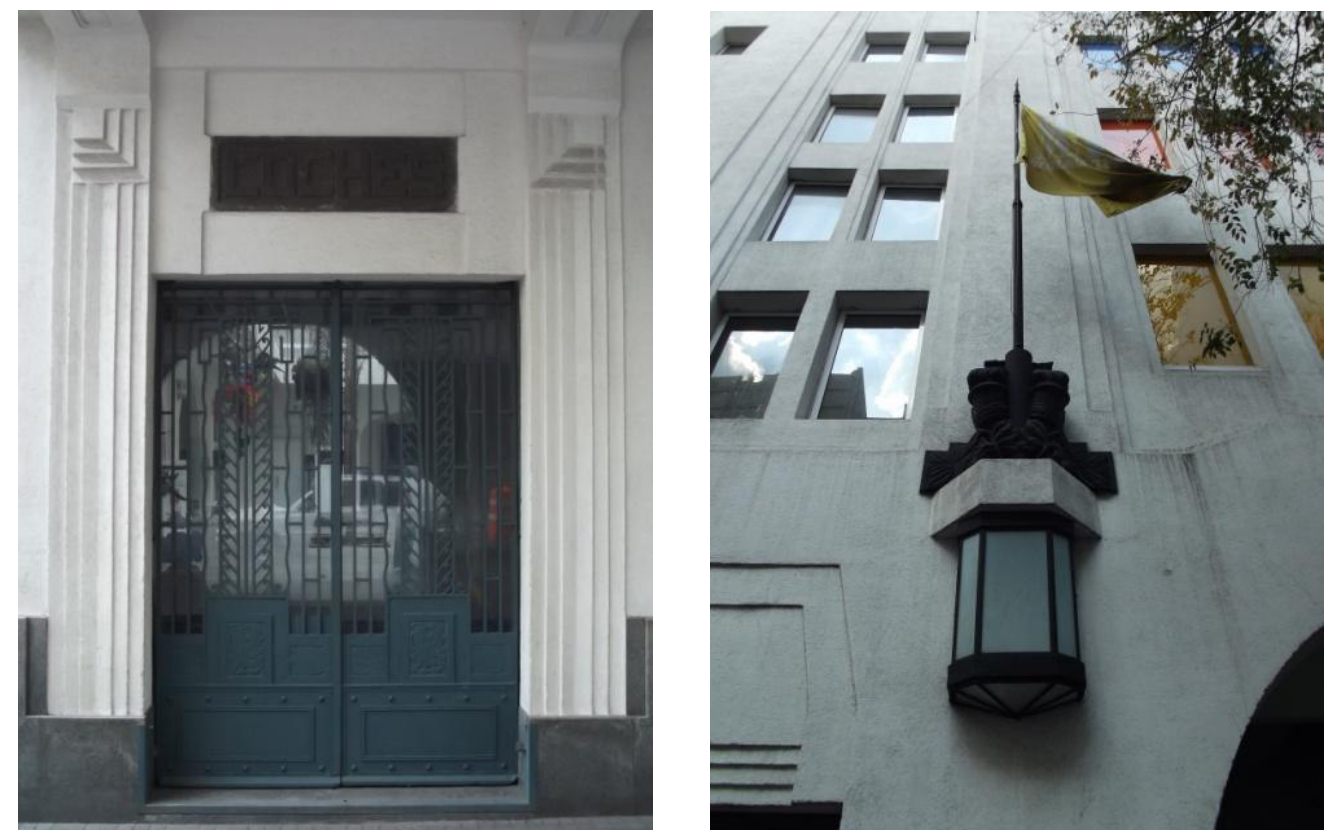

Puerta de coches y lámpara en la Antigua Estación de Policía y Bomberos, México, D.F., 1928.

Un edificio que aparte de estar dentro de la arquitectura moderna de la época significaba las nuevas formas de vida fue el Frontón México (Plaza de la República y Manuel Ramos Arizpe, Col. Tabacalera), levantado de 1927 a 1929 por el arquitecto 
Joaquín Capilla. De planta rectangular dos de las fachadas se organizan con contrafuertes estriados que se aúnan al remate circular de la bóveda rebajada de concreto que cubre el edificio; lleva dos puertas con arcos de medio punto donde se inscriben los letreros, ventanales ochavados y en unos recuadros la figuras de unos personajes jugando pelota vasca. En dos de las esquinas, se localizan otros accesos con arcos abocinados de medio punto y cubiertos por marquesinas; estas esquinas de forma cilíndrica se acompañan de ventanales, uno con dintel quebrado y otro rectangular, para rematar con una placa decorada con un bajo relieve con motivos prehispánicos; es un personaje ataviado a la manera de los "tlatoanis" mexicas y la técnica del aplanado con que fue realizado, rememora la manera en cómo eran trabajados los relieves por los artífices aztecas. El Frontón México se inserta dentro de la Tendencia Geometrista y por algunos otros elementos como las placas y las marquesinas, en la Decorativista, además de resaltar lo indígena prehispánico con el relieve mencionado. Este inmueble después de estar desmantelado desde 1996, había sido restaurado y se quiso poner nuevamente en funciones en noviembre de 2010, pero debido a problemas de los propietarios herederos, nuevamente quedó abandonado.
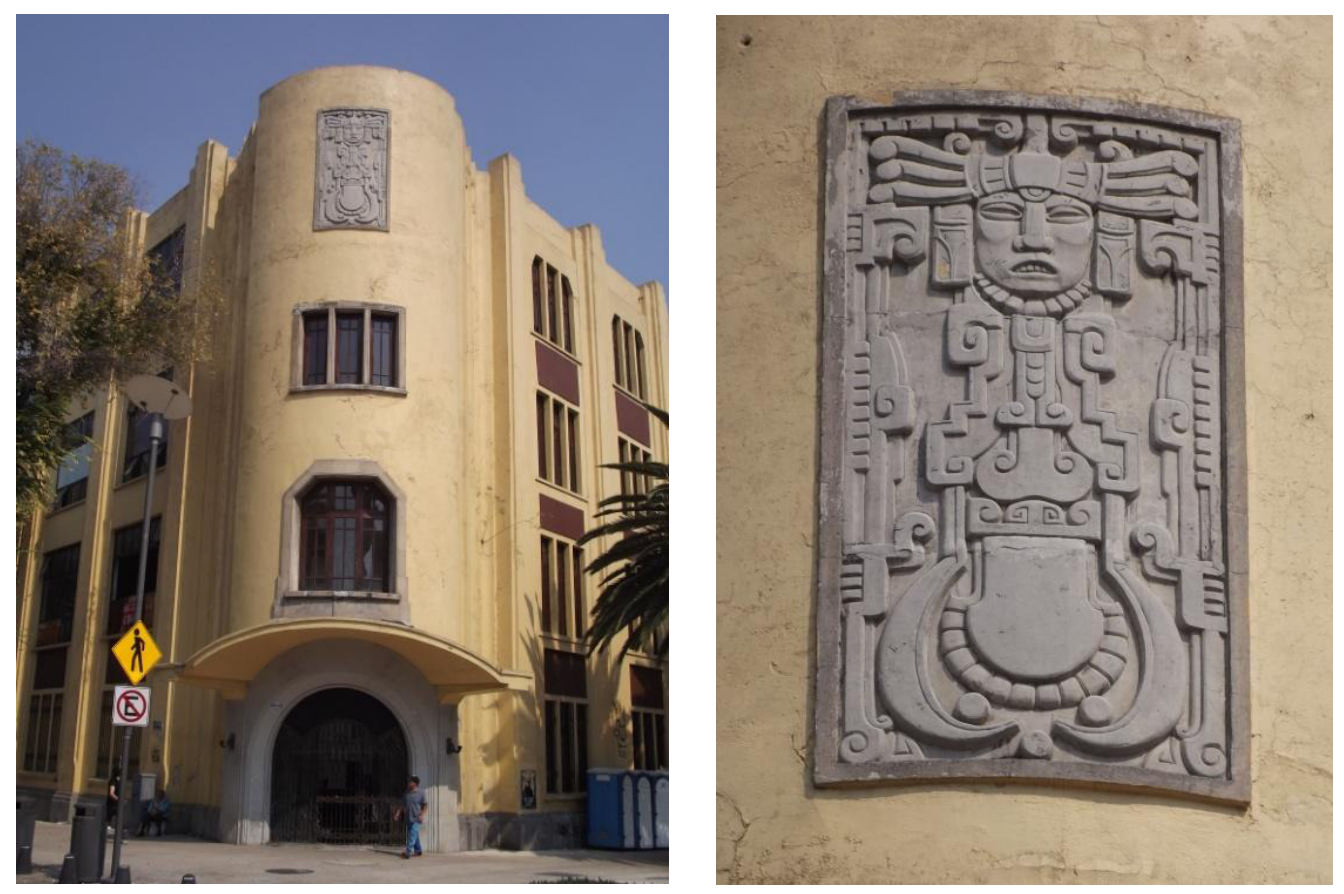

Joaquín Capilla Frontón México, uno de los accesos principales y detalle del relieve de la parte superior con motivos indigenistas, México, D.F., 1929. 


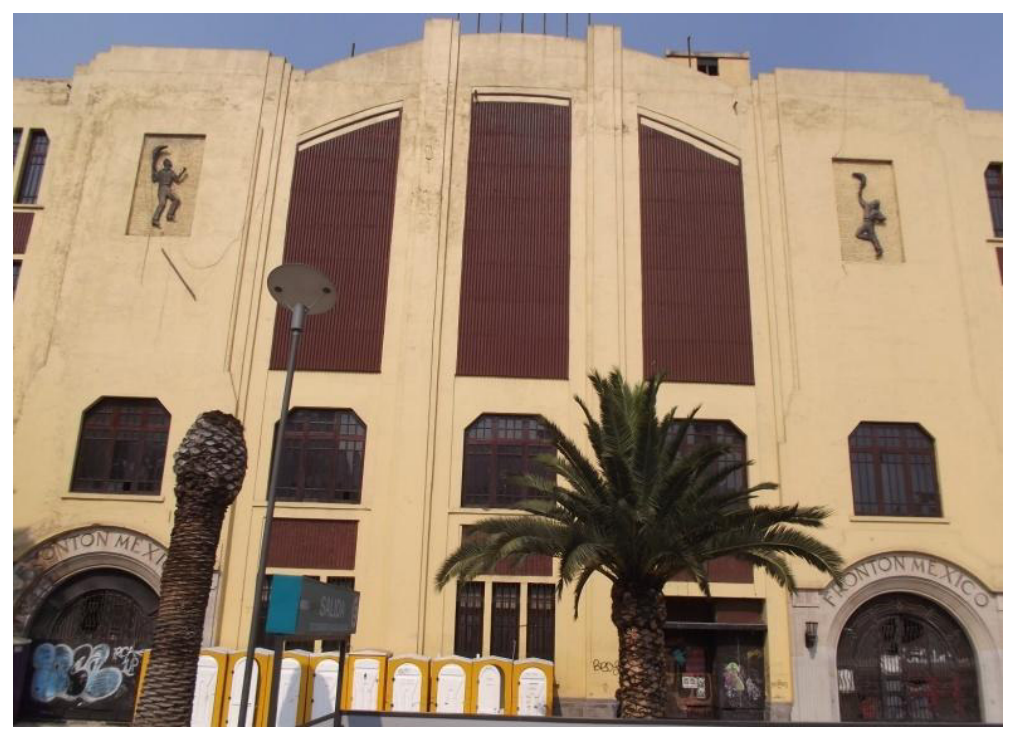

Joaquín Capilla, Frontón México, fachada sur México, D.F., 1929.

El ya reseñado edificio de la Secretaría de Salud (Lieja No. 7, Col. Juárez) de 1926 a 1929 es aún un moderno inmueble que tanto lleva el sello del Art Déco como del Estilo Internacional. Obra también de Carlos Obregón Santacilia, es un armonioso ensamblaje de áreas conectadas con puentes mecánicos y rampas. En su fachada se concatenan cubos que partiendo del central y más pequeño, se adhieren lateralmente uno a cada lado para luego recibir otros dos más de manera perpendicular. En los cinco paramentos se ritman ventanas rectangulares con las intermedias de arco de medio punto, enmarcadas con remetidos perfiles angulosos. El acceso principal se compone de una puerta de dintel quebrado ochavado y arriba de éste se encuentra el escudo nacional.

Toda esta magna construcción se completa con los murales de Diego Rivera (18861957), así como por vitrales proyectados por él, además de las esculturas de Manuel Centurión, los bajorrelieves de Hans Philling y las placas de bronce de William Spratling (1900-1967). En el libro de ART DÉCO. Un país nacionalista. Un México cosmopolita, Enrique X., de Anda le dedica un capítulo a este inmueble al que titula "El Edificio de la Secretaría de Salud: la modernidad frente al castillo". Por sus elementos decorativos esta obra de Obregón Santacilia está dentro de la Tendencia Decorativista, pero principalmente abarca elementos de línea quebradas del Déco Zigzag. 


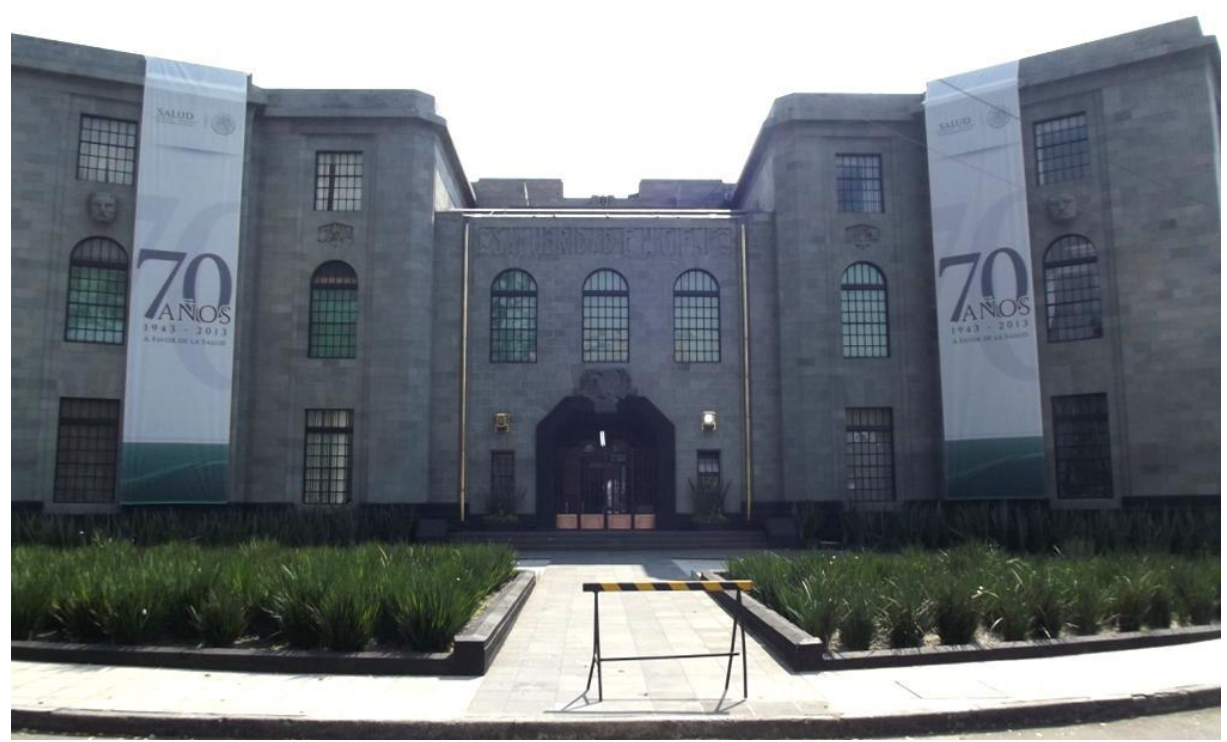

Carlos Obregón Santacilia, Secretaría de Salud, México, D.F., 1929.
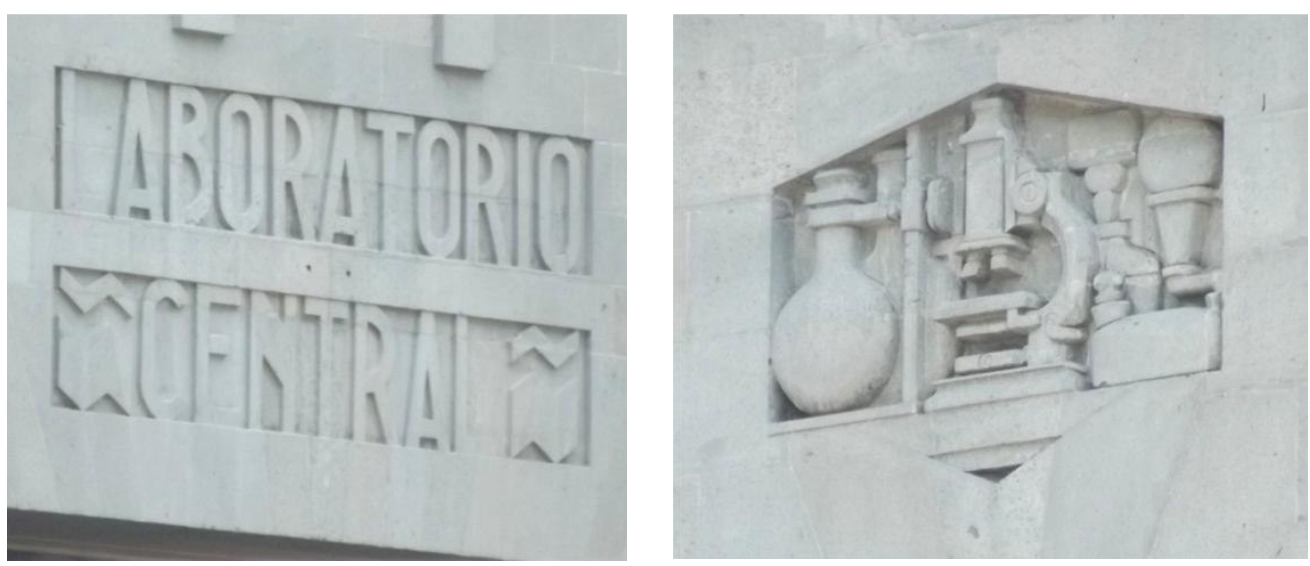

Manuel Centurión, letrero del Laboratorio Central y relieve con instrumentos de laboratorio, Secretaría de Salud México, D.F., 1929.

La Central Telefónica Victoria, ahora Teléfonos de México (Victoria No. 30, Centro), fue edificada por el ingeniero Hugo Lindquist y los arquitectos hermanos Fernando y Miguel Cervantes ${ }^{131} 1931$, nombres inscritos con letras en rehundido en columnas al lado izquierdo y derecho respectivamente. Edificio que estaba de acorde con la modernidad tecnológica postrevolucionaria, la fachada forrada con lajas de cantera clara, expone un sentido de verticalidad ascendente, pues se divide a través de bandas

\footnotetext{
${ }^{131}$ Louise Noelle y CarlosTejeda, Op. Cit., p. 36, dan la fecha de 1938 y al autor lo citan como Manuel Cervantes.
} 
superpuestas que nacen desde el rodapié escalonado confeccionado con cantera obscura y rematan al final del edificio, lo cual se conjuga con ventanales rectangulares divididos en tres, o bien individuales.

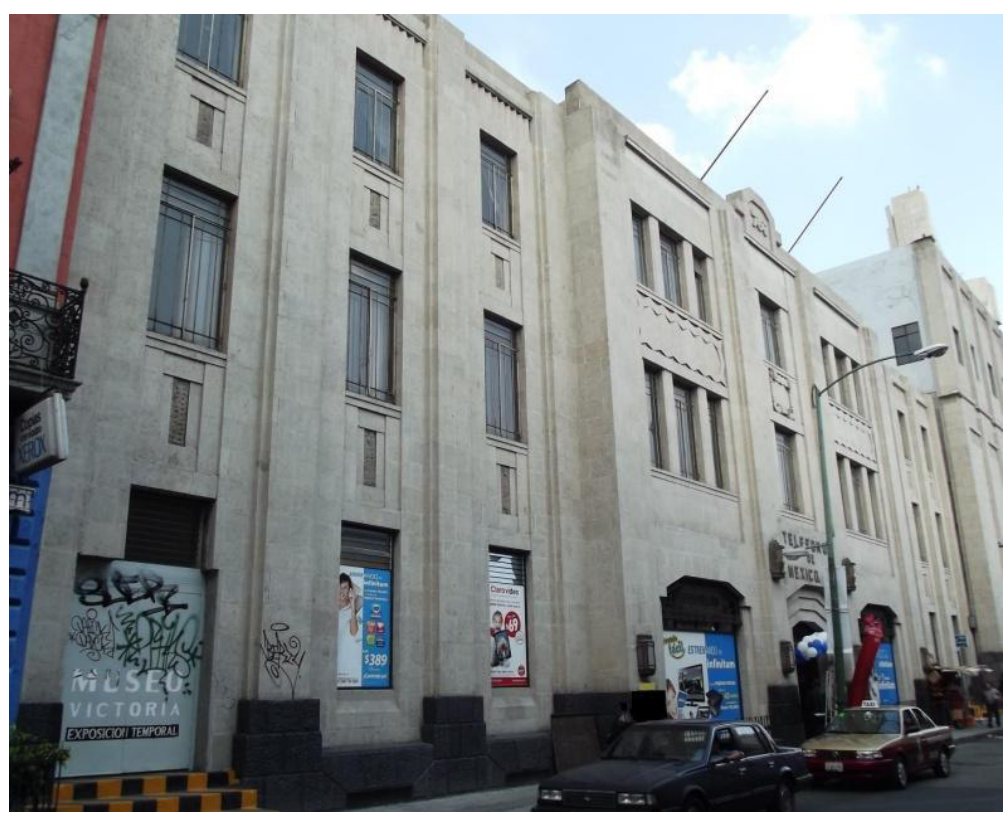

Fernando y Miguel Cervantes, Hugo Lindsguit, Central Telefónica Victoria, México, D.F., 1931.
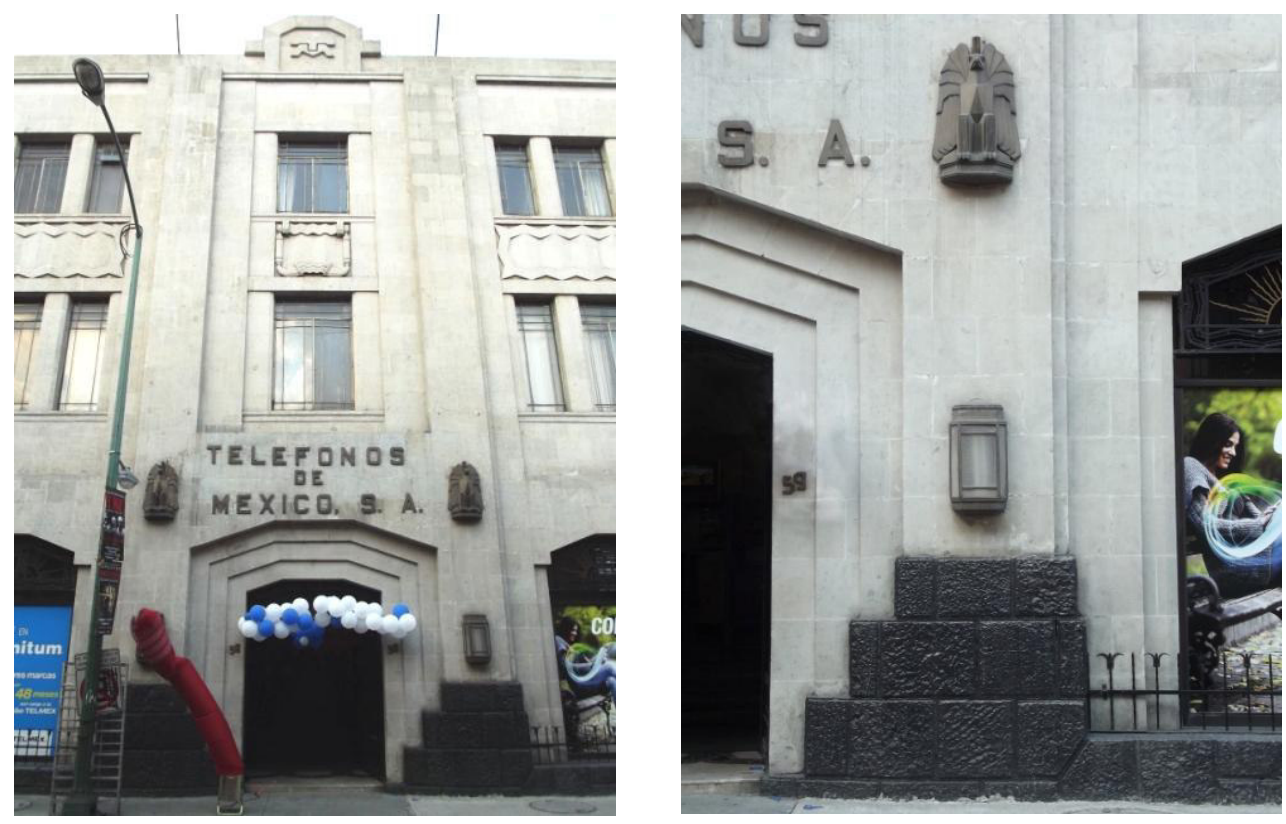

Central telefónica Victoria, calle principal del cuerpo central y detalle del rodapié, lámpara y águila, México, D.F., 1931. 
Tres vanos de arco ochavado se abren en la planta baja: el del acceso principal se conforma con ligeros remetimientos que siguen la forma del arco, dándole un sentido de abocinamiento; los otros dos son amplios ventanales en cuyo remate unas herrerías envuelven el letrero de "Teléfonos", enmarcados por líneas zigzagueantes y unos cuartos de soles resplandecientes. Debajo de los ventanales del segundo nivel, unas molduras planas enmarcan decoraciones geométricas que semejan biombos zigzagueantes, reforzados por molduras que siguen la misma cadencia.

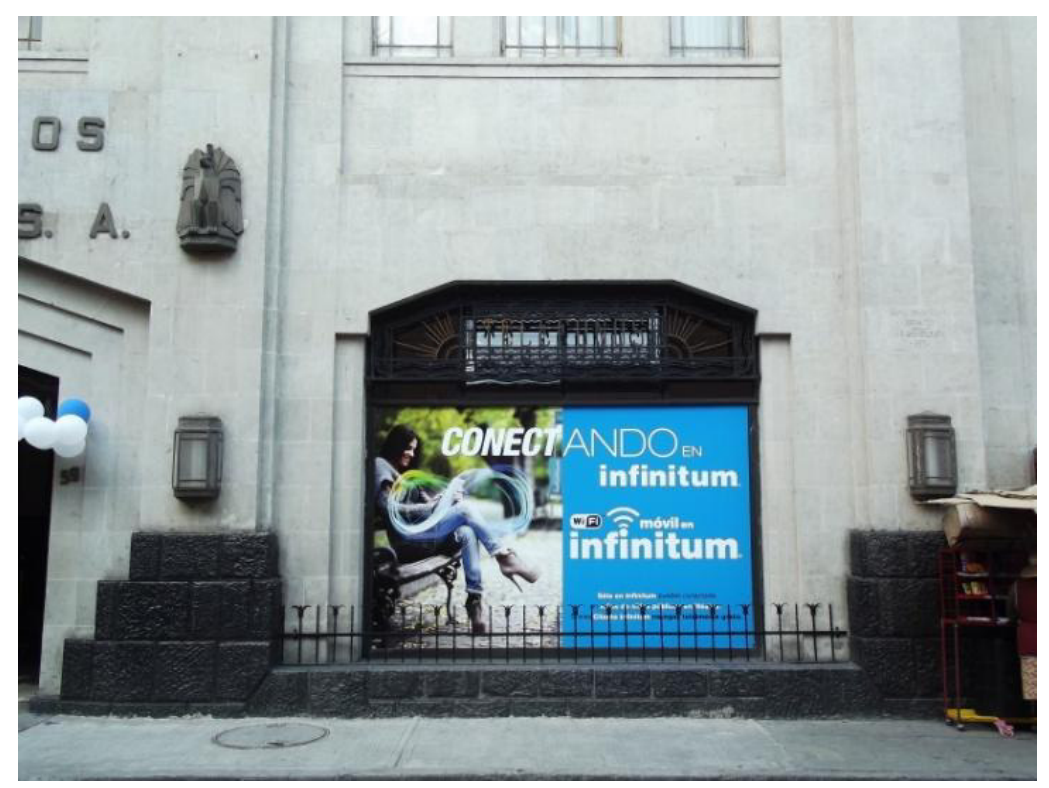

Central telefónica Victoria, ventanal derecho, México, D.F., 1931.

Para consumar la galanura Art Déco de la Central Telefónica Victoria, en las columnas del cuerpo central, dos de cada lado, están colocadas unas lámparas de formas prismáticas y a los lados del letrero unas águilas doradas vaciadas en bronce símbolo de la comunicación telefónica, con estilizaciones geométricas típicamente de la época conformadas por la conexión de prismas y poliedros, sirven a la vez de astabanderas. En las columnas de los extremos del cuerpo central, están grabados los nombres de los constructores. Clara decoración del tipo Déco Zigzag que se hermana con las Tendencias Geometrista y la Decorativista 

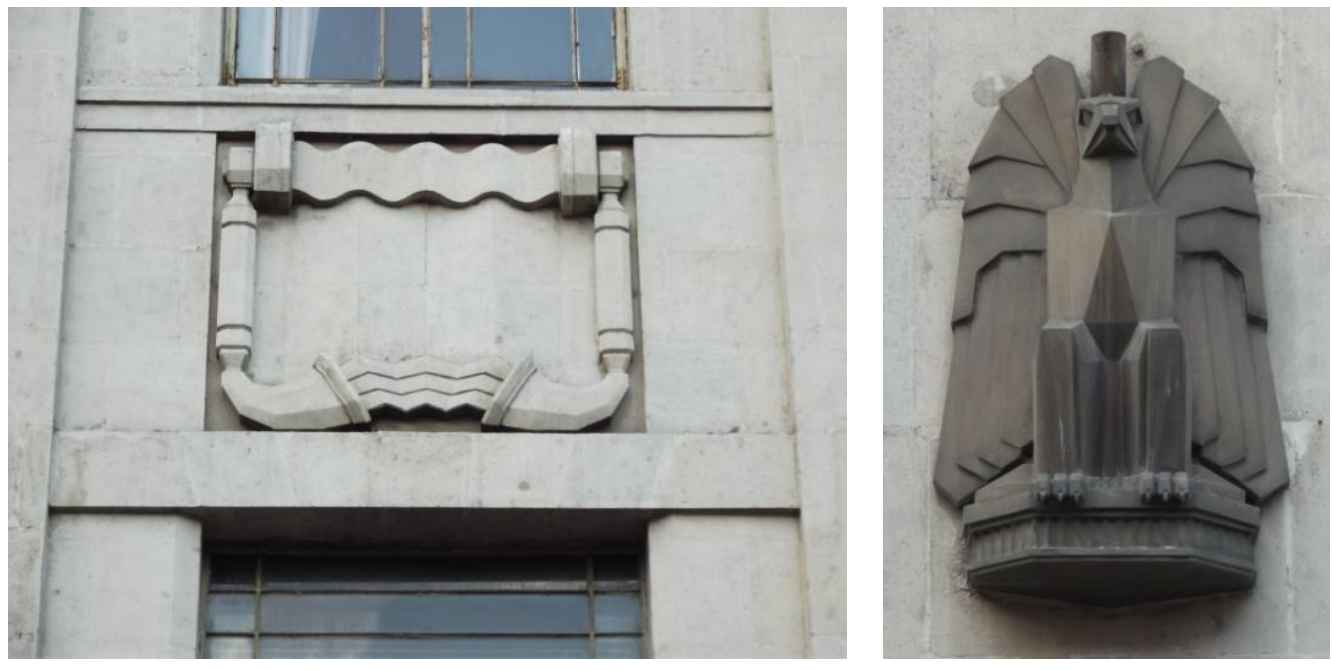

Central telefónica Victoria. Lado izquierdo detalle decorativo alusivo al uso del teléfono; lado derecho águila en bronce símbolo de la comunicación telefónica y usada como astabandera, México, D.F., 1931.
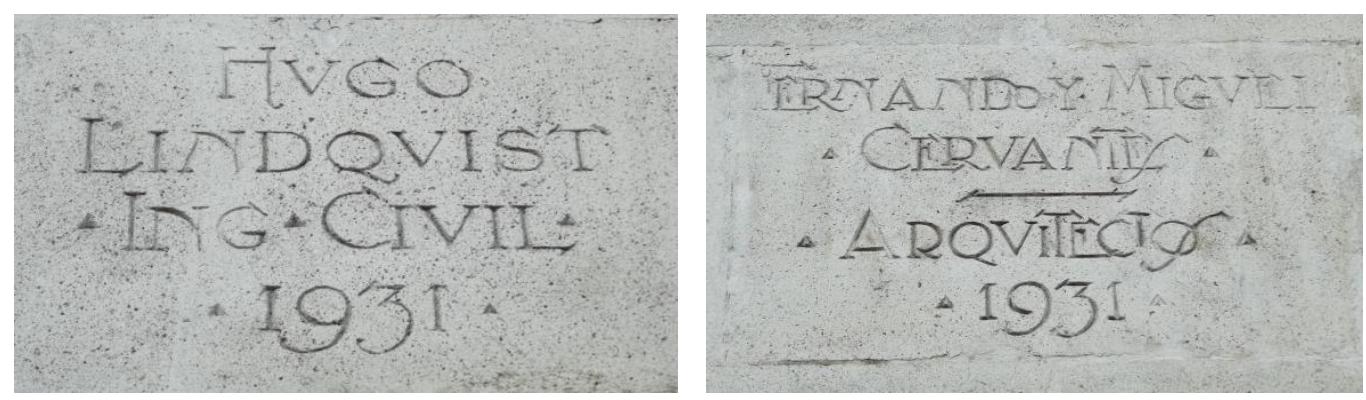

Central Telefónica Victoria, nombres de los constructores en el orden como aparecen citados: Hugo Lindquist Ing. Civil 1931; Fernando y Miguel Cervantes Arquitectos 1931.

Uno de los edificios Déco de apartamentos más famoso es el Edificio San Martín (Av. México No. 167, Col. Hipódromo-Condesa), construido en 1931 por el ingeniero Ernesto Ignacio Buenrostro ${ }^{132}$, cuyo nombre con la falta de algunas letras está del lado superior izquierdo de la marquesina. En la planta baja el único acceso es un arco mixtilíneo de dos perfiles cubierto por una marquesina también de compostura mixta, en la que hay vidrio-blocks que permiten el paso de luz, provocando una asimétrica iluminación natural; en medio de ésta y del arco está el letrero del edificio en letras esculpidas sobre la misma

\footnotetext{
${ }^{132}$ Marisol Flores García en su libro Guía de recorridos urbanos de la colonia Hipódromo, México, INBA, Universidad Iberoamericana, 2002, p. 172, comenta que muy poco se sabe sobre la vida de Ernesto Ignacio Buenrostro, pero al analizar el "Edificio de el Parque de 1935" en la misma Avenida México menciona que es obra de Ernesto Ignacio Buenrostro y de José M. Buenrostro, por los nombres que se encuentran escritos, pero que de ambos no se sabe nada y que tal vez eran familiares.
} 
superficie. El característico rodapié, esta vez en granito rojo se complementa con sendas jardineras cúbicas a los lados de la entrada. Dos niveles más son parte del edificio; las entrecalles de los extremos resaltan sobre la central, consiguiendo articulándose todas entre sí, y ostentan álgidos pares de bandas superpuestas que nacen en la base del arranque y rematan de manera envolvente con ligeros esgrafiados lineales. En la peana de las ventanas del segundo nivel se proyectan hacia el exterior jardineras geométricas y en el remate de las ventanas del tercer nivel, recuadros horizontales guardan decoraciones fitomorfas. Prototípico ejemplo del Art Déco mexicano de la variante Zigzag, el Edificio San Martín hasta finales de 1999 se encontraba -desde hace veinticuatro años- en estado de abandono. Fue restaurado por el arquitecto Carlos Duclaud, dueño del inmueble junto con Claudia Madrazo directora de la empresa La Vaca Independiente, aparte del patrocinio de esta empresa, contaron con el apoyo de Banamex y del señor Imanol Legorreta Molina. Se respetó toda la construcción y decoración exterior e interior, salvo que se le agregó una cochera y dos "Pent House" en la azotea, con el fin de responder a necesidades modernas. Se restauró todo integralmente en el estilo Déco, incluyendo los diez vitrales de Eduardo Villaseñor, el vitralista de Diego Rivera autor también de los de la Secretaría de Salud.
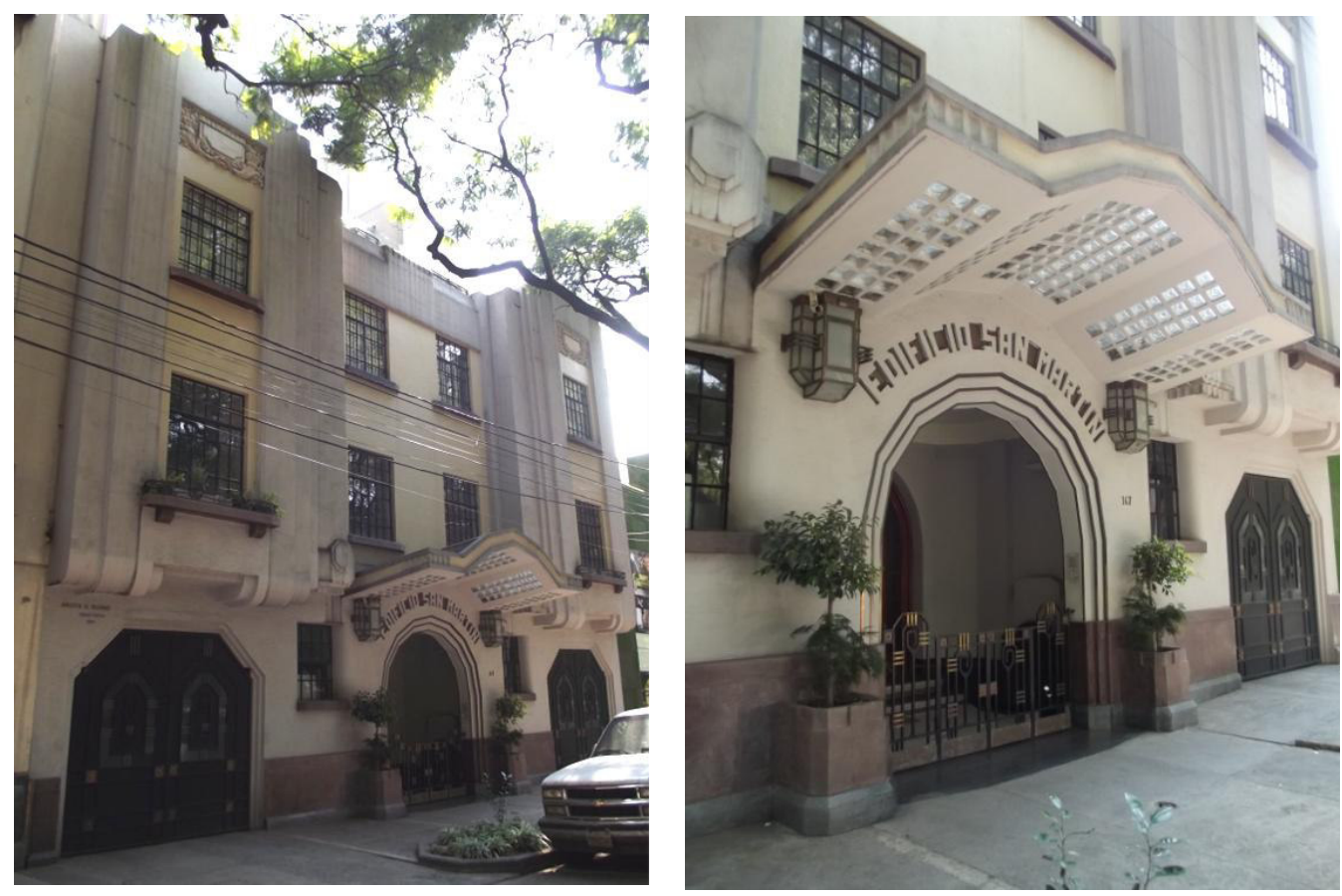

Ernesto Ignacio Buenrostro, Edificio San Martín, México, D.F., 1931. 

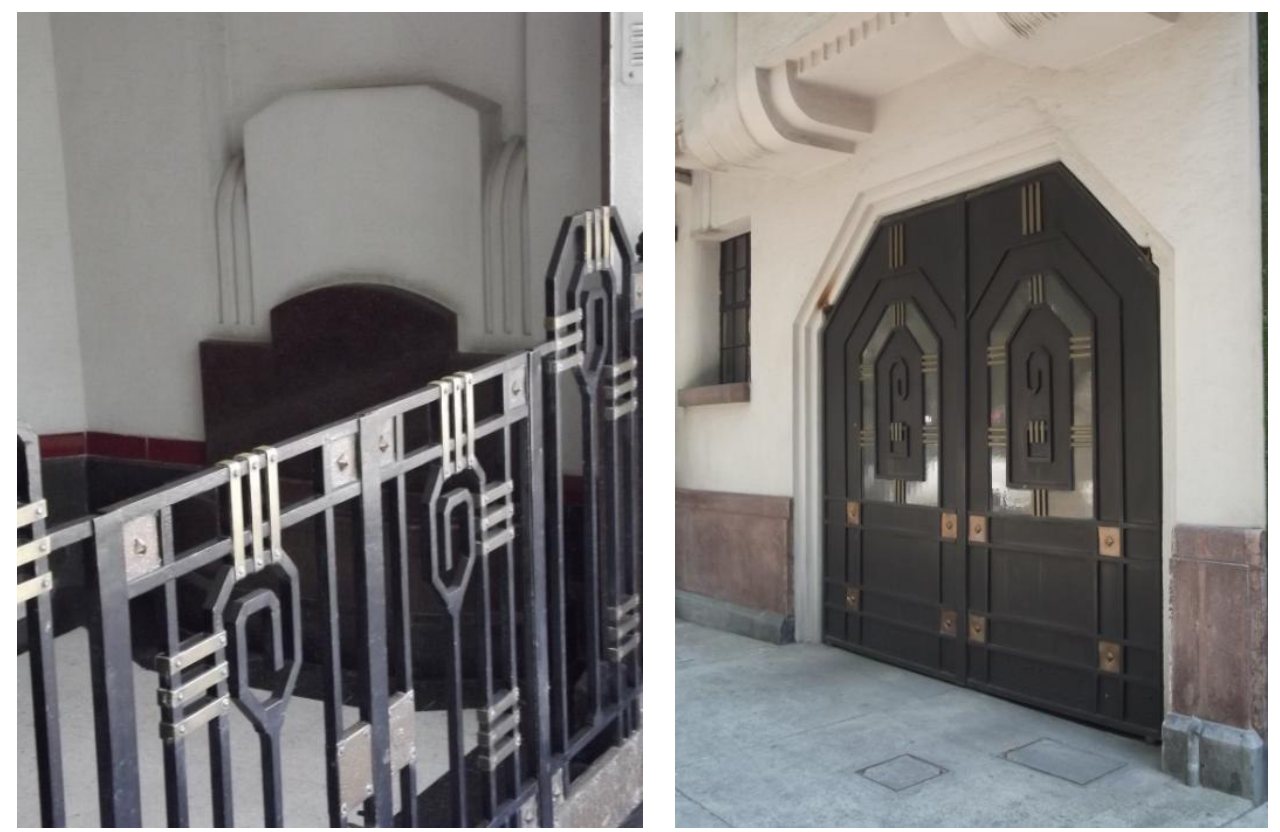

Edificio San Martín, detalle de la rejería de la entrada y de la cochera, México, D.F., 1931.

Los seis apartamentos del edificio fueron subastados con el fin de hacer una labor de adoptar una obra de arte, pues el Edificio San Martín está catalogado como Monumento Artístico por el INBA. De acuerdo a la noticia publicada en el diario Reforma de la ciudad de México por la periodista Virginia Bautista, dice que "El arquitecto [Duclaud] narra que para concluir el rescate del San Martín hizo falta, además de los casi dos años de trabajos físicos, una ardua labor de convencimiento tanto de las autoridades del INBA, para que otorgaran el permiso, como la Asociación de Vecinos de la Condesa, que veía con desconfianza la intervención". ${ }^{133}$ El resultado ha sido exitoso y digno de aplaudir, por eso Claudia Madrazo declaró a la reportera: “Tendríamos otra ciudad si el sector privado pusiera su grano de arena en este sentido. Creo que es fácil criticar, pero debemos cuestionarnos qué hacemos por cambiar nuestra urbe". ${ }^{134}$ Inmueble singular que por sus elementos compositivos es uno de los más connotados ejemplos de la arquitectura Art Déco Zigzag, además representa a la Tendencia Decorativista.

\footnotetext{
${ }^{133}$ Virginia Bautista, "Restauran el Edificio San Martín. Invitan a habitar una 'obra de arte' ", Reforma, México, D.F., viernes 16 de junio del 2000, secc. C, Cultura, p. 1C.

${ }^{134}$ Ídem.
} 


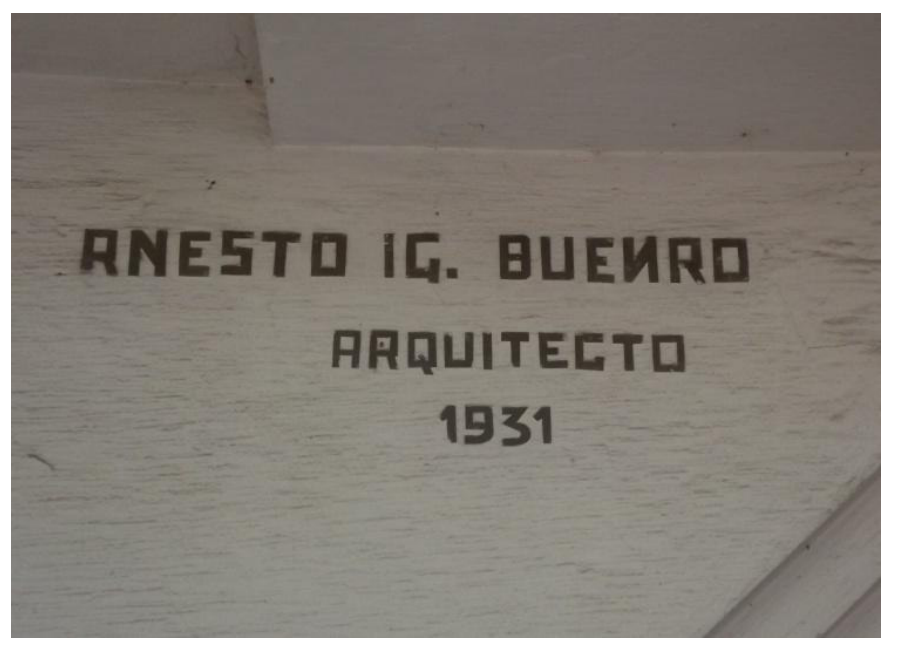

Edificio San Martín, nombre incompleto del arquitecto Ernesto Ignacio Buenrostro, México. D.F., 1931.

Juan Segura (1898-1989), quien había colaborado con Manuel Cortina en el Orfanatorio San Antonio y Santa Isabel, construyó un edificio de apartamentos: el Edificio Ermita (Av. Revolución y Av. Jalisco, Col. Tacubaya), de 1930 a 1931, con varios negocios integrados entre ellos el famoso Cine Hipódromo, hoy teatro Hipódromo, y antes Cine Ermita. Levantado en un terreno triangular, la fachada donde se encuentra el acceso al cine, cuenta con una marquesina que hace las veces de arco mixtilíneo; en cuatro vanos de las ventanas rectangulares, cuatro de ellas presumen bandas oblicuas que apuntan hacia el centro de acceso, con lo que se consigue un efecto de concentración hacia la entrada del cine. En la puerta de acceso a los apartamentos, toda la fachada se eleva a través de finas estrías y en el remate tres aleros recortados en las esquinas se prolongan hacia el exterior, lo mismo que otros más que se acoplan por varias partes del edificio.

Inmueble muy significativo para la historia de la arquitectura mexicana, aunque en deplorables condiciones, Louise Noelle lo describe así: "El inmueble ocupa la superficie de una manzana triangular, se levanta como un bloque compacto en el cual se dispuso, con sentido moderno, una variedad de soluciones a un problema de rendimiento económico, mediante locales para comercios en la planta baja, una sala para cine y tres niveles destinados a departamentos familiares, con la singularidad de estar colocados en torno a un plano cubierto con una vidriera... además, la atractiva silueta frontal del edificio se perfila 
en el espacio, gracias e la ornamentación Art déco, que [Segura] manejó con habilidad". ${ }^{135}$ En su tiempo el Edificio Ermita fue el más alto de la ciudad de México y vino a contrastar en su modernidad arquitectónica con la zona de Tacubaya que se encontraba llena de arrabales y barrios bajos. Carolina Magaña apunta sobre la importancia de este edificio hasta la actualidad: "El edificio Ermita es un icono en la ciudad de México, símbolo de una época en la que se tenía el reto y la libertad de incorporar nuevas ideas con una gran inversión de la Fundación Mier y Pesado para el predio ubicado en su finca" ${ }^{136}$ Y sobre el autor de este el autor de este edificio Noelle dice: "Como en tiempo le corresponde la aparición del estilo Art déco, Segura logra asimilarlo y lo incorpora con un sello personal a sus obras". ${ }^{137}$ Las Tendencias Geometrista y Decorativista son las que mejor quedan aplicadas a este edificio.

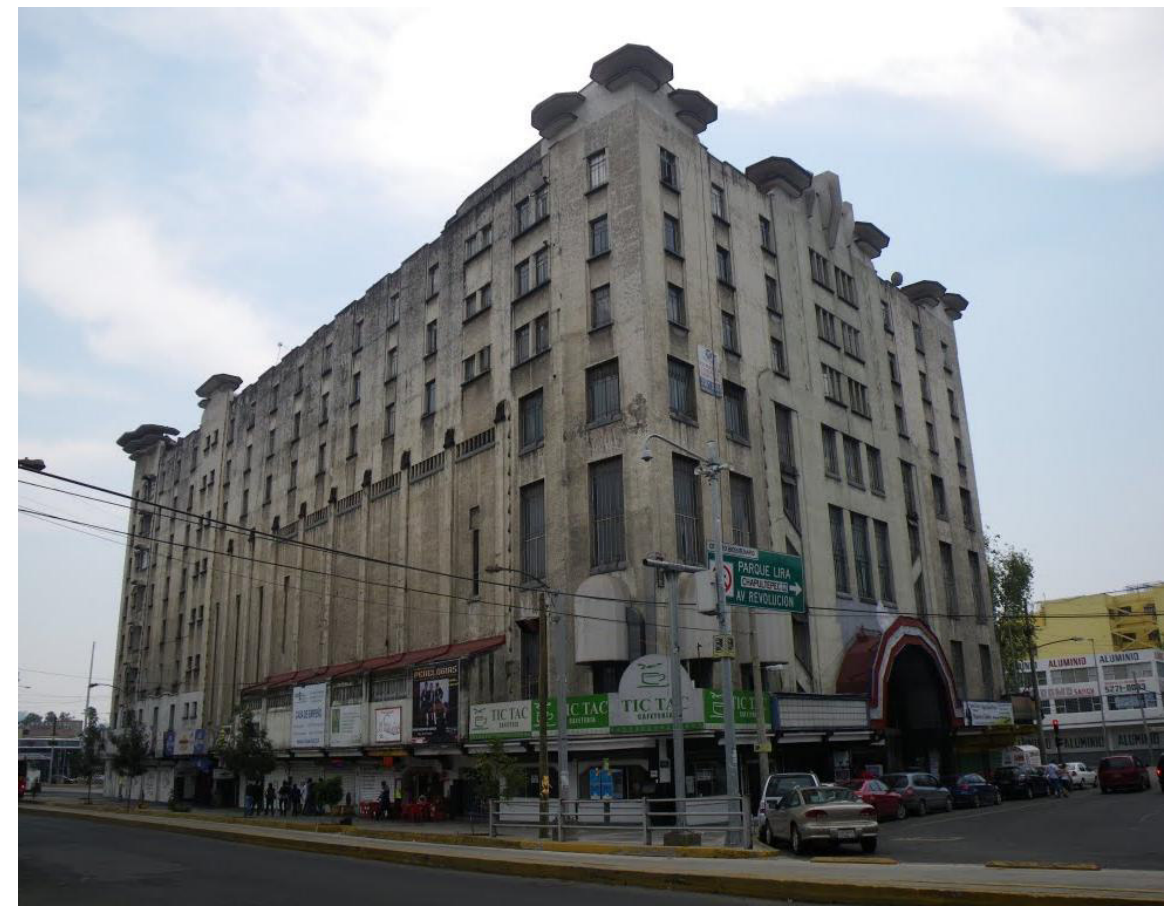

Juan Segura, Edificio Ermita, puerta de acceso al teatro, México, D.F., 1931.138

\footnotetext{
${ }^{135}$ Louise Noelle, Arquitectos contemporáneos de México, México, Trillas, 1993, p. 138.

136 Carolina Magaña Fajardo, El Art Déco en la ciudad de México. Retrospectiva de un movimiento arquitectónico, México, UNAM, Tesis de Doctorado en Arquitectura, 2007, p. 169.

${ }^{137}$ Luise Noelle, Op. Cit., p. 138.

${ }^{138}$ Panoramio, "Edificio Ermita", http://www.panoramio.com/photo/51237081
} 


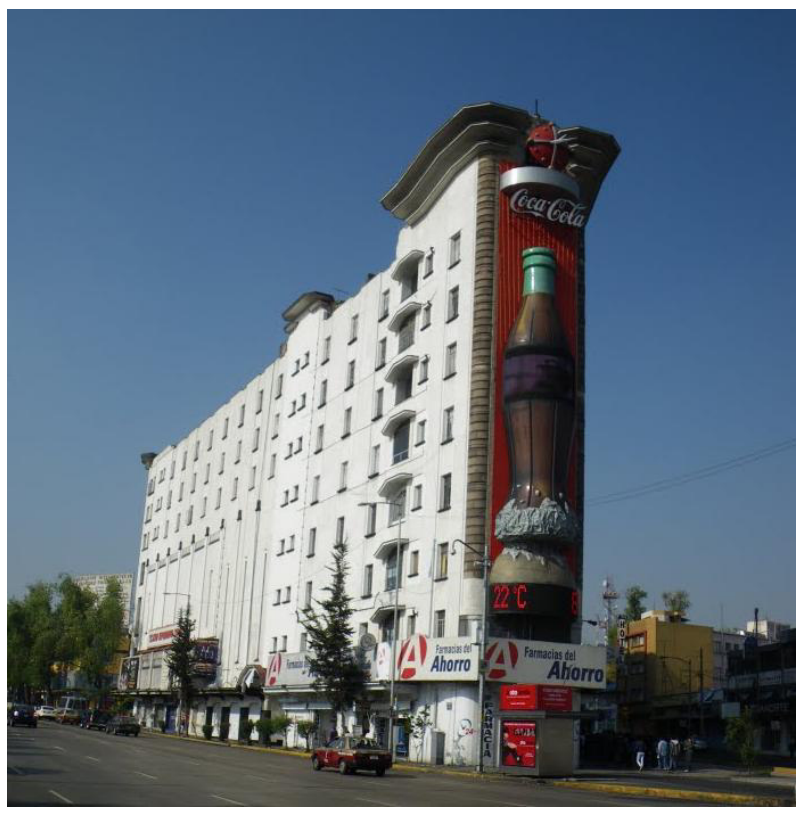

Edificio Ermita, fachada de la avenida Revolución, la única que está restaurada, México, D.F., 1931.139

En la Avenida México, misma donde se ubica el Edificio San Martín, pero ya en la colonia Condesa, en el número 188 se ubica el Edificio Tehuacán, obra de 1931, diseñada y construida por el ingeniero José María Buenrostro, cuyo nombre se inscribe con la fecha en el extremo derecho del inmueble, el cual fue concebido para apartamentos con una elevación de cuatro pisos. Una gran peculiaridad tiene esta construcción y es la marquesina: se forma por una pieza de un cuadrado frontal más un pentágono deforme del lado izquierdo. Siete hileras de cuatro vidrio blocks están en la zona central del cuadrado más un vidrio block aislado del lado derecho. En el espacio que se forma entre las dos molduras salientes de la marquesina, lleva una decoración de zigzags. En la parte interior de la marquesina hacia el lado izquierdo, un trapezoide resguarda decoraciones fitomorfas. Como recientemente ha sido restaurado, finales de 2013, se le agrego una extensión de vidrio a la marquesina.

La puerta de acceso es ochavada y lleva dos recortes abocinados que sólo llegan hasta la tercera parte. El rodapié de mármol negro se prolonga hacia la parte baja de la puerta con formas geométricas desiguales, combinado su diseño el pentágono de la

\footnotetext{
${ }^{139}$ Panoramio, Ibídem.
} 
marquesina. El cuerpo central que sobresale de la superficie se sostiene de una peana terminada en punta de diamante y ornada con estrías frontales; en la parte baja dentro de un cuadrado recortado, relieves de volutas y flores se enmarcan geométricamente, lo mismo en los cuerpos laterales, en los que dentro de estrechos rectángulos verticales, la decoración de flores de cuatro pétalos que están dentro de unos octágonos, van acompañadas de vírgulas geometrizadas, muy similares a las de la reja de entrada del Edificio San Martín. Los repisones de las ventanas están redondeados en las esquinas e inclinados hacia el frente, con lo cual se pausa el ritmo vertical ascendente y se conjuga un cinestimo de las líneas compositivas. Magno prototipo del Art Déco Zigzag y de la Tendencia Decorativisa, el Edificio Tehuacán presume tener una de las más originales marquesinas.
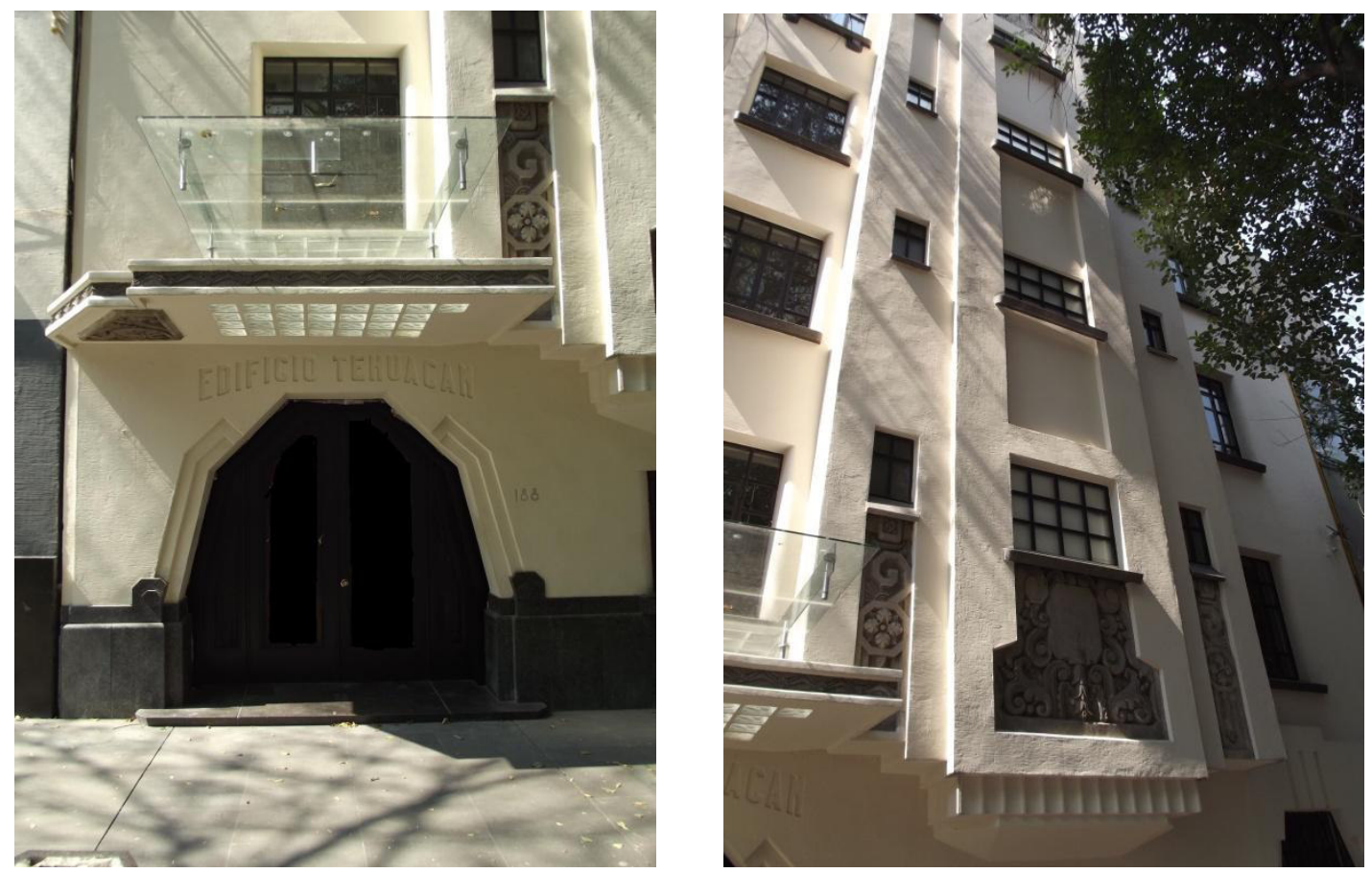

José María Buenrostro, Edificio Tehuacán. Imagen izquierda puertas de acceso y marquesina; imagen derecha, cuerpo central, México, D.F., 1931.

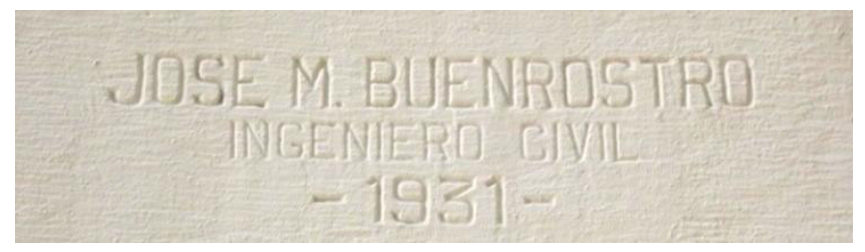

Nombre del ingeniero José María Buenrostro, colocado en el extremo derecho del edificio. 
Un edificio que connotó ruptura, modernidad y Art Déco, fue La Nacional (Av. Juárez y Eje Central Lázaro Cárdenas), erigido entre 1930 a 1932 por los arquitectos Manuel Ortiz Monasterio Popham (1887-1967), Bernardo Calderón y Caso, Luis Ávila y como consultor el arquitecto José Luis Cuevas (1881-1951). Su ubicación enfrente del aún inconcluso Palacio de Bellas Artes, en aquellos años, parecía un reto. A imitación de los rascacielos neoyorquinos, La Nacional mostraba su estructura de concreto aparente, en combinación con la placa de mármol negro que alcanzaba hasta el primer nivel y que en el vano de acceso se prolonga dos pisos más para envolver al letrero del edificio. En el interior, en el vestíbulo de entrada, las puertas de los elevadores, un reloj y el buzón presentan decoraciones geométricas típicamente Déco, así como la puerta de entrada con sus paños de líneas móviles y rítmicas.

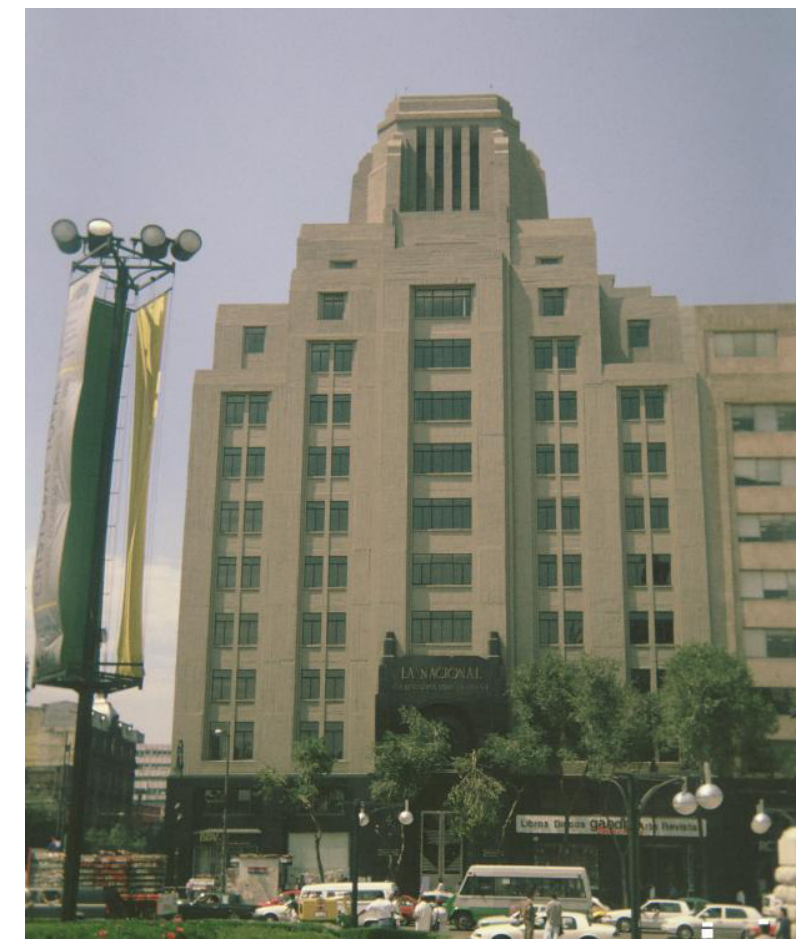

Manuel Ortiz Monasterio Popham, Bernardo Calderón y Caso, Luis Ávila, José Luis Cuevas, La Nacional, México, D.F., 1932.

Una torreta octogonal reforzada con contrafuertes corona el edificio que se eleva con paramentos escalonados y ventanales verticales. "El primer rascacielos mexicano", como se le llamó a este edificio, es "Una síntesis arquitectónica del estilo Déco”, en 
palabras de Enrique X., de Anda. ${ }^{140}$ Otra de las características importantes de este edificio es que su armazón es de acero que salió de las fábricas de la Compañía Fundidora de Fierro y Acero de Monterrey (el coloso acerero que cerró sus puertas en 1986 por negligencia gubernamental), lo que para nuestro estudio en territorio de la región Noreste es significativo que haya sido material fundido en Monterrey para un edificio de la ciudad de México. Al respecto, dentro de la historia de la Fundidora, como se le conocía popularmente, está escrito lo siguiente: "El primer rascacielos de la ciudad de México fue el edificio de La Nacional. Se construyó en 1932 y la Fundidora Monterrey fabricó y montó la estructura que soporta el peso de sus 12 pisos". ${ }^{141}$ El inmueble La Nacional es uno de los mejores exponentes de la Tendencia Geometrista.

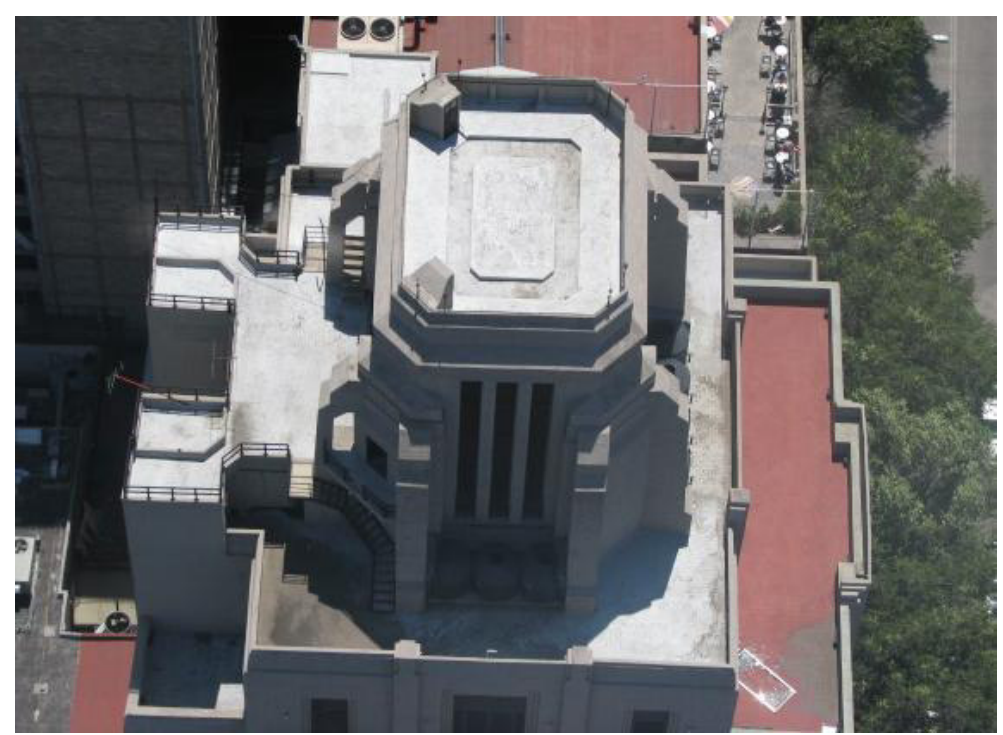

La Nacional, remate del edificio con la torreta, México, D.F., 1932.

El edificio de la Asociación Cristiana Femenina (YMCA) (Humboldt No. 62, esquina con Morelos, Centro), en cuya construcción participaron el arquitecto R.S. Gore, el ingeniero José A. Cuevas (1894-1961), E.H. Adam y J.L. Cordero como arquitecto

\footnotetext{
${ }^{140}$ Enrique X., de Anda, Op. Cit., p. 154.

${ }^{141}$ S/A, "Galería de la Historia. México a través del acero", horno 3 ciencia y tecnología al rojo vivo, Monterrey, N.L., http://www.horno3.org/new_index.html. El Museo del Acero Horno 3 fue inaugurado en septiembre de 2007 dentro de las actividades del Foro Internacional de las Culturas. Se ubica en el Parque Fundidora, en las antiguas instalaciones de la fábrica acerera. En sus salas de exhibición hay fotografías de la construcción del edificio de La Nacional.
} 
escultor, nombres inscritos en una placa con fondo amarillo y grafías de tipo colonial en color azul, fue construido entre 1923 y 1933. Es un cubo que se eleva remarcando la estructura de las pilastras de concreto, las cuales se proyectan hasta la azotea, dándole así un sentido de verticalidad.

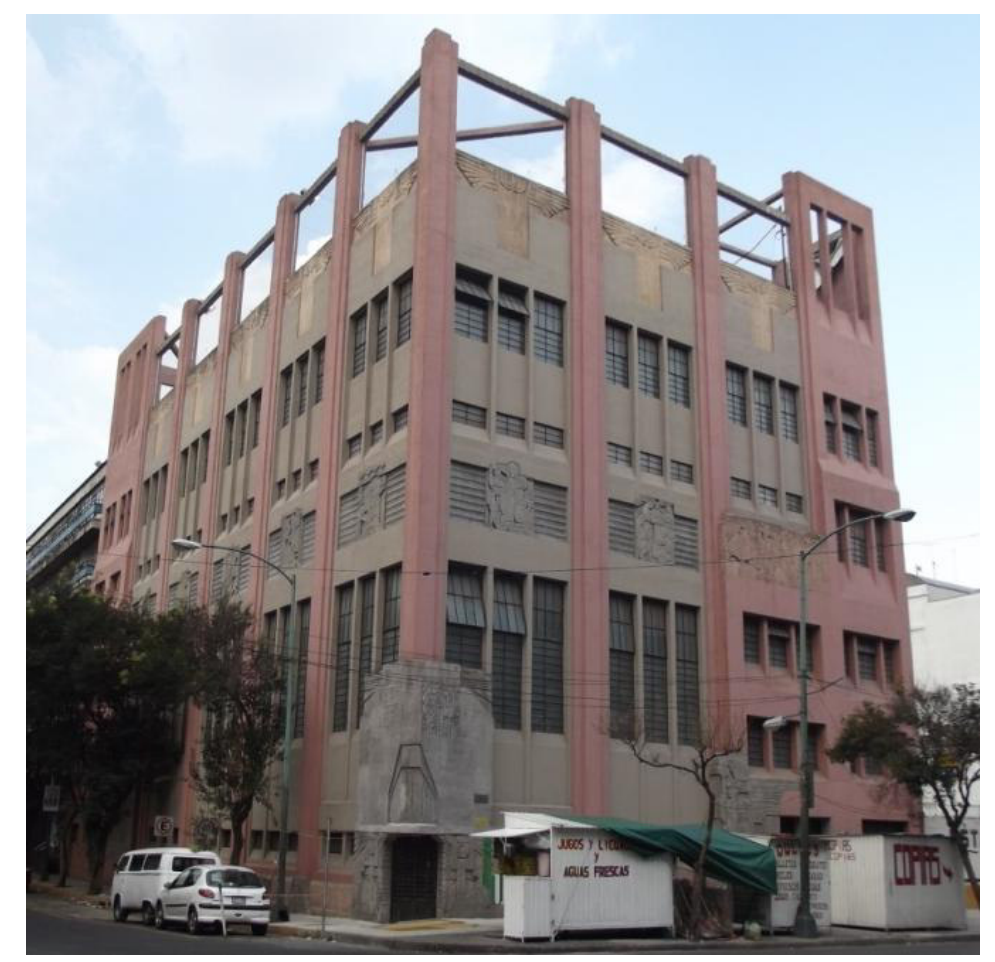

R.S. Gore, José A. Cuevas, E.H. Adam, constructores, J.L. Cordero, escultor, Asociación Cristiana Femenina, México, D.F., 1933.

Sin embargo, lo que más llama la atención y resalta el estilo Art Déco son los relieves en cemento obra de J.L. Cordero, por la firma que aparece en uno de ellos, que rememoran lo prehispánico por su planimetría; con dibujos suaves y alargados la mayoría representan a mujeres en distintas actividades del conocimiento y del deporte. En la entrada principal que se ubica en la esquina, la fachada ochavada ostenta los relieves de indígenas con rasgos olmecoides engalanados con penachos alargados que a manera de atlantes sostienen una especie de ático adosado a los muros: de un lado se lee "ACF 1923-1933” y del otro "ASOCIACIÓN CRISTINA FEMENINA". 

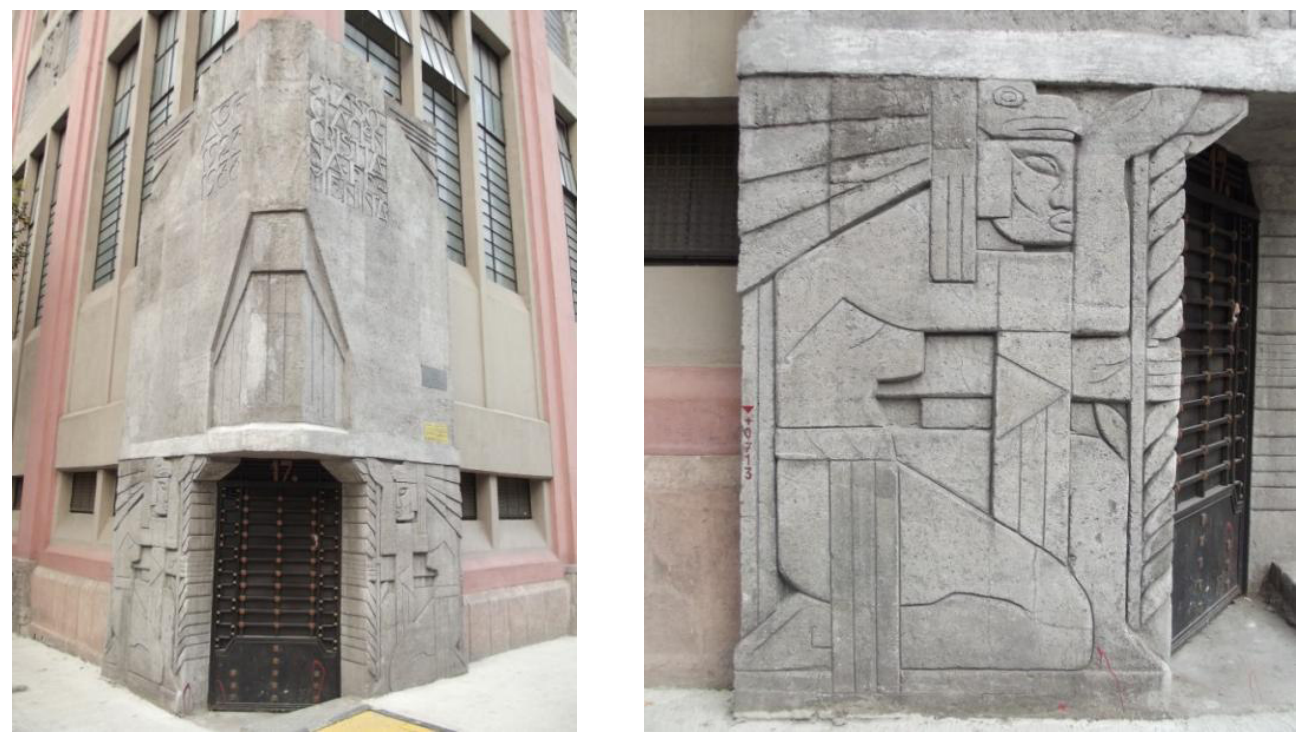

Asociación Cristiana Femenina, fachada principal con marquesina y relieves con rasgos indígenas de J. L. Cordero, México, D.F. 1933.

El rodapié que recorre al edificio, en cada tramo donde se inserta una columna, hay unos relieves trapezoidales que con una magistral abstracción geométrica representan el escudo nacional del águila y la serpiente.

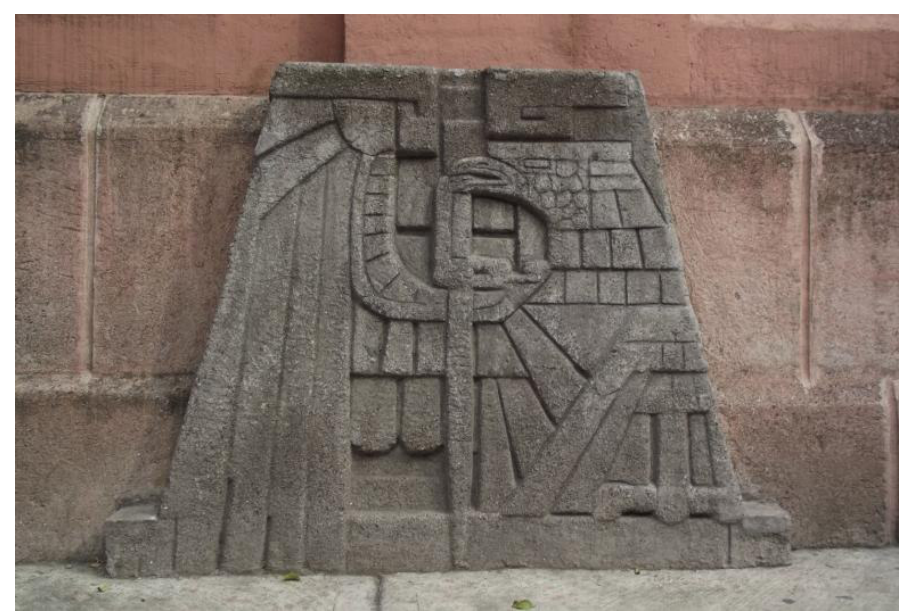

J.L. Cordero, Escudo Nacional, en el rodapié de la calle Humboldt, Asociación Cristiana Femenina, México, D.F., 1933.

En la fachada de la calle Morelos uno de los paneles que se ubica en el segundo nivel, entre varias figuras femeninas y fitomorfas se lee la palabra "LABOR" y a un lado la firma de "Cordero 1933", mientras que en el primer piso de la fachada de la calle Humboldt destacan, entre otros, el panel con la palabra "CIVISMO" que va acompañada de damas de 
las cuales una carga la balanza de la justicia, abajo se lee la palabra "Patria" y más damas y un caballo completan la escena, con la firma del escultor en la parte baja.

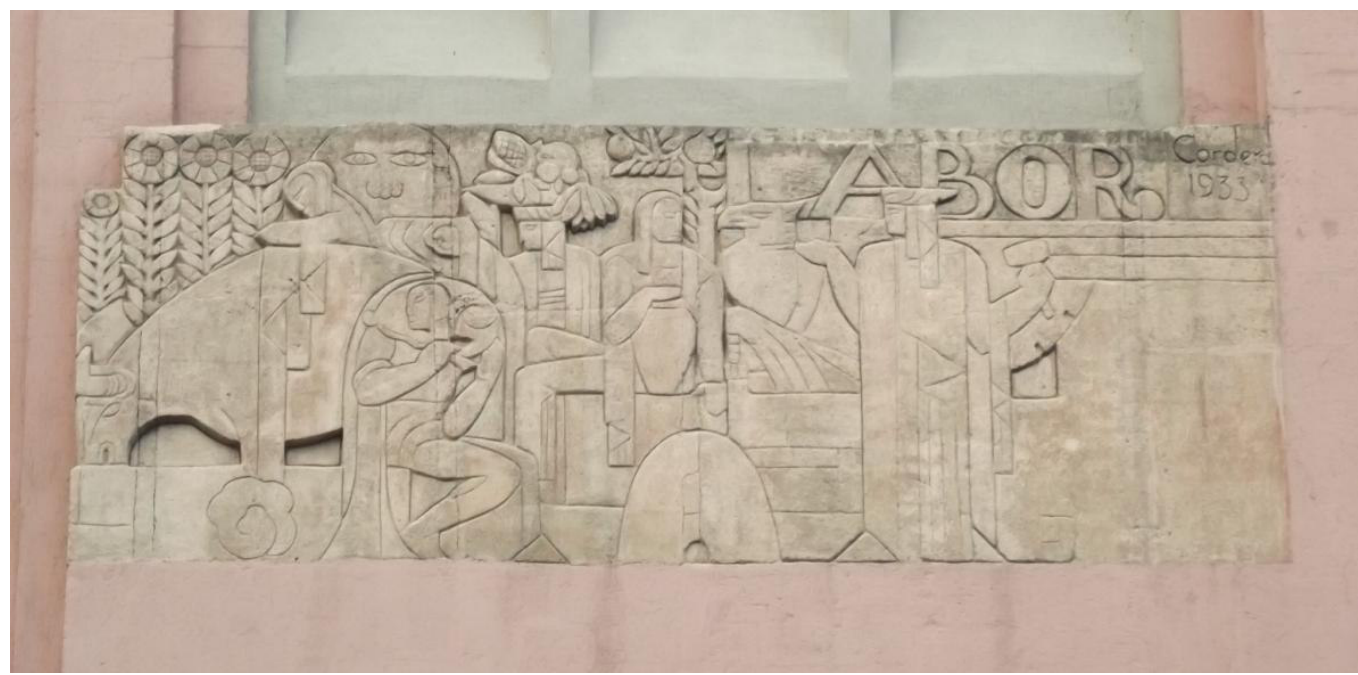

J. L. Cordero, relieve en la calle Humboldt representando la Labor, Asociación Cristiana Femenina. La firma aparece del lado derecho superior, México, D.F., 1933.

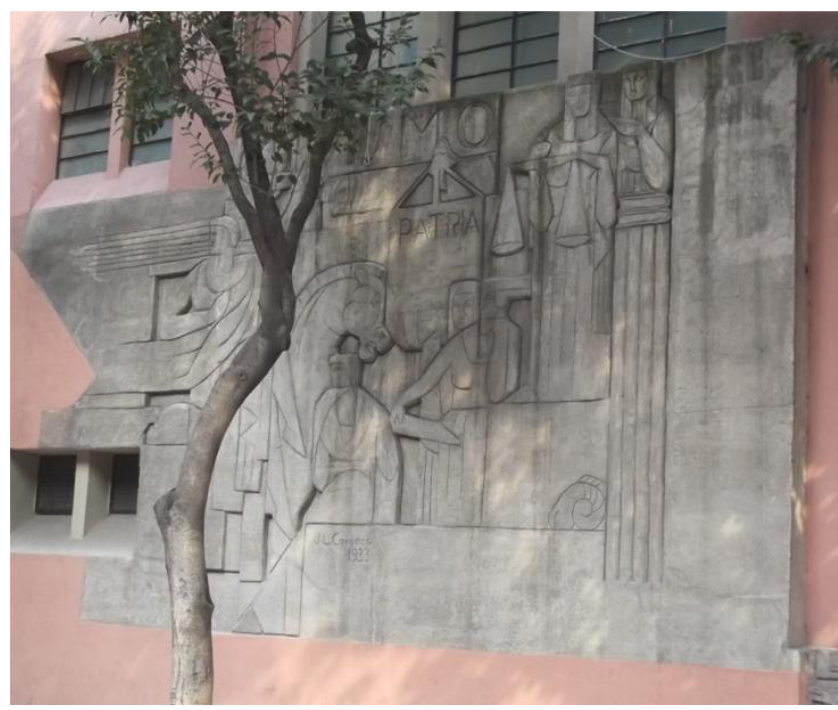

J.L. Cordero, relieve de la calle Humboldt dedicado al Civismo, Asociación Cristiana Femenina, México, D.F., 1933.

El edificio remata con ocho bajorrelieves, cinco en la calle Humboldt y tres en la Morelos, que representan la abstracción de un ser alado, matizándose su dinámica linealidad geométrica Art Déco. La Tendencia Decorativista es la que más destaca de este 
inmueble de la Asociación Cristiana Femenina, así como la Tendencia Plasticista por la integración de los planos cerrados.

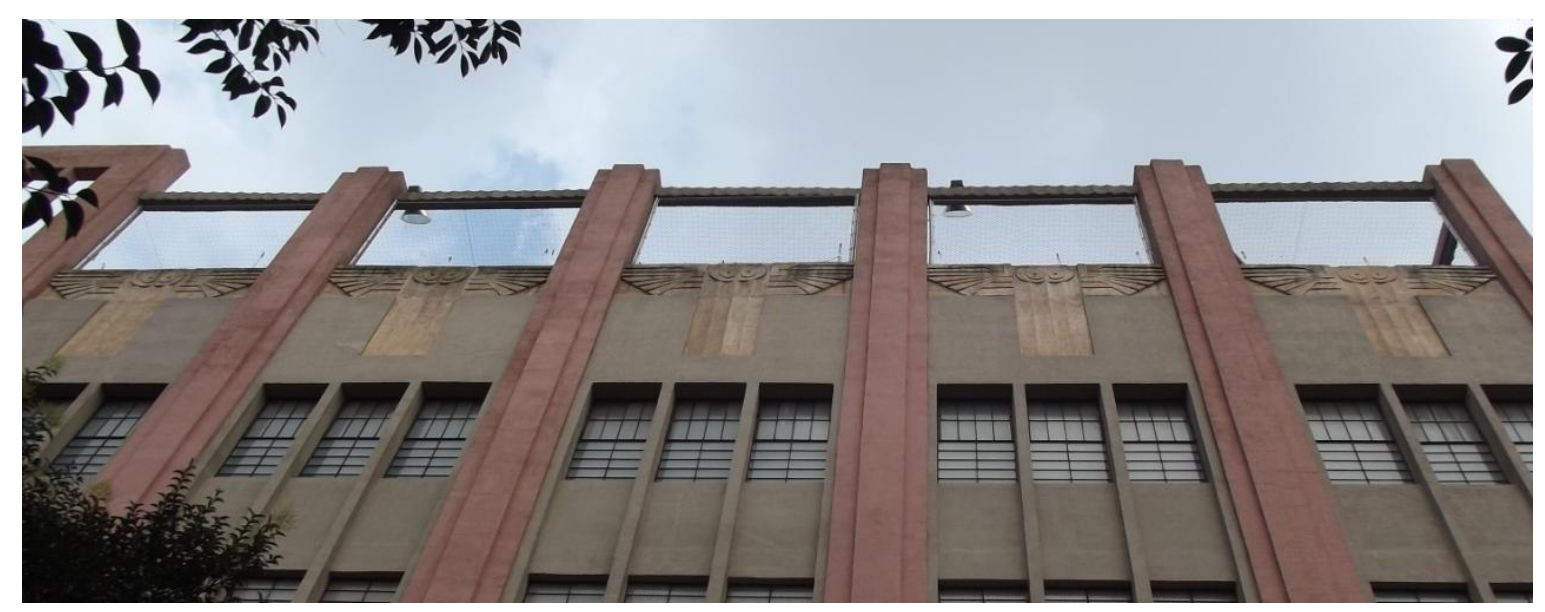

J.L. Cordero, relieves de personajes alados en el último piso de la fachada de la calle Humboldt, Asociación Cristiana Femenina, México, D.F., 1933.

De los casos más llamativos de una decoración interior en Art Déco está el Palacio de Bellas Artes (Cinco de Mayo y Eje Central Lázaro Cárdenas), concluido en 1934, después de dos años de trabajos. Se debe a la mano del arquitecto Federico Mariscal y Piña (1881-1971), quien decoró el suntuoso edificio en la más alta modernidad de la época a través del Art Déco. Además de los materiales como el mármol, ónix, acero, bronce y latón, su decoración es todo un homenaje a la integración plástica de ornamentos, pues los candiles colgantes parecieran un conjunto de gotas congeladas, o bien, las lámparas adosadas a las paredes imitan cactus desérticos iluminados; las taquillas guardan entre sus verticales líneas aceradas una lira símbolo del canto y las cabezas de Chaac que rematan en el barandal del tercer piso, completan su iluminado cuerpo con abstracciones de crótalos, para emparentarse con los dorados mascarones de Tláloc de las puertas de acceso a la sala de espectáculos y confabular todo una excelsitud decorativa con los motivos ornamentales elaborados por la casa Edgar Brandt de París. Los arcos ochavados del primer piso en mármol rosa intenso, sostienen la combinación del mármol también en rosa más claro. Este triunfo del Déco en el Palacio de Bellas Artes, Carlos Flores Marini lo celebra de la siguiente manera: "El gran vestíbulo que precede la entrada principal del teatro, es muestra de la particular combinación que los decoradores de la época supieron hacer entre el Art- 
Deco, tan en boga en la década de los treinta, y los elementos nacionalistas de inspiración prehispánica". ${ }^{142}$
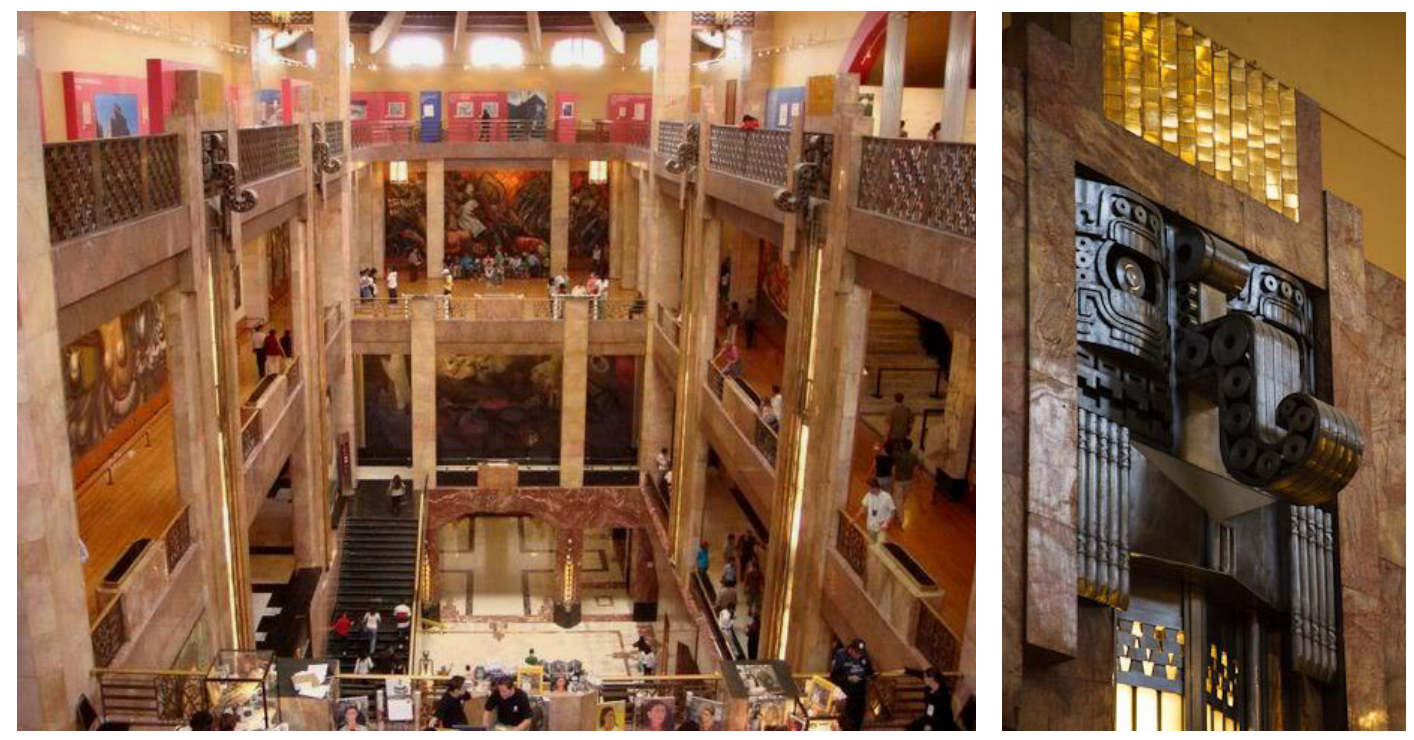

Federico Mariscal, vestíbulo ${ }^{143}$ del Palacio de Bellas y detalle de escultura en bronce de Chaac, ${ }^{144}$ México, D.F. 1934.

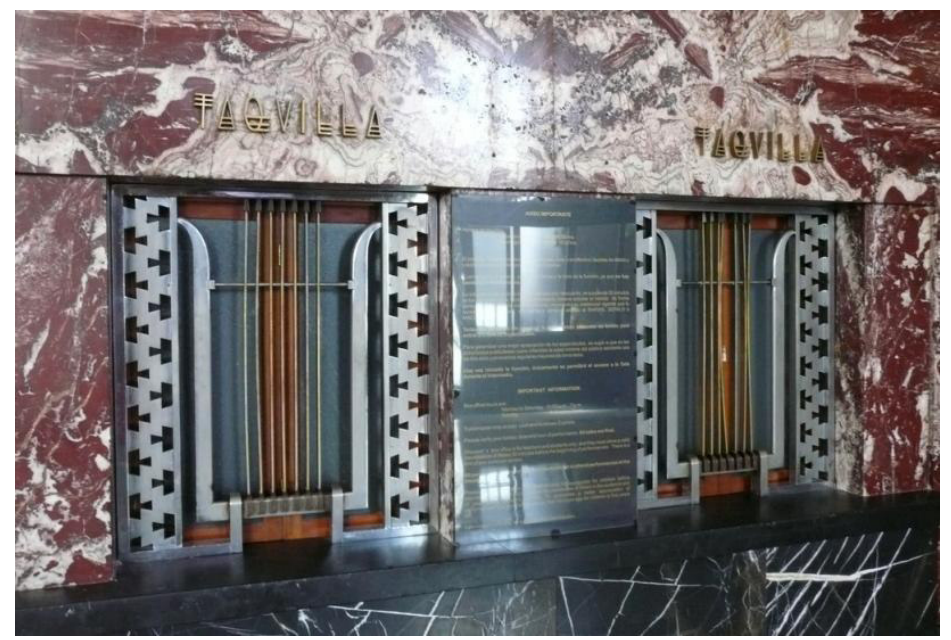

Taquillas del vestíbulo, con abstracciones de una lira, Palacio de Bellas Artes, México, D.F., 1934.145

\footnotetext{
${ }^{142}$ Carlos Flores Marini, "El Art-Deco en el Palacio de las Bellas Artes", Catálogo de la exposición El Art Deco en México, Op. Cit., p 14.

143 "Palacio de Bellas Artes", http://www.skyscrapercity.com/showthread.php?t=381315\&page=3

144 Chocolate Fish Fotos, "Image of Chaac on a light panel inside the Palacio de Bellas Artes", http://www.chocolate-fish.net/img_-9295_lang_spanish

${ }_{145}$ Mariangel Coghlan, "Espacios Musicales. Palacio de Bellas Artes", http://mariangelcoghlan.blogspot.mx/2013/07/espacios-musicales.html
} 
La integración de elementos nacionalistas dentro de un lenguaje moderno que conjugó Mariscal buscaban denotar la herencia cultural del pasado indígena como una antigüedad clásica pero prehispánica, para dar una lectura de un nacionalismo inserto en la cultura de las bellas artes, dentro de un ambiente glamoroso y de refinada elegancia en el más puro y elegante Art Déco, como en ningún otro edificio que se haya construido en el país. En la sala de espectáculos, además de la gran hoja del escenario diseñada por Gerardo Murillo, "Dr. Atl” (1875-1964) con fondo de los volcanes Popocatépetl y el Iztaccíhuatl, realizada por la casa Tiffany en fibra de vidrio, el Déco se explaya en los balcones de los palcos que se asemejan a las ochavadas jardineras manejadas en los edificios de la época.
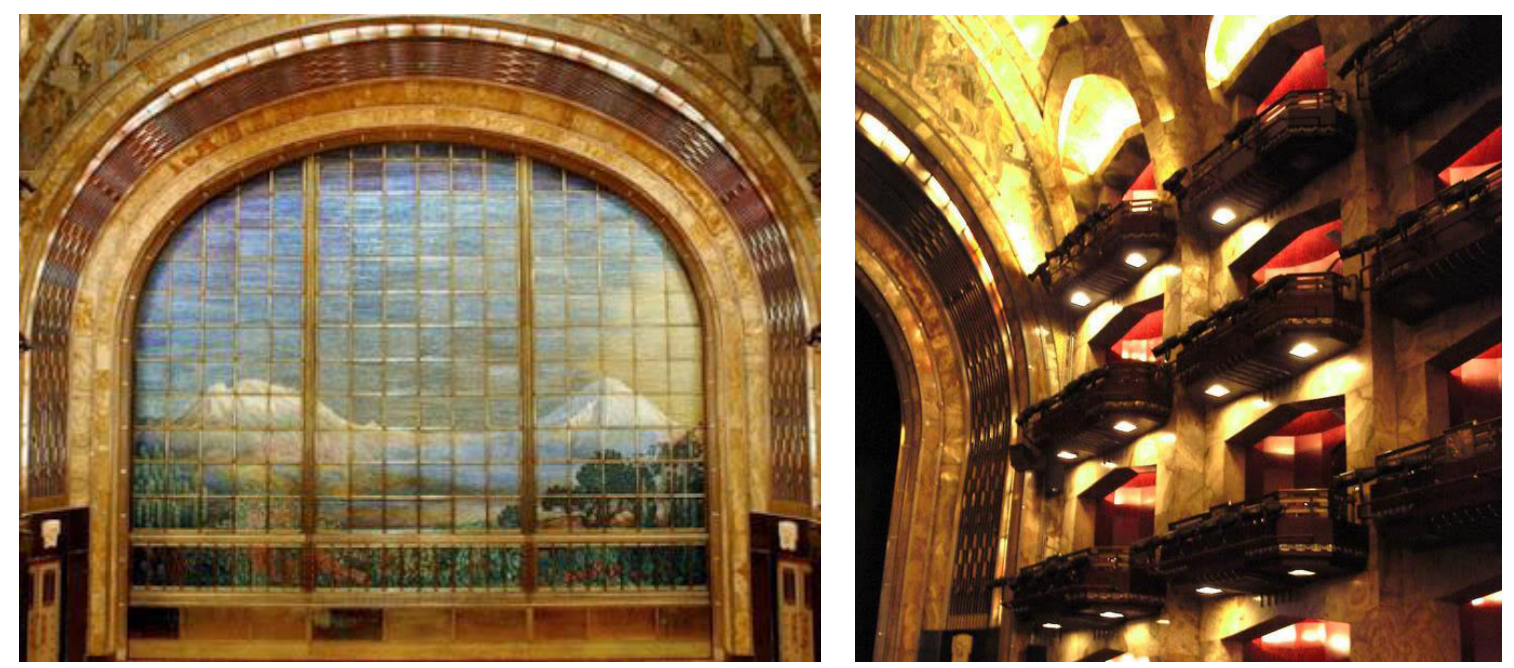

Sala de espectáculos. Del lado izquierdo, Gerardo Murillo, hoja del escenario; ${ }^{146}$ del lado derecho balcones de los palcos. ${ }^{147}$ Palacio de Bellas Artes, México, D.F., 1934.

Símbolo del fausto gusto, el Palacio de Bellas Artes en su interior es un enaltecimiento al Art Déco en México, que lo podemos estudiar bajo la perspectiva de la Tendencia Decorativista y Ecléctico-Mayista, así como del Zigzag y del Aerodinámico, pues conjuga ambos elementos. ${ }^{148}$

\footnotetext{
146 Ídem.

147 "Palacio de Bellas Artes", Ibídem.

${ }^{148}$ Para datos y elementos del Palacio de Bellas Artes, véase el libro: INBA, La construcción del Palacio de Bellas Artes, México, INBA, 1984.

Hay un artículo de Oscar Olivo, "Las bellas artes del palacio", Artes Plásticas, Nos. 1 y 2, octubre 1984 enero 1985, pp. 25-31, en el que a pesar de las exacerbadas críticas al edificio, da y aclara datos sobre la decoración y sus autores.
} 
El ingeniero y arquitecto Francisco José Serrano (1900-1982) levantó el Edificio Basurto (Av. México No.187, Col. Condesa) entre 1942 y 1944 que, aunque sale un poco de la época del Déco, aún integra elementos distintivos de este estilo. La entrada al edificio que se perfila hacia la puerta principal a través de la escalinata de peldaños curvos lo mismo que la techumbre, provoca un juego óptico de perspectiva a profundidad y los muros exteriores se enlazan a través de las curvaturas que unen los muros centrales y los balcones laterales. Con planta de cruz y catorce pisos de elevación "se trata de una de las construcciones más elevadas del momento, con una serie de apartamentos funcionales agrupados alrededor de una imponente escalera, todo dentro de un refinado estilo Art déco". 149
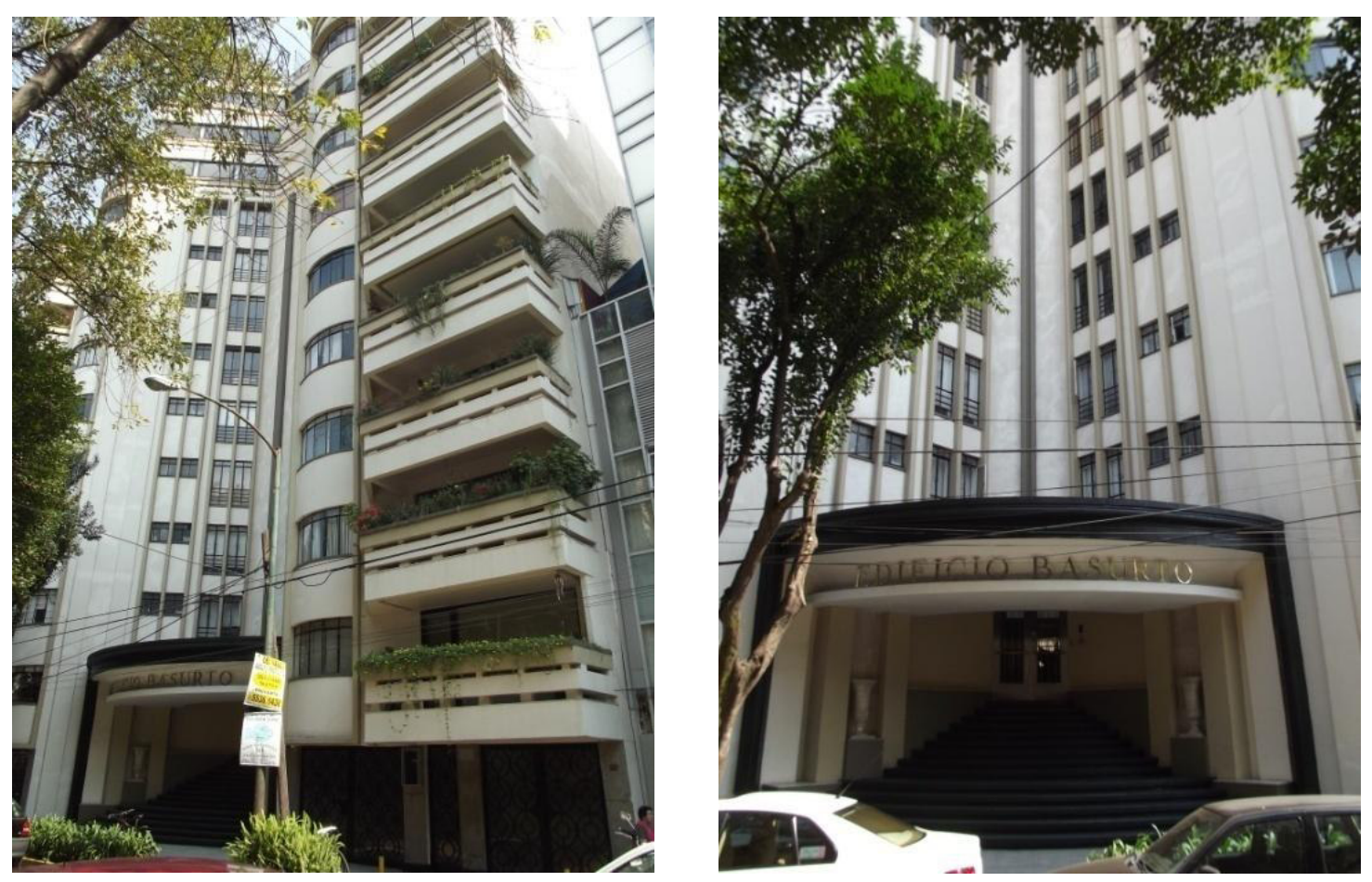

Francisco José Serano, Edificio Basurto, México, D.F. 1944.

Una de las peculiaridades de este inmueble es la escalera circular que en el interior envuelve a todo el edificio a manera de un sinfín y la herrería de círculos que se integran al espacio del barandal. Un juego geométrico de espacios entrantes y salientes con paños y líneas rectas y curvas en posiciones verticales y horizontales hacen del inmueble un

\footnotetext{
${ }^{149}$ Louise Noelle, Op. Cit., p. 142.
} 
ejemplo de la Tendencia Geometrista. Considerada como la obra maestra de Serrano en la tipología de apartamentos, el Edificio Basurto sirvió de modelo para construcciones posteriores.

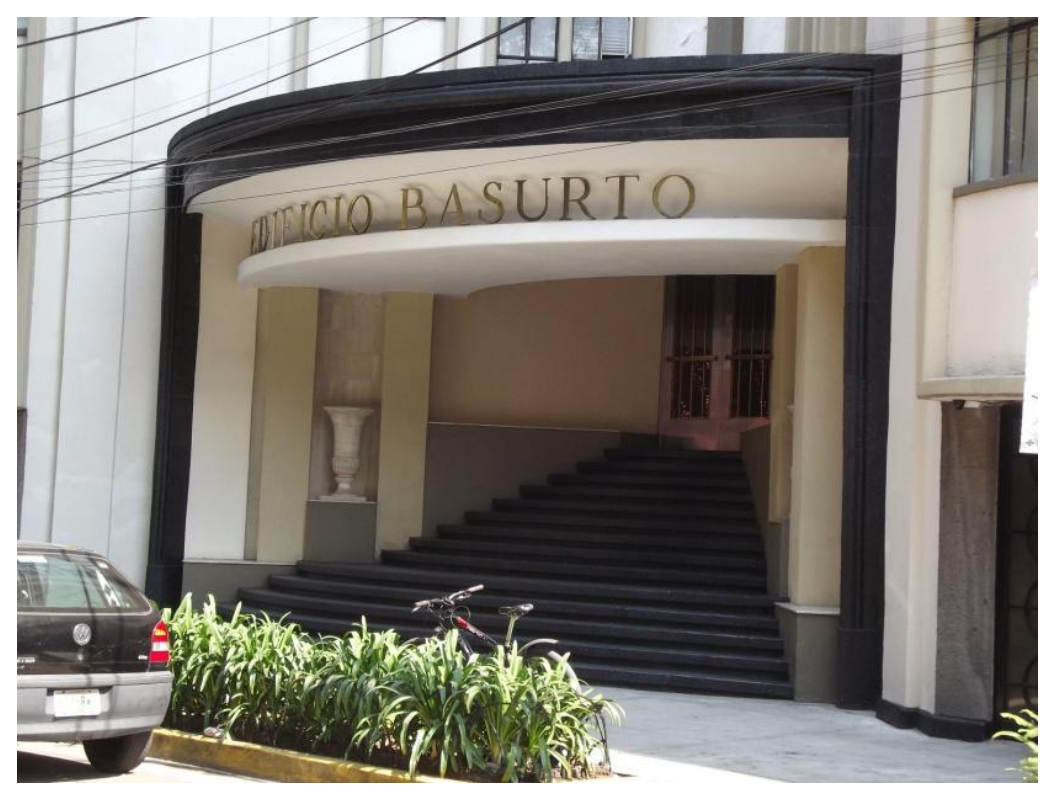

Edificio Basurto, Puerta de entrada, México, D.F., 1934.

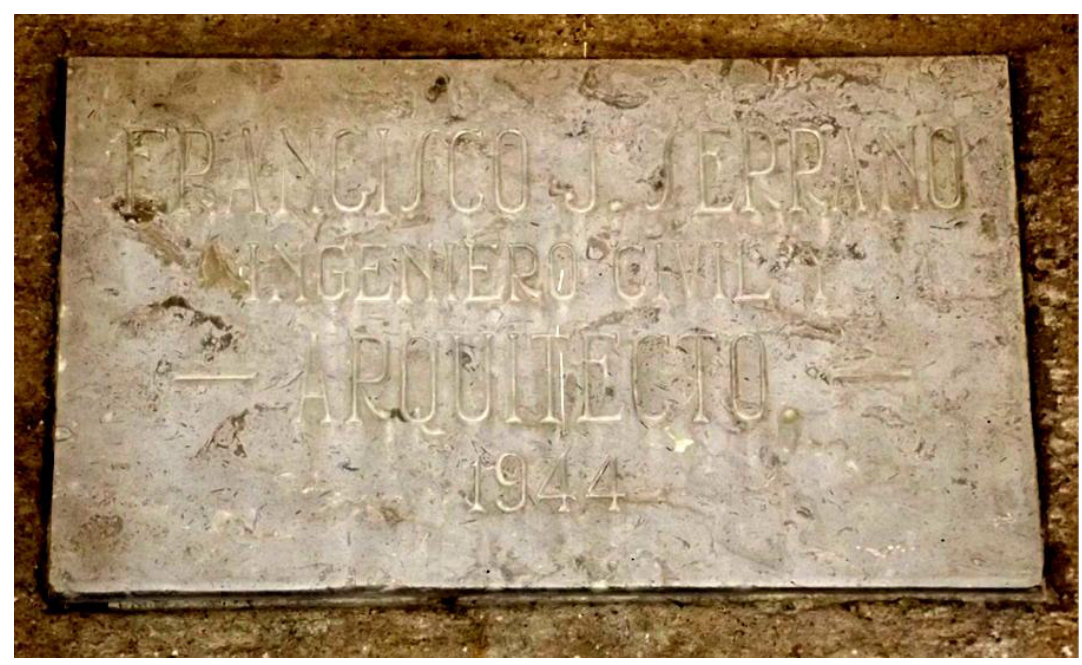

Edificio Basurto, placa con datos del constructor: Francisco J. Serrano/Ingeniero Civil/Arquitecto/1944

Así como estos edificios son ejemplos identificables con el desarrollo del Art Déco en la ciudad de México, hubo casos de nuevas urbanizaciones que también quedaron 
arraigadas como modelos Déco, en especial la colonia Hipódromo Condesa, antes Insurgentes Condesa, cuyo desarrollo se inicia en 1927 con los arquitectos José Luis Cuevas y los aludidos Juan Segura y Francisco José Serrano. Quienes podían habitar este tipo de fraccionamientos, eran la naciente clase media compuesta por profesionistas o personal administrativo de gobierno que buscaban un tipo de vida que estuviera acorde con los avances de la época. Esqueda explica que además de tener el Parque San Martín, la colonia Hipódromo Condesa se ubica como uno de los ejemplos habitacionales típicos del Déco: "Esta colonia nos presenta interesantes ejemplos art deco de carácter residencial, firmados por arquitectos afamados de la época, entre ellos: Brunet, Buenrostro, Capdeville, Cadena, Castillo y Tomasi, Calderón de Palacio, Serrano, Segura, Suárez Ruano, Palencia, Cuevas, Mendiola, Orvañanos y otros más". 150

No sólo se circunscribió el Art Déco a ese fraccionamiento, sino que abarcó inclusive el Centro de la ciudad, colonias ya establecidas como la Doctores, Santa María y Roma, o bien las aledañas a la Hipódromo Condesa, tales como Condesa, Escandón y Tacubaya que se contagiaron del gusto decorativo del Déco. Justamente, estas cuatro últimas colonias se incluyeron en la exposición de Una puerta al Art Deco, en la cual Esqueda, autor del texto del catálogo, esclarece que el trabajo de campo que se hizo para estudiar edificaciones Déco, habitacionales principalmente, en esa área que comprende "una zona delimitada por las avenidas Chapultepec, Cuauhtémoc, Viaducto Miguel Alemán, Martí, Revolución y Tacubaya (hoy Vasconcelos) que confluye nuevamente en la avenida Chapultepec", ${ }^{151}$ conforman 80 kilómetros lineales en un perímetro de 7 km²., en donde "la apreciable cantidad de edificios-habitación permitirá a los estudiosos profundizar en las particularidades de estas construcciones, asimismo en un modo de vida que, enmarcado en un singular estilo decorativo, ha podido sobrevivir hasta nuestros días". ${ }^{152}$

Fuera de la ciudad de México, el Art Déco se propagó por las principales ciudades del país a través de construcciones para casa-habitación y edificios de apartamentos, o bien, en cines, edificios públicos y monumentos, con el mismo sentido de enarbolar la modernidad lograda con el triunfo revolucionario. Ciudades como Guadalajara, Monterrey, Torreón, Puebla, León, Veracruz, o bien, la lejana Mérida, por citar sólo algunas, siguieron

\footnotetext{
${ }^{150}$ Xavier Esqueda, Op. Cit., p. 114.

${ }^{151}$ Xavier Esqueda, Una puerta al Art Deco, Op. Cit., p. 22.

${ }^{152}$ Ídem.
} 
en algunas nuevas construcciones los cánones del Déco. Tristemente, muchas edificaciones han sido derribadas o bien alteradas parcial o totalmente de sus concepciones originales.

En la Península de Yucatán, en Mérida, ciudad capital del estado de Yucatán y la más desarrollada de las urbes de la península, hubo bastantes ejemplos de Art Déco que han sido estudiados por el arquitecto Enrique Urzaiz Lares, de los cuales algunos han sido conservados solamente en la fachada y otros con cambio de giro de su uso original.

La Casa del Pueblo (calle 65 entre calle 48 y calle 50), del arquitecto italiano Ángel Bacchini (1861-1948), se inició en 1926 y es, claro está, una construcción que se inspira en decoraciones mayas. Funcionó como oficinas del Partito Popular del Sureste, aquél que fundara Felipe Carrillo Puerto (1872-1924). Aunque su estructura recuerda un edificio decimonónico porfiriano, en el primer nivel tanto acceso como ventanales son de forma rectangular, pero en el segundo, una serie de balcones imitan en arco maya de forma triangular, reforzando dicha imagen con molduraciones resaltadas. A manera de un entablamento, en el segundo nivel unas decoraciones con triglifos acompañan a metopas que se exornan con serpientes gemelas que sostienen un recuadro, haciendo una alegoría de Kukulkan y Chaac. La casa remata con un ático entre grecas escalonadas que lleva el nombre y encima un triángulo que sostiene una astabandera, en cuyo interior se lee la fecha de construcción: año 1928. Antonio E. Méndez-Vigatá ofrece la siguiente descripción: "La composición de este edificio respondía a los principios de simetría, escala y proporción propugnados por la École des Beaux-Arts de París. Sin embargo, toda su ornamentación derivaba de la arquitectura maya y hacía uso de arcos de dicho estilo para conferir al edificio su carácter prehispánico”. ${ }^{153}$

Por su parte en 1997 Enrique Urzaiz Lares, en su artículo "Arquitectura Neoindigenista del siglo XX en Yucatán” al hablar sobre la Casa del Pueblo aclara sobre las diversas clasificaciones que se le han dado al edificio: “....algunos autores le confieren la categoría de estilo al 'estilo neomaya', otros simple y despectivamente le llaman mayismo, otros más neoindigenismo maya e incluso hay quienes lo incluyen como una vertiente dentro de corrientes históricas, como el academicismo de fines del siglo pasado, el art-déco de los años veintes y treintas o bien el deformado posmodernismo con el que hoy

${ }^{153}$ Antonio E. Méndez-Vigatá, "Política y lenguaje arquitectónico. Los regímenes posrevolucionarios en México y su influencia en la arquitectura pública", en: Edward R. Burian (editor), Modernidad y arquitectura en México, México, Gustavo Gili, 1998, p. 74. 
convivimos", ${ }^{154}$ y el mismo autor la denomina como un Art Déco regionalizado. ${ }^{155}$ Así pues, podemos ver en una combinación del neoindigenismo aplicado a la arquitectura y el Art Déco, por supuesto que la Casa del Pueblo entra dentro de la tendencia EclécticoMayista. Actualmente este edificio alberga las oficinas el Partido Revolucionario Institucional (PRI).

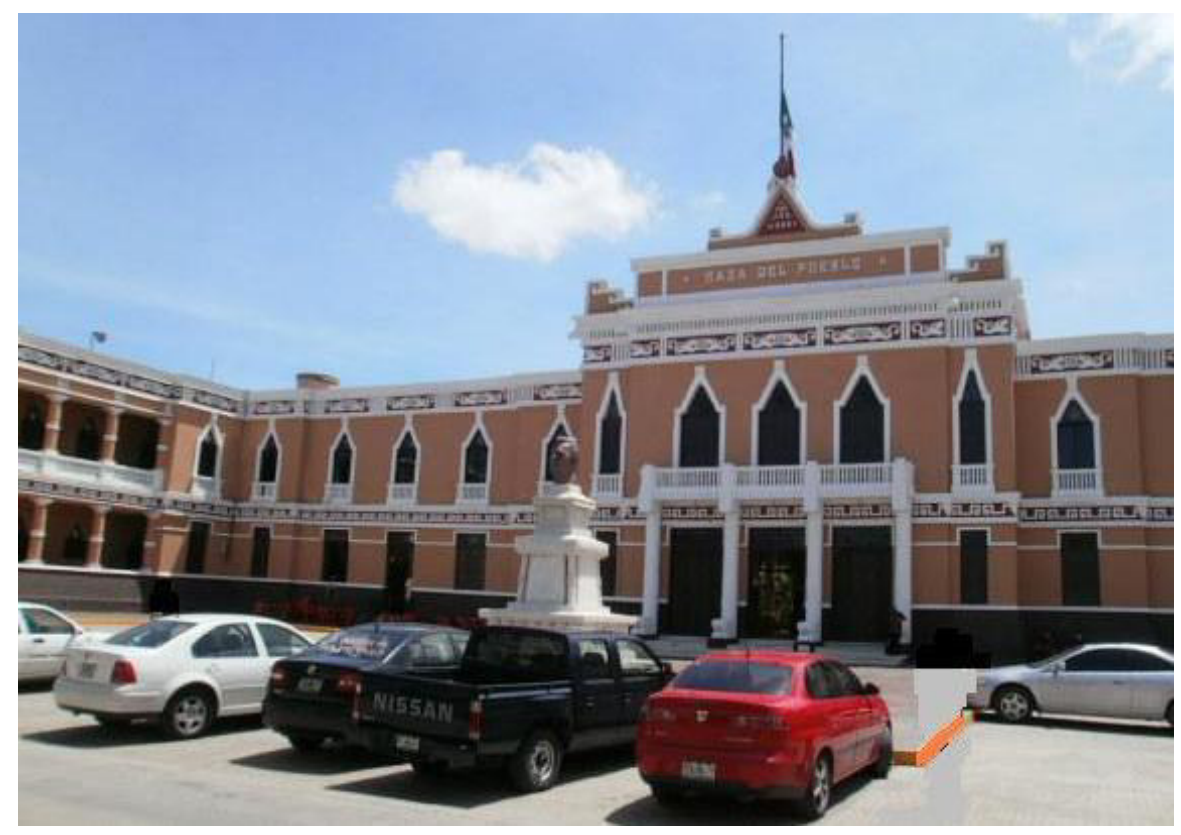

Ángel Bacchini, Casa del Pueblo, Mérida, Yucatán, 1928.

Un caso de arquitectura Déco en Mérida con los componentes de la variante Zigzag de aquellos gloriosos años en que el cine era el máximo entretenimiento familiar y visual fue el Cine Cantarell, ubicado en el centro de la ciudad (Calle 60 No. 499), de cual hoy sólo cuenta con la fachada, ya que el interior lo ocupa una tienda de cadena nacional de electrodomésticos. Enrique Urzaiz dice de este edificio que: "posee una de las más equilibradas y características fachadas art-déco de la entidad". ${ }^{156}$ Construido a mediados de

\footnotetext{
${ }^{154}$ Enrique Urzaiz Lares, “Arquitectura Neoindigenista del siglo XX en Yucatán”, México en el Tiempo, septiembre/octubre 1997, No, 20, p. 21.

${ }^{155}$ Enrique Urzaiz Lares, "Arquitectura de la modernidad posrevolucionaria en Mérida, Yucatán: el equipamiento urbano", en: Carlos Montero Pantoja y María Silvina Mayer Medel (coordinadores), Estudios de Arquitectura y Urbanismo del siglo XX. Memorias del Tercer Encuentro nacional de Arquitectura del Siglo XX del ICOMOS Mexicano A.C., Puebla, Instituto de Ciencias Sociales y Humanidades "Alfonso Vélez Pliego", Benemérita Universidad Autónoma de Puebla, ICOMOS MEXICANO, A.C., 2007, p 166.

${ }^{156}$ Ibídem, p. 167.
} 
la década de los años treinta y de autor desconocido, las paredes del primer piso presentan delicadas estrías, mientras que en la parte alta por arriba de una marquesina ochavada que funcionaba como letrero del cine, los vanos rehundidos de las ventanas llevan pares de ventanales rectangulares, en cuyos amplios entrepaños presentan una decoración con una moldura rectangular y recortes circulares sobrepuestos, formando una abstracción de palmas, la cual se repite en la parte superior de los extremos que se insertan dentro de unas elevaciones escalonadas. Al centro tiene una decoración con forma de balcón, con un dosel formado por molduras acompasadas que integran una composición triangular y unas bandas que caen a los lados a manera de un cortinaje, rematando con un relieve plano con formas triangulares en la parte superior del inmueble, que bien puede rememorar una plataforma prehispánica maya. El Ex-Cine Canderell es un claro prototipo de Art Déco Zigzag, que conlleva la Tendencia Plasticista.

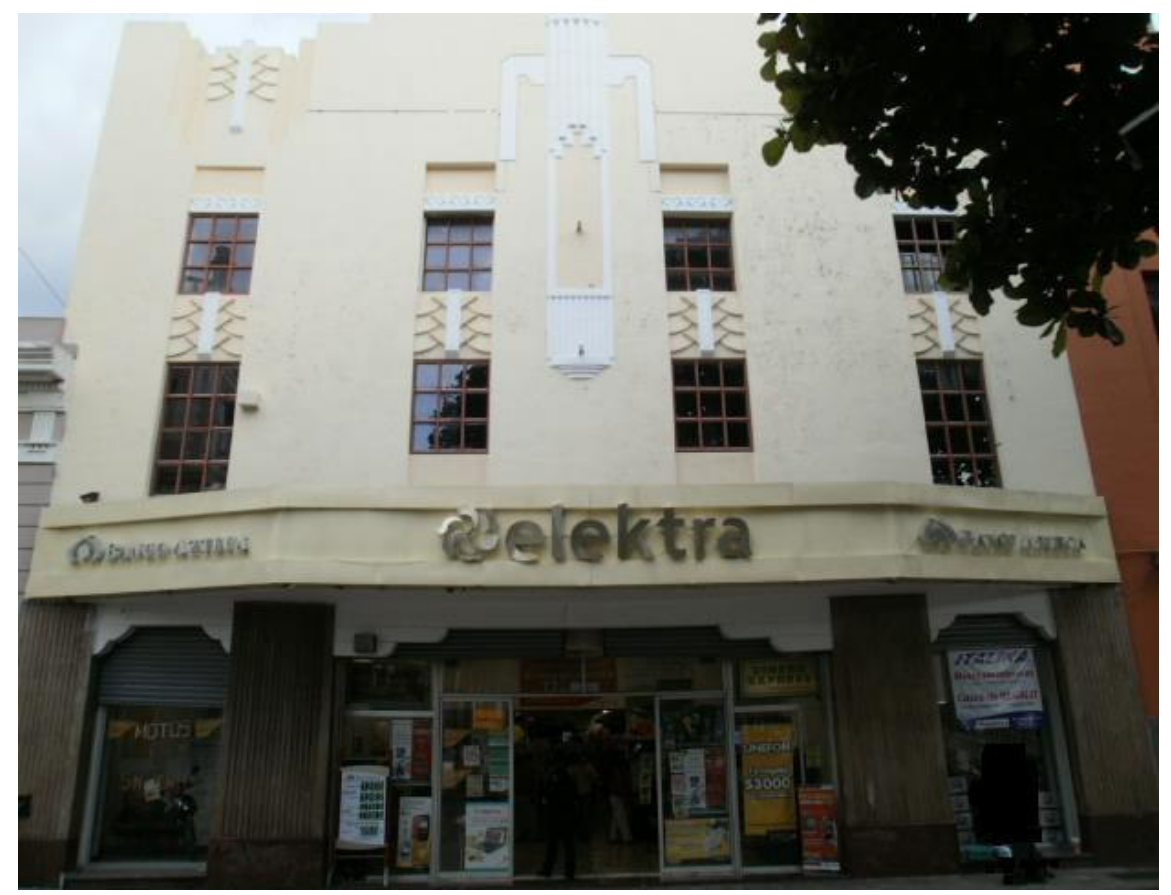

Ex-Cine Canderell, Mérida, Yucatán, mediados de años treinta, siglo XX. 


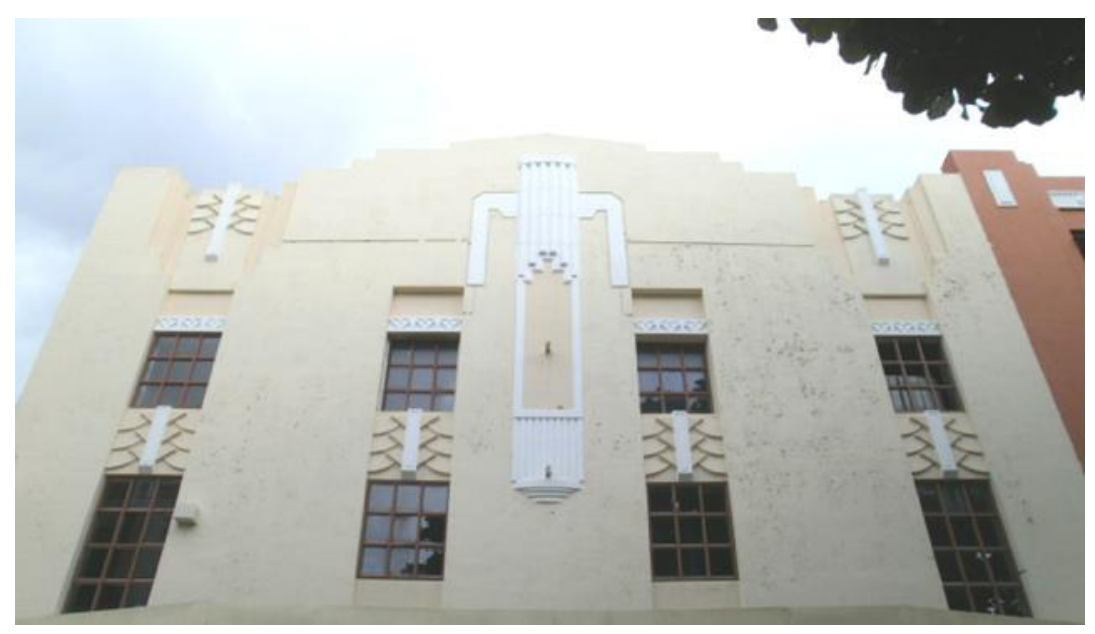

ExCine Canderell, detalle, Mérida, Yucatán, mediados años treinta del siglo XX.

Otro ejemplo en Mérida es el del Edificio La Nacional, de la misma compañía de seguros que levantó el inmueble de la ciudad de México y el de Monterrey. Construido en 1936 por el arquitecto Carlos Castillo Montes de Oca y el ingeniero Alfredo Medina Vidiella, está ubicado en el centro de la ciudad (cruce de la Calle 60 con la calle 59), tiene de tres plantas y su fachada principal es en ochavo. Tiene un rodapié en piedra de color negro, tres marquesinas recortada en las esquinas y se eleva longitudinalmente a través de bandas verticales que dividen los tramos de los muros y rematan a mayor altura del nivel de la techumbre, con el consiguiente efecto de elevaciones escalonadas. En la fachada principal la piedra negra sube por arriba de la marquesina formando un enmarcamiento ochavado. Por arriba de éste, en los dos siguientes niveles las ventanas van enmarcadas por perfiles retranqueados, de la misma manera que se usa en los arcos abocinados. En la parte superior el nombre del edificio se inserta en una placa gris escalonada, con letras gruesas y geométricas, de las que se hicieron representativas del Art Déco, y de la misma manera que la placa, el remate escalonado sirve a la vez de astabandera. "Este es un edificio plurifuncional casi único en Mérida, pues su esquema y características generales son comunes en la ciudad de México y en otras partes del país, pero totalmente atípicos en Yucatán". ${ }^{157}$ El edificio La Nacional es de un Déco de la época del Zigzag, con elementos

\footnotetext{
${ }^{157}$ Enrique Urzaiz Lares, Arquitectura en Tránsito: Patrimonio Arquitectónico de la Primera Mitad del Siglo XX en la Ciudad de Mérida, Mérida, Universidad de Yucatán, 1997, p. 109.
} 
compositivos de la Tendencia Geometrista, que afortunadamente se encuentra en un buen estado de conservación.

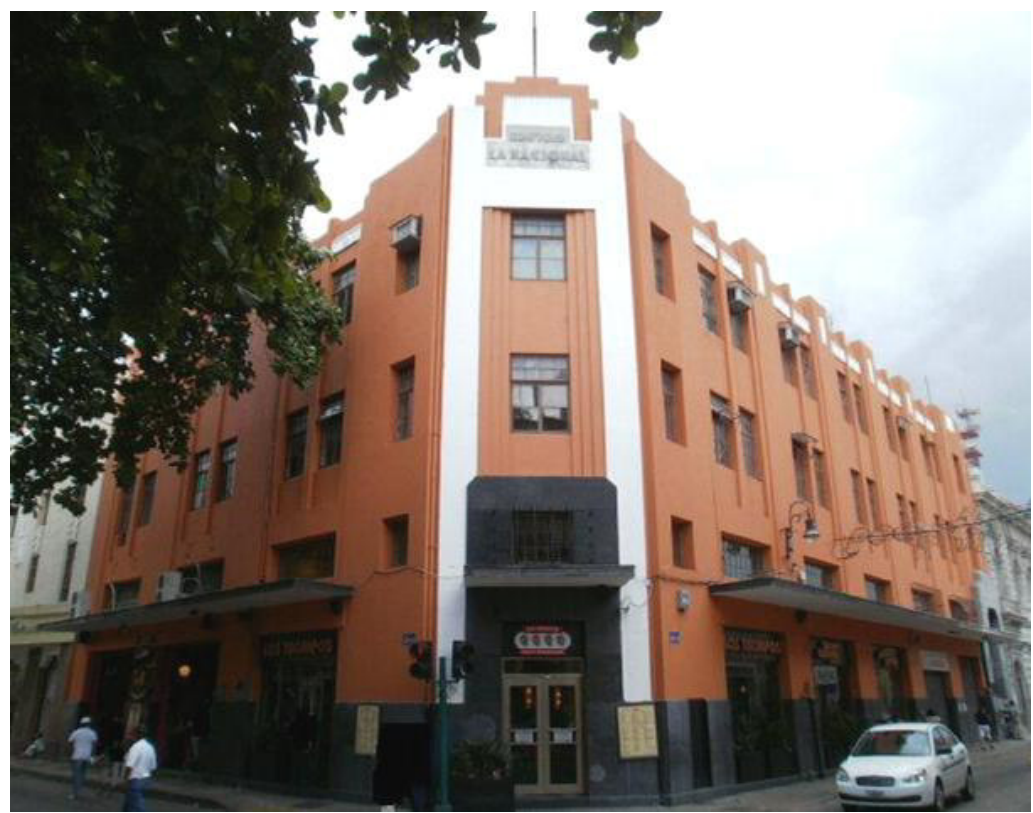

Carlos Castillo Montes de Oca y Alfredo Medina Vidiella, Edificio La Nacional, Mérida, Yucatán, 1936.

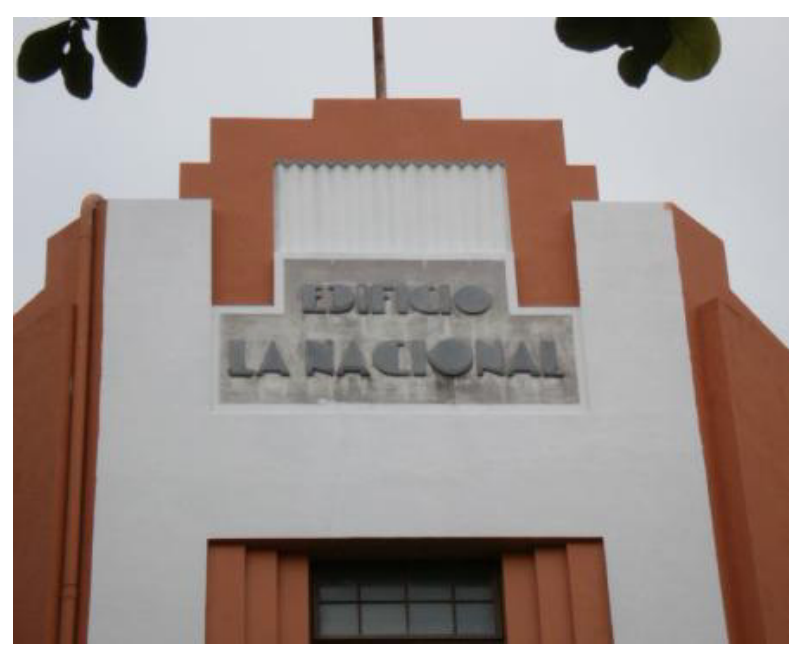

Edificio La Nacional, detalle del letrero, Mérida, Yucatán, 1936.

En el Occidente del país, en la ciudad de Morelia que se distingue por sus edificios y casas de las épocas virreinal y siglo XIX, en el centro histórico (entrecruce de las calles Allende y Morelos) se ubica la casa TRON HNOS Y CIA, nombre tal y como aparece en el 
letrero. El edificio pertenecía a una compañía dedicada a la industrialización de aceites comestibles y en el interior se encontraban sus oficinas administrativas en los pisos superiores y en la planta baja del exterior una gran tienda de abarrotes. Sobre esta edificación la investigadora Catherine Ettinger en un estudio sobre la arquitectura del siglo XX en el centro histórico de Morelia dice: "El Art déco se manifiesta poco en la ciudad de Morelia, limitándose al usa de grecas y escalonamientos en algunas casas. Excepción en este sentido es el Edificio Hermanos Tron, localizado en la Plaza Melchor Ocampo a espaldas de la catedral con una clara expresión Déco, tanto en la modulación de la fachada como en el diseño de la herrería". ${ }^{158}$

Construido en la década de los años 30 del siglo XX, la fachada principal es ochavada y con cantera de la región están forradas las jambas que se elevan hasta el segundo nivel y a manera de un ático se inserta el letrero con cantera también, un recurso de aprovechar los materiales de la región. Con la misma piedra, bandas verticales y ascendentes resaltan los tramos del inmueble, destacándose así la elevación y la geometría. Una marquesina de concreto, que se encuentra en mal estado de conservación, cubre el primer nivel en la fachada principal, un tramo de la fachada oriente de la calle Morelos y los tres tamos de la fachada norte de la calle Allende, haciendo juego con las pequeñas marquesinas que cubren las ventanas del segundo piso, solución de la que el historiador del arte Manuel González Galván (1933-2004) califica: “su autor retoma con ingenio la fórmula de los aleros y pestañas de balcón que fuera obra del barroco local". ${ }^{159}$ Cinco balcones llevan herrerías con formas vegetales dentro de líneas rectas, lo que acentúa las decoraciones del Art Déco y en la puerta de entrada a las oficinas las decoraciones son geométricas y en la parte baja es con rayos expandidos. Otros elementos decorativos son los cuatro relieves que se encuentran en el segundo nivel de la fachada norte de la calle Allende, esculpidos en cantera muestran a ciervos cazados en poses retorcidas que lucen la flecha inserta. Y unas decoraciones más son los cuatro pináculos en cantera que rematan el edificio dos en la fachada norte y don en la fachada oriente, los cuales están concebidos como maceteros circulares con piñas y flores, sostenidos por soportes rectangulares. En el

\footnotetext{
${ }^{158}$ Catherine Rose Ettinger McEnulty. "La presencia del siglo XX en el tejido del centro histórico de Morelia expresiones de integración”, en: Carlos Montero Pantoja y María Silvina Mayer Medel, Op. Cit., p. 73.

${ }^{159}$ Ramón Sánchez Reyna, "El Art Déco, una tendencia en la vida cotidiana", Cultura y Arte, Morelia, Michoacán, Año 3, No. 18, septiembre-octubre de 1998, p. 4, http://www.umich.mx/univ/publica/contacto/sep98/ramon1.html
} 
interior se conserva la escalera con peldaños en granito, lo mismo que el zócalo que sostiene el barandal, el cual son compone de líneas horizontales oblicuas en metal dorado que van ascendiendo al ritmo de la elevación de la escalinata. El edificio de la Casa Tron Hermanos es un modelo de la época del Art Déco Zigzag y de la Tendencia Geometrista con la integración de materiales vernáculos para estar en sintonía con los edificios aledaños.

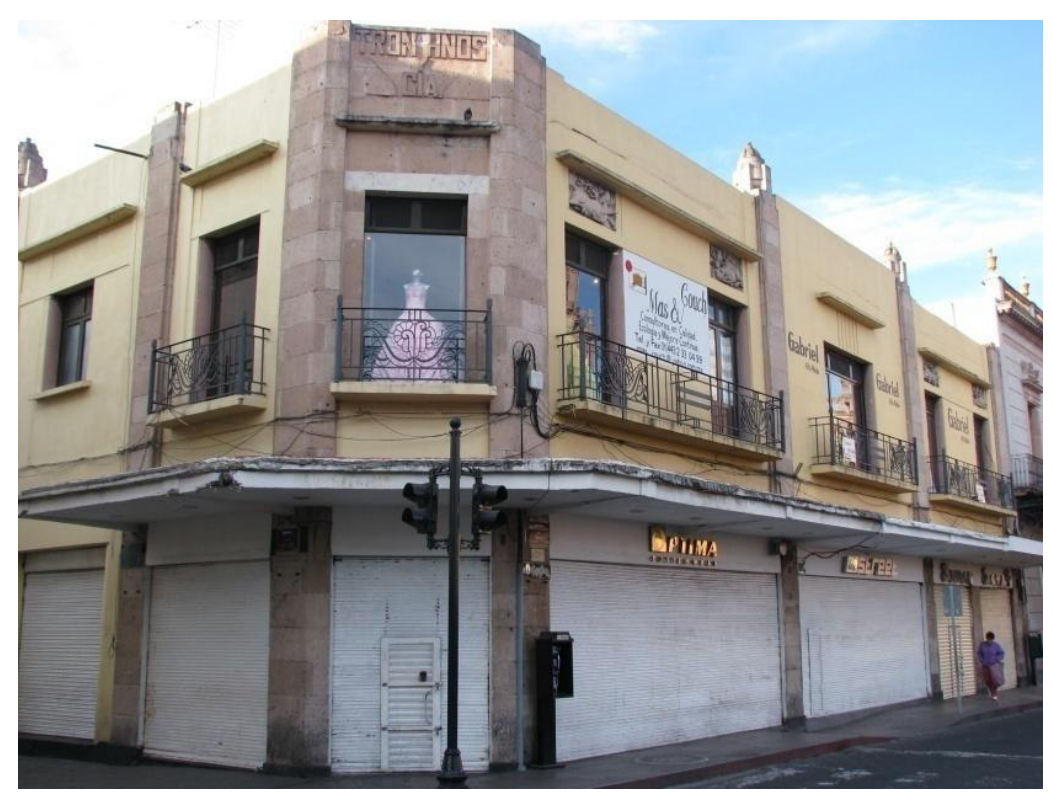

Casa Tron Hermanos, Morelia, Michoacán, finales de los años treinta, siglo XX.

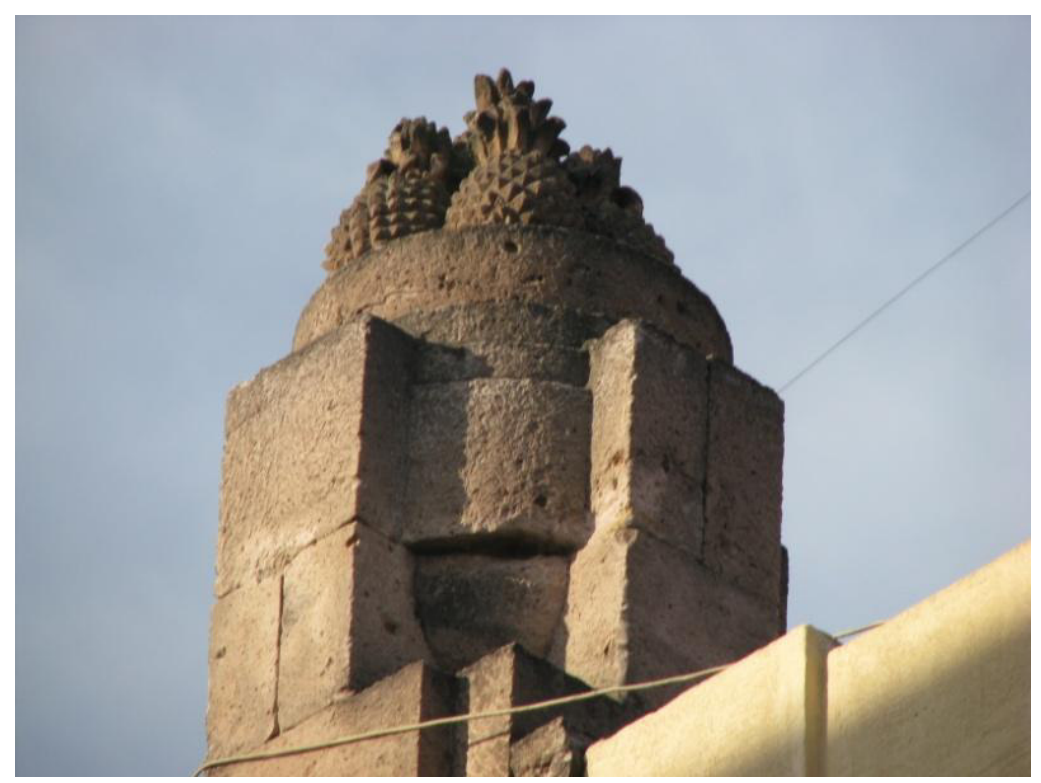

Casa Tron Hermanos, decoración con piñas en el remate de una columna, Morelia, Michoacán, finales de los años treinta, siglo XX. 

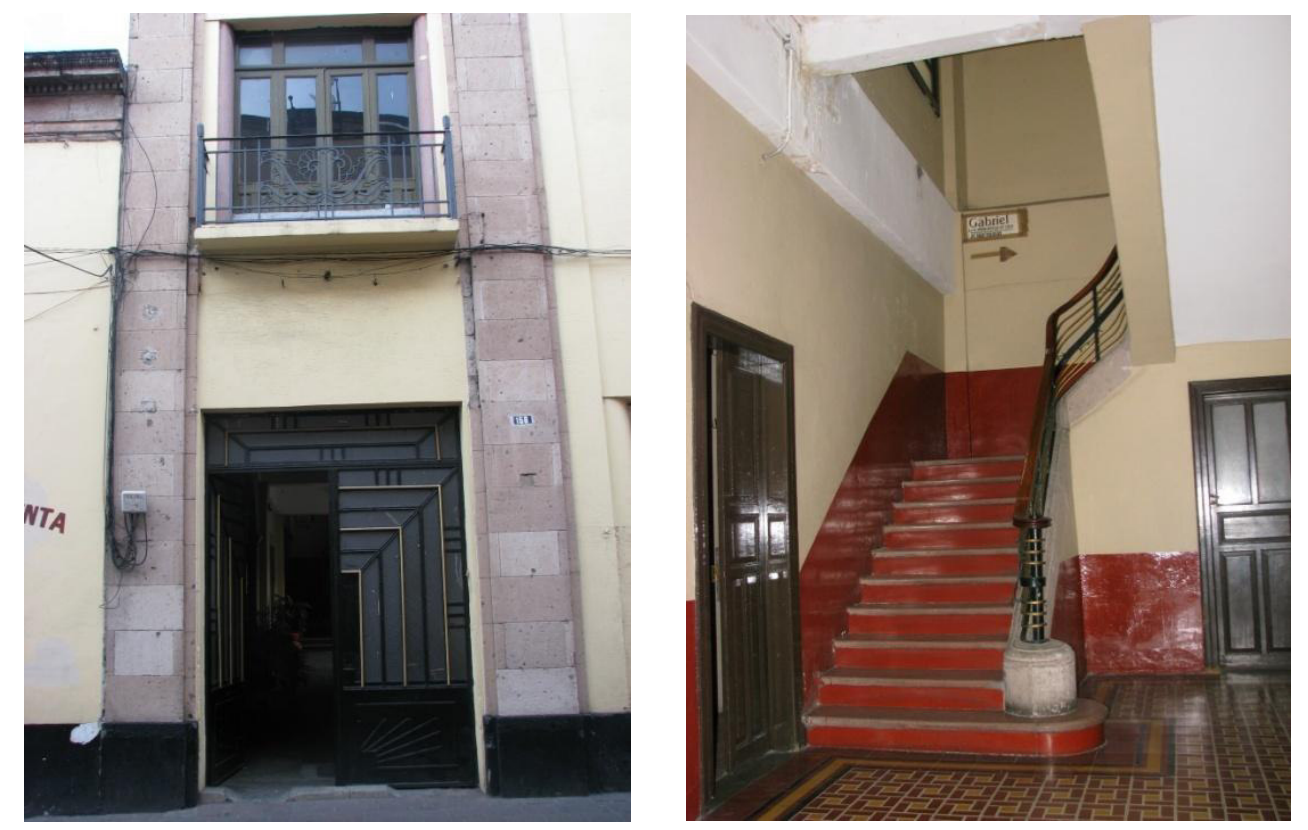

Casa Tron Hermanos. Imagen izquierda, entrada a las oficinas por la calle Morelos; imagen derecha, escalera y barandal. Morelia, Michoacán, finales de los años treinta, siglo XX.

En el noroeste del país, en la ciudad de Durango, capital del estado del mismo nombre, se construyó una grandiosa escuela, el Centro Escolar Revolución, (esquina de las calles Urrea y Gómez Farías) en un "barrio bajo" de la ciudad: Tierra Blanca. Las obras se iniciaron en 1934 y se concluyeron en noviembre de 1936, desconociéndose el autor de esta importante escuela. Es de dos plantas y llama la atención que en la intersección de las calles donde se ubica, se forma una pequeña plazoleta que da acceso a la fachada principal, la cual es una admirable composición de decorados Art Déco, de los más bellos que hay en el país. Los vanos de las tres puertas de acceso presentan recortes acodados, con rejerías de formas ondulantes y cuadradas. Las ventanas del segundo piso son ochavadas, pero a la vez tienen un leve acodamiento con lo cual se acentúa la intención de geometrización. Hacia el remate que consiste en un amplio piñón estriado que abarca las cinco calles de la fachada, unas decoraciones de bandas con pequeñas placas sobrepuestas, unen a la seis columnas con el piñón superior, el cual es escalonado, portando en los extremos escudos y al centro con grafías gruesas y geometrizadas el letrero del plantel, en cuyo centro se inserta el escudo nacional, para concluir la elevación escalonada con la base para el astabandera, 
constituyendo todo un monumento del Art Déco Zigzag. En el "lobby" tres vanos y una trabe forman arcos angulares rebajados con acodamientos en los arranques, enfatizando las composiciones Déco Zigzag del interior. Todo el edificio hecho con cemento es una muestra del Art Déco de las Tendencias Geometrista y Decorativista, así como la herrería de puertas, ventanas y rejerías que la resguardan.

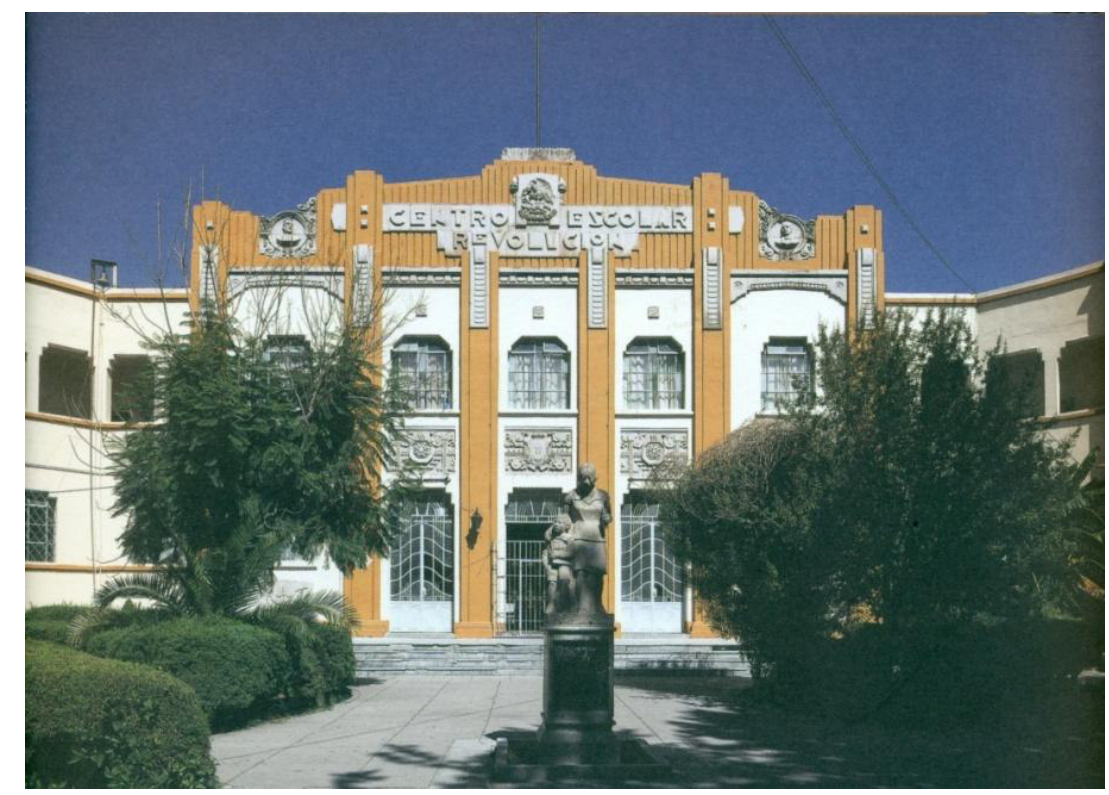

Centro Escolar Revolución, Durango, Durango, 1936. ${ }^{160}$

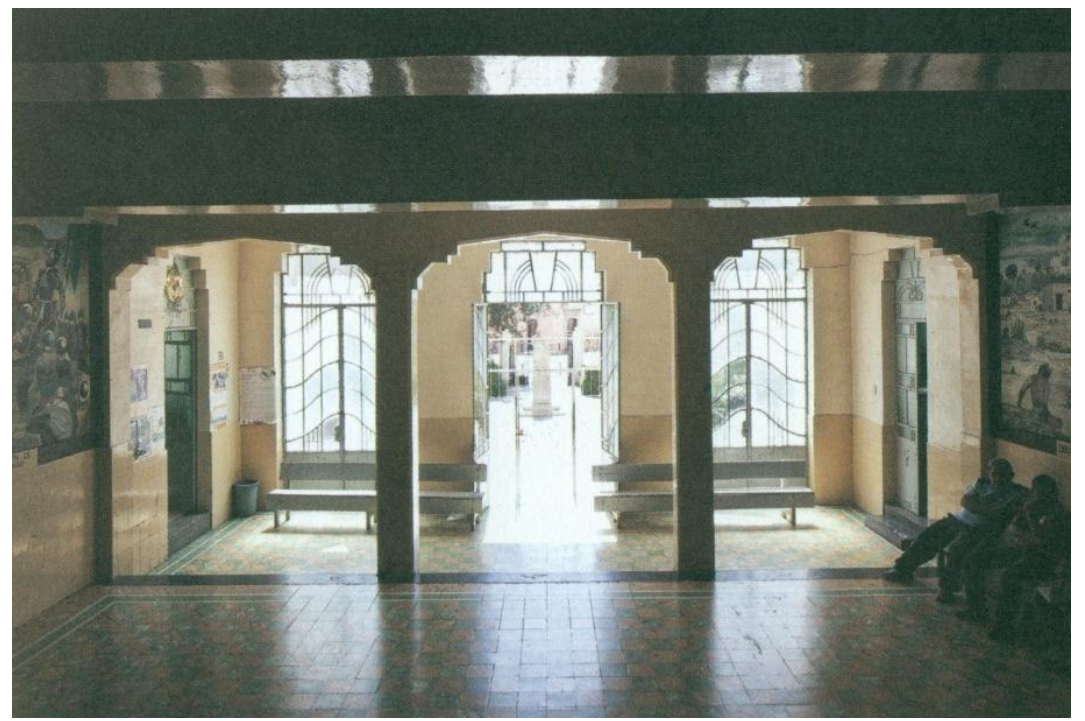

Centro Escolar Revolución, "lobby" en el interior, Durango, Durango, 1936.161

${ }^{160}$ Axel Arañó (editor), Arquitectura Escolar SEP 90 Años, México, SEP, CONACULTA, 2011, p.142. 
Puebla, capital del estado homónimo, es una ciudad en el centro del país que tuvo un fuerte desarrollo urbano en las dos décadas posteriores a la Revolución. Nuevas zonas habitacionales cercanas al centro fueron levantadas bajo los prototipos del Art Déco. Muchas de esas zonas y construcciones han venido a menos, convirtiéndose en barrios de clase baja, pero las casas siguen en pie.

En el centro de la ciudad (calle 3 Norte No. 5), se ubica el Edificio Magda, obra del arquitecto José Fernández, levantado en 1939, dato que se encuentra de lado izquierdo del arco de la entrada con letras metálicas. En un amplio inmueble de apartamentos que tiene dos fachadas, una sobre la calle 3 Norte que es la principal y otra sobre la calle 2 Poniente. Es de cuatro niveles, ocupando la planta baja diversos tipos de comercios. En la fachada principal que da hacia el oriente y abarca cinco tramos, el arco del acceso de entrada es de medio punto y abocinado en tres niveles, el cual está forrado de granito rojo lo mismo que las jambas, mientras que el rodapié es del mismo material pero en color negro. Por arriba del arco se eleva el cuerpo central con tres perfiles angulares que en la parte baja forman un ochavo y rematan escalonadamente y con una astabandera. La misma composición llevan los cuerpos laterales, también resaltados, que arrancan curvadamente y en la parte superior se ornan con bandas horizontes que enmarcan pequeños medios cilindros. Los balcones del segundo piso se ensamblan al muro de manera curva y se separan en tres tramos por medio de pretiles inclinados, recortados sinuosamente. En la fachada lateral norte de la calle 2 Poniente se repiten los mismos elementos compositivos, pero solamente abarca tres tramos. En ambas fachadas los cuerpos que las componen se van alternado en la disposición de su superficie, ya que de los cinco cuerpos de la principal, el central y los dos laterales están más hacia adelante y en la lateral, es a la inversa, de los tres cuerpos que la conforman, el central se encuentra remetido en relación con los dos laterales; solución plástica de la arquitectura Art Déco de intercalar cuerpos geométricos En el interior las escaleras y los pasamanos están forrados con granito negro, lo que denota el lujo que en su tiempo tenía el inmueble. El Edificio Magda es un inmueble que presenta elementos compositivos de la Tendencia Geometrista y una transición entre el Déco Zigzag hacia el Streamline. Es una pena que tan importante construcción moderna Déco que se encuentra en el corazón de la ciudad, esté bastante descuida y con una visible necesidad de mantenimiento.

${ }^{161}$ Ibídem, p. 143. 


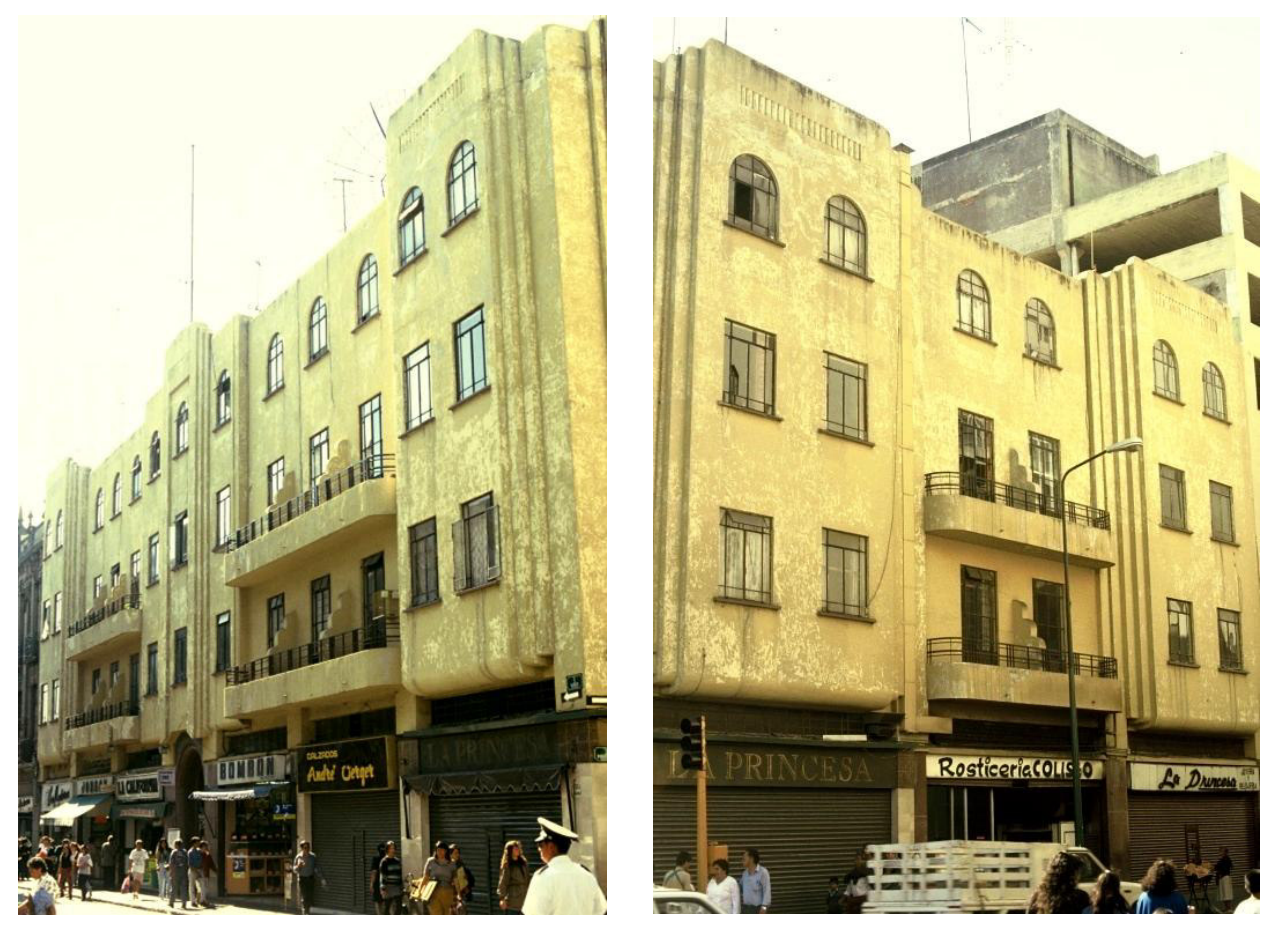

José Fernández, Edificio Magda, fachada principal oriente sobre la calle 3 Norte y fachada lateral norte sobre la calle 2 Poniente, Puebla, Puebla, 1939.
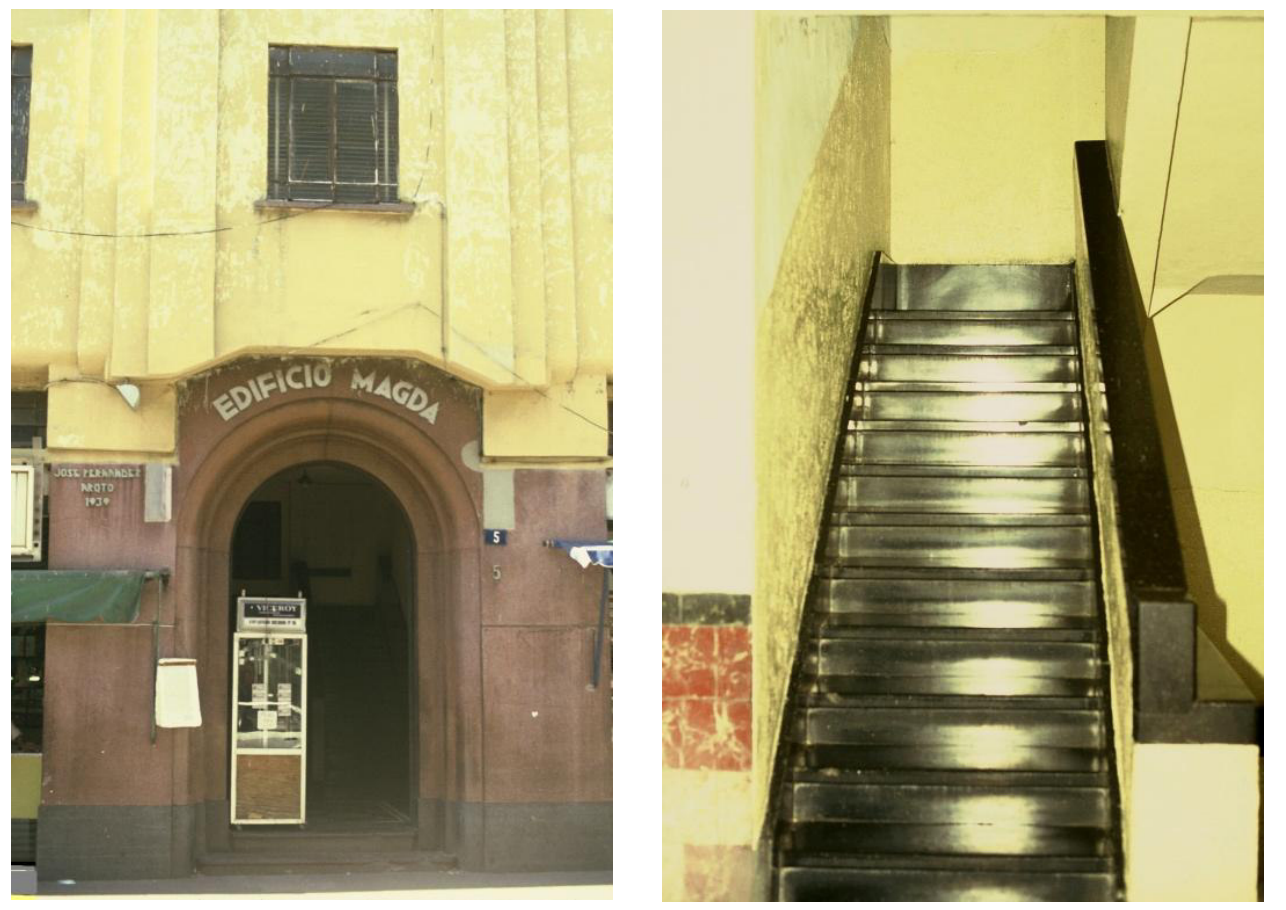

Edificio Magda, puerta de entrada y escalera en el interior, Puebla, Puebla, 1939. 
Como sucedió en todas la ciudades del país, en los años del desarrollo del Déco muchos salas cinematográficas fueron edificadas bajo los esquemas del Art Déco, como en Puebla aconteció con el ExCine Reforma (Reforma esquina con 5 Norte) edificado en $1938,{ }^{162}$ hoy convertido en una tienda de electrodomésticos. Su entrada se compone por dos gruesas columnas circulares con base y capitel circulares forradas con granito negro, lo mismo que los peldaños de la escalinata y las dos fachadas, sur o principal y poniente o lateral, se componen de muros cerrados, con fuerte masividad. En la fachada principal sobre la calle Reforma, el cuerpo central está remetido de los dos laterales, donde un conjunto de ventanas rectangulares se hermanan con siete bandas superpuestas, destacándose la central. Los cuerpos laterales con largos ventanales rectangulares abocinados, se curvean en las esquinas y se disponen más hacia delante del cuerpo central, con lo que el juego de planos asemeja un ensamble de cubos. Cuatro molduras horizontales recorren la parte baja del edificio y tres en la parte alta. Conservándose del edificio original solamente las fachadas, todo el conjunto asemeja una abstracción de una arquitectura palaciega egipcia, denotando ya los elementos del Déco Streamline, al mismo tiempo que presenta las características compositivas de la Tendencia Plasticista.

Otro caso fue el del ExCine Coliseo (2 Poniente, entre 3 y 5 Norte) que fue construido en $1945 .{ }^{163}$ Hoy funciona como tienda de telas, conservando sólo la fachada. Tiene un rodapié en granito obscuro y después de la marquesina y letrero, es interesante la forma en que está concebido el gran ventanal central, pues se forma con ventanas acomodadas angularmente, y las divisiones, así como todo el ventanal es curvo convexo, dándole un cinetismo geométrico a esta parte del edificio. En la parte superior dentro de un recuadro curvado está todavía el nombre del cine: COLISEO. A los lados se integran ventanales rectangulares y los lienzos de los extremos terminan con un adorno de estrías. Para cerrar la fachada, unos muros de menor tamaño y levemente remetidos llevan tres óculos a manera de ventanilla de camarote de barco. Este inmueble es definitivamente de un Art Déco Streamline y conlleva elementos de la Tendencia Plasticista.

\footnotetext{
${ }^{162}$ María Cristina Rocío Silva Angón, "La Arquitectura Art Deco en Puebla. Su valoración y conservación", $V$ Encuentro Internacional Ciudad Imagen y Memoria, Forum UNESCO-Universidad de Oriente, Facultad de Construcciones, Santiago de Cuba, 2007, p. 7.

163 Ídem.
} 


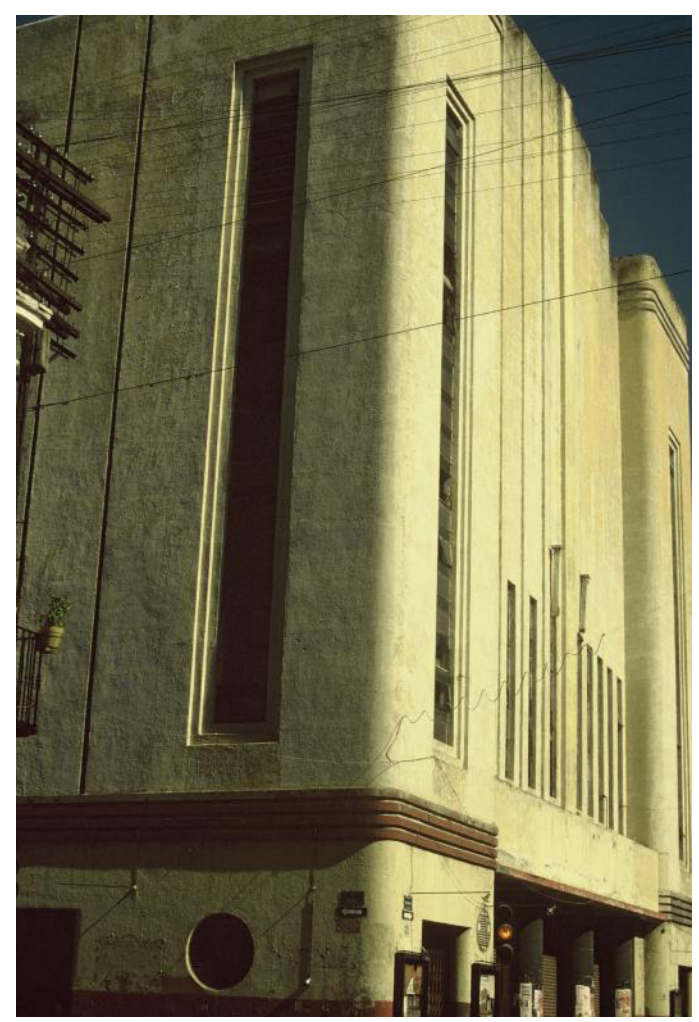

ExCine Reforma, Puebla, Puebla, 1938.

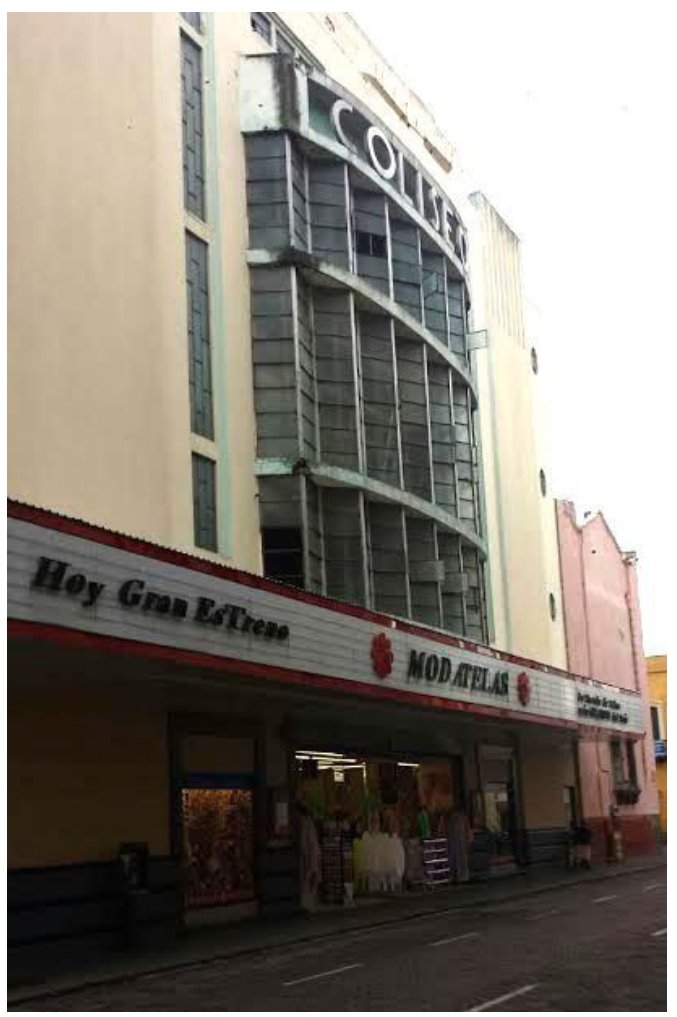

ExCine Coliseo, Puebla, Puebla, 1945.

Éstos son algunos ejemplos de la arquitectura Art Déco en algunas de las ciudades de la república, pero todavía hay mucho por estudiar de este estilo. Algunos investigadores han tomado la línea del Déco y han desarrollado trabajos regionales, como es el caso de Carolina Magaña Fagardo en la ciudad de México, Olga Clarisa Becerra Mercado en Guadalajara, Javier Guerrero Romero en Durango, Rogelio Sánchez Mena en León, Cristina Silva Angón en Puebla y Enrique Urzaiz Lares en Mérida, seguramente entre muchos más que han estudiado o estarán indagando sobre la arquitectura Art Déco en el país y sus trabajos no son divulgados.

\subsubsection{Escultura mexicana y el Art Déco}

Por lo que respecta al campo de la escultura, curiosamente no se han dado características distintivas. Solamente lo que menciona Esqueda: "Los aspectos que tomaba la escultura europea de esos años, que variaba desde lo grandilocuente y la vanguardia hasta la estrictamente decorativa como la escultura de salón vendría a ser la escultura de 
artesanía", 164 a lo que agrega que la ornamentación arquitectónica a veces llega a ser escultórica. Por lo tanto, podríamos inferir que la escultura Déco en México tuvo tres manifestaciones: la monumental, relieves en paneles y en pequeño formato.

En la escultura monumental, entendida como escultura pública, conmemorativa y/o de tamaño grande, destacan las formas humanas con cuerpos enérgicos, hercúleos, de trazos angulosos y composiciones geométricas, matizándose los volúmenes cúbicos. Con una influencia clásica, torsos desnudos, atléticos, de hombres trabajando en las faenas agrícolas y/o industriales, el campesino y el obrero, los triunfos de las luchas revolucionarias. Brazos fornidos, manos membrudas, miradas fijas, conforman un concepto del varón moderno, bien alimentado, enérgico en su complexión y estructura. Las mujeres por su parte, con ropas ligeras, frescas, flamantes en su vestir, o también semidesnudas de la cintura hacia arriba, parodiando a la efigies helénicas, con cortes a la garçonne o sombreros encasquetados, presumen la moda de la época.

En la escultura de relieves en paneles, las figuras humanas tanto masculinas como femeninas, en poses retorcidas se acoplan a los rectángulos que la enmarcan, repitiendo los temas y composiciones de la escultura monumental, que muchas veces van acompañadas de decoraciones florales y otras emergen simplemente solitarias.

Si bien son pocos los objetos escultóricos de pequeño formato que se conocen de escultores mexicanos o radicados en el país que hayan trabajado bajo los lineamientos estéticos del Déco, en todo caso repetían a menor escala los modelos de las efigies monumentales, utilizando principalmente ya sea la piedra o la madera.

En sendos casos, la escultura del periodo Zigzag, los años veinte y parte de los treinta, acusa diseños con caídas de los pliegues de los ropajes en series, angulares, triangulares, con personajes en posturas firmes, con marcada acentuación de lo geométrico. Cuando van en grupo, se colocan axialmente, en equilibrio, acompasadas en su distribución. Ya a finales de los años treinta o incluso en los años cuarenta, las esculturas en su mayoría se presentan exentan, flotantes, como si fuera una base con elementos adosados para acceder a composturas volátiles, acrobáticas, suspendidas en el espacio, son productos de la variante Déco del Streamline, de los diseños aerodinámicos.

\footnotetext{
${ }^{164}$ Xavier Esqueda, El Art Deco. Retrato de una época, Op. Cit., p. 103.
} 
Sin embargo, en ambas variantes del Déco y en sus tres categorías escultóricas, las influencias de la imaginería mesoamericana, especialmente lo maya, lo tolteca y lo mexica o azteca, tienen una notoria influencia en las composiciones cúbicas, geométricas y de volúmenes comprimidos, tal como se manufacturaban las esculturas prehispánicas, tomando en cuenta que lo indígena ya fuera pasado o presente, se tomaba como bandera de los triunfos revolucionarios del México moderno.

Dentro de las esculturas monumentales, en la ciudad de México hay dos que, a nuestro juicio, representan al Art Déco mejor que ningunas otras: el Monumento fúnebre a Álvaro Obregón y el Monumento a la Revolución, que aparte de las fechas en que se erigieron, fueron símbolos patrios de la triunfante modernidad revolucionaria.

El Monumento Fúnebre a Álvaro Obregón de 1935, (Parque La Bombilla) fue un proyecto llevado a cabo a instancias de Aarón Sáenz (1891-1983), quien fungió como Regente de la ciudad de México de 1932 a 1935 y fue amigo personal de Obregón, para conmemorar al caudillo en el mismo lugar donde fuera asesinado por José de León Toral (1900-1929) en el Parque La Bombilla. La obra arquitectónica y escultórica que duró dos años se terminó en el gobierno de Lázaro Cárdenas (1895-1970) y corrió a cargo del arquitecto Enrique Aragón Echegaray (1929), cuyo diseño consistió en un primer cuerpo cúbico de cantera, con puerta de acceso rectangular y un letrero con tipografías doradas mayúsculas que dice Obregón; otro cubo de color claro se eleva verticalmente, que con una calle rehundida en color verde en el paramento frontal, conjuga una linealidad ascendente en planos que se inicia en la escalinata de anchas alfardas, de marcada influencia prehispánica, y que se encadena con el vano de acceso. Pero cuando hablamos de este monumento desde el punto de vista artístico, normalmente lo relacionamos con las esculturas de la entrada creadas por Ignacio Asúnsolo (1890-1965), las cuales representan a dos mujeres robustas, tectónicas, de etnia indígena, vestidas con un peplo, que con posturas angulares en uno de sus brazos, una sostiene el maíz, símbolo de la agricultura, y la otra un mazo, representación del obrero, y ambas con las otras manos portan instrumentos de sus oficios; tanto la colocación de los brazos como las piernas trazan una simetría que protegen el vano de entrada a la cripta. A los lados y ligeramente remetidos, grupos escultóricos encarnan ideales de lucha revolucionaria, del lado izquierdo, y del trabajo agrícola, del lado derecho; en la parte posterior, la águila nacional, de perfil, con las alas abiertas sobre cactus 
desérticos, imagen de la tierra donde nació Obregón. En el interior del monumento, en la cripta, se eleva la figura en bronce del "Manco de Celaya"165, fundida también por Asúnsolo, y más tarde, en 1943, se colocó la mano del general sonorense en una urna transparente con formol, la cual fue retirada en 1989. De planta ochavada, la cripta hace gala del lujo de sus mármoles rosáceos y negros que junto con el techo de alabastro sostenido por vigas de bronce le dan una iluminación al mausoleo en un ambiente de solemnidad que se complementa con las esculturas de dos soldados revolucionarios y dos relieves de musas, los cuatro haciendo el papel de centinelas.
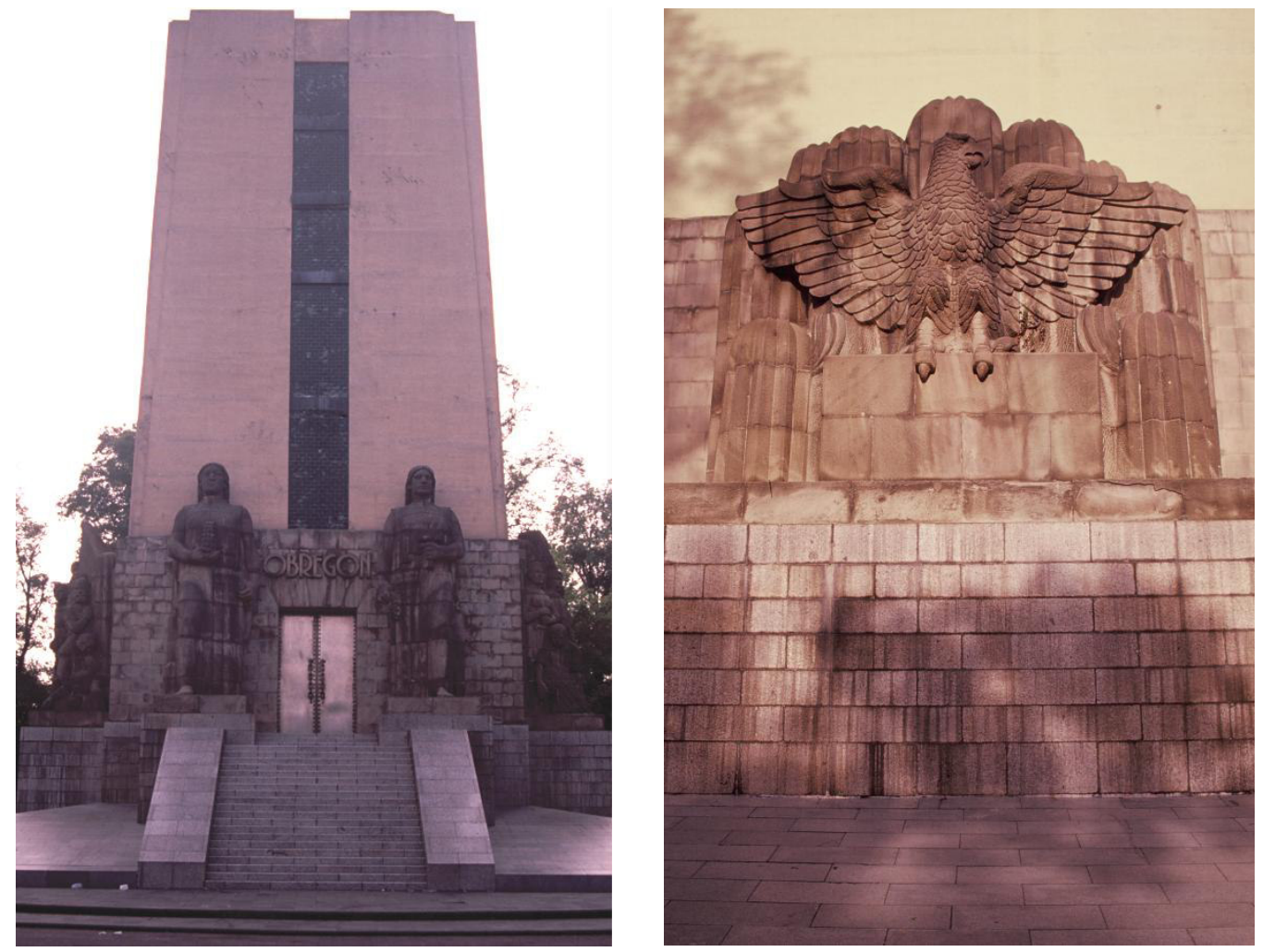

Enrique Aragón Echegaray, arquitectura, Ignacio Asúnsolo, escultura, Monumento a Álvaro Obregón. Imagen izquierda vista principal. Imagen derecha parte posterior del monumento con el águila nacional y los cactus de Sonora, tierra natal de Obregón, México, D.F., 1935.

Sobre su importancia dentro de las obras artísticas en México el Monumento a Álvaro Obregón "se suma a las obras que dan cuenta del Art Déco en nuestro país, y entre

\footnotetext{
${ }^{165}$ Con este sobrenombre se le conoció a Álvaro Obregón después de perder la mano derecha de un cañonazo en una de las batallas sostenida contra la fuerzas de Francisco Villa en Celaya, Guanajuato, en abril de 1915 durante la Revolución Mexicana.
} 
los rasgos identificados para tal clasificación destaca la estructura arquitectónica de trazos geométricos, construcción en concreto, material que otorga solidez y plasticidad a las formas, logrando con ello el aspecto lineal y anguloso". 166

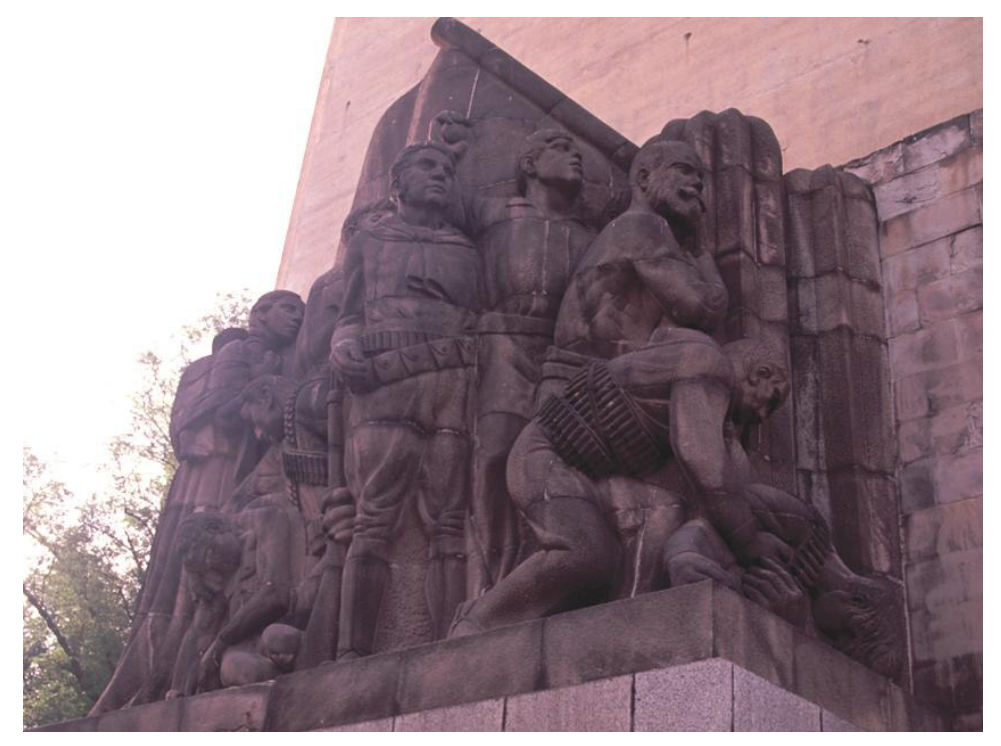

Ignacio Asúnsolo, Monumento a Álvaro Obregón, "La Revolución”, esculturas de lado latera izquierdo México, D.F., 1935.

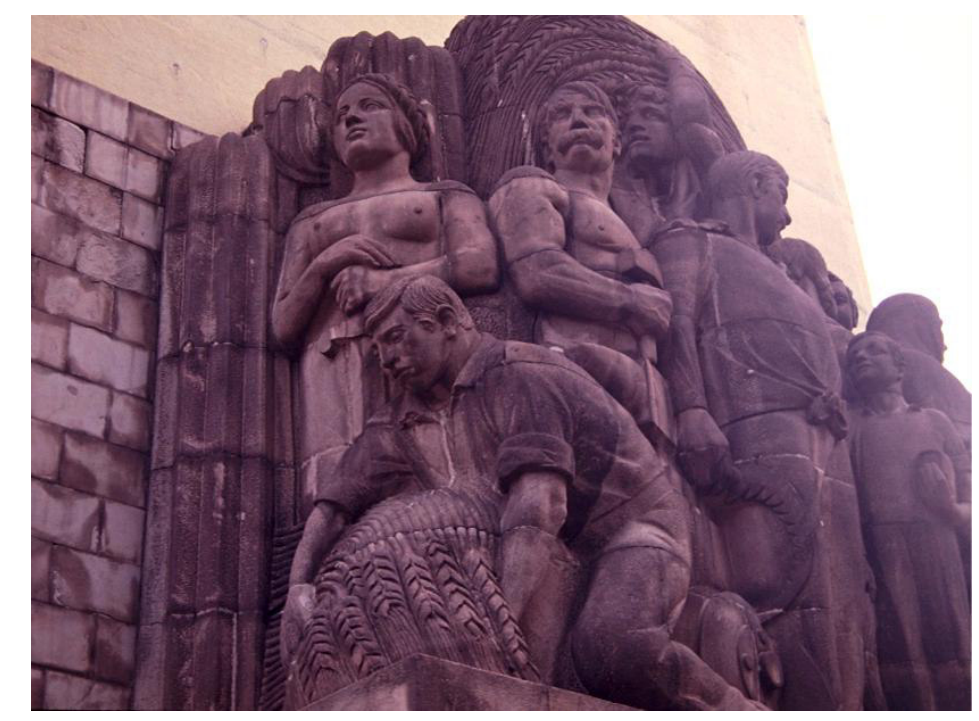

Ignacio Asúnsolo, Monumento a Álvaro Obregón, “Los campesinos”, esculturas del lado lateral derecho, México, D.F., 1935.

${ }^{166}$ Emma Leticia Herrera García; Elsie Mc Phail Fanger; Citlali Salazar Torres, "El monumento a Álvaro Obregón, arte y política. Una obra y un héroe mutilados", Argumentos, México, Universidad Autónoma Metropolitana-Xochimilco, Vol. 22, No. 61, septiembre-diciembre 2009, p. 194. 
En un reportaje del año 2000 del articulista defeño Alberto Barranco Chavarría, narra una visita al mausoleo de Obregón -claro, elevado a los altares patrios por los mismos sangrientos homicidas revolucionarios en el poder de esos años- realizada por niños de primaria que como premio van a rendir un forzoso homenaje: "El monumento al General Obregón, decía la maestra Graciela, con aquella voz que alineaba hasta las bancas, nació de un proyecto de Enrique Aragón, solicitado por el Presidente Lázaro Cárdenas en 1935. Las mujeres de granito que cuidan la puerta y en general los grupos escultóricos, uno referido a la lucha revolucionaria y otro al trabajo agrícola, industrial e intelectual, fueron obra del escultor Ignacio Asúnsolo... quien trabajaba tan enfermo, que los canteros tenían que sostenerlo en vilo". ${ }^{167}$
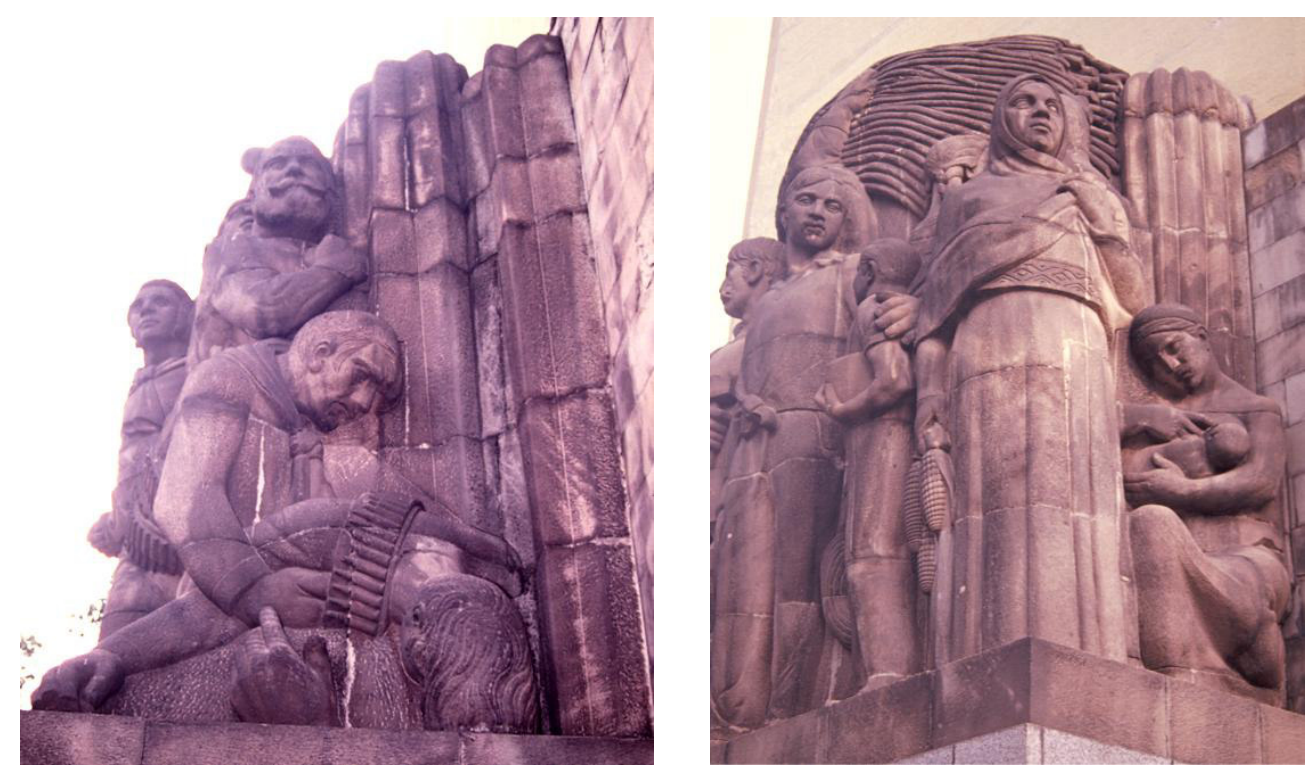

Ignacio Asúnsolo, Monumento a Álvaro Obregón, detalles de "La Revolución” y de la parte posterior de los "Los campesinos, en el cual la mujer que carga las mazorcas de maíz lleva una cinta en la cintura confeccionada con diseños indígenas de rombos entrecruzados formando un diseño Déco Zigzag. En ambos grupos se resaltan los cactus del desierto de Sonora. México, D.F., 1935.

Diez años después de este reportaje, en las fiestas del Centenario de la Revolución, ni por su importancia artística el homenaje pétreo y escultórico, del que algún día fuera

\footnotetext{
${ }^{167}$ Alberto Barranco Chavarría, "Ciudad de la Nostalgia. La mano de Obregón”, Reforma, México, D.F., domingo 11 de junio de 2000, secc. B, Ciudad y Metrópoli, p. 9 B.
} 
denominado como Caudillo revolucionario, ha sido restaurado. Así lo describen en noviembre de 2010: "Pero su monumento luce hoy sucio, deteriorado y con la pintura de la fachada cayéndose a pedazos. La fuente que se ubica frente a él carece de agua y también muestra los signos del abandono. Las puertas de esta obra que comenzó a edificarse en el gobierno de Abelardo L. Rodríguez, están generalmente cerradas..." 168

El Monumento a la Revolución (Plaza de la República, Col. Tabacalera) fue levantado entre 1933 a 1938 por Carlos Obregón Santacilia. Aprovechando la estructura de hierro de lo que iba a ser el Palacio Legislativo en tiempos de Porfirio Díaz (1830-1915), obra del arquitecto y pintor francés Émile Bénard (1844-1929) ${ }^{169}$ proyectada en 1903 y avanzada hacia el año de 1910, Obregón Santacilia cubrió de cantera los cuatro arcos y concluyó con una doble cúpula que descansa sobre un tambor compuesto por pilares rectangulares y cuatro escalonados contrafuertes, obteniendo como resultado un juego geométrico de un cubo sosteniendo una media esfera. En las cuatro esquinas sobre alargados zócalos, grupos escultóricos de figuras robustas cinceladas por Oliverio Martínez (1901-1938), representan triunfos revolucionarios liberales y partidistas: Independencia, Leyes de Reforma, Leyes Agrarias y Leyes Obreras. Para muchos un adefesio, para otros una obra pública más, el Monumento a la Revolución es un arquetipo del Art Déco nacionalista, tanto en su concepción integral arquitectónica y escultórica, como es su proyección ideológica, “Quizás el caso más explícito de la predilección del estado por el art déco". ${ }^{170}$ La actualidad del diseño de este monumento en su época se constata si lo relacionamos con The Anzac Memorial en el Hyde Park de Sydney, Australia, realizado en 1934 por el arquitecto Charles Bruce Dellit (1898-1942), un admirador de Frank Lloyd Wright, y con esculturas de Rayner Hoff (1894-1937). Elevado para conmemorar a héroes de la ANZAC (Australian New Zealand Army Corps) que participaron en la I Guerra Mundial, se concibió como un cubo con arcadas, rematado con niveles escalonados; se

\footnotetext{
${ }^{168}$ Judith Amador Tello, "Monumento a Obregón, en el abandono", Proceso.com.mx, México, D.F., viernes 17 de diciembre de 2010, www.proceso.com.mx/rv/modHome/pdfExclusiva/86493

${ }^{169}$ Muchos han confundido el nombre con el del pintor también francés Émile Bernard (1868-1941).

${ }^{170}$ Daniel Garza Usabiaga, “Arquitectura en México después de la Revolución”, en: Luz María Sepúlveda (coordinadora), Las artes plásticas y visuales en los siglos XIX y XX. El Patrimonio Histórico y Cultural de México (1810-2010). Tomo VI, México, Dirección General de Publicaciones del CONACULTA, 2013, p. 131.
} 
encuentra forrado de piedra clara y rodeado de esculturas, lo cual le da semejanza con el monumento mexicano. ${ }^{171}$

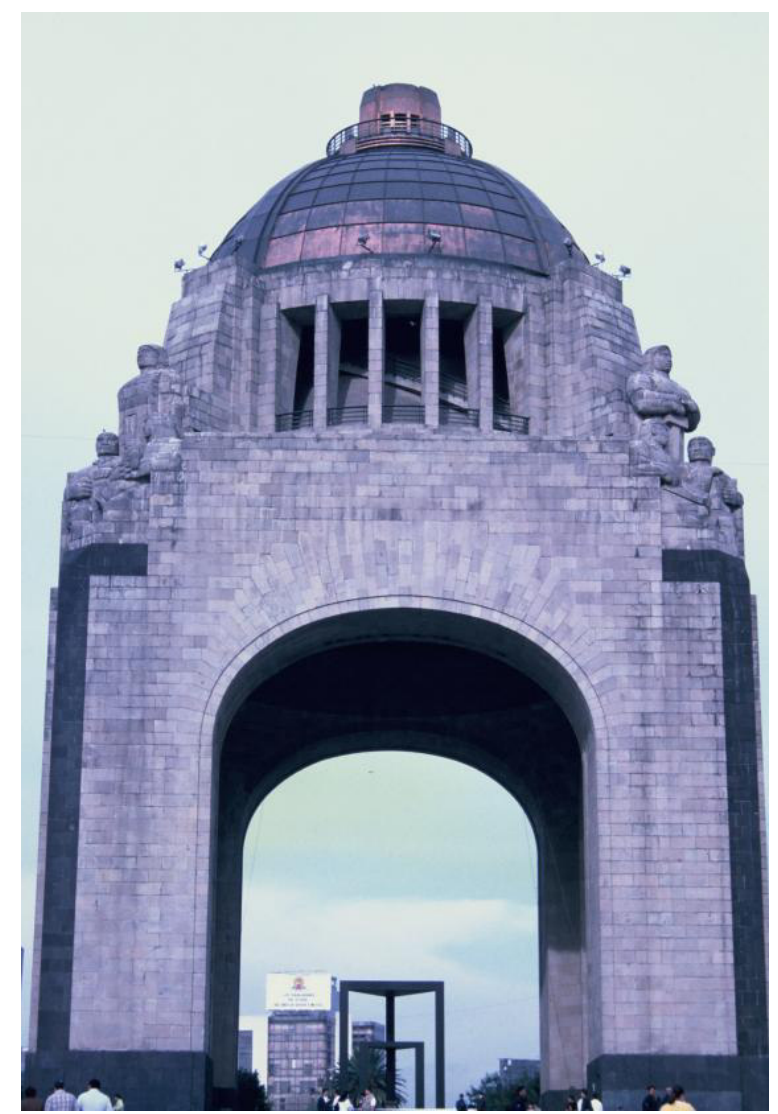

Carlos Obregón Santacilia, Monumento a la Revolución, México, D.F., 1938.

Exaltando la acertada edificación del monumento, así como su creatividad moderna, Luis Ortiz Macedo lo elogia así: “La obsesión de Obregón y Martínez por integrar la arquitectura con la escultura, es otra de las fortunas innegables del Monumento; otra -la cual resalta más y más conforme la ciudad va cayendo en la anarquía fisonómica que ya la caracteriza- es el propósito firme de ordenar los grandes espacios urbanos". ${ }^{172}$ Sesenta y cinco metros de altura tiene este monumento cuya composición ascendente y geométrica le da un definitivo toque de estilo Art Déco, lo mismo que las jardineras laterales y las lámparas lo iluminan, fue reinaugurado el 20 de noviembre de 2010 dentro de los festejos

${ }^{171}$ Véase para hacer una comparación entre ambos monumentos: Bevis Hillier y Stephen Escritt, Art Deco Style, Londres, Phaidon Pres Ltd, 1997, p. 192 y foto p. 191.

${ }^{172}$ Luis Ortiz Macedo, "La plaza de la República y en Monumento a la Revolución", Catálogo de la exposición Art Deco en México, Op. Cit., p 22. 
del Centenario de la Revolución, para lo cual en el espacio central se le integró un elevador transparente para subir al mirador emplazado en la cúpula.
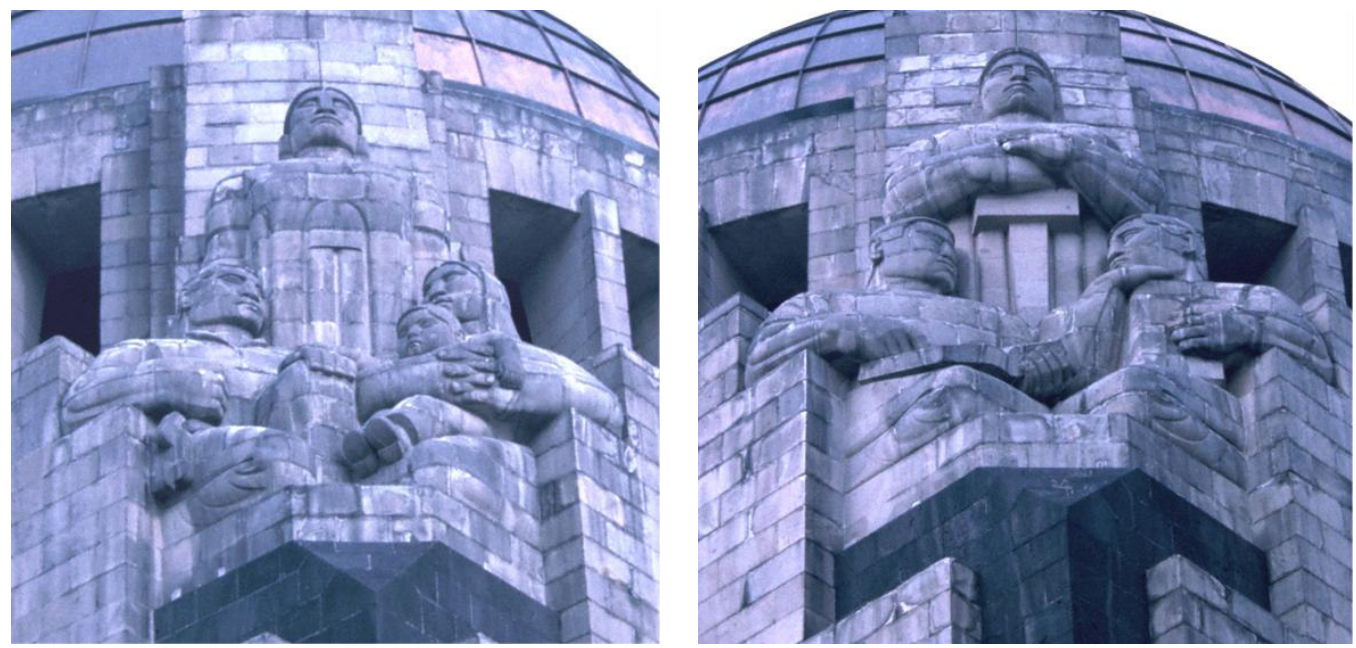

Oliverio Martínez, La Independencia y Leyes de Reforma, Monumento a la Revolución, México, D.F., 1938.
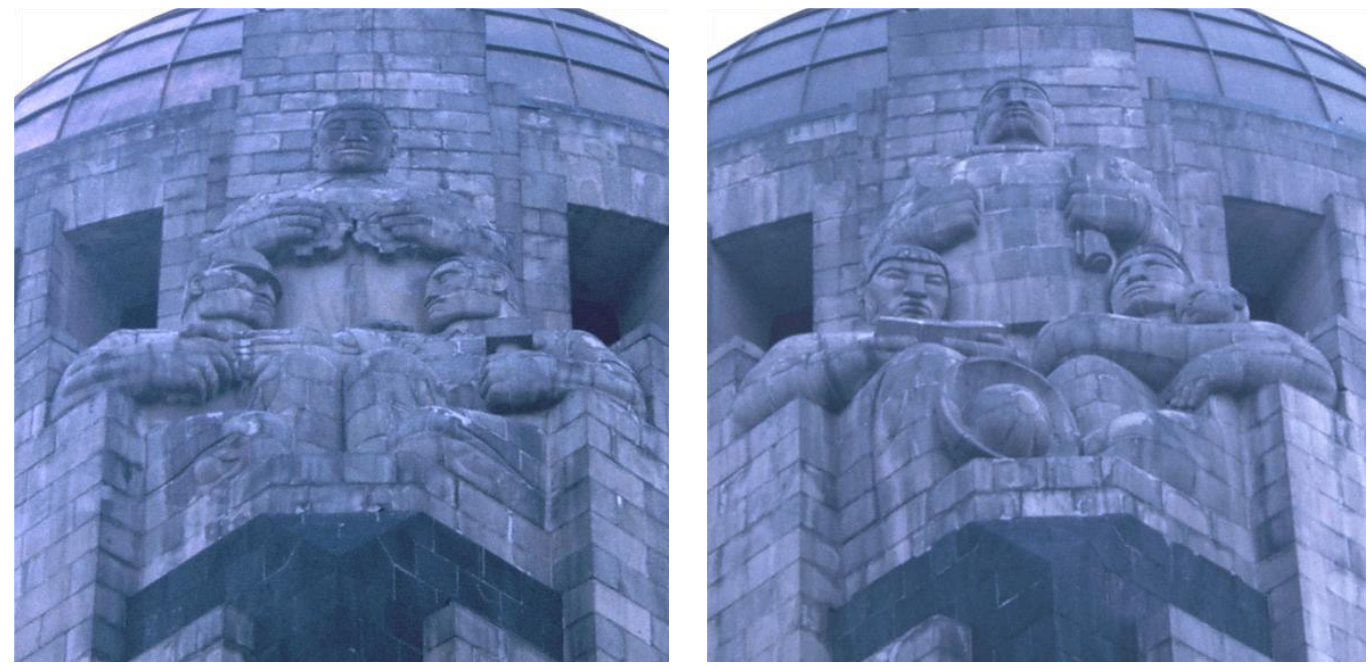

Oliverio Martínez, Leyes Obreras y Leyes Agrarias, Monumento a la Revolución, México, D.F., 1938.

Y José Pijoán escribió en una visita a México: "Hay que hacer justicia al arquitecto que lo hizo crecer: la parte superior, el trompo -la peonza-, está admirablemente resuelta y es original. Su cúpula con aspilladeras abiertas revela que no es para cubrir un lugar cerrado, sino un área por donde circula el aire y pueden pasar las nubes. Los cuatro grupos escultóricos no sólo acaban de mexicanizar el Monumento, sino que empalman para la 
cúspide. Las cabezas esféricas son el intermediario entre el cubo de la base y la esfera de la cubierta. Aquellos grupos tan discutidos - ¡tan discutidos!- son el gran acierto. No se puede imaginar el Monumento a la Revolución sin la nota humana y no abajo como soporte, sino en lo lato beneficiado el triunfo ya logrado". 173

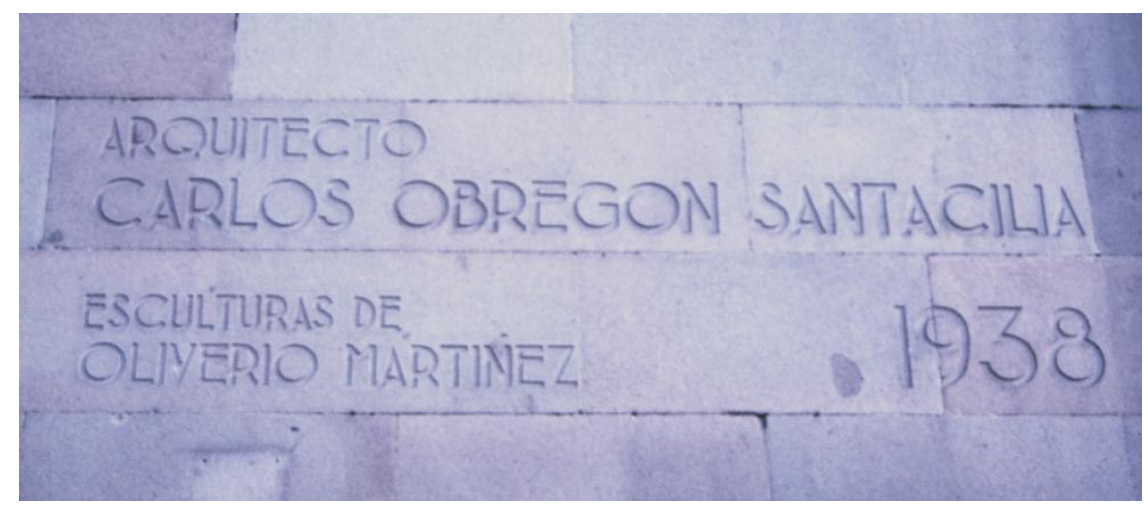

Monumento a la Revolución, nombres del arquitecto y del escultor, México, D.F., 1938.

Fuera de la ciudad de México, hay dos esculturas monumentales Art Déco que son identificables, podríamos decir, a nivel nacional: Monumento a Morelos, en la isla de Janitzio, Michoacán y el de Cristo Rey del Cerro del Cubilete, en Silao, Guanajuato.

La isla de Janitzio en medio del bello lago de Pátzcuaro -cuya significación tal vez sea maíz seco, flor de elote, lugar donde llueve- ${ }^{174}$ fue el lugar escogido por Guillermo Ruiz (1896-1981) para levantar el majestuoso Monumento a Morelos. Único en su género, los trabajos para construirlo duraron cinco años, de 1933 a 1938, bajo un diseño de la estructura por parte del ingeniero de guerra, el Capitán Antonio Rojas García y mano de obra de muchos soldados del ejército comisionados para trabajar en conjunto con lugareños de la isla. ${ }^{175}$ Se trata de una escultura gigantesca de $40 \mathrm{~m}$., de altura, hueca por dentro, que representa al insurgente con el puño derecho levantado y con la mano izquierda sostiene una espada recargada sobre su cuerpo. De pliegues sencillos y verticales el cuerpo es como

\footnotetext{
${ }^{173}$ Jose Pijoán, "Viendo México. El Monumento a la Revolución", en El Universal, México, 8 de julio de 1937, pp. 3 y 12 en Enrique Franco y Agustín Arteaga, "Lo nacional como vanguardia: escultura, identidad e historia", en: Magdalena Zavala y Alejandrina Escudero (Coordinación editorial), Escultura Mexicana. De la Academia a la instalación, México, INBA, Landucci Editores, 2001, 2ª ., edición, p. 129.

${ }^{174}$ Humberto Musacchio, Op. Cit., p. 946.

${ }^{175}$ Enrique Franco y Agustín Arteaga, Op. Cit., p. 127.
} 
un cono truncado, para recibir la cabeza y la prolongación vertical del brazo derecho y el puño cerrado. Del lado izquierdo del cuerpo del insurgente, van cayendo en zigzag los pliegues de la capa que utilizaba el cura Morelos, que por la parte de atrás se resalta el volumen rectangular del plisado de la misma prenda. El paño de la cabeza se ciñe en la parte trasera formando una estrella que a la vez conforma un zigzag. El armazón es de varilla y cemento y la superficie está forrada en cantera rosa de la región que para trasladarla se utilizaron las embarcaciones que cruzan el lago y los artesanos labraron la piedra en la isla. Lily Kassner afirma que el Monumento a Morelos “...ha sido uno de los esfuerzos más atrevidos dentro de la escultura monumental pues mide cuarenta metros de altura y presenta vicisitudes de tipo técnico y obstáculos naturales. La misma isla le sirvió de gran pedestal a la escultura gigantesca". ${ }^{176}$

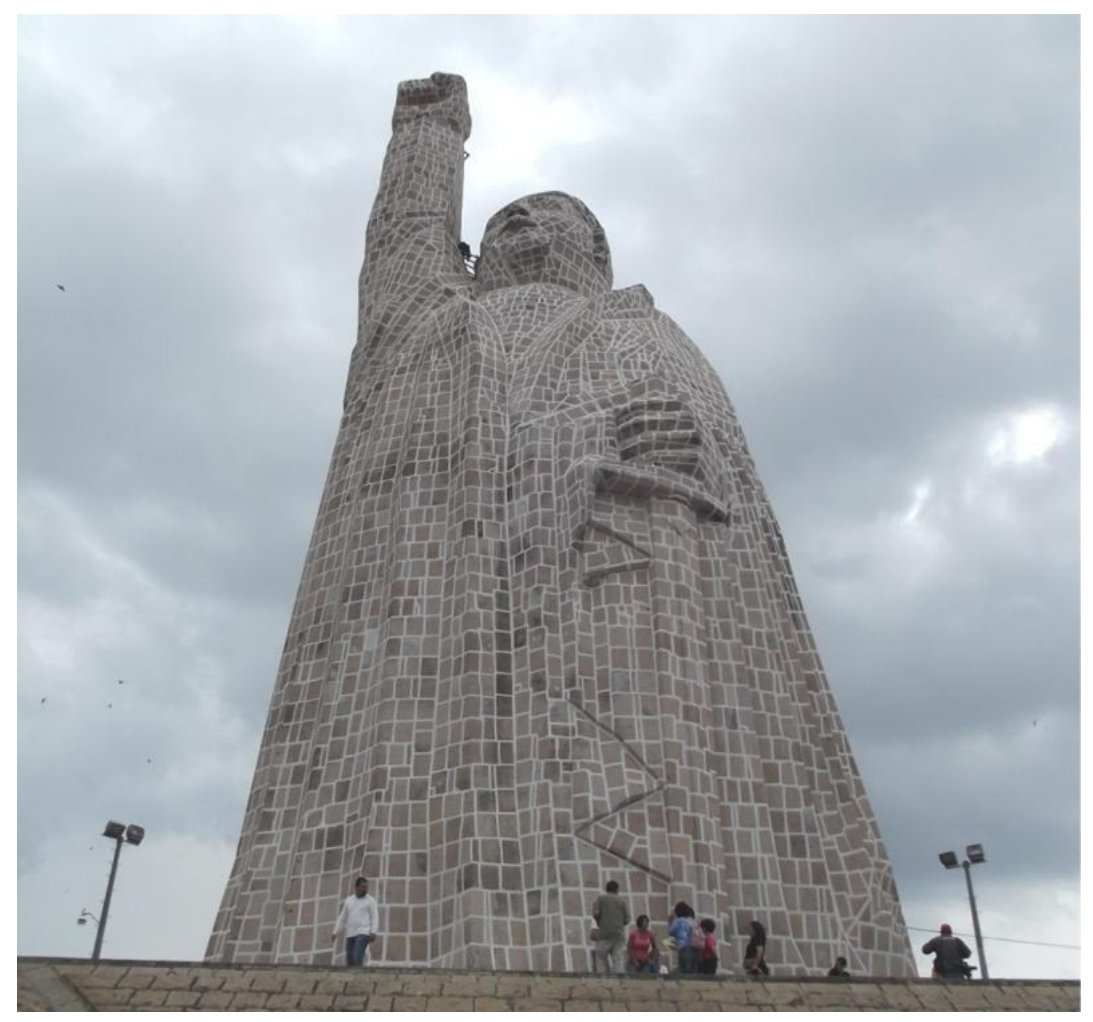

Guillermo Ruiz, Morelos, Janitzio, Michoacán, 1938.

\footnotetext{
${ }^{176}$ Lily Kassner, "Escultura nacionalista", Historia del Arte Mexicano. Arte Contemporáneo II, vol. 14, México, SEP, Salvat, 1986, p. 2048.
} 

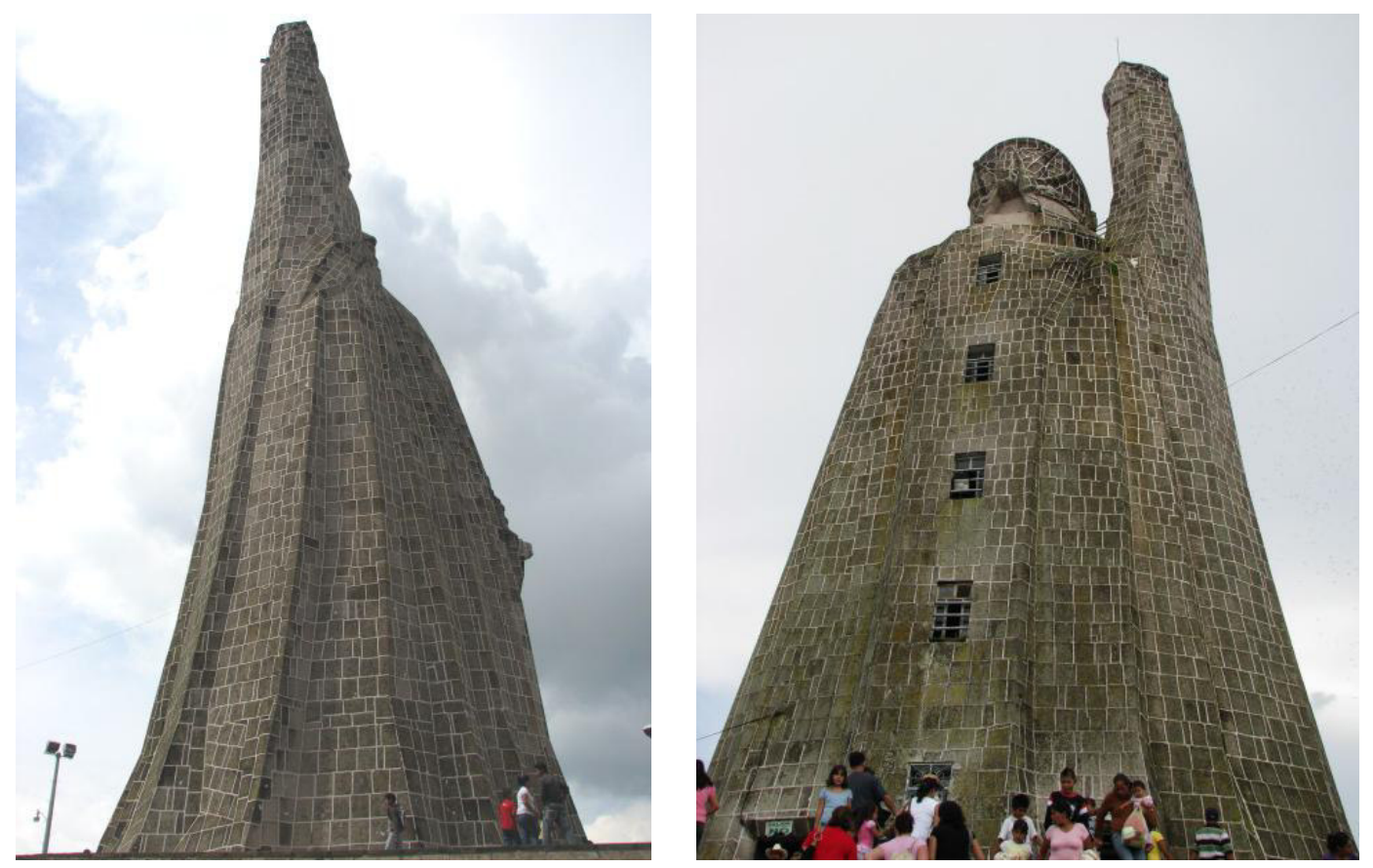

Guillermo Ruiz, Morelos, vistas lateral y trasera, Janitzio, Michoacán, 1938.

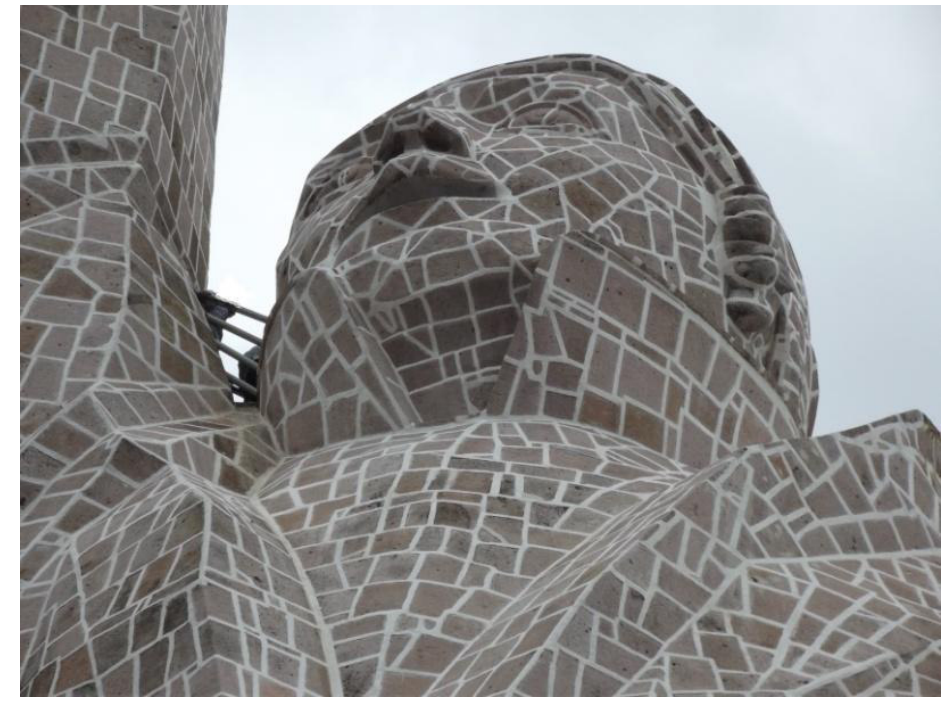

Guillermo Ruiz, Morelos, detalle del rostro, Janitzio, Michoacán, 1938.

En el interior del Morelos, en frescos realizados por Ramón Alva de la Canal (18921085), quien también pintó en la escuela de la isla de Yunuén a los pescadores del lago, se narra la vida del insurgente. Esta megaescultura de Morelos en la isla de Janitzio es un triunfo de la estética Art Déco en México, pues los grandes pliegues de la vestimenta y las 
formas cúbicas, cilíndricas y trapezoidales que lo conforman son elementos compositivos geométricos del Déco. ${ }^{177}$

Aunque ya fue realizado bien entrada la década de los cuarenta, consideramos que el Cristo Rey de Fidias Elizondo (1891-1979) colocado en el Cerro del Cubilete, cerca de Silao, en el estado de Guanajuato, entra dentro del Art Déco. La figura fue realizada en cemento lo que corresponde al cuerpo y de bronce son las manos y la cabeza. Composición de pliegues rectos en el ropaje y formando una verdadera cruz con los brazos abiertos, retrata a un Cristo de rostro apacible y sereno. Mide 20 m., de altura y está acompañado de dos ángeles de $3 \mathrm{~m}$ : uno que representa el martirio al cargar la corona de espinas y el otro con el símbolo del triunfo que lleva una corona imperial. El diseño de la escultura se inició en 1946 y fue colocada en 1949, sobre el Santuario de forma semiesférica obra de los arquitectos Nicolás Mariscal Piña (1875-1964) -hermano del arquitecto Federico Mariscaly Carlos Ituarte. Esta escultura, que substituyó a la que fue dinamitada en 1928, tiene una gran similitud con el Cristo Redentor que se encuentra en Río de Janeiro, Brasil, en el cerro de Corcovado; de $30 \mathrm{~m}$., de altura más los $8 \mathrm{~m}$., del pedestal, fue realizada en concreto por el ingeniero Heitor da Silva Costa (1873-1947) y por el escultor de origen francés Paul Landowski (1875-1961) a partir de 1926 e inaugurada el 12 de octubre de 1931. No queremos decir que Elizondo haya plagiado al Cristo de Brasil, sino que por la época y las tendencias estilísticas hay relación de composición entre ambas imágenes. La efigie de Cristo Rey en lo que corresponde del torso hacia abajo se compone de pliegues verticales rectilíneos que le dan forma a la túnica, que con las placas cuadradas de cantera con que está forrado acentúa su geometricidad, concibiéndose un diseño de tipo Art Déco.

Al respecto del monumento, Rogelio Sánchez Mena dice: "En el Cerro del cubilete, municipio de Silao, Guanajuato se encuentra el Santuario dedicado a Cristo Rey, concebido en total concepto Déco desde la planta arquitectónica, alzados, interiores y acabados, todo

\footnotetext{
${ }^{177}$ En el interior de monumento hay una inscripción que dice que hubo una remodelación en 1976 y una restauración de los murales de 1978 a 1980. Aparecen los siguientes nombres: Restauradores: Rodolfo P. Rojas, Armando Soto C; ayudante, Guadalupe Álvarez A. Ayudantes: Alejandro Muñoz V., Vicente Solano C., Gloria Olvera C., Fidel Guzmán Soto, Gustavo Gabriel de la C., Juan Guzmán Soto. Actualmente, agosto de 2014, los frescos se encuentran bastante descuidados y maltratados.
} 
con el característico simbolismo religioso, hasta la misma concepción del monumento escultórico que se encuentra sobre él". ${ }^{178}$

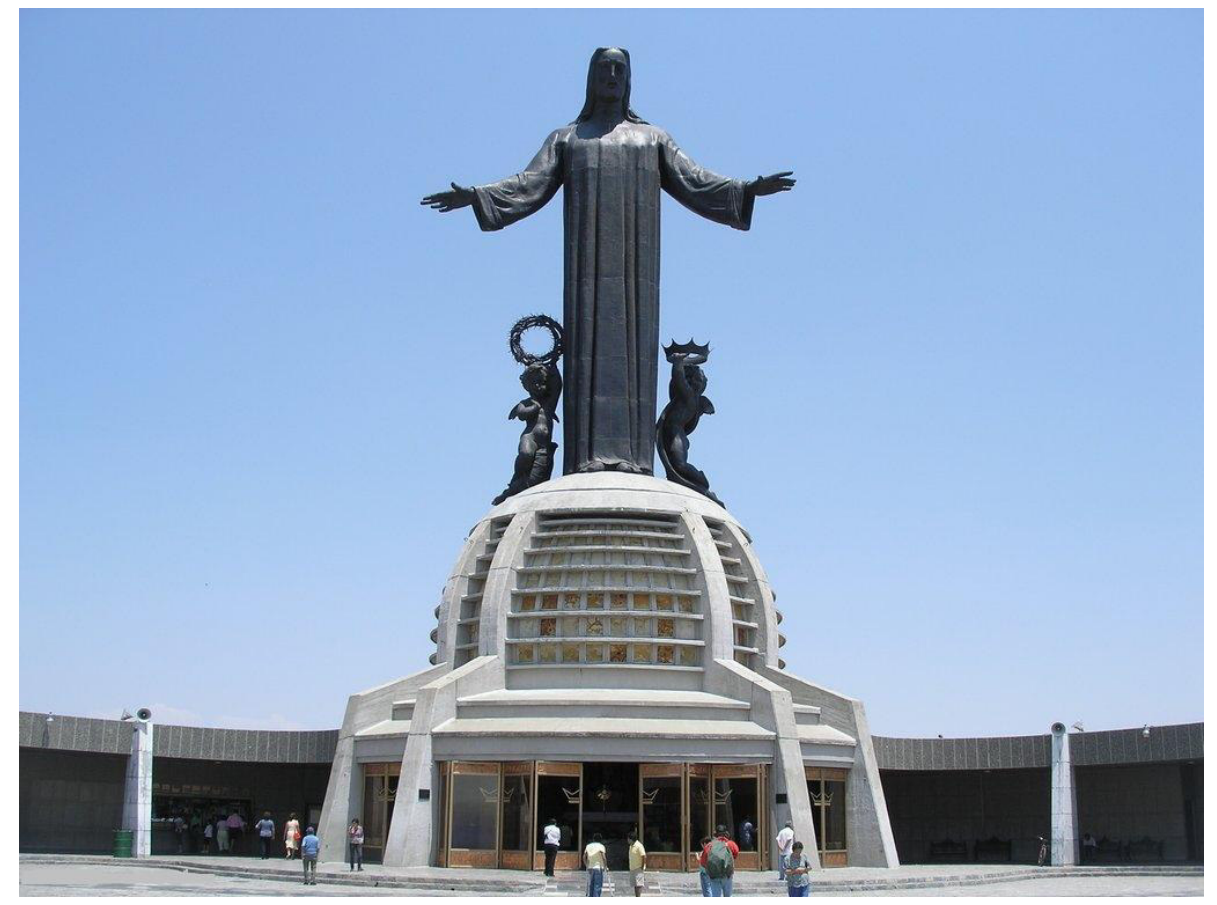

Fidias Elizondo, Cristo Rey, Cerro del Cubilete, Silao, Guanajuato, 1946-1949. ${ }^{179}$

Otra escultura que ha traspasado sus fronteras y que sobre todo después de las exposición sobre Art Déco del Museo Nacional del Arte que la difundió al exponerse una fotografía, es Las Plañideras también del escultor Guillermo Ruiz. Fue realizada en 1932 en cantera de la región y se ubica en el costado exterior poniente de la Catedral en la ciudad de Morelia. Esta trabajada en dos grandes bloques que se unen a la altura de la cintura. Dos mujeres de frente y con la cabeza de perfil y levemente hacia abajo, dejan caer el pelo hacia adelante, el cual les cubre el rostro del que solo se aprecia una tenue línea de la boca. Los brazos cruzados de la plañidera de la derecha forman dos ángulos agudos, mientras que la de la izquierda, uno de sus brazos forma un ángulo aproximadamente recto y el otro pasa por detrás de la dama acompañante para envolverla. Ataviadas con vestido largo, el cuello

\footnotetext{
${ }^{178}$ Rogelio Sánchez Mena, El Art Decó en León, Guanajuato, México, D.F., Instituto Nacional de Antropología e Historia, 1995, p. 41.

179 Zona Turística, "Cerro del Cubilete”, http://www.zonaturistica.com/tips-en/281/cerro-del-cubilete-guanajuato.html
} 
redondo se marca con una banda y luego a la altura de la cintura caen pliegues rectos y una sobre tela recortada oblicuamente va formando zigzags.

El hecho de el escultor haya utilizado la cantera de la región es porque él fomentaba el uso de la talla directa de las piedras de los lugares donde se erigieran los monumentos para estar en sintonía con la arquitectura, tal como es el caso de Las Plañideras que armonizan con la Catedral moreliana. Ruiz se destacó como un innovador de la escultura mexicana a su regreso de Europa y "Sus elegantes y lánguidas formas contrastan con la sensualidad del material y la expresión modernista", ${ }^{180}$ palabras del crítico e historiador del arte Jorge Alberto Manrique (1936) que se aplican cabalmente en Las Plañideras, obra estructurada desde un rectángulo, del cual se van acompasando las formas geométricas curvas, rectas, angulares, triangulares, cuadradas y rectangulares, dando por resultado una composición de tipo Art Déco Zigzag.
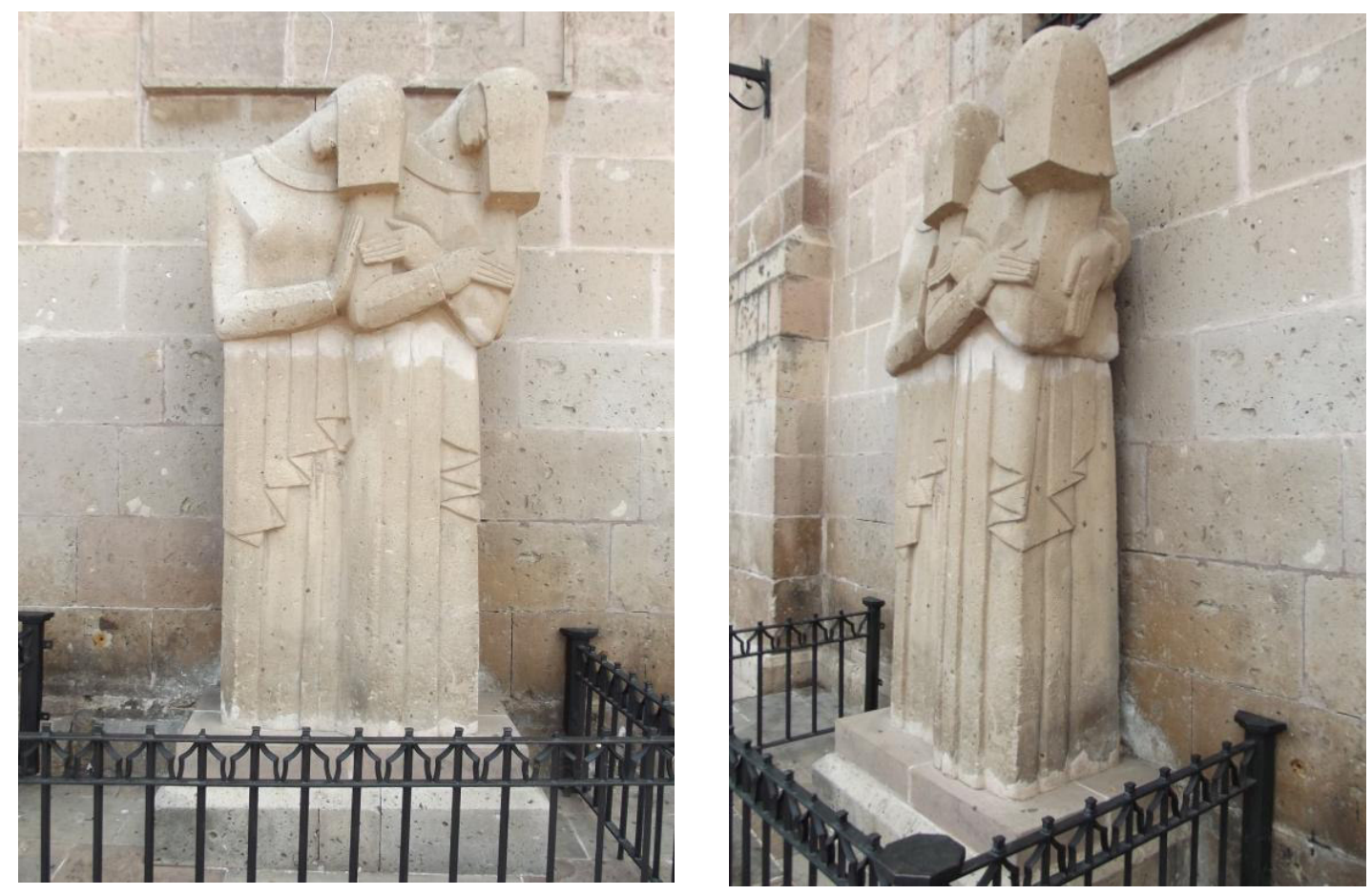

Guillermo Ruiz, Las Plañideras, Morelia, Michoacán, 1932.

\footnotetext{
${ }^{180}$ Jorge Alberto Manrique, “Tres décadas en la escultura 1920-1950”, en: Magdalena Zavala y Alejandrina Escudero, Escultura Mexicana. de la Academia a la instalación, México, INBA, Landucci Editores, 2001, p. 112.
} 
Una escultura que es poco conocida, pese a estar colocada en un lugar bastante transitado y turístico es el Monumento a la Nao de China, ubicada en la Plaza de la Quebrada en el puerto de Acapulco. Fue realizada por Manuel Centurión en 1936 con cemento, varilla y marmolina. Tiene una base rectangular y lo que es en sí la escultura se compone de un prisma rectangular recortado oblicuamente a tres cuartas partes de su altura, para terminar con otro prisma de la misma forma pero más pequeño. En la parte baja unas ondas en forma de zigzag parodian el mar; del lado izquierdo de la escultura está representada la Nao de China en pleno viaje, con el movimiento de las olas representadas por medio de cuatro pequeñas volutas en la proa y dos de mayor tamaño en la popa, más las velas curvas que simbolizan el empuje del viento. En el lado derecho una robusta sirena de rasgos asiáticos en referencia a los pobladores de Filipinas, que era el destino de la nao, con el pelo en movimiento, pero a la vez rígido como se representa en el Art Déco, toca un caracol sostenido con la mano derecha y con la izquierda carga un collar; va montada sobre un pez y grandes volutas figuran los embates del mar.
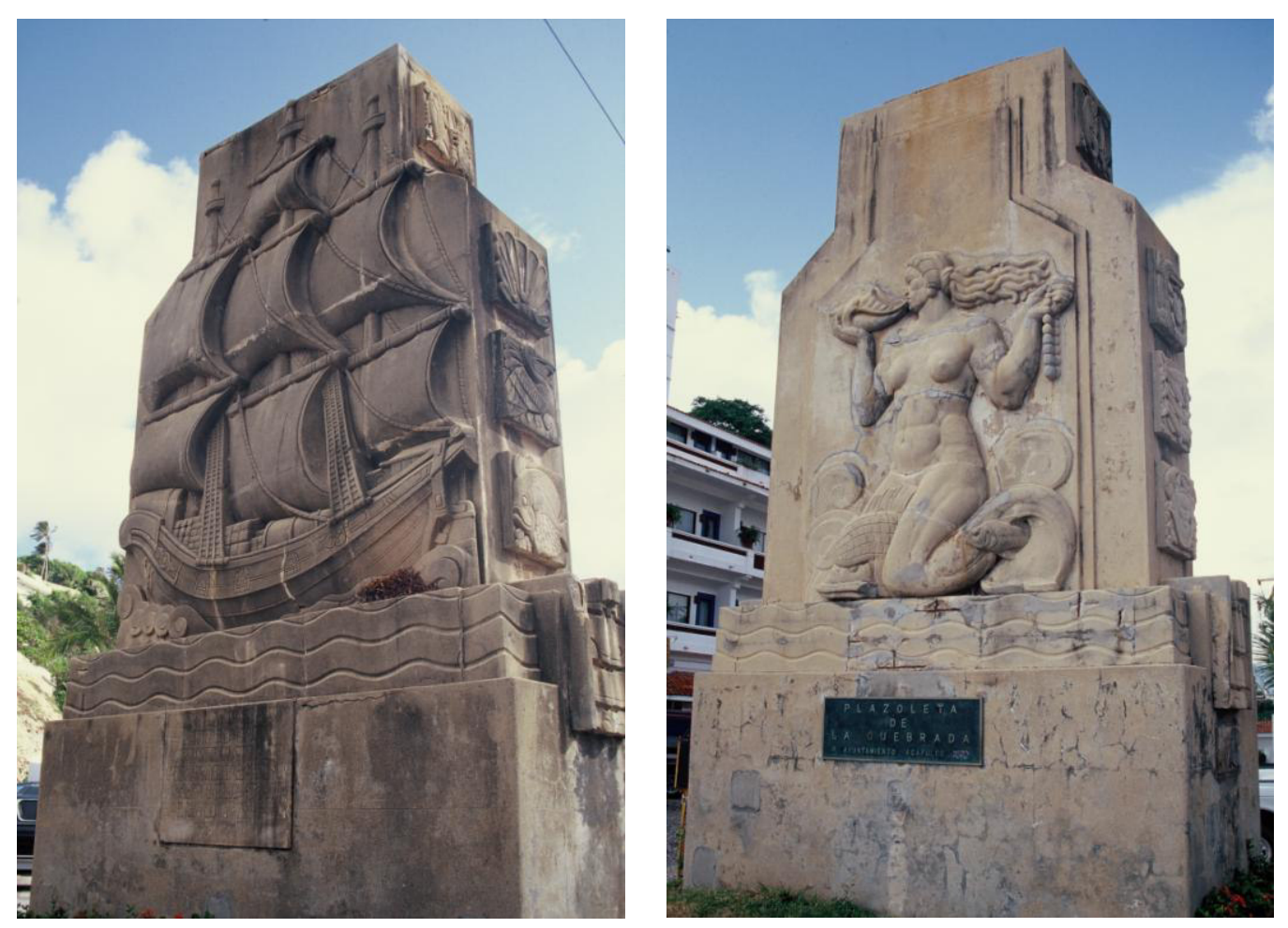

Manuel Centurión, Monumento a la Nao de China. Lado izquierdo de la escultura la Nao de China y lado derecho la imagen de la sirena. Acapulco, 1936. 

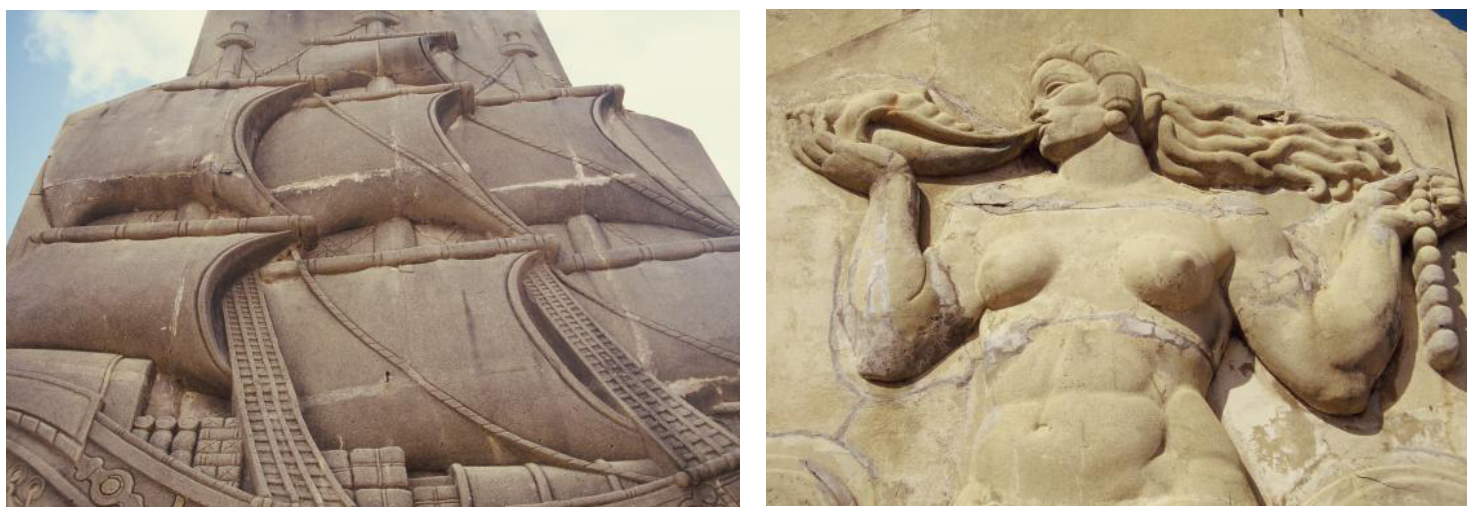

Manuel Centurión, detalles de la Nao y de la sirena del Monumento a la Nao de China. Acapulco, 1936.

En los lomos lleva figuras marinas: en el frontal primero un pez y un cangrejo, luego una concha de mar, un pelícano, otro pez y finalmente una abstracción de la cara de Tláloc, dios de la lluvia de los mexicas, con lo cual se integra el nacionalismo indigenista con el hispanismo de la Nao; en el postrero inicia con dos peces, para continuar con un lagarta envolviendo a una tortuga, después tres peces, un cangrejo, el mismo motivo indigenista de Tláloc y finalmente una placa casi ilegible con el nombre de Manuel Centurión. Es curioso que este magnífico monumento diseñado bajo una estética de componentes geométricos, encuadrados, formas angulosas, todo bajo una estética del Art Déco Zigzag no sea mencionado en los libros dedicados a las creaciones plásticas de la época y se encuentre en un deplorable estado de conservación, además de tener una placa la firma de Manuel Centurión. Hay otra placa que está colocada abajo del la nao en donde se dan los datos de la inauguración de la escultura:

"ESTE MONUMENTO CONMEMORATIVO

AL ARRIBO DE LA NAO DE CHINA A

ACAPULCO FUE CONSTRUIDO SIENDO

GOBERNADOR DEL EDO. EL GRAL Y LIC.

DN. JOSE INOCENTE LUGO Y PTE. MUPAL.

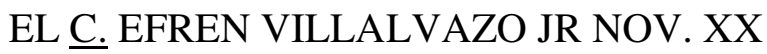

MCMXXXVI." 

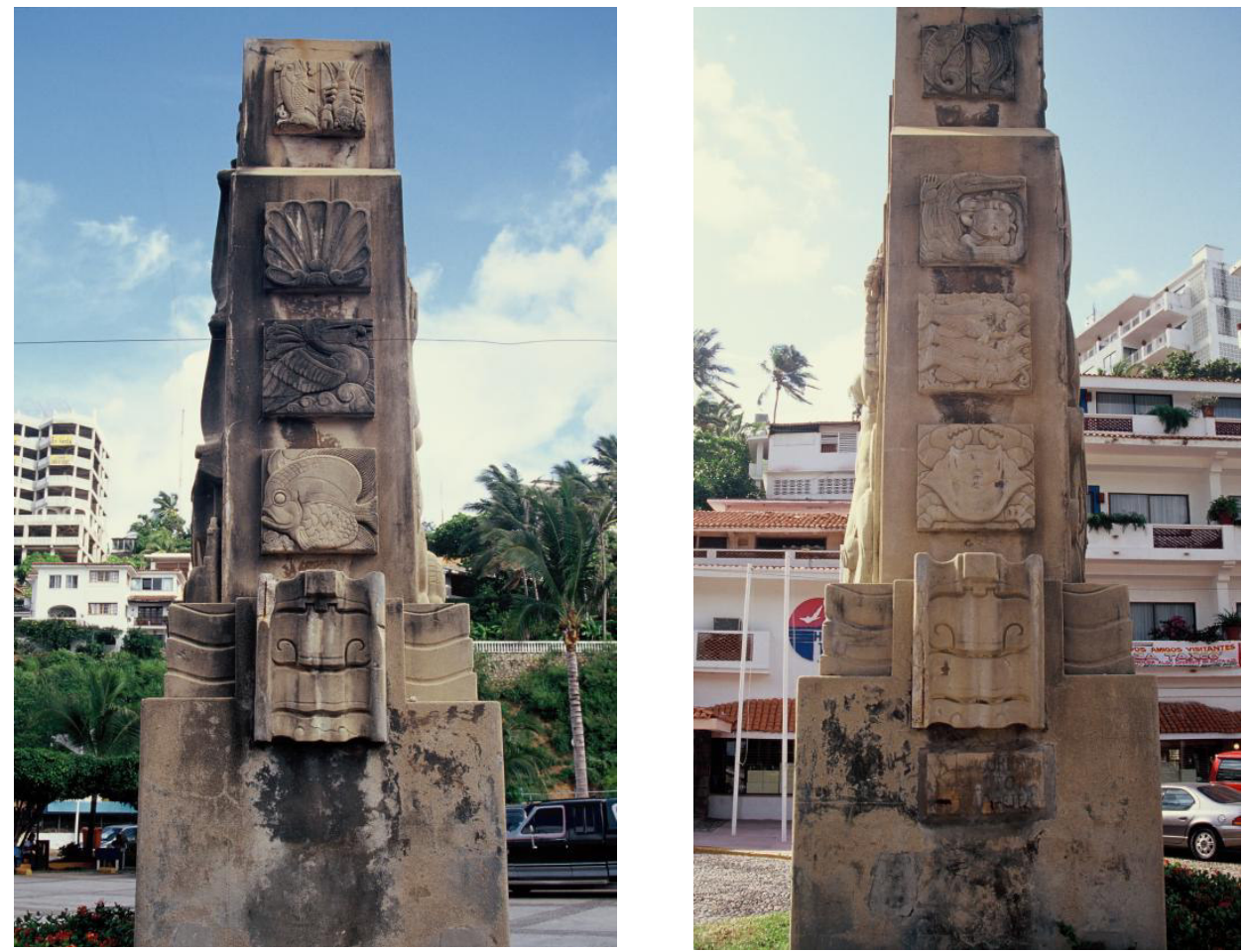

Manuel Centurión, parte frontal y posterior del Monumento a la Nao de China, Acabulco. 1936.
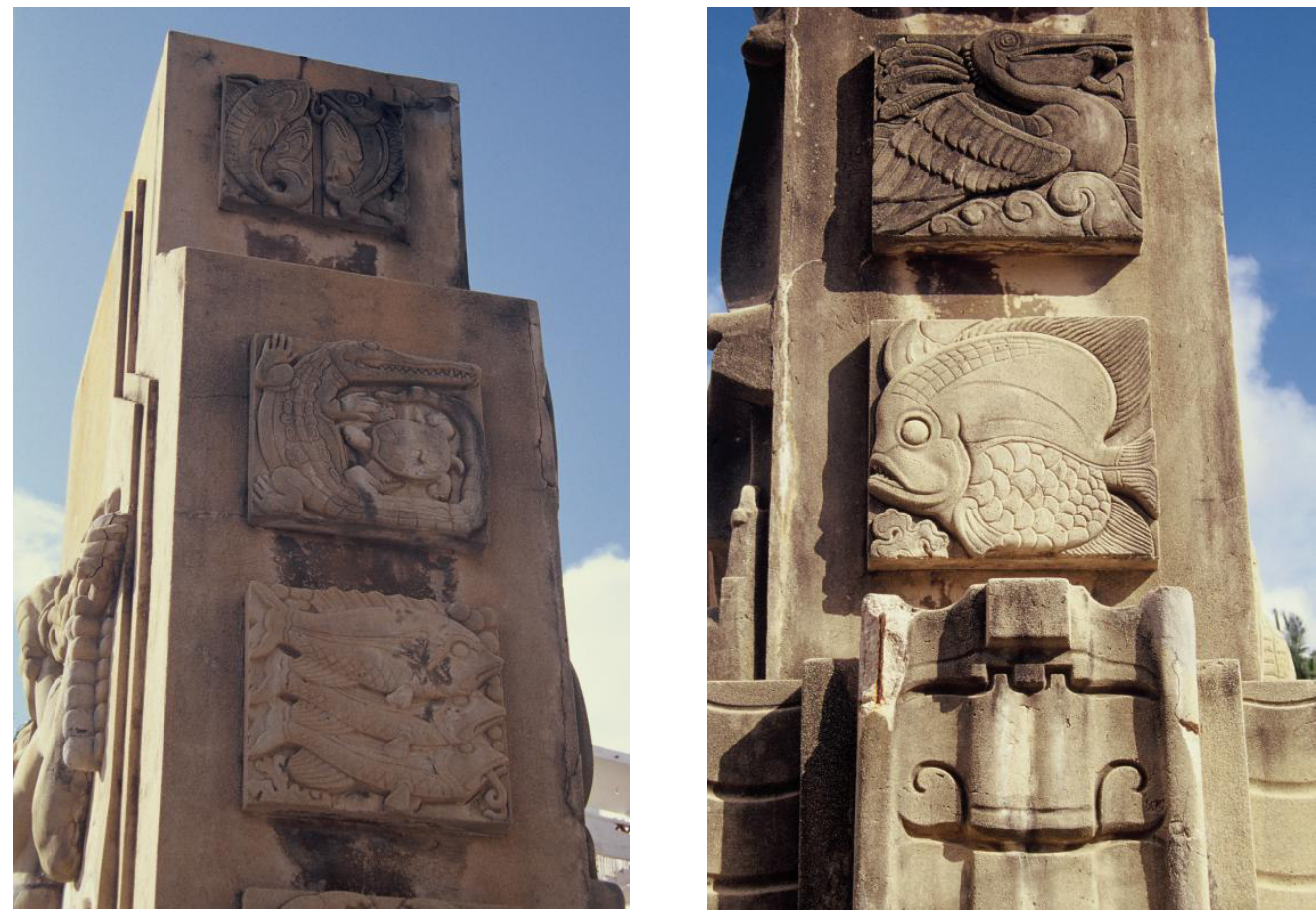

Manuel Centurión, Monumento a la Nao de China. Imagen izquierda, detalles de la parte frontal con el par de peces, el lagarto y la tortuga y los tres peces; imagen derecha, detalles de la parte posterior con el pelícano, el pez y la abstracción de Tláloc, Acapulco, 1936. 


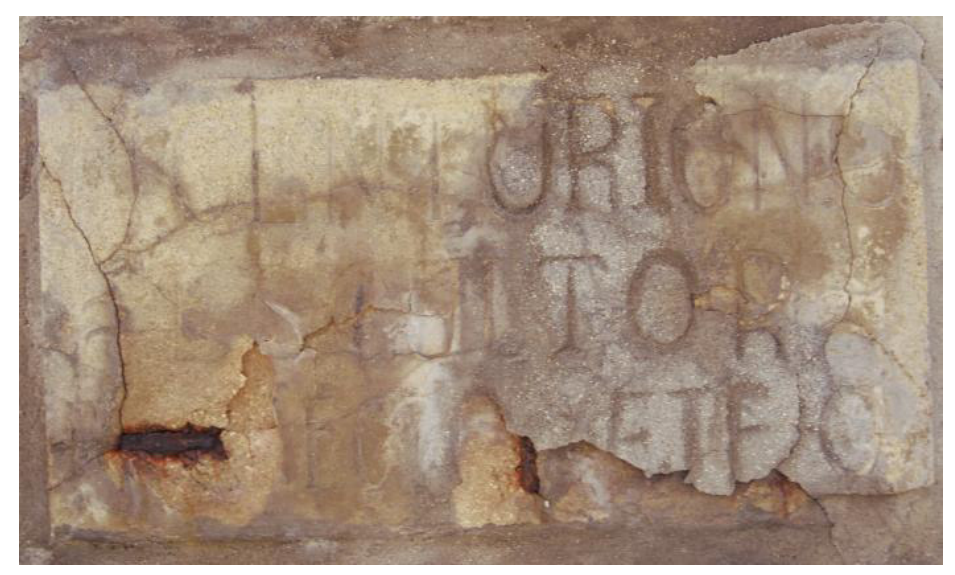

Placa con la firma casi ilegible de Manuel Centurión en la parte posterior del Monumento a la Nao de China.

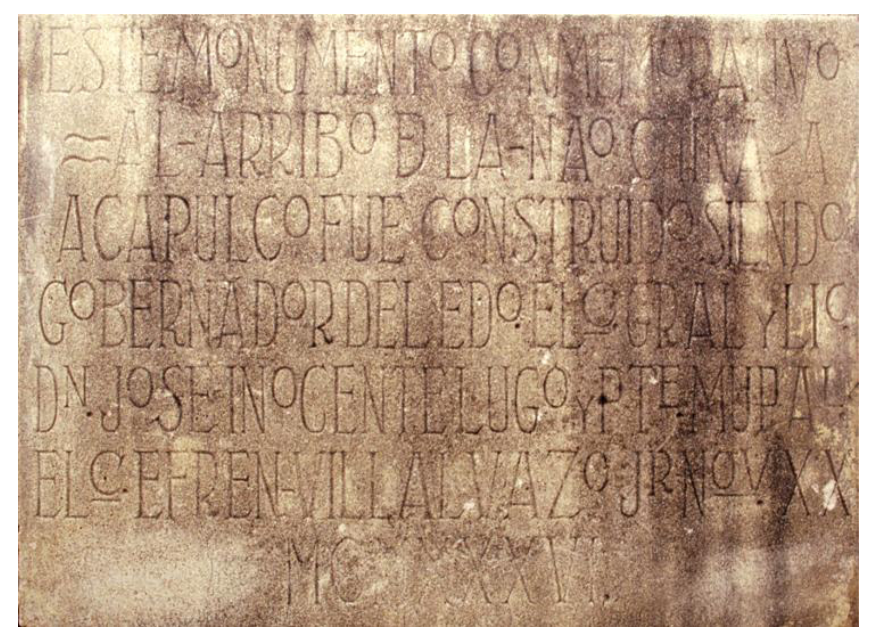

Placa conmemorativa del Monumento a la Nao de China con los nombres del Gobernador y Presidente Municipal de Acapulco, así como la fecha, colocada debajo de la nao.

Del segundo tipo de esculturas, las realizadas en relieves, están como unas de las más logradas las decoraciones de la fachada del también ya referido edificio de la Asociación Cristiana Femenina. Trabajos del arquitecto y escultor J.L. Cordero, ${ }^{181}$ planos en su composición, a manera de esgrafiados, realizados en cemento en 1933, representan a mujeres en alegorías a saberes y en acciones deportivas con poses retorcidas, volátiles,

${ }^{181}$ Enrique X., de Anda, La arquitectura de la Revolución Mexicana, México, Op. Cit., p. 145, dice sobre J.L. Cordero "el arquitecto y escultor", además como ya habíamos mencionado al comentar el edificio en páginas anteriores, la firma aparece en los paneles mencionados cuando describimos el edificio y en la placa con los nombres de los constructores. 
dinámicas. El trato de las líneas que conforman las figuras es suave, pero a la vez las líneas se convierten en perfiles que transmiten la idea de movimiento y resaltan la geometrización de las figuras humanas, así como de las decoraciones fitomorfas que acompañan a algunos de los paneles, exponiendo unos relieves de alta calidad de Art Déco Zigzag.
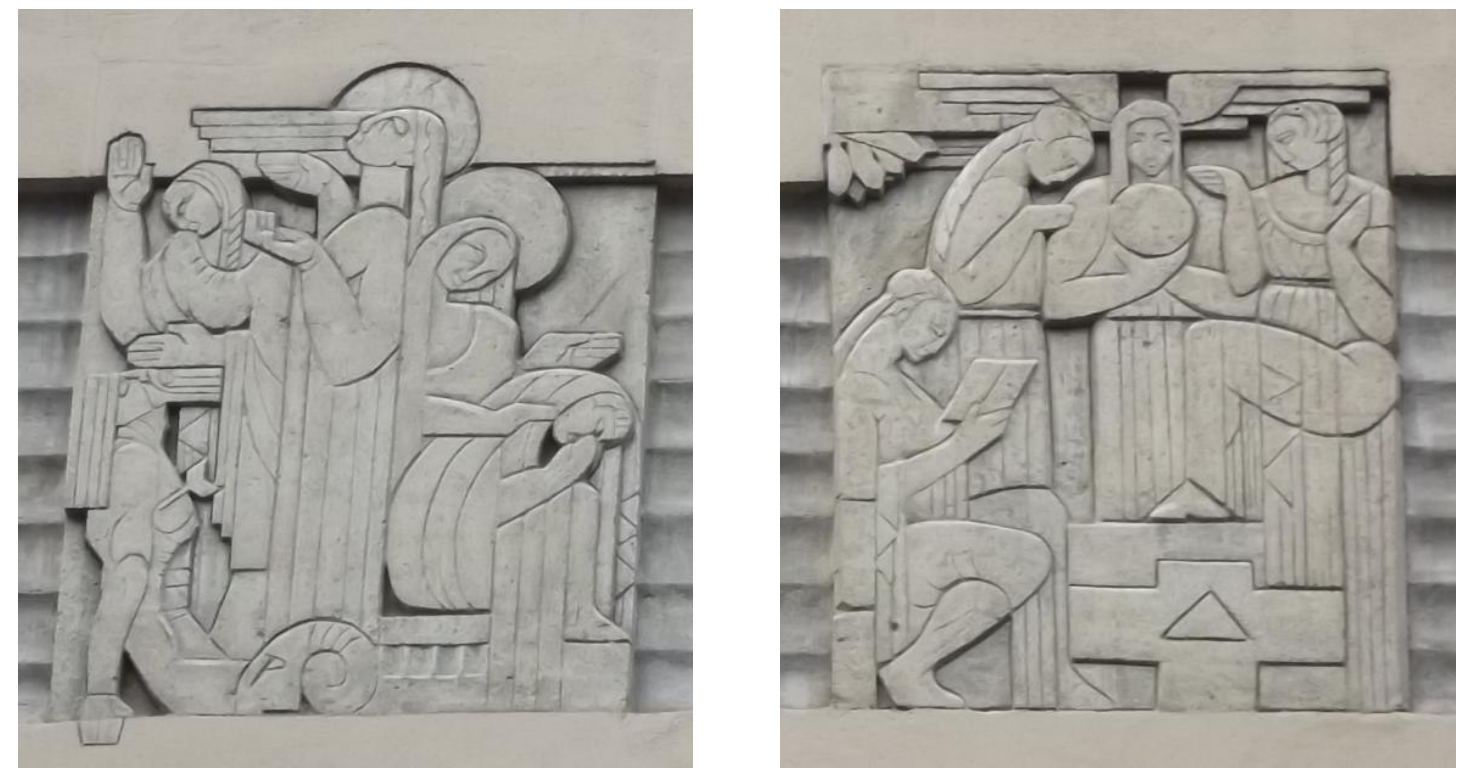

J.L. Cordero, relieves sobre la Calle Morelos alusivos a La Oración y El Estudio Femenino, Asociación Cristiana Femenina, México, D.F., 1933.
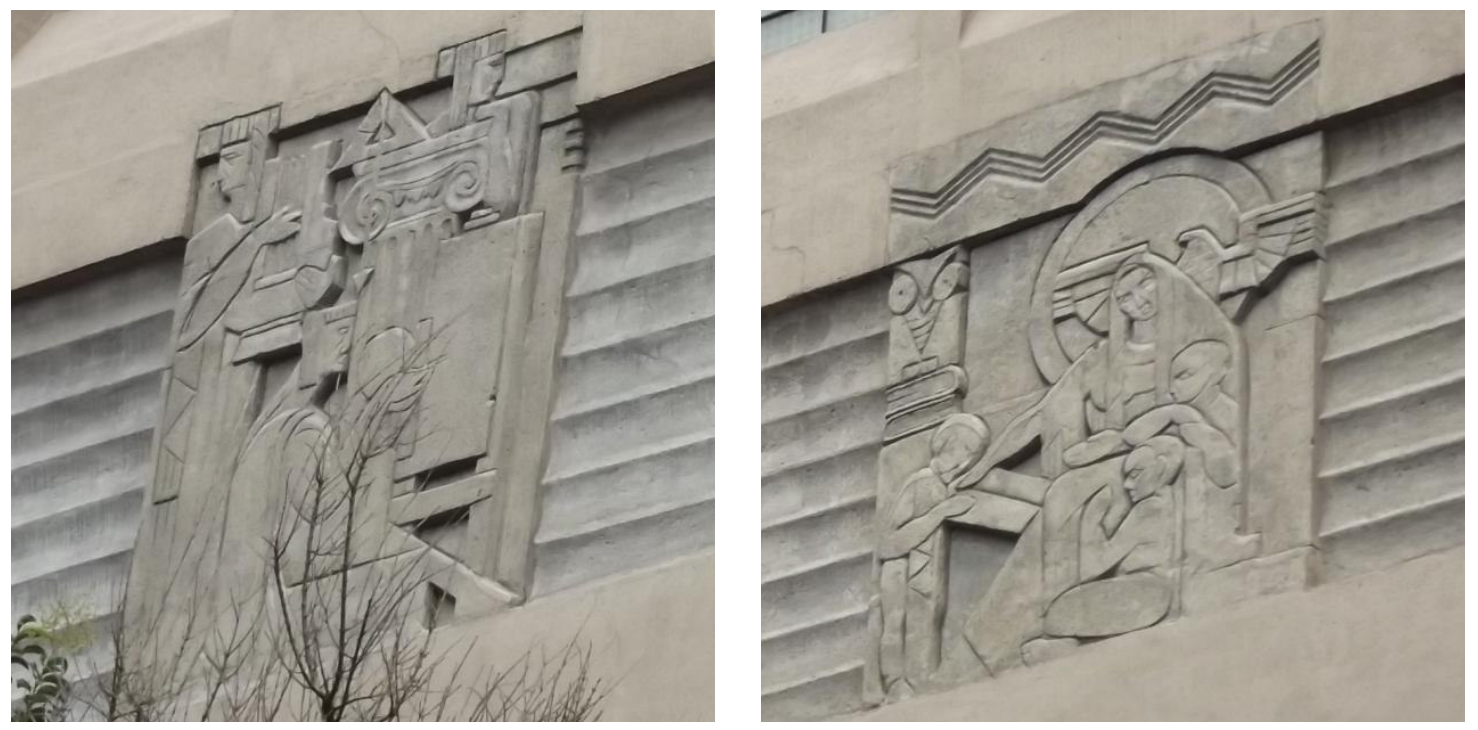

J.L. Cordero, relieves sobre la Calle Humboldt: Las Bellas Artes y La Educación. Asociación Cristiana Femenina, México, D.F., 1933. 

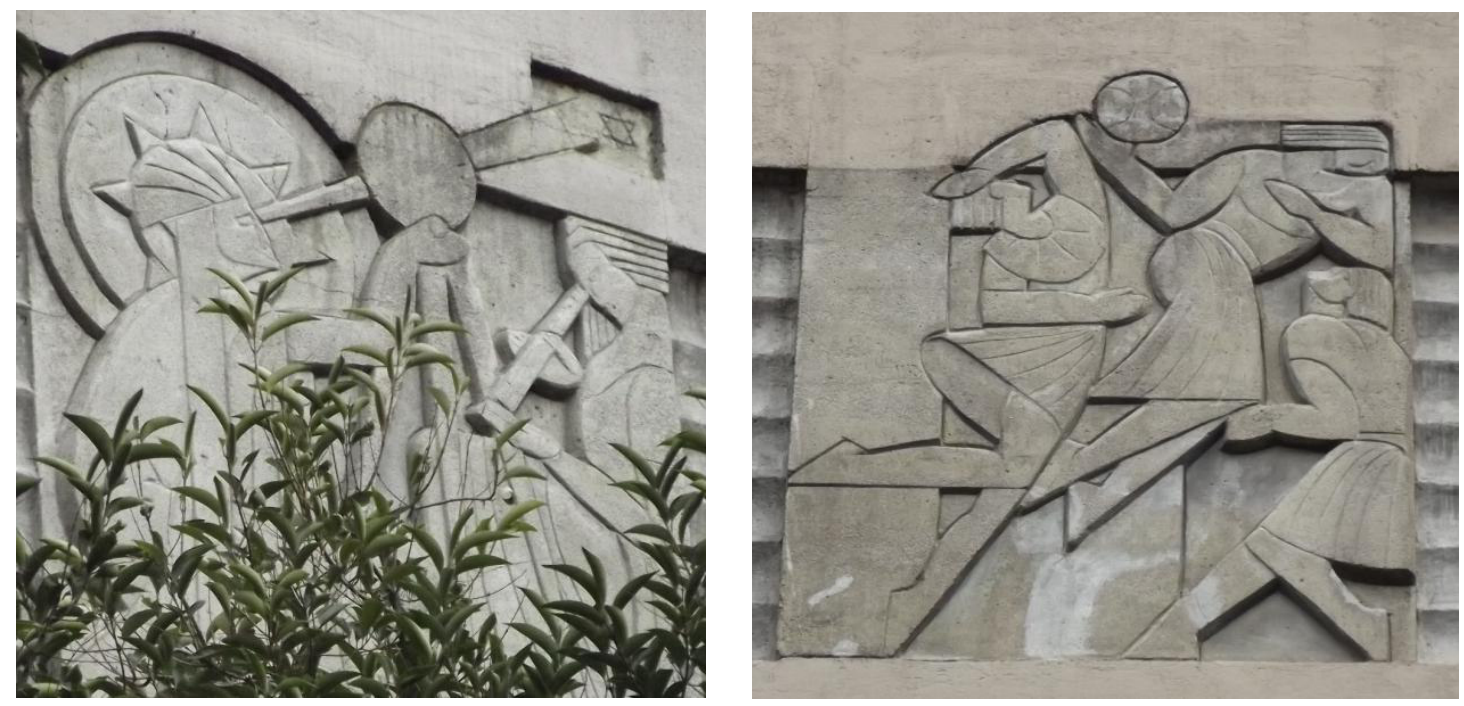

J.L. Cordero, relieves sobre la Calle Humboldt: La Astronomía y El Deporte. Asociación Cristiana Femenina, México, D.F., 1933.

Del tercer tipo de esculturas, las de pequeño formato, destacan las obras del escultor Rómulo Rozo (1899-1964), de origen colombiano, quien se estableció en México a partir de 1931, cuando llegó como agregado cultural de la embajada de Colombia. Había estudiado en Madrid y en París, en esta última en las Academias Colarossi y Julián, instituciones vinculadas con los viajes de los artistas rusos patrocinados por Diaghilev. Una pieza de capital importancia para el Art Déco en México es El Pensamiento de 1931, trabajada en yeso patinado a la encáustica, con medidas de 63 x 42 x 59 cm., Expuesta por primera vez en la Biblioteca Nacional de México, causó gran admiración por captar a un hombre del campo, con su traje de manta, huaraches, sombrero puntiagudo; su pose es de recogimiento, sentado en el piso, con las piernas puesta en posición de "V" invertida, la cabeza escondida dentro de los brazos, es una amalgama de elementos geométricos: la base un rectángulo, las piernas un triángulo, los brazos un cuadrado, el sombrero una circunferencia y la copa otro triángulo. La pieza original de $60 \mathrm{~cm}$., de altura y tallada en piedra se conserva en el Museo de Arte de la Paz, en Bolivia. Otra pieza trabajada en yeso pintado a la encáustica se conserva en una colección particular y fue expuesta en la muestra del MUNAL de 1998. Referente iconográfico del campesino mexicano, desafortunadamente esta escultura fue plagiada y reproducida hasta el cansancio, agregándole una botella de tequila, o un cactus en la espalda, con lo que ha servido de burla 
de los mexicanos en el medio de la caricatura y el cine hollywoodense; también es ya todo un "mexican curious" que se sigue vendiendo entre el turismo extranjero, anexándole la función de librero, cenicero, pisapapeles o simplemente de objeto decorativo. Considerada su obra como mexicana por su estancia en el país, para Esqueda "Rozo fue quien produjo la mayor cantidad de esculturas dentro del estilo art deco". ${ }^{182}$

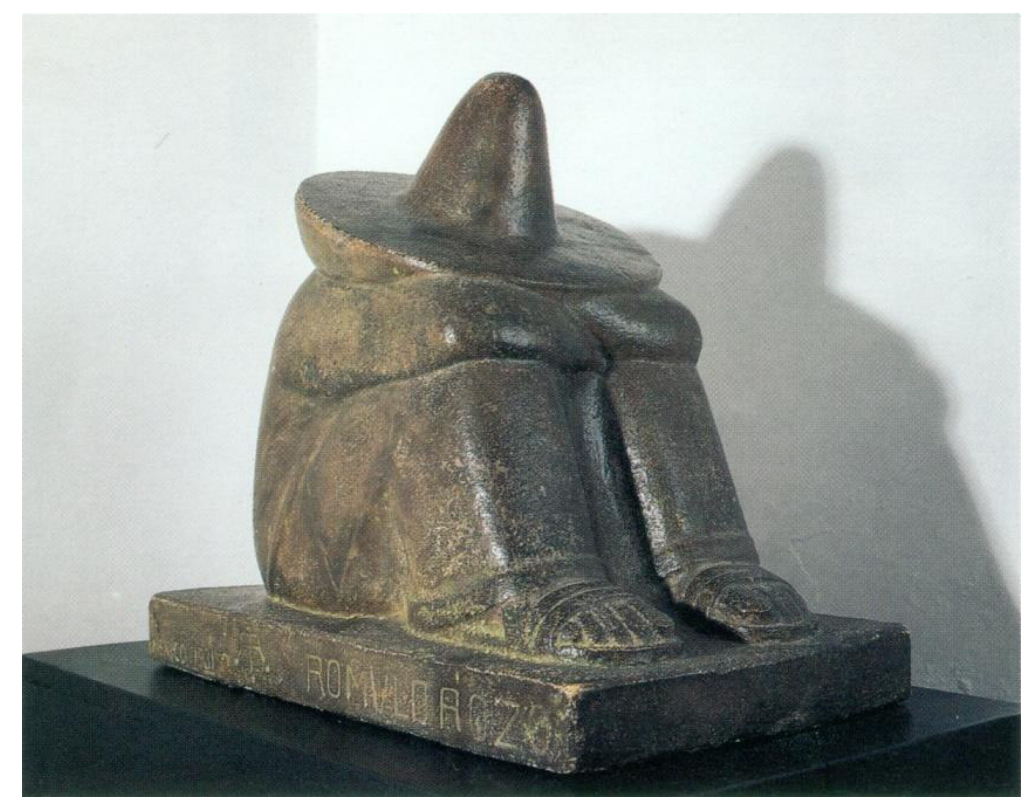

Rómulo Rozo, El Pensamiento, 1931, colección particular. ${ }^{183}$

Otro trabajo de Rozo es un relieve dedicado al trabajo de la fundición que lleva por título Blindador-soldador, fue realizado en yeso patinado con medidas de 50.7 x $41 \mathrm{~cm}$., data del año de 1935 y se conserva en una colección particular. Se representa en un relieve rectangular a dos obreros: el del lado izquierdo con postura frontal, la cabeza girada hacia la izquierda y con el torso desnudo, sostiene unas tenazas y un pedazo de hierro; el de la derecha, posicionado de perfil, suelda con el uso de la careta y las chispas forman una irradiación circular. La complexión robusta de los personajes, sus poses rigurosas, las formas anatómicas compuestas por rectángulos redondeados o la interposición de

\footnotetext{
${ }^{182}$ Xavier Esqueda, Op. Cit, p. 106.

${ }^{183}$ Catálogo de la exposición Art Déco. Un país nacionalista, un México cosmopolita, Op. Cit., p. 131.
} 
rectángulos en la careta y la linealidad de los cables, forman una obra de Art Déco con una temática muy característica de enaltecer el trabajo obrero, resaltando los componentes geométricos como los ángulos del diafragma y las tenazas del blindador, o el ángulo del aparato de soldar del soldador.

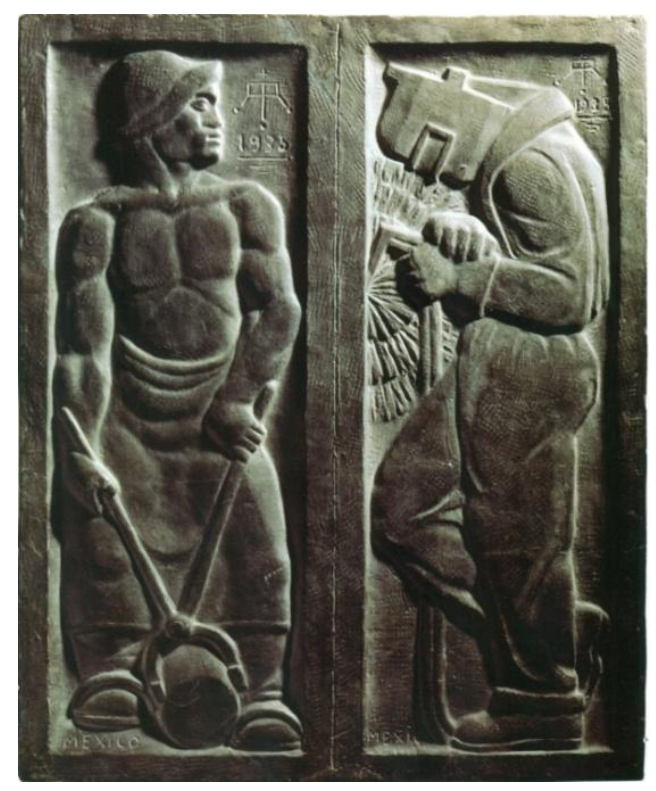

Rómulo Rozo, Soldador-blindador, 1935, Colección particular. ${ }^{184}$

Luis Ortiz Monasterio (1906-1990), escultor que vivió en los Estados Unidos y donde tuvo diversas exposiciones, en los años cuarenta en adelante se destacó por obras monumentales como el Monumento a los Defensores de Puebla, 1943, y el Monumento a la Madre, 1949. En la en la década de los años sesenta se dedicó también al trabajo en pequeño formato, sin embargo, desde temprana época ya trabajaba obras de caballete y cuando fue profesor de escultura en la Secretaría de Educación Pública en los años treinta, trabajó en bronce una pequeña escultura de dedicada al Maestro, con medidas de 59 x32 x $16 \mathrm{~cm}$., que se guarda en una colección particular. Se trata de un homenaje al mentor en su labor de la enseñanza. El pelo se compone de una demarcación de la siluete de un corte de casquete; la nariz es un prisma trapezoidal y tanto ojos como boca solamente está delineados y con volumen. Con líneas curvas y con superficies sobrepuestas se viste al

\footnotetext{
${ }^{184}$ Enrique Franco y Agustín Arteaga, Op. Cit., p. 178.
} 
profesor con traje y los cuellos de la camisa y corbata son formas angulares y piramidales. La mano derecha abierta y el brazo en forma de ángulo, lo mismo que la izquierda en la cual carga un libro. Las piernas juntas y la sugestiva pose del personaje en actitud de impartir clases se transmite con poca anatomía y mucha expresividad. La composición total de este bronce delata la estética de esos años de constituir la figura con formas geométricas y poca figuración, dentro de una de las formas de componer efigies Art Déco.

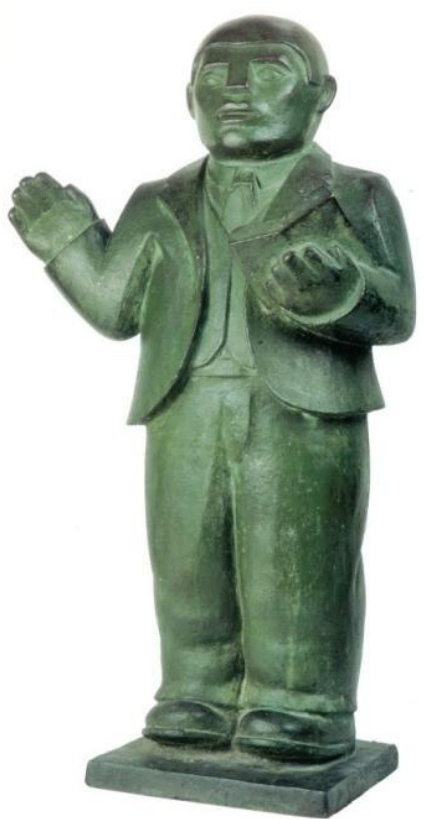

Luis Ortiz Monasterio, Maestro, ca. 1935, colección particular. ${ }^{185}$

Ernesto Tamariz Galicia (1904-1988) fue un prolífero escultor que realizó principalmente obras de gran tamaño para monumentos, utilizando el mármol, la cantera y el bronce. Participó en el concurso para los grupos escultóricos del Monumento a la Revolución, obras que como ya mencionamos fueron talladas por Oliverio Martínez, con quien se asoció y así Tamariz fue su principal colaborador. Principalmente sus obras son realistas y monumentales, aunque eso no le impidió incursionar en el arte abstracto, aparte de experimentar y trabajar diversos lenguajes artísticos. Dentro del Art Déco tiene varias obras como el Monumento a los fundadores de la ciudad de Puebla del año 1928, aunque su obra más conocida es el Monumento a los Niños Héroes de 1951 en el Bosque de

\footnotetext{
185 Ibídem, p. 176.
} 
Chapultepec. Una obra que destaca los elementos de movimiento y de encuadre dentro de un espacio rectangular es Revolución, proyecto de monumento a Venustiano Carranza, esculpido en mármol en 1945, con las medidas de 80 x 128 × 26, que se resguarda en la colección de la familia del artista. Al centro del panel, un brioso corcel levanta las patas delanteras, arremetiendo contra dos hombres con el torso desnudo, de los cuales uno cae al piso y el otro agachando la cabeza intenta detener al equino con el brazo izquierdo. Una mujer semidesnuda monta al caballo, que con la fuerzas del relinche y la velocidad del animal, el pelo se prolonga hacia atrás y deja caer el brazo izquierdo. Un hombre detrás del corcel sostiene un libro y una espada que encaja en un hombre tirado boca abajo: es el símbolo del hombre revolucionario, ilustrado, acabando con la tiranía. Todo es caos y cinetismo, conformado por las figuras cuya anatomía corpulenta es briosa, mientras que la crin y la cola del cuadrúpedo son líneas curvas de trazo firme, lo mismo que los rellenos de los espacios entre las figuras. Exaltada composición que reúne los elementos de las creaciones de la época del Déco Streamline, en las que la figura humana y animal son tratadas con anatomías musculosas, enérgicas y colosales.

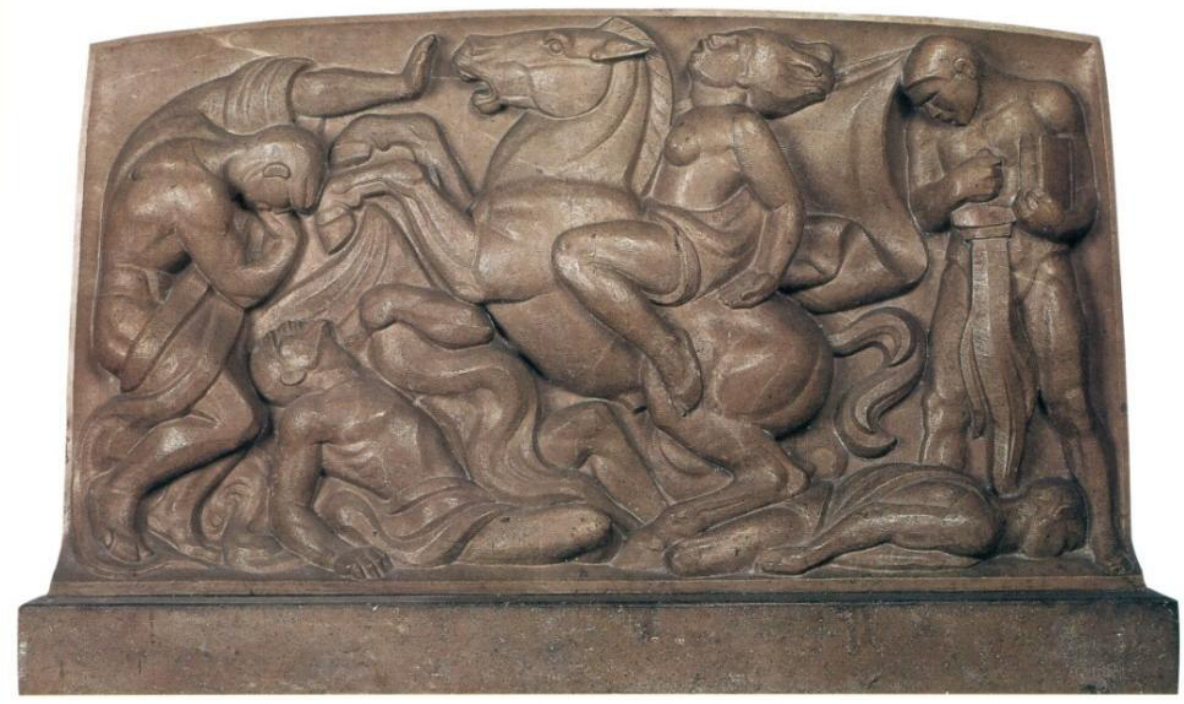

Ernesto Tamariz, Revolución monumento a Venustiano Carranza, 1945, colección particular. ${ }^{186}$

\footnotetext{
${ }^{186}$ Catálogo de la exposición Art Déco. Un país nacionalista. Un México cosmopolita, Op. Cit., p. 139.
} 


\subsubsection{Pintores mexicanos dentro del Art Déco}

La pintura mexicana dentro del Art Déco como tal no ha sido formalmente estudiada. Esqueda en su libro El Art Deco. Retrato de una época cita a varios artistas que por haber integrado elementos característicos del estilo cabe mencionarlos como creadores de obra Déco, así como lo que trabajaron la gráfica. De Anda en el catálogo de la exposición del MUNAL da características más específicas sobre lo que podría considerarse como una pintura Art Déco, ejemplificándolo con los nombres de artistas y sus obras; lo mismo sucede con la gráfica de la que explica sus rasgos distintivos dentro de los años correspondientes al Art Déco y sus principales representantes. Así pues, nos basaremos en las propuestas de Enrique X. de Anda para este tema sobre la pintura. ${ }^{187}$

Los triunfos de los ideales revolucionarios que son las luchas obrero-campesinas se plasmarán en un nuevo arte que busca a la vez la modernización de la plástica. Lo popular, el folclorismo, lo indígena (especialmente el mundo prehispánico) serán, entre otros, temas recurrentes que buscan enaltecer una nacionalidad que no ha encontrado su cimentación. A la par, el maquinismo es una cuestión que se tratará frecuentemente, pues la era de la máquina con toda su carga de fuerza, dinamismo, novedad, se aúna a la directriz imperante del Art Déco: la geometría. De este modo, las luchas obrero-campesinas se representan con los trabajos maquinarios de las industrias y con las faenas agrícolas. El indio, el mestizo, la piel morena, nervuda, atlética, crea en muchas ocasiones una representación ilusoria de los tipos mexicanos, porque en la realidad no son de esta manera, pero fueron concebidos así para fortalecer la palabra lucha en todos sus sentidos. Por esta razón es que consideramos, basados en Enrique X., de Anda, a algunos pintores dentro del Déco, ya que tomaron las influencias de las novedades estéticas europeas de esos años, las amalgamaron con los ideas postrevolucionarios y de la construcción del México moderno.

Los años del Déco van en relación con el desarrollo de la postrevolución en México como ya lo hemos mencionado. El fuerte impulso que se dio a la cultura con José Vasconcelos, en el caso de la pintura desarrolló a muchos artistas, pues había una demanda

\footnotetext{
${ }^{187}$ En el capítulo "La Identidad del Art Déco en México" del catálogo de la exposición Art Déco. Un país nacionalista, un México Cosmopolita, Enrique X., de Anda habla de "La pintura", dentro de "Folclor y prehispanismo" y en el subcapítulo "Maquinismo y fuerza de trabajo" incluye "Pintura e ilustración", pp. 6268.
} 
de obra de arte y un consumidor que las solicitaba. El circuito de producción, distribución y consumo de la pintura se daba entre una nueva clase social de intelectuales e incipientes empresarios que buscaban a los artistas para formar sus colecciones de "vanguardia". A la vez, el fortísimo apoyo gubernamental que recibió el movimiento muralista, hizo que la pintura tuviera una afanosa producción. Al mismo tiempo los grupos culturales y literarios como los Estridentistas y los Contemporáneos, ilustraban sus ediciones con gráficos, viñetas e imágenes de los pintores más destacados.

El Muralismo fue un promotor de lo nacional, ya que relata hechos históricos del pasado inmediato nacional, es decir, la Revolución Mexicana, o bien, alegorías al triunfo de la modernidad tecnológica y de los valores nacionales. Vasconcelos en un principio invitó a Diego Rivera (1886-1957) y a Roberto Montenegro (1885-1968) a decorar los muros del edificio de la Secretaría de Educación, dando así inicio al fuerte desarrollo del Muralismo que invadió los ámbitos de la pintura, hasta la década de los cincuenta. Estos dos artistas, junto con José Clemente Orozco (1883-1949) -“el de los pinceles violentos”, en palabras del escritor Juan José Arreola (1918-2001) y David Alfaro Siqueiros (18961974), ilustraron con sus obras, ya sea de una manera explicativa, crítica, alegórica o ideal, la historia de México, la Revolución, el pasado indígena y las manifestaciones populares, a la vez que trazaron las ambiciones patrióticas para un nuevo país.

Algunas obras de estos pintores, como Montenegro y Rivera, además de su nacionalismo temático, tienen una estética que las hace estar dentro del Art Déco, ya que en la composición llevan la geometricidad, tópicos de la modernidad, o bien, el tratamiento de las figuras humanas responde a las formas usadas en paneles decorativos de estilo Déco.

Roberto Montenegro es uno de los muralistas que más se inscribe dentro del Déco. En algunos de sus murales se percibe cómo las figuras humanas, los fondos angulosos, las composiciones geométricas, denotan el estilo Art Déco. Julieta Ortiz Gaitán al hablar de las tendencias estéticas de Montenegro dice que después de sus "vertientes, la modernista y la nacionalista, coexistirán durante algunos años hasta que se evidencian, en 1928, rasgos geométricos propios del Art-Déco, iniciándose así una tercera etapa definitoria". ${ }^{188}$ En el fresco del mural titulado La Fiesta de la Santa Cruz, 1923-1924, ubicado en el ExColegio

\footnotetext{
${ }^{188}$ Julieta Ortiz Gaitán, Op. Cit., p. 18.
} 
de San Pedro y San Pablo de la ciudad de México, encontramos que algunos de los personajes femeninos, portan faldas vestidos y rebozos con pliegues verticales, o los robustos hombres con fuertes rasgos anatómicos como el campesino y el obrero o los albañiles con el torso desnudo, y todo el entramado de vigas junto con la construcción son de un vigoroso geometrismo ya muy cercano al Art Déco; esta obra es un homenaje nacionalista a la reconstrucción del México postrevolucionario.

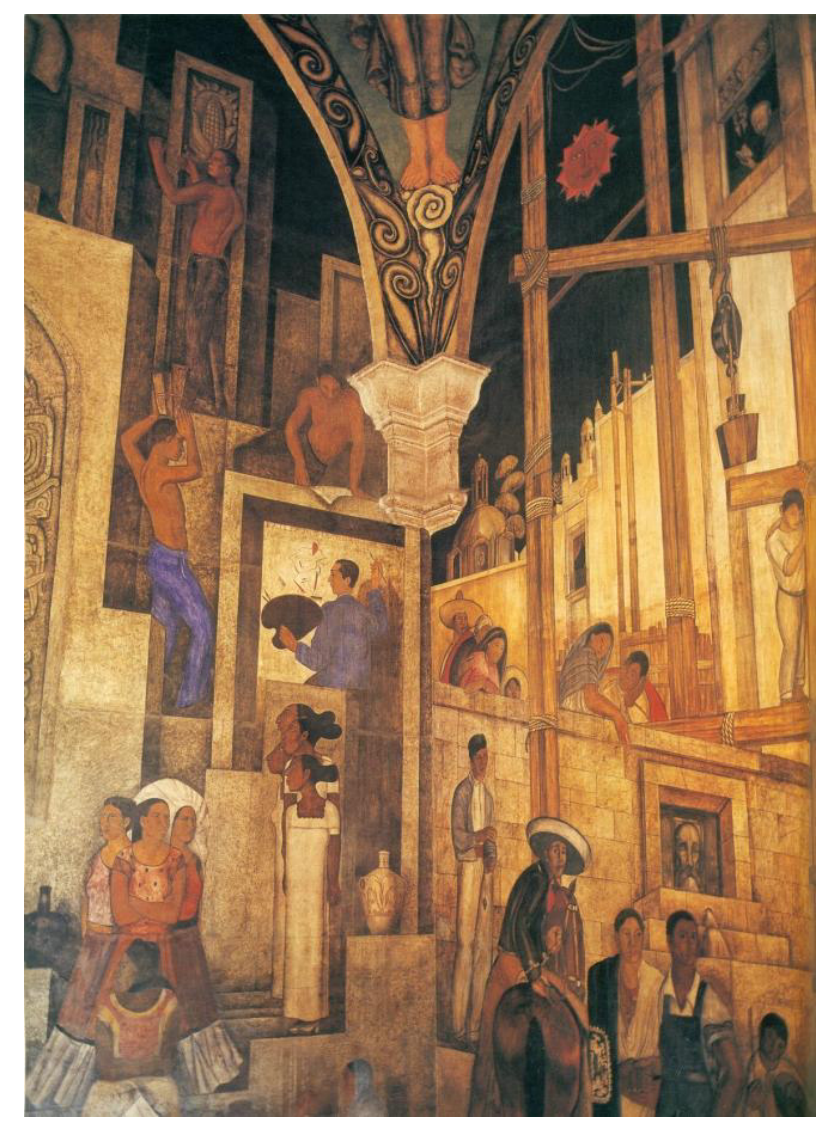

Roberto Montenegro, La Fiesta de la Santa Cruz, detalle, ExColegio de San Pedro y San Pablo, México, D.F., 1924. 189

En la Biblioteca Interamericana, antes iglesia del Exconvento de La Encarnación, está el fresco Iberoamérica de 1924, en el que la mujer central con los brazos abiertos y vestida con un peplo con caídas lineales en los pliegues y un corte moderno a la "Chanel", así como las mujeres que están debajo de los conquistadores y de los libertadores, cuyas

${ }^{189}$ Julieta Ortiz Gaitán, Op. Cit., p. 112d. 
faldas se curvan rígidamente hacia el centro, son claramente tratadas bajo la estética del Art Déco; se resalta la latinidad de la América hispana, reflejo de la ideología de Vasconcelos.

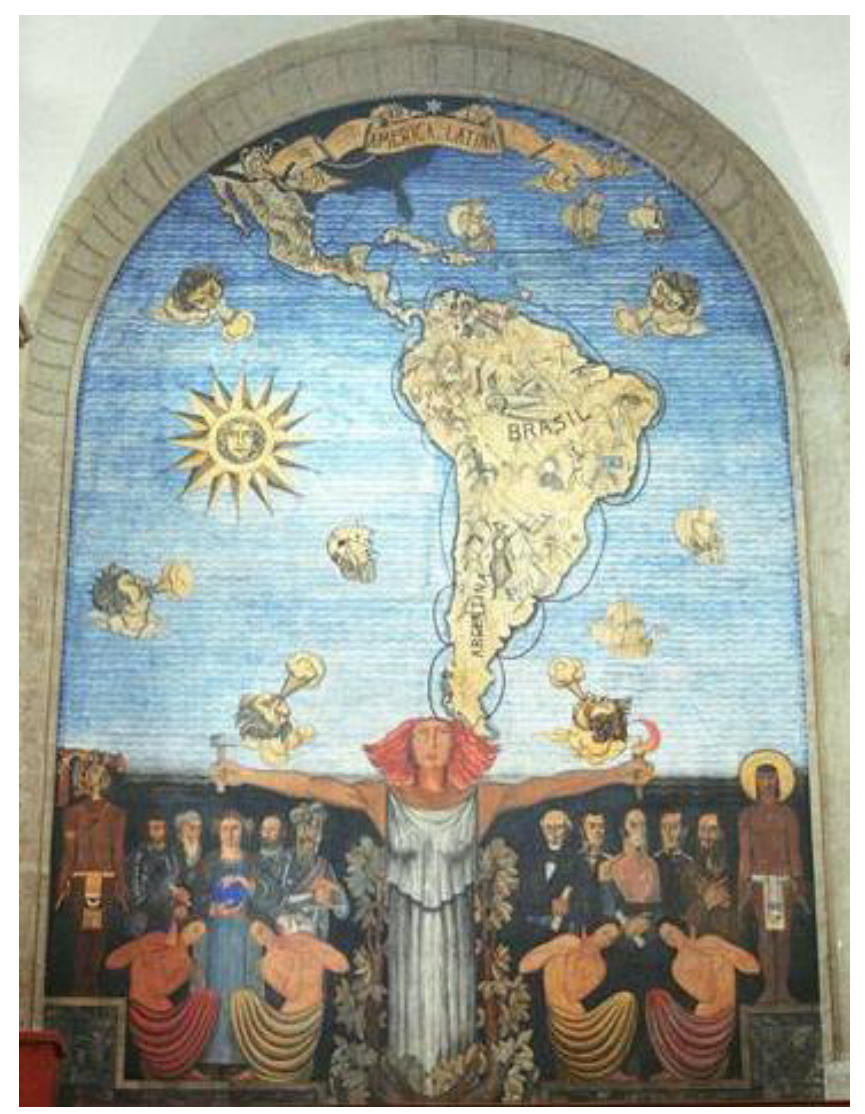

Roberto Montenegro, Iberoamérica, Biblioteca Interamericana, México, D.F., 1924. ${ }^{190}$

Otra de las obras de Montenegro es el mural llamado La Historia que se encuentra en la Biblioteca Lincoln de la Escuela Primaria Benito Juárez en México, D.F., que fue pintado entre 1925 y 1927 junto con otro llamado El Cuento. La historia está representada por una mujer sentada con las manos hacia el frente con las que detiene en una la hoz y en otra el martillo, y atrás de ella está un ángel con dobles alas; de un fuerte nacionalismo por los personajes que aparecen, las figuras centrales fueron tratadas con bastante geometricidad. La Alegoría del Viento, 1928, fresco que se encontraba en el Colegio de San Pedro y San Pablo y actualmente está en el Palacio de Bellas Artes, es una de las obras de

${ }^{190}$ El Universal, "Los murales de Roberto Montenegro", http://fotos.eluniversal.com.mx/coleccion/muestra_fotogaleria.html?idgal=11864 
Montenegro que más se inscribe dentro del Déco. Un ángel cuyo cuerpo es una columna estriada, abre axialmente sus brazos y sus alas tripartitas; acompañado por dos eolos que soplan el viento, en el fondo se concatenan una serie de figuras geométricas en superposición de planos, lo que da un extraordinario impulso lúdico de líneas, ángulos y triángulos, lo cual "aunado al hieratismo de la figura, hace que se inscriba en las categorías estéticas del Art-Déco". ${ }^{191}$

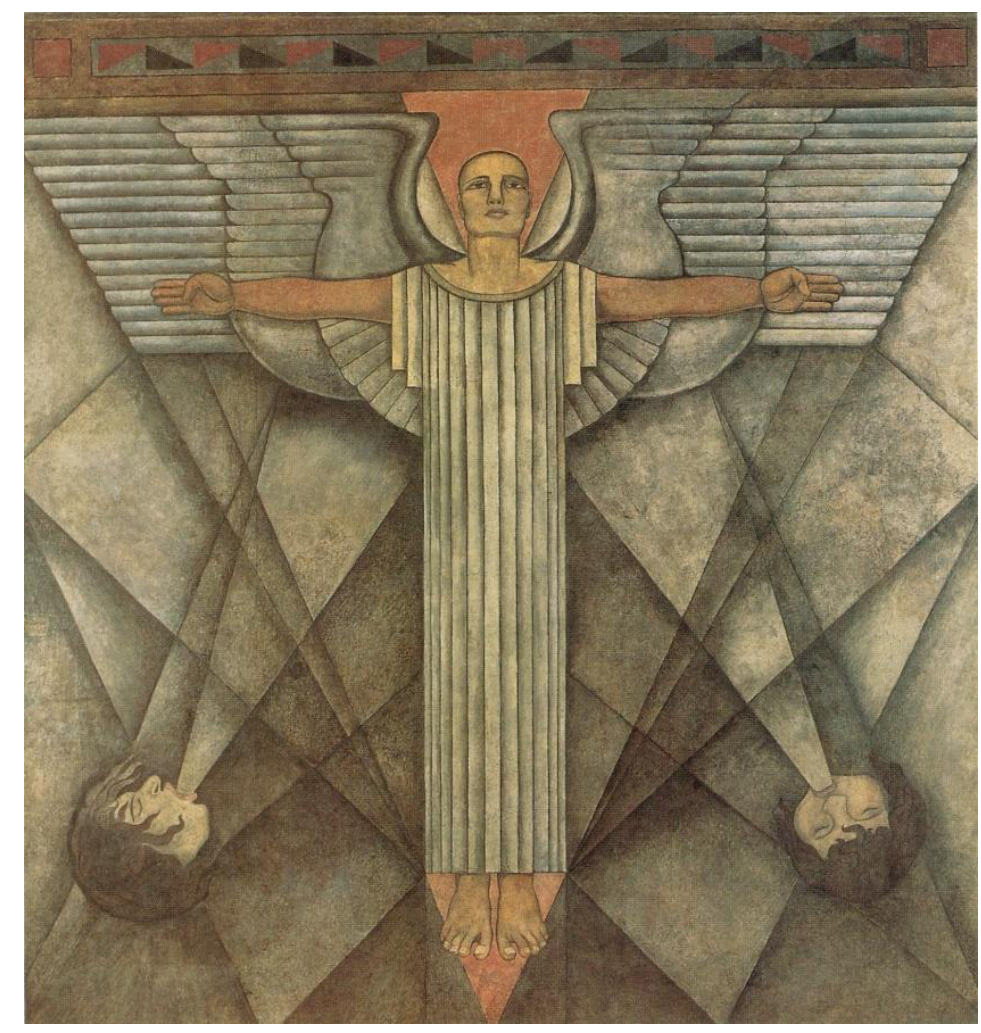

Roberto Montenegro, Alegoría del Viento, Palacio de Bellas Artes, México, D.F., 1926. ${ }^{192}$

Éstas son algunas de las obras que conllevan elementos de la estética de nuestro estudio realizadas por Roberto Montenegro, catalogado por Esqueda como el artista que más trabajó bajo esa tendencia: "Por la fecunda obra de Montenegro durante esos años, podemos decir que ha sido el pintor mexicano que más pintura art deco nos ha dejado, siendo parte de la herencia cultural que nos enorgullece". ${ }^{193}$

\footnotetext{
${ }^{191}$ Ibídem, p. 132.

192 Catálogo de la exposición Art Déco. Un país nacionalista, un México cosmopolita, Op. Cit., p. 155.

${ }^{193}$ Xavier Esqueda, Op. Cit., p. 101.
} 
Para Esqueda la obra de Diego Rivera que ostenta un estilo Art Déco es el mural del Anfiteatro Bolívar en el antiguo Colegio de San Ildefonso de la ciudad de México, llamado La Creación, realizado entre 1922 y $1923 .{ }^{194}$ Al centro del mural emerge una figura masculina con los brazos abiertos que personifica al Pantocrátor y un triángulo debajo de éste representa el Árbol de la Vida; arriba de un medio círculo surgen tres manos de líneas que apuntan hacia los personajes del mural. El hombre desnudo y de espaldas de la derecha y la mujer también desnuda y robusta de la izquierda remiten a las esculturas Déco. Los vestidos largos de algunas de las mujeres que están en ambos lados, fueron tratados con verticalidad a través de las líneas que simulan las caídas de los pliegues. El equilibrio, la simetría, el círculo, el triángulo así como la linealidad que componen el mural, lo hacen inscribirse dentro del Art Déco.

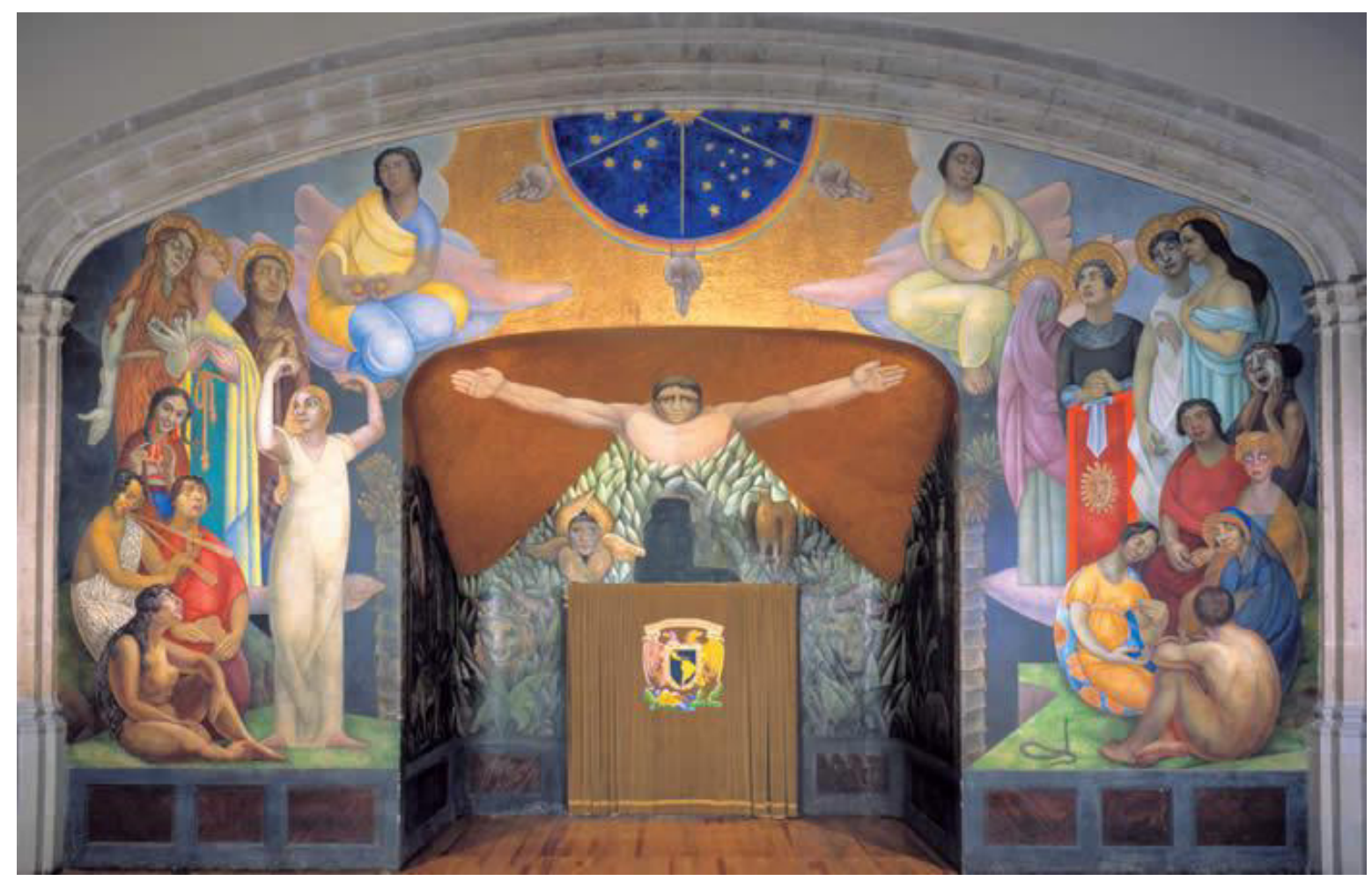

Diego Rivera, La Creación, Anfiteatro Bolívar, Antiguo Colegio de San Ildefonso, México, D.F., 1923.195

\footnotetext{
${ }^{194}$ Ibídem, p. 99.

195 "Diego Rivera. La Creación, 1992",

http://www.sanildefonso.org.mx/mural_anfiteatro.php?iframe=true \&width=810\&height=100\%
} 
Dentro del extenso conjunto de murales del edificio de la Secretaría de Educación Pública, en la planta baja en el primer patio, el que lleva por título Salida de la Mina, 1926, un trabajador vestido con ropa a la usanza indígena, abre los brazos para ser revisado por un guardia, mientras otros trabajadores van saliendo del pozo; con un fondo rocoso y oscuro, resaltan los componentes geométricos de las líneas curvas, ángulos rectángulos, más la siluetas de los cuerpos de los personajes, por lo que éste mural refleja los preceptos del Art Déco de la época del Zigzag.

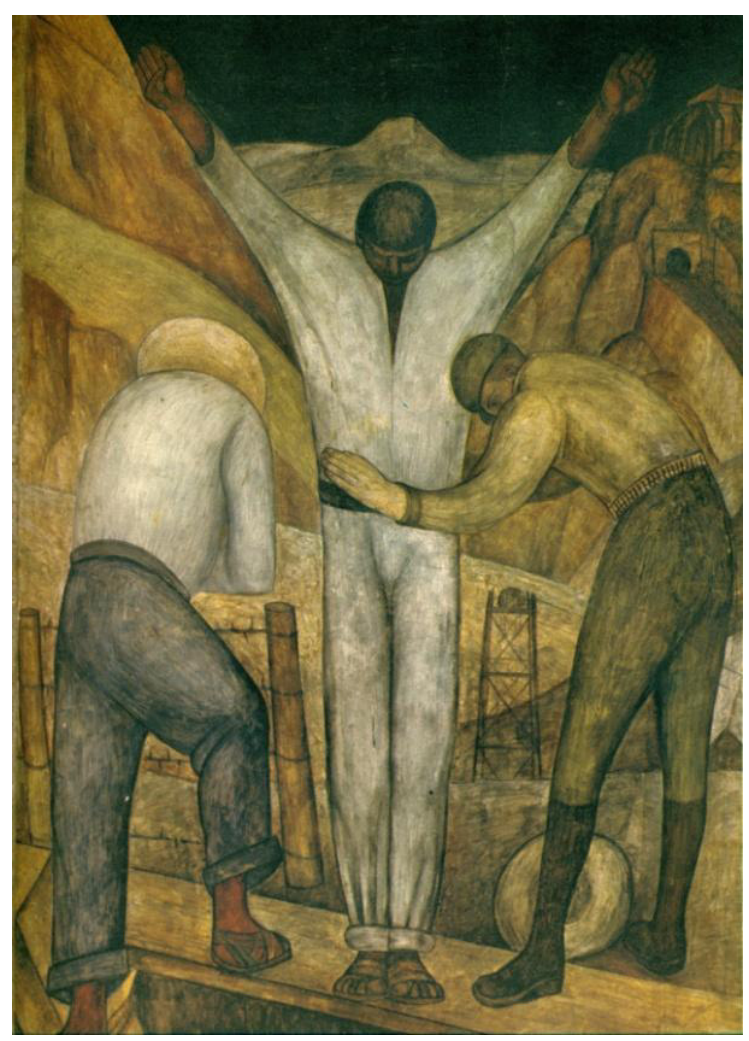

Diego Rivera, Salida de la Mina, detalle Secretaría de Educación Pública, México. D.F., 1926. ${ }^{196}$

Podríamos afirmar que muchos de los bosquejos a lápiz de Rivera para sus murales y dibujos de personas y paisajes, que ahora podemos ver en el Museo Dolores Olmedo en Xochimilco, están tratados con un intenso geometrismo, por lo que se pueden ver como una influencia del Déco, o bien, como trabajos que presentan marcadamente dicho estilo, pues

\footnotetext{
${ }^{196}$ FONDO EDITORIAL DE LA PLÁSTICA MEXICANA, La Pintura Mural de la Revolución Mexicana 1921-1960, México, Banco Nacional de Comercio Exterior, 1960, p. 85.
} 
algunos pertenecen a los murales que Diego Rivera realizó en Detroit en 1932, El hombre y la máquina, donde individuos trabajando en la industria automotriz, entre andamios de fierro, procesos de producción de los monoblocks automotrices, con poses retorcidas, abundan las presencias del movimiento y del maquinismo, concatenados en una filiación geométrica.

Y otra obra que a juicio de Enrique X., de Anda contiene elementos Déco es el Hombre controlador del Universo de 1934, que se encuentra en el Palacio de Bellas Artes, mural iniciado en el Rockefeller Center de New York y destruido por el propio Rivera por desavenencias con el magnate norteamericano. Con una fuerte carga ideológica marxistaleninista, al centro un hombre de facciones sajonas, controla una máquina que abre cuatro rayos luminosos que son las ampliaciones de un telescopio; arriba un gran contenedor cilíndrico y atrás ruedas mecánicas homenajean a la máquina, el progreso científico y a la industrialización. Las bayonetas angulosas de los ejércitos fascistas, contrastan en posición con las banderas de las comunas soviéticas, mientras que las marmóreas y robustas figuras, simbolizan al decadente cristianismo y a la tiranía derrocada. El dinamismo, el facetado y el geometrismo están presentes, bien pueden aludir al Art Déco Streamline, además por las posturas de las luces centrales como si fueran grandes alas, dando la impresión de un avión en pleno vuelo visto angularmente.

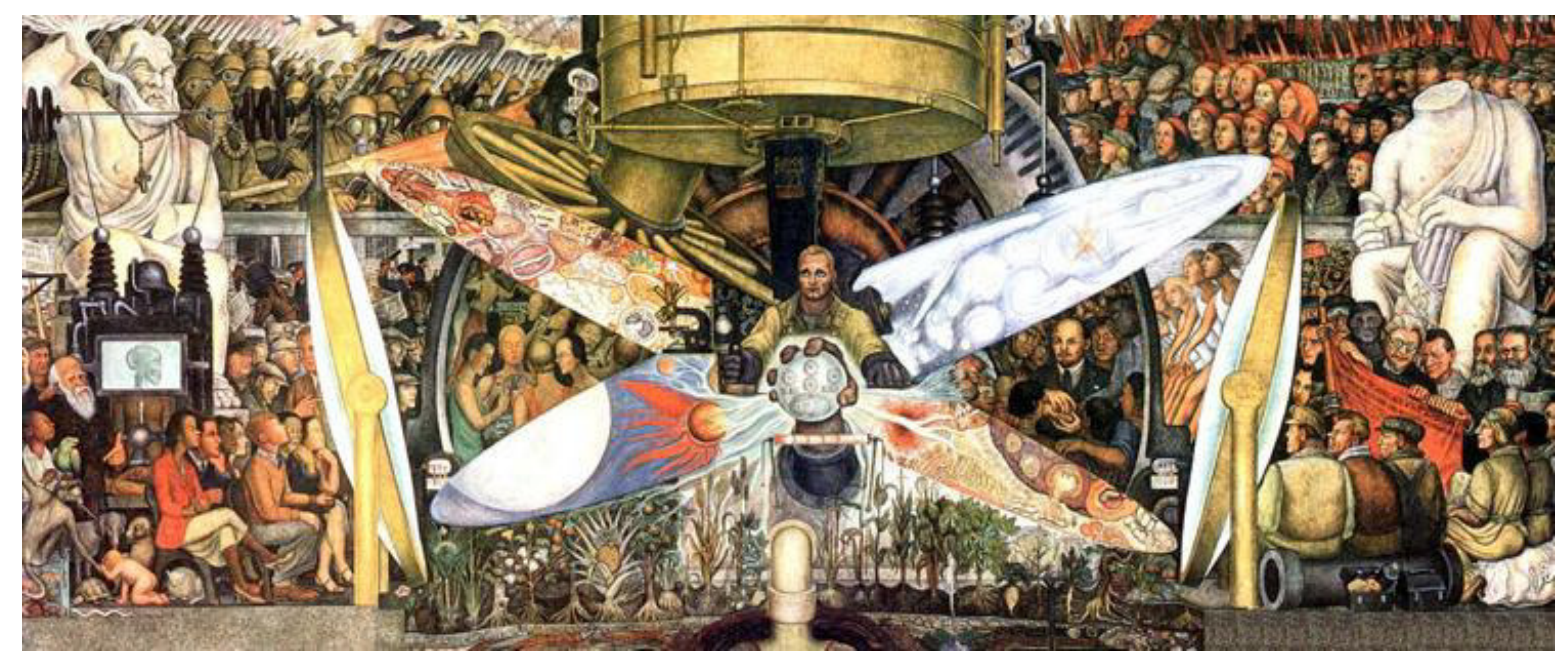

Diego Rivera, El Hombre Controlador del Universo, Palacio de Bellas Artes, México, D.F., 1934. ${ }^{197}$

\footnotetext{
${ }^{197}$ Sandro Landucci Lerdo de Tejada, Los Murales del Palacio de Bellas Artes, México, Américo Arte Editores, Instituto Nacional de Bellas Artes, 1995, pp. 30, 31 y 32.
} 

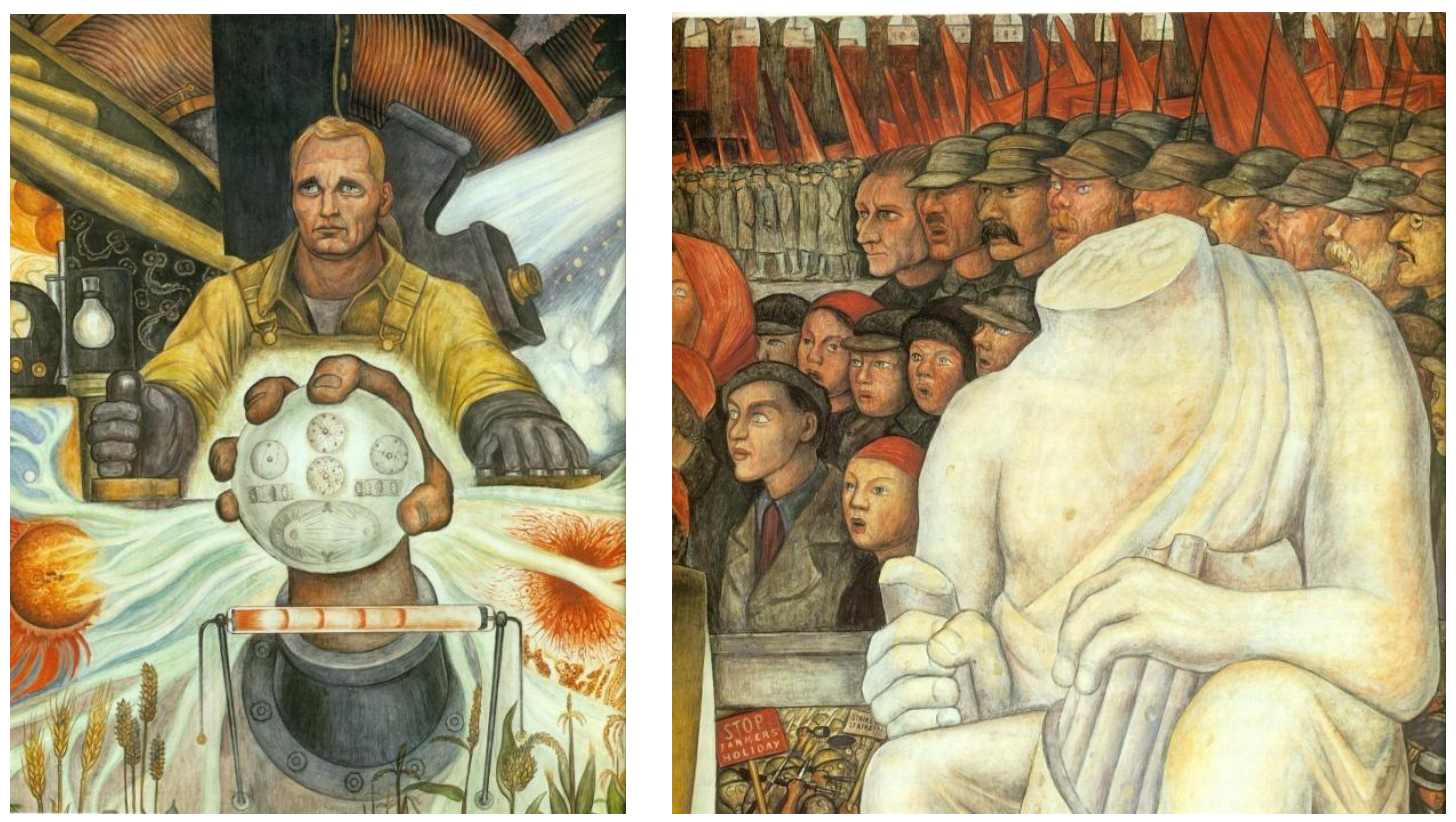

El Hombre Controlador del Universo, detalles. La imagen izquierda es el centro del mural donde un norteamericano maneja una máquina y al frente una mano sostiene una esfera con átomo y células. La imagen derecha se encuentra en el ángulo superior derecho, en donde una estatua decapitada representa a la tiranía vencida gracias al socialismo y al fondo trabajadores comunistas interpretando el himno de "La Internacional", un 1 de mayo en la Plaza Roja de Moscú. ${ }^{198}$

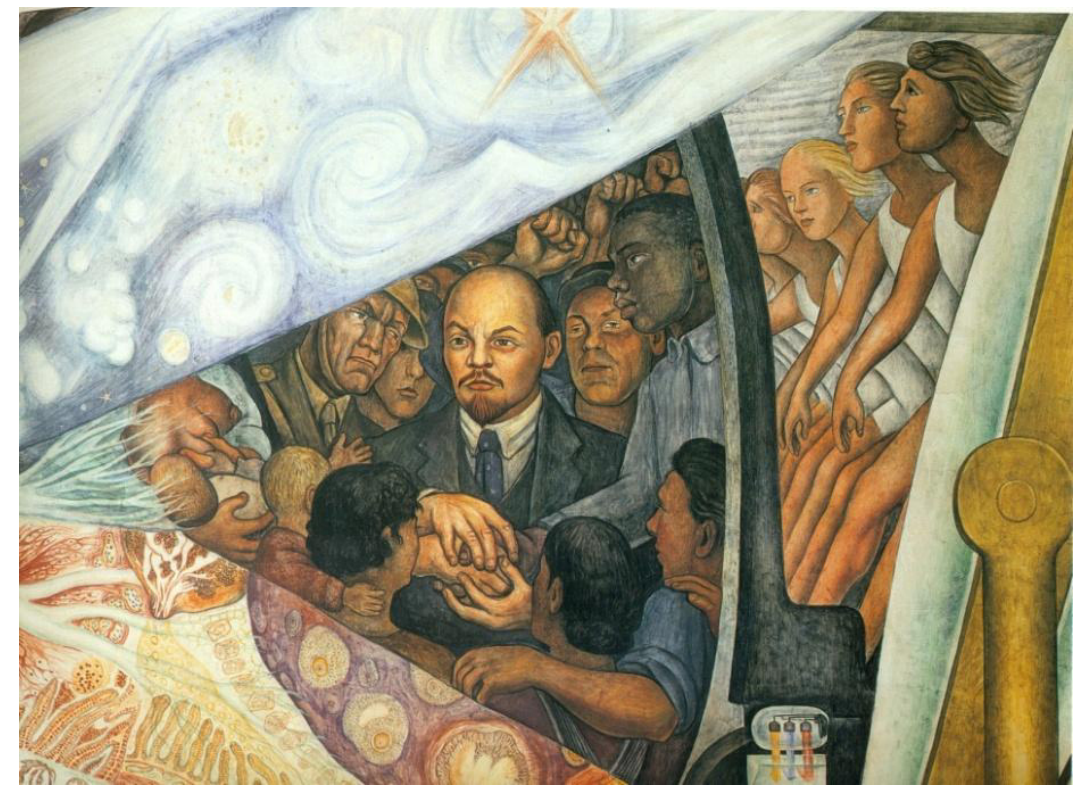

El Hombre Controlador del Universo, detalle parte central derecha, Lenin unifica diversas etnias ante la ampliación de bacterias buenas y astros del firmamento. Al fondo derecho, mujeres soviéticas practicando el deporte. ${ }^{199}$

\footnotetext{
${ }^{198}$ Ibídem, pp. 37 y 41.

${ }^{199}$ Ibídem, p. 39.
} 


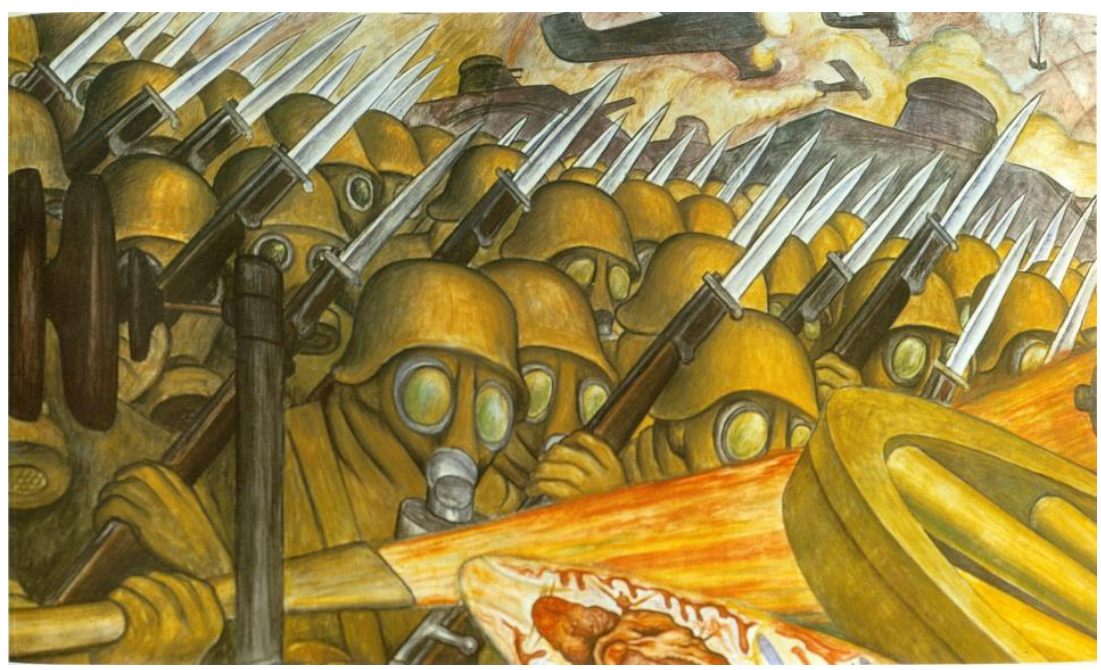

El Hombre Controlador del Universo, detalle sección superior izquierda. Las guerras ocasionadas por el capitalismo con soldados, tanques y aviones. ${ }^{200}$

Máximo Pacheco Miranda (1905-1992), artista poco conocido y casi olvidado, es citado por Esqueda entre los muralistas que trabajaron con la estética del Déco, aunque dice "y en menor grado Máximo Pacheco en sus murales de la Escuela Domingo F. Sarmiento". ${ }^{201}$ La escuela Sarmiento en la ciudad de México fue un modelo pedagógico socialista postrevolucionario; inaugurada en 1927 a la fecha sólo subsisten algunas aulas, donde se conservan 12 murales de Pacheco, ya que todos los exteriores fueron destruidos. El artista empezó la decoración en 1922, cuando era un joven de tan solo 17 años y trabaja de ayudante con Fermín Revueltas en el mural del Excolegio de San Ildefonso Alegoría de la Virgen de Guadalupe. Sus murales son un recuerdo de su infancia, los temas campesinos, ubicados en la presa de su natal Huichapan en el estado de Hidalgo dan cuenta de ello. Niños jugando, en movimiento, divirtiéndose en retozos acuáticos. "Escenas saturadas de color y muchos detalles narrativos representan a los niños, alumnos de la escuela, quienes crecen rodeados por la naturaleza, el amor y la atención de los adultos", ${ }^{202}$ tal como los describe Larissa Ivanovna. El movimiento a su vez se integra con lo geométrico de las poses de los niños y sus anatomías al momento de los clavados, porque

\footnotetext{
${ }^{200}$ Ibídem, p. 35.

${ }^{201}$ Xavier Esqueda, Op. Cit., p. 103.

${ }^{202}$ Larissa Ivanovna Pavliukóva, "Murales de Máximo Pacheco en la Escuela Primaria Domingo Faustino Sarmiento: sobreviviendo al olvido", Crónicas. El Muralismo, Producto de la Revolución Mexicana, en América, México, UNAM, No. 1, 1998, p. 26, www.ojs.unam.mx/index.php/cronicas/issue/view/1384/showToc
} 
en ambos casos los triángulos, los cuadrados, los rectángulos y los círculos componen las escenas. El agua y la arena se conforman con pequeñas ondulaciones, tal como se usaban las decoraciones de paneles de las fachadas e interiores de muchos edificios de la época, como el Folies Bergere de París.

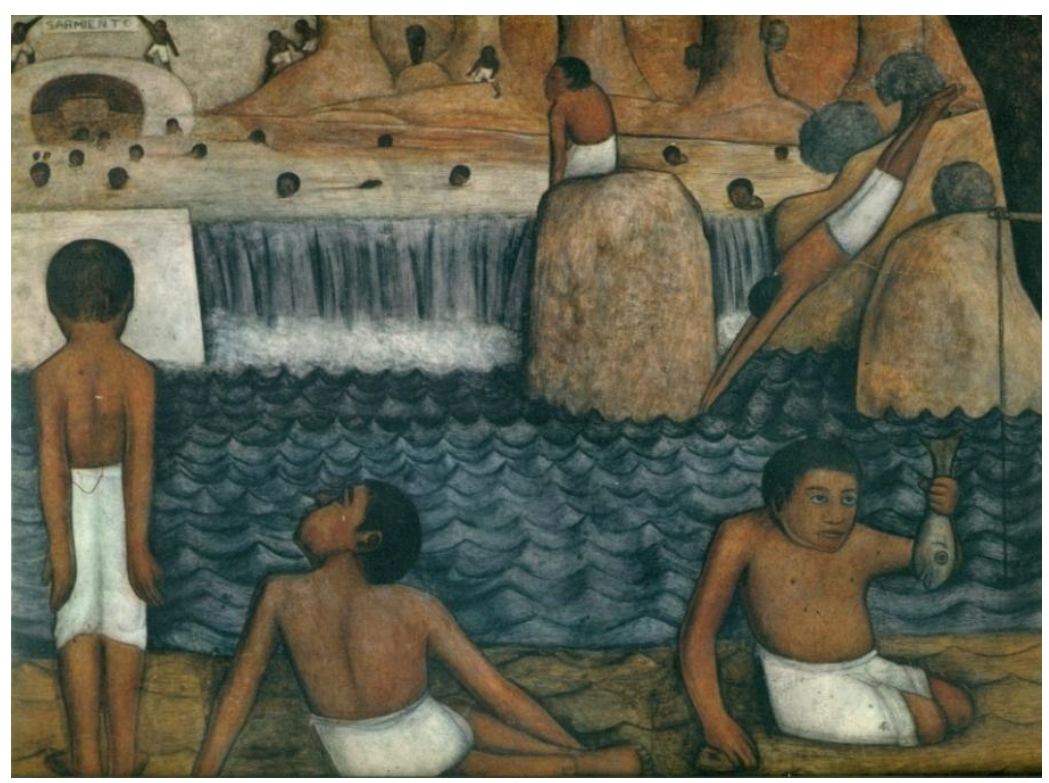

Máximo Pacheco, La Presa de Huichapan, detalle. Escuela Domingo

F. Sarmiento, México, D.F., 1927.203

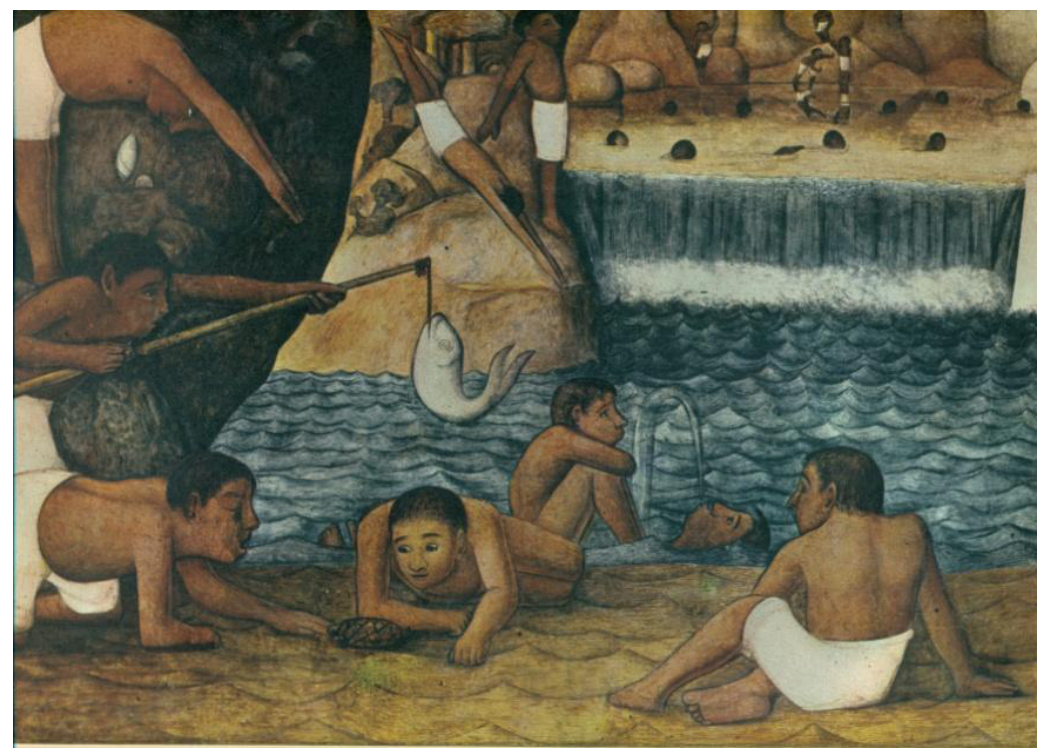

La Presa de Huichapan, detalle. ${ }^{204}$

${ }^{203}$ FONDO EDITORIAL DE LA PLÁSTICA MEXICANA, Op. Cit, p. 99. 
En el mural Campesinas los abundantes magueyes con sus pencas afiladas, triangulares, contrastan con lo rectangular de la pared de la presa, que se pierde en el horizonte hacia el punto de fuga con la intersección de un arcoíris. Estos podrían ser algunos de los elementos de los murales de Pacheco que cabrían, tal como dice Esqueda, en menor medida en el Art Déco.

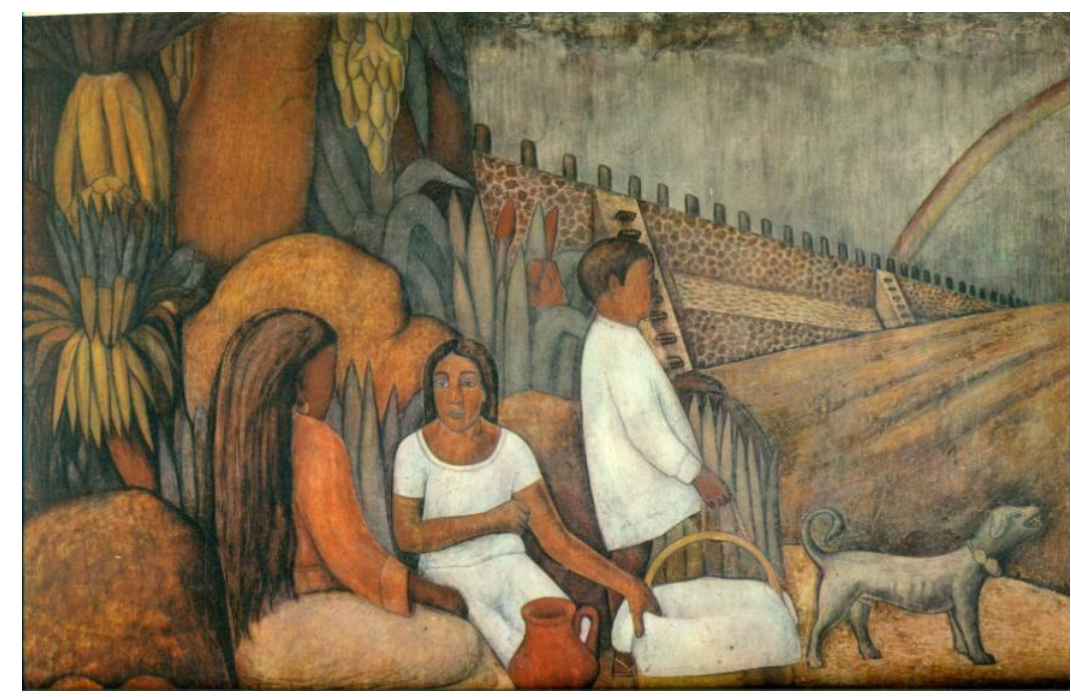

Máximo Pacheco, Campesinas, Escuela Domingo F. Sarmiento, México, D.F., 1927.

En las obras de caballete de los artistas de la época, poco se incursionó en lo que sería el estilo del Déco, ya que la tendencia era resaltar lo indígena o bien, buscar nuevas rutas por lo urbano. Tanto Esqueda como De Anda coinciden en que es Fermín Revueltas (1901-1935) uno de los artistas que más incursionó en el estilo en cuestión. De Anda propone que algunos de los trabajos de Revueltas tienen un dinamismo como si fuera una cinta cinematográfica, ${ }^{205}$ y si a esto le agregamos el geometrismo, finalmente se consigue un efecto de la estética del Déco. Una de sus obras de caballete, el óleo titulado Bailarinas, 1930, con solo las siluetas de la mujeres bailando, dos de ellas están al centro y se cruzan rayos de luz que cambian de color al pasar por el frente de las damas; otra mujer baila en el centro y abajo y a los lados los músicos de la orquesta. La fuerza de la expresión de lo geométrico, el decorado de la escena y la intensidad de la irradiación de la luz son de un

\footnotetext{
${ }^{204}$ Ibídem, p. 98.

${ }^{205}$ De Anda, Op. Cit., p.64.
} 
estupendo Déco de la variante Zigzag. También el trabajo realizado en xilografía para las portadas de la publicación Crisol. Revista de Crítica, en donde colaboró con 27 portadas desde su fundación en 1929 hasta su muerte, e inclusive, algunas de sus imágenes salieron póstumamente, abunda la estética del Déco, con formas cúbicas, líneas oblicuas, chimeneas fabriles, soles radiantes, rostros compuestos con siluetas geométricas, entre muchos otros diseños.
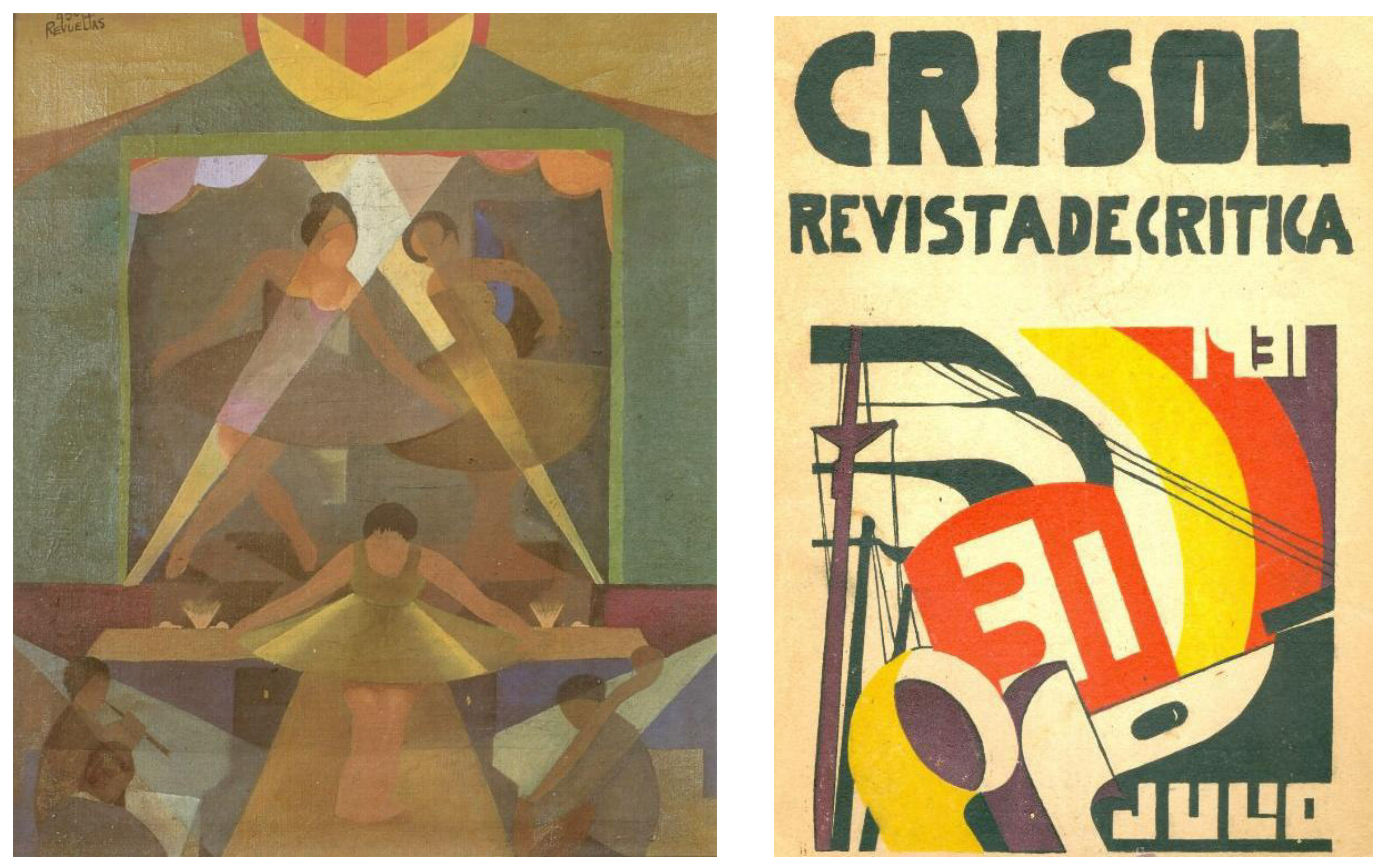

Fermín Revueltas, Bailarinas, 1930, colección particular, ${ }^{206}$ y portada de la revista Crisol de julio de 1931, colección particular. ${ }^{207}$

Sin embargo, en los vitrales la presencia del Déco es inequívoca. Los diseños que Revueltas hizo para La Casa del Pueblo de Sonora en 1933 son de un colorido tenue, pero a la vez penetrante; tratan temas agrarios como en los personajes Emiliano Zapata y La Maestra Rural, díptico donde además resaltan las hojas plantas del maíz, alargadas, puntiagudas, y en otro díptico los temas proletarios como en el Obrero Muerto y el Mitin, se aprecia la fuerza compositiva de líneas diagonales y ascendentes, de composiciones

\footnotetext{
${ }^{206}$ Catálogo de la exposición Art Déco. Un país nacionalista, un México cosmopolita, Op. Cit., p. 123.

${ }^{207}$ Carla Zurián, Fermín Revueltas. Constructor de Espacios. México, INBA, Museo Mural Diego Rivera, Editorial MR, 2002, p. 60.
} 
escalonadas, de integración de cuerpos geométricos, como las chimeneas fabriles y los brazos levantados de los trabajadores, otorgándole toda la estética del Art Déco.
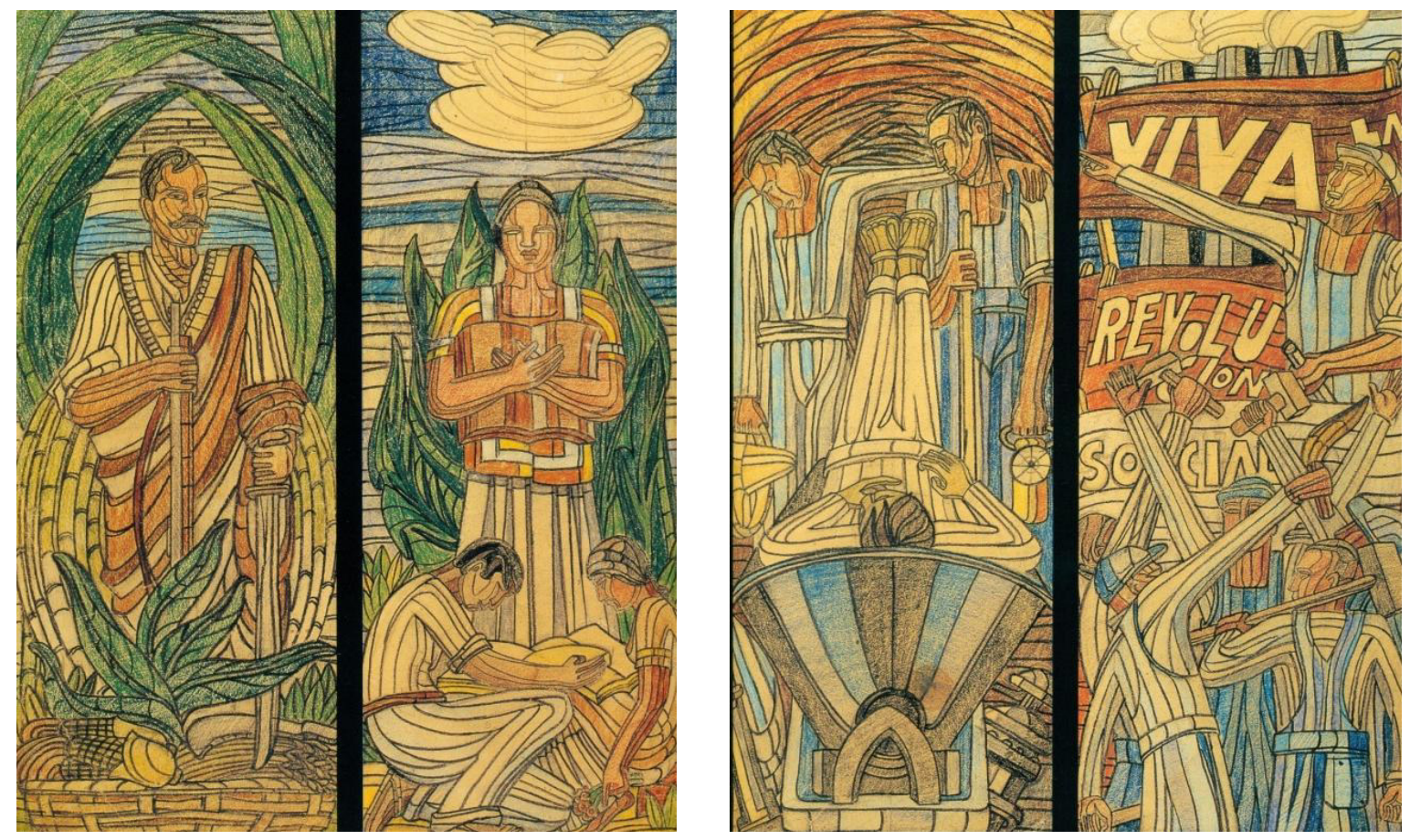

Fermín Revueltas, diseño para los vitrales La Casa del Pueblo de Sonora. De izquierda a derecha: primer díptico, Emiliano Zapata y la Maestra Rural; segundo díptico, Obrero Muerto y Mitin, colección particular 1933. ${ }^{208}$

Otro de sus vitrales instalados por la Casa Montaña de Torreón son los del antiguo Hospital Colonia de Ferrocarrileros, en la ciudad de México, del año 1934, hoy oficinas del Instituto Mexicano del Seguro Social, pues el maquinismo de las locomotoras, el dinamismo del tendido de las vías, así como el trabajo obrero en los caminos de fierro exaltan la geometricidad de la recta, el cubo, el círculo, el cuadrado, máximas de la decoración Déco y de la obra de Revueltas.

La obra de Revueltas merece un estudio específico desde la perspectiva del Déco, ya que su prolífera producción abordó la vanguardia de su tiempo. En el capítulo siguiente al tratar la pintura en Monterrey, ahondaremos un poco más en Fermín Revueltas cuando expliquemos el cuadro de gran formato Alegoría de la Producción de 1934 que se encuentra en el Centro de las Artes.

${ }^{208}$ Ibídem, pp. 114-115. 


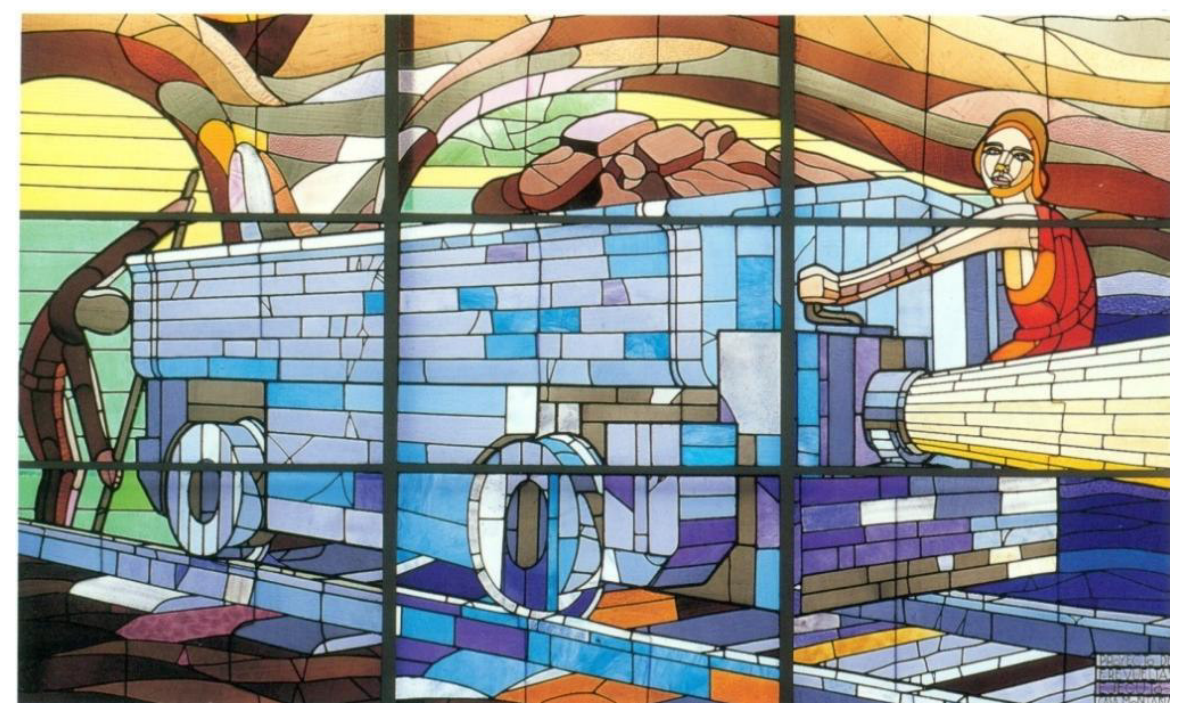

Fermín Revueltas, Túnel ferroviario, antiguo Hospital Colonia de Ferrocarrileros, México, D.F., 1934.209
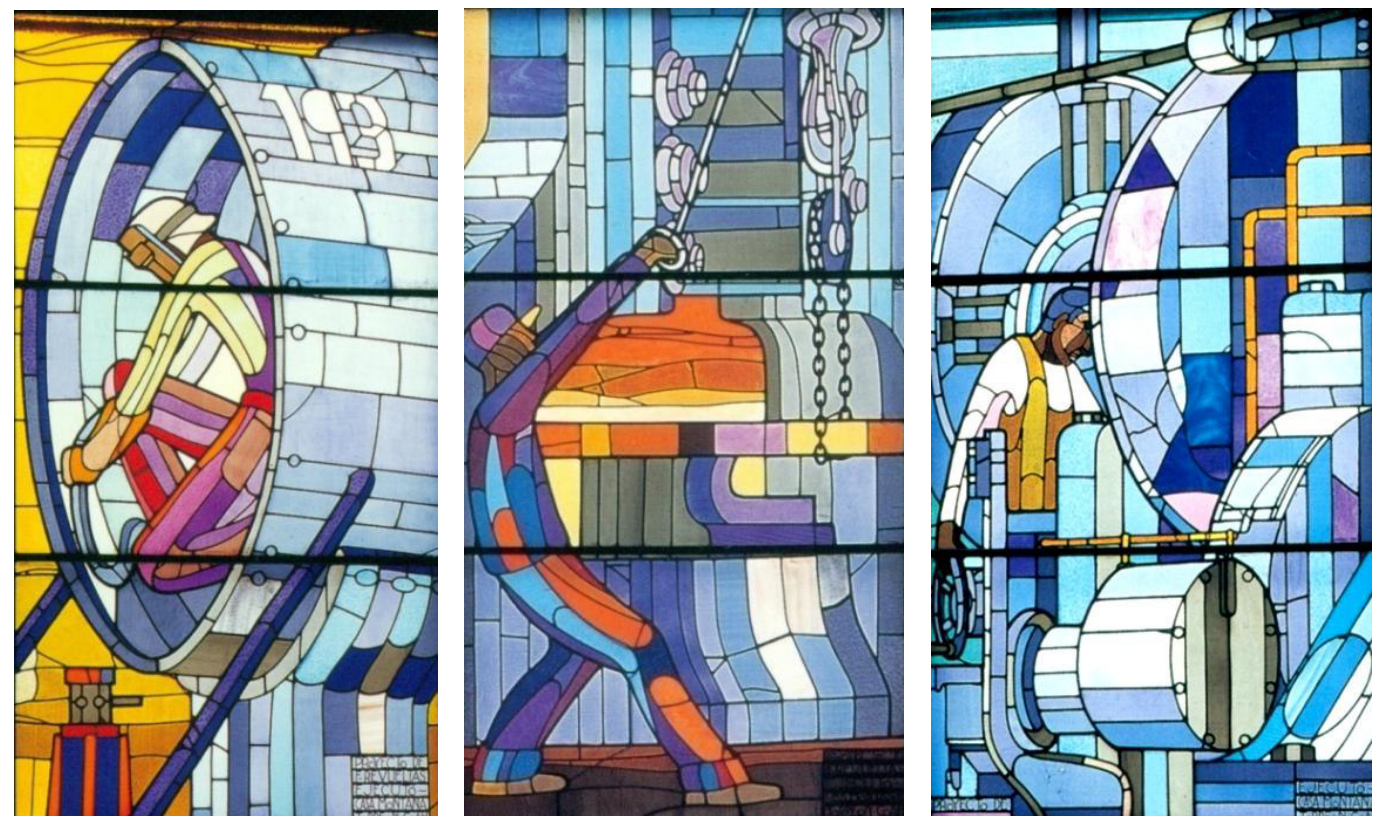

Trabajadores de vía (3), Jalando rieles, ${ }^{210}$ El torno mecánico, ${ }^{211}$ antiguo Hospital Colonia de Ferrocarrileros, México, D.F., 1934.

\footnotetext{
${ }^{209}$ Ibídem, p. 120.

${ }^{210}$ Ibídem, pp. 122-123.

211 Marianne Chauvin (coordinadora), Vitrales, México, D.F., Artes de México, Número 94, junio 2009, portada.
} 
El caso de Jorge González Camarena (1908-1980) es más destacado en sus portadas para la revista Cemento, como ya lo habíamos mencionado en el punto 2.3 de este capítulo, pues el trabajo mismo de la producción de ese material conlleva la fabricación industrial que González Camarena ilustraba con máquinas, operarios, propuestas de nuevos paisajes urbanos e inclusive rurales, pero conceptualizados dentro de la modernidad transformadora del cemento, como los ilustra en su óleo Materia, forma y color, ca. 1929, en el cual en una vista aérea, una portentosa fábrica construida en cemento se conforma con cilindros y cubos, resaltándose la excelsitud de la geometría y el color gris, con todo y un aeroplano que se ve en el fondo derecho, más el ferrocarril en color marrón en la parte baja, obra en la que homenajea al cemento, el material moderno del Art Déco, a la producción industrial y a los transportes modernos.

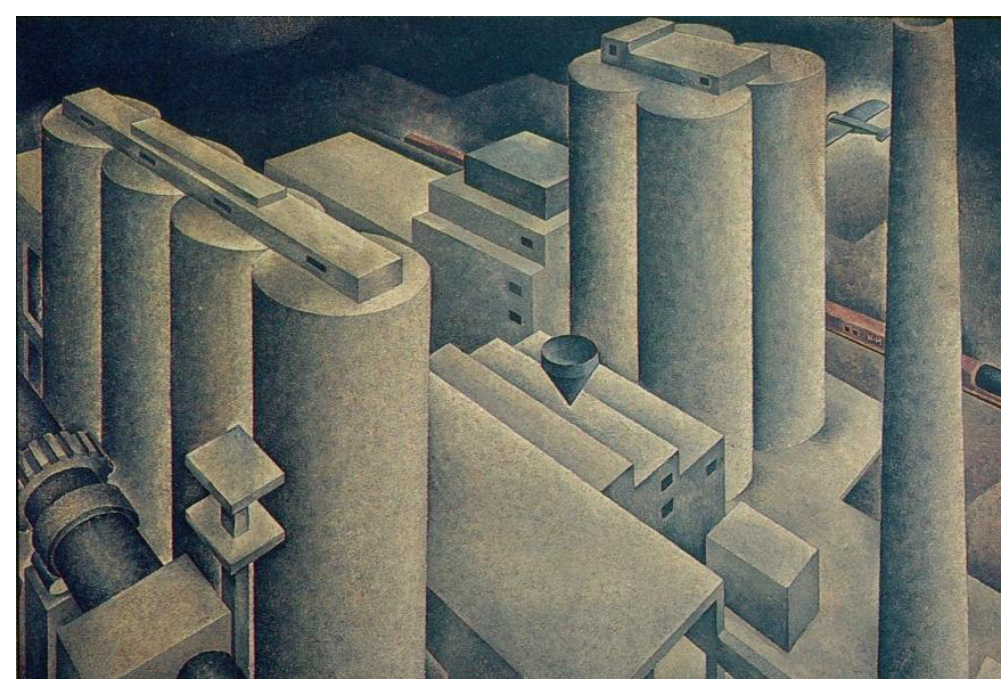

Jorge González Camarena, Materia, forma y color, ca. 1929, colección particular. ${ }^{212}$

Otro óleo que lleva toda la estética del Art Déco es Las bañistas de 1934, que se encuentra en el Museo Nacional de Arte, cuadro en el que González Camarena muestra las nuevas forma de vida de la mujer moderna; damas dibujadas sin definir con precisión sus rasgos, en traje baño o desnudas, aprecian el clavado de una compañera, cuya posición

\footnotetext{
${ }^{212}$ Rocío Guerrero y Cecilia Delgado, El Art Déco. Una nueva alternativa cultural”. México en el tiempo. México, México Desconocido, Año 3, No. 23, marzo/abril 1998, p. $28 .$.
} 
armoniza con el diseño del trampolín, ambos con una verdadera alusión a las aeronaves con diseños del Déco Streamline.

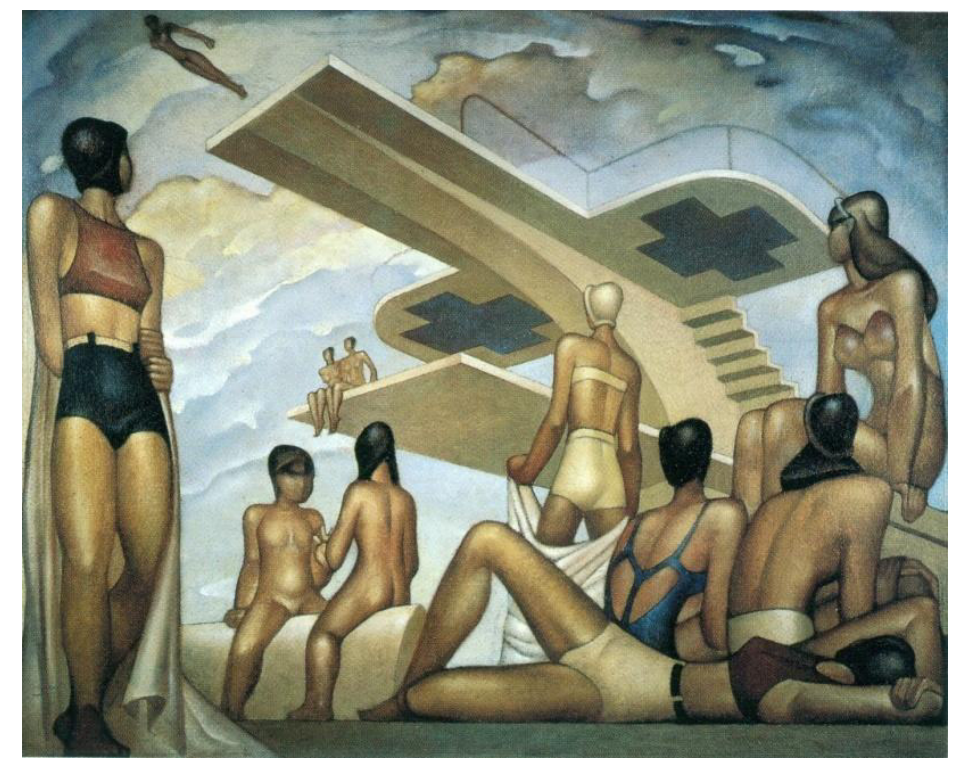

Jorge González Camarena, Las bañistas, Museo Nacional de Arte, México, D.F., 1934.213

Un artista gráfico, y tal vez el más representativo, del Art Déco en México fue Ernesto "Chango" García Cabral (1890-1968). Desde muy temprana edad mostró sus dotes para el dibujo, lo que le permitió en su natal Huatusco, Veracruz, dar clases de dibujo en su escuela a los 12 años. Becado por el gobierno del estado estudia en la Academia de San Carlos e incursiona en el trabajo de caricaturista e ilustrador de revistas. Obtiene una beca del gobierno del Presidente Francisco I. Madero [1911-1913] para ir a estudiar a París donde permanece dos años, entre 1913 a 1915; en la Ciudad Luz trabaja para las revistas La Bayonette, La Rire y La Vie Parisiene. Después de una breve estancia por Madrid, se traslada a Buenos Aires y ahí también ejerce su trabajo como ilustrador en publicaciones periódicas. Al regresar a México en 1918, García Cabral ya tiene toda una formación que lo hace un artista consumado y especializado en el campo de la ilustración y la caricatura.

Debido a la demanda de publicidad por los nuevos productos del consumo masivo, la gráfica es demandada y así como González Camarena trabaja para la revista Cemento, "El Chango" Garcia Cabral lo hará para Revista de Revistas, del periódico Excélsior, donde

\footnotetext{
${ }^{213}$ Catálogo de la exposición Art Déco. Un país nacionalista, un México cosmopolita, Op. Cit., p. 142.
} 
desarrolló e introdujo el Art Déco. Con vivos colores y delicadas líneas sus ilustraciones dirigidas a esa nueva clase burguesa, heredera del gusto elitista porfiriano, de una nueva clase política, burocrática, urbana y consumista, expone principalmente a un tipo de mujer inexistente en México, pero que a la vez busca abrirse camino en la nueva sociedad. Es bien sabido que la mujer mexicana abnegada, de vestido largo, con trenzas, portando rebozo es una realidad. La mujer que emana de las ilustraciones de García Cabral es esa mujer europea, vampiresa, seductora, de coctel, que pregona una liberación femenina, todavía muy lejana en México. Bellos ojos engalanados con líneas negras, pestañas exaltadas por los cosméticos, vestidos entallados pero sin la rigidez del corsé y a la vez subidos hasta la rodilla, de tirantes o escotados se combinan con zapatos cerrados de tacón alto en vivos colores; damas elegantes, de perfil, sugerentes, displicentes, en poses retorcidas o de baile, perseguidas por grupos de hombres elegantes y lujuriosos, en cuyos dibujos se acentúa la línea prolongada y sutil.
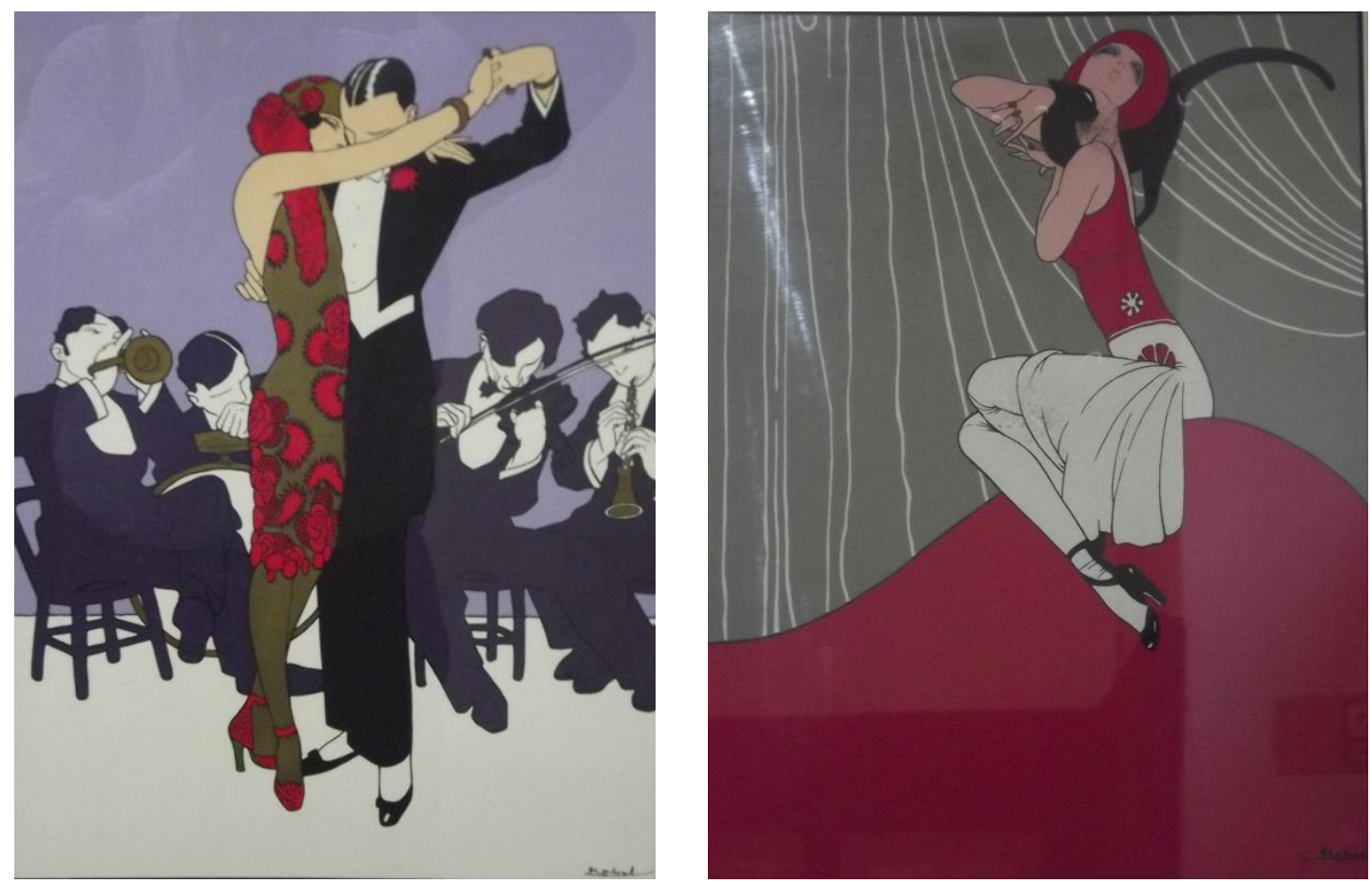

Ernesto García Cabral, Una mirada al Tango y Bailarina, Museo de la Caricatura, México, D.F., 1926.

Sin embargo, charros ataviados con zarapes de Saltillo con diseños geométricos, paisajes mexicanos con personajes nativos de las diversas regiones del país y hasta los 
obreros de la fundición en Monterrey, también son tratados en vivos colores con la estética del Déco. Y por qué no decirlo, García Cabral, desde nuestro punto de vista, durante la segunda mitad de la década de los veinte y la década de los treinta del pasado siglo, fue en México quién más ilustró el Art Déco.
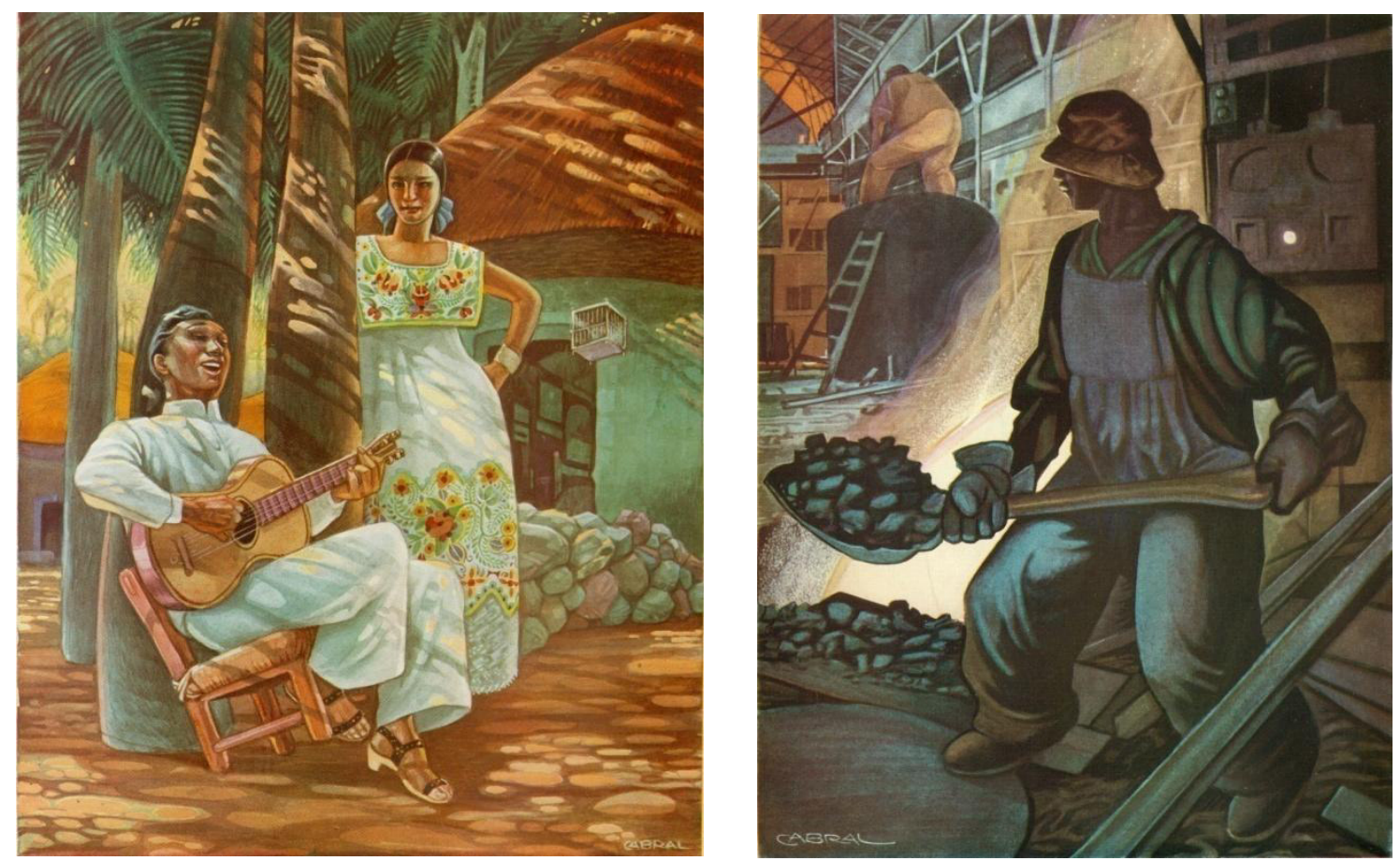

Ernesto García Cabral, Yucatán y Monterrey, ca. 1940.214

Otro artista de los que más trabajaron con ilustraciones dentro del Art Déco fue Miguel Covarrubias (1904-1957), "El Chamaco” quien, desde muy temprana edad, salió al extranjero y trabajó como escenógrafo en París y luego en New York, donde permaneció hasta 1940. Captó con singular interés las tendencias de las ilustraciones de revistas, por lo que logró interpretar las modas de bailes, fiestas y vestuarios de manera magistral, lo cual expresó con sus caricaturas en Vogue, New Yorker y Vanity Fair. En Estados Unidos publicó Negro Drawings, 1927, y The Prince of Wales and Other Famous Americans, 1935, en los que despliega todo un desfile de bailes, individuos, parejas, músicos, modas, manejados con cortes angulosos y composiciones expresionistas en verdaderos relatos de las costumbres sociales de los veinte y los treinta. Otro de sus importantes libros fue Island

\footnotetext{
${ }^{214}$ Casa Bayer, Rincones Mexicanos por García Cabral, México, D.F., Casa Bayer, S.A., s/f.
} 
of Bali, 1937, en el cual ilustra con dibujos, acuarelas y óleos a las mujeres balinesas y algunos monumentos del lugar. Fue muy importante y significativa su participación en una de las ferias donde se exhibieron productos Art Déco Streamline: La Exposición Internacional "Golden Gate" de San Francisco California, entre 1939-1940, donde Covarrubias pintó seis murales en pabellón "Pacific House" sobre la vida humana y animal, así como la economía y el arte de los pueblos que miran hacia el océano Pacífico.
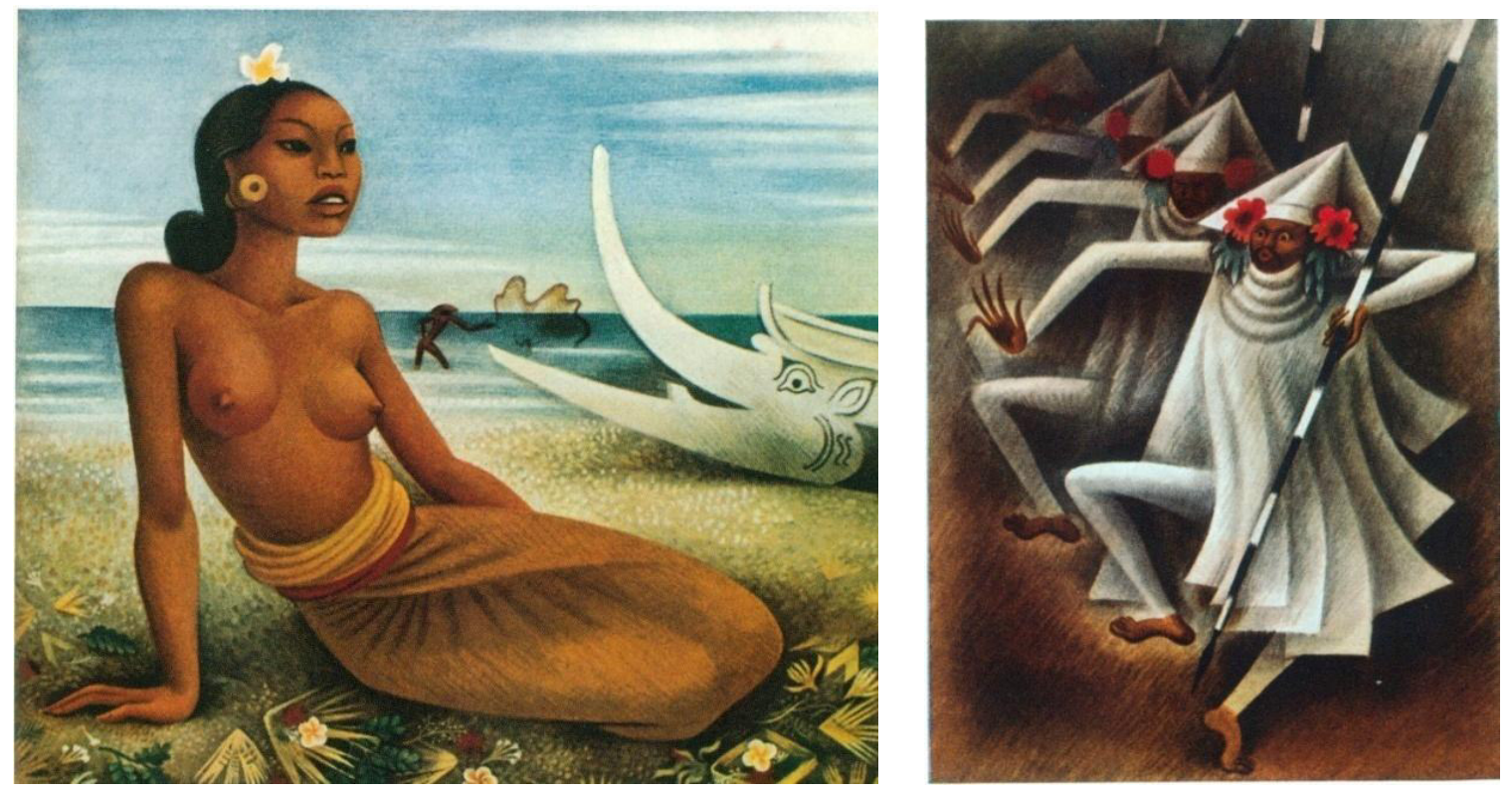

Miguel Covarrubias, escenas de la Isla de Bali: La playa en Sanur y Baris Gedé-danza ceremonial de guerra, 1937.215

Sin embargo, a partir de 1940, cuando regresa a México, sus trabajos como maestro, investigador, arqueólogo, etnólogo, hacen de él un difusor de la cultura nacional. Uno de los libros en el que dio a conocer mucho del folclor nacional fue México South: The Isthmus of Tehuantepec de 1946, que fue editado en esa fecha en Estados Unidos, pero obviamente, el trabajo de texto e ilustración fueron de años anteriores. Este libro fue publicado en español por el Instituto Nacional Indigenista en 1980 con el título de El Sur de México y reproduce todos los dibujos que Covarrubias realizó, en los cuales con trazos rígidos, usando en muchas veces composiciones angulosas y geométricas, expresa todo el sabor, el ambiente, la música o el personaje al que retrata, tales como El Danzón, Pescador

\footnotetext{
${ }^{215}$ Miguel Covarrubias, Island of BALI, Jakarta, Periplus Editions, 1973, reimpresión 2013, ilustraciones vii y v.
} 
del Alvarado, El Huapango, cuando nos acerca a Veracruz; en Oaxaca Mujer mixe de Mogoñé, Huaves de San Mateo del Mar; la interpretación de Benito Juárez, Porfirio Díaz en 1860 o El General Porfirio Díaz en 1908; las descripciones del Istmo de Tehuantepec a través de sus dibujos de Telar de Tehuantepec, Forma de portar el bida-niró para ir a la iglesia, El bida-niró utilizado en ocasiones muy especiales, prenda que Covarrubias la describió así:" Se le conoce como "huipil de cabeza" o "gran huipil" (vida.niró) y en realidad no es otra cosa que una capa ligera o malla de seda o encaje con cuello, mangas y un borde o peplo deencaje almidonado y plisado, unido con listones de seda". ${ }^{216}$ Otros dibujos de la misma zona son Mujer llevando agua, Mujer vendiendo flores, Preparando las tortillas y batiendo chocolate, Sombrero de gala para los hombres, Carreta y músicos ciegos.

Estas imágenes que Miguel Covarrubias dibujó para el Sur de México aunque estén trabajadas en la década de los años cuarenta, bien pueden estudiarse como obras Art Déco, así como algunos de sus lienzos de su obra de caballete.
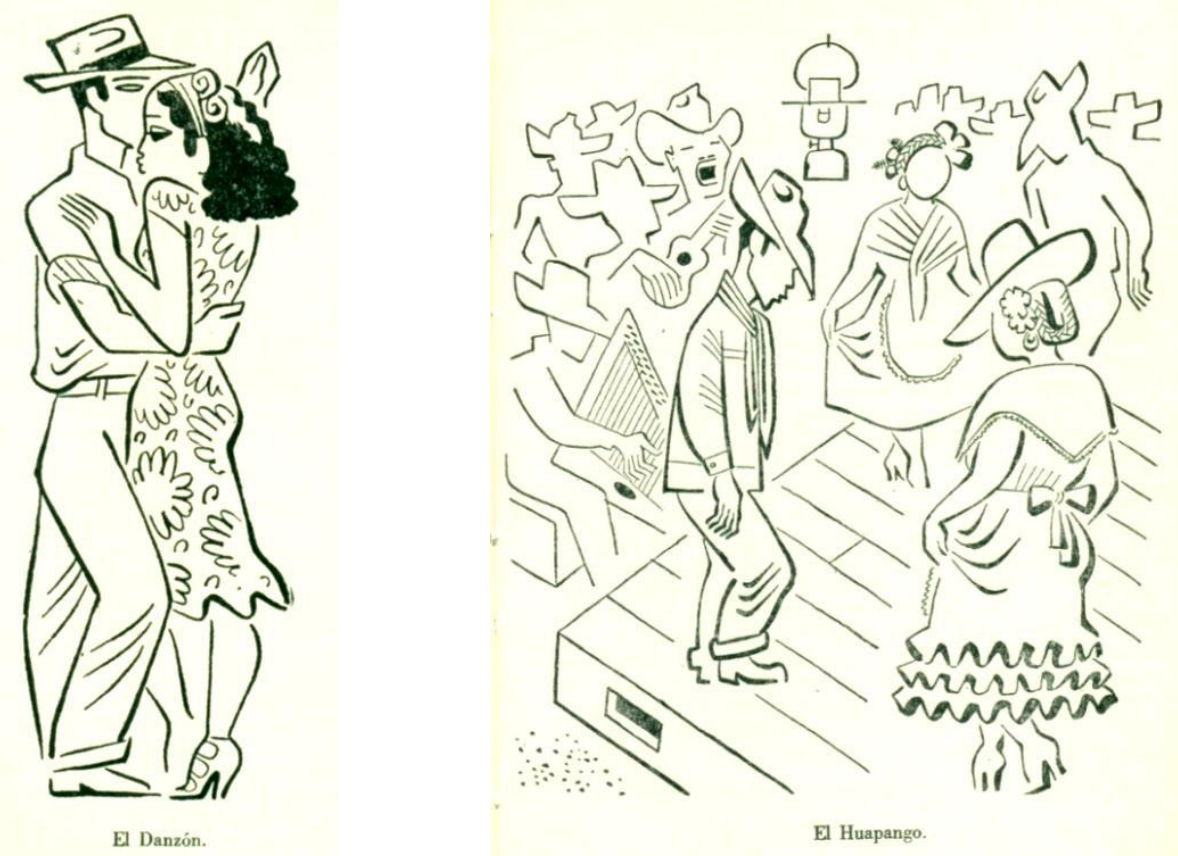

Miguel Covarrubias, dibujos sobre los bailes en el estado de Veracruz: El Danzón y El Huapango, 1947.217

\footnotetext{
${ }^{216}$ Miguel Covarrubias, El Sur de México, México, D.F., Instituto Nacional Indigenista, 1980, 321.

${ }^{217}$ Ibídem, pp. 30 y 45.
} 


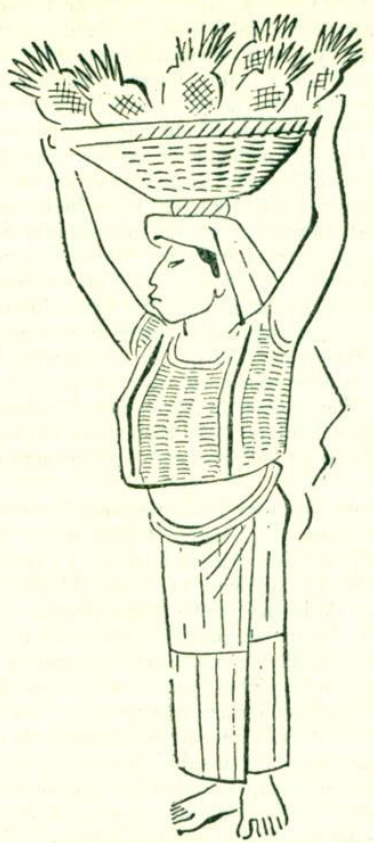

Mujer mixe de Mogoñé.

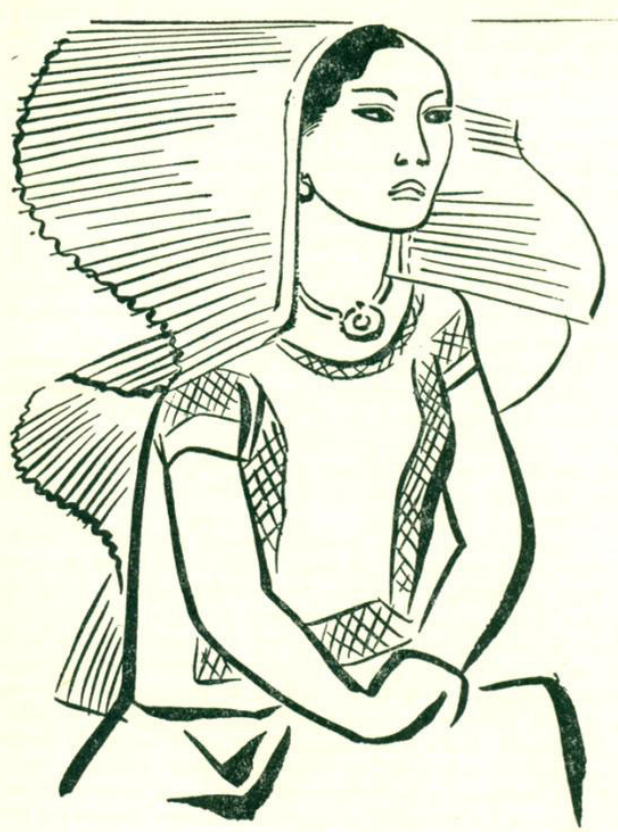

El bida:niró utilizado en ocasiones muy especiales.

Miguel Covarrubias, mujeres del Istmo de Tehuantepec, Oaxaca: Mujer mixe de Mogoñé y El bida:niró, 1947. ${ }^{218}$

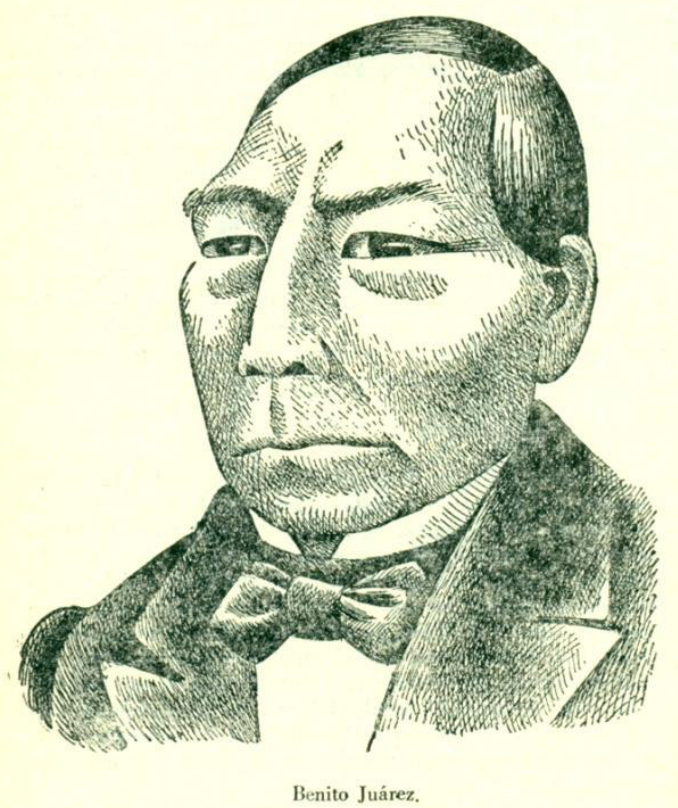

Miguel Covarrubias, Benito Juárez, 1947. 219

${ }^{218}$ Ibídem, pp. 81 y 332.

${ }^{219}$ Ibídem, p. 278. 
Para muchos, tal vez Covarrubias sea más conocido por los murales que realizó para hoteles en la ciudad de México. En 1937 pintó Una tarde de domingo en Xochimilco en el Hotel Ritz y en 1947 Mapa de la Comunicación y México Pintoresco para el Hotel del Prado, obras tristemente desaparecidas con el temblor que azotó a la capital del país en septiembre de $1985 .^{220}$

En este corto camino presentado de la escultura y la pintura Art Déco en México, podemos darnos cuenta que dentro de estas manifestaciones de la plástica, mucho falta por catalogarse y estudiarse, pues queda numerosa escultura pública en el abandono y en el desconocimiento u obra de pequeño formato que no se ha estudiado bajo esta perspectiva, lo mismo que bastante obra mural, así como de caballete a las cuales no se les ha dado la lectura bajo la estética del Déco con la cual fueron realizadas.

${ }^{220}$ El Archivo Covarrubias se encuentra en la Universidad de las Américas-Puebla (UDLAP). Tuve la oportunidad de verlo sin ordenar en 1982, gracias a Eduardo Pérez Peredo, quien trabajaba en Rectoría. Más tarde, en 1986 seguía en las mismas condiciones, arrumbado en una pequeña bodega de periódicos y objetos viejos en la Biblioteca. Durante mi estancia como bibliotecario Referencista de dicha Biblioteca, de 1986 a 1988, en el último año pedí autorización para organizarlo y me di cuenta que había sido salvajemente saqueado, especialmente muchas fotografías de desnudos femeninos de la Isla de Bali. Debido a mi cambio de trabajo hacia Monterrey, sólo organicé por cajas textos, dibujos y fotos, por lo que muchos de los dibujos originales de sus libros y revistas pude tenerlos en mis manos, especialmente los que hizo para el Sur de México. Actualmente el Archivo Covarrubias se ubica en la sección de Libros Raros y Archivos Especiales, en muy buenas condiciones, en la misma biblioteca de la UDLAP.

Sobre la obra de Covarrubias véase:

Sylvia Navarrete, Miguel Covarrubias. Artista y explorador, México, CNCA-ERA, 1993.

"La isla de Bali (extractos) por Miguel Covarrubias", Saber Ver, México, No. 41, marzo-abril 1998, pp. 46-72. Aquí se presentan recopilaciones del libro Island of Bali traducidos al español, con la inclusión de muchas de las ilustraciones que acompañan a la edición original y otras de colecciones particulares. 


\subsection{EL NACIONALISMO MEXICANO EN LA ÉPOCA DEL ART DÉCO}

Así como el indigenismo prehispánico fue una fuente para el Art Déco, queremos brevemente mencionar que hubo por esta época un potente nacionalismo representado de manera diversa a través de las artes plásticas, la literatura, el cine, la música, en donde se buscaba rescatar aquellas imágenes, pasajes o tradiciones que vincularan al México moderno con valores nacionales que reforzaran la tan buscada identidad nacional.

Uno de estos hechos fue la revaloración de las artes populares, mismas que habían sido consideradas como objetos de poca valía y de un consumo para clases económicamente débiles, especialmente entre la élite porfiriana que gastaba en adquirir

productos importados de Francia. Así pues, en el gobierno postrevolucionario de Álvaro Obregón y con motivo de celebrar los cien años de la culminación de la Independencia, se llevó a cabo una gran exposición en Los Ángeles, California y en la ciudad de México en el año de 1921, a la que se llamó Arte Popular Mexicano.

Esta exposición fue uno de los muchos eventos que se llevaron a cabo y quienes colaboraron para la recopilación de piezas fueron Javier Guerrero (1896-1974), Jorge Enciso (1883-1969), Adolfo Best Maugard (1891-1965), Roberto Montenegro y Gerardo Murillo "Dr. Atl" (1875-1964). Fue el Dr. Atl a quien se le encargó la edición de un libro que se tituló Las Artes Populares en México y que sirvió como catálogo de la misma exposición. De aquí, podríamos decir, surge una férrea corriente de enaltecer a las artes populares mexicanas como uno de las raíces verdaderamente autóctonas de la nacionalidad, que tuvo entre sus adeptos, además de los ya mencionados, a muchos artistas más quienes fueron verdaderos evangelizadores de esta tendencia. Al respecto de esto María Teresa Pomar enuncia: "El trabajo de Atl tuvo grandes repercusiones en la revalorización de las artes populares y al ser éstas objeto de exposiciones y reconocimiento mundial, crearon una corriente entre distinguidos intelectuales mexicanos como Luis Covarrubias, Francisca Toor, Gabriel Fernández Ledesma, Carlos Mérida, Vicente Lombardo Toledano, Leopoldo Méndez, Alfonso Caso, Manuel Toussaint y el extraordinario Diego Rivera, quienes 
dedicaron parte de su tiempo y preocupaciones a la investigación y divulgación de las artes populares".221

El caso de la literatura mexicana también siguió esta línea nacionalista a través de la Novela de la Revolución Mexicana durante la fase llamada de Institucionalización. Se escribieron obras en las décadas de los veinte y los treinta, en las cuales se ensalzaba la gesta revolucionaria a través de sus caudillos convertidos en héroes y se trazaban las costumbres de los lugares, así como de sus gentes, con la finalidad de convocar al ideal triunfante de la lucha armada, a una visión nacionalista de un México que rescata los valores del triunfo revolucionario. Tal es el caso de Martín Luis Guzmán (1887-1976) con sus obras El águila y la serpiente, 1928, La sombra del caudillo, 1929, Memorias de Pancho Villa, 1938-1939; de Rafael Felipe Muñoz Barrios, conocido como Rafael F. Muñoz (1899-1972) quien escribió Memorias de Pancho Villa, 1923, ¡Vámonos con Pancho Villa!, 1931, o bien ya en 1941 Se llevaron el cañón para Bachimba; o de José Rubén Romero (1890-1952) quien el nacionalismo lo combina con un regionalismo de su natal Michoacán con Apuntes de un lugareño, 1932, Mi caballo, mi perro y mi rifle, 1936, La vida inútil de Pito Pérez, 1938.

No podemos dejar de citar, en el campo de la poesía, al zacatecano Ramón López Velarde (1888-1921), con el poema Suave Patria, escrito con motivo de los cien años de la consumación de la Independencia, en donde se enaltece de manera panegírica los valores de la nación mexicana.

Sin embargo, una de las apasionadas personalidades por resaltar lo nacional fue José Vasconcelos (1882-1959), quien desde la fundación del Ateneo de la Juventud en 1909 ya propugnaba por ideales nacionalistas. Más tarde, cuando en el gobierno de Adolfo de la Huerta (1881-1955) [mayo a noviembre de 1920] es designado en 1920 Jefe del Departamento Universitario y de Bellas Artes, lanza planes y proyectos por salvaguardar todo aquello que resaltara el nacionalismo; más adelante con Álvaro Obregón fue nombrado Secretario de Educación Pública, de 1921 a 1924, sede desde donde trabajó infatigablemente por la alfabetización, por rescatar las artes populares y el folclor nacional, a través de las Escuelas de Oficios donde se perfeccionaban las habilidades de producción

221 María Teresa Pomar, "Presentación”, en: Dr. Atl, Las Artes Populares en México, México, Instituto Nacional Indigenista, 1980, Serie Artes y Tradiciones Populares, No. 1, p. IX. Esta es una reedición del agotado libro de la exposición de 1921. 
de artesanías, y por el establecimiento de Bibliotecas Públicas en comunidades y pueblos de más de tres mil habitantes, ya que había una fuerte crisis de conciencia nacional histórica, pues los mexicanos no sabíamos, exactamente, quiénes éramos. Para esto, uno de los recursos de Vasconcelos fue el Muralismo pictórico, el cual serviría como agente de lectura de imágenes de la historia nacional y de los triunfos de la Revolución, pues dicho programa estaba avalado por el Presidente Obregón.

Dentro de las muchas obras que escribió Vasconcelos, hay algunas que resaltan ese apasionado nacionalismo que él tanto defendió, aunque siempre apologizando la herencia española como la verdadera creadora de la nacionalidad mestiza mexicana, en libros tales como Quetzalcóatl, 1929, Breve Historia de México, 1937; sus novelas autobiográficas en las cuales además narra el fraude electoral del 29 cuando lanzó su candidatura contra Pascual Ortiz Rubio, Ulises criollo, 1935, La tormenta, 1937, El desastre, 1938, y el Proconsulado, 1939. Y, aunque el tema está más encaminado hacia resaltar la hispanidad de la América no anglosajona, La raza cósmica, 1925, conlleva mucho de mexicanidad.

Por lo que respecta al cine, como en muchas partes, en México también impactó sobremanera por su sonoridad la película The Jazz Singer, 1927, dirigida por Alan Crosland (1894-1936) y producida por la Warner Brothers. Será hasta 1931 cuando aparece la primera película en el país del cine sonoro mexicano como tal, pues hubo intentos anteriores, y que da inicio a la nueva industria cinematográfica. Nuevamente la modernidad tecnológica se incorpora a la vida nacional y muchas salas de cine se construyen bajo la estética del Art Déco. La película de ese año fue Santa, dirigida por el español Antonio Moreno (1887-1967) y estelarizada por Lupita Tovar (1910). ${ }^{222}$ Con la fotografía de Alex Phillips (1900-1977) y el sonido de los hermanos Rodríguez, la segunda versión de la famosa novela de Federico Gamboa (1864-1939) -la primera fue filmada en 1918- es el punto de arranque del cine mexicano sonoro. Emilio García Riera explica que la cinta "sí tuvo buen éxito, a pesar de lo rudimentario de su realización: estrenada el 30 de marzo de 1932 en el cine Palacio, duró tres semanas en cartelera y fue vista por el público, ahora sí, como el auténtico comienzo del cine sonoro mexicano". ${ }^{223}$ Sugestivo el dato que haya sido

\footnotetext{
${ }^{222}$ Lupita Tovar cumplió 103 años en 2013. Es la última noticia que se tiene de ella. Reside en Estados Unidos.

${ }^{223}$ Emilio García Riera, Historia del Cine Mexicano, México, SEP, 1986, p. 81.
} 
el estreno en el Cine Palacio, pues fue uno de los templos cinematográficos de la capital que ostentaba decoraciones Art Déco.

Este nuevo cine se desarrollará bajo diversas orientaciones, tales como los temas históricos, revolucionarios, rurales y de la vida moderna, muchos de ellos exaltando el nacionalismo mexicano. Tres películas de Fernando de Fuentes (1895-1958), El compadre Mendoza, 1933, uno de los clásicos del cine nacional con tema revolucionario, lo mismo que Vámonos con Pancho Villa, de 1935, la cual es una adaptación hecha por Xavier Villaurrutia (1903-1950) de una novela de Rafael F. Muñoz, con música de Silvestre Revueltas (1899-1940) y Allá en el Rancho Grande, 1936, la película que hizo consolidar la industria cinematográfica de México y que obtuvo el primer premio internacional al ganar en Venecia en 1938 el premio por la fotografía de Gabriel Figueroa (1908-1998) y además de lanzar al primer ídolo cantante del cine, Tito Guízar (1908-1999), son una trilogía que aunque tratando temas revolucionarios y rurales, resaltan el nacionalismo a través de las locaciones, música y canciones que reflejan un México pintoresco y ranchero que mucho gustó al público mexicano y al extranjero.

Algunas películas de la época cuya escenografía, fotografía y ambientación conllevan la estética del Art Déco son: Janitzio, 1934, dirigida por Carlos Navarro con fotografía de Jack Draper (1892-1962), en la que se caracteriza a indios purépechas, se ubica en la isla del místico lago de Pátzcuaro en donde más tarde se levantara una de las estatuas del Art Déco mexicano, el ya explicado Monumento a Morelos de Guillermo Ruiz; Redes, 1934, dirigida por el austriaco Fred Zinnemann (1907-1997) y los mexicanos Emilio Gómez Muriel (1910-1985) y Julio Bracho (1909-1978), relata la realidad social de pescadores veracruzanos, con interesantes escenas de redes y pescados que se acompasan con la música de Silvestre Revueltas. Dos Monjes, 1934, de Juan Bustillo Oro (1904-1988), cuyo recurso expresionista de luces y sombras, así como los colores blancos y negros en la vestimenta de los personajes le dio un carácter de cine de vanguardia. Y del mismo Bustillo, la risible cinta de Cantinflas, Ahí está el detalle, 1940, con la cual el cómico de México inicia su carrera de largometrajes, recoge los modos de vida de una familia de la clase media alta de la ciudad de México, en la que se aprecian los decorados modernos de la lujosa residencia, como los zigzag típicamente Déco de la escalera. 
No podemos dejar de mencionar la importante participación del soviético Sergei Eisenstein (1898-1848) en México con el intento de la filmación ;Qué viva México!, 1931, cinta que busca reproducir la vida social del país; además, realizó una serie de dibujos sobre personas y lugares de México. La presencia de Eisenstein tuvo un gran impacto en realizaciones posteriores de directores mexicanos.

Entonces, el cine nacional se convierte en una industria de los tiempos modernos de los años treinta, que intentaba dar a los mexicanos un retrato de su historia, de sus costumbres, de su Revolución y de su nueva vida. Moda de la época de la naciente clase media, como uno de los nuevos medios de diversión, el asistir al cine, el cual se veía en grandes salas nuevas, lujosas, iluminadas con luz neón, descritas así en el libro La República de los cines: "El déco adornó las enormes fachadas de los cines con motivos geométricos: ángulos rectos, perfiles trapezoidales $\mathrm{y}$, en algunos casos, elementos de arquitectura prehispánica, como grecas y mascarones. También se llevó a los interiores, donde enmarcó puertas, ventanas y bocaescenas, o apareció en el diseño de muebles, lámparas, jardineras, barandales y abrazaderas. Durante casi dos décadas, el déco representó para los habitantes de las grandes ciudades del país algo más que un estilo arquitectónico: una manera de vivir y de interpretar la modernidad". 224

Si el cine va de la mano con el desarrollo del Art Déco en México, lo mismo sucedió con la radio. Si bien desde el final de la larga dictadura del gobierno del Gral. Porfirio Díaz, ${ }^{225}$ en 1911 la Red de Radio Nacional que consistía de 9 aparatos de telegrafía y radiocomunicación ya tenía contacto con algunos países del continente y en 1916 el gobierno de Alemania regaló al Presidente Venustiano Carranza [1914-1920] un radiotransmisor que emitía con gran potencia desde el Castillo de Chapultepec, donde se encontraba la casa presidencial. Pero fue en Monterrey, la capital industrial de México, en la región Noreste, donde se dio el gran acontecimiento radiofónico: en 1919 el joven y futuro ingeniero Constantino de Tárnava Garza (1898-1974), desde su casa ubicada en las calles de Padre Mier y Guerrero, logró la primera radiodifusión con dos radioaficionados; por eso es que a Tárnava se le considera "El Padre de la Radiodifusión en México", quien más tarde, el 9 de octubre de 1921 desde su mismo domicilio realiza el primer programa en

\footnotetext{
${ }^{224}$ Francisco H. Alfaro y Alejandro Ochoa, La República de los cines, México, Clío, 1998, pp. 38-39.

${ }^{225}$ Porfirio Díaz gobernó de 1877 a 1880 y luego ininterrumpidamente desde 1880 hasta abril de 1911 cuando renuncia con el estallido de la Revolución Mexicana.
} 
vivo con la siglas TND, Tárnava Notre Dame, su apellido más el nombre de la universidad norteamericana donde obtuvo el título de Ingeniero Eléctrico.

En la ciudad de México el 21 de septiembre de 1921 se ofreció un programa de música transmitido desde el desaparecido Teatro Ideal, hasta el Teatro Nacional, hoy Palacio de Bellas Artes y unos días después, el 27 de septiembre de 1921, se transmite el primer programa radiofónico desde el Teatro Ideal. Al año siguiente, a finales de 1922, el Presidente Álvaro Obregón apoya el desarrollo de la radio y funda su gobierno la JH, la primera emisora diseñada y construida en México, manejada por la Secretaría de Guerra y Marina, que inició sus operaciones formales en 1923. En esos mismos años, el aguerrido José Vasconcelos, a quien más vinculamos con el Muralismo y sus campañas educativas, estaba sorprendido con el novedoso invento de la radiodifusión, a tal grado que en su despacho personal en el centro de la capital, tenía su propia emisora la CYH, ya que Vasconcelos siempre pensó que con ese maravilloso modelo de transmisión radiofónica se podían llevar a cabo muchos de sus proyectos educativos, como la creación de radios culturales para enaltecer los valores nacionales. Sin embargo, estos proyectos radiofónicos no se consolidan en lo que sería la radio, formalmente hablando de ella. Fue hasta mayo de 1923, cuando el periódico El Universal Ilustrado funda la CYL, operada por la Casa del Radio, que se dedicó a traer a México discos y aparatos de transmisión; su programación era de corte musical así como comercial y los primeros mexicanos que podían adquirir un aparto receptor eran los de la clase alta y política. Se escuchaban las piezas de foxtrot, de ragtime, de baladas francesas, podríamos decir, que la música moderna comercial de aquellos años. Y en el mismo año, la compañía cigarrera El Buen Tono, cuyos dueños eran los hermanos Duprá de origen francés, lanzan la CYB a instancias de las sugerencias del financiero Raúl Azcárraga, convenciendo a los empresarios franceses que una estación de radio serviría como el principal agente de anuncios comerciales para sus productos del cigarro; así, el 14 de septiembre de 1923 sale al aire la CYB, que transmitiera la ceremonia del aniversario de la Independencia en el 15 de septiembre de ese mismo año y durante sus 7 años de existencia sentó las bases de la radiodifusión en México, con sus propios técnicos, su propio personal administrativo, transmitiendo programas musicales, culturales, noticiosos, creando la radionovela en México y con anuncios comerciales. Para 1929 la estación cambia de siglas a XEB que "para entonces habían innovado la vida cultural, 
técnica y de entretenimiento del México modernos adscrito a la corriente art déco, esta emisora desde sus inicios, fue testigo de un sinnúmero de aplicaciones en cuanto a impacto cultural y social". 226

Pero el gran acontecimiento radiofónico del país es cuando el empresario Emilio Azcárraga Vidaurreta (1895-1972), hermano de Raúl creador de la CYB, lanza la XEW el 18 de septiembre de 1930. Estación que existe hasta la fecha y de donde más tarde surgiría Telesistema Mexicano, actualmente Televisa, una de las televisoras más grandes del mundo, fue la catapulta de la radiodifusión comercial en el país, con noticieros de corte tanto nacional como internacional, donde además de escuchar música extranjera, se dieron a conocer los grandes de la música mexicana ranchera como Pedro Infante (1917-1957), Jorge Negrete (1911-1953), Tito Guízar (1908-1999), el Mariachi Vargas de Tecatitlán de Silvestre Vargas (1901-1985), o de las baladas y boleros como Toña "La Negra" (19121982), Agustín Lara (1900-1970), Pedro Vargas (1908-1989), Antonio Badú (1914-1993), y muchos tantos más que entre 1930 y 1950 conformaron una época de oro de la canción mexicana. A cuántos de esos artistas dibujó el maestro del Art Déco gráfico en México, "El Chango" García Cabral, inmortalizándolos aún más con su diestra mano, en elegantes caricaturas, enfatizando la línea, el color y los fondos geométricos en esa ambientación moderna, urbana, refinada de los años del Déco.

"La voz de América Latina desde México", eslogan que hiciera famoso el locutor Leopoldo Samaniego desde los inicios de las estación y que identifica a la XEW, qué más Déco que sus antiguas instalaciones de la década de los años treinta, cuyo balcón, rejería de las ventanas, no eran otra cosa sino una amalgama de herrerías en formas de rayos que vitalizaban la fuerza expresiva de la modernidad maquinista y tecnológica, así como las siglas de las estación que estaban rodeadas de ondas hertzianas, todo le imprimía a la fachada del edificio un ambiente del imaginario de la radiotransmisión con diseños cien por ciento Art Déco Zigzag.

\footnotetext{
${ }^{226}$ Jesús Flores y Escalante, Pablo Dueñas, "El Art Déco y la radiodifusión: forma de vida urbana”, Relatos e historias en México, México, D.F., Editorial Raíces, Año II, Número 22, junio 2010, p. 60.
} 


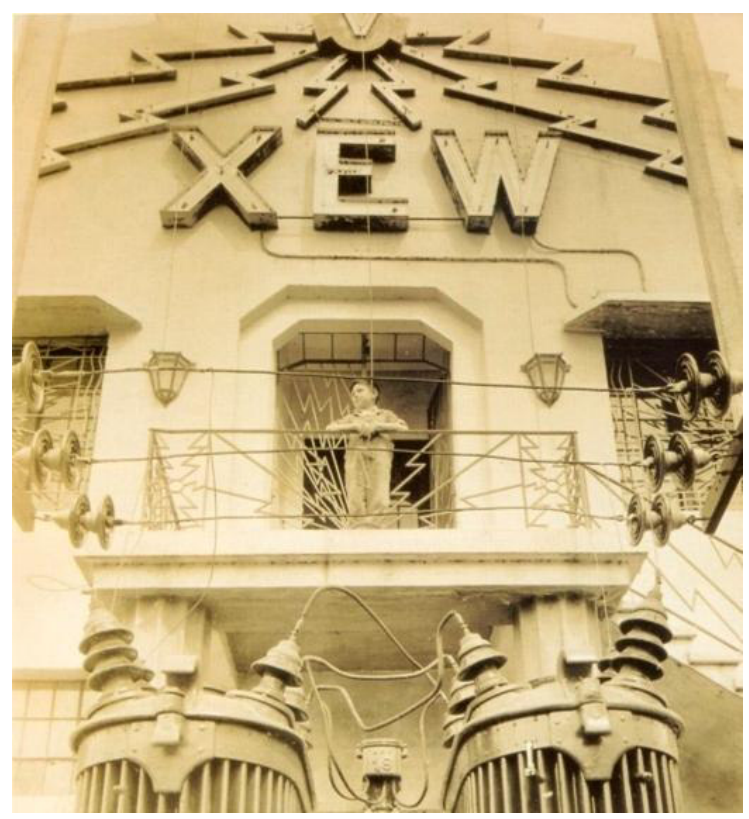

XEW, México, D.F., ha. 1935.227

Por una parte la radio comercial, por otra, la oficial. El recién fundado partido de estado, el PNR (Partido Nacional Revolucionario) con el fin de difundir su plataforma política, sus acciones gubernamentales, resaltar el patriotismo postrevolucionario, exaltar los valores del indigenismo y de las luchas obrero y campesinas, funda la XEFO, como una estación de gobierno, que entre otras cosas buscaba crear, y como tal lo consiguió, un nacionalismo de estado y partidista. La estación fue vendida a particulares en 1946, al final del gobierno del Gral. Manuel Ávila Camacho [1940-1946]. Durante el Cardenismo se fundó La Hora Nacional en 1937, transmitida los domingos por la noche a través de la XEDT, emisora que pertenecía al Departamento Autónomo de Prensa y Publicidad, dependiente del Ejecutivo Federal. La finalidad del Gral. Lázaro Cárdenas fue que mediante una hora oficial y única, ya que se prohibía a las demás estaciones transmitir durante el programa, era difundir todo su plan de gobierno, sobre todo una vez que se había cvsentado fuertemente en la silla presidencial, una vez que había expulsado al Gral. Elías Calles del país. Entre discursos oficiales, se transmitía música vernácula, anécdotas históricas, claro que estuvieran a favor del partido en el poder, con el objetivo de crear un nacionalismo político de estado, ensalzando los logros revolucionarios y de la nueva

\footnotetext{
${ }^{227}$ Catálogo de la exposición Art Déco. Un país nacionalista. Un México cosmopolita, Op., Cit., p. 115.
} 
familia política dirigida por la mano firme del Gral. Cárdenas; porque como dice Abelardo Villegas, en su tiempo Lázaro Cárdenas afirmaba que el gobierno, su gobierno, era el árbitro y regulador de la vida social del país, con un interés por ayudar a obtener una mejor vida para todas las clases sociales y no sólo a las clases obreras y campesinas, pilares de la ideología postrevolucionaria. ${ }^{228}$ Como fuerte promotor de la tecnificación del país, el Gral. Cárdenas permitió la importación de aparatos domésticos receptores de las transmisiones radiofónicas, con lo cual el número de oyentes se multiplicó y podríamos afirmar que junto con el cine, la radio se convirtió en el entretenimiento familiar por excelencia.

Los años treinta de la tecnificación y el maquinismo del Déco de la época del Streamline se reflejan en la radio, ya que la estación del ingeniero Tárnava cambia de siglas de la CYH a la XEH en 1931, estación de AM que existe hasta la fecha en Monterrey. Su contenido musical, daba a conocer muchas piezas de la música norteamericana, desde el Charleston, hasta el Boogie boogie, la canción romántica, además de los noticieros y la publicidad de la Casa Guajardo, fabricante de refrescos y de la Cervecería Cuauhtémoc, entre otros temas. A partir de 1932 el eslogan de la estación fue "La voz de Monterrey desde 1921". Y otro hecho relevante para la radio en Monterrey fue la creación, también en 1931, de la XET, “El Pregonero del Norte”, estación que sigue transmitiendo con el lema de "La T Grande", con los contenidos rítmicos de la música norteña y los anuncios comerciales. El hecho de que hubiera dos estaciones bien asentadas y desarrolladas en Monterrey en la década de los treinta, significó a la vez la compra de aparatos domésticos de radio, que debido a la cercanía con la frontera con Laredo, Texas, la importación de la mismos era muy económica y las familias de trabajadores obreros, clase media y ni se diga de niveles económicamente superiores pudieron de hacerse de estos aparatos, lo que significaba un mejoramiento en la capacidad de consumo y permitía estar al día de los acontecimientos tanto nacionales como mundiales.

La radio universitaria surgió cuando la Universidad Nacional funda su estación Radio UNAM, en el mismo año que se fundó La Hora Nacional, en 1937. Con la finalidad de difundir el quehacer universitario, sus eventos, divulgar la música mexicana y las tradiciones del país, con lo que la estación se posicionó con el paso de los años como el

${ }^{228}$ Abelardo Villegas, "El sustento ideológico del nacionalismo mexicano", UNAM, El Nacionalismo y el Arte Mexicano (IX Coloquio de Historia del Arte), México, UNAM, IIE, 1986, p. 396. 
modelo de la radio universitaria. Un año más tarde, en 1938, Emilio Azcárraga funda en la ciudad de México la XEQ (hermana de la XEW), otra de las grandes radiodifusoras comerciales del país que transmitía música en español, emisora que ha hecho inolvidables muchos programas y artistas nacionales que van siendo los número uno en su época. Y en el año de 1941 se crea la XEJB, la primera estación de una entidad federativa que fue la del Gobierno de Jalisco, con la cual se reforzaba la ideología partidista oficial en uno de los estados con mayor desarrollo del país, tanto en lo económico, en lo político y el cultural, tomando en cuenta que grandes personalidades del mundo del arte y la cultura en México han sido oriundos del estado de Jalisco.

Entre los años 1930 a 1940 el número de radiodifusoras creció enormemente en el país, por lo que se tuvo que reglamentar la transmisión y sus usos a través de la Ley de Vías Generales de Comunicación. Pero el desarrollo de la radio a la par con el Art Déco en el mundo y en México es por los diseños de los aparatos receptores, aquellos modelos conocidos como "capilla", por tener una composición a manera de arco gótico apuntado, o los de tipo "casa", que eran cúbicos; en ambos casos, primero en madera, luego en baquelita, para dar salía al sonido, en las bocinas se realizaban diseños geométricos, como los radios Pilot o los Stewart Warnes de fabricación norteamericana, los cuales llevaban tres líneas verticales ascendentes, que luego se acompasaban con tres bandas de la base y tres escalonamientos en los bordes, creando una reducción de las composiciones arquitectónicas de los grandes edificios Déco.

También estaban aquéllos legendarios radios Philips, holandeses, que tanto se vendieron por todo México, de tipo “capilla”, cuyas bocinas eran protegidas por una circunferencia, atravesada en el centro por tres líneas ondulantes y cuatros estrellas distribuidas equilibradamente, con lo que ayudaban al receptor a imaginar a las ondas hertzianas en un juego aerodinámico, como si fuera una danza al ritmo de la voz y la música o un escenario donde se estaba llevando a cabo el espectáculo. Igualmente los $R C A$ Victor, también de manufactura estadounidense, de gran tamaño, cuadrados, curveados en los flancos laterales, con la bocina protegida por una celosía de formas rectangulares y recortadas curvilíneamente en las esquinas y a la vez con tres grandes bandas verticales al centro que se conjugan con el grupo de tres triglifos en la parte inferior, implantando verdaderos esquemas Art Déco y remedando a los muebles de los grandes diseñadores 
europeos emanados de la Exposición parisina de 1925. Otros tantos diseños de los años cuarenta, cuando las bocinas rectangulares en posición horizontal se recortan en fajas que caen de un lado, o aquellos de líneas radiales, como las bandas decorativas de los edificios Streamline.

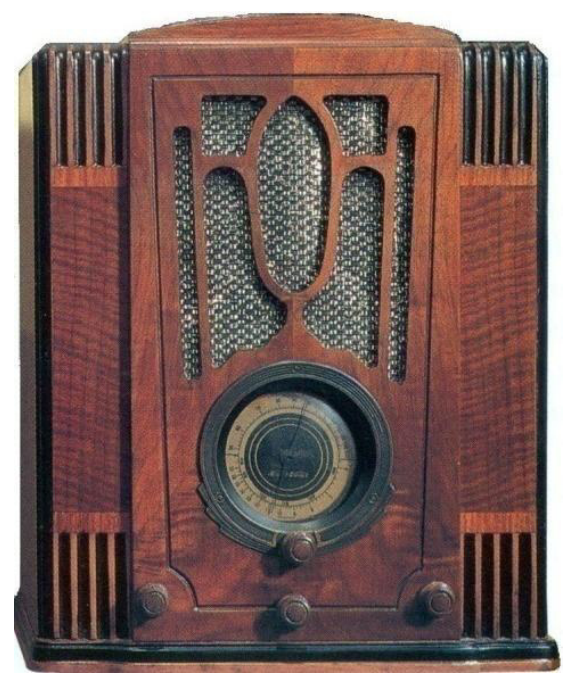

Radio Stewart Warnes, 1929. Colección particular. ${ }^{229}$

En síntesis, como explicara la Doctora Joy E. Hayes, Catedrática de la Universidad de Iowa, ${ }^{230}$ hubo una estrecha relación entre la radio, el nacionalismo, la cultura popular y el Art Déco en México entre 1920 a 1940, tal como lo exponemos desde nuestro análisis, están fraternizados a través de los diseños de esas cajas receptoras que entre botones, pantalla de sintonía y protectores de bocinas crearon objetos Déco, desde el tipo Clásico Moderno hasta el Streamline.

Por lo que respecta a la música académica, en la década de los veinte, treinta y principios de los cuarenta surgen las grandes personalidades de la época: Carlos Chávez (1899-1978), Blas Galindo (1910-1993), Pablo Moncayo (1912-1958), Silvestre Revueltas (1899-1940), Candelario Huízar (1883-1970) y Miguel Bernal Jiménez (1910-1956),

\footnotetext{
${ }^{229}$ Felipe Gálvez, "Voz jinete del aire", México en el Tiempo, México, D.F., Año 3, No. 23, marzo/anril 1998, p. 12.

${ }^{230}$ La Dra. Joy. E, Hayes tuvo una estancia de seis meses en la Universidad de Monterrey, de enero a junio de 2000, a través de una beca Fulbright. En varias conversaciones que tuve con ella hablamos de esa relación de elementos que exponemos aquí. Su interés de estar en Monterrey fue por los hechos históricos del origen de la radiodifusión en el país.
} 
quienes con algunas de sus composiciones entraron dentro de ese mexicanismo que buscaba resaltar la identidad nacional, para lo cual utilizaron ritmos autóctonos de etnias indígenas, temas populares regionales y, en algunos casos, temas virreinales.

Carlos Chávez fundó en 1928 la Orquesta Sinfónica de México, así como el Conservatorio Nacional en el mismo año, dentro de esa etapa de fuerte promoción cultural heredada del vasconcelismo. De sus composiciones destaca por su integración de ritmos y temas autóctonos mexicanos, seris y yaquis de Sonora y huicholes de Nayarit, la Sinfonía India, 1935, estrenada en 1936 en Estados Unidos. Con Daniel Ayala (1908-1975), Pablo Moncayo y Salvador Contreras (1912-1982), Chávez formó parte del "Grupo de Los Cuatro", quienes buscaban difundir su propia música.

Blas Galindo desde muy joven fundó una banda en su natal Venustiano Carranza (antes San Gabriel), Jalisco, lo cual mucho influyó en una de sus composiciones más difundidas, Sones de Mariachi, que escrita a finales de los años treinta se basa en canciones como el Son de La Negra, El Zopilote y Los Cuatro reales, y fue estrenada por el mismo Carlos Chávez en New York en 1940 con motivo de la Exposición de Arte Mexicano.

El también jalisciense Moncayo tuvo una fuerte actividad con la Sinfónica de México; su composición Huapango, 1941, pieza sinfónica que se inspira en tres sones veracruzanos entre ellos El Siquisirí, se ha convertido en la imagen nacional de la música sinfónica para representar lo mexicano; sin embargo, ha sido demasiado utilizada en fondos musicales de diversa índole cuando se quiere hablar de México por lo que ha caído en el choteo. El zacatecano Candelario Huízar recibió fuertes influencias de las bandas de su natal Jerez, lo cual integró en su obra Pueblerinas de 1931, obra en la que se aprecian los ritmos a manera de la tambora y los instrumentos de metal, con un fuerte sabor de folclorismo.

Otro caso muy importante de la música de esa época fue el michoacano Miguel Bernal Jiménez. Con formación musical en Roma, su principal actividad la llevó en su natal Morelia en el Conservatorio de las Rosas y no en la ciudad de México como los demás músicos. Colonialista, algunas de sus composiciones buscan transmitir el sabor musical de esa período, como una de las vetas del nacionalismo mexicano; tal es el caso del Cuarteto Virreinal, 1937, que se basa en las rondas infantiles A la víbora, Naranja dulce, Pase la escogida, Pica perica. También participó, durante los primeros años de la década de los 
cuarenta en el cine, al realizar la música para películas que narran historias virreinales e independistas como fueron las cintas La Virgen que forjó una Patria, 1942, bajo la dirección de Julio Bracho (1909-1078), la cual al año siguiente ganó el Premio Anual de la Academia de Ciencias y Arte Cinematográficas por ser la película mejor musicalizada; $E l$ padre Morelos, 1942 y El rayo del sur, 1943, ambas bajo la dirección de Miguel Contreras Torres (1904-1981).

Sin embargo, dentro de ese nacionalismo virreinal, Bernal Jiménez escribió en 1940 el drama sinfónico Tata Vasco, con argumento del padre Manuel Muñoz, en tres cuadros y cinco actos, obra en la que resalta la figura del ilustre Obispo Vasco de Quiroga (h.14701565), utilizando nombres y algunas frases en lengua purépecha; fue estrenada precisamente en la apacible ciudad de Pátzcuaro el 15 de febrero de 1941, en el templo San Francisco, para conmemorar el cuarto centenario de la llegada de Don Vasco a dicha ciudad. $^{231}$

Mención aparte merece el duranguense Silvestre Revueltas, pues su labor como difusor de la música contemporánea mexicana, y más tarde como Director de la Orquesta Sinfónica Nacional, la combinó con su tarea más loable y degustada: la de compositor. Bien se puede decir de su obra musical que en la mayoría de sus composiciones combina las nuevas tendencias de la música de vanguardia con los ritmos autóctonos de varias regiones de México, entresacados del referente de las bandas pueblerinas, danzas folclóricas y ritmos populares. Realizó muchos temas de películas y una amplia variedad de obras para ensambles menores y orquestas sinfónicas. Además de las conocidos temas de películas de la época vale la pena mencionar Ranas, 1931, El renacuajo paseador, 1936, ${ }^{232}$ Homenaje a García Lorca, 1936 y unas de las más consumadas Sensemayá, 1938, inspirada en el poema del cubano Nicolás Guillén (1902-1989) y La noche de los mayas, 1939. Su fuerte nacionalismo integrado a su música se interrelaciona con los años del Déco, ya que por su corta vida, precisamente son los años veinte y treinta los de su producción, aunado a que era hermano del pintor Fermín Revueltas y además fue retratado por el escultor Carlos

\footnotetext{
231 Otto Mayer-Serra, Músicos y Música de Latinoamérica, México, Atlante, 1947, vol. I, pp. 105-106.

232 El renacuajo paseador obra poco difundida y Redes, 1935, lo mismo que la Sinfonía India de Carlos Chávez fueron ejecutadas aquí en Monterrey, con motivo de los cien años de los natalicios de Revueltas y Chávez, en la temporada Verano 99 de la Orquesta Sinfónica de la UANL, bajo la dirección de Félix Carrasco.
} 
Bracho (1899-1966) es un pequeño busto en basalto negro, efigie en la que el cabello ondulado fue tratado a la manera de las curvas de ramos o tallos enmarcados dentro de la estética Art Déco. Por la calidad de sus composiciones a Revueltas se le ha considerado como el mejor compositor mexicano de la primera mitad del siglo XX.

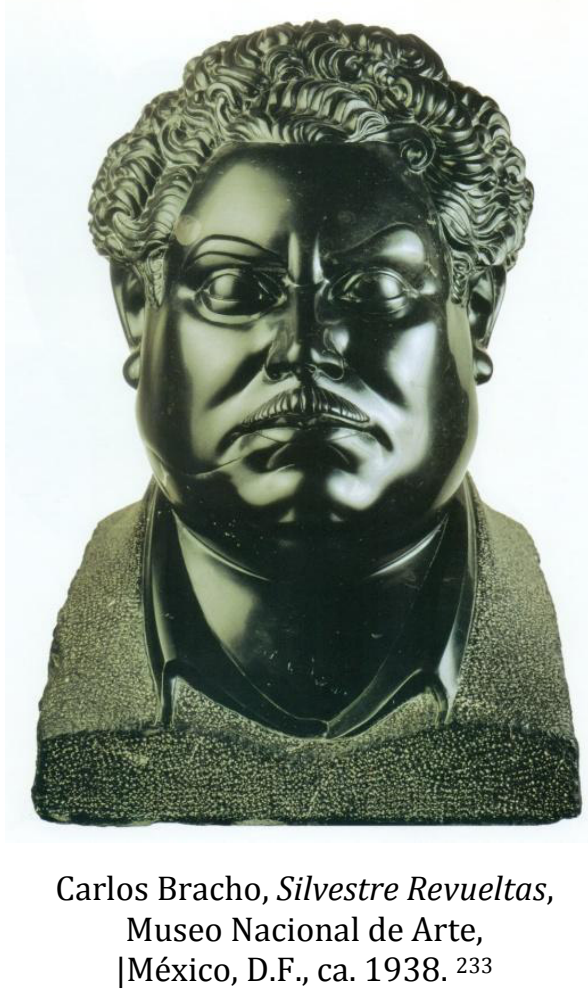

Con literatura, pintura, cine, radio, música, entre otras vertientes, sus creadores buscaban contribuir con la fuerte tendencia de la afirmación nacionalista que se dio entre las décadas de los veinte y los treinta. Literatura que narraba el origen de la transformación de un México rural a uno moderno. Murales y óleos que mostraban a la Revolución como gestadora del cambio, así como el nuevo rostro del país, del que se exaltaban sus tradiciones. Películas, cine, la nueva forma de gastar el ocio, en producciones que ensalzaban lo nacional revolucionario, con un fuerte afán nacionalista y que se veían en lujosas y nuevas salas cómodas, con luz neón, decoradas modernamente bajo los cánones del Art Déco. La radio con sus programas de música folclórica y la radio oficial en

${ }^{233}$ Enrique Franco y Agustín Arteaga, Op. Cit., p. 204. 
búsqueda de crear un nacionalismo político de Estado. Música de concierto, de nuevos creadores; compositores que emergen bajo la tutela de las campañas culturales y que resaltan lo mexicano a través de sus obras, las cuales son estrenadas en México y en el extranjero y más tarde tendrán una sala de conciertos acorde con su tiempo: el teatro del Palacio de Bellas decorado en el más puro Art Déco.

La cultura en México se moderniza buscando una integración de lo nacional y el Art Déco se nacionaliza exaltando su modernidad. 


\section{EL ART DÉCOEN EL NORESTE DE MÉXICO}




\section{1. EI NORESTE DE MÉXICO: NUEVO LEÓN Y COAHUILA}

El Noreste de México es una región que abarca los estados de Tamaulipas, Nuevo León y Coahuila.

Tamaulipas es el estado que está situado más al oriente. Tiene una extensión superficial de $79.384 \mathrm{~km}^{2}$, colindando al este con el Golfo de México, al oeste con Nuevo León, al norte con Texas en los Estados Unidos y al sur con Veracruz y San Luis Potosí. Sus orígenes como estado vienen de la fundación de la Provincia de La Nueva Santander en 1746. Ya como el actual estado de Tamaulipas con toda su territorialidad tiene su origen el 7 de febrero de 1824 cuando se instaura la primera república federal. La capital del estado es Ciudad Victoria. Después de la Revolución y en los años treinta del siglo XX su economía e impulso se vio reflejado por la ganadería y la agricultura como hasta la fecha. Una ciudad que ha sido substancial para su desarrollo es el puerto de Tampico fundado desde 1554 y es el segundo puerto más importante del país.

Nuevo León se encuentra en medio de Tamaulipas y Coahuila. Su extensión territorial es de $64.924 \mathrm{~km}^{2}$. Sus colindancias son al este con Tamaulipas, al oeste con Coahuila, al norte con Tamaulipas y una pequeña parte con Texas y al sur y suroeste con San Luis Potosí. Los orígenes datan cuando desde 1582 se intentara fundar la ciudad Monterrey en un territorio que recibió en nombre del Nuevo Reino de León, ordenanza autorizada por el mismo Felipe II en su política de población de la parte norte de la Nueva España. Guardando prácticamente la misma superficie cuando se forma la Provincia de Nuevo León en 1786, el 5 de julio de 1821 se conforma el estado de Nuevo León con capital Monterrey, dentro de la primera república federada. En el siglo XX Nuevo León despegó como el titán industrial de México en la ciudad de Monterrey, donde la industria del acero, cemento, vidrio y cerveza desarrollaron fuertemente a la ciudad, convirtiéndola en la segunda más importantes del país, después de la capital de la república, donde además de sus industrias, destaca por su entidades financieras y sus centros educativos de nivel superior.

Coahuila es el estado del Noreste que más hacia el poniente se encuentra. Sus fronteras están delimitadas por el este con Nuevo León, por el oeste con Chihuahua y Durango, el norte con Texas y el sur con Zacatecas y San Luis Potosí. Tiene una extensión 
territorial de $151.571 \mathrm{~km}^{2}$, siendo el tercer estado más grande del país después de Chihuahua y Sonora. En los tiempos del virreinato, durante el siglo XVII Coahuila quedó comprendida entre La Nueva Vizcaya y la Nueva Extremadura. En 1786 dentro de la Intendencia de Durango, estaba la Provincia de Coahuila que rebasaba el río Bravo, actual frontera con Texas. El 25 de junio de 1824, dentro de la primera república federal se crea el estado de Coahuila con capital Saltillo. Sin embargo con la guerra contra Texas de 1836 se pierde una gran parte del territorio, quedando como límite el cauce del rio Bravo. Durante la fase armada de la Revolución Coahuila tuvo una destacada participación. Una vez establecida la paz, Coahuila continuó con la ganadería como uno de los principales motores de desarrollo, pero ya para los años cuarenta en la zona de Torreón con la industria láctea y Monclova con el acero, el estado viró hacia un desarrollo más activo, tanto en lo económico como en lo social.

Como mencionamos en la introducción, del Noreste de México tratamos solamente los estados de Nuevo león y Coahuila, por tener más afinidades en el desarrollo del Art Déco.

\subsection{El ART DÉCO EN NUEVO LEÓN}

En Nuevo León el desarrollo del Art Déco tuvo mucha presencia pues en Monterrey la industrialización caminaba a pasos agigantados dentro de la modernidad postrevolucionaria. Educación y servicios tanto públicos como privados estaban en la necesidad de modernizar su arquitectura y decoración, proceso en el cual también entrará unos años más tarde la iglesia católica con nuevas construcciones y ornatos en sus templos. El esparcimiento moderno con las salas de cine, además de las decoraciones de espacios interiores con vitrales y murales en edificios públicos, van de la mano con el levantamiento de monumentos en la ciudad. En otros municipios también hubo algunas manifestaciones del Déco, como fue en Anáhuac, pueblo fundado en 1933 donde hay bastantes construcciones de tipo Art Déco, pero que no todas son significativamente destacadas en su estética. El caso de Linares, que se considera como el segundo municipio más importante, después del área metropolitana, tiene algunos ejemplos del Déco que se han mantenido en 
pie. Sabinas Hidalgo y Salinas Victoria poseen también algunos ejemplos dignos de ser estudiados.

\subsubsection{Monterrey, capital industrial de México y sus producciones Art Déco}

A partir de la década de 1920, la vida regional siguió con altibajos en materia política. En ese año Monterrey contaba con 88.497 habitantes. A toda costa, las autoridades del gobierno estatal buscaban restablecer la paz social y la pujanza económica interrumpida por la revolución. Lamentablemente no pudieron cumplir con su objetivo, ya que las distintas facciones revolucionarias entraron en pugna con los partidarios del Plan de Agua Prieta.

Pero después, los integrantes del grupo político de Sonora se dividieron y entre ellos también comenzó el separatismo. De 1920 a 1927 se dieron cambios tanto a nivel nacional como regional, que de una u otra forma van a impedir el despegue industrial de Monterrey. No obstante y a pesar de los problemas políticos, el país preparó las bases para un repunte económico que permitiera el desarrollo de los principales aspectos socioeconómicos.

A partir de 1920 hubo una buena cantidad de capitales tanto regionales como extranjeros que promovieron la vida productiva nacional. El florecimiento industrial regiomontano trajo como consecuencia el renacimiento de las actividades socioeconómicas por lo que de 1927 a 1936, las empresas industriales pasaron de 663 a 1047. En cierta forma, el auge industrial se vio apoyado por la promulgación de una ley de Protección a la Industria en 1927 y la ley de la jornada máxima del trabajo que legislaba jornadas de ocho horas. A pesar de problemas económicos de orden mundial, la ciudad continuó su crecimiento.

Es en estos tiempos que se funda la empresa Cementos Portland Monterrey, S.A., el 28 mayo de 1920 por Lorenzo Zambrano H. Gutiérrez (1888-1935), pero que inició como tal las actividades productivas hasta 1922, con un horno marca Allis-Chalmers con capacidad para producir cuarenta y cinco mil toneladas anuales. Tan sólo un año después, la 
compañía cementera obtenía una medalla de plata en la Exposición Internacional de Río de Janeiro, Brasil y en 1924, la de oro. ${ }^{1}$

Cabe mencionar que la creación de esta firma significa mucho para el desarrollo del Art Déco en la ciudad, pues como anotamos en el capítulo anterior, el cemento simbolizaba ese material moderno, entre otros, con el cual se construía una nueva arquitectura sólida e imperecedera, y que además la plasticidad del material servía como medio para ornamentar mediante aplanados las diversas integraciones decorativas del Déco.

Por lo que respecta a vías de comunicación terrestre hacia el exterior es importante señalar que en 1925 quedó concluida la carretera Monterrey-Saltillo y se hacían los preparativos para la carretera Monterrey-Ciudad Victoria y ya para 1927 las empresas, así como el floreciente comercio, hicieron que aumentara el flujo migratorio hacia la entidad y el tráfico vehicular en Monterrey, lo cual ocasionó que se instalaran los primeros semáforos.

En este tiempo veremos cómo la ciudad de Monterrey empieza a expandirse hacia otros puntos. Por ejemplo, al poniente comienzan a poblarse los alrededores del cerro del Obispado. Por Hidalgo, se construye el Hospital Muguerza. Se amplió la Avenida Madero, también al poniente, con la edificación del Hospital Universitario. Igualmente, se proyectaron la ampliación de las Avenidas Cuauhtémoc y Colón, para facilitar el acceso a la Estación de Ferrocarril del Golfo -actual Casa de la Cultura- situada al norte de la Plaza Zaragoza.

Durante la gubernatura de Aarón Sáenz (1891-1983), 1927 a 1930, y la alcaldía de Jesús María Salinas, Monterrey entró en un proceso de desarrollo notable: se trazaron y ensancharon las principales calles de la ciudad; se pavimentaron muchas calles; se instalaron semáforos en las principales avenidas para solucionar el incipiente problema de tráfico. En 1928, Sáenz apoyó el proyecto de algunos industriales de la ciudad para introducir el gas natural proveniente de Texas, el cual llegó en 1930 después de realizar las obras de un gasoducto desde Reynosa; amplió las calles Morelos y Zaragoza, planeó la prolongación de Pino Suárez, promovió estudios para la canalización del Río Santa

\footnotetext{
1 Eduardo Martínez Celis (ed), "Monterrey 400. Los Forjadores de su Progreso: Lorenzo H. Zambrano Gutiérrez", El Diario de Monterrey, Suplemento especial, La Enciclopedia de Monterrey, Monterrey, N.L., 29 de octubre de 1995, pp. 10, 15 y 17.
} 
Catarina, incrementó los trabajos de abastecimiento de agua, se iniciaron las carreteras Monterrey-Laredo, Monterrey-Ciudad Victoria y la Monterrey-Saltillo fue remozada.

Para evitar un crecimiento desordenado en 1927, las autoridades estatales promulgaron una ley de construcción, con la intención de regular la urbanización de la ciudad, además de que entre 1927 y 1931 se realizaron obras de relevante valor arquitectónico para la ciudad de Monterrey: el Palacio Federal, el Hospital Muguerza, el Círculo Mercantil Mutualista de Monterrey, las escuelas Presidente Calles y Fernández de Lizardi, todas éstas realizadas por la empresa Fomento y Urbanizaciones S.A. (FYUSA); las llamadas escuelas monumentales como la Fernández de Lizardi y Elías Calles, la Monterrey, la Nuevo León, la Revolución, la Álvaro Obregón, la Garza Ayala, la Miguel F. Martínez y el nuevo edificio para el Hospital González (más tarde Hospital Civil); el Hotel Monterrey, los alojamientos para turistas llamados Regina y Cerro de la Silla, el edificio Isaac Garza, la Compañía de Seguros La Nacional y el Mercado del Norte, entre otros.

Todos estos avances fueron el preludio para asentar las bases en el crecimiento y desarrollo económico y social de Monterrey. Sin embargo, la ciudad tenía muchas carencias que era necesario solucionar. Por ejemplo, en materia de salud, había pocos hospitales en la localidad, entre los cuales sobresalían el González, el San Vicente y el de Ferrocarriles.

Y para apoyar a la educación, se dictó una ley de instrucción pública que estimuló el establecimiento de varios planteles escolares. Para solventar los gastos de todas esas obras de beneficio social se aumentaron algunos impuestos, entre ellos el predial urbano; sin embargo, en el campo de la de educación profesional los estudiantes no tenían muchas opciones donde pudieran realizar estudios formales. Las únicas escuelas existentes de estudios superiores eran el Colegio Civil, la Escuela Normal, la Escuela de Derecho y la de Medicina. Y a pesar de algunos problemas, el buen ritmo que se llevaba en el campo educativo no declinó, por lo que a fines de la década de los veinte comienzan los preparativos para fundar una universidad en la localidad, en cuyos comités y diversas reuniones participaron el doctor Pedro de Alba (1887-1960) y el licenciado Héctor González (1882-1943).

El crecimiento económico exigía casas y bancos que apoyaran un crecimiento continuo y firme para Monterrey por lo que surgieron varios proyectos como la creación de 
la Compañía Mexicana de Préstamos Acumulativos y el Banco Comercial de Monterrey, además de la reestructuración de dos bancos con capitales regionales surgidos durante el porfiriato. Más tarde, las actividades económicas derivadas por las diligencias comerciales e industriales provocaron como consecuencia la demanda de bienes y servicios, lo que motivó que en 1925 se abriera el Centro Bancario de Monterrey, conformado por los representantes de los bancos Nacional de México, de México, de Nuevo León y del Mercantil de Monterrey.

Respecto a usos y costumbres de la época, podemos decir que al regiomontano promedio le gustaba acudir a la Alameda a pasear, nadar en los baños de la Alberca Monterrey y El Nogalar, o visitar la Quinta Calderón. Por las noches se iba a las tandas de algunos teatros de la localidad, a las temporadas de zarzuela que era muy apreciada entre la clase alta. La música y los bailes de moda eran el charleston y el fox trot. Todavía se respiraba un ambiente muy exclusivo y familiar. A pesar del crecimiento demográfico, todos se conocían -o al menos de oídas-, a pesar de que se consideraba a Monterrey como la cuarta ciudad más poblada del país. Monterrey se enorgullecía al tener el Hotel Ancira, considerado en esta década como el más moderno del país. ${ }^{2}$

Como se advierte, durante la década de los veinte, el país fue lentamente encontrando la paz. Monterrey de nuevo encontró el camino para la apertura comercial e industrial y la estabilidad económica. Electo gobernador el 4 de octubre de 1927, Aarón Sáenz administró uno de los gobiernos más prolíficos hasta entonces. Algunas de las actividades o reformas que realizó, fueron: el establecimiento de impuestos a la propiedad territorial, a la industria, profesiones y herencias.

En la década de los treinta hubo un fuerte incremento poblacional, ya que había más o menos 138.000 habitantes en la zona metropolitana. Precisamente, el censo de 1930, arrojó la cifra de 132.000 personas económicamente activas, de las cuales unas 25,000 laboraban en las industrias de la ciudad. ${ }^{3}$ Y a pesar del rebote de la Depresión del 29, las fábricas de la ciudad siguieron produciendo, con todo y que hubo un gran número de desempleados.

\footnotetext{
2 Andrés Montemayor, Historia de Monterrey, México, Asociación de Editores y Libreros de Monterrey, 1971, pp. 329-336.

3 Rodrigo Mendirichaga, "Industria: crecimiento de un gigante", Enciclopedia de Monterrey, Tomo 1, Monterrey, N.L., El Diario de Monterrey-Grijalbo, 1996, p. 440.
} 
Aunque el ritmo de crecimiento económico en el país era lento, durante el sexenio de Lázaro Cárdenas se incrementó la inversión privada empresarial, lo cual se vio reflejado en la ciudad de Monterrey. Había en operación cerca de cuatrocientas industrias y en esos años se crearon otras veinte, entre la cuales "en 1934 fueron: Compañía Asarco Mexicana, S.A.; Afinación de Plomo y separación de oro y plata; Metalúrgica Mexicana; Peñoles, S.A.; Textiles de Monterrey, S.A.; Hilados y Tejidos de Algodón. En 1936: Compañía Cigarrera La Moderna, S.A., Empaques de Cartón Titán. S.A., Industrias de Monterrey, S.A., Planta Galvanizadora, Cristales Mexicanos, S.A., Vidrio Plano, S.A., Cristalería, S.A., Fábricas Monterrey, S.A., etc.”. ${ }^{4}$

Como ya hemos anotado en el capítulo anterior, la creación del Banco de México como oficina central reguladora de las operaciones financieras del país, consolidó las operaciones de crédito, inversión y emisión de moneda. Así pues, en Monterrey se crearon varias empresas financieras, las cuales reforzaron el desarrollo comercial e industrial de la ciudad. Destacan la Sociedad General de Crédito, S.A., en 1933, un año más tarde el Banco Popular de Edificación y Ahorro, S.A. En 1936 la Compañía General de Aceptaciones, en 1937 Financiera Aceptaciones y Seguros Monterrey del Círculo Mercantil, S.A., y en 1939, Financiera de Crédito, S.A.

En esta década, el desarrollo urbano de la ciudad se había renovado con las colonias Mitras, las primeras construcciones de la Vista Hermosa y se iniciaba la expansión hacia el otro lado del río Santa Catarina en lo que más tarde sería la exclusiva Colonia del Valle en el municipio de San Pedro. Hacia el norte, además de la expansión de caseríos humildes cercanos a las fábricas, se levantó una plaza de toros, la Monumental Monterrey; y el Campo Militar Mariano Escobedo, ahora Parque Niños Héroes, se había iniciado a construir en 1931, cuando la zona militar estaba bajo el mando del general Juan Andrew Almazán (1891-1965).

Fue en esas décadas, los veinte y los treinta, cuando se desarrolló también el Art Déco en Monterrey, pues obedecía a ese ideal de modernidad postrevolucionaria, tanto de la ciudad de México como de otras urbes; así pues en la capital del estado de Nuevo León y en otros municipios se emprendió la tarea de levantar edificios y producir obras que

\footnotetext{
${ }^{4}$ José P. Saldaña, ¿Y qué hicimos?..., Monterrey, N.L., Al Voleo-El Troquel, 1988, pp. 83-84.
} 
apoyaban esa misma imagen del centro del país. Escuelas, edificios de la administración pública, arquitectura asistencial, de servicios, del ocio, comercial, religiosa, así como obras de artes plásticas y decorativas, tales como murales, vitrales y esculturas, daban esa modernidad artística.

Para el caso de la arquitectura Art Déco en Monterrey, el arquitecto Juan Manuel Casas propone que hubo algunas variantes estilísticas en relación con lo producido en la ciudad de México, ya que si el arco ochavado fue muy utilizado en México, D.F., aquí fue raro su uso; la decoración prehispánica es escasa, ya que aquí no hay un referente de esa índole, pues no hubo el desarrollo de culturas indígenas como las mesoamericanas; y que aunque los decorativismos geométricos del Déco dan monumentalidad, la mayoría de las construcciones no se elevaron más de dos pisos. ${ }^{5}$ Entonces, además de las características dadas para el análisis de los edificios, agregaremos cuando sea necesario los puntos dados por el arquitecto Casas.

\footnotetext{
5 Juan Manuel Casas García, Documento de recomendaciones para una ciudad en su $401^{\circ}$ aniversario,
} Monterrey, N.L., Tesis de Licenciatura en Arquitectura, Universidad Autónoma de Nuevo León, 1997, p. 89. 


\section{2.1. 1. ARQUITECTURA ESCOLAR}

\section{a. Escuela Fernández de Lizardi}

Esta escuela se ubica en la calle Serafín Peña s/n., entre Modesto Arreola, Silvestre Aramberri y Porfirio Díaz, con disposición al oriente.

La construcción se llevó a cabo de 1927 a 1930, inaugurándose el 4 de octubre de 1930, según consta en una carta dirigida al Lic. Aarón Sáenz (1891-1983), Secretario de Educación Pública con fecha 4 de septiembre de ese mismo año, en la cual el informante explica el estado de terminación de la escuelas Álvaro Obregón y Fernández de Lizardi: "Los trabajos están bastante avanzados en ambas escuelas y creo que quedarán casi terminadas, si es que algo falte, para el día 4 de octubre... El menaje para ambas escuelas está también casi terminado y creo que contaremos con él para la fecha de la inauguración". 6

La autoría del edifico fue del arquitecto de origen español Cipriano J. González Bringas, como consta en una carta firmada por él mismo en papel con sello de su despacho, dirigida al entonces gobernador Aarón Sáenz el 26 de noviembre de 1929, donde aclara cuestiones de gastos invertidos en la construcción de dicha escuela al decir: "No me ha sido posible averiguar la cantidad invertida durante el curso de las obras, porque mi actuación como Director de ellas...”. Para terminar la misiva expresa: "Me permito manifestar que no tengo inconveniente en encargarme de la terminación completa de las obras por la cantidad anteriormente expuesta". 7 Más adelante contó con la ayuda del ingeniero Miguel Osuna Treviño.

Además de la asistencia del ingeniero Osuna, González Bringas tuvo como ayudantes a Paulino Benavides y Cayetano García, a quienes los mencionan en un artículo titulado "El Espíritu Constructivo de la Ciudad de Monterrey", publicado en el Álbum de Aniversario de la Fundación de la Ciudad de Monterrey, 159620 de septiembre 1946, en

\footnotetext{
${ }^{6}$ Archivo General del Estado de Nuevo León, (AGENL) Sección Documentos: Educación/Construcción de Escuelas Públicas, años 1927 a 1936, Caja 2. No sabemos el nombre de quien escribe la carta, ya que no pudimos descifrar la firma, pues sólo la acompaña las letras en máquina AO/pw.

${ }^{7}$ Ibídem. Carta del arquitecto C.J. González Bringas al Señor Lic. Don Aarón Sáenz, Gobernador del Estado de Nuevo León. La ayuda del Ing. Miguel Osuna se comprueba por cartas dirigidas por éste al señor Teófilo Garza, Presidente del Comité Constructor de la Escuela, para solicitarle material necesario para la construcción.
} 
donde se elogia la labor constructiva del Lic. Sáenz al decir que: “...ejecutó la construcción total de la Escuela Fernández de Lizardi; monumental y bien planeado edificio en el que se fundieron seis pequeñas escuelas y que fue proyectado por el Ing. González Bringas, que recibió un premio de un mil pesos por su brillante trabajo y asumió la dirección técnica de la construcción; los maestros contratistas don Paulino Benavides y don Cayetano García dirijieron [sic] el trabajo material". ${ }^{8}$

FYUSA fue la empresa constructora que se encargó de la edificación y que hizo las principales obras de gobierno de esa época, tal como se cita en el Catálogo Nacional Monumentos Históricos Inmuebles: "La Escuela Primaria J.J. Fernández de Lizardi se construyó en el año de 1928, por una compañía constructora, misma que se hiciera cargo de edificar la Escuela de Oficios Gral. Álvaro Obregón y el Palacio Federal. Según informes proporcionados, el costo de este edificio estuvo a cargo del Gobierno Municipal, padres de familia y vecinos de esta escuela". 9 Sin embargo, también hay que considerar el donativo por 250 dólares que otorgó la compañía petrolera Marland Oil Company of México, S.A., en febrero de 1928, mediante su representante el señor Chester H. Westfall. ${ }^{10}$

De acuerdo a las fechas de construcción, esta casa de estudios fue la primera de una serie que tiene planta en E y que llevó el nombre de Monumental, -como también otras de las que analizaremos aquí- tal y como lo enuncia el Inspector del Tercer Distrito, el profesor Andrés Sauceda, en carta fechada el 4 de septiembre de 1928, dirigida al Alcalde de Monterrey en turno Don Jesús M. Salinas Jr., en donde además describe las instalaciones: "El edificio a que he venido haciendo referencia llevará el nombre de ESCUELA MONUMENTAL “FERNÁNDEZ DE LIZARDI”. En ella habrá capacidad para 1,400. alumnos de uno y otro sexos; contendrá 28 salones de clase, distribuidos entre la planta alta y la baja; un subterráneo donde quedarán instalados el departamento de Talleres para el adiestramiento manual de los alumnos de la misma escuela, el servicio sanitario y la bodega de la misma; un gimnasio moderno perfectamente dotado; una

\footnotetext{
${ }^{8}$ J.A. Cruz (editor), "El Espíritu Constructivo de la Ciudad de Monterrey", Álbum de Aniversario de la Fundación de la Ciudad de Monterrey, 159620 de septiembre 1946, Monterrey, N.L, s/e, 1946 sin página.

${ }^{9}$ INAH-SEP. Catálogo Nacional Monumentos Históricos Inmuebles. Nuevo León, tomo 4, México, SEP, INAH, Programa Cultural de las Fronteras, Gobierno del Estado de Nuevo León, 1984, p. 1892; José P. Saldaña, Op. Cit., p. 66.

${ }^{10}$ AGENL, Op. Cit. Existen las cartas donde el señor Westfall explica que a pesar de la crisis de las compañías petroleras, dona los 250 dólares mencionados; hay otras epístolas de agradecimiento al señor Westfall por parte del gobierno estatal.
} 
instalación completa para los servicios de agua y drenaje, un 'auditórium' amplio salón destinado para todos los actos que haya que verificar la mencionada Escuela y suficientes departamentos para el personal Directivo". ${ }^{11}$ Este plantel estaba de acuerdo y cumplía con el programa postrevolucionario y vasconcelista de levantar escuelas públicas como símbolo de nacionalismo y progreso "como es el caso de la Fernández de Lizardi, ubicada muy cerca de la Alameda Escobedo, cuyas características decorativas de grecas y motivos prehispánicos de los años treinta enlazan al edificio con las corrientes art decó". ${ }^{12}$

José P. Saldaña, al referirse al plantel y al alcalde Jesús Ma. Salinas, dice: "Durante su gestión como Alcalde se realizó la construcción de la escuela Fernández de Lizardi, construcción que en su tiempo fue considerada monumental". ${ }^{13}$

Al igual que otras edificaciones, en junio de 2000 se anunció que la Escuela Fernández de Lizardi quedará amparada como monumento del siglo XX por el INAH, y el INBA. ${ }^{14}$

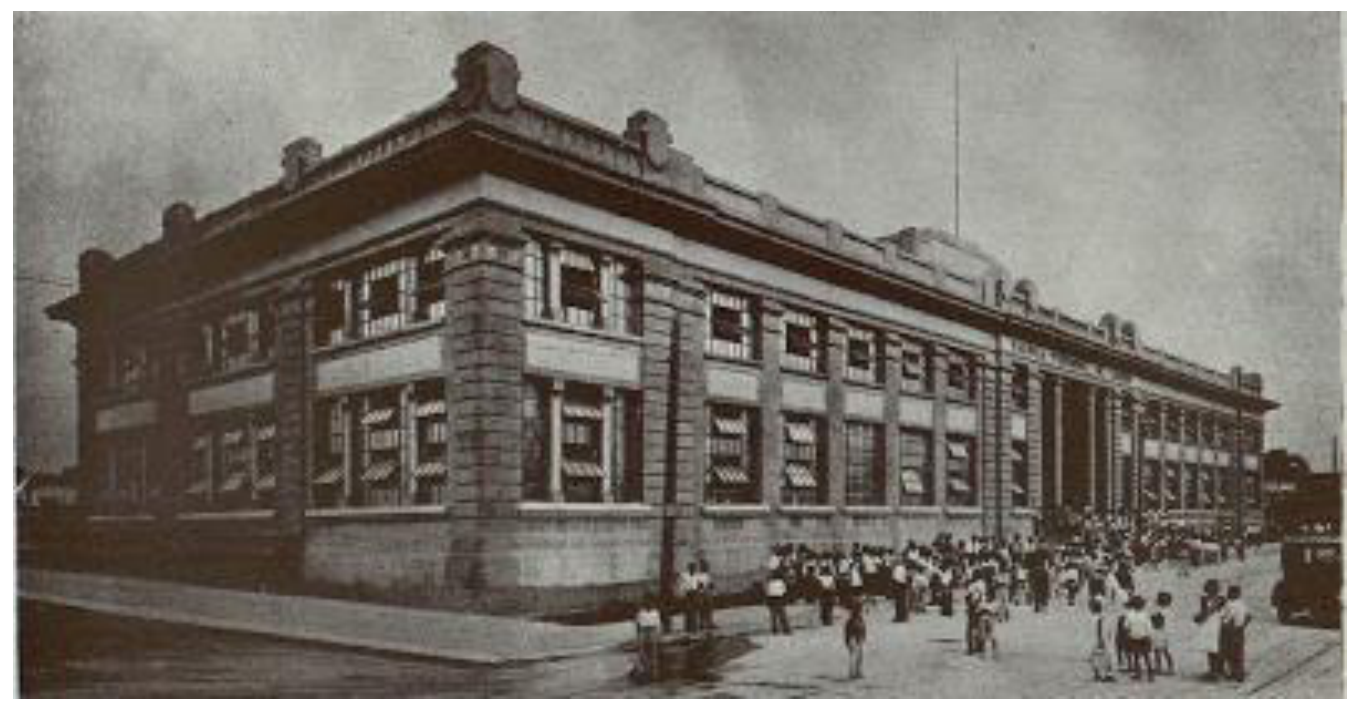

Fotografía de la escuela al inicio de sus actividades. ${ }^{15}$

\footnotetext{
${ }^{11}$ Ibídem. Carta dirigida al C. Presidente Municipal, D. Jesús M. Salinas Jr., por el Inspector Andrés Sauceda, con el título de Proyecto de la Escuela Monumental.

12 Oscar Eduardo Martínez, "Monterrey, ciudad vieja, ciudad nueva. Su arquitectura y urbanismo". La Enciclopedia de Monterrey. Tomo II. La capital industrial de México, Monterrey, N.L., Milenio, Multimedios, 2008, $2^{\text {a }}$ edición, p. 280.

${ }^{13}$ José P. Saldaña, Op. Cit., p. 61.

${ }^{14}$ Vicente Guerrero, "Quedarán protegidos edificios del Siglo 20”, El Norte, Monterrey, N.L., lunes 12 de junio del 2000, secc. Vida, p. 1.

15 http://cdigital.dgb.uanl.mx/la/1080074131/1080074131.html
} 
El exterior del inmueble presenta una acusada geometría, pues asemeja tres cubos ensamblados por los lienzos de los muros, que llevan líneas horizontales como motivos decorativos y ventanales rectangulares, cuyas divisiones las hacen unos parteluces cuadrados con base y capitel con decoraciones cuadradas superpuestas y fuste tablereado, ${ }^{16}$ con lo cual se acentúa aún más el signo de geometrización, esencia del Art Déco. Es de dos plantas y en el remate superior, una especie de balaustrada recorre todo el edificio, resaltando unos dados colocados en relación con los soportes estructurales.

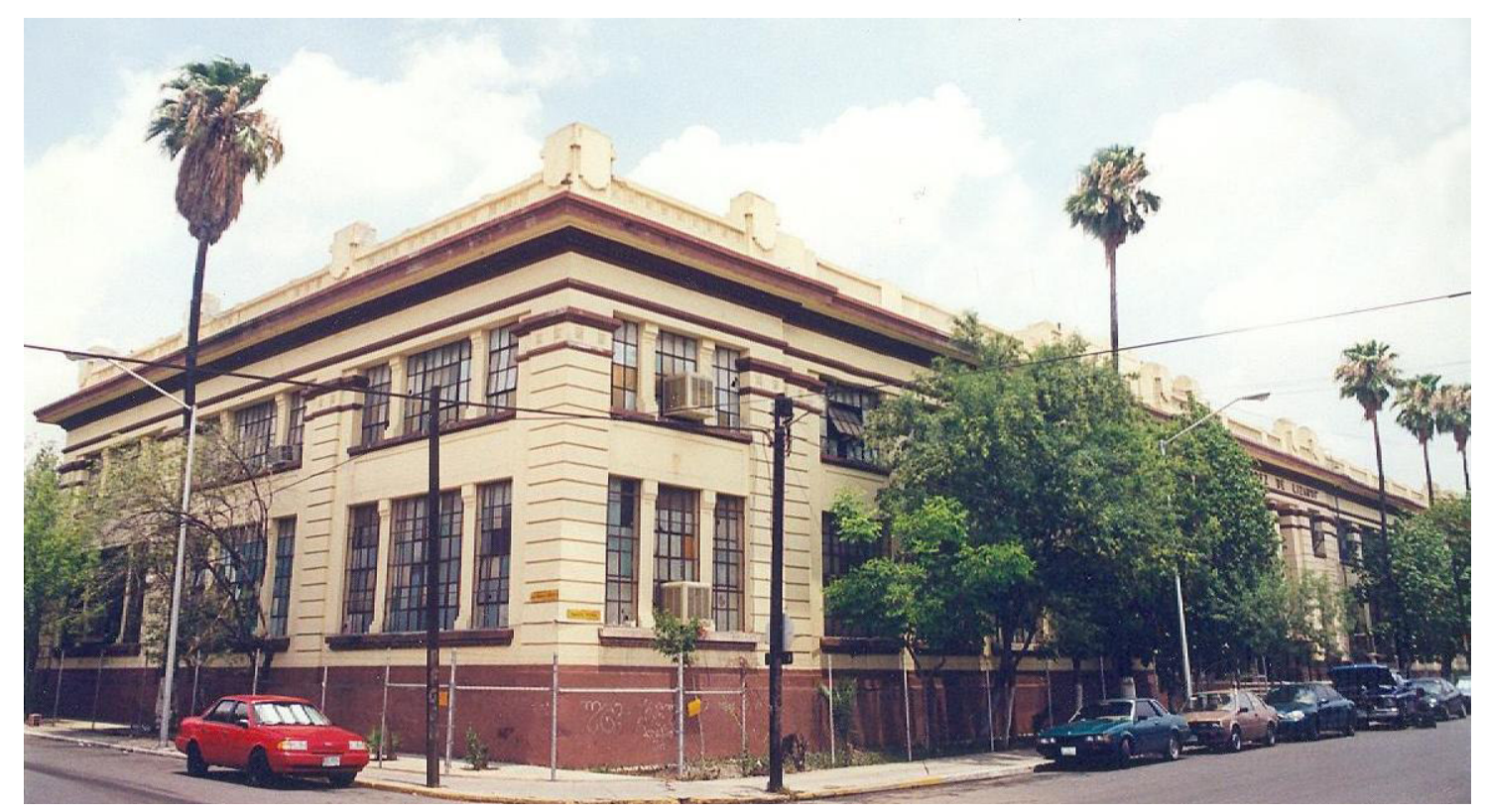

Vista de la escuela desde la esquina de las calles Modesto Arreola y Serafín Peña.

A la entrada principal se accede después de una escalinata con piso de granito, material modelo para la arquitectura Art Déco. Unas pilastras cuadradas con base, anillo y capitel, dos adosadas a los muros y dos en el vano de acceso, forman un portal rectangular. La base de las columnas se remarcan por un par de molduras que se continúan por todo el rodapié, elemento típico de la arquitectura Déco, el cual está resaltado por el cambio de

\footnotetext{
${ }^{16}$ El término "tablereado" lo usamos con la significación que le da Manuel González Galván 'Barroco tablereado' en: "Génesis del barroco y su desarrollo formal en México", Historia del Arte Mexicano, México, SEP, Salvat, 1986, vol. 6, p. 823) cuando se refiere a columnas y paneles ornados solamente con una canaladura que simula un rectángulo, o bien un rehundido que remarca la forma como si fuera el recorte de un tablón de madera. Aunque él lo aplica al Barroco mexicano, nosotros lo aplicamos en el estricto sentido de composición y no de estilo.
} 
color; lo que equivale al anillo y capitel de las pilastras se convierten en los muros en un par de molduras que a la misma altura también recorren todo el exterior y resguardan decoraciones en forma de punta de diamante. Las líneas horizontales que simulan almohadillados están distribuidas en las estructuras de soporte.

Lo que es el cuerpo central de la fachada principal está en un nivel más hacia el frente en relación con el muro de la pared y hace juego con los extremos de la misma fachada, los cuales también se proyectan hacia el frente, dándole al conjunto una elegante simetría; sendos cuerpos se adosan a los paños mediante perfiles angulares almohadillados. Este juego de planos y el resalte de los laterales, es una de las particularidades de la arquitectura Art Déco.

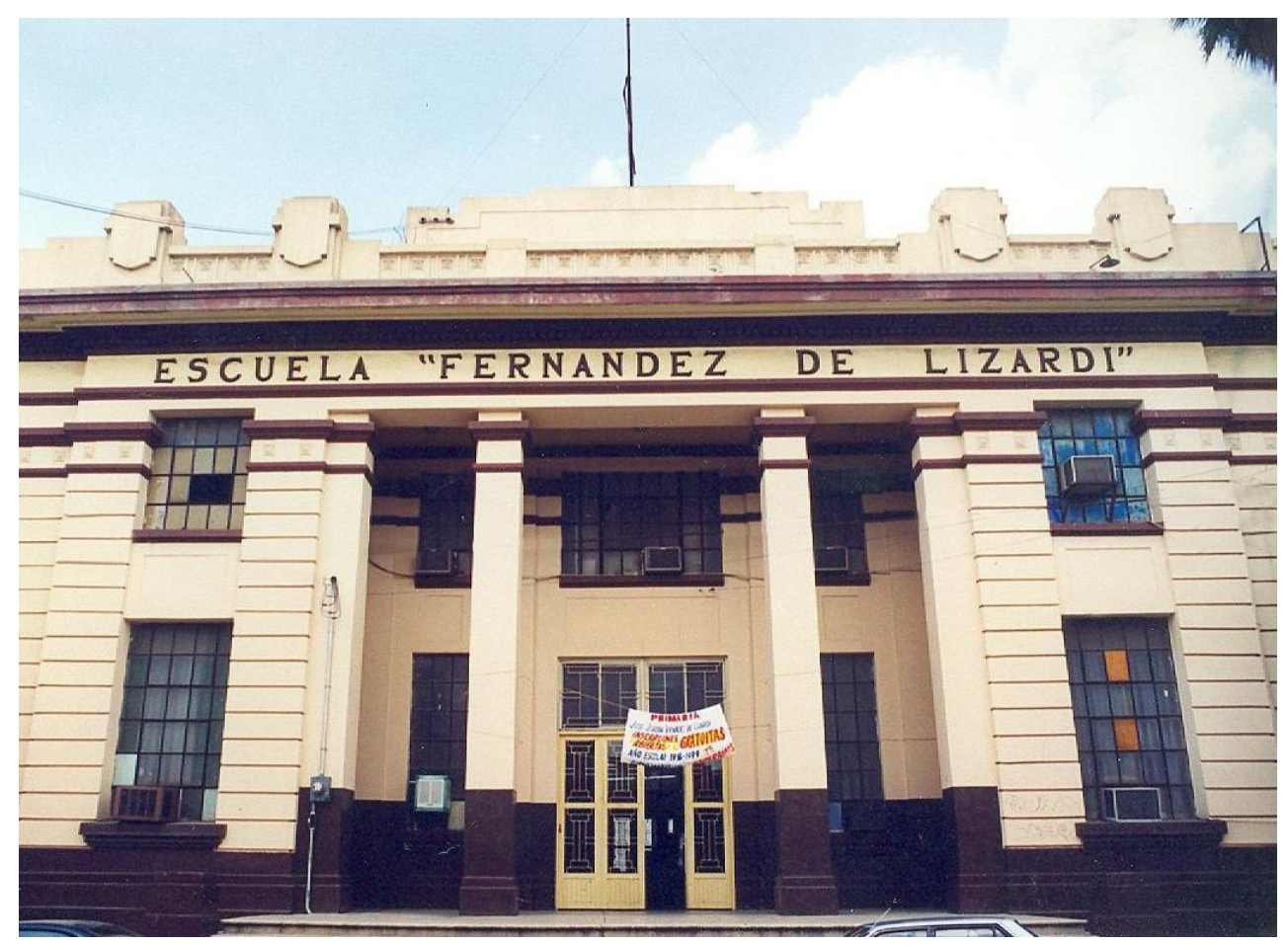

Acceso principal de la escuela en la portada sur sobre la calle Serafín Peña.

En la entrada principal y encima del vano de acceso al pórtico está inscrito el nombre de la institución con letras de tipo clásico. En el remate y después de la cornisa, la falsa balaustrada está ornada con los recuadros que custodian las decoraciones a manera de punta de diamante y cuatro dados, dos a cada lado, los cuales llevan escudos en tres de sus caras, con lo que se preponderan los ángulos superpuestos. Al centro y en medio de los 
dados, la base de la astabandera se compone de dos tableros escalonados, pareciendo una plataforma prehispánica tolteca. La herrería de la puerta de la entrada forma el dibujo de unas columnillas de capitel y base doble. Todos estos componentes hacen que el edificio sea un digno ejemplo de las Tendencias Decorativista, Elementos Exteriores y Geometrista.

En el exterior el edificio denota un Art Déco Neoclásico Moderno pues lleva las columnas cuadradas parodiando un estilo toscano, pero además por los perfiles angulares de los dados y los planos superpuestos estaría dentro del Déco Zigzag. Sin embargo, por las columnas cuadradas y las líneas horizontales de las estructuras de soporte, remite al edificio de la Kunstschau de Viena, 1908, de Emil Hoppe (1876-1957), secesionista de Viena, antecedente formativo del Art Déco.

Los espacios interiores repiten las molduras decorativas del exterior y en los techos se escalonan y se ritman con rectángulos rehundidos, extendiendo la geometricidad Déco por todo el interior, lo que le da un ambiente de armonía simétrica espacial. Las fuentes de luz eléctrica en los techos aún conservan las decoraciones de círculos concéntricos, mas no las lámparas originales.

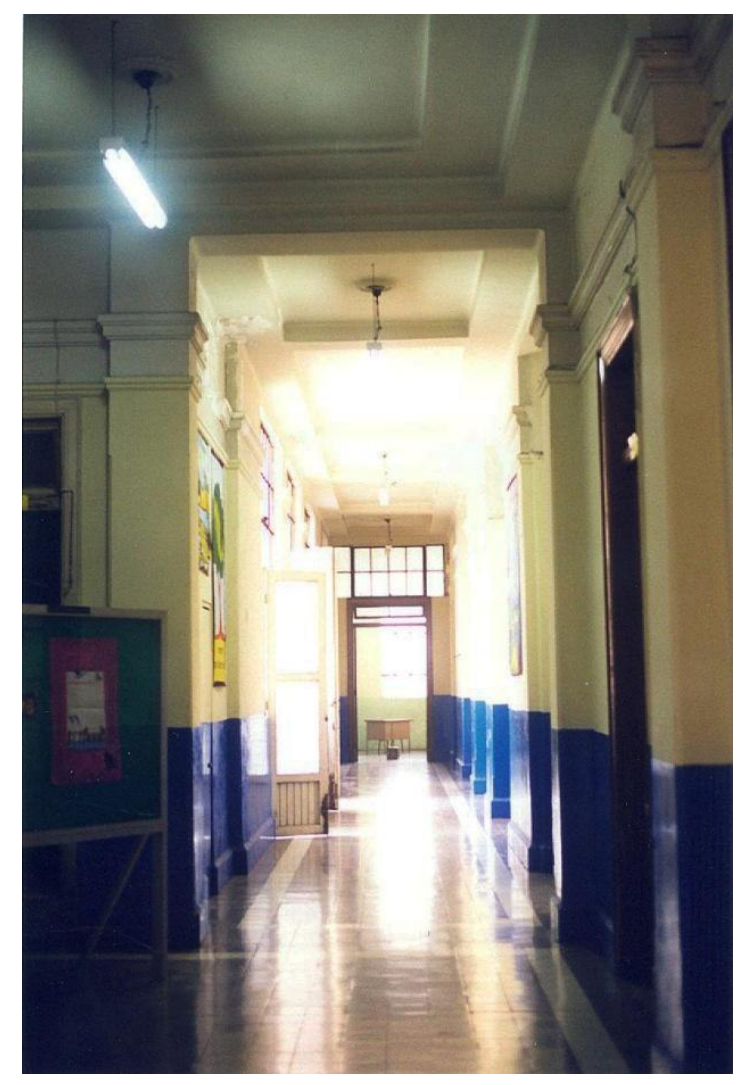

Pasillo interior con las pilastras y en el techo los rectángulos rehundidos. 
En el interior, algo que destaca del estilo Déco es la escalera que conduce al segundo nivel. Los peldaños están forrados de granito color crema, así como los pilarotes cuadrados de soporte de los barandales, las cuales llevan rectángulos tablereados rehundidos en sus cuatro caras, enfatizando el sentido geométrico del Art Déco. La forja de los barandales se compone de óvalos y roleos alternados.
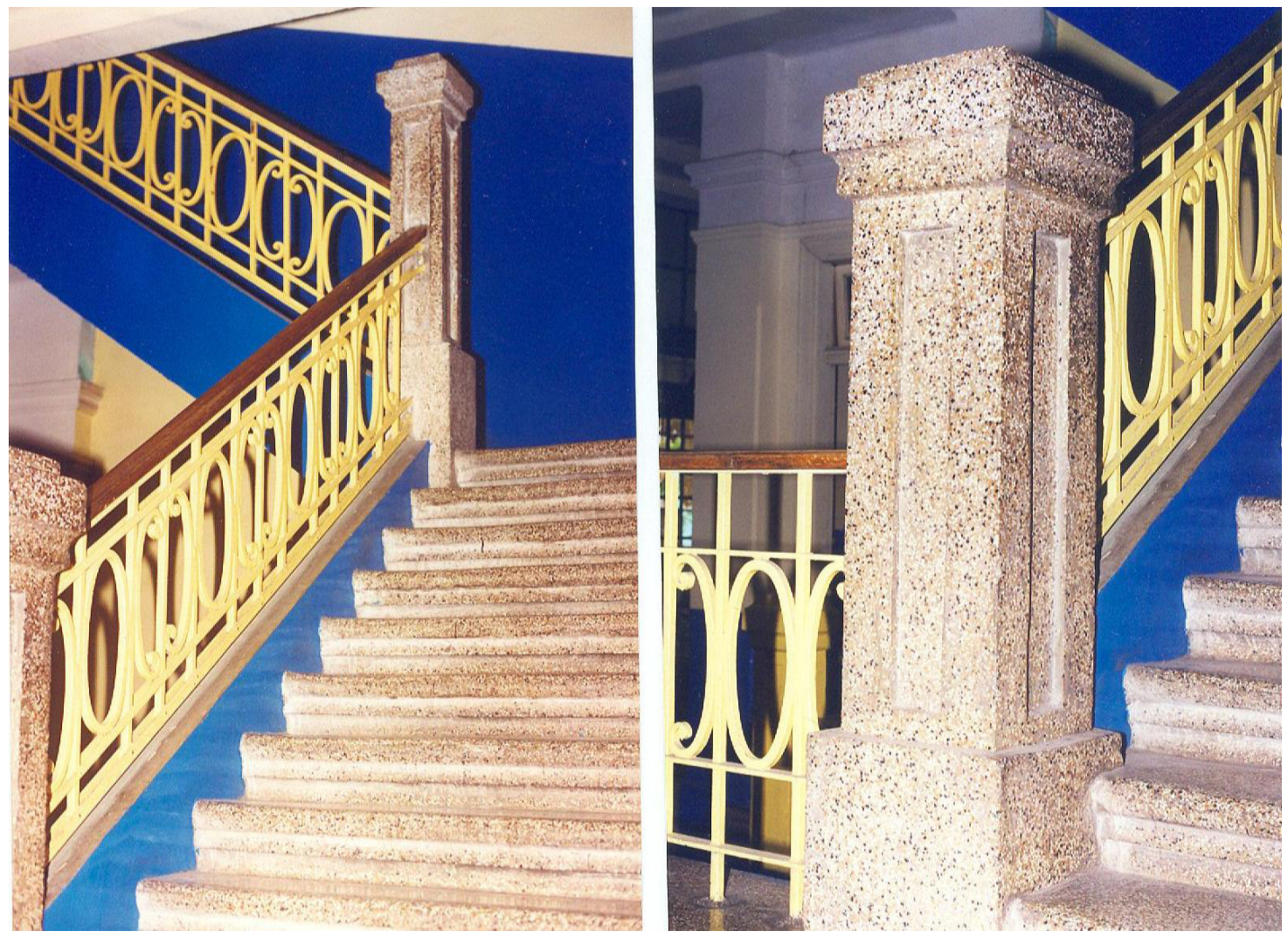

Escalera. En la imagen derecha el detalle del pilarote.

En el segundo nivel está el Auditorio, cuya gradería tiene una disposición oval. La herrería del barandal de la gradería alta, repite los motivos de la escalera. Lamentablemente el Auditorio está en un penoso estado de conservación.

En el patio se aprecia la distribución de los cuerpos que le dan la forma de $\mathrm{E}$ al edificio: dos laterales y uno central de mayor altura. El enlace de éstos es una amalgama de cubos, unidos por la linealidad de la cornisa que recorre todos los cuerpos. Las pilastras están compuestas por fustes almohadillados. Además de este tipo de pilastra los vanos de los ventanales del primer y segundo nivel de los cuerpos laterales norte y sur están 
divididos por parteluces cuadrados con base y capitel escalonado y fuste con tablereado rectangular. En la parte superior una cornisa recorre todo el perímetro de los cuerpos laterales y divide al segundo y tercer piso del cuerpo central. Debajo de la cornisa una moldura dentada le da el carácter del Neoclásico Déco. De igual manera que en el exterior, un pretil con dados recorre todo el remate de los cuerpos laterales. Los dados llevan la misma decoración de escudos a manera de escapularios adheridos con una moldura. Si hacemos una abstracción del dado, asemejaría un producto industrial de la época como una estufa, una lavadora, o bien, algún artefacto doméstico como un buró o un armario o por qué no, un objeto meramente decorativo y de lujo emanado de un "atelier" como un alhajero, un reloj, o cualquier otra cosa parecida. Con las escaleras que conectan con el segundo nivel, la perpendicularidad de éstas afianza el trazo lineal del conjunto, el cual es una ligazón de volúmenes cúbicos que explayan la semántica geométrica del Art Déco.

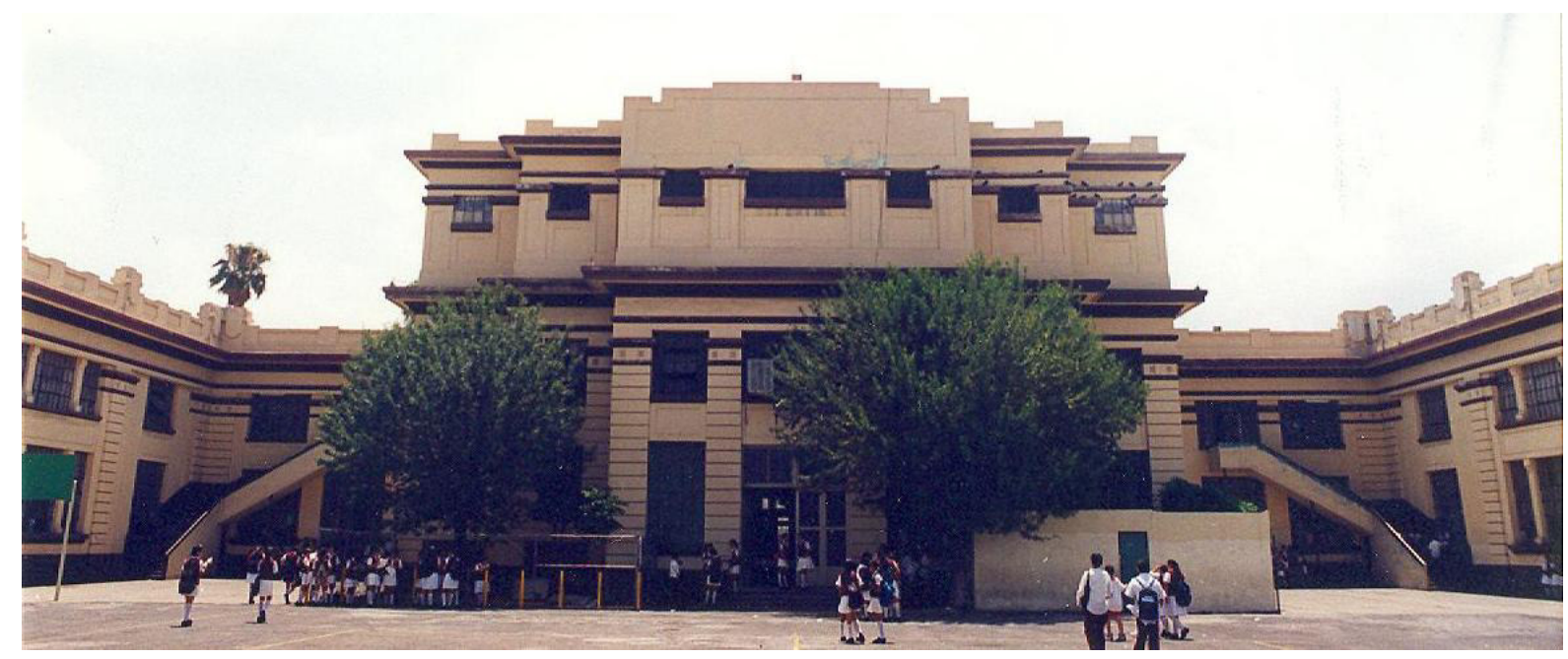

Vista desde el patio del cuerpo central y parte de los cuerpos laterales.

El cuerpo central tiene tres niveles: el primero corresponde a la Biblioteca y el segundo y tercero al Auditorio. En lo concerniente a su distribución espacial, se superponen al cubo principal desplazándose hacia el frente, dos cuerpos de mayor a menor. Los dos primeros niveles llevan, como en los cuerpos oriente y poniente, pilastras con almohadillado. El segundo y tercer cuerpo se separan por una cornisa, la cual en la parte baja lleva dentados clásicos como adorno. El tercer cuerpo de la parte frontal, pareciera un homenaje al purismo decorativo geométrico, pues la distribución de los rectángulos y 
cuadrados de las ventanas se complementan con los leves rehundidos de los tablereados igualmente rectangulares y cuadrados.

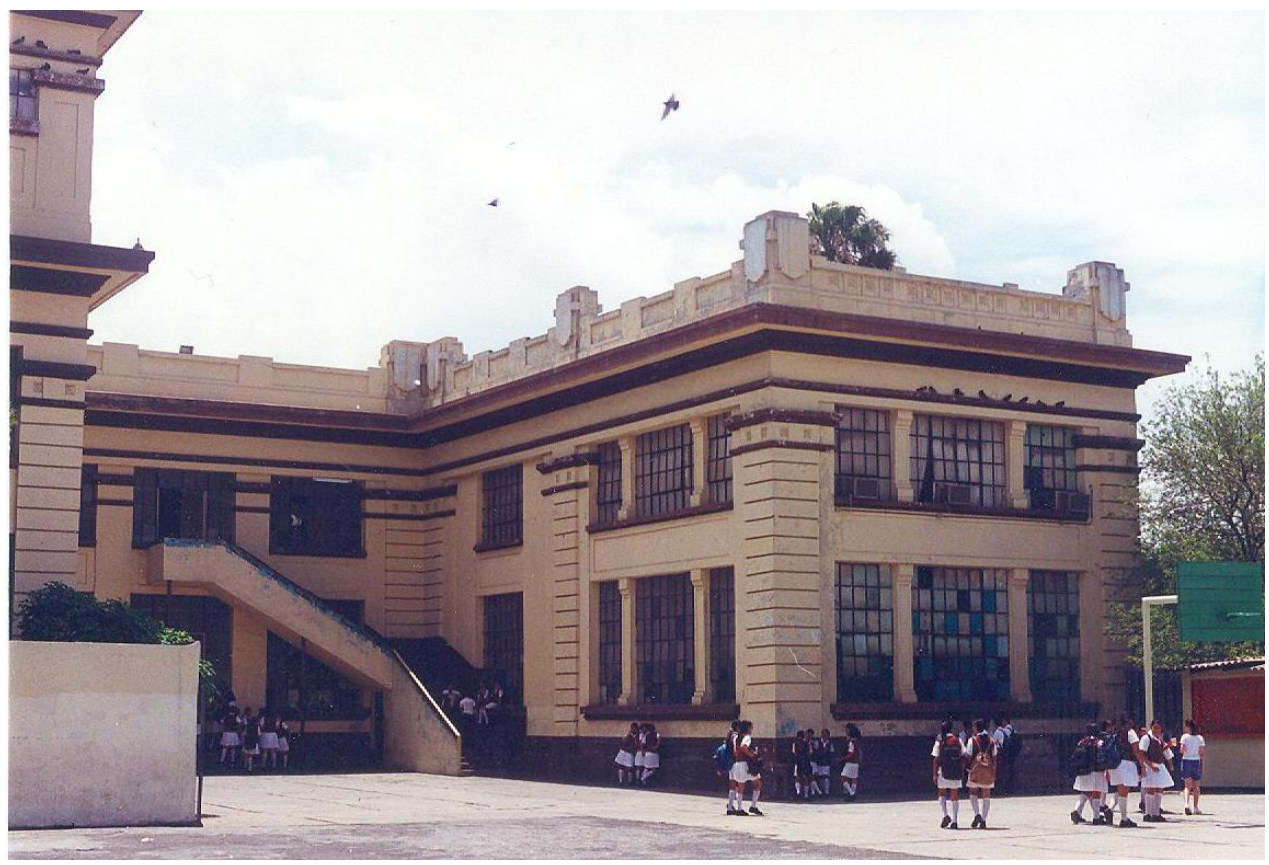

Cuerpo lateral poniente.

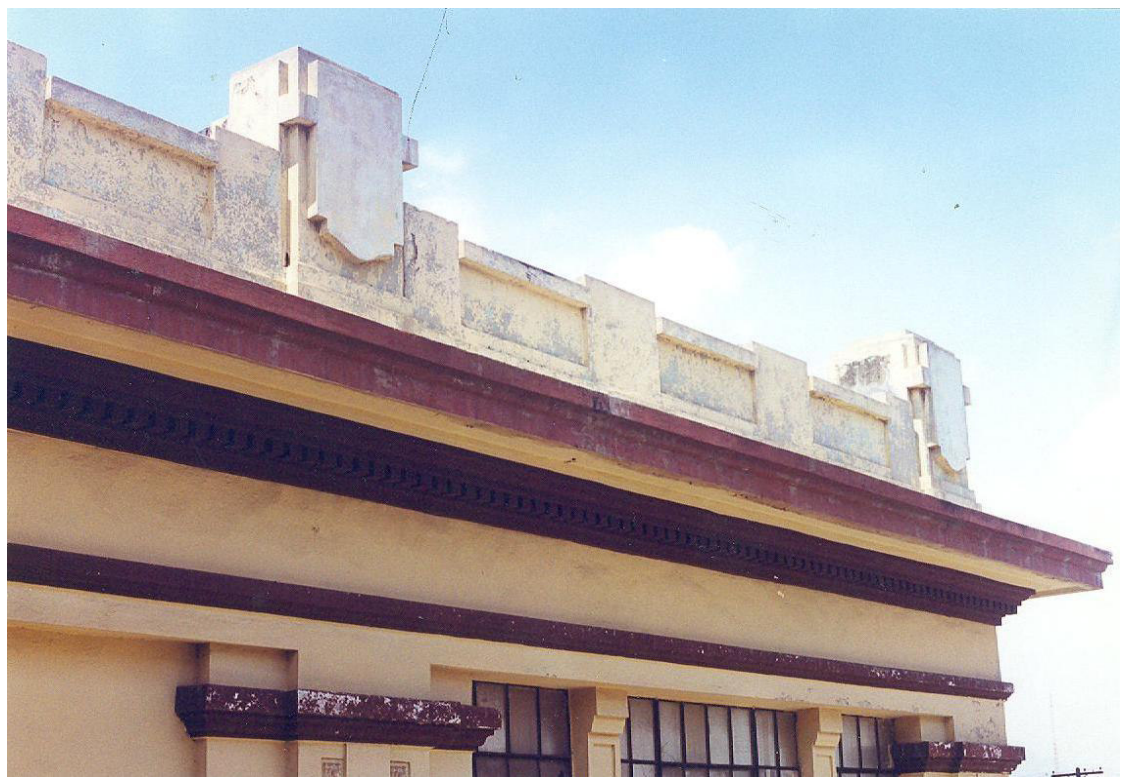

Detalle de la parte superior del cuerpo lateral poniente con la cornisa y la moldura dentada, así como el pretil y los dados del remate. 
En los ventanales laterales del primer y segundo nivel los claros de las ventanas se separan por pilastras tablereadas, mientras que en las del tercer nivel sobresalen cinco pequeñas pilastras engalanadas también con rehundido tablereado. El remate del tercer nivel cierra con una composición a manera de piñón escalonado y moldurado que hace juego con la base de la astabandera de la fachada principal. Finalmente, para conjugar el equilibrio de horizontalidad, un pretil con pequeña almenas recorre por la parte superior del tercer nivel, salvo en la parte frontal donde se encuentra la base de la astabandera.

Este cuerpo central es todo un triunfo del lenguaje de la línea recta, el cuadrado, el rectángulo y, por supuesto, el cubo, como un tributo a la modernidad precisa, calculada y simétrica del Art Déco, por lo que lo inscribimos como uno de los más álgidos modelos de la Tendencia Geometrista.

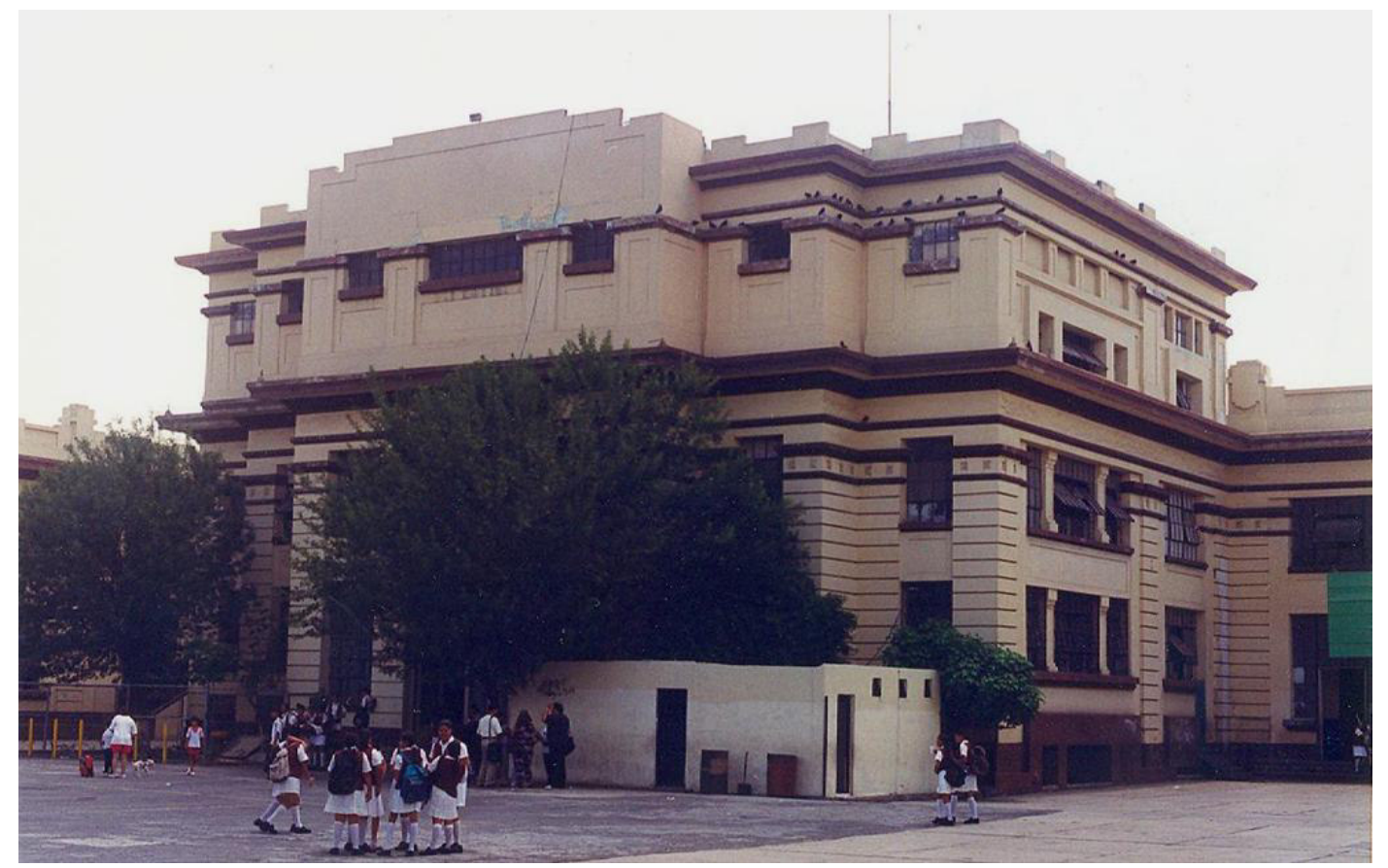

Cuerpo central.

La monumentalidad de la Escuela Fernández de Lizardi se compagina con la excelsitud de sus decorados geométricos puristas, lo que afirma su calidad como un magno ejemplo de Art Déco, Neoclásico Moderno, en parte Zigzag y, por supuesto, inscrito en la Tendencia Geometrista. 
Cabe aclarar que todos los decorados de este edificio están trabajados con cemento, el material moderno del Art Déco, y se utilizó la marca Cementos Hidalgo y acero de la Fundidora Monterrey, ${ }^{17}$ completando entonces el esquema de educación, nacionalismo, industria, progreso y materiales modernos de la época.

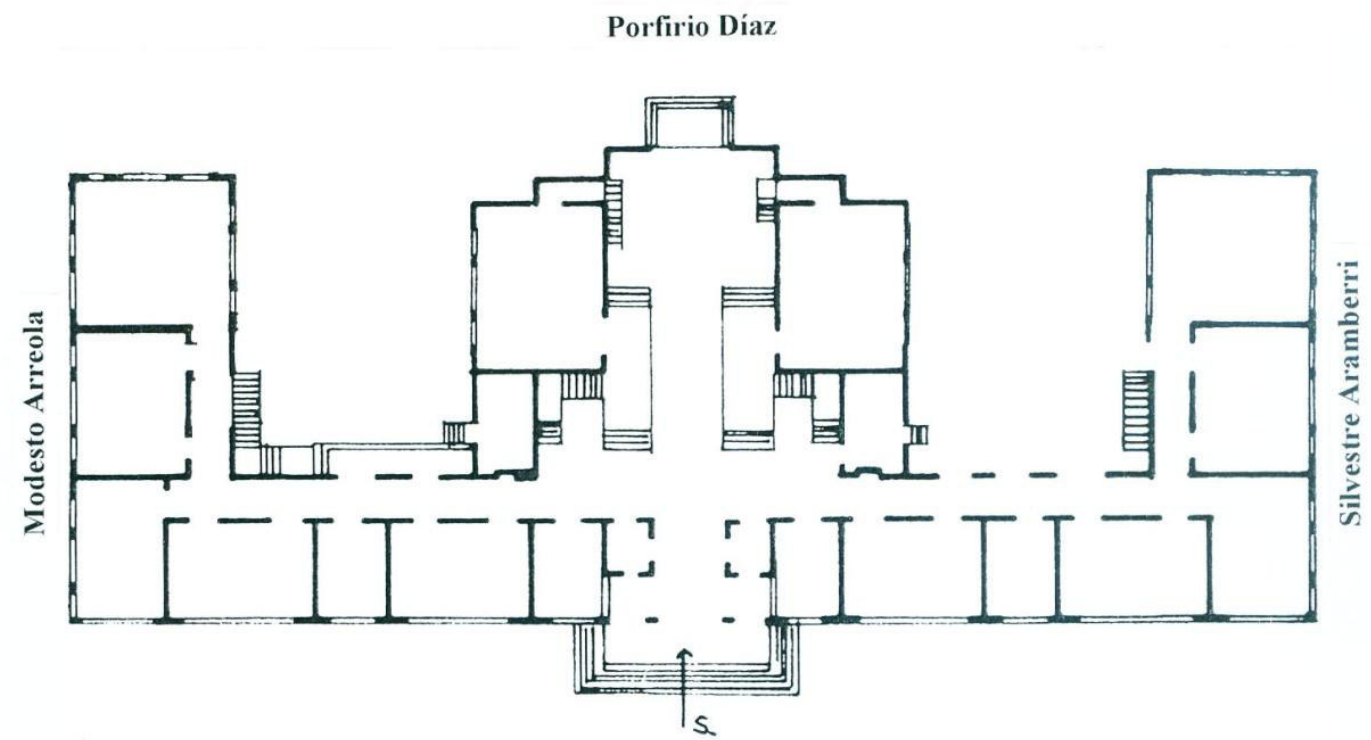

Serafín Peña

Plano de la Escuela Fernández de Lizardi.

INAH; SEP. Catálogo Nacional de Monumentos Históricos Inmuebles. Nuevo León. Tomo 4, México, SEP, INAH, Programa Cultural de las Fronteras, Gobierno del Estado de Nuevo León, 1984, p. 1891.

\section{b. Escuela Industrial Álvaro Obregón}

El imponente edificio de esta escuela se localiza en la esquina del cruce de las calles Félix U. Gómez con Francisco I. Madero, abarcando toda una manzana. De acuerdo a la entrada en ochavo, la orientación del inmueble es hacia el surponiente.

17 AGENL, Op., Cit. Hay una serie de cartas entre las empresas Cementos Hidalgo, S.A., y la Compañía Fundidora de Fierro y Acero de Monterrey, S.A., con el Gobierno estatal, donde se solicita material y se envía el mismo. 
Las obras de construcción se iniciaron el 4 de octubre de 1928, cuando se colocó la primera piedra, bajo la iniciativa del gobernador en turno, Aarón Sáenz Garza (1891-1983), quien gobernó Nuevo León entre 1927-1931. ${ }^{18}$ La firma constructora fue FYUSA, tal como se comprueba por listas de raya de la empresa existente en el Archivo General de Estado de N.L. ${ }^{19}$ Aunque no encontramos citado el autor o autores del proyecto, posiblemente también hayan sido los arquitectos Manuel Muriel y Antonio Lamosa, pues fungían con ese puesto en FYUSA en el año de $1929 .{ }^{20}$ Enrique X., de Anda en su obra Arquitectura de la Revolución Mexicana. Corrientes y estilos de la década de los veintes cita como autor al Ing. Manuel Marín, dato que obtiene de la revista Cemento, No. 38 de noviembre de 1930; sin embargo, De Anda incluye al inmueble en un cuadro de edificios sin fecha identificada, no da estilo y pone como estado del inmueble "desconocido". 21

Para noviembre de 1929 se hablaba del magno proyecto y construcción de la Escuela Álvaro Obregón, tal como se lee en el artículo "LA INSTRUCCIÓN PÚBLICA EN EL PROGRESISTA ESTADO DE NUEVO LEÓN”: "Siendo Monterrey un gran centro industrial, el Gobierno ha emprendido la creación de una gran Escuela Industrial que sirva para preparar debidamente a los futuros obreros de sus múltiples industrias. Con este objeto está en construcción actualmente un gran edificio destinado a la Escuela Industrial, que comprende salones de administración, suficiente número de número de salas de clase y seis grandes talleres en donde podrán instalarse cómodamente los departamentos más importantes de una escuela moderna de esta clase". ${ }^{22}$

La superficie donde fue construida la escuela tiene $17.122 \mathrm{~m}^{2 .}$ Toda la estructura de acero fue fabricada y montada por la Compañía Fundidora de Fierro y Acero de Monterrey

\footnotetext{
${ }^{18}$ Universidad Autónoma de Nuevo León, 1933-1993: una historia compartida, Monterrey, N.L., UANL, 1994, p. 189.

${ }^{19}$ AGENL, Sección Documentos: Educación, Asunto: Escuela Industrial Álvaro Obregón, Año: 1930-1931, Caja 1. "FOMENTO Y URBANIZACIÓN, S.A. /Lista de Raya/Correspondiente a la semana No. 38 del 20 al 26 de Sept. de 1930.-/ Trabajos de Construcción./Nombre de la calle ESCUELA INDUSTRIAL. "A. Obregón".

En el Catálogo Nacional Monumentos Históricos Inmuebles. Nuevo León, tomo 4, p. 1892 al referirse a la Escuela Fernández de Lizardi se cita que su edificación se llevó a cabo "por una compañía constructora, misma que se hiciera cargo de edificar la Escuela de Oficios Gral. Álvaro Obregón y el Palacio Federal”.

${ }^{20}$ Jueves de Excélsior, "Edición Especial pro Monterrey”, Excélsior, México, D.F., noviembre de 1929.

${ }^{21}$ Enrique X., de Anda, Arquitectura de la Revolución Mexicana. Corrientes y estilos de la década de los veintes, México, UNAM, IIE, 1990, Cuadro 16, No. 26.

${ }^{22}$ Jueves de Excélsior, Op. Cit., sin página.
} 
y se presupuestó un costo total de la construcción en 400.000 pesos. ${ }^{23}$ Se utilizó cemento de las compañías regionales "Cementos Hidalgo, S.A." y "Cementos Portland Monterrey, S.A.”, tal como consta en las facturas pagadas por el Gobierno del estado a dichas compañías. $^{24}$

La planta del edificio es un trapezoide y fue planeado en dos niveles: en el primero se ubicaron las oficinas del Director, Secretaría, Sala de Profesores, Sala de Empleados, vestíbulo y un gran hall con escalera, dos laboratorios, uno de física y otro de química, además de dos baños; en el exterior seis grandes talleres. En el segundo piso un hall, una biblioteca, un Departamento de Exámenes Físicos, dos grandes salones de dibujos, seis salones de clase y dos sanitarios. ${ }^{25}$

En el informe de gobierno 1928-1929 de Aarón Sáenz, al referirse al panorama de la Educación en el estado, menciona las obras de la Escuela Industrial Álvaro Obregón y la necesidad de crear una "Junta Técnica Consultiva que determine qué cursos deben seguirse en esta escuela, qué talleres deban de establecerse en ella y cuál debe ser la naturaleza de la enseñanza que se imparta..."26 La junta quedó constituida por el Licenciado José Benítez Leal, representante del gobierno del estado, el Ingeniero Emilio Leonarz, Señor Joel Rocha, Señor Lorenzo Zambrano, Señor H. Himes y el Señor Luis G. Sada, empresarios de diferentes industrias de Monterrey.

José P. Saldaña al hablar de los años 1929 y 1930 y elogiar la administración gubernamental de Aarón Sáenz solamente dice: "Por la misma época se fundó y se construyó el edificio de la Escuela Técnica Álvaro Obregón, situada por la Avenida Madero y Félix U. Gómez, que ha prestado servicios de alta calidad en cuanto a la enseñanza técnica mecánica". ${ }^{27}$ Por su parte, Oscar Eduardo Martínez escribe al referirse a edificios oficiales: "Igualmente, y con gran trascendencia para la ciudad, se construyó la escuela

\footnotetext{
23 Ídem.

${ }^{24}$ AGENL, Sección Documentos: Educación, Asunto: Escuela Industrial Álvaro Obregón, Año: 1930-1931, Caja 1. Facturas a pagar el 30 de marzo de 1930 a Cementos Hidalgo, S.A., la cantidad de \$264.24 pesos y el 5 de abril de 1930 a Cementos Portland Monterrey, S.A., por \$ 155.09 pesos, ésta última firmada por el Gobernador Aarón Sáenz.

${ }^{25}$ Israel Cavazos et al, "Panorama Educativo de Nuevo León al finalizar la década de 1920”, 1930-1950.50 Aniversario de la Escuela Industrial y Preparatoria Álvaro Obregón. Reseña histórica, Monterrey, N.L., UANL, 1980, s/p.

${ }^{26}$ Ibídem, s/p.

${ }^{27}$ José P. Saldaña, ¿Y qué hicimos?...Monterrey en el siglo XX. Monterrey, N.L., Al Voleo-El troquel, 1988, p. 61.
} 
industrial Álvaro Obregón al oriente de la avenida Madero, inaugurada en el año de 1930. La grandiosa construcción fue la de mayores dimensiones en su género y también fue resuelta eclécticamente con acentos decorativistas, un excelente ejemplo de la arquitectura déco industrial". 28

Antes de la conclusión de los trabajos y preparando la apertura de la escuela, el 3 de agosto de 1930 se anunció que vendría el Jefe del Ejecutivo a cortar el listón inaugural: "Para el 4 de octubre vendrá a Monterrey el Presidente de la República, Ing. Ortiz Rubio. Será invitado a la inauguración de la Escuela Industrial, también será la apertura de la Escuela Fernández de Lizardi y la inauguración de la presa de Los Herrera". ${ }^{29}$ Unos días después, el martes 26 de agosto, llegaron procedentes de la ciudad de México los ingenieros Eugenio Alemán y Spencer Holguin para ocupar respectivamente los puestos de Director y Subdirector del plantel. El Ingeniero Alemán vertió su opinión con mucha admiración sobre la escuela y su proyección académica en la región noreste, así como del alcance que tendría para la actividad industrial regiomontana una institución de esta categoría: "El edificio destinado para la escuela es algo admirable -nos expresó el Ing. Alemán- añadiendo que va a ser un plantel que dará mayor prestigio al estado y ayudará a impulsar la industria. No solamente en la República -agregó- sino que en muchas poblaciones de Estados Unidos no existe algo semejante en cuanto al local, y posiblemente también en la organización que se le dará", 30

Ante tal relevancia para la ciudad y el país, la inauguración de la Escuela Industrial Álvaro Obregón se convertía en todo un acto político y educativo, porque por una parte se le rendía homenaje al recién fallecido Presidente Electo para su segunda gestión, poniéndole su nombre la escuela, y por otra, era como tal la primera escuela industrial del país. Era por esa razón que estaba prevista la visita del Presidente de la República. Entonces para dar más relevancia a la apertura del plantel educativo en septiembre de 1930 se planeó abrir una exposición de arte: "El Sr. Profesor Higinio Vázquez Santana, jefe del departamento de Bellas Artes, acompañado del profesor Don Andrés Osuna, director de

\footnotetext{
${ }^{28}$ Oscar Eduardo Martínez, "Monterrey: ciudad vieja, ciudad nueva. Su arquitectura y urbanismo", en: Cavazos Garza, Israel (coordinador), La Enciclopedia de Monterrey. Tomo II La Capital Industrial de México, Monterrey, Milenio, Multimedios, 2008, p. 280.

${ }^{29}$ El Porvenir, Monterrey, N.L., domingo 3 de agosto de 1930, p. 4.

${ }^{30}$ El Porvenir, Monterrey, N.L., viernes 29 de agosto de 1930, p. 4.
} 
Instrucción Pública del estado, visitó el edificio de la Escuela Industrial Álvaro Obregón a fin de elegir los salones que habrán de utilizar para la exposición de pintura de las diversas escuelas que dependen de Bellas Artes, y de la de Pintura al Aire Libre que fundara en Monterrey el maestro Ramos Martínez". 31 Hay que tomar en cuenta que el mismo Aarón Sáenz fundó en Monterrey una escuela de pintura como las que se habían instituido en 1913 en la capital del país bajo la dirección de Alfredo Ramos Martínez (1871-1946); eran las Escuelas al Aire Libre, siendo la más famosa y mencionada la de Santa Anita. Ramos Martínez al ser oriundo de Monterrey, influye en el Gobernador Sáenz para que en Monterrey se siguiera el modelo de "los barbizonianos" mexicanos. La escuela se inició en febrero de 1928 con local propio y al parecer tuvo duración hasta el final del gobierno de Sáenz en 1931. Fungía como director de la escuela de pintura Ramón Cano Manilla (18881974), quien había estado en la Escuela de Aire Libre de Chimalistac. Como dice Horacio Salazar: "No se tienen noticias de pintores o artistas que hayan iniciado su formación en esta escuela, aunque la verdad es que todavía falta mucho por investigar al respecto. $\mathrm{Su}$ breve existencia, además, explica en parte ese desconocimiento". ${ }^{32}$ Con toda la parafernalia de la inauguración de la escuela industrial, más la exposición de arte que se ubicó en la planta alta donde "la comitiva observó una exposición de pinturas de alumnos de las escuelas primarias traídas de la capital del país a cargo del profesor Hipólito Vázquez Santana", 33 Aarón Sáenz quien ocupaba la Secretaría de Educación Pública (del 5 de febrero al 8 de octubre de 1930), iba tendiendo las cuerdas para amarrar puestos políticos de más envergadura con las obras que había desarrollado en Nuevo León.

La escuela fue inaugurada el 4 de octubre de 1930, dos años después de haber sido colocada la primera piedra. Asistió en representación del Presidente, el general. Plutarco Elías Calles, el Jefe Máximo de la Revolución. Sobre la formación que se podía adquirir en la flamante Escuela Industrial, la siguiente cita nos los explica claramente: "Los jóvenes en ella inscritos cursaban en un plan de dos años los oficios de automecánico, carrocero, electricista, ebanista, fundidor y modelista. También podían optar por la carrera de Maestro

\footnotetext{
${ }^{31}$ El Porvenir, Monterrey, N.L., lunes 29 de septiembre de 1930, p. 5.

${ }^{32}$ Horacio Salazar, "La entrada al nuevo siglo", en: Xavier Moyssén (ed.), Artes Plásticas de Nuevo León 100 Años de Historia Siglo XX, Monterrey, N.L., Museo de Monterrey, 2000, p. 44.

${ }^{33}$ Edmundo Derbez García, "Escuela Industrial y Preparatoria Técnica Álvaro Obregón”, Memoria Universitaria, Año I, Num. 9, octubre de 2010, p. 11.
} 
Mecánico por un periodo de cuatro años".34 Aunque se menciona que se iniciaron las actividades académicas hasta el 24 de octubre de ese mismo año, ${ }^{35}$ fue realmente hasta el sábado 1 de noviembre cuando se empezaron definitivamente los cursos y los trabajos en los talleres, estando con cupo lleno los de mecánica de coches y electricidad, quedando solamente algunos lugares en herrería, fundición, ebanistería y carpintería. ${ }^{36}$

Cabe mencionar que a la escuela se le llamara Álvaro Obregón, y como decíamos al principio que entre otras cosas tuvo el objetivo de ser un acto político de Aarón Sáenz, fue porque con esto homenajeaba al Caudillo de la Revolución que había sido asesinado tan sólo tres meses antes por José de León Toral (1900-1929), en el restaurante La Bombilla en la ciudad de México, mientras festejaba su triunfo para ser Presidente por segunda vez.

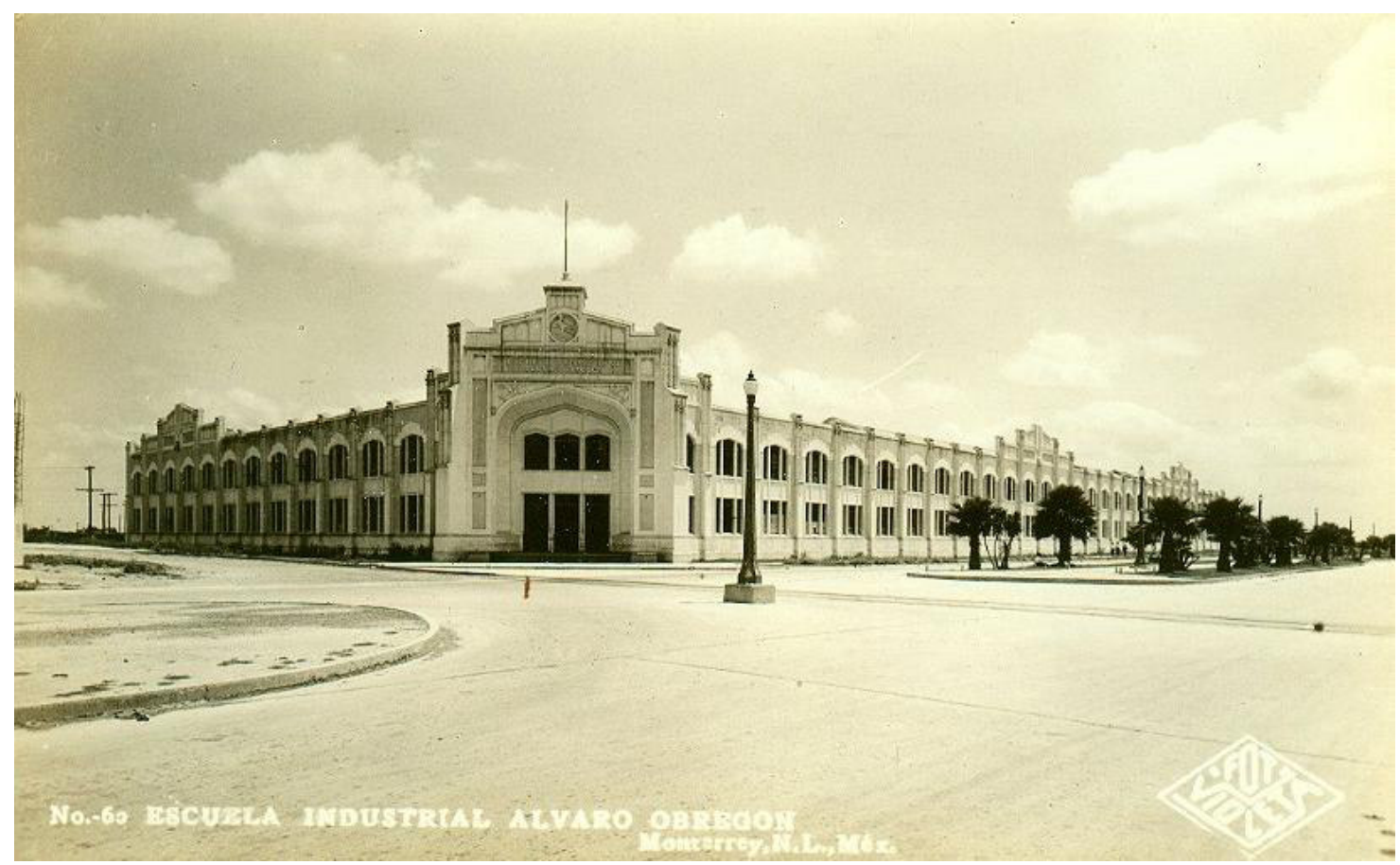

La escuela recién concluida en $1930 .^{37}$

\footnotetext{
34 Francisco Javier Barrientos Claudio, "La educación preparatoria y tecnológica”, en: Cavazos Garza, Israel (coordinador), La Enciclopedia de Monterrey. Tomo III Nuevo León: visión al futuro, Monterrey, Milenio, Multimedios, 2008, p. 214.

${ }^{35}$ Universidad Autónoma de Nuevo León, 1933-1933: una historia compartida, Monterrey, N.L., 1994, p. 189.

${ }^{36}$ El Porvenir, Monterrey, N.L., domingo 26 de octubre de 1930, p. 4.

${ }^{37}$ Héctor Javier Barbosa Alanís, Monterrey. Descubra el ayer de nuestra ciudad. Monterrey, N.L., Agencia Promotora de Publicaciones, 2010, p. 95.
} 
El edificio de la Escuela Industrial Álvaro Obregón es de dos niveles y la planta de tipo angular en forma de $\mathrm{L}$ acostada en lo que corresponde a oficinas y aulas y se adapta en torno a un patio donde se ubican los talleres.

El exterior tiene un estilo sui géneris ecléctico, ya que lleva arcos apuntados rebajados y columnillas de tipo gótico, lo que le da un giro de un neogótico hispanoflamenco o más bien, por el arco gótico rebajado de tipo Tudor, a la vez contiene un neogótico inglés. Todos las decoraciones exteriores están trabajadas en aplanados de cemento, el material moderno del Art Déco.

En los lienzos de los cuerpos laterales, en el primer nivel las ventanas se dividen en tres vanos rectangulares, siendo el central más amplio y separados por pilastras cuadradas. En el segundo nivel y con la misma segmentación, el vano se cierra en la parte superior con un arco Tudor, cuyo extradós resaltado presenta acodamientos a la altura entre la imposta y la aduela, prolongándose hasta unirse con los rectángulos que envuelven a los letreros, armonizando lo gótico con lo geométrico; entre cada grupo de ventanas, destacan un par de columnas alargadas de influencia gótica y capitel floreado que descansan sobre una pilastra. La muy acertada descripción del exterior por parte del arquitecto Miguel Román dice: "Es de estilo ecléctico dominando el gótico inglés, pues todos los vanos están rematados con arcos Tudor y entre ellos los espacios se decoran con estribos que se levantan adosados hasta el antepecho de los vanos de la planta superior y a partir de allí con un par de columnillas rematadas con florones que contrarrestan la horizontalidad del edificio". ${ }^{38}$ Dentro de unos tableros rectangulares se inscriben por pares con letras de influjo gótico iguales a las de la fachada, los nombres de los talleres ofrecidos por la escuela industrial: carpintería, herrería; mecánica, fundición; automóviles, electricidad: toda una consolidación de una ciudad industrial, que acoge las ideologías postrevolucionarias vasconcelistas de que solamente con la educación México saldrá de su retraso, por lo que edifica una institución educativa para estudios técnicos industriales. En el remate de los tableros se eleva un frontón roto, cuyo tímpano lleva a cada lado una galería de tres arcos ciegos tipo Tudor y para ornar el centro caen verticalmente siete bandas, las cuales salen desde lo alto envolviendo el remate del edificio, siendo las de los lados más gruesas y las

\footnotetext{
${ }^{38}$ J. Miguel Román C, Colores del alma. Los vitrales de Roberto Montenegro en la Universidad Autónoma de Nuevo León; una revisión histórica e iconográfica, Monterrey, N.L., UANL, 2008, p. 34.
} 
cinco restantes con formas a manera de hilo de baquetón; el adorno abstrae una cascada de agua congelada, terminando en forma de punta de flecha, con lo que se consigue un efecto de contraposición de la altura del arco, un juego decorativo a través de líneas verticales descendentes que se hizo uno de los fundamentos generales del Art Déco, pero especialmente del Zigzag.

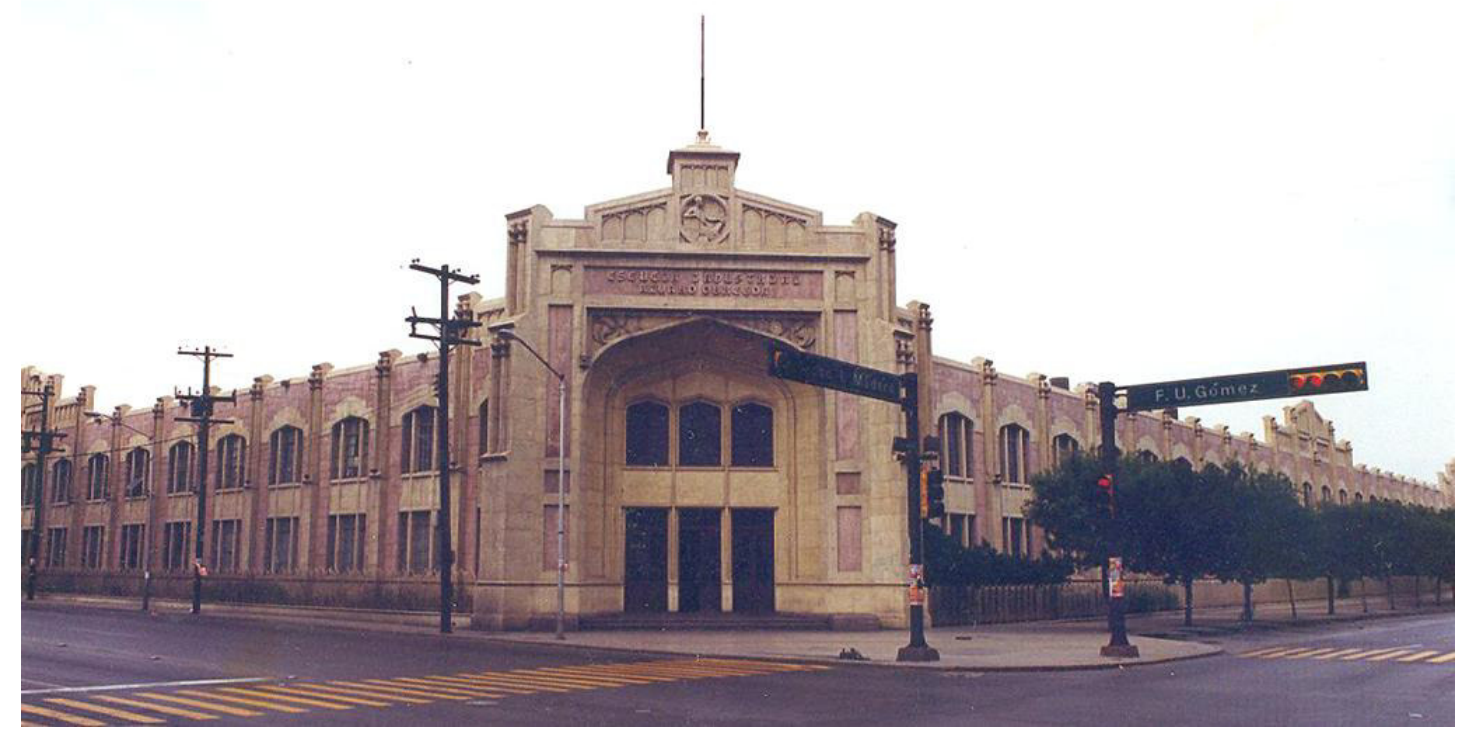

Vista general.

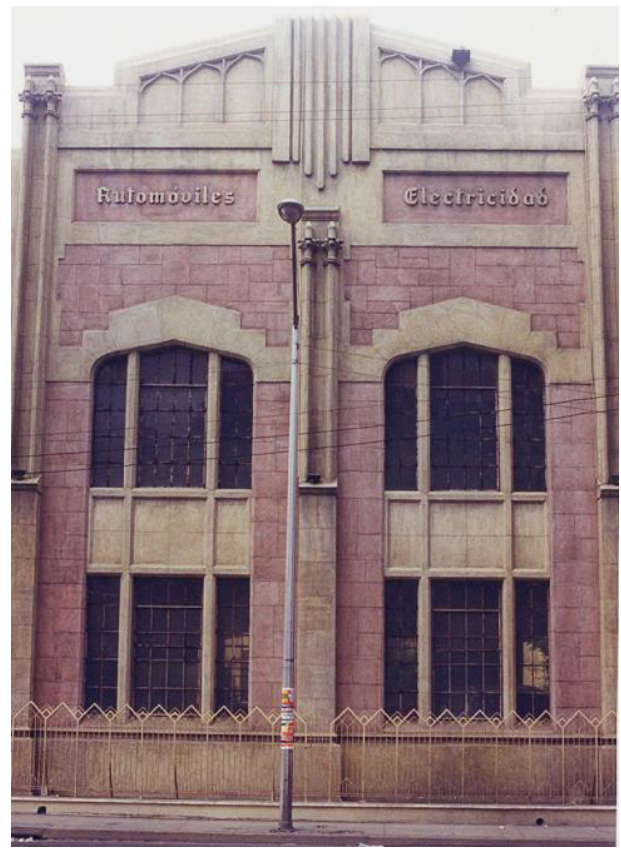

Vista de una parte del cuerpo lateral poniente. 
La fachada principal dispuesta en ochavo es un sugestivo espécimen decorativo. Una escalinata de dos peldaños y resguardada por sendos zócalos cuadrados, -todo esto en granito, material de uso típico en el Art Déco- se conecta con el vano de acceso, que describiremos más adelante, el cual está colocado hacia atrás de la superficie y detrás de un arco Tudor abocinado; el arco lleva alfiz moldurado y en las enjutas dentro de unos círculos se desplazan unas decoraciones naturalistas a manera de hiedras de las que se usaban en las construcciones góticas. Las jambas se conciertan por medio de cuatro recuadros moldurados que llegan hasta el nivel del rectángulo que enmarcan el letrero, llevando inserto el último recuadro un arco Tudor. El nombre inscrito de la escuela es un importante Elemento Exterior de la Tendencia Decorativista, cuyas letras moldeadas en cemento no son de las usadas en los tiempos del Déco, sino que tratan de imitar escrituras góticas.

El remate escalonado más bien parece un frontón roto, cuyo tímpano se orna con tres arcos ciegos Tudor en cada lado y en el centro se implanta un cubo de mayor altura con techumbre de cuatro aguas también escalonadas que asemeja la torre de un alcázar, el cual exhibe un medallón y arriba de éste una galería de cuatro arcos ciegos de tipo Tudor adornan al cubo más otras dos caras laterales. El sentido de ascenso se prolonga con la base de la astabandera que parece un pináculo o un balaustre geométrico. La fachada la resguardan dos contrafuertes escalonados en tres niveles, de los cuales el segundo y tercero portan un par de columnillas de influjo gótico. La geometría de las jambas y la proyección de altura escalonada le dan a la fachada una identificación con el Art Déco.

El vano de acceso tiene dos niveles: el de abajo tiene tres puertas rectangulares de acceso separados por dos pilastras con base cuadrada que sustentan una pequeña columnilla que se eleva por encima del límite de las ventanas del segundo nivel hasta el tímpano; en este nivel tres antepechos se corresponden con los vanos formados por arcos Tudor con molduras que recorren el perímetro de cada uno. Realmente en este vano de acceso no hay en sí decoraciones o elementos distintivos Art Déco, sino más bien un estilo neogótico.

Aunque dentro de las clasificaciones propuestas para la arquitectura Art Déco no hay una que sea del tipo neogótico, para ejemplificar el caso de la Álvaro Obregón en su exterior y relacionarla con el Déco, sí hay paradigmas con estas influencias en Estados Unidos, Canadá e Irlanda como las que cita Eva Weber: "La iglesia de Tulsa de Goff 
ejemplificó una estilizada variante gótica del zigzag Art Decó que puede verse en otras estructuras religiosas de la época. Fue utilizada por Adrian Gilbert Scott en la St. James Church de Vancouver y por Barry Byrne en iglesias americanas así como en su Church of Christ the King en Cork, Irlanda (1928). El único ornamento de la iglesia de Cork era un estilizado relieve de Cristo entre los pórticos de John Storrs. El Art Decó medievalista se consideró también apropiado para el Masonic Temple de Detroit (1928)". 39 Se está refiriendo a la Boston Avenue Methodist Church en Tulsa, Oklahoma, erigida entre 1927 y 1929 por el arquitecto norteamericano Bruce Alonzo Goff (1904-1982), construcción grandiosa, considerada como uno de los mejores ejemplos de arquitectura religiosa Art Déco, catalogada en el National Register of Historic Places en 1978 y en el National Historic Landmark en 1999; la iglesia de St. James en Vancouver, levantada entre 19351937 por el arquitecto inglés Adrian Gilbert Scott (1882-1963) es de pequeñas proporciones, lo mismo que la Church Christ the King en Cork, Irlanda, obra del norteamericano Barry Byrne (1883-1967), cuya imagen de Cristo con los brazos abiertos diseñada por el escultor John Storrs (1885-1956) es una máxima expresión del Art Déco, como muchas de las obras de este artista. Sin embargo, el Masonic Temple en Detroit, es de grandes dimensiones, monumental y colosal construcción, es el más grande templo masónico del mundo, realizado entre 1920 y 1926 por el arquitecto estadounidense George DeWitt Mason (1856-1940) \& Company. Éste inmueble es el más parecido a la Escuela Álvaro Obregón, ya que utiliza tanto en su exterior como en su interior arcos Tudor, así como la inserción de tres paneles para los vanos de las ventanas, separados por dos columnas, aunque nada tenga que ver en sus proporciones y distribución de espacios con la escuela de Monterrey. Sin que tengamos referencia alguna, posiblemente Aarón Sánez, importante miembro de la masonería en México, visitó este magno edificio y haya sugerido a los arquitectos de FYUSA construir algo similar en estilo, o bien que los propios Muriel y Lamosa hayan estado en el templo masónico o lo conocieran por referencias bibliográficas o fotográficas.

Lo que sí está más que claro, es que se planeó y construyó un inmueble de amplio tamaño, de altura todavía como los edificios porfirianos o incluso virreinales con sólo dos niveles, con finos acabados y que al mismo tiempo albergara patrimonios artísticos, por

\footnotetext{
${ }^{39}$ Eva Weber, Art Deco, Madrid, Lisba, 1993, p. 31.
} 
esta razón es que se la ha llamado "Escuela Monumental”, junto con otras instituciones educativas como la Escuela Fernández de Lizardi, contemporánea de la Álvaro Obregón y las que se levantaron posteriormente, la Presidente Calles, la Escuela Nuevo León, la Escuela Monterrey, la Escuela de la Revolución y la Escuela Abelardo L. Rodríguez.

Por lo que respecta a la decoración del cubo inserto en el tímpano, un medallón se ubica en la parte baja. El medallón es todo un "clásico" del Art Déco: una mujer sentada de perfil descansa el brazo derecho sobre el escudo de Monterrey y el otro sobre un libro abierto que descansa en sus piernas. Lleva sombrero encasquetado adornado con flores, lleva blusa sin mangas escotada, traslúcida, que permite ver que no porta sostén; la falda larga va cayendo en gajos, como un zigzag. La feminidad de la dama se denota además en la delicadeza de la soltura de las manos y en todo el porte en sí.

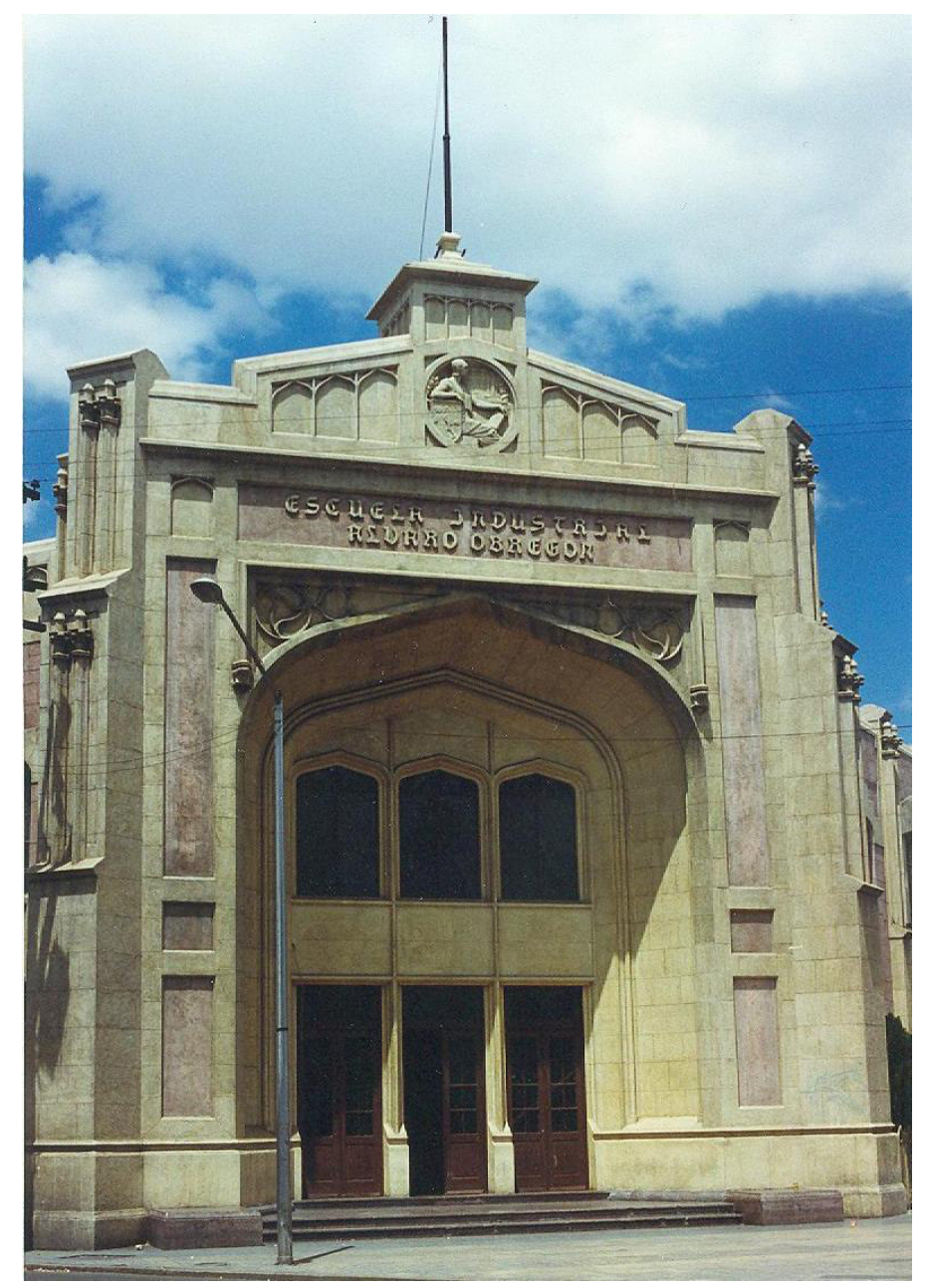

Fachada principal. 
Esta efigie es toda una representación de la mujer moderna de los "Años Locos", los veintes, la liberación femenina. El sombrero es de los que usaban las damas en París, que manejaban coches descapotados o viajaban en ellos, o surcaban los mares en los grandes trasatlánticos, como esas mujeres de las portadas de la revista Vogue de París que pintara el español Eduardo García Benito (1891-1981), ${ }^{40}$ o para la edición Vogue de Estados Unidos con sus portadas ilustradas por George Plank (1883-1965). La blusa y falda de la dama del medallón no son otra cosa que diseños a la Coco Chanel (1883-1971); la blusa suelta, con una caída libre en bandas verticales y que a los lados se desploman en pliegues, como los que se aprecian en el lado derecho, los cuales se conjugan con los dobleces de la falda; ropa ligera, fresca, revolucionaria en su confección y diseño, tal como lo explica Lourdes Cerrillo Rubio: "La ropa de Chanel se podía llevar sin corsé, era cómoda, se amoldaba al cuerpo y le permitía moverse libremente, pues estaba realizada con un tejido flexible, el jersey, hasta entonces sólo utilizado en prendas interiores". ${ }^{41}$

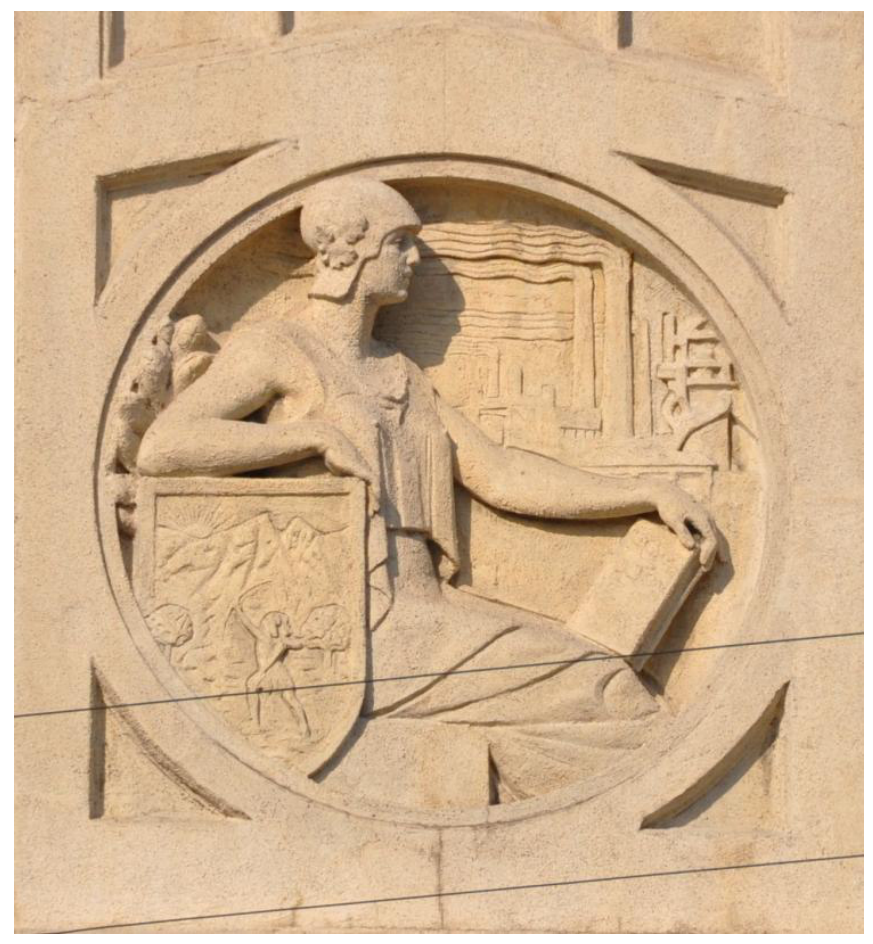

Medallón.

\footnotetext{
${ }^{40}$ Teresa Ortega-Coca, Eduardo García Benito y el Art-Déco, Valladolid, Ayuntamiento de Valladolid, Fundación Municipal de Cultura, Diputación de Valladolid, 1999, p. 27.

${ }^{41}$ Lourdes Cerrillo Rubio, La moda moderna. Génesis de un arte nuevo, Madrid, Siruela, 2010, p. 121.
} 
La mano izquierda de la dama de la Escuela Industrial Álvaro Obregón la descansa sobre un libro insignia de la ciencia, del avance científico, de la modernidad y, por qué no, de las campañas educativas Vasconcelistas que tanto promovieron la lectura y la distribución de los libros, con el fin de hacer de México un país "culto" que saliera del atraso. Símbolo de la postrevolución a través de la educación y la cultura, además de representar el saber que se obtiene en una escuela, curiosamente exclusiva para hombres. El brazo derecho y a la vez junto con la mano detienen el escudo de Monterrey, aquél antiguo blasón solicitado por el Gobernador y Capitán general Nicolás de Azcárraga, quien mantuvo el poder del Nuevo Reino de León de 1667-1676 y que una vez nombrado en el puesto pidió a la Regente del Reino Margarita de Austria la autorización para un escudo, mismo que fue otorgado cinco años después el 9 de mayo de 1672. La tradición que se ha mantenido por muchos años de la parte central de la insignia, muestra en un primer plano a un indio que aparece del lado derecho ataviado con faldellín y penacho de plumas con arco y flecha en actitud de caza apuntando hacia el sol; después y más al fondo, dos árboles de cada lado se colocan al pie del majestuoso Cerro de la Silla y detrás de éste en la parte superior izquierda, una parte del sol aparece con sus poderosos rayos. ${ }^{42}$

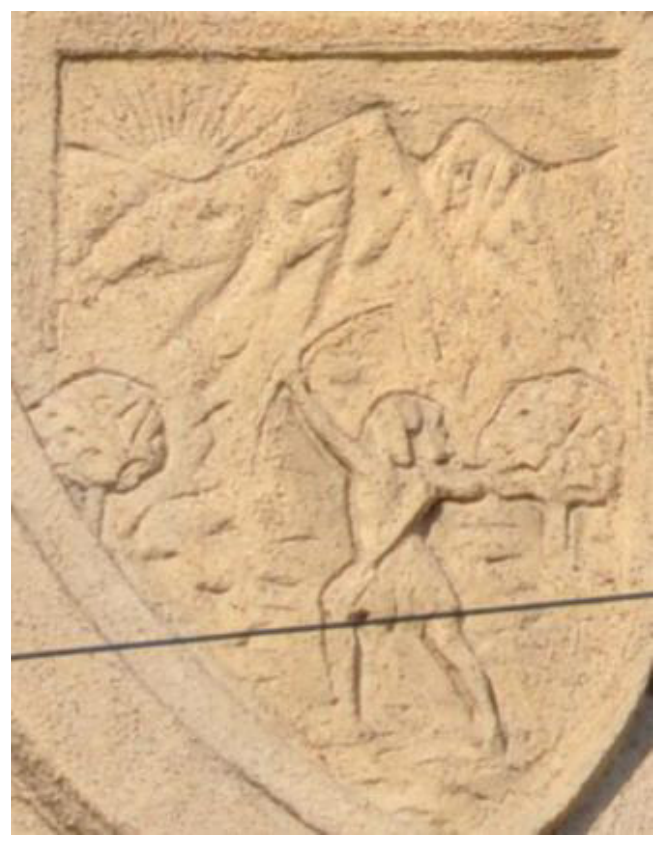

Medallón, detalle del escudo de Monterrey.

\footnotetext{
${ }^{42}$ Israel Cavazos Garza, Isabel Ortega Ridaura, "Monterrey. Capital de Nuevo León”, VV.AA., Nuevo León a través de sus municipios. Tomo III, Monterrey, N.L., Milenio, Multimedios, 2010, p. 303.
} 
Detrás del brazo de la dama, sobresalen unos frutos apilados que seguramente son naranjas o la hoja del arbusto en flor, refiriéndose a la labor agrícola de los cítricos de la región. Pero una parte que destaca por su relación con la ciudad es la parte del fondo del medallón en la que toda una semántica del trabajo industrial se expresa a través de una nave que se ubica inmediatamente detrás de la mano de la dama y de cuatro chimeneas que se van distribuyendo hacia atrás en tamaño y grosor; de ellas emana el humo producto de la manufacturación fabril, pero es el humo industrial, abundante, de mayor grosor que sus propios conductos, de curvas rigurosas que se expanden formando un ángulo recto junto con la chimenea, en un efectivo geometrismo "porque es ahora el humo de las fábricas, de las locomotoras, de los trasatlánticos, de los aviones, de los automóviles, el humo devastador del progreso técnico", 43 en palabras de Xavier Esqueda, uno de los grandes expertos del Déco en México. Es a la vez el humo del Estridentismo, movimiento contemporáneo de los años del Art Déco, que si bien como lo explica el propio Esqueda que "No podemos afirmar que esta producción literaria sea art deco, ya que el término se refiere a las artes visuales, pero los estímulos estéticos que son parte de éste, fueron los mismos que influyeron a los estridentistas para su aspiración innovadora", ${ }^{4}$ además, sus poemas, manifiestos y escritos fueron ilustrados, entre otros, por Jean Charlot (1898-1979) y Ramón Alva de la Canal (1892-1985) y muchas de esas ilustraciones son composiciones con formas geométricas, líneas rectas oblicuas, cubos elevados, que caen en la estética del Déco. Movimiento que le cantó al maquinismo y a la vida urbana moderna del aeroplano, del tren, del automóvil, del barco, de la fábrica, del teléfono, tuvo una corta duración de seis años, de 1921 a 1927. Por eso, el humo es la fumarada imborrable del estridentista Manuel Maples Arce (1898-1981), de las fábricas cuyo olor omnipresente es sinónimo de modernidad industriosa, maquinista, que domina el horizonte urbano como en el caso de Monterrey. ${ }^{45}$ En su oda a la Revolución de sus Poemas Interdictos, 1927, pareciera que Maples Arce le corea al medallón de la Escuela Industrial Álvaro Obregón:

\footnotetext{
${ }^{43}$ Xavier Esqueda, Una puerta al Art Deco, México, Centro de Investigación y Servicios Museológicos, UNAM, 1980, p. 13.

${ }^{44}$ Xavier Esqueda, El Art Deco retrato de una época, México, Centro de Investigación y Servicios Museológicos, UNAM, 1986, p. 137.

${ }^{45}$ José Manuel Prieto González, "Monterrey como Estridentópolis: vigencia del ideal urbano de la vanguardia histórica mexicana", Palapa, Colima, México, Universidad de Colima, vol. IV, núm. I, enero-junio, 2009, p. 23.
} 
"las fábricas se abrasan, en el incendio del crepúsculo...

el humo de las factorías perdidas en la niebla del tiempo..." 46

Al lado de la cuarta chimenea, la más pequeña, otros dos tubos se amalgaman con una nave industrial y todo el conjunto se enlaza con la torre colocada del lado derecho de las chimeneas, colmada de tuberías, niveles, conexiones, en una verdadera representación de un alto horno. Paisaje industrial que pareciera una representación de la Fundidora de Monterrey, como luciría en aquellos años de su intensa actividad.

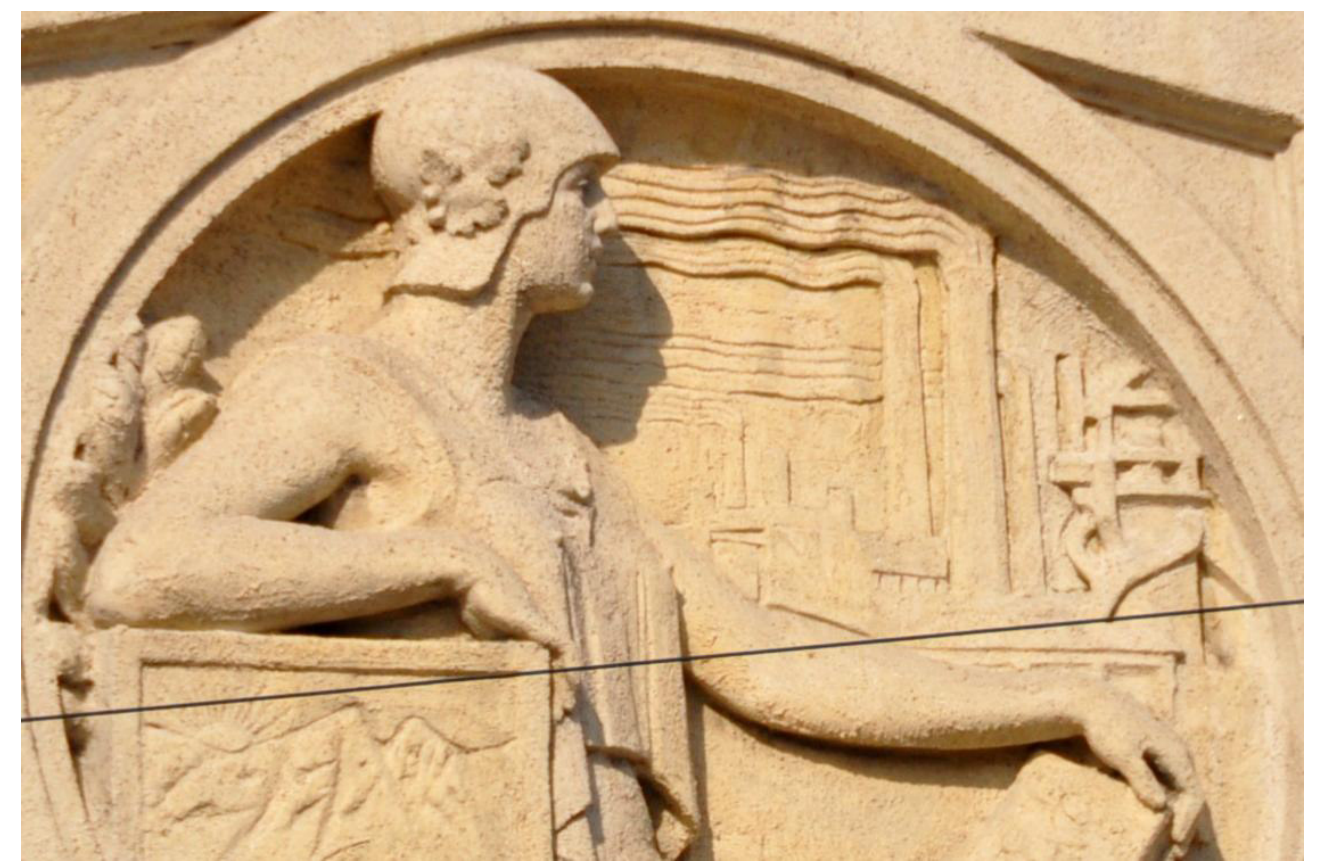

Medallón, detalle de las chimeneas y el humo. Detrás del brazo derecho están los naranjales.

Cuatro elementos en el medallón: el escudo de Monterrey, la dama, lo agrícola y lo industrial, destacando más el de la mujer. Porque el concepto de la mujer abnegada, sumisa, pueblerina, de trenzas y rebozo, cambia por un modelo llegado del extranjero de mujeres llamativas, atrevidas, seductoras, modernas, que importaron la moda de la dama vestida a la francesa, o la neoyorkina, con pelo a lo garzón, con sombrero encasquetado, que conducían

\footnotetext{
${ }^{46}$ Manuel Maples Arce, Poemas Interdictos, Jalapa, Ediciones de Horizonte, 1927, pp. 52-53.
} 
un auto, viajaban, leían literatura europea y de vanguardia, desarrollando una vida urbana y cuya imagen fue retratada en las iconografías del Déco, como lo hiciera Ernesto "Chango" García Cabral (1890-1968) en Revista de Revistas en la década de los treinta. ${ }^{47}$

Como hemos visto, este medallón de la Escuela Industrial Álvaro Obregón es todo un icono del Art Déco en México y en el mundo. Hasta donde sabemos, no hay otro igual en ninguna parte del país, por lo que con mayor razón se convierte en un legado patrimonial de la ciudad y que tan sólo por sí solo, vale la pena todo el edificio.

En el interior y antes de pasar al vestíbulo está colocada una placa en la que se da la información de la construcción de la escuela bajo el gobierno de Aarón Sáenz entre 1928 y 1930.

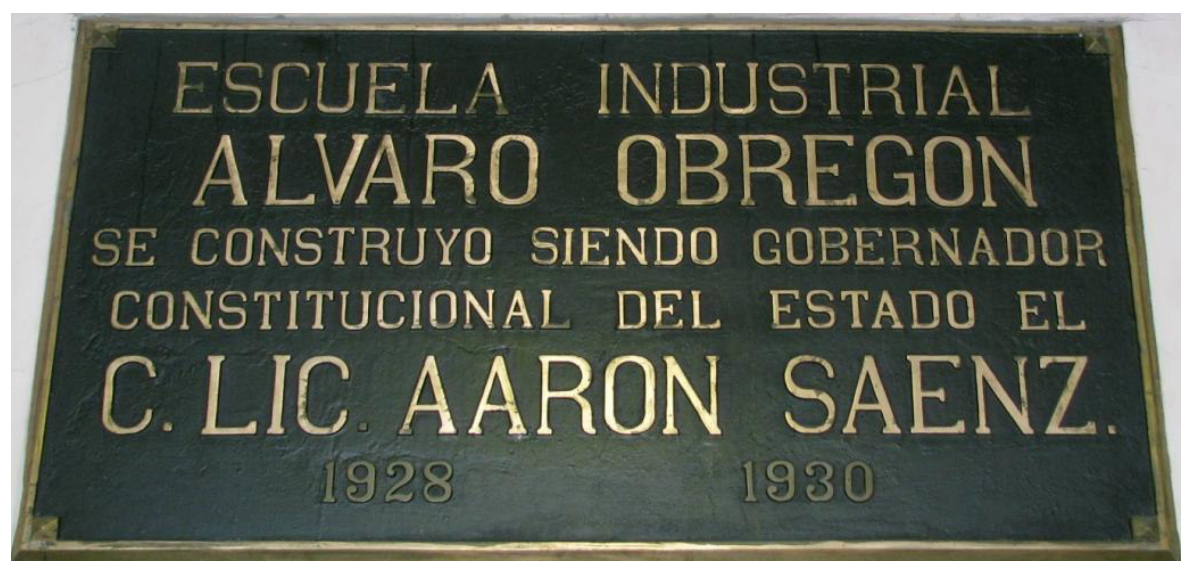

Placa con la fecha de construcción.

El vestíbulo dispone de un espacio cuadrado al centro y dos laterales a cada lado en forma trapezoidal. Seis columnas individuales y cuatro pares más, todas ochavadas, se prolongan hasta el segundo nivel, donde sostienen tanto piso como techumbre. Están apoyadas en un pedestal también ochavado, resaltando la parte bajo con un anillo de mosaicos. A la mitad del fuste se ensamblan las trabes que sostienen el piso del segundo nivel. La base del fuste hace juego con el capitel por el color dorado, lo que le da un efecto visual de resaltar los elementos sustentantes. Los capiteles dorados mantienen la forma ochavada: después de dos anillos, el capitel, que se abre hacia lo alto, va decorado con rombos cóncavos, los cuales ritman un magnífico juego de triángulos isósceles en

\footnotetext{
${ }^{47}$ Enrique X., de Anda Alanís, "El Art Déco: formas y razones" "La identidad del Art Déco en México”, en: MUNAL, Art Déco. Un país nacionalista. Un México cosmopolita, México, INBA, 1998, pp. 53 y 66.
} 
disposición vertical que constituyen un verdadero zigzag, para terminar con el ábaco moldurado también en forma ochavada.

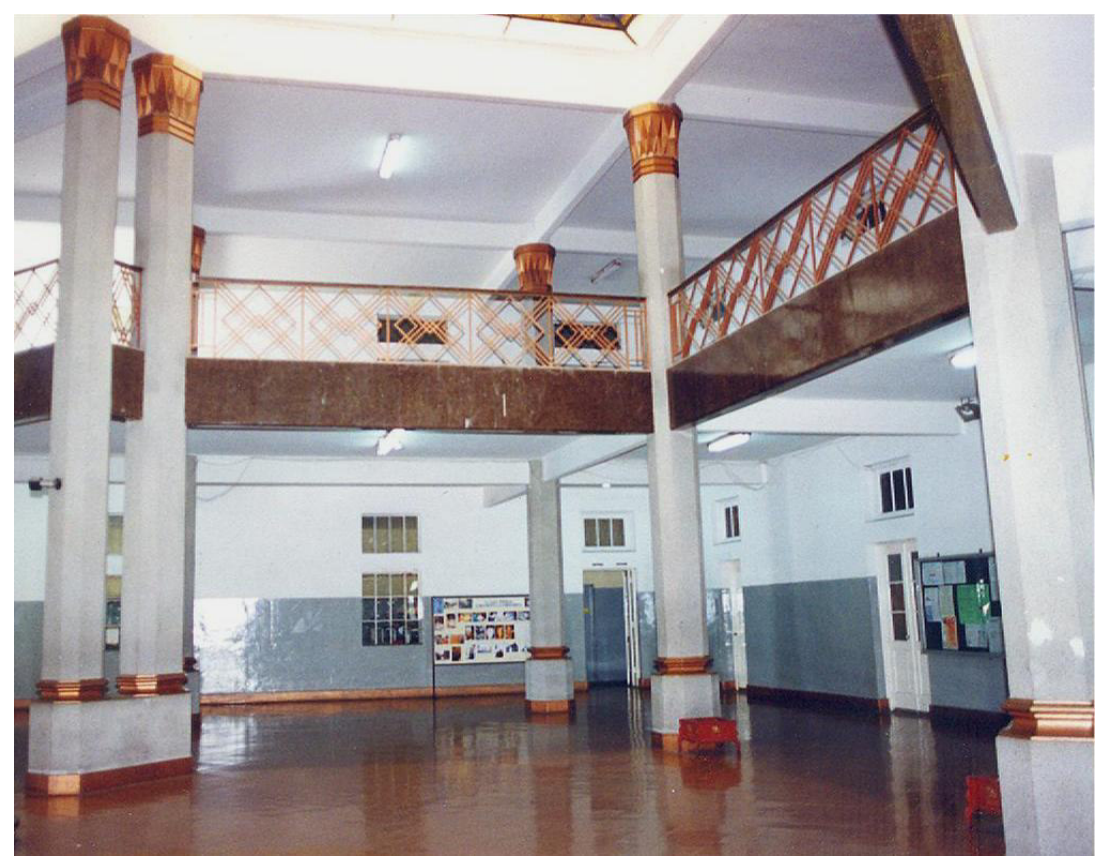

Vestíbulo, detalle.

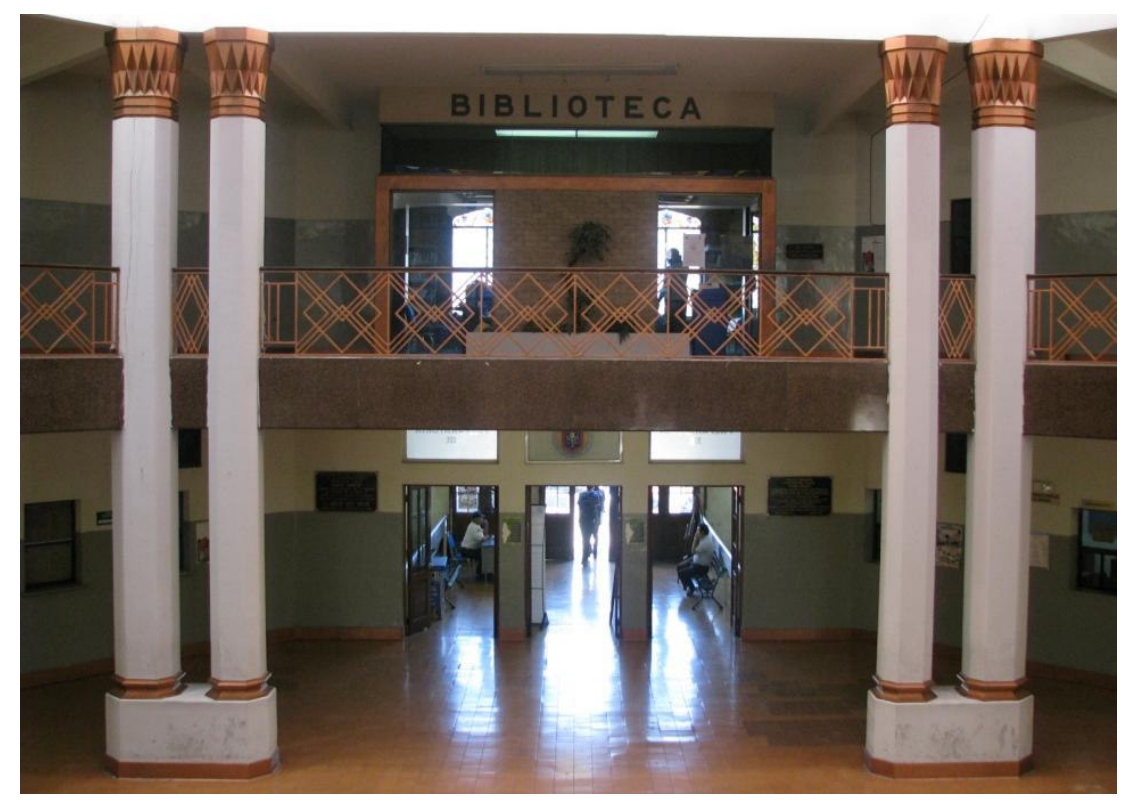

Vestíbulo. Vista hacia la entrada. 
Estas columnas del vestíbulo reflejan tanto la búsqueda como la creación de diseños inconfundiblemente Art Déco del tipo Zigzag, en donde se acentúa la geometricidad en los siguientes componentes: en la horizontalidad del zócalo del pedestal, base del fuste y anillos del capitel; en el volumen de las columnas y los pedestales; en los polígonos triangulares de los capiteles que en su unión inversa de dos, otorgan una secuencia dinámica de la línea quebrada. Todo una conquista de los esquemas geométricos del Art Déco, que a la vez emanan la modernidad del uso del concreto, pero que lo engalanan con diseños glamurosos y refinados.

La escalera que lleva al segundo nivel se ubica al centro del vestíbulo se compone de un tramo central y dos laterales. Está forrada de granito, material usado constantemente en el Art Déco, que también protege el revestimiento exterior de los peldaños y se prolonga hacia el segundo nivel en la base del barandal que da hacia el vestíbulo. El granito por su brillo provoca en el interior un ambiente de elegancia, además de reflectar la entrada de la luz. El tramo central se inicia con una ligera curvatura hacia fuera, llega hasta un descanso donde conjuntamente con un busto de Obregón sobre un pedestal, se abren tres vanos en forma de arco Tudor en donde se ubican tres vitrales.

En el busto de Álvaro Obregón la cabeza está en posición de tres cuartos. Descansa sobre una base cuadrada de granito que se adorna con rectángulos rehundidos, siete por el frente y seis de cada lado, otorgándole un ritmo decorativo a través de figuras geométricas. Después el pedestal también forrado de granito se ensancha para conformar un cubo, en cuya cara principal se inserta una placa en mármol verde con la inscripción: “ÁLVARO OBREGÓN / OCT. 4 / 1930.” En la parte de abajo una estrella de cinco picos decorada con alas adorna la placa. Éste es el símbolo de la Escuela Pitagórica utilizado en las academias donde estudiaban las tradiciones del sabio matemático. Adoptado por la masonería es el símbolo del hombre, que abarca la sección áurea, pero del hombre compañero, donde además en la estrella se trazan la escuadra y el compás pitagórico, emblema de las sociedades masónicas. El pedestal lleva biselados sus perfiles y termina con un tablero cayendo a manera de escapulario en forma de punta de flecha, con cinco estrías rectangulares que ritman con la decoración exterior del edificio. Si hacemos una abstracción del pedestal en su parte superior, ésta se forma por tres escalonamientos, como si fueran las plataformas de un templo, ya que en la última, de abajo hacia arriba, los 
rectángulos verticales rehundidos representarían vanos de acceso; podría ser la alusión al Templo de Salomón de los masones, ya que si está la estrella anteriormente explicada, la representación del Templo completaría el símbolo masónico. En sí el pedestal es toda una composición Déco por el conjunto de elementos geométricos ensamblados.

El barandal de la escalera trabajado en fierro se inicia con una línea curva que termina en un acodamiento cuadrado. Después un ensamble de rectángulos en posición de 45 grados, se van acoplando en un ritmo de uno y luego tres concéntricamente; la unión de los tres rectángulos con el siguiente grupo, provoca que se cree un cuadrado con otros cuatro pequeños cuadros en el centro de rectángulo individual; la continuidad de todo el ensamble da la idea de líneas que van armando un conjunto de tracerías geométricas infinitas.

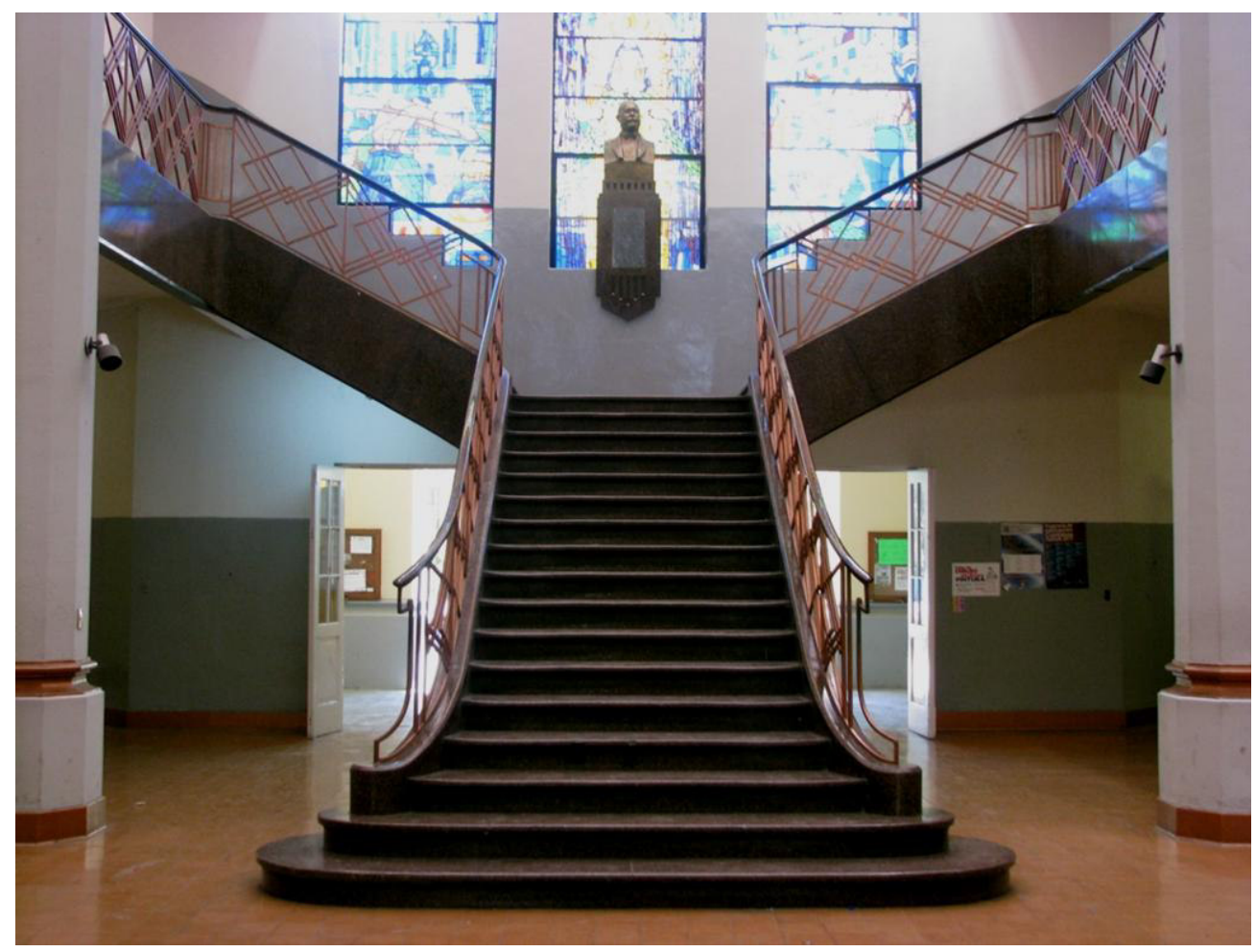

Escalera del vestíbulo.

En el barandal del segundo nivel se continúa con el mismo modelo, sólo que en lugar de rectángulos se utilizaron cuadrados. En el espacio que queda entre las dos columnas, en el segundo nivel las figuras son tres rombos concéntricos que conciertan con 
el diseño de los capiteles. El barandal se va dividiendo en tramos separados por líneas rectas que dividen a los grupos de tres rectángulos o tres cuadrados; el efecto del geometrismo a través de las figuras del rectángulo, el cuadrado y la línea recta vertical es totalmente un ejemplo del Art Déco Zigzag de lo más característico que se pueda encontrar en los referentes de esta variante del Déco. El diseño del barandal fue del Manuel Muriel y los trabajos de herrería corrieron a cargo de José Trinidad Vargas, tal como lo demuestra una carta donde se habla del presupuesto para esta obra: "Según dibujo número cinco que me mostró el Sr. Ing. Muriel, el precio que hago dicho barandal será el de: \$0.80 OCHENTA CENTAVOS KILO SIENDO TODOS LOS MATERIALES POR MI CUENTA Y AJUSTADO EN TODAS SUS PARTES AL PLANO Y OBSERVACIONES

DEL Sr. Ing. Muriel, comprometiéndome a instalar en su lugar lo que comprende en trabajo de mi ramo, exceptuando desde luego todo lo que se refiere albañilería, pues ese trabajo se hará por cuenta de los constructores de dicha escuela. Monterrey, N.L. 2 de julio de 1930. Firma José Trinidad Vargas". 48

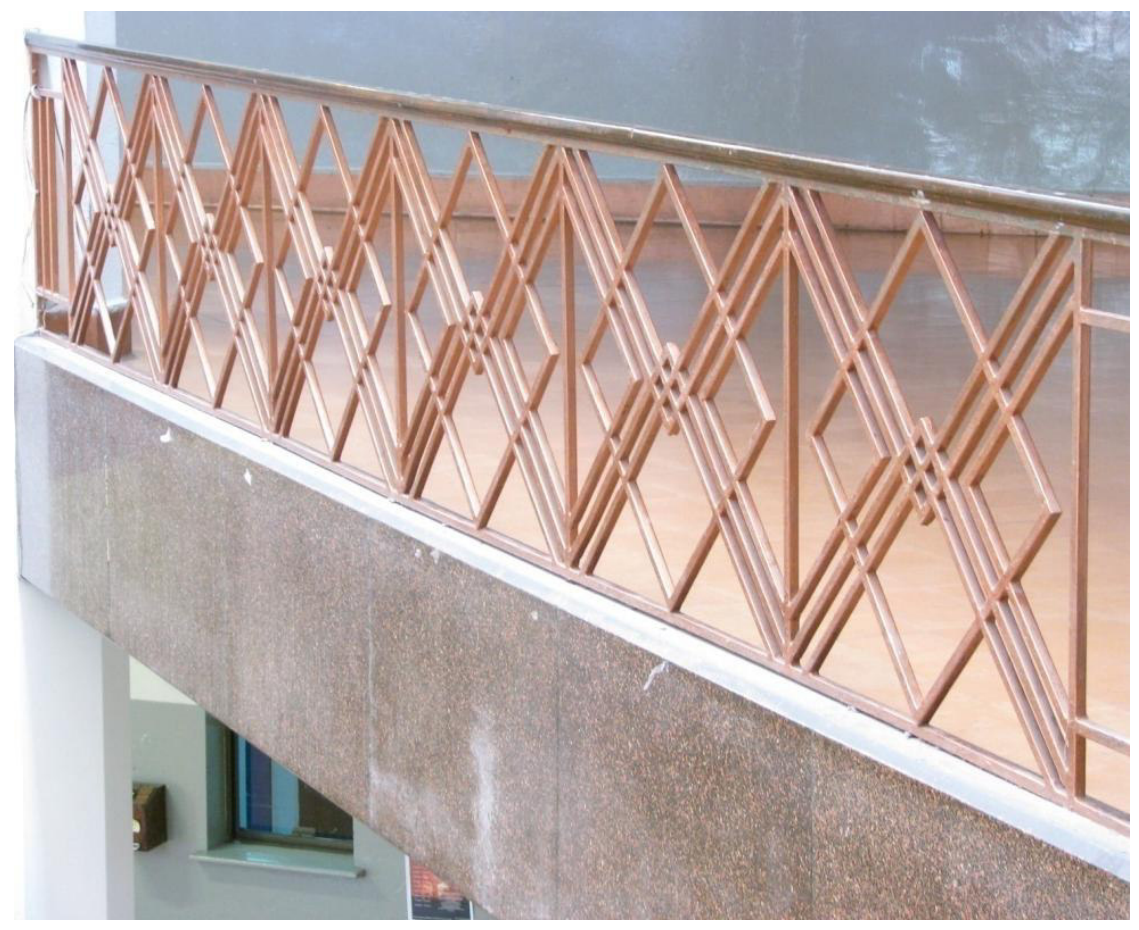

Barandal del segundo piso.

\footnotetext{
${ }^{48}$ AGENL, Sección Documentos: Educación, Asunto: Escuela Industrial Álvaro Obregón, Año: 1930-1931, Caja 1.”PRESUPUESTO PARA EL BARANDAL DE LA RAMPA Y ESCALERA DE LA ESCUELA ÁLVARO OBREGÓN".
} 
En el exterior se forma un patio en forma de "L". A ambos lados se distribuyen de manera angular unos portales: el de la derecha que mira al sur se conforma por 21 arcos Tudor sostenidos por columnas ochavadas sin capitel, con base cóncava y con pedestal también ochavado; el de la izquierda orientado hacia el poniente con el mismo tipo de arcos y columnas, los vanos son solamente ocho. Originalmente tres talleres y un gimnasio se desplazaban en los portales del lado derecho: electricidad, mecánica, que aún conservan su nombre, y donde está ahora la cancha de básquet, estaba el de herrería, cuyo nombre fue quitado. Un solo taller está del lado izquierdo que es el de carpintería. En el patio dos talleres más, automotriz y fundición, completan el número de los seis que se anuncian en el exterior; debido a los árboles que han invadido la fachada es prácticamente imposible poder visualizarlos.

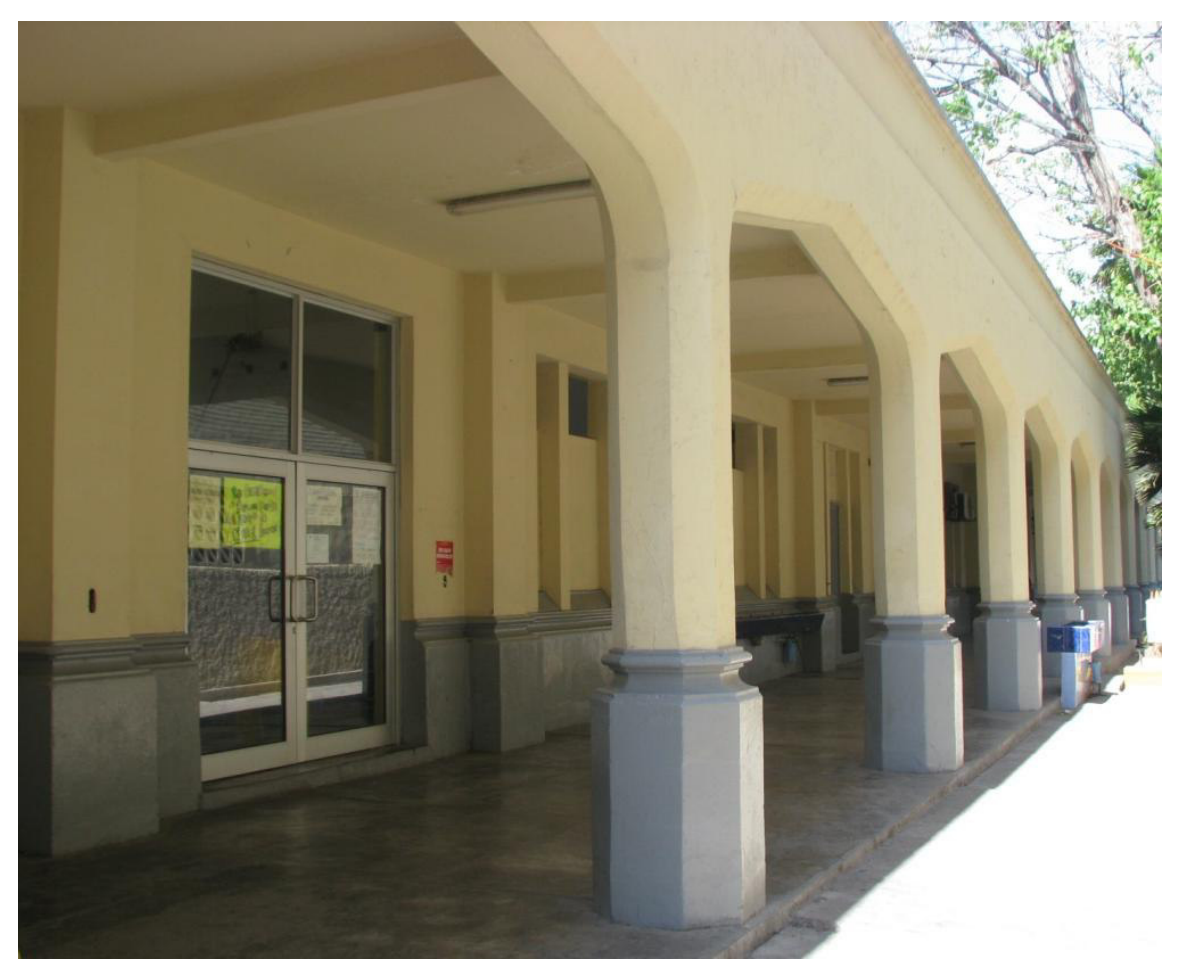

En el patio, arcos del portal sur.

En interior del inmueble y en el segundo nivel hay un vestíbulo central y atrás de éste se ubica la Biblioteca. A ambos lados del vestíbulo se distribuyen los salones de clase. Las columnas que se prolongan desde el primer nivel llevan un anillo a nivel del piso, para 
crear la sensación de que fueran independientes, pero ostentan la misma decoración en los capiteles.

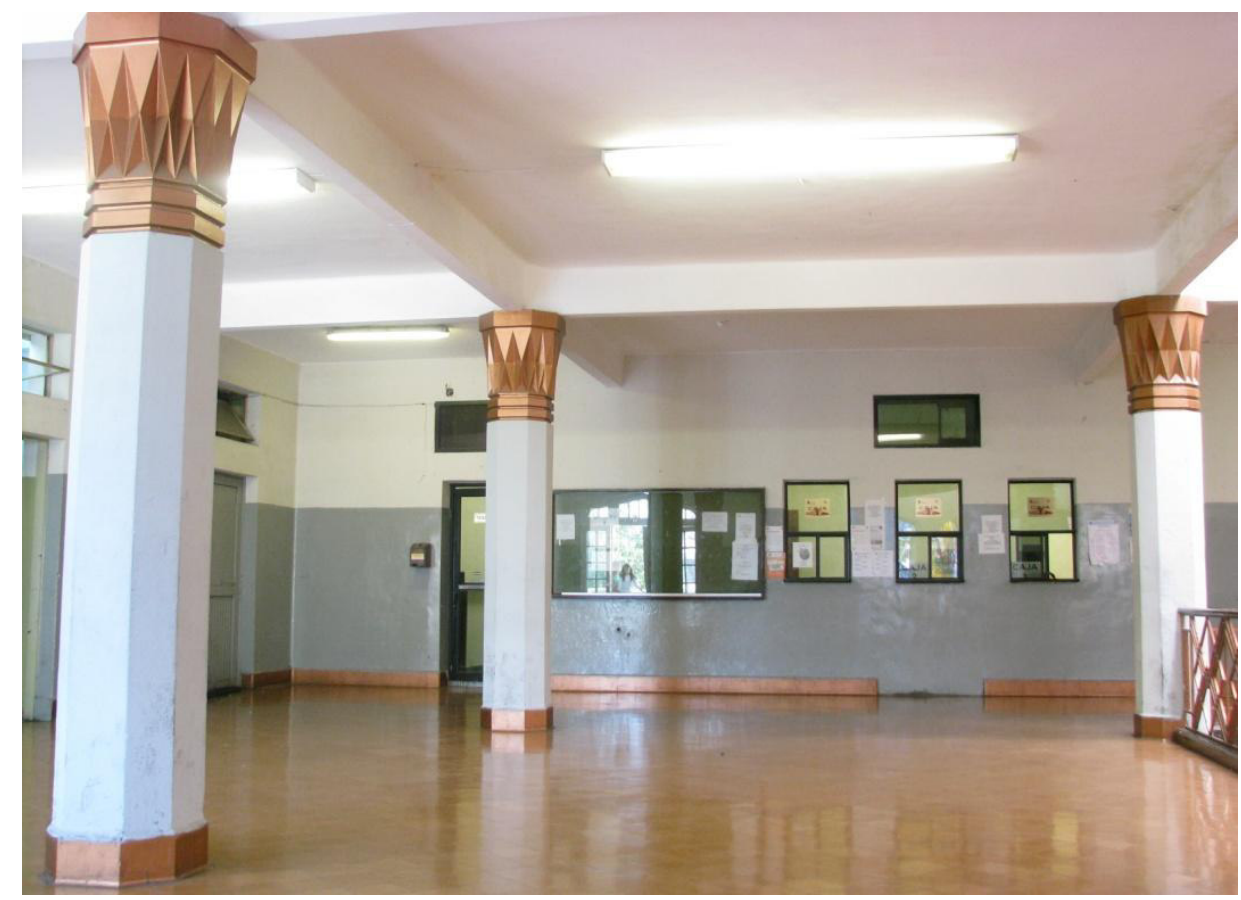

Columnas del vestíbulo del segundo piso.

En el exterior también angularmente se forman dos largos corredores, protegidos por antepechos sin decoración. Los vanos de las paredes se constituyen con arcos Tudor con un par de pilastras, tal como sucede en el exterior en el segundo nivel. Entre cada arco el espacio lo divide una pilastra con moldura y remata con un merlón güelfo, es decir cuadrado, moldurado. La unión de los lienzos laterales es ochavada y lleva tres vanos en forma de arco Tudor; los dos laterales son puertas de acceso y el central de mayor altura es ciego y a la vez contiene a otros tres arcos del mismo tipo donde se empotran los vitrales de la escalera. El arco central se resalta hacia el frente con jambas y tímpano triangular que termina protegido por cornisas. Este tímpano hace contraste en su posición ascendente con el motivo decorativo de las bandas y las cinco molduras que se inserta en el remate central del muro, que terminando en dos aguas, dos motivos decorativos similares y de menor tamaño, pero sólo de tres molduras cilíndricas, remarca los límites. Esta distribución de triángulos y líneas rectas verticales ofrece una lectura de la ornamentación geométrica de la 
variante Zigzag, ya que unos triángulos miran hacia abajo y otros se perfilan hacia arriba, consiguiéndose el efecto de un dinamismo decorativo.

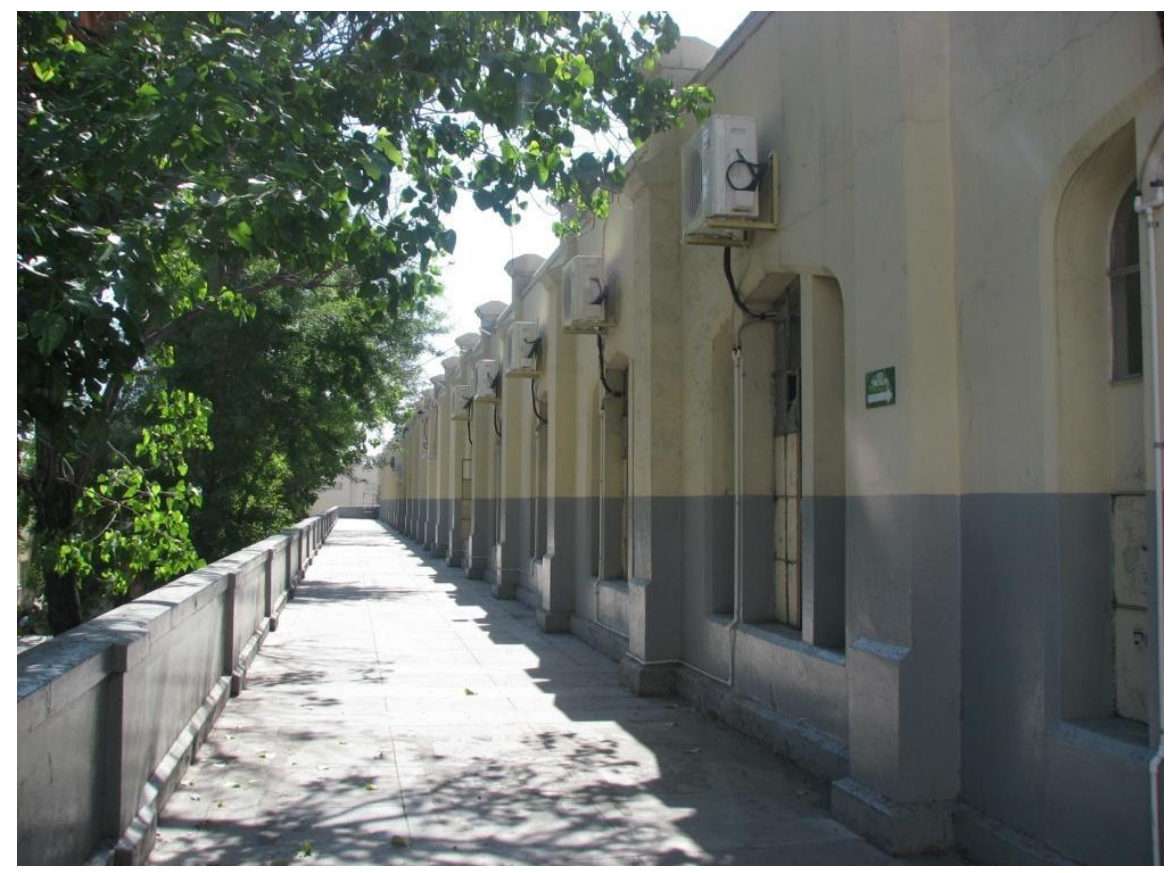

Corredor sur del segundo piso.

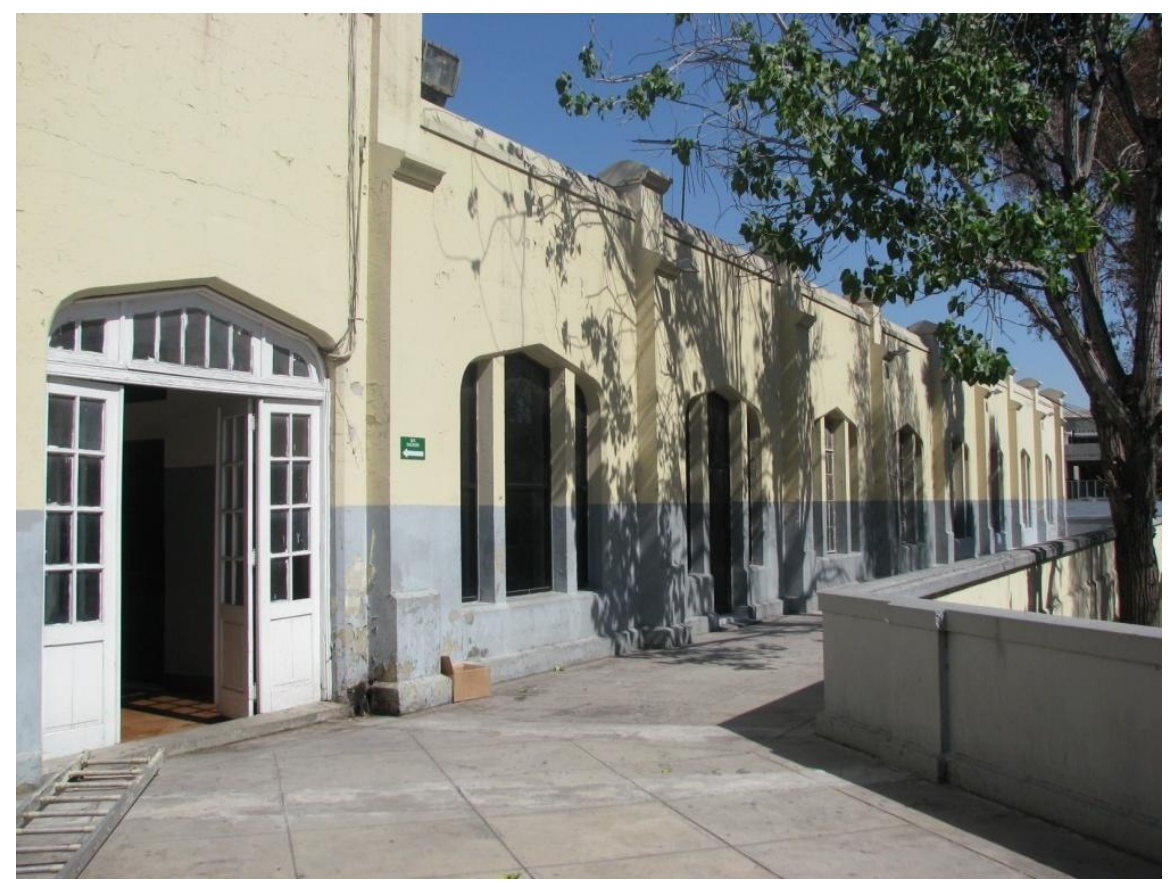

Corredor poniente del segundo piso. 
Uno de los magnos atractivos de este edificio son sus vitrales emplomados: el del plafón del techo del segundo nivel de $35 \mathrm{~m}^{2}$ que se abre en la cubierta e ilumina el vestíbulo y los tres de 3.05 x $1.50 \mathrm{~m}$., que se ubican en el muro del descanso de la escalera. Obra de Roberto Montenegro (1885-1968) se titulan Alegoría de la Técnica y data del año 1930; éste es el nombre que da Julieta Ortiz Gaitán, ${ }^{49}$ estudiosa de la obra del artista, quien describe a los vitrales de la siguiente manera:

"Montenegro repite en el gran tragaluz del plafón, el motivo iconográfico y formal con leves variantes- de los murales Iberoamérica, [Iglesia del exconvento de La Encarnación, ahora Biblioteca Iberoamericana, 1924] Alegoría del Viento [Colegio de San Pedro y San Pablo, 1926 ó 1928] y Maquinismo [Desaparecido, se encontraba en el Colegio de San Pedro y San Pablo, 1926-1927 ó 1928] : una figura femenina central con los brazos abiertos en cruz, enmarcada por círculos concéntricos que semejan un gran engranaje; la acompañan el sol y la luna tratados en brillante colorido y lleva una especie de boa emplumada en tonos vivos de verdes. Se ve también el escudo del Estado de Nuevo León.

En el descanso de la escalera de este vestíbulo, Montenegro diseñó tres variantes: en el central, una figura alegórica recoge la guirnalda verde que proviene del vitral del plafón, y en los vitrales de los lados, se recrea el tema del trabajo obrero que recoge esta guirnalda, símbolo tal vez, de los frutos del trabajo.

El esquema compositivo guarda cierta simetría armoniosa y los vivos cromatismos le confieren un aire de brillantez inusitada. La figura principal del plafón posee un aire de sofisticado refinamiento y sus líneas rectas y esquemáticas la remiten a soluciones previas del art-deco. El vitral destaca por su gran valor cromático y sus grandes dimensiones". ${ }^{50}$

José Roberto Mendirichaga en su libro Patrimonio Plástico de la UANL al comentar sobre estos trabajos de Montenegro dice:

\footnotetext{
${ }^{49}$ Gracias al Mtro. Xavier Moyssén Lechuga tuve la oportunidad de conocer a la Dra. Julieta Ortiz Gaitán, cuando estuvo como Profesora de la Maestría en Humanidades en la UDEM. En 1997 y 2000 platiqué con ella sobre los vitrales de la Escuela Industrial Álvaro Obregón y sus elementos estéticos Art Déco. Me comentó que al no tener nombre ella los denominó Alegoría de la Técnica. Tuve el gran privilegio de que me obsequiara un ejemplar de su Tesis de Maestría.

50 Julieta Ortiz Gaitán, Roberto Montenegro: Producción Mural (1919-1966), México, UNAM, Tesis de Maestría en Historia del Arte, 1989, Apéndices, Vitrales, sin página.

Las anotaciones de la ubicación de los murales las tomamos del libro de la misma autora Entre dos mundos: los murales de Roberto Montenegro, México, UNAM, IIE, 1994, pp. 119, 131 y 134.

En el catálogo de la exposición Art Deco. Un país Cosmopolita, un México Nacionalista, foto p.141, ficha 33, p. 168, citan al vitral como anónimo y dan la fecha de 1934.
} 
"De una cosa no tenemos duda: los vitrales "del Álvaro", como solemos decir erróneamente en sinalefa, haciendo perder la vocal intermedia, son bellísimos. El Sol y la Luna, presentes en la configuración del artista, simbolizan el ritmo de la actividad fabril y educativa; y abajo, el Cerro de la Silla, con el escudo alegorizado de Monterrey, remueve las fibras más sensibles de nuestro ser por el cariño al nativo lar. Es un plafón polícromo como los hay muy pocos en México y, diríamos, en el mundo.

Luego, en las figuras de la doble escalinata, se representa la fuerza de los altos hornos de la extinta Fundidora y de la industria de la época que, paralela, surgió junto con Cervecería y Fundidora - la dos empresas madres para conformar el Monterrey Moderno...decorado único de un arte nuevo, proyectado por Montenegro y realizado en la capital por la casa Claudio Pellandini, ya desaparecida". ${ }^{51}$

La más amplia descripción e interpretación de los vitrales ha sido la de J. Miguel Román en el ya citado libro Colores del alma, donde basándose en lo descrito por Ortiz Gaitán, da una lectura más amplia de las imágenes, por lo que incluiremos lo más relevante y novedoso, ya que resultaría demasiado extenso incluir todo el texto. En los Anexos incluye unos dibujos realizados por él mismo con las dimensiones exactas de los vitrales. Sobre el del plafón central dice que Mendirichaga lo llama Alegoría de la Enseñanza, "sin embargo el diseño no tiene ningún atributo o elemento iconográfico propio de esta labor". ${ }^{52}$ Román le llama Alegoría del Espíritu Industrial y escribe al respecto: “... justo detrás de la figura principal conformada por una mujer en composición frontal con los brazos extendidos en cruz, podemos apreciar una gran rueda de engranes como síntesis representativa de la maquinaria industrial. Con los brazos abiertos en forma de cruz, esta figura femenina descansa sus manos en el sol y la luna, que a mi parecer representa el trabajo continuo...Como símbolo de grandeza, triunfo o dignidad, pende sobre sus brazos una larga guirnalda que puede ser de laurel u olivo".53

Al respecto de los vitrales de la escalera, Román inicia con el del lado izquierdo, nominándolo con el título que le dio Mendirichaga de Alegoría de la Industria 1, número que Román agrega para su mejor identificación: "Aquí hay tres personajes... Los tres

\footnotetext{
${ }^{51}$ José Roberto Mendirichaga, Patrimonio Plástico de la UANL, San Nicolás de los Garza, N.L., Universidad Autónoma de Nuevo León, 1991, pp. 11-12.

${ }^{52}$ Román, Op. Cit., p. 42.

${ }^{53}$ Ibídem.
} 
portan gorras azules y pantalones de trabajo de mezclilla... Detrás de estos personajes Montenegro ha representado el conjunto de chimeneas que todavía se yerguen en el ahora Parque Fundidora. Se trata del horno Alto $\mathrm{n}^{\mathrm{o}} 1$, y las tres chimeneas que le acompañan, así como las naves que están justo delante de ellas". 54 Al de la derecha Román lo denomina Alegoría de la Industria 2 y afirma que: "No tan afortunado resulta el título que Mendirichaga registra para este vitral como Alegoría de la agricultura y la ganadería, pues no encontramos en él la iconografía en la que se pueda sustentar alguna de estas actividades del campo". ${ }^{55}$ Curiosamente en el libro de José Roberto Mendirichaga no hay ninguna mención a dichos nombres de los vitrales que cita Román, además de haberle preguntado personalmente al Doctor Mendirichaga al respecto, quien afirma que él nunca dio esas denominaciones. ${ }^{56}$ Sobre este vitral de la derecha Román describe: "En esta pieza aparecen tres personajes desnudos del torso vistiendo pantalón de mezclilla y con las cabezas descubiertas... Detrás de ellos se aprecia una intrincada red de tuberías y conductos elevados de cielo abierto. Se puede apreciar una tolva vaciando hierro al rojo vivo. Esta intrincada red de conductos y estructuras es usual en el interior de las naves de Fundidora". 57

Al vitral central de la escalera Román lo llama Apoteosis del general Álvaro Obregón: "Se trata de una columna en distintas tonalidades de oro, delante de la cual un busto de mujer en actitud solemne sostiene una corona, quizá de laureles, de la que se desprenden por ambos lados largas guirnaldas que continúan en los vitrales que la flanquean". 58

En el plafón de la Escuela Industrial Álvaro Obregón, al centro una mujer se sostiene en el firmamento con los brazos abiertos en forma de cruz, mirando hacia el frente. El cabello es rubio abultado que cae por detrás a la altura de los hombros; lleva una

\footnotetext{
${ }^{54}$ Ibídem, p. 44.

${ }^{55}$ Ibídem, p. 45.

${ }^{56}$ Platiqué con el Doctor José Roberto Mendirichaga el viernes 17 de junio del 2011 sobre este punto. Revisamos entre los dos su libro de Patrimonio Plástico de la UANL y en ninguna parte aparecen esos nombres. El otro libro que Román cita de Mendirichaga en la bibliografía de su libro es La estética de José Vasconcelos, obra que no trata este tema. Hay otro autor con el mismo apellido en la bibliografía del libro de Román que es Rodrigo Mendirichaga, Los cuatro tiempos de un pueblo. Nuevo León en la Historia, Monterrey, Instituto Tecnológico de Estudios Superiores de Monterrey, 1985, en cuya página 362 sólo se menciona cuando fue inaugurada la escuela y su costo.

${ }^{57}$ Román, Op. Cit.,p. 45.

${ }^{58}$ Ibídem, p. 47.
} 
gargantilla y porta un vestido largo azul hasta los pies desnudos. El vestido muy de moda de los años veinte al estilo de los diseños de Chanel en el corte del cuello, sin manga y de tirantes gruesos, así como de la soltura en su caída como de la misma manera lo hacía el diseñador Paul Poiret (1879-1944), ostenta un color azul marino combinado con otras tonalidades. Una gran guirnalda confeccionada con hojas de olivo o laurel cae por encima de los brazos y pasando por el frente a la altura del vientre, termina en motas en ambos lados; como si fueran esas grandes mascadas otoñales o invernales de la moda femenina parisina, aquí se muestra como un atributo al triunfo de lo industrial.

Detrás de la mujer la rueda de engrane es la obvia analogía con el espíritu de la escuela, lo industrial, así como de la ciudad; varios círculos concéntricos de tonalidades claras envuelven al engrane, hasta cerrarse en uno color verde. De esos círculos emanan radiaciones como si salieran de una combustión de hierro incandescente. La mano derecha de la dama apunta al sol con cara y la otra a una luna en cuarto creciente de perfil con rostro rígido.

Dentro de la iconología astrológica el sol representa el poder, la vitalidad, la autodeterminación, el carácter personal; la luna, alude a las fluctuaciones, el instinto, las relaciones. ${ }^{59}$ Por tradición, el sol representa el día y la luna la noche, así cuando aparecen los dos, hablan de la eternidad, de todos los tiempos. También el sol ha representado la fuerza viril, heroica, de la creación, de la dirigencia y la luna de lo variable y lo femenino. ${ }^{60}$ En el siglo de la Ilustración, los atributos tanto del sol como de la luna eran, entre otros, la significación de la eternidad y el tiempo, tal como lo explican los grabadores Hubert Gravelot (1699-1773) y Charles Nicolas Cochin (1715-1790) ${ }^{61}$ y en la iconografía cristiana el sol es el atributo mariano de la brillantez y la luna es el de la pureza, atributos que tanto se representaron el arte religioso virreinal. ${ }^{62}$

Entonces, podemos inferir que el sol y la luna son semántica del poder y la vitalidad de lo industrial, de los cambios de la ciencia y la tecnología, del triunfo de estos saberes en el tiempo y la prolongación a futuro de que gracias a la industria se mejorarán las

\footnotetext{
${ }^{59}$ Juan F. Esteban Lorente, Tratado de Iconografía, Madrid, Istmo, 2002, p. 147.

${ }^{60}$ José Antonio Pérez-Rioja, Diccionario de símbolos y mitos, Madrid, Tecnos, 2008, p. 413

${ }^{61}$ Huber Gravelot; Nicolás Cochin, Iconología, México, Universidad Iberoamericana, 1994, pp. 222 y 248.

62 Antonio Rubial García, Domus Aurea. La capilla del Rosario de Puebla, México, Universidad Iberoamericana, 1990, p. 70.
} 
condiciones de vida humanas. Estas son solamente algunas interpretaciones que ofrecemos, sin embargo pueden proponerse otras indagaciones que puedan aplicarse a estos símbolos.

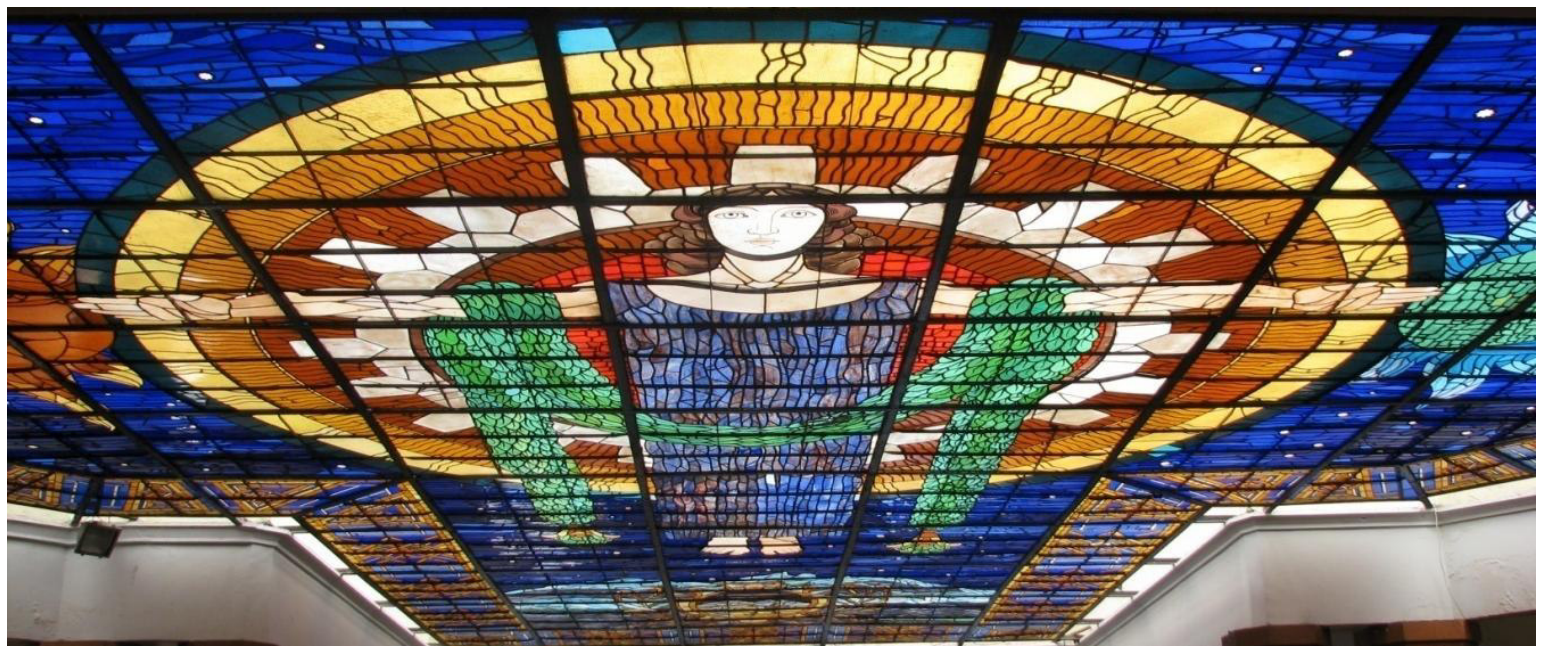

Plafón del vestíbulo.

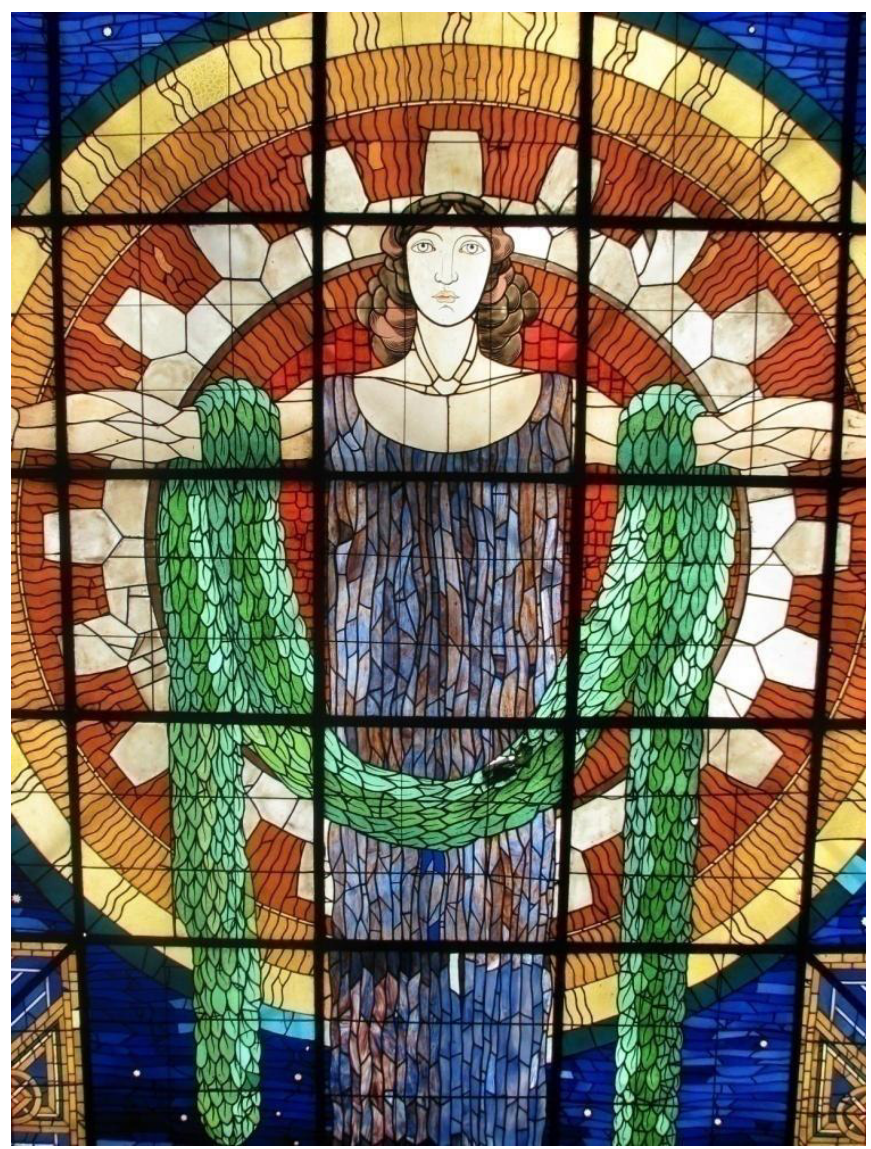

Figura femenina del vitral del plafón. 

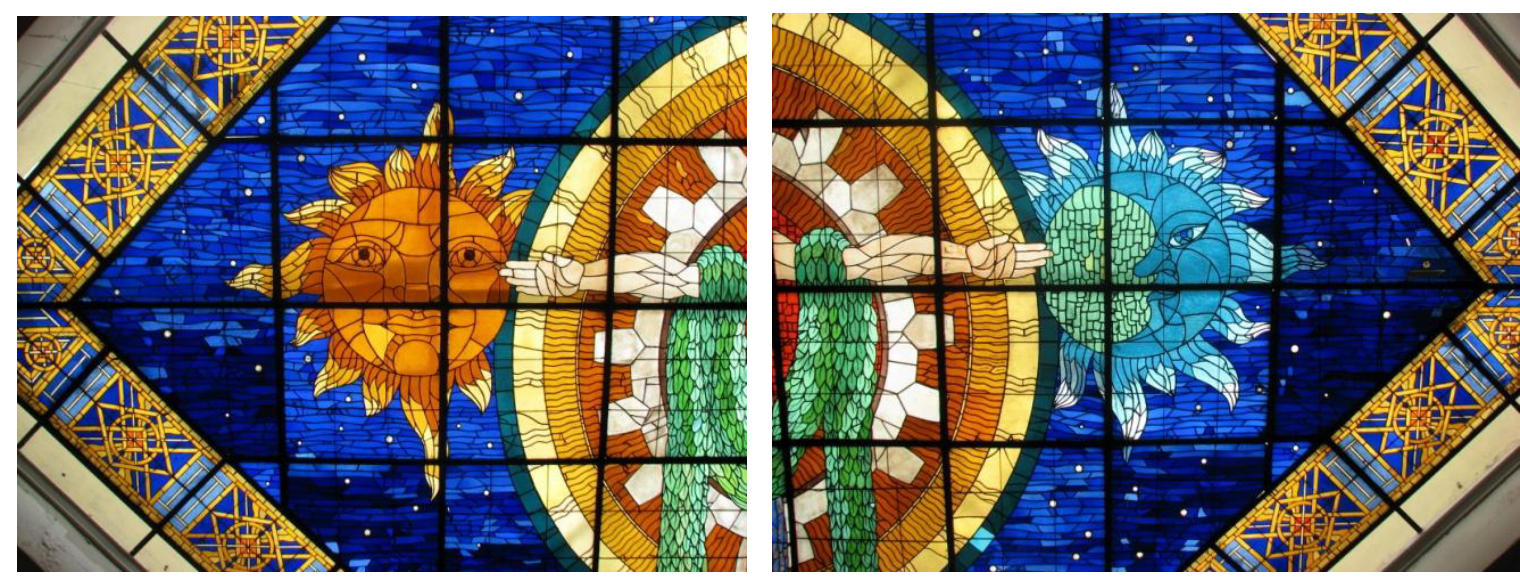

Detalles del sol y la luna en el plafón.

Debajo de los pies de la mujer, el flamante Cerro de la Silla, símbolo de la ciudad, aparece detrás del escudo de Monterrey, envuelto en un enmarcamiento de ramificaciones de líneas sinuosas y una cabeza de león en la parte superior. Del lado derecho varios cerros que por su dibujo y ubicación parecieran la Loma Larga, constituyen el valle de Extremadura y del izquierdo solamente planicies complementan el paisaje. Como fondo luce una intensa bóveda celeste con múltiples estrellas. La cenefa que rodea al plafón se compone de cuadros en azul con dibujos geométricos en color dorado: un cuadrado naranja se forma al centro por el entrecruzamiento de dos triángulos y a la vez se forman otros cuatro pequeños cuadrados por el cruce de dos delgadas líneas amarillas.

Otros dos triángulos laterales se unen y un círculo los envuelve para que un rombo a su vez enmarque a las demás figuras. Como fondo de cada recuadro los acompaña una $\mathrm{X}$ de formas sinuosas. Es evidente que Montenegro estaba al día de las Vanguardias europeas, más que a muchos movimientos artísticos los pudo contemplar en vivo en su estancia por Europa, sobre todo en París. Estos cuadrados del plafón guardan una fuerte relación con los trabajos de De Stijl. Unos rectángulos en tono azul celeste unen a cada recuadro. Es un entrecruzamiento de las figuras geométricas de tracerías encadenadas y superpuestas que hacen juego con los diseños del barandal, con un resultado extraordinario de ritmo de Art Déco Zigzag. 


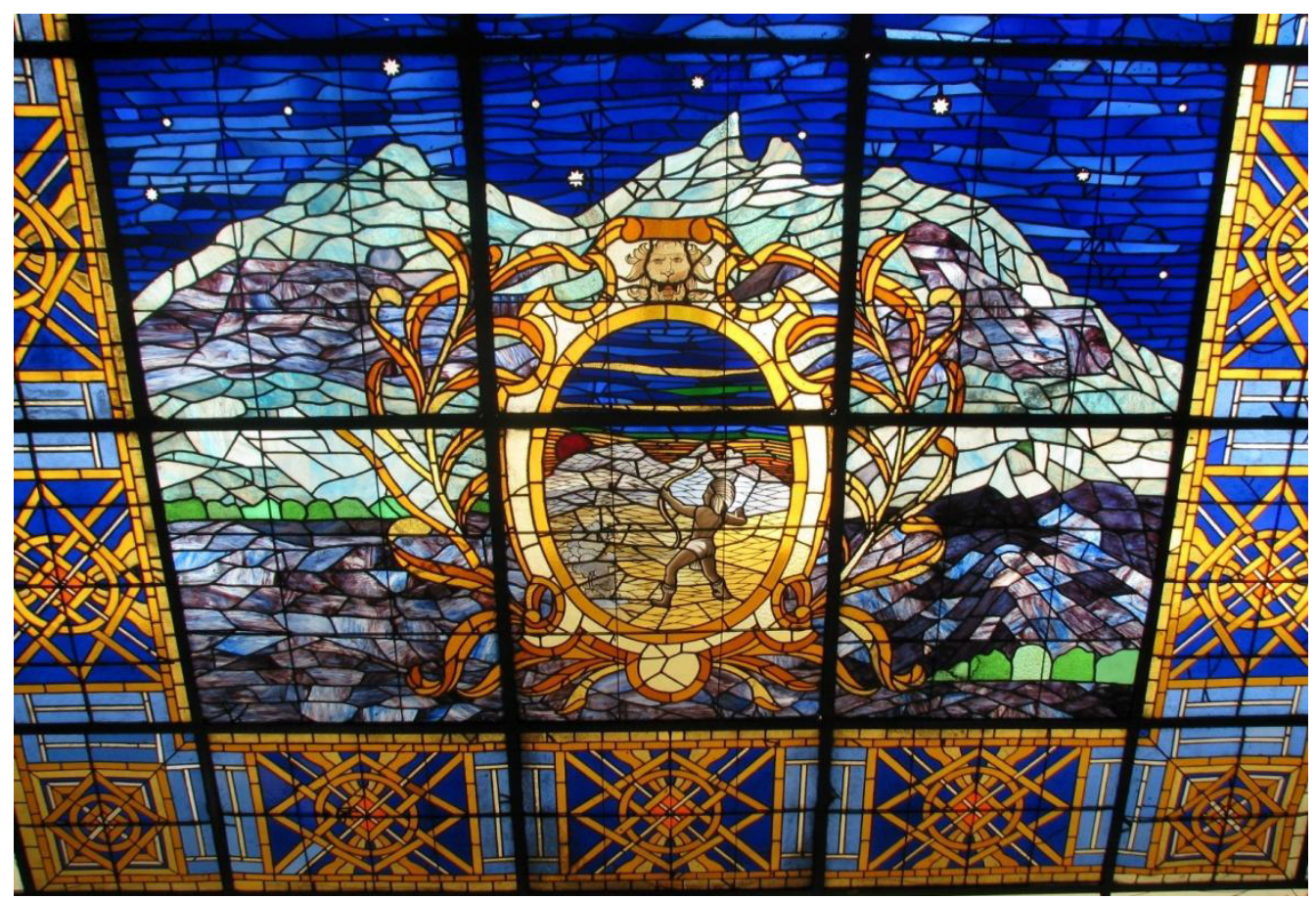

Debajo de los pies de la figura femenina del plafón, detalle del escudo, del Cerro de la Silla, de las estrellas y de la cenefa.

Los tres vitrales de la escalera están insertos en arcos Tudor y los laterales en la parte inferior van escalonados, haciendo juego con los peldaños y los rectángulos del barandal. En el de la derecha hay tres hombres obreros con el torso desnudo, representaciones del hombre de la era de la máquina muy dentro de la estética del Déco, de los cuales dos sostienen una gruesa guirnalda de olivo o laurel y el otro trabaja con un martillo; ductos en la parte inferior conducen hierro incandescente que luego cae en la parte central izquierda de un gran crisol. Los tubos, conexiones, ruedas en un verdadero laberinto de composiciones industriales, aluden a las fábricas de la ciudad, que como apunta Román podría referirse al interior de la Fundidora, además por la representación de la fundición del fierro. Entre tonos azul y blanco ese fondo industrial pareciera una creación plástica cubista por la forma de ir amalgamando las partes y las diferentes opciones de visualizarlas, pero a la vez en la variante del Tubismo de Fernand Léger (1881-1955), que en algunos de sus cuadros las formas cilíndricas se van acoplando de manera ascendente.

El vitral izquierdo presenta a tres hombres: el del centro con el torso desnudo estira los brazos para sostener la guirnalda, que a su vez es cargada por el otro obrero que está detrás, mientras que un obrero más lleva en su hombro un paquete. Los tres portan boinas y 
dos, camisa azul, aludiendo a la ropa de trabajo confeccionada en mezclilla. Dos canastas, una con pan y otra con frutas hacen insinuación al alimento de los trabajadores y/o a la abundancia de la tierra mexicana. En la parte frontal tres ductos conducen fierro fundido y en el fondo naves industriales con chimenea, vuelven a retratar las instalaciones de la gran Fundidora, como lo explica Román, y como a la vez se aprecia en el medallón de la portada principal. Con unos ligeros cambios, pero de un gran parecido, podríamos inferir que el medallón también pudo ser obra del mismo Montenegro.
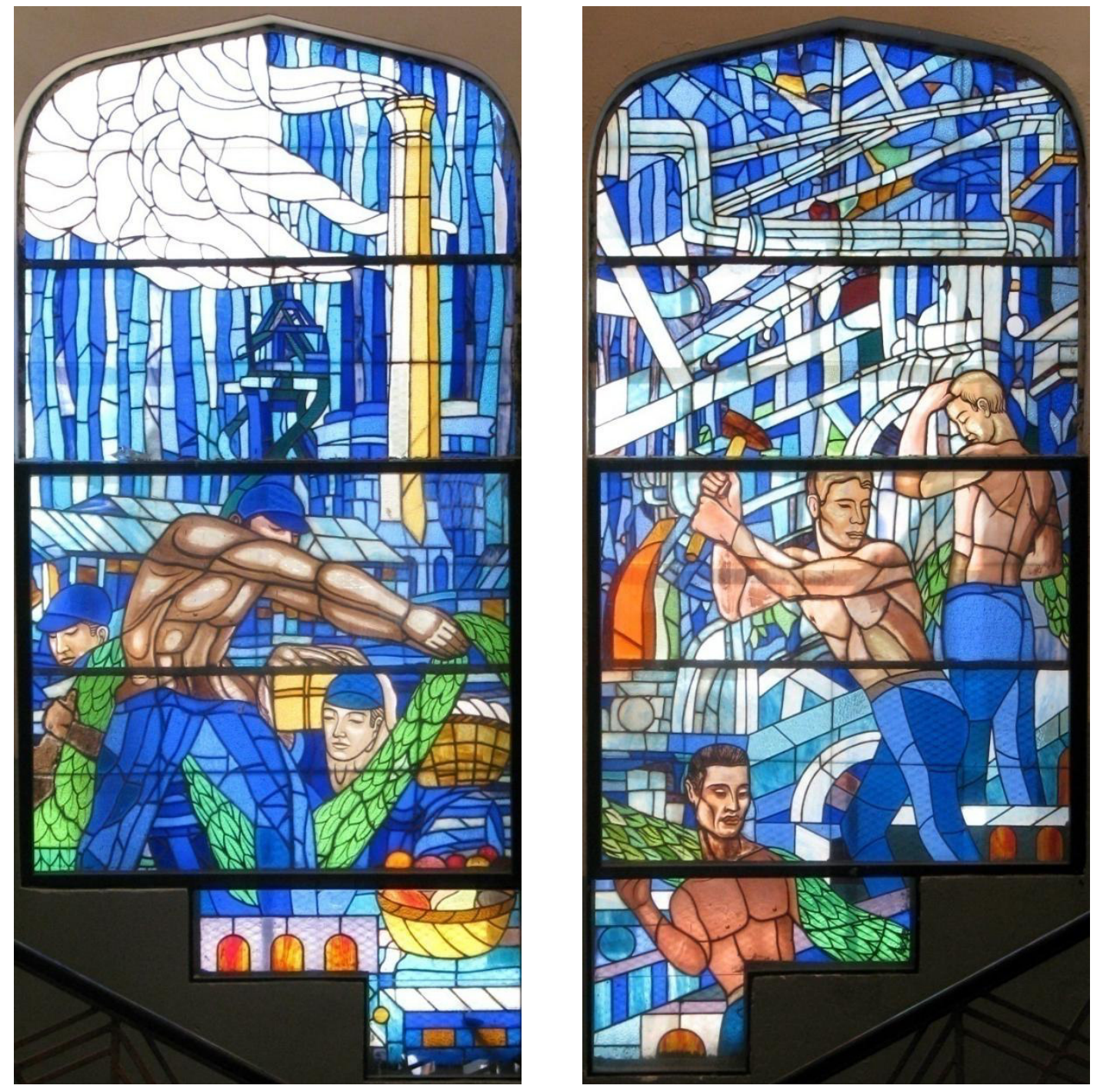

Vitrales de la escalera de los lados izquierdo y derecho. 
En el vitral del centro una mujer de rostro blanco, con tocado al estilo egipcio en color azul, le recoge el pelo rubio que cae hacia atrás. Le cuelga una gargantilla y viste con túnica en color dorado de cuello redondo y bordado. La decoración de la tela asemeja a los trabajos de Piet Mondrian, donde se acoplan figuras geométricas rectangulares, cuadrados, medios círculos, en tonos suaves, separados por líneas gruesas negras, pues la túnica de la mujer se forma por rectángulos superpuestos en posición vertical con las esquinas levemente curveadas. Que la dama lleve atuendo tipo egipcio es porque se pone muy de moda por el descubrimiento de la Tumba de Tutankamón en 1922 y los cuatro años más de excavaciones por parte de Howard Carter (1874-1939), como lo comentamos en el capítulo 1, ya que lo exótico de esta cultura, así como su geometricidad en sus diseños tanto arquitectónicos como artísticos, tiene una fuerte incorporación en la estética del Déco. Posteriormente de la cabeza de la mujer aparece una estrella de cinco picos que a su vez, detrás de ella, brotan unas flamas en forma de sol y luego una gran columna de fuego. La mujer condecora con una corona circular formada por la guirnalda de olivos o laureles a Álvaro Obregón, en toda una significación política del inmerecido cumplido al militar y político revolucionario; la guirnalda se extiende a los vitrales laterales para resaltar que los obreros rinden también homenaje a Obregón. A los lados de la columna de fuego, en fondo azul se destacan levemente dos pequeñas flamas, como si fueran dos veladoras que eternamente cuidan el monumento del Caudillo exterminado. Más allá de la connotación política, el vitral enumera elementos de su composición de un acendrado geometrismo como son los triángulos de la estrella, el círculo de la corona, el hieratismo de la figura, componentes todo de tipo Art Déco.

Sobre la hechura de los vitrales, como ya citamos anteriormente, Mendirichaga afirma que fue la casa Pellandini la que se encargó del trabajo, mientras que Román menciona de una carta que se encuentra en el AGENL, con fecha del 10 de octubre de 1930, misma que firma el Ing. Florentino Arroyo, quien se desempeñaba como Jefe del Departamento de Fomento del Gobierno del Estado. En dicha carta, entre otros, se pagan unos "FLETES. Notas benjamín Salinas por Fletes acarreto y maniobras emplomados $\$ 102.22$ pesos". 63

\footnotetext{
${ }^{63}$ AGENL, Sección Documentos: Educación, Asunto: Escuela Industrial Álvaro Obregón, Año: 1930-1931, Caja 1. "VALE a la Tesorería General del Estado por la cantidad de \$600.00."
} 


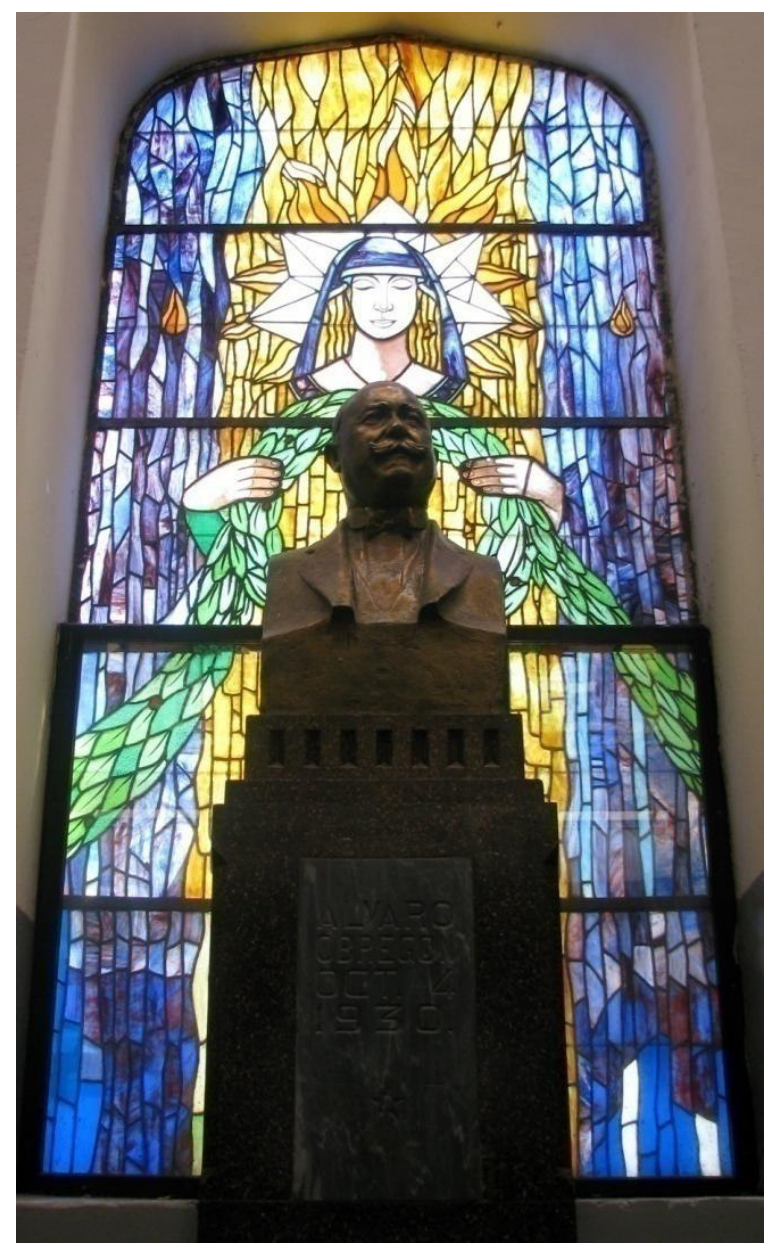

Vitral central de la escalera.

Sigue la incógnita de quién llevó a cabo el montaje de los vitrales, aunque el mismo Román hace mención de una visita a la casa Montaña de Torreón, sin que se pueda afirmar que es esa casa se hallan ensamblado los vitrales.

El edificio ha tenido varias intervenciones de mantenimiento y restauración, algunas de ellas relatadas en placas conmemorativas. En 1964, talleres y laboratorios fueron modernizados e inaugurados por el Presidente Adolfo López Mateos en noviembre de 1964. En 1987 una importante restauración de inmueble, especialmente de los vitrales que fueron reparados in situ y algunas piezas fueron llevadas a Torreón a la Casa Montaña. En 1989 talleres, auditorio, vitrales y equipo de cómputo recibieron renovación y mantenimiento. En junio de 2000 se anunció que el edificio de la Escuela Industrial Álvaro 
Obregón también quedó protegido por el INAH, y el INBA, como monumento del siglo XX. ${ }^{64}$

Después del recorrido por este excelso edificio de la Escuela Industrial Álvaro Obregón nos encontramos con un ejemplo a nivel local, regional, nacional e inclusive internacional de totalizar los principios del Art Déco: una exploración por las creaciones geométricas, una construcción de gran envergadura, decorados con motivos de la época, uso del cemento y nuevos materiales, y para el caso de México, la fusión de la modernidad postrevolucionaria con la educación y el progreso industrial.

Por el análisis realizado al inmueble, proponemos catalogar a la Escuela Industrial Álvaro Obregón como un Art Déco Neogótico, término basado en la explicación que dimos al principio, ya que no existe una clasificación como tal hasta ahora, y de un Art Déco Zigzag. A la vez, por los vitrales, este edificio también comparte la Tendencia Decorativista.

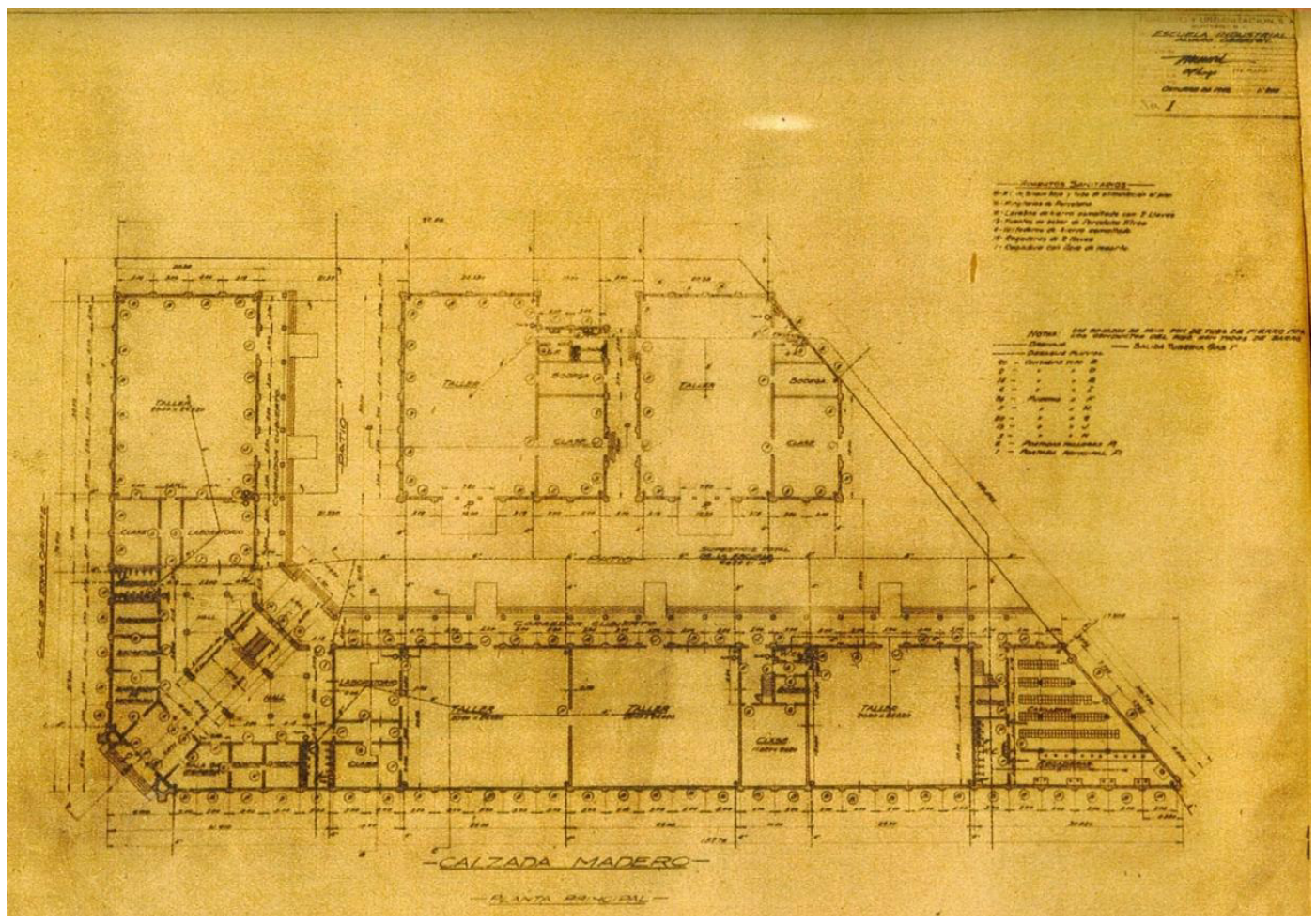

Plano de la planta principal.

\footnotetext{
${ }^{64}$ Vicente Guerrero, Ibídem.
} 


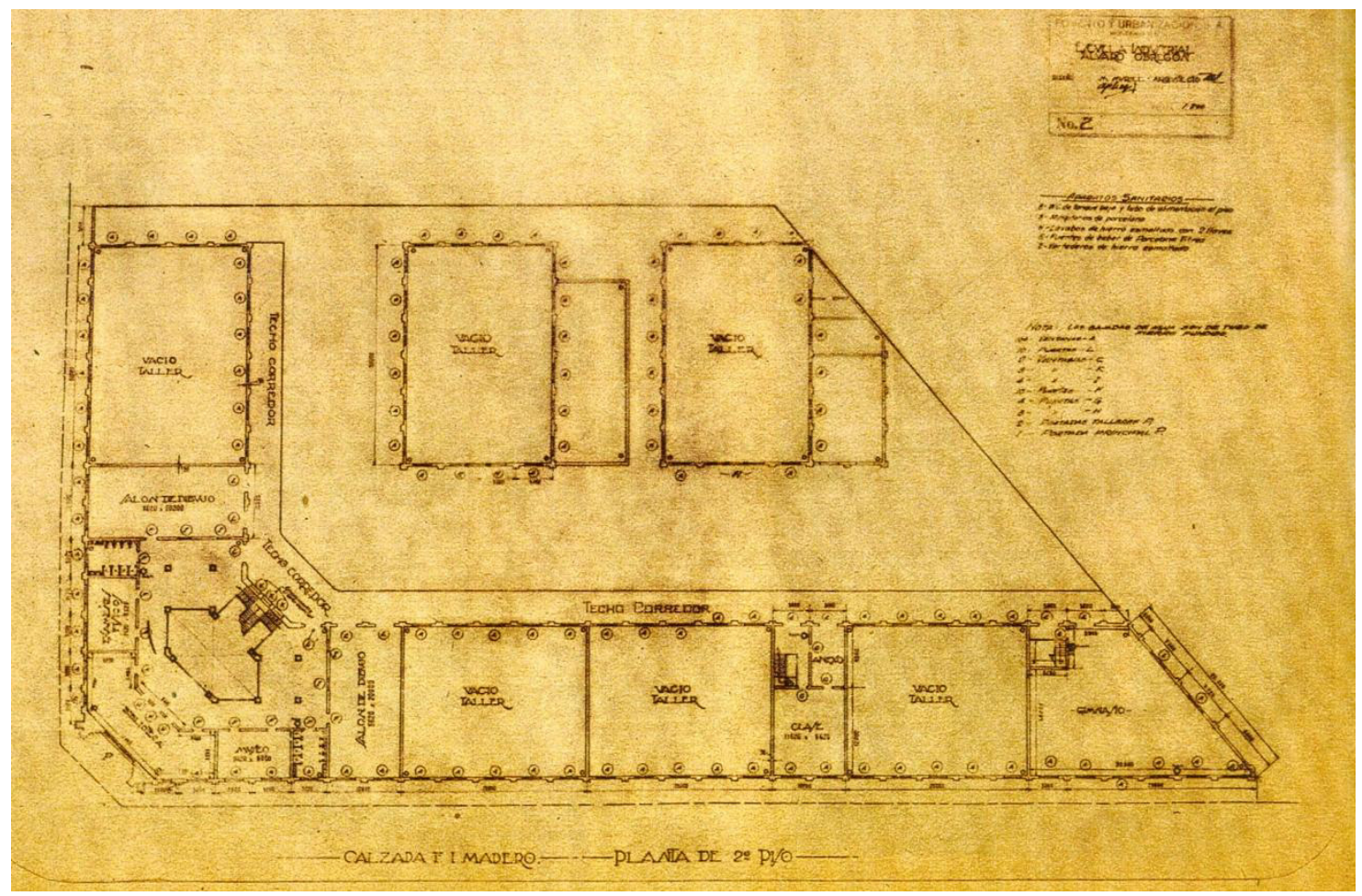

Plano del segundo piso.

Jueves de Excélsior, "Edición Especial Pro Monterrey”, Excélsior, México, D.F., noviembre de $1929 \mathrm{~s} / \mathrm{p}$.

\section{c. Escuela Nuevo León}

Se localiza en la calle Félix U. Gómez 750, ocupando toda una manzana entre las calles Carlos Salazar, Jerónimo Treviño y J. G. Leal. La orientación de la entrada principal es hacia el oriente.

Sobre esta escuela sólo encontramos la referencia en el libro de Concreto y Efímero que fue FYUSA quién proyectó el edificio, la misma empresa que diseñó la demás escuelas, y el encargado de la construcción fue el ingeniero Miguel Osuna Treviño. ${ }^{65}$ Otro dato con el que contamos es la placa que se encuentra en el vestíbulo de entrada, en donde se da la fecha de construcción de 1935 a 1936 y la fecha de inauguración, 2 de mayo de

\footnotetext{
65 Juan Manuel Casas García, Rosana Covarrubias Mijares, Edna Mayela Peza Ramírez, Concreto y efímero. Catálogo de arquitectura civil de Monterrey. 1920-1960. Monterrey, N.L., CONARTE, 2012, p. 224.
} 
1936, bajo el gobierno estatal del general Anacleto Guerrero Guajardo (1892-1980) quien fue gobernador de 1936 a 1939 y Heriberto Montemayor que como alcalde solamente estuvo un año entre 1935 y 1936.

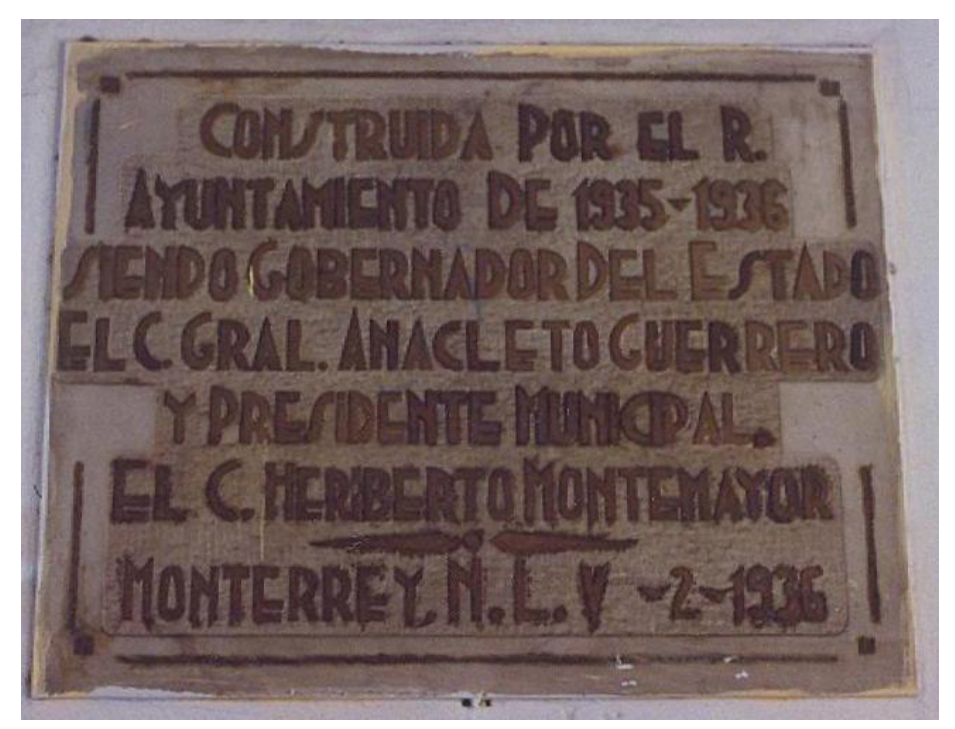

Placa ubicada en la entrada con la fecha de construcción.

Este edificio también posee planta en forma de E y es de doble nivel. En la fachada principal, el cuerpo central y los extremos laterales están más hacia el frente en relación con los lienzos que se unen al cuerpo central. Los ventanales del cuerpo central están dispuestos verticalmente y los restantes en forma horizontal, lo que ayuda a resaltar la primacía del cuerpo medular del frontis.

El cuerpo central es un interesante conjunto de elementos yuxtapuestos. Después de una escalinata de tres peldaños curvos viene la pared donde se encuentra la puerta de acceso de forma casi cuadrada y encima de ésta, un ventanal tripartita con vanos rectangulares verticales. Arriba del ventanal se registra el nombre de la escuela con letras de finos cortes angulosos, donde destaca la inclinada $\mathrm{S}$ por su delicado diseño; este letrero de material metálico y sobrepuesto es una de las particularidades de la Tendencia Decorativista, Elementos Exteriores. Este lienzo que remata en forma rectangular proyecta un acertado geometrismo Déco, reforzado por las grafías del letrero. 


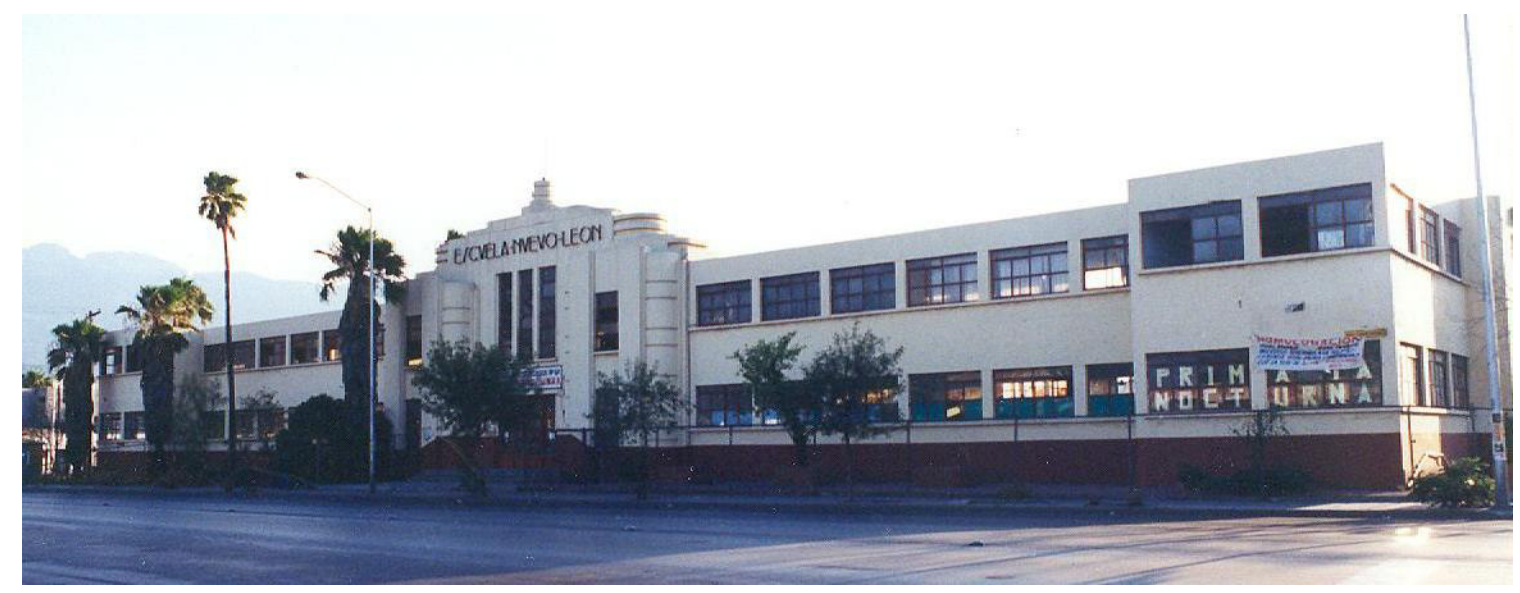

Vista de conjunto.

A cada lado de puerta y ventanal sobresalen unas ventanas rectangulares; a los lados de éstos se superponen dos lienzos verticales superpuestos, el primero ligeramente más corto de ancho y alto del segundo, con lo que se obtienen perfiles angulosos y en la parte superior el efecto de escalonamiento, corolario del Art Déco. Los paneles se adjuntan al muro principal a través de medios cilindros ornados con cuatro pares de bandas horizontales rehundidas, que al tocar la pared se unen a ésta con dos angostas y elevadas molduras superpuestas y escalonadas. Estos cilindros son de un claro Déco del tipo Streamline que usa como rasgo distintivo los diseños curvos aerodinámicos, provenientes, entre otros, de alas de avión o chimeneas de barcos e industrias.

Ligeramente detrás del muro del letrero y a nivel de los lienzos yuxtapuestos se inician en sentido ascendente y escalonado unas plataformas curveadas de subrayado tipo Streamline, que en número de cinco llegan a la base de la astabandera; la tercera plataforma se concierta de tres partes y dos bandas rehundidas, que equilibra la altura en relación con el frontis. Esta fusión de plataformas semeja un barco invertido de trazos arqueados, como los concebidos con barandillas tubulares curvas del Style Paquebot francés.

La astabandera, componente de la Tendencia Decorativista, Elementos Exteriores, se asienta en la última plataforma y se configura por cuatro anillos horizontales, el mayor que sirve de base y tres más que disminuyen mínimamente de tamaño, por lo que nuevamente la idea de elevación es alcanzada. 


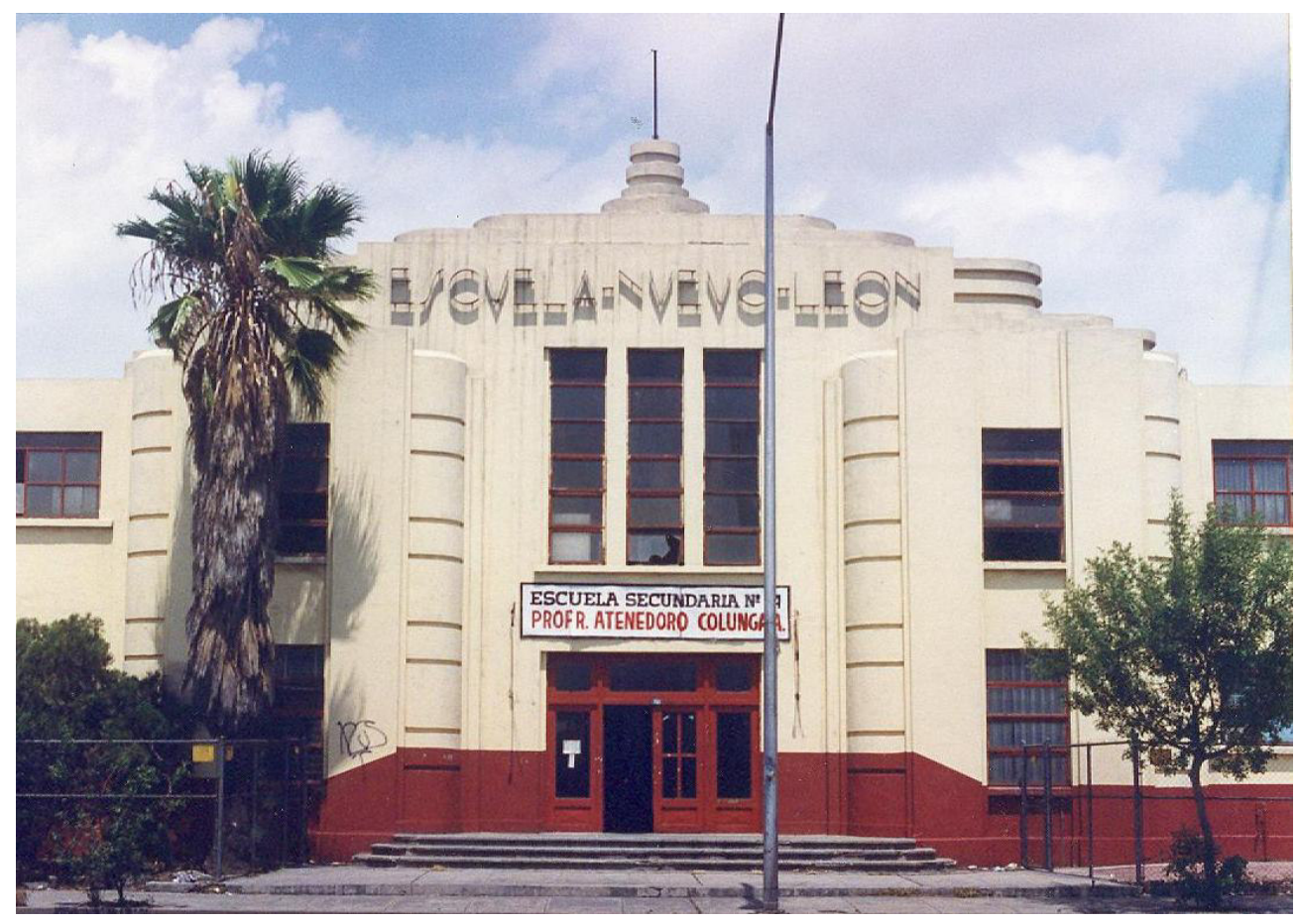

Entrada principal. A los lados los lienzos superpuestos y los medios cilindros. Atrás del letrero los escalonamientos curvados y en la parte superior los anillos de la base de la astabandera.

Queremos sugerir que tanto las plataformas descritas como la astabandera, aparte de representar un caso de componentes del Streamline, por la imagen de simbolizar conceptos náuticos, se acercaría a la variante de la arquitectura Tropical Déco.

En el interior del lugar casi nada se conserva de decoración. En el patio el cuerpo central tiene un portal con arco de medio punto y techumbre y paredes esféricas que tal vez servía como escenario, pero que no denota ningún rasgo Déco. De las dos áreas laterales que tenía el patio, sólo se conserva la del norte, ya que la del sur se eliminó por unas construcciones posteriores. Del bloque lateral norte y del cuerpo principal equivalente al oriente, los salones aún mantienen los vanos de las puertas en forma de T.

Las aulas del cuerpo central, sólo las del primer nivel aún preservan los vanos de las puertas a manera de una L invertida, lo cual serían los únicos rasgos de geometrismo. En la marquesina del primer nivel del cuerpo central, todavía está sostenida por unas ménsulas escalonadas, sin ninguna decoración, de las utilizadas en los años del Déco. Todos los pasillos del segundo nivel, así como la escalera del cuerpo central, están protegidos por una balaustrada horizontal tubular de marcada ascendencia Streamline. 


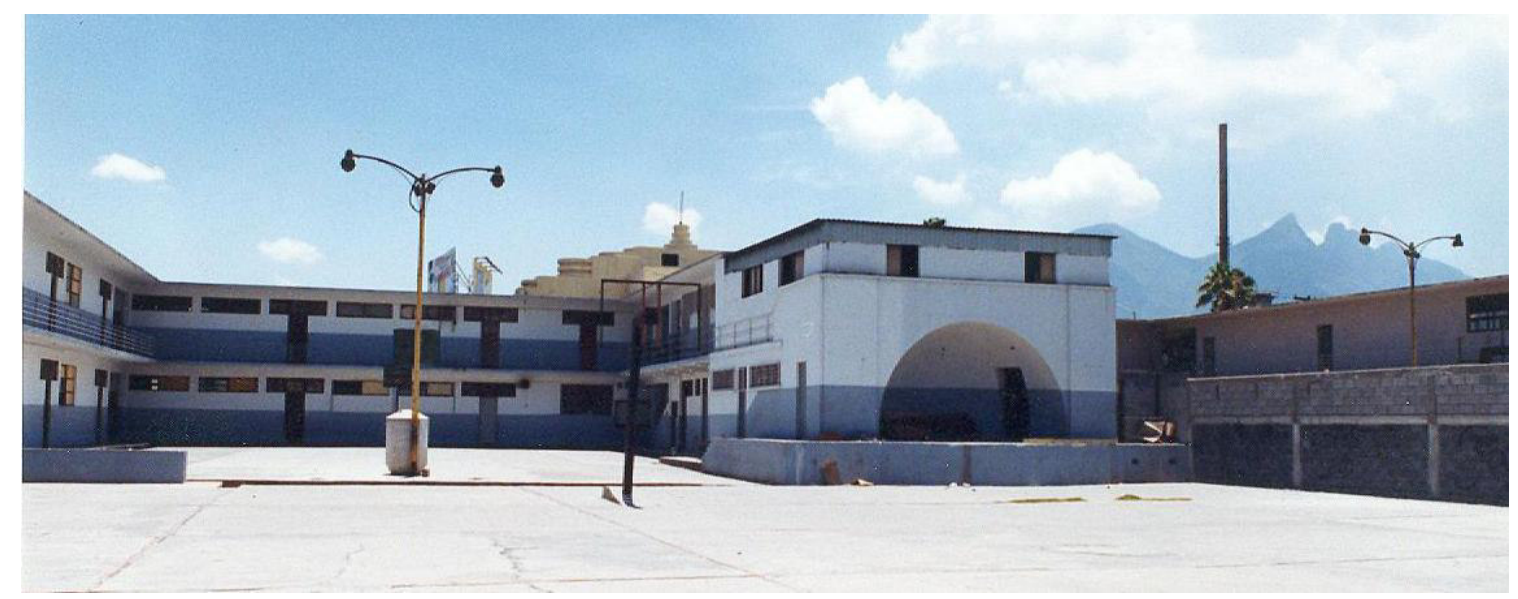

Portal en el cuerpo central y la inclusión de unas construcciones en el cuerpo lateral sur.

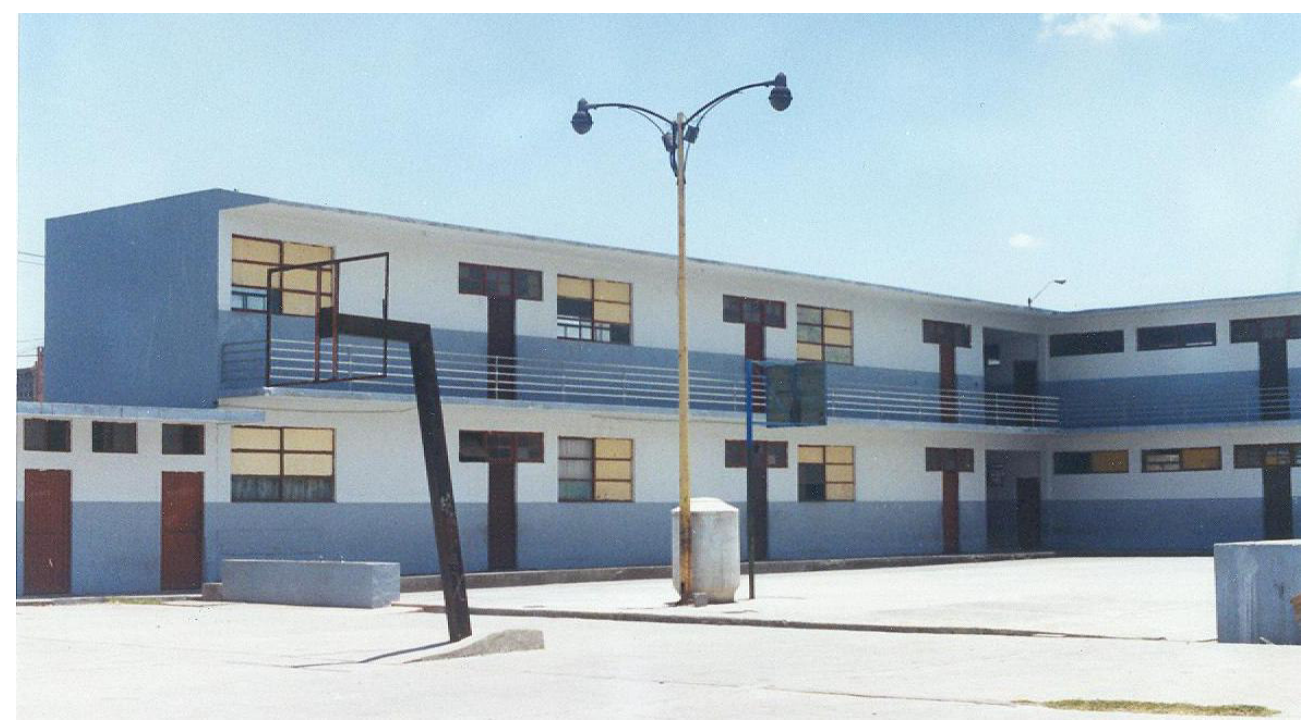

Cuerpo lateral norte y parte del central.

En julio del año de 1998 la escuela estaba sufriendo cambios en las fachadas laterales norte y sur, perdiéndose los nombres de "Niños y Niñas" que indicaban la entrada respectiva. Hasta la fecha se encuentra, principalmente el interior, en un mal estado de conservación.

Como hemos visto, la Escuela Nuevo León es de un Déco Streamline, con la subvariante Tropical Déco y la Tendencia Geometrista.

Después de ser utilizado parte del edificio como bodega, desde 2003 funciona como el Instituto de Capacitación Evaluación y Certificación en Competencias para el Trabajo. El 
patio ahora es estacionamiento y se han perdido además de entradas laterales mucho de la construcción original.

\section{d. Escuela Monterrey}

La dirección de esta escuela, es Juan Méndez Norte 1408, entre Democracia y Juan Guzmán, Colonia Sarabia, orientada hacia el poniente. La zona donde está ubicada la Escuela Monterrey siempre ha sido de alta peligrosidad, por lo que ha sido y es difícil la conservación del edificio, ya que en las entradas laterales son ocupadas por maleantes y gente sin hogar, por lo cual las imágenes demuestran la falta de mantenimiento y conservación del plantel.

Sobre la construcción de este plantel Juan Manuel Casas dice en el libro de Concreto y Efímero que los años de construcción fueron entre 1935 a 1939, con varias

interrupciones y que fue FYUSA quien se encargó del proyecto y construcción. ${ }^{66}$ Otra información son los datos de la placa que se encuentra en el vestíbulo, en donde se asienta que fue construida durante el mandato del general Anacleto Guerrero como gobernador del Estado de Nuevo León y del Presidente Municipal, el profesor Manuel Flores, alcalde de la ciudad de 1939 a 1940. La fecha de inauguración el 14 de septiembre de 1939. Una referencia más es una mínima mención en un artículo de Nicolás Duarte Ortega, titulado “Cuando los Inspectores sí Inspeccionaban”, en el que asienta al referirse a los años cuarenta que: "como parte del gran programa de la Revolución Mexicana, se habían empezado a levantar grandes edificios escolares, algunos de ellos por sus dimensiones y diversidad de servicios, de carácter monumental, de los que aún nos quedan ejemplos como las escuelas Monterrey, Revolución, Fernández de Lizardi y Calles..." 67

La planta de edificio es en forma de E, como la Nuevo León, la Fernández de Lizardi y la Presidente Calles. El conjunto es de dos niveles y aunque fue construida tres años después que la Nuevo León, por la planta, el trazo y la construcción en sí, podemos inferir que seguramente fue el mismo arquitecto quien diseñó ambos planteles.

\footnotetext{
${ }^{66}$ Juan Manuel Casa et al., Op. Cit., pp. 222-223.

${ }^{67}$ Nicolás Duarte Ortega, "Cuando los inspectores sí inspeccionaban”, Monterrey 400: Una Historia de Progreso, Monterrey, N.L., El Norte-Castillo, 1996, p. 169.
} 
Cabe señalar que todo el exterior, salvo el cuerpo central de la fachada principal, una moldura cuadrada y una cornisa de poco vuelo recorren todo el remate del segundo nivel, extendiendo así el sentido de horizontalidad.

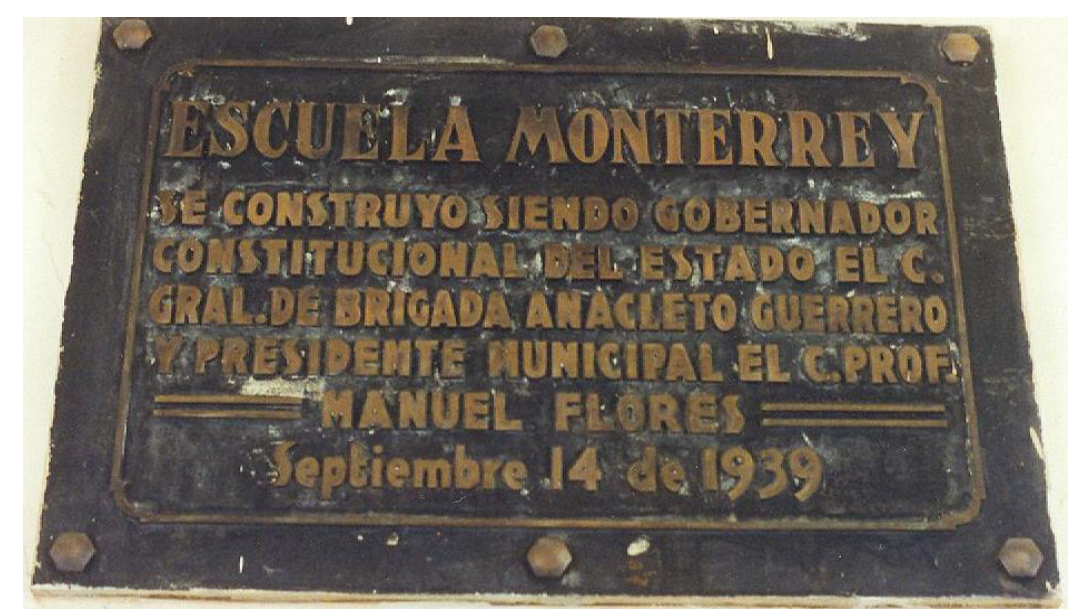

Placa en la entrada con la fecha de inauguración.

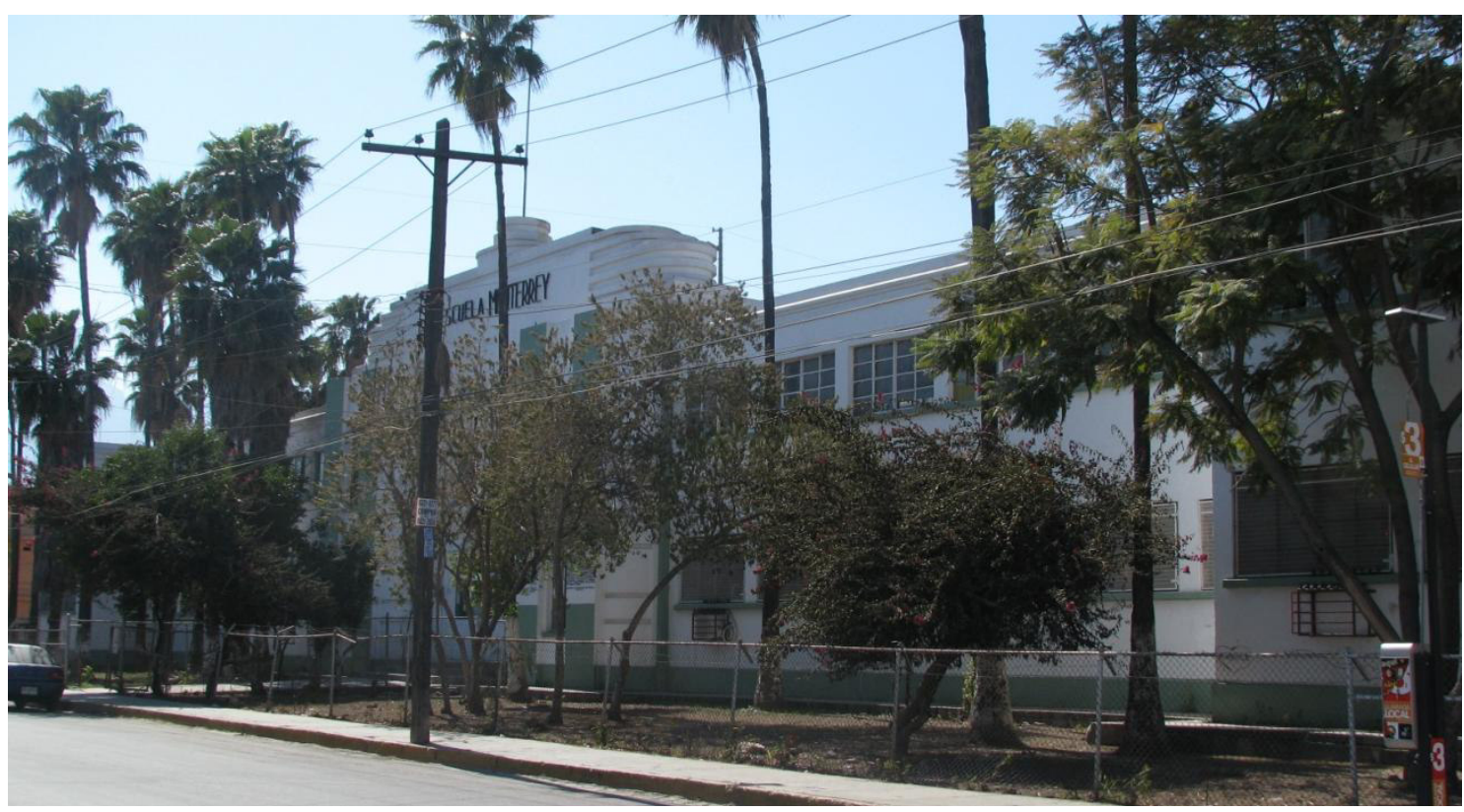

Vista del edificio pero con la invasión de árboles es difícil captar sus componentes estilísticos.

El cuerpo central destaca del resto de la fachada, pues se compone de la adhesión de partes. Una escalinata de tres peldaños ochavados conduce a la puerta de acceso de forma casi cuadrada; arriba de la puerta unas ventanas geminadas con vanos rectangulares 
verticales y bases de ladrillo, se integran entre sí en una fusión de rasgos geométricos, por medio de una moldura vertical rehundida. Tanto puerta como ventanas llevan un perfil remetido que las enmarca. Después de las ventanas, como uno de los apartados de la Tendencia Decorativista, Elementos Exteriores, se inscribe el nombre de la institución con grafías trabajadas en metal; la palabra escuela es de menor tamaño que el vocablo Monterrey, pero ambos llevan el diseño de letras delgadas y angulosas. El predominio del cuadrado, el rectángulo y la línea recta de las piezas que constituyen el lienzo del cuerpo central, junto con la escalinata, revelan la identidad del Art Déco: la geometría.

Al lado de la puerta y ventanas despuntan unos paneles rectangulares en cuyo centro se abren en cada nivel vanos rectangulares para ventanas, con la misma composición que las del frontis principal; abarcando los dos niveles y junto a las ventanas, se superponen dos lienzos verticales, el primero levemente menos ancho que el segundo, cuyo ensamble deja entrever un perfil angular. A través de medios cilindros adornados con cuatro pares de bandas horizontales rehundidas y una individual en la parte superior, los paneles se unen al muro principal por medio de dos estrechas molduras sobrepuestas. Todo ese maridaje de lienzos, molduras y ventanales verticales con los cilindros de bandas horizontales emanan de las propuestas geométricas del Art Déco. Los medios cilindros, como ya mencionamos en la Escuela Nuevo León, provienen de la variante Déco Streamline, la cual toma modelos, ya fueran de objetos de producción industrial, o bien, de esquemas aerodinámicos curvos que sugerían velocidad.

El muro del frontis remata en forma escalonada, al cual se acoplan unas bandas curvas, de las cuales el interespacio que se forma entre la penúltima y última, pasa por el frontis, articulando ambos conjuntos. Análogamente a la Escuela Nuevo León, el juego de bandas evoca la referencia de lo náutico, pues remite a la zona de cubierta de las proas y popas de los trasatlánticos, protegidas por tubos curvos en posiciones horizontales, ejemplares de claro linaje Streamline. La astabandera está sostenida por dos anillos del mismo tamaño y grosor, que si nuevamente lo referimos con lo naval, pareciera un bote salvavidas con flotadores circulares.

Así como lo explicamos en la Escuela Nuevo León, estas correspondencias marinas del Streamline nos permiten deducir que también hubo un influjo del Tropical Déco en el diseño de la Escuela Monterrey. 


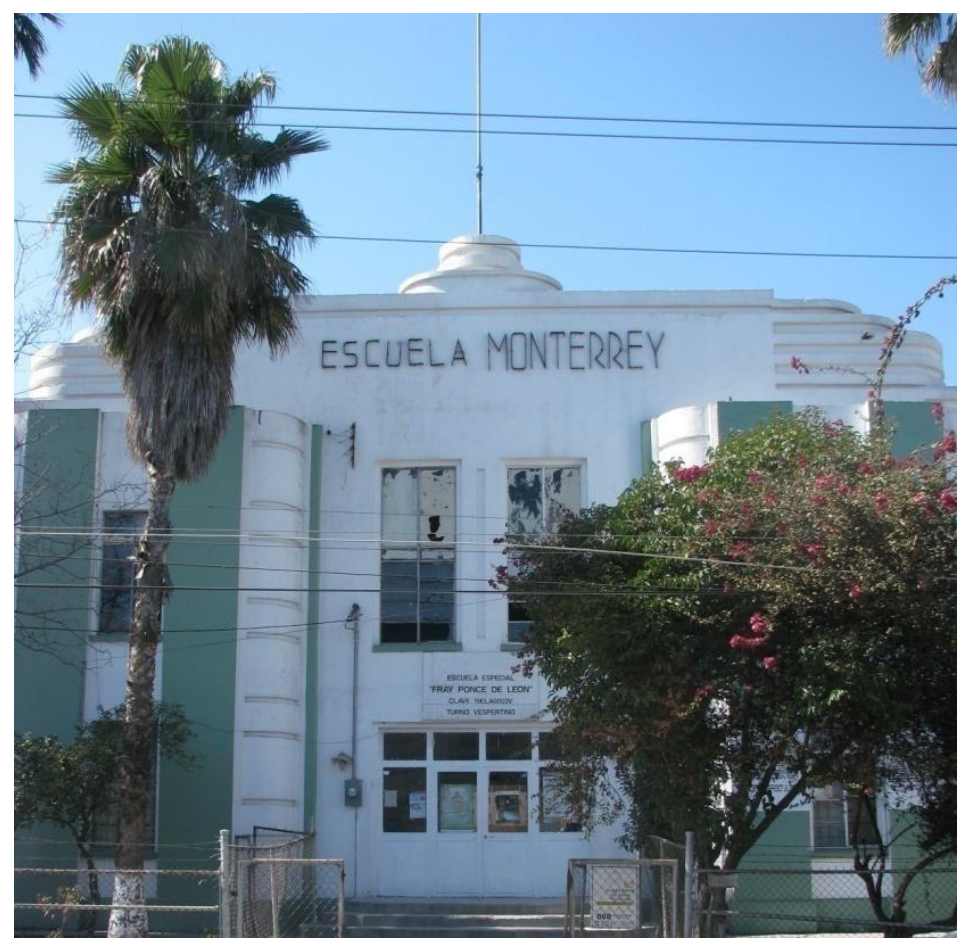

Cuerpo central de la fachada principal.

Al lado de la puerta de entrada y ventanas geminadas, despuntan unos paneles rectangulares desplazados hacia el frente del nivel del cuerpo central: dos lienzos se superponen, el primero levemente menos ancho que el segundo cuyo ensamble deja entrever un perfil angular, resguardando ventanas rectangulares en los dos niveles. A través de medios cilindros adornados con cuatro pares de bandas horizontales rehundidas y una individual en la parte superior, los paneles se unen al muro principal por medio de dos estrechas molduras sobrepuestas. Todo ese maridaje de lienzos, molduras y ventanales verticales con los cilindros de bandas horizontales emanan de las propuestas geométricas del Art Déco. Los medios cilindros, como ya mencionamos en la Escuela Nuevo León, provienen de la variante Déco Streamline, la cual toma modelos, ya fueran de objetos de producción industrial, o bien, de esquemas aerodinámicos curvos que sugerían velocidad.

En las fachadas laterales norte sobre la calle Juan Guzmán y sur sobre la calle Democracia donde se ubican las entradas, a continuación de unas escalinatas de cemento compuestas por cuatro peldaños rectangulares y escalonados, la pared se desplanta ligeramente hacia el frente después de una moldura; los vanos de la puerta y ventana son 
rectangulares y en medio de éstos se insertan unas inscripciones que indican a los niños en la entrada norte y a las niñas en la sur.
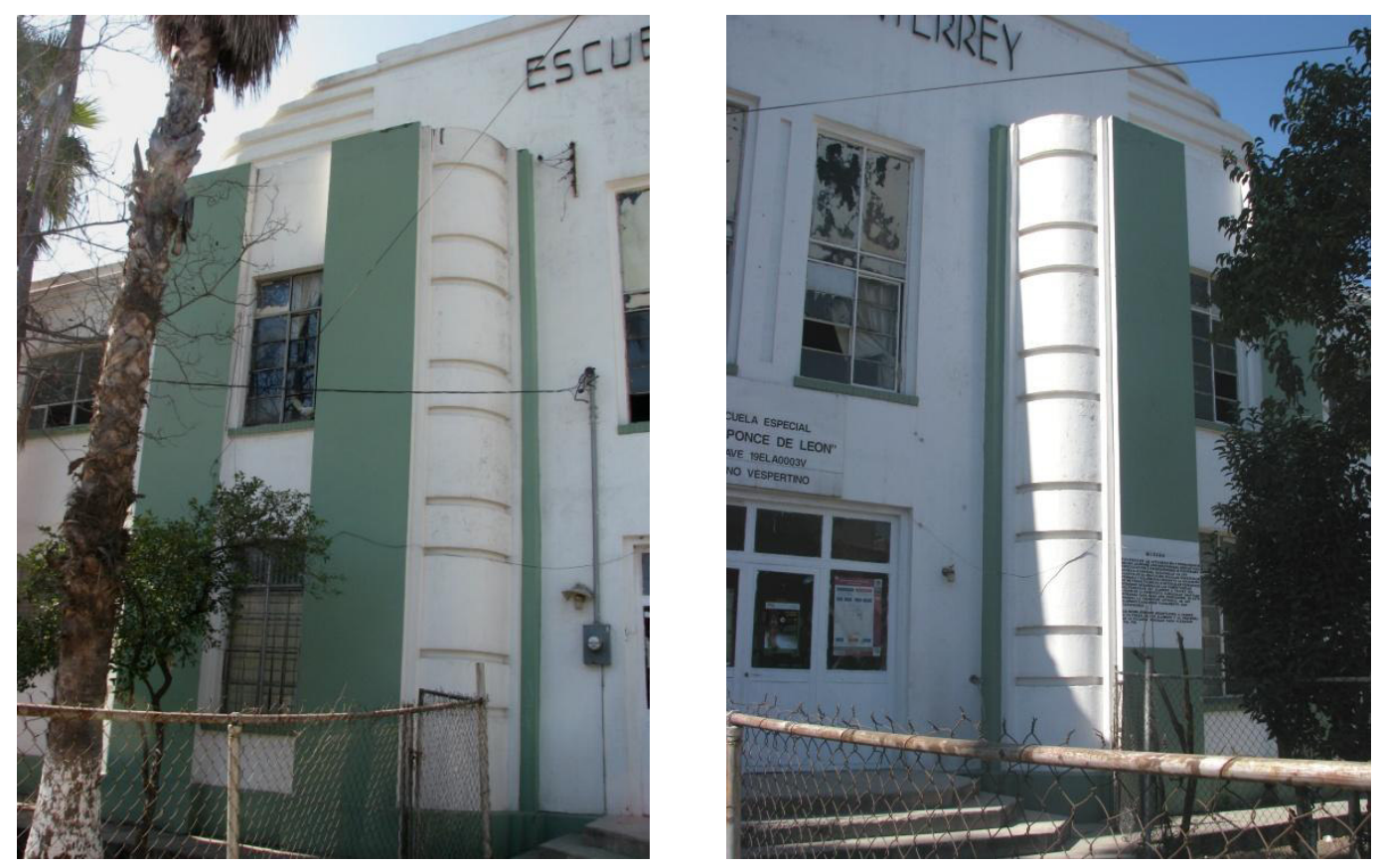

Paneles sobrepuestos a los lados de la entrada.
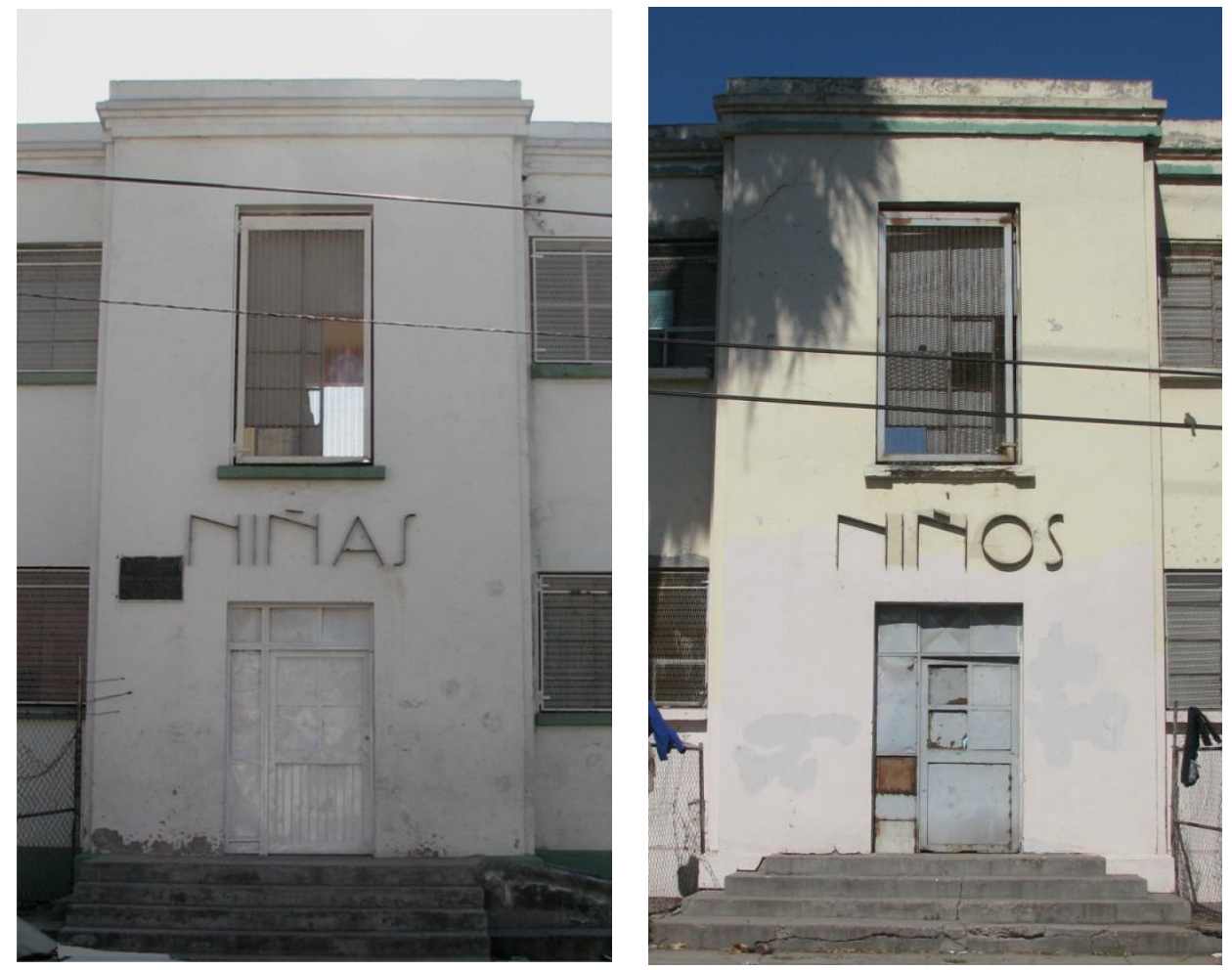

Entradas laterales de las fachadas sur y norte. 
Las letras metálicas comparten el alfabeto Art Déco de trazos delgados y marcados ángulos: las "enes" elevan la línea oblicua y las "eñes” conciertan su cejilla en la misma disposición sesgada que la línea intermedia; las "eses" son angostas y delicadas, mientras que la $\mathrm{A}$ es angulosa y la $\mathrm{O}$ mantiene una perfecta circunferencia. Estos letreros, de la Tendencia Decorativista, Elementos Exteriores, son de un genuino estilo Art Déco, por las características descritas y su acendrado geometrismo.

Los cuerpos laterales norte y sur que miran hacia el patio interior, los salones comparten en puertas y ventanas una composición en $\mathrm{T}$, dando así un ligero indicio de geometrización.

En los salones del cuerpo central los vanos de puerta y ventana crean una L invertida, los cuales se organizan simétricamente unos frente a otros. En este mismo cuerpo, la marquesina está sostenida por ménsulas escalonadas, lo cual era bastante utilizado en los años del Déco.

Todos los pasillos del segundo piso, así como la escalera, llevan un barandal en hierro con cuadrados tubulares acomodados en dos niveles horizontales, con lo cual se destaca la geometrización lineal propia de los presupuestos Déco.

De acuerdo a nuestra observación, todo el edificio está trabajado con concreto y aplanados de cemento, el material moderno de los años del Art Déco y símbolo del progreso económico.

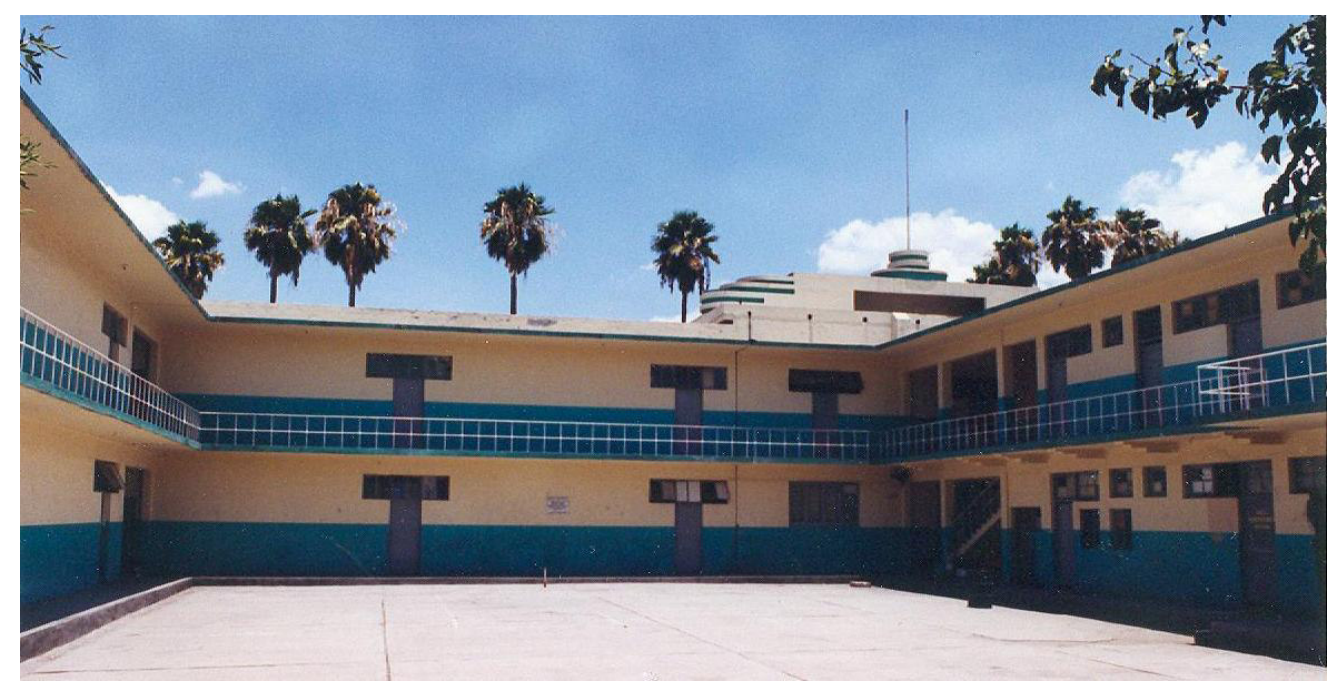

Cuerpo lateral sur y el cuerpo intermedio. 


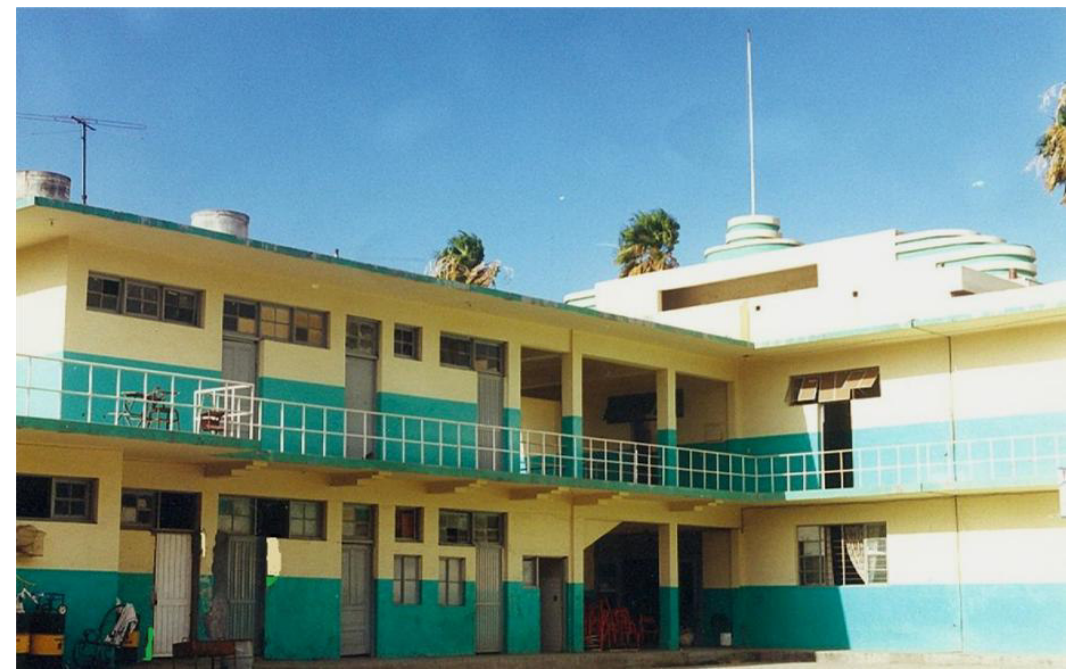

Vista del cuerpo intermedio desde el lado norte.

La Escuela Monterrey es un claro ejemplo de la variante Déco Streamline, de la subvariante Tropical Déco y Tendencia Geometrista, pero su estado de conservación es lamentable, ya que por la zona en la que está ubicada tiene baja población estudiantil, además que los vecinos no hacen algo por conservarla.

\section{e. Escuela Presidente Calles}

La Escuela Presidente Calles se ubica en la calle Francisco I. Madero s/n., entre Porfirio Díaz, Ignacio Vallarta y José María Arteaga, con orientación al norte.

Fue proyectada en el año de 1933 por la constructora FYUSA, Fomento y Urbanización, S.A., como un centro escolar que albergara la Escuela Normal para Profesores. Las obras se concluyeron 1941. Aunque no tenemos el dato exacto del arquitecto que la realizó, de acuerdo a los miembros de la constructora, seguramente fueron sus autores los arquitectos Manuel Muriel y Antonio Lamosa, ${ }^{68}$ aunque Juan Manuel Casas cita que el ingeniero Arturo Olivero Cedeño "afirma ser el autor del proyecto

\footnotetext{
${ }^{68}$ De acuerdo a una publicación de Jueves de Excélsior, "Edición Especial Pro Monterrey", noviembre de 1929, sin números de página, aparece una publicidad de la compañía FYUSA, como constructora del Palacio Federal, en donde citan los siguientes puestos y nombres: Presidente, Federico T. de Lachica; Gerente de Monterrey, Víctor de Lachica, Gerente de México, Ing. Baldomero Parra; Apoderado, Lic. Carlos Prieto; Arquitectos, Manuel Muriel, Antonio Lamosa; Ingenieros, Juan Garza Lafón, Antonio Pliego. Nos basaremos en estos nombres para la atribución de autorías de los edificios a estudiar que hayan sido construidos por esta empresa.
} 
arquitectónico cuando trabajó para FyUSA; sin embargo, esto no pudo ser comprobado en otras fuentes"; el mismo Casas atribuye la conclusión del inmueble al ingeniero Antonio Sava. ${ }^{69}$ Los materiales utilizados fueron el cemento, el concreto, el granito y el granzón.

El edificio se encontraba bastante deteriorado en octubre de 1987, con vidrios rotos y paredes pintadas con graffitis, sin embargo con motivo del remozamiento de la Calzada Madero se proyectaba restaurar también algunos de sus edificios. ${ }^{70}$ La restauración como tal se llevó a cabo a finales de 1995 y principios de 1996 por parte del INAH, proceso en el cual se dignificó el edificio, resaltando sus elementos estilísticos; se cambió la rejería exterior, imitando un estilo Déco, pero se perdió una placa que se encontraba en el vestíbulo, en la cual se inscribía la fecha de inauguración del centro escolar. ${ }^{71}$ En junio del 2000 se anunció que la Escuela Presidente Calles, entre otros edificios, quedaría protegida como monumento del siglo XX por el INAH y el INBA ${ }^{72}$.

El análisis que a continuación presentamos es con el fin de demostrar que el inmueble lleva el estilo Art Déco, sin embargo, Oscar Eduardo Martínez al ubicar a la escuela Calles en la década de los treinta dice que "más tarde, se terminaría la escuela Plutarco Elías Calles en la avenida Madero, otro ejemplo más de las tendencias decorativistas en la ciudad y una marcada tendencia de inspiración socialista, al recurrir al constructivismo". 73

\footnotetext{
${ }^{69}$ Juan Manuel Casas, Op. Cit., p. 151.

${ }^{70}$ Yolanda Barrera, "Invierten 100 millones en monumentos", El Norte, Monterrey, N.L., martes 6 de octubre de 1987, secc. Cultural, p. 1.

${ }^{71}$ Entrevista sostenida el miércoles 18 de junio de 1998 con la profesora Palmira Guerrero Chavarría, Directora de la Escuela primaria Andrés Quintana Roo, -turno matutino que labora en el plantel Escuela Presidente Calles- quien nos informó de la restauración. Ante nuestra pregunta por la placa desaparecida, nos comentó que al concluir los trabajos de reparación se perdieron dos cosas: la placa y los planos originales que se custodiaban en la Dirección, pero que al trabajar tres turnos y escuelas diferentes en el edificio, son muchas las manos que han transitado por las oficinas directivas.

En mayo de 1993, en una visita a la escuela, fuimos atendidos por una directora del turno vespertino (no tenemos el nombre), quien nos mostró los planos originales. En dicha visita pudimos aún ver la placa.

En los recorridos culturales sobre el patrimonio de la ciudad organizados por el CONARTE y la UNESCO, participamos en el de "Escuelas Monumentales" el sábado 27 de septiembre de 2008. La escuela se conserva bien, aunque con muchos muebles inservibles arrumbados en diversas partes del edificio.

${ }^{72}$ Vicente Guerrero, "Quedarán protegidos edificios del Siglo 20", El Norte, Monterrey, N.L., lunes 12 de junio del 2000, secc. Vida, p. 1.

73 Oscar Eduardo Martínez, "Monterrey, ciudad vieja, ciudad nueva. Su arquitectura y urbanismo". La Enciclopedia de Monterrey. Tomo II. La capital industrial de México, Monterrey, N.L., Milenio, Multimedios, 2008, 2a edición, p. 280.
} 


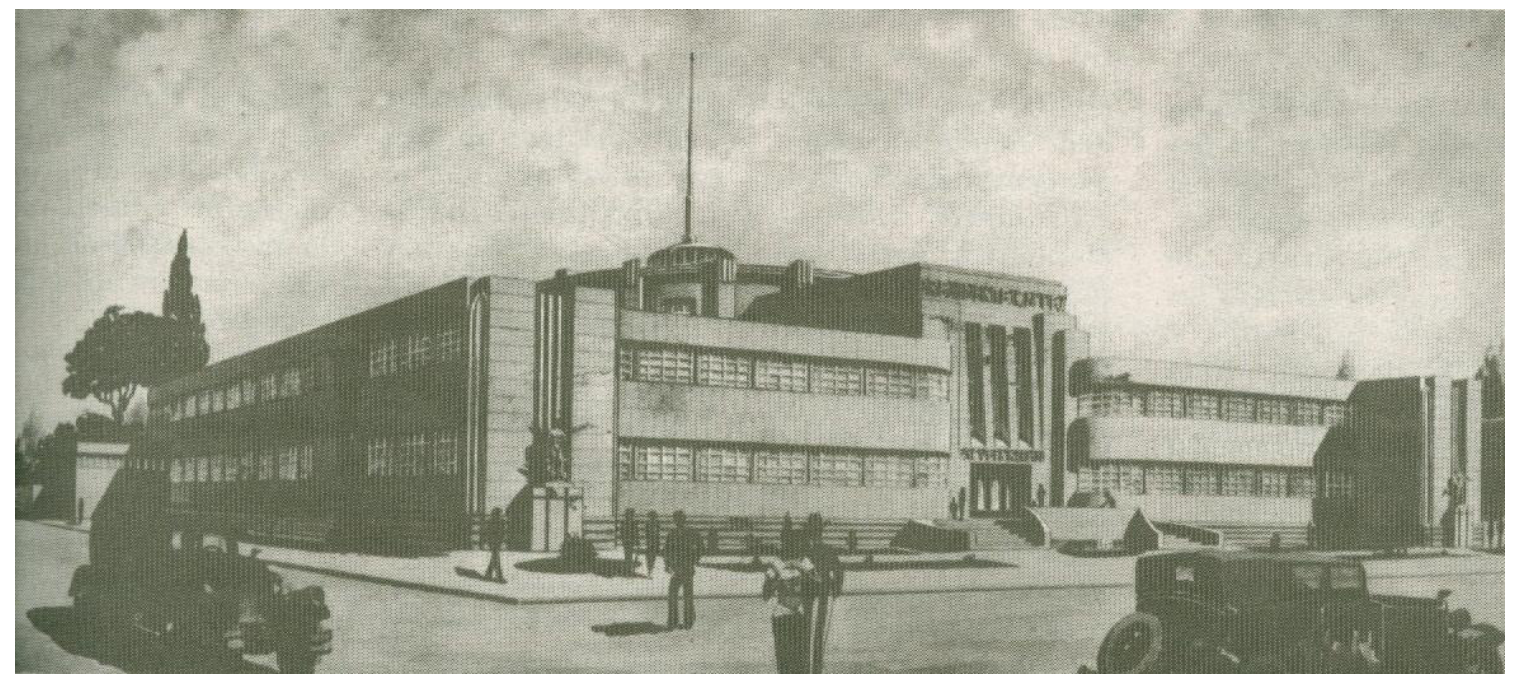

Grabado de 1933 con el alzado del plan original para la Escuela Presidente Calles. ${ }^{74}$

La escuela tiene una planta en forma de E, como la tienen también otras de las escuelas que estudiaremos aquí y que son conocidas como las Monumentales. Sin ninguna información documental que avale esto, pero nos han dicho que el motivo de la planta es por el apellido Elías del Presidente Calles.

La fachada principal del edificio da al norte sobre la avenida Madero. Se compone de un cuerpo central y dos laterales, dándole un armonioso sentido de simetría, lo cual es una de las constantes de la arquitectura Art Déco.

El cuerpo central se eleva más que los laterales y se encuentra remetido en relación con toda la fachada. La entrada principal es un vano rectangular horizontal cuya trabe sostiene un ventanal rectangular vertical tripartita; tanto puerta como ventanal están enmarcadas por decoraciones de aplanado trabajadas con cemento, el material moderno del Art Déco, a manera de almohadillado, mismas que se unen en la parte baja con otras que se distribuyen en los extremos laterales del cuerpo central, que en grupos de tres se proyectan hacia el exterior y rematan de manera escalonada. Todo esto da una unidad de linealidad horizontal y de geometrismo, elemento esencial del Art Déco, así como también lo es el letrero con grafías de la época que denomina al inmueble ubicado en la parte superior, rasgo distintivo de la Tendencia Geometrista, Elementos Exteriores. En un espacio rehundido rectangular, se distribuyen letras individuales de cortes angulosos a nivel de la

\footnotetext{
${ }^{74}$ UANL, "Se inicia la construcción del edifico para la normal”, Memoria Universitaria, No. 8, agosto de 2013, p. 6.
} 
superficie, de las que destaca la delicadeza de la $\mathrm{S}$ inclinada; con el mismo tipo de grafías, pero ahora sobrepuestas en el dintel de la puerta se lee "Esc. Primaria". Con la restauración se colocaron unas lámparas poliédricas, del tipo Art Déco.

El remate se conforma por unas delicadas molduras geométricas escalonadas que se inician con una greca cuadrada, misma que se conecta con otra colocada frontalmente; las molduras integran una especie de tímpano, el cual se abre para recibir la astabandera y su base, que se compone de tres superposiciones ochavadas. Este remate luce con excelsitud la característica del Déco de elevarse a manera de zigurat o de templo prehispánico mesoamericano.

El cuerpo central se ensambla con el exterior del Salón de Actos, que se eleva como un gran cubo en un segundo plano, más aún que el cuerpo central; la parte superior se orna con una banda de motivos que asemejan motas colgantes, sostenidos de una molduración proyectada hacia fuera.

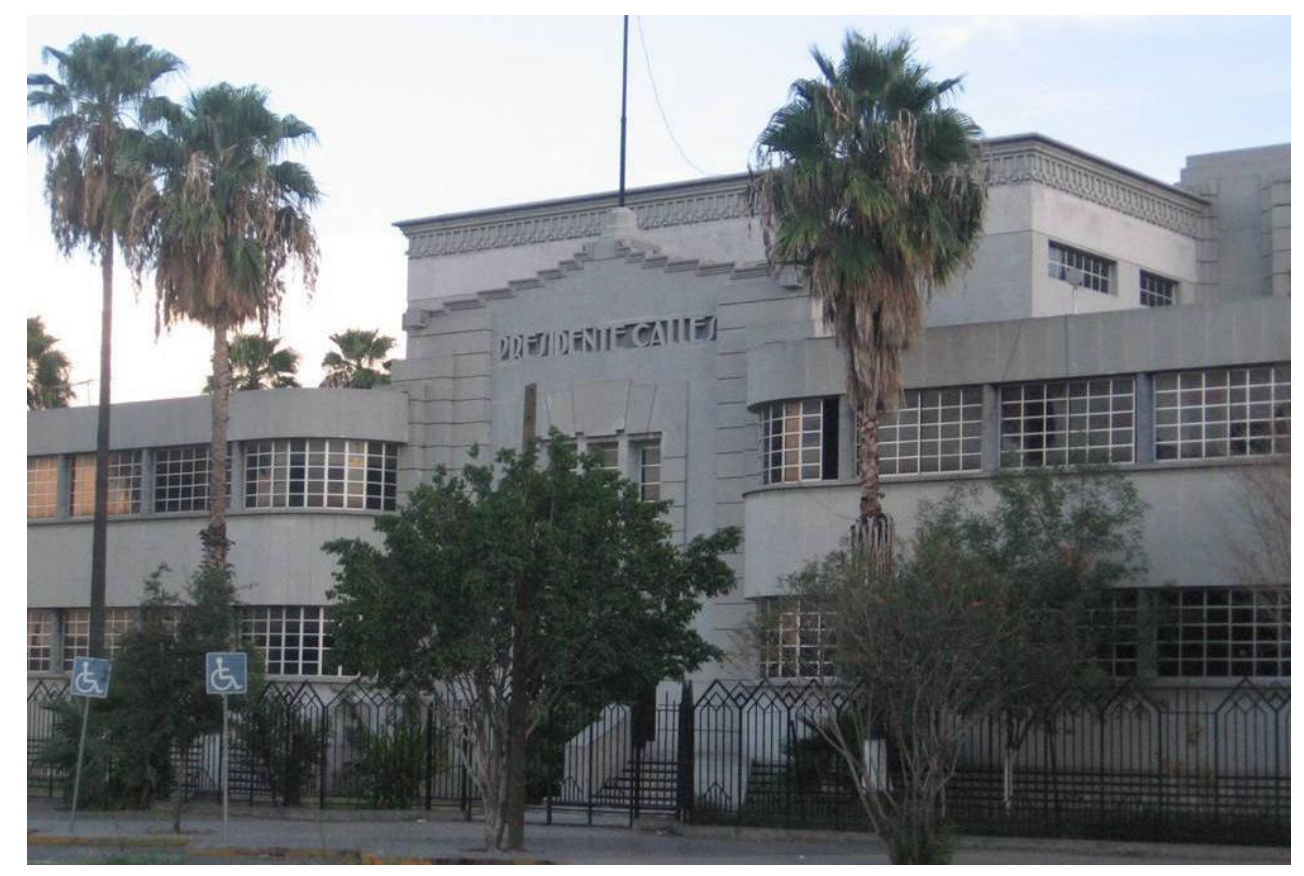

Escuela Presidente Calles. El cubo detrás de la portada corresponde al salón de actos.

Los cuerpos laterales de la misma fachada norte son dos pisos y están colocados más hacia el frente en relación con el central, al que se unen curvándose hacia adentro, tal vez como una influencia del Streamline en el que se utiliza en ocasiones las fachadas 
curvas, o la línea aerodinámica curva. Ventanales que se distribuyen horizontalmente en ambos pisos llevan rejería reticular y están organizados a través de rectángulos divididos por columnas sin base ni capitel, lo que remite a las composiciones Art Déco de tipo Neoclásico Moderno. Todas las paredes de los cuerpos laterales están revestidas de aplanados de cemento que simulan placas rectangulares colocadas en forma vertical. Cada extremo de estos cuerpos termina con unas composiciones geométricas, las cuales sirven de fondo para unas obras escultóricas que analizaremos más adelante.

El vano de acceso principal carece de marquesina, lo que es una característica del Art Déco de Monterrey, a diferencia del de la ciudad de México, tal como lo explica Juan Manuel Casas. Enfrente del cuerpo central está una escalera de acceso de doble rampa. Los peldaños son independientes cada uno, ligeramente curvos. El pasamanos, en la parte ascendente, es también curvo en sentido inverso a las doblamientos de los cuerpos laterales y es recto en el segmento frontal que forma un pretil. La decoración que lleva la escalinata en el pasamanos se forma por una amplia banda de pizarras con motivos que incluyen "ves" invertidas, o bien, triángulos superpuestos que recorren toda la escalera, formando un verdadero Zigzag, rasgo distintivo del primer periodo del Art Déco. La concatenación de estas formas le da al edifico un alto sentido estilístico Déco del tipo Zigzag, que convierte a esta escalinata en una de las máximas expresiones de este estilo en México.

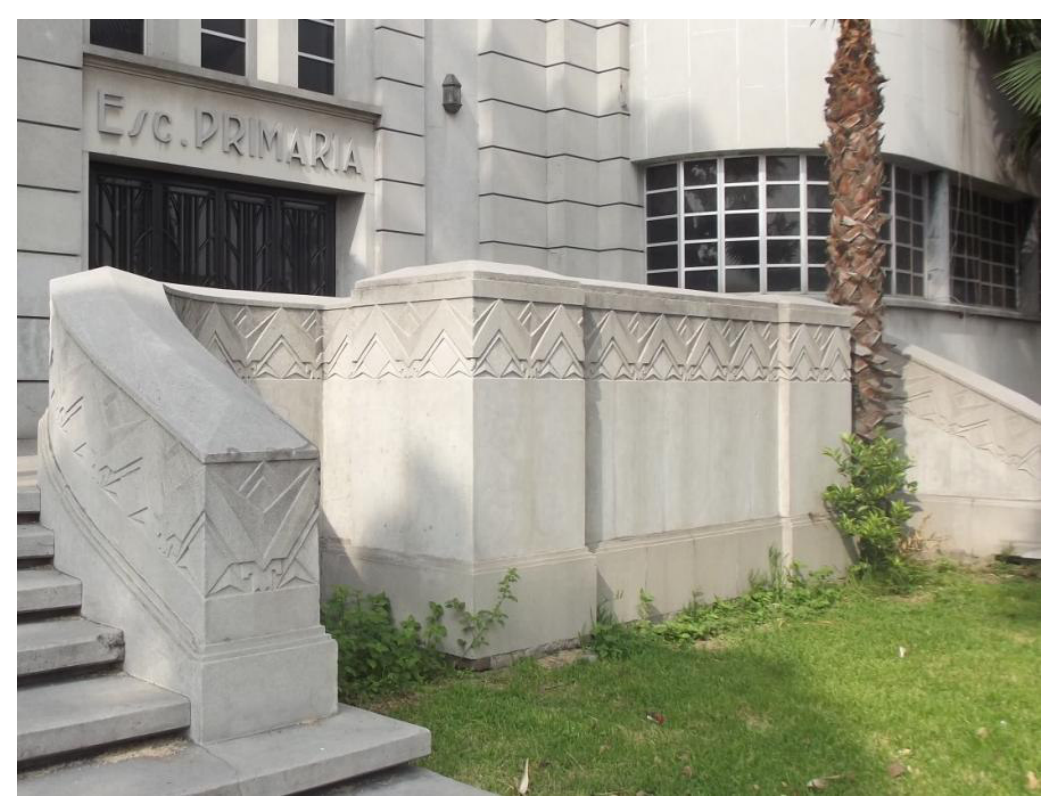

Detalle de la decoración tipo zigzag en el pasamanos de la escalera y en el pretil. 


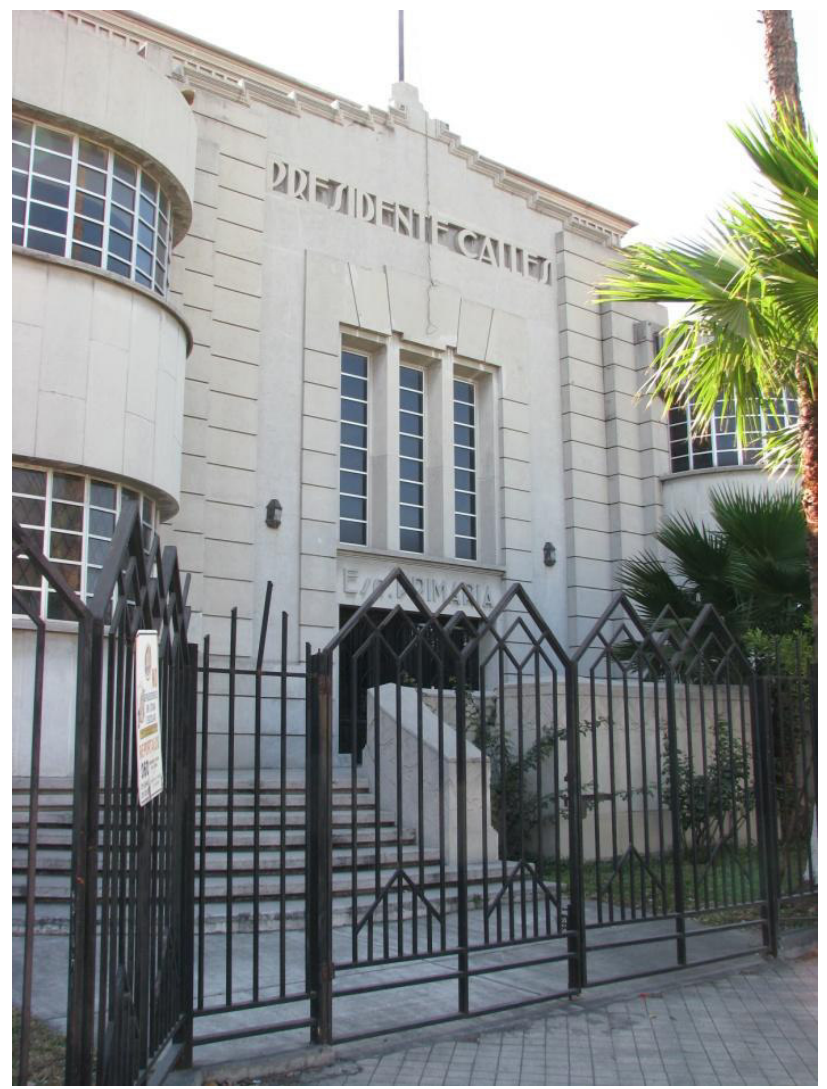

Acceso principal a la escuela con la escalinata.

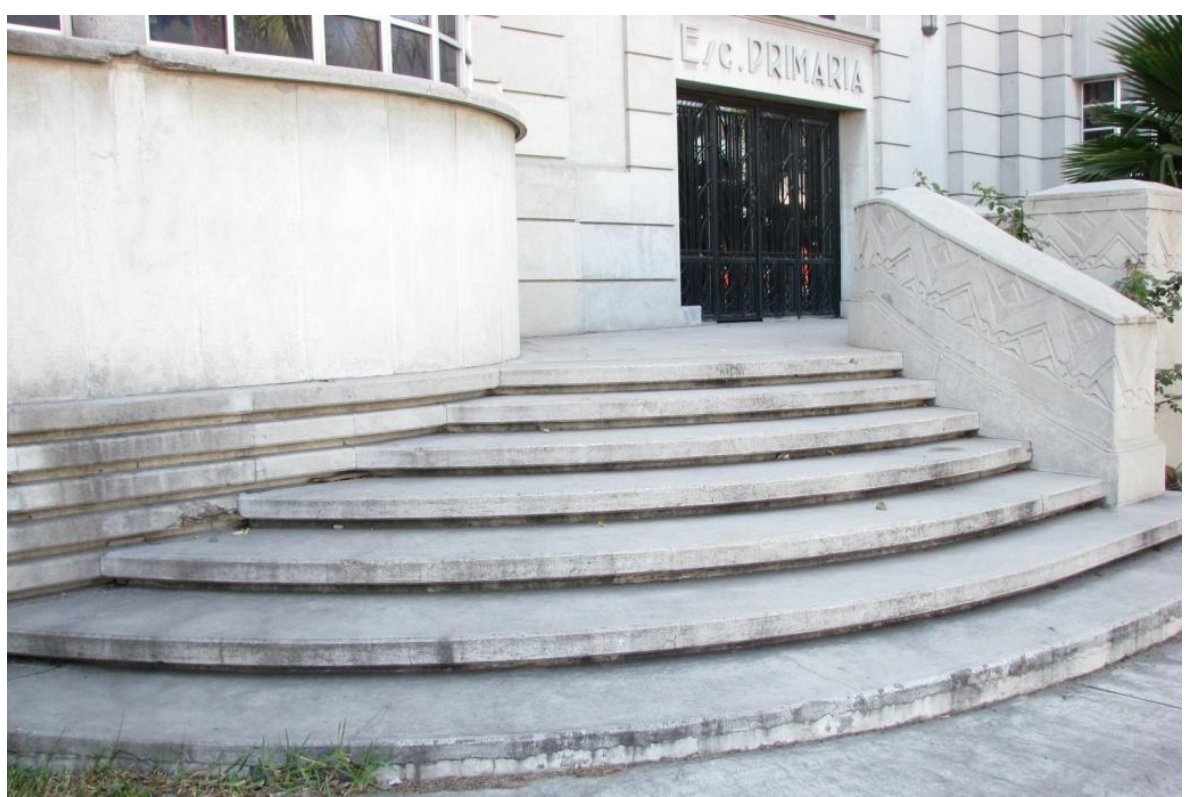

Escalera vista desde el lado izquierdo. 
Los extremos de los cuerpos laterales finalizan con unas formas cúbicas que sirven de fondo para unas esculturas, como ya habíamos mencionado. Son unas composiciones de tres partes: dos estructuras de almohadillados rectangulares horizontales y un remetimiento a manera de entrecalle de estrías verticales que bien parecieran caídas de agua congelada; en conjunto, es un juego de perfecta linealidad, parodiando un radiador o algún objeto industrial, como los emanados de la exposición del 25 en París.

Las imágenes se encuentran sobre unos zócalos cúbicos de concreto forrados con marmolina, cuyo frente se decora con un enmarcamiento de tres molduraciones superpuestas, y en las partes laterales dos bandas también superpuestas, envuelven al cubo, tal como sucede en algunas edificaciones Art Déco, consiguiendo así un efecto de exaltar lo geométrico. En la parte superior del zócalo una placa cuadrada que sirve como base para la escultura, presenta decoraciones como de letras "as" mayúsculas sin travesaño y los espacios crean triángulos isósceles, alternados, inversamente unos con otros, lo que provoca una sensación de pequeños zigzags, rasgo netamente distintivo del Art Déco.

Las tallas en cantera son obra de Manuel Centurión (1883-1952) ${ }^{75}$, cuya firma aparece en la escultura del lado izquierdo correspondiente al campesino, en la base del lado

75 Es poca la información que hemos encontrado con respecto a la producción de Manuel Centurión, por lo que presentamos una recopilación de datos que encontramos en las bibliografías consultadas, con el fin de completar la obra del escultor con las efigies de Monterrey.

Lily Kassner en su Diccionario de escultores mexicanos del siglo XX da las fechas de 1883 y 1952 para nacimiento y muerte. Al citar las obras del artista no menciona las de la Escuela Presidente Calles, sólo incluye las siguientes: 1910, Medalla conmemorativa del centenario de la Independencia; El último esfuerzo, Jardines del Golden State, San Francisco, Cal.; Estatua de Cuauhtémoc, en Brasil sin decir la ciudad; Emperador, Jardín de Teotlis, Rancho del Artista, México, D.F. 1946, Estatua ecuestre de Simón Bolívar, trasladada al puerto de Veracruz en 1975; relieves y frisos neoclásicos del Banco de México, México, D.F.; Cuatro relieves realistas dedicados a las cuatro edades de México con los símbolos de Quetzalcoatl, Colón, Oriente y La Patria, SEP, México, D.F.; Aplicaciones decorativas, SSA, México, D.F.; Desnudo de Mujer, proscenio cine Alameda, México, D.F.; Fray Bartolomé de las Casas, Preparatoria (antiguo convento de San Pedro y San Pablo), México, D.F.; Placas del Banco de Londres y México, México, D.F.; Placas del Puente de Mezcala, Jalisco; Placas del Edificio de la Compañía de Seguros La Nacional, México, D.F.

Al término de una conferencias que dictó la Dra. Kassner en el Museo de Arte Contemporáneo (MARCO) en Monterrey el 13 de marzo de 2008, platicamos al respecto de las esculturas de Centurión y afirmó desconocerlas. Le obsequié la información obtenida y dijo que la incluiría en la próxima edición del Diccionario.

Enrique X., de Anda en Art Déco. Un país nacionalista, un México cosmopolita, en la p. 174 da para nacimiento y muerte los años de 1882-1948. De sus obras cita Alegoría de la electricidad, ca. 1926, relieve en hierro colado en el Instituto Politécnico Nacional, p. 42; un Escudo Nacional en el mostrador del Banco de México, sin fecha, es atribuido, p. 157; Caballo marino, 1929 reproducción de la talla original en piedra que se encuentra en la escalera de la Secretaría de Salud, p. 140 y en el mismo lugar, "las esculturas de los doctores Eduardo Liceaga y Ángel Gaviño, sobre las escalinatas principales al primer piso”, p. 91.

El mismo De Anda en su libro La Arquitectura de la Revolución Mexicana. Corrientes y Estilos de la década de los veinte, anota que son obras de Centurión: los relieves de influencia prehispánica del 
derecho; en la efigie del lado derecho que representa al obrero, en la base del lado izquierdo.

La escultura del lado izquierdo representa a un campesino, parado con el cuerpo hacia el frente, pero con la cabeza volteando a la derecha, mirando a su compañero ubicado en el otro extremo. Porta un overol y camisa de manga corta, lo que permite apreciar la hercúlea musculatura de sus brazos. Con la mano izquierda, sostiene unas espigas planas y geométricas que se acomodan por el frente de la pierna izquierda, alcanzando a cubrir parte del vientre y en la parte inferior y hacia la derecha, una hoz completa la iconografía del agricultor. Con la mano derecha, sujeta una pala plegada a la pierna derecha y por la parte trasera, unas hojas de maíz nacen pegadas al pantalón del personaje. Las miguelangelescas manos ponderan su robustez y vigorosidad, emblema del trabajo campesino, mientras en la cabeza resaltan los pómulos alargados y en el cuello la musculatura, así como la "manzana" traqueal.

La escultura del lado derecho encarna a un obrero, que al igual que la anterior, está en postura frontal, con la cabeza volteada a la izquierda. Viste con un uniforme coordinado de manga larga, cuyo chaquetín se ciñe a la altura de la cintura. La mano derecha descansa sobre un yunque, el cual a la vez está sostenido por una base pedregosa; por la parte lateral de la pierna derecha, se recargan unas largas tenazas. La mano izquierda apresa el mango de un martillo, el cual se recarga sobre el perfil de la pierna derecha y atrás de ésta, un engrane circular completa la significación del trabajo fabril. El yunque, las tenazas y el martillo, representan el trabajo de la fundición, el cual era uno de los más significativos de

desplante de la torre de la esquina del Edificio de Policía y Bomberos de la ciudad de México que hacen referencia al fuego y al agua, p. 144; en el inmueble de La Nacional, un relieve sobre placa de bronce colocado encima del vano de ingreso, cuyo tema es una sugerencia al seguro de vida, p. 155.

Esqueda en El Art Déco. Retrato de una época, en la p. 106 da las fechas de 1885-1948. En la misma página, además de indicar la imagen de Bolívar de 1946, con los mismos datos de la Enciclopedia de México, asienta que dentro del estilo Art Déco ejecutó "las esculturas... para el edificio de la Secretaría de Salubridad".

Sobre las fechas de nacimiento y muerte, Humberto Musacchio, en su Diccionario Enciclopédico de México y en la Enciclopedia de México, edición 1993, coinciden en que nació en Puebla, Pue., en 1883 y murió en la ciudad de México en 1952. Musacchio cita que Centurión es autor de los "relieves y frisos neoclásicos” del Banco de México, de los relieves Cuatro Edades de México, Quetzalcóatl, Colón, Oriente y La Patria en la Secretaría de Educación Pública y de los paneles de la Secretaría de Salud. En la Enciclopedia de México sólo mencionan que es autor de una escultura de Simón Bolívar de 1946 y que ésta fue trasladada a Veracruz en 1975. 
la producción industrial. La cabeza está tallada con más suavidad que la del campesino, y las manos, aunque membrudas y fuertes, no ostentan tan marcadamente sus rasgos.
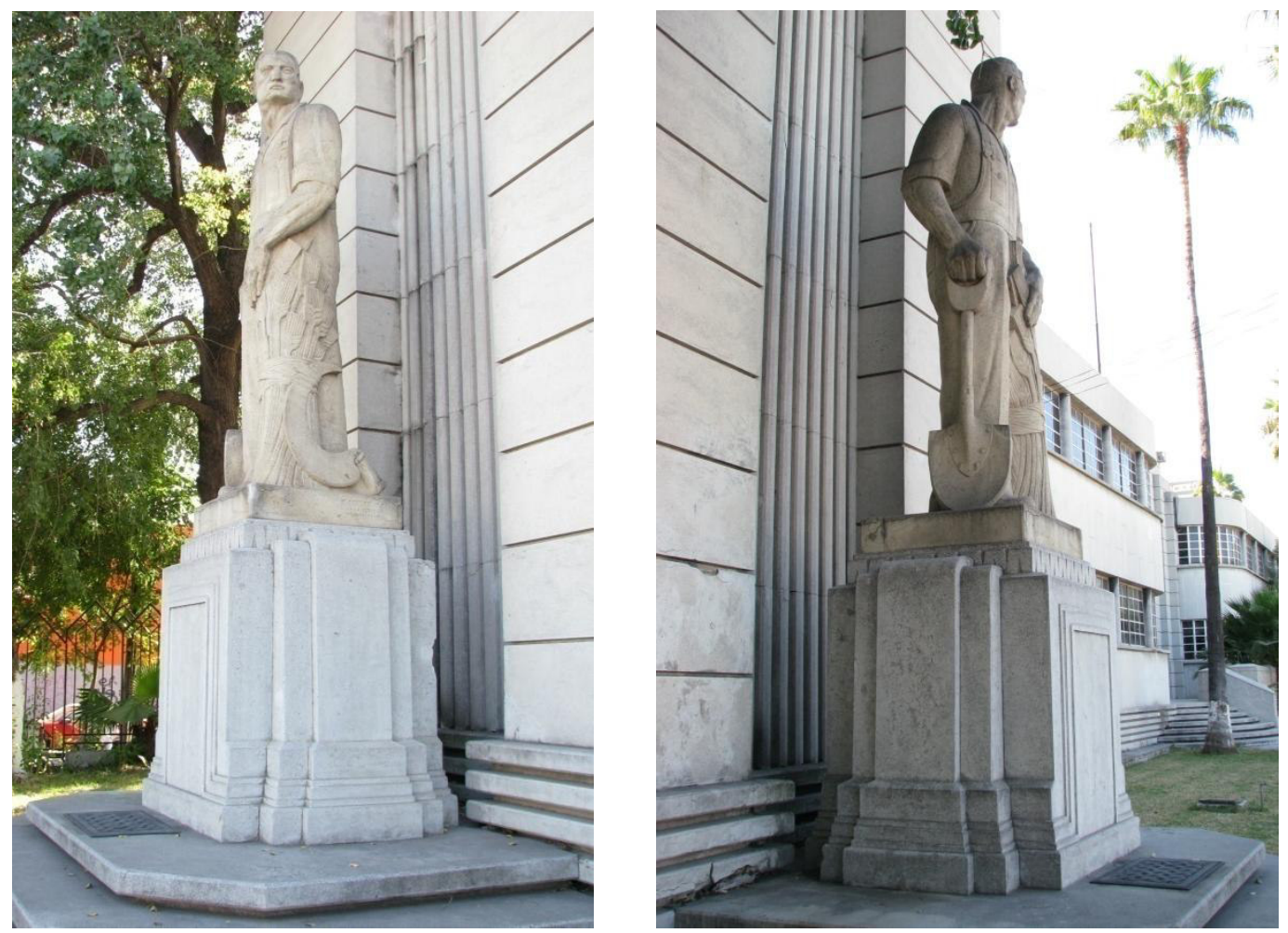

Escultura del campesino. La imagen izquierda con las espigas de trigo y la de la derecha con la pala. Atrás de las figura se aprecian las líneas estriadas del muro.

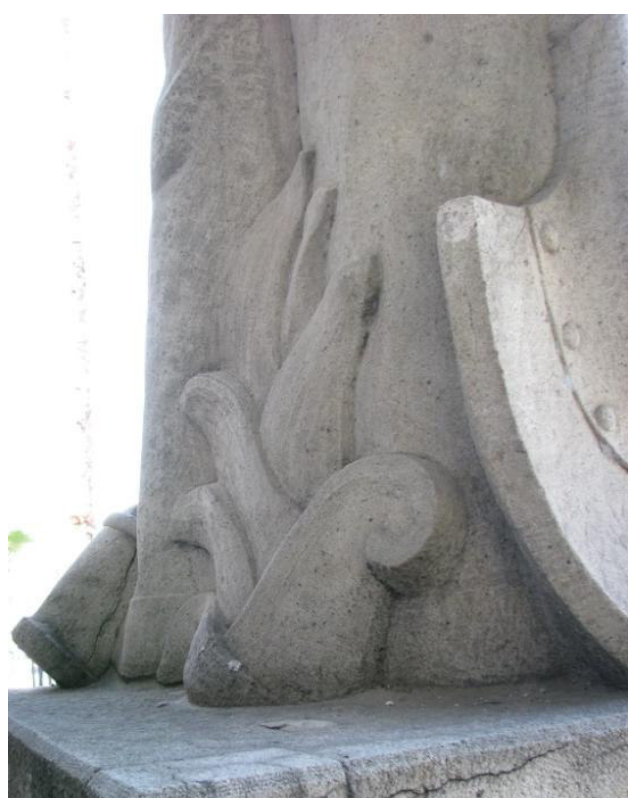

Detalle de la plantas de maíz.

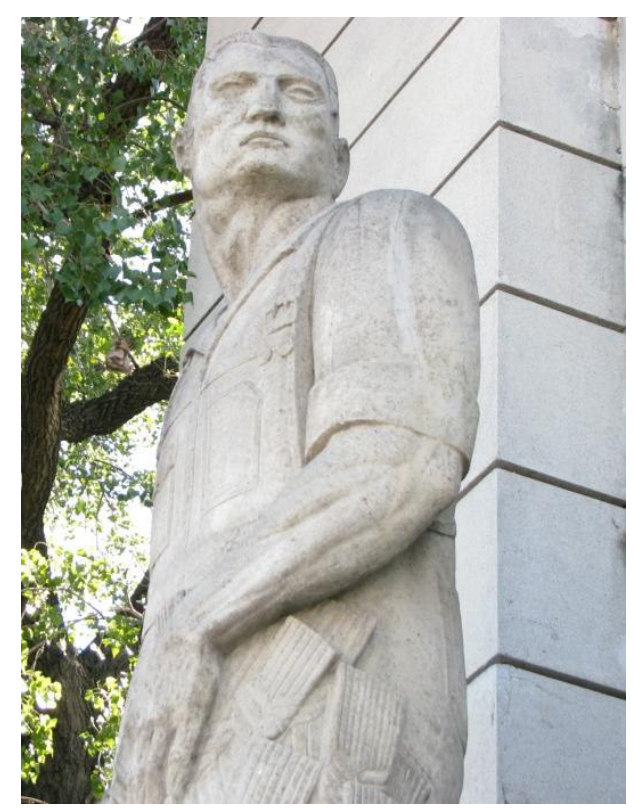

Campesino, detalle. 

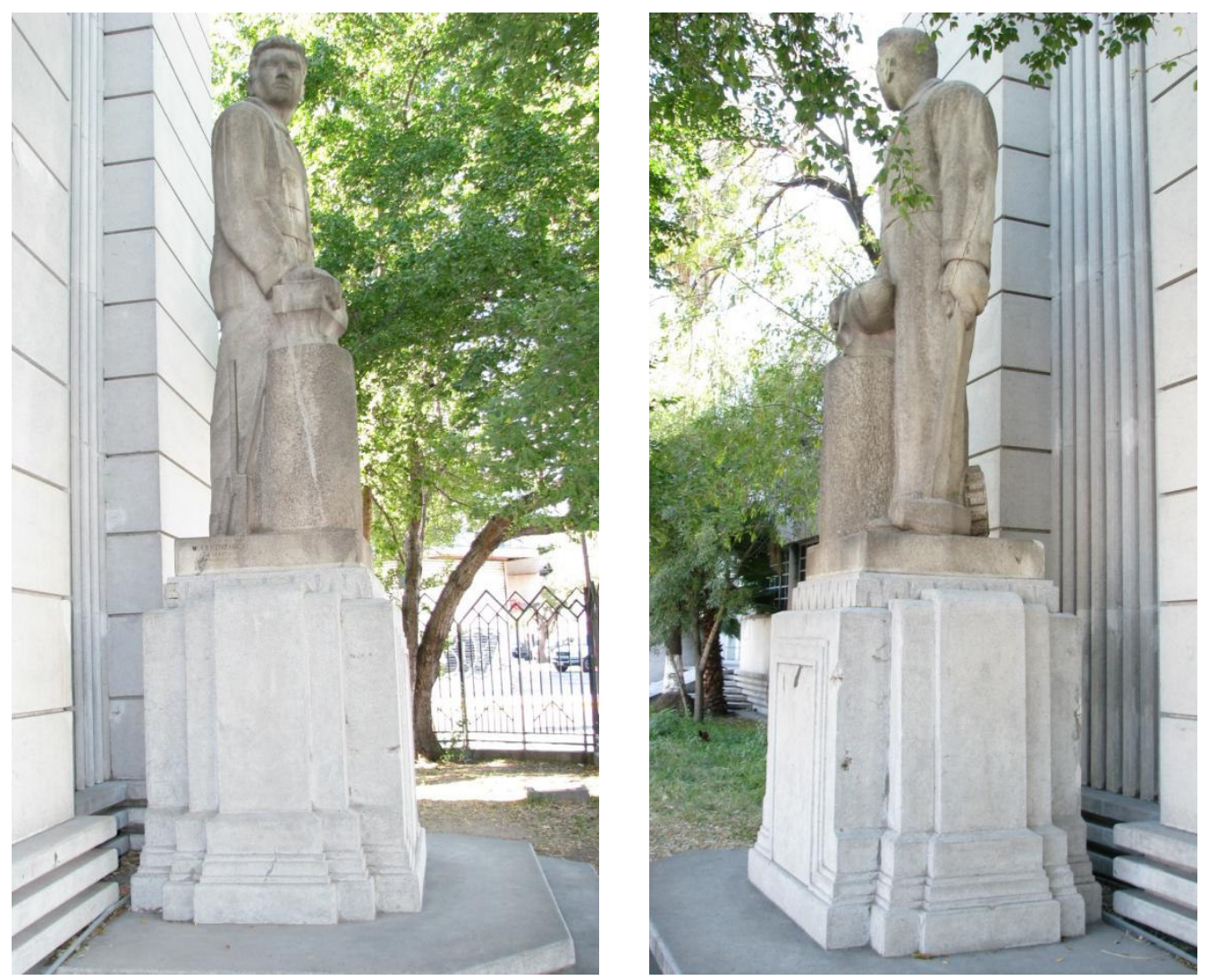

Obrero. En la imagen izquierda descansa la mano sobre el yunque y en la de la derecha lleva el martillo.

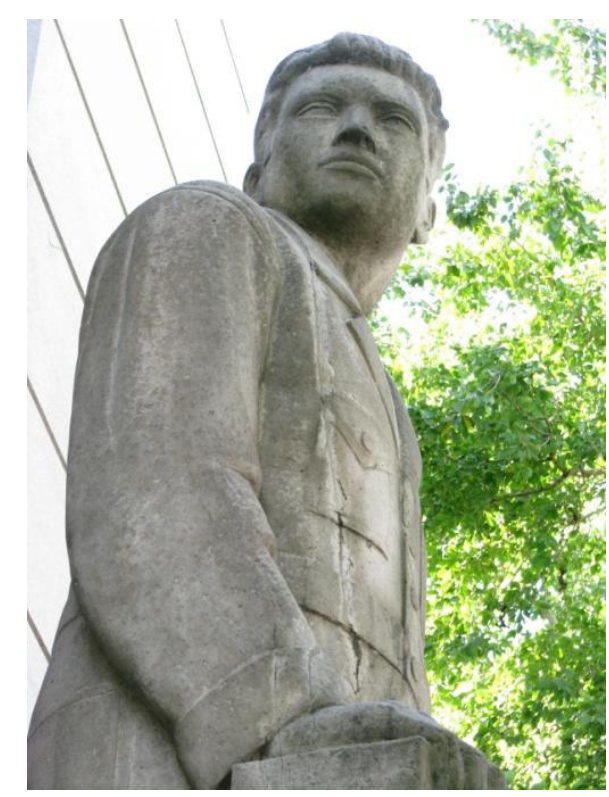

Obrero, detalle.

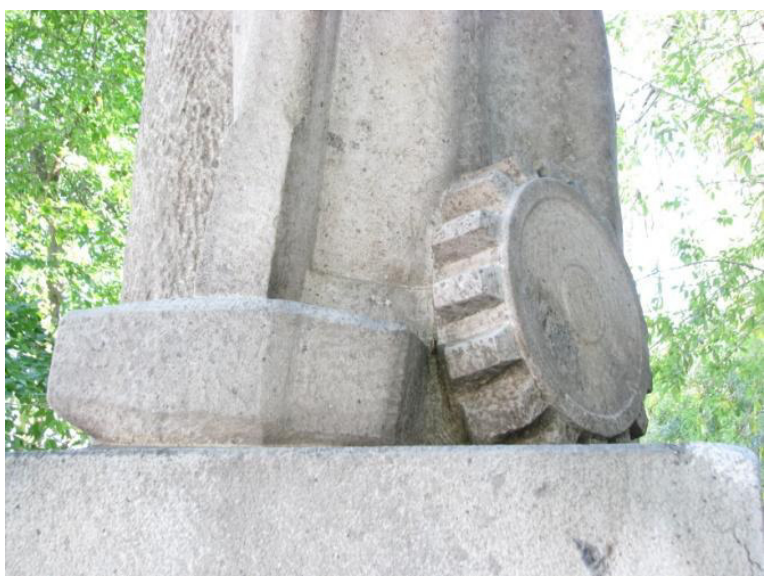

Detalle del engrane y de la cabeza del martillo. 
Ambas esculturas se conjugan atinadamente con los fondos alargados, lo que les refuerza su hechura geometrizada, tectónica, sólida, tal como lo concibe el Art Déco, asemejándose por su factura, a las de Asúnsolo del monumento a Obregón; además, la postura equilibrada y simétrica de los personajes, dirigiéndose la mirada uno a otro, consuman junto con la estética Déco, el ideal triunfante postrevolucionario callista de las luchas obrera y campesina.

Sin embargo, estos personajes más bien parecieran europeos, incluso rusos, pues no personifican tipos mexicanos, lo cual era algo común, pues la influencia del comunismo soviético en sus ideologías a favor de las clase obrero y campesina, los artistas tomaban como modelo a ciudadanos de aquellas regiones, como fue el caso del mismo Diego Rivera.

Los cuerpos de las fachadas oriente y poniente continúan con el tratamiento que llevan los cuerpos laterales de la fachada principal: vanos rectangulares en las ventanas, divididos por pequeñas columnas sin base ni capitel. La entrada es un rectángulo casi cuadrado y el ventanal es tripartita, al igual que el de la fachada principal; puerta y ventanal están en un plano hacia adentro en relación con la superficie del lienzo, al cual se adhieren mediante curvaturas de un cuarto de cilindro de la misma pared, que en la parte superior, al nivel de la trabe del ventanal, presentan a manera de decoración, tres líneas horizontales, fusionando planos, líneas y cuerpos geométricos, es decir, un armazón Art Déco. La herrería de la puerta en la parte baja lleva una decoración de líneas rectas con el ensamble de líneas quebradas levemente curvas que asemejan a una lira; en la parte alta de las líneas rectas laterales salen líneas curvas si fueran tallos de hojas pero sin flor.

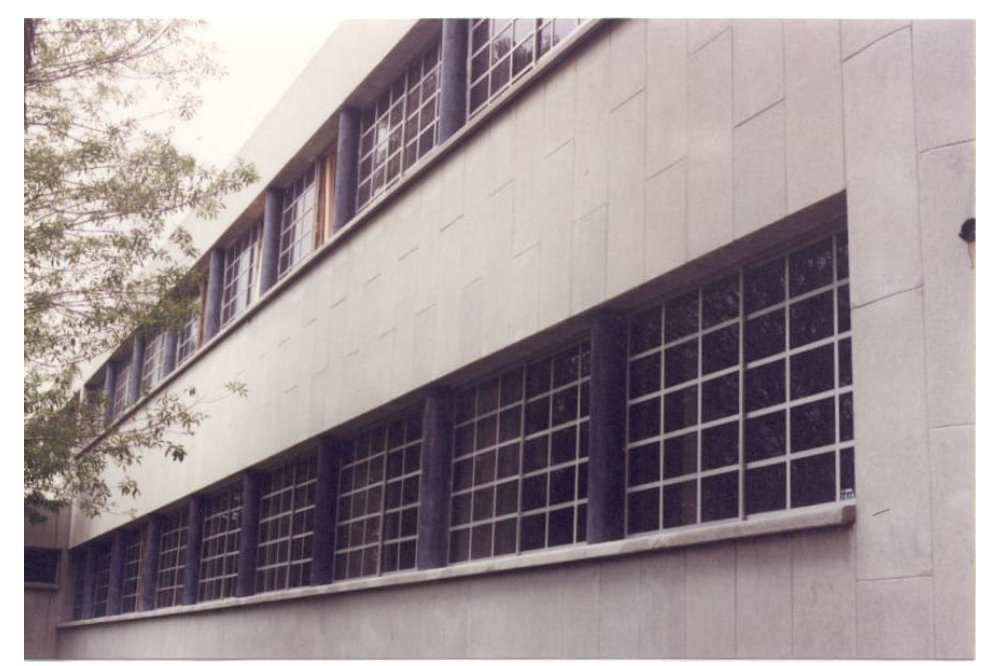

Detalle de la fachada oriente. 


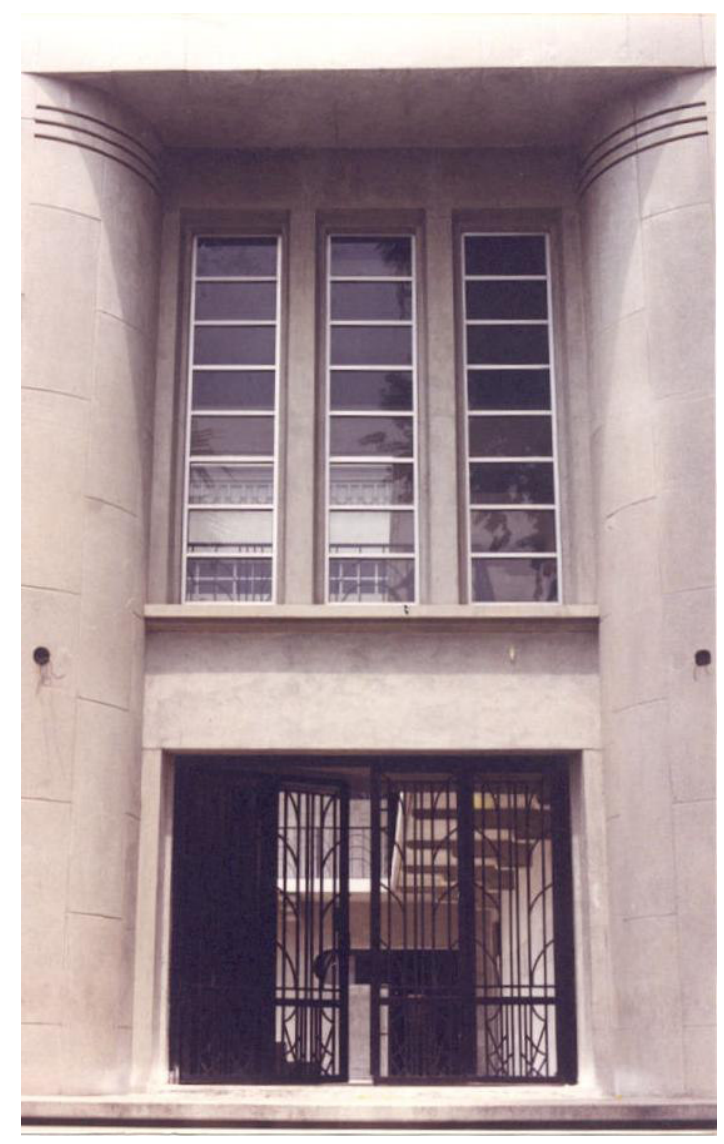
Entrada por la fachada oriente. En la parte superior de los cuatros de cilindro va la decoración de líneas horizontales.

El vestíbulo es amplio y luminoso. En medio de dos medias muestras forradas con granito rojo, base ochavada y capitel corintio, un espacio a manera de nicho se forma con perfiles angulares con un efecto de abocinamiento; esta composición es un uso recurrente del Art Déco en general, en especial de la Tendencia Geometrista. Al centro, un busto en piedra del Presidente Plutarco Elías Calles sobre pedestal rectangular contrasta con el fondo de granzón negro; el juego cromático se complementa con el piso en color vino y límites negros. En el mismo vestíbulo hay otras columnas que sostienen las trabes, que son iguales a las medias muestras mencionadas: base ochavada, fuste en granito rojo y capitel corintio elaborado con cemento, por lo cual representan al Neoclásico Moderno. Son cuatro y están colocadas dos de cada lado. Las trabes están decoradas con motivos de zigzags, lo mismo que el perímetro de un rectángulo rehundido del techo, de donde cuelga una lámpara que no es original de la época de construcción. 


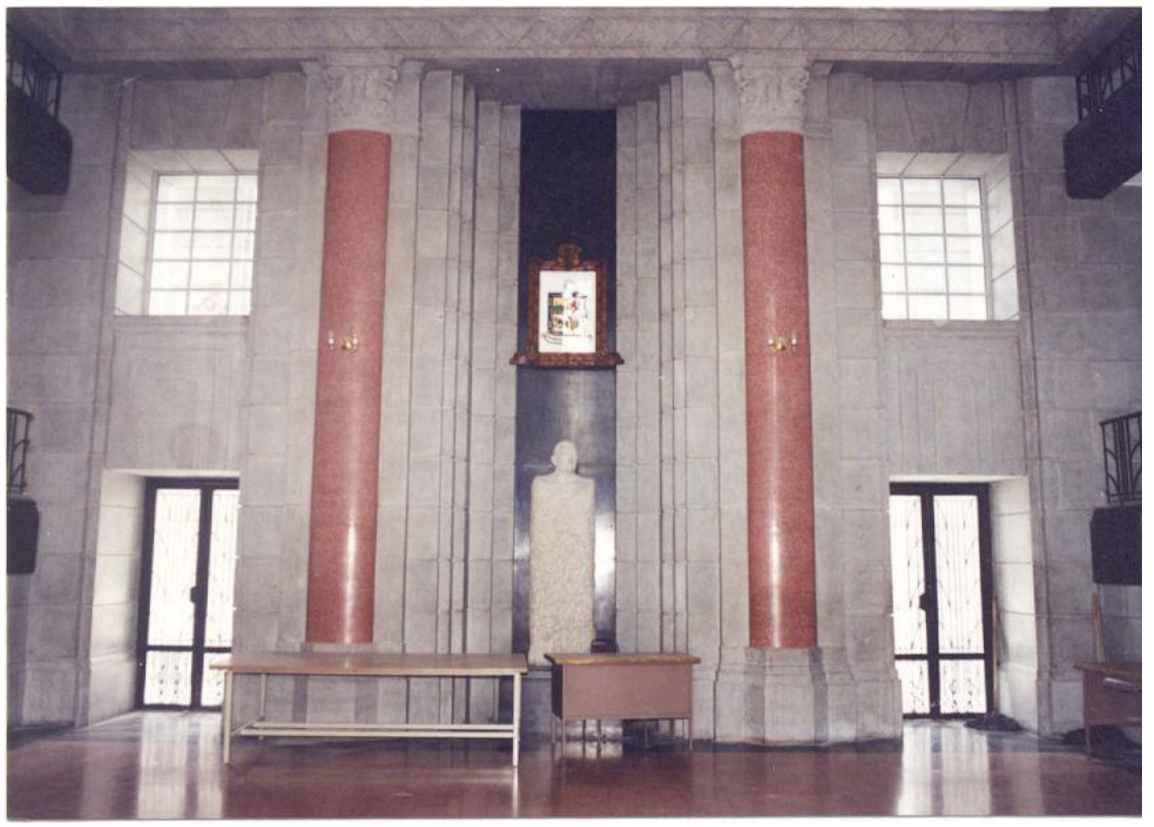

Vestíbulo con el busto de Plutarco Elías Calles.

Entonces, el Neoclásico Moderno y el Zigzag se conjugan armónicamente en el vestíbulo, donde además el uso de los materiales modernos de la época como el granito y el granzón hablan de ese lujo que se buscaba en el Art Déco.

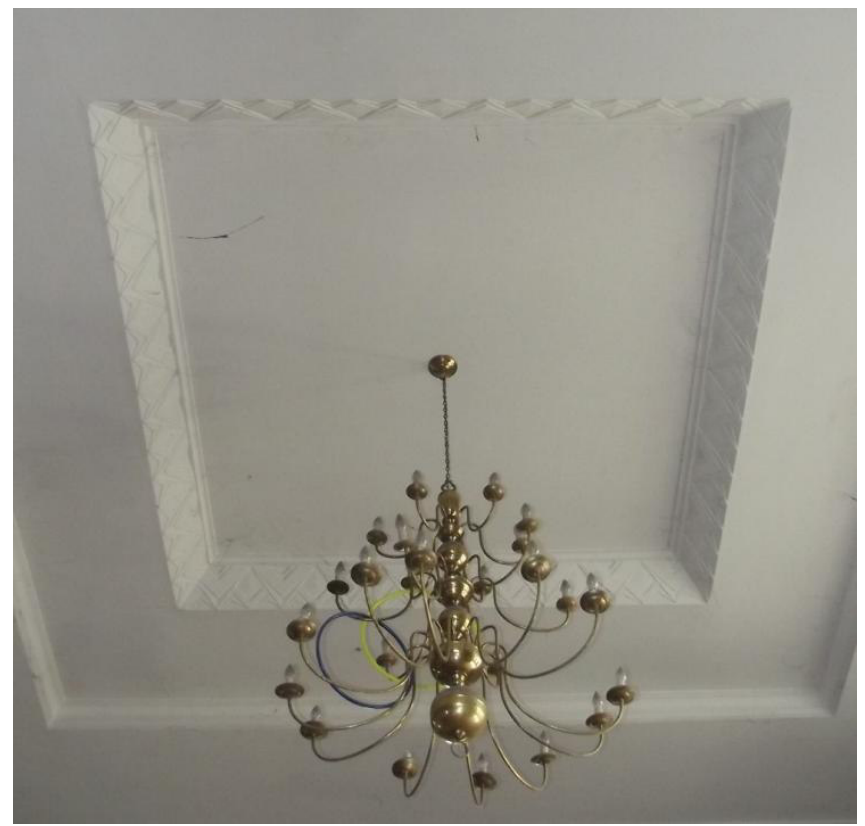

Rectángulo rehundido en el techo del vestíbulo con el perímetro decorado con motivos de zigzags. 
La escalera es de cuatro tramos y está bien demarcada por una banda en color negro, trabajada en granzón y los peldaños están forrados con placas de granito rojo, al igual que los fustes de la columna, lo que hace ritmar cromáticamente con el piso del vestíbulo. Los barandales llevan líneas verticales, con otras que caen lateralmente con una ligera curvatura.

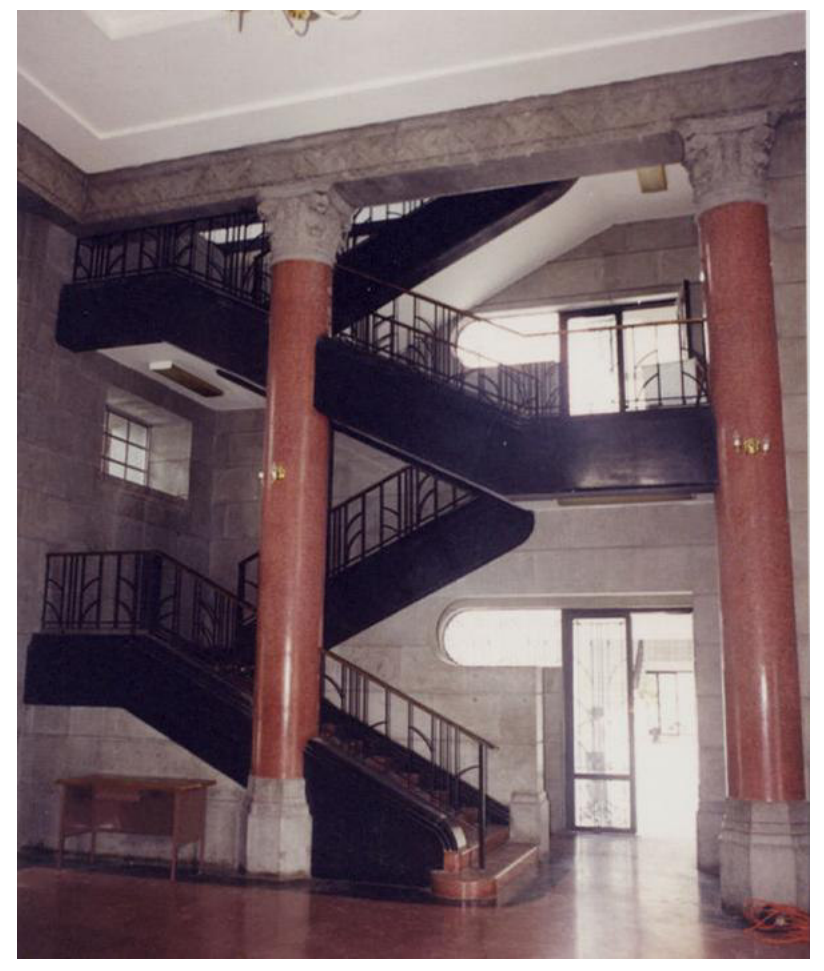

Columnas laterales con las trabes decoradas con zigzags y los cuatro tramos de la escalera.

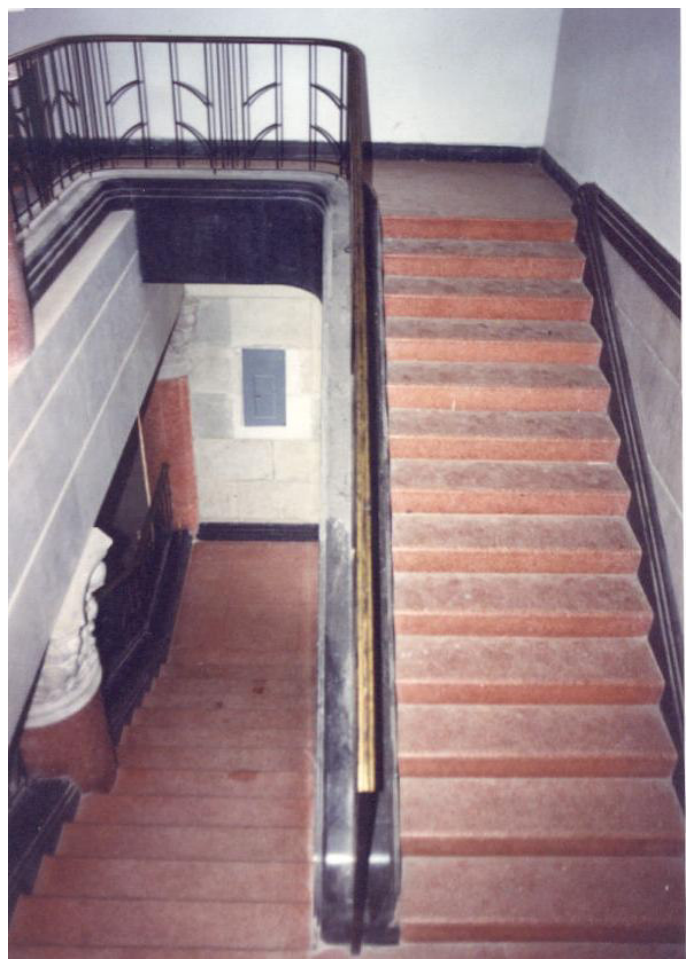

Peldaños y barandales de la escalera.

En el piso superior se encuentra un Salón de Actos. De aquí cabe destacar las cuatro columnas, sin base, fuste en granito rojo y capitel redondo en cemento. El capitel lleva dos bandas en la parte baja, para luego mostrar enlazamientos de "ves" invertidas en zigzags, para rematar con un par de líneas ondulantes. Por el uso de la columna, podría parecer que el Salón de Actos estaría dentro de Neoclásico Moderno, pero más bien por la decoración del los capiteles y el uso del granito en los fustes predomina el Art Déco de la variante Zigzag. 


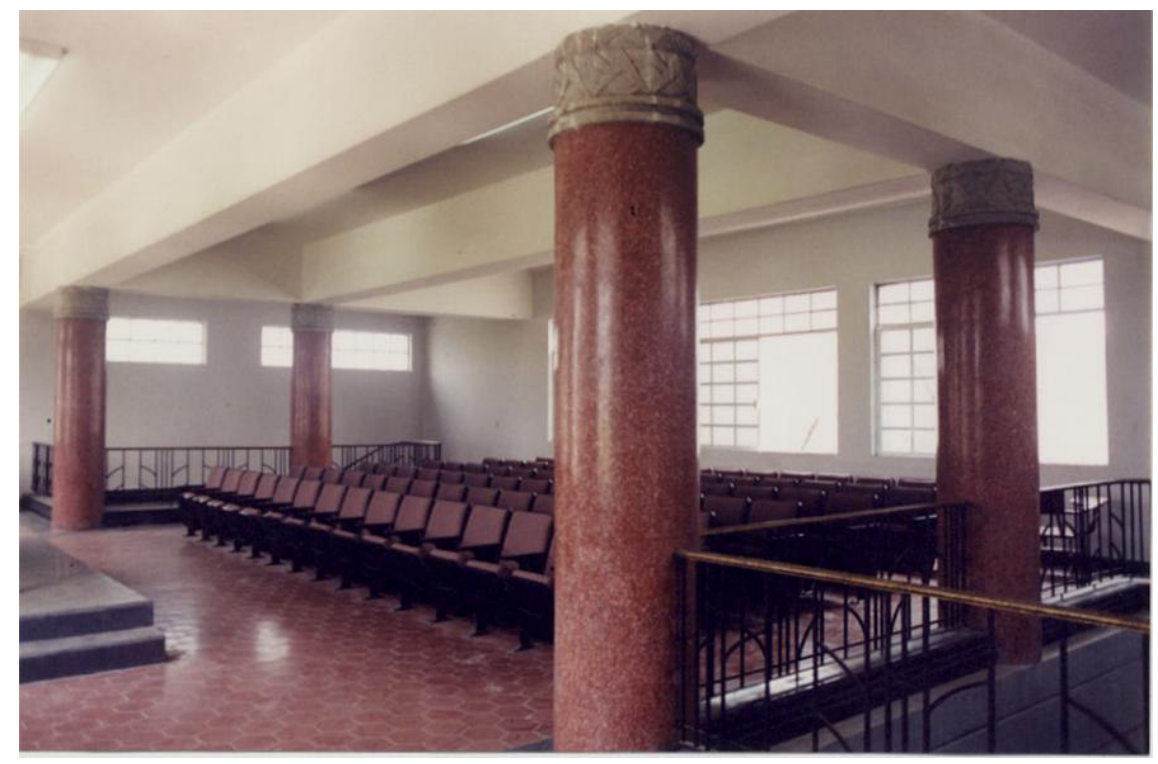

Salón de actos.

Los salones de clase se distribuyen por los tres cuerpos del edificio. Las entradas de la planta baja miran al patio y las del segundo nivel a corredores. Resalta el vano de acceso que tiene una forma de T, lo que acentúa la composición geométrica. Una marquesina corre por todo los dos niveles y está sostenida por ménsulas escalonadas con decoraciones en forma de espiral. Este tipo de ménsulas se incluyen en la Tendencia Decorativista, Elementos exteriores. Le herrería del barandal del segundo nivel se forma con un ritmo de líneas verticales en grupos de cuatro, dos y una, con líneas que se interponen formando casi unas elipses, ya que están bastante geometrizadas. En las puertas la decoración de la herrería asemeja a unos tallos y ramas sin flor de una planta.

El vano de acceso y salida del segundo nivel y que conecta a pasillos y escalinata, además del espacio rectangular, en la parte superior se prolonga una ventana que se extiende rectangularmente, pero que termina en línea curva, asemejando una ventanilla de un barco, un automóvil, un ferrocarril, o inclusive una curva aerodinámica muy de la variante Streamline. Si en los tiempos del Déco la alteridad dada a los productos industrializados fue una constante, no es extraño, entonces, que se incorpore esta innovación en las construcciones de la época. La forja remeda tallos con racimos sin hojas, mientras que en la parte baja el entrecruzamiento de líneas pareciera un juego de luces y agua, como en una fuente petrificada. 


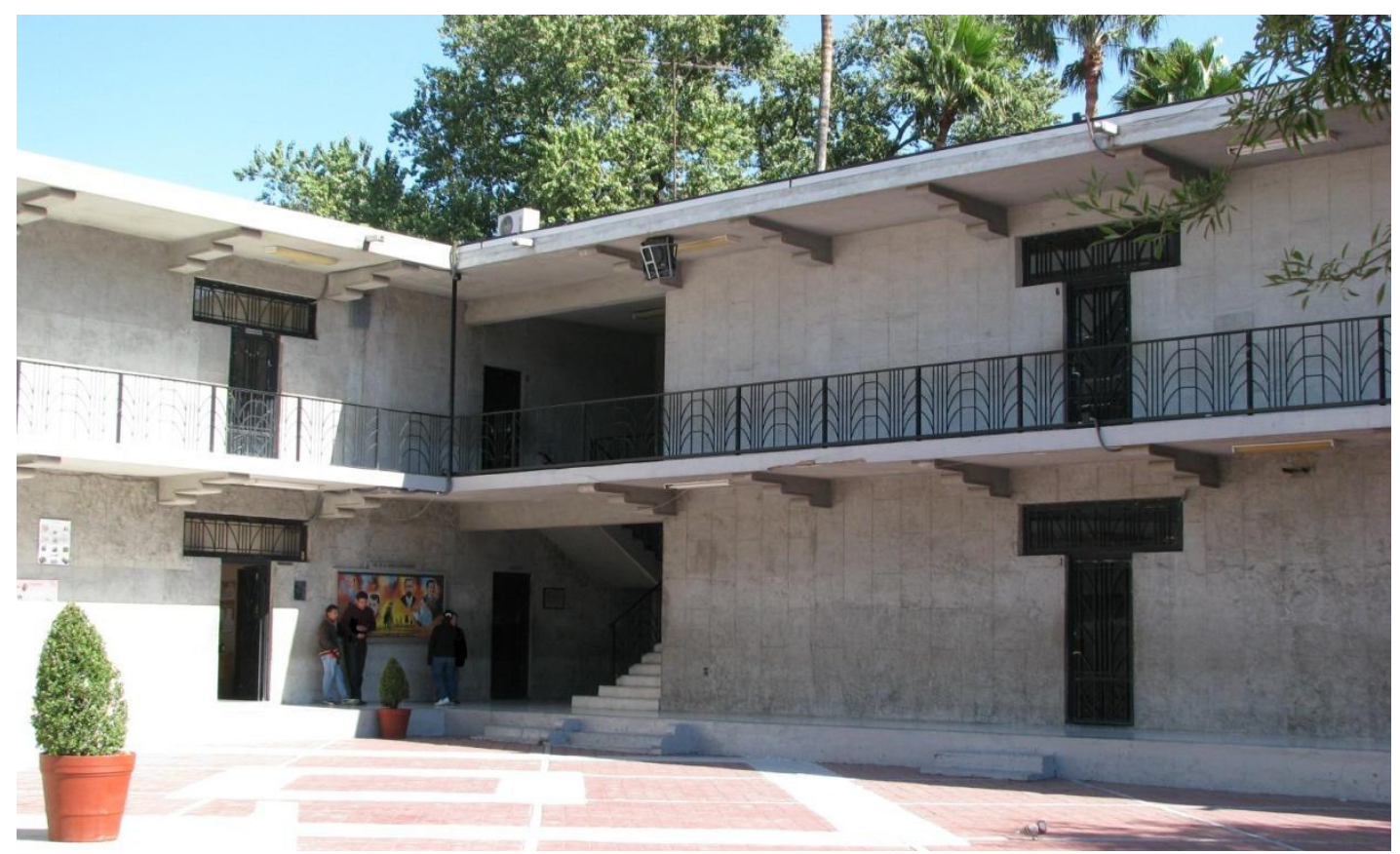

Vanos de acceso en forma de $\mathrm{T}$ de los salones. En ambos niveles las marquesinas sostenidas por las ménsulas escalonadas.

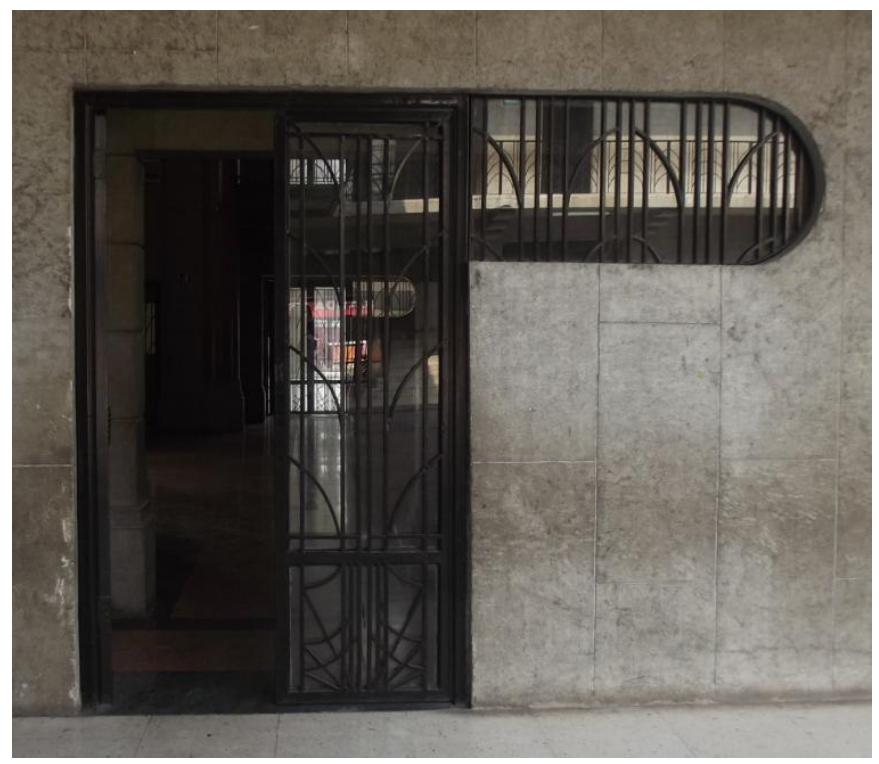

Puerta de acceso y salida del segundo nivel.

En el patio se ubica un teatro al aire libre, cuya fachada mira al sur. Se trata de un magnánimo frente escénico compuesto por tres niveles y cinco calles. Lo que es en sí el 
escenario se forma de una plataforma curva con dos escalinatas laterales. El frente lleva cuatro pilares cuadrados que alcanzan los tres niveles, con líneas horizontales simulando bloques; culminan los pilares con decoraciones que mencionaremos más adelante.

A los extremos del frente, unas torres adheridas expresan toda la robustez y geometricidad del Déco. Son cúbicas y a manera de contrafuertes se adhieren cuatro molduraciones angulares superpuestas, de menor a mayor, cuyo remate se eleva con ligero escalonamiento, que hace juego con la también elevación escalonada del cubo. En la parte baja tiene vanos de acceso, en cuya trabe simulan una clave principal. El resultado de estas torres evoca las influencias mesoamericanas, tal vez de los tableros escapularios de Monte Albán, o bien, de un zigurat mesopotámico. No queremos decir que el(los) autor(es) hayan escogido directamente elementos decorativos zapotecos o mesopotámicos, sino que en los tiempos del Déco tanto extranjero como nacional, mucho se hicieron libres adaptaciones de esa índole, como ya lo explicamos en los capítulos 1 y 2 . La torre también tiene acceso en el segundo nivel, cuyo exterior como interior extiende la decoración de estrías horizontales, lo que acentúa la imagen de geometricidad.

El primer nivel del frente escénico funciona como un nártex, el segundo es una balconada con forja como la ya descrita y el tercero son las ventanas del Salón de Actos.

En el remate de los pilares, dentro de recuadros, unas decoraciones palmeadas consiguen imprimir la idea de movimiento; y en el coronamiento de los mismos pilares, unos pequeños rectángulos redondeados completan el tratamiento del ornato.

Debajo de cada ventana, el adorno es una serie de bandas verticales superpuestas, con terminaciones curvadas y enmarcadas por un recuadro. Dichas bandas se enlazan por unas "ves", que ofrecen un sentido rítmico. Cada uno de los enmarcamientos asemejan una alfombra, cuyo esquema establece una fuerte relación con los diseños hoffmannianos de la Secesión de Viena.

El exterior de la parte superior del Salón de Actos está ornado con una banda de motivos que asemejan a unas motas colgantes, las cuales consisten en unas flechas que apuntan hacia figuras de triángulos, trapecios y abstracciones de flor de lis

El teatro por sí solo es un ejemplo de Art Déco del periodo Zigzag, pues la exaltación de lo geométrico está en íntima relación con los motivos decorativos, que es, precisamente, una propuesta del Déco. 


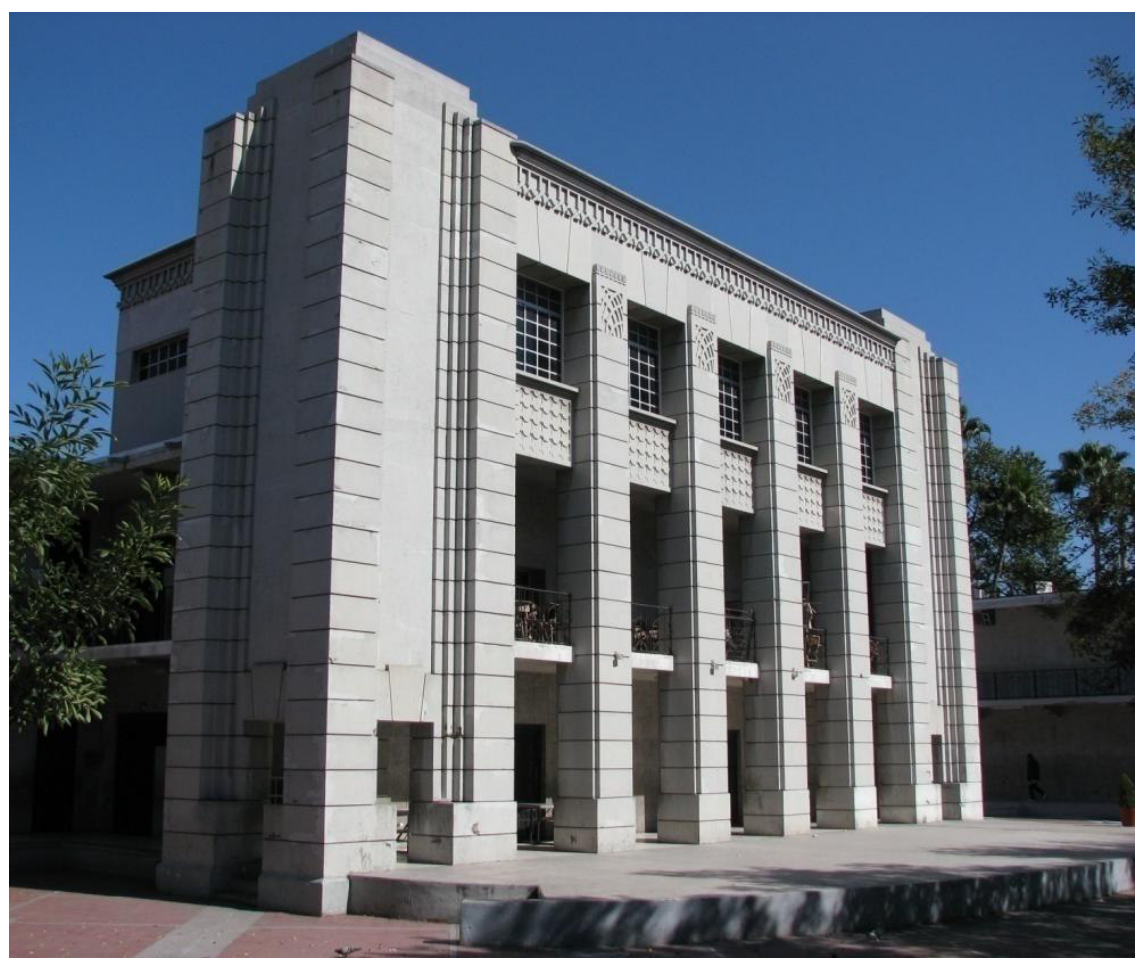

Teatro.

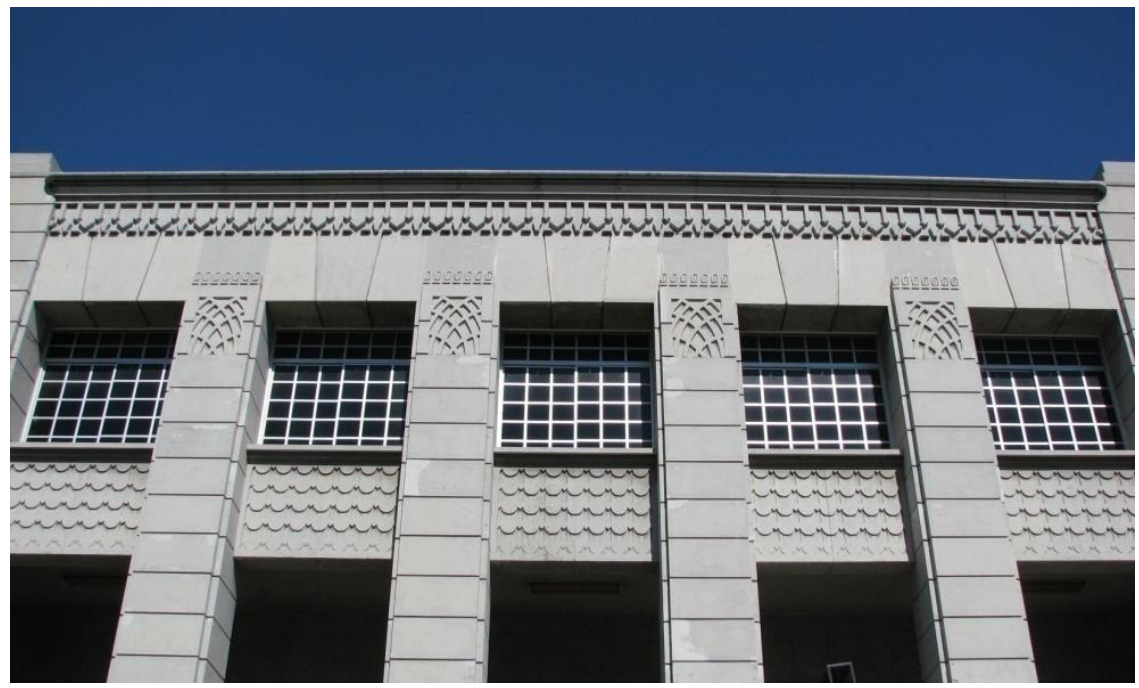

Decoraciones de la parte baja de las ventanas, del remate de los pilares y de la banda superior del teatro.

La Escuela Presidente Calles es uno de los ejemplos más completos del Art Déco en el Noreste de México e inclusive a nivel nacional. Como un todo, no comparte una sola 
de las tendencias o de los tipos de Art Déco. Por una parte, es Neoclásico Moderno, por otra, Zigzag, además expresa elementos de las Tendencias Geometrista y Decorativista.

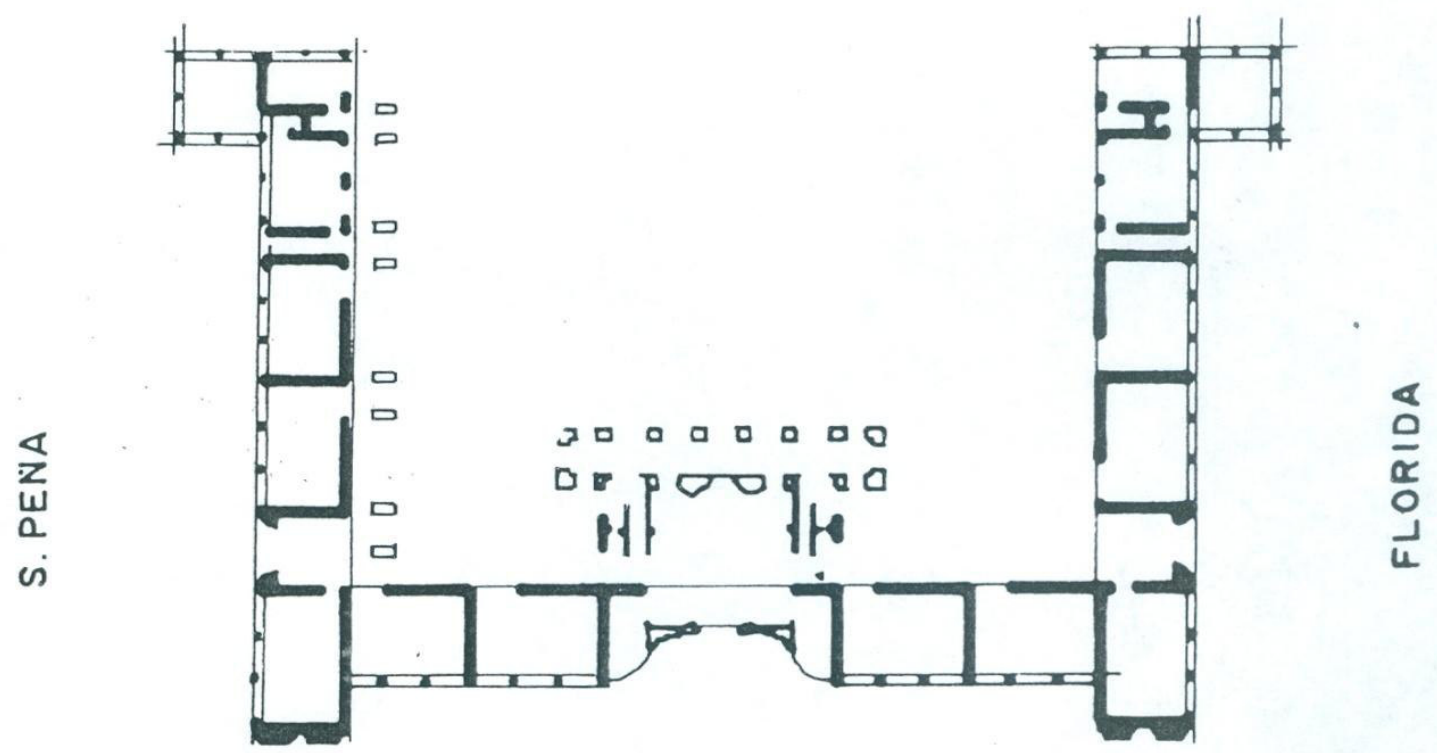

\section{MADERO}

\section{Plano de la Escuela Presidente Calles.}

INAH; SEP. Catálogo Nacional de Monumentos Históricos Inmuebles. Nuevo León. Tomo 4, México, SEP, INAH, Programa Cultural de las Fronteras, Gobierno del Estado de Nuevo León, 1984, p. 1803.

(En este plano aparecen las calles de los cuerpos laterales como Serafín Peña y Florida, cuando en sí son Porfirio Díaz e Ignacio Vallarta). 


\subsubsection{ARQUITECTURA GUBERNAMENTAL}

\section{a. Palacio Federal}

Este espléndido inmueble se ubica en Washington 600 Oriente, dentro de la Plaza de la República. La fachada principal está situada hacia el sur que da a la Plaza de la República, otra hacia el norte en la calle Washington, una al oriente en la calle Zuazua y otra al poniente que mira a la calle Zaragoza.

La edificación se llevó a cabo por la empresa constructora FYUSA. Se inició en tiempos del gobernador Aarón Sáenz un 28 de agosto de $1928^{76}$ y estuvo concluido para finales de 1929 tal como lo demuestra una publicidad de la época: "PALACIO FEDERAL EN MONTERREY. Proyectado y contratado a precio fijo y en construcción por FOMENTO Y URBANIZACIÓN, S.A. Este soberbio edificio, construido a iniciativa del actual gobernador de Nuevo León, licenciado don Aarón Sáenz, y contratado con la Secretaría de Comunicaciones durante la Presidencia del señor general Plutarco Elías Calles, siendo Ministro de Hacienda el señor don Luis Montes de Oca, será terminado durante el presente mes". ${ }^{77}$ También se comprueba que FYUSA fue la compañía encargada de las obras del Palacio Federal por una serie de cartas con membrete de la constructora que se encuentran en al Archivo General del Estado. ${ }^{78}$

Sobre el Palacio Federal José P. Saldaña señala que: "Percatándose el Lic. Sáenz de la falta de un edificio apropiado para los servicios de correo y telégrafo, así como de otras instalaciones federales, proyectó y construyó el Palacio Federal. Para dicho proyecto escogió el terreno que el general Gral. Antonio I. Villarreal, en su calidad de gobernador, había destinado para la construcción de una plaza que llevaría el nombre de La República". ${ }^{79}$ Por su parte, Israel Cavazos Garza, al relatar la década de los veinte

\footnotetext{
${ }^{76}$ INAH; SEP, Catálogo Nacional Monumentos Históricos Inmuebles. Nuevo León, tomo 4, México, SEP, INAH, Programa Cultural de las Fronteras, Gobierno del Estado de Nuevo León, 1984, p. 1910.

77 Jueves de Excélsior, "Edición Especial Pro Monterrey”, noviembre de 1929, sin página.

78 AGENL, Sección: Monumentos y Edificios, Asunto: Construcción del Palacio Federal. Esta caja contiene más de cien hojas con cartas cuyo contenido concierne a la edificación del Palacio Federal.

${ }^{79}$ José P. Saldaña, Op., Cit., p. 61.
} 
solamente aclara: "Monterrey sufrió metamorfosis notables con la construcción del Palacio Federal". 80

De la autoría del Palacio Federal creemos que fueron los Arquitectos de FYUSA Manuel Muriel y Antonio Lamosa, pues en la ya citada publicidad de noviembre de 1929 de esta empresa, aparecen los nombres de dichas personas. ${ }^{81}$ Sin embargo, en un artículo publicado por Deyanira González en el periódico El Norte, en un pie de fotografía del inmueble pone como autores a Augusto Petri y Manuel Muriel, pero sin citar ninguna fuente. ${ }^{82}$ En su obra Arquitectura de la Revolución Mexicana. Corrientes y estilos de la década de los veintes Enrique X., de Anda pone como autor al Ing. Manuel Marín, citando como fuente a la revista Cemento, No. 33 de enero de 1930. De Anda incluye al inmueble en un cuadro de edificios sin fecha de identificación y, al igual que la Escuela Industrial Álvaro Obregón, no informa sobre el estilo, asienta el estado actual del inmueble como desconocido y sobre el giro del mismo informa que fue para Palacio Municipal, cuando nunca se pensó como tal, ni ha funcionado de esa manera. ${ }^{83}$

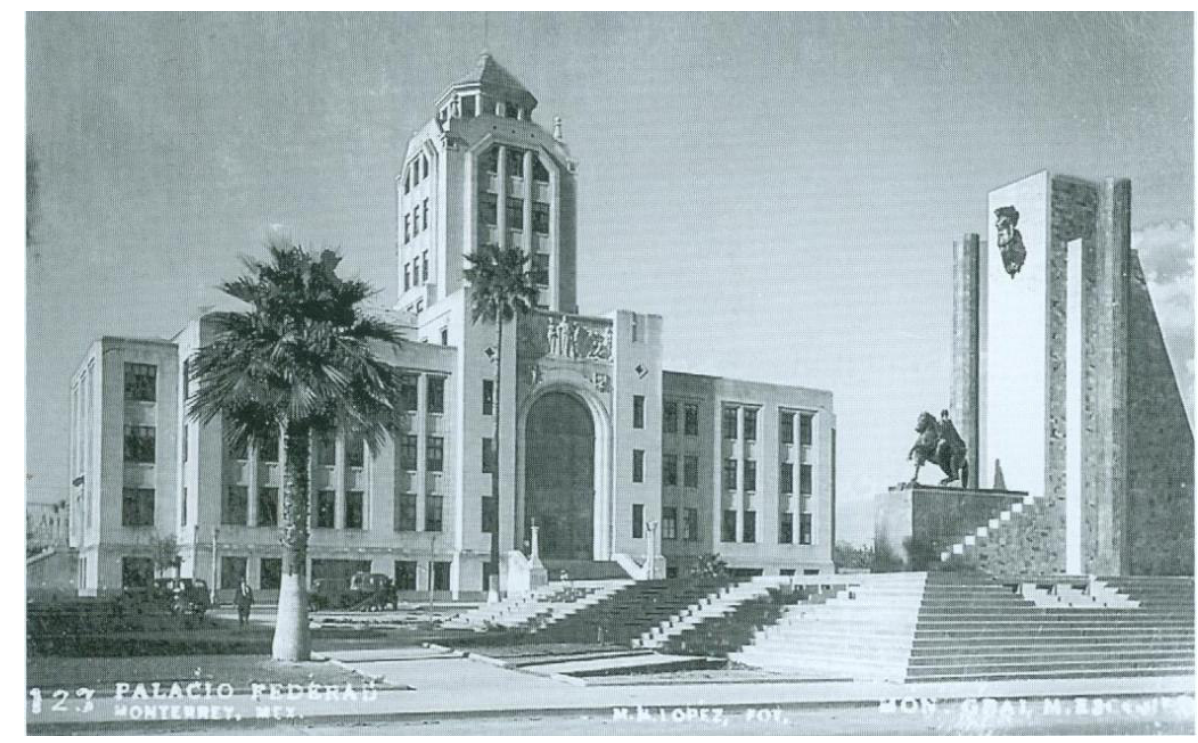

Palacio Federal recién concluido. ${ }^{84}$

\footnotetext{
${ }^{80}$ Israel Cavazos Garza, Breve historia de Nuevo León, El Colegio de México, Fideicomiso Historia de las Américas, Fondo de Cultura Económica, 1994, p. 200.

${ }^{81}$ Ibídem, nota 68.

82 Deyanira González, "Evitan que Monterrey pierda Memoria", El Norte, Monterrey, N.L., domingo 8 de octubre del 2000, secc. Bienes Raíces, p. 1.

${ }^{83}$ Enrique X., de Anda, Op. Cit., Cuadro 16, No. 43.

${ }^{84}$ Héctor Javier Barbosa Alanís, Monterrey. Descubra el ayer de nuestra ciudad. Monterrey, N.L., Agencia Promotora de Publicaciones, 2010, p. 48.
} 
Como fue de suponerse, este sobresaliente palacio sería uno de los protegidos por el INBA, y por el INAH, como uno de los mejores edificios del siglo XX en Monterrey, cuando se hizo el anuncio en el año 2000. ${ }^{85}$ A partir de 2003 el edificio tuvo una importante restauración para volver a ocuparlo con oficinas gubernamentales como el CONARTE, salas de exposición en la planta baja, la Dirección de Turismo y se adecuó una pequeña oficina para el correo.

La planta del Palacio Federal es un rectángulo, con dos pequeños más adosados en el oriente y en el poniente. El inmueble tiene cuatro elevaciones en los cuerpos laterales, cinco en el medio y una torre central con cuatro pisos y un mirador, lo que hace que sean en total nueve los niveles. Los materiales usados en la construcción fueron hierro de la Fundidora en sus estructuras, cemento ${ }^{86}$ y placas de cantera en el exterior.

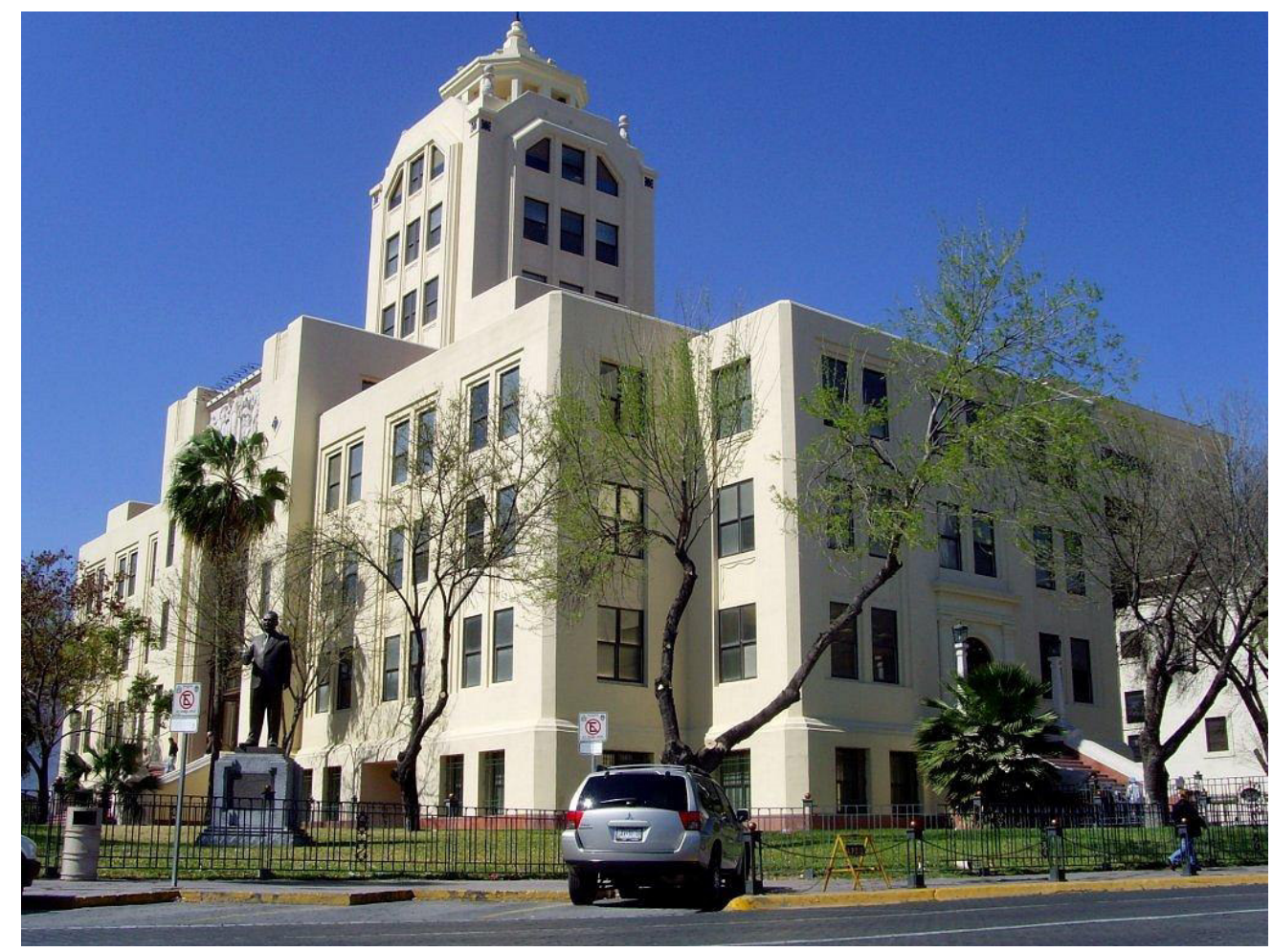

Palacio Federal, fachada sur y oriente.

\footnotetext{
${ }^{85}$ Vicente Guerrero, Ibídem.

${ }^{86}$ S/A., Catálogo de Monumentos del Estado de Nuevo León, Monterrey, N.L., Secretaría de Educación y Cultura, 1984, p. 75; AGENL, Sección: Monumentos y Edificios, Asunto: Construcción del Palacio Federal.
} 
En su estructura, en sí, el Palacio Federal es una armazón de cubos que se van elevando y creciendo muy mínimamente de tamaño hasta que se alza la soberbia torre, es decir, el sentido de geometría, de escalonamiento y de elevación, caracteres primordiales del Déco, están plenamente expuestos, por lo tanto lleva la composición a la manera de la Tendencia Geometrista.

El palacio tiene cuatro entradas en cada punto cardinal En la fachada sur que es la principal y da hacia la Plaza de la República, se desplanta una escalinata de una sola rampa forrada de granito rojo. En el arranque de los antepechos, un mismo tipo de columnas y lámparas, descansan en un grueso pedestal cuadrado. El vano de acceso es un gran arco de medio punto que abarca tres pisos. En las enjutas lleva escudos: el águila nacional del lado izquierdo y el emblema de Monterrey del lado derecho, en el cual el indio ha perdido la cabeza. El arco está resguardado por paredes rectangulares con ventanas rectangulares que abarcan tres pisos. En el remate de estas paredes hay unos mosaicos de talavera colocados en forma de rombo y más arriba unas líneas estriadas envuelven a los muros, característica típica del Art Déco Zigzag. En la parte superior del arco, en un ábaco, un gran relieve homenajea al trabajo. Esta portada forma parte del cubo central del lado sur, que se ensambla con el edificio, resaltando su altura que alcanza los cinco niveles y su disposición hacia el frente.

El arco del vano de acceso está protegido por una estructura de madera con recuadros, cuya puerta de acceso se forma por dos lienzos rectangulares con vidrio. Cada lienzo lleva una forja serpenteante, que aunque no es propiamente Art Déco, sí un interesante motivo decorativo.

Si todo el Palacio Federal es un atractivo edificio Art Déco, lo es aún más por el extraordinario panel que remata la fachada sur. Tratado en bajo, medio y alto relieve, representa a la justicia colocada entre el trabajo industrial y agrícola. Al centro una mujer en posición hierática, porta un tocado en la cabeza; de gesto adusto viste una blusa que se curvea en la cintura con pliegues verticales y una falda larga con tablones enhiestos. Parada en medio de pilastras con bases simuladas a través de dos molduras oblicuas, sostiene un espada con la mano derecha: es el símbolo de la justicia. 


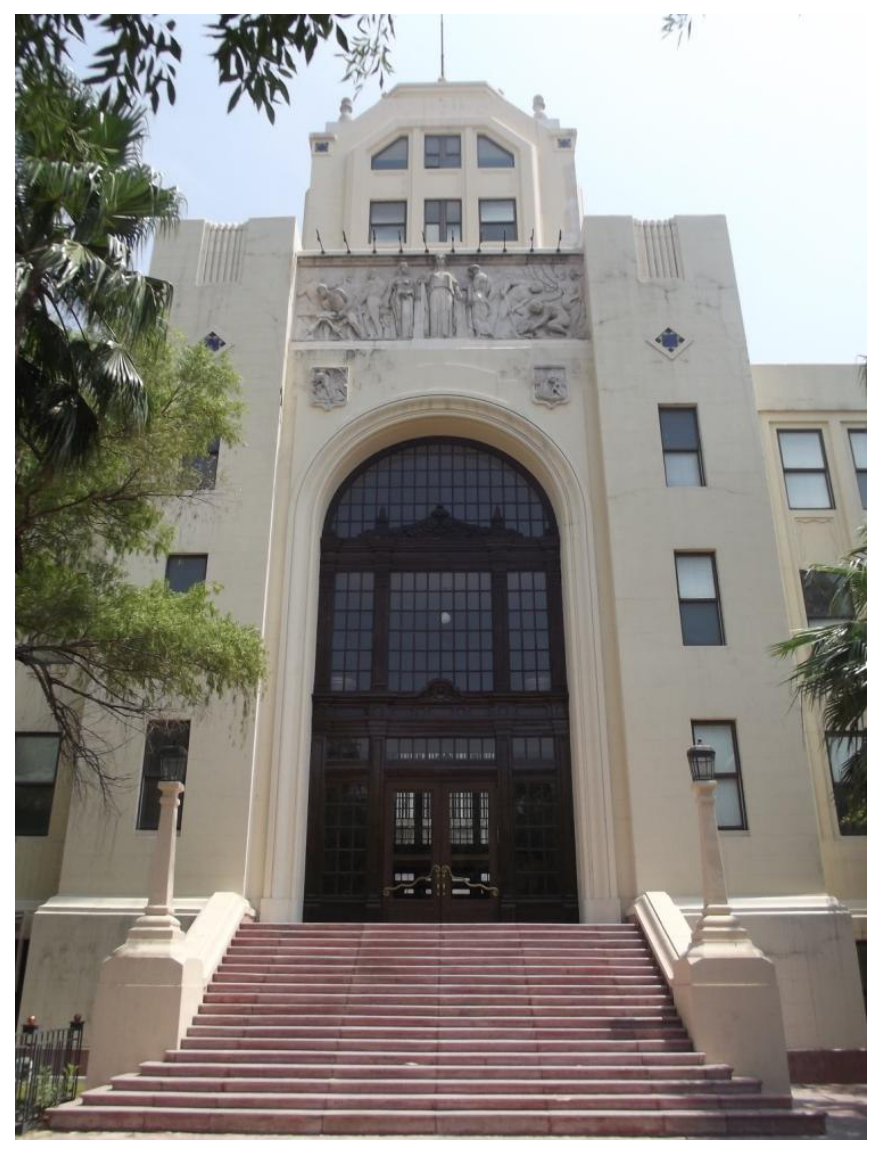

Portada principal o sur.

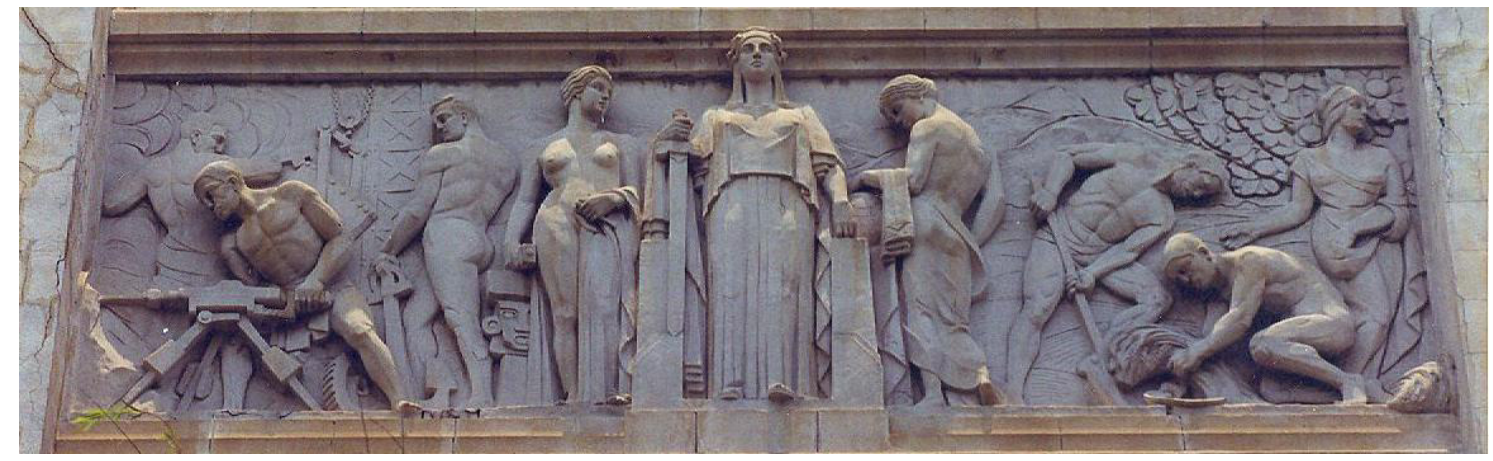

Panel escultórico de la portada sur.

La parte izquierda del panel se inicia con una corpulenta mujer desnuda de corte clásico, parada de frente, la cual arropa una pierna y el vientre con la mano izquierda, mientras que con la derecha sostiene un mazo; mano y martillo descansan sobre una cabeza prehispánica de fuerte influjo teotihuacano y recalcado geometrismo. Tres corpóreas y musculosas figuras humanas desnudas están inmersas en la tarea fabril: la primera, de 
derecha a izquierda, de espaldas y de perfil mueve una palanca, la cual está a un lado de un engrane; la segunda hercúleamente trabaja con una geométrica perforadora; la tercera también de espaldas y de perfil y en un segundo plano se ocupa en la fundición; en bajo relieve y en un tercer plano, una torre y nubes del humo, ultiman la significación del mundo del trabajo industrial.

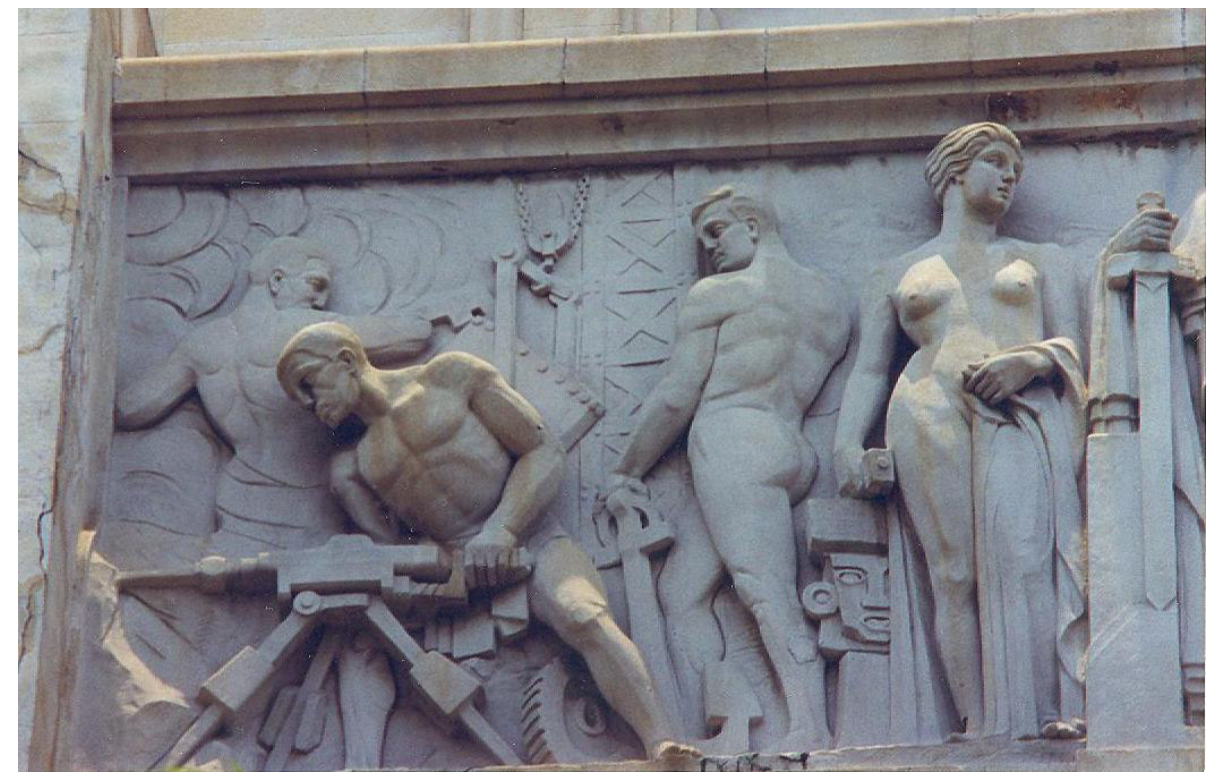

Panel de la fachada sur, detalle del lado izquierdo.

Al lado derecho de la justicia, una robusta mujer de corte clásico, colocada de espalda, la cual lleva descubierta, cubre el resto de su cuerpo con el vestido que va cayendo. El brazo izquierdo descansa sobre una esfera y carga una toalla que cae verticalmente que en el extremo inferior lleva un ornato en forma de "V" abierta. Dos hombres semidesnudos afanan la tierra: uno de pie labora con el azadón y otro agachado recoge las espigas, debajo de las cuales hay una hoz. Una mujer con sombrero encasquetado, muestra un pecho, y con la mano izquierda que lleva hacia su vestido, retrata la participación de la mujer en la siembra de la semilla. Esta dama es una distintiva representación de la moda de su época, pues además del sombrero, el tipo de vestido parisino o neoyorkino, con la caída de los pliegues en zigzag y entallado, era como vestían las mujeres de alcurnia en sus actividades sociales. En el ángulo superior derecho, hojas 
petrificadas de arbustos simulan un segundo plano y detrás del hombre se ve la silueta de cerros en un tercer plano. El trabajo agrícola es lo que encarna esta parte del panel.

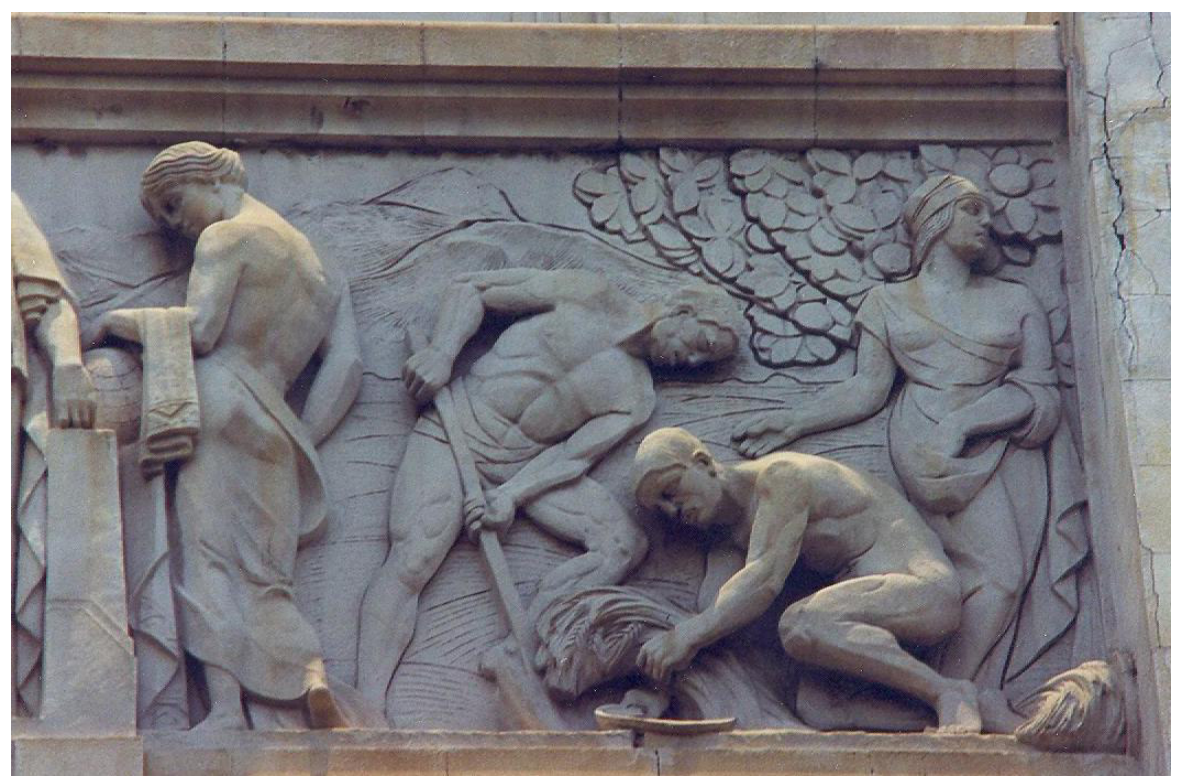

Panel de la fachada sur, detalle del lado derecho.

Por una parte, este fastuoso conjunto escultórico es un claro arquetipo Art Déco, por la corpulencia de las figuras humanas, por sus composiciones geométricas, por la temática misma; cabe recalcar que las caídas de los ropajes de las mujeres forman zigzags, por lo que además de la época en que se realizó el panel y por el tratamiento técnico, lo inscribimos dentro del Art Déco Zigzag. Por otra parte, los triunfos de la Revolución Mexicana, como el trabajo industrial y agrícola, eran los éxitos justos del cambio social emanados de ella y esto es lo que expresa este panel, aunado que son las representaciones del trabajo de Nuevo León en la ruta citrícola y el de la fundición en la ciudad de Monterrey, por lo que además del ser un caso de Déco Zigzag, lo es también un Art Déco que bien podemos bautizar como Nacionalista.

Este panel tiene una cualidad más: que en relación con los edificios de la ciudad de México, donde se levantaron los primeros ejemplos de arquitectura Art Déco en el país, no hay alguno que tenga algo parecido.

En nuestra indagación no encontramos la autoría del grupo escultórico, ni de los escudos. 
La fachada norte mira hacia la calle Washington. Un arco ochavado, como los utilizados en la Secesión de Viena, era el acceso a un estacionamiento; a cada lado, unas escaleras forradas de granito rojo, material manejado en el Art Déco, están protegidas por gruesos antepechos con pasamanos elevados por taludes. Un rodapié en granito del mismo color que el de las escaleras, recorre las bases del arco y de los antepechos. En el cruce de los antepechos con el arco, sobre un plinto cuadrado, se elevan unas pilastras estípites, con base y capitel, las cuales sostienen unas lámparas cúbicas, que sin ser del tipo peculiar Art Déco de estar empotradas en la pared, comparten la función de iluminar la entrada así como la geometricidad de los tiempos del Déco; por lo tanto, entran en la Tendencia Decorativista, Elementos Exteriores. Las rampas de las escaleras continúan en posición perpendicular y su resguardo es un barandal de rectángulos tubulares.

El vano de acceso es un alto arco de medio punto moldurado en el extradós que abarca tres niveles; está protegido por una estructura de madera, la cual en la parte baja forma la puerta de entrada. A los lados, lienzos superpuestos con ventanas rectangulares van adornados en la parte superior con un rombo, cuyo interior está adornado con azulejos de talavera en azul y amarillo con trazos geométricos, lo cual le da un sello de mexicanidad. En el remate, unas estrías verticales a manera de baquetones se curvan para integrarse hacia adentro, o bien, de dentro nacen para crear la sensación de una cascada de agua congelada, lo cual es uno de las peculiaridades decorativas del Art Déco. Ventanas, rombo y líneas verticales le imprimen a la fachada la impresión de altura.

Por encima del arco resalta una decoración escalonada y en las enjutas unos escudos en relieve: el de la izquierda es el de Monterrey, cuyos atributos son el indio con arco y flecha tirándole al sol, dos naranjales y el cerro de La Silla; el de la derecha, es el emblema nacional del águila y la serpiente. Además de la buena calidad escultórica de los escudos, éstos reflejan el ideal postrevolucionario del Nacionalismo Mexicano, muy en boga en esos años.

En el remate del cuerpo central, dentro de un espacio rectangular rehundido, hay una galería de cuatro ventanas con arcos de medio punto, lo cual concierta y equilibra la composición con el arco del vano de acceso. 


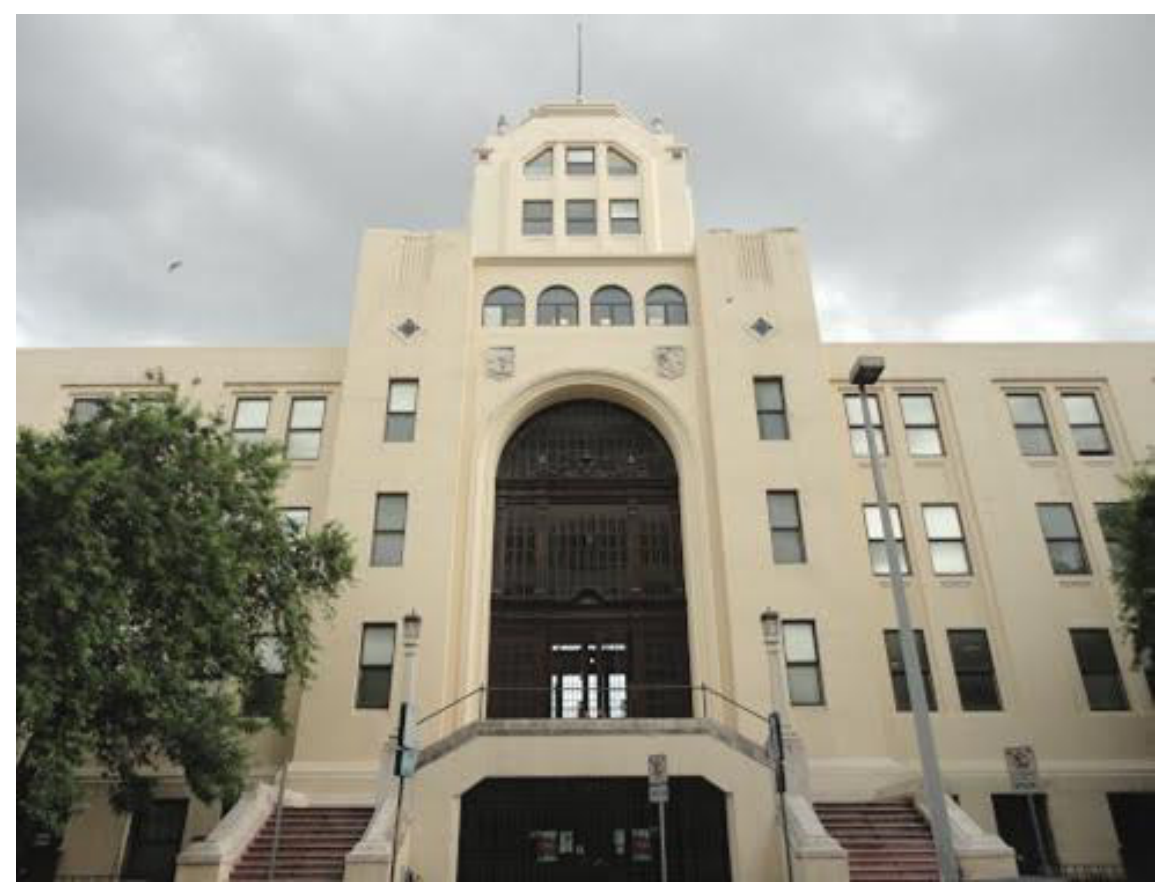

Fachada norte.

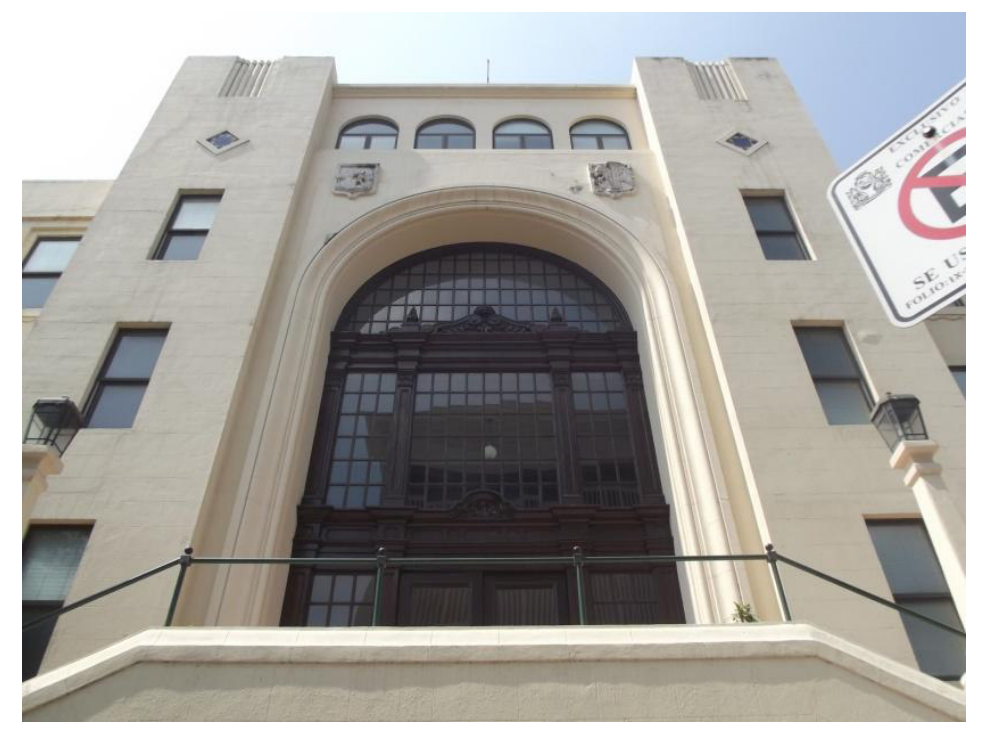

Detalle de la fachada norte.

Como una muestra del nacionalismo indigenista del Palacio Federal, en las fachadas oriente y poniente, en el inicio del pasamanos de los antepechos de la escalera, la cual está revestida con granito rojo, se ubican unas esculturas de Quetzalcóatl, cuyos diseños bien pudieron tomarse del mismo Templo de Quetzalcóatl de Teotihuacán, Estado de México, o del Castillo de Chichén-Itzá, Yucatán, en su versión maya de Kukulkán. Por 
la composición, asemeja a las alfardas del Templo de Teotihuacán, que terminan con la cabeza de la Serpiente Emplumada, pero también tiene semejanza con el Castillo maya, aunque para Xavier Moyssén Echeverría al referirse al inmueble y dar como fecha de construcción 1930, dice que "las alfardas de las escaleras terminan en cabezas de serpientes mexicas", ${ }^{87}$ lo cual después del descubrimiento y exposición los restos del Templo Mayor en la ciudad de México, también aparecen las alfardas con la cabeza de Quetzalcóatl; en sendos casos, se parodia en el Palacio Federal a la escalera de algunas de las citadas plataformas piramidales, protegida por alfardas y con la cabeza del Gemelo Divino, que con el pasamanos completa su cuerpo de sierpe.

Como ya hemos anotado en los capítulos anteriores, por su geometrismo lo mesoamericano cayó muy bien dentro de las propuestas del Art Déco; así pues, estas cabezas de Quetzalcóatl, soportadas por un pedestal cuadrado forrado de granito rojo y biselado por el frente, están tratadas geométricamente, por lo que estas efigies son de un Art Déco al que podríamos llamar Nacionalista Prehispanista, pues comparten los diseños de cualquiera de las culturas que rindieron culto a Quetzalcóatl, o bien, si las tomamos como un influjo maya estarían dentro de la Tendencia Ecléctico-Mayista planteada por Enrique de Anda. Las portadas de las fachadas oriente y poniente se componen por un arco de medio punto moldurado, enjutas remarcadas por perfiles, pilastras tablereadas y entablamento con el friso sin decoración. Por estas propiedades, dichas portadas entran en la clasificación del Art Déco Neoclásico Moderno.

En los muros se disponen las ventanas en grupos de seis, dos por cada nivel; enmarcadas por un gran rectángulo, las ventanas en sí están en un plano hacia atrás en relación con la superficie, pues se conectan con el muro por perfiles angulosos, consiguiéndose así la trasposición de planos, lo que fue muy utilizado en la etapa del Art Déco Zigzag. En la base de las ventanas del segundo y tercer nivel, unos rectángulos moldurados guardan unas ondulaciones, que contrastan con la linealidad de los perfiles, dando por resultado decorativo la proyección de planos superpuestos. Aparte de ser un caso de Déco Zigzag, estos muros entran en la Tendencia Geometrista.

\footnotetext{
87 Xavier Moyssén Echeverría, "El Nacionalismo y la Arquitectura”, Anales del Instituto de Investigaciones Estéticas de la UNAM, México, UNAM, Vol, 14, No. 55, 1986, p.129.
} 


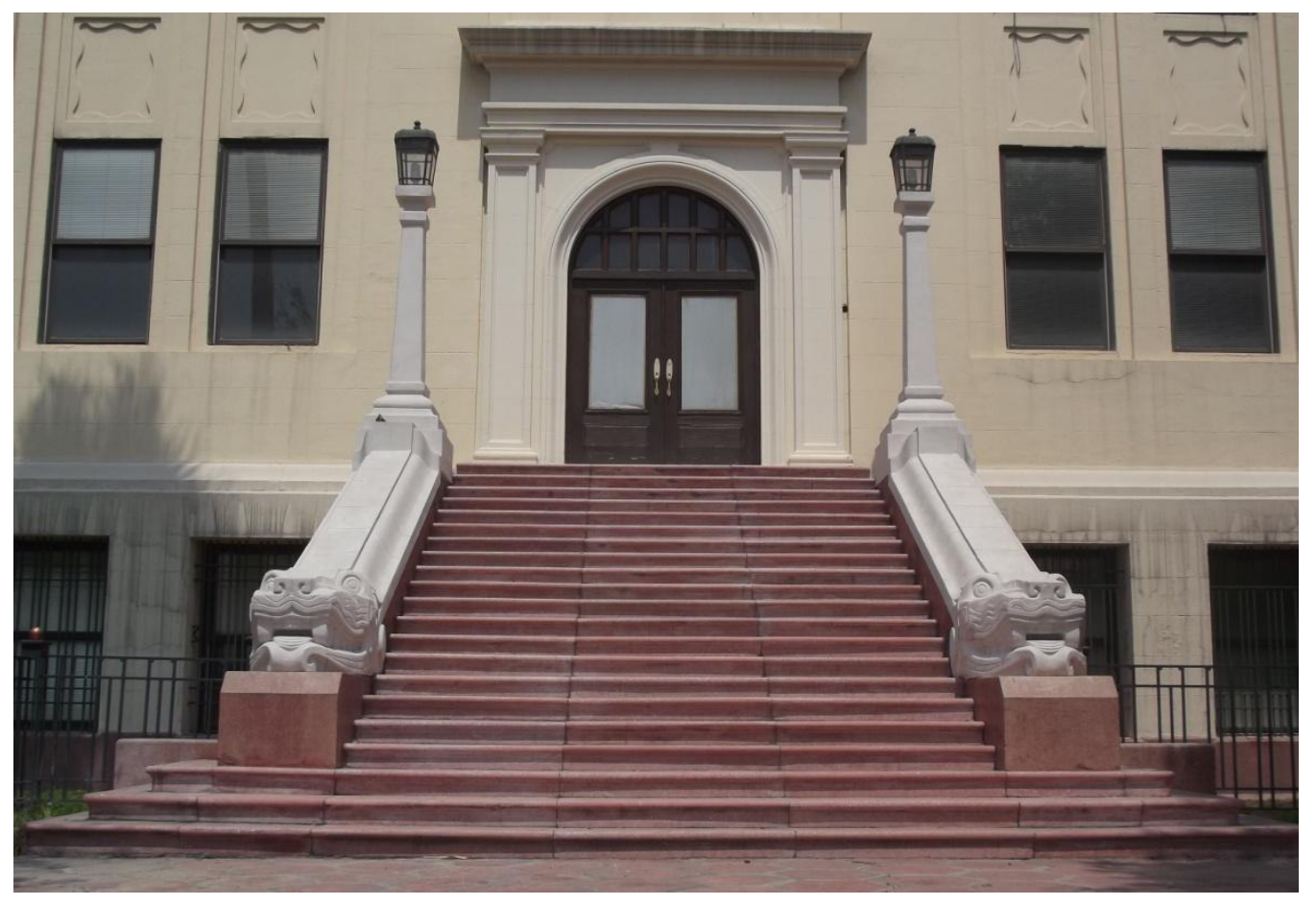

Portada oriente con las alfardas y cabezas de Quetzalcóatl.

La torre de cuatro niveles más el mirador se elevan al centro del edificio. Sus cuatro caras ochavadas resaltan la proyección ascensional. Las ventanas se enmarcan por una gruesa moldura de perfiles angulosos que sigue el trazo ochavado. De la misma manera que en los lienzos de las fachadas norte y sur, debajo de las ventanas del tercer y cuarto nivel, ahora en recuadros, los marcos envuelven decoraciones serpenteantes. En la parte superior de los ángulos de unión de los lienzos se repite el motivo decorativo de talavera, iguales a los de la fachadas oriente y poniente, nada más que ahora son cuadrados, con lo que se le quiso vincular al Palacio Federal con el Nacionalismo Mexicano.

El mirador de la torre remite al Pabellón Studium-Louvre, de Albert Laprade (18831978), de la exposición parisina del 25, pues lleva la misma concepción de una planta ochavada, pilastras cuadradas y techumbre a manera de pagoda. En la arista de la techumbre descansa la astabandera.

En las cuatro esquinas de la torre están colocadas sobre un pedestal cuadrado, unas acróteras que simulan un balaustre. 


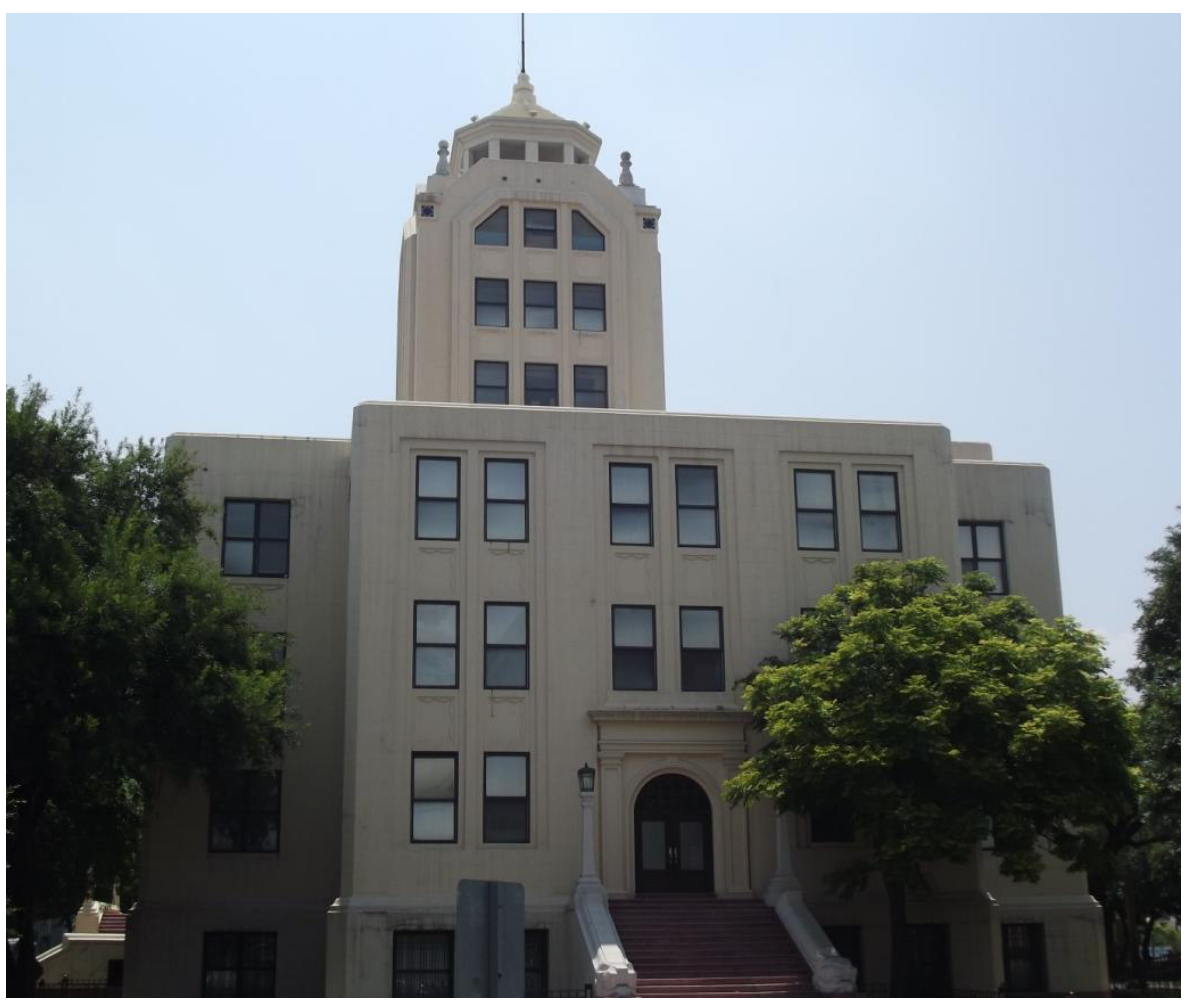

Vista de la torre desde la fachada poniente.

El interior del Palacio Federal tiene planta rectangular con tres niveles y está cubierta por bóvedas de lunetos que junto con los amplios ventanales le dan un mayor sentido de la espacialidad. A la mitad del lado oriente se ubicada la escalinata, la cual está cubierta de granito rojo. Al inicio de la escalera una lámpara de bombilla esférica descansa sobre un zócalo ochavado y una pequeña base de la misma forma también forrado de granito rojo; el alargado fuste se compone de cuatro largos roleos unidos por medio de tres anillos y cuatro roleos más están sobrepuestos en la parte baja.

El diseño de este fuste presenta las formas sinuosas del Art Nouveau, pero estilizadas hacia las geometricidad del Art Déco. La presencia del granito rojo en las losetas de la escalera y en el zócalo denota la modernidad del material lujoso de los años del Art Déco.

En el primer descanso de la escalinata una placa con el escudo nacional señala los años de inicio y conclusión del palacio. 


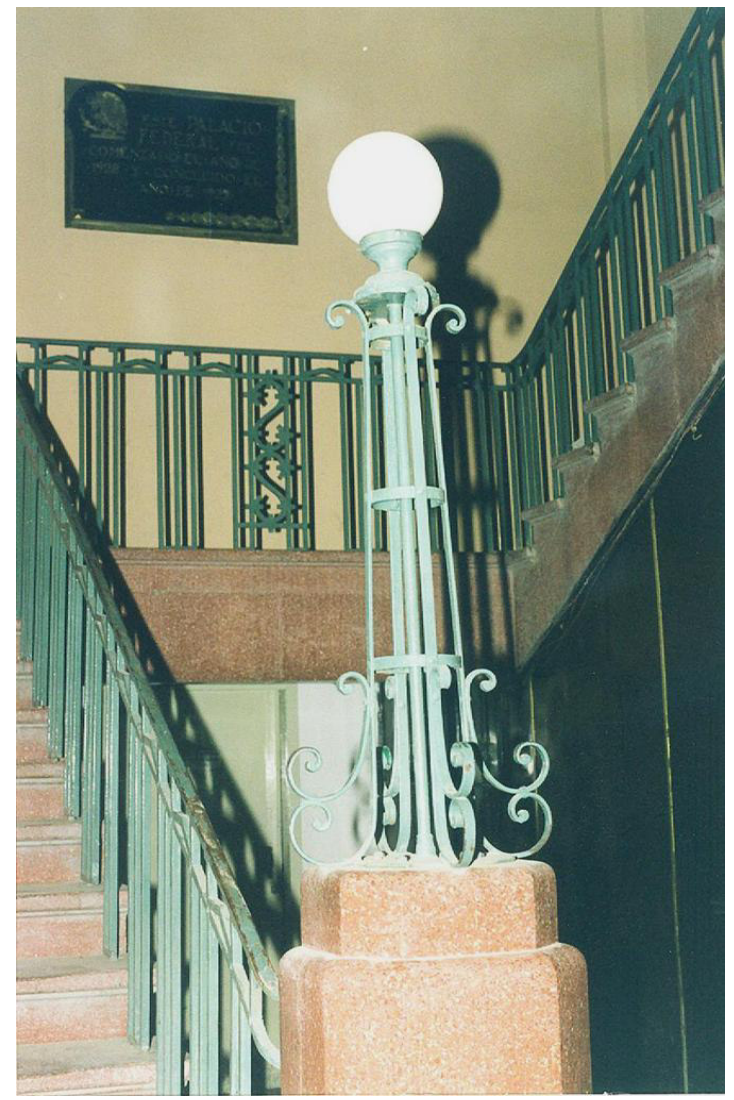

Lámpara en el inicio de la escalera.

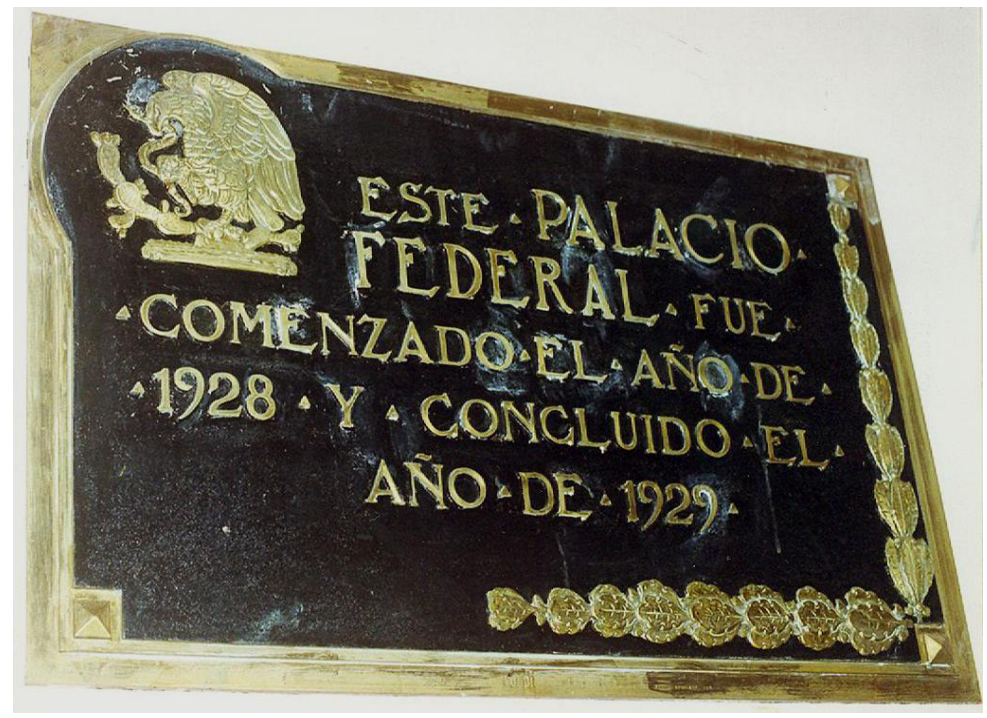

Placa en el primer descanso de la escalera con las fechas de construcción del edificio. 
Unas tectónicas columnas ochavadas se elevan abarcando los dos primeros niveles cargan las trabes del corredor del último piso. La base cubierta por mosaicos rojos verticales, el fuste ochavado que lleva un anillo de granito rojo un poco antes del capitel, en el cual equino y ábaco también están revestidos por granito del mismo color, completan la columna. La geometricidad del fuste y el granito rojo invisten a estas columnas como patrones de la arquitectura Déco. En el segundo y tercer nivel las oficinas se interconectan por unos puentes colocados en el lado norte, los cuales están forrados de granito rojo.

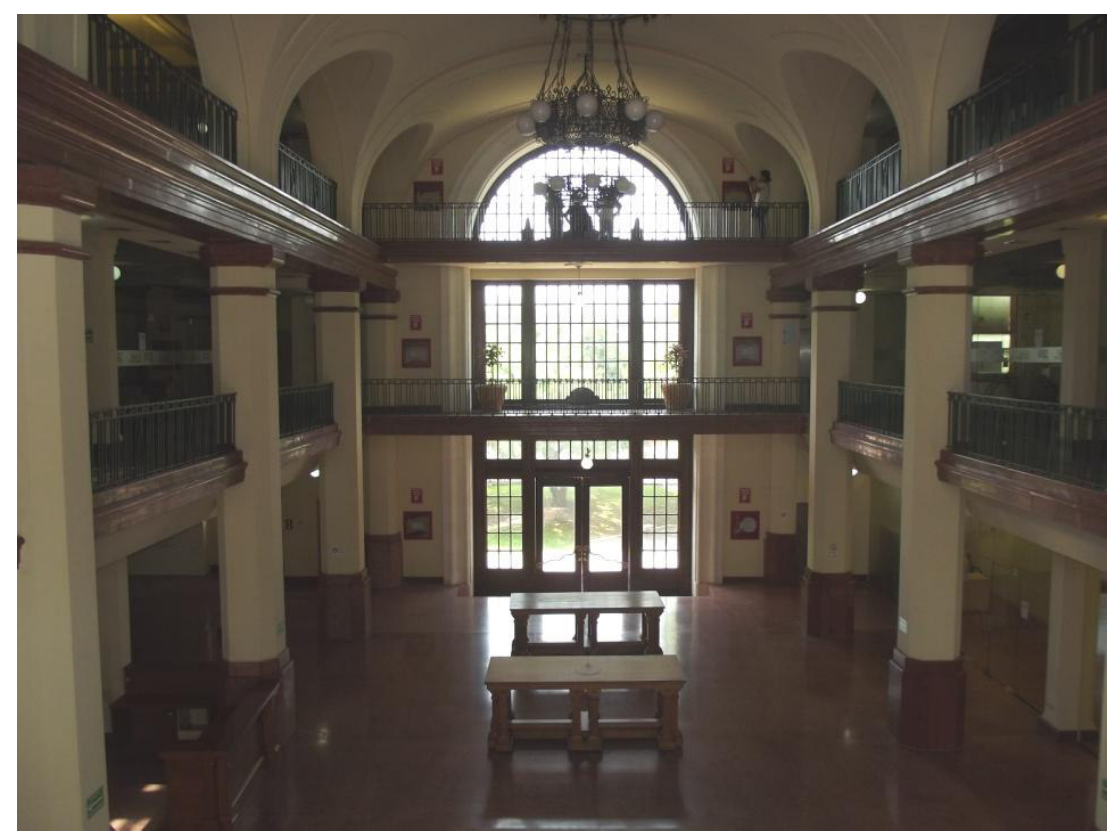

Interior del edificio con las columnas que abarcan los dos primeros pisos y en el fondo los corredores que conectan las oficinas.

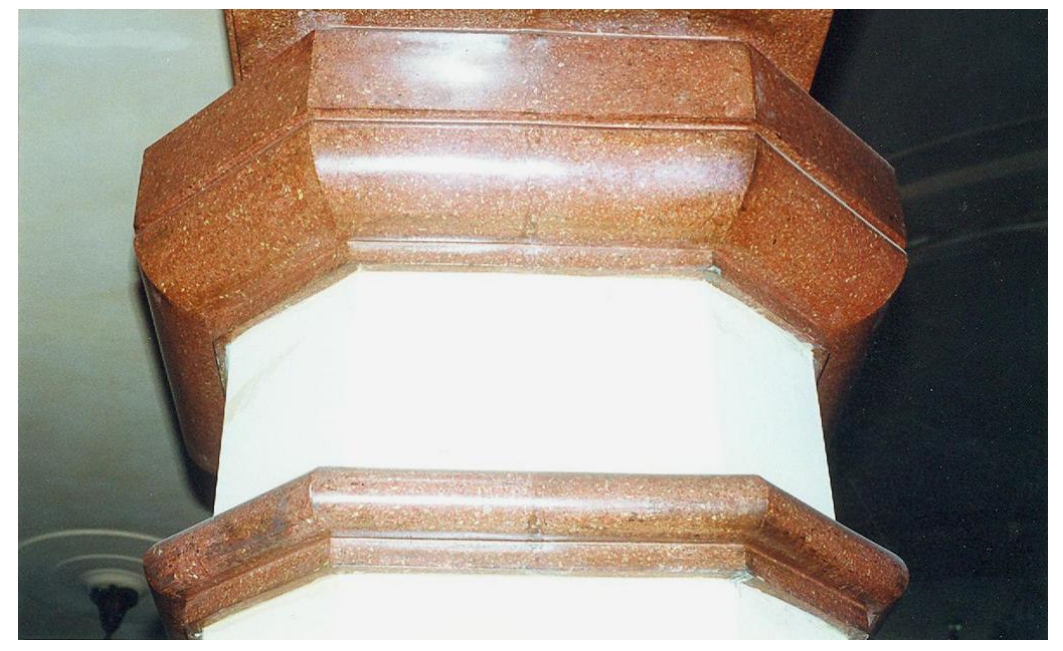

Detalle del capitel de una columna. 
Tanto en el segundo como en el tercer nivel, las columnas que sostienen los muros y techumbre también son ochavadas. Tiene un capitel a manera de pirámide invertida truncada, al cual se adhieren unas gotas de caída curva y doble moldura. La geometría sumada a la decoración de las gotas completa un cuadro significativo del Art Déco tipo Zigzag.

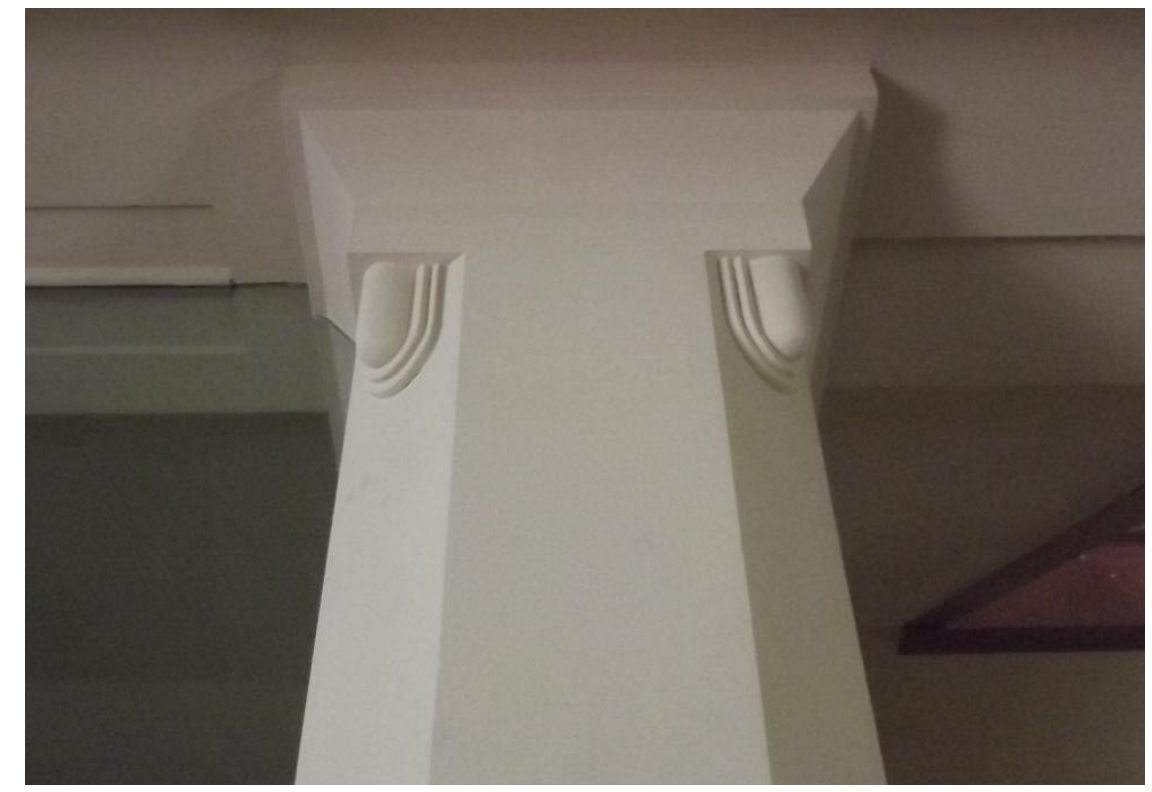

Detalle del tipo de columna de segundo y tercer nivel.

El barandal de la escalera, de los corredores de los pisos, así como de los puentes, están trabajados con herrajes, cuyo diseño es de la siguiente manera: tres líneas verticales, espacio con remate a manera de frontón, tres líneas y así sucesivamente. Al centro unas eses enmarcadas dentro de líneas verticales interrumpen el ritmo, el cual continúa nuevamente. Todo el barandal pareciera un friso clásico de triglifos y metopas, por lo que aunado a la linealidad esta forja es una buena muestra decorativa del Déco Neoclásico Moderno.

Todavía en algunas partes de los techos del segundo y tercer nivel se conservan las decoraciones de las instalaciones para las lámparas colgantes. Consisten en un anillo más dos círculos yuxtapuestos, que así como en los muros exteriores enaltecen una de las semánticas del Art Déco que es la superposición de planos. 


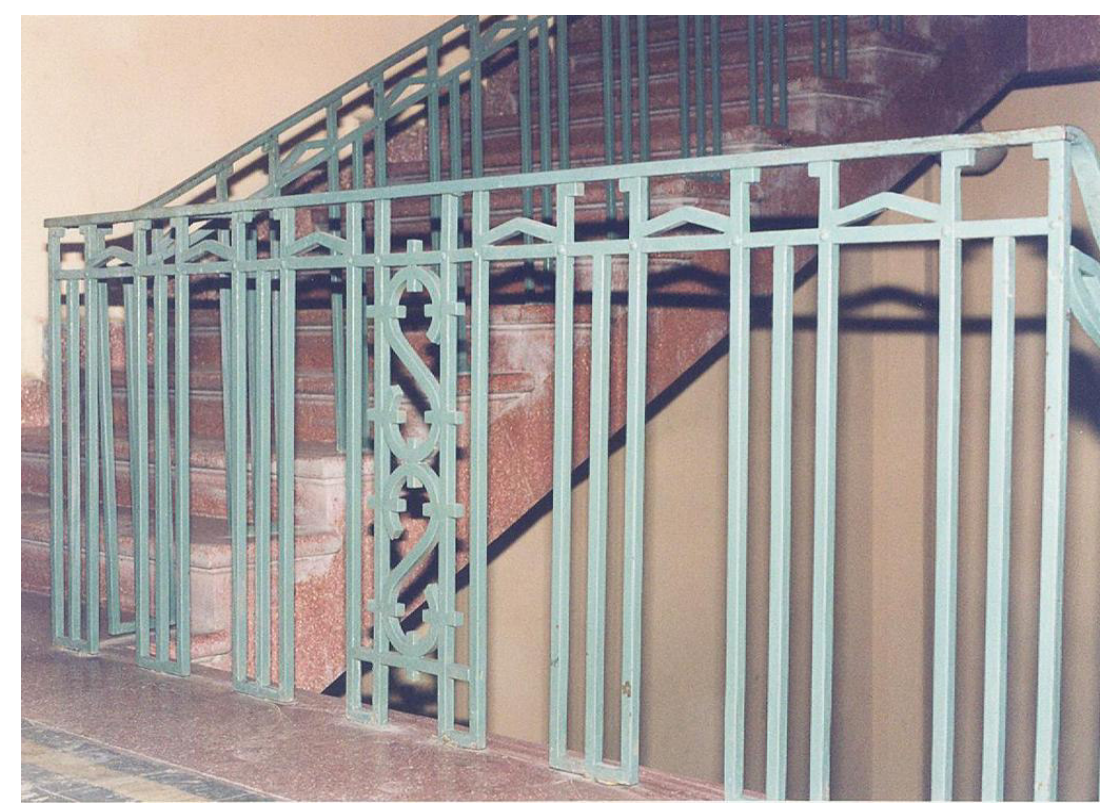

Detalle de la forja de los barandales.

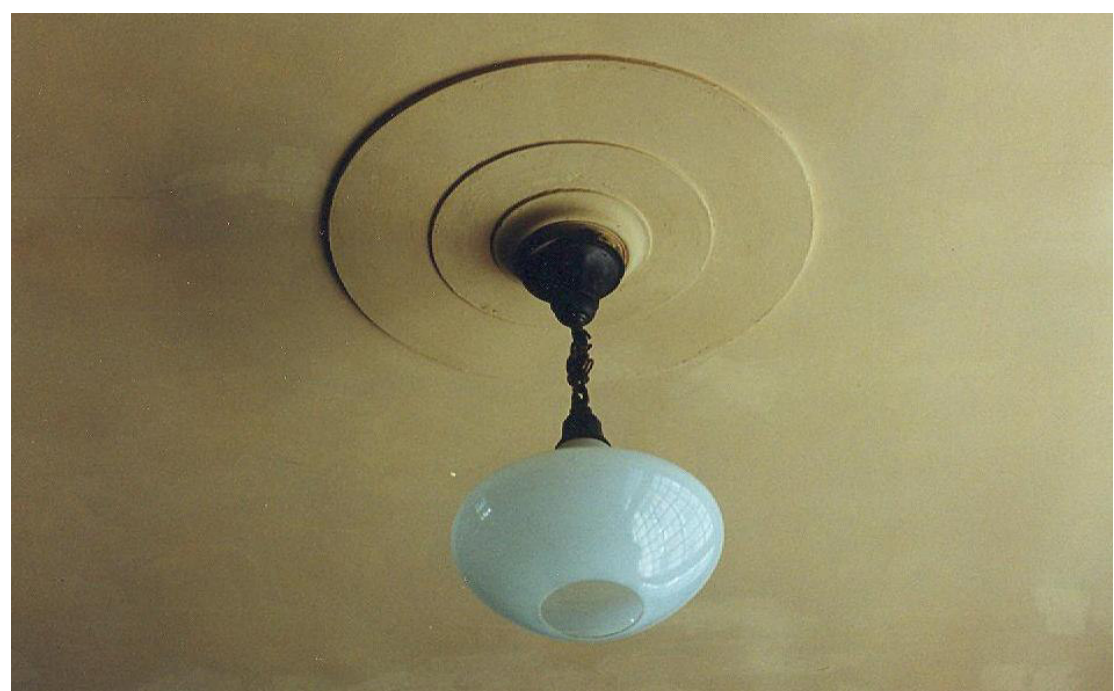

Decoración de las instalaciones de las lámparas que se conservan en el segundo y tercer piso.

La techumbre del espacio interior se cubre con una bóveda de medio cañón de nueve tramos con lunetos que asemeja a una cubierta neoclásica, la cual descansa sobre trabes cubiertas de granito rojo es un claro ejemplo del Déco Neoclásico Moderno. En cada 
tramo cuelgan candiles confeccionados en metal, con un cierto influjo de motivos arabescos, que sin ser lenguaje del Art Déco destacan por su buena calidad.

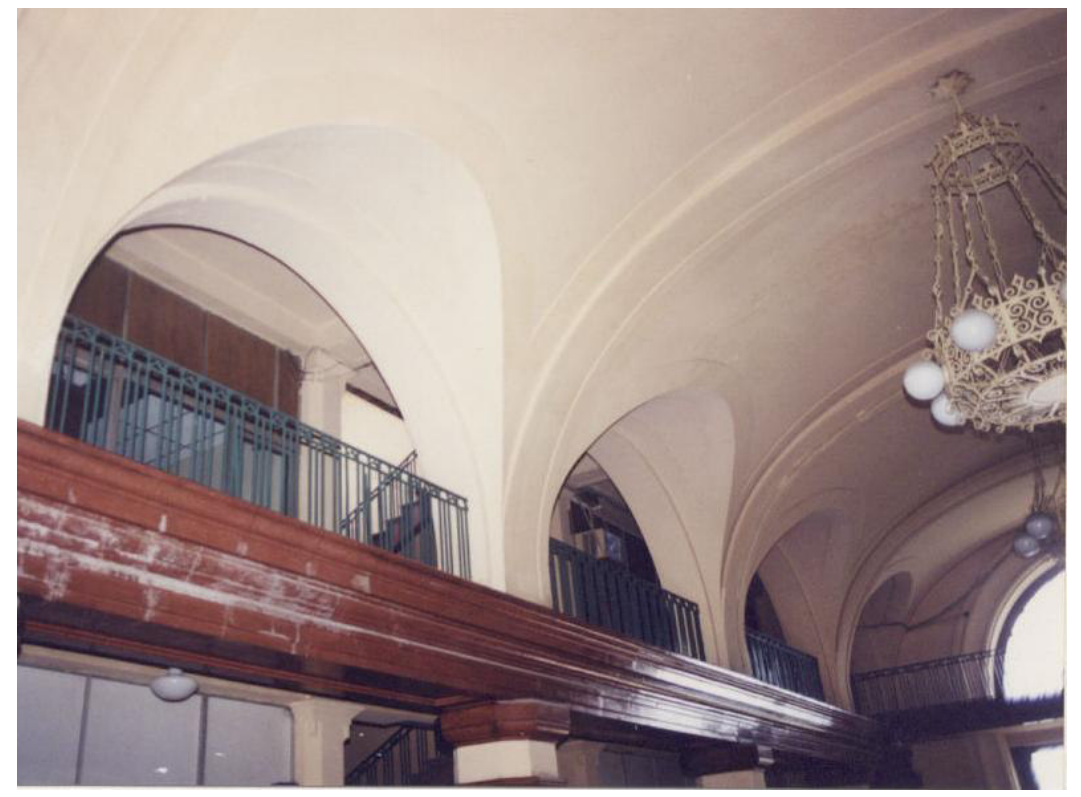

Detalle de la bóveda y los lunetos.

Dentro de una de las prerrogativas del Art Déco estaba el buscar la decoración para cualquier tipo de objeto o mobiliario de un inmueble. La modernidad tecnológica industrial era otros de los principios que se aplicaba a la vida cotidiana. Así pues, el moderno Palacio Federal y sus nueves niveles, lo cual lo convertía en esos años en el edificio más alto de la ciudad, necesitaba de un elevador para facilitar el ascenso. Todavía se conservaba hasta antes del año 2003 anclado en el segundo piso; cuando se hizo la restauración del edificio, se le integraron dos nuevos elevadores. En la puerta llevaba una ornamentación que consistía en molduras que formaban un par de rectángulos y en la parte superior desplegaba una hilera de grecas geométricas entrelazadas de tipo Art Déco Zigzag.

Al respecto de la importancia y de la ornamentación de tipo Déco del Palacio Federal, Juan Manuel Casas manifiesta: "El Palacio Federal es pieza clave en el desarrollo arquitectónico de la ciudad por muchas razones, de entre las que destacan dos capitales: fue el primer edificio de más de cuatro pisos en Monterrey y por veinte años el más alto cediendo después ese lugar al Edificio Chapa-; con su construcción se instala 
simbólicamente el estilo Art Déco en la ciudad, hecho con el que la arquitectura regiomontana se pone en camino de la modernidad". 88

Y de la decoración Oscar Eduardo Martínez enuncia: "El Palacio Federal muestra una propuesta de ornamentación muy liberal de la corriente art déco utilizando una gran variedad de elementos, desde serpientes prehispánicas hasta vitrales emplomados, aunque no todos resueltos exitosamente". ${ }^{89}$ No sabemos a qué se refiere el arquitecto Martínez con los vitrales emplomados, pues el Palacio Federal carece de ellos.

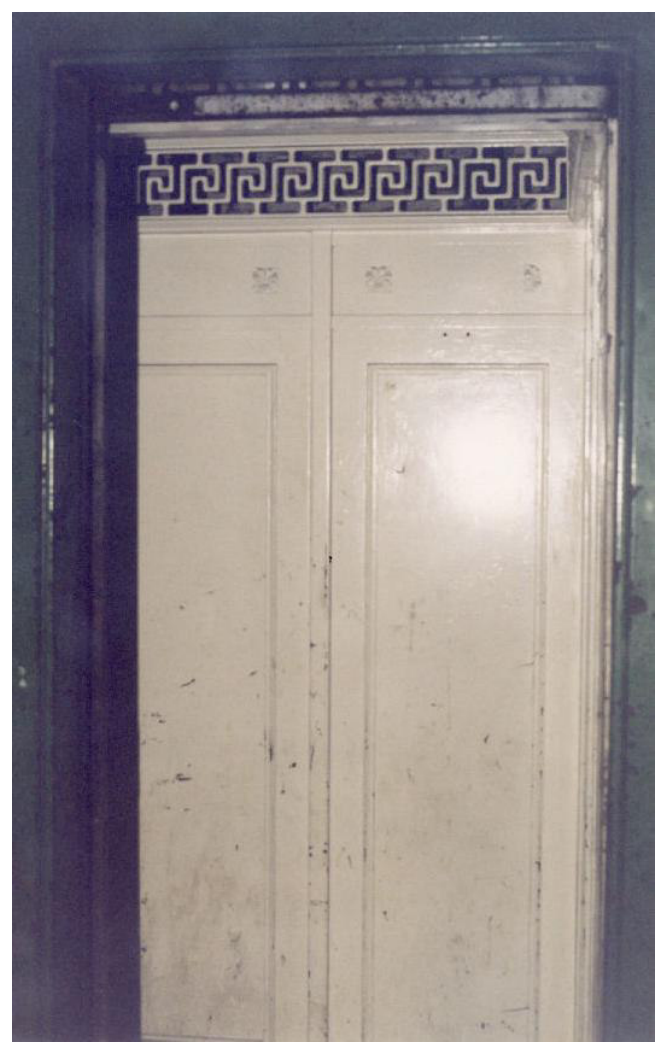

Puerta del elevador que se conservaba en el segundo piso.

\footnotetext{
${ }^{88}$ Juan Manuel Casas García, Documento de recomendaciones para una ciudad en su $401^{\circ}$ aniversario, Monterrey, N.L., Tesis de Licenciatura en Arquitectura, Universidad Autónoma de Nuevo León, 1997, p. 128.

${ }^{89}$ Oscar Eduardo Martínez, "Monterrey, ciudad vieja, ciudad nueva. Su arquitectura y urbanismo". La Enciclopedia de Monterrey. Tomo II. La capital industrial de México, Monterrey, N.L., Milenio, Multimedios, 2008, 2a edición, p. 279.
} 
El Palacio Federal es uno de los más plausibles edificios Art Déco, tanto a nivel nacional como internacional, pues conlleva una gran mayoría de elementos compositivos de la etapa correspondiente a la década de los veinte, por lo que este magno edificio público es un digno ejemplar del Art Déco combinación del Neoclásico Moderno, del Zigzag, de la Tendencia Geometrista y de la Tendencia Nacionalista Prehispanista propuesta por nosotros.

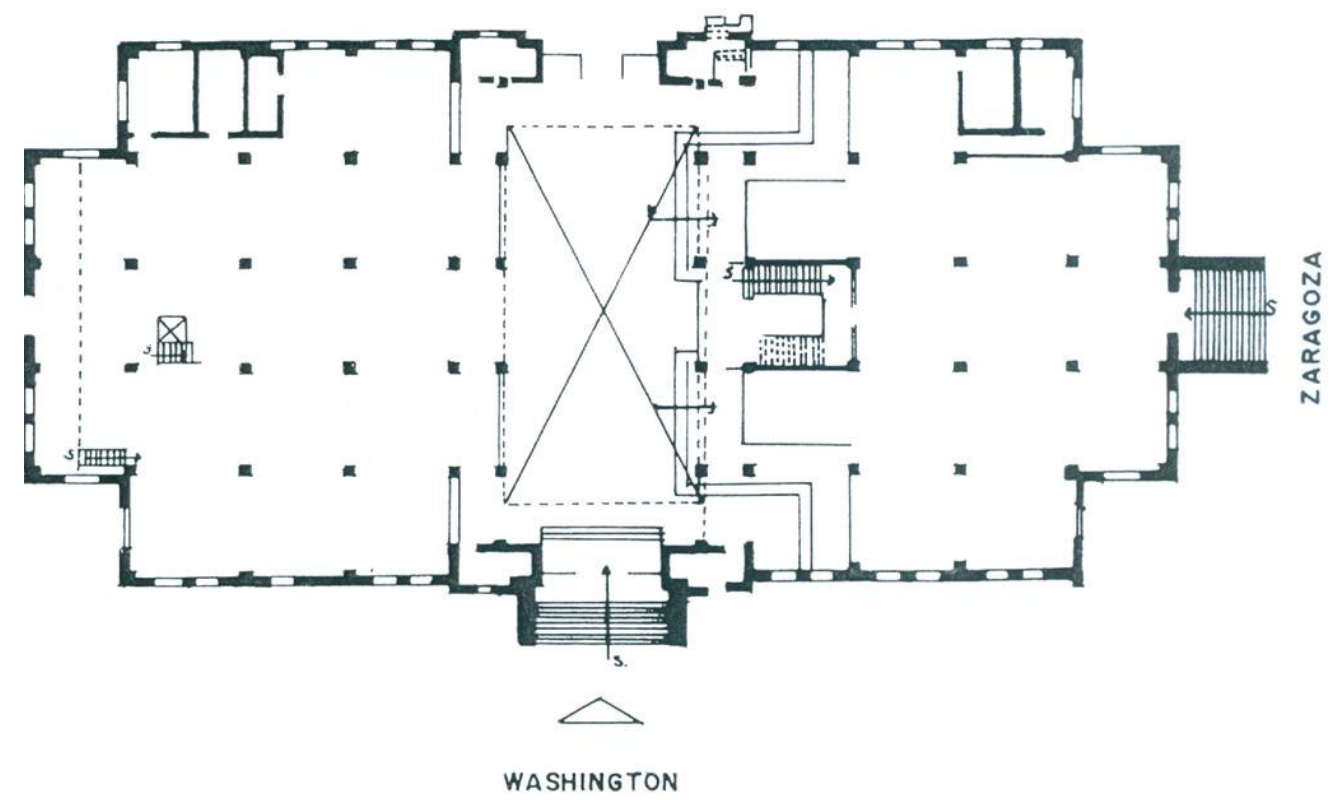

Plano del Palacio Federal.

INAH; SEP. Catálogo Nacional de Monumentos Históricos Inmuebles. Nuevo León. Tomo 4, México, SEP, INAH, Programa Cultural de las Fronteras, Gobierno del Estado de Nuevo León, 1984, p. 1803. 


\subsubsection{ARQUITECTURA DE SERVICIOS}

\section{a. Mercado del Norte}

El Mercado del Norte se ubica en la manzana comprendida por las calles Privada Colón, Juan Méndez, Díez Gutiérrez y Jiménez, con orientación hacia el sur en su entrada principal. Abarca por el frente 82 metros y por los lados 48.7 metros.

Fue construido entre 1928 a 1930 para desarrollar el comercio en la zona norte que para aquellos años ya eran los límites del centro de la ciudad. De acuerdo a una placa que aún se conserva en la fachada sur, el mercado fue inaugurado el 6 de junio de 1930. El diseño del edificio fue del arquitecto de origen español Cipriano J. González Bringas y la construcción estuvo bajo la dirección del ingeniero Miguel Osuna Treviño. ${ }^{90}$ Era todo un centro comercial moderno y lujoso, donde se utilizaron los materiales de sillar para los muros y losa de concreto en los entrepisos, así como cemento en los aplanados exteriores. Su estado actual es de un tremendo abandono y subsisten algunos comercios, además que dicha zona se ha convertido en un barrio bajo y de mucha peligrosidad, por lo que las fotografías demuestran el mal estado de conservación.

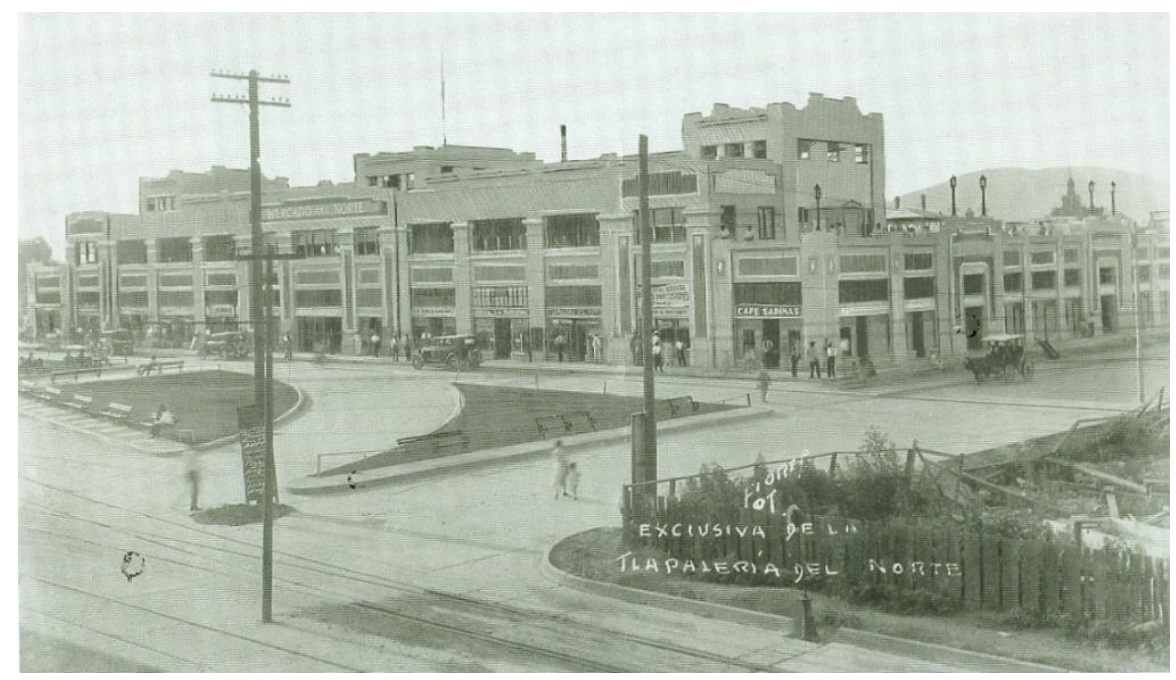

Mercado del Norte recién terminado en junio de $1930 .{ }^{91}$

\footnotetext{
${ }^{90}$ Juan Manuel Casas García, Rosana Covarrubias Mijares, Edna Mayela Peza Ramírez, Concreto y efímero. Catálogo de arquitectura civil de Monterrey 1920-1960, Monterrey, N.L., CONARTE, 2012, p. 43.

${ }^{91}$ CONSEJO PARA CULTURA Y LAS ARTES DE NUEVO LEÓN, Nuevo León imágenes de nuestra memoria. Monterrey, N.L., Consejo para la Cultura y las Artes de Nuevo León, 2003, p. 54.
} 
En la parte exterior las dos fachadas principales que dan a la Privada Colón y a la calle Díez Gutiérrez, la decoración de tipo geométrico se forma con pilastras tablereadas con capitel toscano. En la parte superior del tablereado lleva unas decoraciones florales de forma cuadrada. Las pilastras que conforman los espacios de los accesos principales y de los locales, se unen por medio de entablamentos también tablereados, con lo que se forma un armónico juego de composiciones verticales y horizontales. Seis puertas de cada lado de la entrada principal de estas fachadas se desplazan al mismo nivel y con la misma composición; son los accesos a locales comerciales individuales.

En el acceso principal que da a la Privada Colón que mira hacia el sur, se eleva el segundo piso que se recorta en su elevación en el penúltimo vano de la planta baja y en la parte superior se abren unos vanos rectangulares; en el centro un piñón que se eleva escalonadamente se inscribe el letrero trabajado en azulejos de fondo banco y letras negras bastantes geometrizadas que dice "Centro Comercial del Norte Rusos Turcos Regaderas". Los vanos han sido cerrados hasta la mitad y les colocaron posteriormente unos ventanales.

En las esquinas de la planta alta, los entablamentos frontales y laterales llevan unos tablereados que se elevan escalonadamente en un solo nivel, cerrando en la parte superior de la misma manera.

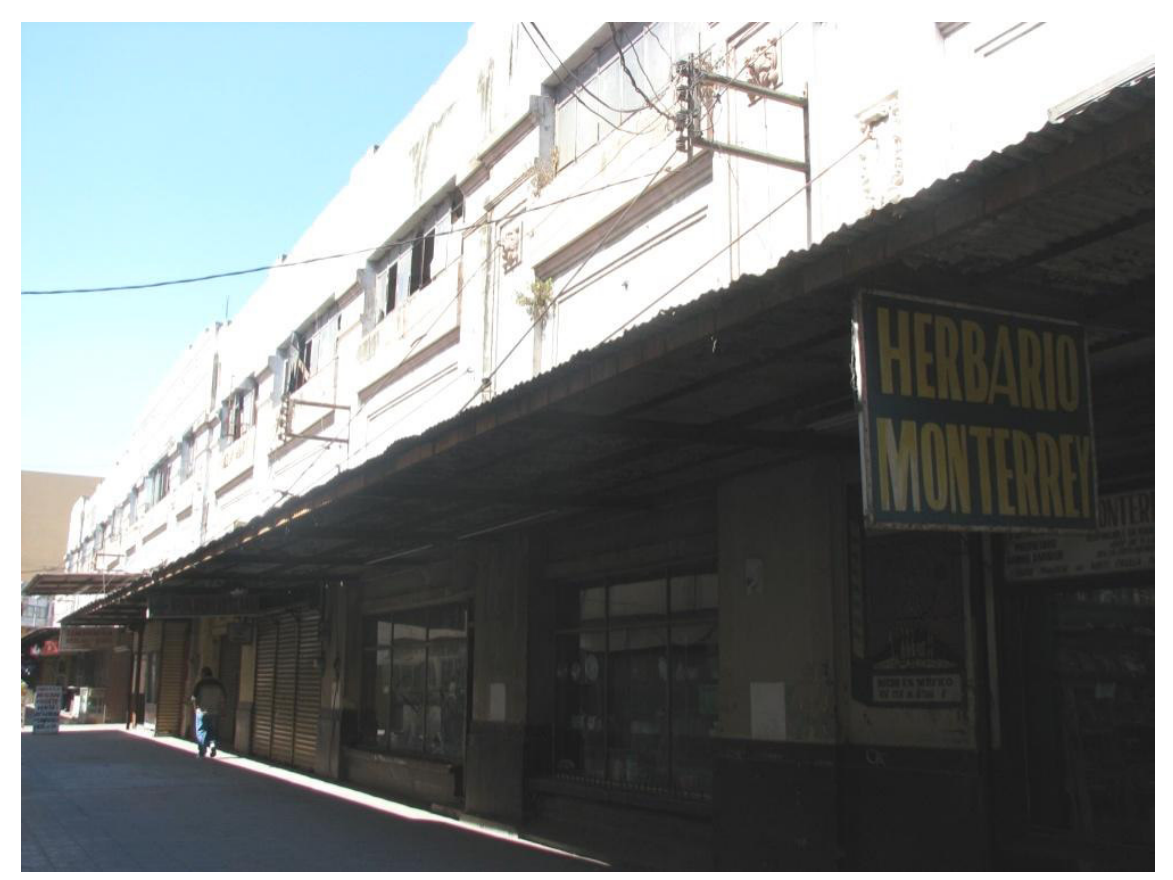

Fachada principal sur hacia la Privada Colón. 


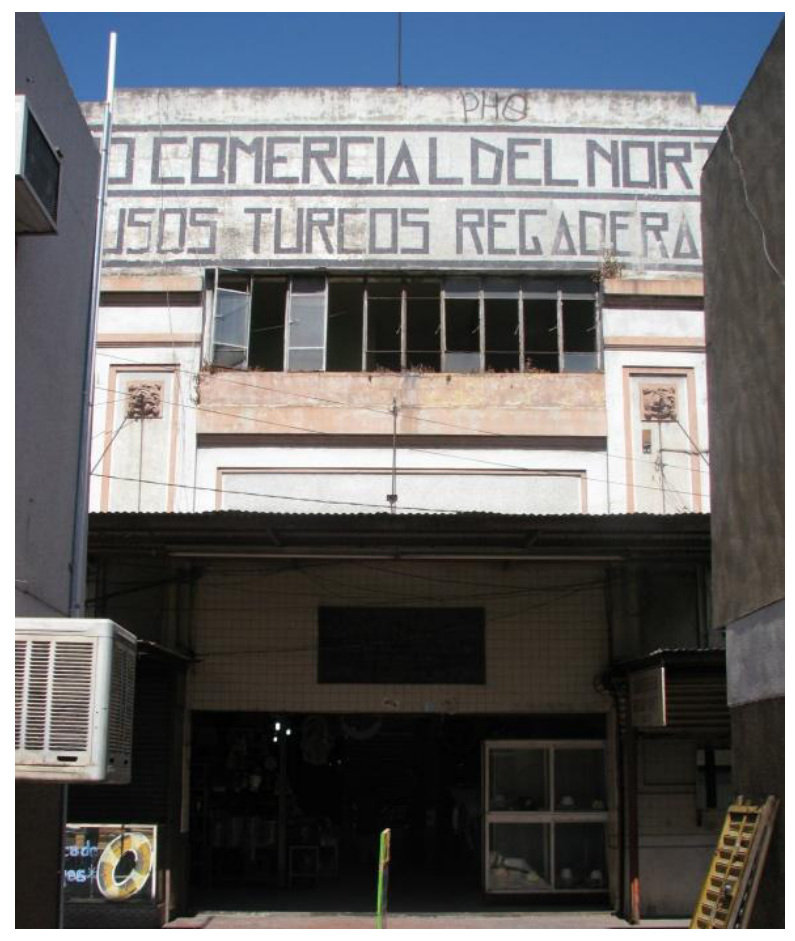

Entrada principal sobre la Privada Colón.

Inmediatamente detrás de la segunda planta de la fachada principal sobre la Privada Colón se anexa un cubo de tres niveles, cuyo frente remata con una moldura saliente y los laterales con un piñón escalonado respectivamente que rematan con dos elevaciones, los cuales junto con las elevaciones de las pilastras de las esquinas se obtiene un efecto visual como si fueran las pirámides prehispánicas zapotecas de Monte Albán en Oaxaca, centro arqueológico citado en el Capítulo 2. Esto es una mera interpretación de las influencias prehispánicas en el Art Déco que se realizó en México, ya que por su geometricidad encajaban muy bien los elementos decorativos de algunas de las culturas indígenas, sin con que esto queramos decir que el autor del proyecto lo haya pensado de esta manera.

La fachada de la calle Díez Gutiérrez, que mira hacia el norte, a diferencia de la que da hacia la Privada Colón, la segunda planta sólo se eleva en los tres espacios centrales y de la misma manera que la otra remata con un piñón donde se inserta un letrero que dice "Centro Comercial del Norte". Los vanos igualmente fueron cerrados hasta la mitad y se colocaron ventanales; con el paso del tiempo se han ido instalando tuberías y cables exteriores sin ninguna planeación ni consideración a los decorados, además de que en años posteriores, en 1950 y en 1983, le han agregado a los lados unos cuartos que desarmonizan con el diseño original. En la planta baja, el penúltimo local de cada lado las pilastras están 
decoradas con motivos florales enmarcados dentro de un cuadrado y se elevan por encima del nivel del resto de la fachada; por encima del entablamento, un remate escalonado con un ábaco enmarcado con una moldura también remite a las construcciones zapotecas de Monte Albán. El juego rítmico de rectángulos en posiciones vertical y horizontal exalta por sí mismo una decoración geométrica típicamente Art Déco.

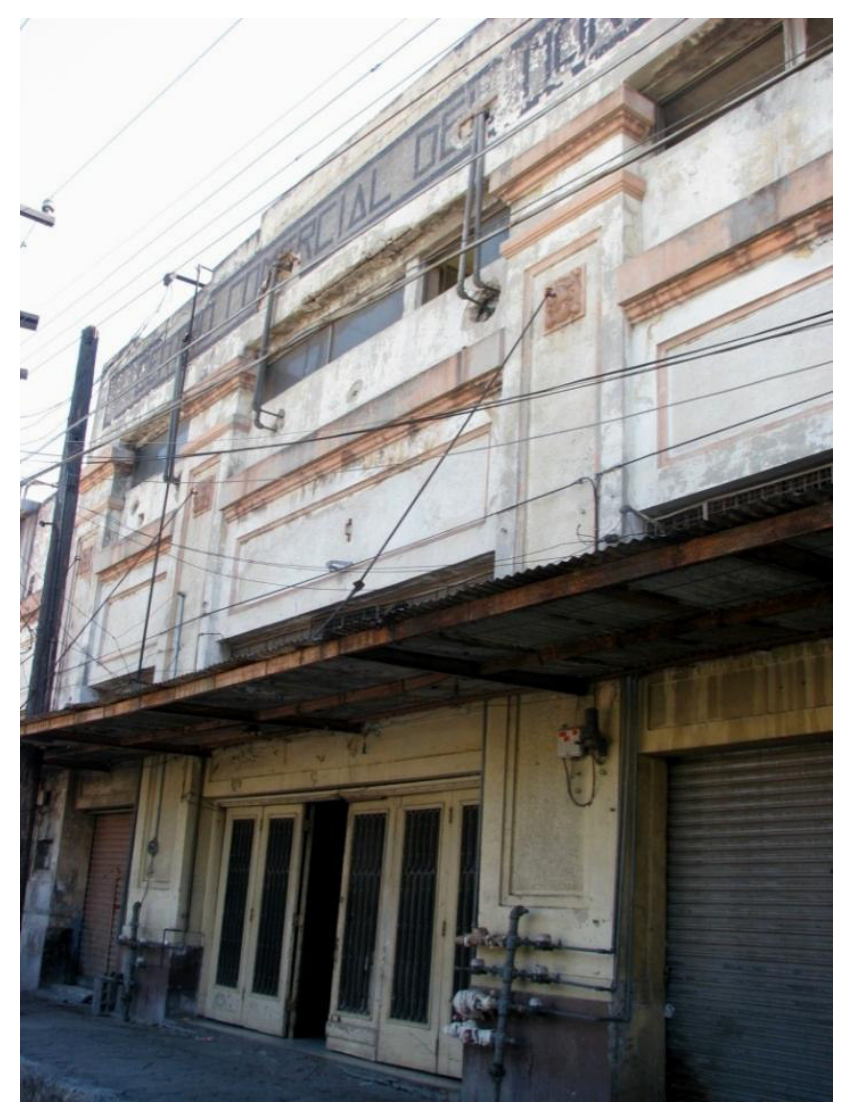

Acceso por la fachada norte en la calle Díez Gutierrez. Las tuberías y el cableado la han invadido por completo.

Los exteriores de las fachadas de las calles Juan Méndez, hacia el oriente, y Jiménez, hacia el poniente, se disponen de la siguiente manera: nueve vanos están enmarcados entre pilastras cuadradas y entablamentos rectangulares que rematan con una moldura horizontal cuadrada; el tercero y séptimo vanos eran puertas de acceso al mercado, hoy clausuradas. En estas puertas aún se conservan los letreros de "Centro comercial del Norte" y se resaltan unos acodamientos en la parte superior que rematan con dos elevaciones escalonadas donde se colocaron unas lámparas con base, fuste y linternilla 
octagonal, de las cuales todavía se conservan algunas aunque sin funcionar. La composición de estas puertas prepondera su diseño geométrico rectangular. En estas fachadas cada pilastra se prolonga levemente a manera de almena del límite del nivel superior, lo mismo que en las esquinas, con lo que se acentúa el sentido de elevación y la armonización de la geometría con los juegos visuales del cubo el cuadrado y el rectángulo.

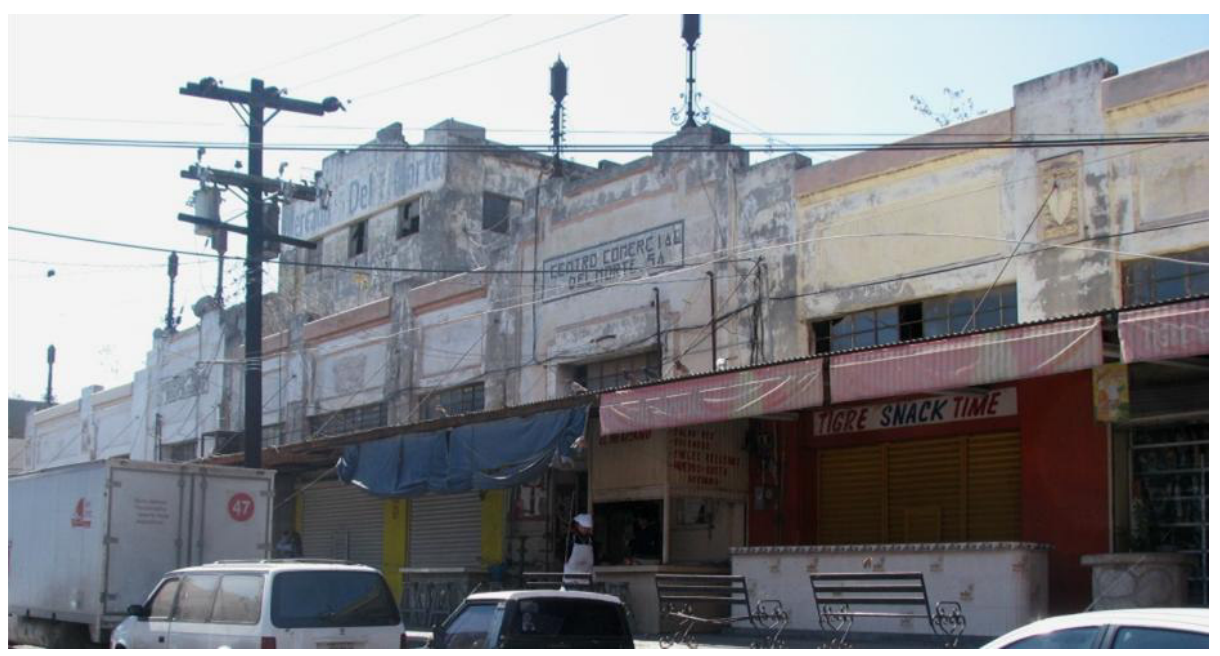

Fachada oriente sobre la calle Juan Méndez. Aún se pueden apreciar algunas farolas y la elevación del cubo escalonado de la segunda planta.

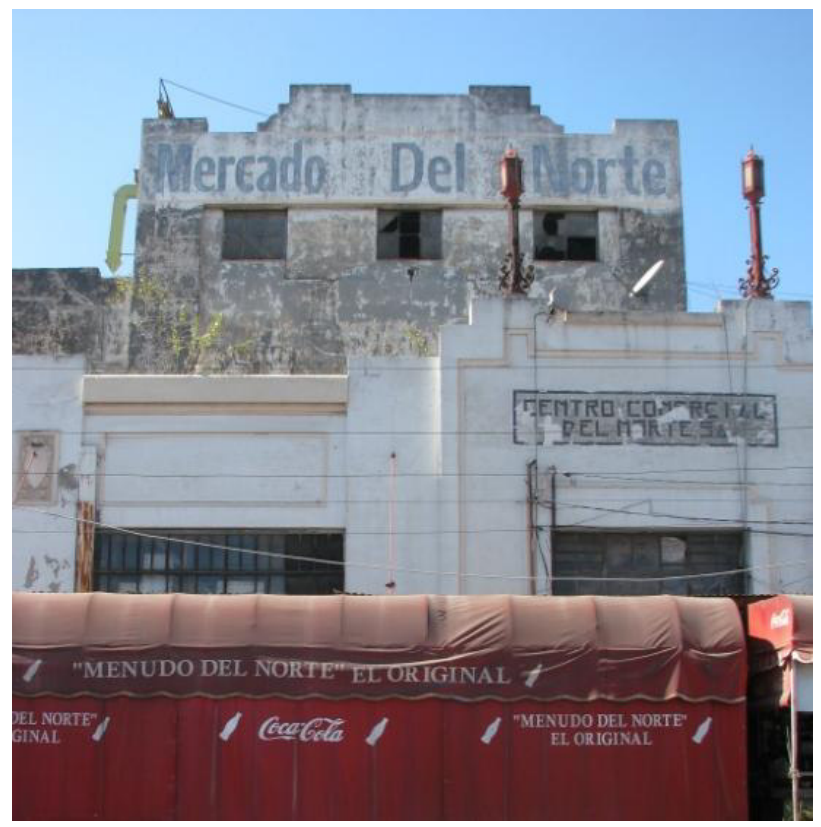

Cubo de la segunda planta con los detalles de la elevación escalonada sobre la fachada oriente. 


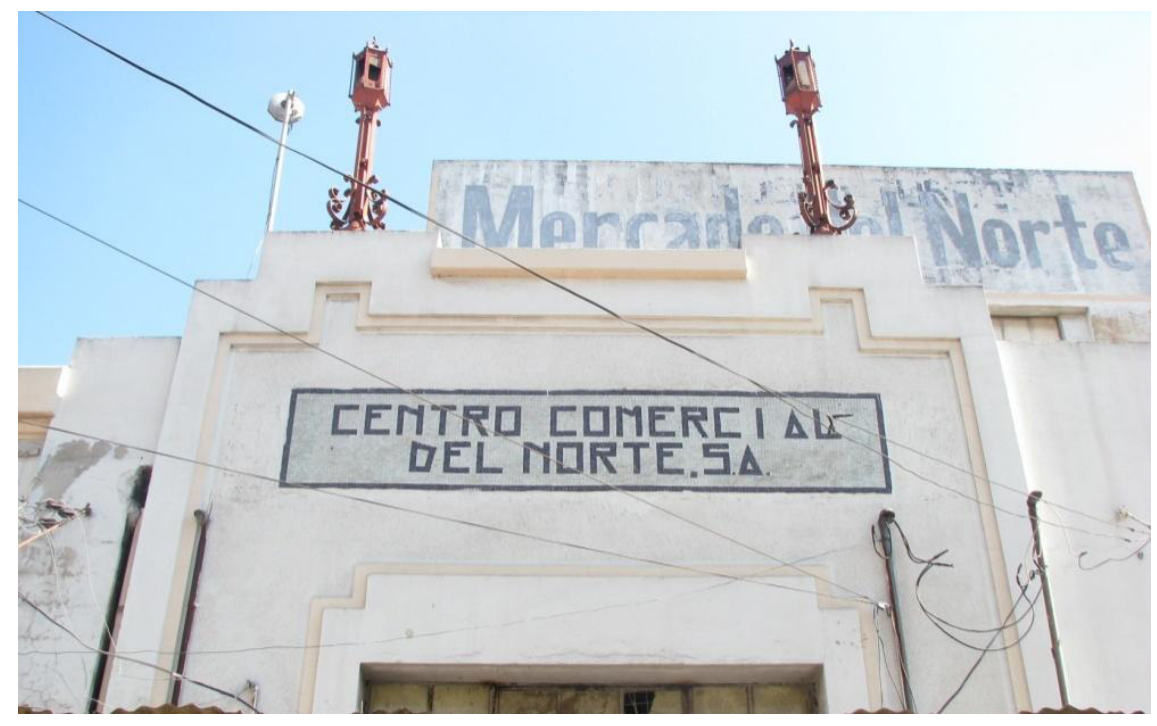

Detalle de la parte superior de una puerta de la calle Jiménez.

En las cuatro fachadas se colocaron en la década de los años 50 del siglo XX unas marquesinas de lámina a la altura de los cerramientos de las puertas, con lo cual además de perderse la visibilidad de los decorados geométricos, afea más el edificio pues están sumamente oxidadas y maltratadas. Aunado a esto, la invasión de puestos exteriores, toldos y cables, entre muchas cosas más, contribuyen a estropear todavía más la imagen del inmueble.

Este edificio en su parte exterior es de un tipo del Art Déco Zigzag, por los componentes geométricos de rectángulos verticales y horizontales, así como la disposición de cubos ensamblados que lo integran y el cerramiento de planos, por lo que además comparte las Tendencias Geometrista y Plasticista.

En la parte interior no había decoración alguna y aún siguen funcionando algunos locales, pero el deterioro y el abandono hacen que no luzca nada de lo que algún día fue este mercado, además de un incendio devastador en el año de 1953. La segunda planta donde se encontraba los baños se encuentra cerrada. En 1983 se hizo una remodelación del inmueble, pero desde entonces no se ha hecho nada por mantenerlo, por lo cual se encuentra en un decaimiento total. 


\section{DÍEZ GUTIÉRREZ}

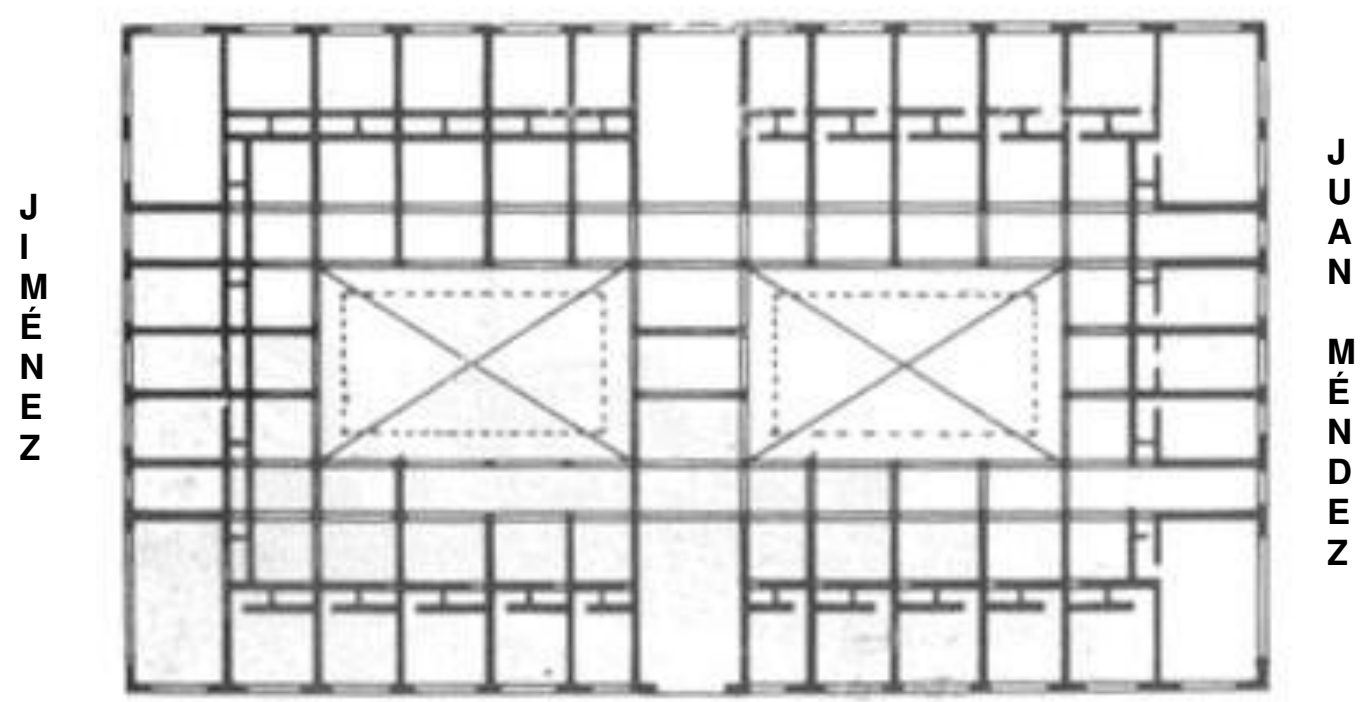

PRIVADA COLÓN

\section{Plano del Mercado del Norte.}

INAH; SEP. Catálogo Nacional de Monumentos Históricos Inmuebles. Nuevo León. Tomo 4, México, SEP, INAH, Programa Cultural de las Fronteras, Gobierno del Estado de Nuevo León, 1984, p. 1795.

\section{b. Edificio La Nacional}

La Compañía de Seguros La Nacional que construyó el afamado edificio en la ciudad de México y que citamos en el capítulo 2, tenía planeado edificar en las más importantes ciudades del país inmuebles para sus oficinas administrativas. Así fue el caso de Monterrey, ya que desde la década de los años veinte del pasado siglo se tenía el proyecto de levantar una sucursal, tal como se demuestra en una fotografía de ese año que se conserva en la Fototeca del Instituto Tecnológico de Estudios Superiores de Monterrey. La empresa del proyecto era FYUSA, que fue la encargada de hacer las escuelas monumentales citadas en la tipología de "Arquitectura Escolar" y el Palacio Federal, pues aunque era una constructora privada, muchos de sus accionistas eran políticos postrevolucionarios, como el mismo general Plutarco Elías Calles. La propuesta de FYUSA no fue finalmente la realizada, ya que tuvo modificaciones. 


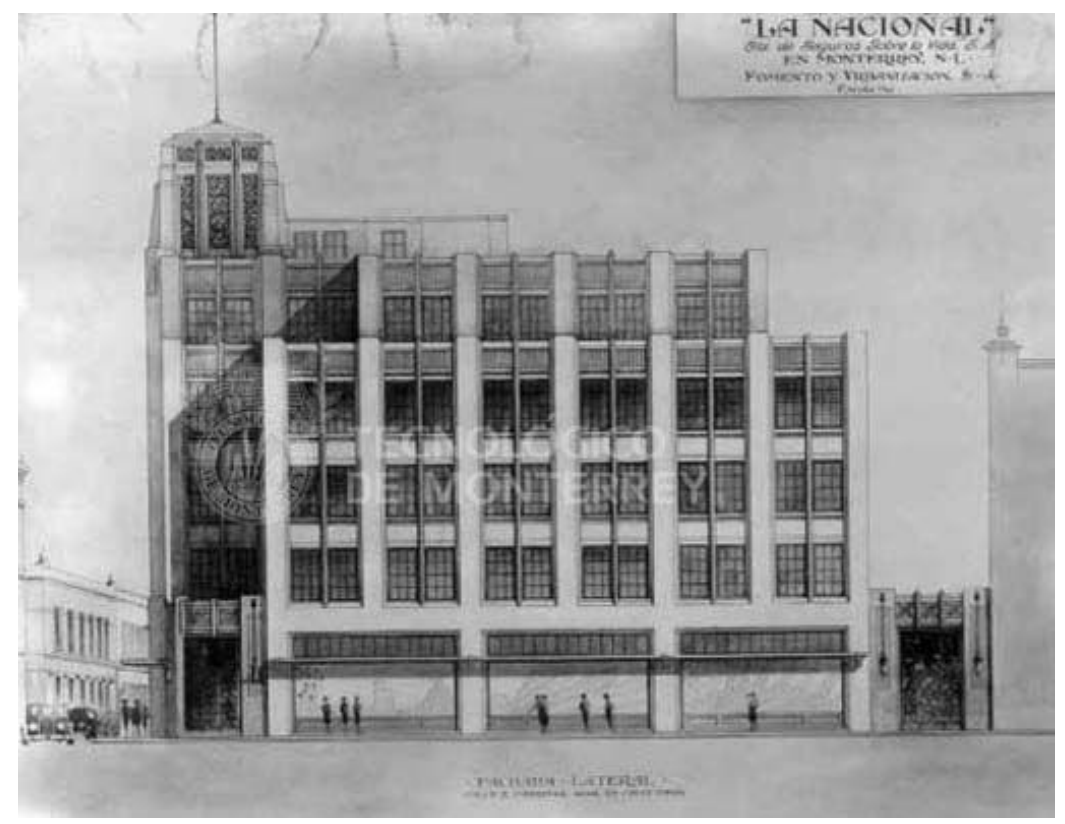

Dibujo de FYUSA para el proyecto de La Nacional en la década de $1920 .{ }^{92}$

La ubicación de estas oficinas de La Nacional es José María Parás 802, con dirección al oriente y con dos fachadas más: la de la calle Padre Mier con orientación al norte y la de Emilio Carranza con orientación al poniente. La fachada que miraría hacia el sur quedó contigua con un edificio que está al lado, por lo que prácticamente se perdió. Con el cerramiento de la calle Parás para uso peatonal, la plantación de árboles y el crecimiento del comercio, es bastante difícil mirar la fachada principal del inmueble.

Las obras de construcción se iniciaron en agosto de 1938 y se contrató al ingeniero Armando Díaz Moreda, ${ }^{93}$ quien hizo modificaciones al proyecto original de FYUSA. La planta se conforma con dos rectángulos interceptados, con lo que da una forma de cruz griega. Un año y medio después el edificio quedó concluido en lo que fue su primera etapa con planta baja y cuatro niveles más, iniciando sus funciones en 1940. Se utilizó un armazón de hierro, fabricado en la Fundidora Monterrey, con cemento y concreto.

Inicialmente el edificio fue concebido para que tuviera la planta baja y cuatro niveles en las fachadas oriente y poniente y cinco en las otras dos del sur y norte. Así se concluyó la primera etapa. Para 1946 se amplió un piso más en las fachadas oriente y poniente, sin alterar el diseño original. Y como se puede constatar por una fotografía de la

\footnotetext{
92 ITESM, Fototeca Tecnológico de Monterrey, Época A-27 Gobierno de Álvaro Obregón (1920-1924), No., de fotografía 602.

93 Juan Manuel Casas García, Rosana Covarrubias Mijares, Edna Mayela Peza Ramírez, Op. Cit., p.85.
} 
década de los años cuarenta, La Nacional tenía la planta baja en color negro, lo mismo que unos marcos escalonados típicamente Art Déco que había en las dos entradas, la principal de la calle Parás y la otra en la calle P. Mier, además de que circundaba al edificio una marquesina, elemento también característico de los años del Déco.

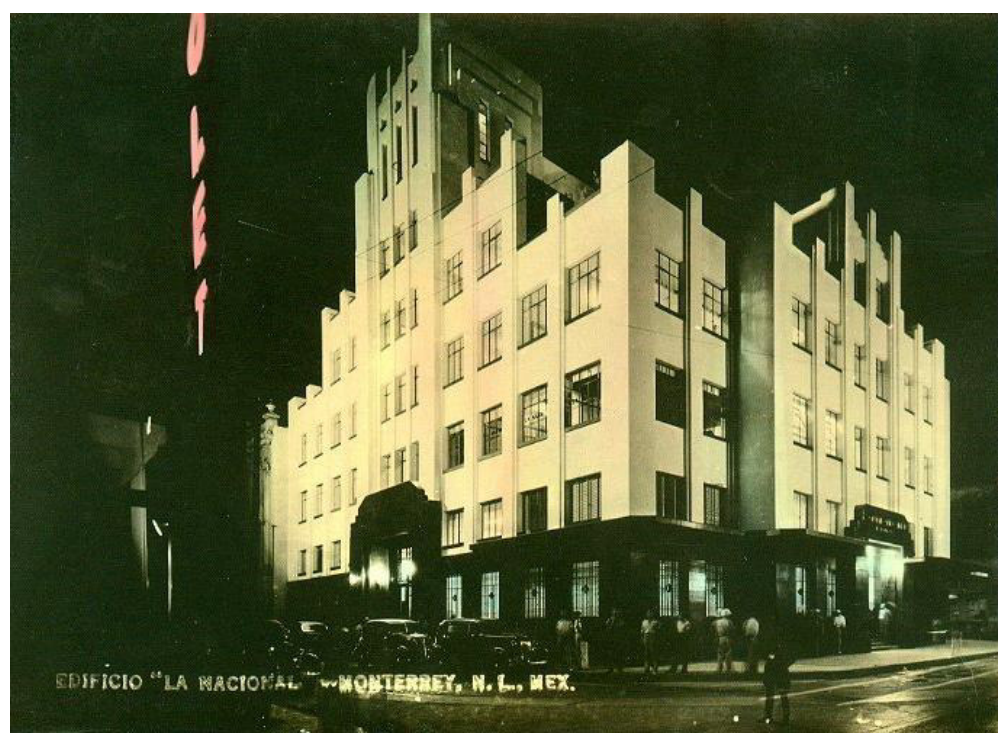

Foto de La Nacional en la década de $1940 .{ }^{94}$

Con el cambio de propietario del edificio en 1972, el crecimiento vehicular y la adaptación de los espacios de la planta baja para ser rentados para diversos tipos de comercios, fueron las razones por las que le despojaron de esos elementos originales.

Una intervención más tuvo el inmueble a mediados de los años ochenta, cuando fue forrado completamente con azulejos cafés, con la finalidad de protegerlo de la humedad, con lo que perdió su apariencia constructiva de los aplanados de cemento.

Lo que se preserva de Art Déco es la estructura ascensional, el escalonamiento superior y la composición a través de cubos. En la fachada oriente que es la principal sobre la calle Parás y donde ahora está el único acceso, al centro se eleva una torre de seis niveles, más la planta baja, que destaca de todo el edificio por su altura y por estar levemente desplazada hacia el frente. Tres calles se separan por dos molduras resaltadas, más las pilastras de cada lado que también sobresalen para conseguir el juego de planos. Cada nivel y cada calle llevan ventanas rectangulares, pero en el sexto las ventanas se

\footnotetext{
${ }^{94}$ Ibídem., p.84.
} 
prolongan más en su tamaño y están acompañadas en la parte superior por otras ventanillas cuadradas. Las dos molduras de las calles y las pilastras laterales se alargan, pasando el nivel de la techumbre, conformado así una representativa característica del Déco del periodo Zigzag. En las vistas laterales de la torre hacia el poniente y el oriente, dos placas yuxtapuestas ayudan a fortalecer el sentido de escalonamiento que luce todo el edificio.

Esta composición era la simulación de los remates de los rascacielos neoyorkinos, con el enaltecimiento de los diseños geométricos.

A los lados de la torre central se ensamblan dos cuerpos de cinco niveles y dos entrecalles que se forman con la pilastras de mayor altura que van adosadas a la torre y otras dos de menos altitud. Continuando con el escalonamiento y viéndolo desde el centro hacia los lados, después de los cuerpo de cinco niveles, son cuatro los pisos que se anexan a la estructura en cada lado y también de dos calles, separadas por una pilastra con la misma composición que la del cuerpo anterior y una de más grosor que hace ángulo con la fachada norte de la calle P. Mier y con la otra parte del edificio que mira hacia el sur y que aún se puede observar a pesar de estar pegado a otra construcción.

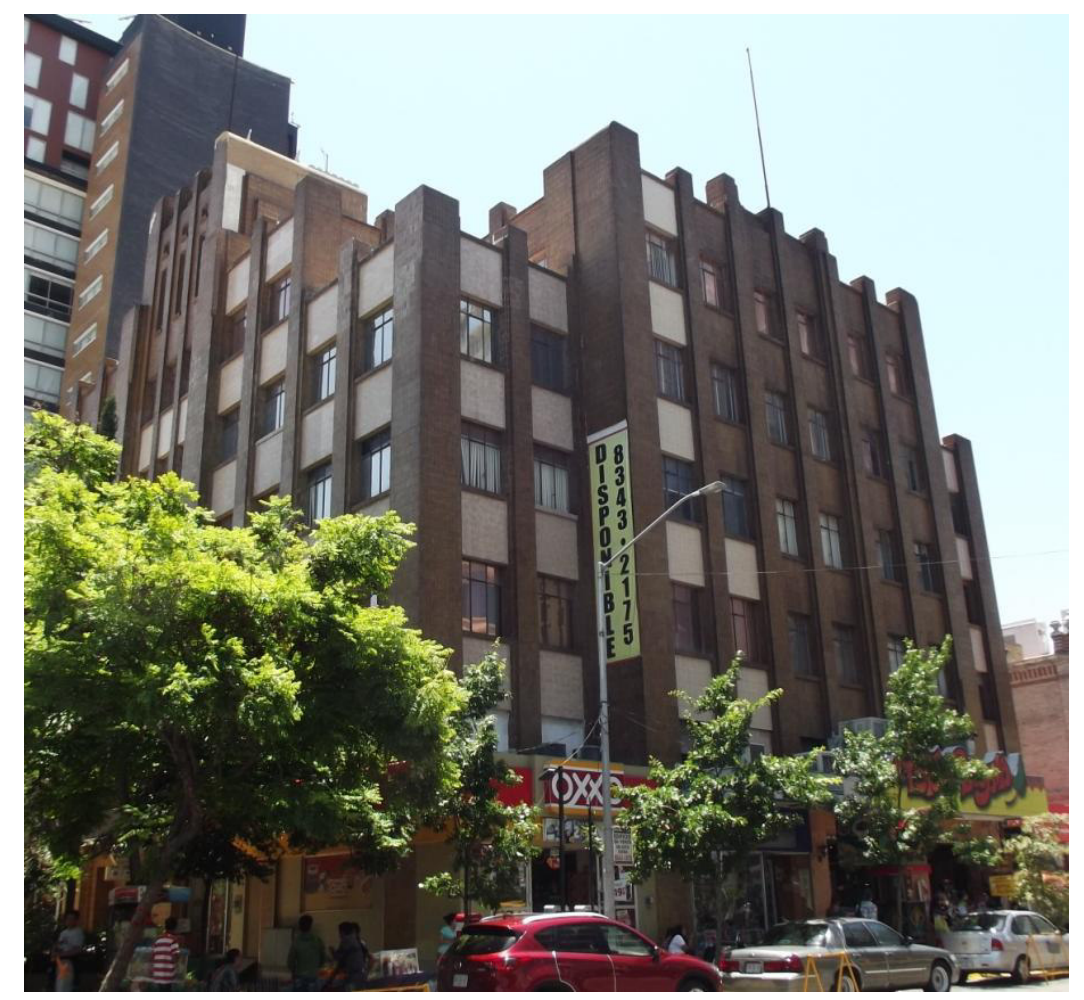

Vista desde el lado nororiente sobre la calle P. Mier . En la fachada principal u oriente de la calle Parás es donde se ubica la torre de seis pisos. 

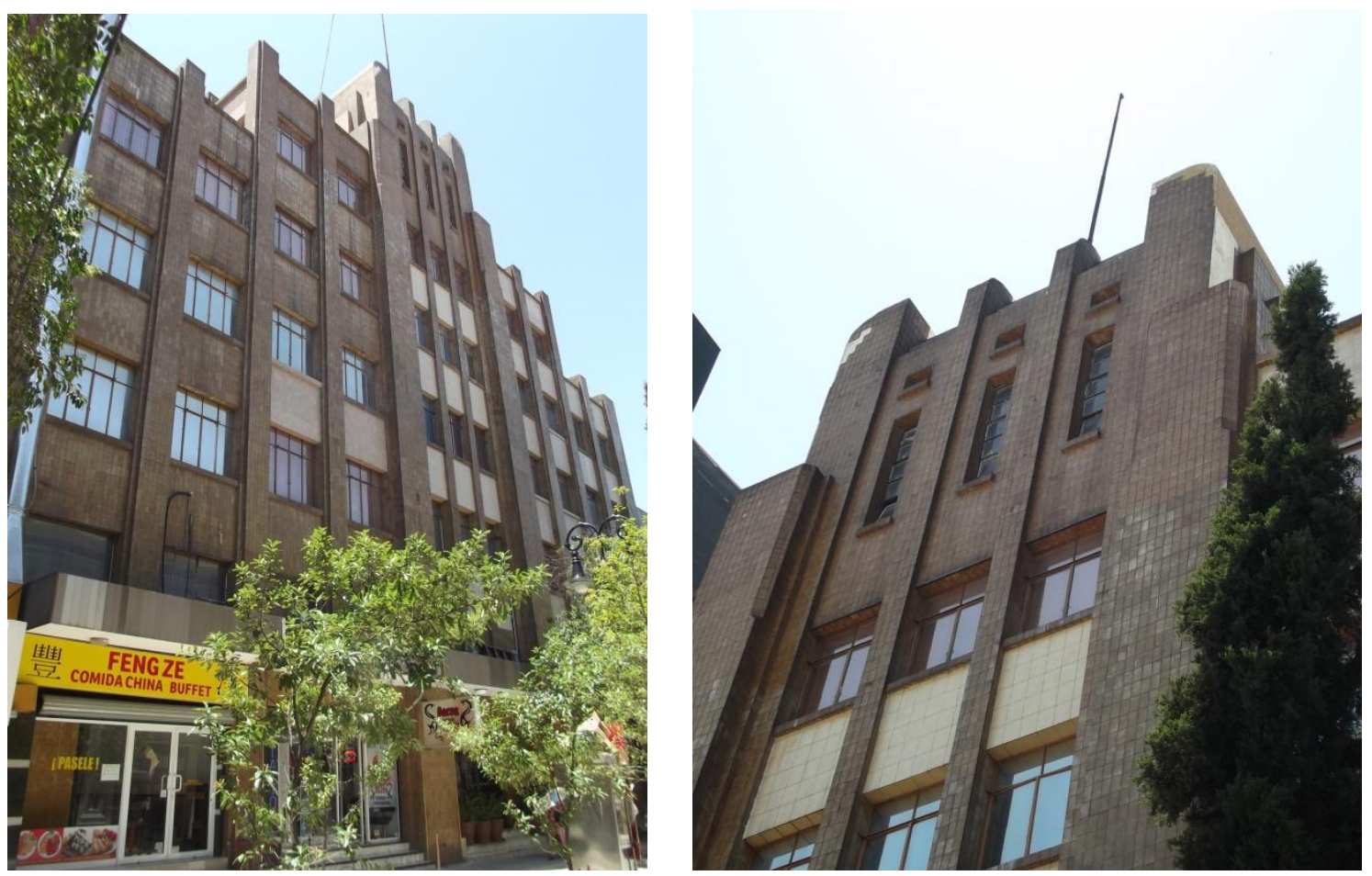

Fachada principal sobre la calle Parás u oriente y detalle del remate del cuerpo central.

Es bastante significativo para un ejemplo de Art Déco Zigzag que un edificio como el de La Nacional, el enlace de poliedros cúbicos induce a parodiar esas influencias mesopotámicas de los zigurats y/o prehispánicas de las plataformas piramidales, que con su geometría ascensional y escalonada, buscaban manifestar los logros de los materiales como el acero y el concreto para alcanzar mayores alturas, antes impensables, dentro del ambiente de modernidad y confort, tal como sucedía con las oficinas de esta compañía aseguradora.

Las fachadas norte en la calle P. Mier y poniente en la calle Emilio Carranza llevan la misma composición. Además de la planta baja, se eleva un cuerpo de cinco pisos con cinco calles o tramos verticales que en el caso de la fachada norte sobresale desplazándose hacia el frente. Cada calle está separada por pilastras: la central es rectangular y termina de la misma manera; las dos que le siguen a ambos lados llevan una banda anexada en la superficie y terminan escalonadamente; las que continúan también son escalonadas y de un tamaño menor; finalmente, las de los extremos son unas gruesas pilastras rectangulares y rematan con mayor altura, lo que hace sugerir mayor elevación de los pisos y un juego alternado de prominencia de cubos. 
A cada lado del cuerpo de cinco pisos de ambas fachadas mencionadas, norte y poniente, unos cuerpos de cuatro pisos y dos calles se integran al conjunto. Las ligeras pilastras que están adyacentes al cuerpo central, rematan con dos delicados tramos de escalonamiento; la que equivale a la pilastra central, lleva también una banda superpuesta como en la otra fachada; y las pilastras de los extremos abarcan ambas lados, ya que se forman angularmente.

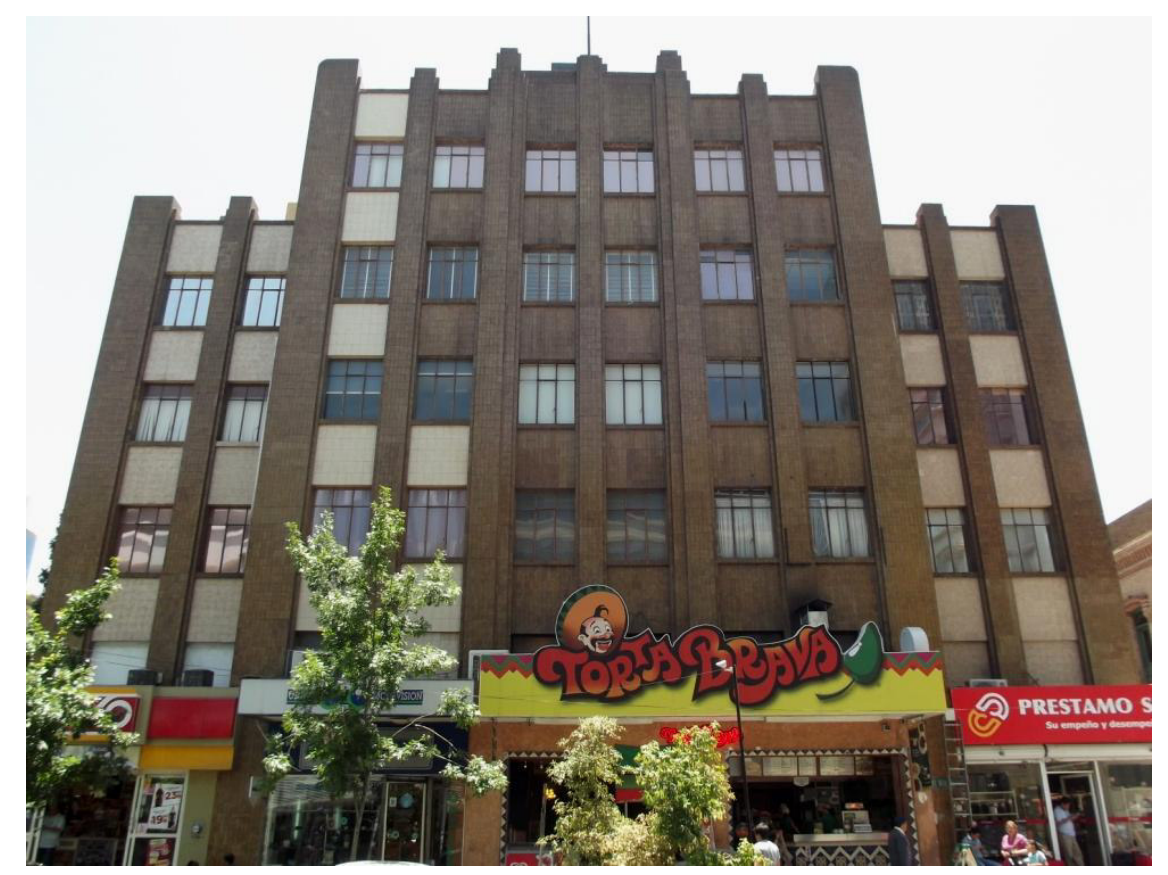

Fachada norte hacia la calle P. Mier.

Los elementos Déco están en el exterior, ya que en el interior debido a las restauraciones, así como adaptaciones contemporáneas de equipamiento de oficinas y climatización no se conserva nada, pero todo el inmueble está en muy estado de conservación. ${ }^{95}$

El edificio de La Nacional a pesar de haber perdido su originalidad por los cambios mencionados, sigue guardando su diseño escalonado, con la inserción de cuerpos cúbicos y

\footnotetext{
${ }^{95}$ En entrevista el lunes 18 de junio de 2012 con la señora Blanca Alavez Sosa, administradora del edificio y copropietaria del mismo, nos informó que lo habían adquirido recientemente, sin precisar fecha, y ahora pertenece al Grupo Inmobiliario la Silla, S.A. de C.V. En esa ocasión pudimos constatar el buen mantenimiento que le han dado al inmueble.
} 
el juego de planos, por lo que es un caso de Art Déco de la variante Zigzag y un prototipo de la Tendencia Geometrista.

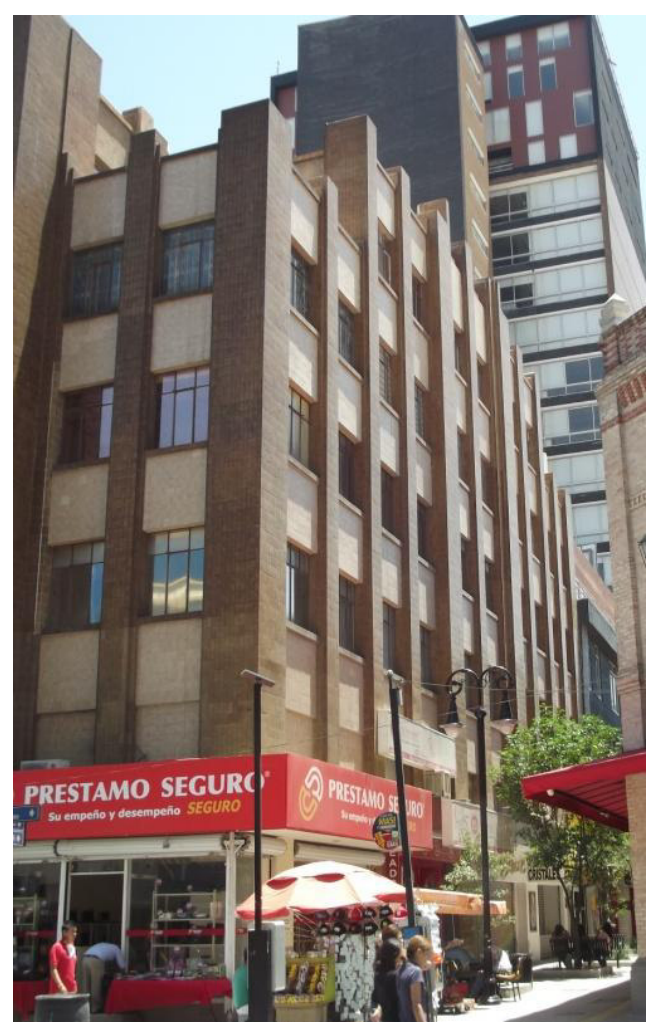

Fachada poniente de la calle Emilio Carranza. 


\subsubsection{ARQUITECTURA ASISTENCIAL}

\section{a. Hospital Civil}

El Hospital Civil, ahora Hospital Universitario Dr. José Eleuterio González, se localiza en la calle Madero s/n, entre Gonzalitos y Salvatierra, con orientación al sur.

El proyecto de un hospital que atendiera la creciente demanda de la población de la ciudad se inicia durante el gobierno de Francisco Cárdenas en el año de 1932, de quien José P. Saldaña se expresa así: "Entre sus obras más sobresalientes, destaca la construcción de Hospital Civil (Gonzalitos). Recibió críticas por lo alejado que se encontraba del centro de la ciudad". 96

Para explicar el desarrollo constructivo del Hospital Civil, Santiago Roel incluye una nota de pie de página del Dr. Arnulfo Treviño: "Siendo gobernador del Estado don Francisco Cárdenas, hombre virtuoso y de gran talento, tuvo la idea de edificar en Monterrey un hospital a la altura de una gran ciudad, formó una Junta de Médicos en la que figuraron el Dr. Eusebio Guajardo, actual Benemérito del Estado de Nuevo León, el Dr. Francisco Rocha, el eminente cirujano desaparecido Dr. Ángel Martínez Villarreal y el Dr. Francisco Vela González, actual director del hospital, los que, patrocinados por un ingeniero norteamericano especialista en la construcción de hospitales, llevaron a cabo la grandiosa idea del ya finado gobernador Cárdenas; por uno de los más graves errores de la política, dicho gobernante abandonó el gobierno dejando erigida la estructura del nuevo hospital. Lo sucedió en el gobierno el Lic. Pablo Quiroga, quien continuó las obras y fue en el año de 1938 que con la llegada al gobierno del Gral. don Anacleto Guerrero, por ley del Estado fue creada la Beneficencia Pública del mismo". ${ }^{97}$

El ingeniero al que hace referencia Arnulfo Treviño fue el doctor (y no ingeniero) William Henry Walsh, quien vino de Chicago a formar parte del comité del proyecto del hospital. Los otros miembros de dicho comité eran: al ingeniero Leopoldo Quijano, encargado de la arquitectura; el arquitecto e ingeniero Eduardo Belden Gutiérrez (f?-1965), resistencia y estructura; y el ingeniero Antonio Sava, consultor técnico y quien propiamente

\footnotetext{
96 José P. Saldaña, ¿Y Qué Hicimos?... Monterrey en el siglo XX. Monterrey, N.L., Al Voleo-El Troquel, 1988, p. 69.

${ }^{97}$ Santiago Roel, Nuevo León, Apuntes históricos. Monterrey, s/e., 1963, $11^{\text {a }}$ edición, p. 357.
} 
se encargó de la construcción como tal. Los trabajos de edificación se iniciaron el 3 de mayo de 1933, todavía bajo el gobierno de Francisco Cárdenas; se continuaron en el gobierno de Pablo Quiroga. ${ }^{98}$ Quienes hicieron los planos y a la vez se les atribuye la obra es a Leopoldo Quijano y a Eduardo Belden: "Los planos del nuevo hospital, trabajo encomendado al ingeniero Leopoldo Quijano y al arquitecto Eduardo Belden, están muy adelantados...".99 Según Oscar Eduardo Martínez, el inmueble es obra de Eduardo Belden: “En esos años [la década de los treinta] se construyó el Hospital Civil que ahora lleva el nombre de Universitario. Aun cuando se asume que su planta diseñada en forma de " $\mathrm{X}$ " por especialistas norteamericanos de Chicago, se atribuye el proyecto al arquitecto-ingeniero Eduardo Belden". 100

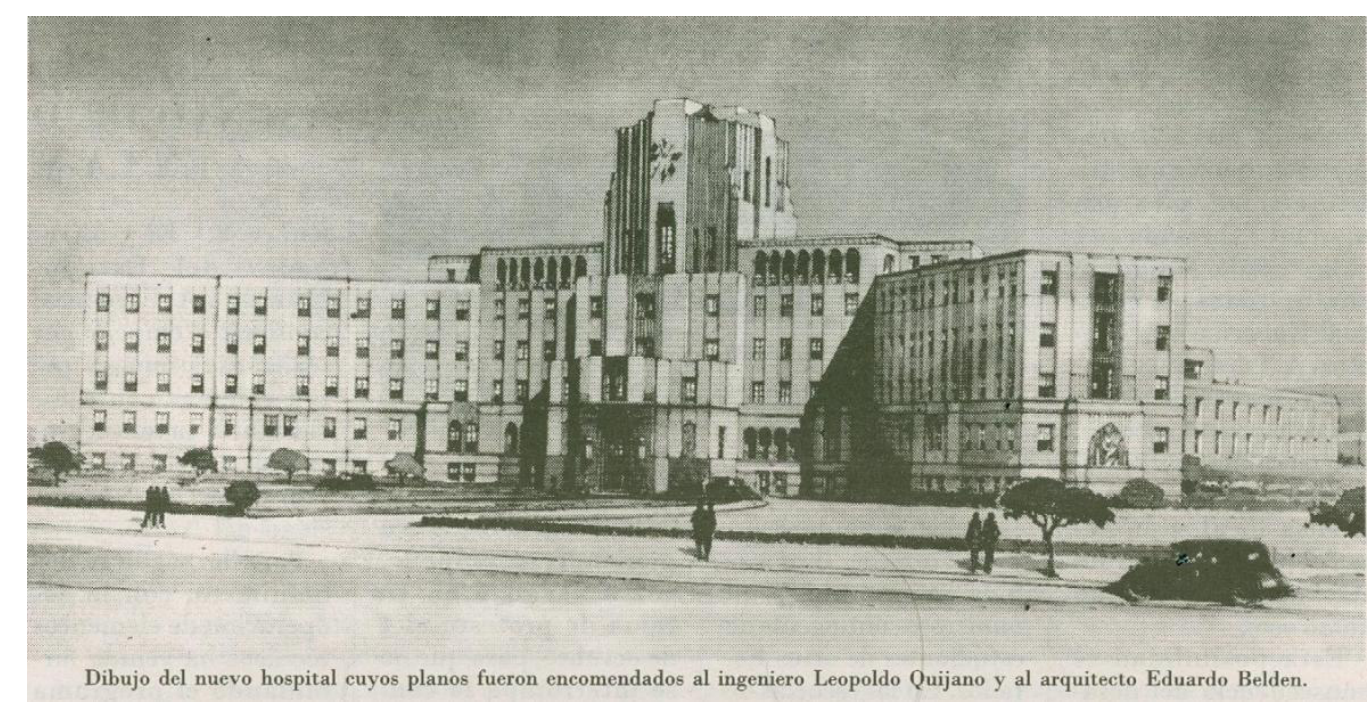

Dibujo del Hospital Civil antes de iniciarse su construcción en enero de 1933.101

En el año de 1937, durante el mandato como gobernador del Estado del general Anacleto Guerrero, se llevó a cabo en el aún inconcluso nosocomio la Exposición de Mayo,

\footnotetext{
${ }^{98}$ Agradezco a las alumnas Ana Lucía Aguilar y Lucía Farías quienes nos otorgaron esta información que ellas obtuvieron en entrevista con el Dr. Hernán Salinas Cantú en la Facultad de Medicina del UANL el 23 de noviembre de 1999.

${ }^{99}$ Universidad Autónoma de Nuevo León, "Será el más moderno el nuevo hospital a edificarse pronto", Memoria Universitaria No. 1, enero de 1933. Monterrey, N.L., Universidad Autónoma de Nuevo León, 2013, p. 4.

${ }^{100}$ Oscar Eduardo Martínez, "Monterrey, ciudad vieja, ciudad nueva. Su arquitectura y urbanismo", La Enciclopedia de Monterrey. Tomo II. La capital industrial de México, Monterrey, N.L., Milenio, Multimedios, 2008, $2^{\text {a }}$ edición, p. 280.

${ }^{101}$ Universidad Autónoma de Nuevo León, Op. Cit., p. 4.
} 
en donde se exhibieron productos regionales. Esto se hizo con la intención de obtener ganancias para continuar con las obras del Hospital Civil. ${ }^{102}$

Para 1938 el hospital abrió parcialmente sus servicios: “A cinco años de haberse iniciado su construcción, el Hospital Civil Dr. José Eleuterio González entra en servicio a partir del 30 de septiembre de 1938, aunque los antecedentes de la institución se remontan a 1860". ${ }^{103}$ A partir de 1939, ya en el gobierno del general Bonifacio Salinas, se continuaron con los planes para su conclusión, así que para noviembre de 1943 el Hospital Civil estaba prácticamente terminado.

La sucesión del desarrollo de la construcción del Hospital Civil está relatada en una placa que se encuentra en el vestíbulo de la entrada principal. Ahí se ratifica que la dirección de obras estuvo a cargo del ingeniero Antonio Sava.

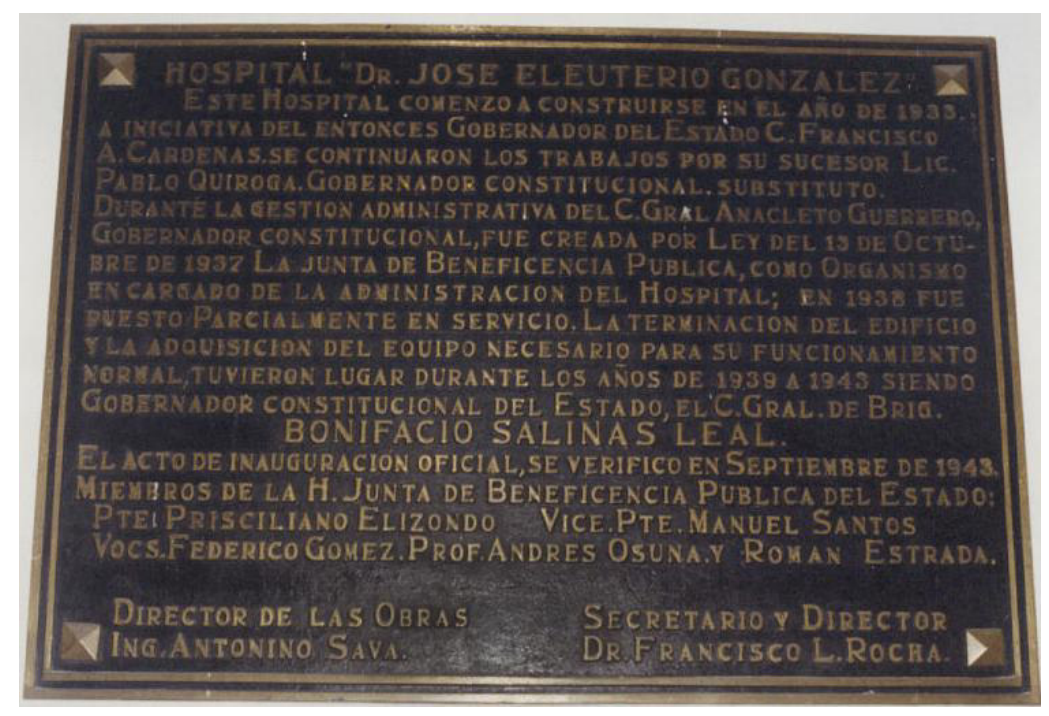

Placa en el vestíbulo.

Así como las escuelas monumentales y el Palacio Federal, por sus cualidades estilísticas el Hospital Civil estaba en la lista de los patrimonios arquitectónicos que serían custodiados por el INAH y el INBA. ${ }^{104}$

\footnotetext{
${ }^{102}$ Héctor Javier Barbosa Alanís, Recuerdos de Monterrey, Monterrey, N.L., s/ed., 1993, p. 131.

103 José Garza, "400 Fragmentos de Historia", Monterrey 400: Una Historia de Progreso, p. 262. El fragmento es el 140.

${ }^{104}$ Vicente Guerrero, Ibídem.
} 


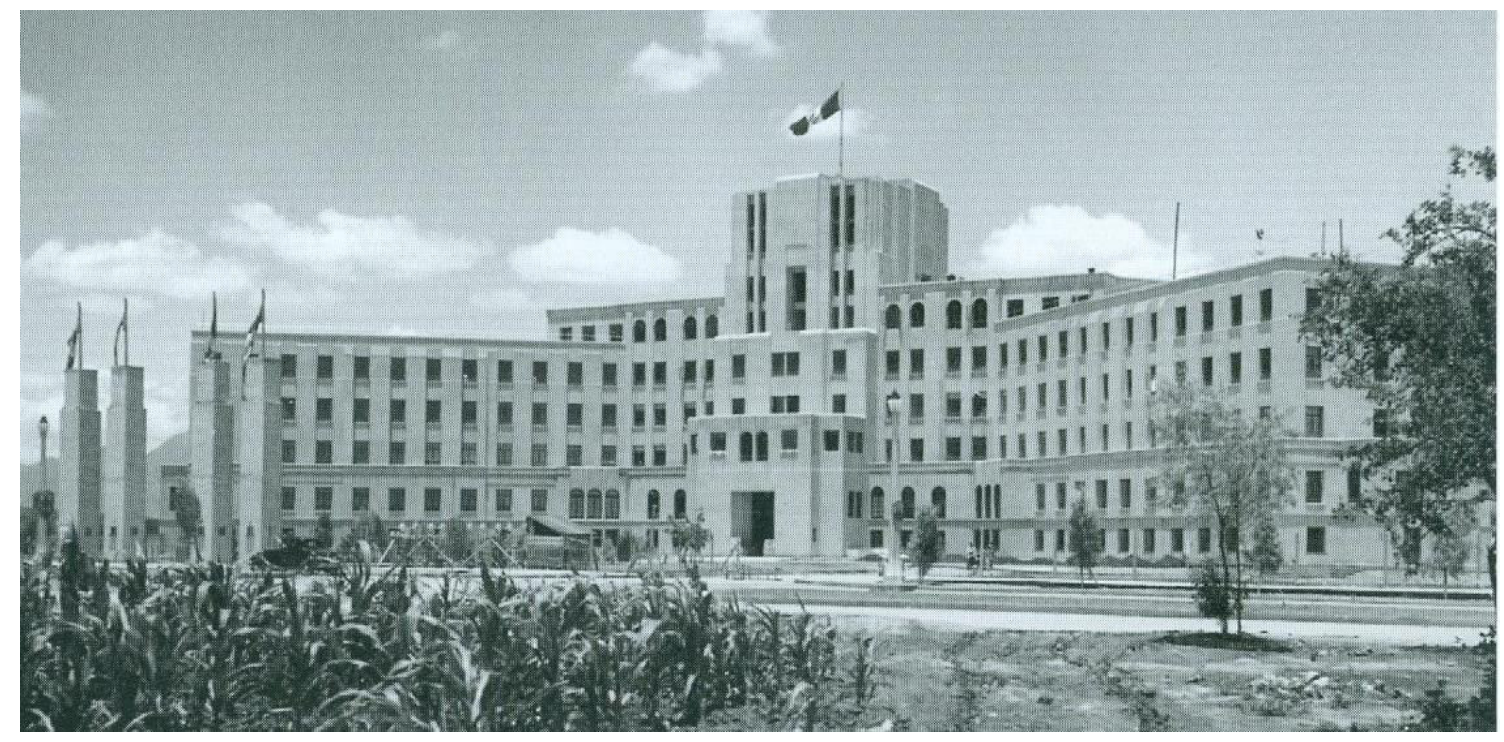

El hospital concluido en 1943.105

La planta del edificio es una $\mathrm{X}$ acostada. Al centro se eleva un cuerpo central de nueve niveles del cual se proyectan al sureste, suroeste, noreste y noroeste cuatro cuerpos y uno más hacia el norte, mismo que quedó integrado en las ampliaciones llevadas a cabo en 2006. El hospital es una armazón de cubos, así como líneas verticales y horizontales que le dan un sello de geometrismo, por lo tanto, un inmueble estilo del Art Déco en algunas de sus partes como es el cuerpo central del edificio y algunas decoraciones del vestíbulo.

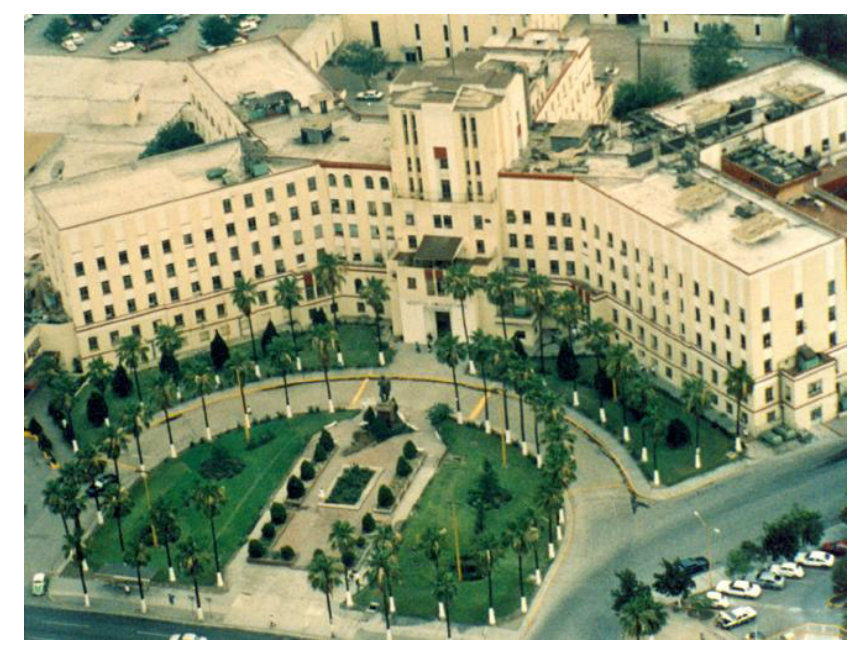

Vista aérea del hospital antes de la remodelación de 2006. ${ }^{106}$

\footnotetext{
${ }^{105}$ Héctor Javier Barbosa Alanís, Monterrey. Descubra el ayer de nuestra ciudad, Monterrey, N.L., Agencia Promotora de Publicaciones, 2010, p. 101.

${ }^{106}$ http://www.medicina.uanl.mx/hu/acerca-de/historia/
} 


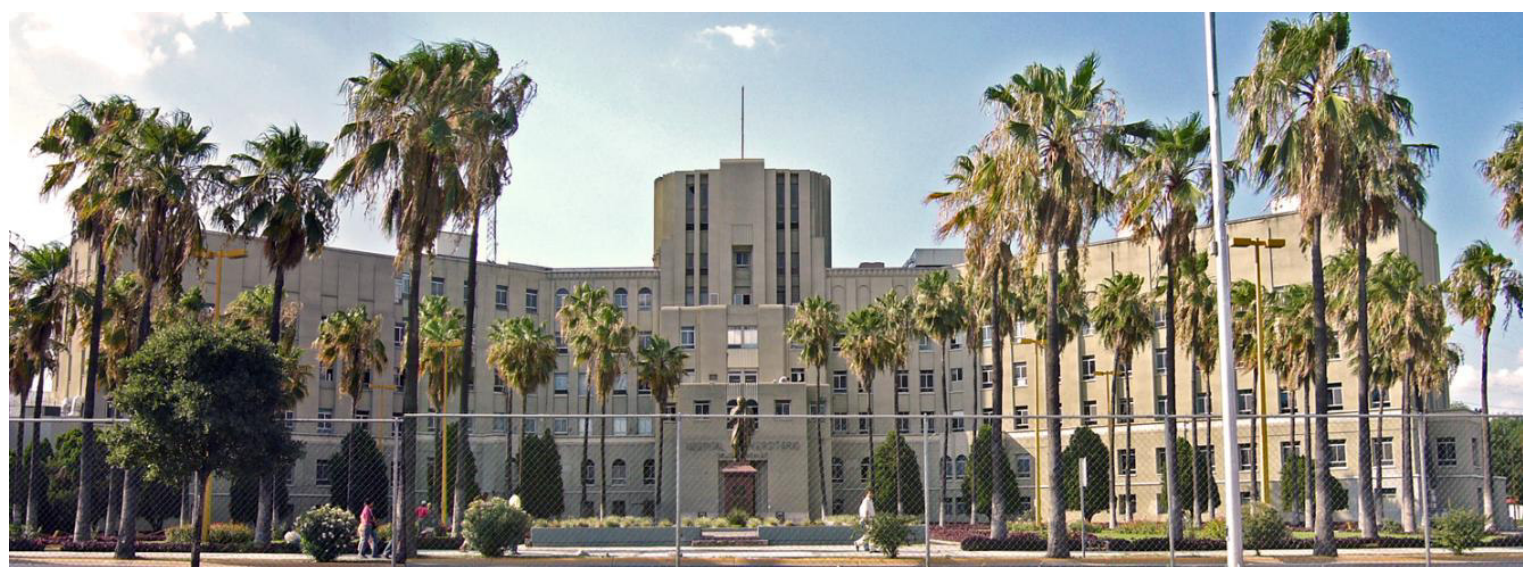

Vista frontal del Hospital. ${ }^{107}$

En la fachada principal, el cuerpo central es un sugestivo enlace a su vez de tres prismas rectangulares que se elevan escalonadamente, dando la imagen de un zigurat.

El primero que aunque en altura abarca tres niveles en sí solo tiene dos, se desplanta hacia el frente de dos cuerpos adheridos que también forman parte de él, pero están en un plano hacia atrás. El vano de acceso es un rectángulo abocinado, lo cual se forma por perfiles angulosos. Arriba se registra el nombre del hospital, pero no es el original. En el segundo nivel de este primer cuerpo un par de ventanas con vano formado por arco de medio punto se coronan con unas estrías que se enclavan en el techo. A los lados y en los cuerpos adheridos las ventanas son rectangulares. El cerramiento de los planos, que es una de las originalidades de la arquitectura Art Déco de la Tendencia Plasticista, se aplica claramente en este primer cuerpo.

El segundo cuerpo, es decir el segundo cubo, lleva una entrecalle central con ventanas geminadas verticales que se eleva muy ligeramente de los demás componentes. Los paneles verticales que están a los lados de la entrecalle central están más hacia el frente en minúscula proporción; asemejan una yuxtaposición de bandas que envuelven a todo el cuerpo, lo que se logra por los perfiles angulosos laterales, los cuales integran a otras entrecalles con ventanas rectangulares que ahora están situadas más hacia atrás que cualquier parte de todo el cuerpo, para luego terminar con otros planos cerrados en cada extremo, también con la semejanza de una banda que circunda al edificio, como una característica propia del Art Déco.

\footnotetext{
${ }^{107}$ Foto: Fernando Lisceur, CONARTE.
} 
El tercer cuerpo que se eleva más que todo el edificio, es una apoteosis de las composiciones arquitectónicas geométricas del Art Déco. Al centro un plano principal, con la misma idea de parecer una banda envolvente que se eleva por encima de todo el cuerpo, lleva un vano vertical rectangular desde la base hasta un poco más de la mitad, el cual se bisela profundamente y después tres enmarcaciones llegan a una ventana vertical. En el dintel del vano, unas estrías rematan el espacio. Después de este primer plano se acoplan hacia atrás otros tres más: el segundo por medio de un amplio perfil angular, y el tercero y cuarto por ventanas angostas verticales enmarcadas por acentuadas molduras. Las extremos laterales están trabajadas de la misma manera con la superposición de planos, a diferencia que éstos son tres y cerrados, pero que en la parte baja hay unos primas rectangulares, uno mayor y otro menor que dan el efecto de escalonamiento. En sin este tercer cubo es todo un juego de elementos lineales que consiguen un cinetismo visual, ya sea si se ve de adelante hacia atrás o en sentido inverso.

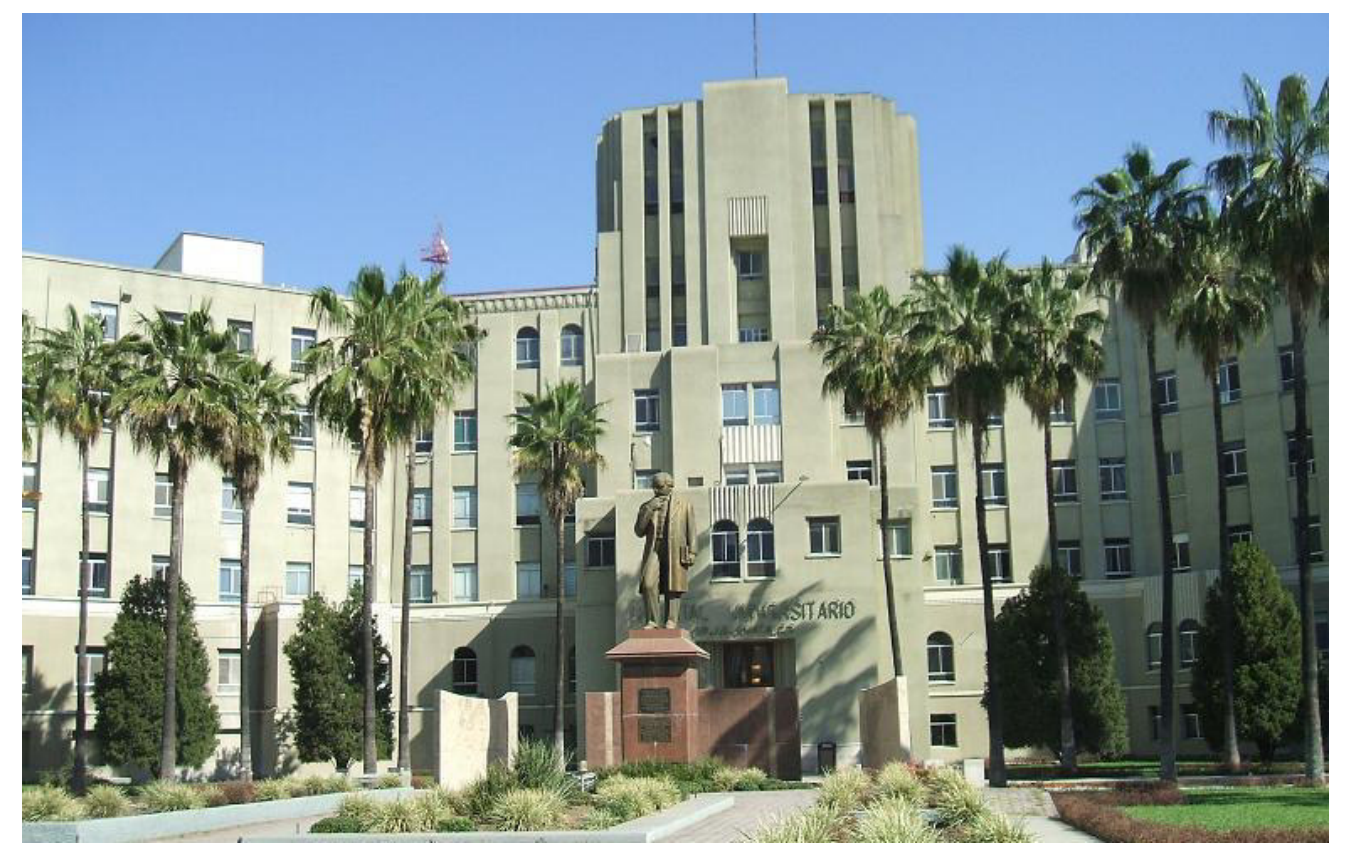

Cuerpo central de la fachada principal. ${ }^{108}$

Todo este conjunto de cubos que completan la fachada, presumen una ornamentación conseguida por medio de las verticalidades de las ventanas y paneles, de los perfiles angulosos, de la yuxtaposición de los planos y del escalonamiento que induce a

\footnotetext{
${ }^{108}$ Foto: Fernando Lisceur, CONARTE.
} 
abstraer un zigurat, como ya lo habíamos mencionado. Es decir, el Hospital Civil tan sólo por este cuerpo central es un inmueble más de la arquitectura Art Déco, ya que contiene todos los esquemas decorativos necesarios para pertenecer a este estilo. Y aunque se haya proyectado, iniciado y construido en la década de los treinta, el cuerpo central es plenamente Art Déco Zigzag y, obviamente, un modelo más para la Tendencia Geometrista.

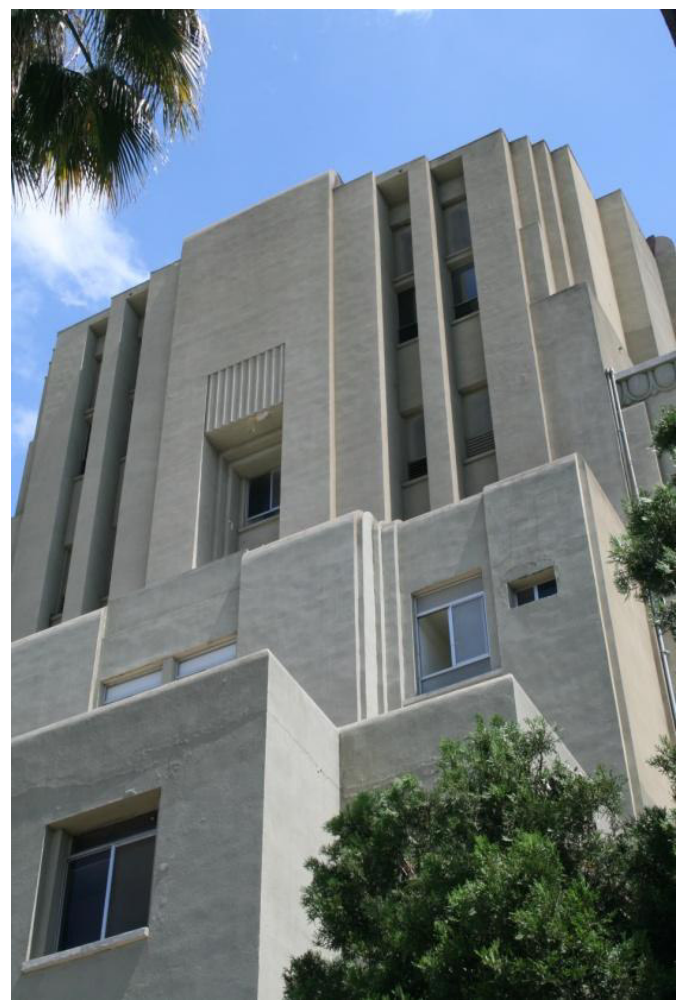

Detalle de la elevación de los tres cubos del cuerpo central. ${ }^{109}$

Por toda la fachada sur o principal, se incorpora frontalmente un cuerpo cubico de dos niveles, lo que incrementa el armazón de poliedros. Los muros de las crujías que abarcan cinco niveles, sólo se ornan con aplanados verticales que van colocados en medio de las ventanas rectangulares y en un plano hacia delante en relación con la superficie. En el cerramiento del muro en el quinto nivel lo hace por medio de arcos de medio punto, que en la parte derecha fueron cerrados. Tanto los aplanados como las ventanas favorecen la verticalidad ascendente del edificio. En algunas partes se conservan aún unas molduras con

\footnotetext{
${ }^{109}$ Foto: Fernando Lisceur, CONARTE.
} 
gotas elípticas como en las cornisas del segundo nivel del cuerpo frontal adjunto y del quinto nivel de los muros de las crujías.

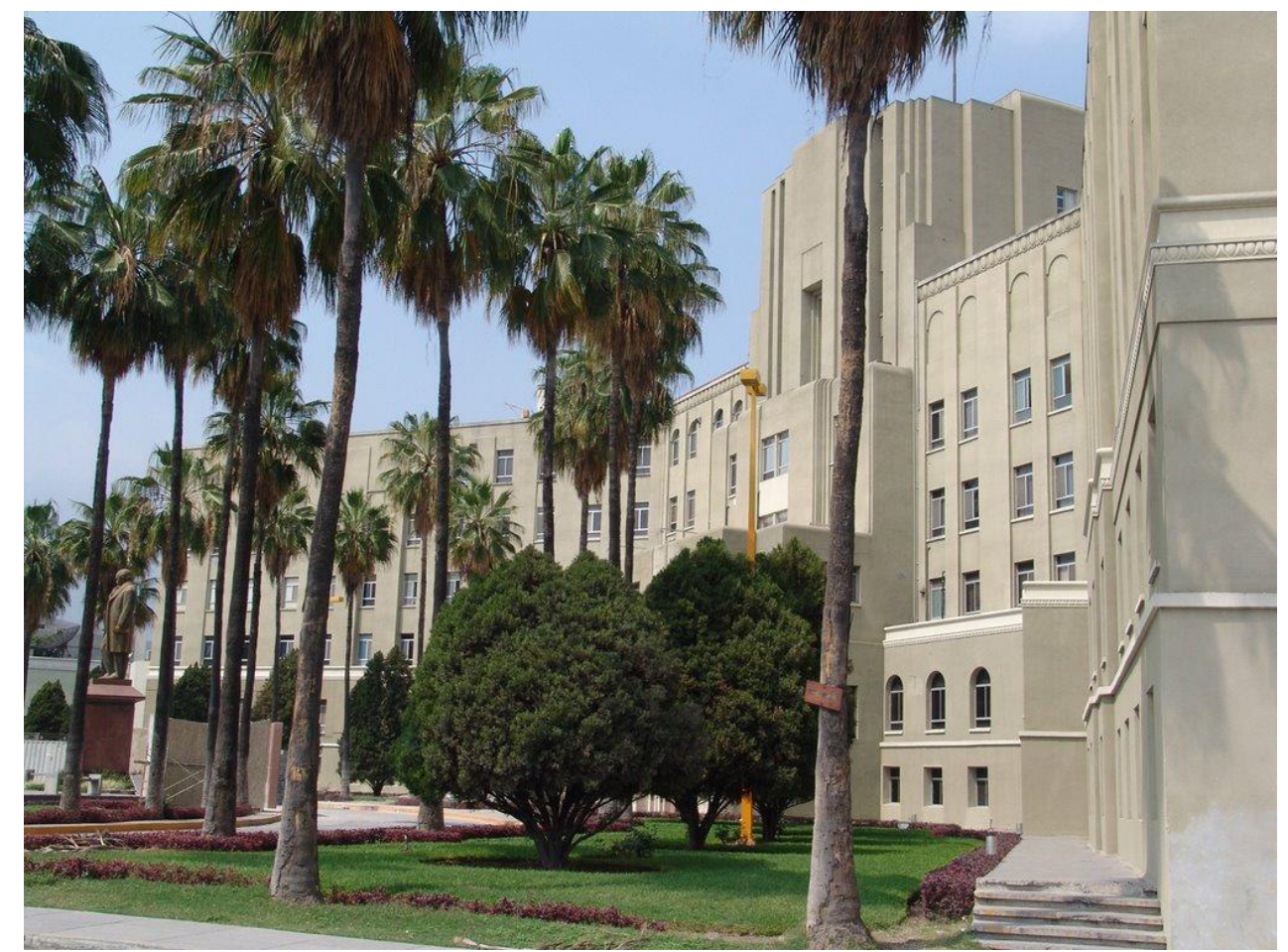

Vista de la fachada principal desde el lado suroriente desde donde se ve el cuerpo adherido de dos niveles y las molduras de las cornisas con decoración de gotas elípticas. ${ }^{110}$

En el vestíbulo del hospital sólo se conservan como elementos Art Déco un par de candiles, ambos ochavados y de tres niveles, cuyo grosor va de mayor a menor de arriba hacia abajo. El diseño prismático y geométrico es típicamente del que se utilizaba en los años del Déco. Uno lleva cristales verde opaco, ornado con botones dorados y en la parte superior unas decoraciones de tipo hindú, lo cual se usó como uno de esos motivos exóticos de los años de entreguerras. El otro está integrado por cristales blanco opaco y contiene por ornato, además de los botones dorados, una especie de guirnaldas entre rectángulos horizontales.

\footnotetext{
${ }^{110}$ Foto: Fernando Lisceur, CONARTE.
} 


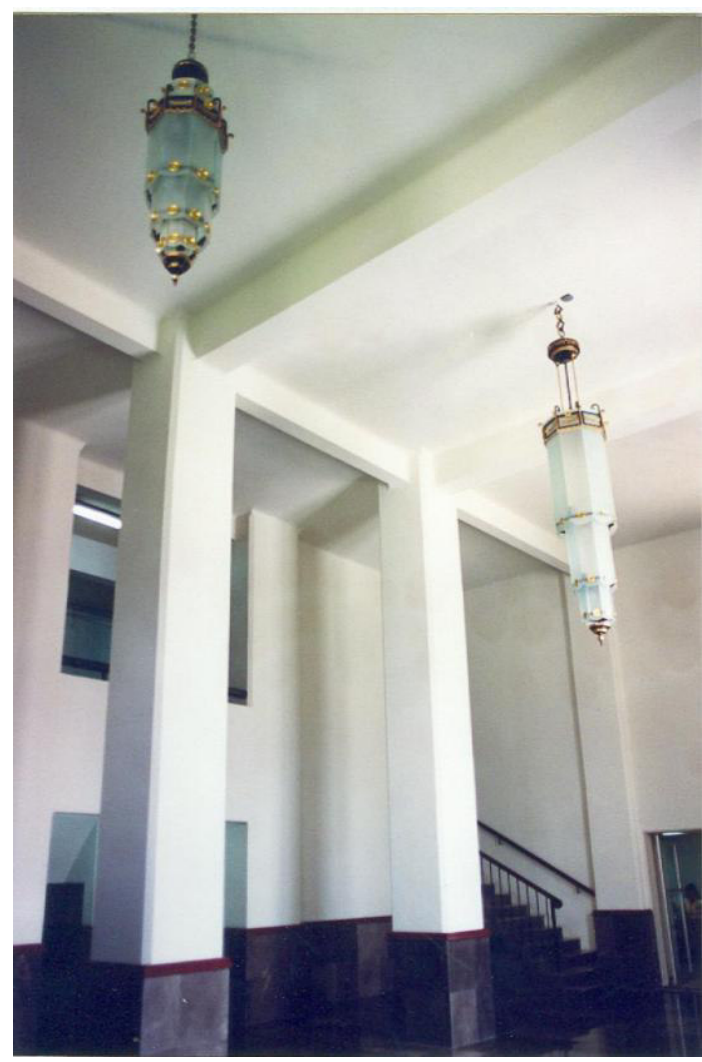

Candiles del vestíbulo.

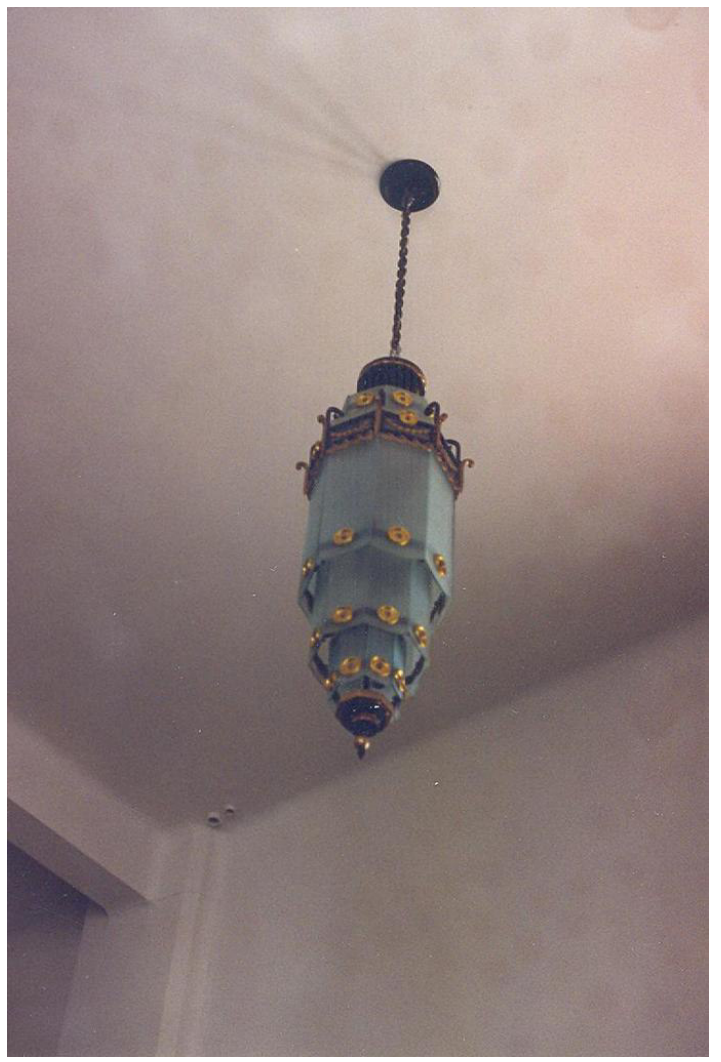

Candil izquierdo.

La puerta de acceso al vestíbulo tanto sus lienzos como ventanas geminadas están trabajadas en madera de cedro. El diseño lleva un trazo de recortes escalonados dentro de unos hexágonos de fuerte influjo prehispánico, especialmente de los ornatos del prototipo azteca o mexica, los cuales fueron bastante utilizados tanto en el extranjero como en México, e inclusive, fue tal su expansión que a objetos, muebles, gráficos o construcciones de esta naturaleza le llamaban Estilo Azteca, especialmente en los Estados Unidos. En la unión de las ventanas se configura un parteluz que a manera de columna tanto en lo que correspondería al zócalo como al capitel se conforma un escalonamiento, que en la caso del zócalo simula una plataforma piramidal de tres niveles. Los recortes de la puerta y el abocinamiento del marco a través de los perfiles angulares, logran enfatizar el geometrismo de esta parte del edificio. Dentro del Art Déco, esta puerta pertenece al Zigzag, por el efecto causado por los recortes, pero nosotros agregaríamos, como en el Palacio Federal, que también es un Déco Nacionalista Prehispanista. 


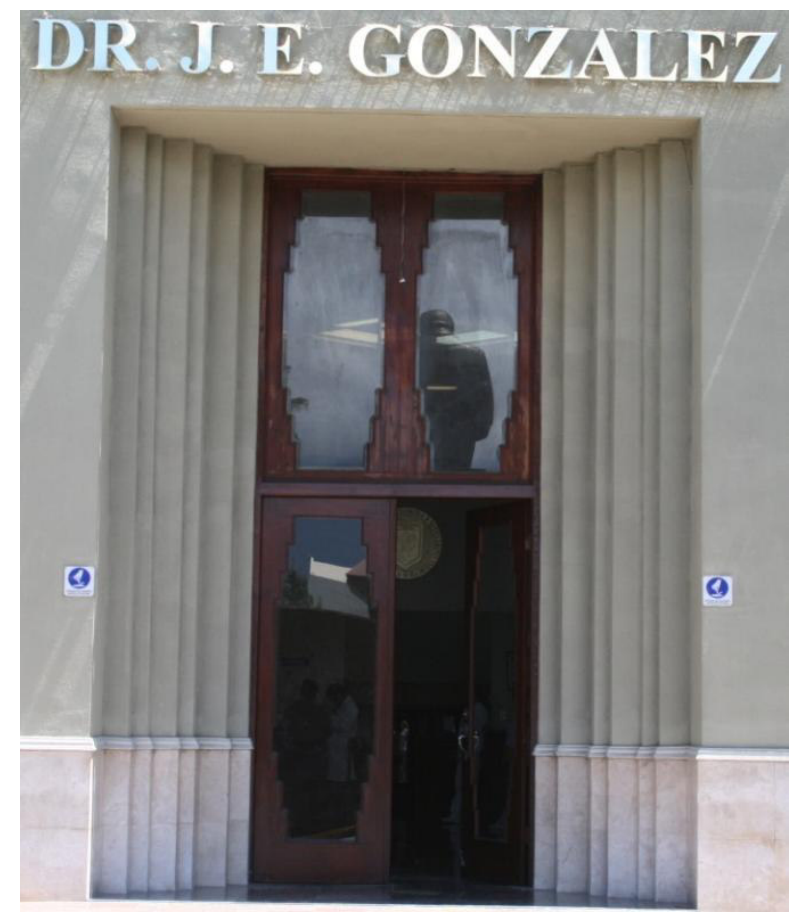

Puerta de la entrada principal.

Como hemos analizado, el Hospital Civil en muchas de sus partes ostenta varios atributos estilísticos del Art Déco, especialmente del Zigzag, y se encuentra dentro de la Tendencia Geometrista. Sin embargo, debido a diversas ampliaciones y remodelaciones realizadas desde 2001 a 2009, la parte posterior se ha perdido por completo, aunque el edificio en el exterior aún mantiene los elementos estéticos de tipo Art Déco, lo mismo que en la puerta de entrada al vestíbulo y las lámparas del techo. 


\subsubsection{ARQUITECTURA DEL OCIO}

\section{a. Cine Lírico}

El Cine Lírico se ubica en la calzada Madero 137 poniente, entre la calle Colegio Civil y la avenida Juárez. Su orientación es hacia el sur.

Inicialmente fue construido como teatro y su propietario era el señor Mariano Militello. Entre 1940 y 1942 el teatro sufrió una reconstrucción casi total, la cual fue obra de diseño y construcción del ingeniero Arturo Olivero Cedeño. ${ }^{111}$ De esta manera con sus nuevas instalaciones el teatro continuó con sus operaciones, pero en 1944 cuando fue adquirido por Atracciones Mundiales ${ }^{112}$ fue utilizado como sala cinematográfica hasta su decadencia en la década de 1990, cuando se le instaló un segundo piso para integrar otra sala de cine y se perdió su interesante diseño y decoración original. Desde 1997 el edificio se encuentra abandonado y cerrado el acceso al público.

Podríamos decir que el cambio de giro de teatro a cine de este espacio del espectáculo se debió a que unas cuantas calles y sobre la misma calzada Madero se empezó a construir en 1938 un cine-teatro que llevó el nombre de Florida, en los terrenos de una carpa que fue propiedad del señor Carlos Landeros, quien incursionó como director y guionista allá por 1921 con la cinta Landeros nos ha tomado el pelo. ${ }^{113}$ En 1940 el Florida abrió sus puertas y era una competencia para el Lírico, ya que ambas salas se encontraban por una de las calles más transitadas de la ciudad, con camellón central, muchos comercios y que era disfrutada como paseo familiar y dominical. Igual que muchos otros cines, el Florida cerró sus puertas en 1994.

En junio de 2007 la techumbre de madera fue reparada y sustituida con estructura metálica y de lámina, además de ser retiradas las butacas y alfombras para evitar algún incendio, pero desafortunadamente no se ha hecho ninguna otra acción por conservarlo. ${ }^{114}$

\footnotetext{
${ }^{111}$ Juan Manuel Casas García, Rosana Covarrubias Mijares, Edna Mayela Peza Ramírez, Op. Cit., p. 181.

112 "La evolución del cine a través de los años", Perfil, Monterrey, N.L., marzo 2006 Prepa Tec Campus Valle Alto, http://prepatec.mty.itesm.mx/perfil_online

${ }^{113}$ Sepúlveda, Nazario, "El cine en Monterrey", La Enciclopedia de Monterey. Tomo I. Una ciudad con memoria, Monterrey, N.L., Milenio, Multimedios, 2008, 2ª., ed., p. 382.

${ }^{114}$ Gustavo Mendoza Lemus, "Trabajan sobre techado del Lírico", El Porvenir, Monterrey, N.L., miércoles 27 de junio de 2007, http://www.elporvenir.com.mx/notas.asp?nota_id=142084
} 


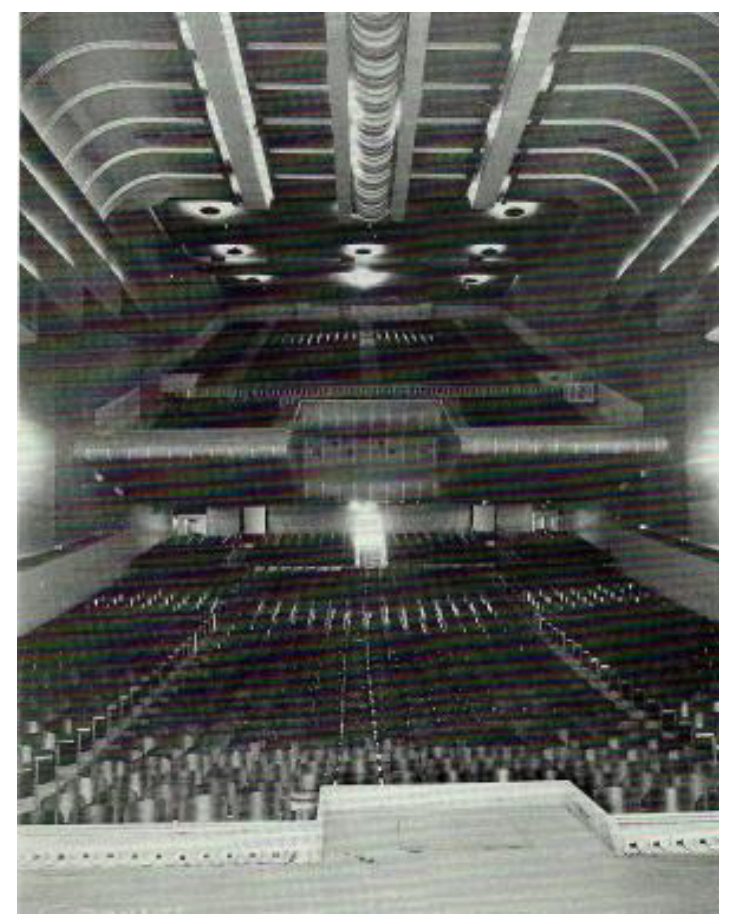

Interior hacia 1950.115

En junio de 2007 la techumbre de madera fue reparada y sustituida con estructura metálica y de lámina, además de ser retiradas las butacas y alfombras para evitar algún incendio, pero desafortunadamente no se ha hecho ninguna otra acción por conservarlo. ${ }^{116}$

$\mathrm{El}$ acceso se forma con un pórtico con cuatro columnas estriadas con capitel dórico y un nártex que daba paso a la triple entrada. Aún se conserva parte del letrero de "Cines Lírico 1 y 2 ".

El resto de la fachada que se desplanta a nivel de las puertas de entrada se compone de un lienzo saliente con tres rehundidos rectangulares que se van remetiendo a través de tres de perfiles angulosos, los cuales en la parte superior ostentan una moldura a manera de capitel con lo que se consigue el efecto de un recuadro. Dicha moldura a la vez se conecta con una línea horizontal que se extiende en el mismo nivel a través de toda la fachada. El remate en la parte superior es un techo de dos aguas, en cuyo vértice presenta una decoración de tipo floral y se forma un tímpano entre el espacio del remate y el límite de los tres recuadros. Dos lienzos, uno de cada lado están remetidos y van decorados en la

\footnotetext{
${ }^{115}$ Francisco H. Alfaro y Alejandro Ochoa, La República de los cines, México, Clio, 1998, p. 50.

${ }^{116}$ Gustavo Mendoza Lemus, "Trabajan sobre techado del Lírico", El Porvenir, Monterrey, N.L., miércoles 27 de junio de 2007, http://www.elporvenir.com.mx/notas.asp?nota_id=142084
} 
parte superior con unas ligeras molduras horizontales que demarcan un espacio como si formaran el capitel de una pilastra. En la parte superior, una moldura decora todo el remate.

Las ventanas que se aprecian a medio nivel de los tres remetimientos fueron abiertas en 1990 cuando se instaló el segundo piso para una segunda sala.

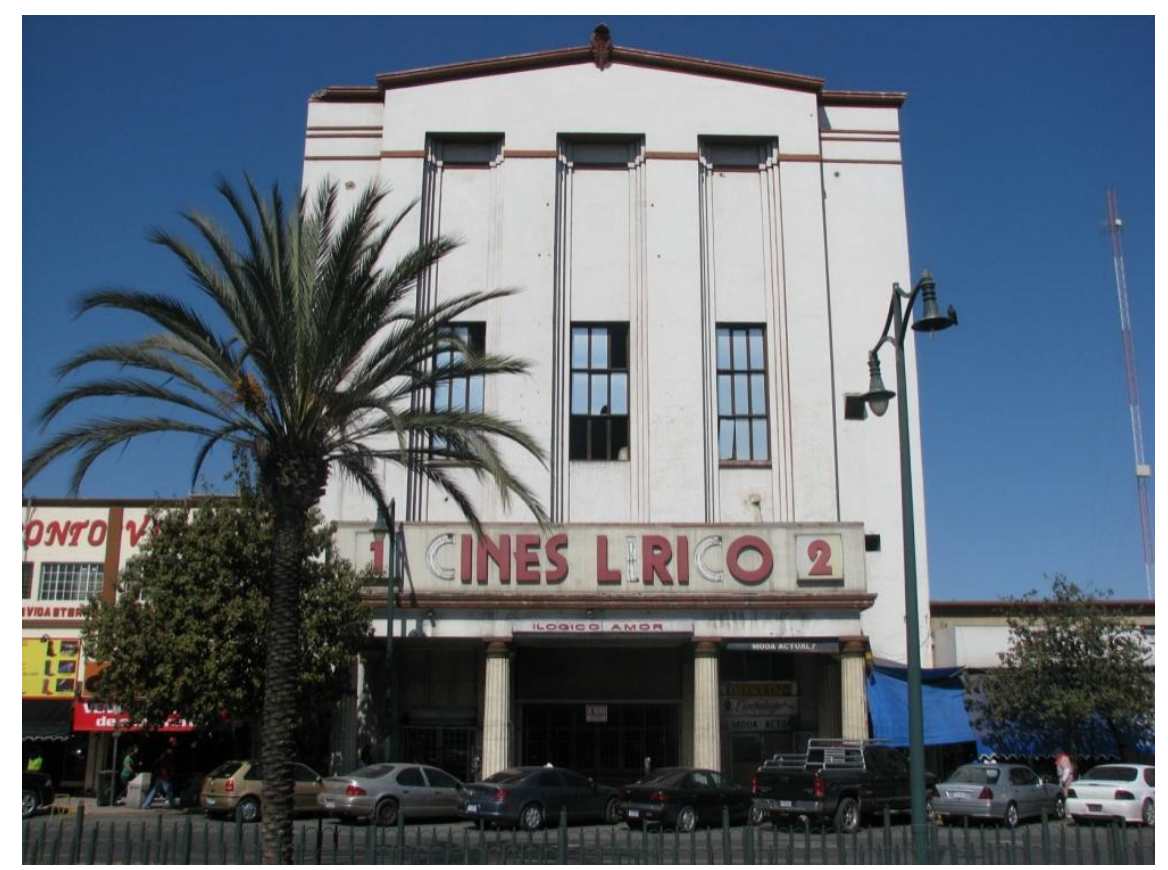

Estado actual del Cine Lírico.

El interior gozaba de la máxima modernidad de la época, teniendo una galería alta. La gran sala se iluminaba con cuatro grandes cubos escalonados empotrados en la pared; de la parte superior salían las ráfagas de la iluminación, la cual se completaba en el plafón que se acoplaba a las paredes curvilíneamente. Tres canales en el techo sostenían las luminarias y el del centro resaltaba por llevar por ornato medios círculos de colores que con bandas horizontales que cruzaban perpendicularmente se completaba toda una decoración elegante y moderna de tipo Streamline. Todo eso desapareció con la instalación de un segundo piso para acondicionar otra sala.

El Cine Lírico es un ejemplo del Déco Neoclásico Moderno, pues con las columnas dóricas, el nártex, la terminación en dos aguas se crea la apariencia de un templo clásico, además de tener la composición geométrica entre rectángulos y un ángulo obtuso, acentúa el geometrismo mezclado con elementos clásicos. 
Solamente la fachada es lo que conserva este edificio de la decoración Art Déco, pues el interior está completamente desmontado y todo el inmueble se encuentra en un estado ruinoso, a pesar de estar en una zona comercial.

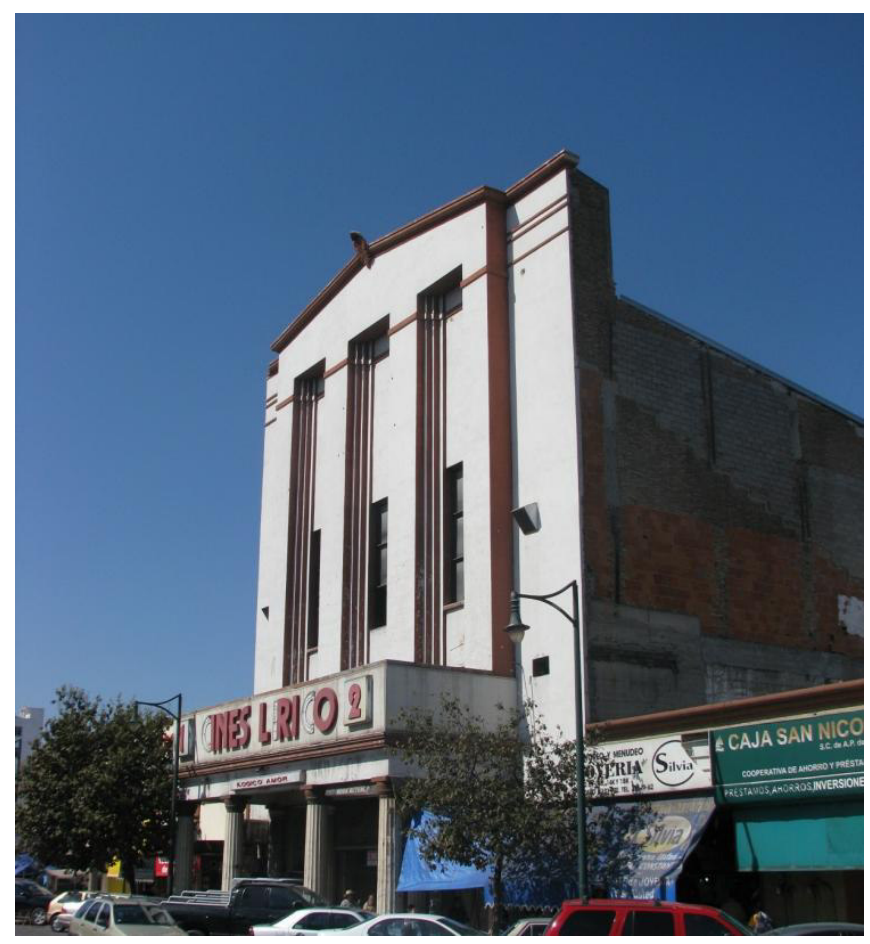

La fachada es lo único que se conserva de estilo Art Déco Neoclásico Moderno.

\section{b. Cine Encanto}

El edificio que ocupó el cine Encanto se ubica en las calles Julián Villagrán, esquina con Isaac Garza con orientación hacia el oriente en el centro de Monterrey.

Se construyó entre 1941 a 1942, siendo autor del diseño el ingeniero-arquitecto Luis Fernando Flores "uno de los más prolífico diseñadores de su tiempo", 117 quien a la vez supervisó la construcción. ${ }^{118} \mathrm{El}$ inmueble gozaba de una soberbia y moderna elegancia tanto en su exterior como en el interior, tal como eran los cines de la época. Como en el país se estaba desarrollando los que se ha llamado la Época de Oro, muchas salas cinematográficas se abrían en las principales ciudades, tal como lo explica el crítico

\footnotetext{
${ }^{117}$ Juan Ignacio Barragán, Enrique Díaz Díaz, Arquitectos del Noreste. Monterrey, N.L., Del Noreste, Edición Especial, Nos. 10-11-12, Urbis Internacional, 1992, p. 26.

${ }^{118}$ Juan Manuel Casas García, Rosana Covarrubias Mijares, Edna Mayela Peza Ramírez, Op. Cit., p. 177.
} 
Nazario Sepúlveda: "En cines grandes y nuevos que eran inaugurados en Monterrey en los primeros años de la década de 1940, como el Florida, el Encanto y el Elizondo, los regiomontanos llenaban las salas para conocer y disfrutar los filmes de distintos géneros que realizaba en cine nacional". ${ }^{119}$

Como un dato anecdótico de la época, en el acceso del cine Encanto se empezaron a vender unos productos elaborados con masa para tortillas. Eran unos pequeños recuadros fritos en aceite y aderezados con sal que se producían en una tortillería cercana al cine. Le empezaron a llamar "Conchitas Encanto" por parecer pequeñas conchas de mar y por venderse en la sala de cine. Fue tal el éxito que años más tarde se comercializaron y ya para 1957 tenía marca patentada. Hasta la fecha es una de las botanas más consumidas en la ciudad y pertenecientes a una gran empresa de alimentos.

Como se puede apreciar en la fotografía del año de 1942, en el espacio de acceso una pilastra con casetones ayuda al sostenimiento de una enorme marquesina que se curvea en la esquina para prolongarse por la pared lateral; entre dos molduraciones, una banda estriada recorre la marquesina dándole un efecto de dinamismo.

Arriba de la marquesina, hacia la derecha se empotraba el letrero, cuyo extremo izquierdo se conectaba hacia el muro con cinco hileras curvas de casetones empotrados dentro de molduras horizontales y que se prolongaban ascendentemente en mismo número hacia arriba, pero nada más en dos secciones; en el otro extremo, el mismo motivo decorativo se repite haciendo juego con la curvatura de la marquesina.

Un prisma rectangular paralelepípedo dividido en seis secciones conformaba la parte principal de la fachada. Las cuatro primeras partes eran lienzos separados por una ligera moldura rectangular; el quinto tramo se conformaba con amplias estrías rehundidas enmarcadas entre biseles, pero que del lado derecho las últimas tres estrían caían en dos tramos a manera de persianas verticales. Remata la fachada en un tramo completamente liso. La sección derecha del prisma se articula con el llamativo letrero que describiremos posteriormente y la cara lateral izquierda, además de llevar la misma composición de la parte frontal, iba adornada con tres molduras verticales, la del centro en color gris y las otras dos en blanco, resguardadas en el tramo cuatro por dos bandas a manera de jambas.

\footnotetext{
${ }^{119}$ Sepúlveda, Nazario, "El cine en Monterrey", La Enciclopedia de Monterey. Tomo I. Una ciudad con memoria, Monterrey, N.L., Milenio, Multimedios, 2008, 2a ., ed., p. 384.
} 
El ensamble de elementos decorativos de este prisma que conformaba la fachada era de un geometrismo extraordinario.

Otro prisma rectangular de más altura se ensambla perpendicularmente y forma parte de la fachada lateral sur, pero la parte frontal se conecta a la fachada principal formando un enlace de cubos. El fragmento frontal ostentaba unas decoraciones en placas de cobre insertas en un espacio en forma de letra ele invertida, las cuales aludían a diseños escenográficos. Continuaba en la fachada lateral un muro de menor altura, en cuya parte superior había dos pares de aleros unidos por medio de cuatro pequeñas columnas lisa y un tercer muro de menor altura que el anterior, rematado por cinco aleros. Todo el conjunto de la fachada lateral producía el efecto visual del dinamismo a través del escalonamiento y de una semántica aerodinámica.

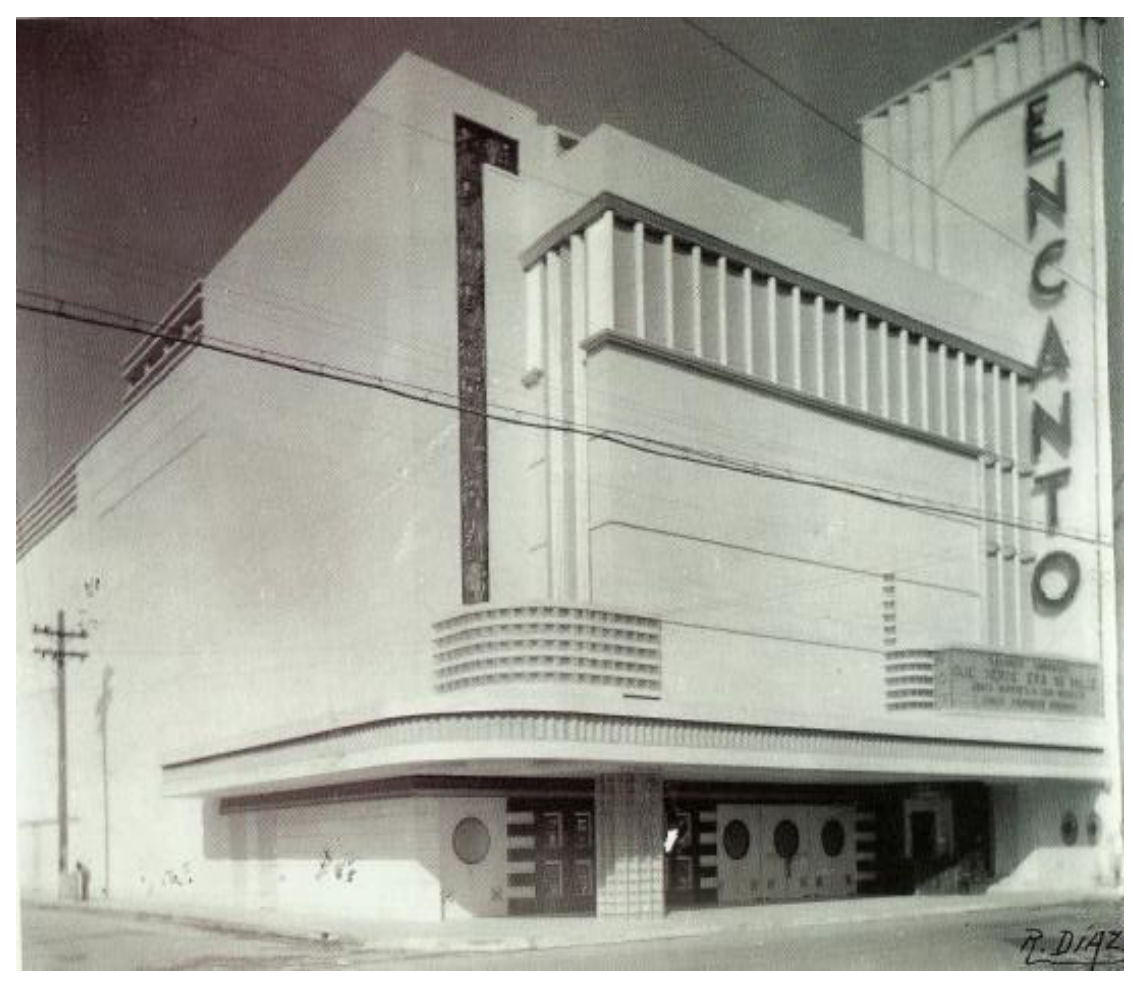

El cine recién inaugurado en $1942 .{ }^{120}$

Desafortunadamente toda esta espléndida decoración de tipo Déco Streamline se perdió desde una remodelación realizada en 1958 cuando el cine cambió de propietarios y

\footnotetext{
${ }^{120}$ Juan Manuel Casas García, Rosana Covarrubias Mijares, Edna Mayela Peza Ramírez, Op. Cit., p. 176.
} 
fue el mismo arquitecto Flores quien se encargó de la limpieza de los elementos decorativos. ${ }^{121}$

Lo único que se conservó de esa restauración y del posterior deterioro que el inmueble ha sufrido desde finales de la década de 1980 es el letrero. Empotrado perpendicularmente sobre el lado derecho de la fachada principal, es un prisma rectangular que se compone de dos placas unidas. Hacia el frente una moldura que se curvea en la parte superior resguarda el letrero. En la parte superior y hacia atrás, en ambos lados se acoplan a manera de persiana unas bandas en posición vertical, creando el efecto visual del Zigzag para terminar en la parte superior con una moldura. Es de esos letreros que tanto se utilizaron en los palacios del espectáculo cinematográfico y que hicieron toda una época, que servían de iluminación para las calles y era un referente visual. Este letrero en su posición vertical y lateral, así como en la moldura curva se asemeja al Orinda Theater también del año de 1941, obra del arquitecto Alexander Aimwell Cantin (1876-1964), autor de múltiples obras en la zona de Pacífico californiano de San Francisco y alrededores, muchas bien conservadas y catalogadas como Art Déco Streamline. ${ }^{122}$

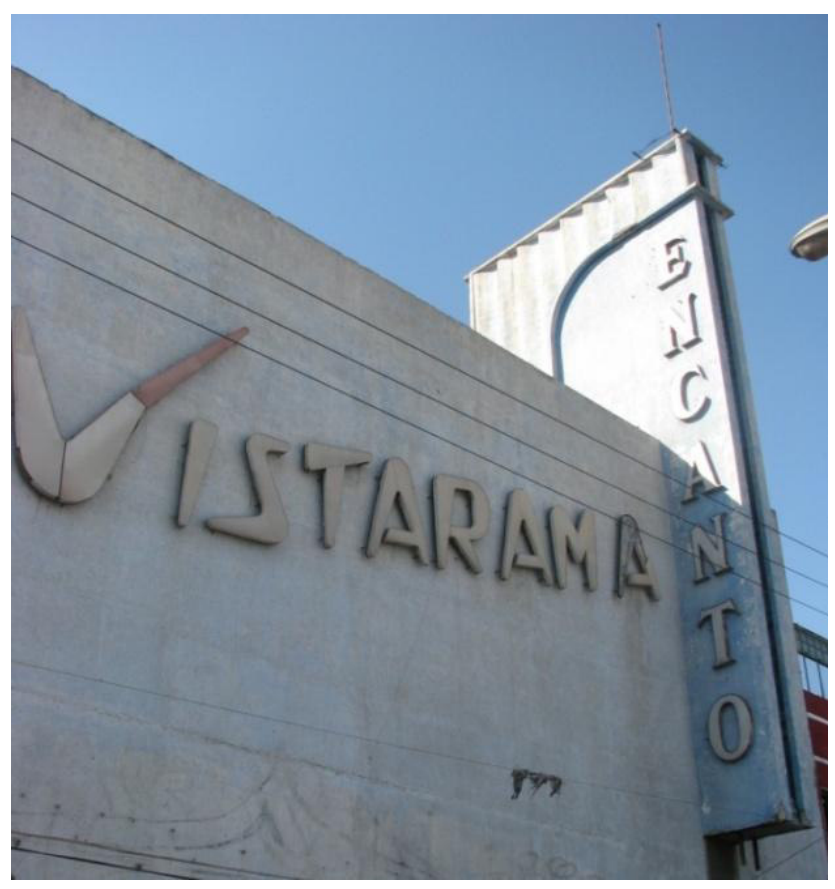

Letrero del cine en la actualidad.

\footnotetext{
121 Ídem.

${ }^{122}$ Susan A. Sternau, ART DECO. Flights of artistic fancy, New York, Smithmark, 1997, p. 100.
} 
Sin duda alguna el autor del edificio estaba muy bien enterado de los lenguajes modernos del Bauhaus, De Stijl y del Constructivismo ruso, ya que el ensamble de cuerpos geométricos, en un ejercicio de abstracción cúbica, es el resultado que muy a la manera de los trabajos de los constructivistas logró el arquitecto Flores en el Cine Encanto. Entre muchos otros ejemplos, nos puede remitir al diseño del arquitecto ruso Boris Velikovski que hiciera en 1928 para la sede del Centrosoyus de Moscú. ${ }^{123}$ Vielikovski, quien fue miembro de la OSA (Asociación de Arquitectos Contemporáneos), uno de los primeros movimientos del constructivismo soviético, busca integrar dentro de una arquitectura utilitarista formas geométricas cúbicas, para obtener grandes espacios y un lenguaje moderno de la mano del diseño industrial e ingenieril. El parecido en la forma de integrar el letrero del Centrosoyus y del Cine Encanto nos habla claramente de las influencias acogidas por el arquitecto Flores.

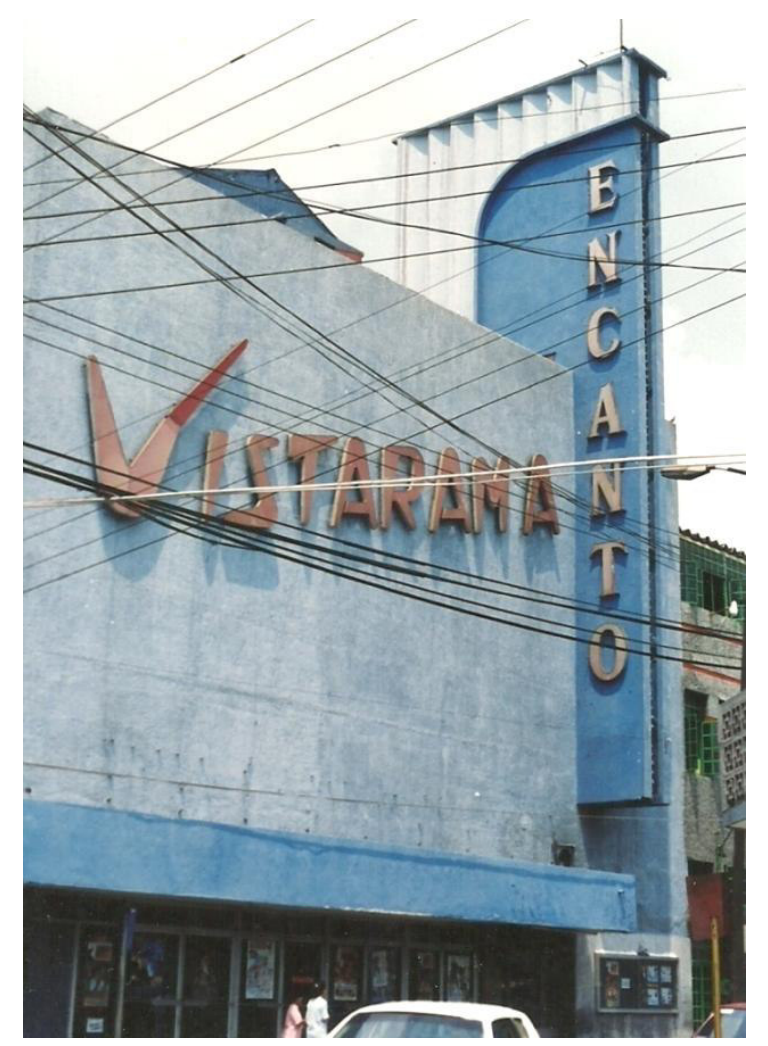

El cine en sus últimos años de funcionamiento en 1998.124

\footnotetext{
${ }^{123}$ Vittorio de Feo, La arquitectura en la U.R.S.S. 1917-1936, Madrid, Alianza Editorial, 1979, p. 177.

${ }^{124}$ Foto: Mónica Barreda Ortiz y Blanca Rodríguez Güemes.
} 
El moderno lenguaje de un Déco Streamline había desaparecido con la mencionada restauración de 1958, sin embargo aún se conservaban algunos elementos, para quedarse como un ejemplo de la Tendencia Plasticista por el cerramiento de planos. Desde finales de los años 1980 el Cine Encanto cayó en un total abandono y descuido. Fueron tapadas sus entradas con block, le tumbaron la marquesina y el interior fue totalmente desmantelado para convertirlo en bodega. El inmueble queda como un vestigio de lo que fue una zona de entretenimiento donde hubieron a la vez otros cines y teatros.

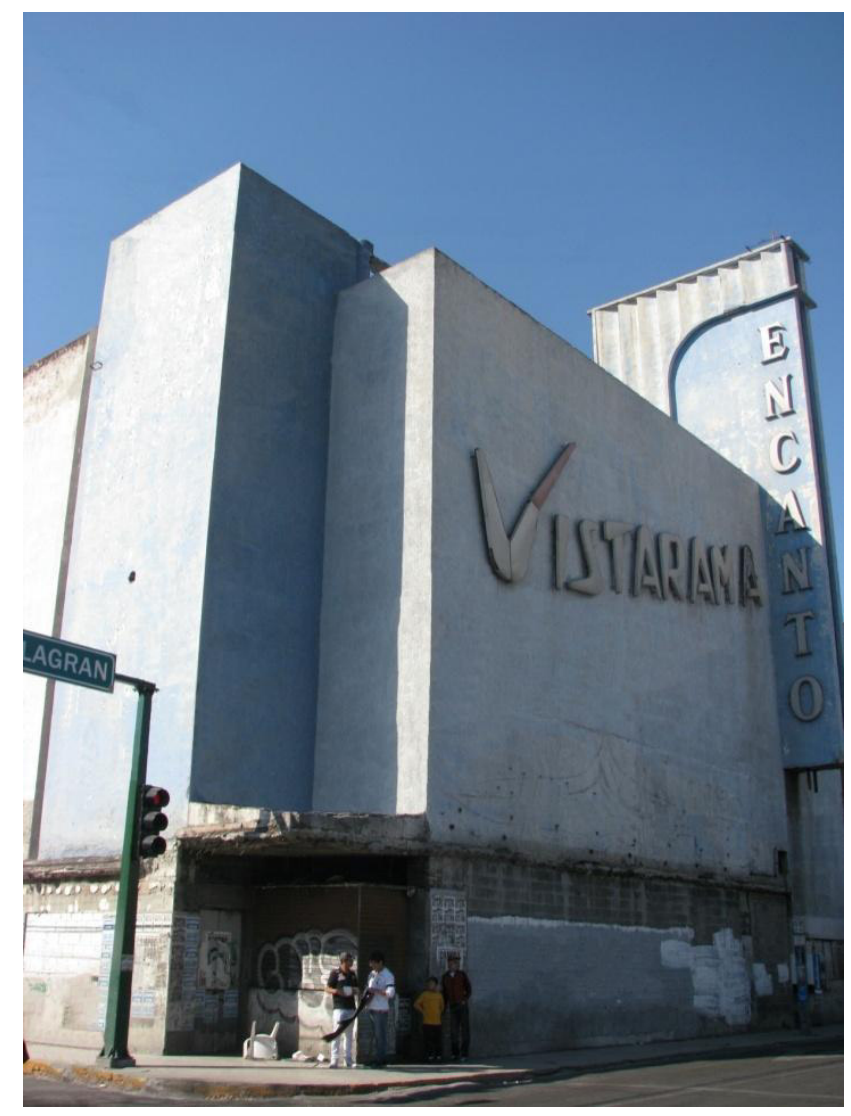

Estado actual del inmueble.

\section{c. Cine Monterrey}

El Cine Monterrey se localiza en la calle José Silvestre Aramberri y la privada José Marroquín Leal, con orientación hacia el suroeste y enfrente de la Alameda.

Su construcción se inició en 1946 bajo el diseño y supervisión de los autores del proyecto: el arquitecto Lisandro Peña Jr., (1910-1986) y el ingeniero Arturo Olivero 
Cedeño. ${ }^{125}$ El arquitecto Peña fue uno de los grandes maestros de la arquitectura en Monterrey. Su formación en Estados Unidos le permitió tener una visión muy amplia de los movimientos modernos en ese país, así como de las vanguardias europeas. Acuarelista, maestro universitario, músico de jazz y un apasionado de las manifestaciones culturales, sus trabajos abarcaron diversos estilos, pero siempre de excelente calidad, lo que el arquitecto Juan Ignacio Barragán describe así: "Si bien su obra mayor no posee un estilo definido, ésta se caracterizó por su potencia escenográfica, comparable a los mejores edificios historicistas norteamericanos de los años treinta. Se trataba del típico arquitecto artista que trabaja para ingenieros y constructoras; éstos lo contrataban por su creatividad y la calidad de presentación de sus proyectos y perspectivas". ${ }^{126}$

A un año de iniciadas las obras, este nuevo palacio del espectáculo fue inaugurado en diciembre de 1947 con una función de gala, convirtiéndose por cerca de diez años en el cine más importante de la ciudad. El propietario de este cine era el empresario norteamericano William Jenkins, quien tenía varias salas en la ciudad de México, el día de la inauguración, en su discurso expresó que se abrirían próximamente dos cines más en Monterrey: el Cine Aracely y el Cine Reforma.

Fue tan trascendental la apertura de esta sala, que la primera función estelar fue anunciada con la presencia de importantes personalidades del medio artístico tanto nacional como local y se presentó en estreno la cinta Soy un prófugo del cómico Mario Moreno "Cantinflas" (1911-1993). Desde cuatro días antes se inició la venta de boletos para la inauguración que se dio el 19 de diciembre del citado año de 1947, en una época en que el país transitaba del gobierno militar, hacia el gobierno civil, en la inmediata postguerra y con una fuerte influencia del "american way of life", que entre otras cosas, se imitaba a través de estos palacios cinematográficos.

Para esos años, los cuarenta, ya era una costumbre en la ciudad, como en otras tantas del país, el ir bien vestidos para asistir al cine y todavía más a uno tan glamuroso como el Monterrey. Nazario Sepúlveda comenta aquel fenómeno social: "Ir al cine en esa época significaban para los regiomontanos, un ritual de elegancia, educación y buen gusto. A las salas importantes, a los estrenos, se asistía de saco, corbata y sombrero y las damas

\footnotetext{
125 Juan Manuel Casas García, Rosana Covarrubias Mijares, Edna Mayela Peza Ramírez, Op. Cit., p. 183.

${ }^{126}$ Juan Ignacio Barragán, Enrique Díaz Díaz, Arquitectos del Noreste. Monterrey, N.L., Del Noreste, Edición Especial, Nos. 10-11-12, Urbis Internacional, 1992, p. 27.
} 
llevaban sus mejores vestidos, sombreros y zapatos de tacón alto y medias de nylon, según la moda de estos tiempos." 127

La ubicación del cine era ideal para el esparcimiento familiar, ya que al encontrarse enfrente de la Alameda, a la vez servía de paseo por la zona. Así funcionó por cerca de 25 años, pues en la década de los años setenta, el excesivo tráfico, la aparición de nuevas salas cinematográficas y el decaimiento de la zona hicieron que el Cine Monterrey dejara de ser un centro de atracción de primera instancia.

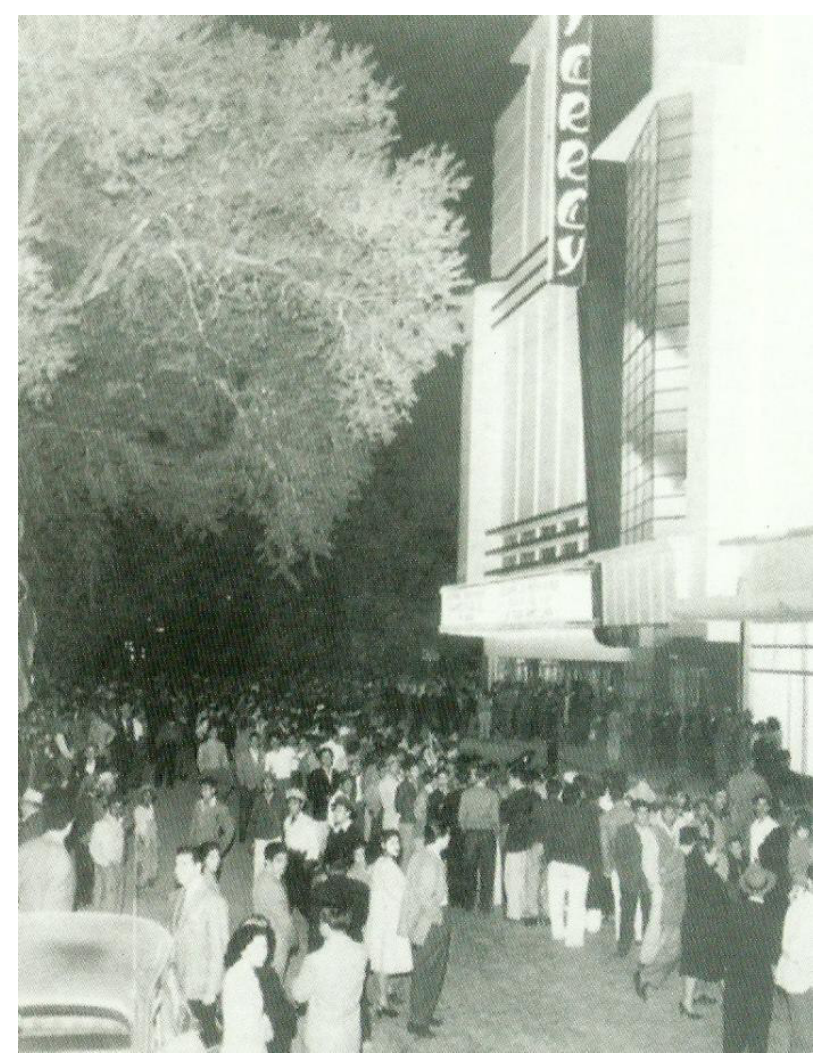

El cine hacia 1950 en una función nocturna. ${ }^{128}$

Como otros tantos inmuebles este centro cinematográfico fue quedando en desuso a finales de las década de 1980 y cerrado definitivamente en 1992. Tuvo en su interior una capacidad para más de cuatro mil espectadores, en tres niveles, tenía en tres niveles: luneta,

\footnotetext{
${ }^{127}$ Sepúlveda, Nazario, "El cine en Monterrey", La Enciclopedia de Monterey. Tomo I. Una ciudad con memoria, Monterrey, N.L., Milenio, Multimedios, 2008, 2a., ed., pp. 38-384.

${ }^{128}$ Foto en: Juan Manuel Casas García, Rosana Covarrubias Mijares, Edna Mayela Peza Ramírez, Op. Cit., p. 182.
} 
dos mil ciento cincuenta butacas; balcón, mil trescientas y anfiteatro, mil doscientas. Fue brutalmente destruido en 2004 para cederlo a comerciantes ambulantes y ahora es un estacionamiento, conservándose solamente la fachada en total abandono.

Durante un tiempo, entre 2011 y 2013 se instalaron algunos comercios informales en lo que fue el lobby, con lo que se destruyó todavía más lo poco que se conservaba de decoración Art Déco.

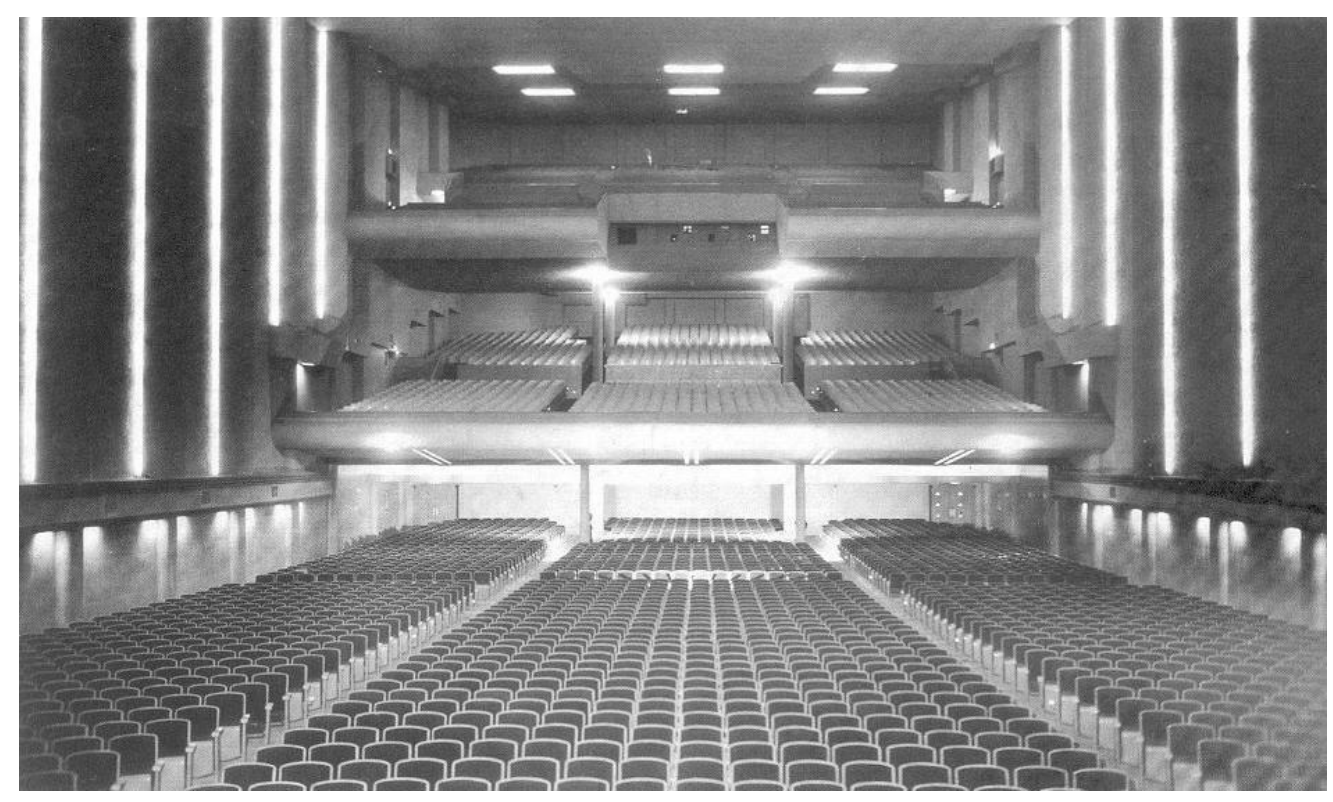

Interior del cine hacia 1950.129

Del exterior se conservan las fachadas en penosas condiciones, pero aún se pueden apreciar sus formas decorativas del Déco Streamline. El acceso se hacía por las puertas que se ubicaban en la esquina formada por la confluencia de las calles y por la calle Aramberri y arriba de éstas se distribuía el letrero luminoso. En la intersección de las calles Marroquín y Aramberri en lo que es la fachada principal se eleva un gran vano cubierto con cristales rectangulares detrás de los cuales se apreciaba la escalera que llevaban a la zona de balcón, en un segundo nivel, y al anfiteatro o galería en un tercer piso. Al estar iluminado el interior, proyectaba una gran luminosidad hacia el exterior. Para proteger este espacio se distribuyen unas jambas a cada lado, todo enmarcado por unas ligeras molduras que sobresalen levemente. Esta área es curva lo que le da un enfoque dinámico al edificio,

\footnotetext{
${ }^{129}$ Francisco H. Alfaro y Alejandro Ocho, La República de los Cines, México, Clío, 1998, p. 31.
} 
lo cual se refuerza con seis secciones de paños verticales limpios de decoración, separados por molduras que se elevan y continúan por encima del vano para rematar con otra sección horizontal que se recorta a nivel del inicio de la jamba izquierda del vano central.

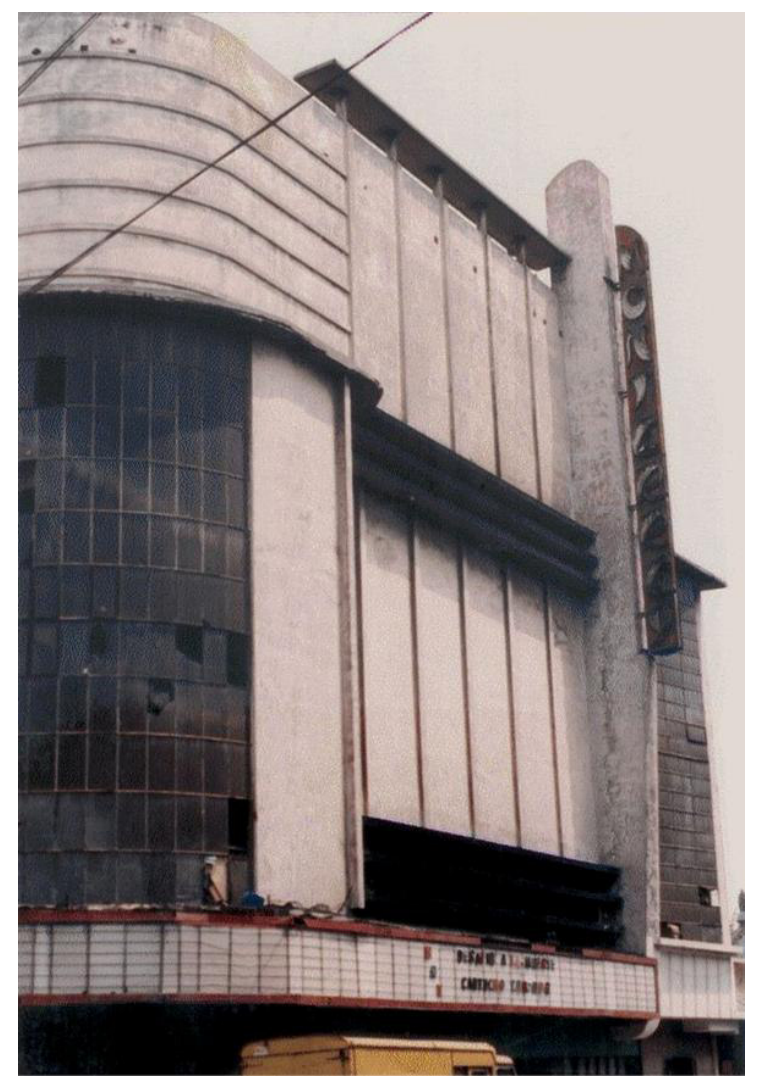

El cine aún abierto al público en 1992 pese al deterioro. Sólo funcionaba la luneta. ${ }^{130}$

Justo en la última sección de la fachada principal este recorte se conecta con una banda quebradiza que desciende en tres partes para adherirse con tres secciones horizontales, también carentes de ornatos, ubicadas al nivel de las tres cuartas partes de la fachada lateral izquierda o poniente sobre la privada José Marroquín Leal.

En lo que corresponde a la fachada sur que da a la calle Aramberri se inicia con tres aleros en color café, como se concibió desde el proyecto original, mismos que se repiten a en la parte media. Cinco secciones verticales sin decoración alguna separadas por molduras rematan en un alero en la parte superior, el cual se encuentra sostenido por igual número de

${ }^{130}$ Foto: Mónica Barrera Ortiz y Blanca Rodríguez Güemes. 
columnillas, con lo que se obtiene la sensación de espacialidad y aerodinamismo. Hacia el lado derecho en una banda vertical ensamblada perpendicularmente, recortada en la parte inferior y redondeada en la superior se inserta el letrero, como si fuera el timón de un barco o de un aeroplano, manufacturado en metal y que en sus tiempos de esplendor brillaba con sus intensas luces.

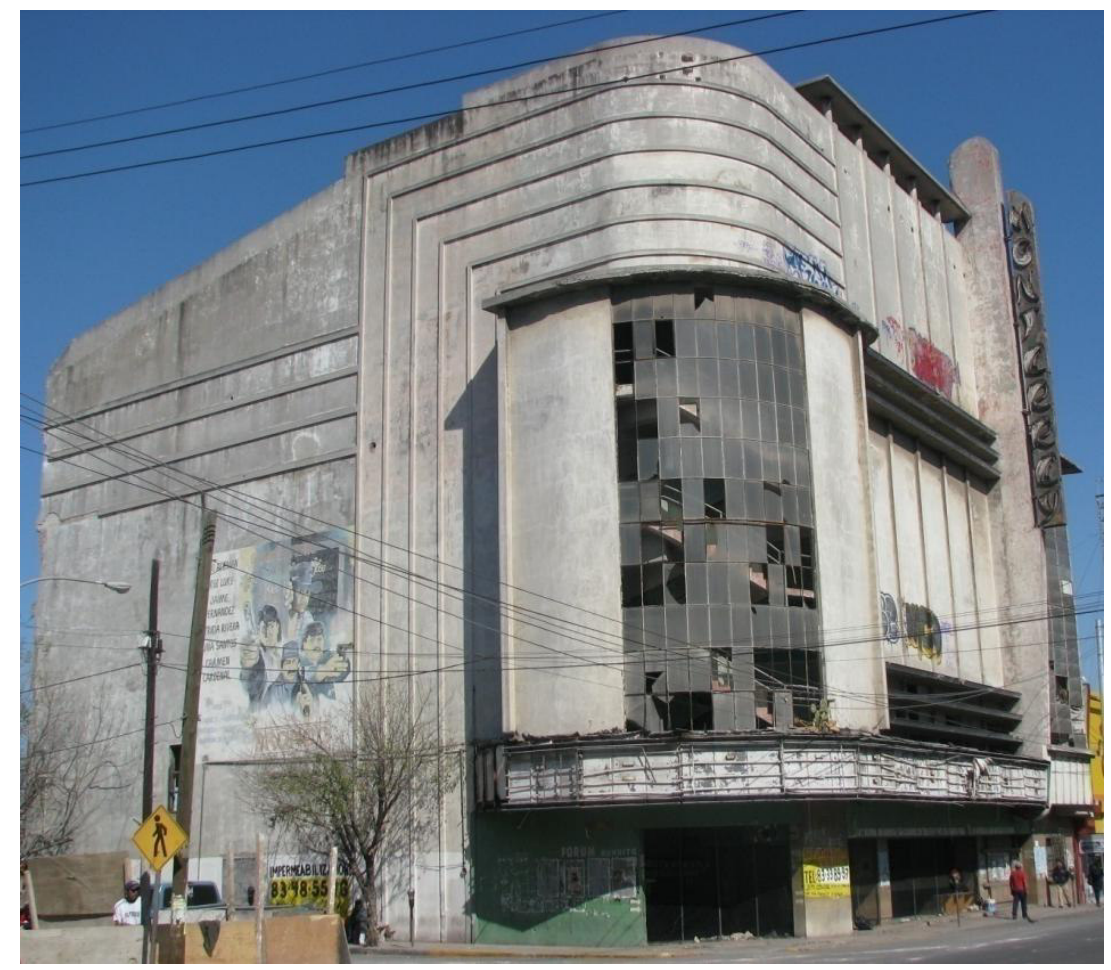

Condiciones actuales de la fachada.

Hacia la derecha del letrero se levanta otro ventanal con forma de un prisma irregular y coronado con una marquesina. Hacia arriba el muro se prolonga hasta el nivel de toda la fachada y remata de una manera recortada y angulosa.

El exterior del Cine Monterrey es toda una exposición del Déco Streamline, pues la limpieza de los paños de los muros, la conjunción de bandas, la curvatura de la fachada principal, los aleros y el acoplamiento de juegos geométricos, son formas que nos remiten a los diseños de aeroplanos o de formas aerodinámicas y del diseño industrial de esos años. 


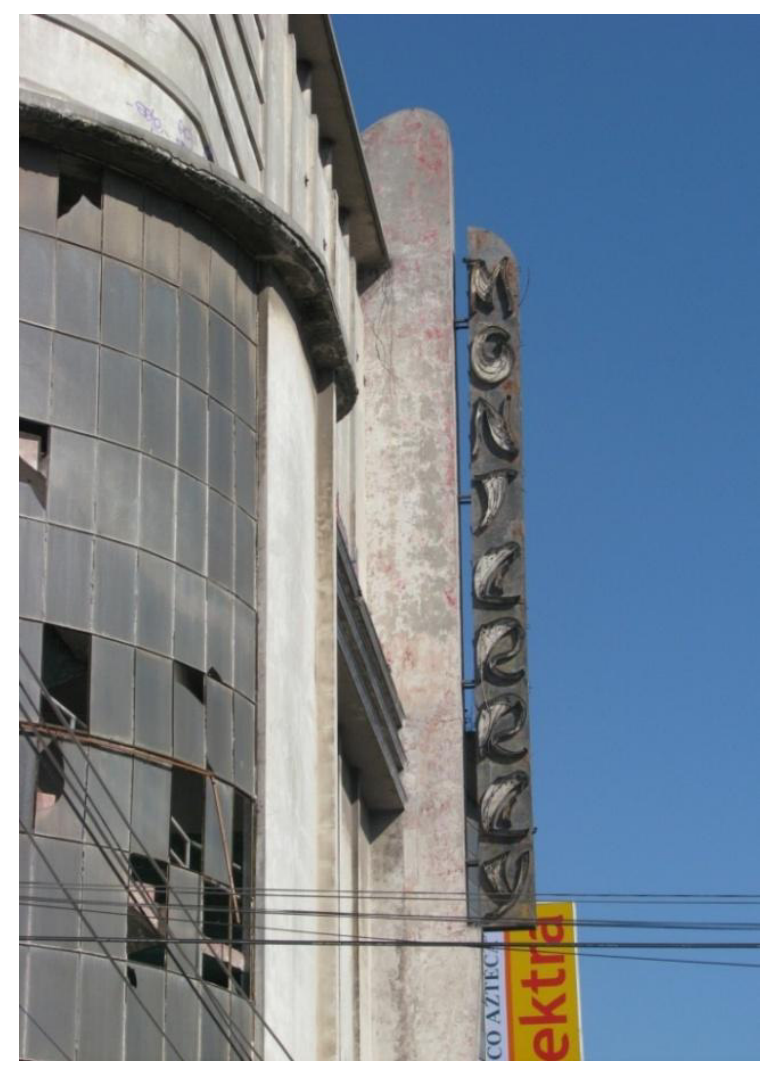

Letrero original.

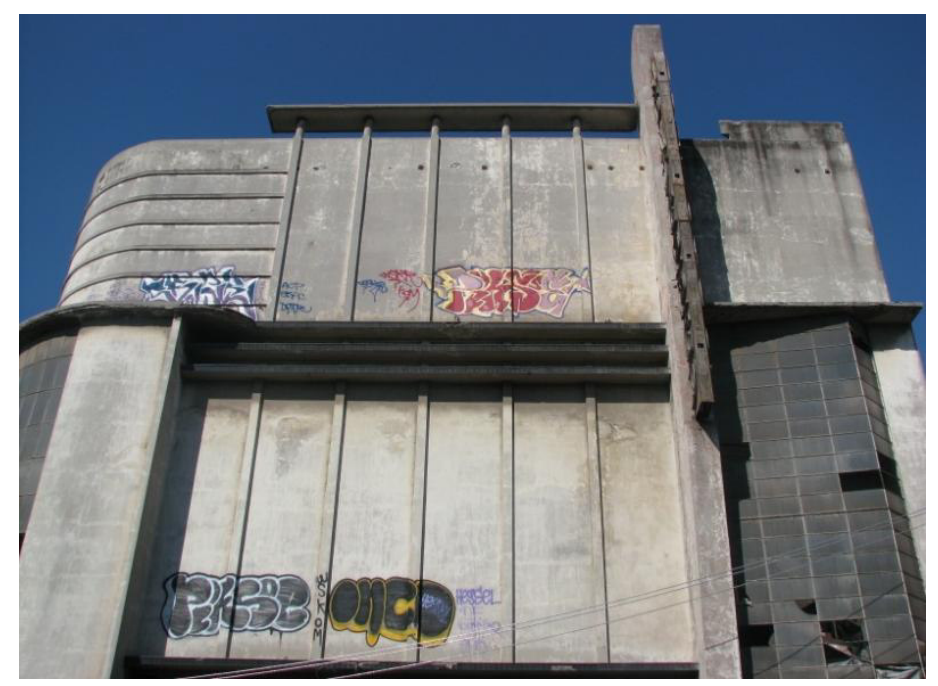

Fachada lateral sur. Del lado derecho está el ventanal en forma de prisma irregular.

En el interior aún se conservan algo de las decoraciones del destruido vestíbulo: cuatro aleros escalonados de mayor a menor desde el nivel del techo y en diferentes 
colores daban toda una movilidad visual, lo que se acentuaba al acoplarse curvadamente en diferentes partes, como era en la taquilla semicilíndrica.

Gracias a que la fachada del Cine Monterrey fue declarada monumento protegido por el INAH es que se ha salvado de ser destruida totalmente.

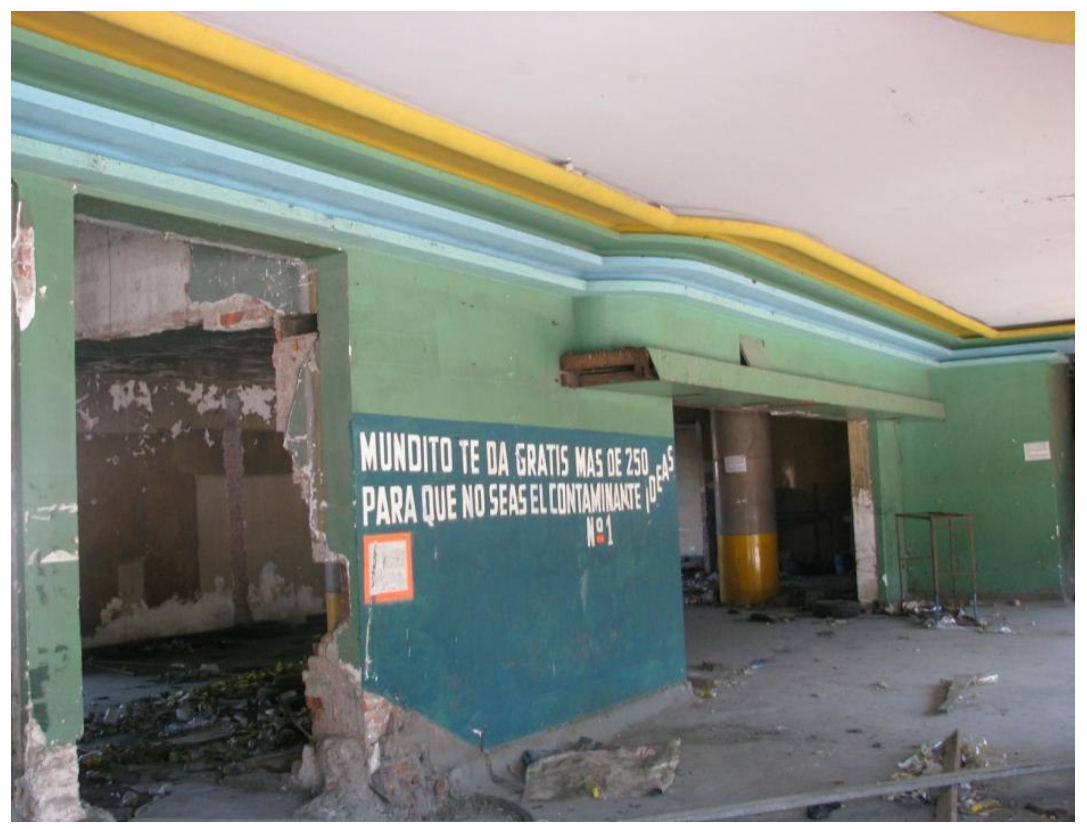

Restos del vestíbulo.

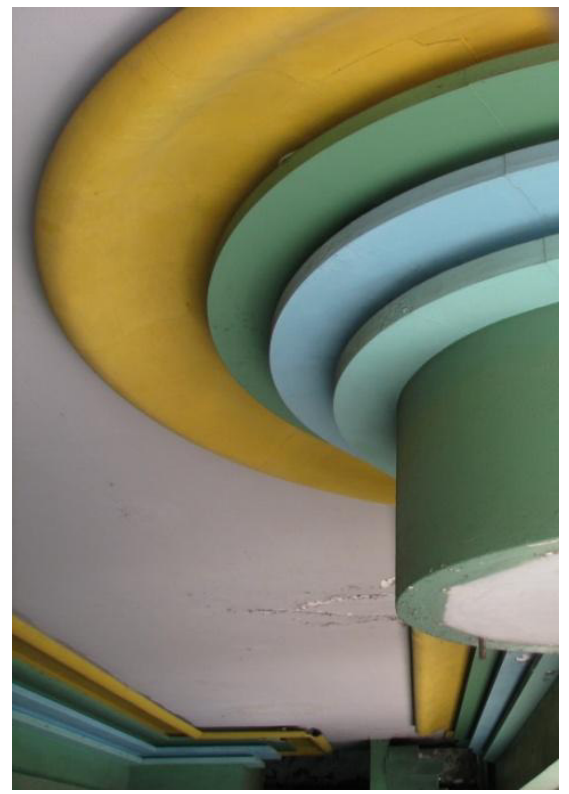

Decoraciones curvas que correspondían a la taquilla. 


\section{d. Cine Reforma}

El Cine Reforma fue un inmueble que se ubicaba en calzada Madero No. 350 Oriente, entre las calles Hermenegildo Galeana y Emilio Carranza, en el centro de Monterrey, con ubicación hacia el norte.

Debido a su cierre en 1992 y al abandono, un fuerte incendio ocurrido el miércoles 27 de septiembre de 2006 provocó que se consumiera todo el interior y se derrumbara el techo, quedando en pie solamente la fachada. Por razones de seguridad los restos fueron demolidos en diciembre del mismo año.

El propietario del Cine Monterrey, el norteamericano William Jenkins, al ver el rotundo éxito con la apertura de esa sala cinematográfica, contrató a los mismos arquitectos que diseñaron y construyeron el Cine Monterrey para edificar una sala de las mismas características y que compitiera con el Cine Lírico y el Cine Florida que se ubicaban en la misma calzada Madero. Así pues, el arquitecto Lisandro Peña Jr. (1910-1986) -de quien hablamos en lo dedicado al Cine Monterrey- y el ingeniero Arturo Olivero Cedeño hicieron el diseño, se emprendieron las obras a principios de 1947 bajo el mando de ingeniero Aníbal Treviño y se inauguró el viernes 23 de enero de 1948 por la noche con otra película de "Cantinflas", A volar joven. ${ }^{131}$

Igual que su hermano el Cine Monterrey, como se le llegó a conocer, el Cine Reforma era de los más elegantes y con mayor capacidad. Con tres niveles, en la luneta cabían mil novecientas cincuenta butacas, en el segundo nivel conocido como preferencia o balcón había mil trescientas localidades y en el anfiteatro o galería del tercer nivel había unas gradas de cemento con capacidad para 1200 personas sentadas convenientemente. El total que podían asistir era de cuatro mil, cuatrocientas cincuenta, contra las cuatro mil seiscientas cincuenta del Cine Monterrey.

La pujanza comercial de la calzada Madero en esos años, las películas de la Época de Oro, sus estrellas y directores, la bonanza de la economía mexicana después de la Segunda Guerra Mundial y el despegue económico de la ciudad con sus múltiples fábricas y su cuantiosa producción de acero para exportar, hicieron que las familias regiomontanas

\footnotetext{
${ }^{131}$ René Sánchez, "Cines del ayer: Cine Reforma” http://cineramaonline.blogspot.mx/2007/05/cines-del-ayercine-reforma.html
} 
tuvieran una economía más desahogada que les permitía asistir a las funciones de cine, ya que era uno de los entretenimientos más degustados, aparte de tener la oportunidad de asistir a alguna de las tres salas que se ubicaban muy cerca una de otras sobre la misma avenida.

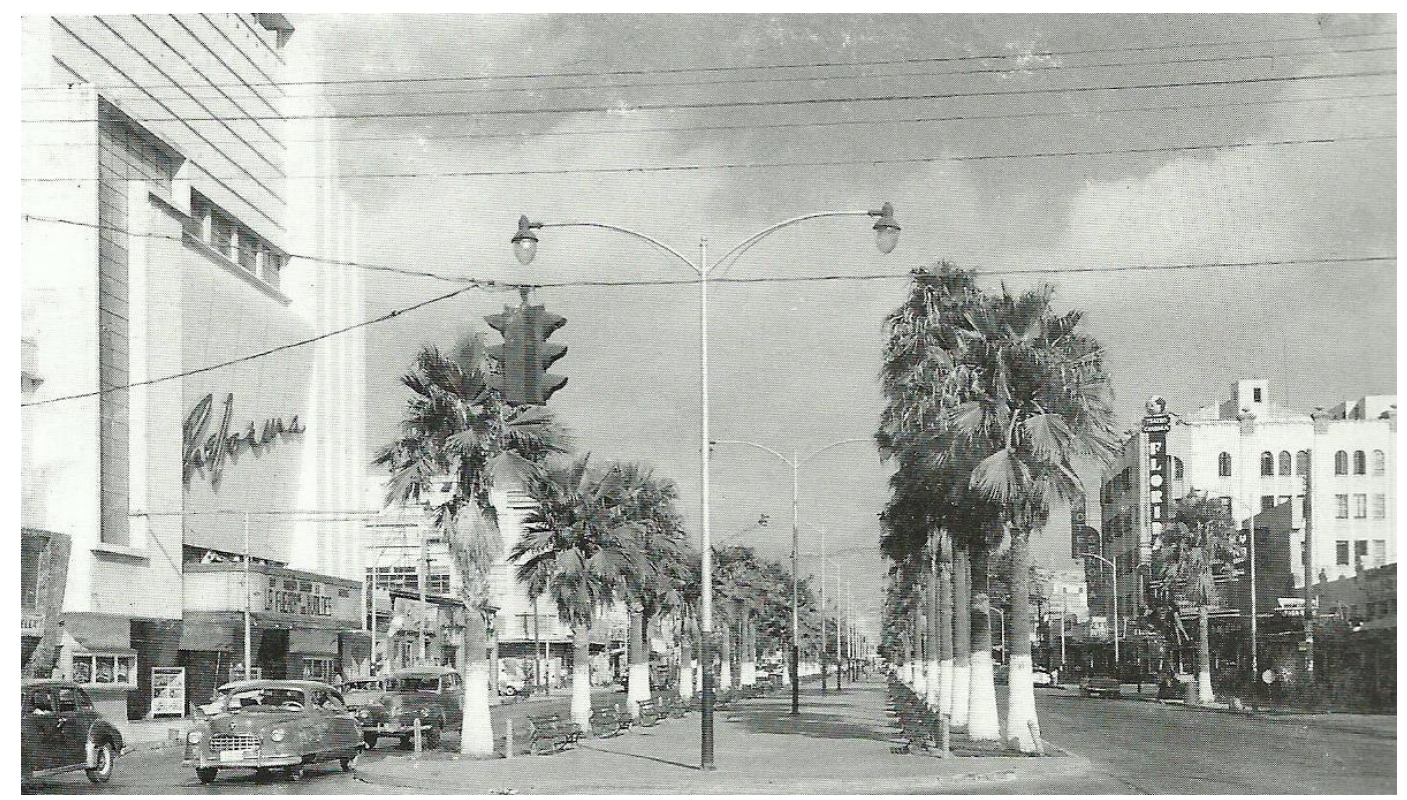

Del lado izquierdo, el cine recién inaugurado en $1948 .{ }^{132}$

En una yuxtaposición de formas geométricas, la fachada la describiremos de derecha a izquierda, ya que tanto vertical como horizontalmente se forma de tres partes. En el primer nivel de lado izquierdo había un muro cerrado blanco para luego dar espacio a la entrada del cine en la parte central, en cuyo vestíbulo dos columnas forradas con granito sostenían el letrero que se proyectaba hacia el exterior de manera ochavada. De lado derecho había un ventanal que iluminaba las oficinas.

En lo que correspondía a un segundo nivel de la fachada, un espacio para ventanas en forma de letra ele invertida estaba enmarcado con molduras salientes y el espacio que quedaba y que formaba un rectángulo era un muro cerrado en color claro. Al centro y entre dos galerías de cinco espacios rectangulares, uno abajo y otro arriba, el letrero del cine se acomodaba inclinadamente sobre cinco placas de cemento con una superficie de leves cuadrículas y que se envolvían en la parte superior hacia adentro. De lado derecho, cuatro

\footnotetext{
${ }^{132}$ Foto en: Héctor Javier Barbosa Alanís, Monterrey. Descubra el ayer de nuestra ciudad, Monterrey, N.L., Agencia Promotora de Publicaciones, 2010, p. 81.
} 
pilastras cuadradas protegen las ventanas que iluminaban las escaleras interiores. La primera pilastra se eleva hasta el remate superior, la segunda a tres cuartas partes de la anterior y las dos últimas un nivel inferior, logrando un extraordinario juego de formas cúbicas ascendentes.

El último nivel se forma con un lienzo dividido por siete espacios horizontales, separados por unas molduras; en la parte superior de la sétima parte de la divisiones, unos pequeños círculos asemejaban a las cabezas chatas de tornillos, como si toda esta parte de la fachada fuera la semejanza a una lámina industrializada, como eran las placas laminadas que se ocupaban en los autobuses camiones, barcos y aviones en un lenguaje de geometría más industrial del Art Déco Streamline. El lienzo se interrumpe con la superposición de la pilastra de más altura, pero se continúa hasta el límite derecho de la fachada.

En la parte superior y al centro, en lo que sería el remate, un alero sostenido por seis columnillas redondas se ensambla con la pilastra mayor, donde se recrea una combinación de un espacio horizontal abierto, con uno vertical cerrado.

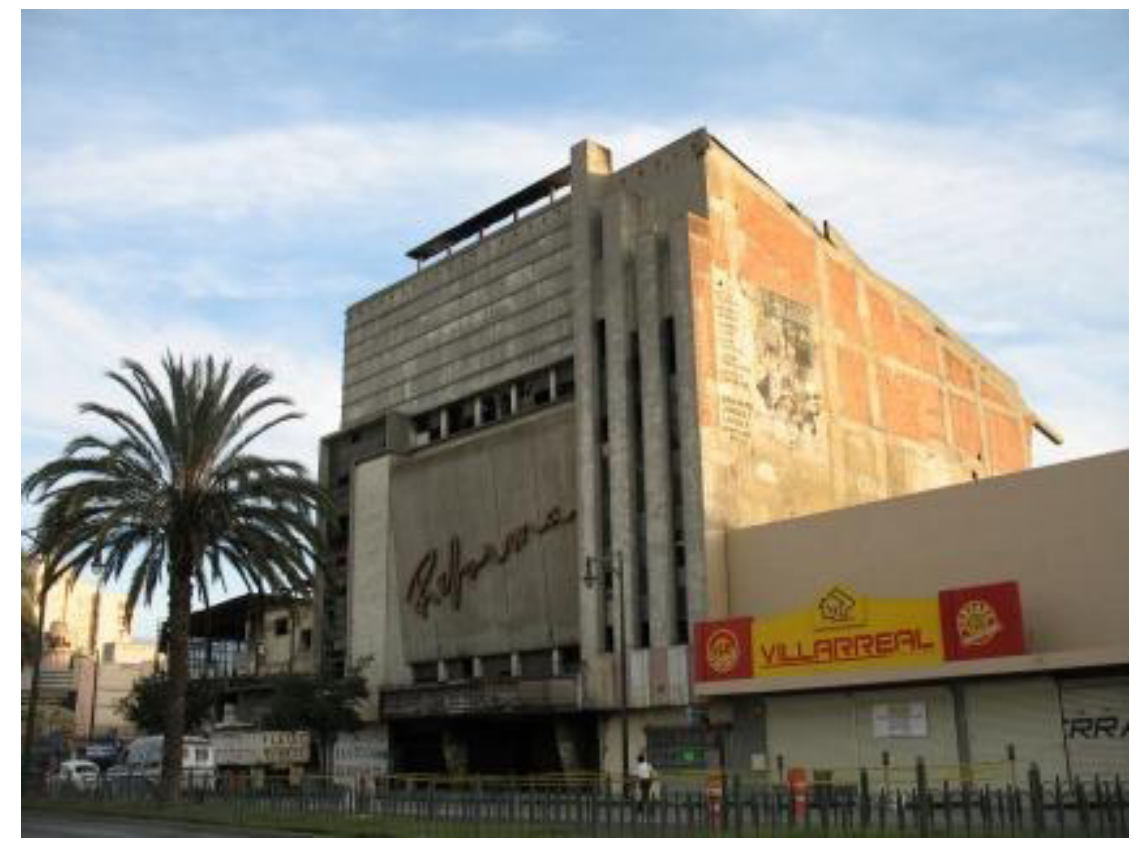

Vista completa del cine antes del incendio en 2006.

Si bien la fachada del Cine Reforma ya es un Art Déco tardío del tipo Streamline y algunos de sus elementos podrían caber inclusive dentro del Funcionalismo, la fuerte influencia del De Stijl es evidente tanto en el uso de las formas geométricas integradas 
asimétricamente, como en el uso de la ele invertida del ventanal. El famoso café de Rotterdam De Unie levantado en 1924 por Jacobus Johannes Pieter Oud (1890-1963) fue derrumbado en 1940 y reconstruido en 1986 en la misma ciudad, pero en otra calle por el arquitecto Carel Weeber. ${ }^{133}$ Lleva una ele recostada con otras eles circunscritas dentro del mismo espacio en el segundo cuerpo de la fachada; dentro de la ele están cinco ventanas rectangulares. Como podemos ver ésta fue la solución del arquitecto Peña, que si bien el café ya había sido derribado, el conocimiento del lenguaje del De Stijl era notorio.

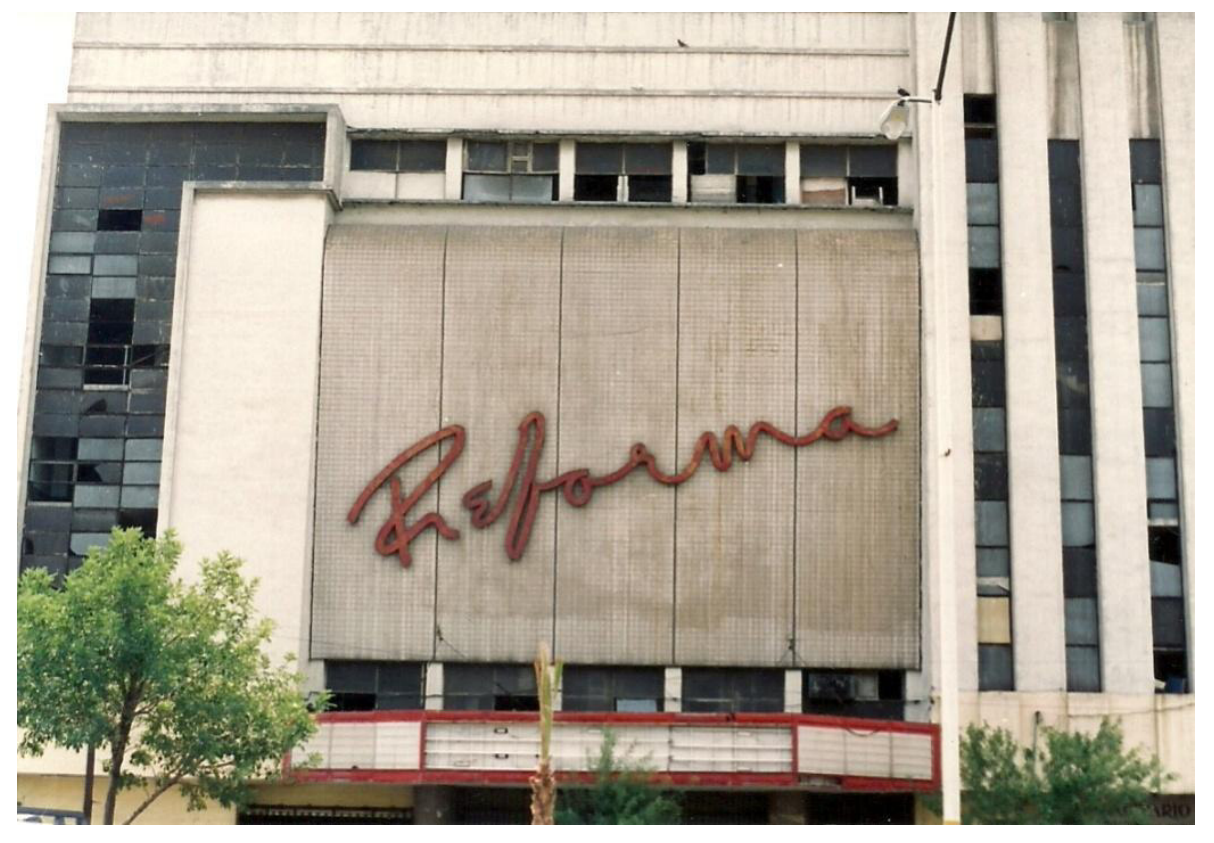

Detalle del cuerpo central de la fachada en 1992 cuando ya estaba cerrado. ${ }^{134}$

El uso de los elementos geométricos, especialmente de las formas cúbicas y rectangulares, la amalgama de estos mismos, la alternancia de los espacios abiertos y cerrados, el uso del alero como si fuera la parte de un aeroplano, la semántica industrial de la parte superior, hacen que el estilo que abiertamente se manifestaba en el Cine Reforma era un Déco Streamline de fuerte ascendencia norteamericana, donde la imagen de lo moderno en México pasaba de un Art Déco nacionalista, hacia uno de tendencia internacional.

\footnotetext{
${ }^{133}$ Carsten-Peter Warncke, DE STIJL. 1917-1931, Köln, Taschen, 1993, pp. 107-108.

134 Foto: Mónica Barrera Ortiz y Blanca Rodríguez Güemes.
} 


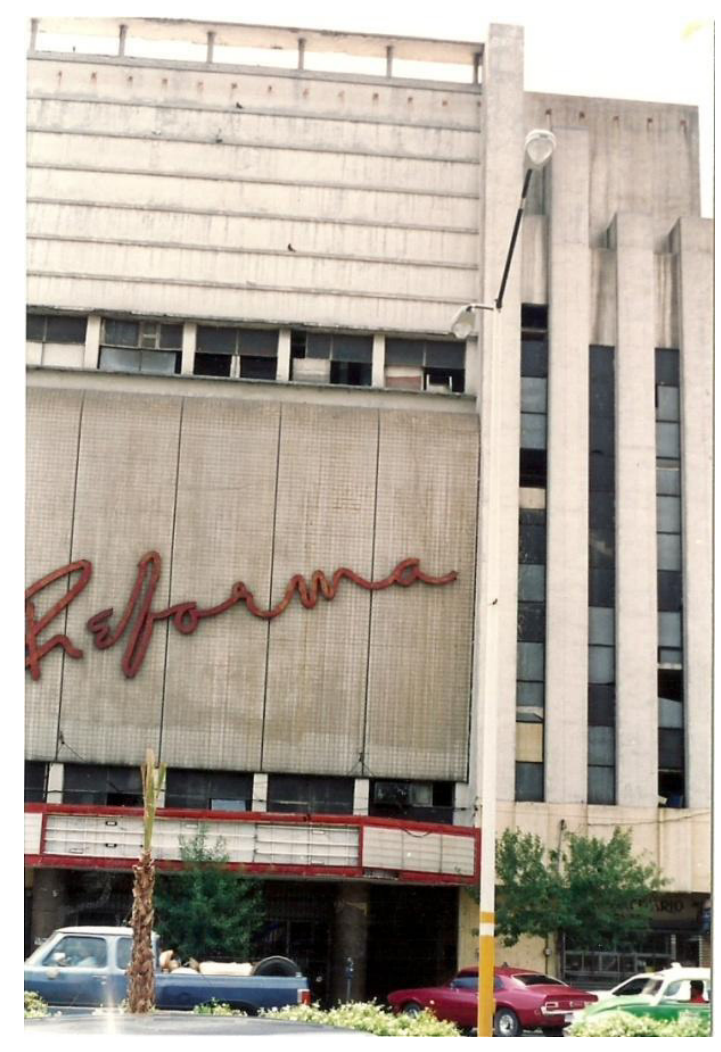

Detalle del lado derecha de la fachada en 1992.135

Cuando el cine iba ser demolido después del incendio, se suscitaron muchas críticas e incluso se llegó a afirmar que estaba catalogado como patrimonio nacional por INAH, ya que después se habló de una posible reconstrucción de la fachada en abril de 2008; pero de acuerdo a una investigación periodística de Juan Zapata Pacheco se dio a conocer que eso era una falacia y que no había ningún documento al respecto. ${ }^{136}$ Inclusive el arquitecto Benjamín Valdés, quien fungía en ese entonces como Director de Obras del Centro INAH Nuevo León, habló sobre la posible reedificación que proponían algunos organismos y personalidades de la cultura de la ciudad, pero también afirmando que no había documento alguno donde se hubiera declarado al Cine Reforma monumento nacional ni regional. ${ }^{137}$

Lo único que hay para considerar al Cine Reforma como monumento es lo que hizo la Agencia para el Desarrollo Urbano de Nuevo León (APDUNL) entre marzo y octubre de

\footnotetext{
${ }^{135}$ Foto: Mónica Barrera Ortiz y Blanca Rodríguez Güemes.

${ }^{136}$ Juan Zapata Pacheco, "Reconstruirán fachada del Cine Reforma”, El Porvenir, Monterrey, N.L., jueves 3 de abril de 2008, secc. Cultural, http://www.elporvenir.com.mx/notas.asp?nota_id=206088

${ }^{137}$ Entrevista con el arquitecto Benjamín Valdés en su casa el sábado 26 de mayo de 2012, donde reafirmó la declaración que él dio en 2008 sobre el Cine Reforma.
} 
2007, bajo la dirección del arquitecto Juan Ignacio Barragán. Dentro de mil edificaciones, el Cine Reforma tiene el número de identificación 0623, pero como advirtió Barragán cuando el edificio fue demolido que ese catálogo no tenía ningún valor legal y sólo era un material de investigación de la arquitectura del estado de Nuevo León. ${ }^{138}$

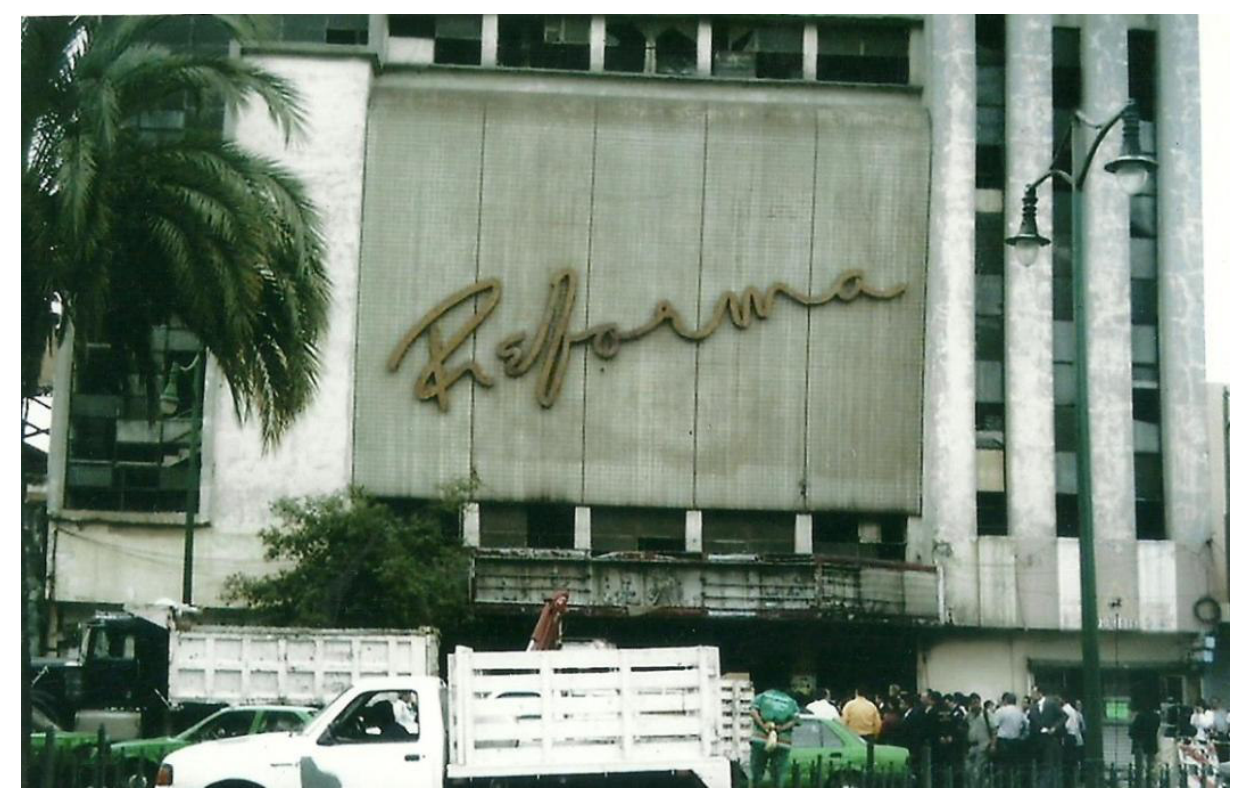

El cine al día siguiente del incendio el 28 de septiembre de 2006.

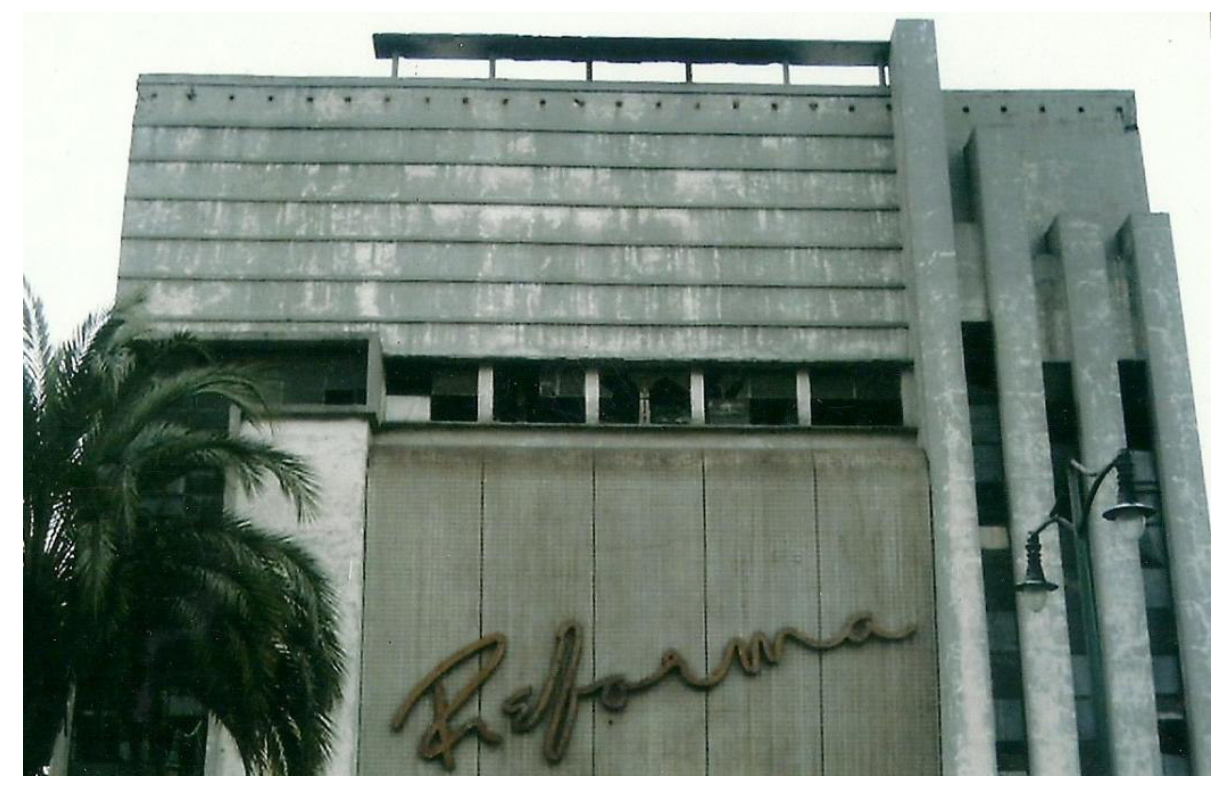

Parte superior del cine al día siguiente del incendio.

\footnotetext{
${ }^{138}$ Abraham Vázquez, "Destacan en catálogo su valor arquitectónico", El Norte, Monterrey, N.L., domingo 21 de enero de 2007, secc, Vida, p. 3.
} 


\section{e. Sociedad Recreativa Acero}

El edificio de la Sociedad Recreativa Acero se ubica dentro de lo que fueron las instalaciones de la Compañía Fundidora de Fierro y Acero de Monterrey, hoy Parque Fundidora, a un lado de la Escuela Adolfo Prieto, con orientación al sur de la fachada principal.

La Fundidora Monterrey, como se le conoció popularmente, inició sus actividades en 1900 y cerró sus puertas en 1986, después de haber sido nacionalizada por el gobierno federal. Lo que fuera la acerera más grande de Latinoamérica, acabó en ruina por el mal manejo de los funcionarios gubernamentales. Dentro de sus magnas instalaciones contaba con una escuela, áreas recreativas y de esparcimiento. Por esta razón es que el 7 de julio de 1923 se creó la Sociedad Recreativa Acero y para su funcionamiento se pensó en construir un edificio de múltiples usos, tales como funciones de cine, teatro, conciertos, bailables así como los deportes voleibol y básquetbol.

El inmueble fue construido por la empresa FYUSA (Fomento y Urbanización Sociedad Anónima) a partir de 1929 e inaugurado el 4 de octubre de $1930 .{ }^{139}$ A pesar de no tener los datos de los autores de la obra, seguramente fueron los arquitectos Manuel Muriel y Antonio Lamosa, quienes se encargaban de diseñar y proyectar la mayoría de las obras de dicha constructora. La razón para que esta compañía se encargara de la construcción de este edificio fue porque el Lic. Carlos Prieto, accionista y alto funcionario de la Compañía Fundidora de Fierro y Acero de Monterrey, era a su vez apoderado general de FYUSA.

El edificio está construido con concreto armado y viguería de acero. Es planta rectangular, un solo piso y tiene dos cuartos en alto utilizados como utilería. Tiene dos entradas, una orientada hacia el sur que es la principal y que mira hacia el Parque Fundidora y otra con dirección al norte hacia la calle Prolongación Madero, en las cuales se encuentran unos relieves Art Déco.

La fachada sur que mira hacia el parque está compuesta por un vano de acceso flanqueado por poliedros rectangulares de mayor altura, los cuales llevan un par de ventanas rectangulares en posición vertical. Los muros que se extienden a los lados presentan a manera de rodapié una parte levemente resaltada; cuatro ventanas cuadradas a

\footnotetext{
${ }^{139}$ Información otorgada por la Coordinación de Patrimonio Cultural del CONARTE.
} 
cada lado están colocadas en rehundido. Por arriba de las ventanas una ancha moldura recorre el edificio, recortándose en el vano de acceso y en la parte superior, otra moldura más delgada en la misma disposición, rima con el juego geométrico de las superficies de la construcción. En las esquinas de los muros para ensamblarse con las paredes laterales, una pilastra en rehundido amalgama los lienzos, continuando con el ritmo de planos salientes y profundizados.

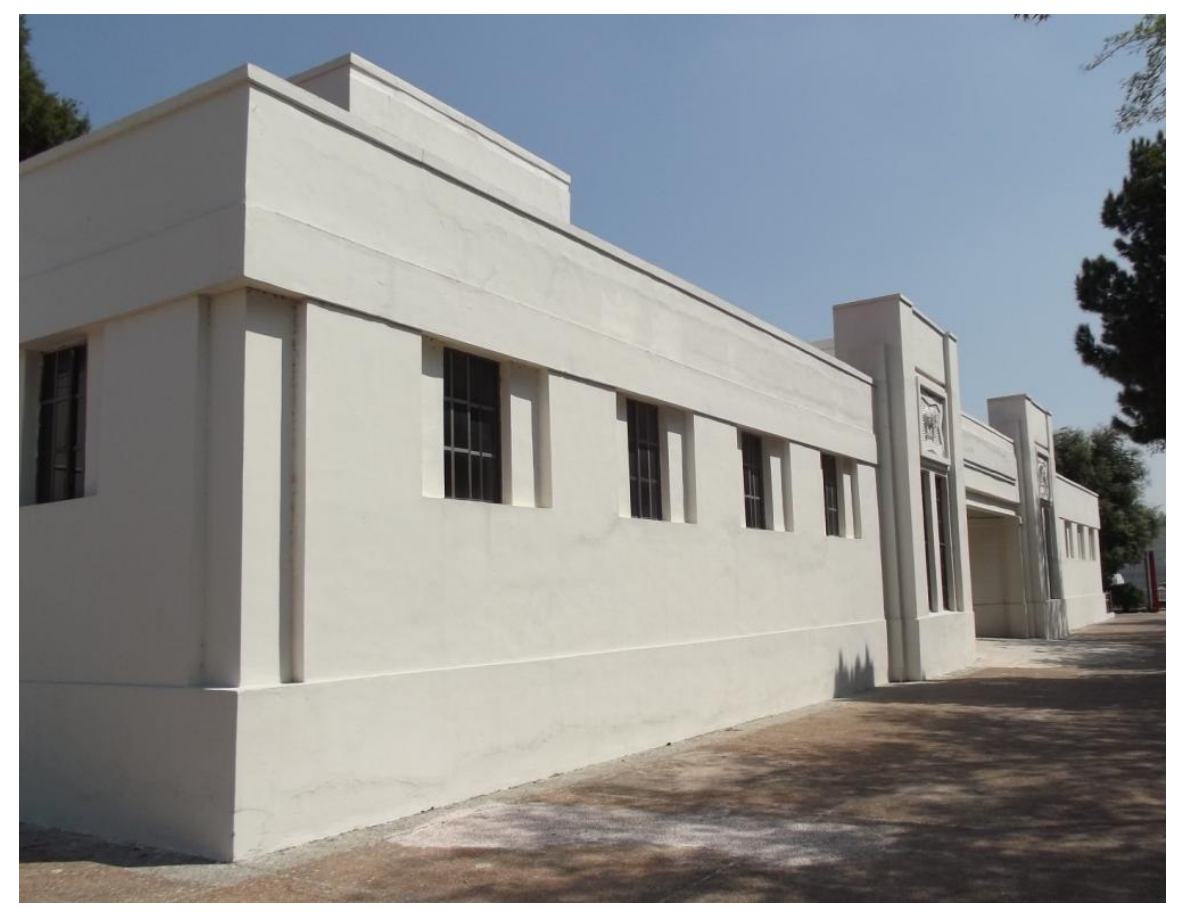

Fachada sur.

El vano de acceso de la fachada sur es rectangular y el espacio que se proyecta hacia lo que es ya la entrada tiene forma ochavada. Unas medias muestras de pilastras ochavadas con todo y capitel empotradas lateralmente sostienen una trabe que sirve de sostén para un tablero, en el cual se proyectan hacia el frente dos tableros más superpuestos y de menores dimensiones, para terminar con una moldura que armoniza en su forma con la otra moldura superior que recorre esta fachada y las laterales. Para seguir proyectando el acentuado geometrismo, las medias muestras de pilastras y el mismo tablero del vano de acceso se ensamblan con un delicado relieve rectangular, todo como si se tratara de un armazón de elementos geométricos superpuestos, algo muy desarrollado en el los diseños del Art Déco 
Zigzag. A la vez cabe destacar que el rodapié y los capiteles se proyectan hacia el interior del espacio de la entrada, con el fin de prolongar la linealidad de la parte frontal.

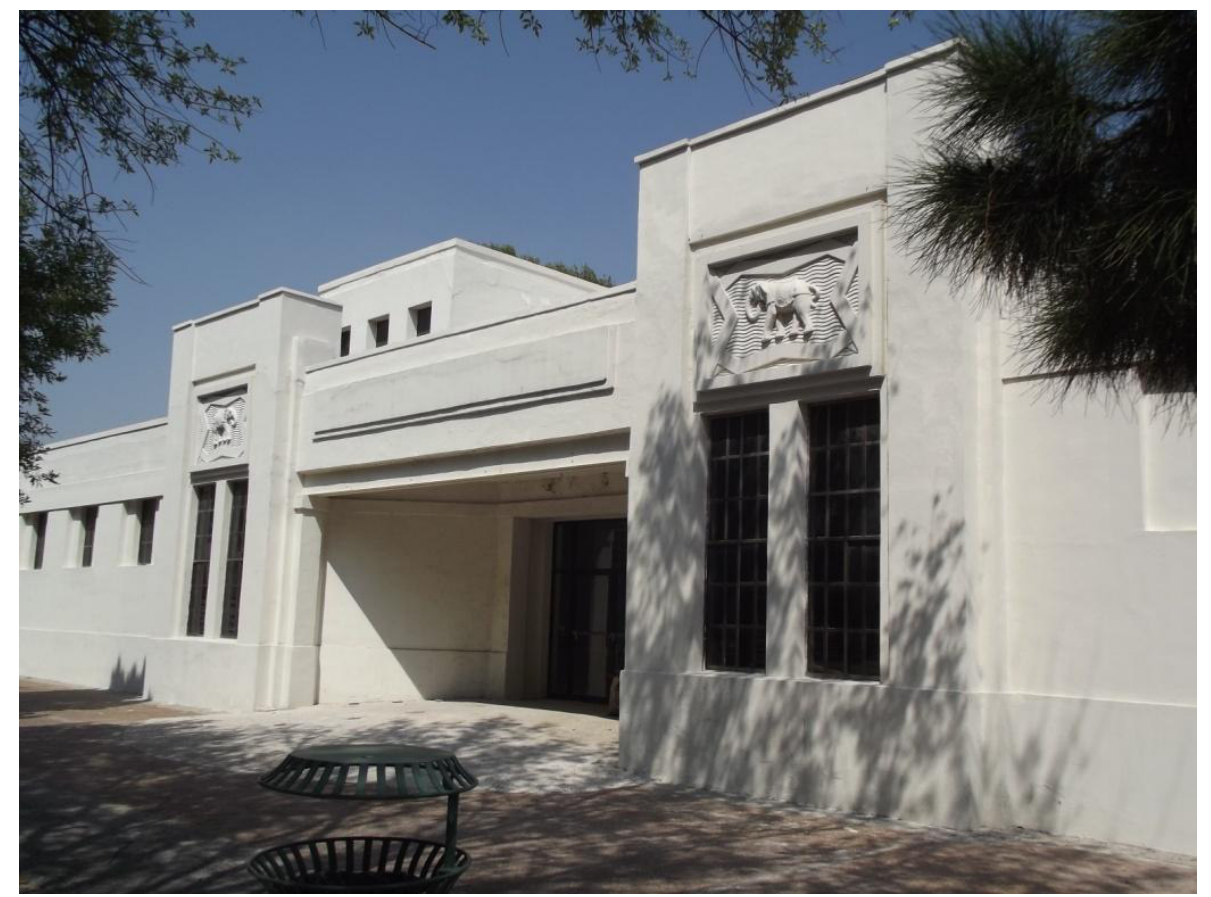

Parte central de la fachada sur. En los poliedros, arriba de las ventanas se aprecian los relieves.

Los poliedros verticales de la fachada sur como llevan más altura y están desplazados hacia el frente, incrementan el efecto de verticalidad y de la construcción espacial cúbica. Tanto las influencias del Bauhaus o del Constructivismo son latentes, ya que además en el centro de estos poliedros, el nivel se rehunde y en la parte superior de las ventanas, dos marcos sobrepuestos resguardan unos magníficos relieves Déco Zigzag.

Dentro del marco de los relieves unas líneas quebradas envuelven a un elefante; el fondo se compone de líneas ondulantes que se van acoplando de arriba hacia abajo de manera superpuesta. El elefante era el símbolo de la Compañía Fundidora de Fierro y Acero de Monterrey. Los elefantes están colocados mirándose mutuamente; llevan por adorno una colgadura en la silla de montar, misma que está decorada con bordados alrededor.

El adorno del paquidermo izquierdo tiene a un personaje en el centro, que significa el obrero que se desempeña en el trabajo de la fundición, el cual está representado con su 
overol, una pala carbonera y al lado de la pierna izquierda como fondo se aprecian las torres de las chimeneas de la fábrica.

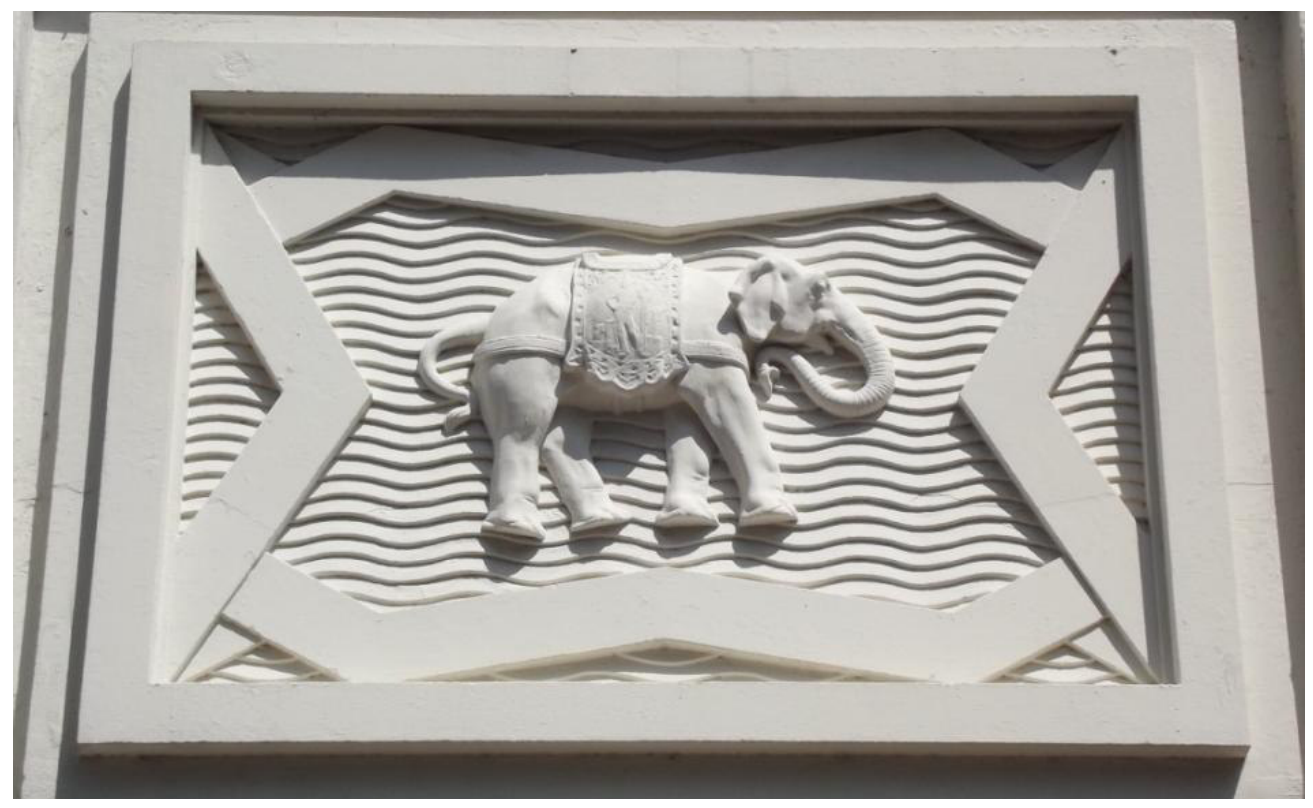

Relieve del lado izquierdo.

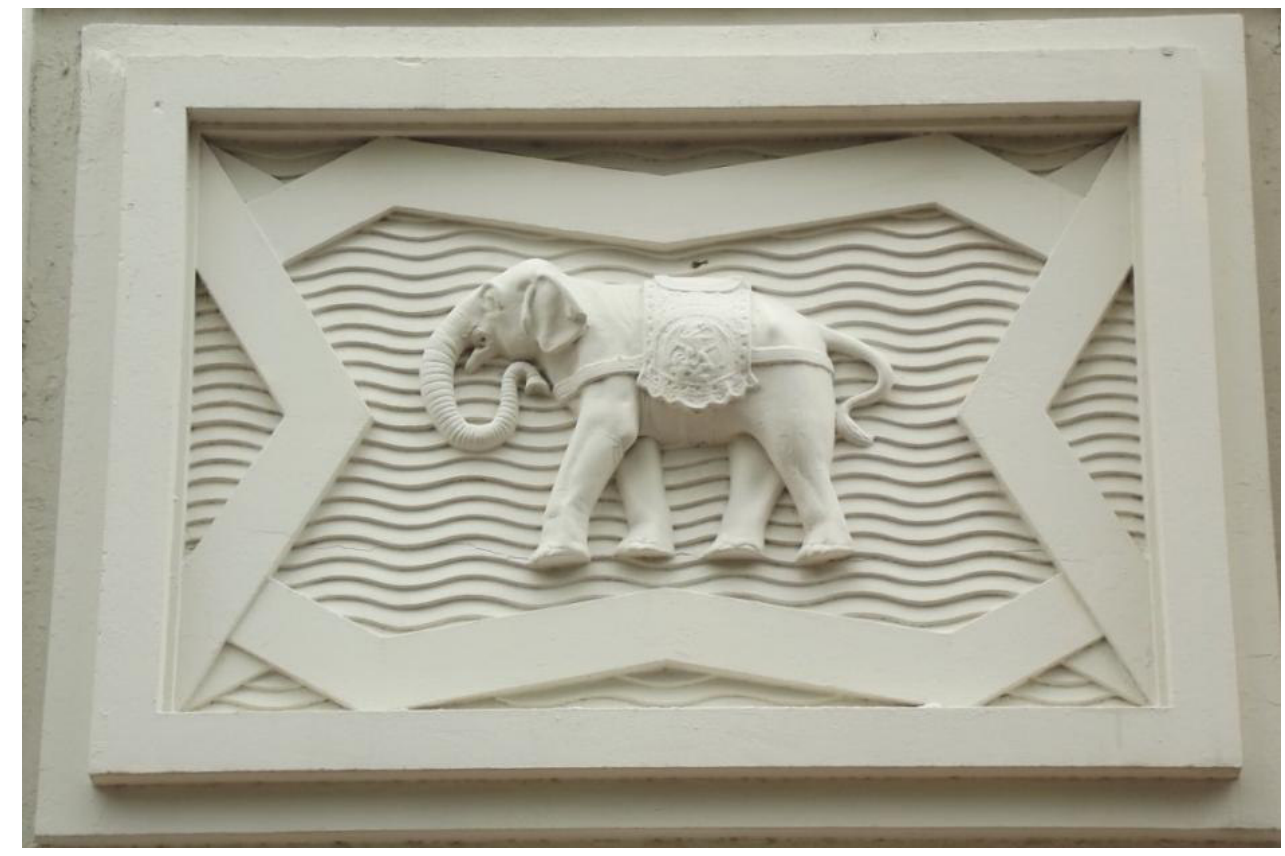

Relieve del lado derecho. 
En el del lado derecho está el escudo nacional, con lo cual se remarcaba el nacionalismo postrevolucionario, muy vigente en esos años. Las líneas quebradas forman unos zigzags ampliados y las líneas onduladas proporcionan en las imágenes la idea de movimiento, ya que van cayendo en una intercalación de cada una y se acompasan con el paso del elefante, la fauce abierta y la ondulación de la trompa; además, las sinuosidades nos remiten al famoso trabajo de El Cometa, elaborado a finales de los años veinte, por el artista francés Maurice Guiraud-Riviére (1881-1947), escultura en bronce de aquella dama cuya pelo extendido se convierte en la cauda ondulante del cometa.

Son unos magníficos relieves que denotan toda la estética del Art Déco Zigzag, con su geometrismo rimando con la semántica de la decoración figurada del consorcio acerero.
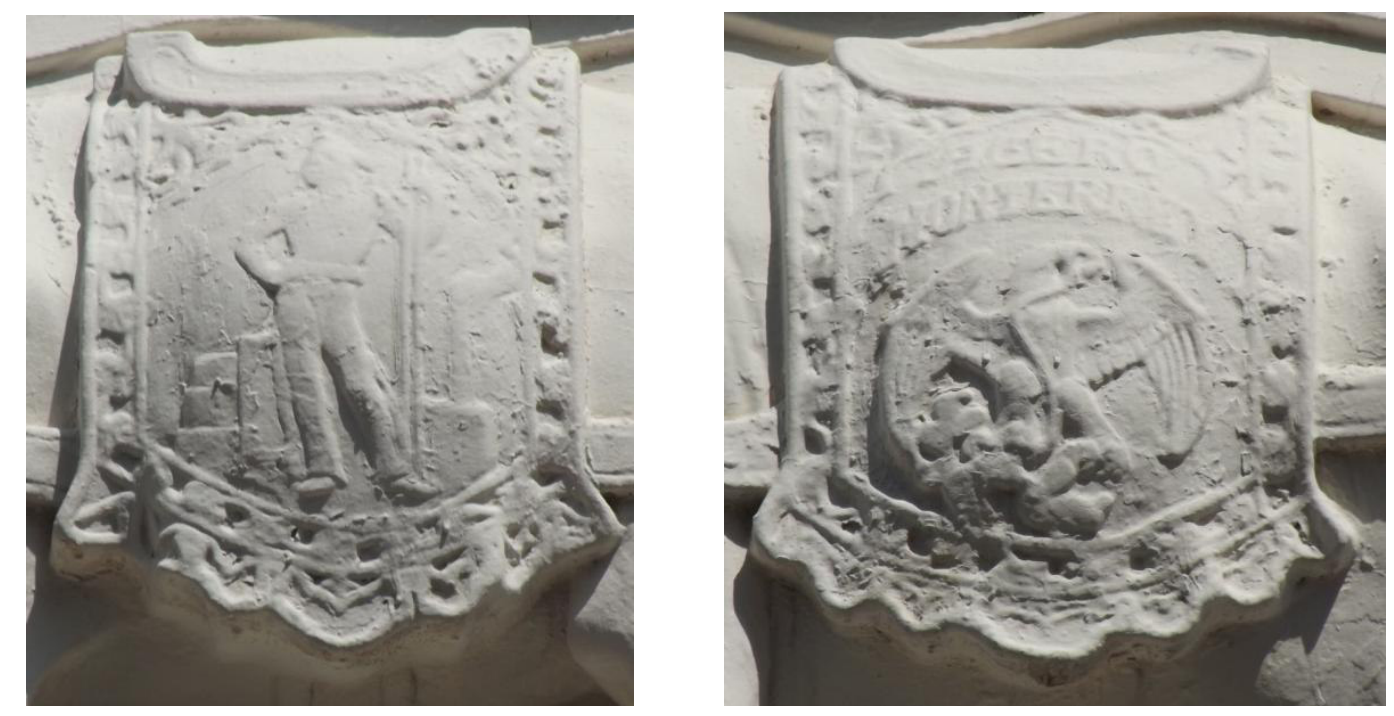

Detalles de las sillas de los elefantes con el obrero en el de la izquierda y con el escudo nacional en el de la derecha en el cual se lee "ACERO MONTERREY".

La fachada norte está conformada por un cuerpo central desplazado hacia adentro del nivel del resto de la fachada. Cinco vanos rectangulares forman las puertas de acceso; arriba de éstas unos relieves, para luego continuar con ventanas cuadradas. Cada vano está separado por cuatro pares de gruesas bandas superpuestas que en la parte baja se resaltan a manera de zócalos. A los lados se ensamblan dos cuerpos poliédricos rectangulares, colocados hacia más hacia el frente en relación con el cuerpo central. Estos cuerpos están compuestos por cuatro pares de bandas superpuestas con un zócalo corrido. Entre cada grupo de bandas están colocadas ventanas rectangulares. 
Los cinco bajo relieves planos son un verdadero juego de zigzags con las líneas quebradas y rítmicas que sobresalen del mismo fondo ondulante, como los relieves de la fachada poniente. Las líneas van dibujando anagramas de la empresa. Al centro lo que pareciera una $\mathrm{V}$ invertida, es más bien una $\mathrm{A}$, que significa "Acero" y detrás se conforma una $M$ abierta de Monterrey, para complementar la marca comercial "ACERO MONTERREY”. La línea sigue su juego zigzagueante, geométrico; abajo se forma un moño con dos volutas y arriba la líneas siguen su camino abriéndose en forma de V. Un rombo resalta en la intersección de los segmentos de la M. Encerrados entre la A y la M, se aprecian unas grafías estilizadas con contornos angulosos: son una $\mathrm{R}$ y una $\mathrm{A}$, que significan "Recreativo Acero".

Estos fastuosos relieves son de un enfatizado Art Déco Zigzag, con esos diseños que estaban al día con lo que se adornaban los grandes espacios de las construcciones, de los decorados, de las escenografías, de los estampados que se realizaban en cualquier parte del mundo donde se desarrollaba el Art Déco: desde las luces que se cruzan en la escenas de Metrópolis, hasta las luminarias de los espectáculos hollywoodenses, pasando por los paneles de Edgar Brandt y los diseños revelados en la gran Exposición de 1925.

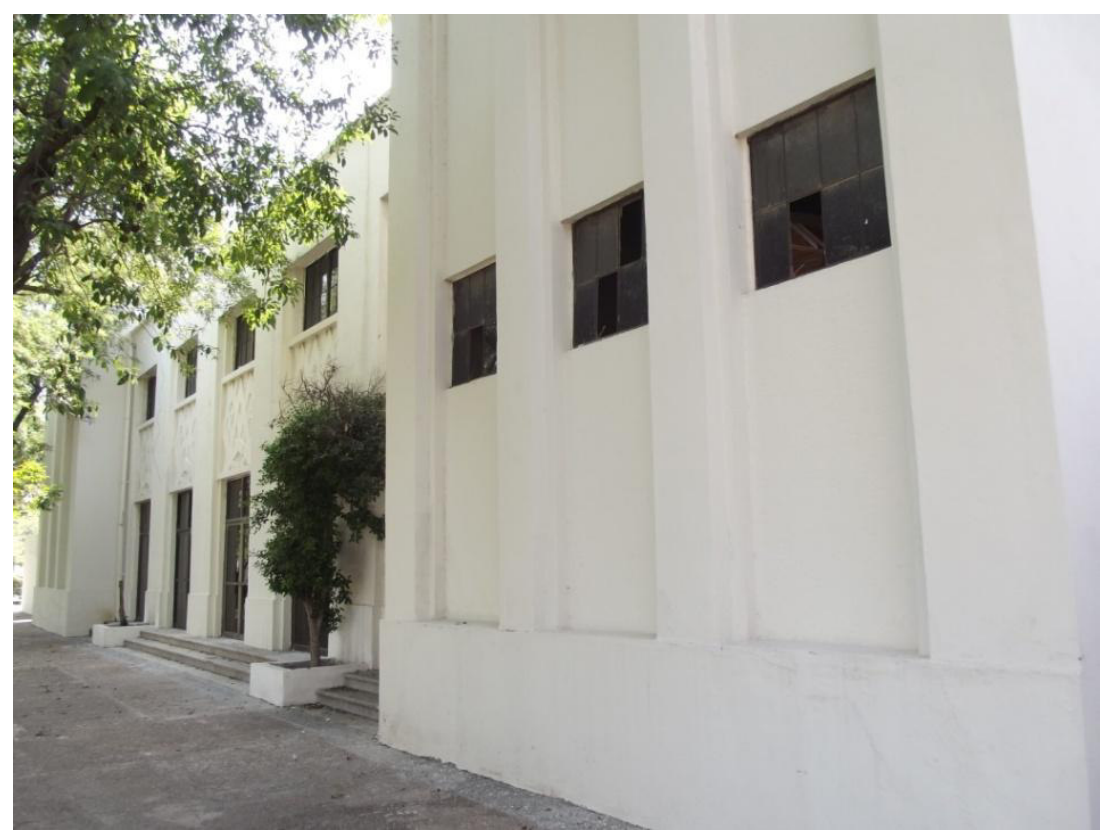

Fachada norte. 


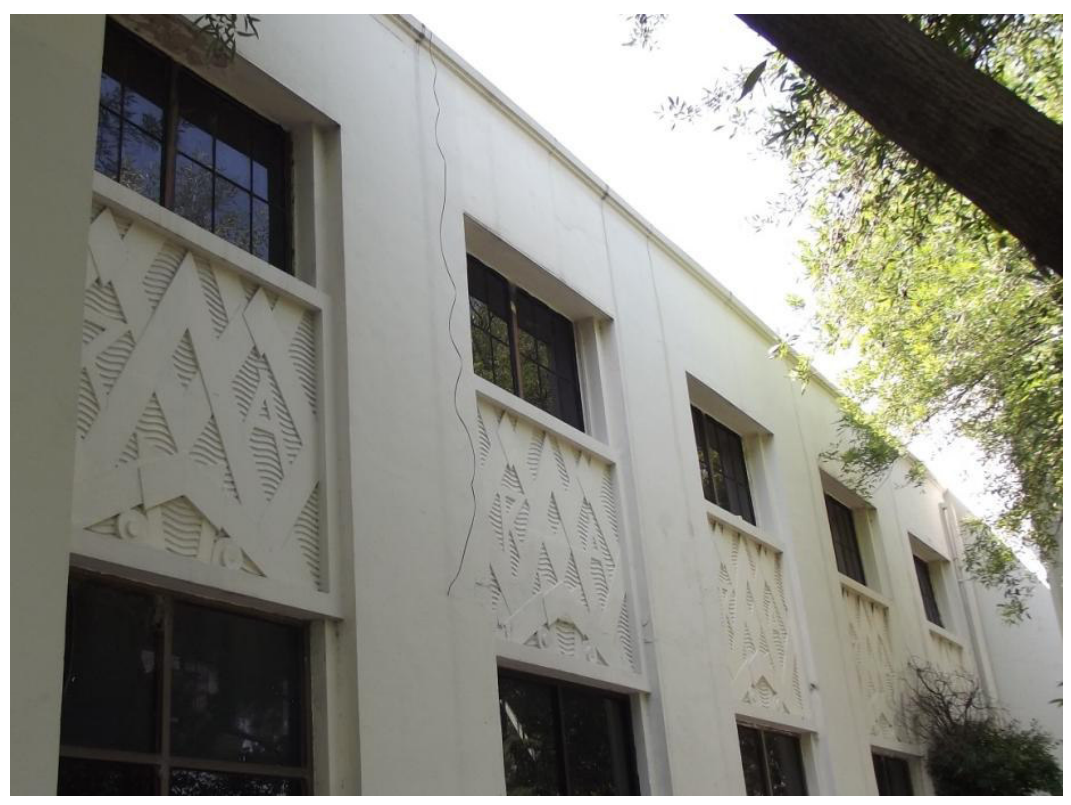

Relieves de la fachada norte.

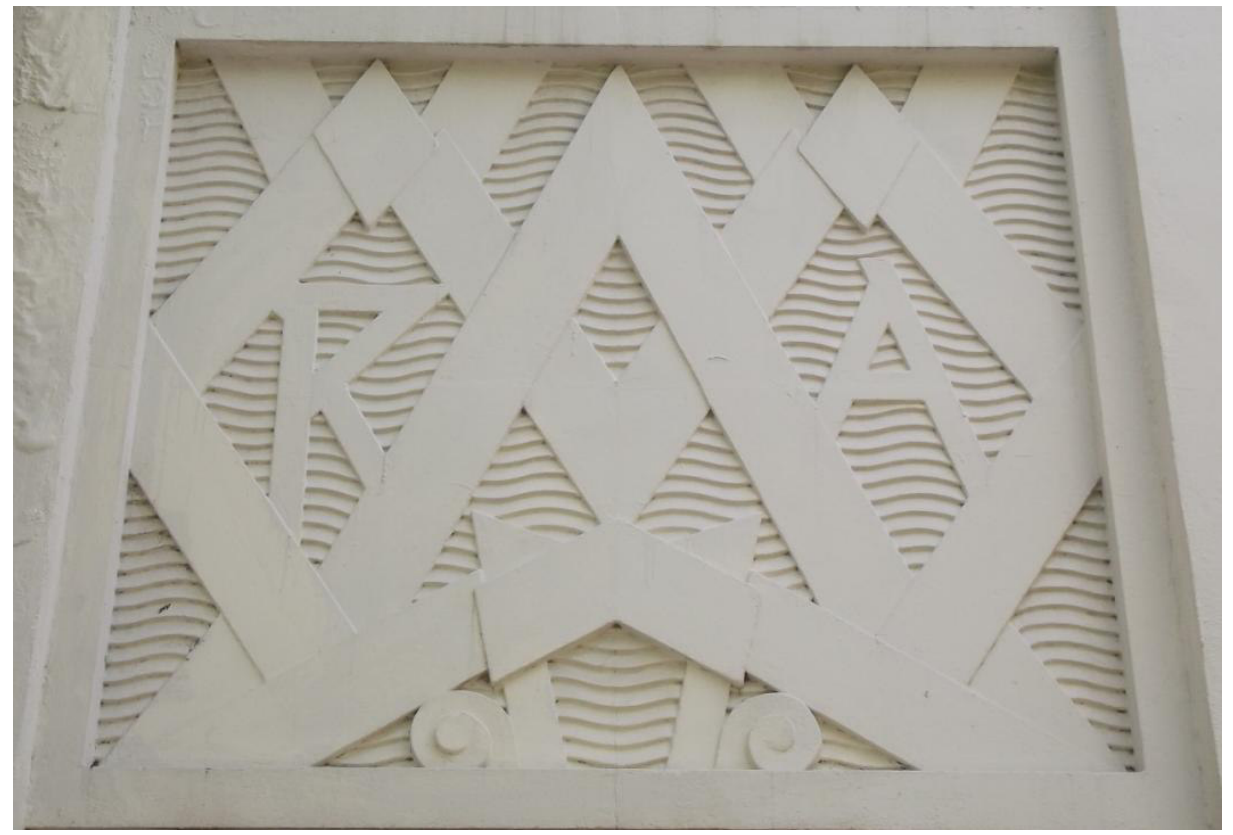

Detalle de uno de los relieves.

Este edificio de la Sociedad Recreativo Acero es un representativo ejemplo del Art Déco de la época del Zigzag, porque además del conjunto de cubos y decoraciones geométricas a través de molduras tanto verticales como horizontales, a la vez los estupendos relieves conllevan toda la semántica de las formas zigzagueantes, de líneas quebradas que remiten a los diseños que representaban los impulsos de la energía eléctrica, 
de la velocidad, de la radiotransmisión, que este caso exaltaban la fuerza del acero y sus bondades para la construcción de grandes espacios, así como de elementos fabriles, de maquinaria pesada, donde el progreso alcanzaba toda a través de la industrialización.

Actualmente el inmueble funciona como un espacio para actividades culturales del Parque Fundidora, aunque con escaso uso. 


\subsubsection{ARQUITECTURA RELIGIOSA}

\section{a. Iglesia de Cristo Rey}

La Iglesia de Cristo Rey se ubica en la calle Julián Villagrán 1001, entre Reforma y la avenida Madero con orientación al poniente, en el centro de Monterrey.

Fue mandada a construir por agradecimiento de un favor especial concedido por Cristo Rey a los empresarios Ignacio A. Manuel y Alberto Santos, según consta en una placa de la entrada. Fue diseñada por el ingeniero y arquitecto Eduardo D. Belden Gutiérrez (f.?-1965) y las obras fueron realizadas por el ingeniero Juan Doria Paz. El diseño está inspirado en la iglesia de Notre Dame de Raincy, Francia, obra de los hermanos Auguste (1874-1954) y Gustave Perret (1876-1952) realizada entre 1922 y 1923. De hecho, se ha dicho que la Iglesia de Cristo Rey es un plagio de la construcción francesa. Eduardo D. Belden quien estudió en el Massachussetts Institute of Technology fue para el arquitecto Oscar Eduardo Martínez, uno de los que más utilizó el Art Déco en sus construcciones particulares. ${ }^{140}$ Ocupó el cargo de primer presidente de la Sociedad de Arquitectos de Nuevo León, A.C., fundada en 1957.

Las obras de la iglesia se iniciaron en 1944, pero una tragedia hizo que se paralizaran: el 28 de diciembre de dicho año, al estar vaciando la bóveda con concreto, la cimbra no aguantó el peso, se vino abajo y aplastó al ingeniero Doria Paz y a 17 albañiles. El abatimiento por la desgracia envolvió a toda la ciudad y los trabajos se paralizaron, por lo que la construcción se terminó hasta cuatro años después, consagrándose el templo en octubre de $1948 .{ }^{141}$

La planta es rectangular tipo basilical con tres naves. La torre campanario se encuentra inserta al frente y al centro de la fachada principal. Está construida con concreto armado y forrada de ladrillo.

Aunque ya muy tardía para el desarrollo del Art Déco, sin embargo, la Iglesia de Cristo Rey posee elementos de este estilo en la torre y en un altar del interior.

\footnotetext{
${ }^{140}$ Oscar Eduardo Martínez, "Monterrey: ciudad vieja, ciudad nueva. Su arquitectura y urbanismo", en: $L a$ Enciclopedia de Monterrey. Vol. II. La capital industrial de México, Monterrey, N.L., Milenio, Multimedios, 2008, 2a ., edición, p. 280.

${ }^{141}$ José P. Saldaña, ¿Y qué hicimos?...Monterrey en el siglo XX, Monterrey, N.L., Producciones Al Voleo-El Troquel, 1988.
} 


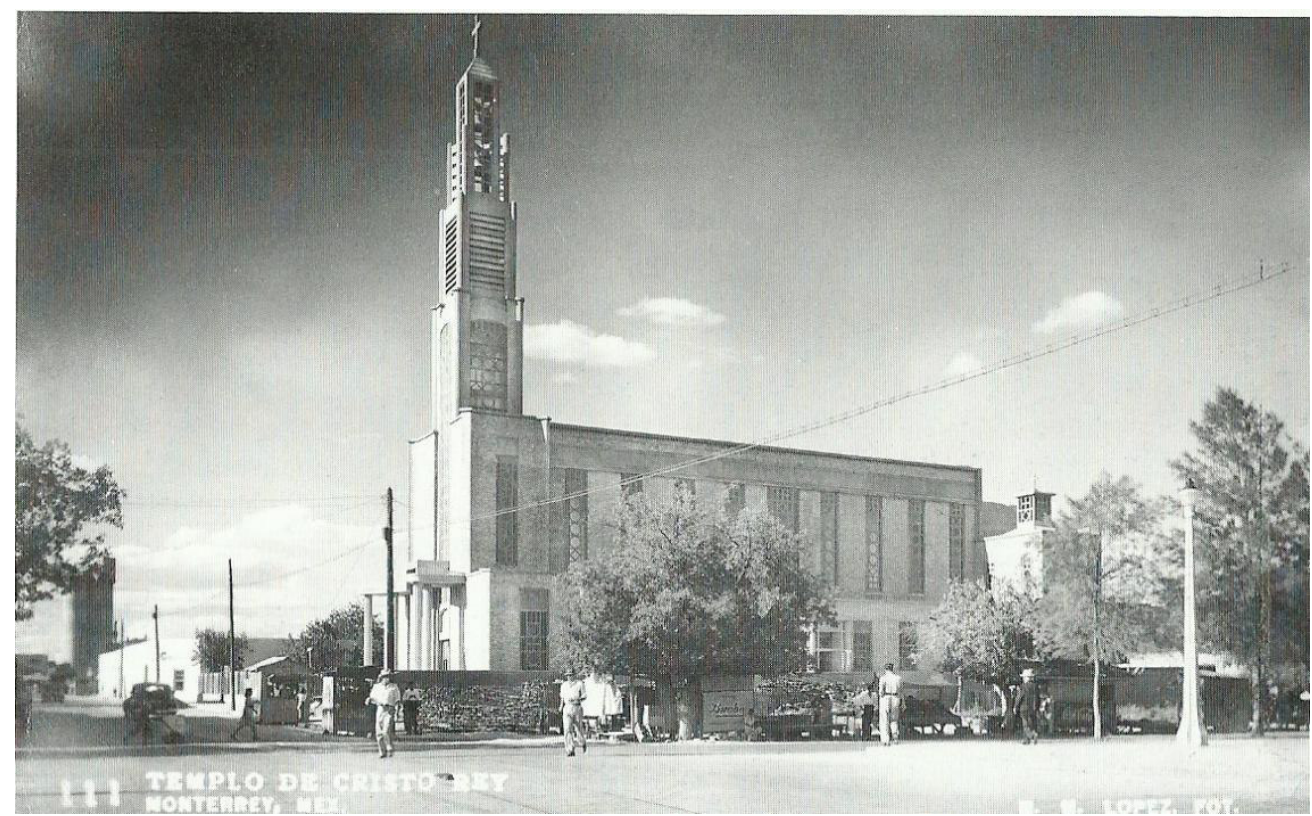

La iglesia de Cristo Rey hacia 1950. ${ }^{142}$

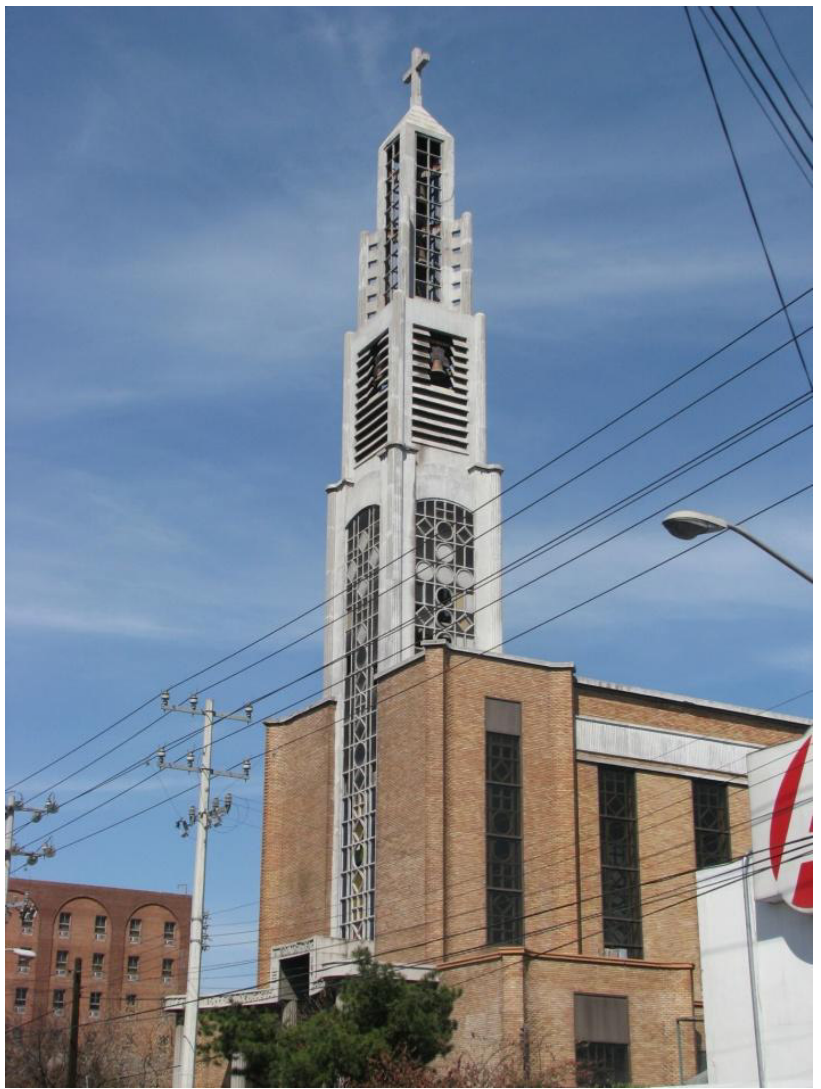

Iglesia de Cristo Rey.

${ }^{142}$ Héctor Javier Barbosa Alanís, Monterrey. Descubra el ayer de nuestra ciudad, Monterrey, N.L., Agencia Promotora de Publicaciones, 2010, p. 67 
La torre campanario elaborada en concreto y sin recubrimiento alguno se eleva en tres niveles cúbicos escalonados, rematando con una cruz. El primer nivel se sostiene sobre la trabe de la entrada principal, el cual está adornado con ventanales de formas geométricas de rectángulos, cuadrados, rombos y círculos; en las cuatro primeras partes lleva unos cristales en colores amarillos en la parte central y en los laterales verde y azul, lo que nos remite a los colores y diseños utilizados por los miembros de De Stijl, tales como Composición XVII de 1919 de Theo van Doesburg (1883-1931), que se encuentra en el Gemeentemuseum en La Haya, en la cual resaltan, entre otros, los recuadros de color verde o el Rombo, 1921, colección de The Art Institute of Chicago, y el Rombo con azul, amarillo y rojo, 1921-1925, conservado en la National Gallery of Art en Washington, ambos de Piet Mondrian (1872-1944), obras en las que destacan las figuras del rombo más los colores amarillo y azul. ${ }^{143}$ En la parte central dos círculos resguardan cruces griegas y en la parte superior cuatro rombos forman una cruz latina. En las otras tres caras del primer nivel de la torre también lleva las mismas decoraciones de los ventanales, con la diferencia de que sólo abarcan la mitad, pues los cuerpos laterales de la bóveda cubren a la torre. Cada uno de los ventanales rematan en un arco rebajado y el cerramiento se da con una banda ligeramente curveada; están resguardados por unas jambas planas y en las uniones de cada una de las aristas hay un cilindro estriado que termina con unas leves molduraciones.

El segundo cuerpo de la torre es un cubo de menor proporción cuyas paredes se forman a manera de ventana de celosía con lamas horizontales. En las aristas también aparecen cilindros estriados adosados que asemejan unos cactus, lo cual se relaciona con la variante del Pueblo Déco desarrollada en el sur de los Estados Unidos con los "Indios Pueblo" y que a la vez es muy típica en el Noreste de México.

El tercer cuerpo que disminuye más en grosor, es un cubo con celosía formada con recuadros y remata en forma piramidal para sostener la cruz. En cada una de las uniones de las caras, unos mismos cilindros estriados de la mitad de altura del cubo se unen, pero ahora con unas prolongaciones cuadrangulares lo que pareciera los dientes de un peine.

En esta torre campanario y sus tres cuerpos apreciamos que la forma ascensional y piramidal está fuertemente relacionada con los rascacielos norteamericanos en su

\footnotetext{
${ }^{143}$ Carsten-Peter Warncke, De Stijl 1917-1931, Colonia, Taschen, 1993, pp. 66, 70 y 71.
} 
concepción de irse elevando de manera escalonada, como en el caso del Chrysler Building edificado en 1930 por William Van Alen (1883-1954), el Empire State Building de 1931, diseñado por el arquitecto William F. Lamb (1883-1952), miembro de la firma Shreve, Lamb and Harmon o The RCA Building realizado entre 1931 a 1940 bajo el diseño de Raymond Hood (1881-1934), estando los tres edificios ubicados en New York. A la vez, esta torre campanario, por una parte denota una composición de tipo industrial como si fueran piezas emanadas de una manufactura fabril y por otra, parecieran diseños del Déco Streamline con todo y su semejanza entre el gris cementero con el plateado metálico aerodinámico.

En la torre de la Iglesia de Cristo Rey encontramos la distribución de lo geométrico tanto en el diseño de las figuras como en lo escalonado a través de cubos, características distintivas del Art Déco, aunado a las referencias Streamline y al uso del cemento, el material moderno del Déco, que pesar de haberse construido en la segunda mitad de la década de los años cuarenta del pasado siglo, ostenta los elementos compositivos del Déco.

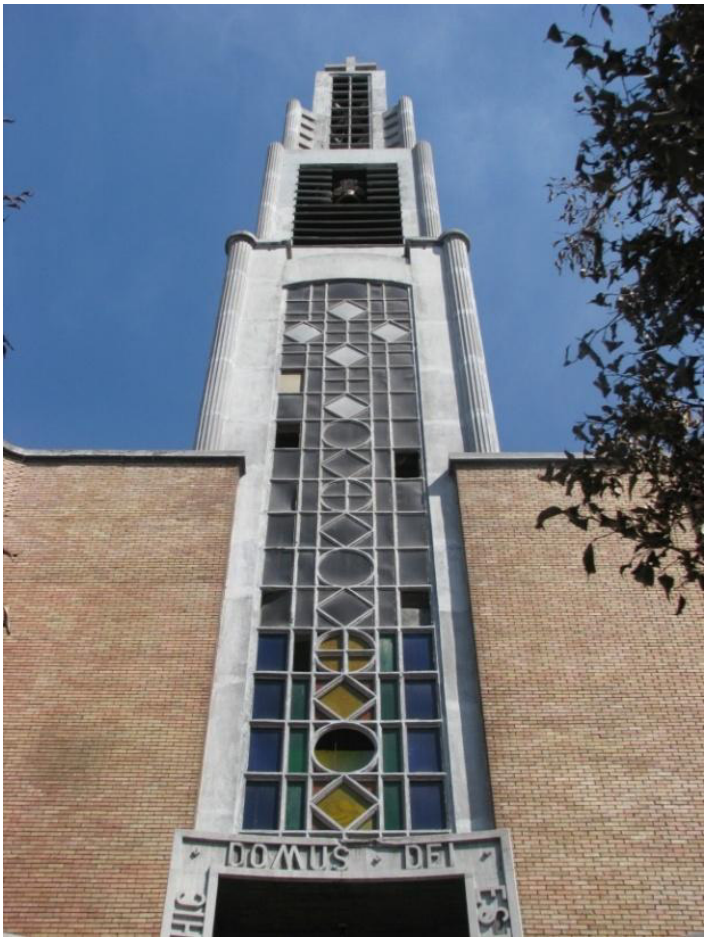

Torre campanario vista de frente.

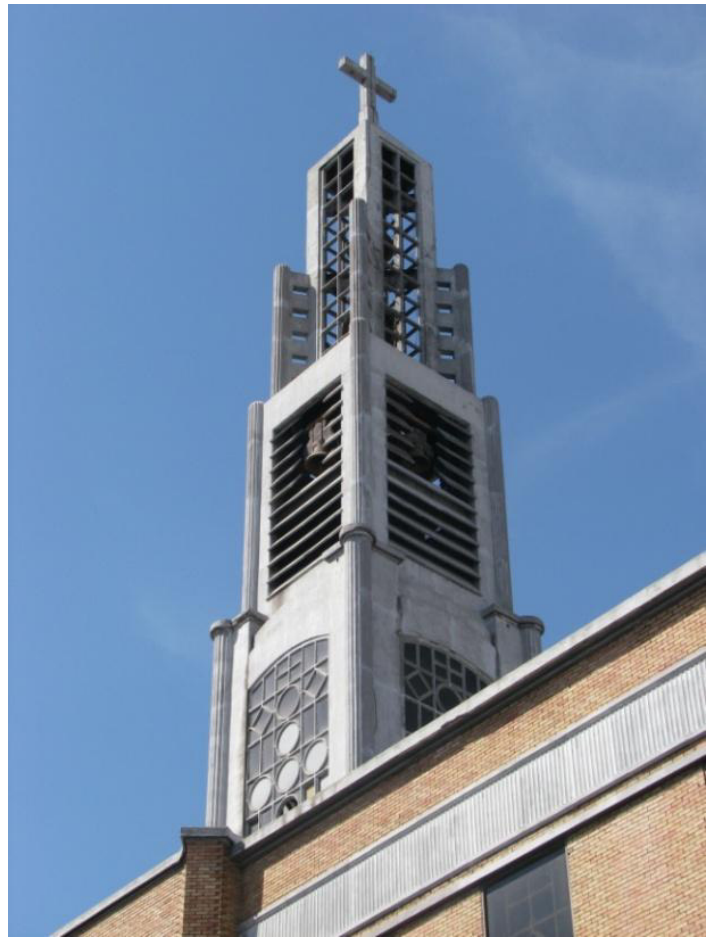

Torre campanario, detalle. 
En el interior de la iglesia, que es de planta basilical de tres naves siendo la central más alta, en la nave lateral derecha a la altura del crucero se encuentra un altar dedicado a la Virgen de Guadalupe, cuyo diseño posiblemente sea del mismo Eduardo Belden. Lo que más destaca es el anagrama mariano que está arriba del cuadro de la guadalupana, el cual se forma por las letras "V" invertida y "M", que aunque su significación y uso es muy antiguo, la manera en como está representado aquí por medio de grafías muy angulosas, componen una verdadera decoración Déco del tipo Zigzag. El anagrama en letras doradas rehundidas con una línea vertical al centro de tono dorado mate y dos tréboles en los extremos, está inscrito sobre una placa redonda de mármol de dos niveles. A su vez esta placa redonda está sobrepuesta encima de otra placa circular de mayor tamaño del mismo material, la cual está decorada por rayos dorados.

Los rayos son veinticuatro, doce a manera de espinas de maguey en tono dorado mate que combinan con la línea vertical del anagrama y los otros doce en color dorado como las letras están representados como espigas de trigo; destaca de estos rayos lo anguloso, sobre todo en las terminaciones de las espigas, que en contemporaneidad con los murales de Ángel Zárraga analizados en este capítulo en el apartado "Las artes plásticas y las artes decorativas", son muy similares a la antena que sostiene el ángel de la séptima de las bienaventuranzas: "Bienaventurados los pacíficos porque ellos serán llamados hijos de Dios" de la Catedral de Monterrey, en cuyo análisis mencionamos la semejanza con el remate del edificio Chrysler.

Siendo lo prehispánico por su geometricidad un motivo decorativo utilizado en el Art Déco de México como de algunos lugares de Estados Unidos, los rayos del anagrama están fuertemente parecidos a las puntas de maguey de la Piedra del Sol o Calendario Azteca, una de las principales piezas arqueológicas del Museo Nacional de Antropología, símbolo del sacrificio a Huitzilopochtli, motivo decorativo de muchos objetos de la cultura mexica.

Por lo tanto, en este anagrama lo geométrico de estos rayos tienen una doble referencia dentro de la estética del Art Déco: la variante Zigzag ya mencionada y el referente prehispánico que alimentó a muchas decoraciones del Déco realizado en el país. 


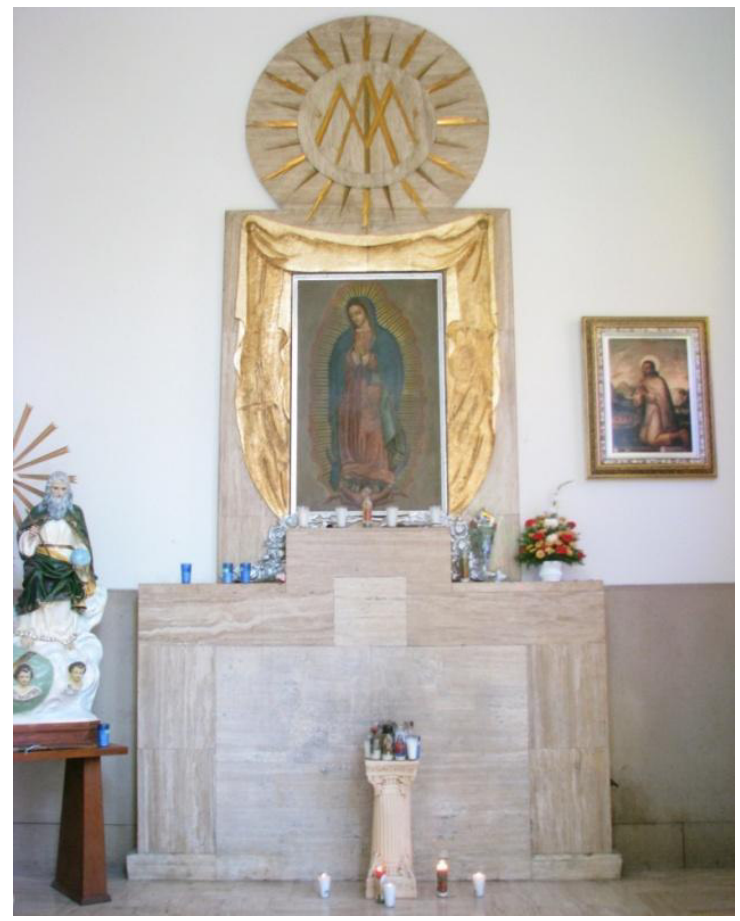

Altar de la Virgen de Guadalupe.

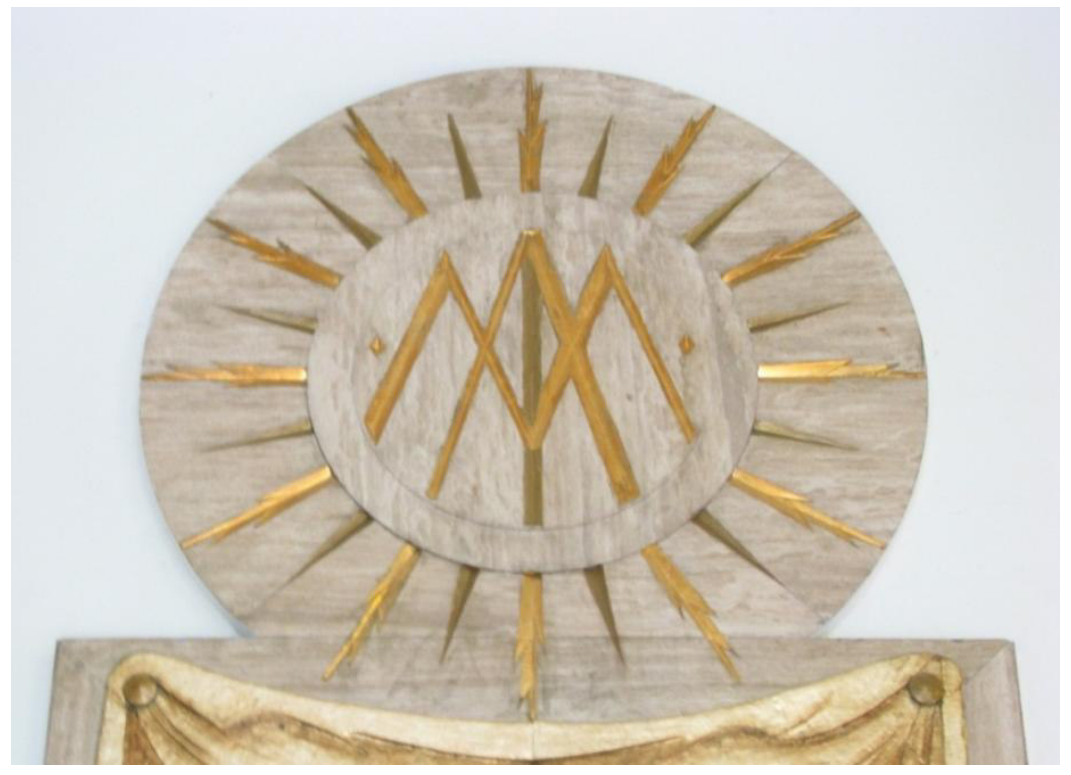

Anagrama mariano en el altar de la Virgen de Guadalupe.

Tanto los círculos concéntricos de las placas de mármol, así como los diseños angulosos y triangulares de las grafías y los rayos, destacan el geometrismo que aunque tardíamente por la época en que fue realizado este anagrama, pertenece a la variante Art Déco Zigzag. 


\subsubsection{ARQUITECTURA COMERCIAL}

\section{a. La Esquina Famosa}

En esquina de las calles Hermenegildo Galeana y José Silvestre Aramberri se encuentra un local comercial que lleva el nombre de La Esquina Famosa. Su fachada es en ochavo, apuntado hacia el noreste. Juan Manuel Casas da el dato que posiblemente sea una obra de mediados de la década de los cuarenta del siglo XX, pero se desconoce su autor. ${ }^{144}$ Está hecha con concreto y aplanados de cemento. Su planta es un ochavo por el frente, unido a un ángulo recto por detrás y cuenta con dos niveles.

Se trata de un pequeño negocio familiar del giro cerrajería, conservado en muy buenas condiciones y se ha convertido en un punto referencial de la zona. Es imposible captar el edificio libre de la invasión de cables eléctricos, debido al tipo de electrificación exterior que existe en todo el país.

En la fachada principal tiene la entrada que es un vano de tres partes: uno para la puerta y dos para aparadores de exhibición. Por las fachadas laterales norte y oriente comparten la misma distribución de vanos: un ventanal de exhibición y una puerta de acceso. Además las tres fachadas llevan una decoración de estrías horizontales bien remarcadas, así como una marquesina con una pequeña incisión en el borde frontal, que si bien no es como las que indica Enrique X., de Anda que sólo abarcan la puerta, son una característica del Art Déco de cubrir todo el edificio.

Por arriba de la marquesina en la fachada principal hay tres vanos rectangulares y en las laterales dos, que son iluminación del espacio interior que podría parecer que su nivel es hasta la marquesina, pero que se prolonga más la altura.

De la fachada principal salen de los extremos dos contrafuertes que despegan su altura perpendicularmente, proyectándose hacia el frente. En lo que corresponde al segundo piso, los contrafuertes llevan vidrio block creando un rectángulo a manera de ventana y en la parte superior los bordes se suavizan al estar recortados suavemente. Estos elementos le

\footnotetext{
144 Juan Manuel Casa García, Rosana Covarrubias, Edna Mayela Peza Ramírez, Concreto y efímero. Catálogo de arquitectura civil en Monterrey 1920-1960, Monterrey, N.L., CONARTE, 2012, p. 143.
} 
dan un fuerte carácter de aeroespacialidad, por lo que es un claro ejemplo de arquitectura Déco Streamline.

En lo que corresponde al segundo piso hay un balcón con rejería de formas sinuosas. El muro que se rehunde lleva una puerta así como dos ventanas con lo que se forma un marco que envuelve a los vanos. Por la parte superior de esto, está el letrero de la casa comercial. La recortada techumbre que cubre al balcón descansa en unas zapatas cuadradas adosadas a los contrafuertes formando una única pieza, con lo que el geometrismo se recalca aún más.

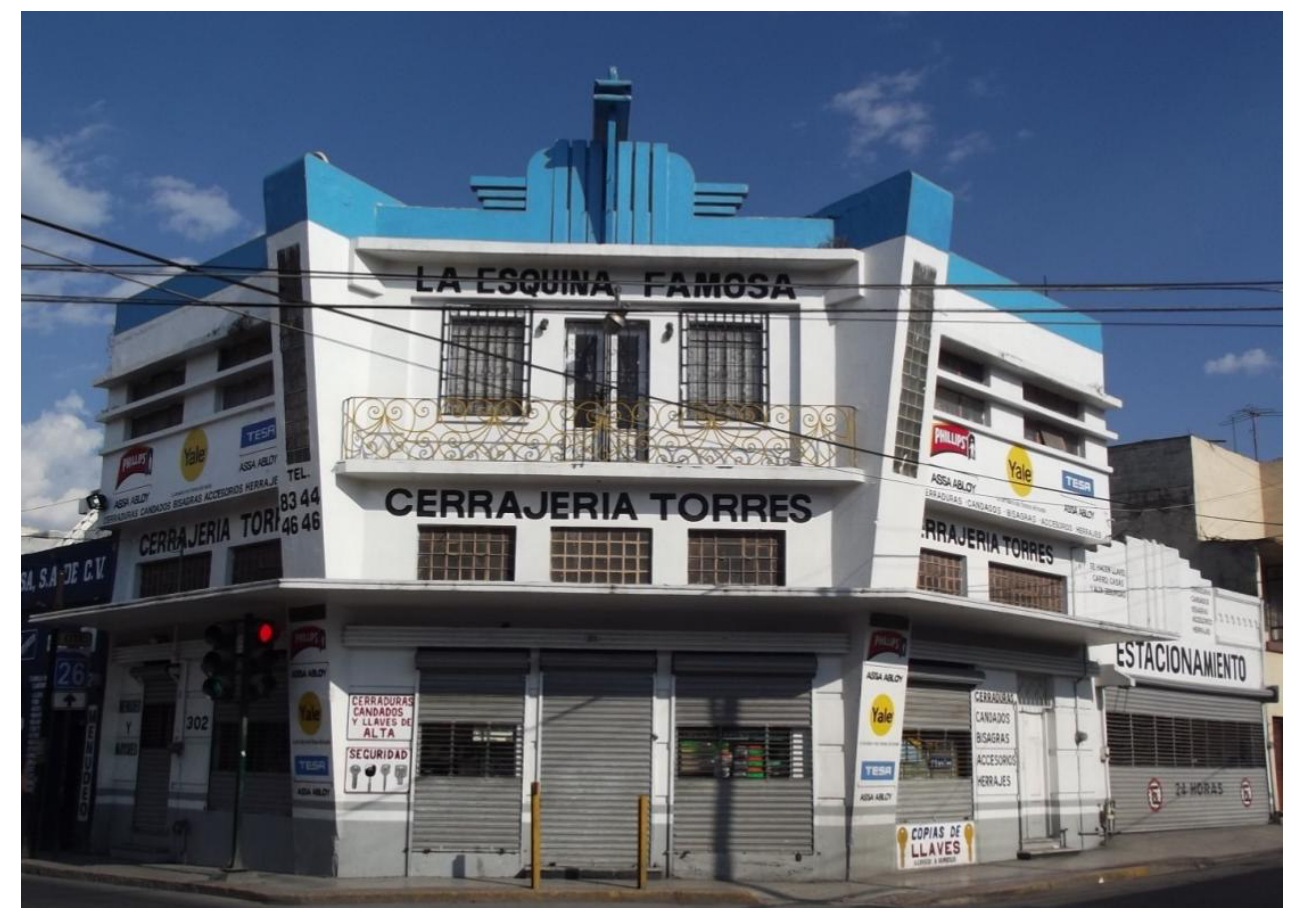

Vista de la fachada principal.

En la parte superior parte superior de la fachada principal hay un escultura cuyo diseño es una abstracción geométrica. Sobre un zócalo alargado un piñón curveado en las esquinas se compone por recortes de líneas verticales levemente resaltados y a los lados se ensamblan tres tablillas de menos a mayor como si fueran alas de un aeroplano. Al centro y en posición de intersección, sobre una base triangular invertida se ensamblan dos tablas rectangulares alargadas, atravesadas por la base que sobresale por encima. Pareciera la abstracción de un pájaro o de cualquier elemento volátil. Este elemento es todo un intenso 
diseño Streamline, donde su semántica aerodinámica es latente y a la vez es lo que más llama la atención del edificio.

En conjunto con los contrafuertes más el componente de la parte superior hacen que La Esquina Famosa pareciera un proyecto de una nave espacial, cuando ya a finales de los años cuarenta después de las II Guerra Mundial, la lucha por el espacio era una de las tareas a cumplir de los diseños industriales y que al mismo tiempo influyeron en la arquitectura Art Déco Streamline como claramente se aprecia en este comercio.

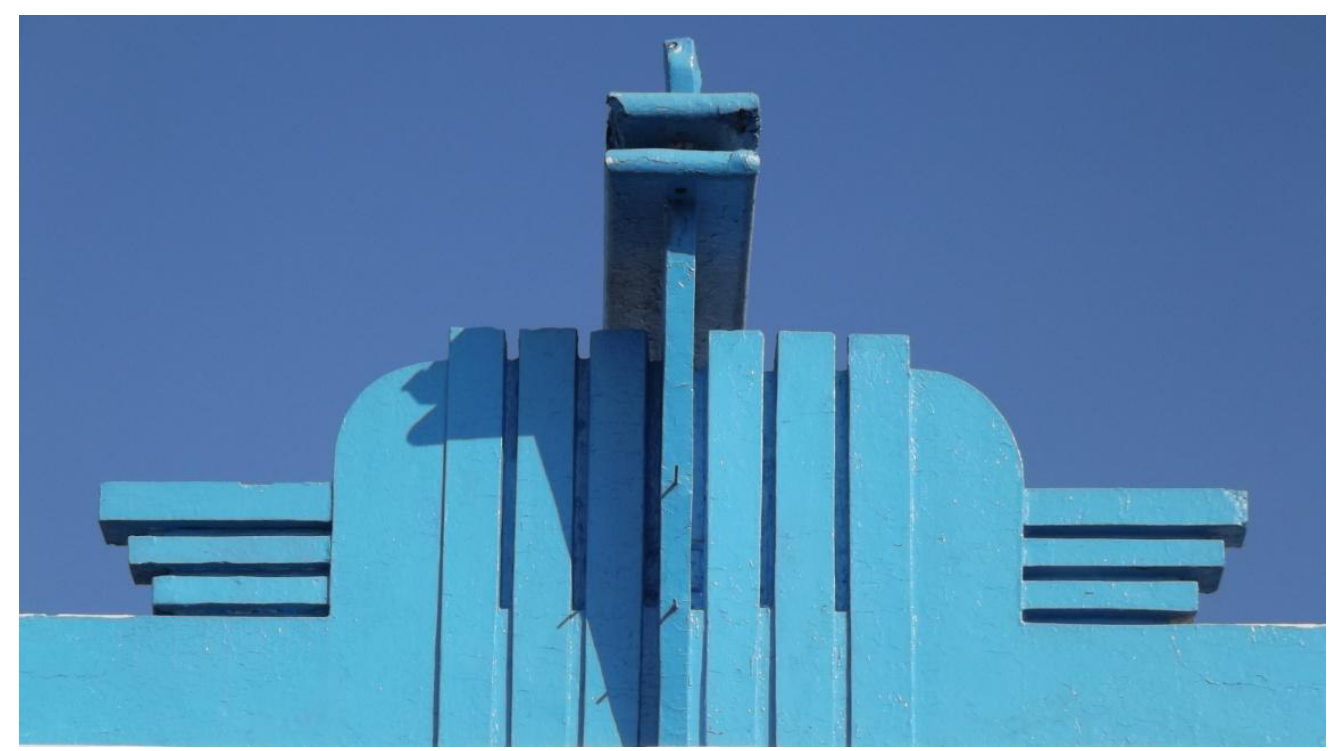

Detalle de la escultura Streamline de la parte superior.

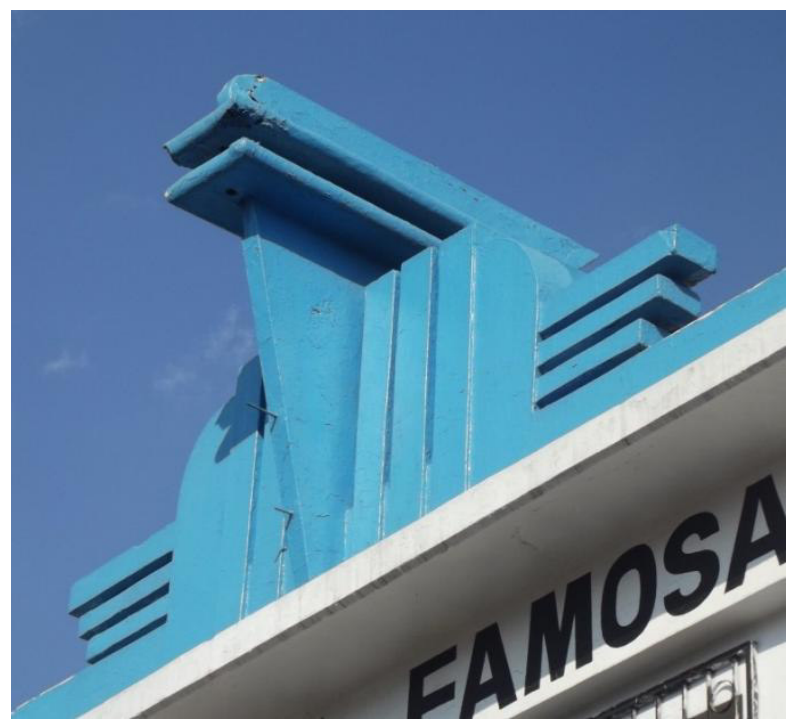

Vista lateral de la escultura Streamline. 
En las fachadas laterales norte, sobre la calle Aramberri, y poniente, en la calle Galeana, en el segundo nivel las ventanas rectangulares llevan además del repisón, una moldura intermedia de mayor tamaño y un dosel alargado de más dimensión que las cubre. Este crecimiento de repisón, moldura y dosel se combina con la posición inclinada de los contrafuertes, favoreciendo la significación de la aeroespacialidad, es decir del Art Déco tipo Streamline.

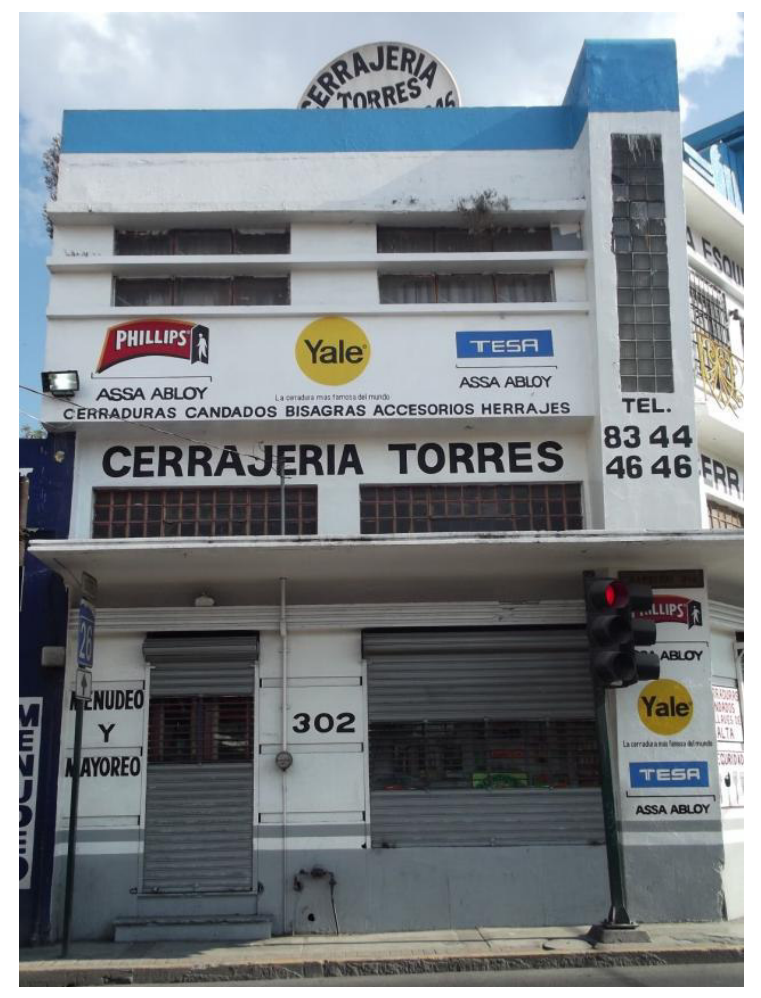

Fachada norte de la calle Aramberri.

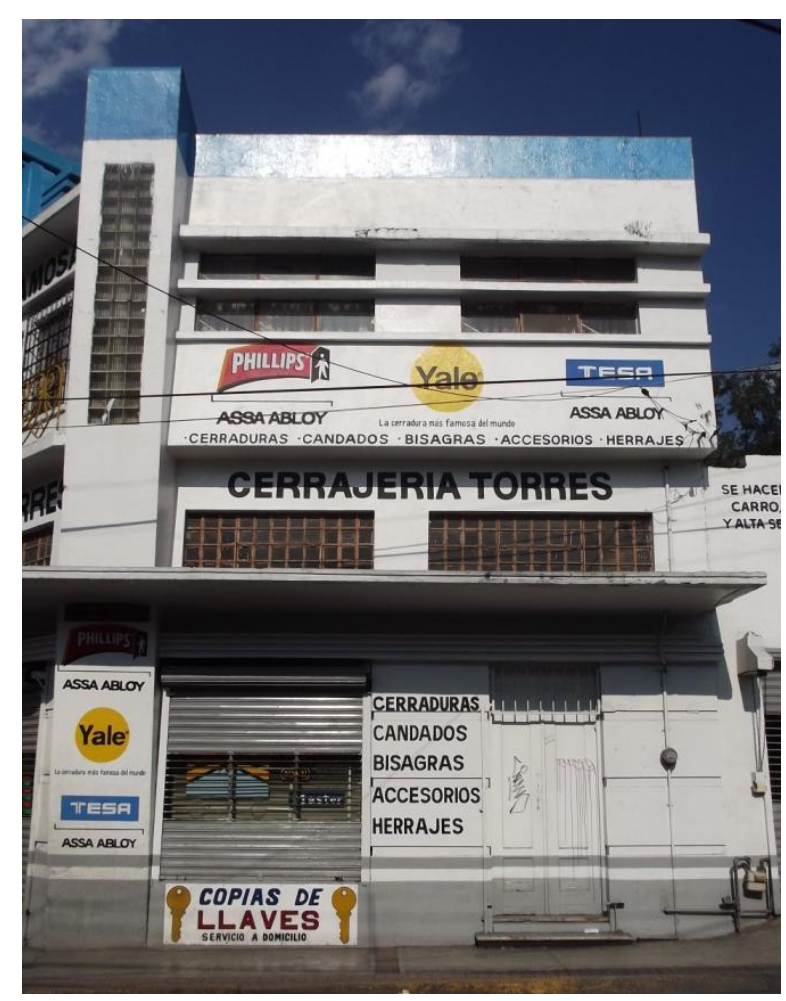

Fachada poniente sobre la calle Galeana.

A un lado de la fachada poniente en la calle Galeana, se adoptó el estacionamiento del negocio comercial. Por arriba de la entrada y del lado izquierdo el remate es escalonado elevándose en tres niveles y en medio todavía se conserva un motivo decorativo que consiste en una placa con tres molduras redondeadas que descansan a su vez sobre otras molduras rectangulares y que envuelven al remate, ornato propio del Art Déco Zigzag. Por el tipo de decoración, posiblemente fue obra del mismo arquitecto y formó parte de una casa vecina. 


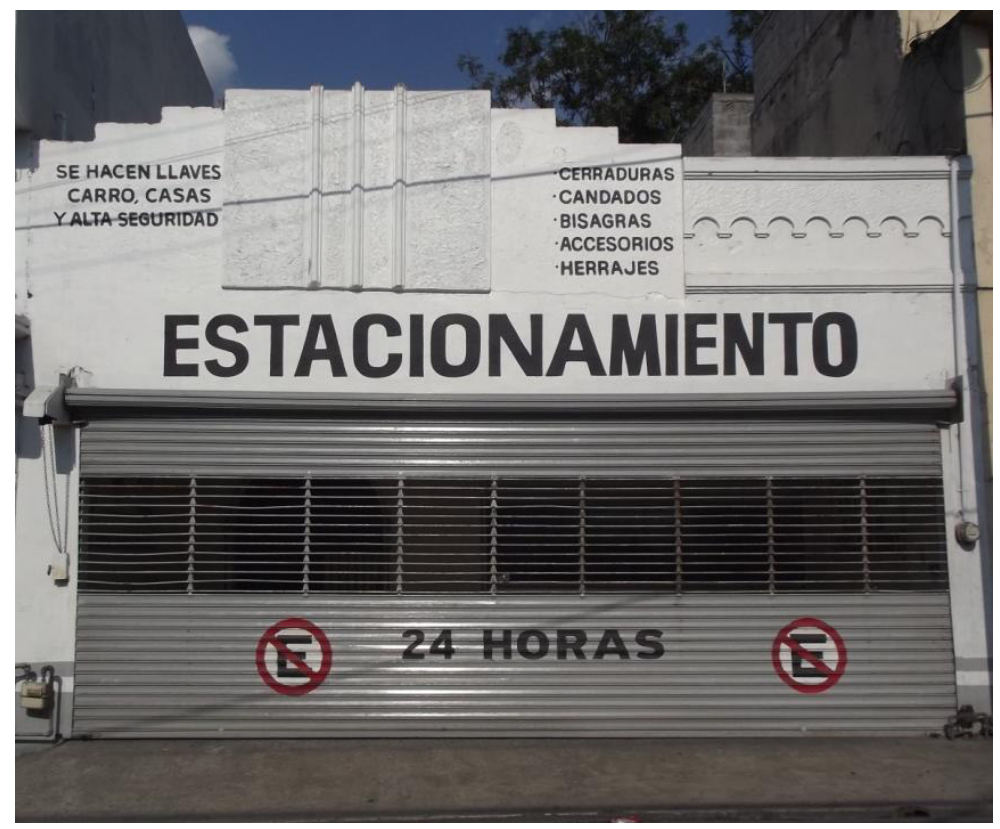

Estacionamiento sobre la calle Galeana.

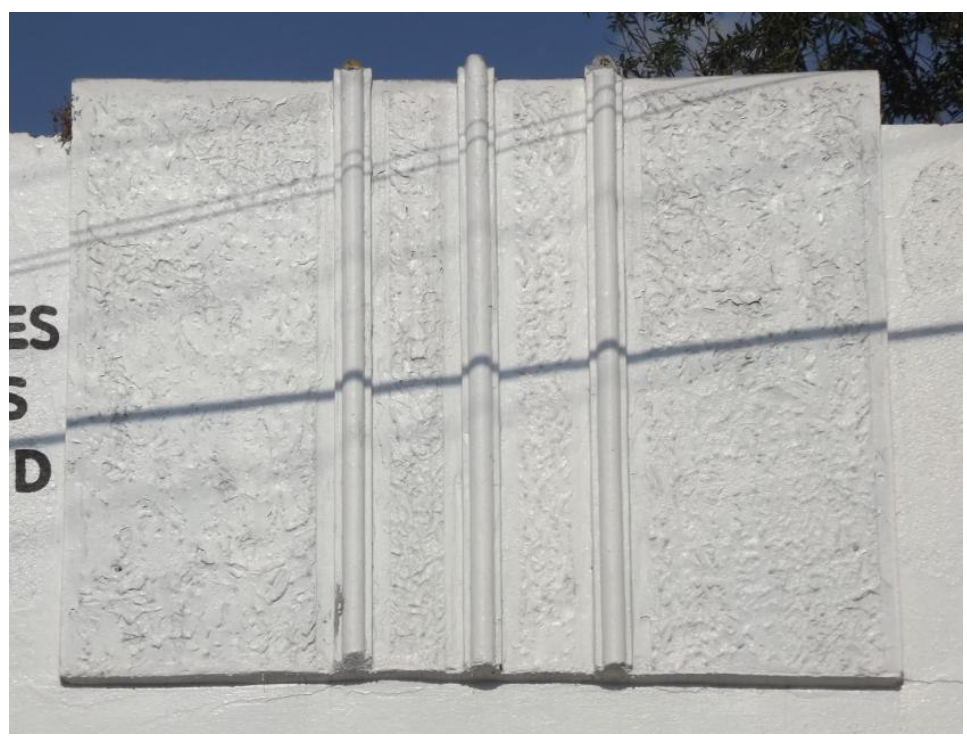

Detalle de los motivos decorativos del remate del estacionamiento.

La Esquina Famosa es un evidente prototipo del Art Déco Streamline, compartiendo elementos de la Tendencia Decorativista y a la vez anuncia la integración del Lenguaje Moderno de la arquitectura internacional. 


\subsubsection{URBANISMO Y RENOVACIÓN}

\section{a. Plaza General Treviño o del Chorro}

Esta plaza se localiza entre las calles Jerónimo Treviño al norte, Isaac Garza al Sur, Mariano Arista al oriente y Dr. Coss al poniente, muy cerca del primer cuadro de la ciudad.

Ninguna referencia encontramos sobre este lugar, salvo la hecha por Héctor Javier Barbosa en su libro Recuerdos de Monterrey, en el que reseña: "En las calles de General Treviño y Doctor Coss se localiza la plaza que se llamó Niño Artillero y después General Treviño, aunque popularmente es la del Chorro, nombre debido a esta fuente monumental de estilo Art Deco, construida en los años treinta". ${ }^{145}$

El conjunto de la Plaza General Treviño comprende una fuente al centro y a su alrededor cuatro bancas más seis bases para lámparas, que originalmente eran ocho. En cada esquina de la plaza hay lámparas con su respectiva base. El mobiliario de este espacio recreativo público está hecho con cemento y es una muestra del desarrollo urbano de los años treinta, pues sin tener más datos para comprobarlo, denota diseños de esa época.

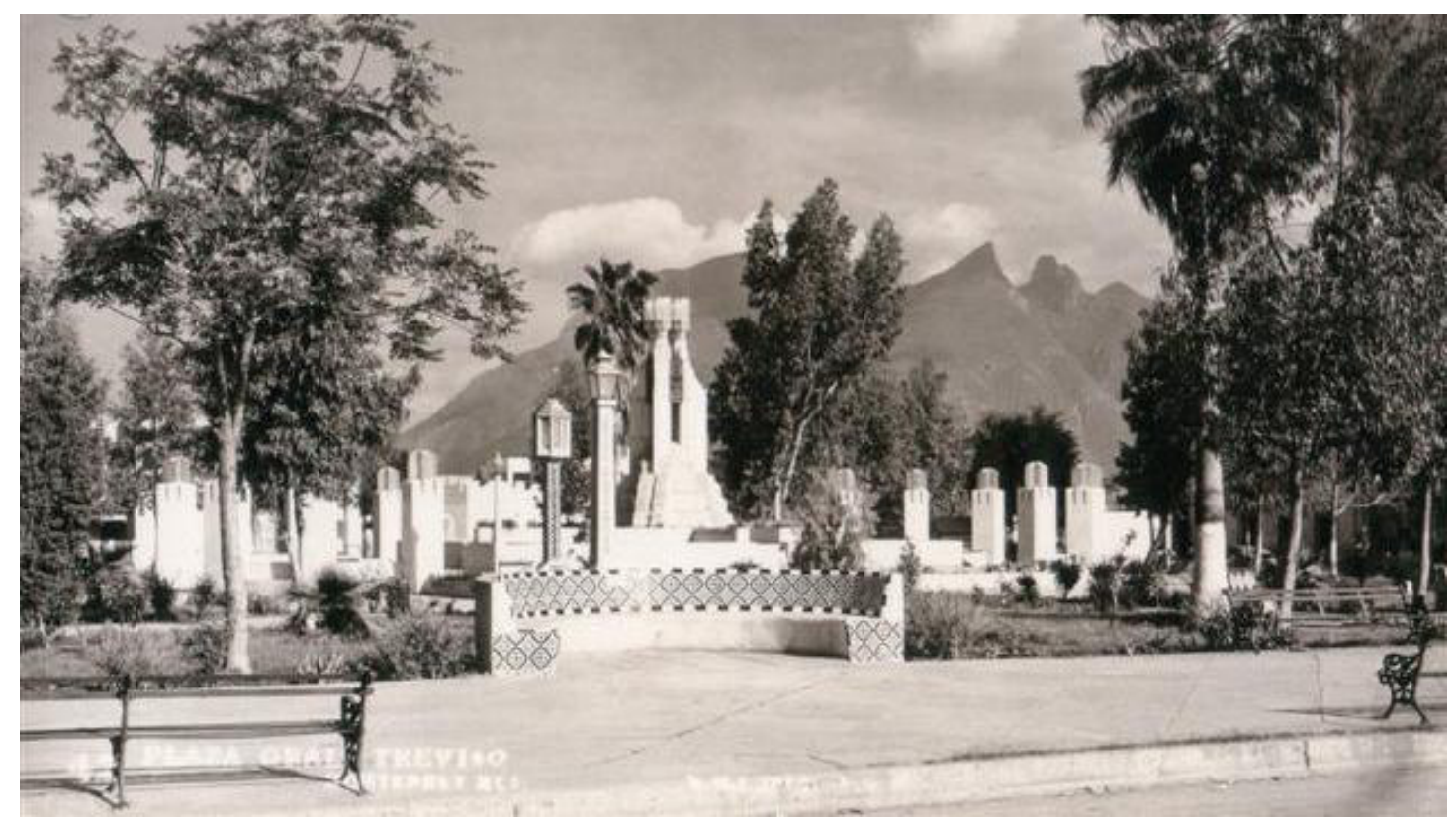

La plaza hacia 1950.146

\footnotetext{
${ }^{145}$ Héctor Javier Barbosa Alanís, Recuerdos de Monterrey. Monterrey, N.L., s/ed., 1993, p. 107.

146 www.mexicoenfotos.com
} 
Sobre la calle Dr. Coss y casi con la esquina de la calle Jerónimo Treviño se encuentra una placa original de la época, sobreviviendo ante las constantes pinturas que le han puesto a la pared de la casa donde está colocada. Ahí está el nombre original que se le dio: "Gral. Treviño".

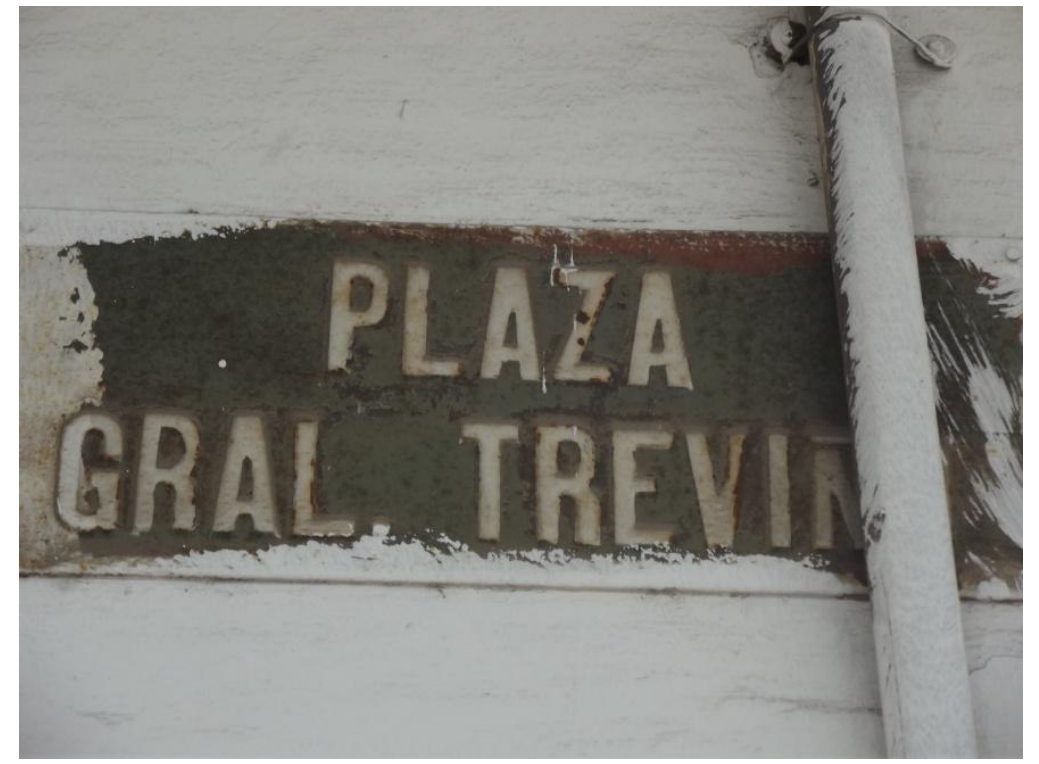

Placa en la calle Dr. Coss.

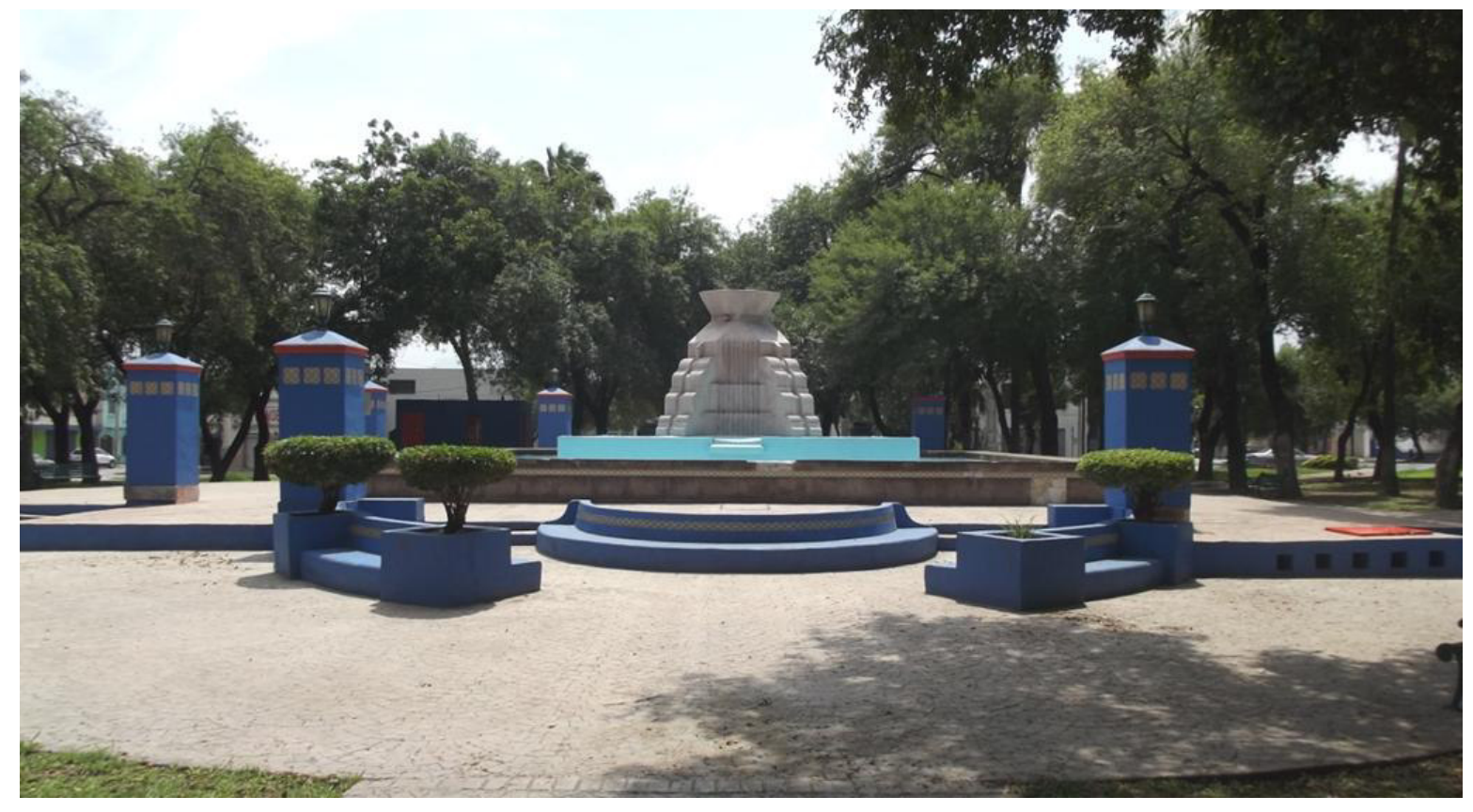

La plaza desde la calle Dr. Coss, vista poniente. 
Una de las cosas que más llama la atención de la plaza es la fuente, que sin agua -como la mayoría de las fuentes en México, de acuerdo al referente popular- ciertamente pareciera una escultura parodiando caídas de chorros de agua. Protegida la fuente por un pretil se forma una pila cuadrada, que a su vez rodea la base de la fuente, pasando por unas jardineras. La fuente en sí es un atrayente grupo de volutas verticales escalonadas que miran hacia los cuatro puntos cardinales intermedios; estos grupos de volutas se adhieren a cuatro de las ocho caras del ochavado bloque central, del cual las otras cuatro caras se embellecen con tres niveles de estrías escalonadas cóncavas en sentido ascensional y creciendo en altura. Precisamente la utilización en la gran exposición de París de 1925 del motivo decorativo de estrías como si fuera agua congelada, es de la misma manera como están tratadas aquí, que con las volutas que asemejan borbotones de agua, completan todo un lenguaje de caídas acuáticas solidificadas y geometrizadas. Las caras se recortan biseladamente y convergen a una base cuadrada donde se asienta una especie de tina también ochavada. Todo el acopio de las partes que plasman la composición de la fuente es un supremo resultado de decorativismo y geometrismo Art Déco.

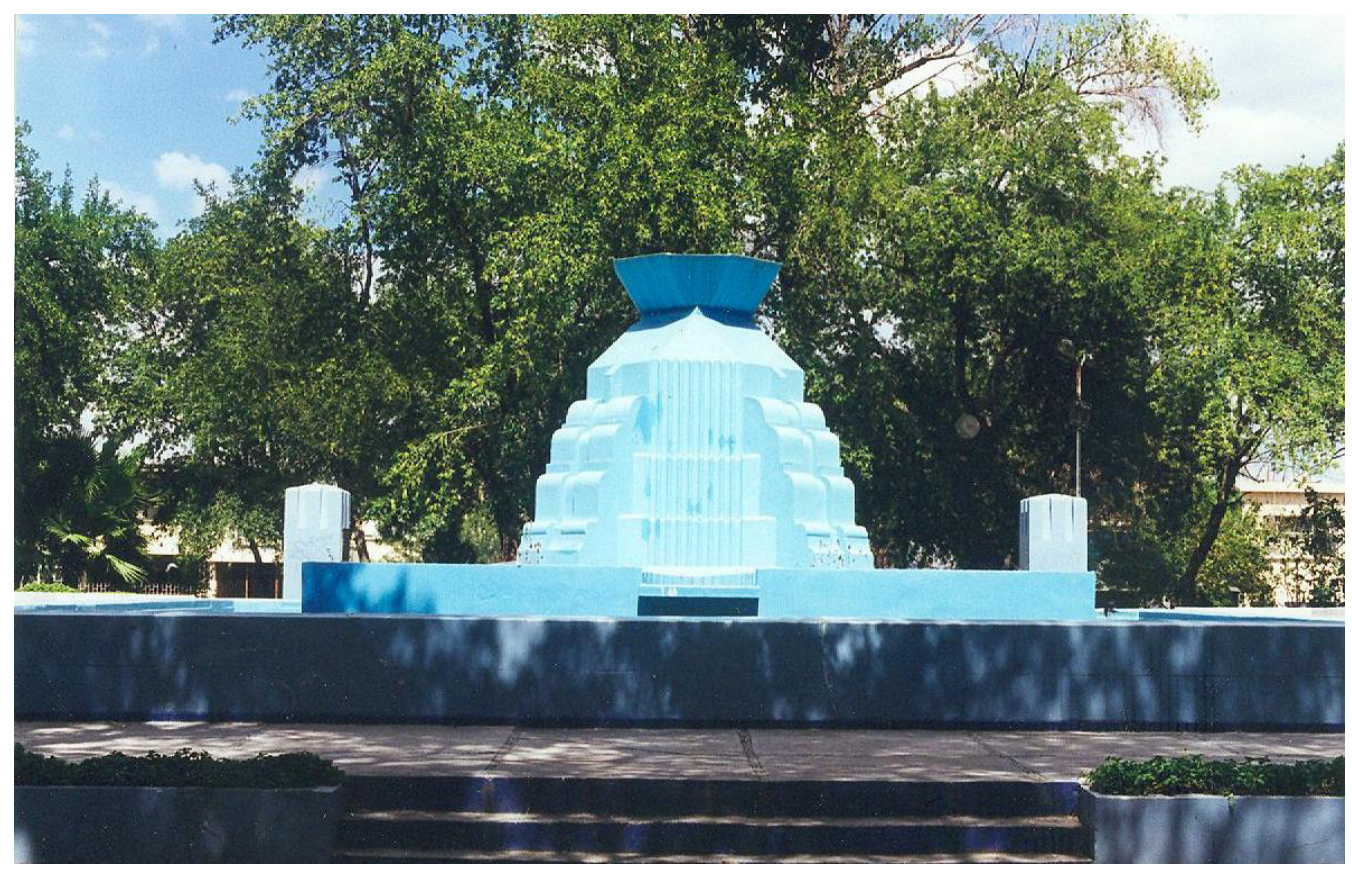

Lafuente con dos pilares al fondo, antes de la restauración de 2003. 
El zócalo de la fuente, salvo en las esquinas cuadradas, también va decorado con estrías, pero éstas son planas. Cuatro semicírculos se proyectan hacia el frente del zócalo en dirección de los cuatro puntos cardinales, que también están ornados con estrías planas; así pues, la fuente sin agua, de todos modos transmite la idea del líquido que baja suavemente. Círculo, cuadrado, estrías, todo entra, cabe y es Art Déco.

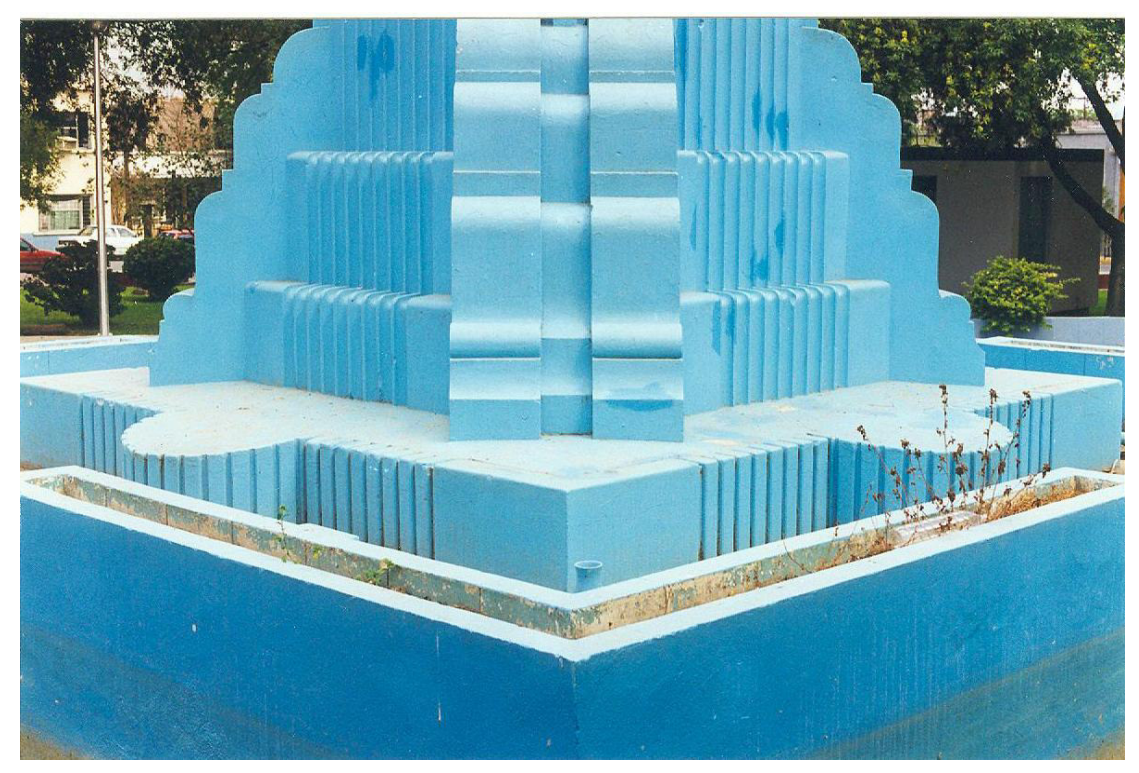

Zócalo de la fuente.

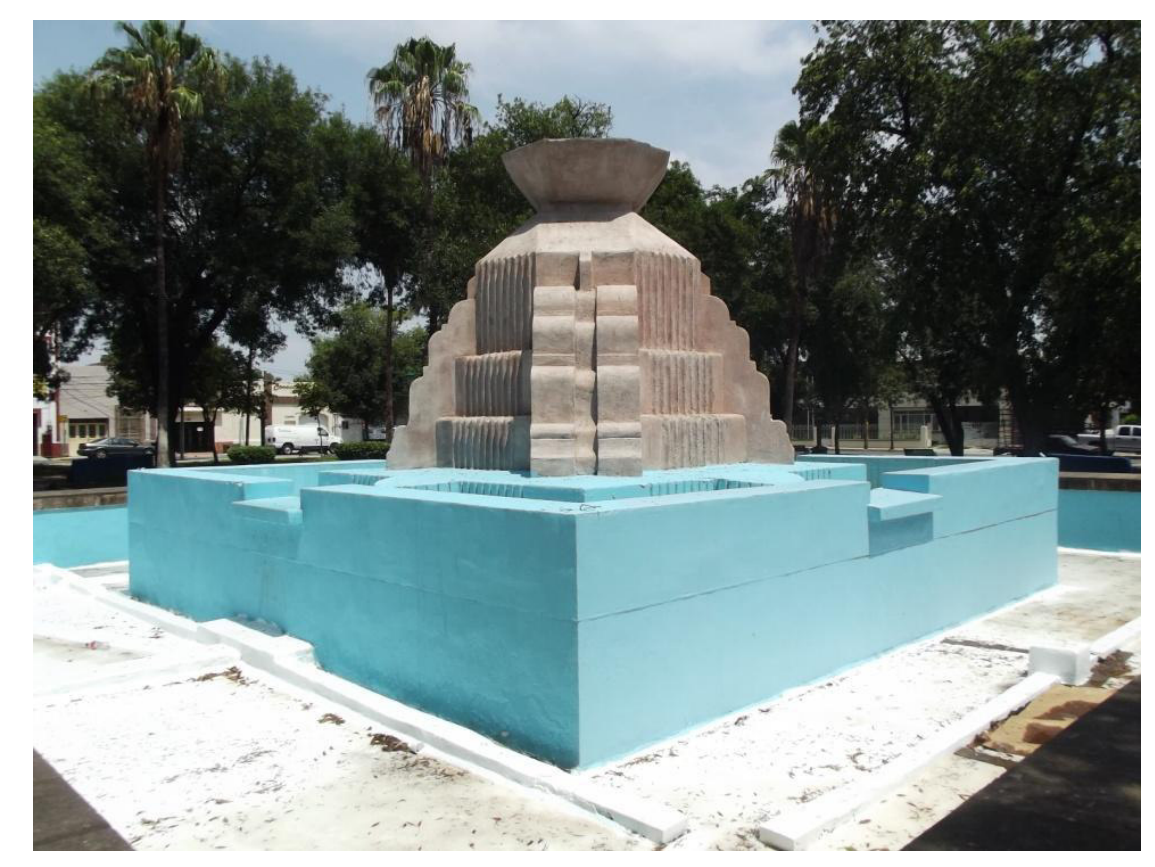

Vista actual de la fuente. 
Seis pilares cuadrados de los diez que tuvo la plaza en un principio y que servían como base para unas luminarias, están colocados simétricamente en relación con la pila de la fuente. Llevaban en cada lado un par de recortes oblicuos hacia adentro, formándose doce pequeñas pilastras, tres de cada lado, levemente redondeadas en la parte superior, que abstraían la imagen de unos sugerentes cactus petrificados, los cuales se utilizaron especialmente como motivos decorativos en la variante norteamericana Pueblo Déco, que por la cercanía de la Región Noreste y de Monterrey con la frontera norteamericana de Texas, tuvieron su influjo en el Art Déco de la localidad. Desafortunadamente con la restauración de 2003, ante la ignorancia y desconocimiento, fueron forrados con cemento y azulejos, perdiéndose por completo su diseño original.
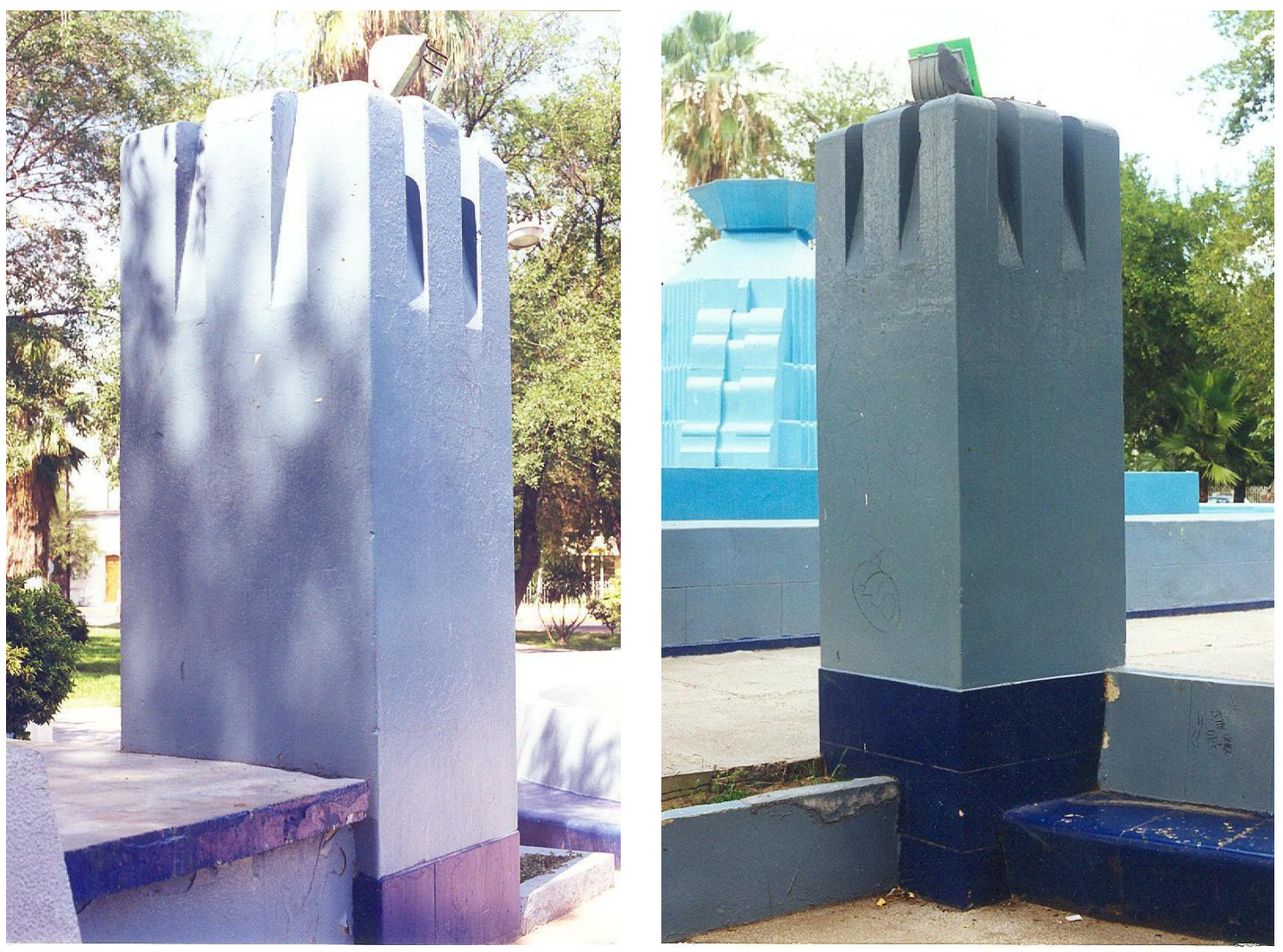

Imagen de 1998 de los pilares con abstracciones de cactus que perdieron su diseño original en la restauración de 2003. 


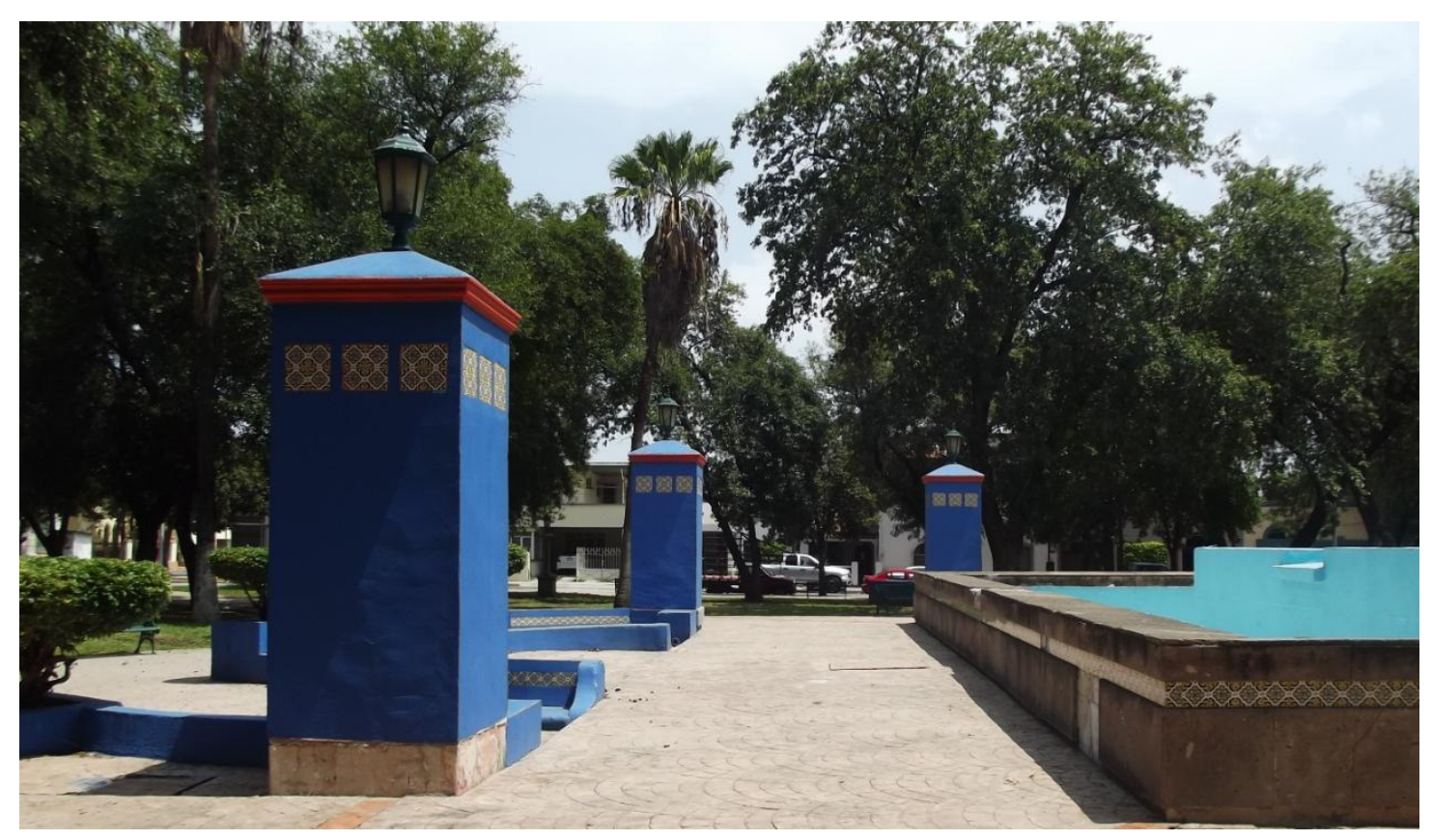

Tres de los pilares en sus condiciones actuales.

Un par de singulares bancas convexas y otras cuatro cúbicas dispuestas oblicuamente y que a su vez son jardineras, se distribuyen en el centro de la plaza y, por decirlo así, acompañando a la fuente. Líneas rectas y curvas, prismas rectangulares y cúbicos que componen las formas de las bancas, acrecientan el sentido geométrico de los componentes Art Déco de la plaza.

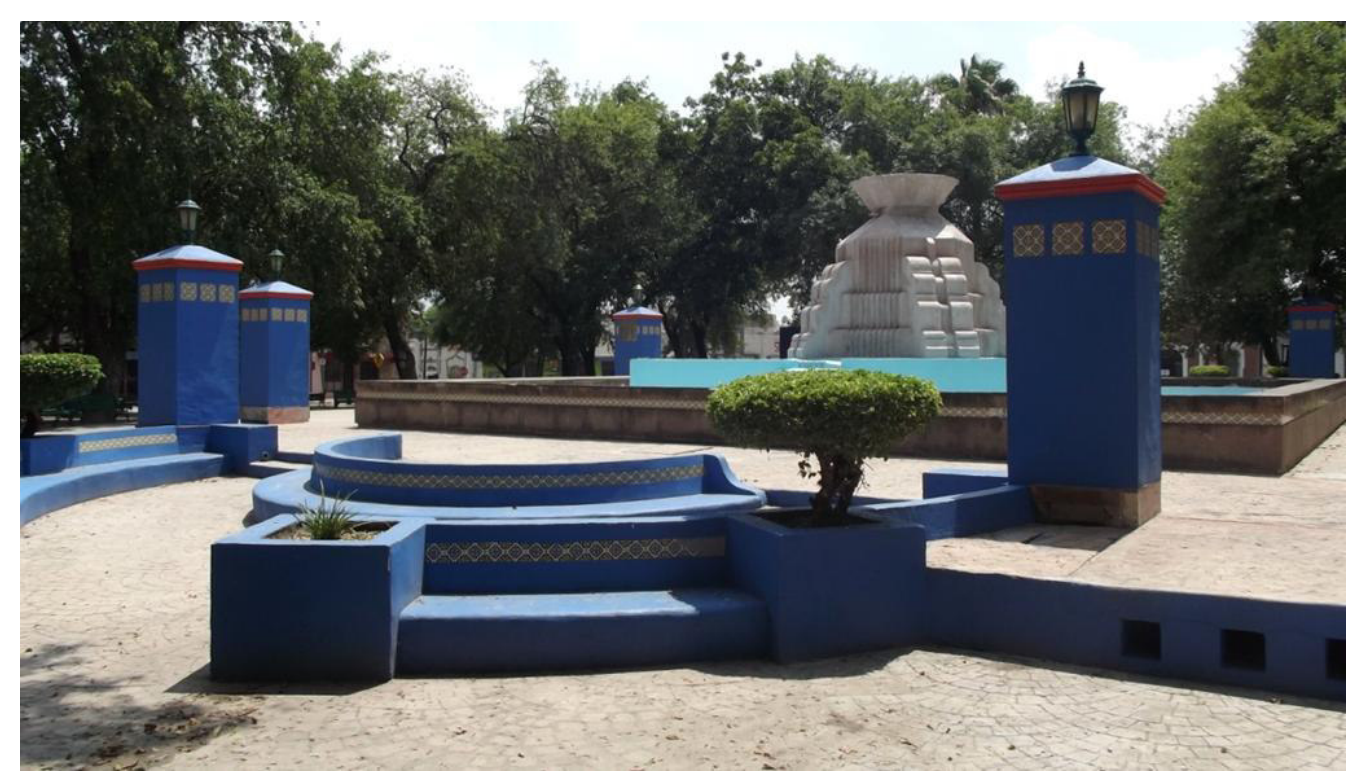

Bancas curvas, las jardineras cuadradas, más cuatro pilare y la fuente. 
Para darle un toque de mexicanidad a la plaza, en cada esquina se colocaron cuatro lámparas decoradas con talaverescos azulejos. Un zócalo cuadrado y una base también cuadrada y de menor tamaño se atavían con pequeñas líneas oblicuas. Luego el dado está forrado por azulejos con decoraciones florales y vistas pintorescas mexicanas. Arriba del dado, cuatro hileras escalonadas pero con ligeras curvaturas semejan los soportes de un atril. Una pilastra cuadrada revestida de azulejos con ornatos de líneas oblicuas y serpenteantes que forman zigzags sostienen una peana donde se soportaba la bombilla.

Los paisajes de los dados que no son Art Déco, exhiben escenas folclóricas del centro de México, ya que son panoramas del altiplano central y del lago de Xochimilco, tan ajenos a la cultura del noreste de México, pues se ven los cerros y las campiñas a la manera de esa zona, así como una trajinera con todo y su remero con el cargamento de flores.

Una mixtura de geometría con intenciones ornamentales mexicanas es el resultado de los pedestales de estas cuatro lámparas, pues en los años del Art Déco en el país, la modernidad postrevolucionaria iba de la mano con la búsqueda de identidad nacional y como sucede en muchos casos, el centralismo se impone como modelo de la esencia de la nacionalidad

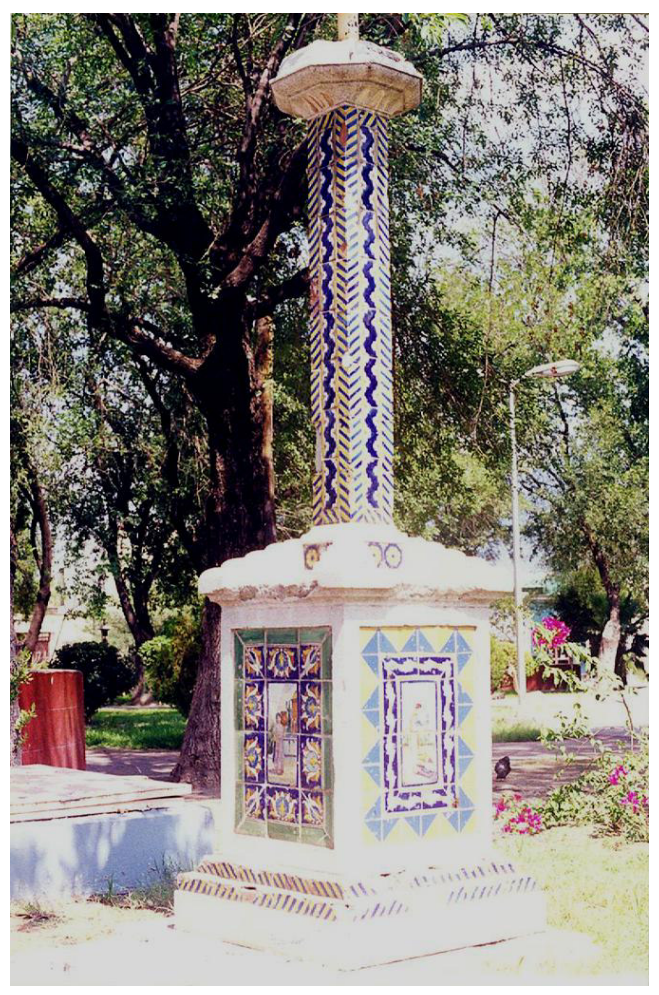

Una de las cuatro bases de las lámparas.

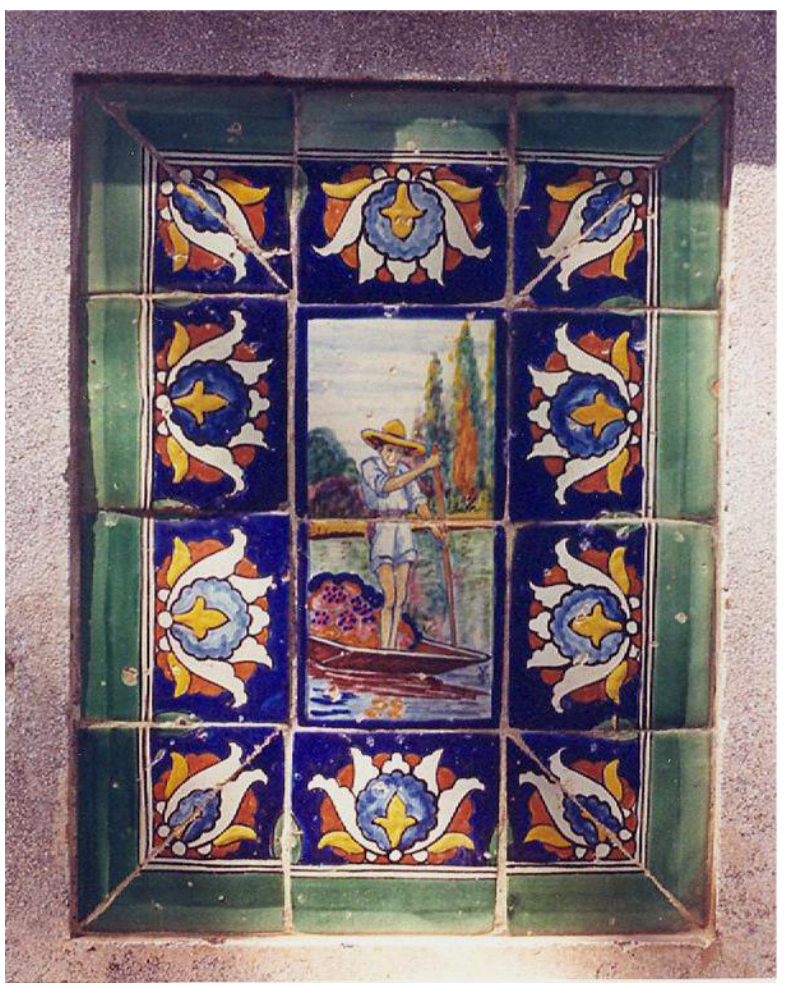

Paisaje pintoresco mexicano en una de las caras de un dado. 
Esta llamativa plaza Art Déco fue trabajada en el material de moda de la época, el cemento y ha sido constantemente pintada de diferentes colores, pero en muchas ocasiones sin tener el más mínimo cuidado de las tonalidades que deberían aplicar. Por sus detalles geométricos en la fuente la incluimos dentro del Art Déco Zigzag y por sus lámparas dentro de la Tendencia Decorativista.

Como muchos casos más, la Plaza General Treviño o del Chorro está algo desatendida en su conservación, primero por el descuido mismo tanto de vecinos como de paseantes; y segundo, por la poca atención que los municipios en general ofrecen a lugares de esparcimiento. Y a pesar de que hubo con la intención de rescate por parte del INAH, el INBA y un Consejo de Universidades locales, esta notable plaza Déco sufrió una restauración en primavera de 2003, que la despojó de los accesorios de inmobiliario y sólo quedó como Art Déco la fuente, las bancas y las pilastras de las cuatro lámparas. 


\subsubsection{LAS ARTES PLÁSTICAS Y LAS ARTES DECORATIVAS}

\section{a. Murales en la Catedral de Monterrey de Ángel Zárraga}

El Arzobispo Guillermo Tritschler y Córdova (1878-1952) ocupó la silla episcopal de 1941 a 1952. Con una gran visión por el arte moderno, invitó al pintor Ángel Zárraga (1886-1946) para que trabajara en un proyecto para decorar el presbiterio. Zárraga que había vivido en Europa desde 1907, al no poder integrarse al movimiento del Muralismo, desde 1922 a 1941 pintará diversos murales en edificios e iglesias en Francia. A su regreso al país pinta murales en el Club de Banqueros y los laboratorios Abbott. No concluyó un encargo mural para la biblioteca de la Ciudadela, pues la muerte lo alcanzó el 22 de septiembre de 1946.

Los murales de la Catedral fueron trabajados entre 1942 a 1945. El diseño original no corresponde a lo que finalmente se pintó. ${ }^{147}$ Aunque ya han sido descritos en el libro de La Catedral de Monterrey de Tomás y Xavier Mendirichaga ${ }^{148}$, incluiremos algunas interpretaciones propias dentro de las corrientes artísticas e influencias que manejaba el artista como es el Art Déco, pues Zárraga justamente vive en la Ciudad Luz en los años de entreguerras, los años del desarrollo del Déco. Su religiosidad católica está presente en estos murales por lo que analizaremos los elementos iconográficos, además de mencionar algunos hallazgos dentro de los murales. La disposición de los mismos para describirlos será: ábside, muro derecho, muro izquierdo y bóveda.

El ábside se inicia de arriba hacia abajo con el Espíritu Santo sobre un resplandor de 21 rayos. Tres líneas de cada lado bajan hacia la escena de la Virgen María y de la Señora Santa Ana. El resplandor apunta hacia una corona, simbolizando el poder de Dios Padre, quien del lado derecho vestido con túnica dorada apunta con una mano hacia Jesús y con la otra sostiene la corona de espinas. La Santísima Trinidad está puesta de manifiesto. Debajo del Padre un ángel con manto púrpura en la mano izquierda muestra un manifestador con la hostia y con la derecha carga un cáliz, ambos objetos en referencia a la eucaristía. El

\footnotetext{
${ }^{147}$ Existen unas fotografías de los bosquejos originales catalogadas y recogidas por el P. Raúl Mena Seifert en el Catálogo de la Catedral.

148 Tomás y Xavier Mendirichaga, "Los Murales de Zárraga", La Catedral de Monterrey, Monterrey, EMEDICIONES, 1990, 2a., ed. pp. 57-61.
} 
arcángel Gabriel con manto rosa y diadema extendida de flores, porta la azucena de la pureza, misma que es irradiada por el Espíritu Santo; con la mano derecha apunta hacia una estrella en el broche del otro ángel en alusión a la Stella Maris, (estrella del mar, como madre guía) de las Letanías Lauretanas; María con vestido rojo y manto azul como viste la Inmaculada Concepción, acepta en actitud de sumisión su encarnación y de su vientre irradia luz en forma de ondas, porque dará vida al Salvador. Según citan Tomás y Xavier Mendirichaga el tema de este mural en palabras del propio artista es La Glorificación de la Virgen bajo el Misterio de la Trinidad. ${ }^{149} \mathrm{Al}$ fondo se aprecia el Cerro de la Silla, con lo cual Zárraga coloca a la Anunciación en la ciudad regia, imponiéndole un fuerte carácter regional a la escena.

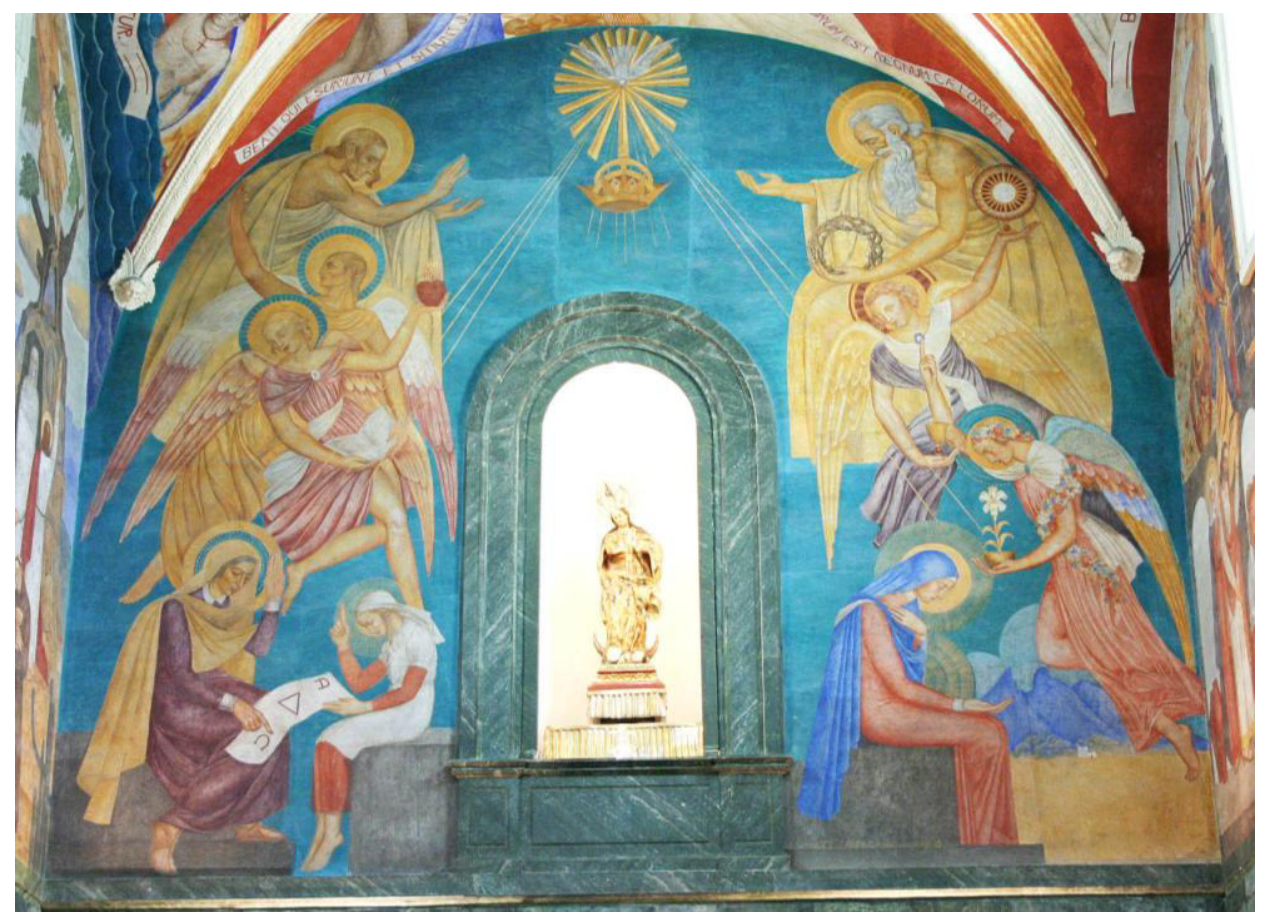

Mural del ábside.

Del lado izquierdo del mural, Cristo con túnica blanca abre las manos para recibir la corona de espinas que le envía el Padre. Debajo unos ángeles sostienen un libro que se refiere a las Bienaventuranzas de la bóveda, una de las cuales es señalada por uno de los seres seráficos y el otro muestra el Sagrado Corazón de Jesús. En el broche de la capa del

\footnotetext{
${ }^{149}$ Ibídem, p. 57.
} 
ángel con túnica rosa están inscritas las letras AZ, iniciales del nombre del artista, lo que fue descubierto por el P. Raúl Mena quien ocupó el puesto de Capellán de la Catedral entre 2007 a 2012. Santa Ana con túnica color vino y manto dorado recibe también los rayos del Espíritu Santo porque fue concebida. Ella instruye en la lectura a través del alfabeto griego a la Virgen niña quien porta vestido rojo, casaca y pañoleta blanca, esto en correlación con su pureza terrenal; esta tradición de presentar a la Virgen mientras aprende a leer fue iniciada en el siglo XIV. ${ }^{150}$ El alfa y la omega son la interpretación de Cristo anotada en El Apocalipsis 22, 11, y la delta, el triángulo, según la tradición griega, ${ }^{151}$ es la denotación de lo femenino de Ana y María, abuela y madre del Redentor. La firma está debajo del asiento de la Virgen y dice “ÁNGEL ZÁRRAGA mexicano 1942 43”.

Varios elementos dentro de la estética del Art Déco encontramos en este mural del ábside. Primeramente, la composición triangular de tipo piramidal se observa en la paloma del Espíritu Santo y los rayos que emana, como en la decoración de la puerta de entrada del pabellón La Maitrise de Galerías Lafayette de la Exposición parisina del 25, obra de los arquitectos Joseph Hiriart (1888-1946), Georges Tribout (1890)-1970) y Georges Beau (1892-1958). Del lado izquierdo Las manos de Cristo se abren como las de la fotografía de la bailarina Claire Baurov ${ }^{152}$ que inspiró a tantos diseños de los años 20 y 30 del pasado siglo, mientras que la posición de las manos de la Virgen y de su madre son como las de las esculturas de Pierre Le Faguays (1892- 1935) o los relojes en vidrio del italiano ErnstMarius Sabino (1878-1961). ${ }^{153}$ Los pliegues de las túnicas, especialmente la de la Virgen o los mantos tanto de la Virgen como de Santa Ana, son una clara referencia de los diseños de tipo Zigzag del Art Déco, o bien son tratados a la manera de los cuadros de la pintora polaca Tamara de Lempicka (1898-1980), avecindada en París en los mismo años en que Zárraga vivía en la Ciudad Luz. Del lado derecho y hacia abajo, definitivamente es Gabriel el arcángel una clara referencia a unos de los carteles publicitarios de la gran Exposition Internationale des Arts Decoratifs et Industriels Modernes de 1925: la posición volátil del

\footnotetext{
${ }^{150}$ Las más antiguas representaciones de esta iconografía y tradición están en los muros de la iglesia de Croughton, Northam-Lonshire, Inglaterra y en los vitrales de la catedral de Orvieto, Italia, ambas del siglo XIV y de aquí viene su expansión Véase: Pamela Sheingorn, "The Wise Mother: The Image of St. Anne Teaching the Virgen Mary", Gesta, XXXII/1, The Internacional Center of Medieval Arte, 1993, pp. 69-70.

${ }^{151}$ José Antonio Pérez-Rioja, Diccionario de Símbolos y Mitos, Madrid, Tecnos, 2008, 8a ., ed., p. 432.

${ }^{152}$ Véase: Paul Menz, Art Déco: 1920-1940, Barcelona, Gustavo Gili, 1974, p. 63.

${ }^{153}$ Victor Arwas, Art Deco, New York, Abrams, 2000, p. 148; Alastair Duncan, The Encyclopedia of Art Deco, London, Quantum Books, 1998, p. 105.
} 
arcángel de Zárraga es como la mujer del diseño firmado por Robert Bonfils (1886-1971), cuyos pliegues abultados de su vestido son convertidos en las alas del ser celestial. ${ }^{154}$
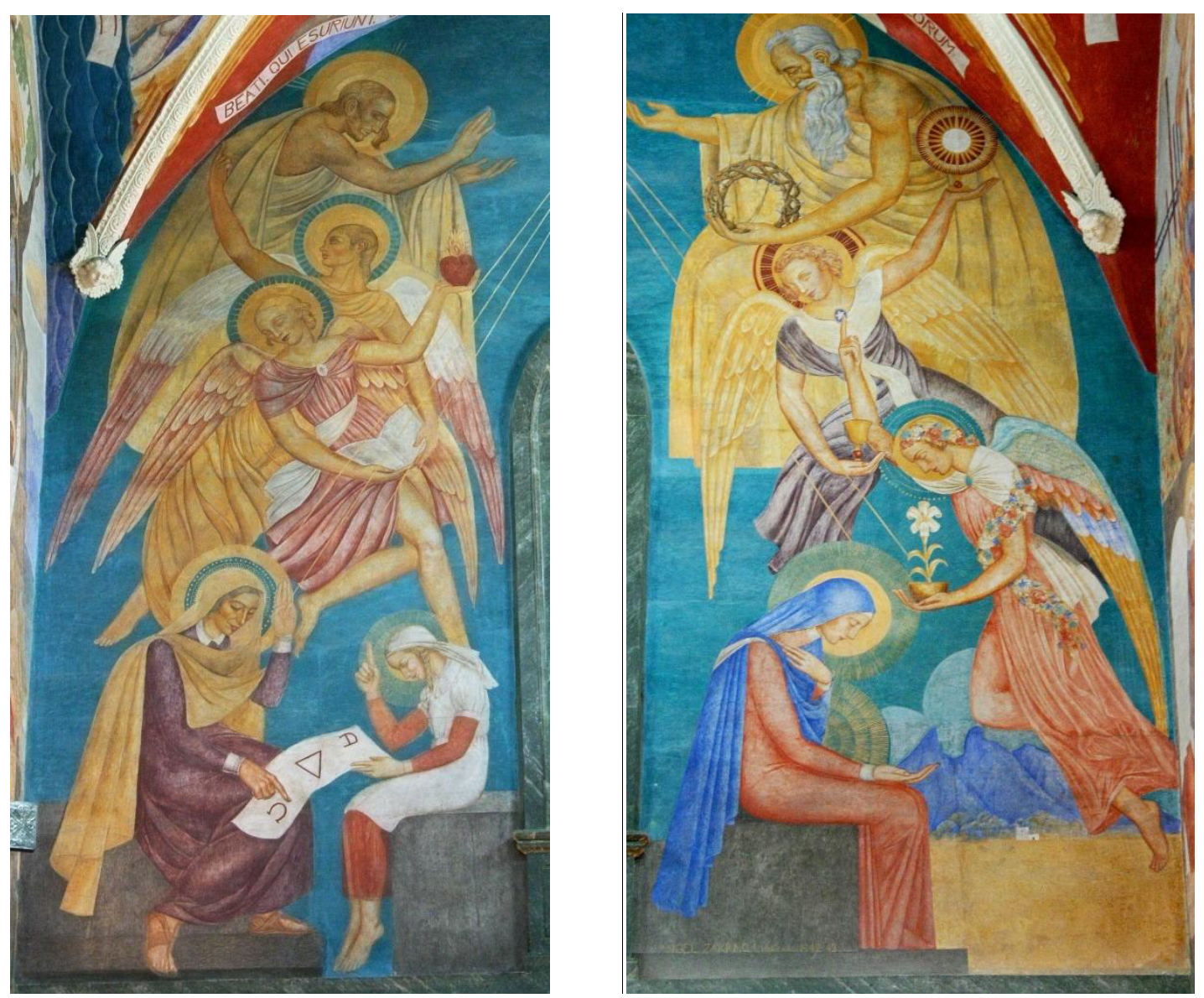

Detalles del lado izquierdo y derecho del mural del ábside.

En el mural del lado derecho o muro sur, en la parte de abajo se relatan tres pasajes bíblicos. Del lado izquierdo el milagro de la bodas de Caná. La Virgen con su manto azul y rojo detrás de Jesús le dice de la falta de vino a lo que el Redentor ordena vaciar agua en unas ánforas. Al sirviente no se le ve el rostro y en su brazalete se leen las letras AZ, iniciales del nombre del muralista. ${ }^{155}$ Del lado derecho se narra la multiplicación de los panes y los peces; Pedro con túnica blanca le explica a Jesús de la necesidad de comida, a lo que Cristo pide los panes, que aquí sólo aparecen tres en lugar de cinco como narran los

\footnotetext{
154 Jean-Paul Bouillon, Diario del Art Déco, Barcelona, Destino, 1989, p. 167

${ }^{155}$ El lunes 15 de marzo del 2010 al platicar con el P. Mena de algunos detalles de los murales, descubrimos dichas letras del brazalete.
} 
evangelios, y los dos peces que son acercados por un sirviente vestido con túnica amarilla; una serie de triángulos con base curvada forman un tapiz azulado para simular el mar. Al centro en un primer plano y con mayor tamaño, la Resurrección en el momento preciso en que Cristo sale de su tumba y se eleva hacia los cielos con la mano en alto símbolo de su triunfo. El resplandor de su cabeza con siete rayos es en alusión a las siete palabras y carga un largo pendón con el emblema de la cruz. Un soldado duerme sobre su escudo y el otro en actitud de asombro levanta los brazos y suelta su pica; en el cinturón de este escolta se lee ÁNGEL ZÁRRAGA, palabras descubiertas por el P. Mena. Toda la narración bíblica se enlaza a través de arcadas unas en rojo, de lado derecho y otras en negro, del lado izquierdo.

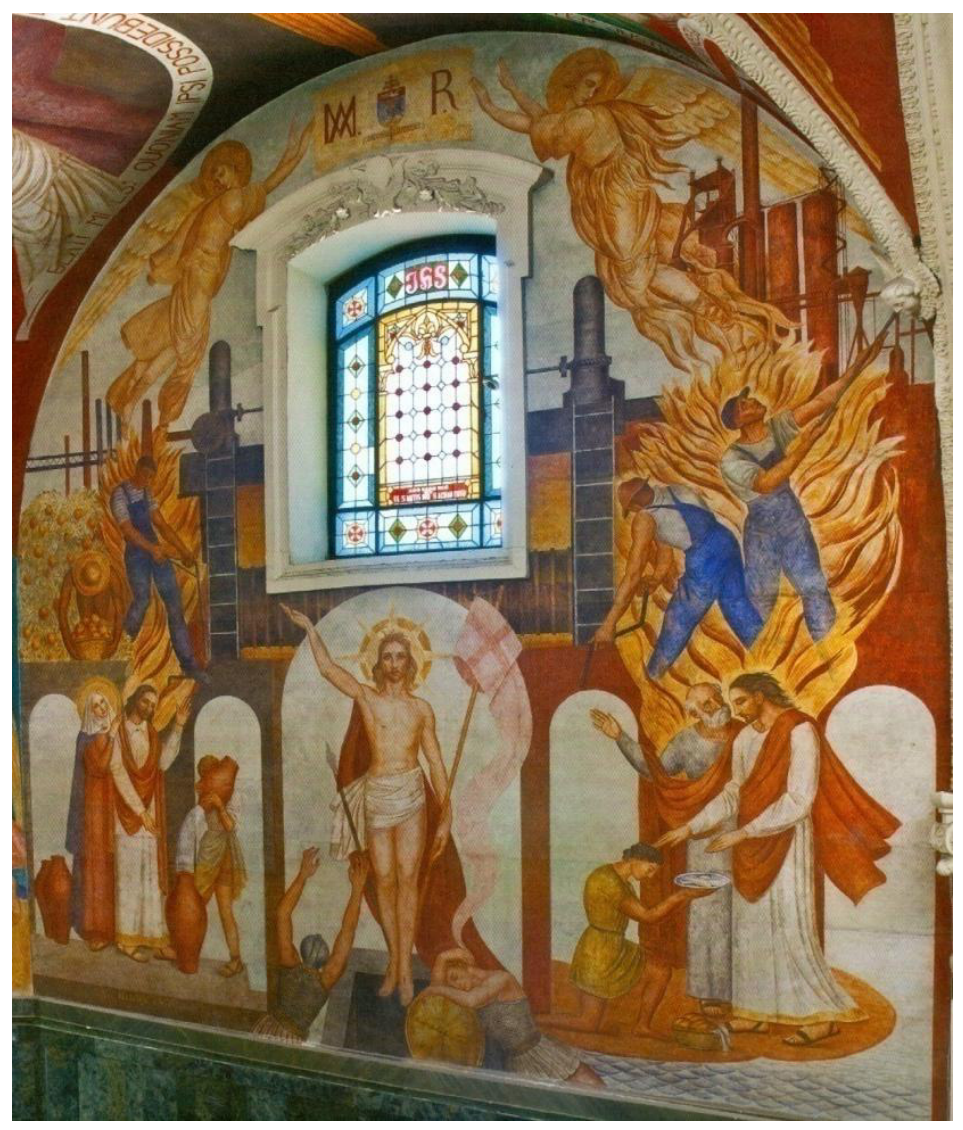

Mural del lado derecho o sur.

En la parte superior son presentadas dos actividades laborales de Nuevo León: del lado izquierdo el trabajo agrícola de los naranjales son caracterizados por un hombre con sombrero, agachado, de piel morena a quien no se le ve el rostro que recoge en un cesto los 
frutos; al fondo se aprecian los sembradíos del cítrico. Hacia la derecha un obrero en plena faena de fundición se enlaza a través de un tubo que pasa por debajo de la ventana con dos compañeros posicionados en el otro extremo. Llamas, chimeneas, tubos ambientan la industria del acero de Monterrey que en esos años se producía en grandes cantidades en la legendaria Fundidora, símbolo del progreso industrial de esta ciudad.

Por arriba de la ventana unos ángeles de gran tamaño sostienen una cartela con el anagrama de la Virgen, mismo que resguarda el escudo del Arzobispo Tritschler, el cual lleva los vocablos latinos "CRECAMUS-INILLO PEROMNIA”. La firma está debajo de las bodas de Caná: “ALELUJA, 6-V-1945”, palabra y fecha en señal de la conclusión de todos los murales.

Los pliegues de las túnicas del mural del ábside y las ya mencionadas posiciones de las manos son elementos que nos remiten al Art Déco, como en el caso de la posición de los brazos y manos de Cristo resucitado que están dispuestas como las dibujará el artista español Eduardo García Benito (1891-1981) en las portadas de la revista Vogue en 1929. ${ }^{156}$ La postura de las manos que Zárraga usa para el centinela que suelta su pica es como la de las damas del bajorrelieve del comedor del pabellón de la Embajada Francesa de la Exposición del año 25 obra del escultor Max-Blondat (1879-1926). ${ }^{157}$

En la composición del sirviente que carga las ánforas en las Bodas de Caná hay una referencia al pintor francés Raphael Delorme (1895-1962), el cual trabajó figuras musculosas femeninas en acciones de servidumbre dentro de un Neoclásico Moderno Art Déco.

Es interesante como el tema del trabajo industrial y agrícola representado en el panel del Palacio Federal de 1929, construido por la empresa FYUSA, o en el escudo del frontón de la Escuela Industrial Álvaro Obregón de 1930, inmueble también levantado por FYUSA, ambos con una clara estilística Art Déco donde se hace referencia y homenaje laboral a la misma temática, haya sido tratado también por Ángel Zárraga con sus figuras musculosas y sus composiciones geométricas tanto en los personajes como en la representación de lo fabril.

\footnotetext{
156 Ortega-Coca, Teresa, Eduardo García Benito y el Art-Déco, Valladolid, Ayuntamiento de Valladolid, 1991, p. 72.

157 Theodore Menten, The Art Deco Style, New York, Dover, 1972, p. 171.
} 


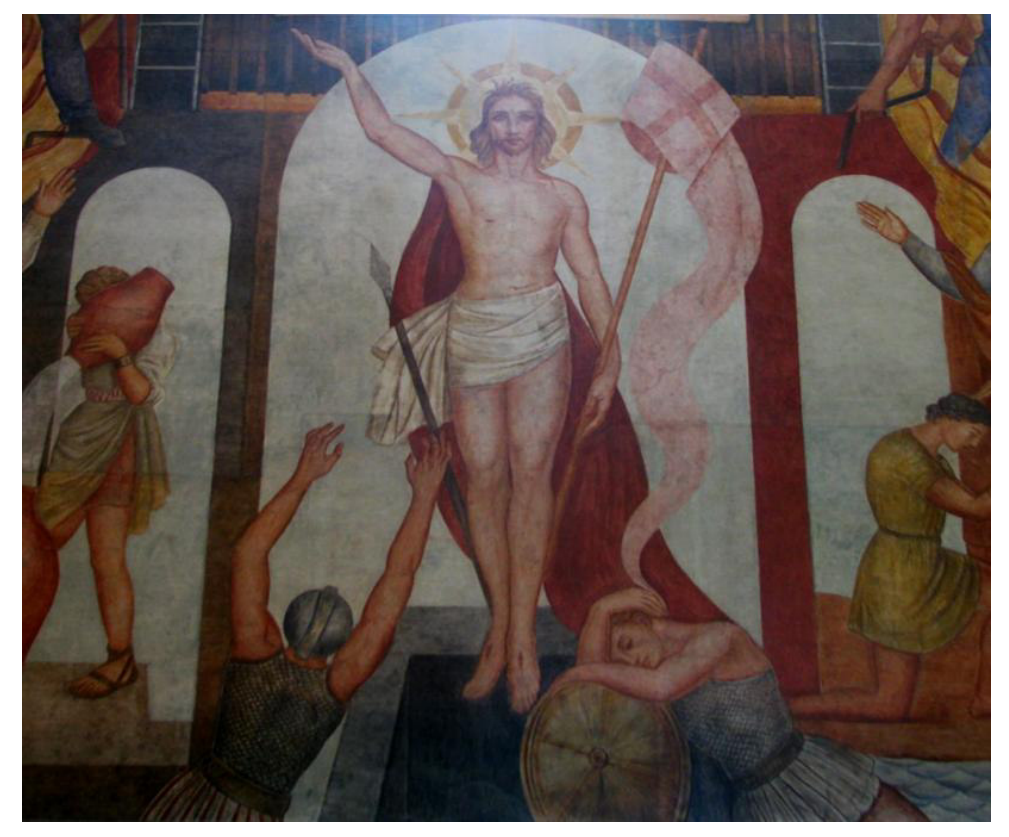

Cristo y centinela con los brazos en alto en el muro sur.

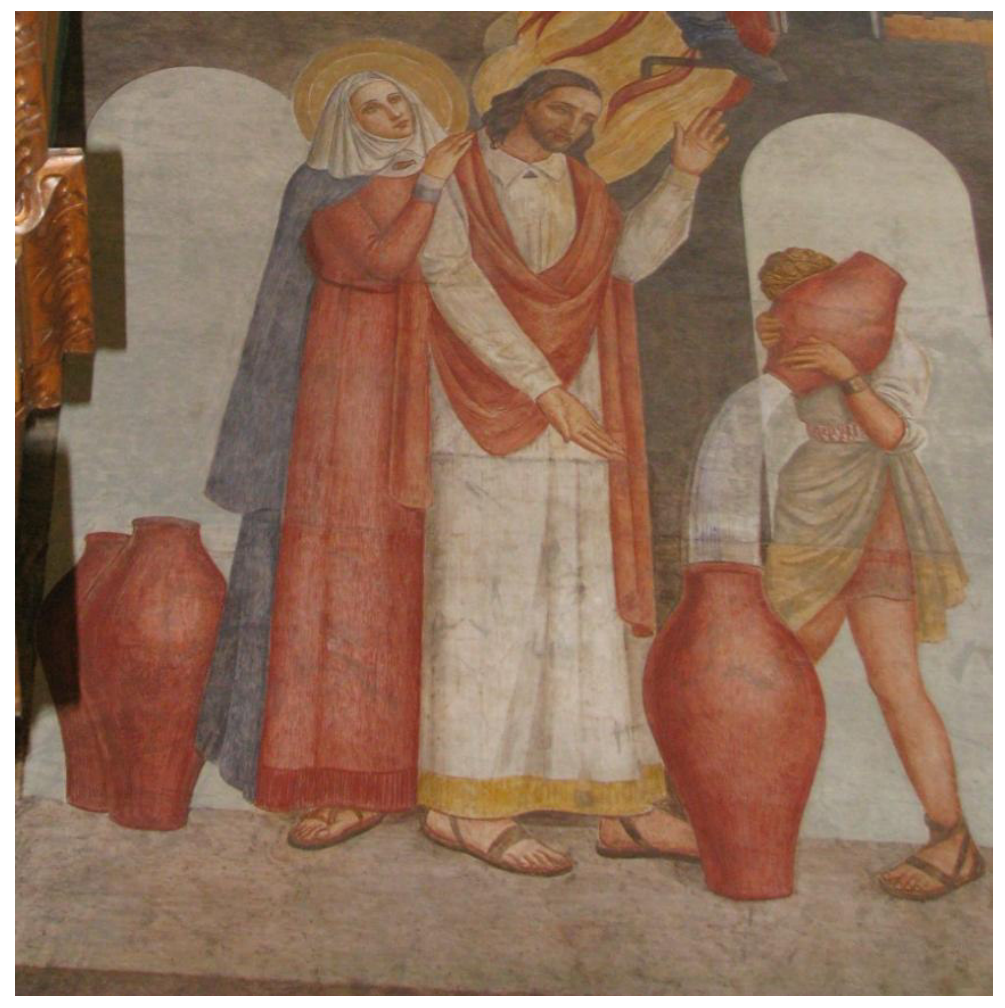

Milagro de las Bodas de Caná en el muro sur. 


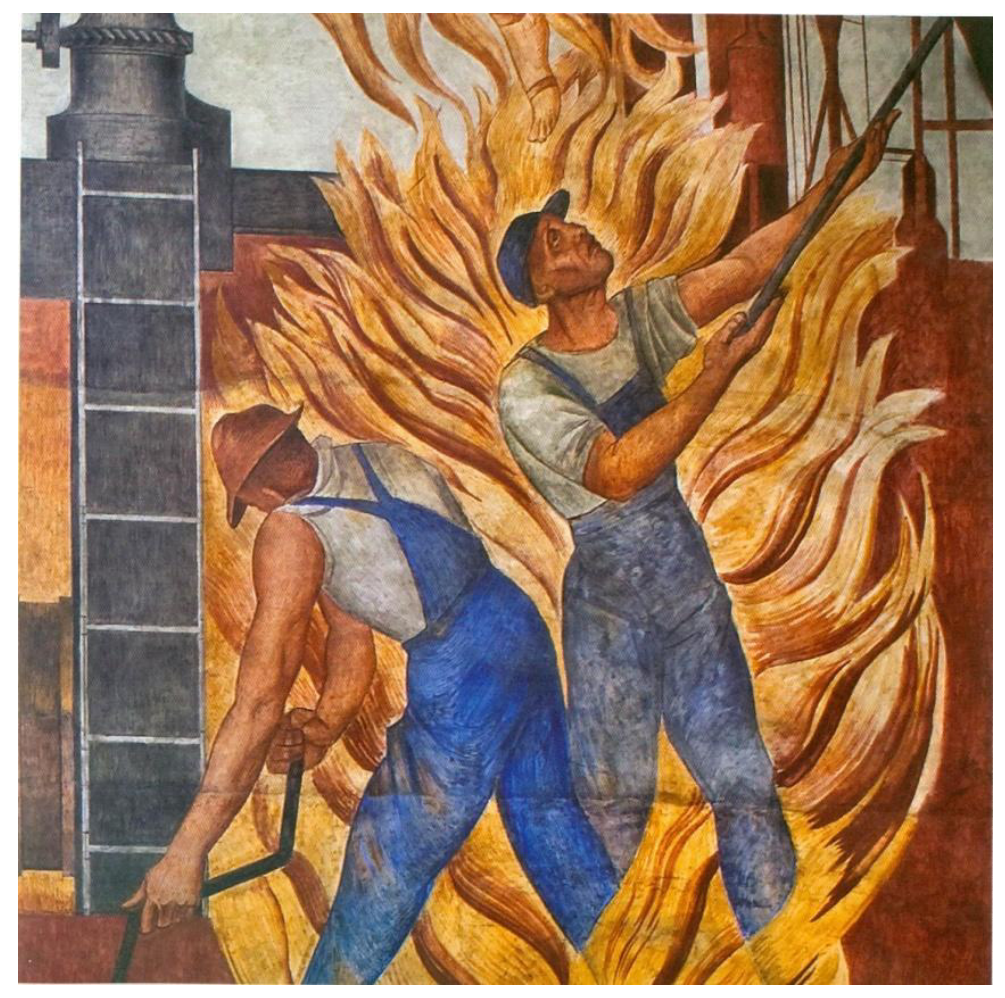

Trabajo de la fundición en el ángulo superior derecho del muro sur.

Pasajes bíblicos y de la evangelización del Noreste de México son expuestos en el mural del lado izquierdo o muro norte. Al centro La Piedad, donde la Virgen vestida con túnica morada, símbolo del luto y manto azul en relación con lo celestial sostiene a su hijo muerto, que yace en su regazo con los brazos caídos; detrás de ella un resplandor simboliza la luz de la salvación y al mismo tiempo la luz solar de la región montañosa de Nuevo León. Toda la escena descansa sobre un pedrusco montículo. Debajo de La Piedad, un franciscano carga a un indio delante de una hoguera. Ambas escenas significan la redención, ya que Cristo al morir da la vida eterna y el fraile evangelizador salva de las llamas eternas al aborigen a través de la cristianización, por lo que de todo el conjunto emanan unas radiaciones transparentes denotando la expansión del cristianismo.

Del lado derecho en un primer plano un franciscano da la comunión a un indígena hincado, que por su vestimenta con la capa era un personaje de mayor jerarquía; en el extremo unos cactus hieráticos entornan la evangelización de estas tierras. En un segundo plano está representado otro milagro de Jesús que es la Resurrección de Lázaro: de la cueva donde fue inhumado el hermano de Marta y María sale andando envuelto en vendas y 
Cristo con túnica blanca y manto rojo levanta la mano para llevar a cabo su prodigio. Arriba de la cueva, un árbol hueco guarece a la pequeña Virgen del Roble, la advocación mariana local y ésta es una de las pocas representaciones existentes.

Del lado izquierdo del mural en primer plano está el milagro de la sanación de un ciego, en el que Jesús con la mismas vestiduras, unta el lodo en los ojos del invidente al cual Zárraga viste como un personaje del siglo XX; el bastón roto alude al milagro de la recuperación de la vista, pues ya no será necesario usarlo. Una barda de tabiques separa a la escena del segundo plano en donde un franciscano sostiene una cruz y consuela a un indígena quien se hinca recibiendo la confortación espiritual. Al fondo unas edificaciones con almenas infieren el conjunto conventual franciscano de San Andrés que existió en la ciudad. Un maguey pinta el paisaje mexicano y en el fondo del mural la cordillera de la Sierra Madre ambienta todos los acontecimientos narrados en la localidad.

Remata el mural igual que el anterior con ángeles de gran tamaño, ahora sustentando una cartela con el anagrama de Cristo y un par de indígenas sostienen el escudo de Monterrey. La firma en el ángulo inferior derecho: “ANGEL ZÁRRAGA 1945”. Esto nos indica que fue terminado antes que el de enfrente que fue el último.

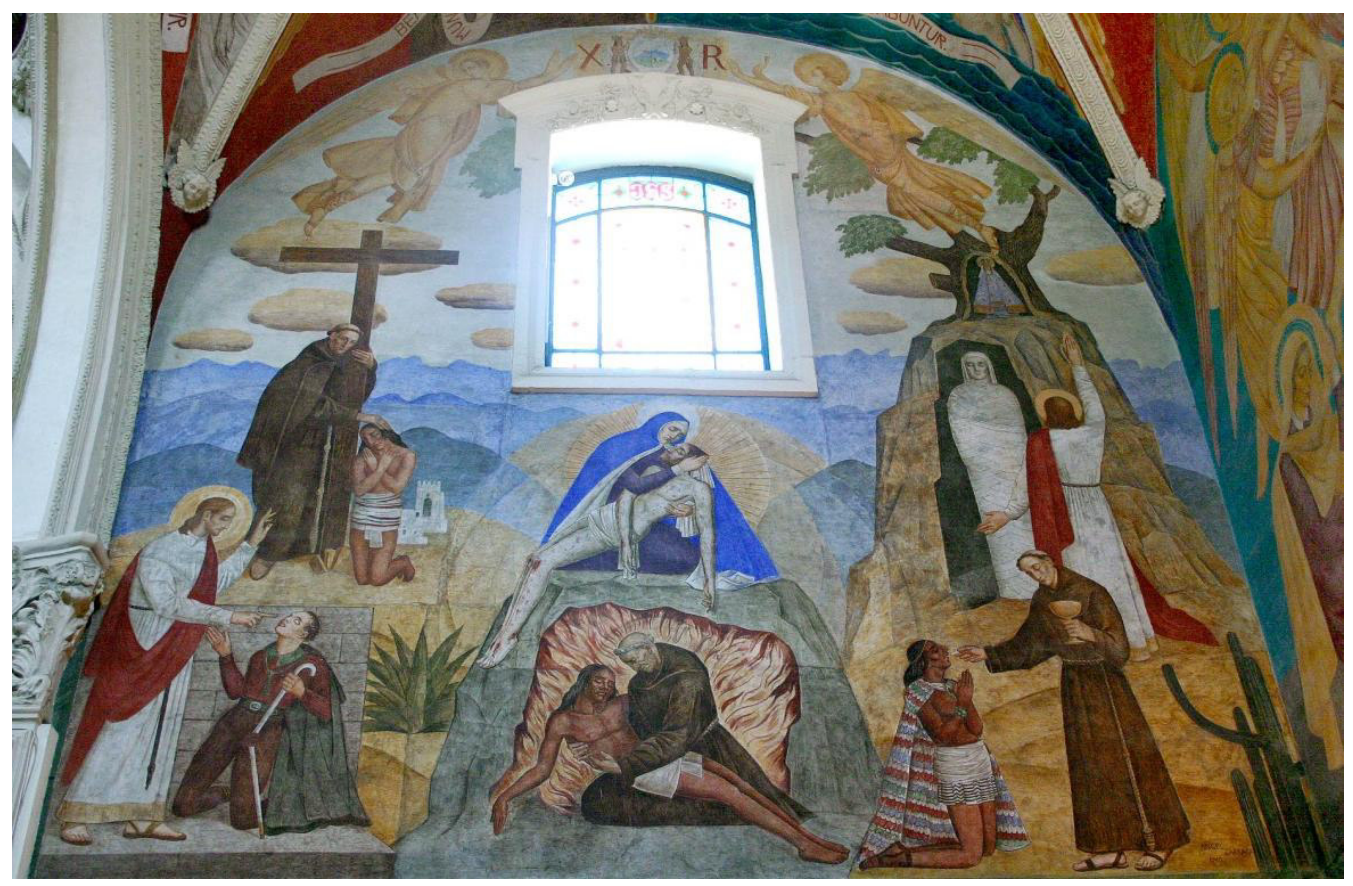

Muro del lado izquierdo o norte. 
Además de la posición de brazos y manos de Cristo en el Milagro de Lázaro, que están como hemos mencionado en el mural sur en la Resurrección, dos elementos vegetales son claros ejemplos del Art Déco. Uno es el cactus ubicado del lado derecho del fraile que da la comunión, cactácea que por su propia naturaleza es recta, lineal, geométrica y que también fue una imagen para las ambientaciones nacionalistas; claro ejemplo de la variante Pueblo Déco que utiliza como elementos decorativos los cactus del desierto como el que aparece en este mural para ambientar el paisaje semidesértico de la región noreste. El otro es el maguey, que está detrás hacia la derecha de la Sanación del ciego, el cual está trabajado con dibujos bastante geometrizados y con la distribución de las pencas en equilibrio, mata que fue una referencia del mexicanismo postrevolucionario y que por la forma misma de la planta quedaba muy "ad hoc" para el geometrismo del Déco. En la composición de La Piedad destacan las figuras del triángulo que se forma con la Virgen y su hijo muerto, así como el trapecio que se perfila con la caída de las manos de Cristo, enfatizándose así el geometrismo característico del Art Déco.

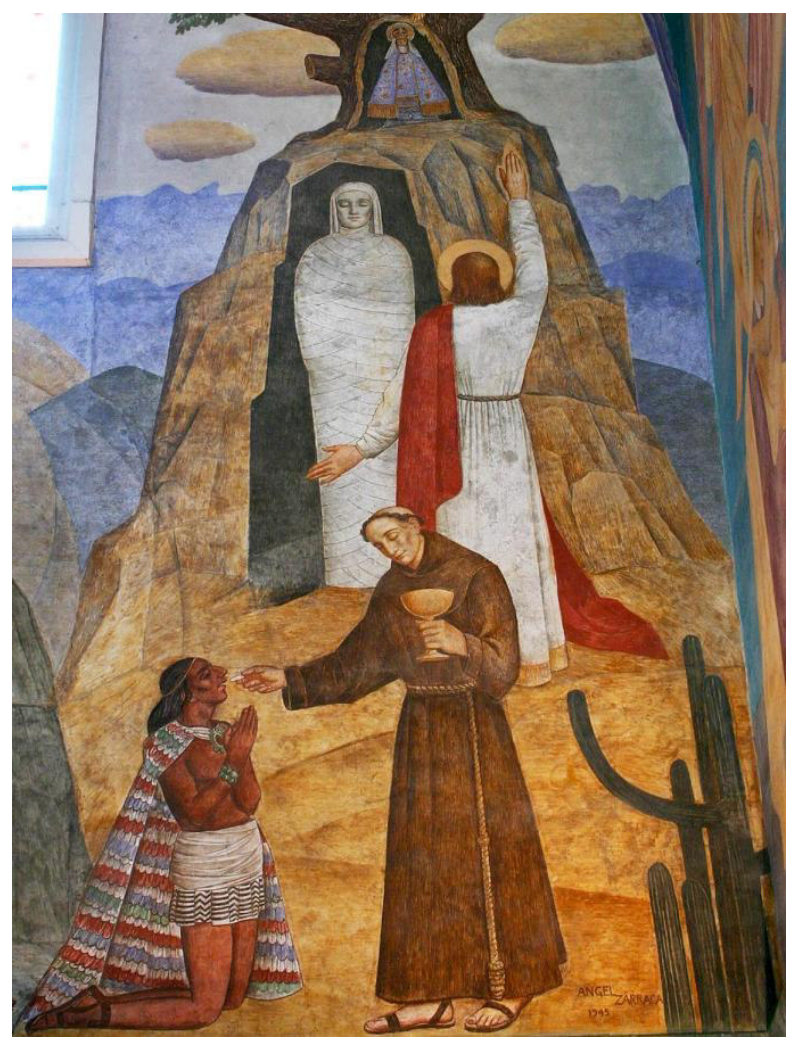

Detalle del lado derecho del muro norte. Las manos de Cristo con la posición de la Resurrección del mural sur y el cactus con su diseño geométrico. 


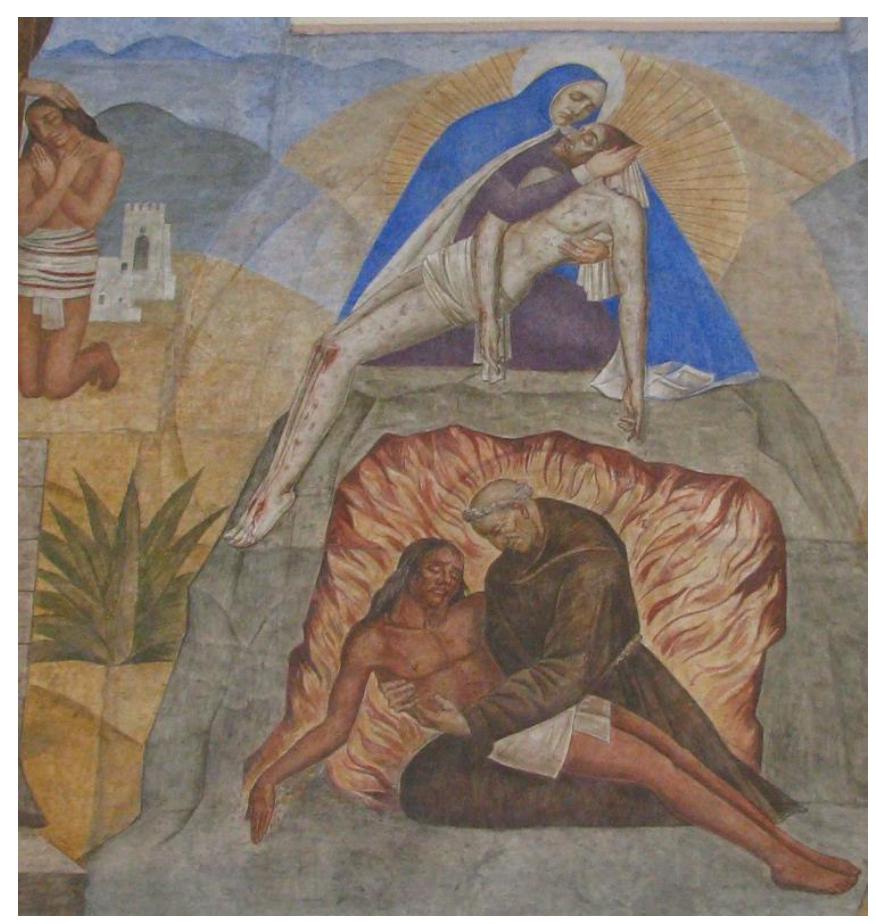

Detalle del muro norte con escena de La Piedad y el maguey al lado izquierdo.

En la bóveda del presbiterio dividida en cuatro partes, ocho de las Bienaventuranzas de San Mateo están representadas alegóricamente por medio de ángeles y filacterias con los textos en latín, pero sin seguir el orden del texto bíblico. Al fondo colindando con el muro del ábside, a la izquierda la cuarta Bienaventuranza: "Bienaventurados los que tienen hambre y sed de justicia porque ellos serán saciados"; un ángel con vestido entallado azul extiende su mano diestra para consolar a una mujer hincada con velo y túnica en gris, mientras con la otra abraza al ángel compañero. En un segundo plano trigo y frutos representan la abundancia. A la derecha la primera de las Bienaventuranzas: "Bienaventurados los pobres de espíritu, porque de ellos es el reino de los cielos"; el ángel con vestido blanco sostiene una esfera azul rodeada de estrellas y dentro de ella una pareja alude a las almas en el cielo.

En el siguiente tramo a la derecha la tercera Bienaventuranza: "Bienaventurados los mansos porque ellos poseerán la tierra”. Un ángel con túnica marrón y sombrero encasquetado sostiene una esfera armilar y toca la cabeza de un joven con el torso desnudo quien se sostiene cogiendo la esfera celeste. Luego la Bienaventuranza ocho: "Bienaventurados los perseguidos por causa de la justicia porque de ellos es el reino de los 
cielos". El ángel con túnica verde y capa blanca, carga en sus piernas un cosmos que un hombre flechado toca con una de sus manos, personaje que es una clara referencia a san Sebastián.

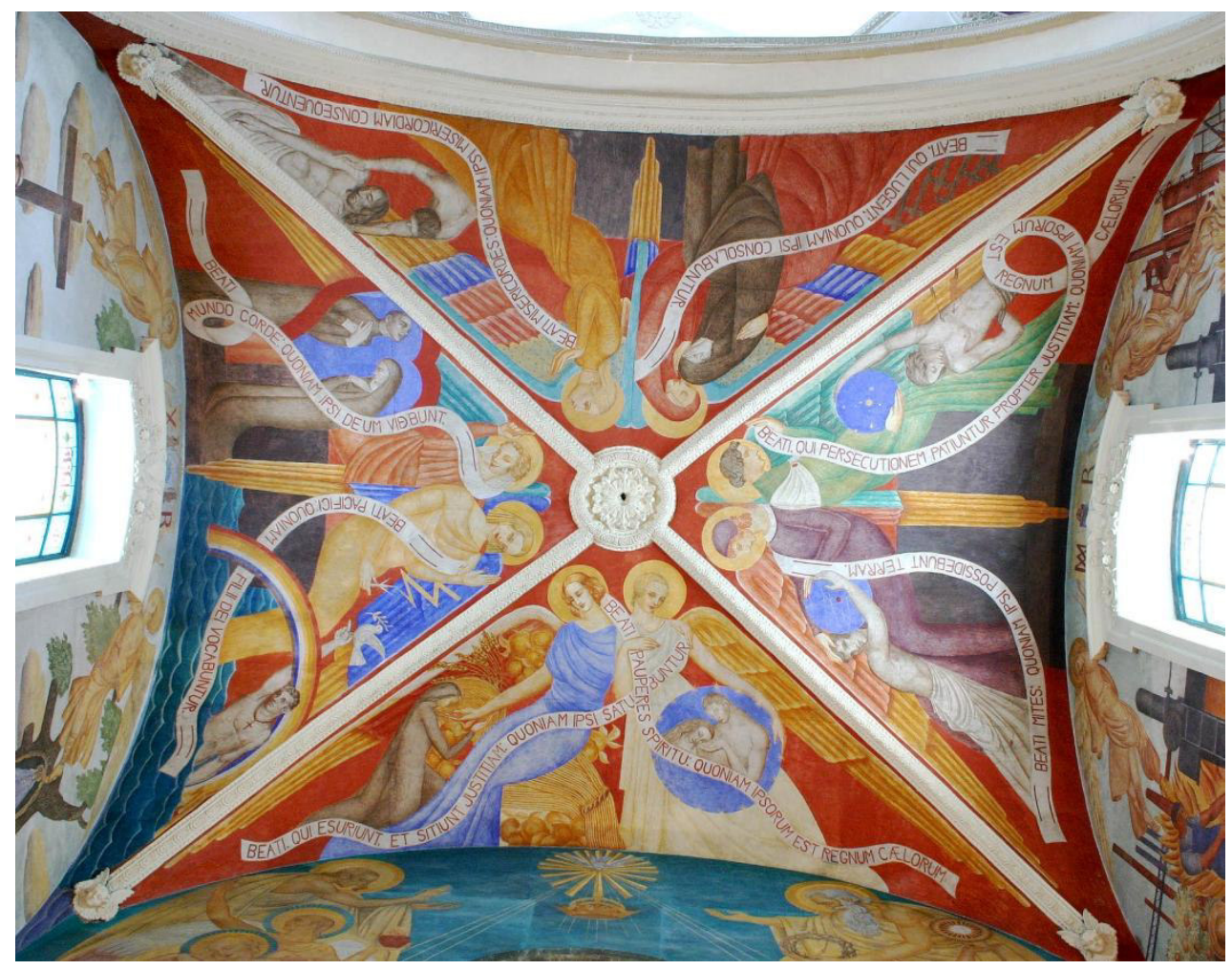

Bóveda del presbiterio con las Bienaventuranzas.

En el segmento que da hacia la nave principal la segunda Bienaventuranza: "Bienaventurados los que lloran, porque ellos serán consolados", que es lo que hace el ángel ataviado con un largo vestido rojo, reconfortando a una mujer cubierta con túnica color café. Continúa la quinta de las bendiciones: "Bienaventurados los misericordiosos, porque ellos alcanzarán misericordia". El espíritu celestial porta un vestido naranja y con las manos en actitud orante mira al cielo, mientras que en el lado inferior derecho un hombre rescata a otro que se encuentra desfallecido.

Las dos últimas Bienaventuranzas corresponden a la sexta y séptima: "Bienaventurados los limpios de corazón porque ellos verán a Dios". Un sonriente ángel con vestido rojo exhibe un pequeño libro en su mano derecha y la otra la recarga en el hombro de su compañero; abajo dentro de un corazón una pareja eleva sus oraciones. Y la 
séptima: "Bienaventurados los pacíficos porque ellos serán llamados hijos de Dios". La paz se representa con la paloma que lleva una rama en el pico, a la cual muestra un hombre en el mar y el arco iris significando el perdón y la unión después de la tormenta todo el relación con el diluvio universal, es decir, la concordia en el mundo antiguo y que en el moderno se simboliza con el rayo que es aparado en un pararrayos sostenido por el ángel con vestido naranja.

En estas últimas escenas de las Bienaventuranza 7 que se encuentra en límite con el muro norte, es donde más se distinguen elementos del Art Déco. El rayo es un verdadero Déco Zigzag de los años 20, esas representaciones de la fuerza de la energía eléctrica que tanto abundaron en la decoración así como en la herrería, más aún en México con la electrificación postrevolucionaria de muchas ciudades y pueblos, mientras que el pararrayos se asemeja a la aguja con la que remata el edificio Chrysler en New York obra de William Van Allen (1883-1954) de 1930, uno de los iconos del Art Déco norteamericano. Las olas del mar parecen esas ondulaciones que tanto se usaron en los relieves y ornatos de los años 30 como en la fachada del teatro Folies Bergére de París.

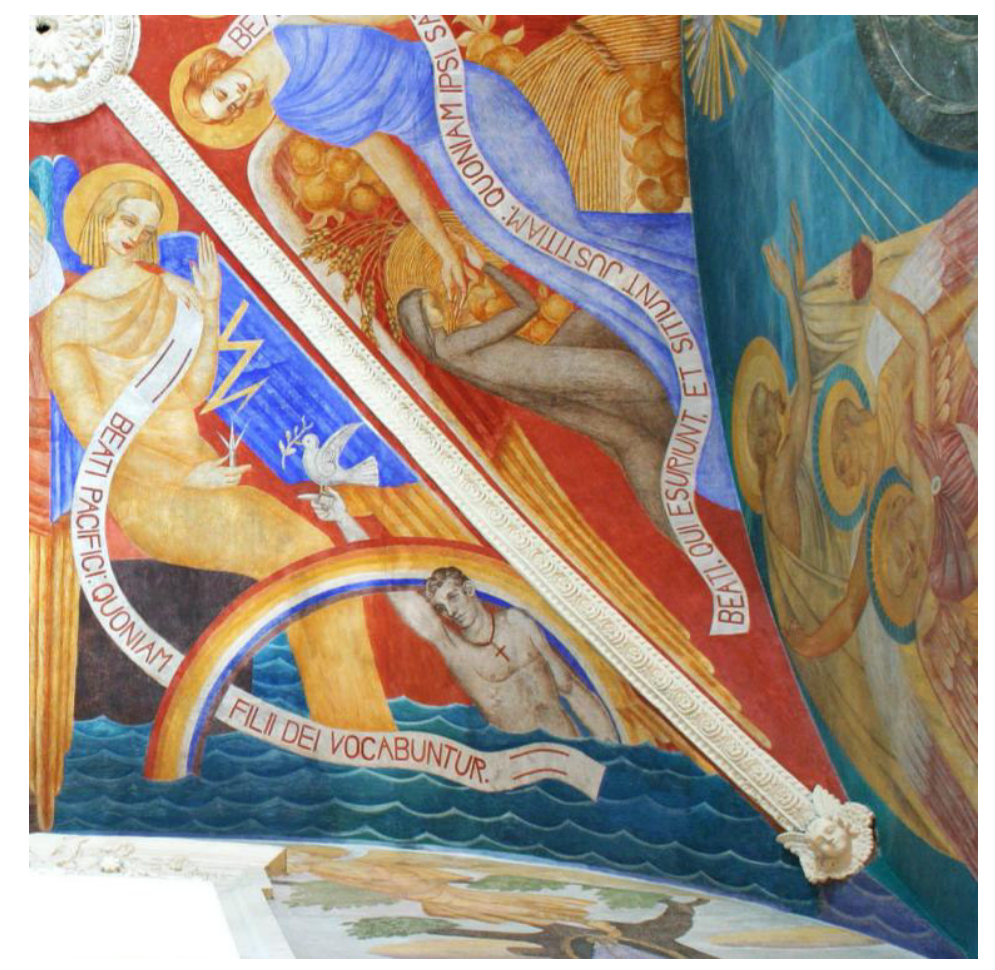

Detalle de la Bienaventuranza 7. 
En el caso del segmento junto al muro sur o derecho, en la Bienaventuranza 3, el ángel que sostiene una esfera celeste tiene varias correlaciones: primero, el retrato que el mismo Zárraga hizo del ensayista Eugenio D'Ors, en el cual el intelectual fue retratado con dicho instrumento, o bien, con el Ciclo de Vida del año 1918 del escultor norteamericano Paul Howard Manship (1885-1966) y con el monumental Atlas que carga una enorme esfera obra trabajada en 1937 por el artista norteamericano Lee Lawrie (1877-1963) que se encuentra en la plaza del Rockefeller Center de New York. El ser alado que porta un pequeño sombrero revela la moda francesa de aquellos años de entreguerras, lo que nos dejar ver las influencias del Art Déco en los personajes de Zárraga.

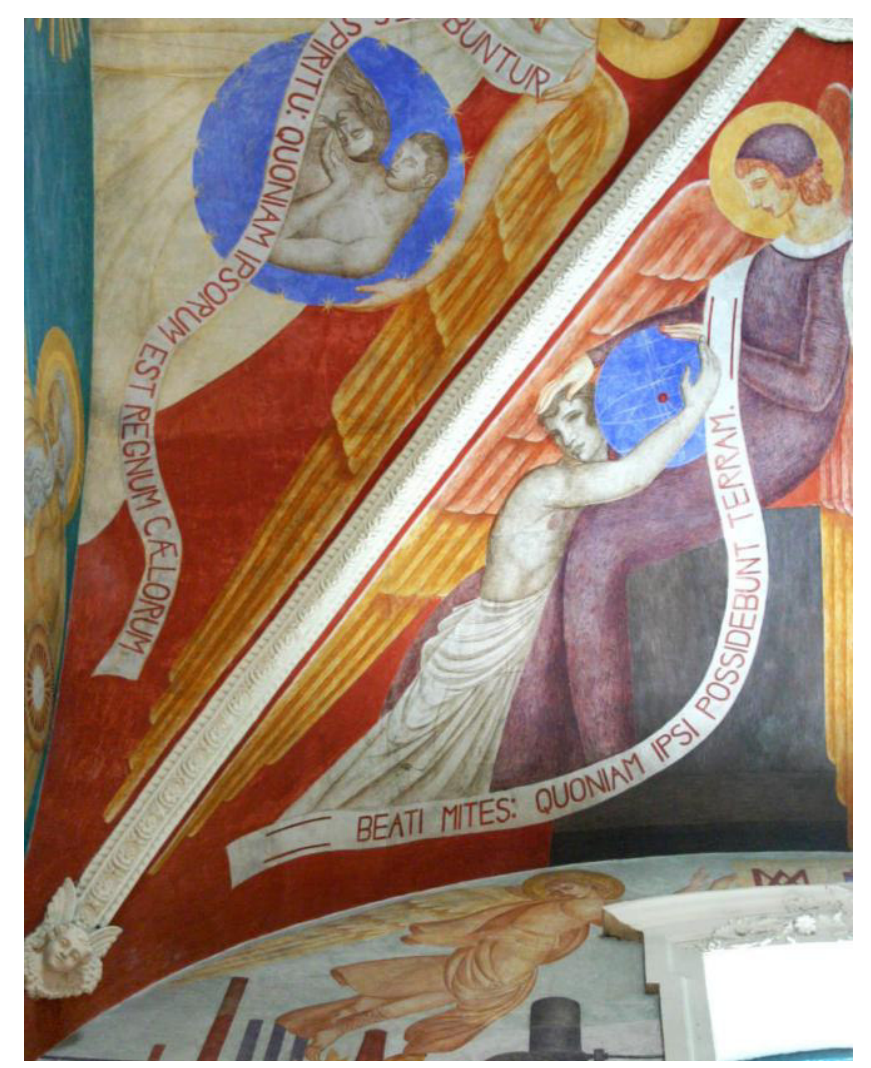

Detalle de la Bienaventuranza 3.

Por supuesto, en los cortes de pelo de algunos de los ángeles también se acusa la moda de la época del desarrollo del Art Déco, de los "Años Locos", como sucede en los que están en el tramo que da hacia el ábside en las Bienaventuranzas 4 y 1: la raya en medio con el pelo plegado en la mitad de la cabeza y el resto cayendo de manera ondulada 
de uno de los seres celestiales y el corte a la garçonne con cola pegada al cuello del otro, manifiestan la moda parisina del arreglo de la cabellera de las damas .

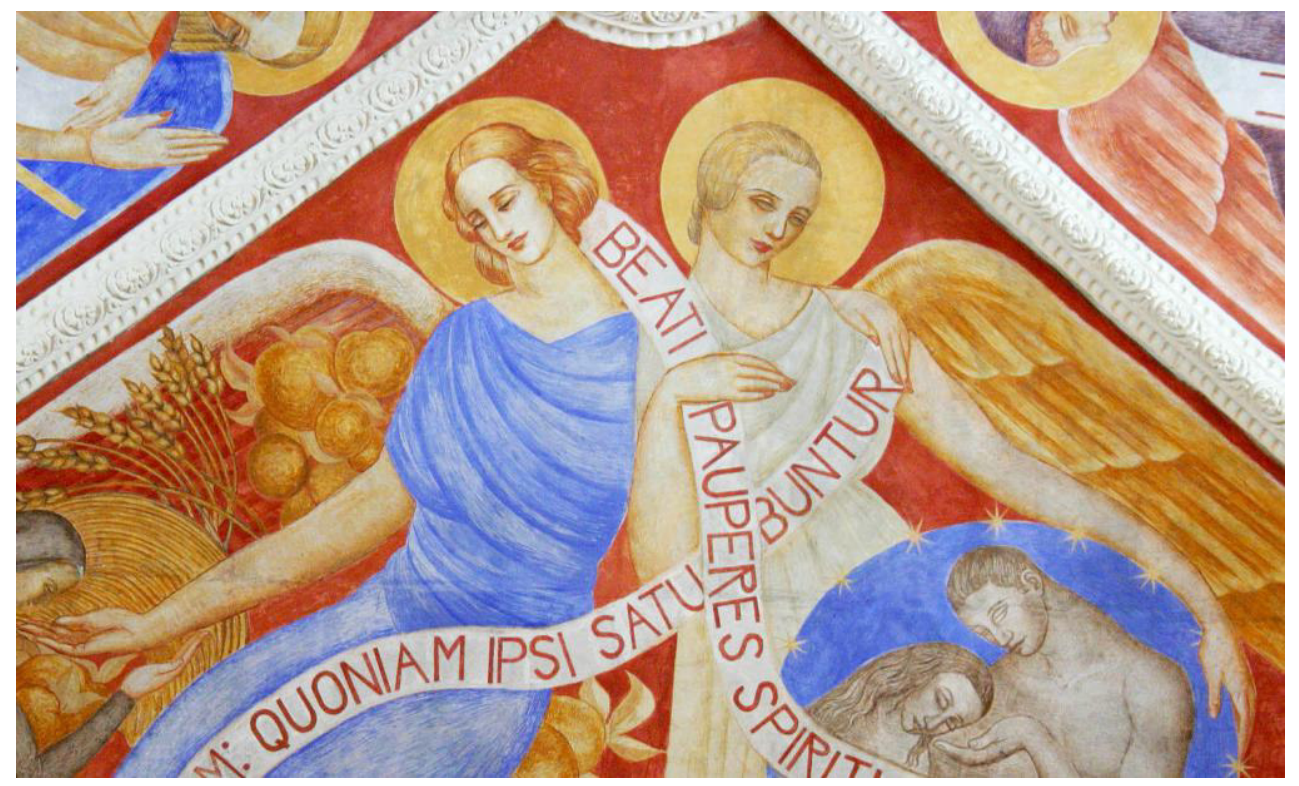

Detalle del corte de pelo de los ángeles de las Bienaventuranzas 4 y 1.

En la unión de las alas de los ángeles de los otros tres segmentos, es decir en la Bienaventuranzas 2 y 5, 3 y 8, 6 y 7, hay una indiscutible referencia al Art Déco. Se conforman una elevaciones escalonadas como las mismas columnas que André Ventre (1874-1951) y Henry Favier (1888-f.?) utilizaran en la Puerta de Honor del puente Alexandre III de la excelsa Exposición Internacional de 1925, que a través de líneas verticales plegadas a la columna, van ascendiendo de manera escalonada y que fue un referente muy utilizado en la arquitectura y decoración del Déco, especialmente de la variante Zigzag.

Y otras características más de Art Déco de las alas de los seres seráficos de la bóveda son el alargamiento, la estilización, la composición en secciones adosadas, el acomodo de estar sobrepuestas una encima de otra, generando la visión de verlas escalonadamente, con sus puntas redondeadas, que aluden a la velocidad, a la energía, tratadas por Ángel Zárraga de manera muy similar a los diseños del maestro del vidrio René Lalique (1860-1945), como en las Bienaventuranzas 8 y 2. 

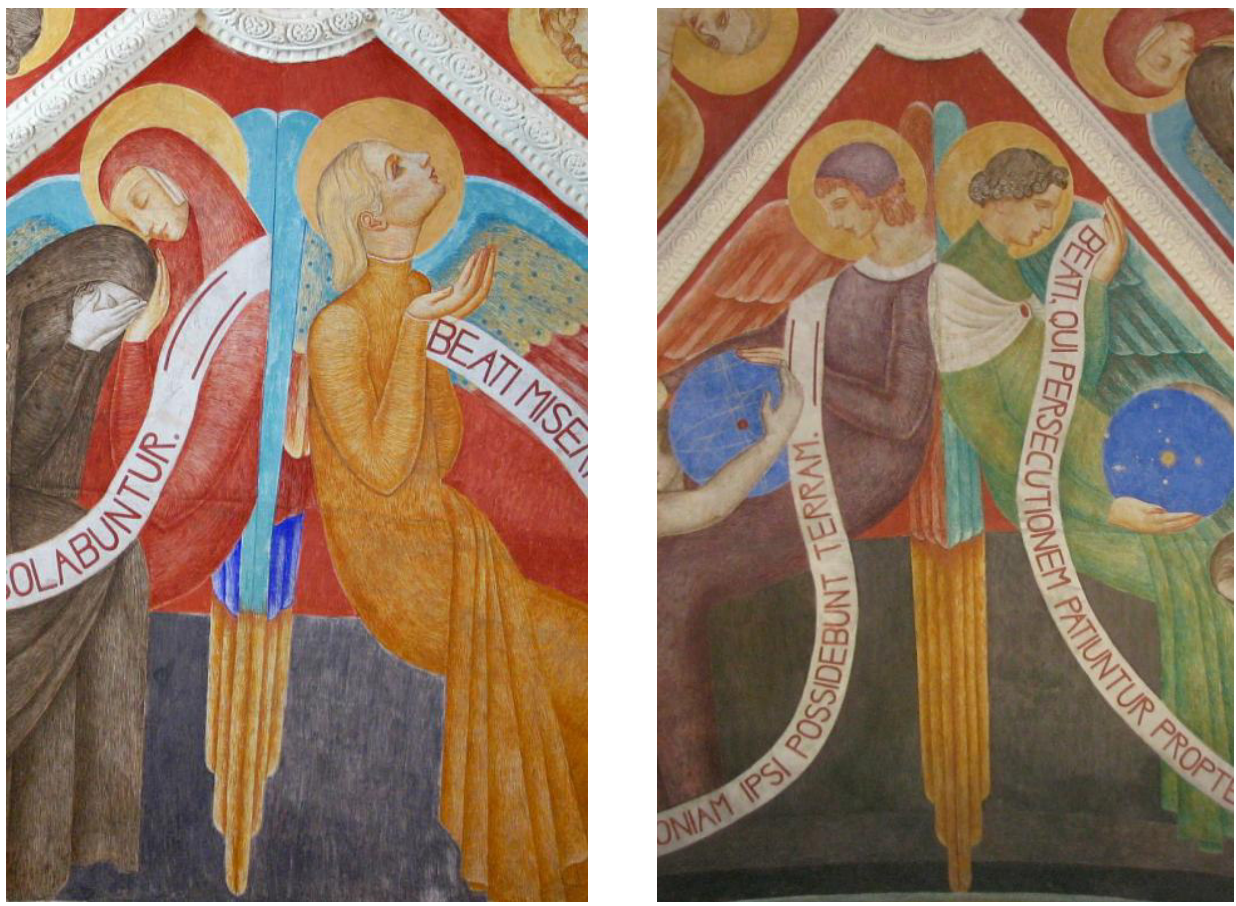

Detalle de la unión de las alas en los ángeles de las Bienaventuranzas 2 y 5, 3 y 8.

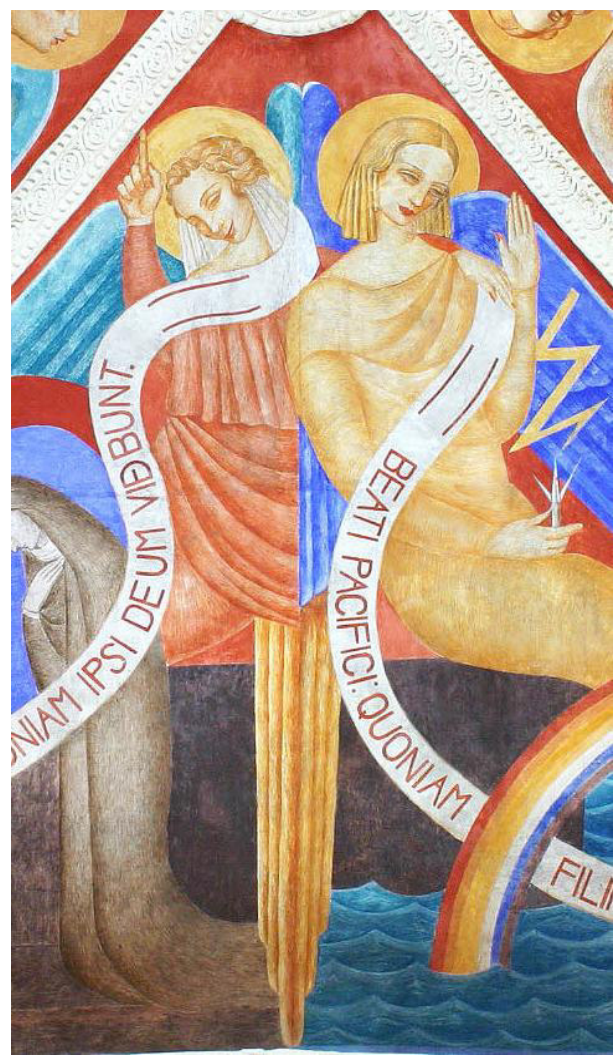

Unión de las alas en los ángeles de las Bienaventuranzas 6 y 7. 


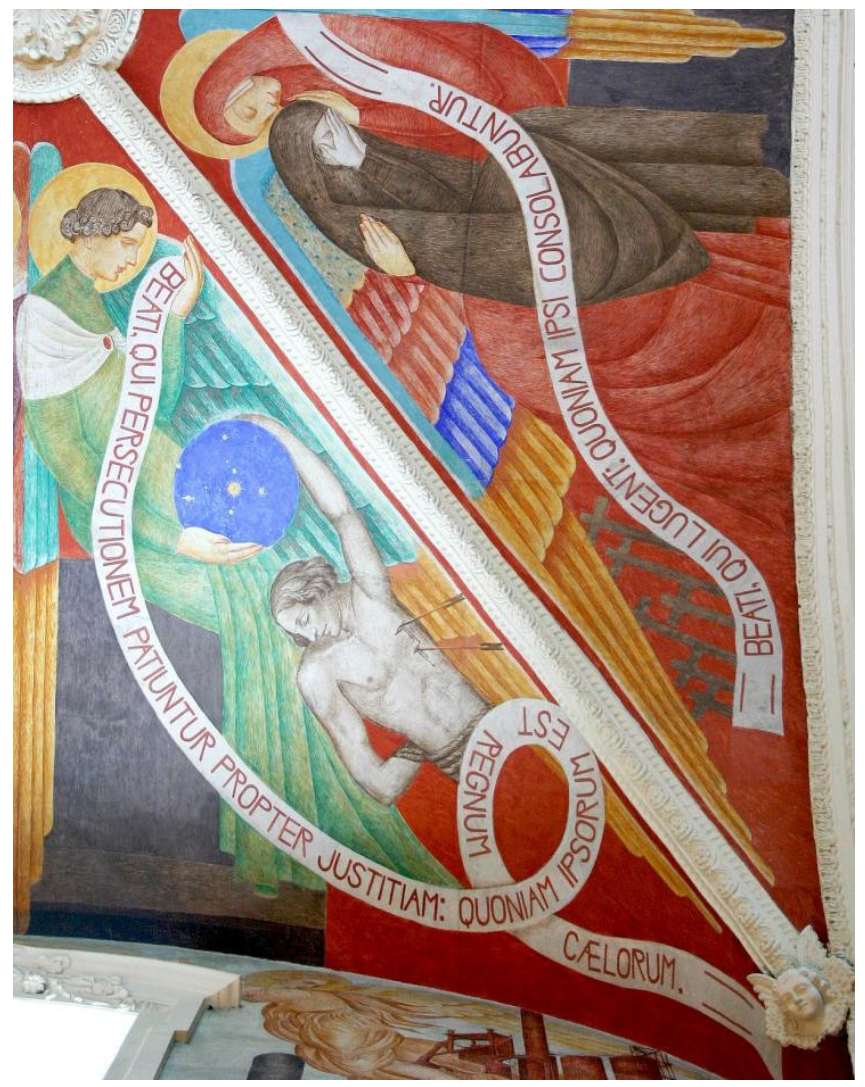

Detalle de las alas de los ángeles en las Bienaventuranzas 8 y 2.

Estos magníficos murales llevan una composición con figuras algo rígidas tal y como se trazaban los diseños pictóricos de esa época. Los colores suaves remiten a los grandes murales del Renacimiento italiano como los mismos de Fra Angelico (1395-1455) y que Zárraga adapta a sus necesidades contemporáneas. El equilibrio de las formas en cada una de las escenas consigue transmitir un conjunto armonioso de gran riqueza espiritual, no sólo por los temas mismos, sino por la suavidad del tratamiento de los murales en sí.

\section{b. Mural de la Casa del Campesino de Crescenciano Garza Rivera}

Lo que actualmente se conoce como Casa del Campesino se ubica en las calles de Abasolo y Mina, en el centro de la ciudad. Tiene sus orígenes en el primer cuarto del siglo XVIII como una construcción civil que después pasó a ser el Hospital del Rosario. Durante el siglo XIX fue el Colegio de Niñas y luego el Colegio de San José. 
El Presidente Lázaro Cárdenas en febrero de 1936 expropió el edificio, donándolo a la Liga de Comunidades Agrarias y desde entonces se le conoce como Casa del Campesino o Casa del Agrarista y lo que era la capilla fue convertida en el Auditoriun Emiliano Zapata. Ahí se pensó en decorar con un lenguaje del régimen cardenista los triunfos de la Revolución y las nuevas leyes agrarias, en contra de la visión de un pasado que sólo favorecía a las élites como fueron la época de la colonia y el Porfiriato, épocas de las que el pueblo de México se emancipó gracias a las luchas de Independencia iniciadas por Miguel Hidalgo y por la Revolución Mexicana.

Los Maestros Aurelia Elizondo Ferrara y Juan Manuel Martínez Gutiérrez en una investigación sobre los murales titulada El Mural de la Casa del Campesino ${ }^{158}$ realizada en 1993-1995, gracias al profesor Flavio Reyes consiguieron un ejemplar de la Revista Pedagógica de Nuevo León de 1937, en donde encontraron el dato que inicialmente los trabajos de ejecución de los murales con la técnica del fresco para el auditorio de la Casa del Campesino fueron realizados por el artista Gustavo García Gloryo, quien a la fecha es completamente desconocido. Se sabe por una cartela en los mismos murales que la autoría fue de Crescenciano Garza Rivera y ayudantes y no fue hasta que se dio a conocer la información de Elizondo y Martínez que la clara manera diferente de trabajar el pincel en la bóveda no pertenece a un mismo artista.

Sin tener la fecha exacta, los murales de la Casa del Campesino se iniciaron en 1937 por García Gloryo, quien muere repentinamente a mediados de año, pues se sabe que para sustituirlo se designó a Garza Rivera en el mes julio ${ }^{159}$ y para agosto de ese mismo año ya estaba trabajando en ellos. ${ }^{160}$ Tampoco se sabe la fecha precisa de la conclusión de las pinturas, sin embargo, sólo encontramos el dato de que en febrero Garza Rivera y su equipo se atareaban con celeridad ${ }^{161}$ y debido a que aparece una escena alusiva a la industria petrolera expropiada por el Presidente Cárdenas el 18 de marzo de 1938, posiblemente para

\footnotetext{
${ }^{158}$ Aurelia Elizondo Ferrara y Juan Manuel Martínez Gutiérrez, El Mural de la Casa del Campesino, San Pedro Garza García, N.L., Universidad de Monterrey, Tesis de Maestría en Humanidades, 1995.

${ }^{159}$ Declara el Secretario de Gobierno en el asunto del pintor Vicario Román”, El Porvenir, Monterrey, N.L., domingo 11 de julio de 1937, p. 4.

160 "El artista Garza Rivera da principio a la decoración de la Casa Agrarista", El Porvenir, Monterrey, N.L., viernes 14 de agosto de 1937, p. 4.

161 "Los murales del Auditorium Emiliano Zapata se concluyen con rapidez", El Porvenir, Monterrey, N.L., viernes 25 de febrero de 1938, p. 4.
} 
mediados de ese año se terminó con la decoración del Auditorio, aparte de tener la fecha de conclusión de ese año en un escudo, pero sin decir el mes.

Crescenciano Garza Rivera ${ }^{162}$ nació en Monterrey el 14 de febrero de 1895. Sus estudios de pintura los realizó a temprana edad primero en Monterrey, bajo la dirección del artista saltillense Eligio Fernández (1891-1979) y luego a partir de 1909 en la Academia de San Carlos de la ciudad de México para después trasladarse a Europa por donde viajó por varias ciudades para asentarse en París en 1912, donde estudió en la Ecole de Beaux Arts. Más tarde, en 1914 se trasladó a Madrid por recomendación de Ernesto "EL Chango" García Cabral (1890-1968) y de su paisano el escultor nuevoleonés Fidias Elizondo (18911979). En 1916 recibió en Barcelona la medalla de oro por su cuadro La vendedora de flores y en la capital de España realizó un mural llamado El Parnaso, de lo que se desconoce en qué lugar lo realizó, según relata su hija Catalina Garza Rivera. ${ }^{163}$ En la capital española gracias a los escritores Ramón del Valle Inclán (1866-1936), Amado Nervo (1870-19191) y Alfonso Reyes (1889-1959) le organizaron una exposición en 1918 en el Ateneo de Madrid con treinta y tres cuadros, donde obtuvo muy buena acogida de la crítica y que visitó la misma Reina Eugenia Victoria. Sus años por Europa fueron fructíferos, era visto como un joven artista cuya obra tenía relación con Julio Ruelas (18701907) y Roberto Montenegro (1887-1968), así como con artistas extranjeros como el argentino Julio Manuel Gavazzo (1888-1965), el belga Félicien Rops (1833-1898) y el italiano Alberto Martini (1876-1954).

Regresó a México y trabajó en el periódico El Universal como dibujante de 1921 a 1926. De 1927 a 1936 radica en Houston, Texas, donde tuvo bastante actividad. Fue uno de los dibujantes principales del The Houston Gargoyle New Magazine y llegó a ser el Director Artístico de la misma revista. En The Houston Artist Gallery presentó su obra

\footnotetext{
${ }^{162}$ En la citada tesis de Elizondo y Martínez viene una amplia biografía del artista. Aquí nos basamos en dicha investigación, en Israel Cavazos Garza, Diccionario Biográfico de Nuevo León, Tomo I, Monterrey, N.L., Universidad Autónoma de Nuevo León, 1984, en el artículo de Xavier Moyssén, "Un dibujante erótico: Crescenciano Garza Rivera", Anales del Instituto de Investigaciones Estéticas, México, UNAM, Vol. XVI, No. 63, 1992, pp. 137-147 y en la tesina de Fernanda Salazar Gil, Un acercamiento a las ilustraciones de tipo decadentista de Crescenciano Garza Rivera en el periódico El Universal entre 1921 y 1925, México, Instituto de Investigaciones Estéticas, UNAM, Tesina de La Especialidad en Historia del Arte, 2004.

${ }^{163}$ Gustavo Mendoza Lemus, "Pide revivir el acervo de Crescenciano Garza Rivera", Milenio, Monterrey, N.L., martes 6 de abril de 2010, p. 36.
} 
comprendida por treinta dibujos en tinta, inaugurándose la exposición el 15 de noviembre de 1931, siendo altamente favorecido por la crítica.

A partir de 1936 viene a radicar a Monterrey, donde permanecerá hasta su muerte. Aquí mismo en 1938 le publicaron Fantasías de C. Garza Rivera, con cincuenta dibujos y la crítica de veintinueve escritores, tales como José Francés, Ramón Gómez de la Serna, incluyendo a Alfonso Reyes. En 1946 pintó al óleo dos versiones de La Fundación de Monterrey, una se encuentra en el "lobby" del Hotel Monterrey y la otra en el Museo del Noreste; estos cuadros tal vez sean la obra más conocida del pintor. Murió a los 63 años, un 3 de junio de 1958, poco después de ser nombrado Director del Departamento de Arte de la Universidad de Nuevo León.

$\mathrm{Su}$ estilo estaba fuertemente imbuido en el Simbolismo de fin de siglo XIX y principios del XX, pero más bien en el Decadentismo finisecular que él prolonga hasta bien entrados los años veinte, caracterizado por la presencia de lo oculto, la muerte, lo siniestro, en la lucha por transmitir el valor de la angustia por la vida, escenas que para Garza Rivera están enmarcadas en sus dibujos dentro de fondos oscuros, donde las anatomías se presentan con poses retorcidas, donde "El cuerpo desnudo, recurrente, está trabajado con un tratamiento detallado en marcar los músculos y la estructura ósea; las sombras con que los define les da una suavidad muy especial y la carne casi puede palparse. Los escorzos también son característicos en sus ilustraciones, tanto en figuras masculinas como en los desnudos femeninos que generalmente, denotan estados de éxtasis o de muerte". ${ }^{164}$

Los murales han sufrido diversas restauraciones, sin embargo en los últimos 20 años las dos más importantes que se han realizado son: la primera que dirigió el maestro Manuel Serrano de la compañía Restauro, S. A., de la ciudad de México, en donde empleó a alumnos de la Facultad de Artes Visuales de la UANL, bajo la coordinación de Pablo Simental Hernández. Los trabajos se realizaron entre julio de 1992 a noviembre de 1993, teniendo la supervisión a cargo del INAH Regional.

Después de esta restauración el auditorio tuvo varias funciones y diversas actividades y por falta de mantenimiento los murales nuevamente empezaron a deteriorarse severamente. En 2004, la investigadora del Cenidiap (Centro Nacional de Investigación, Documentación e Información de Artes Pláticas) en un artículo titulado "Hacia una

\footnotetext{
${ }^{164}$ Maria Fernanda Salazar Gil, Op. Cit., p. 62.
} 
legislación para la defensa del patrimonio y el muralismo" hacía referencia de la urgente necesidad por conservar murales, especialmente los pintados en las décadas de los años 20 y 30 del siglo pasado, ya que muchos se están perdiendo, por diversas causas, entre ellas por la modificación de los inmuebles. De los de la Casa del Campesino comentó: "Otro ejemplo es el mural del artista de Monterrey Crecenciano Garza Rivera, [sic] que pintó en todo el auditorio de la Casa del Campesino en esa ciudad, misma que se encuentra en proceso de destrucción; no obstante, nadie hace nada por impedirlo". ${ }^{165}$

La segunda restauración es la que se llevó a cabo de julio de 2010 a abril de 2011. Estuvo al frente del maestro Manuel Verástegui y su equipo, pertenecientes al INAH. Aunque el edificio de la Casa del Campesino se reinauguró el 20 de noviembre de 2010, los murales estaban en plena restauración.

La parte del Auditorio que lleva elementos Art Déco es el muro norte, que es la apoteosis del cardenismo. En la esquina izquierda mientras un hombre vestido con camisa roja y pantalón negro, colores representativos del socialismo, lee un libro como significación de la educación socialista de la época, otro, un obrero con gorro tipo quepí y sin camisa, de cuerpo musculoso, se atarea en la fundición del metal, trabajo de alta significación para la ciudad de Monterrey. La figura del obrero se compone por un rectángulo en el torso, los brazos en posición de ángulos obtusos y un triángulo en la postura de las piernas; este geometrismo se completa con los tres cilindros de los contenedores y el poliedro ubicado atrás de la cabeza del trabajador que aumenta el volumen del espacio interior.

Entre bandas oblicuas y curvas que forman arcos, así como dos más que se prolongan hacia al fondo a manera de escorzo, se leen muchos de los parabienes instaurados en el cardenismo y que representaban los logros sociales de la postrevolución: de abajo hacia arriba se lee "Botiquín comunal", "Trabajo en colectividad del ejido"; al fondo sobre color rosa se lee "Sindicato" y hacia abajo "Banco de crédito agrícola", "Liga de comunidades agrarias", "Comisariado ejidal"; hacia la derecha "Sociedad de crédito ejidal", "Banco de crédito ejidal" y hacia arriba "Sociedad cooperativa ejidal" y "Maestro

\footnotetext{
${ }^{165}$ Guillermina Guadarrama Peña, "Hacia una legislación para la defensa del patrimonio y el muralismo", discurso visual. Revista digital del Cenidiap, México, Centro de Investigación, Documentación e Información de Artes Plásticas, No. 10, enero-marzo 2004, http://disucrsovisual.cebart.gob.mx/anteriores/dvweb10/index.html
} 
rural". Esta composición remite a la estética de los grabados que para la revista Horizonte y para ilustrar los poemas estridentistas hicieran Ramón Alva de la Canal (1892-1985) y especialmente Jean Charlot (1898-1979) en aquella portada con unos altos arcos con el remate inclinado y arriba corriendo un ferrocarril. ${ }^{166}$ Como mencionamos en el capítulo anterior en "Los estudios del Art Déco en México" al reseñar el libro de Xavier Esqueda, si El Estridentismo no fue un movimiento dentro de la estética del Déco, sí se nutrió del pensamiento vanguardista y muchas de las ilustraciones que se utilizaron para su publicaciones por su acentuado geometrismo entrarían como obras del Art Déco.

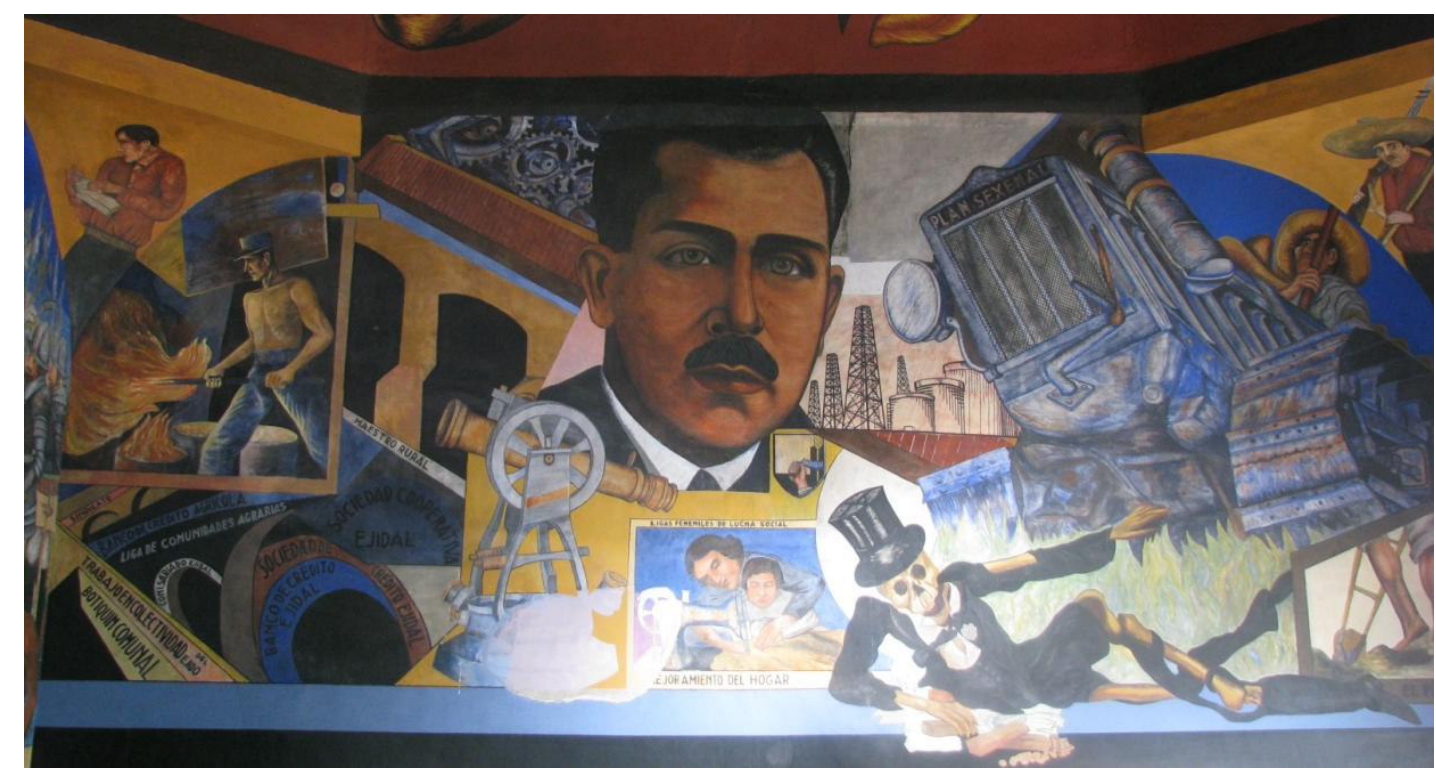

Mural norte.

Después de la escena anterior, un telescopio de gran tamaño divulga que en México se está llevando a cabo la investigación científica. A la derecha sobre unos arcos, una chimenea inclinada en ladrillo descansa sobre ellos y más arriba un engranaje maquinario completa toda la semántica de lo fabril, del maquinismo, de la industrialización, que durante el cardenismo se vio bastante favorecido. Los arcos nos recuerdan en parte los que pintaba Giorgio de Chirico (1888-1978) como podrían ser sus cuadros Misterio y melancolía de una calle de 1914 o el más cercano en el tiempo a Garza Rivera Plaza de

\footnotetext{
${ }^{166}$ Luis Mario Schneider, El Estridentismo: México 1921-1927, México, UNAM, 1985, ilustraciones en blanco y negro 5 y 7.
} 
Italia con estatua ecuestre de 1936, ${ }^{167}$ pero en el mural de las Casa del Campesino las jambas se doblan y además la inclinación ascendente del remate sirve como sostén de la chimenea, conjunto que acentúa el geometrismo característico del Déco. Por lo que respecta a los engranes industriales de las máquinas, como también anotamos en el capítulo 2 al describir las características de la pintura Déco en México, lo fabril, lo maquinario, representa ese espíritu de industrialización y que además los elementos geométricos que componen a las partes mecánicas como estas ruedas y engranes, así como su disposición fugada, denotan la estética Art Déco cercana al Streamline.

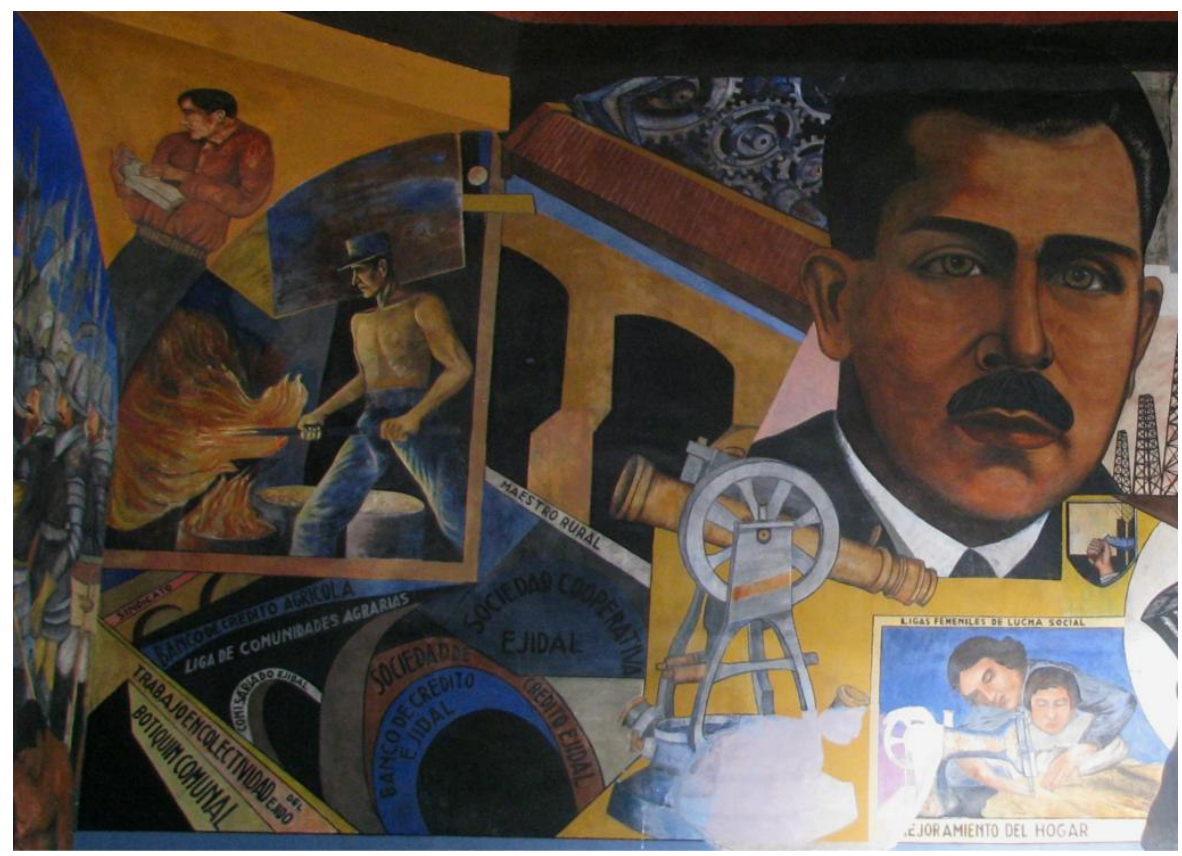

Detalle del lado izquierdo del mural norte.

En la parte central del mural norte, hacia abajo en un recuadro con las leyendas "Ligas femeniles de lucha social" y "Mejoramiento del hogar", se representa a una madre que enseña a su hija a coser con máquina, aquellas Singer alemanas que tanto se distribuyeron y vendieron por todo el país. Hacia arriba un escudo sindical con una mano alzando una hoz y más hacia el fondo unas torres y grandes contenedores de petróleo, rinden homenaje a la expropiación del 18 de marzo de 1938, lo que nos da el dato que

\footnotetext{
${ }^{167}$ S/A, Giorgio de Chirico, Barcelona, Poligrafía, 1995, imágenes 14 y 55, amabas en colecciones particulares.
} 
Garza Rivera se encontraba trabajando en los murales cuando este acto político se llevó a cabo. Estas torres con sus formatos, cúbicos, como torres truncadas y ensambladas por líneas cruzadas que denotan la estética Déco Zigzag y los contenedores como grandes cilindros, hacen un todo de cuerpos geométricos, representando la era industrial de los años del Streamline.

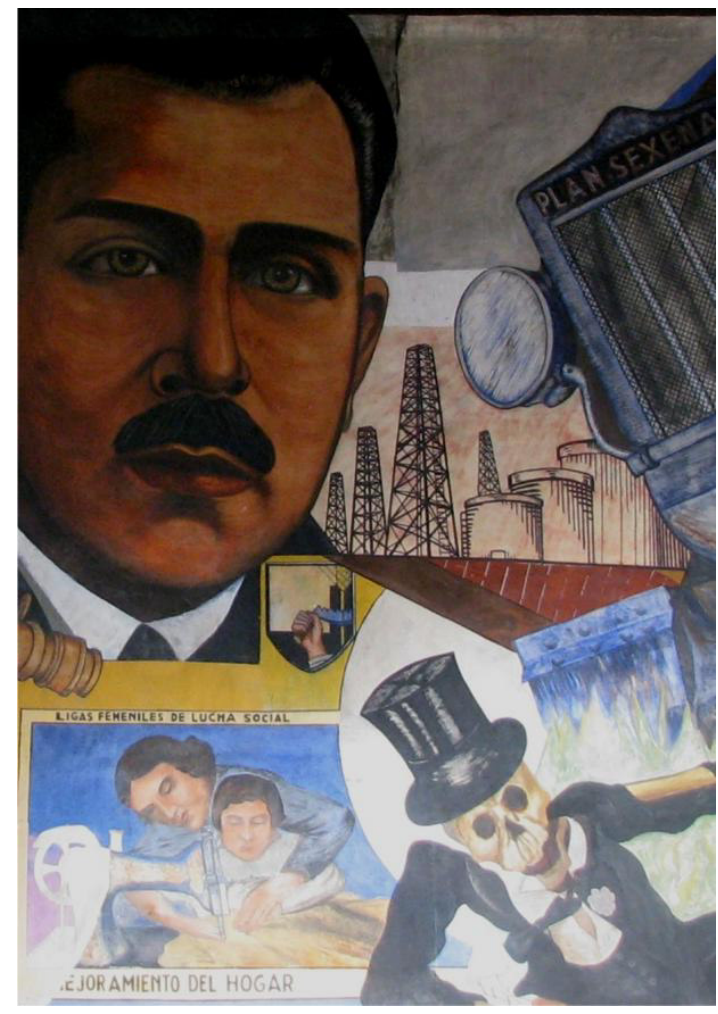

Parte central del mural norte.

Luego de la prolongación de la leve vista de una parte de la chimenea y hacia el lado derecho del mural, está una de las más enérgicas representaciones del cardenismo y el agrarismo: un potente tractor conducido por dos campesinos muestran la modernidad triunfante del gobierno cardenista que ha favorecido con la reforma agraria el antes cargado y obsoleto trabajo del campo, caracterizado por un arado rudimentario con el que trabaja un campesino del cual sólo se le ven las pantorrillas por atrás y que se aprecia del lado inferior derecho dentro de un trapecio donde dice "El pasado" y por el personaje agrario en la parte superior que carga un fusil y un azadón, del cual sólo se ve del torso para arriba y en posición frontal. En esta escena Crescenciano Garza juega con los planos y las imágenes, 
formulando un cinetismo en el las direcciones de avance del tractor hacia el frente y del hombre del campo hacia dentro, que como explica Enrique $\mathrm{X}$ de Anda, fue una de las características de la pintura Art Déco y que expusimos en el capítulo 2.

El poderoso tractor, casi como un tanque de guerra, en su marcha se inclina para mostrar su engranaje rodante, arrasa con un esqueleto vestido elegantemente que protege su dinero, mientras su esmoquin se desgarra; es la clase burguesa capitalista y opresora, en términos del socialismo de la época, cuyo reinado ha terminado con la instauración de los triunfos de la Revolución, del socialismo, del cardenismo. Asimismo, es una clara insinuación a los empresarios regiomontanos con los que Cárdenas no tuvo, al menos públicamente, una relación fraterna. El hecho de que Garza Rivera incluya el símbolo de la muerte nos habla de su característico estilo en sus ilustraciones, ya que era uno de sus temas muy recurrentes como buen seguidor del Decadentismo. ${ }^{168}$

El tractor lleva el lema de "PLAN SEXENAL", la propuesta del Partido Nacional Revolucionario (PNR) en diciembre de 1933, donde quedaría un periodo presidencial de 6 años como ya había sido reformado en la Constitución, incluye la educación socialista, la reforma agraria, el reparto de tierras, la industrialización del campo, el apoyo a los sindicatos a través de nuevas centrales obreras y campesinas, nacionalizar los bienes del suelo, lo que recordaba el Plan Quinquenal de la Unión Soviética, pero respetando a los capitales privados.

Como una mera hipótesis, aquí hay una conexión con la película de Sergei Eisenstein (1898-1948) La línea general (Lo viejo y lo nuevo) del año 1929, donde el trabajo agrario colectivo logra la transformación hacia un futuro industrializado, todo emanado gracias la revolución, igual que en México. En la película la escena del potente tractor conducido por una dama, muestra los cambios sociales que se vivían en la nueva Rusia Soviética que aquí en México sucedía algo similar con los cuantiosos apoyos al campo. Tomemos en cuenta que Eisenstein estuvo por México entre 1930 y 1932 para filmar ¡Que Viva México!, obra inconclusa, pero que durante su estancia se relacionó con

\footnotetext{
${ }^{168}$ Fernanda Salazar Gil menciona que son pocas las ilustraciones que encontró de Crescenciano Garza en el archivo de El Universal que como tal se puedan catalogar como decandentistas, a pesar que se le reconozca como un artista que trabajo bajo este estilo. Así pues, la muerte de este mural es un ejemplar muy sui géneris dentro de la obra de Garza Rivera. Op. Cit., pp. 44-45.
} 
artistas e intelectuales, por lo que seguramente su influencia llegó a Crescenciano Garza Rivera.

Este tractor también incorpora la estética de la máquina como una composición geométrica, cúbica en el cuerpo del aparato, cilíndrica en el escape lateral posicionado verticalmente, en la circunferencia del foco de la luz, en las líneas verticales del radiador, en los eslabones horizontales de las bandas de arrastre, todo enfatizando el geometrismo de lo Déco, de lo industrial de la época del Streamline.

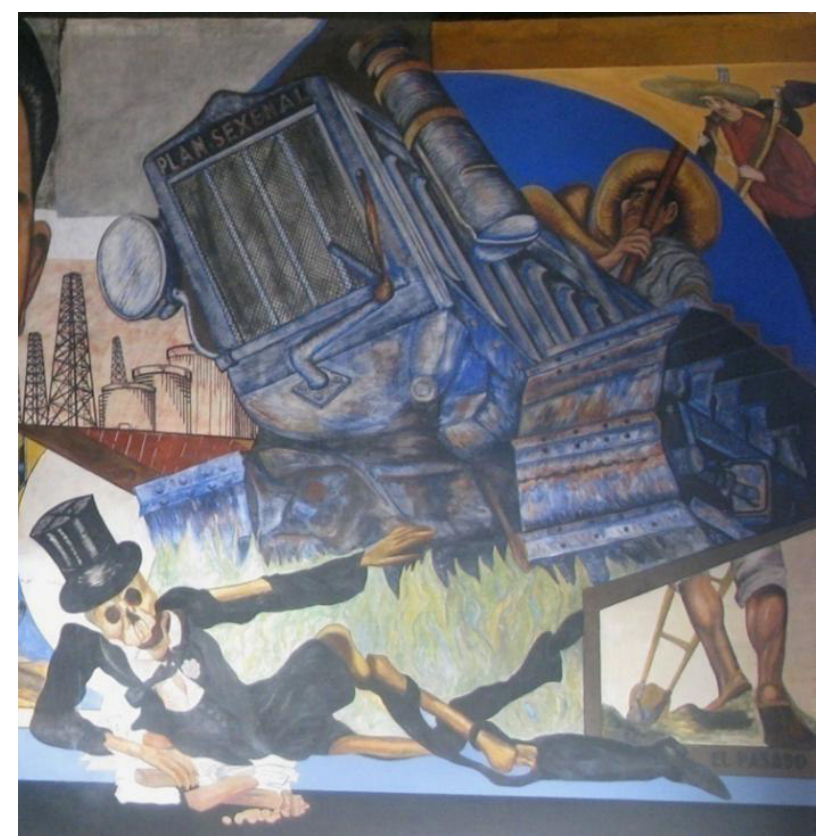

Detalle del lado derecho del mural norte.

Y al centro, el Presidente Lázaro Cárdenas del Río (1895-1970). Durante su mandato se crearon la Confederación de Trabajadores Mexicanos en 1936 y en 1938 la Confederación Nacional Campesina. En 1937 Cárdenas nacionalizó los ferrocarriles y en 1938 la ya mencionada expropiación petrolera, considerada el acto más revelador de su actividad política en defensa de la soberanía. Su acciones a favor de los campesinos se vio plasmado en el reparto de 18.3 millones de hectáreas, tal como se representa en otras escenas de los murales de la Casa del Campesino. Por eso, todas las actividades expuestas en el mural norte son para rendirle culto en pleno ejercicio de su presidencia al hombre que construía el nuevo México triunfante de la Revolución, cuyos frutos se cosechaban en los años treinta cuando se desarrollaba el Art Déco en México. 
Aunque es bien claro que este mural no destaca por su gran calidad artística y que junto con el resto de los demás murales se perciben las imperfecciones de trazo, proporción, perspectiva y volumen, lo incluimos por su valor histórico, por la época en que fue realizado y por los elementos de la estética Déco que contiene.

\section{c. Mural Alegoría de la Producción de Fermín Revueltas}

El mural se ubica en el frontispicio del teatro del Centro de las Artes, que se encuentra en el interior de la Pinacoteca, dentro del complejo del Parque Fundidora. Fue pintado en 1934 con la técnica del fresco por Fermín Revueltas Sánchez (1901-1935), mide 3.67 por $11.71 \mathrm{~m}$.

Este mural llegó en septiembre del año 2000 a Monterrey, bajo un acuerdo con Banca Serfín, hoy Banco Santander, quienes eran propietarios de la pintura. Originalmente fue el Banco Nacional Hipotecario Urbano y de Obras Públicas, S.A. (actualmente BANOBRAS), una instancia financiera que creó en 1933 el gobierno de Abelardo L. Rodríguez para fomentar la obra pública, industrial y urbana por parte del gobierno, ante la imperante necesidad del rezago en el que se encontraba el país como consecuencia de la Revolución y las secuelas de la Gran Depresión de 1929 en los Estados Unidos. A un año de su fundación en 1934, el primer gerente de la institución, el Ingeniero Gonzalo Robles Fernández (1891-1980), quien había estudiado en Valparaiso University, Indiana, la carrera de ingeniería civil sanitaria con cuyos estudios le otorgaron posteriormente en México el título de Ingeniero Agrónomo e Hidráulico, invita a Fermín Revueltas para que proyectara una pintura de grandes dimensiones que ilustrara las acciones del recién instituido organismo estatal, cuya actividad principal sería la promoción de obras de carácter público de gran envergadura con el fin de modernizar a la nación y mejorar las condiciones de trabajo y vivienda.

Entre los años 1960 a 1962 el mural fue restaurado y desprendido, colocándolo en un bastidor móvil y así poder ser traslado con la remodelación del edificio donde se ubicaba. Cuando se llevó a cabo la extraordinaria exposición Art Déco: Un país nacionalista, un México cosmopolita, entre noviembre de 1997 a abril de 1998 en el Museo Nacional de Arte, el mural fue exhibido a la entrada de la muestra. Podríamos decir que por 
primera vez era mostrado al público en general, ya que por estar en una oficina de gobierno era prácticamente imposible visitarlo.

Por veinticinco años fue el acuerdo para que el mural Alegoría de la Producción permanezca en Monterrey, por lo que aún tendremos muchas años más para conservarlo y admirarlo.

Fermín Revueltas es el caso de un artista que nace con el porfiriato, crece con la Revolución y hace su obra en la postrevolución. De una familia de artistas, caso tal vez único en México en aquellos años, su hermanos Silvestre músico, José escritor, Rosaura bailarina y actriz, hizo estudios en Austin y en Chicago, cuando por la inestabilidad política en el país a causa de la Revolución su padre lo mandó a los Estados Unidos a Austin, Texas, al colegio jesuita de Saint Edward's, junto con su hermano Silvestre; hacia 1918 viajaron a Chicago para regresar a México en 1920. Aunque Fermín traía algunas herramientas técnicas de pintura y dibujo, fue realmente hasta que ingresó a la Escuela de Pintura al Aire Libre en Chimalistac bajo la dirección del artista nacido en Monterrey, Alfredo Ramos Martínez (1871-1946) donde adquirió los conocimientos que hicieron tomar una técnica definitoria. Con esa formación en la escuela al aire libre es que va a iniciar sus trabajos, pero gracias a la relación que lleva con el poeta Manuel Maples Arce (1898-1981) es que se acerca a los lenguajes e ideologías de vanguardia al vincularse con el movimiento Estridentista.

Los años inmediatos a la fase armada de la Revolución, 1920-1922, de la instauración del caudillaje con Álvaro Obregón, de la transición hacia una búsqueda de una nueva gobernabilidad en el país, son también para Revueltas años de evolución entre su influencia impresionista por el paisaje y el color y el vanguardismo novedoso. En este vanguardismo es donde nace en él una pasión por lo urbano, lo industrial, cambiando el paisaje del campo por el de las urbes plagadas de avances tecnológicos y de pabellones fabriles, en donde la nueva casa del trabajador proletario obtiene una significación dentro del mundo moderno y la mujer cobra importancia en la vida social y del trabajo obrero.

No fue poca su producción a pesar de lo corto de su vida. Grabados, ilustraciones, obra de caballete y mural dejan en claro a un artista consolidado y de vanguardia, que como expresó Luis-Martín Lozano: "se dio la oportunidad de practicar un trabajo lineal y 
geométrico, que lo coloca como uno de los más visionarios artistas de la vanguardia en México, quizá sólo junto con Ramón Alva de la Canal”. ${ }^{169}$

Revueltas participa activamente con Manuel Maples Arce en la revista de corta duración titulada Irradiador, pues sólo se editó de septiembre a noviembre de 1923, la cual tenía un contenido vanguardista de la poesía y buscaba que las ilustraciones que la acompañaran estuvieran de acuerdo con los contenidos literarios, por lo que Fermín Revueltas concibe grabados de "propuestas cubo-geometrizantes que otorgaban a la publicación un toque de modernidad". ${ }^{170}$ Son ilustraciones fuertemente imbuidas dentro del lenguaje del Cubismo, del Constructivismo, de Futurismo, cuyo geometrismo le dan dirección hacia la estética del Déco.

También colaboró con la revista Crisol desde 1929 hasta su muerte, porque la publicación siguió editándose hasta 1952. De contenido político, social y económico donde participaron intelectuales y políticos, el maquinismo triunfante de las fábricas y sus chimeneas, de los ferrocarriles potentes, de aviones veloces, de torres para la extracción petrolera, o la ciudad como el hábitat de progreso mecanizado fueron los temas ilustrados por Revueltas. Carla Zurián explica esa etapa del artista: "Las viñetas interiores confirmaron su versatilidad creativa, pues no solamente realizó cenefas de raigambre art déco, sino un variado espectro de diseños cubistas, abstractos, constructivistas y de corte histórico, con el recurso de la tinta y la xilografía". ${ }^{171}$

En su pintura de caballete, así como en la acuarela, armonizaba el paisaje del campo en el trabajo agrícola, con los cables de la conducción eléctrica. El mundo urbano con la vivienda para las clases trabajadoras, lo ilustra con el despliegue de la electricidad al servicio de la población, llenando el paisaje citadino con líneas rectas y oblicuas. En su obra mural y en sus vitrales, también le cantó al triunfo del trabajo obrero y campesino, a la historia y al paisaje nacional, donde la modernidad vanguardista, tecnológica, fabril está al servicio de la persona, hombre/mujer mujer/hombre, dentro de un fuerte y vivo colorido.

\footnotetext{
${ }^{169}$ Luis-Martín Lozano, "Revueltas: pintor entre revoluciones y renacimientos, 1921-1923”, en: Consejo para la Cultura y las Artes de Nuevo León, Fermín Revueltas y la modernidad, de lo rural a lo urbano, Monterrey, N.L., Consejo para la Cultura y las Artes de Nuevo León, 2004, p. 20.

${ }^{170}$ Laura González Matute, "Fermín Revueltas: artista comprometido con su trabajo y su tiempo", en: Consejo para la Cultura y las Artes de Nuevo León, Op. Cit., p. 26.

${ }^{171}$ Carla Zurián, Fermín Revueltas constructor de espacios, México, Instituto Nacional de Bellas Artes, Editorial RM, 2002, p. 58.
} 
Aunque ya hablamos de Fermín Revueltas en el Capítulo 2, si le dedicamos más espacio en su biografía que a ninguno otro artista es porque fue el pintor que más trabajó la estética del Déco en el país, a pesar de su corta edad y su prolífica producción, ya que como afirmó la experta en su obra Carla Zurián: "Realizó anteproyectos art déco, sobre alegorías clásicas, con la misma soltura con la que representó las hoces y cananas; los rieles y el trabajo de campo". ${ }^{172}$

Al centro del mural la pieza más grande es una potente turbina de la que podemos ver sus partes interiores. Detrás de ella, llamas del fuego maquinista se expanden irradiando el triunfo de la tecnología. Hacia el frente del lado izquierdo, en posición de descansando y con el torso desnudo un hombre mira el progreso humano. Del lado derecho, también desnuda del torso una mujer de pie vierte un abundante chorro de agua hacia una vasija sostenida por otra mujer y que bebe el líquido. Una dama más que voltea hacia el otro lado, cubre su desnudez con un cántaro. Hombres y mujeres que surgen de las emanaciones de la turbina, son los nuevos mexicanos que ahora gozan del triunfo postrevolucionario y de la nación moderna bajo el amparo del maquinismo.

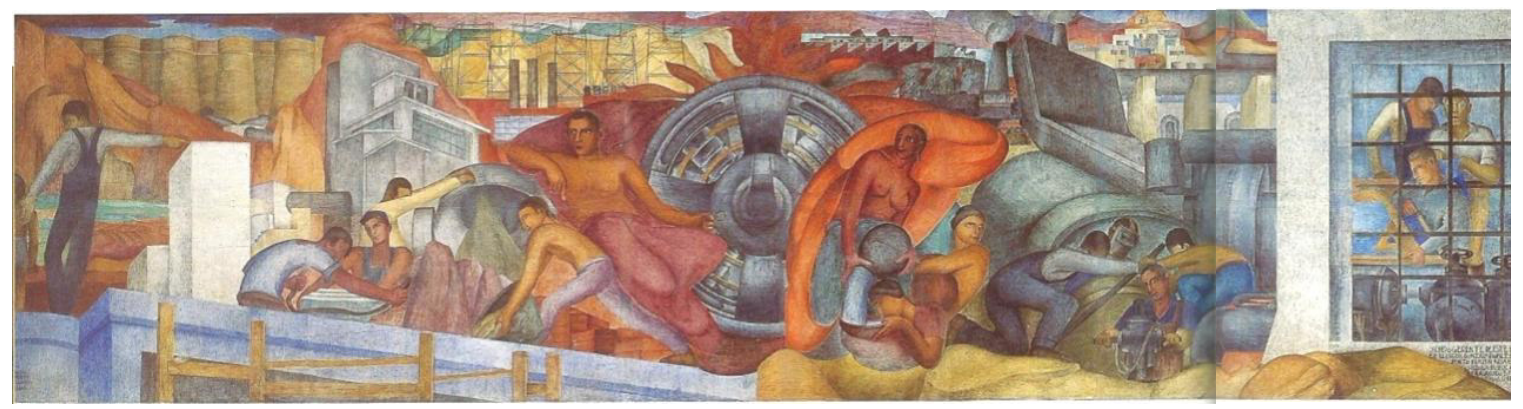

Mural en el frontis del Teatro del Centro de las Artes. ${ }^{173}$

Como anotamos en capítulos anteriores que en la época de los “Años Locos” o en las décadas inmediatas a la Revolución mexicana, la mujer en el país toma una nueva posición social, trabaja en la producción de bienes, participa en la vida política, se instruye con la educación ofertada por el estado, así pues la presencia de tres damas en el mural de

\footnotetext{
${ }^{172}$ Carla Zurián, "Fermín revueltas: el sortilegio del color", en: Consejo para la Cultura y las Artes de Nuevo León, Fermín Revueltas y la modernidad, de lo rural a lo urbano, Monterrey, N.L., Consejo para la Cultura y las Artes de Nuevo León, 2004, p.39.

${ }^{173}$ Todas la fotos fueron obtenidas de: Consejo para la Cultura y las Artes de Nuevo León, Fermín Revueltas y la modernidad, de lo rural a lo urbano, Monterrey, N.L., Consejo para la Cultura y las Artes de Nuevo León, 2004.
} 
Alegoría de la Producción es un mensaje de cambio para la sociedad mexicana, porque la mujer también es parte de la construcción del México moderno, en un ambiente de trabajo antes exclusivo de varones.

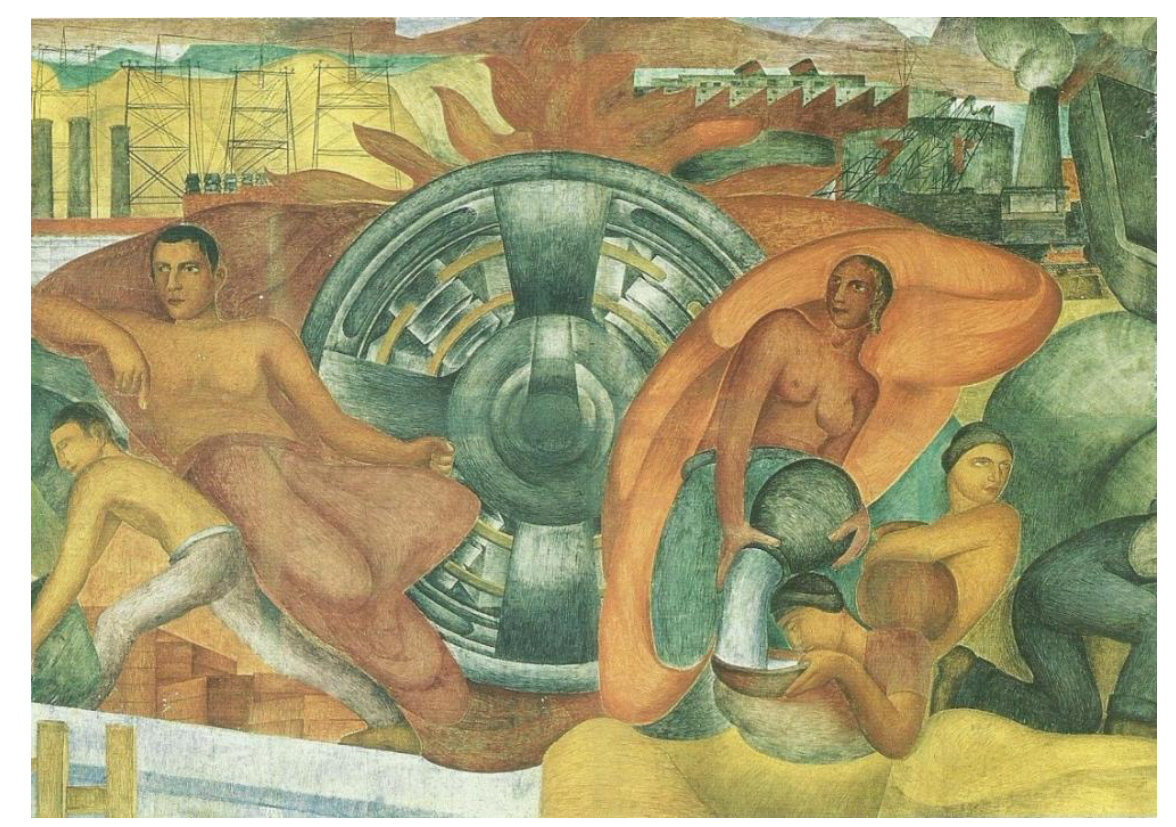

Parte central del mural. Al fondo izquierdo se aprecia una estación hidroeléctrica, a la derecha una refinería y más hacia arriba un buque dentro de un puerto.

Del lado izquierdo del hombre, el trabajo de la construcción lo llevan a cabo cuatro albañiles en diferentes posturas. Un trabajador con las piernas abiertas vacía cemento y al fondo se aprecian unos ladrillos apilados. Otro albañil con ambos brazos vacía una revolvedora. Después dos trabajadores más acomodan bloques de concreto. Es la industria de la construcción, con cemento, el material moderno del Art Déco y que daba tanto beneplácito por las múltiples posibilidades de uso, así como por su durabilidad. Poliedros cúbicos se elevan en distintos niveles: son las nuevas ciudades, las urbes modernas que se edifican con la tecnología del concreto armado. Y atención, la fábrica que se encumbra por medio de varios niveles, que luce su apariencia de cemento, con amplios ventanales cuadriculados, con techumbres que rompen el equilibrio de la perspectiva y con paredes curvas en sus parte más alta, nos exporta hacia los diseños Bauhaus y ni se diga a la fábrica Fagus de Walter Gropius (1883-1969) y Alfred Meyer (1881-1929). Todo este conjunto, hombres y construcciones forman un triángulo junto con la montaña que está detrás de la 
factoría y que divide el fondo en dos grandes obras de la ingeniería: a la derecha, una central generadora de energía eléctrica, con un gran ventanal y tres chimeneas, acompañadas de cinco estaciones elevadoras.

Torres de alta tensión forran el paisaje montañoso y al fondo una apacible laguna; es toda la semántica de la producción de la energía eléctrica, especialmente resaltando las elevadas torres de acero que conducen con su inmensa líneas de cableado la electricidad y que fue tan retratado por Revueltas en muchas de su obra de caballete y gráfica, ante la impresión que le causara esa transformación de la vida mexicana.

Del lado izquierdo, la gruesa cortina de concreto de una presa, así como su tubería completan las acciones de gran envergadura que serían patrocinadas por la nueva institución bancaria estatal; y para cerrar la escena, al frente un hombre con overol señalando con el dedo índice, le explica a un niño la importancia de las edificaciones elaboradas con el cemento. Toda esta parte del mural está colocada en la parte superior de una obra en construcción con todo y andamios, es decir, lo que se está haciendo por la modernización del país.

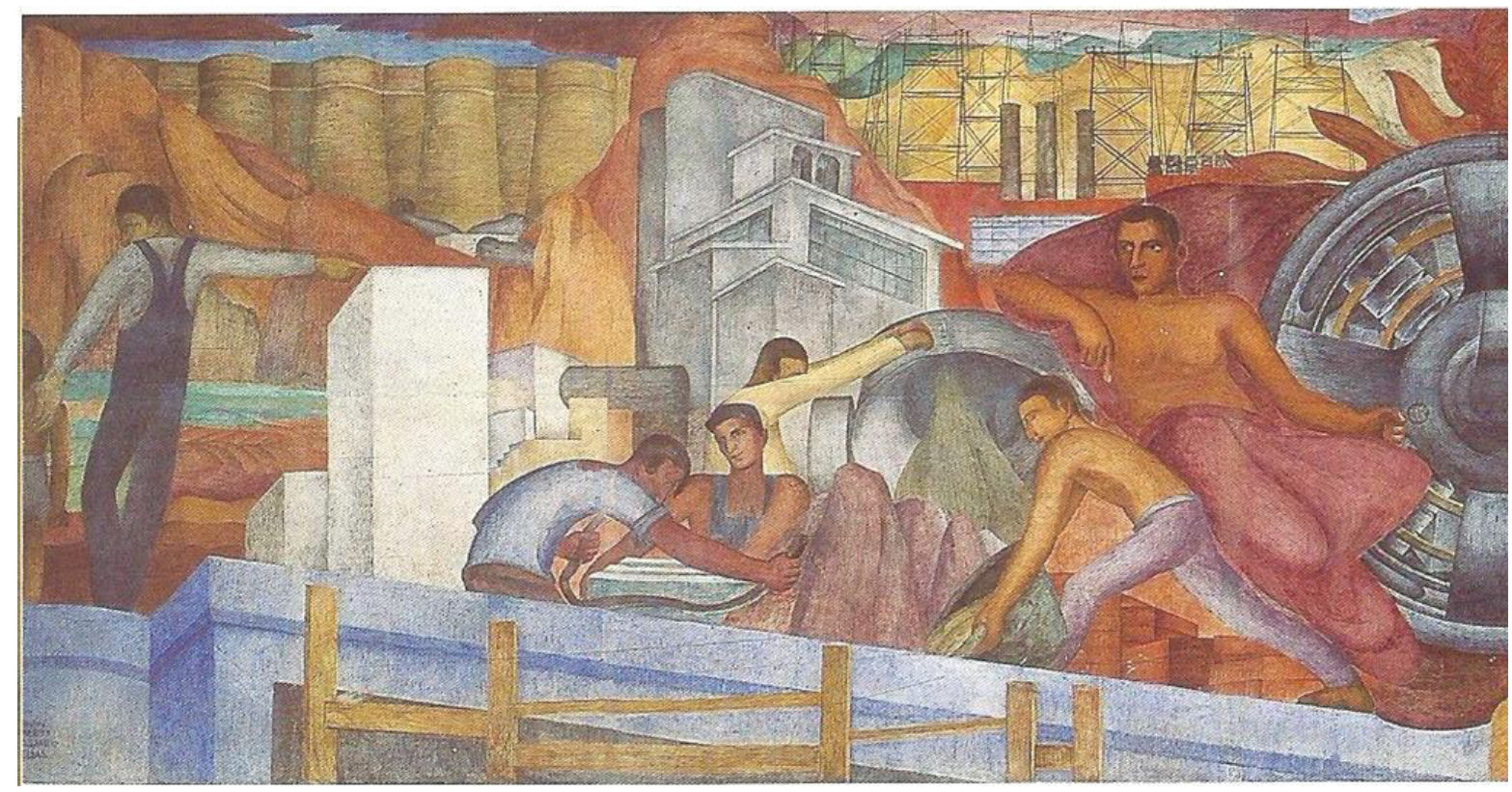

Parte izquierda.

Del lado derecho de las mujeres cuatro hombres trabajan en tareas obreras: el que está al frente manipula un taladro picando piedra, dos hombres se esfuerzan con una berreta 
y atrás un soldador con careta. Imponentes piezas obtenidas a través de la fundición de acero nos hablan de la grandeza de dicho material para la consecución de magnas obras de la ingeniería al servicio de la humanidad. En el fondo hacia la izquierda tres grandes tanques, uno detrás de las flamas y dos de ellos numerados, más dos chimeneas humeantes y tres grúas mecánicas presentan una refinería de petróleo, producto de la tierra que en México abunda y que en eso años aún estaba en manos de compañías extranjeras. Más hacia atrás se entrevé un vigoroso barco carguero que se asoma en su flote por el agua detrás de los pabellones de un puerto. Hacia la derecha de las portentosas partes industriales y en un segundo plano, una gruesa tubería sostenida por pilares de concreto se prolonga hacia el fondo en serpenteante pero geométrica disposición, para perderse en el horizonte. Unas cúbicas casas se disponen ascendentemente para demostrar que el obrero ha sido retribuido tanto en sus condiciones laborales como de vivienda.

Para concluir toda esta escenografía, en un cuarto con amplio ventanal, se observan tres hombres: el primero, un ingeniero está sentado y con actitud pensante trabaja con regla y escuadra sobre un plano; el segundo está de pie y con un plano en la mano le da indicaciones a un operario vestido con overol y gorra de mezclilla. Al frente unas válvulas y un alternador nos indican que es la sede de la fábrica desde donde se controlan todas las funciones mecánicas.

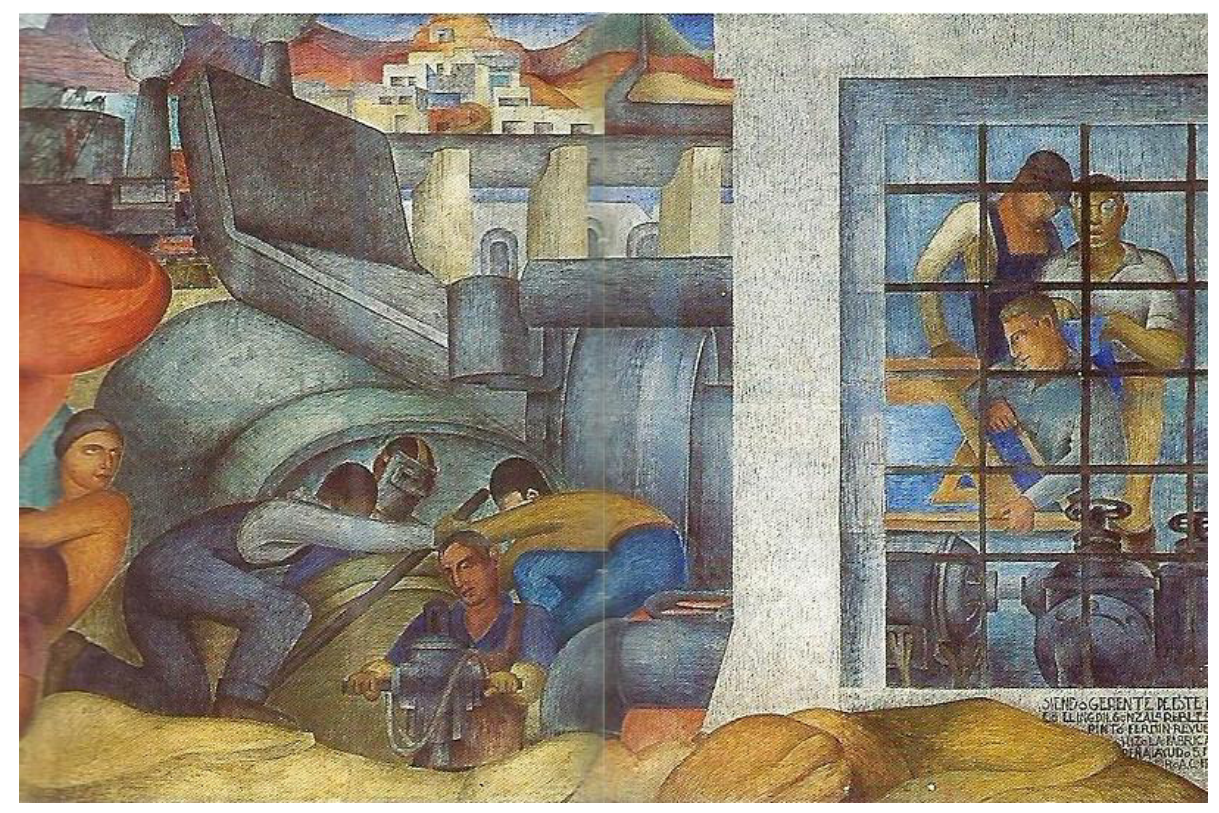

Parte derecha. 
En la parte baja del muro está la leyenda de la conclusión del mural:

\author{
"SIENDO GERENTE DE ESTE \\ BANCO EL ING. DN. GONZALO ROBLES \\ PINTÓ FERMÍN REVUELTAS \\ HIZO LA FABRICA T \\ PEÑA AYUDÓ S.FIGUE \\ ROA C. 1934"
}

El geometrismo que contiene este mural, elemento esencial de las composiciones Art Déco, está presente por todas partes. Al centro, observamos círculos con la turbina y sus partes concéntricas, las cuales se forman en la ilusión óptica del girar de la hélice, así como los plintos circulares de las bielas interiores. Entre la posición del hombre y la mujer se formaría un triángulo invertido que envuelve al círculo de la turbina y con las flamas se forma otro triángulo de menor tamaño, mientras que con la postura del hombre recostado a un lado de la turbina se concierta la figura de un romboide.

En el grupo de hombres que trabajan en la construcción, el primero que está con las piernas abiertas forma un triángulo, así como otro que se obtiene con su postura inclinada y sus brazos, además del rectángulo que se consigue con la pierna y brazo izquierdos. El que sostiene la revolvedora conforma un ángulo obtuso, mientras que el que carga los ladrillos, con sus brazos se dispone un romboide. Si trazamos el contorno de todo el grupo da por resultado un trapezoide. Los círculos están presentes en la boca de la revolvedora, así como en su fondo y rueda y en el contenedor de cemento.

El hombre que está de espaldas al extremo izquierdo con el niño, en su posición de señalamiento perfila un ángulo recto y un triángulo con la leve abertura de su pierna.

En el grupo de mujeres, un trapecio en posición vertical se logra con el contorno. Triángulos se crean con el brazo y torso de la mujer que sostiene el cántaro obscuro y con el brazo y mano de la que está bebiendo.

Con los obreros que están a la derecha de las mujeres se forman dos romboides: uno con el perímetro de sus cuerpos y otro con la colocación inclinada de la barra. Son más que evidentes las formas circulares del gran crisol y de las demás partes industriales manufacturadas con hierro fundido, así como del enorme prisma oblicuo y prolongado.

El ventanal con su retícula y el rectángulo del cuarto de máquinas, así como los instrumentos de trazo del ingeniero, hablan por sí solos del enaltecimiento de la geometría. 
Los cilindros y los conos truncados están presentes en la colosal cortina de la presa, en las chimeneas de la estación eléctrica, en los tubos humeantes de la refinería, en los ductos del agua y en las partes industriales, e incluso hasta el cilindro oblicuo está presente en las chimeneas del barco carguero.

La línea recta, perpendicular y oblicua recorre todo el trazo del mural, pero toma más su posición y presencia en los andamios y cornisa del frente, en las torres y cables de la energía eléctrica, en la cuadrícula del ventanal, llegando a las grúas mecánicas y hasta las antenas del buque.

Es sumamente importante recalcar los elementos cúbicos del mural. Si el Art Déco se alimentó de las posturas estéticas del Cubismo, Constructivismo, Bauhaus y De Stijl, movimientos en los cuales se impulsó el ejercicio de acomodar formas cúbicas en sus diseños, pinturas, bosquejos arquitectónicos, en el mural Alegoría de la Producción apreciamos como Fermín Revueltas posiciona en varias segmentos las formas cúbicas, como es en la escena de la construcción, en la cual se destaca más su presencia, tal como sucede con los tabiques rojos, los poliedros cúbicos de diferentes tamaños y colores tenues, así como con la fábrica que se aloja en lo alto. También en el fondo del lado derecho del mural, en la representación de la vivienda obrera las casas están proyectadas por medio de cubos en tríos, dúos o individuales.

Y no podía faltar en este mural decir de su lenguaje Art Déco Zigzag, pleno de elementos compuestos con los triángulos escalenos del puerto coloreados en bermellón, con las rocas filosas y puntiagudas, con las torres petroleras, con los diseños angulosos de las construcciones, las mismas poses y acomodo de los personajes e inclusive con las flamas detrás de las turbinas.

Toda esta alegoría del mural pareciera que anticipa los que en años inmediatos y en tiempos del Art Déco se hiciera en México bajo el cardenismo: en 1936 se funda la Confederación de Trabajadores Mexicanos, el sindicato para la defensa de los trabajadores obreros que estuvo al lado del partido y del gobierno; en 1937, se crea el Instituto Politécnico Nacional para profesionalizar la educación técnica al servicio de la creciente industria, aunque ya en Monterrey se había creado la Escuela Industrial Álvaro Obregón en 1930, la primera en su tipo en México. Para el mismo año de 1937 la industria eléctrica se unifica bajo la Comisión Federal de Electricidad y un año más tarde, tal como lo retrata 
Revueltas, se inicia el primer proyecto hidroeléctrico en Ixtapantongo, Estado de México, junto a la Presa Colorines. Y para 1938, la Expropiación Petrolera deja en manos del gobierno mexicano la producción del "oro negro. Obras plasmadas en la Alegoría de la Producción para las oficinas del banco que fue creado con ese fin y que interpretadas según la creatividad del artista bajo los cánones de las vanguardias de su tiempo con la estética del Art Déco, unos años después serían una realidad de la construcción del México moderno, industrializado, con ayuda de la máquina, donde el hombre y la mujer forman parte de una sociedad nueva construida dentro las urbes ahora armadas con concreto, acero, agua entubada, luz eléctrica, combustibles petrolíferos, bajo la conciencia educativa de la ingeniería.

Sobre las cualidades artísticas del mural Alegoría de la Producción, el pintor de origen guatemalteco Carlos Mérida (1891-1984), quien se integró al movimiento muralista mexicano y cultivó en su obra la abstracción geométrica y el geometrismo, se refirió de esta manera: "En este fresco del Banco Hipotecario intervienen las máquinas -hermosos elementos plásticos que habrían seducido a Uccello-, la electricidad, la fuerza hidráulica, domesticadas por el hombre para servirse de ellas, orquestadas dentro de alegorías románticas y tradicionales. El hombre y la mujer en medio de esas fuerzas, dóciles ya, señoreándolas". 174

Otra de las características de este mural que lo inscriben dentro del Art Déco es la manera como Revueltas integra a través de una facetación de planos las diversas escenas y las figuras humanas; dicha facetación se logra con la disposición proporcionada de las figuras geométricas y las líneas que conducen a visualizar todo el contenido temático expresado alegóricamente, con un cromatismo de tonos suaves, tenues y equilibrados, entre café, bermellón, amarillo, naranja, verde y azul, blanco y gris, que no distrae de una parte hacia otra o que no acapara más la atención de algunos de sus componentes. Las líneas oblicuas y perpendiculares nos conducen hacia los extremos y los grupos cúbicos y poliédricos nos inducen a mirar hacia el fondo. De la misma manera que el centro nos expande hacia los lados, de los lados regresamos al centro y ambos segmentos nos transportan hacia la parte superior.

\footnotetext{
${ }^{174}$ Carla Zurián, Fermín Revueltas constructor de espacios, Op. Cit., pp. 97 y 100.
} 
Para Enrique X., de Anda el aporte técnico de este mural Alegoría de la Producción y de otros trabajos del pintor, estriba en lo siguiente: "La cualidad que yo advierto en el trabajo de Revueltas es el esquema de marco rebasado, es decir, que el tema dibujado se manifiesta como parte de una realidad, por supuesto dinámica, que pareciera presentarse a los ojos del pintor -y del espectador- como una cinta cinematográfica que va corriendo, y de la cual queda en la mente, y en el lienzo, no un recuadro completo sino tal vez dos en sus límites fronterizos. Así es como interpreto el movimiento virtual expresado por el déco". ${ }^{175}$

Como ya explicamos en el Capítulo 2 sobre el desarrollo del Art Déco en México y los pintores que incursionaron dentro de esta estética, la diferencia con Revueltas es que abordó antes que ningún otro la modernidad de la tecnología eléctrica, arquitectónica y del paisaje urbano, representado no sólo la historia antigua o los símbolos triunfantes de la Revolución y/o su crítica como lo hicieron otros artistas del Muralismo, sino que captó e ilustró lo que el país también estaba viviendo que era su modernización postrevolucionaria.

Si bien es cierto que Máximo Pacheco, quien ayudó a Revueltas en su mural del Colegio de San Ildefonso, ya había pintado en los murales de la escuela Domingo F. Sarmiento la presa de su natal Huichapan entre 1922-1926 o Diego Rivera pintó el trabajo obrero industrial en Detroit en el mural El hombre y la máquina de 1932 y en el Palacio de Bellas Artes El hombre controlador del universo en 1934, mismo año del mural Alegoría de la Producción, es en éste último donde la visión del maquinismo, la industria, el petróleo, la ciencia, la ciudad, el cemento, la electricidad, las presas, los puertos y los buques, todo al servicio de la humanidad, son vistos desde una perspectiva nacional, es la razón por la cual nos atrevemos a afirmar que esta obra de Revueltas, en su temática, en su trazo y en su técnica, lo hacen el mural con más estética Art Déco de México.

El hecho que se encuentre en Monterrey y no por mera casualidad, sino porque se le buscó un destino adecuado, la Alegoría de la Producción queda bien instalada en la capital industrial del país.

\footnotetext{
175 Enrique X., de Anda Alanís, “La identidad del Art Déco en México”, Catálogo de la exposición Art Déco. Un país nacionalista, un México cosmopolita. México, INBA, 1997, $1^{\text {a }}$ edición, 1998, $1^{\mathrm{a}}$ reimpresión, p. 63-64.
} 


\section{d. Esculturas de Adolf Laubner: la Virgen de la Purísima y los Ángeles}

Las esculturas de la Virgen de la Purísima y seis ángeles se encuentran en la Basílica de la Purísima Concepción, antes solamente templo, ubicada en las calles Serafín Peña, entre Lic. Verdad y Miguel Hidalgo, con ubicación de la portada principal hacia el oriente. Construida entre 1940 y 1946 bajo el diseño del arquitecto Enrique de la Mora y Palomar (1907-1978), la obra fue galardonada con el Premio Nacional de Arquitectura de 1946. Los trabajos de construcción estuvieron bajo la supervisión del ingeniero Armando Ravizé Rodríguez. El generador de la obra fue el VII Arzobispo de Monterrey, el doctor Guillermo Tritschler y Córdova (1878-1952), clérigo visionario y fuerte promotor del arte sacro moderno, como lo anotamos al tratar el tema de los murales de la Catedral.

La actual edificación se hizo en los mismos terrenos donde estuvo ubicada la antigua iglesia, que según las crónicas se inició su construcción en 1759 después de una terrible inundación y que gracias a una imagen mariana de bulto de pequeñas dimensiones conservada por una india tlaxcalteca, salvó a la ciudad de una catástrofe peor. Donde ya existía una pequeña ermita en la casa de la india Antonia, quien conservaba la imagen desde mucho tiempo antes, se levantó una pequeña capilla a la Virgen de la Concepción conocida como "la Zapatera", por ser el oficio del esposo de la señora Antonia. ${ }^{176}$ Debido al crecimiento de la devoción por la imagen, a partir de 1841 se hizo una ampliación y una construcción de manera que se fue agrandando y adecuando a las necesidades de los feligreses, hasta su demolición en 1942 para dar cabida al magno proyecto de la actual Basílica.

La iglesia cuenta con obras de arte moderno de grandes artistas mexicanos o habitados en el país como los mexicanos Federico Cantú (1907-1989), Jorge González Camarena (1908-1980), Jesús Guerrero Galván (1910-1973), Benjamín Molina, Efrén Ordóñez (1927), el alemán Herbert Hoffmann-Ysenbourg (1907-1973), el húngaro Erno Koch (1898-1970), quien vivía en Estados Unidos, con lo que la constituye en un verdadero museo de Arte Sacro.

\footnotetext{
${ }^{176}$ José Antonio Portillo Valadez, La Purísima Concepción en Monterrey. Templos e imágenes más antiguas. Monterrey, N.L., s/e., 2006, pp. 12-17.
} 


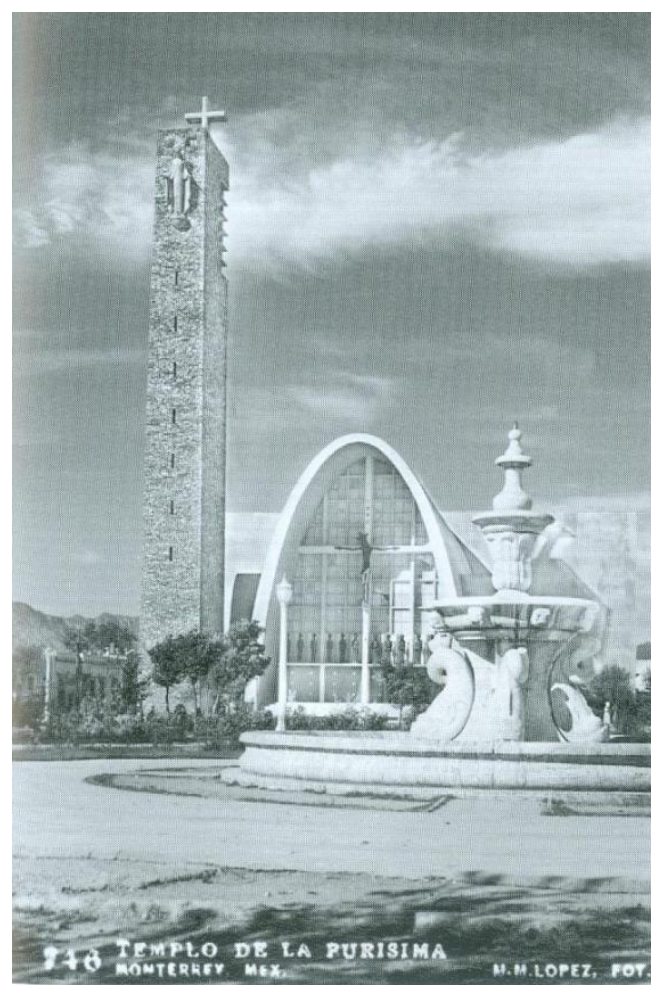

Templo de la Purísima hacia 1950.177

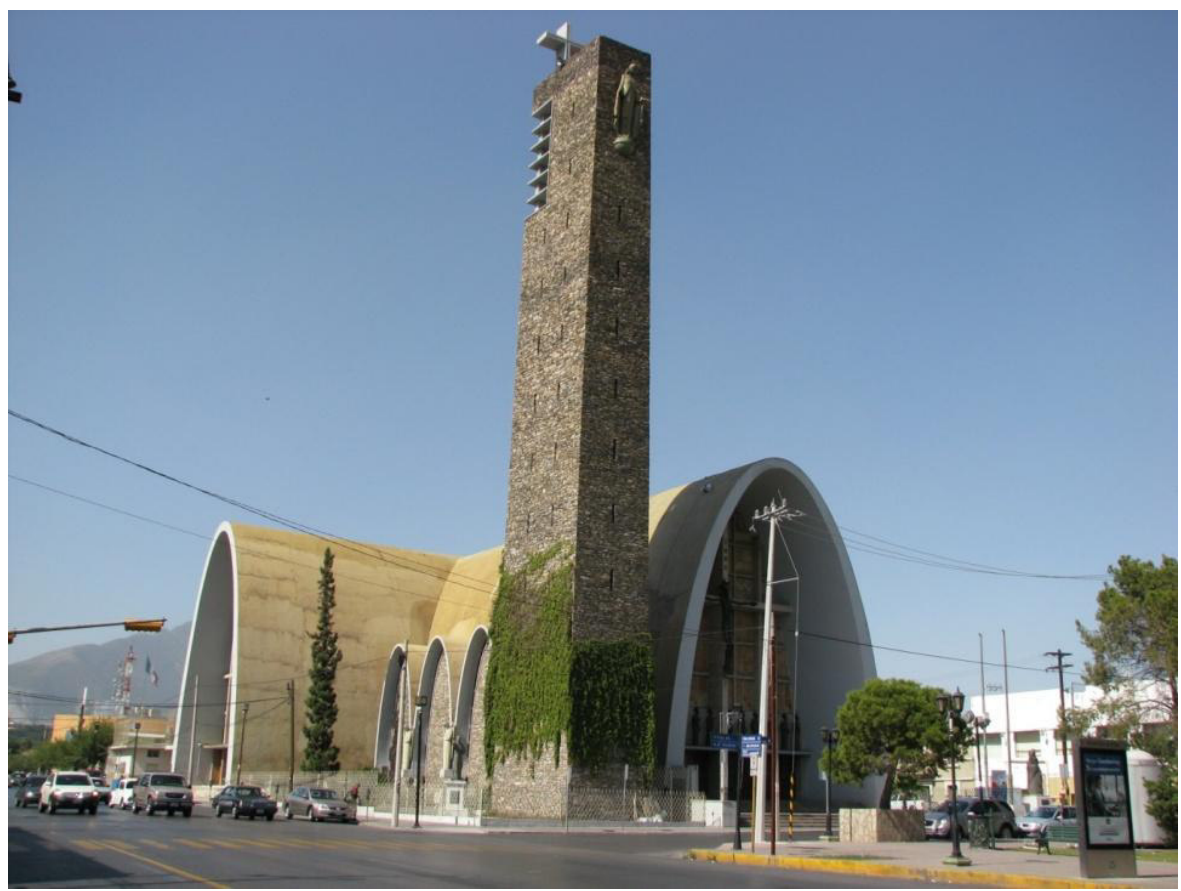

Basílica de la Purísima Concepción.

${ }^{177}$ Héctor Javier Barbosa Alanís, Monterrey. Descubra el ayer de nuestra ciudad, Op. Cit., p. 65 
Otro de los artistas que participaron fue el escultor de origen alemán Adolf Laubner Mayer (1906-1967). Hizo sus estudios en su país natal y en 1930 llega a México, radicando en la capital de la república a partir de 1932. En 1947 fue invitado como profesor del Instituto Tecnológico y de Estudios Superiores de Monterrey, cambiando su residencia permanente a la capital del estado de Nuevo León, donde vivirá hasta su muerte. ${ }^{178}$ Cuando se iniciaron los planes para el nuevo templo de La Purísima, como se le conoce popularmente, y con la llegada del arzobispo Tritschler a la ciudad en 1941, el prelado buscó a varios artistas renombrados para que trabajaran en la decoración de la nueva iglesia y de este modo fue como Laubner se integró al proyecto. Tritschler había conocido a Laubner en la ciudad de México en casa del sacerdote y literato Octaviano Valdés, donde se llevaban a cabo reuniones entre artistas e intelectuales católicos. ${ }^{179}$

Las obras que Laubner realizó para la iglesia de La Purísima son seis ángeles y una Virgen. Si bien ya son de los años 1945-46, conservan dentro de su diseño los elementos del Art Déco.

Los ángeles están situados en el exterior, tres en el lado norte y tres en el lado sur, colocados entre las intersecciones de los arcos laterales que funcionan como ventanales. Son iguales en toda su composición, salvo el peinado. Con una altura de 1.50 m., están trabajados en piedra artificial, "vaciados en color verde claro por el maestro Manuel Bermeo". ${ }^{180}$ De gran delicadeza lineal, los ángeles están en actitud orante, con las manos replegadas, la cabeza agachada y están descalzos. La fuerza de la geometricidad está presente en toda la imagen, iniciándose con la esfera que forma la cabeza; las manos forman un triángulo isósceles muy alargado y truncado en la parte superior y un cuadrado se conforma con el torso y la parte superior de la túnica, que con la caída de las mangas se equilibra la posición angular de los antebrazos. La túnica cae en finos pliegues, siendo más ancho el central, con lo que se enfatiza la verticalidad; esta segunda parte del cuerpo se forma con un cilindro que se ensambla con el cuadrado descrito. Las alas se despliegan en un triángulo isósceles invertido y truncado en su parte baja y en las orillas se resalta la

\footnotetext{
${ }^{178}$ Lily Kassner, Diccionario de escultores mexicanos del siglo XX. Tomo I, México, CONACULTA, 1997, pp. 441-442.

${ }_{179}$ Aureliano Tapia Méndez, La Virgen Chiquita. Historia de una imagen y de sus templos, Monterrey, N.L. Al Voleo-El Troquel, 2003, Iconografía, sin página.

${ }^{180}$ José Antonio Portillo Valadez, Op. Cit., p. 32.
} 
linealidad a través de un borde. La parte superior termina en formas curvas, cubriendo la espalda del ser celestial.

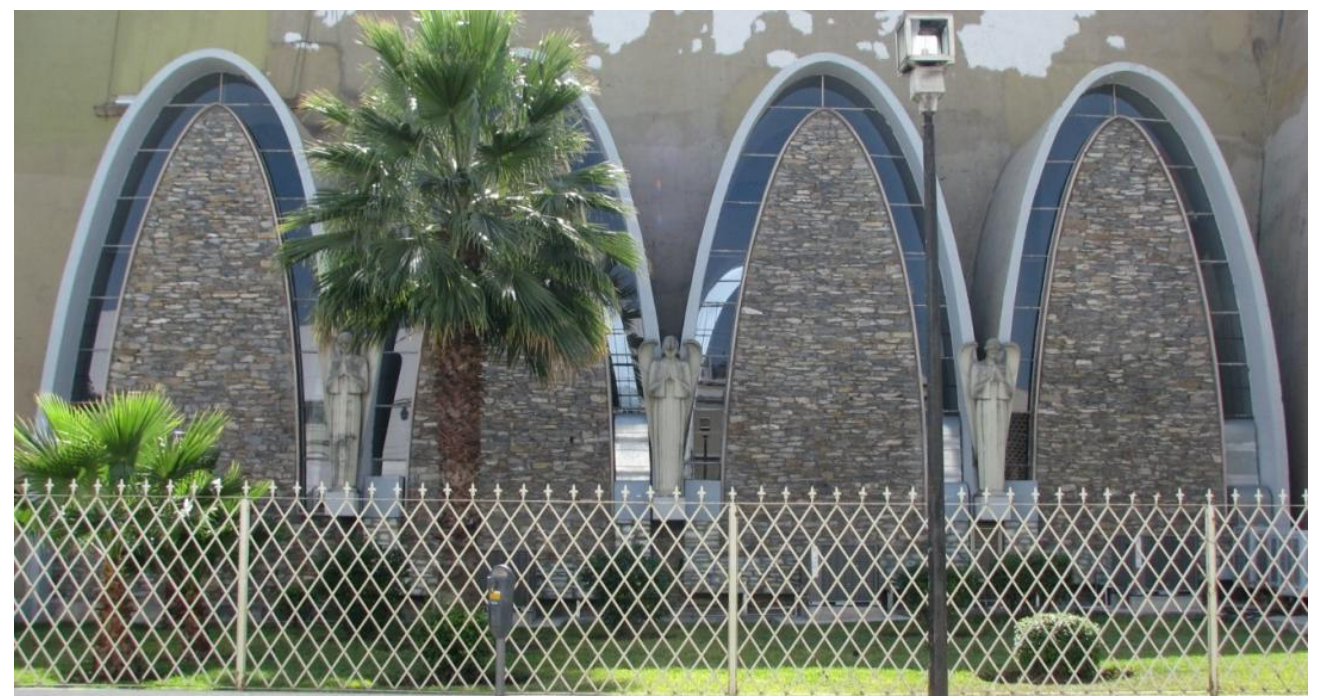

Ángeles del lado norte.
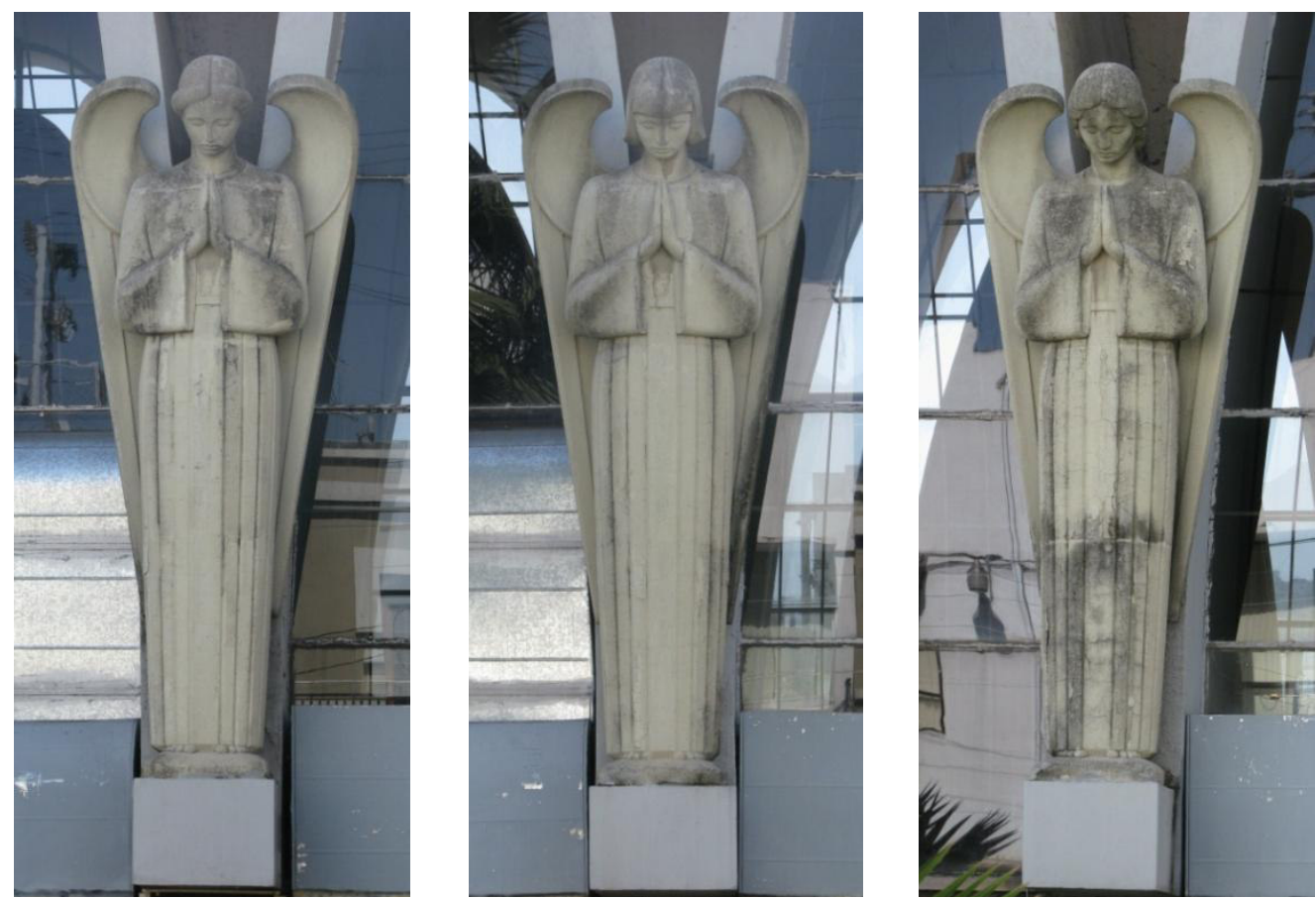

Primer ángel del lado norte. Segundo ángel del lado norte. Tercer ángel del lado norte.

Esta manera de concebir a los ángeles nos remite a las composiciones de Roberto Montenegro en sus Alegorías del Viento y de la Técnica, que están mencionadas en la 
Escuela Industrial Álvaro Obregón de este capítulo, donde lo industrial se resalta a través de la geometría, así como lo aerodinámico de las figuras, tal como en este caso lo concibe Laubner, obteniéndose con estos ángeles figuras del Art Déco de la variante Streamline.

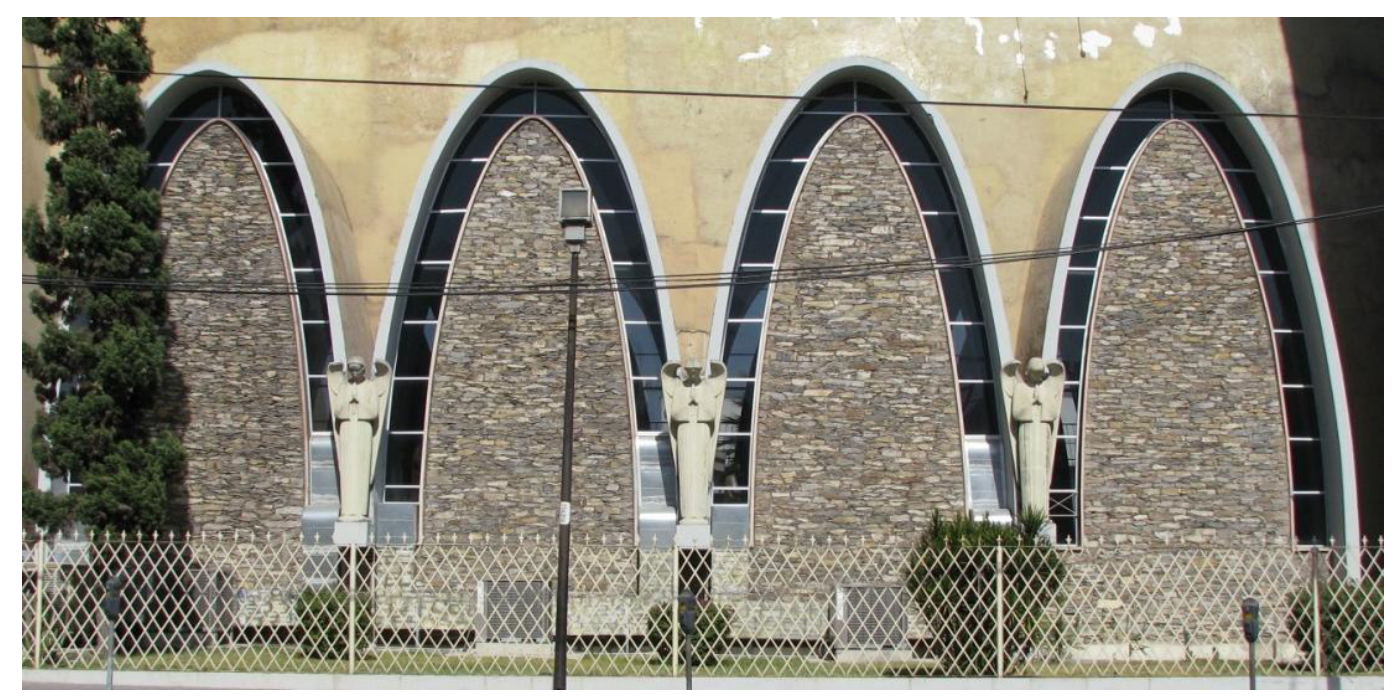

Ángeles del lado sur.

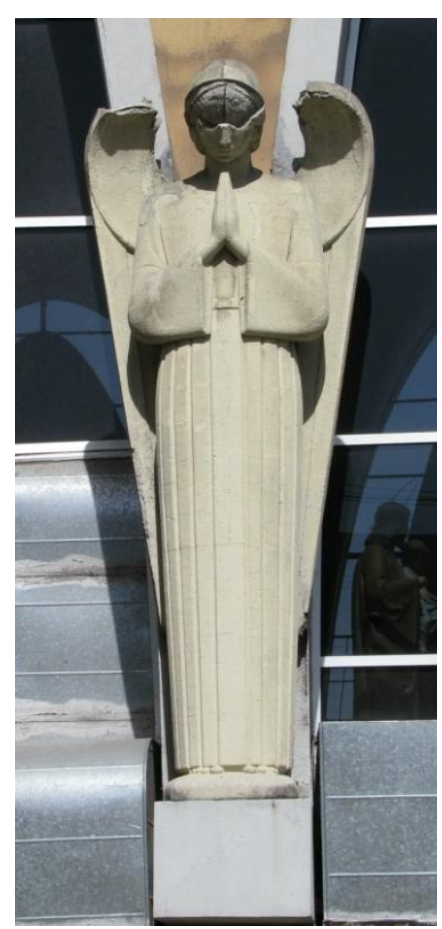

Primer ángel del lado sur.

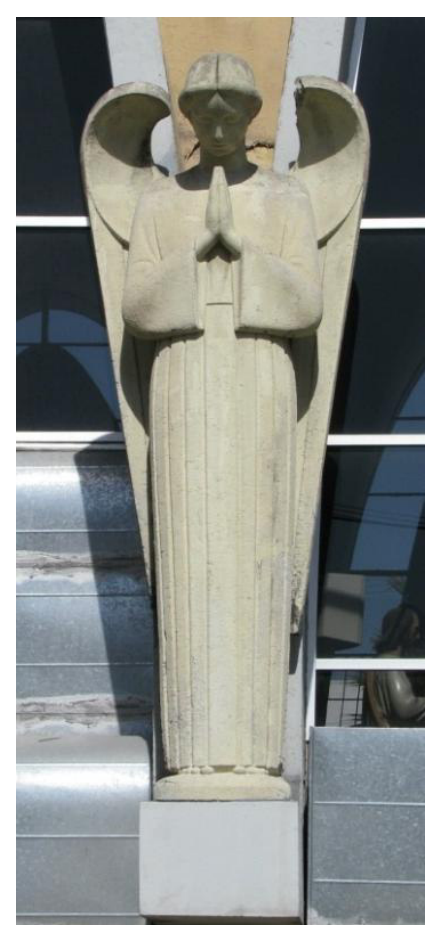

Segundo ángel del lado sur.

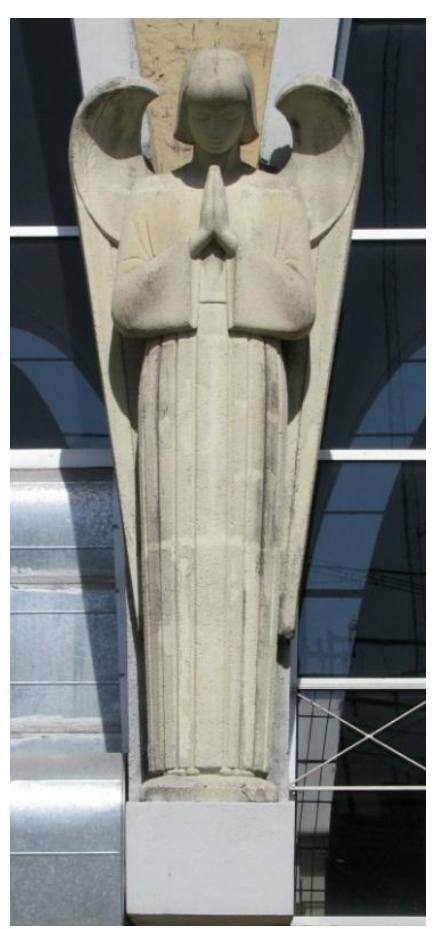

Tercer ángel del lado sur. 
Sin duda alguna la obra más conocida de Laubner es La Virgen de la Purísima. Se encuentra en la parte superior de la torre campanario de la Basílica. Mide 6. 5 metros y está hecha en terracota, ensamblada en siete partes y fue cocida en los hornos de la Ladrillera Monterrey. ${ }^{181}$ Con una fuerte influencia de las esculturas medievales, Laubner concibe a la Virgen con un rostro sereno, mirando hacia abajo, las manos extendidas hacia el frente y parada sobre un globo terráqueo. La cabeza va cubierta con un velo largo que deja ver el inicio del pelo, cuyo peinado es con raya en medio y ondulaciones. La aureola de santidad se forma con una varilla metálica detrás de la cabeza. La Virgen lleva una capa que se abrocha por el frente a la altura del pecho y se abre formando un triángulo isósceles, para luego bajar en pliegues sobre los antebrazos; dichos pliegues caen de manera descendente, acortándose a la altura de los pies. El cuerpo de la cintura hacia abajo se conforma por un cilindro que disminuye su grosor en la parte inferior. Viste con un vestido entallado en el que se resaltan estrías verticales, reforzando el sentido de alargamiento de la figura. Parada sobre el mundo, pisa a la serpiente símbolo del mal tal como se representa a la Inmaculada. La esfera lleva un cinturón que resalta por la mitad y dos estrellas a cada lado en referencia a las Letanías Lauretanas del Rosario mariano: "Estrella del Mar" y "Estrella de la Mañana".

El artista, crítico e historiador del arte, el mexicano Jorge Crespo de la Serna (18871978) expresó el siguiente comentario sobre la Virgen de Laubner: "Es de grandes líneas verticales con los pies firmemente asentados en la esfera del mundo sobre la serpiente. Manos y brazos en actitud protectora levanta un poco el manto para formar ondas que equilibran la forma tubular rectilínea del cuerpo. Es de gran sencillez y gusto", 182

Como se puede apreciar en esta crítica y en la imagen en sí, en la Virgen destacan los elementos y cuerpos geométricos del círculo, el triángulo, el cilindro, la esfera, destacándose ante todo la linealidad de la efigie, que como en el caso de los ángeles, la amalgama de formas remiten a piezas de corte industrial y a los diseños de Montenegro. Además con el sentido de la ingravidez que Laubner le imprime a la figura, pues fue

\footnotetext{
${ }^{181}$ José Antonio Portillo Valadez, Ídem. Aureliano Tapia Méndez, Op. Cit., p. 86.

182 Alfonso Rubio y Rubio, “Adolf Laubner", Universidad Mexicana del Noreste, Educadores de Nuevo León. Monterrey, N.L., Universidad Mexicana del Noreste, 1996, p. 92.
} 
concebida específicamente para colocarse en la torre, y con la exaltación de la suspensión en el espacio, todavía más se resalta la consecución de una obra Déco del tipo Streamline.
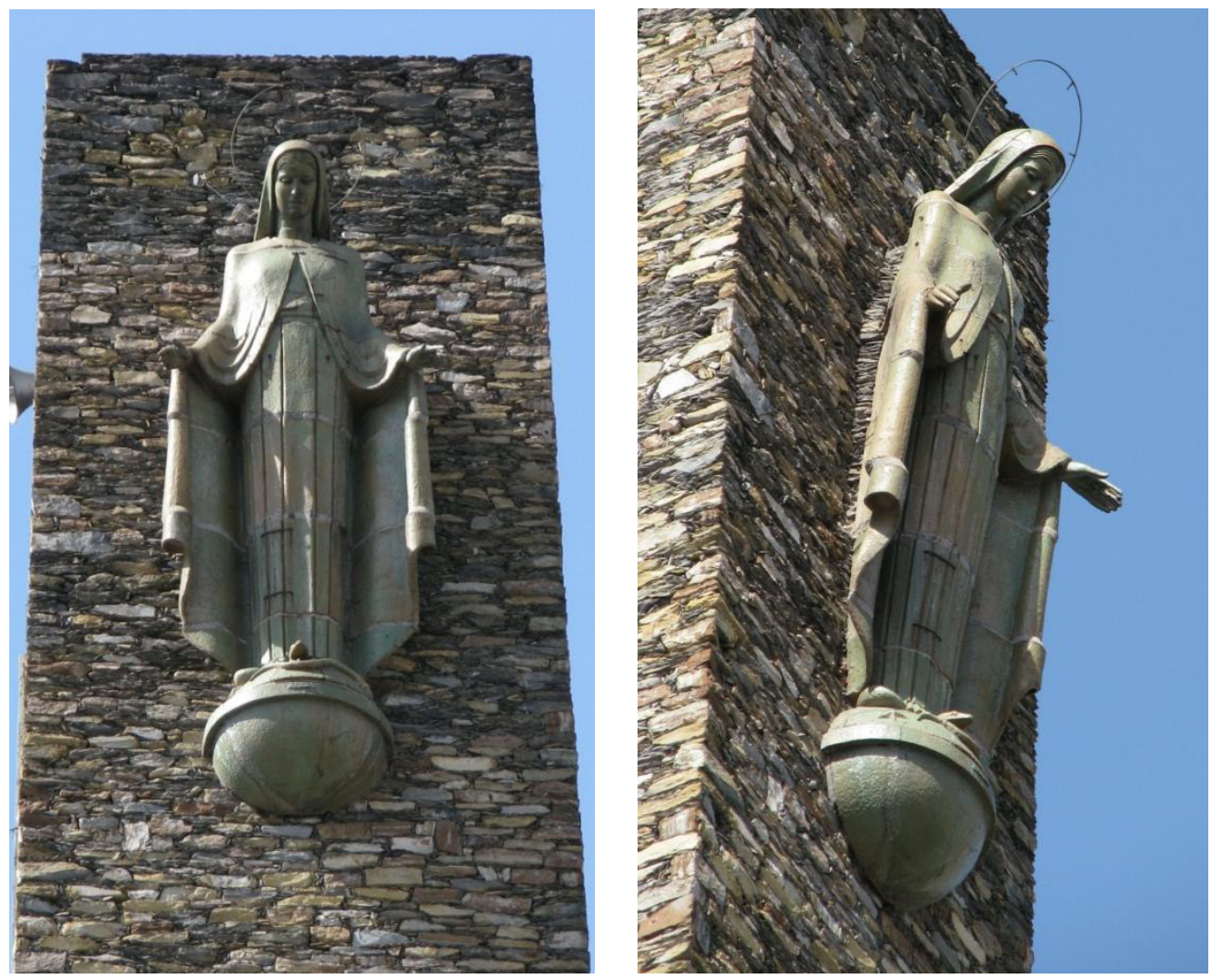

La Virgen de la Purísima en la torre vista de frente y de perfil.

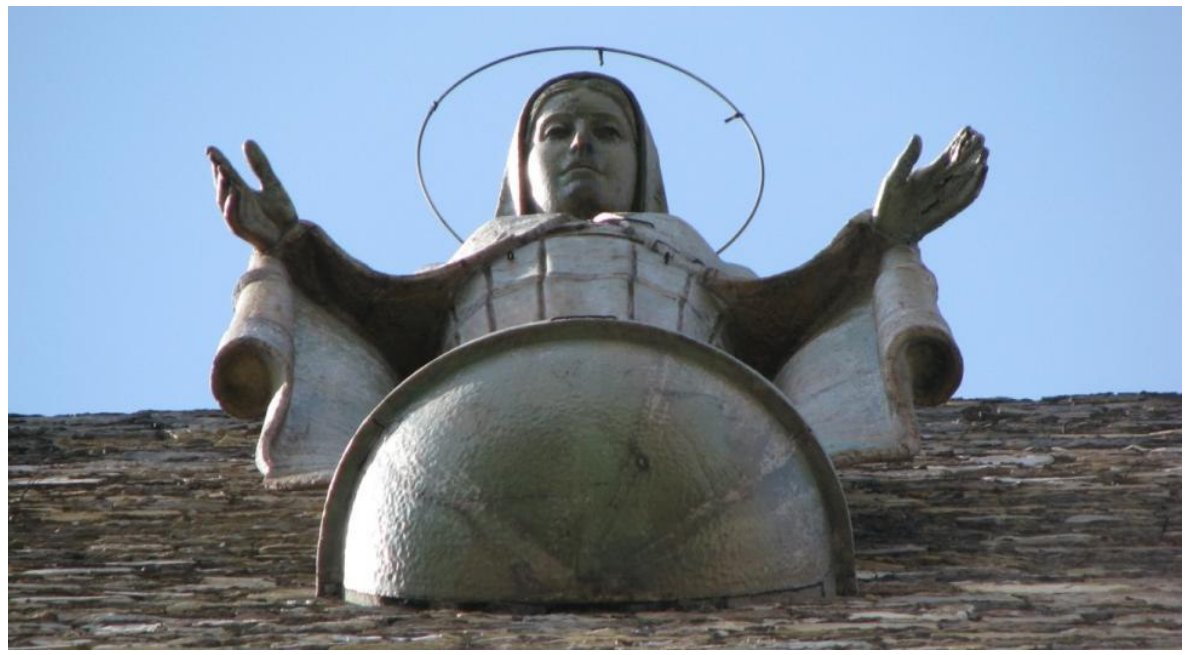

Virgen de la Purísima vista desde abajo. 
Estas obras de los Ángeles y la Virgen, como decíamos al inicio que a pesar de ser realizadas en los años cuarenta, aún conservan esa estética de la geometricidad típica del Art Déco Streamline.

Laubner tuvo una fuerte admiración e interés por el diseño industrial y las producciones en serie, por lo que hizo diez piezas de terracota en pequeño formato de 100 $\mathrm{cm} .{ }^{183}$ Antes de morir y ante las aclamadas críticas por su Virgen permitió que se reprodujeran imágenes de $60 \mathrm{~cm}$., hechas en serie, que aún se comercializan en la ciudad de Monterrey y que muchas familias las conservan en sus casas.

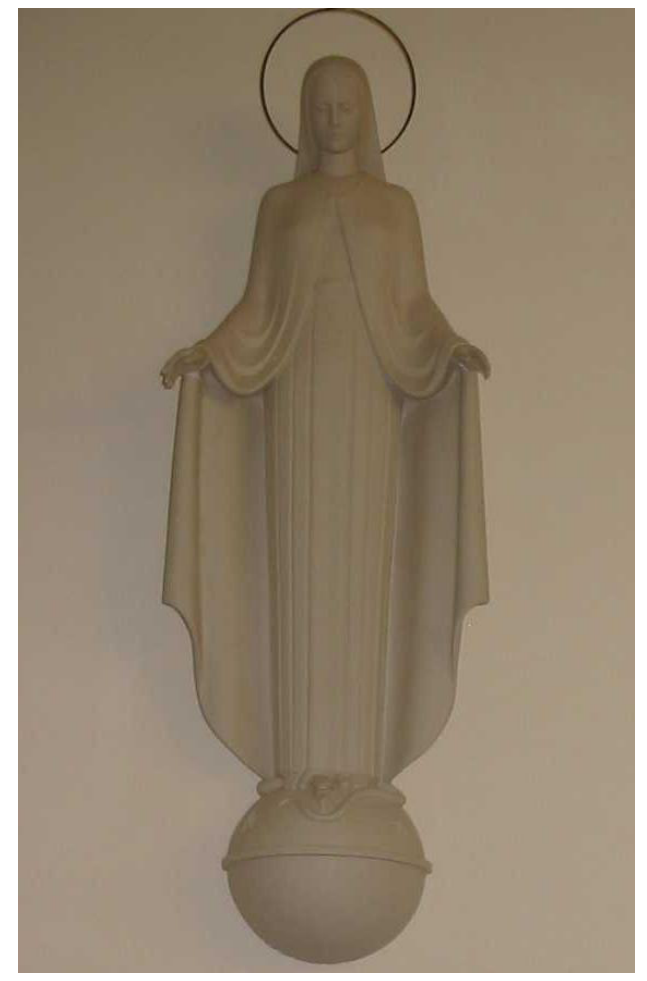

Adolf Laubner, Virgen de la Purísima de pequeño formato de $100 \mathrm{~cm}, \mathrm{~s} / \mathrm{f}$. Colección particular.

\footnotetext{
${ }^{183}$ En 2010 un propietario de una de estas piezas me pidió hacer un estudio para poder vender la pieza a un coleccionista. En el mismo año, el P. Raúl Mena encontró restos de otra pieza en el Seminario Diocesano de Monterrey.

Aureliano Tapia Méndez, Op. Cit., en la sección Iconografía sin página, reproduce una de esas imágenes y menciona que fueron hechas en terracota y fundidas en los hornos de Ladrillera Monterrey.
} 


\section{e. Monumento a Mariano Escobedo de Guillermo Ruiz}

El Monumento a Mariano Escobedo se encuentra en el Municipio de Escobedo, área metropolitana de Monterrey, sobre la avenida Sendero s/n, a la entrada de la plaza comercial del mismo nombre. Fue puesta es ese lugar recientemente, a finales del mes de marzo de 2014, con motivo de remodelaciones viales en esa zona. Anteriormente se ubicaba a la entrada del casco municipal, a donde fue removida de su lugar original en 1978, durante la gestión como gobernador del doctor Pedro Zorrilla Martínez (1933-1999). La obra hecha por el escultor Guillermo Ruiz (1894-1965) fue concebida para un monumento que se erigió en 1948 en la denominada Plaza de la República, espacio que se encuentra enfrente de la entrada principal del Palacio Federal. El gobernador en turno Arturo Bonifacio de la Garza (1905-1952) fue quien ideó el monumento a Mariano Escobedo y contrató al artista Guillermo Ruiz, que se había distinguido como escultor del gobierno presidencial de Lázaro Cárdenas, con varias obras en Michoacán, que dentro del Art Déco destacan Las plañideras en Morelia y el majestuoso Morelos en la Isla de Janitzio, obras ya mencionadas en el capítulo 2.

Mariano Escobedo (1826-1902) fue un militar y político que participó en las guerras de intervención norteamericana y la segunda francesa, en la cual se destacó por aprehender en Querétaro al emperador Maximiliano. Fue además gobernador de San Luis Potosí y Nuevo León, Ministro de Guerra y Marina, Diputado y Presidente de la Suprema Corte de Justicia.

Pocos datos hemos encontrado de la escultura dedicada a Escobedo. Lily Kassner en "La escultura nacionalista" de la Historia del Arte Mexicano solamente menciona la estatua, no da referencia alguna, salvo que está en Monterrey, ${ }^{184}$ y sólo en el Diccionario de escultores mexicanos del siglo XX sí da fecha. ${ }^{185}$ Justino Fernández da la fecha de 1949 que seguramente se refiere a la colocación del monumento, del cual comenta: "El difícil problema que presenta tal tipo de escultura, fue resuelto muy hábilmente por el artista, pues

\footnotetext{
184 Lily Kassner, "Escultura nacionalista”, Historia del Arte Mexicano. Arte Contemporáneo II, vol. 14, p. 2048.

${ }^{185}$ Lily Kassner, Diccionario de escultores mexicanos del siglo XX. Tomo II, México, CONACULTA.. 1997, p. 239.
} 
desplegando la capa del jinete la hizo formar parte integrante con el caballo y el brazo extendido del general, haciendo un todo compacto en el heterogéneo conjunto". ${ }^{186}$

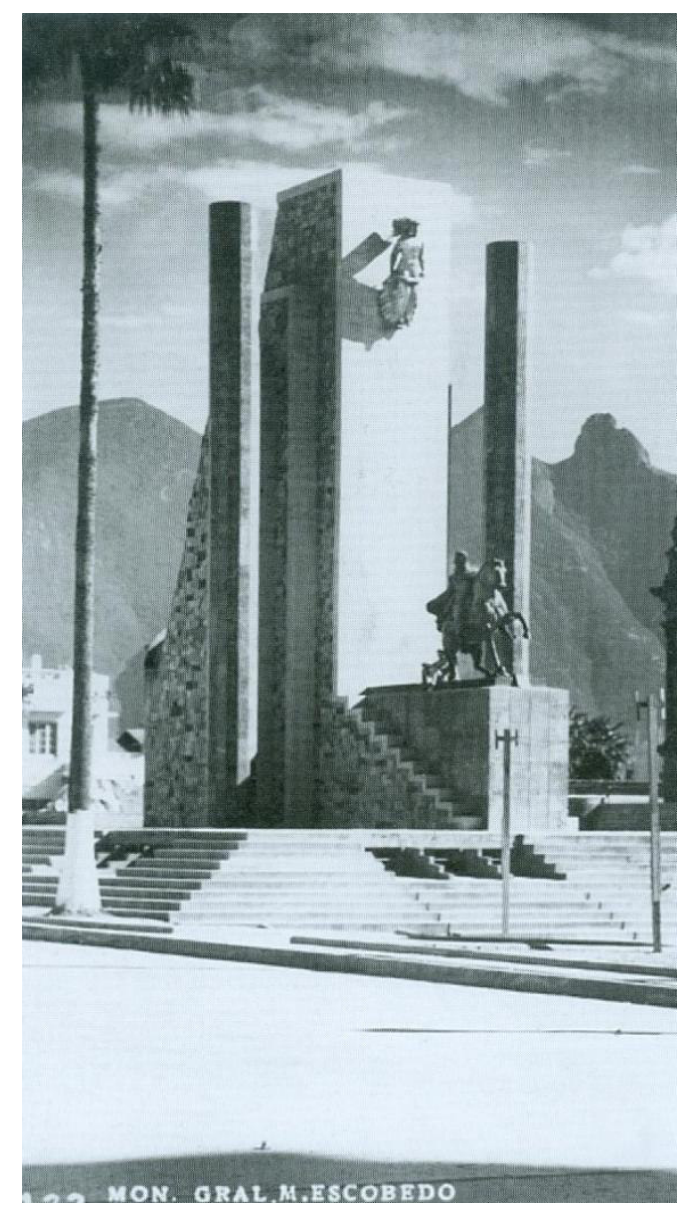

Monumento a Mariano Escobedo recién inaugurado a inicios de 1949.187

El excronista de Monterrey, don José P. Saldaña, habla de la restitución de un monumento a Escobedo que databa de 1917. Señala que en 1947 y durante la Alcaldía de Félix González Salinas se construyó el nuevo monumento. Según el narrador regiomontano "La inauguración causó una ola de protestas por la falta de proporción de la escultura. Se presentaba a Escobedo montado en un "poney" que, con una de sus patas, aplastaba la cabeza de una serpiente. Era una mala imitación del escudo nacional, y en uno de los costados del monumento se levantaba un muro cuya función se desconocía. A raíz de las

\footnotetext{
186 Justino Fernández, Arte Moderno y Contemporáneo de México. El Arte del Siglo XX, tomo II, p. 122.

${ }^{187}$ Héctor Javier Barbosa Alanís, Op. Cit., p. 90.
} 
protestas, se trató de corregir la escultura eliminado la serpiente, el muro y algunos otros detalles". ${ }^{188}$ Aquí encontramos varios desaciertos: no sabemos a qué se refiere Saldaña al apuntar que se eliminó la serpiente, pues aún forma parte de la escultura, ni tampoco qué quiere decir que es una mala imitación del escudo nacional. La supuesta desproporción entre montador y corcel es una tergiversación, pues no se está tomando en cuenta la intención del escultor en la pose del animal y la extensión de la capa del protagonista. Aparte, la fecha otorgada no es posible, ya que la escultura aún no se encontraba terminada.

En la estatua ecuestre dedicada Escobedo vaciada en bronce, el jinete rompe con la tradicional postura de ir cabalgando a paso lento o en briosa carrera. Aquí el montador gira hacia el lado derecho, torciendo el torso y volteando la cabeza hacia el mismo punto, en una postura inusual de las estatuas ecuestres. El brazo diestro lo extiende y la mano abierta muestra sobre su palma un olivo, símbolo de la victoria. Esta excepcional concepción del personaje aclara la visión moderna que Guillermo Ruiz tenía de la escultura y de la ruptura con los paradigmas académicos.

El caballo también está incorporado con un modo desemejante al común denominador de las esculturas ecuestres, ya que Guillermo Ruiz lo sitúa en el momento en que el caballero lo frena con la mano izquierda y así el corcel agacha la parte trasera de su cuerpo, lo encoge, pero la cabeza da un tenue giro hacia la izquierda y abre las fauces. Alternado una pata delantera y una trasera en el aire, el equilibrio del animal se completa con la cola, la cual cae como un torrente de agua confeccionado con delicadas estrías curvas.

La pata delantera derecha que está ligeramente levantada, se sostiene al pisar una serpiente enroscada, cuya significación es del enemigo. Al haber pertenecido Mariano Escobedo al grupo liberal, es obvio que se refiere a los miembros del partido conservador, quienes pidieron a Napoleón III ayuda para conseguir un monarca extranjero que viniera a gobernar México y fueron ellos quienes invitaron directamente a Maximiliano a venir como emperador. En la base sobre la que descansa la escultura y a un lado de la cola, está la firma del autor y el año de conclusión de la pieza: 1948.

${ }^{188}$ José P. Saldaña, Op. Cit., p. 105. 


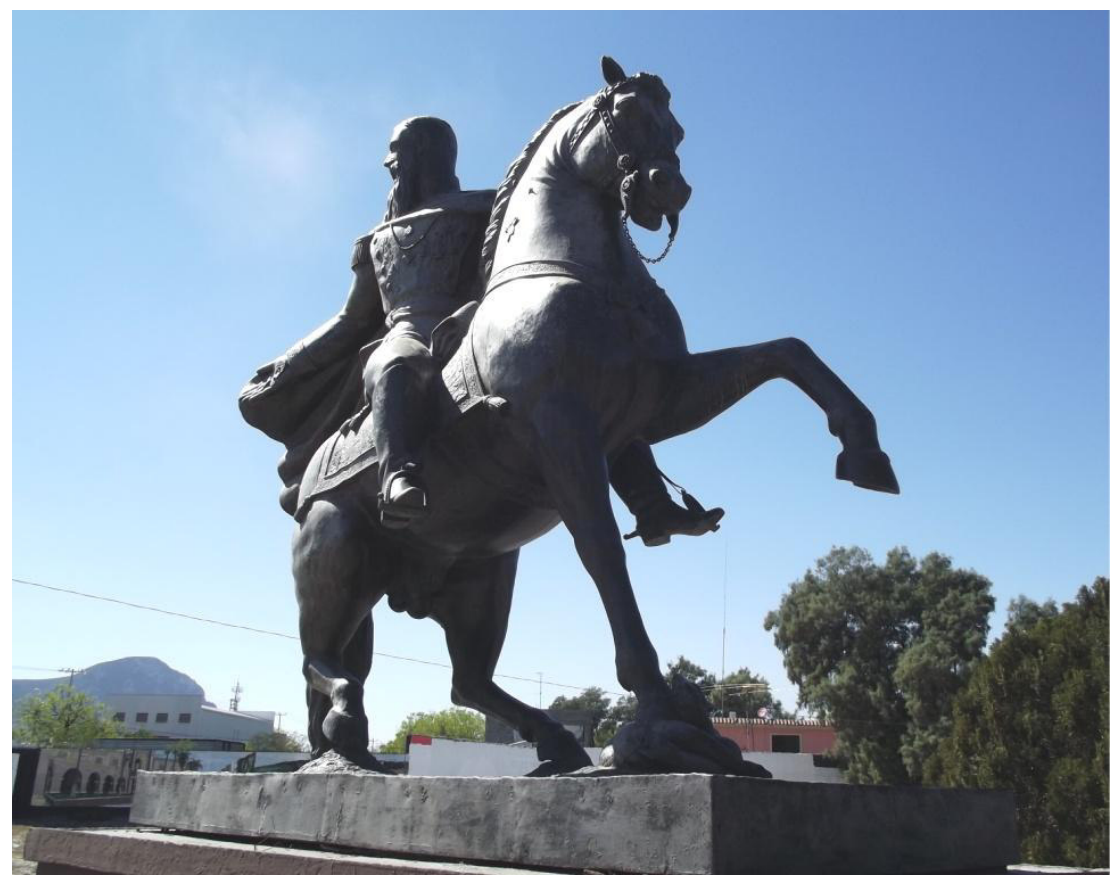

La estatua en el casco del municipio de Escobedo en 2013.

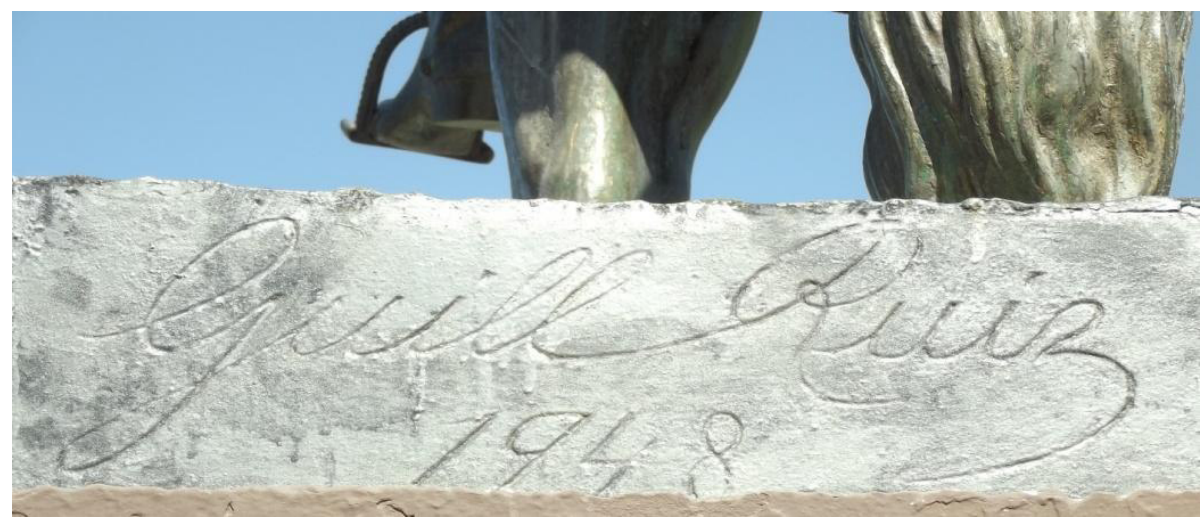

Firma y año.

En la capa de Escobedo es donde más se presencia el estilo de Ruiz. Vista la escultura del lado izquierdo, la capa se aúna al brazo a través de cuatro inclinados pliegues semirrígidos. En la parte de atrás y con la misma disposición al final de la capa, a través de cuatro superposiciones, los plisados forman un delicado zigzag que a pesar de tener la intención de tener un diseño serpenteante, apuntan hacia una composición geométrica.

Vista la efigie por el otro lado, es decir el derecho y por la parte trasera, la capa lleva unos plisados que cuando terminan también forman unos zigzags serpenteantes que se conjugan con los que tiene el personaje por el lado izquierdo. Y en la pierna izquierda de 
Escobedo, el pantalón también se pliega angularmente formando tres zigzags. Desde esta misma perspectiva se distingue la caída del pelo de la cola del equino, la cual aunque de formas sinuosas, éstas son algo rígidas, menos alabeadas, como si fueran humo industrial, tal como se representa lo serpenteante en el Art Déco.

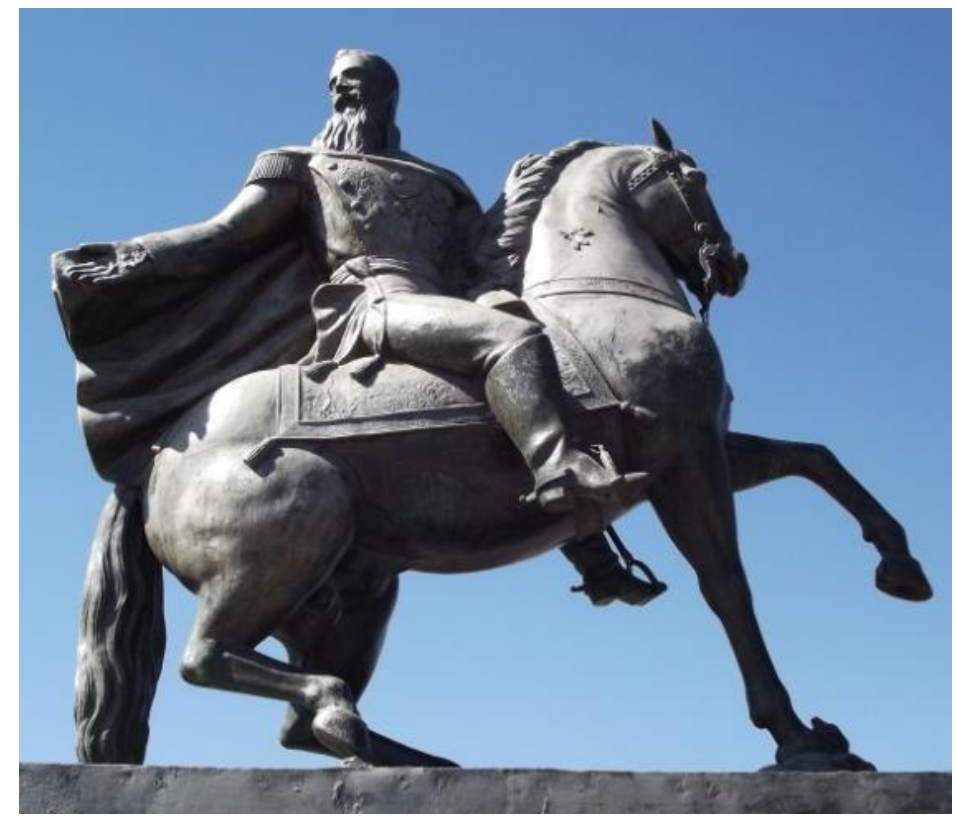

Vista del lado izquierdo.

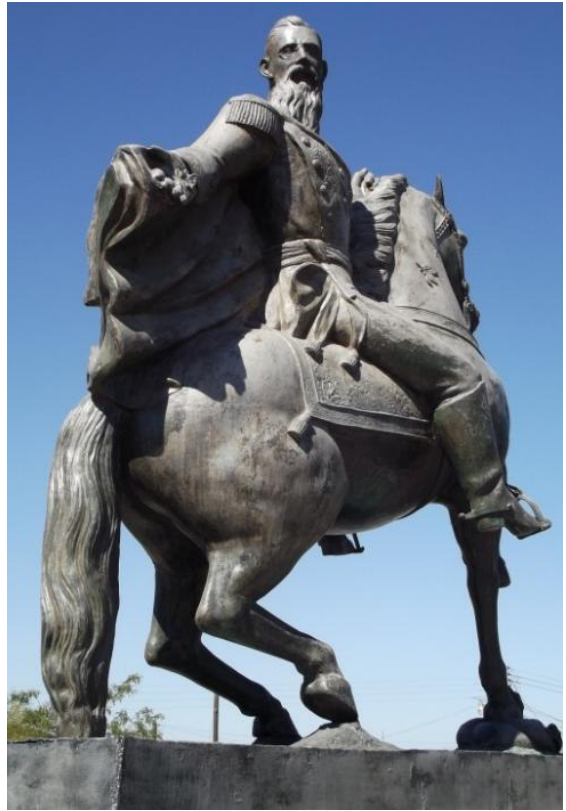

Zigzags serpenteantes de la parte final de la capa.

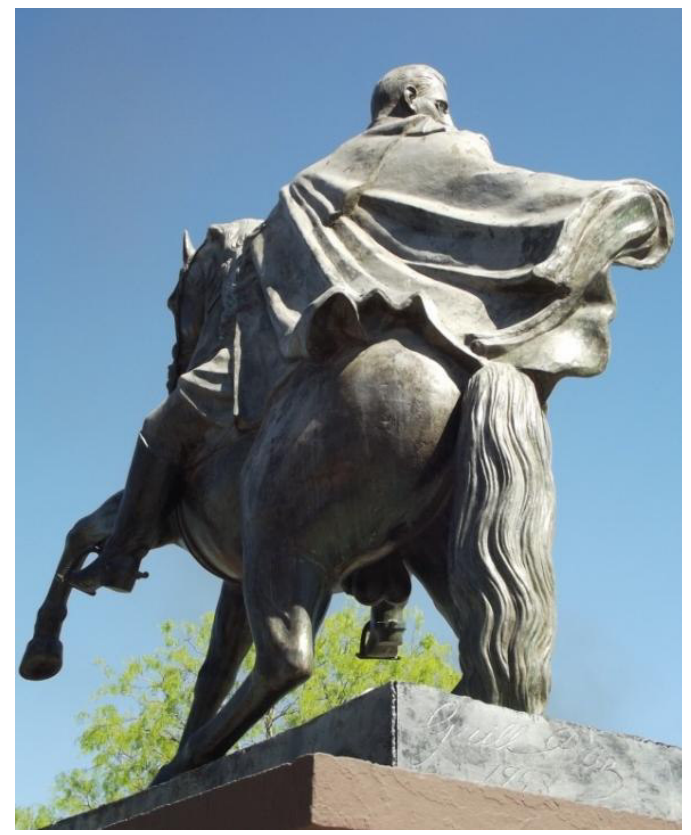

Vista por la parte trasera del lado derecho. 
Aunque esta escultura es de finales de los años cuarenta del pasado siglo y sean pocos los elementos Art Déco que demuestra, es importante recalcarlos ya que son una representación del Déco Zigzag y una constante particularidad de las obras de Guillermo Ruiz.

\section{f. Vitrales del Aula Magna del Colegio Civil}

El Aula Magna es un auditorio que se instaló dentro de lo que era el patio del Colegio Civil, edificio original de 1794, con adaptaciones en 1859 y con una remodelación total en 1933 para albergar el bachillerato y facultades de la Universidad de Nuevo León fundada en ese año.

Las obras de remodelación corrieron a cargo de FYUSA, la empresa constructora de las escuelas Álvaro Obregón, Presidente Calles, Fernández de Lizardi, Nuevo León, Monterrey, de La Revolución y el Palacio Federal. Se le dio un estilo neocolonial, que fue otro de los lenguajes arquitectónicos de los años treinta y cuarenta del siglo veinte.

Con el fin de darle una luminosidad diferente y que además fueran obras de arte de gran formato que exaltaran los ideales revolucionarios, se contrató al artista Roberto Montenegro (1886-1968) para que diseñara unos vitrales para el auditorio. Fueron montados por la Casa Montaña de Torreón, Coahuila.

Son ocho vitrales que se distribuyen cuatro en el muro izquierdo y cuatro en el derecho: dos de 1.40 por 2.50 m., que se ubican entrando en la parte baja; otros dos de 3.00 por $2.50 \mathrm{~m}$., en la parte alta, en la platea, en correspondencia con los anteriores; cuatro de 7.00 por $2.50 \mathrm{~m}$., en la luneta, empotrados en un espacio con arco tudor.

Estos vitrales ya han sido estudiados por José Roberto Mendirichaga en 1991 en el libro Patrimonio Plástico de la UANL, haciendo una breve descripción y en 2008 por Miguel Román en la obra Colores del Alma, donde lleva a cabo un exhaustivo estudio documental e iconográfico, por lo que nosotros lo que haremos aquí es una interpretación bajo la estética del Art Déco. Los nombres de cada vitral se los han otorgado los autores mencionados, debido a que no hay ninguna documentación que haya registrado cómo los llamaron cuando fueron instalados. 
Roberto Montenegro que se había iniciado en la pintura desde su infancia, en 1904 tuvo la oportunidad de ir a estudiar a la Academia de San Carlos, donde fue alumno del maestro español Antonio Fabrés (1854-1936). En 1905 gana una beca para ir a Europa, junto con Diego Rivera, entre otros importantes artistas. Estuvo en Madrid de 1906 a 1909, trabando amistad y relación con grandes artistas y escritores tales como Ignacio Zuloaga, Antonio Machado, Miguel de Unamuno, gracias a las recomendaciones de su primo, el poeta Amado Nervo. Se estableció en París de 1910 a 1914, donde tomó cursos en la Escuela de Bellas Artes y en la academia de Filippo Colarossi en la calle de la Grande Chaumiére, nada menos a donde iban los pintores rusos de esa época. Estando en la Ciudad Luz conoció a Picasso y al pintor barcelonés Hermenegildo Anglada Camarasa (18711959), quien en 1914 al inicio de la I Guerra Mundial lo invita a Palma de Mallorca donde Montenegro pintó sus primeros murales en el Antiguo Círculo Mallorquín, actualmente Parlamento de las Islas Baleares y que en la historiografía lo habían registrado como el Casino de Mallorca. Son cuatro paneles y el plafón en óleo sobre tela con temas mallorquinos concluidos en $1919 .^{189}$

Su estancia en Europa fue definitiva para conocer los lenguajes de la Vanguardias como el Postimpresionismo, el Cubismo, el Dadaísmo. A su regreso a México en 1920 tuvo un intensa actividad como muralista, trabajando La familia rural, de 1923 y Alegoría del Mundo Indígena, 1921 a 1924, ambos en el edifico de la Secretaría de Educación Pública. Otro de sus famosos murales es La fiesta de Santa Cruz de 1923-1924, ubicados en el Antiguo Colegio Máximo de San Pedro y San Pablo en la ciudad de México.

Como ya indicamos en el estudio del vitral de la Escuela Industrial Álvaro Obregón, los murales de tipo Art Déco de Montenegro son el desaparecido Maquinismo y Alegoría del Viento, así como los relieves de la Alegoría del Teatro del Parque México de la Colonia Condesa en el D.F., mencionados en el capítulo 2.

La Casa Montaña encargada de realizar los vitrales de Montenegro fue fundada primeramente en 1913 en San Luis Potosí por el vitralista español, oriundo de Barcelona, Ramón Montaña Simón. En 1917 cambió su sede a Torreón, Coahuila, ciudad donde han seguido trabando ininterrumpidamente. Directamente Ramón Montaña ensambló los

\footnotetext{
189 Julieta Ortiz Gaitán, Entre dos mundos: los murales de Roberto Montenegro, México, UNAM, 1994, pp. 85-86.
} 
vitrales bajo el proyecto de Montenegro. No hay información sobre las relaciones de trabajo entre esta casa y Montenegro, más que el anecdotario y las firman en los vitrales, ya que desafortunadamente en 1945 un incendio consumió gran parte de los archivos y en una huelga en 1971, la casa fue saqueada por trabajadores inconformes, perdiéndose otra gran parte de los documentos. En el año de 2001 los vitrales fueron restaurados por la misma Casa Montaña. ${ }^{190}$

Para su descripción empezaremos con los vitrales del muro izquierdo de atrás hacia delante, es decir de la entrada hacia al escenario, para después pasar a los del muro derecho, de adelante hacia atrás, en sentido de la manecillas del reloj. Del muro izquierdo iniciaremos con La antorcha, luego La Revolución que está arriba en la platea, luego con La Industria y Las Artes; en el muro derecho continuamos de adelante hacia atrás con La Ciencia, La Agricultura, La Reconstrucción que está arriba, para finalizar con La mano y la estrella. Las fotografías fueron obtenidas del libro de José Roberto Mendirichaga.

\begin{tabular}{|ll|}
\hline \multicolumn{2}{|c|}{ Escenario } \\
\cline { 2 - 2 } Las Artes & La Ciencia \\
La Industria & La Agricultura \\
$\begin{array}{l}\text { La Revolución } \\
\text { (arriba) }\end{array}$ & $\begin{array}{l}\text { La Reconstrucción } \\
\text { (arriba) }\end{array}$ \\
La antorcha & La mano y la estrella \\
& Entrada \\
\hline
\end{tabular}

Distribución de los vitrales.

El primer vitral es La Antorcha, objeto de culto de la humanidad, cuyos significados están asociados con el triunfo, la inmortalidad, la eternidad, o bien es utilizada "en los ritos de iniciación por cuanto purifica e ilumina". ${ }^{191}$ Y es que la Revolución Mexicana según el

\footnotetext{
${ }^{190}$ Miguel Román, Colores del Alma, Monterrey, N.L., Universidad Autónoma de Nuevo León, 2008 , p. 57.

${ }^{191}$ Udo Becker, Enciclopedia de los símbolos, México, Océano, 1996, p. 26.
} 
discurso oficial vino a reconstruir la nación con un fuego nuevo, pero que al final de cuentas resultó más de lo mismo.

Una columna jónica con estrías sostiene al pebetero del que brotan abiertamente las llamas en tonos blancos, amarillos y rojos. Unas flamas flotantes a cada lado equilibran la composición, de manera muy similar al vitral central de la escalera de la Escuela Industrial Álvaro Obregón en la coronación de Obregón.

Al fondo, círculos concéntricos se expanden centrífugamente en varia tonalidades azul y blanco. A los lados, la decoración de las plantas del maíz con sus mazorcas, se unen en su colocación con el vitral de la parte de arriba que es el de La Revolución. La producción de fuego que sale de un recipiente como el del vitral, no expandiría sus llamas tan abiertamente. Más bien, este fuego saldría de una estufa de gas; es un fuego industrial más que natural, así como la curvatura de las llamaradas es bastante uniforme que asemeja a hojas alargadas. Se puede decir que conforman un zigzag curvo, que junto con la solidez del cilindro de la columna y el hiperboloide del pebetero, conjugan un geometrismo Déco.

En muchos diseños de los años del Art Déco se utilizaron los círculos concéntricos para representar las ruedas industriales o la expansión de la energía. Uno de los casos más significativos de la publicidad sobre estos tópicos fue la del Niagara Mohowak Power Company Building en West Syracurse, New York. Magnánimo edificio construido entre 1930-1932 obra de la firma Bley \& Lyman ${ }^{192}$-Lawrence H. Bley (1884-1939) y Duane S. Lyman (1886-1966)- convertido en uno de los más extraordinarios ejemplos del Déco norteamericano Zigzag, en su publicidad sobre Generation, Illumination, Gas, Transmission, ${ }^{193}$ (que ilustramos en el Capítulo 1) salvo en el de Illumination, donde el uso de las circunferencias concéntricas proyectan la idea de la propagación energética, motivo decorativo que es uno de los referentes del Art Déco. Tal es el caso de lo que el artista Roberto Montenegro crea en este vitral, al colocar los círculos concéntricos con tonalidades suaves, así como con las divisiones de cada aro, con lo que se provoca visualmente la irradiación de la luz.

Sobre las plantas del maíz las analizaremos en el siguiente vitral de La Revolución.

\footnotetext{
192 Carla Breeze, American Art Deco, New York, Norton and Company, 2003, p. 72.

${ }^{193}$ Bevies Hillier \& Stephen Escritt, Art Deco Style, Londres, Phaidon Press Ltd, 1977, p. 85.
} 


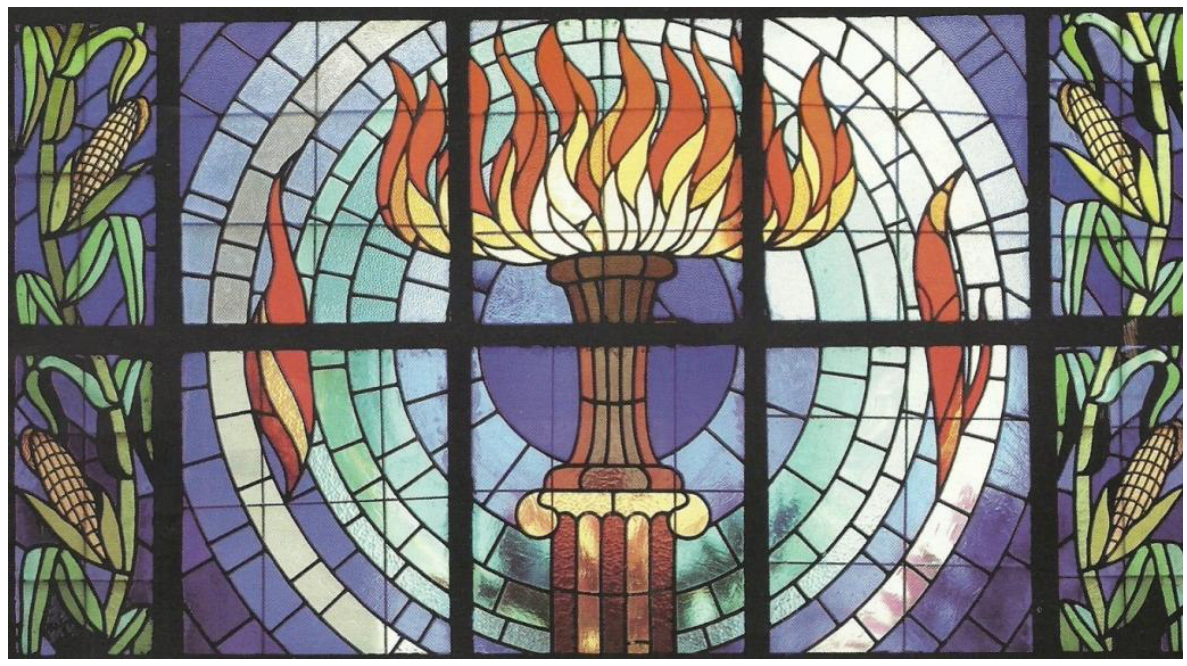

La Antorcha.

El vitral de La Revolución se encuentra alineado en la parte superior con el de La Antorcha. Al centro de la parte inferior un libro abierto muestra sus páginas hacia los tres personajes revolucionarios, un militar, un obrero y un campesino. Es una referencia a las campañas de educación que surgieron después de la Revolución con las brigadas vasconcelistas. El libro está acompañado de dos haces de trigo, uno a cada lado. Posteriormente unas hojas de laurel están aplastadas por un objeto y a la derecha en una caja, una corona invertida y un cetro con una pequeña mano se encuentra dentro de ella. Es el poder real que ha sido vencido por la lucha revolucionaria, por eso el laurel aunque es símbolo de la victoria, aquí es sinónimo de la investidura imperial y la corona invertida con el centro es también una simbolización del derrocamiento del poder monárquico. Aunque en México no había ninguno de los dos tipos de gobiernos en esos años, es una clara indicación de la caída de la dictadura porfirista.

En ningún mural ni obra pictórica de la época vemos que un soldado revolucionario se represente como lo hace aquí Montenegro con uniforme militar, botas y quepis, todo en color verde. Caminado y ascendiendo una pendiente carga una bandera roja con letras negras que dicen textualmente "REVOLUCION". Es obvia la referencia al cuadro de Eugene Delacroix (1789-1863) La Libertad conduciendo al pueblo, ya que el militar, lo mismo que los otros dos personajes, son de rostro con facciones indígenas porque es gente del pueblo que lucha por la emancipación de sus compatriotas. 
Del lado derecho un obrero con su overol azul acerca una antorcha hacia la corona, ya que si el poderoso humillaba al pueblo, ahora el pueblo quema al poderoso. Del lado contrario un campesino con sombrero, cargando un fusil porta carrilleras cruzadas en el pecho, que es como comúnmente se le representa, y su mirada relajada la dirige hacia la izquierda. El hecho de que obrero y campesino traigan las mangas arremangadas es señal que están en la lucha, en la beligerancia, tal como si estuvieran en sus labores de trabajo. Detrás unas llamas rojas y amarillas denotan los episodios bélicos y de destrucción que completan la escenografía de la fase armada de la rebelión.

En los extremos, unas plantas de maíz con mazorcas que nacen desde abajo y se conectan con el vitral de La Antorcha, enarbolan la dieta del mexicano y figuran como la principal producción del campo nacional.

La firma de Roberto Montenegro está del lado izquierdo de la corona: "R. Montenegro proyectó". Y de lado derecho, la de la vidriera: "Casa Montaña ejecutó".

Dentro de los elementos Art Déco el ordenamiento de las espigas de trigo constituyen una decoración Zigzag tanto en el límite del tallo como en sí en las semillas. Luego encontramos que en la forma de ir acomodando los ladrillos o tabiques en los que está parado el militar, éstos son unos cubos y poliedros irregulares dispuestos de manera longitudinal, conformando un geometrismo que se continúa en el rectángulo que se consigue con la postura de las piernas del militar.

Las flamas de antorcha y las de la parte posterior extienden sus llamaradas de manera serpenteante, sin embargo su curvatura es un tanto cuanto rígida, tal como se usa en las composiciones Déco.

Las plantas del maíz de los extremos bien podrían ser más un diseño Nouveau que Déco, sin embargo si nos remitimos al famoso mueble de Paul Follot (1877-1941) exhibido en la Exposición de 1925 en París, el aparador circular con madera e incrustaciones de marfil en cuya sección frontal lleva unas decoraciones fitomorfas con flores y delicados pétalos que resguardan los androceos centrales y las hojas se van cuadrando a todo el conjunto decorativo de manera ascendente, de forma similar Montenegro resuelve encuadrar a la planta del maíz, pero con la caída angular de las hojas, las cuales además de irse distribuyendo simultáneamente, forman una ornamentación Decó del tipo Zigzag. 


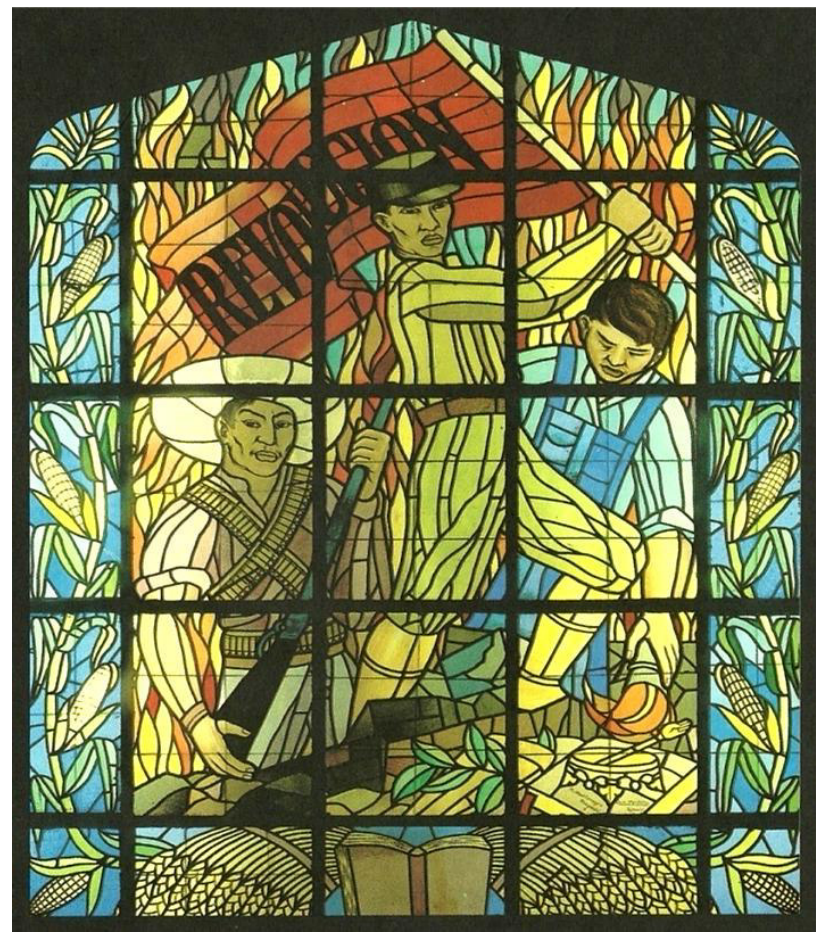

La Revolución.

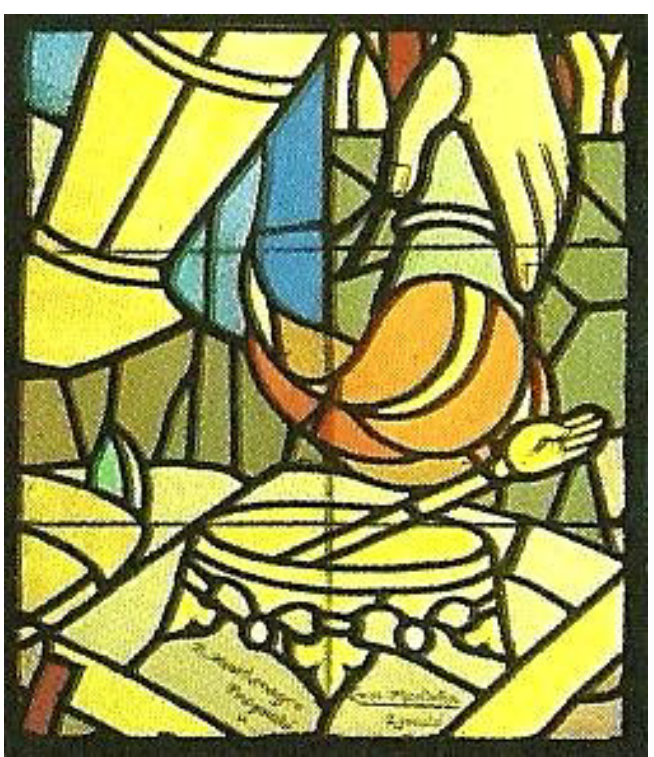

Detalle de la Revolución. Del lado derecho se lee "R. Montenegro proyectó". Del lado derecho "Casa Montaña ejecutó".

Al vitral de La Industria tanto Mendirichaga como Román lo denominan de la misma manera. Mide $7 \mathrm{~m}$., de alto por $2.50 \mathrm{~m}$., de ancho. La representación de la industria es un tema bastante recurrente en los años del Art Déco como ya hemos venido mencionando, pues era la etapa de grandes descubrimientos y desarrollos tecnológicos en la que la máquina es la vía del progreso de las naciones; más aún lo era para México, que se transformaba, al menos en el discurso, en una nación moderna.

Este vitral se inicia al frente con una gran rueda en color verde grisáceo con rayos, de las que se usan para mover motores de grandes máquinas; detrás, tres obreros vestidos con overol azul, zapatos amarillos y sin camisa están acomodados de manera escalonada, de pie, con las piernas abiertas, uno inmediatamente detrás del otro. El primero baja los brazos para sostener la rueda con las manos, el segundo con los brazos levemente alzados carga en la mano izquierda unas tenazas y con la derecha un martillo, y el tercero, también con los brazos hacia abajo, sostiene en ambas manos unas palancas. Detrás de esta parte del vitral, el fondo va cambiando de tonalidades entre azul, verde claro y amarillo y a los lados unas columnillas sinuosas. 
Antes de llegar a la mitad, en unos escalones están dos obreros más, ataviados de la misma forma que los anteriores. Uno que va caminando y volteando la cabeza sostiene una larga bandera que ondea serpentinamente con cuadros en blanco y negro y en rojo y negro. Son colores que por una parte anuncian el final de la Revolución, el blanco y el negro, y por otra, la libertad para asociarse sindicalmente y proteger los derechos de los trabajadores lo representan los colores negro rojo, por eso es que se alternan unos recuadros y otros.

Al centro, un generador eléctrico con un tubo por el lado izquierdo y después otro obrero que con los brazos abiertos y mirando hacia arriba, parece que presagia tiempos de cambio gracias a la era industrial.

En el fondo, en un tercer plano de un lado y del otro en colores rosa y café, el panorama de fábricas industriales. Oficinas y naves, chimeneas y humos que inundan el horizonte. Es el triunfo del maquinismo, de la industria, en una apoteosis de los tiempos de cambio gracias a la máquina.

Este frenesí por el maquinismo, además de resaltar la transformación de México, la moda por el mecanicismo y la industria fabril de la producciones en serie, estaba acaparando la atención de la vida moderna de esos años, tal como lo anotamos en el primer capítulo. Y si a esto le agregamos que Montenegro convivió cercanamente con Sergei Eisenstein durante su estancia en México en aquellos dos años entre 1930 y 1932, es razón por lo cual nos atrevemos a pensar que hubo intercambio de ideas entre ambos artistas sobre el triunfo de la máquina para el progreso de la humanidad, tal como lo relata el cineasta ruso en Lo viejo y lo nuevo de 1929.

Sin lugar a dudas este vitral es el que contiene más elementos Art Déco. Primero la presencia del lenguaje de lo industrial se inicia con la rueda que está colocada al frente, es el corazón de la máquina cuidada y trabajada por los obreros, rueca que echa a andar el generador eléctrico y que ambos son parte del gran despegue fabril coronado por las elevadas chimeneas y sus abundantes fumarolas, el humo del Déco en palabras de Xavier Esqueda, concepto explicado en el Capítulo 1. Industria mecanizada para el bienestar y desarrollo de la nación, abanderada y admirada por la clase obrera, misma que está formada por hombres fuertes, robustos, atléticos y que es favorecida por los triunfos de la Revolución. 
La geometría y su acomodo equilibrado de la rueda del frente y los obreros, da a la primera parte de la escena un ritmo de construcción geométrica ascendente: el circulo, luego el triángulo isósceles de las piernas, el trapecio de los brazos del primer trabajador y los ángulos obtusos con los brazos del otro, para continuar con un doble trapecio formado con la postura de los brazos del tercer obrero y las palancas que él manipula. El acomodo de los tres cuerpos resalta especialmente por los ovoides de las cabezas, las cuales se acoplan una detrás de la otra, diferenciándose por el corte de pelo y las facciones. Continúa el acoplamiento de lo geométrico con los rectángulos de los escalones y nuevamente el círculo del generador, el cual está alternado en los planos con un ángulo equilátero compuesto por las piernas del abanderado y por un ángulo obtuso instalado en la pierna del otro obrero. Los cuadrados insertos en la bandera van curveándose al ritmo del movimiento del lábaro, que si bien su disposición es sinuosa, es más bien geométrica.

En las fábricas, los cubos con pequeños recuadros parecieran dibujos de Piet Mondrian (1872-1944) en alzado y la techumbre de la nave industrial se forma con ángulos escalenos lo que concierta un zigzag, para terminar con los conos truncados de las esbeltas chimeneas, siete del lado izquierdo y nueve del derecho.

Un extraordinario e intenso geometrismo del tipo Art Déco Zigzag es lo que se instrumenta en la concordancia de las figuras de este vitral.

Consideramos que un componente bastante distintivo del Déco es el obrero que está detrás del generador con la posición de los brazos abiertos y las manos hacia el frente. Una de las figuras que mucho influyó y que es una de la más referidas como ejemplo del estilo es el Prometeo que se encuentra en la explanada del edificio de la RCA en New York. Escultura en bronce dorado trabajada en 1930 por el artista norteamericano Paul Manship (1885-1966), misma que ya comentamos en el capítulo 1, desplanta al personaje como si estuviera cayendo dentro de una pila con los brazos y manos abiertas ${ }^{194}$; el trabajador del vitral de La Industria lleva una posición bastante similar a la de Manship, por lo que ambas imágenes se hermanan como modelos del estilo Art Déco. Sin embargo, todavía más cercana a esta imagen está el grabado de la artista inglesa Eileen Mayo (1906-1994), quien

\footnotetext{
${ }^{194}$ Bevies Hillier \& Stephen Escritt, Art Deco Style, London, Phaidon Press Ltd, 1977, p. 78.
} 
capta una escena del ballet La gata de George Balanchine, ca. 1927, ${ }^{195}$ donde la posición del bailarín, hincado y bailando con su pareja, es exactamente igual a la del vitral, con la diferencia en que el danzante está de espaldas y el obrero va de frente.

Son esos imaginarios, esas escenas, esa estética de lo geométrico que inunda los ambientes artísticos de la glamurosa época del Déco, de la que Montenegro estaba bien enterado y transmitía en sus diseños.

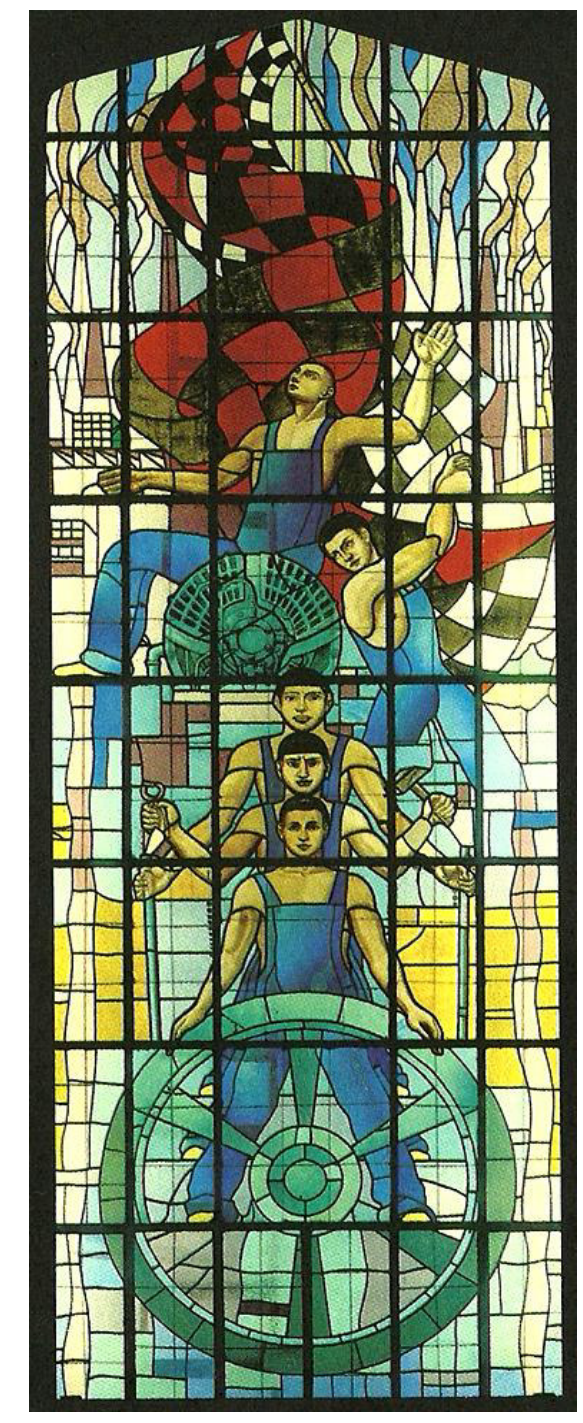

La Industria.

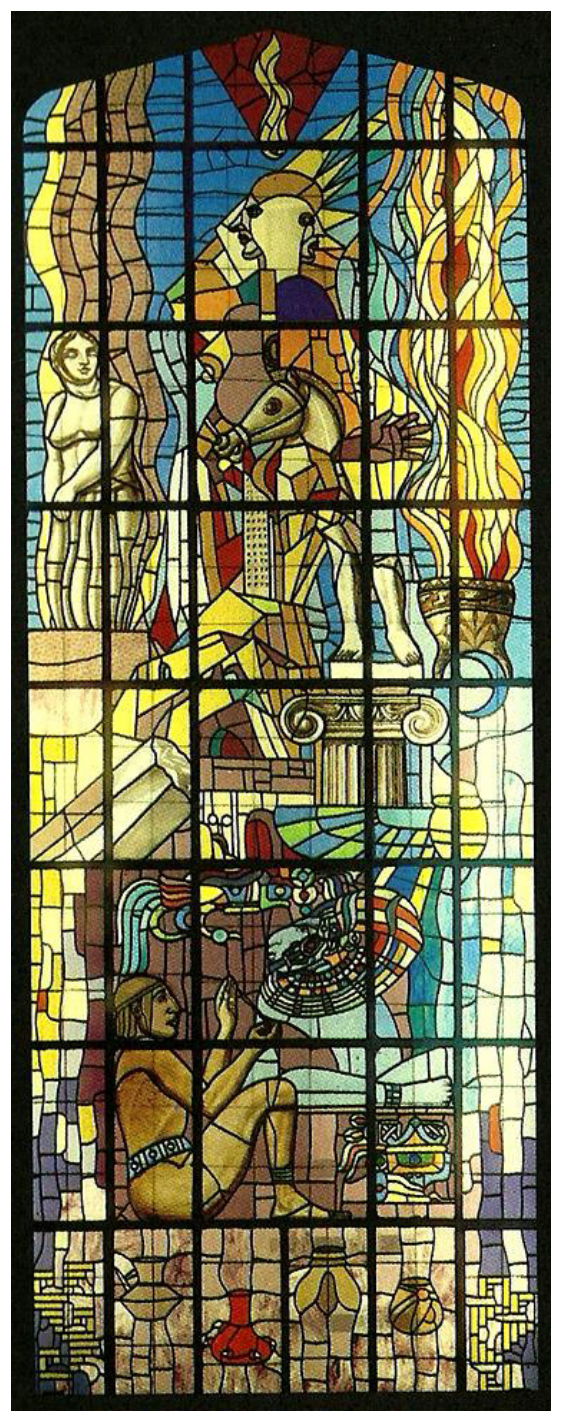

La Historia.

195 FUNDACIÓN “LA CAIXA”, Catálogo de la exposición Los Ballets Rusos de Diaguilev 1909/1929. Cuando el arte baila con la música, Barcelona-Madrid, Fundación "la Caixa", TURNER, 2011, p. 65. 
El vitral siguiente es denominado por Mendirichaga como La Historia ${ }^{196}$ y por Román como Las Artes ${ }^{197}$. En la parte baja a los extremos unos pequeños tubos amarillos horizontales y verticales parecen ser hatos de bejuco, en donde en el de la izquierda se aprecia una greca de tipo maya o mexica. Cuatro piezas cerámicas aluden a la rica alfarería de los pueblos indígenas, destacándose la pieza en rojo y las decoraciones de las dos del lado derecho. Hacia arriba un hombre sentado en el piso y de perfil vistiendo solamente una pulsera en el tobillo y cinturón de "maxtlac" o taparrabo, ambos en color azul, sostiene entre sus manos un instrumento, al parecer una espátula de un artista. Frente a su pie está lo que Román le ha identificado como "un cartucho de la escritura maya"198 en varios colores. Un poco más elevado está un hombre cuyo cuerpo es azul claro, sentado en posición de loto; porta un gran tocado multicolor y sus rasgos son del tipo de los grupos mayas. Posiblemente intenta representar una escultura terminada por el artista indígena que porta algún instrumento de trabajo. Detrás de la cabeza del personaje en azul emerge un glifo indígena que se prolonga hacia la cabeza del artista; tal vez sea una alusión al dios Quetzalcoátl, el gemelo precioso, pues las plumas que cuelgan por el lado izquierdo son una de las representaciones de esta deidad.

En el siguiente nivel una pilastra ochavada y rota cae sobre una puerta con arco de medio punto y dentro de un desacomodo de construcciones se eleva una torre tipo rascacielos; luego de un tapiz en verde y morado, una columna con capitel jónico sostiene unos pies de una escultura clásica. La conjunción de estos elementos simbolizan la arquitectura.

La cabeza de un caballo, una mano de piel obscura, diferentes siluetas de objetos se apilan para terminar con dos perfiles de máscaras y atrás de ellas, unas luces en forma de rayos. Todo esto dentro de un lenguaje cúbico, bien podría interpretarse como una escenografía teatral.

Del lado izquierdo arde el fuego en un cuenco del que emerge una Venus helénica, que aparentemente es la poseedora de los pies descritos, lo cual constituiría una imagen de la escultura clásica. Fuertes llamas sinuosas brotan detrás de ella. Y del otro lado, de un

\footnotetext{
${ }^{196}$ Mendirichaga, Op. Cit., p. 13

${ }^{197}$ Román Op. Cit., p. 74.

${ }^{198}$ Ibídem, p. 75.
} 
sahumerio indígena, muchas llamas multicolores serpentean hacia lo alto. Ambas columnas de fuego resguardan a la llama central, inserta en un triángulo.

La colocación de componentes cubistas donde se van amalgamando piezas angulosas donde finalmente se eleva una alto edificio, conlleva composiciones geométricas que buscando una óptica de construcción crean perfiles angulosos, lo mismo que los poliedros intrincados detrás del rascacielos y los destellos luminosos que acompañan a las caretas, nos da una relación hacia la estética Déco del tipo Zigzag.

Construcción de la nación moderna y construcción de las nuevas ciudades. La arquitectura con cemento, el material moderno del Art Déco, permite la osadía de elevar pisos y más pisos con todos los servicios de iluminación y climatización. Utopía hecha realidad principalmente en los Estados Unidos en los años del Déco y que en México pronto se harían los primeros experimentos. Así como aparece en este vitral, un rascacielos se eleva encima de la multitud de cuerpos amontonados, de esta manera Montenegro utiliza dicho elemento dentro de la composición como lo hiciera la artista del Déco, Tamara de Lempicka( 1898-1980), quien en varios de sus cuadros incluyera en el fondo los cúbicos rascacielos, como en su óleo sobre madera Retrato de Madame Boucard, 1931, colección privada, con lo que se observa que el lenguaje pictórico de Montenegro estaba dentro de la estética de la época, la del Art Déco. ${ }^{199}$

El mundo indígena prehispánico concordó muy bien con el Art Déco por sus diseños geométricos y escalonados, entre otros, pero aquí sólo vemos la greca en la parte baja del lado izquierdo y su enlace con los pequeños filamentos horizontales y verticales.

El vitral de La Ciencia es denominado por Mendirichaga como La Ciencia y la Sabiduría ${ }^{200}$ y por Román como La Enseñanza, ${ }^{201}$ pero lo dejaremos con el nombre de La Ciencia por la palabra que está en el segmento superior. En la parte inferior de izquierda a derecha hay varios instrumentos de investigación científica: un dínamo productor de luz, un telescopio para la observación de objetos, un equipo de destilación química y dos antenas de transmisión de electricidad. Son herramientas utilizadas en la física y la química.

En el siguiente nivel una mujer con vestido amarillo sentada y de frente muestra un libro abierto y alza la mano izquierda en actitud de atención hacia sus alumnos: a la

\footnotetext{
${ }^{199}$ Gilles Néret, Tamara de Lempicka, Köln, Taschen, 1993, p. 46.

${ }^{200}$ Mendirichaga, Op. Cit., p. 14.

${ }^{201}$ Román, Op. Cit., pp. 80-81.
} 
izquierda, un niño hijo de un obrero, caracterizado por su vestimenta de overol azul, carga un poliedro en representación de la geometría; a la derecha, una niña tomando asiento observa una esfera terrestre en la cual se resaltan las coordenadas y los paralelos simbolizando la geografía.

Posteriormente una mujer vestida de azul colocada hacia la izquierda y en posición de tres cuartos, recarga su brazo derecho sobre cinco libros que llevan inscripciones de áreas del conocimiento en el lomo y una lápida que detiene con su brazo y mano derecha lleva la palabra "LEX", es decir, la ley, que por el contenido de las imágenes del vitral se ha de referir a las leyes científicas. Es interesante cómo hay un cercano parecido en la postura a la mujer del medallón de la fachada de la Escuela Industrial Álvaro Obregón, la cual también sostiene un libro sobre sus piernas.

Hacia arriba otra mujer sentada y de perfil en sentido opuesto a la anterior, porta un vestido verde. Sostiene entre sus manos una esfera celeste la cual observa con atención. Es la astrología, misma que se refleja en la parte superior.

Hasta aquí, el fondo que se inicia en la parte baja en color azul para luego continuarse en verde, marca la mitad del vitral.

Detrás de la tercera dama, en un segundo y tercer plano, resaltándose los tonos amarillos, del lado izquierdo se ve un libro abierto apuntado hacia lo que parece un laboratorio; en el centro dos cubos amarillos y encima de uno de ellos edificios; después se van elevando partes de lo que se asemeja a una fábrica o un laboratorio de grandes dimensiones, por qué no, todo este conjunto puede referirse a un centro de investigación científica de una institución de educación superior.

En la parte superior se muestra el cosmos. Al frente en un círculo amarillo una estrella de ocho picos resguarda la palabra ciencia que se encuentra protegida por un anillo en azul claro con rayos. Una banda deforme con puntos blancos alude al Vía Láctea. El sistema solar está representado con algunos astros: a la izquierda aparentemente hay un cometa con su larga cauda, la luna en cuarto creciente, así como los planetas Tierra y tal vez Venus por su cercanía al sol. Del lado derecho se encuentran Saturno y posiblemente Urano por su posición, para cerrar en la parte superior con una porción del sol del cual sólo se ve una parte de su centro y algunos rayos, todo dentro del inmenso cielo azul. 
Si Román titula a este vitral La Enseñanza es por las alegorías y la forma en cómo están expuestas algunas materias científicas, así como por la primera mujer que está en actitud de impartir alguna asignatura, mientras que Mendirichaga que agrega la palabra Sabiduría es porque las mujeres podrían haber sido concebidas alegóricamente como representantes de algunos saberes.

Elementos Art Déco de la variante Zigzag los notamos en la transmisión de la electricidad, ya que el rayo que se conecta de una antena a otra lleva la evidente forma de la línea quebradiza, además de que los rayos de la fuerza eléctrica fueron tantas veces representados durante esa época a través de esa manera. Lo mismo en la estrella de ocho picos, que además de formar un zigzag, al constituirse con cuatro rombos insertos conlleva un geometrismo intrínseco, además de la línea ininterrumpida que se utiliza a la hora de realizar su trazo. Y en la parte del sol que se aprecia, los rayos sinuosos y su alternancia con los más pequeños formados por triángulos son también un referente del Déco Zigzag.

Si uno de los postulados de la época del Déco es el maquinismo industrial, la ciencia era la base de esos inventos, tal como se enarbola en este vitral, por lo que el hecho de que se represente un laboratorio con sus formas geométricas cúbicas y sus tubos fabriles, por una parte el geometrismo está presente y por otra se destaca la industria y su base científica. Además, las pequeñas edificaciones cuadradas del fondo de los laboratorios, nuevamente y de inmediato nos exportan a las imágenes de Tamara de Lempicka donde utiliza los cubos con pequeños recuadros para figurar las construcciones de la época, en obras tales como Andrómeda, 1928, colección privada, o Retrato masculino inacabado, 1928, Musée National d' Art Moderne en París. ${ }^{202}$

Y un postulado más, la mujer. Si bien el conocimiento era reservado para los hombres, en los años del Déco como ya lo hemos mencionado, tanto en el mundo occidental como en México, la mujer tomó una nueva posición social y de participación activa, tal como se le representa en este vitral, no sólo como la maestra transmisora de conocimientos, sino como la poseedora del saber, lo cual se simboliza a través de las damas con los globos tanto terráqueo como celestial, con la ley y los libros. Además, como anotamos arriba, la segunda mujer en su postura nos recuerda a la del medallón de la Escuela Industrial Álvaro Obregón que es todo icono del Art Déco.

\footnotetext{
${ }^{202}$ Gilles Néret, Op. Cit., pp. 26 y 50.
} 


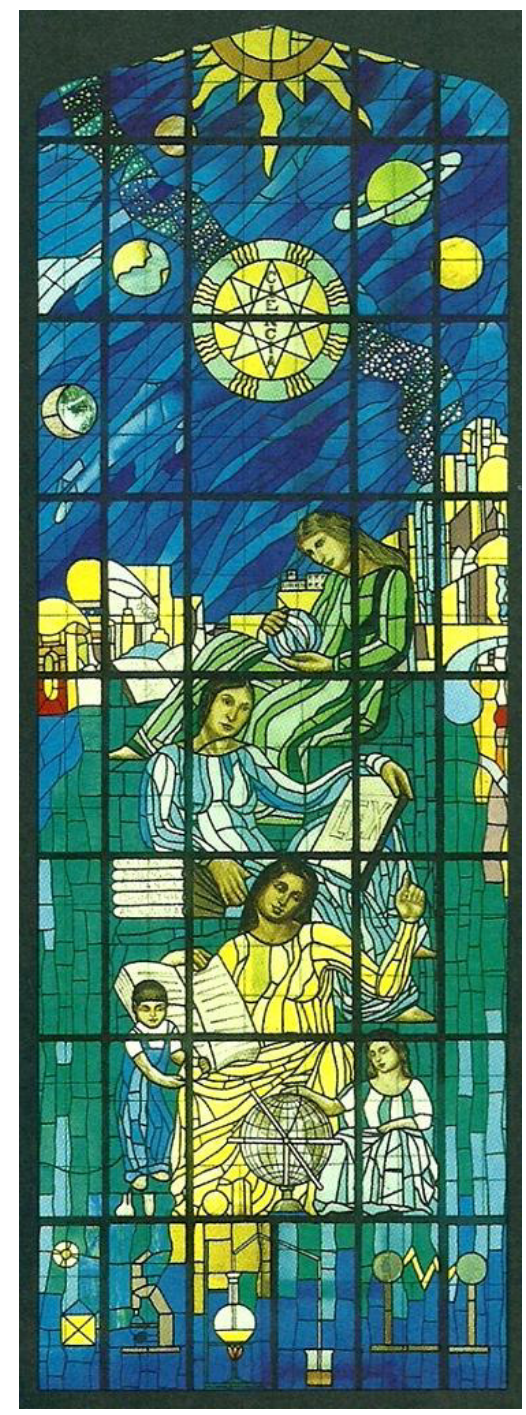

La Ciencia.

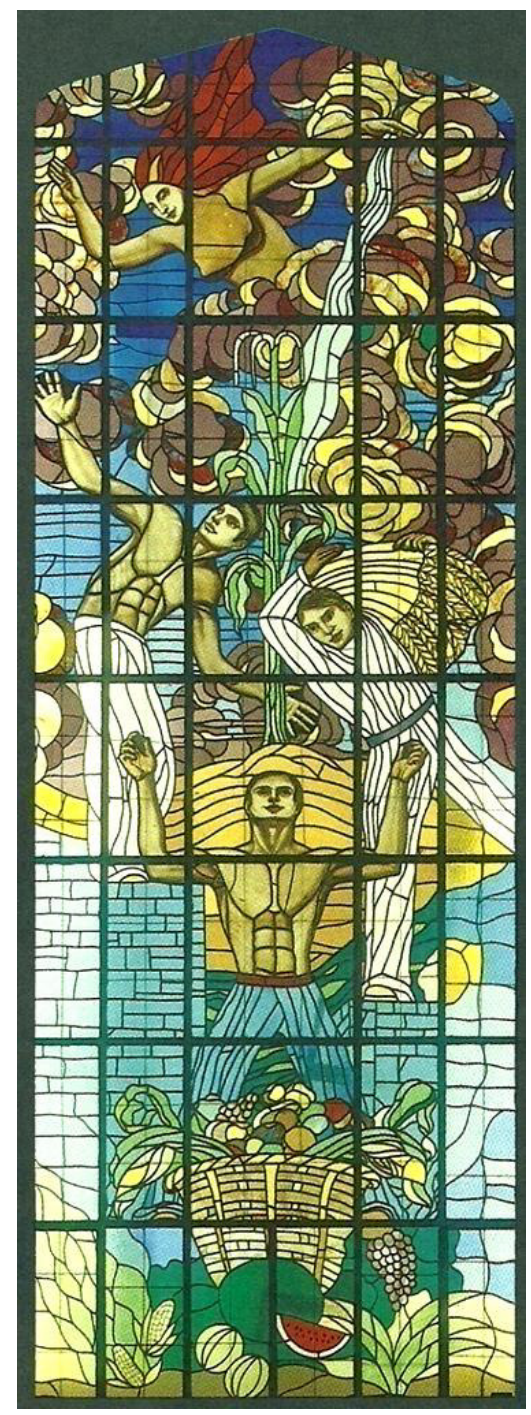

La Agricultura.

En el vitral de La Agricultura en la parte baja hay productos del campo que adornan la tierra, como unas mazorcas, unos melones, una sandía abierta, un maguey y al parecer unas hortalizas en color verde fuerte. Una canasta, parodiando a un cuerno de la abundancia derrama su contenido de frutas y verduras.

Un hombre al frente con las piernas abiertas alza los brazos y su mirada se dirige hacia el horizonte. Viste pantalón en azul con cinturón rojo y el torso va desnudo. Pareciera como si estuviera dando las gracias por la tierra pródiga, por los triunfos campesinos postrevolucionarios del reparto y las leyes agrarias. 
Detrás de este hombre unas líneas curvas en verde constituyen la tierra profunda para luego posicionarse la tierra fértil representada en color naranja. Del lado derecho, en una barda en azul se para un campesino vestido todo de blanco con cinturón azul, inclinando su cuerpo hacia la izquierda y cargando espigas de trigo sobre su espalda. Del lazo izquierdo, otro campesino de perfil, con pantalón blanco y el torso sin vestimenta gira su cuerpo, abre brazos y manos y mira hacia el horizonte; por el frente de su mano izquierda, en el centro del vitral una esbelta planta de maíz impone su presencia, pues es la dieta esencial del pueblo mexicano.

Entre nubes cafés y amarillas, irrumpe el torso de una mujer desnuda, con abundante caballera en rojo y sepia, prolongada hacia atrás por la fuerzas del viento. El brazo derecho lo eleva como a modo de bendición y el izquierdo que estira horizontalmente, de su mano brota un chorro de agua que va hacia la planta del maíz. Es alguna diosa de la tierra que viene a proteger el campo mexicano. Lo curioso es que no sea un dios prehispánico, el mismo Tláloc, dios de la lluvia, del agua, el que irriga al maíz, sino tal vez sea la diosa Cibeles, monumento que seguramente mucho apreció Montenegro durante su estancia en Madrid de 1906 a 1909. Pero aquí va con el pelo suelo, posiblemente por su etimología en griego Kibele "la del pelo" y desvestida a diferencia de la efigie madrileña.

Montenegro utilizó también una canasta con frutos en el vitral de la escalera de la Escuela Industrial Álvaro Obregón, pero no tan elaborada como la de esta escena. Sin embargo, entrando en los elemento Art Déco el primer hombre con sus piernas abiertas forma un triángulo isósceles, un trapecio con su torso, en el que destacan los cuadros del abdomen, los ángulos casi rectos de los brazos, el triángulo equilátero de su cuello y el casi cuadrado de su cara. Este personaje es de un geometrismo extraordinario en su composición que lo hace todo un prototipo del estilo.

El campesino de la derecha también forma un triángulo isósceles con sus piernas, un rectángulo en torso y cabeza y un ángulo recto con su brazo derecho. Y el de la izquierda, nuevamente nos remite al Prometeo de Paul Manship, como en el vitral de La Industria, que inclusive en este caso está aún más cercano, pues el personaje lleva una postura de doblar el cuerpo hacia el lado derecho como en la escultura de Manship. 
Pero hay un elemento muy marcado dentro de la estética del Déco que es la mujer de la parte superior, tanto en la postura de brazos como en el pelo. Mencionaremos dos ejemplos que están en estrecha relación en la manera en que Montenegro trató a esta figura, sin que con esto afirmemos que tomó el modelo de ahí. Primero, una de las más características esculturas del Art Déco: Faune et Nimphe, de 1925, ejecutada en bronce con pátina negra por uno de los más connotados artistas del Déco, Pierre Le Faguays (18921935), expuesta en la gran exposición parisina de 1925 en el Pabellón Goldscheider y que ahora se encuentra en una colección privada de Londres. La posición del brazo derecho de la ninfa que lo sube a la cabeza, también podemos relacionarla con el campesino que carga el hato de trigo. Pero, la posición estirada del brazo izquierdo con la mano deteniendo al fauno, está en una cercana correlación con la mujer del vitral, así mismo lo aéreo del cabello que se vuela hacia atrás. ${ }^{203}$ La segunda pieza es de otro de los grandes maestros del Déco, el vidriero René Lalique (1860-1925), cuya Victorie de 1925, hoy en la Gallery 1925 de Londres, ${ }^{204}$ rememora las alas de la Victoria de Samotracia, pero en este caso es en el pelo que se extiende vigorosamente hacia atrás, mientras la cabeza hacia delante equilibra la composición. Entonces y en síntesis, esa moda de presentar a algunas mujeres con la cabellera extendida hacia atrás es un referente bastante utilizado en el Art Déco, tal como lo hizo Montenegro en el vitral de La Agricultura.

En el vitral de La Reconstrucción de la misma manera que en el vitral de $L a$ Revolución que se encuentra enfrente, en la parte baja están al centro un libro abierto y a los lados las espigas de trigo. Los tres hombres ahora se encuentran en actitud de serenidad y en posición de descanso militar. Al centro el soldado quien con la mano izquierda ahora lleva una bandera ondeante con la inscripción "RECONSTRUCCION" (textualmente) y la derecha la sostiene en el hombro del obrero; viste con el uniforme militar, pero ésta vez en lugar de quepis porta una gorra tipo policía.

A la derecha, inclinando levemente la cabeza está el campesino, pero sin carrilleras, ni fusil, ni sombrero; viste con camisa y pantalón de manta blanca, cinturón en rojo y calza huaraches. En la mano izquierda porta un instrumento de labranza y la mano derecha la posiciona en el hombro del castrense. Del lado izquierdo está el obrero con su overol azul,

\footnotetext{
${ }^{203}$ Alastair Duncan (ed.), Encyclopedia of Art Deco, London, Quantum Books, 1988, p. 37.

${ }^{204}$ Arwas, Op. Cit., p. 242.
} 
camisa blanca y botas industriales amarillas. Con ambas manos detiene una pala, objeto que más bien se asocia con el trabajo de campo que con el fabril. Tanto el campesino como el obrero traen las mangas abrochadas, los tres están en calma, en armonía fraterna porque se ha dado la reconstrucción del país. Así mismo, los ladrillos apilados y en orden debajo de las piernas del soldado, interpretan el restablecimiento del orden y la paz social entre los mexicanos. En el fondo en lugar de llamas hay abundantes plantas de maíz en crecimiento, aún sin las mazorcas, significando la abundancia de la siembra. Haciendo juego con esta decoración, en las cenefas laterales se repite el ornato del maíz. Debajo de las piernas del campesino en un recuadro verde están las firmas: "R. Montenegro proyectó", "Casa Montaña Torreón ejecutó”.

Las piernas abiertas de los tres personajes forman triángulos isósceles, cuyo ritmo forma un Déco Zigzag de grandes dimensiones. Los ladrillos acomodados escalonadamente llevan un diseño cubista y se consigue un geometrismo lineal con los instrumentos de trabajo del obrero, del campesino y con la posición oblicua del tubo de la bandera. Las figuras robustas de los hombres, su posición hierática, sus cuerpos musculosos son del tipo de las representaciones humanas de los años del Art Déco que se usaron tanto en pintura como en escultura y en relieves. Los elementos Déco del trigo y las plantas del maíz son del mismo tipo que las del vitral de La Revolución.

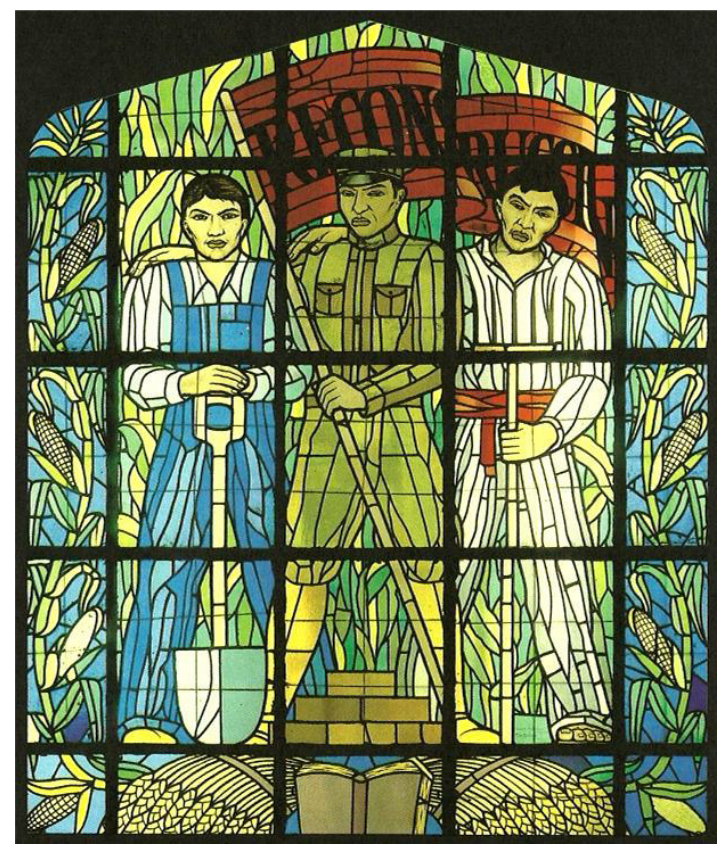

La Reconstrucción. 
El último de los vitrales es La mano y la estrella, título que se le ha dado por Mendirichaga y Román por los dos componentes que aparecen al frente. La mano abierta y morena es porque lleva el color de la piel de los indígenas y mestizos mexicanos, las manos trabajadoras que lucharon en la Revolución. Recibe a una estrella amarilla de cinco picos; es la estrella bolchevique del triunfo de la revolución rusa, ya que era sinónimo del trastrocamiento de un régimen autoritario como era el imperio zarista, por una sociedad igualitaria como la soviética y que de la misma manera en México se quitó una dictadura porfirista de más de treinta años por un gobierno que enaltecía los triunfos obreros y campesinos. Entonces la estrella denota los triunfos de la Revolución, además de recibir tres halos nubosos que pueden ser la clase campesina, obrera y militar retratada en dos de los vitrales, en el de La Revolución y en de La Reconstrucción, o también se puede interpretar como la creación de nuevas leyes agrarias, obreras y a la Constitución de 1917, idearios políticos enaltecidos por el gobierno postrevolucionario.

En el fondo está expuesto el sistema solar con el sol al centro en color rojo y el firmamento con doce estrellas de cinco puntas y veintitrés astros en forma de círculos, distribuidos en los aros que se van expandiendo en diferentes tonalidades en blanco, verde y azul. Las cenefas con plantas y mazorcas que están en los extremos, se enlazan visualmente con el vitral de La Reconstrucción que se ubica en la parte alta.

Los elementos Déco de este vitral son la geometría de los cilindros de los dedos de las manos y el juego de figuras que se dispone con los triángulos de las estrellas, así como con los círculos del fondo, todo concertando una ornamentación geométrica Art Déco Zigzag. Los halos que caen sobre la estrella son muy similares a las emanaciones del humo industrial de las chimeneas, curvos, pero a la vez rígidos, tal como se representa en los diseños Déco. Sobre la planta del maíz y sus componentes, así como el fondo con los círculos expandidos, ya lo comentamos en el vitral de La Antorcha, que en este vitral de $L a$ Mano y la Estrella lo que cambia son las astros celestiales y los colores, pero tomemos en cuenta que Montenegro ya había utilizado también las estrellas en el cielo dentro del vitral de la Escuela Industrial Álvaro Obregón. 


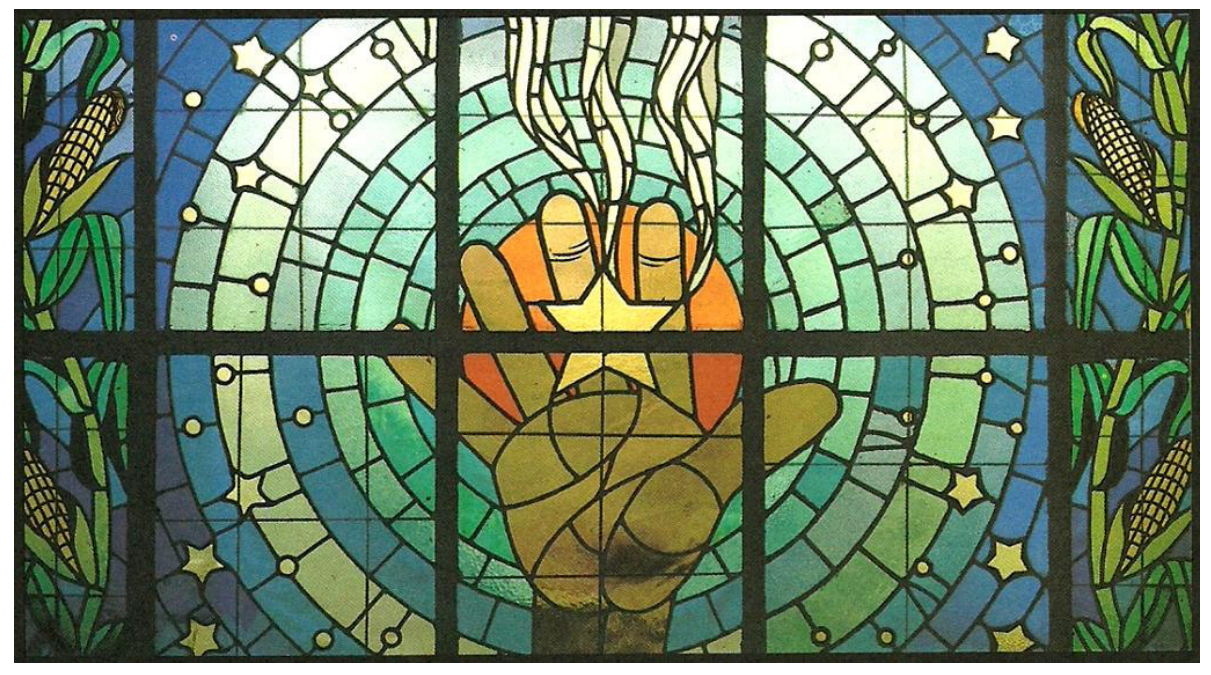

La Mano y la Estrella.

Estos vitrales presentan un colorido como geométrico Art Déco de tipo Zigzag y el nacionaliso imaginativo de la postrevolución está presente, ya que al ser colocados en un plantel de educación superior, tratan de transmitir la ideología de que gracias a las luchas revolucionarias se sembró la paz en el país y tanto la educación como la ciencia pudieron florecer. 


\subsubsection{ARQUITECTURA EN CUATRO MUNICIPIOS DE NUEVO LEÓN}

\section{a. Anáhuac}

Ciudad de Anáhuac es la cabecera municipal de Anáhuac, Nuevo León. Fue fundada el 5 de mayo de 1933 como una cabecera política del Sistema Nacional de Irrigación 04, del lado izquierdo del río Salado y al sur de las vías del ferrocarril que va de Monterrey a Nuevo Laredo, Tamaulipas. El nombre viene de Valle de Anáhuac en el centro de México y la fecha de la fundación fue elegida para conmemorar la Batalla de Puebla del 5 de mayo de 1862, cuando el ejército mexicano derrocó al francés, siendo la razón para denominar así al Municipio.

Desde 1925 bajo el mando del general Plutarco Elías Calles, se instalaron los primeros trabajadores al margen del río Salado para iniciar las obras del Sistema de Irrigación y dos años más tarde se empezaba a construir la presa Don Martín, la cual se inaugura en octubre de 1930 con la misma presencia del general Elías Calles, en representación del Presidente, el ingeniero Pascual Ortiz Rubio. Era la época del Maximato.

Una vez que se tenían los elementos para atraer pobladores a la zona, se inicia la planeación de una ciudad en 1931 por unos arquitectos de apellidos Azcárraga y Mendiola, pero quién hace el diseño final es el ingeniero Pedro Pedrero M., sin tenerse más datos al respecto. ${ }^{205}$ La ciudad es muy original en su traza, ya que las calles son redondas y convergen a una plaza principal en forma de circunferencia. Viene la inauguración de la ciudad, la construcción de los primeros edificios de servicios, pero desde el principio hubo una serie de problemas y enfrentamientos por el reparto agrario, lo que provocó que ya en tiempos del gobierno del general Lázaro Cárdenas se constituyó un fuerte Sindicato de Obreros y Asalariados Agrícolas en 1935, así como la creación del Municipio de Anáhuac, teniendo como cabecera municipal a la misma cabecera del Sistema de Irrigación. El propio Presidente Cárdenas en el teatro Apolo de Ciudad de Anáhuac hizo una nueva repartición de tierras y la creación de otros tres ejidos. Sin embargo, en 1937 se dio una fuerte sequía

\footnotetext{
205 “Anáhuac", Enciclopedia de los Municipios de México. Nuevo León. México, Instituto Nacional para el Federalismo y el Desarrollo Municipal, Gobierno del Estado de Nuevo León, 2005. http://www.elocal.gob.mx/work/templates/enciclo/nuevoleon/municipios/19005a.htm
} 
en la región que se prolongó por siete años, hasta 1944, con lo que la población se redujo notablemente. ${ }^{206}$ Esta situación fue narrada en El luto Humano, novela de 1943 del escritor José Revueltas (1914-1976).

En Ciudad de Anáhuac o solamente Anáhuac, existen muchas construcciones de los años treinta y cuarenta del siglo pasado, muchas de ellas con elementos Art Déco; sin embargo, no todas poseen elementos de calidad como para ser estudiadas en este trabajo, pues presentan decoraciones mínimas que no consideramos pertinente incluir. Las construcciones que analizaremos son el Palacio Municipal, el Edificio Agrario, la Escuela Cuauhtémoc, y la Fuente Obelisco.

\section{a.1. ARQUIETCTURA GUBERNAMENTAL}

\section{a.1.1. Palacio Municipal}

El Palacio Municipal se ubica en la calle Juárez s/n., entre Hidalgo y Mariano Escobedo, con orientación hacia el noroeste frente a la Plaza Juárez. Fue construido en 1933, tal vez bajo el diseño del ingeniero Pedro Pedrero. Es de un solo piso y tiene una planta en forma de E en posición horizontal, ya que se manejó la hipótesis en su tiempo de que muchos edificios construidos bajo el mando de Plutarco Elías Calles o durante el Maximato se erigían así en alusión al apellido del “Jefe Máximo de la Revolución”. De elementos tipo Art Déco sólo se conserva en la fachada la entrada al inmueble, ya que lo han ampliado y remodelado con el paso de los años.

La puerta de acceso está proyectada hacia al frente. Es rectangular y lleva la composición de abocinamiento que se forma con cinco remetimientos rectangulares que van de mayor a menor, como se utilizó con arcos abocinado en algunos edificios de la ciudad de México, componente descrito por Enrique X. De Anda y que explicamos en el capítulo 2. En la parte superior remata con una moldura. La altura de la puerta es menor que la del resto del edificio.

206 Hortencia Camacho Cervantes, “Anáhuac. Puerta de entrada a Nuevo León”, VV.AA. Nuevo León a través de sus municipios, Vol. I, Monterrey, N.L., Milenio, Multimedios, 2010, p. 123. 
Después de la puerta, otra parte saliente hacia el frente se adosa al edificio. Tiene cuatro ventanales rectangulares, dos a cada lado de la puerta, separados por pilastras en las que se resaltan unas molduraciones en los biseles. En la parte superior de las ventanas emerge una moldura achaflanada, como a manera de un talud de una plataforma prehispánica; luego una decoración como una cuerda que está pintada con los colores de la bandera nacional, verde, blanco y rojo. Dentro de un tablero, unas decoraciones en forma de grecas prehispánicas de tipo mexica dentro de un recuadro, se desplazan horizontalmente con la originalidad de estar orientadas hacia la derecha e izquierda respectivamente de cada lado y por encima de ellas, un zigzag complementa la decoración, demarcando el espacio del tablero una moldura cuadrada. Igual que en la puerta de entrada, un perfil recorre el filo del remate.

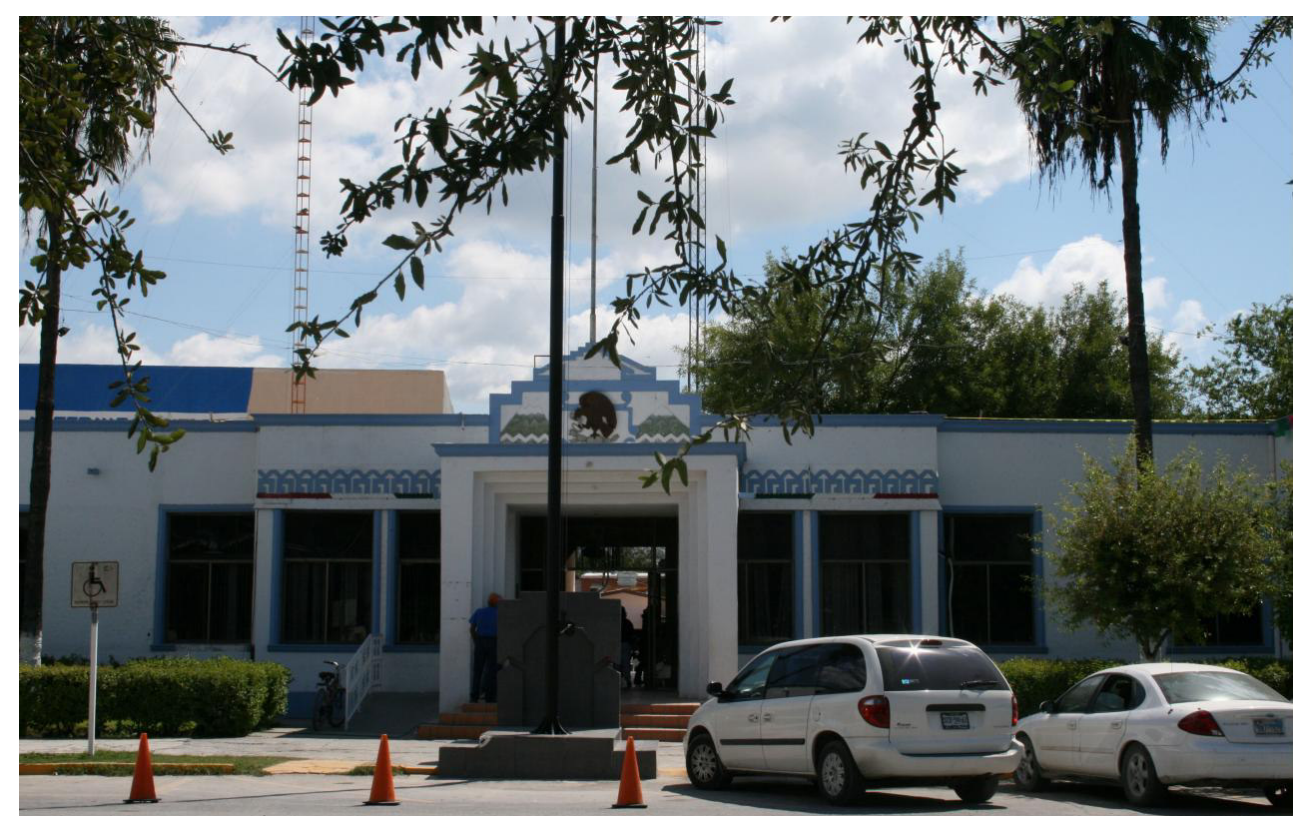

Palacio Municipal de Anáhuac. A los lados de la puerta están las decoraciones con grecas.

Por encima de la puerta se inserta un ábaco escalonado. Lleva al centro el escudo nacional con el águila y la serpiente con unas vírgulas indígenas a cada lado y los volcanes Iztaccíhuatl de lado izquierdo y el Popocatépetl del derecho, decorados en la parte baja con un zigzag en color blanco. Sobrepuesta en el ábaco, la base de la astabandera parodia una pirámide prehispánica con un tablero, un talud y luego unos escalonamientos. 
La idea de inculcar un nacionalismo indigenista en una zona donde nada tenía que ver la herencia prehispánica es la razón por la cual se utilizaron esos motivos, ya que las grecas fueron ornamentaciones utilizadas tanto en objetos utilitarios, religiosos y en arquitectura. La decoración a manera de una cuerda como el zigzag es la representación de la serpiente, en este caso de Quetzalcóatl, la serpiente emplumada, el gemelo precioso, que junto con las grecas se implantan dentro de un tablero tal como eran las decoraciones de las grandes plataformas indígenas tanto de Teotihuacán, como de México-Tenochtitlán.

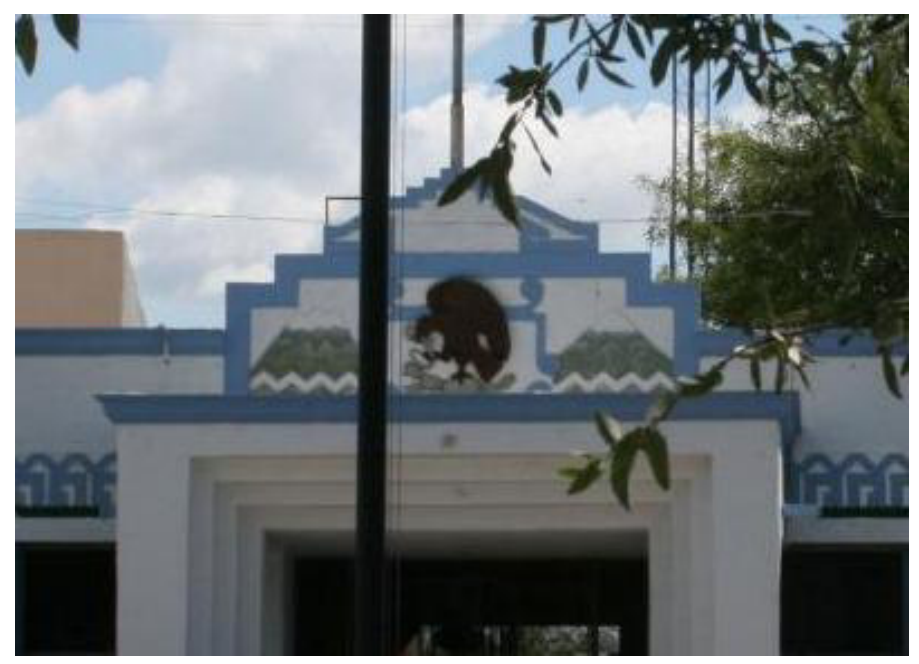

Detalle en el ábaco escalonado del escudo nacional, los volcanes y la astabandera.

El escudo nacional del ábaco si bien es para inculcar el nacionalismo, es asimismo la referencia a lo prehispánico con las vírgulas, símbolo de la voz, es decir, que habla el escudo a través de las obras del estado que busca crear un patriotismo de fuerte raigambre indigenista. Lo mismo sucede con los volcanes, que por la forma de su colocación es como se ven desde la ciudad de México, el centro del Valle del Anáhuac, nombre con el que se ha denominado a la nueva ciudad del Noreste y a la que había que crearle una identidad, ya que sus pobladores vendrían de otras partes cercanas de la región. Además, ciudad de Anáhuac era la única fundación como tal en el norte de la República bajo los dictámenes del nacionalismo postrevolucionario, ideado y concebido en las oficinas centrales de la capital del país.

Con todo el lenguaje de lo geométrico y de los motivos prehispánicos, aunado al material moderno del Art Déco, el cemento, estamos ante un edificio que con toda su 
sencillez constructiva, acoge los elementos del Déco Zigzag y claramente los de la Tendencia Geometrista, a los cual le agregamos como en el Palacio Federal, el termino de Nacionalista Prehispanista, ya que presenta los rasgos decorativos de las culturas indígenas prehispánicas, especialmente de la cultura mexica o azteca.

\section{a.1. 2. Edificio Agrario}

El Edificio Agrario está situado en la calle Juárez s/n., entre las calles Margarita Maza de Juárez y Mariano Escobedo, también frente a la Plaza Juárez, orientado hacia el oriente. Su forma es cúbica y de dos plantas. La parte frontal se compone de tres paramentos, desplazándose hacia el frente el central. Se accede al edificio por una puerta rectangular que aún conserva las lámparas originales de forma cúbica. En la parte superior lleva tres ventanas rectangulares, siendo la central de mayor tamaño; debajo de ésta, el letrero que fue colocado desde su inauguración se conserva intacto:

\section{"CNI \\ Sistema Nacional \\ De Riego No. 4}

$1933 "$

Las siglas CNI significan "Consejo Nacional de Irrigación”. Un letrero posterior que dice ahora "Centro de apoyo para el desarrollo rural", impide que frontalmente se aprecien las letras originales referidas.

En la parte superior de la ventana central remata el edificio con un ábaco escalonado, en cuya parte central fue colocado un escudo que fue creado para el municipio, aunque ése ya no es utilizado porque se instituyó otro en 1984.

Los lienzos laterales llevan un par de ventanas rectangulares en ambos pisos y en la segunda planta en la parte superior llevan un recuadro con unas molduraciones verticales que le imprimen un sentido cinético muy de la etapa del Art Déco Zigzag. Las ventanas en los dos pisos van separadas por una pilastra cuadrada que lleva dos molduras angulares con lo que se resalta la geometricidad, mismas molduraciones que se repiten en la unión a la parte central de la fachada y a las columnas de los extremos que también abarcan las fachadas laterales, las cuales ostentan tres lienzos unidos por el mismo tipo de pilastra cuadrada como las descritas en la fachada principal. Cada lienzo lleva par de ventanas en 
ambos pisos y rematan con las mismas molduraciones verticales enmarcadas en pares por tableros rectangulares, con una decoración tipo doble escapulario. Sin querer afirmar que haya sido tomado de ahí, pero esta decoración de inmediato nos remite a los tableros de Monte Albán en Oaxaca, ciudad prehispánica zapoteca que mencionamos en el Capítulo 2. Posiblemente con ese afán de inculcar un nacionalismo indigenista, la inserción de formas prehispánicas en una nueva ciudad, contribuiría al desarrollo de una identidad nacional.

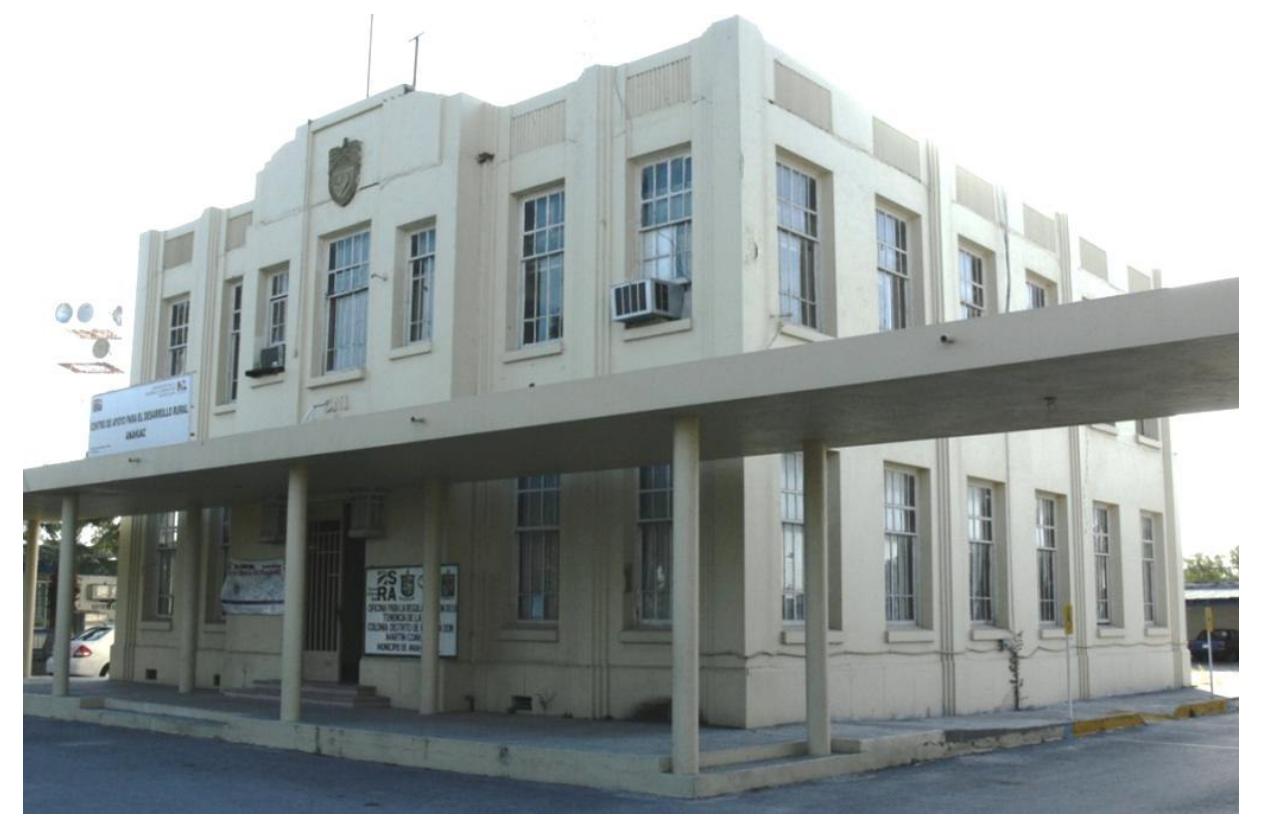

Vista de frente y de la fachada lateral norte.

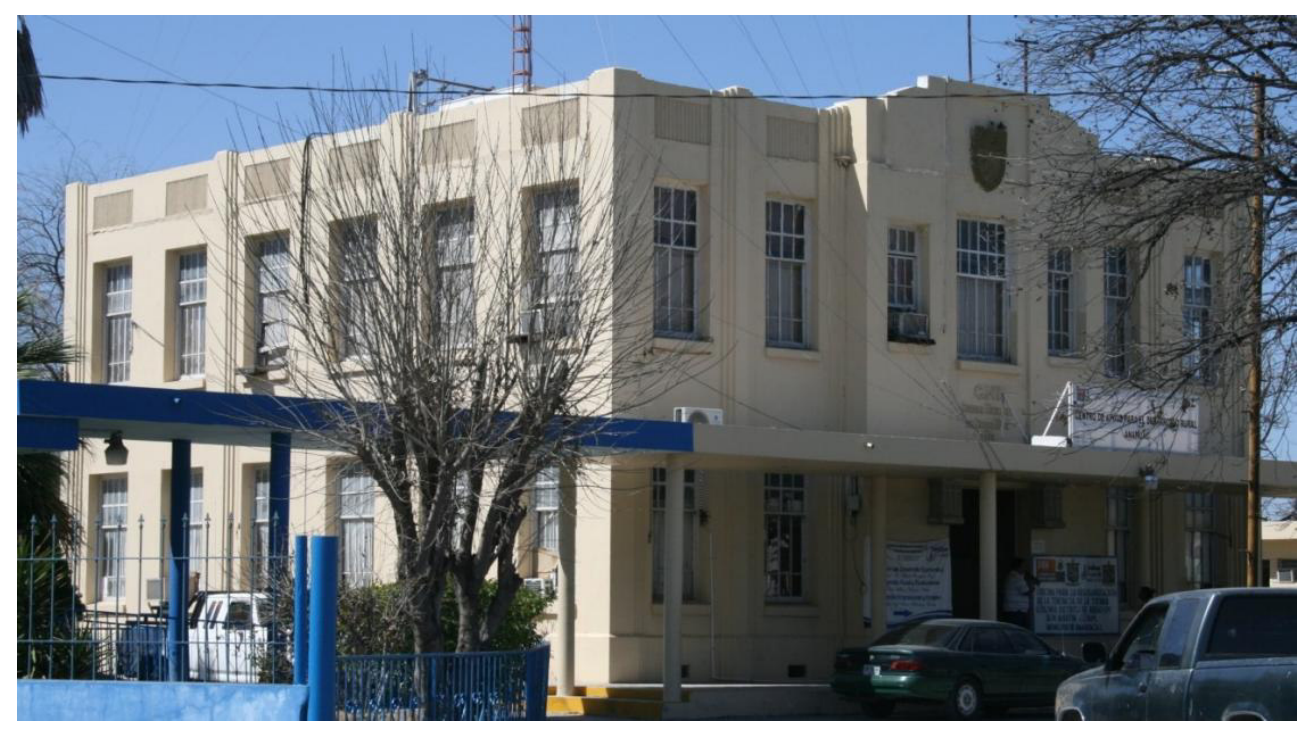

Vista de frente y de la fachada lateral sur. 
En la parte interior del edificio no se conserva nada de decoración y ha sido adaptado a las necesidades burocráticas contemporáneas, además de instalare climatización con lo cual si es que tuvo algún detalle tipo Déco, esto se ha perdido.

Es un edificio sencillo pero que por su decoración exterior y su composición es un ejemplo del Art Déco Zigzag y de la Tendencia Geometrista.

\section{a.2. ARQUITECTURA ESCOLAR}

\section{a.2.1. Escuela Cuauhtémoc}

La Escuela Cuauhtémoc, además de tener el nivel de educación Primaria, también es un Centro de Capacitación del Magisterio, la No. 1915. Se ubica en carretea Don Martín 600 con vista al poniente.

Es un inmueble de una planta que se compone de tres partes. Primero, un cuerpo central desplazado hacia el frente, donde la puerta de acceso es rectangular. Con unas sencillas letras se ve la leyenda de "Escuela". En la parte superior el remate se eleva escalonadamente para terminar en forma de ochavo donde está colocado un busto de Cuauhtémoc, el último gobernante mexica en los tiempos de la conquista española. Nuevamente los recursos históricos del mundo indígena son utilizados en esta población para exaltar las glorias del pasado prehispánico, en este caso del último gobernante mexica a quien se le ha catalogado como un héroe por resistir la conquista española. En los extremos laterales del remate unos poliedros cúbicos levemente remetidos, más unas molduras angulosas conforman un conjunto de elementos geométricos que le dan a la portada el sentido de una composición Art Déco.

Junto a la portada y desplazados hacia atrás, se unen unos lienzos con ventana rectangular que en la parte superior ostentan una decoración de molduras angulosas y a su vez el lienzo se encuadra con gruesas pilastras que llevan adosadas un perfil anguloso, con lo cual se consigue un efecto de resaltar hacia el frente las pilastras, mismas que se elevan levemente del nivel del techo.

A cada lado de los lienzos y remetidas más hacia atrás, unas puertas rectangulares enmarcadas por pilastras también llevan en la parte superior la decoración de las estrías 
angulosas, para luego continuar con dos pares de ventanas que se enmarcan por tres pilastras con la misma solución de los perfiles angulosos adosados, pero con la diferencia que las pilastras se unen en la parte inferior a través de una gruesa faja, formando una E acostada. Las pilastras de esta parte del edificio, también se elevan ligeramente de la altura de la techumbre.

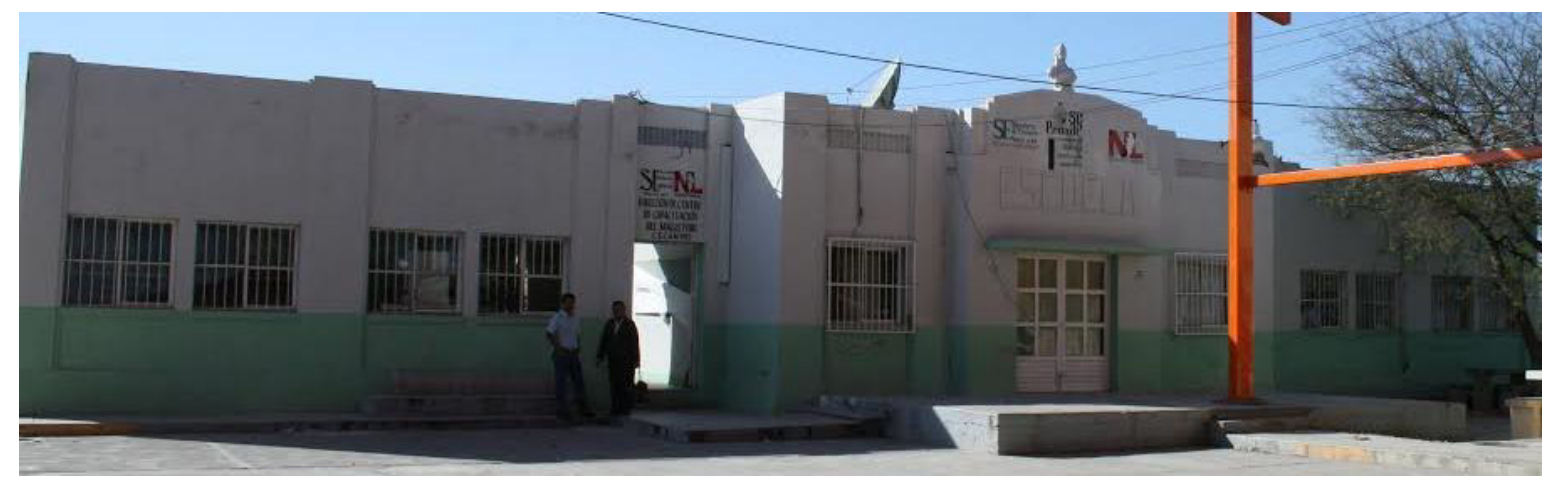

Escuela Cuauhtémoc.

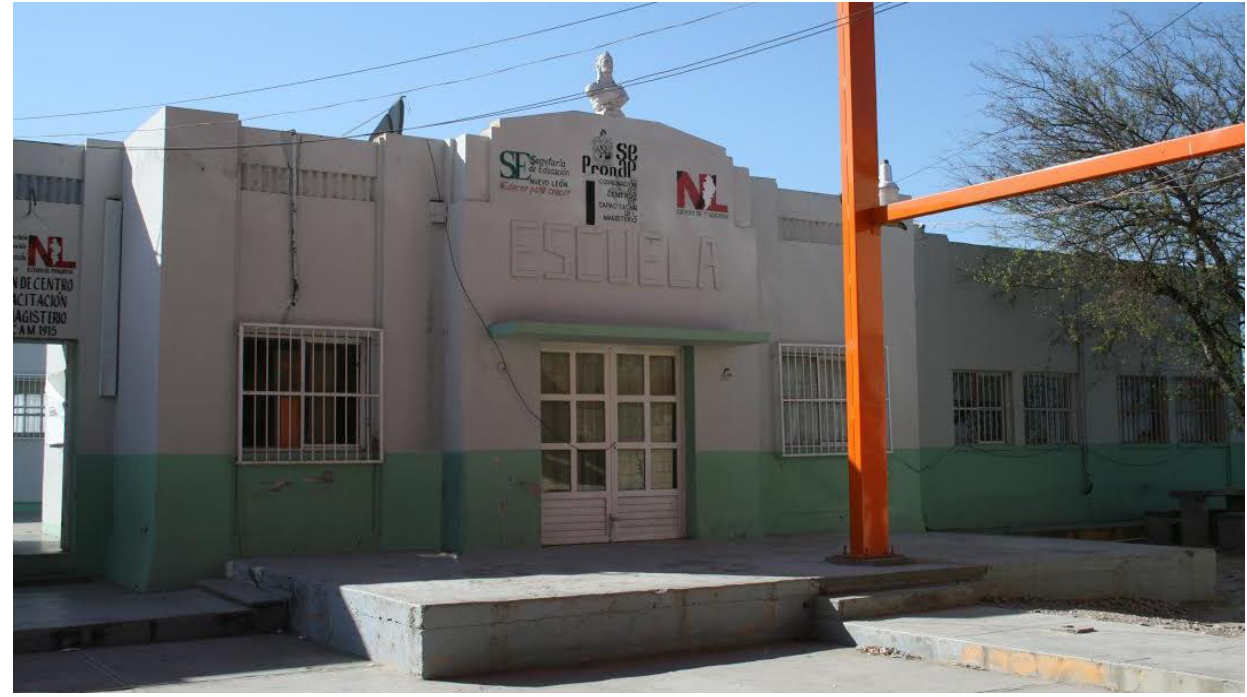

Portada principal.

El juego de niveles que se sobreponen de adelante hacia atrás, hace que la planta tenga una composición de juegos lineales y en lo que corresponde al inmueble se ensamblan poliedros cúbicos para lograr una armazón geométrica que aunada a las decoraciones de las estrías angulosas, la consecuencia estilística es de un edificio del tipo Art Déco Zigzag y de la Tendencias Geometrista. 


\section{a.3. URBANISMO Y RENOVACIÓN}

\section{a.3.1. Fuente Obelisco}

La Fuente Obelisco se levanta al centro de la Plaza Juárez y es el símbolo de la fundacion de la ciudad. Realizada en concreto, está sustentada sobre una plataforma de piedra labrada; cuatro arbotantes circulares sostienen al conjunto que se forma de tres

partes. En la primera, cuatro pilastras angulares circunscriben a un cubo, con lo que cuatro caras del cubo quedan rehunidas y en las cuales se insertan los arbotantes; debajo de éstos, unas pequeñas placas de acero en color negro con un botón al centro sirven de adornos.

En el segundo cuerpo se repite el mismo modelo compositivo como en el primero, con la diferencia de que ahora acoge el obelisco que forma el tercer cuerpo. Una placa de formas geométricas colocada en dirección hacia el norte muestra el escudo original en la parte superior y la inscripcion que dice:

\section{"CIUDAD ANAHUAC \\ FUNDADA POR LA \\ COMISION N DE IRRIGACION \\ EL 5 DE MAYO DE 1933."}

En cada cara de las pilastras se repite el adorno de las pequeñas placas de acero.

El último cuerpo de la fuente es un oblesico recortado en la parte superior y de ahí el nombre. Se eleva a manera de un prisma cuadrangular. Como mencionamos en el capítulo primero de las carácterísticas generales del Arte Déco, los elementos de la cultura egipcia se tomaron como modelos para el Déco en Europa, que en este caso sirve para conmemorar la fundación de Anáhuac con un recurso estético geométrico.

Toda la fuente es un ensamble de poliedros cúbicos que se van acomplando de manera escalonada y los arbotantes a manera de contrafuertes, a la vez simulan chorros de agua en caída. Aunque es sencilla en su composición, su diseño es netamente de tipo Art Déco de la etapa Zigzag, donde se resaltan los componentes geométricos, muy a la manera de los diseños constructivistas soviéticos. 


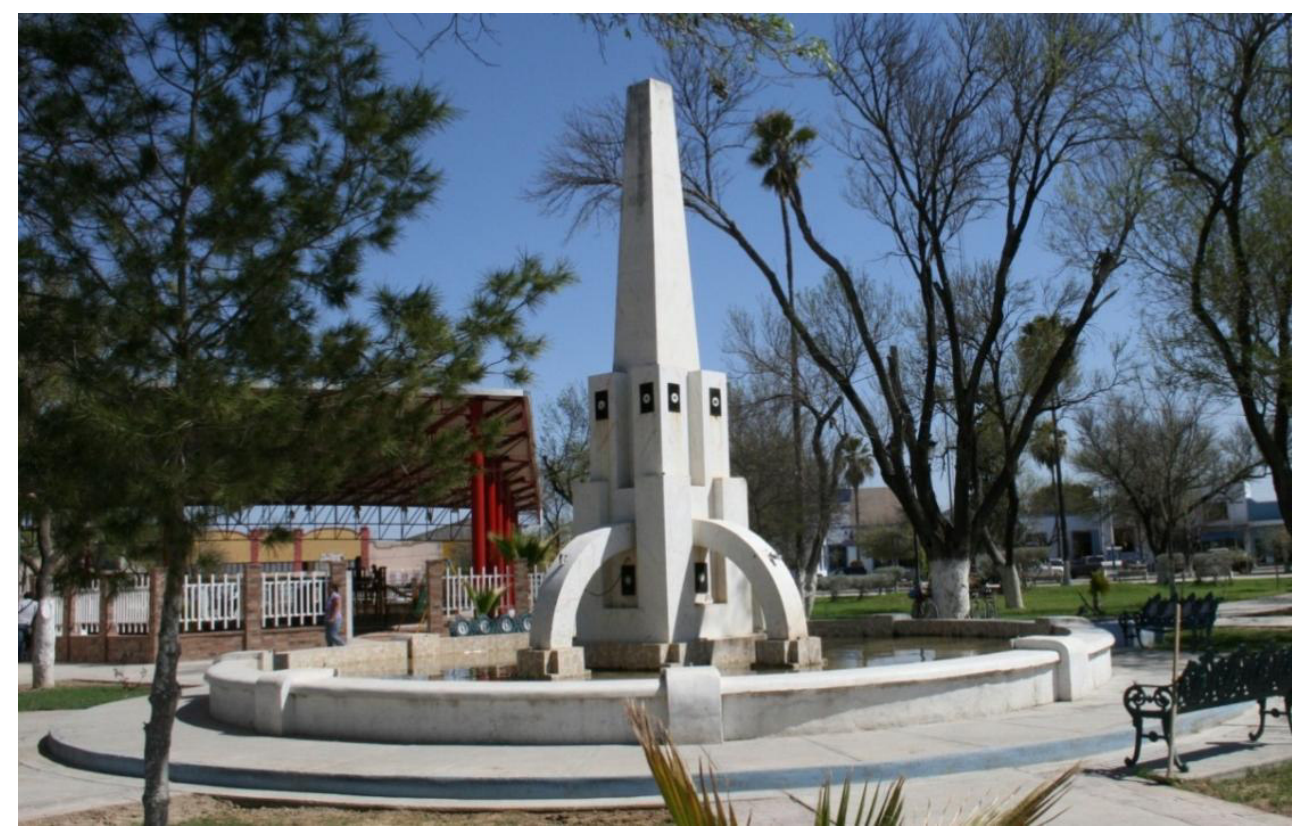

Fuente Obelisco.

En lo que corresponde a la pila ésta es circular, por lo que armoniza con el diseño de la plaza. Lleva ocho bandas que se envuelven hacia el interior, motivo decorativo que fue muy utilziado en los edificios de la época y que fue uno de los elementos distitntivos Art Déco de la variante Zigzag.

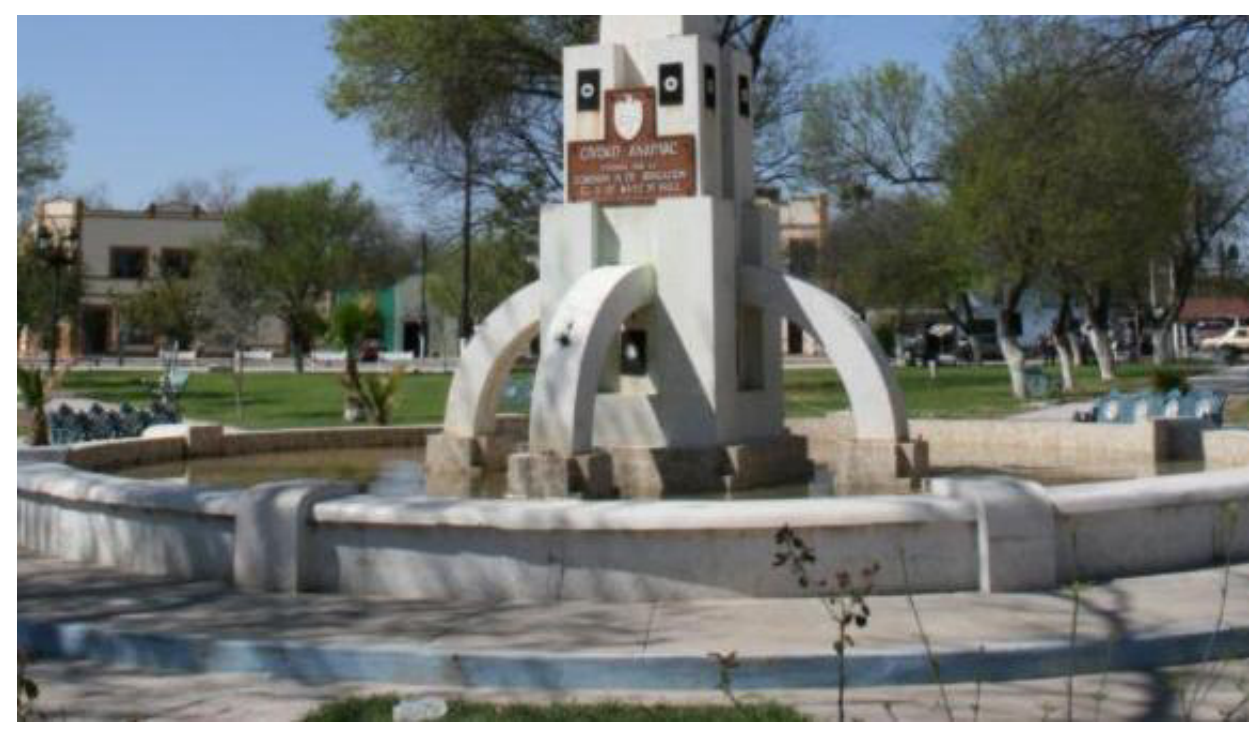

Detalle de la pila y las bandas que la envuelven. 


\section{b. Linares}

La ciudad de Linares se inicia como una pequeña Villa, fundada con el nombre de San Felipe de Linares en 1712 en honor al Rey Felipe V y al Virrey de la Nueva España Don Fernando de Alencastre Noroña y Silva, duque de Linares y marqués de Valdefuentes (1641-1717), quien ocupó gobernó el virreinato de 1710 a 1716. Paulatinamente la pequeña villa se fue poblando y se llevo a cabo la traza; para el año de 1774 ya había en la villa cerca de 1.500 habitantes.

Por su importancia y progreso que tuvo en la zona sur de Nuevo Reino de León y la contribución que tuvo para el desarrollo de otras villas y ciudades, la villa fue declarada ciudad y sede de la diócesis del mismo nombre en 1777 , con lo cual su crecimiento tanto poblacional como económico le permitió un amplio desarrollo para el consecuente siglo XIX.

Pasadas las guerras de Independencia y con la consumación de la misma, Linares siguió siendo un centro comercial de fuerte importancia y se destacó por su desarrollo en el ámbito educativo. Tuvo comunicaciones bien establecidas con diversas poblaciones y en 1890 se instaló el ferrocarril Linares-Monterrey.

En el siglo XX durante la alcaldía de Francisco Flores Saldaña, entre los años 19041907, se reestructuró la traza urbana y el apogeo que se veía en la ciudad se vino abajo durante los años de la Revolución. Sin embargo, para 1928 un nuevo impulso económico hizo que la ciudad volviera a retomar su cauce: la plantación de naranjos que hasta la fecha son los principales productos que se comercian y exportan. Otra fuente de su economía es la industria de los dulces de leche de cabra, típicos de la región y representantes de la gastronomía nuevoleonesa. $^{207}$

Algunas construcciones que se erigieron entre los años 30 y 40 como símbolo del progreso postrevolucionario aún se conservan en pie, de las cuales destacamos cuatro que ostentan elementos del Art Déco.

\footnotetext{
${ }^{207}$ La información de Linares fue tomada del trabajo de Armando Leal Ríos, "Linares. Primera sede episcopal de Nuevo León", VV. AA. Nuevo León a través de sus municipios. Tomo III, Monterrey, N.L., Milenio, Multimedios, 2010.
} 


\section{b.1. ARQUITECTURA COMERCIAL}

\section{b.1. 1. Gasolinería}

En el cruce de las calles Hidalgo y Carlos García Gutiérrez con orientación hacia el norte, en lo que son las orillas del centro de Linares, se ubica una gasolinería que fue construida en 1936, pero que en una reciente remodelación fue destruida y sólo se conservó el portal donde estuvo la bomba despachadora. En el plano del Catálogo de Monumentos de Nuevo León se aprecia cómo era el inmueble y en la parte que fue derruida ahora se encuentra una moderna estación de gasolina. Sólo la parte frontal en líneas punteadas es lo que quedó en pie.

La decoración que ostentaba el edificio hizo que fuera catalogado por el INAH y lo que quedó del inmueble sigue llamando la atención, por lo que en la Guía de Patrimonio Arquitectónico de Nuevo León dice lo siguiente: "Sin duda, destaca el hecho de que por ser una gasolinera, supondría que no fuera resuelta de manera artística, pero esta esquina es de particular interés por su estilo vinculado al Art Déco, denotado por el escalonamiento de los perfiles". 208

La parte que se conserva consiste en un portal sostenido por cuatro columnas cuadradas de concreto, una pared trasera, techumbre y adornos. Un pequeño pretil recorre perimetralmente el techo por arriba; en las esquinas, así como en ambas partes laterales se elevan a manera de almenas escalonadas unos adornos, en los que se resalta una moldura que recorre todo el pretil. Estos adornos geométricos son típicamente de la etapa Art Déco Zigzag. La techumbre se prolonga del límite formado por las columnas y el pretil, formando así por los tres lados unos aleros que le imprimen un sentido de proyección hacia el exterior.

En los extremos de la pared trasera, un par de pilastras ochavadas y recortadas (difíciles de captar con el semáforo y el poste de luz que se atraviesan) se prolongan hacia atrás del muro en la parte superior, elementos muy distintivos de las construcciones Déco, así como el adorno central de la pared que se eleva por encima de la techumbre, el cual

\footnotetext{
${ }^{208}$ José Manuel Prieto, Guía de Patrimonio Arquitectónico de Nuevo León, Monterrey, N.L., Consejo para la Cultura y las Artes, 2009, p. 52.
} 
consiste en un escalonamiento de cinco niveles resaltado por una molduración y que se recorta hacia abajo en la parte central, lugar donde se inserta la fecha de construcción de 1936, la cual está enmarcada por una filete en forma de rectángulo con escalonamientos descendentes hacia abajo y con un pequeño cuadrado inserto en la parte inferior.

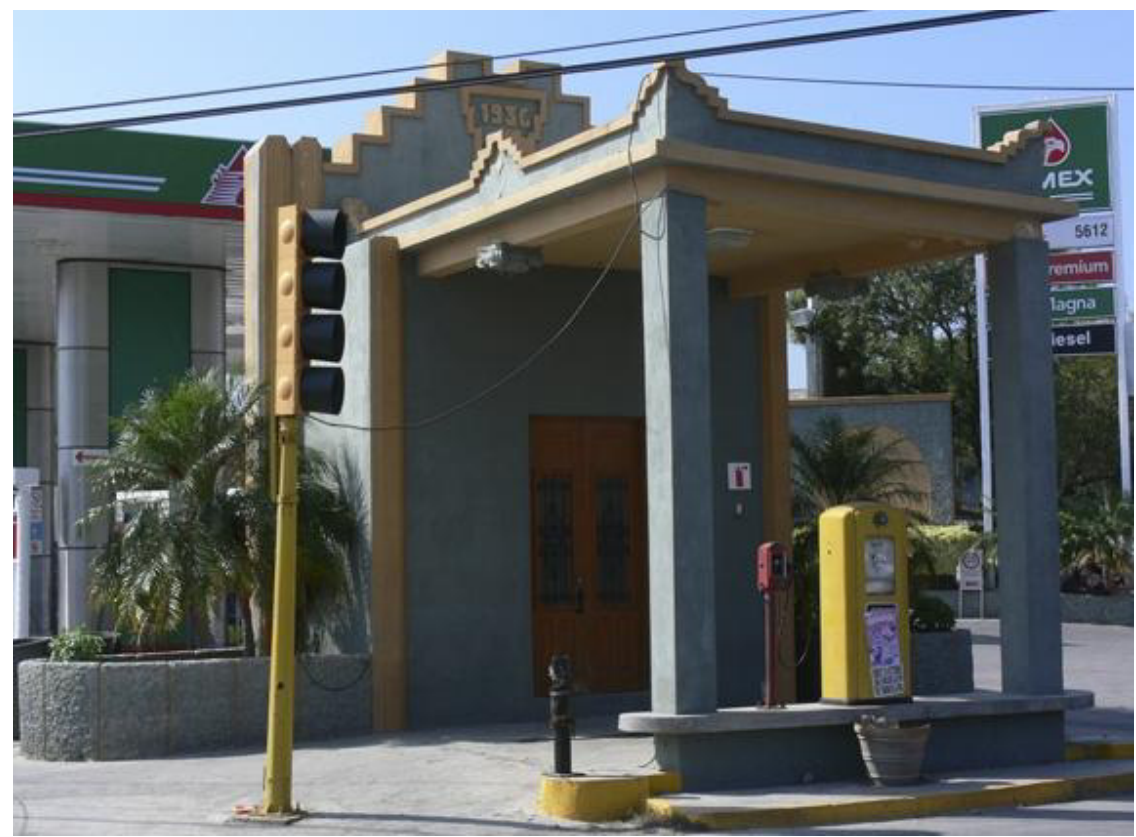

Antigua estación de gasolina.

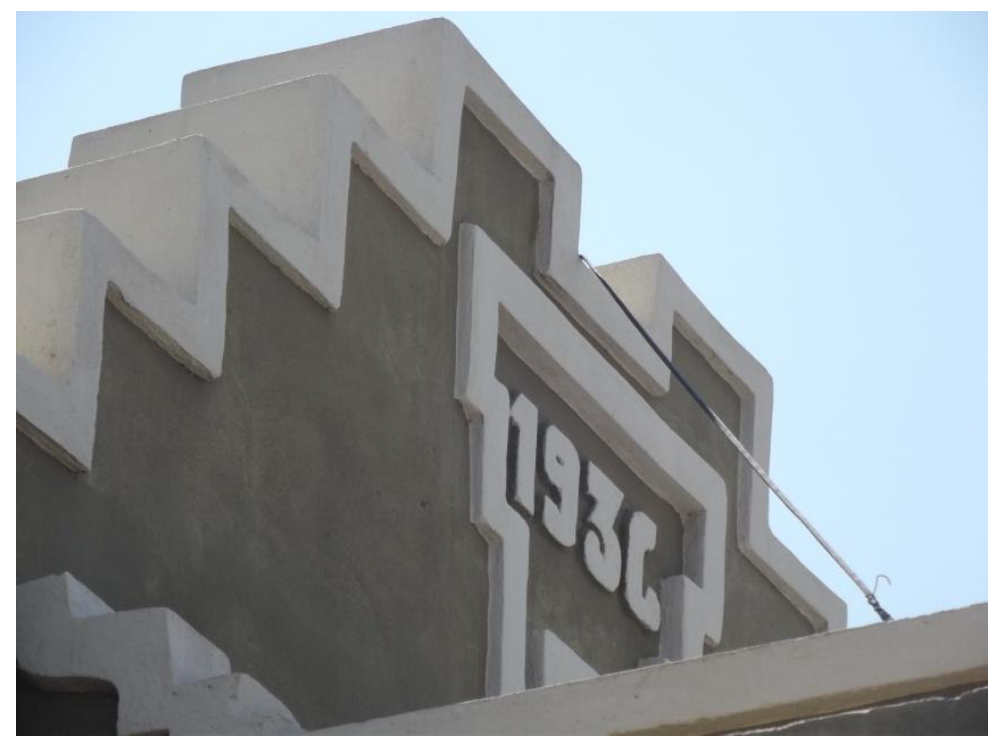

Detalle de la fecha. 
A pesar que se preserva solamente esta parte de lo que fue un comercio más amplio, afortunadamente podemos apreciar los elementos decorativos del tipo Déco Zigzag, incluyendo la fecha de construcción, con lo cual aunque sea un ejemplo de pequeñas dimensiones, su calidad decorativa lo hace un espécimen de muy buena calidad del estilo Art Déco dentro de la Tendencia Geometrista.

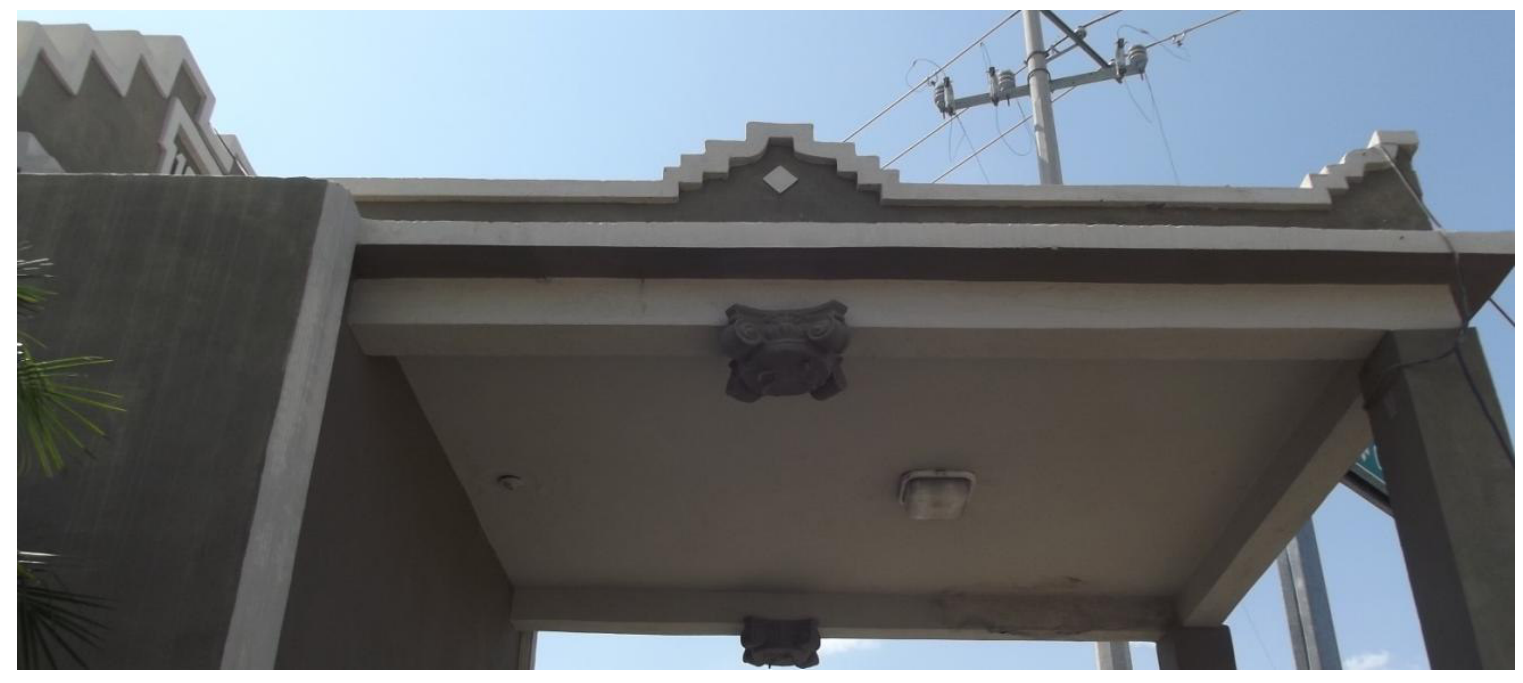

Detalle de la decoración Déco Zigzag.

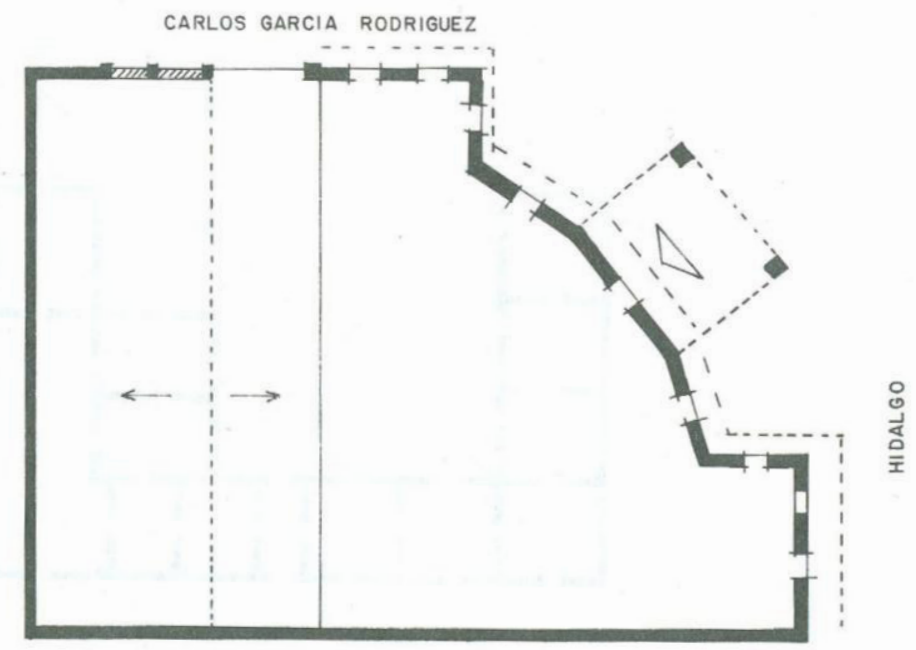

Plano de la gasolinería.

INAH; SEP. Catálogo Nacional de Monumentos Históricos Inmuebles. Nuevo León. Tomo 3, México, SEP, INAH, Programa Cultural de las Fronteras, Gobierno del Estado de Nuevo León, 1984, p. 1333 


\section{b.1.2. Casa-comercio Melesio Elizondo}

En las esquinas de las calles Morelos y Allende en el centro de Linares se encuentra una modesta tienda donde antes estuvo, hasta la década de los ochenta del pasado siglo, un comercio llamado "Melesio Elizondo". Actualmente la tienda es de abarrotes en general y a la vez funciona como casa habitación. Tiene dos fachadas: la de la calle Morelos que mira hacia el sur es más grande y la de la calle Allende que da hacia el poniente es menor dimensión.

No encontramos datos de su construcción, ni autor ni fecha, sólo en el Catálogo de Monumentos Históricos del Instituto Nacional de Antropología e Historia está como una edificación del siglo XX ${ }^{209}$, que por sus elementos compositivos consideramos que haya sido construida en la década de los años treinta. Los materiales utilizados fueron sillares para las muros y cemento para los aparejos de las paredes. El edifico es de una sola planta y tiene la forma de un rectángulo. En el interior aún conserva parte de techumbre con viguería que en algunas partes de la casa ha sido substituida por placa de concreto.

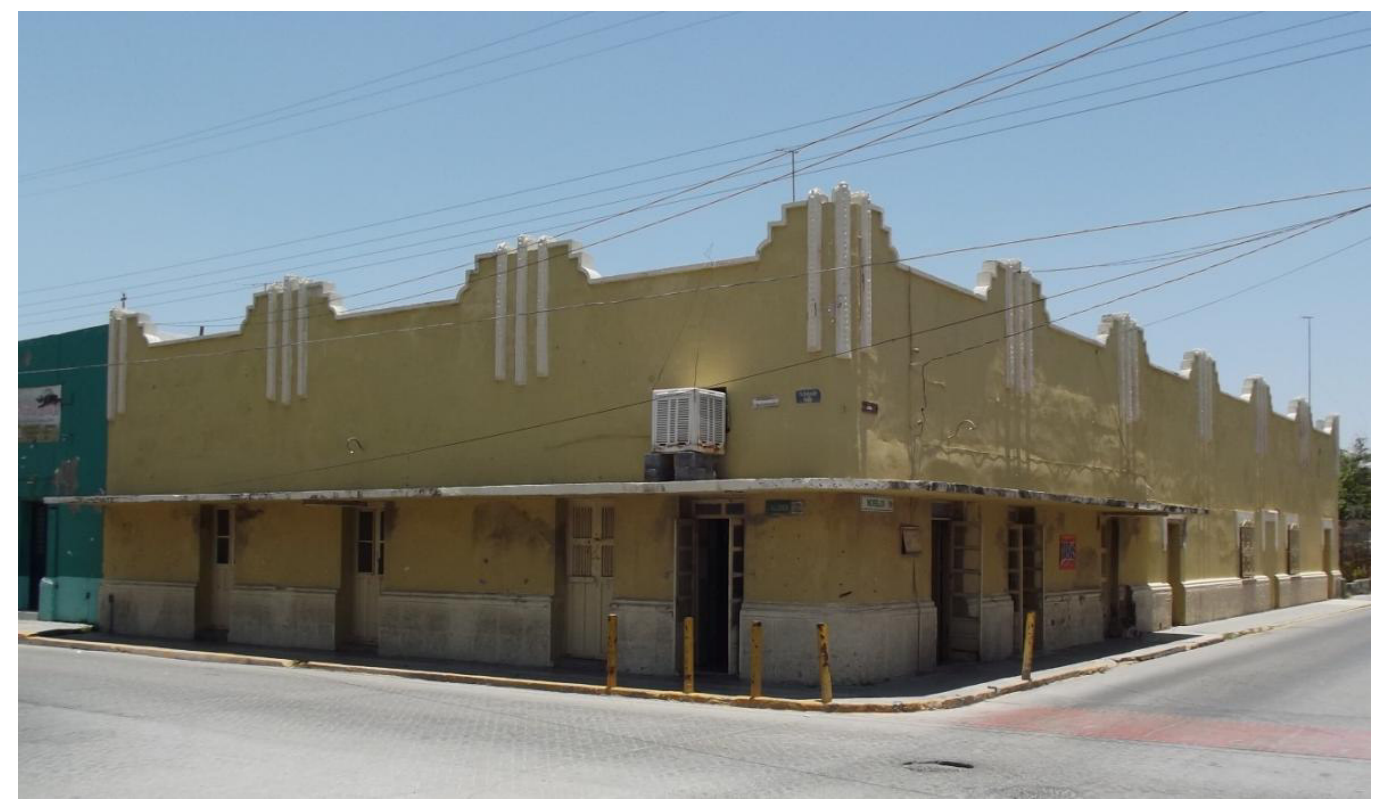

Vista general.

209 INAH, Catálogo Nacional de Monumentos Históricos Inmuebles. Nuevo León, Tomo 4, México, SEP, INAH, Programa Cultural de las Fronteras, Gobierno del Estado de Coahuila, 1986, p. 1333. 
Por la calle Allende la casa tiene cuatro puertas de entrada, una de las cuales que es la primera de derecha a izquierda es acceso a la tienda y por la Morelos son seis las puertas, la primera y segunda de izquierda a derecha también son entradas al comercio.

Toda la casa lleva un rodapié de cemento corrugado en color blanco que ya no es el original y que lo delimita una doble moldura. Una marquesina de concreto sin ningún tipo de decoración cubre las cuatro entradas de la calle Allende y solamente tres de las calle Morelos.

En todo el edificio en la parte superior corre una moldura que se va elevando escalonadamente con tres recortes: el primero es curvo y los dos siguientes angulares. Las elevaciones forman piñones donde la moldura del remate que recorre todo el inmueble recibe a grupos de tres gruesas molduras verticales estriadas, de las cuales la central es más larga. Estas molduras van adornadas con pequeñas pomas y se prolongan envolviendo al piñón, como si lo sujetaran por la parte de arriba, característica muy típica de las construcciones Art Déco Zigzag, lo mismo que los escalonamientos de la moldura del remate.

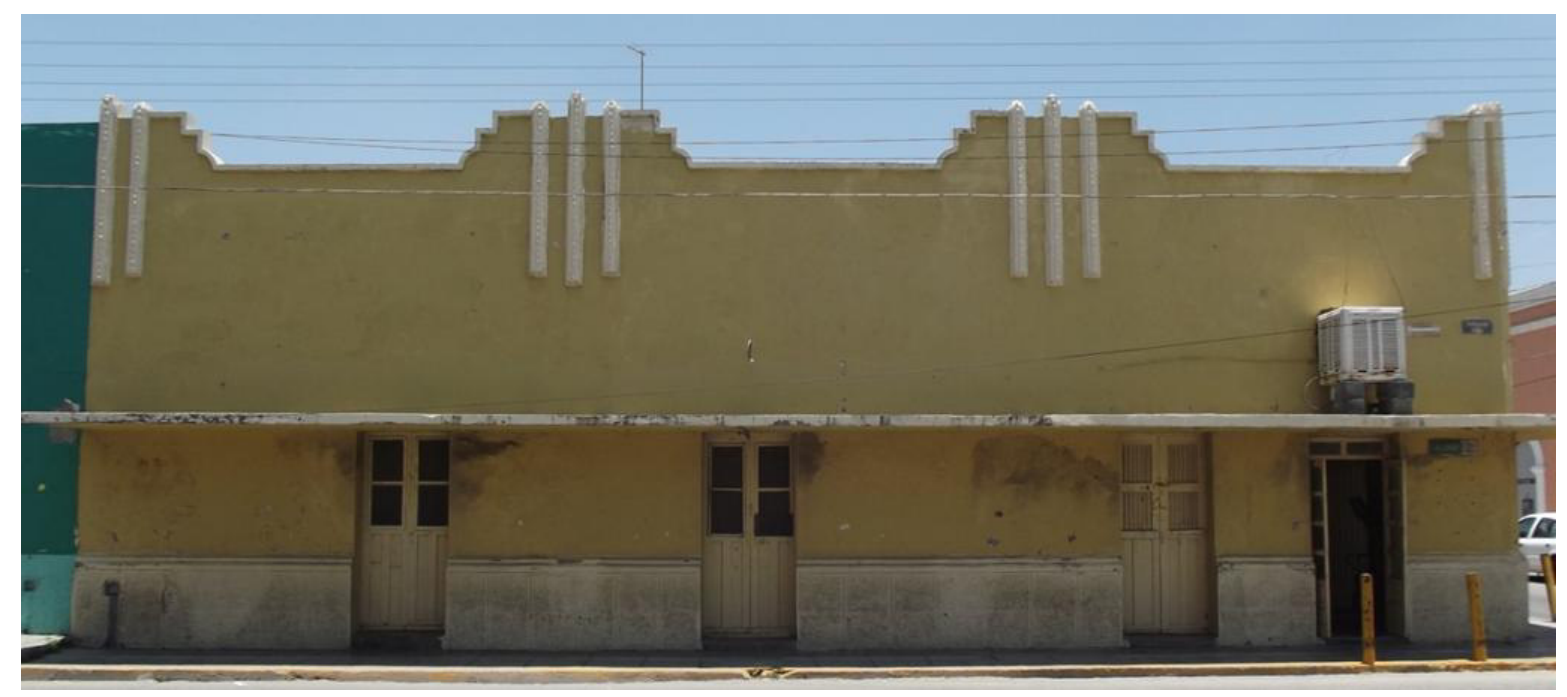

Fachada de la calle Allende o poniente.

En la fachada de calle Allende o poniente son tres los grupos de molduras: de izquierda a derecha, el primero solamente lleva dos molduras, mientras que ya el segundo y tercer piñón son tres las molduras. En la esquina de la calles Allende y Morelos, la moldura central marca la unión de los lienzos, para continuar en la fachada de calle Morelos o sur 
con seis grupos de molduras, terminando el último piñón solamente con dos molduras, donde concluye la construcción.

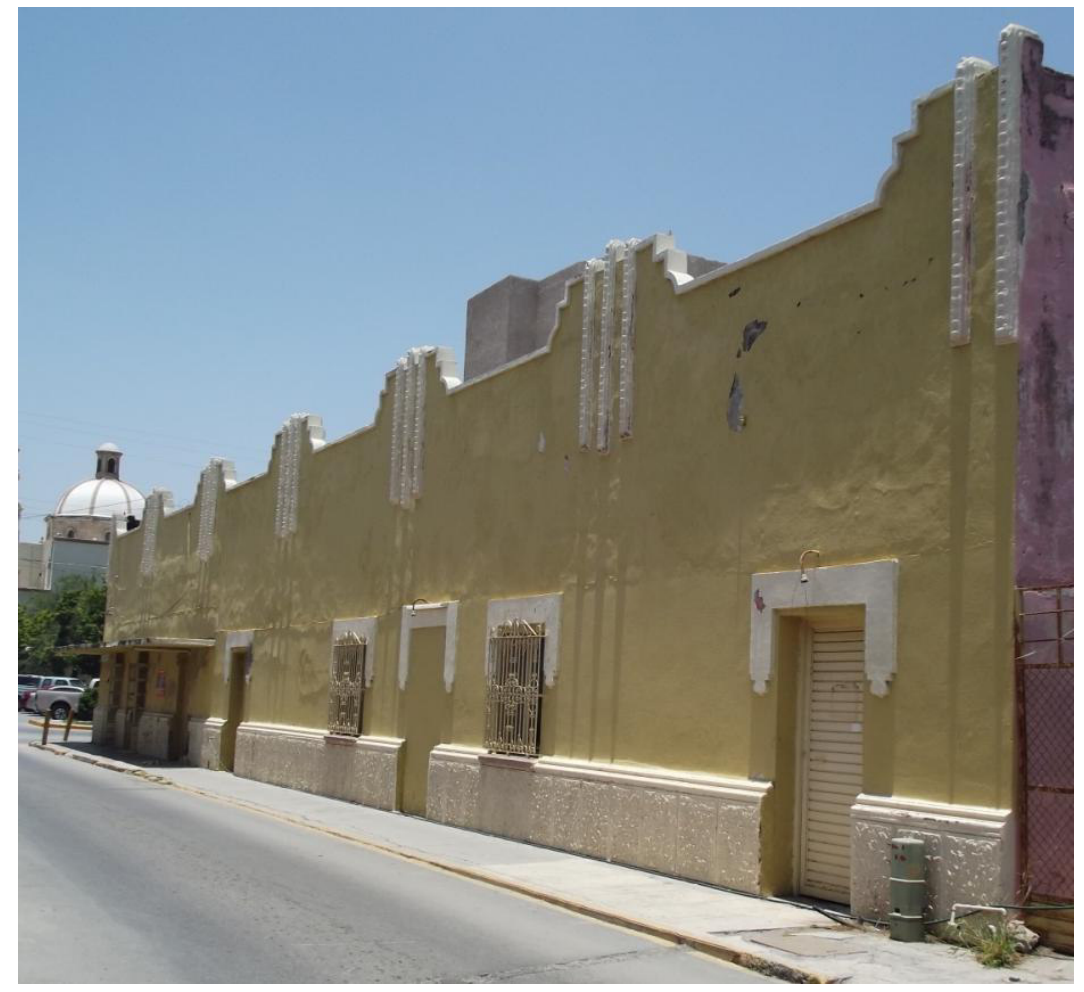

Fachada de la calle Morelos o sur.

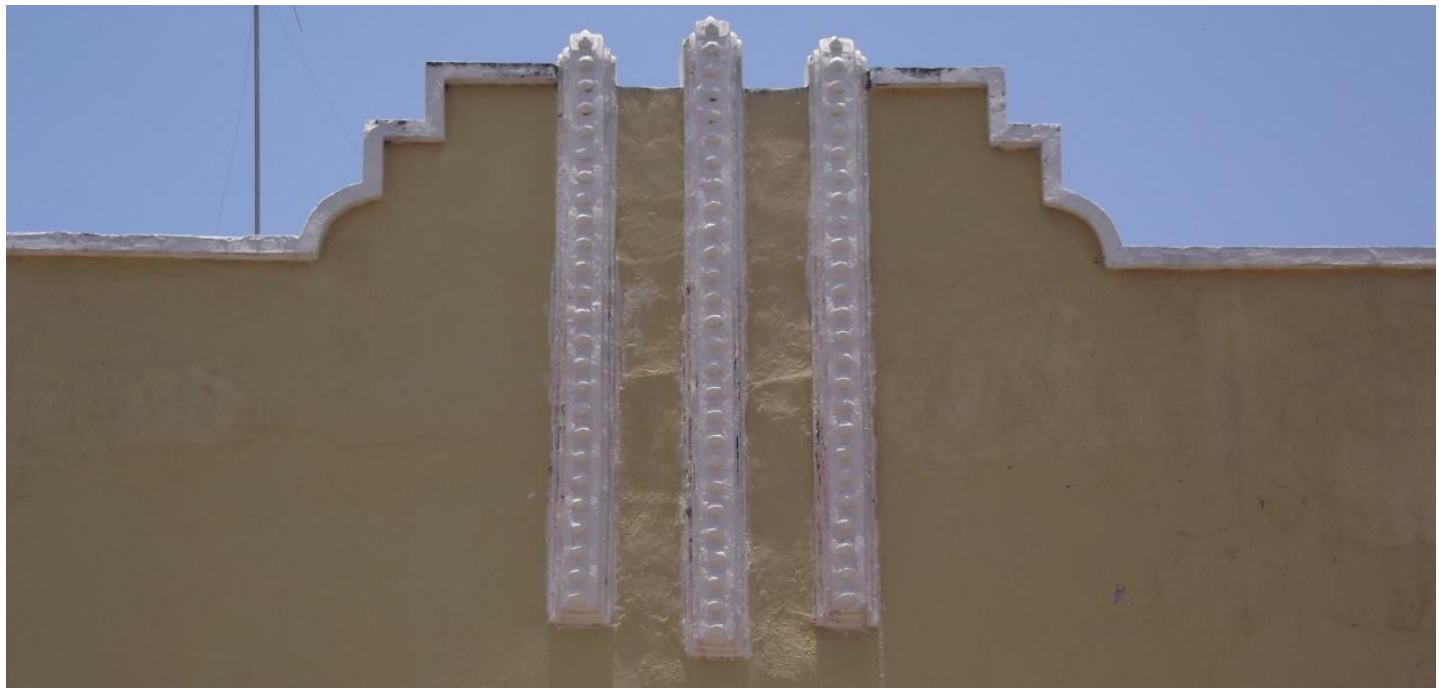

Detalle de la moldura de la parte superior, un piñón y las molduras estriadas con decoraciones de pomas. 
En el interior de la casa no se conserva decoración alguna y el deterioro es notable. A pesar de ser una sencilla construcción, son rescatables e interesantes las composiciones Art Déco Zigzag que ostenta en las fachadas, que además debido a los ornatos también es un caso del Déco de la Tendencia Decorativista.

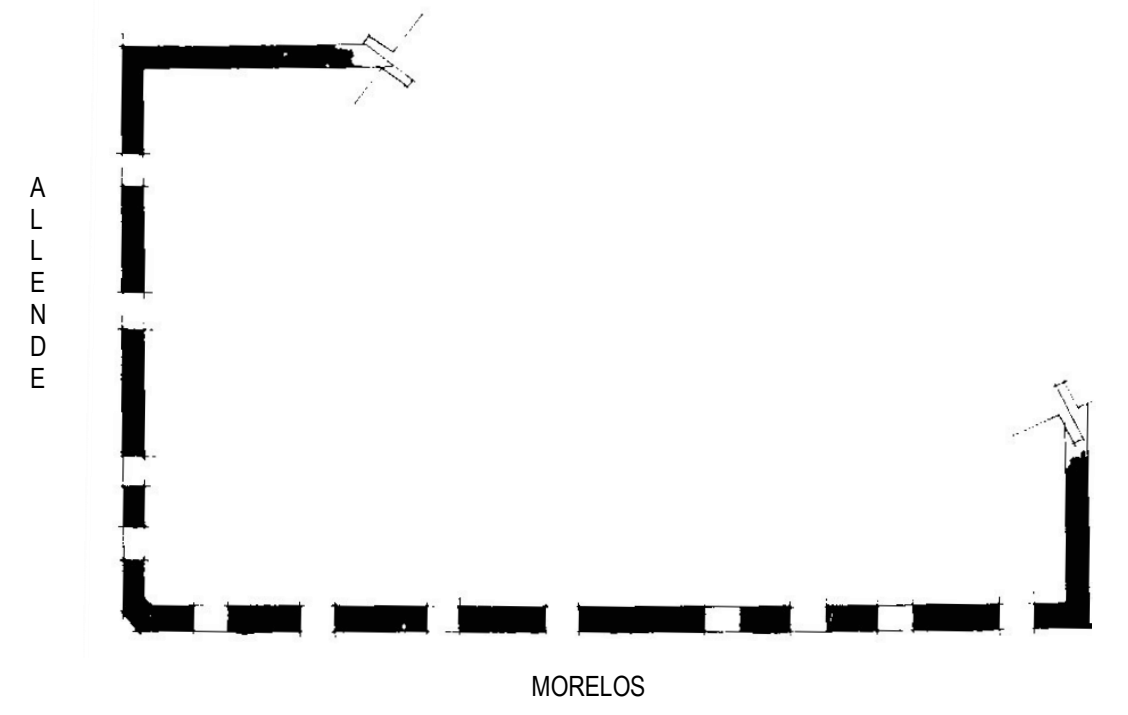

Plano de la Casa-Comercio.

INAH, Catálogo Nacional de Monumentos Históricos Inmuebles. Nuevo León, Tomo 4, México, SEP, INAH, Programa Cultural de las Fronteras, Gobierno del Estado de Coahuila, 1986, p. 1333.

\section{b.1.3. Botica Morelos}

La Botica Morelos se ubica en la calle Morelos 107, esquina con Madero, con fachadas en ambas calles: la de la calle Morelos mira al norte y la de la calle Madero al poniente.

La fundación de esta botica data de 1924, cuando su propietario el señor Pablo Salce Arredondo (1899-1973), decide crear este tipo de negocio después de haber trabajado para un médico de nacionalidad francesa. De formación autodidacta, el señor Salce Arredondo fue un apasionado de la historia de México y con un fuerte espíritu nacionalista indigenista es que decidió construir su negocio farmacéutico bajo ese estilo, ya que la casa 
donde fue instalada la botica era una construcción porfiriana de principios del siglo XX y que fue remodelada. Quince años duraron las obras para darle la forma al inmueble, pues es en 1939 cuando la Botica Morelos toma su apariencia que se conserva hasta la fecha. Desafortunadamente no encontramos datos de autoría y construcción, sin embargo la señora Martha Rodríguez ${ }^{210}$ empleada de la botica desde hace treinta y dos años, nos informó que la heredera y propietaria actual María de la Luz Salce González, hija del señor Pablo Salce y su esposa Elvira González, no tiene la información, a pesar de tener constantemente visitas para reportajes televisivos, periodísticos e históricos, pues como ella misma dice que fue su propio padre quien elaboró los diseños de construcción para toda la casa y el negocio, así como los aparadores, muebles y equipos tanto de la botica como de oficina, dándoles indicaciones a los trabajadores y dirigiendo personalmente las obras.

Es primordial mencionar que en la ciudad de Linares hay una escuela Primaria que lleva el nombre de Pablo Salce Arredondo y en la Biblioteca de la Universidad de Texas en Austin, en la Benson Latin American Collection se conserva su biblioteca personal con su nombre, abarcando libros principalmente de historia de México desde 1594 hasta 1965.

La construcción tiene sillares en los muros y techumbre de placa de concreto con vigas de acero. Los aplanados de los muros son de cemento. Es de un solo piso y la planta es forma de rectángulo.

La Botica Morelos es un caso excepcional en Linares, ya que es todo un referente por su acendrado estilo nacionalista indigenista, destacando los diseños de corte mexica o azteca y mayas.

En la fachada de la calle Morelos, de izquierda a derecha hay una puerta que es de acceso a las oficinas, para luego continuar con una ventana y cuatro puertas. En la calle Madero también de izquierda a derecha primero hay una puerta de acceso, después un recuadro, continuando con una ventana y después tres puertas, siendo la última más ancha.

Haremos la descripción del exterior del edificio iniciando por la parte baja y letreros de las fachadas, para dejar al final las decoraciones de la parte alta que abarcan toda la botica.

${ }^{210}$ Entrevista con la señora Martha Rodríguez en la Botica Morelos el viernes 28 de junio de 2013. 


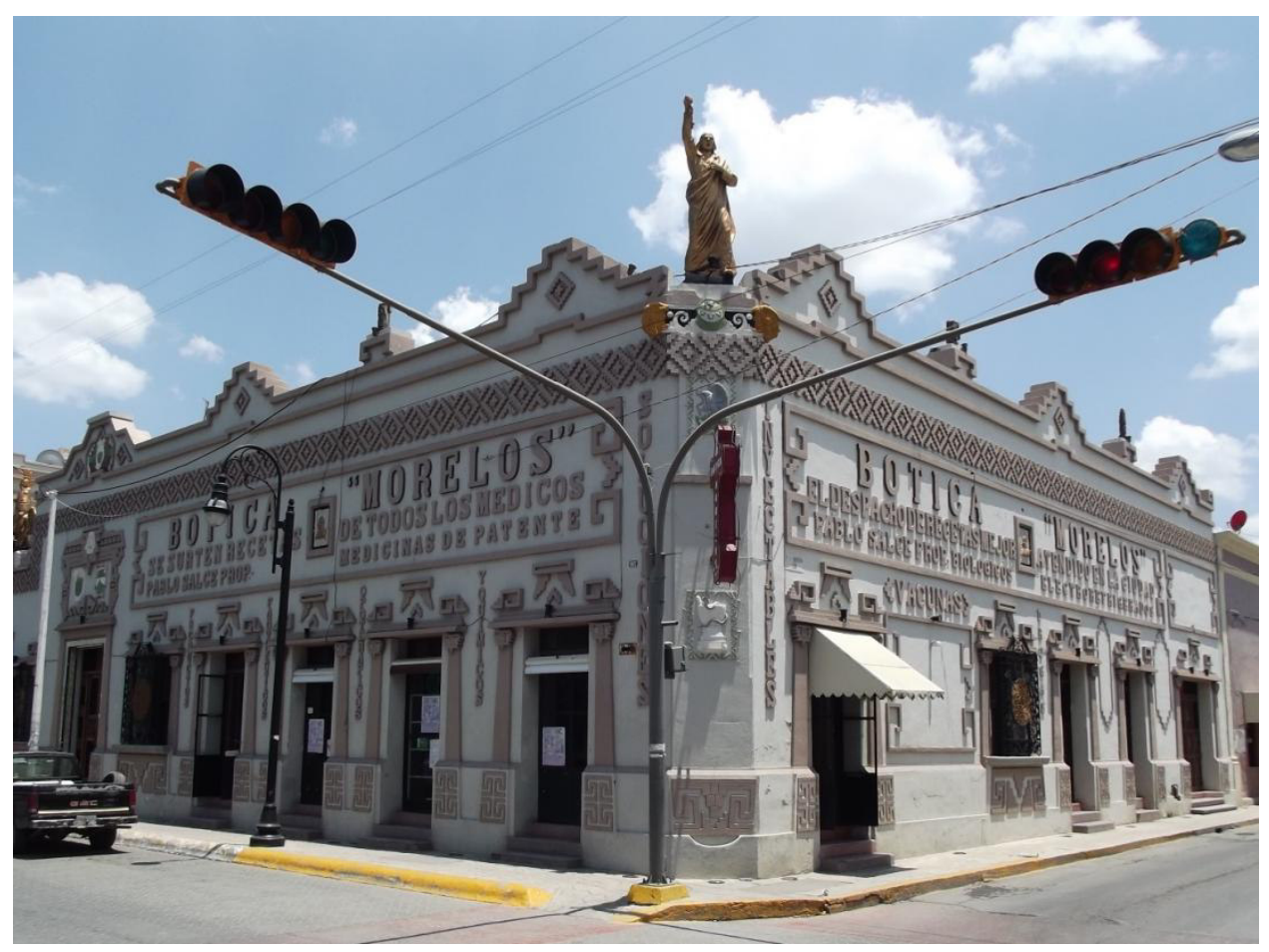

Vista general.

En la calle Morelos en la fachada norte, iniciando con la primera puerta de izquierda a derecha, ésta lleva tres peldaños forrados con losetas en rojo. El perímetro del vano está forrado con azulejos en amarillo, azul claro y obscuro con ornatos de grecas escalonadas con formas de escuadras y una pequeña espiral geometrizada. En lo que equivale al zócalo, unos bajorrelieves planos tienen la forma de unas cruces que se parecen a los dibujos que los indios huicholes plasman en su telares y objetos artesanales. Las jambas también en bajo relieve plano, se abren para dar la idea de la base de una plataforma piramidal, ya que se junta con la trabe que pasa por encima de la parte superior de la puerta. Una cornisa tripartita y escalonada igualmente simula una construcción prehispánica.

Por encima de la puerta y a manera de ábaco, están enmarcados dos escudos: el de la izquierda es el de Monterrey, con el indio apuntando hacia el sol, el cerro de La Silla y los naranjales; el de la derecha no hemos podido descifrarlo y tal vez se refiera a una invención del señor Pablo Salce sobre el linaje familiar. Lugareños afirman que es el escudo de Linares, pero no corresponde en nada con dicha heráldica.

El enmarcamiento de los escudos consiste en abstracciones de diseños mexicas. En la parte baja unas figuras geométricas escalonadas y con espirales están acompañadas por 
vírgulas geométricas. A los lados grupos de vírgulas se enlazan con un recuadro que protege a un rectángulo más pequeño y en la parte superior una plataforma con taludes resguarda a pirámides truncadas. Al centro, un escudo blanco con el águila nacional y el sol, está dentro de un contorno que termina en la parte baja con una punta de maguey.

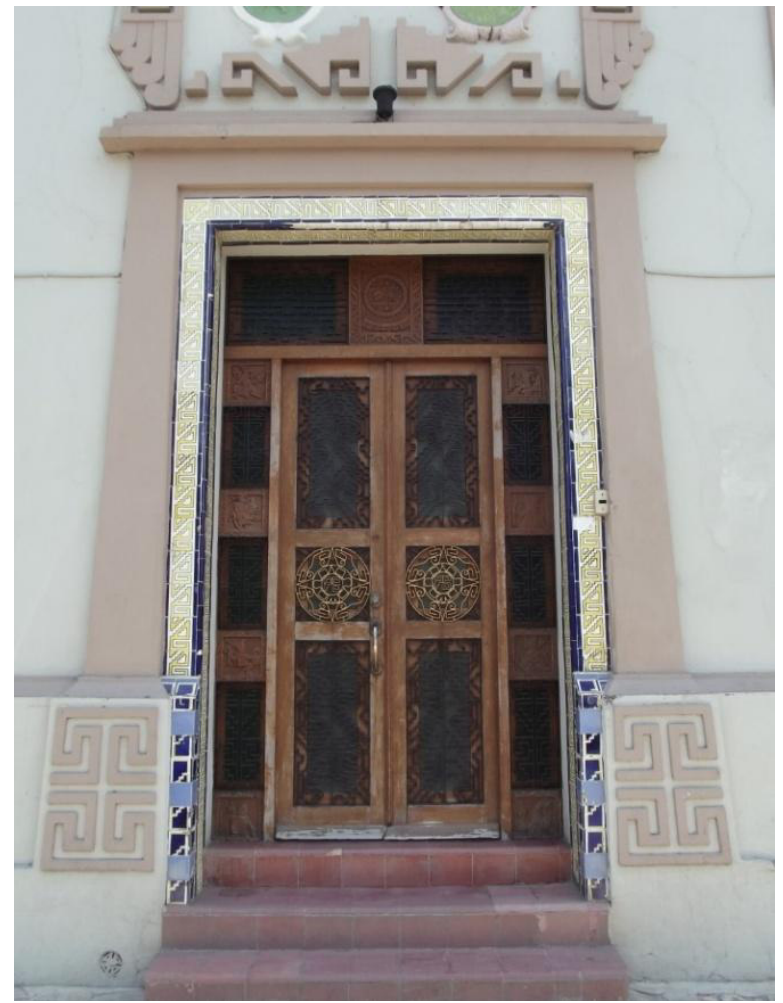

Primera puerta de izquierda a derecha de la fachada norte sobre la calle Morelos.

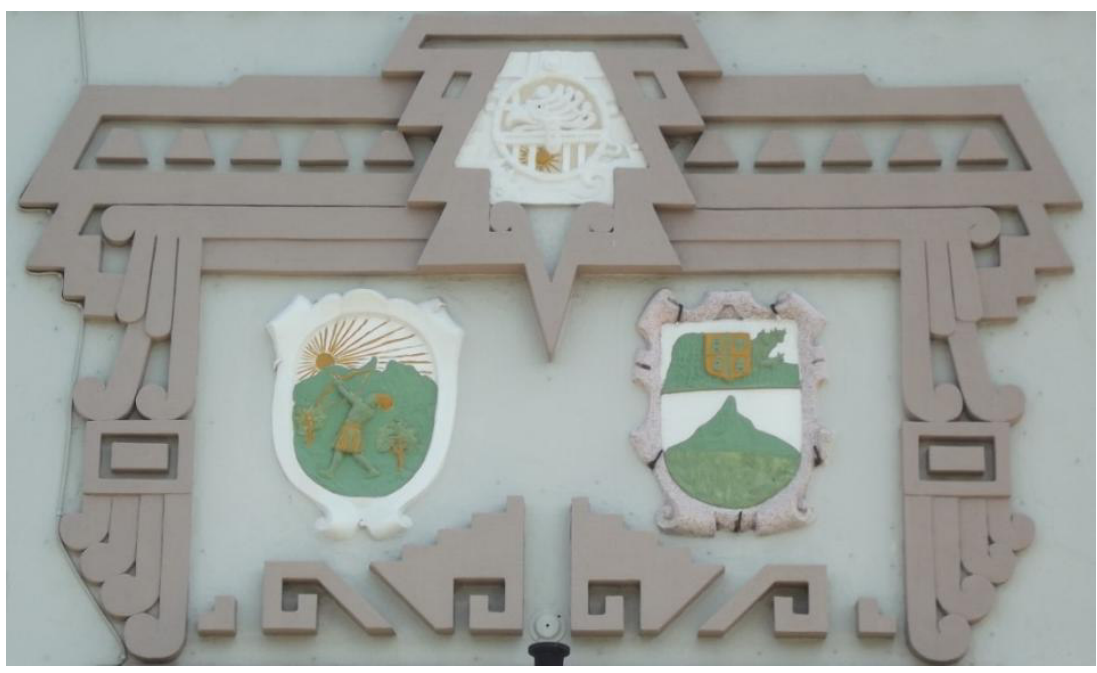

Detalle del ábaco de la primera puerta de la fachada norte sobre la calle Morelos. 
En la misma fachada norte después de la puerta sigue la ventana, pero la describiremos cuando tratemos la de la fachada poniente, ya que son iguales.

Continúan cuatro puertas que comparten las mismas características. Para entrar hay tres peldaños forrados con losetas rojas. Igual que la primara puerta, en lo equivalente al zócalo llevan un adorno que forma una cruz. Las jambas levemente inclinadas son más amplias en la parte de abajo y se van reduciendo mínimamente. Los capiteles se forman por un contorno de cuatro zigzags a los lados, en donde el tercero se prolonga formando un rombo y una punta de maguey en la parte inferior; en la parte interior del capitel dentro de un ovoide, un triángulo isósceles simboliza la espina de maguey para el autosacrificio. La cornisa es tripartita y escalonada y por arriba de ésta y en la misma dirección de los capiteles, unas espirales geometrizadas y con adornos escalonados escudan a un pequeño motivo decorativo también compuesto por escalones tanto en la parte interior como exterior. Finalmente, en lugar del tímpano, un rectángulo horadado sostiene unas ínfulas recortadas geométricamente en la parte interior que caen oblicuamente. Todos los ornamentos de las puertas matizan abstracciones geométricas de diseños mexicas, que como mencionamos en el capítulo 2, iban muy de acorde con el Art Déco, especialmente del periodo Zigzag.

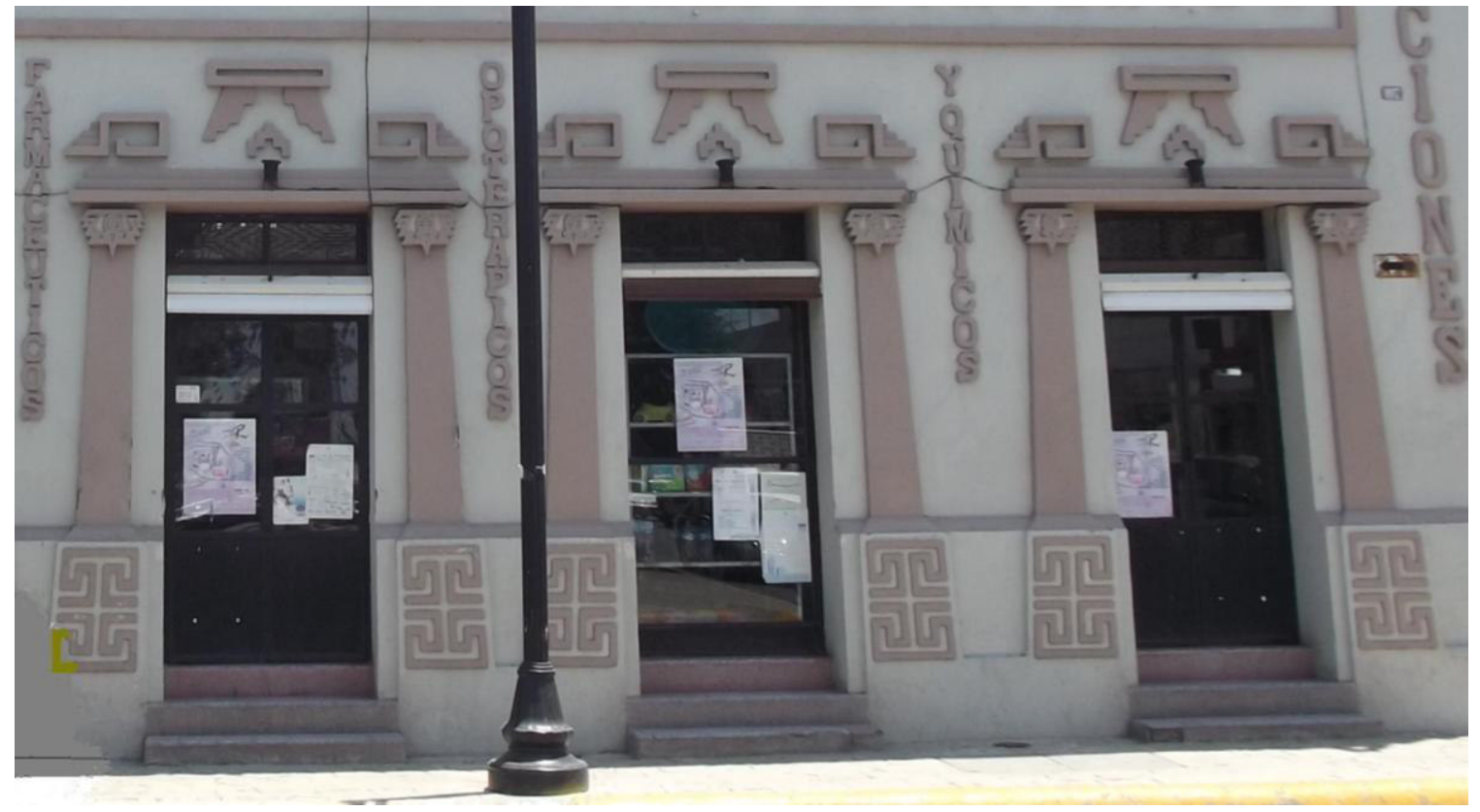

Tres de las cuatro puertas de la fachada norte sobre la calle Morelos. 
Entre los espacios de la ventana y las puertas hay unos letreros verticales que dicen textualmente: PRODUCTOS FARMACEUTICOS OPOTERAPICOS Y QUIMICOS. Por arriba un letrero con el nombre de la botica en letras grandes va enmarcado rectangularmente por una moldura, en cuyos lados se forman unas espirales geométricas y unos ornatos escalonados como los que llevan las puertas arriba de la cornisa:

\section{BOTICA "MORELOS" \\ SE SURTEN RECETAS DE TODOS LOS MEDICOS \\ PABLO SALCE PROP. MEDICINAS DE PATENTE}

En medio de este letrero se encuentra enmarcado un busto de color dorado en bajo relieve del cura José María Morelos y Pavón (1765-1815), héroe de la insurgencia, personaje en cuyo honor el señor Salce denominó a su botica, además por estar ubicada en esa calle.

Al final del muro y con letras de mayor tamaño colocadas verticalmente se lee: SOLUCIONES.

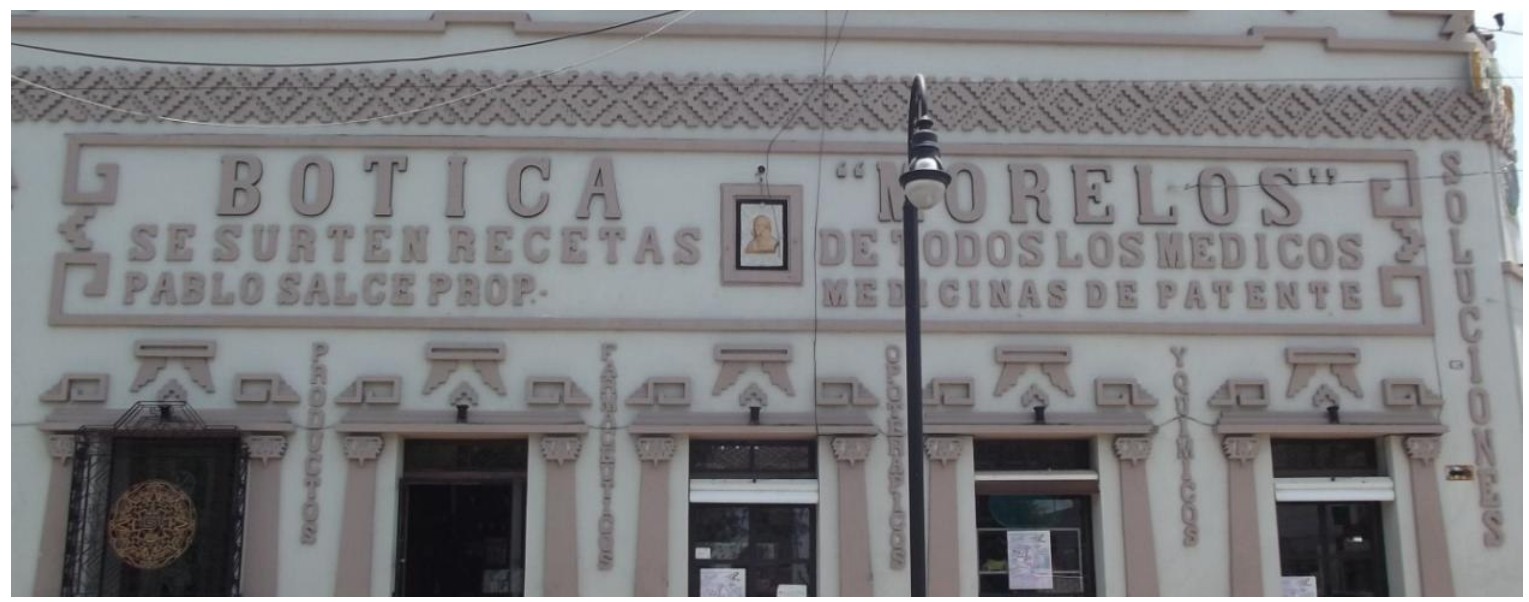

Letreros de la fachada de la calle Morelos.

En la calle Madero en la fachada poniente hay cuatro puertas que tienen la misma decoración que las de la calle Morelos; la última puerta donde se acaba el edificio tiene la diferencia de ser más ancha en el vano. Entre la primera puerta y la ventana, hay uno recuadro con el mismo diseño del letrero de la calle Morelos, mismo que se repite por arriba de la última puerta, mientras que en los espacios que hay entre la segunda, tercera y cuarta puerta están colocados unos adornos consistentes en unos recuadros colocados 
verticalmente, cuyas partes superior e inferior son recortes angulares escalonados que remiten a los diseños decorativos mexicas.

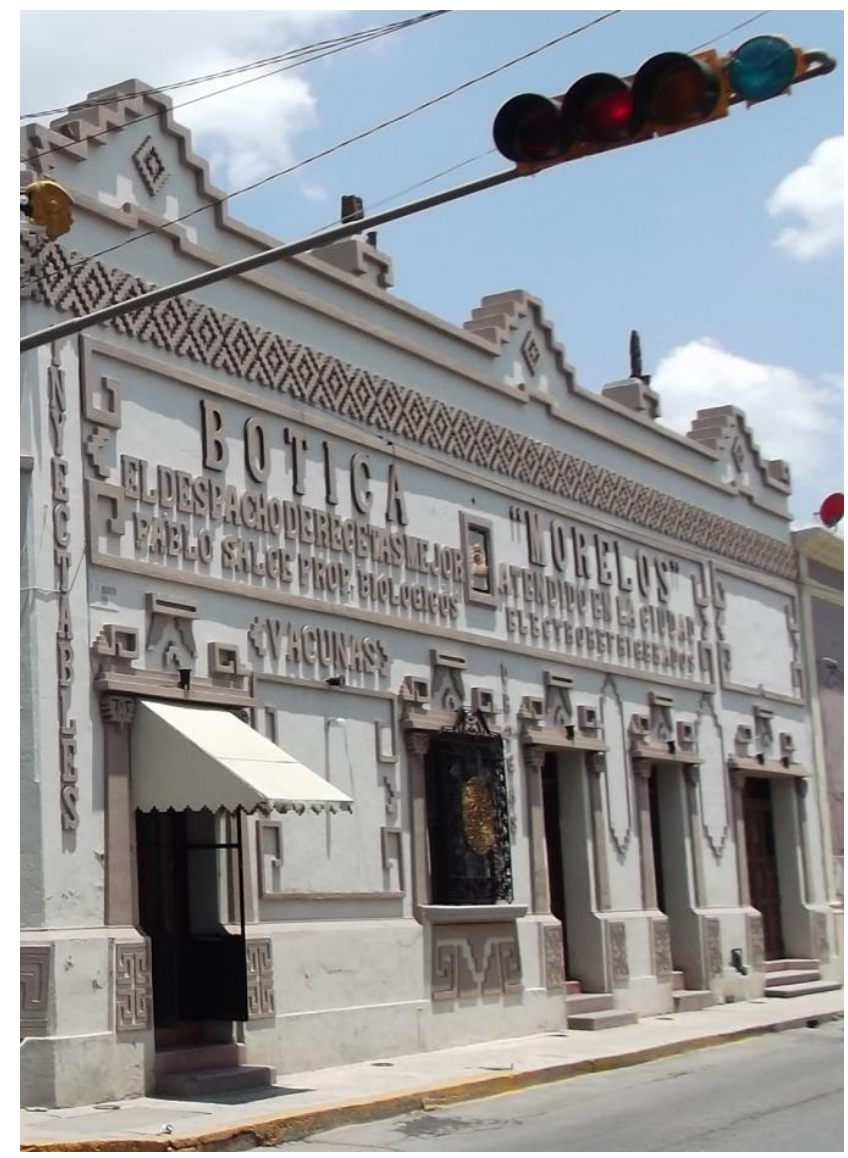

Fachada poniente sobre la calle Madero.

La ventana, que es idéntica a la de la fachada norte en la calle Morelos, también lleva la misma composición de las puertas en lo concerniente a las jambas, capiteles, cornisas y ornamentos de la parte superior; por debajo del repisón hay un adorno compuesto por dobles espirales geometrizadas que convergen hacia una pirámide invertida colocada en el centro y que hace juego con dos escuadras escalonadas colocadas en la parte inferior. Todo este adorno lleva un trazo de trapecio, recordando las plataformas piramidales prehispánicas.

La herrería de la ventana está conformada por grecas que componen los cuatro soles de la cosmovisión mexica que apuntan en direcciones intermedias de los puntos cardinales y al centro en color dorado, el círculo que representa al quinto sol, en una clara 
interpretación de la Piedra del Sol mexica. La parte superior termina de forma trapezoidal, en cuyo interior se reproducen plataformas piramidales escalonadas. Geometría e indigenismo prehispánico mexica, dentro de la estética del Art Déco Zigzag.

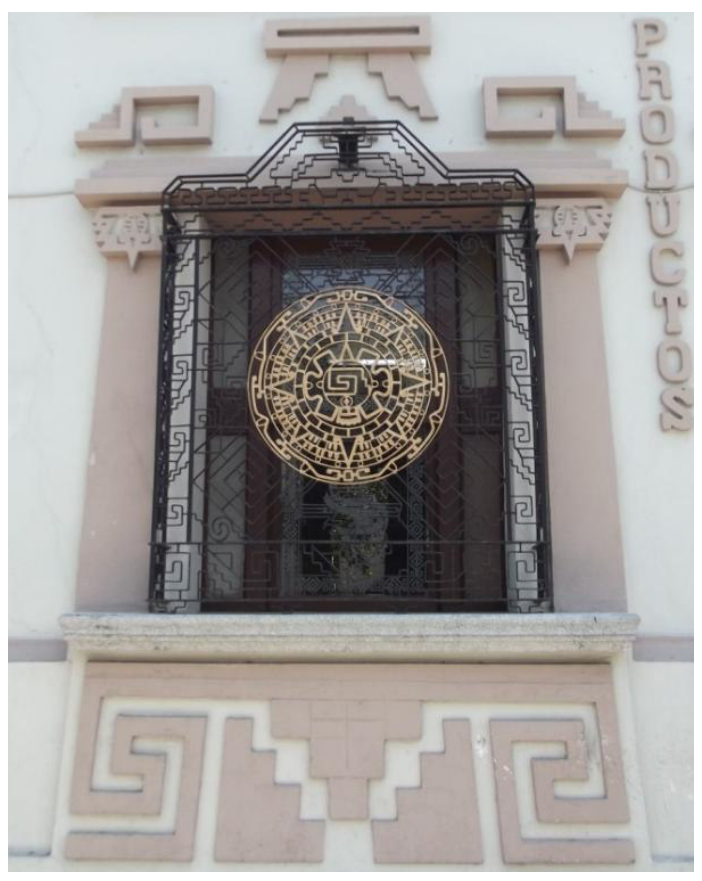

Ventana de la fachada norte en la calle Morelos.

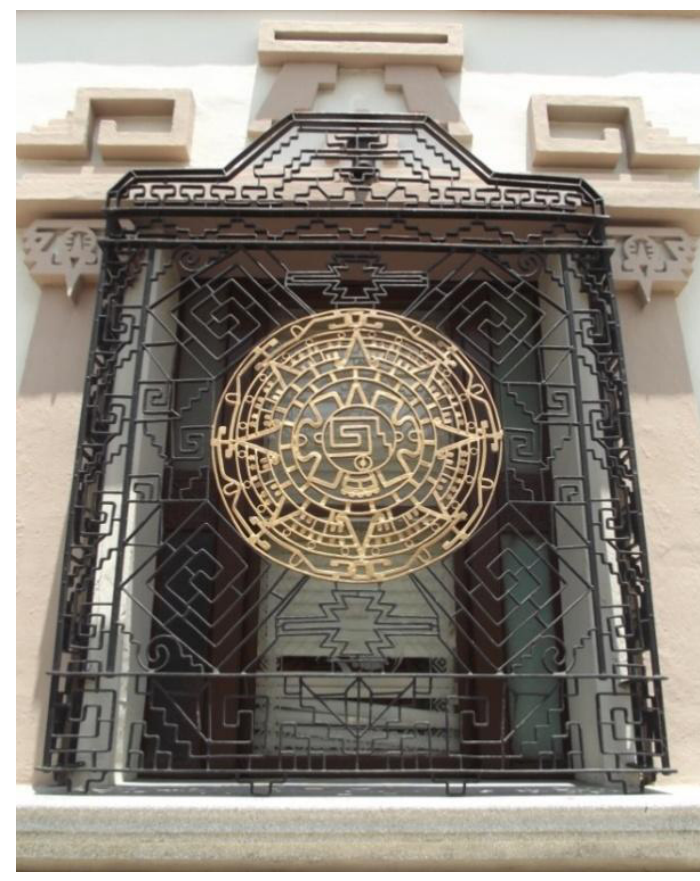

Herrería de la ventana de la fachada poniente en la calle Madero.

Los letreros de la fachada poniente sobre la calle Madero se inician con el de INYECCIONES, colocado verticalmente al lado izquierdo de la primera puerta. Luego el de VACUNAS, acompañado por ornatos escalonados, que se encuentra arriba del recuadro ubicado entre la primera puerta y la ventana. Y uno más en posición vertical entre la ventana y la segunda puerta: DROGAS.

Un letrero de gran tamaño abarca toda la fachada por arriba de las puertas y ventanas y lleva el mismo enmarcamiento como el de la fachada norte, así como el busto de Morelos en el centro. La inscripción fielmente indica:

BOTICA "MORELOS"

EL DESPACHO DE RECETAS MEJOR ATENDIDO EN LA CIUDAD PABLO SALCE PROP. BIOLOGICOS ELECTROREFRIGERADOS 


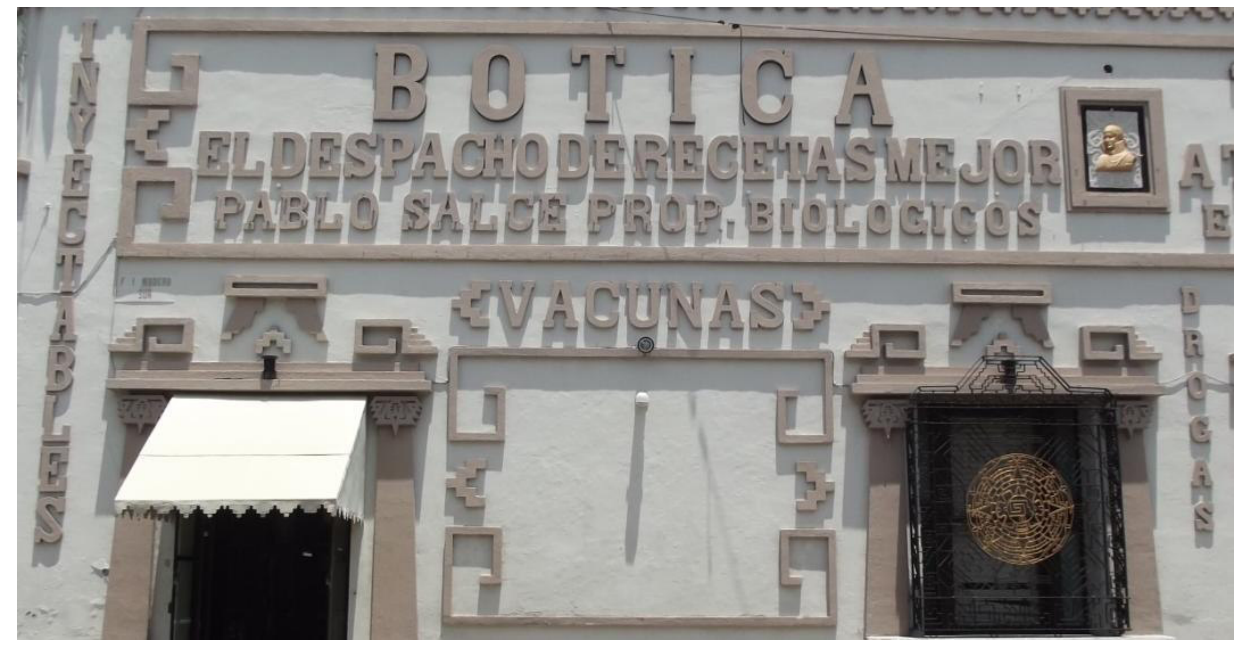

Detalle de los letreros de la fachada poniente en la calle Madero.

En la intersección de las dos fachadas, la unión forma un muro en ochavo de dimensiones cortas. En el segmento equivalente al zócalo, la decoración es similar a la de la parte baja de las ventanas, sólo que ésta está más comprimida. Al centro del muro un relieve de un mortero con su pilón, más bien parece un sahumerio prehispánico, ya que lleva decoraciones de grecas, roleos y escalonamientos; del interior del vaso del mortero sale una serpiente, símbolo de la farmacia y uno de los atributos del dios griego Asclopio, Esculapio para los romanos, deidad de la medicina. ${ }^{211}$ Este instrumento está enmarcado por figuras de roleos y escaleras, lo cual además de su proyección simbólica indigenista mexica, es un objeto decorativo Art Déco de tipo Zigzag.

Después del mortero, a la altura de las tres cuartas partes hay una moldura en donde se incrusta perpendicularmente el letrero original, el cual fue manufacturado con lámina pintada de rojo y tiene forma de cruz con recortes angulares debajo de la intersección y recortes curvos en la esquinas. En el perímetro lleva adornos en formas de grecas color amarillo. La parte superior es una abstracción de un mortero y su pilón; el eje horizontal lleva la palabra BOTICA y en el vertical MORELOS. La base de la cruz es una composición de recortes semicurvos y en la parte baja lleva el nombre del propietario: P. SALCE. Estas letras blancas son de luz neón, una de las modernidades de la época de los años del Art Déco, así como los letreros luminosos de formas geométricas.

\footnotetext{
211 José Antonio Pérez-Rioja, Diccionario de Símbolos y Mitos, Madrid, Tecnos, 2008, 8ª ., ed., p. 409.
} 
Después del letrero y ya sobre el muro, está el escudo nacional, enmarcado de la misma manera que el mortero, con vírgulas y escaleras para imprimirle un sentido enérgicamente nacionalista.

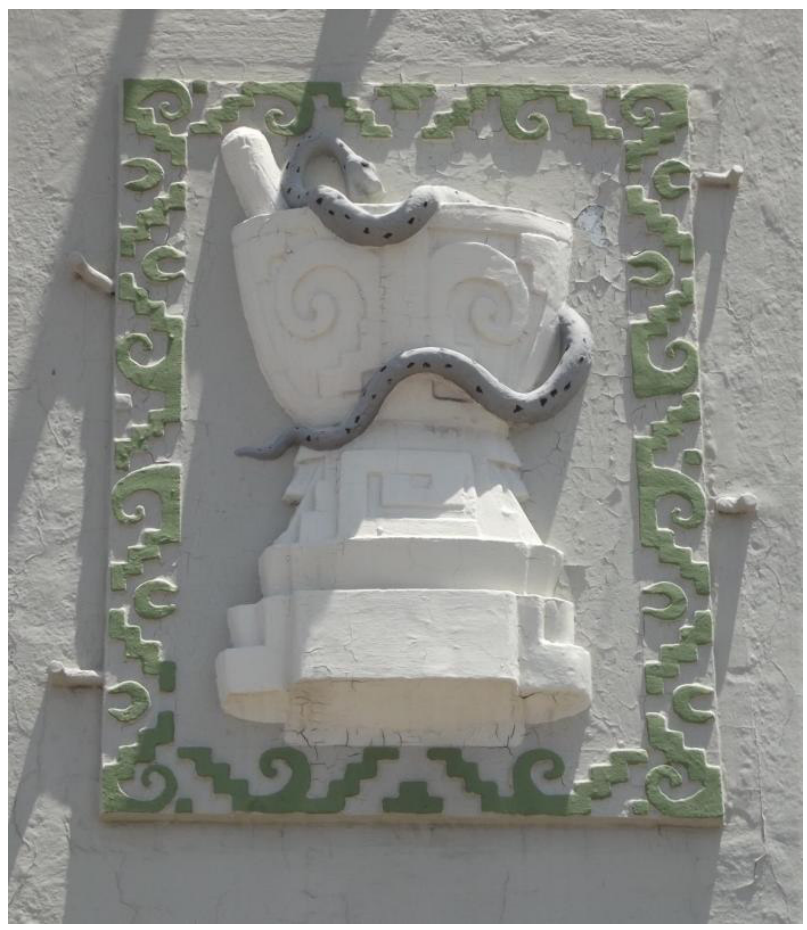

Mortero.

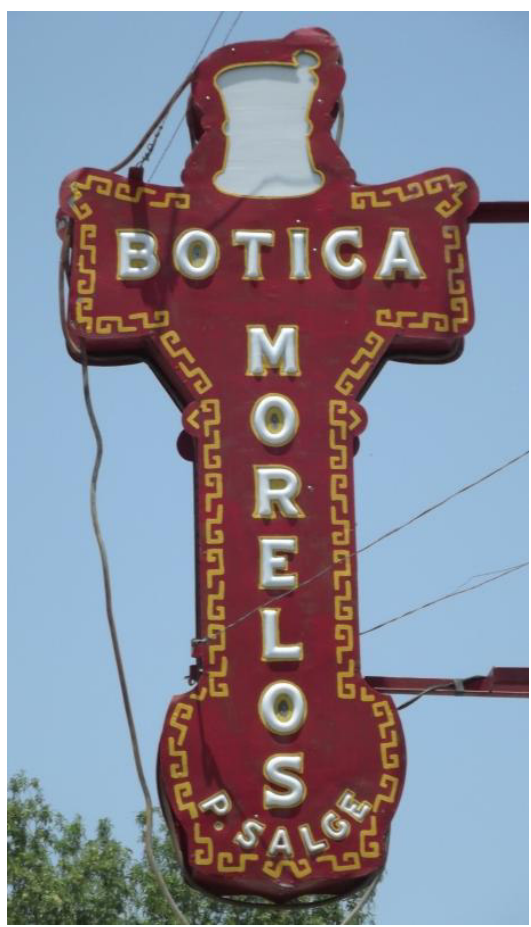

Letrero.

Toda la botica lleva en la parte superior a manera de cenefa unos mosaicos de tipo maya como los que hay en el Cuadrángulo de las Monjas de Uxmal en Yucatán. Los mosaicos son rombos con recortes escalonados tanto en el interior como en el exterior que llevan insertos una cruz griega. Para completar la linealidad de la cenefa tanto arriba como abajo de los espacios entre los rombos están colocados medios rombos, con lo que además de darle ese sentido indigenista, en este caso maya, es un adorno de tipo Déco Zigzag que enluce toda la fachada. En el caso del muro ochavado de intersección, por arriba de la cenefa están dos caballeros águilas que protegen un escudo o "chimalli" que está en medio de unos roleos.

Por arriba de la cenefa corre una moldura que se eleva cada vez que hay un piñón en el remate, que son tres por cada fachada. El primer piñón de izquierda a derecha de la fachada norte sobre la calle Morelos se conforma por una elevación con taludes a manera de plataforma piramidal. En su interior hay un escudo no descifrado, acompañado por 
ornatos como los mosaicos de la cenefa. Hay dos piñones más en esta fachada que se elevan escalonadamente y que llevan como adorno el miso tipo de mosaico maya. Entre estos dos último piñones sobre un peque zócalo a manera de tablero recortado hay ídolo indígena de tipo mexica.

En el pequeño muro de la confluencia de las fachadas en la parte superior está una estatua de Morelos de gran tamaño, la cual lleva la mano derecha levantada cargando la antorcha símbolo de las guerras de independencia.

En la fachada poniente de la calle madero hay tres piñones idénticos a los dos últimos de la fachada norte con su composición escalonada; entre ellos hay dos ídolos de tipo mexica, parados sobre análogos zócalos como el de la fachada de la calle Morelos.

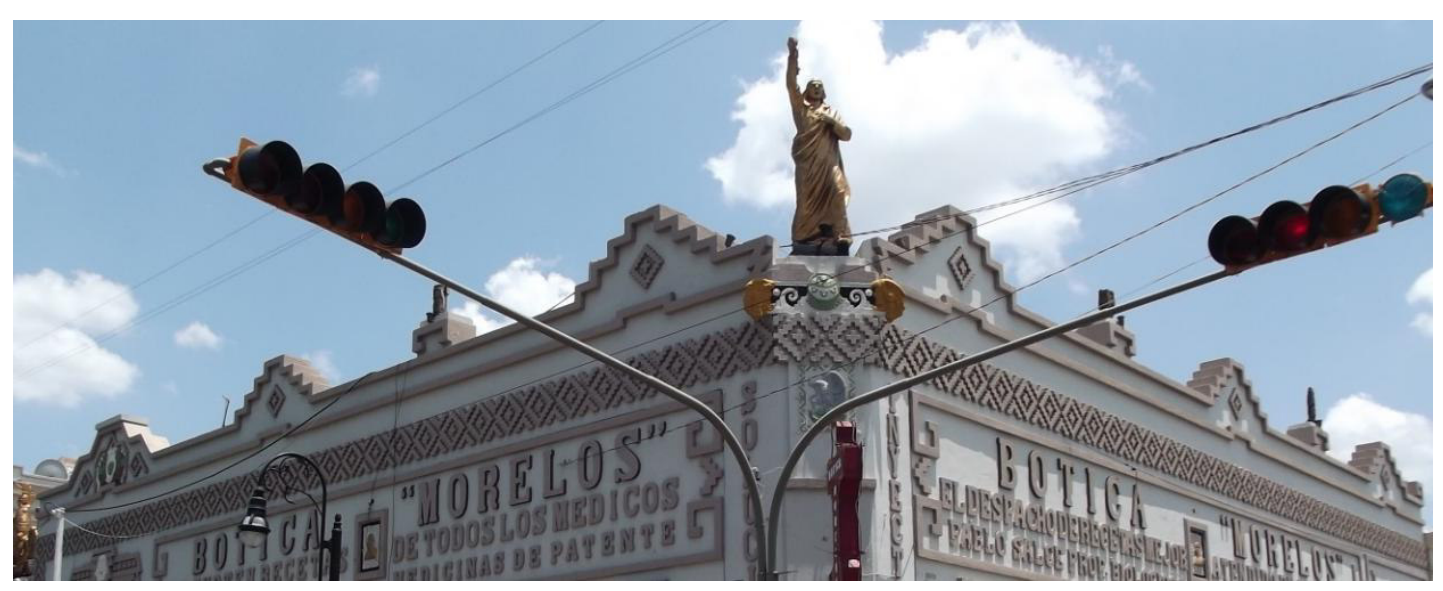

Cenefa, moldura y piñones en las dos fachadas.

Dentro de la botica hay dos cuadros hechos en 1974 en base a fotografías de la época, que aunque son de poca calidad artística muestran cómo era la botica cuando inició actividades un 8 de enero de 1924 y cómo quedó transformada un 1 de enero de 1939. El lienzo de 1924 lleva la siguiente inscripción:

"1924 Enero 8, La Botica "Morelos" Cuando la inició su fundador En casa rentada en la Esquina De las Calles Primera Sur y Primera Poniente.”

Y el del 1939 el epígrafe apunta:

"La Botica "Morelos" del día $1^{\circ}$ de Enero de 1939 en adelante, en el mismo lugar, ahora local propio, restaurado con su Característica y nacionalista fachada, tal como se conserva frente a la plaza principal

Cruzamiento de las avenidas Morelos y Madero." 


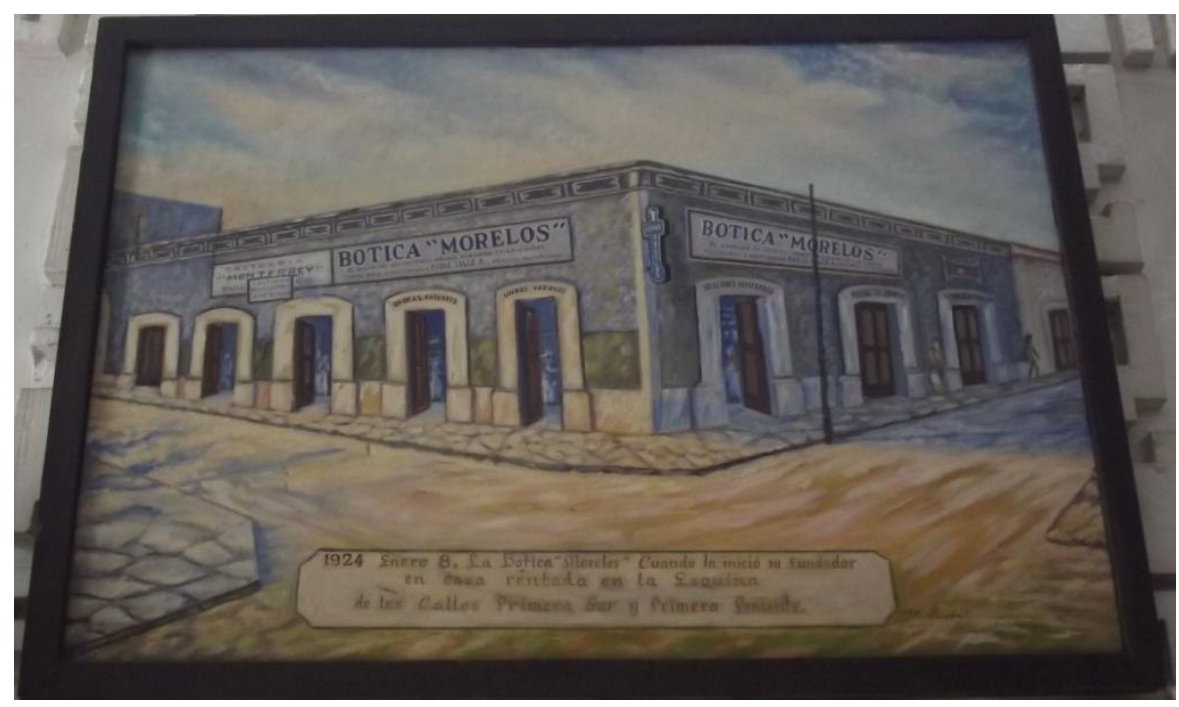

La botica cuando inició actividades en 1924.

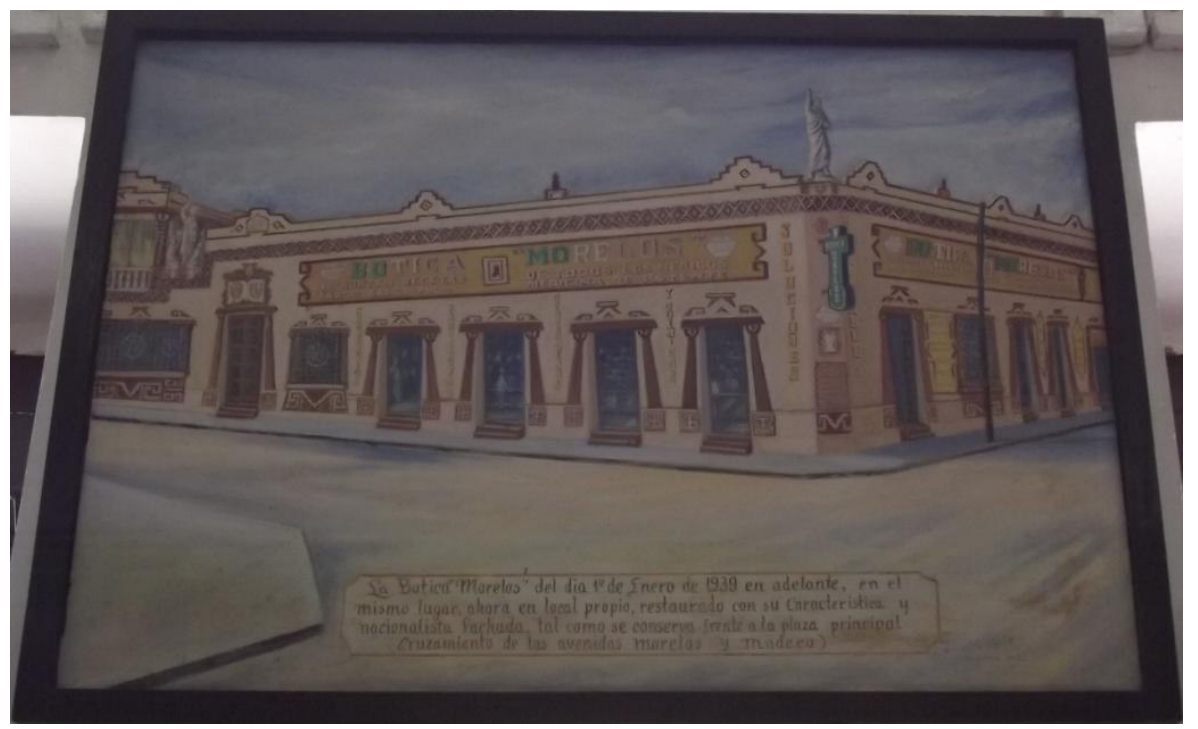

La botica cuando quedó concluida la remodelación en 1939.

La decoración indigenista está por todas partes en el interior de la botica, en el piso, mobiliario, techo, lámparas, puertas. En el caso del piso que está forrado de losetas rojas, al centro está una representación en vivos colores de la Piedra del Sol con la cara del dios de la guerra Huitzilopochtli, enmarcado por roleos con atavíos de escalonamientos. Además, el piso tiene junto al mostrador una banda ornamentada con grecas adheridas a escuadras 
escalonadas. El decorado netamente indigenista mexica, además resalta el geometrismo del Art Déco de tipo Zigzag.

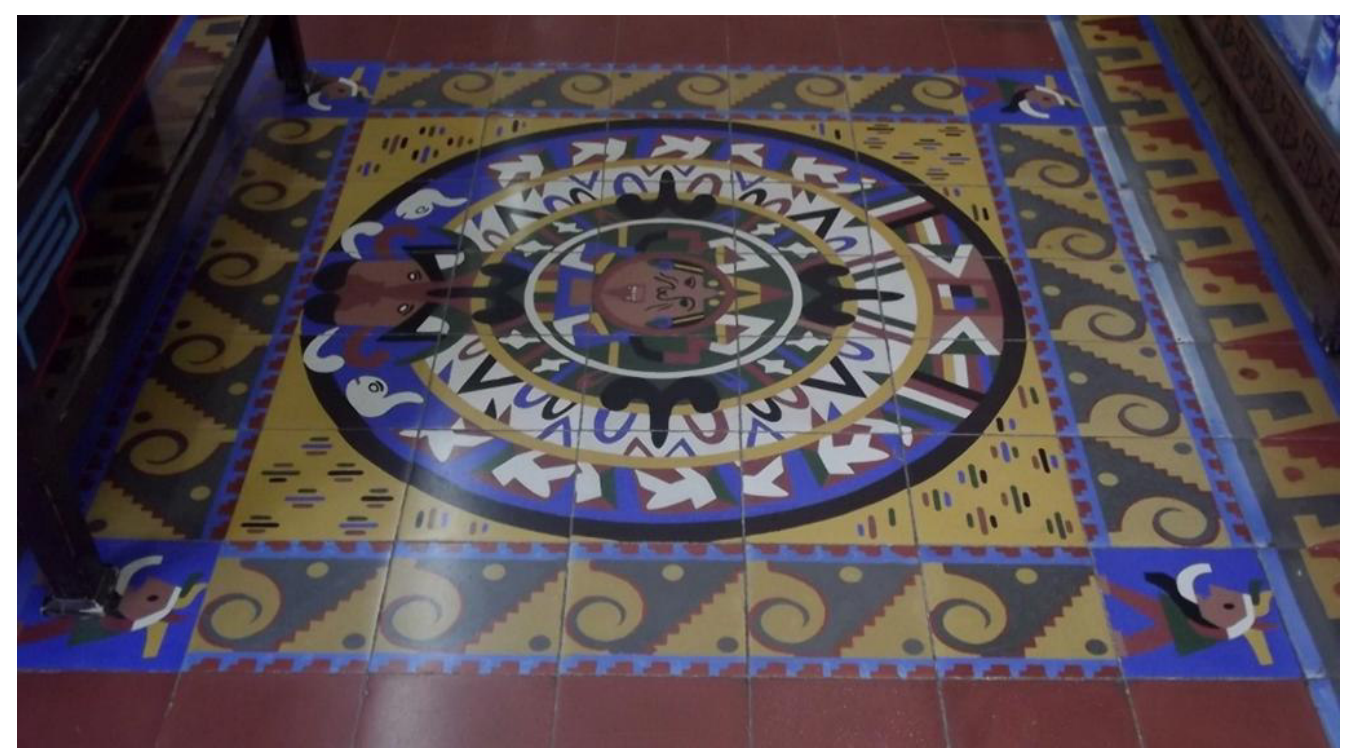

Piso con decoración de la Piedra del sol y la banda de grecas junto al mostrador.

Del mobiliario destacan, entre tantas otras cosas, los sillones en madera que hacen juego con la decoración de Déco Nacionalista Prehispanista mexica del piso.

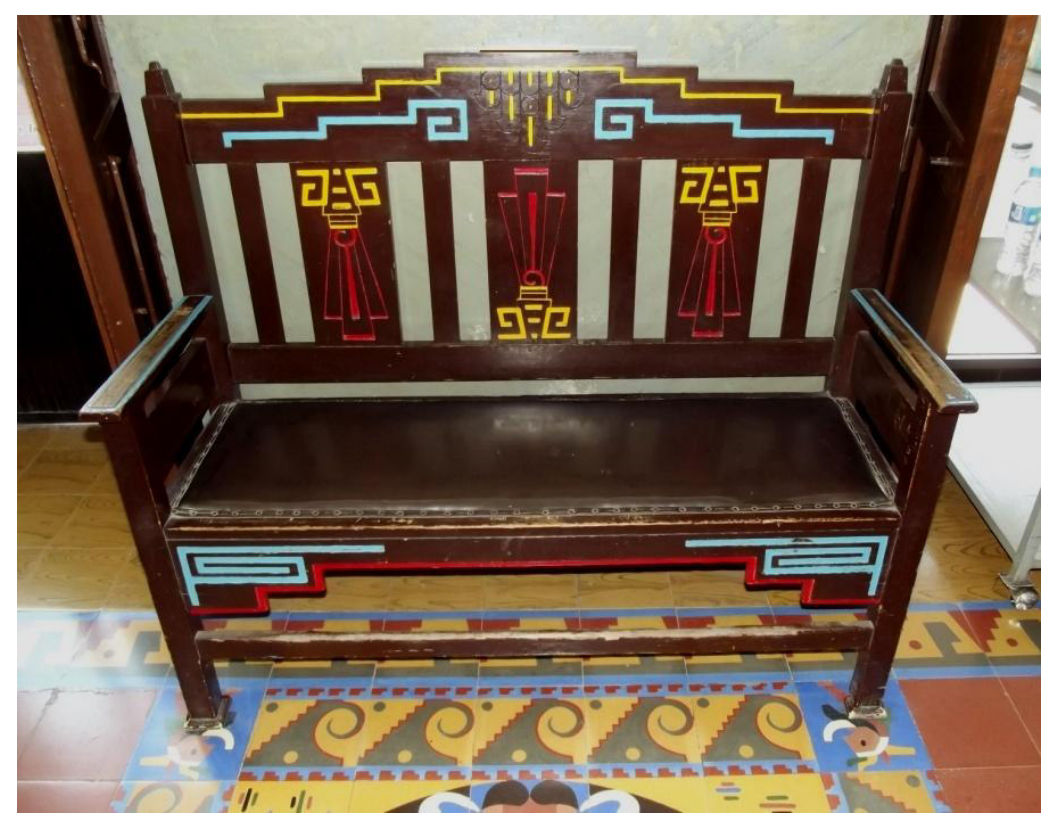

Sillón con decoraciones indigenistas mexicas. 
Otro ejemplo de la decoración indigenista en el mobiliario es la decoración de la parte superior central del armario principal, donde el águila devorando a la serpiente, parada sobre un nopal y éste a la vez posicionado sobre una piedra y que representa al escudo nacional, está acompañado por "chimallis" o protecciones y atuendos de guerra. El remate del armario se eleva en forma de ochavo decorado con una hilera de zigzags; a los extremos de los escudos, van unas abstracciones de plataformas escalonadas en posición vertical y abajo unas grecas sueltas y otras aunadas a escuadras escalonadas, completan toda la semántica del ornato indigenista.

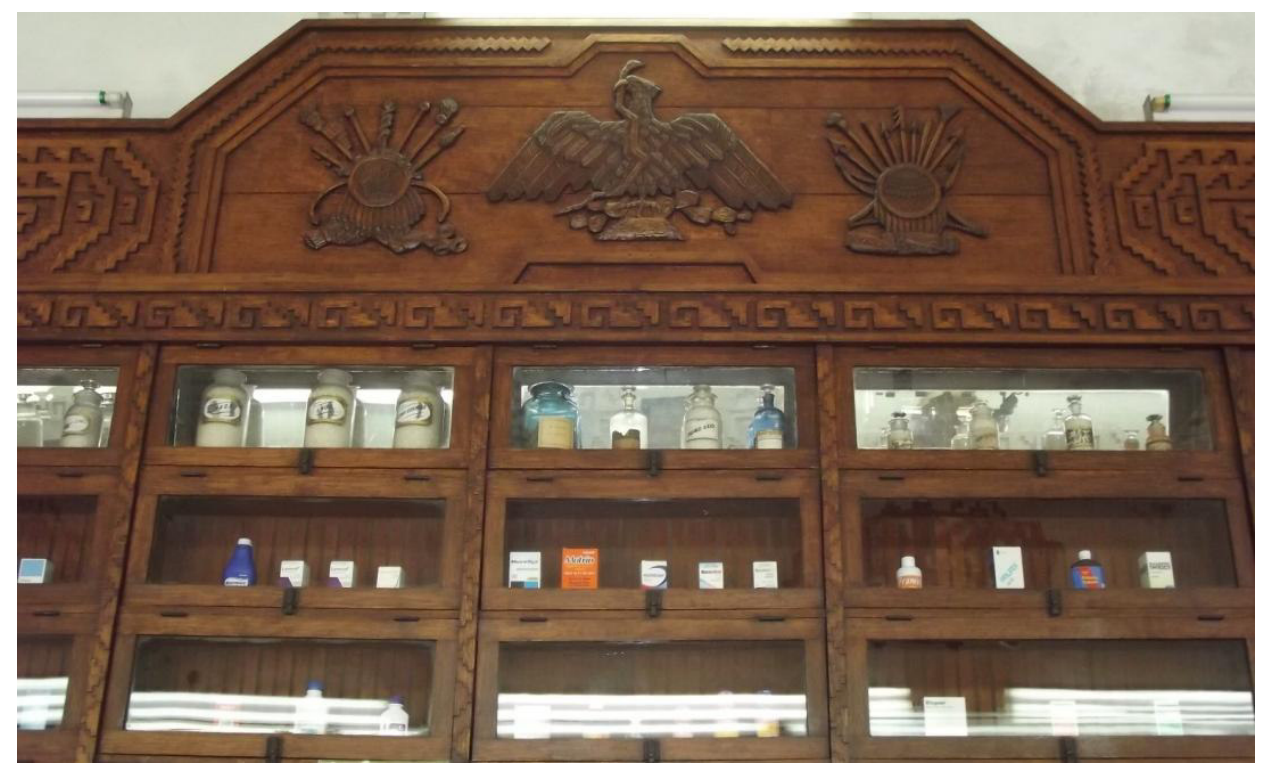

Parte superior del armario principal.

Una división de madera para las oficinas y caja de la botica, en la parte central y superior termina en forma de ochavo, igualmente como en el armario mencionado, exhibiendo el centro de la Piedra del Sol mexica, acompañada por un Caballero Tigre y un Caballero Águila. El recorte elevado es por medio de dos ángulos y dos taludes para simular una plataforma piramidal, reforzada con dos molduras que siguen el mismo ritmo lineal.

La decoración de todo este panel incluyendo las puertas es un "horror vacui" de grecas, escuadras escalonadas así como espirales geometrizadas; dos celosías a cada lado de un vano central lucen una rejería con cuatro espirales, una en cada esquina y el resto es 
una secuencia de escalonamientos. Por lo que respecta a la celosía a un lado de la caja, la herrería expone una abstracción de la Piedra del Sol, acompañada también de grecas y elevaciones escalonadas.
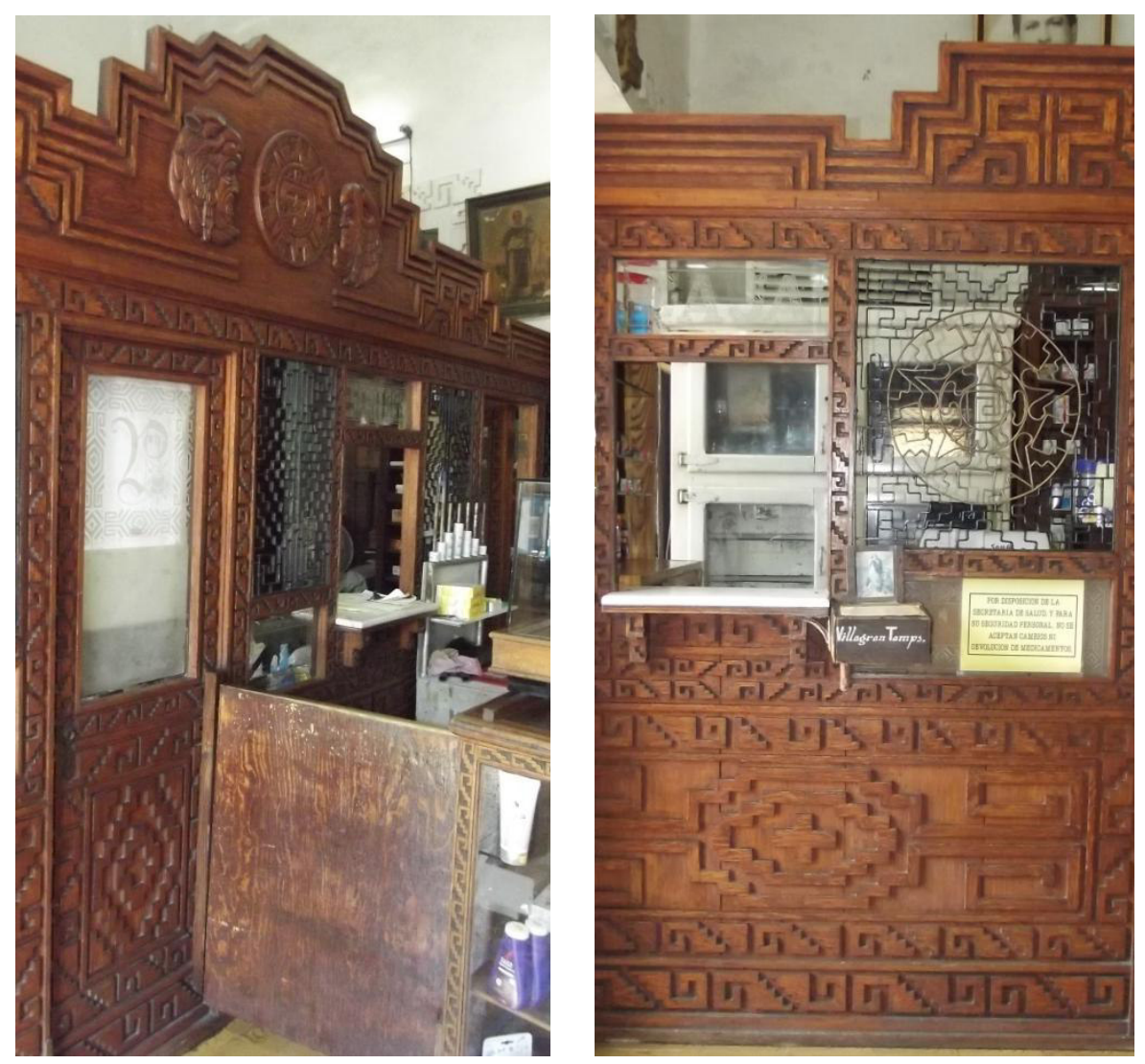

Panel divisorio para oficinas y caja. A la izquierda, la parte central elevada con el Caballero Tigre, la Piedra del Sol y el Caballero Águila. A la derecha la ventana de la caja y la celosía con la abstracción de la Piedra del Sol.

El techo está formado por cuatro tramos que se sostienen por medio de tres vigas de acero. El perímetro de cada espacio está decorado por medio de grecas pegadas a un par de escuadras escalonadas que simulan alas de águila y en cada esquina hay un mosaico de tipo maya; hacia dentro del espacio, unas grandes espirales geometrizadas forman un recuadro con líneas quebradas en forma de zigzag. En el último tramo de izquierda a derecha, en el centro hay una decoración con la forma abstracta de la Piedra del Sol. Las vigas están ornadas con una hilera de mosaicos mayas como los de la cenefa de las fachadas del exterior que inclusive podemos decir que son como los utilizados en Uxmal, Yucatán, en el 
edificio conocido como El Cuadrángulo de las Monjas. Del segundo, tercer y cuarto tramo cuelgan unas llamativas lámparas de metal.

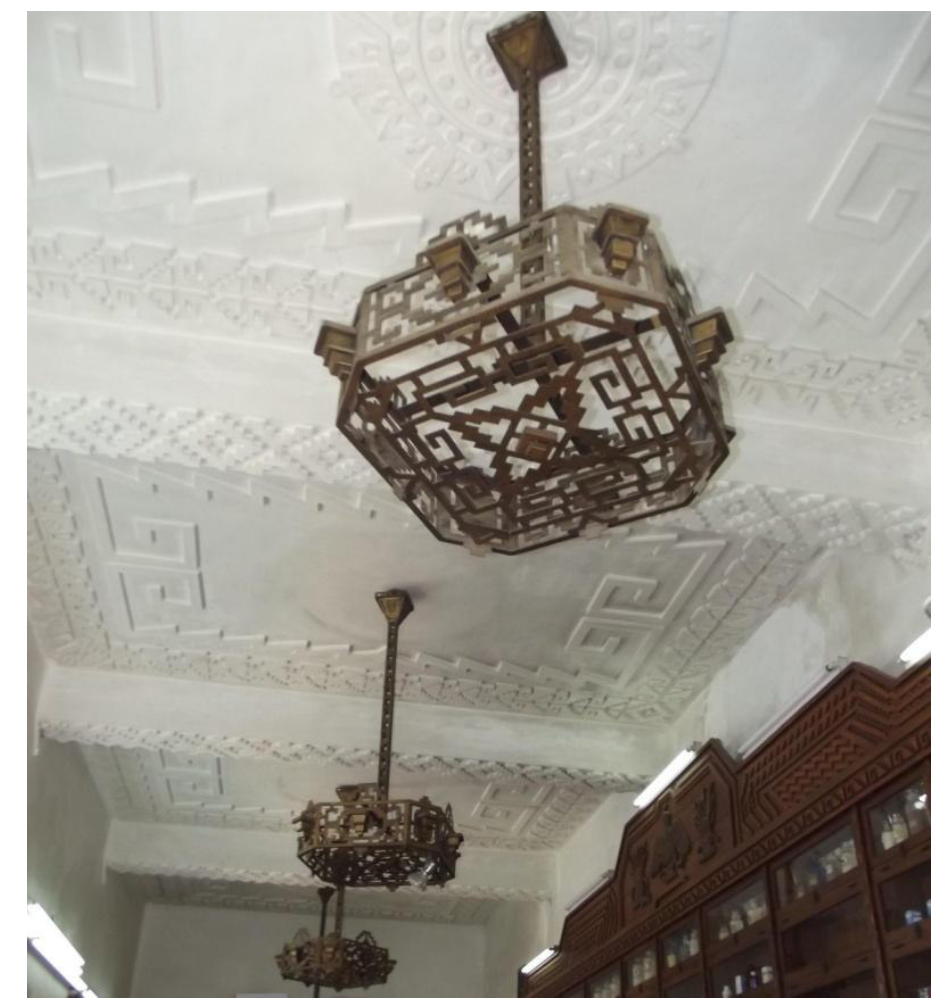

Detalle del techo y las tres lámparas.

En la composición de las lámparas la parte que va pegada al techo tiene la forma de una pirámide truncada y el tubo que une a la canasta de la bombilla está perforado con formas de grecas. La canasta es octagonal, con cuatro lados grandes y cuatro chicos, los cuales llevan fijada una pirámide invertida. Los lados grandes están compuestos por unos hexágonos alargados con tramos en forma de gradería y rematan con una abstracción de pirámide escalonada; los lados chicos se forman con un rectángulo acodado y rematan con una pequeña elevación escalonada. La base en la parte central se forma por el cruzamiento de dos hexágonos con sus recortes angulares que se unen a grecas y rectángulos que forman el ochavo. El diseño de estas lámparas que busca seguir el estilo indigenista es la vez un distintivo objeto decorativo Art Déco de tipo Zigzag. 


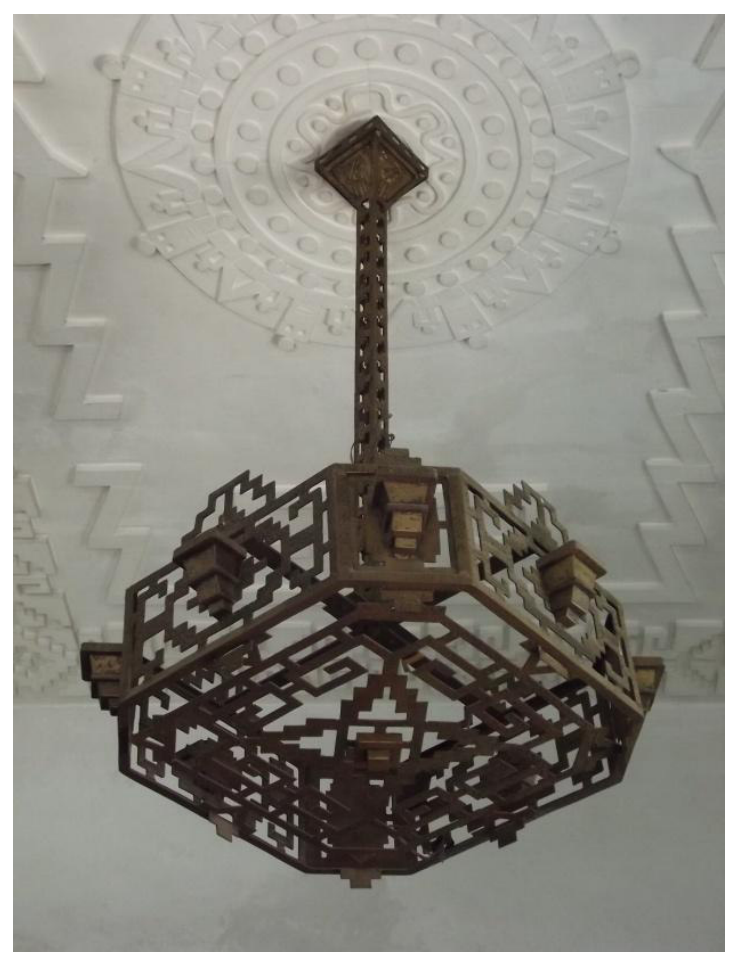

Lámpara del último tramo, con la decoración de la abstracción de la Piedra del Sol en el techo.

Así como explicamos en el Capítulo 2, en el punto 2.4 sobre el prehispanismo como fuente de inspiración para el Art Déco, comentamos que la influencias mexica o azteca y maya vinieron en muchos casos por la valoración que de estos pueblos hicieron los norteamericanos y utilizaron motivos decorativos de dichas culturas en edificios Art Déco, así como por los investigadores extranjeros que atraídos por el exotismo de lo indígena, México era un paraíso virgen para estudiar la arqueología prehispánica.

La Botica Morelos es un caso tan excepcional como extravagante de una decoración Neoindigenista, como también se le ha llamado a este tipo de arquitectura. Pero viéndola desde la óptica del Art Déco, como anotamos en el capítulo anteriormente mencionado, los diseños indígenas prehispánicos por su geometrismo y exotismo histórico servían afinadamente para ornar los productos de toda índole de la época del Déco.

Lo que llama la atención es que este edificio de la Botica Morelos no tiene que ver con las influencias mencionadas, ni tampoco por la ubicación geográfica, ya que la ciudad de Linares en el estado de Nuevo León, no está vinculada en lo más mínimo con las culturas mesoamericanas, tan lejanas territorial como culturalmente. Fue el diseño propio 
del señor Pablo Salce, apasionado lector de la historia antigua del país, así como su afición por la arqueología, quien le dio el toque indigenista nacionalista a su comercio farmacéutico. Podemos tomar en cuenta que en eso años había un fuerte movimiento de revaloración del mundo indígena en todos su ámbitos como búsqueda de la identidad nacional, pero dicho movimiento tuvo mucha fuerza en el centro y sur de México, pero escasa en el noreste del país.

Ante esta situación de los motivos decorativos de la Botica Morelos, estamos ante un edificio que posee plenamente los elementos del Art Déco Zigzag y que al ostentar principalmente componentes mexicas o aztecas y en menor medida mayas, no podemos solamente catalogarlo como un ejemplo de la Tendencia Ecléctico-Mayista, porque en todo caso sería Ecléctico Mexica-Mayista.

Así como propusimos en el Palacio Federal que las cabezas de Quetzalcóatl en dos de sus fachadas podríamos clasificarlas como un Art Déco Nacionalista Prehispanista, porque tanto pueden ser teotihuacanas, toltecas-mayas o mexicas, de la misma manera para la Botica Morelos la denominación propuesta le cuadra convenientemente, ya que comparte elementos que en su mayoría están inspirados en la civilización mexica o azteca, pero muchos de ellos también aparecen en las culturas teotihuacana y tolteca, así como los mosaicos mayas de Uxmal también se parecen a los diseños mixtecas de Oaxaca. Pero al final de cuentas, la intención del señor Salce era preponderar lo indígena de los mexicas, pueblo conquistado por los españoles, suceso con lo que se termina la época prehispánica y que se tomó como la bandera del nacionalismo mexicano en la época de los años del Déco.

En síntesis la Botica Morelos que exalta intensamente lo geométrico tanto en el exterior como en el interior a través de las decoraciones indigenistas, comparte como un inmueble Art Déco, el Zigzag, la Tendencia Geometrista y por supuesto la Decorativista, así como un Déco de tipo Nacionalista Prehispanista. 


\section{b.2. ARQUITECTURA DEL OCIO}

\section{b.2.1. Teatro Benítez}

El Teatro Benítez está ubicado en la calle Juárez s/n, entre Hidalgo y Madero, con vista al sur frente a la Plaza Principal.

Fue fundado el 8 de agosto de 1940 por los hermanos Adolfo y Artemio Rodríguez, formando parte de la cadena de Cines Rodríguez. El Gran Teatro Benítez, como originalmente se llamó, tenía más de 1.300 butacas, repartidas en tres niveles que eran anfiteatro, luneta baja y alta. Aunque llevaba el nombre de teatro, realmente funcionó como sala cinematográfica, pero como sucedió con muchos otros cines del país, ante la escasez de público fue cerrado el 7 de febrero de $1991 .^{212}$ Después de más de veinte años, sigue abandonado, a pesar de que hubo un intento por darle nuevamente uso, junto con otros inmuebles de la ciudad, ante un proyecto que lanzó el gobierno municipal en septiembre de 2013. En lo que fueron las entradas laterales para subir a las lunetas se instalaron oficinas del gobierno del Estado de Nuevo León.

Los materiales utilizados fueron ladrillos, cemento y techumbre de lámina. La planta es rectangular.

Lo que conserva de Art Déco el Teatro Benítez es la fachada y la taquilla. La entrada se conforma por tres puertas rectangulares, siendo la central más amplia. Una amplia y gruesa marquesina servía a la vez para la colocación de los letreros de la cartelera cinematográfica. En el gran muro de la fachada que se levanta por arriba de la marquesina, el lienzo central que abarca tres cuartas partes, se desplaza levemente hacia el frente; esta parte del muro está formado por tres calles: la del centro se rehunde levemente y está resguardada a ambos lados por una hilera, que sobresale del nivel, forrada de mosaicos en verde y blanco, los cuales llevan por adorno unas grecas, ornatos de tipo indigenista que resaltan el geometrismo de Art Déco y que fueron bastante empleados como diseños del Déco Zigzag, así como el cromatismo conseguido con los colores de los mosaicos; en la

\footnotetext{
212 Gobierno Municipal de Linares Nuevo León, “Teatro Benítez”, Linares Nuevo León, Hualahuises Nuevo León, Instalación y Primera Sesión del Comité Pueblo Mágico, Linares, N.L., jueves 5 de septiembre de 2013, http://pueblomagicolinares-hualahuises.com/pdf/1sesion.pdf
} 
parte baja lleva una ventana rectangular en posición horizontal, más arriba y en el centro está colocado transversalmente el letrero y por encima se encuentra un óculo. Las otras dos calles a los lados de las hileras con grecas, en la parte baja y en posición vertical está la ventana que es rectangular y en la alta tienen óculos a la misma altura que el del centro.

Los lienzos laterales del muro están mínimamente colocados hacia atrás en relación con el lienzo central; lucen en la parte baja una ventana en posición vertical con forma rectangular y en presentan óculos a la misma altura que los del lienzo central. Estos lienzos están compuestos por seis grandes estrías, con lo que le da a la fachada un enfoque de cinetismo, como si fuera la representación de ondas de agua congelada o también semeja las láminas de las techumbres de las naves industriales.

La fachada del Teatro Benítez presume toda una estilística de Art Déco Streamline, pues los óculos simulan escotillas de barcos y/o ventanas de aeroplanos, así como el muro que pareciera un aparato maquinario de uso industrial. Al mismo tiempo, el tenue juego de movimiento de las superficies de los lienzos, ayuda a reforzar el ritmo de movimiento y de ensamblaje de las partes.

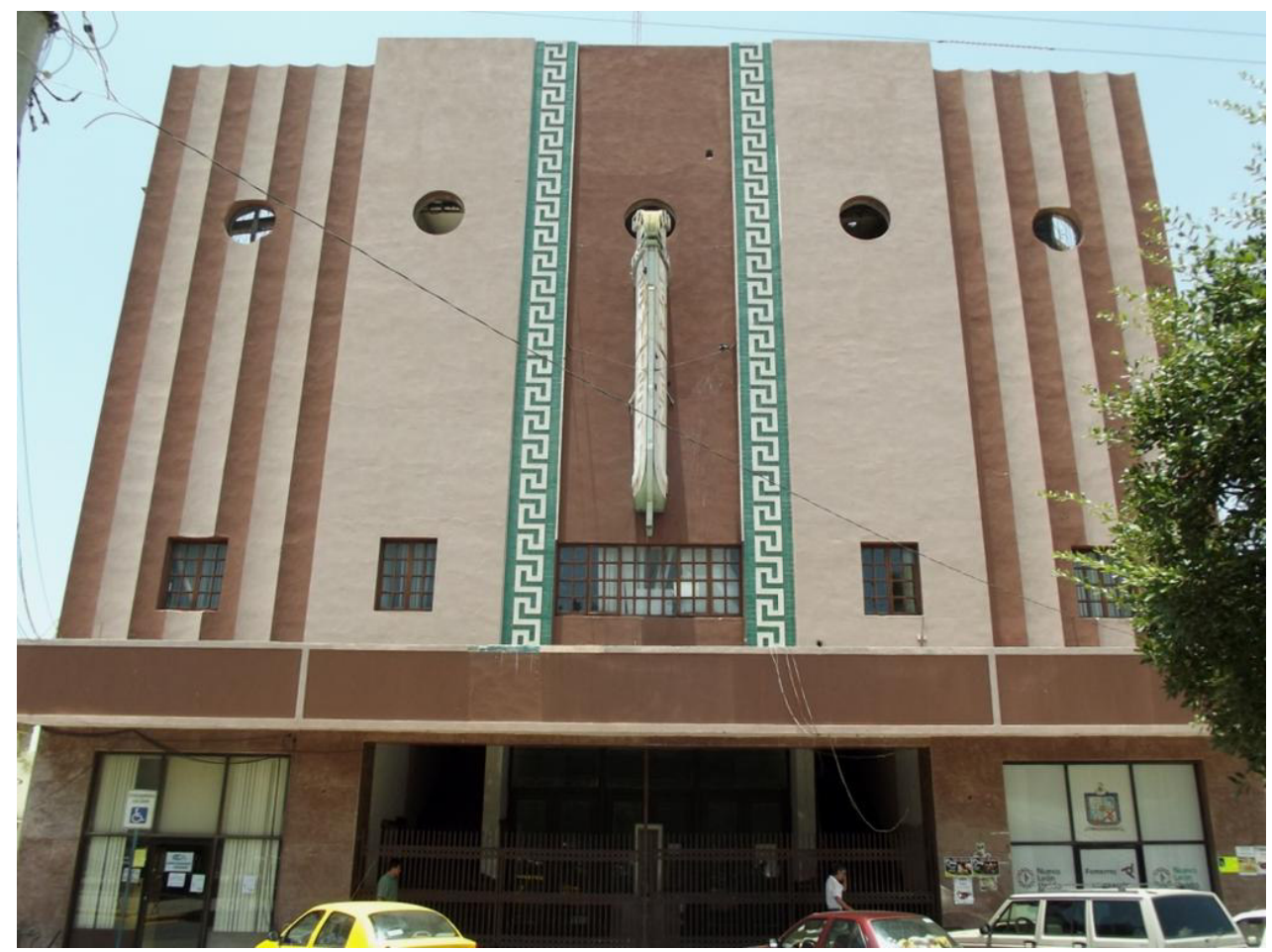

Cine Benítez, fachada. 
El letrero es de lámina. En la sección superior, en un cuarto de círculo y siguiendo la forma circular está la palabra GRAN con letras en color blanco. Una par de figuras geométricas planas compuestas por un cuadrado y una pirámide truncada, sirven para encubrir los tubos empotrados en el muro que soportan el letrero y para sostener las letras en blanco de la palabra TEATRO. La siguiente parte del letrero es un rectángulo que en la parte baja se curvea y se dilata hacia el muro; lleva con letras blancas sobre fondo rosa el nombre del cine BENÍTEZ y una flecha apunta en dirección de la entrada. Un filamento en color azul claro sobresale en ambos extremos de esta parte del letrero y se dilata en la parte baja, con lo que le otorga ligereza, así como esbeltez al objeto; un claro diseño Streamline como se usaba en los letreros de las salas del espectáculo de los años del Art Déco, con formas aerodinámicas, que en este caso simula la pala de un timón de barco o de la cola de un aeroplano, cuando los diseños de estos aparatos eran curveados en los dobleces de las esquinas o ángulos.

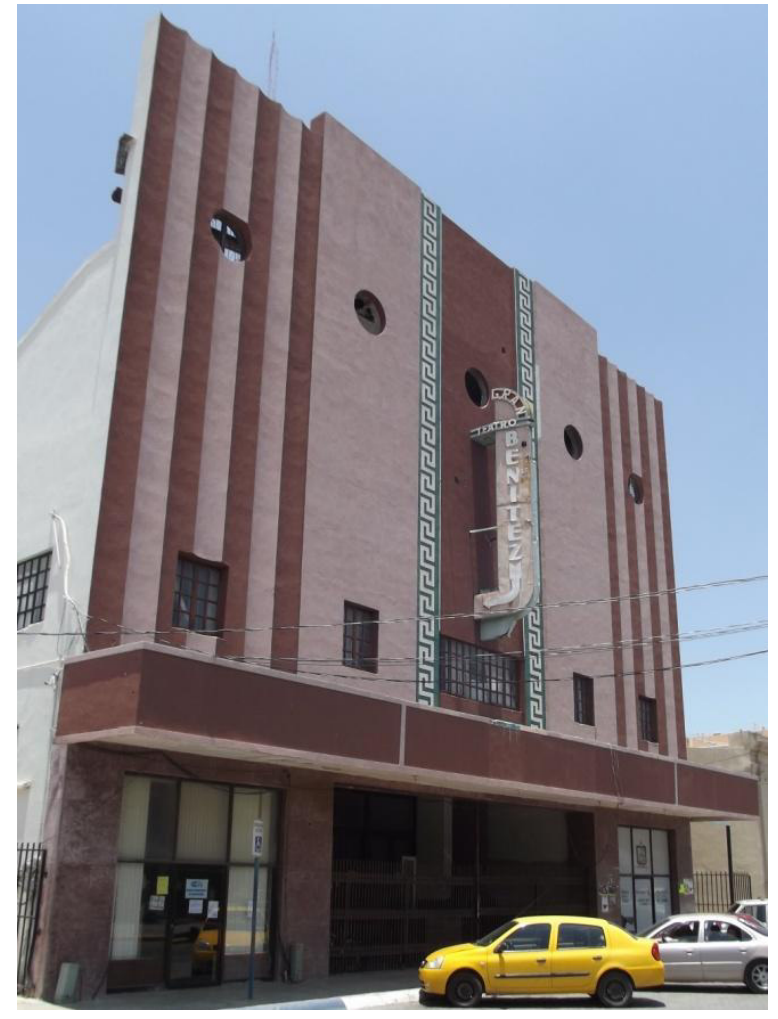

Vista lateral de la fachada.

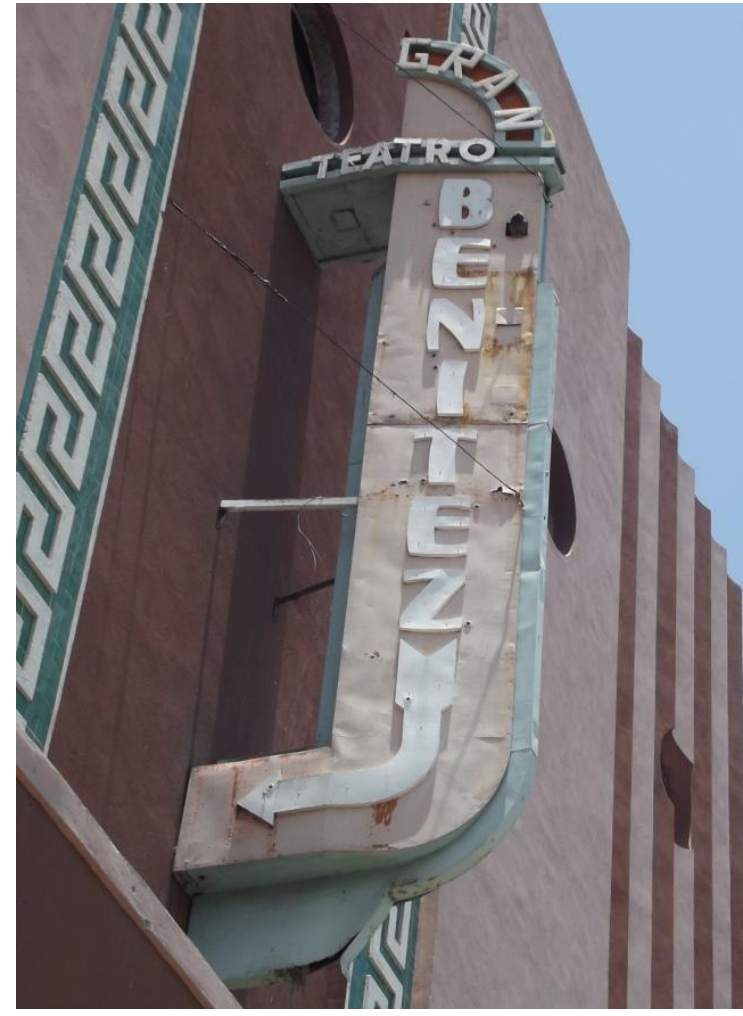

Letrero. 
En el vestíbulo aún permanece la base de lo que fue el mostrador de la taquilla. Está hecho con ladrillo forrado con piedra de granito rosa, material ampliamente utilizado en las construcciones Art Déco, y tiene una altura de un metro. Es de forma ochavada, cuyas paredes laterales son más largas. Un par de molduras rectangulares la recorren tanto en la parte baja como en la alta. En lo que en sí es el mostrador se prolongan al frente y a los lados unas figuras rectangulares, mientras que en la parte de atrás está abierta para la entrada del despachador. En la parte interior es redondeada y recortada oblicuamente en las paredes laterales para conseguir más espacio.

La forma de esta base de la taquilla con su diseño ochavado y los pares de las molduras en las paredes remarcan el geometrismo del tipo Art Déco Zigzag, mientras que la forma del mostrador que es la abstracción de una ave, nos remite directamente a un diseño representativo del Déco Streamline.
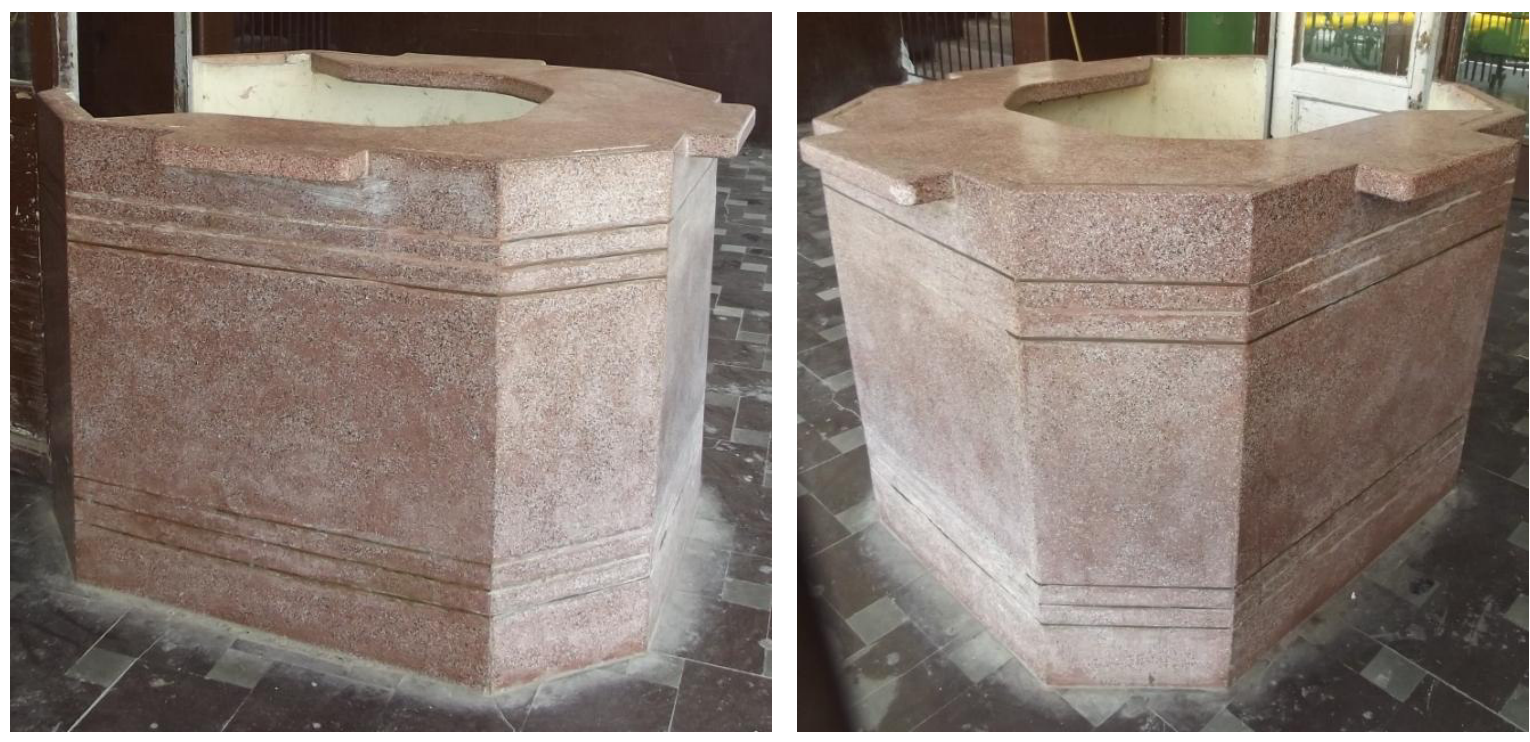

Base de la taquilla vista por ambos lados laterales.

En el Teatro Benítez predomina el Art Déco Streamline, aunque como anotamos tanto por las grecas de la fachada como por la composición de la taquilla es un Déco Zigzag y también podemos incluir la Tendencia Decorativista si bien de manera mínima por las dos hileras de las mencionadas grecas. 


\section{c. Sabinas Hidalgo}

Lo que hoy es la cabecera municipal de Sabinas Hidalgo, fue un pueblo fundado en1693, como tantas poblaciones de esos años, con el fin de establecer beneficios de tierras y de minas; el nombre original fue Real Santiago de las Sabinas. Durante el siglo XVIII se fue desarrollando el poblado y para tiempos de la independencia ya contaba con 1.600 habitantes.

En 1829 la población recibe el título de Villa de Santiago de Sabinas Hidalgo, en honor al héroe de la insurgencia. Durante el siglo XIX con los altos y bajos en la nación, la villa siguió su vida y un paulatino crecimiento. En 1882 con la llegada del ferrocarril que iba a Villaldama, la minería, el comercio y la ganadería nuevamente recuperaron sus bonanzas.

En las prosperidad porfiriana y ante el atractivo de sus valles, allá por 1904 unos excursionistas llegaron a la Villa en un automóvil francés, lo cual causó gran expectación y más aún que ante el asombro del alcalde, el Sr. Pablo de los Santos, compró el vehículo para quedárselo en el poblado y de ahí la tradición de que el primer automóvil de Nuevo León estuvo en Sabinas.

Después de los años de las luchas revolucionarios, ya en tiempos de la postrevolución, en el año de 1926 se inició la carretera nacional que va hacia la frontera en Nuevo Laredo, Tamaulipas, pasando por Sabinas Hidalgo, suceso que vino a darle una nueva promoción al poblado. ${ }^{213}$ Dos años después se edificó el único monumento Art Déco que tenemos registrado en la ciudad: el Cine Olimpia.

Cabe aclarar que en 1971 la villa fue elevada al rango de ciudad con el nombre de Sabinas Hidalgo.

\footnotetext{
${ }^{213}$ Héctor Jaime Treviño Villarreal, “Sabinas Hidalgo capital del norte nuevoleonés”, VV. AA. Nuevo León a través de sus municipios. Tomo IV, Monterrey, N.L., Milenio, Multimedios, 2010, p. 84.
} 


\section{c.1. ARQUITECTURA DEL OCIO}

\section{c.1. 1. Cine Olimpia}

El Cine Olimpia se ubica en el centro de la ciudad en la calle Hidalgo No. 115, entre Mutualismo y Victoria, con orientación al sur.

Fue fundado en 1928 por Eleazar Cavazos, Pedro González Gómez y Estela Flores de Cavazos, con una capacidad de 390 butacas. El señor Eleazar Cavazos fungió como propietario hasta el año de 1945 cuando pasó a manos de su hijo Horacio Cavazos Flores.

Como les sucedió a tantas salas cinematográficas, a finales de la década de los ochenta del siglo pasado el cine vino en crisis y fue cerrado el 12 de mayo de 1991. Reabierto el 17 de junio de 2010, fue un acontecimiento para la pequeña ciudad, ya que recupera la historia del lugar como el sitio de esparcimiento muchos de aquellos habitantes que dejaron su natal poblado para ir a estudiar y/o a trabajar a la capital del estado. ${ }^{214} \mathrm{El}$ señor Horacio Cavazos falleció en octubre de 2011 y actualmente el propietario es el señor Arnaldo Edgar Cavazos Botello, nieto del fundador y que a pesar de la escasa audiencia, sigue manteniendo abierto el cine que actualmente sólo ofrece funciones los fines de semana.

Lo que el Cine Olimpia conserva de Art Déco es la fachada y el vestíbulo de entrada, el cual tiene tres accesos que se componen de arcos ochavados acompañados por cuatro pilastras con zócalos que se engalanan con cuatro estrías verticales que en la parte inferior se recortan en formas angulares hacia el interior. Las pilastras se seccionan a la mitad de la altura de la fachada, pasando por detrás de una marquesina de concreto que seguramente fue puesta después, sin tener la fecha de su inclusión. En el recorte de las pilastras, una segunda sección de las mismas se conecta de manera remetida, llevando por adorno tres estrías con la misma disposición que las anteriores. Estas pilastras a tres cuartas partes de la altura de la fachada también se truncan en la parte superior, además de dos biselados en los extremos, para soportar unas pilastras todavía más remetidas en el nivel de

214 Eduardo Alvarado Ginesi, "El Cine Olimpia en Sabinas Hidalgo", Reportajes de Alvarado. Televisa Monterrey, viernes 4 de noviembre de 2011, http://www.veengle.com/s/cine\%20olimpia.html 
los dos conjuntos anteriores, llevando solamente dos estrías como ornamento. Al ser estas pilastras las superiores, las dos centrales se elevan más que las de los extremos.

El efecto visual de ascensión se consigue por medio del remetimiento de las pilastras y con el adelgazamiento en número de las estrías, además del coronamiento que provocan las dos pilastras centrales en la parte superior, lo que le da un amplio sentido de elevación geométrica, típicamente del Art Déco Zigzag.

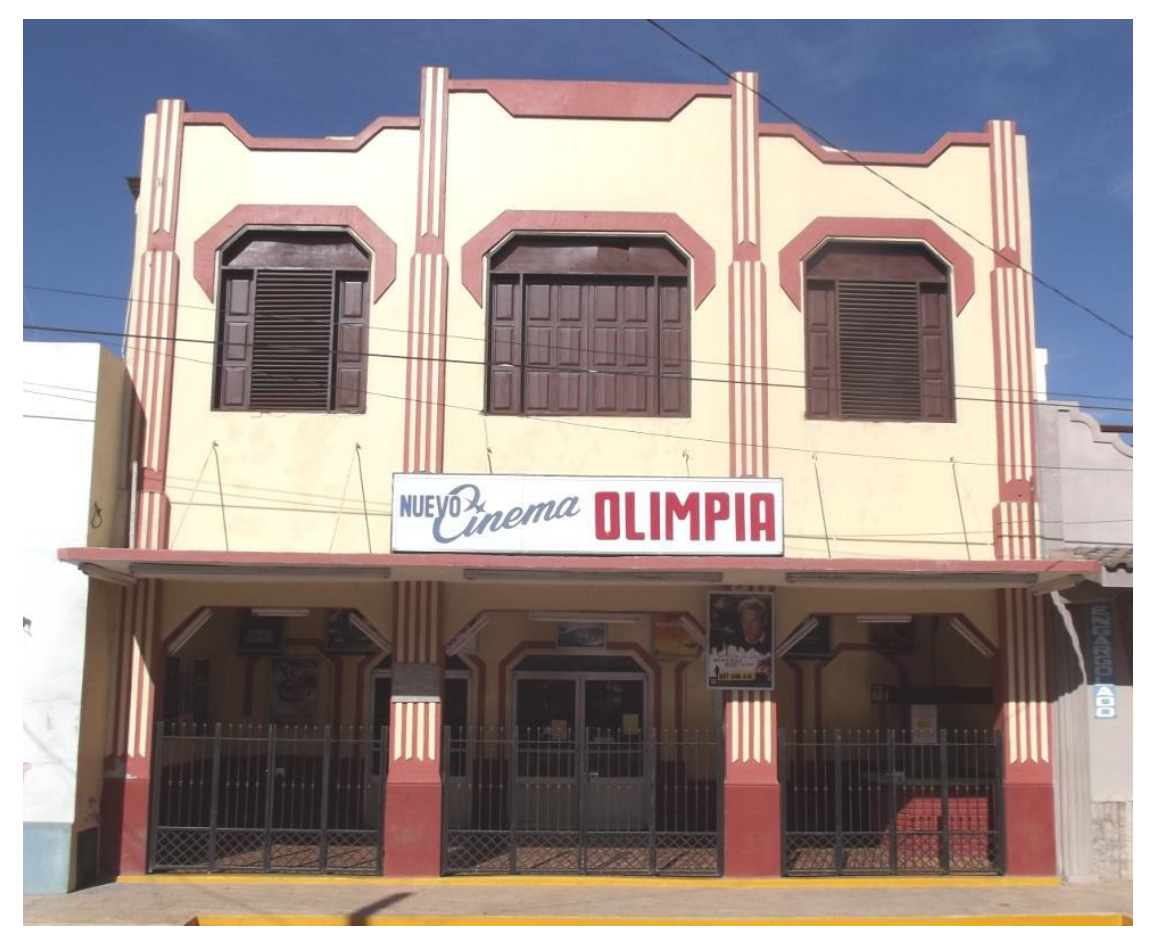

Fachada del cine.

En el segundo cuerpo tres ventanas se corresponden con los arcos de la entrada, llevando también arcos ochavados, que en su parte superior van ornados con molduras que los envuelven, semejando unos brazos que acogieran el arco. En el remate superior central se resalta una molduración recta que cae en forma trapezoidal inversa, combinando su juego geométrico con los remates laterales, pero con la diferencia que éstos están seccionados, remarcando una moldura la línea del trapecio opuesto. El efecto espacial que se logra es de una armonía geométrica serpenteante, pero conseguida con líneas rectas.

Todo el conjunto de formas geométricas de verticales, horizontales, ochavos, trapecios invertidos, ascencionalidad, se fortalece con el juego cromático bicolor de resaltar 
las molduras, pilastras y sus zócalos con el color marrón y el resto de la fachada y la estrías en color amarillo.

En el vestíbulo la puerta central y una lateral (que fue abierta en la década de los años setenta del siglo XX) están enmarcadas por molduraciones en ochavo y tres arcos ciegos llevan la misma forma decorativa. Originalmente, en los extremos estaban puertas de acceso y a los lados de la puerta principal los espacios eran utilizados para la propaganda de la cartelera. Estos ochavos se fusionan en diseño con los arcos de la fachada, resaltándose así la orientación de lo geométrico del Déco Zigzag.
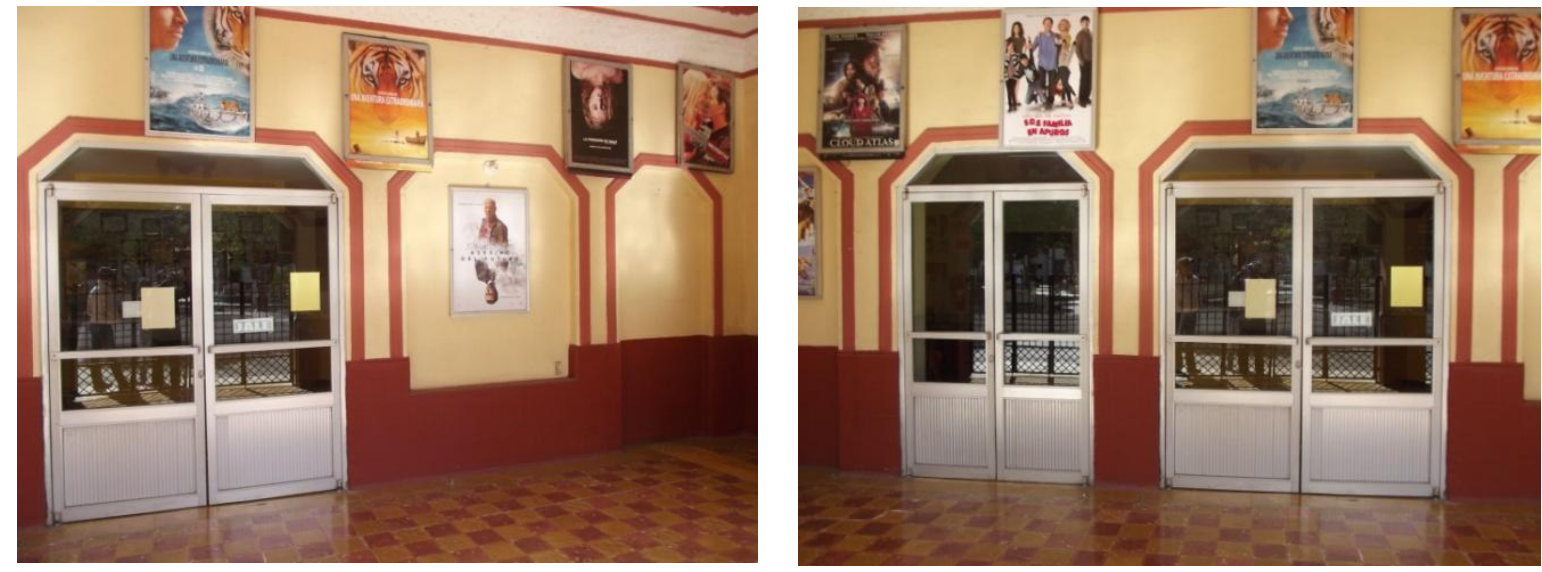

Imagen izquierda, puerta central y puerta lateral tapiada. Se nota el espacio original para las carteleras. Imagen derecha, puerta central y lateral abierta sobre lo que era el espacio para la publicidad.

En la parte interior no se conserva nada de elementos Art Déco. Lo que corresponde al segundo piso es donde se encuentra el cuarto de proyecciones. En el vestíbulo una placa colocada en la fachada alude a los cincuenta años de la inauguración del cine: 1928-1978, con los nombres del fundador, su esposa, su hijo y de la esposa de este último.

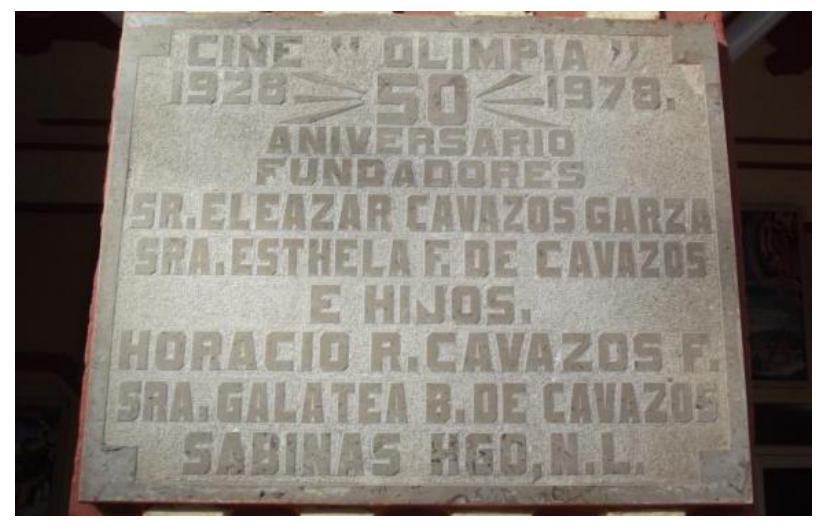

Placa del quincuagésimo aniversario del cine. 
Y a pesar de ser pequeño el Cine Olimpia, por la antigüedad del mismo, lo bien conservado que se encuentra y que denota muy bien sus elementos decorativos Art Déco Zigzag, es un caso insólito que en este municipio aún se preserve este muy buen ejemplo de la arquitectura Déco nacional y de Nuevo León dentro de la Tendencia Geometrista.

\section{d. Salinas Victoria}

La pequeña Villa de Salinas Victoria, actualmente muy cerca de la zona metropolitana de Monterrey, tienes sus orígenes allá por 1600 cuando se funda el Puesto de las Salinas, que más tarde en 1636 el nombre cambió por Misión de Nuestra señora de Guadalupe del Valle de las Salinas.

De población escasa con actividades ganaderas y de la minería, durante los siglos de la época virreinal fue un poblado con poco desarrollo demográfico. Ya para los años de la consumación de la Independencia los habitantes tomaban conciencia de su terruño, por lo que solicitaron que fuera elevado a rango de ciudad, solicitud denegada por el gobierno republicano, el cual un 4 de marzo de 1826 sólo accedió a darle la categoría de Villa (la que conserva hasta nuestros días), fecha que se toma como la de la fundación. ${ }^{215}$

Al ser cabecera municipal del municipio del mismo nombre, se erigieron edificios en los años de la reconstrucción postrevolucionaria, como es el caso de la escuela Dr. Lucas Lazcano que presenta elementos de Art Déco.

\section{d.1. ARQUIETCTURA ESCOLAR}

\section{d.1.1. Escuela Dr. Lucas Lazcano}

En el centro de la villa, en la plaza principal, se erigió la escuela Dr. Lucas Lazcano, ubicada en la calle Hidalgo No. 214, esquina con Juárez, con orientación al sur. El edificio data de 1942 a 1943, lo cual se sabe por las fechas que se encuentran en el remate de la

\footnotetext{
215 Enrique Maldonado Cervantes, "Salinas Victoria Centro histórico del valle de las Salinas", VV. AA. Nuevo León a través de sus municipios. Tomo IV, Monterrey, N.L., Milenio, Multimedios, 2010, p. 94.
} 
fachada principal; además, es obra de Merced Quintero, información que se exhibe en una placa de mármol blanco que se encuentra al lado derecho de la puerta de acceso.

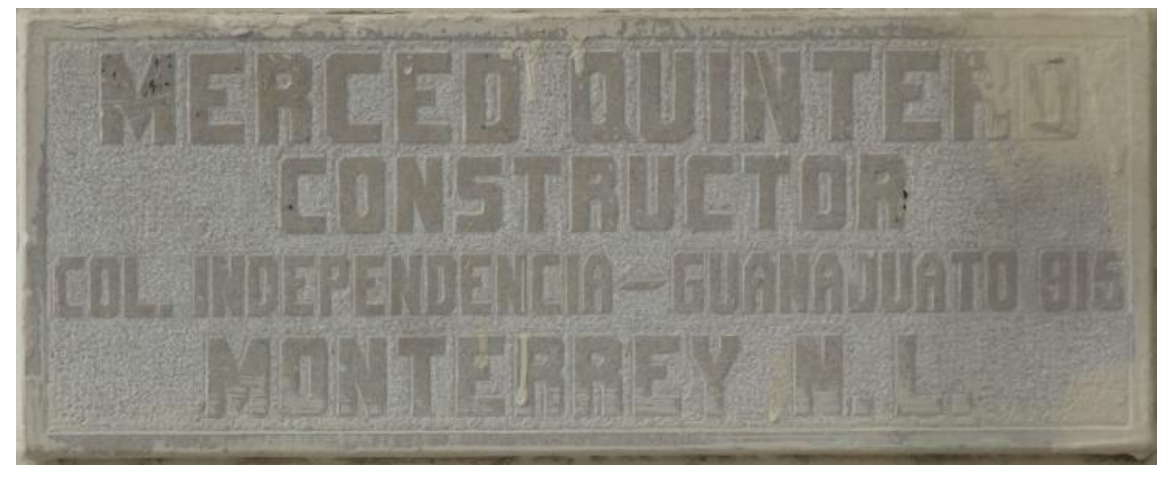

Placa con el nombre del constructor.

Inmueble de dos plantas, la fachada principal está en ochavo en la intersección de las calles Hidalgo y Juárez. La entrada principal desde la calle está flanqueada por zócalos alargados que conducen hacia tres peldaños escalonados para llegar a la puerta de acceso, la cual lleva un arco elíptico rebajado abocinado que se forma por varias molduras, similar a las construcciones Art Déco de la ciudad de México, tal como lo explica Enrique X., de Anda, citado en el capítulo 2. En el segundo piso un ventanal tripartito se divide por dos parteluces rectangulares, quedando en la parte baja de los tres espacios un recorte achaflanado con la finalidad de proyectar hacia el interior más luz. En lo que es cada ventanal, la disposición de siete pequeñas ventanas rectangulares, aunque pareciera algo muy simple y obvio, le imprimen un juego de equilibro geométrico ente verticales y horizontales que contrastan con las curvas del arco rebajado.

La elevación del muro de la fachada se recorta en la parte superior con tres molduras curvas y escalonadas para rematar con un ábaco conformado por un rectángulo recortado curvilíneamente en los ángulos superiores y un piñón sobrepuesto por encima con forma de medio círculo, donde se insertan la palabra "Escuela" y las fechas "1942 1943”. Este ábaco se proyecta hacia las fachadas laterales a través de dos extensiones cuadradas, curveadas en el vértice superior, con lo que se equilibran las disposiciones de rectas y curvas, que nos evocan a una abstracción de la vista frontal de un aeroplano, con su cuerpo central y las alas extendidas con todos y sus "flaps", muy dentro de los diseños del Art Déco Streamline. 


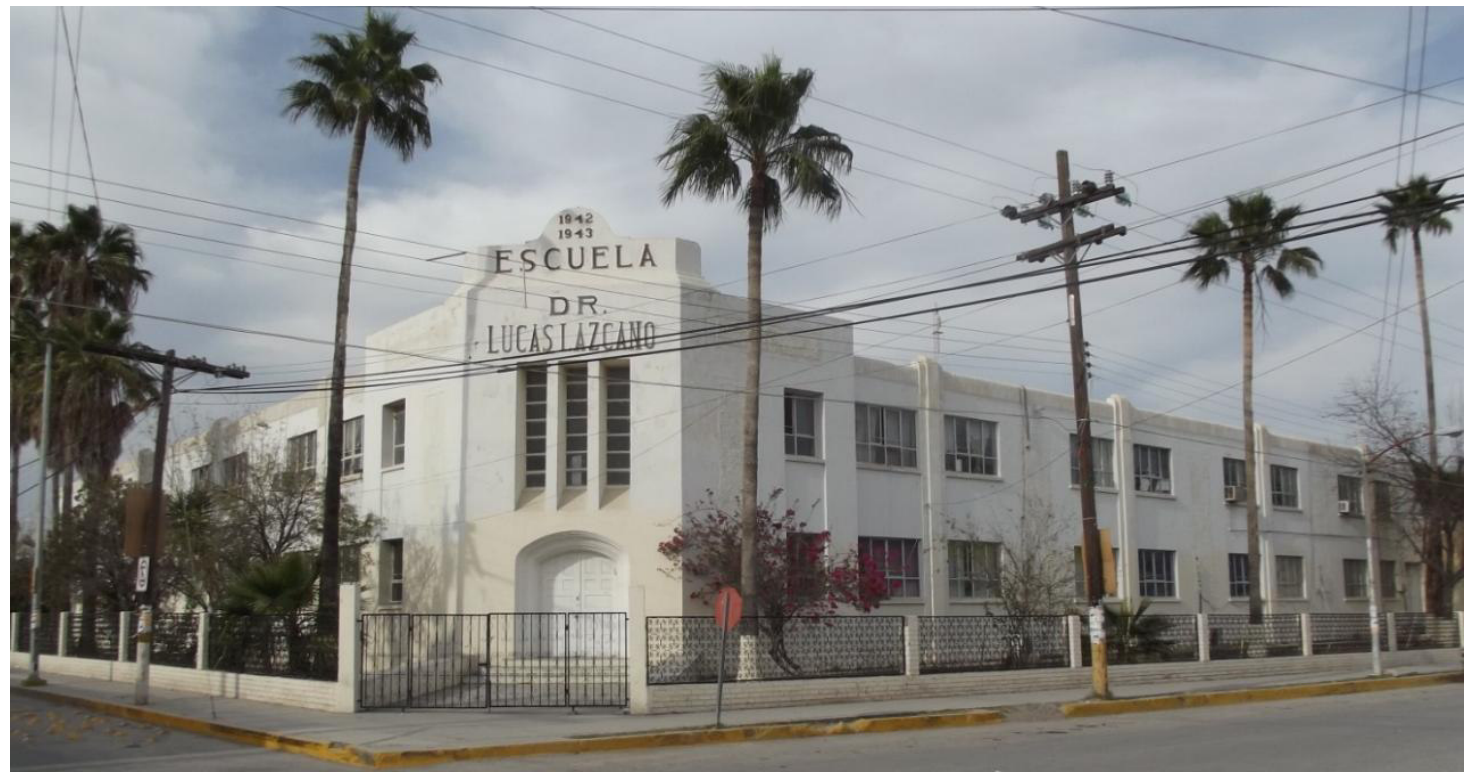

Vista general.

La fachada principal se proyecta hacia los cuerpos laterales del edifico a través de lienzos que se encuentran dispuestos hacia delante; primero, un rectángulo alargado en posición vertical está enmarcado por dos ligeras líneas que envuelven una superficie rugosa para luego dar paso a dos ventanas rectangulares, una en cada piso, conectadas por medio de un tablero rehundido. En la parte superior, trabajado de la misma manera que el recuadro vertical, se desplaza un rectángulo en posición horizontal, dándole a esta parte de la fachada una conjunción de líneas rectas, cuadrados y rectángulos, acentuando el geometrismo característico del Art Déco.

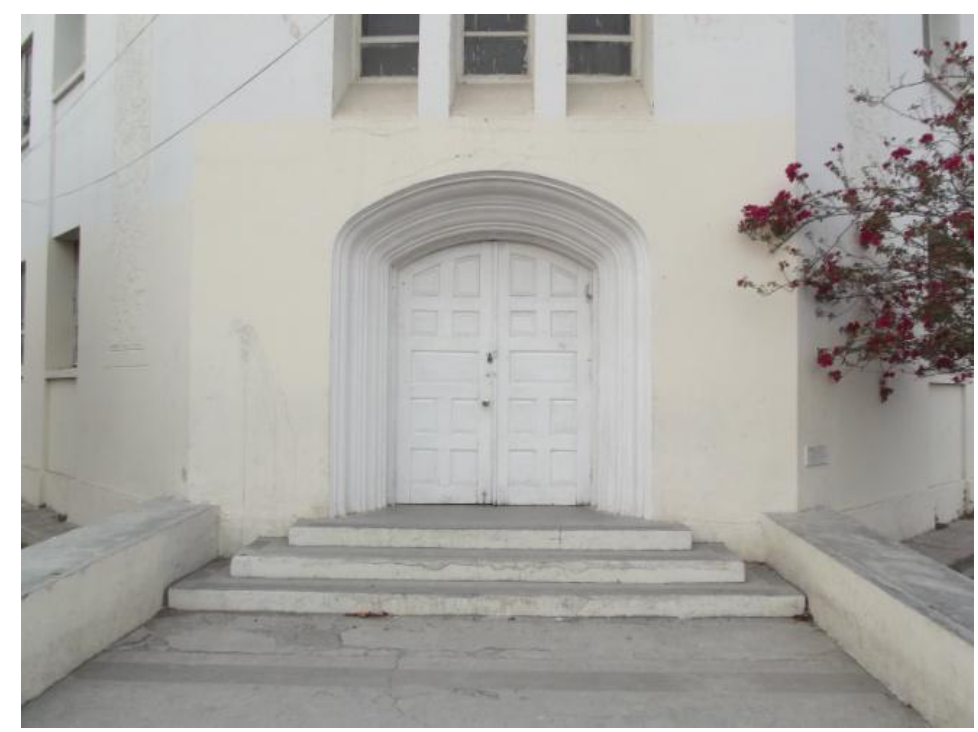

Entrada principal y puerta de acceso.

691 
Los cuerpos de las fachadas laterales se encuentran colocados hacia atrás en relación con el nivel del cuerpo de la fachada principal. Cinco espacios se acomodan entre cuatro pilastras, siendo los laterales más angostos que los tres centrales. Hilera de ocho ventanas rectangulares se distribuyen en cada piso, dando un total de dieciséis; en los tres espacios centrales las ventanas se separan por medio de un recuadro rectangular en posición vertical, el cual lleva el miso tratamiento que los recuadros de la fachada principal, con lo que se hermanan en la decoración geométrica.

Sin embargo, lo que más resalta de los cuerpos laterales es la decoración que presentan las pilastras y el remate superior. Las cuatro pilastras se componen de una banda ancha y una más delgada que se envuelven en la parte superior hacia dentro de la azotea, característica muy típica de las construcciones Art Déco. Cuatro lengüetas terminadas en punta de flecha caen adosadas a la banda menor y dos de menor tamaño a cada lado de la mayor. El efecto visual de escalonamiento que se obtiene con la curvatura que se forma al prolongarse las bandas hacia adentro, nos remite a las múltiples decoraciones de la gran Exposición de 1925 de París y al Hospital Civil, del que seguramente el arquitecto Quintero tuvo influencias, pues en esos años de 1942 y 1943 el nosocomio estaba abriendo sus puertas para el servicio médico e impactaba por su moderna arquitectura. Al mismo tiempo, con los diferentes tamaños de las lengüetas yuxtapuestas en las pilastras, más se enfatiza una decoración de tipo Déco Zigzag.

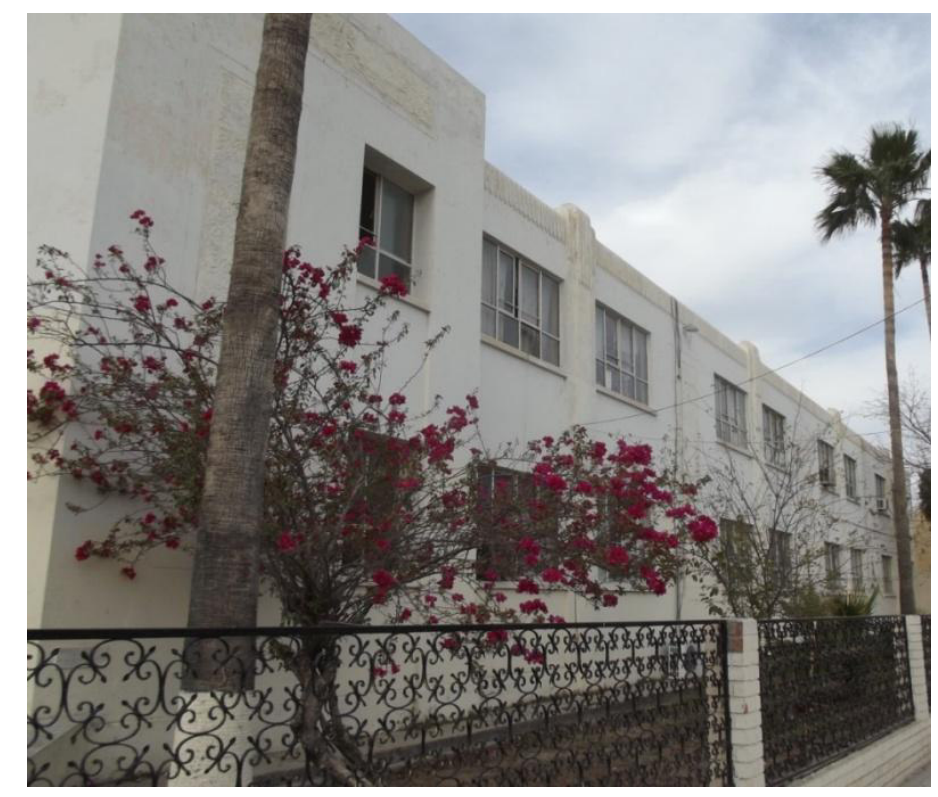

Fachada lateral oriente sobre la calle Hidalgo.

692 
En la parte superior a lo largo del remate de los muros laterales, el mismo atavío de las lengüetas recorre todo el perímetro; al ser de menor tamaño, conjugan el ritmo escalonado con las lengüetas de las pilastras y le dan cerramiento al edificio en lo que respecta a la decoración, envolviéndolo en una gala similar a flequillos de colgaduras o cortinajes, resaltando la ornamentación de tipo Déco Zigzag, que era ya poco usual para ser un edificio de los años cuarenta.
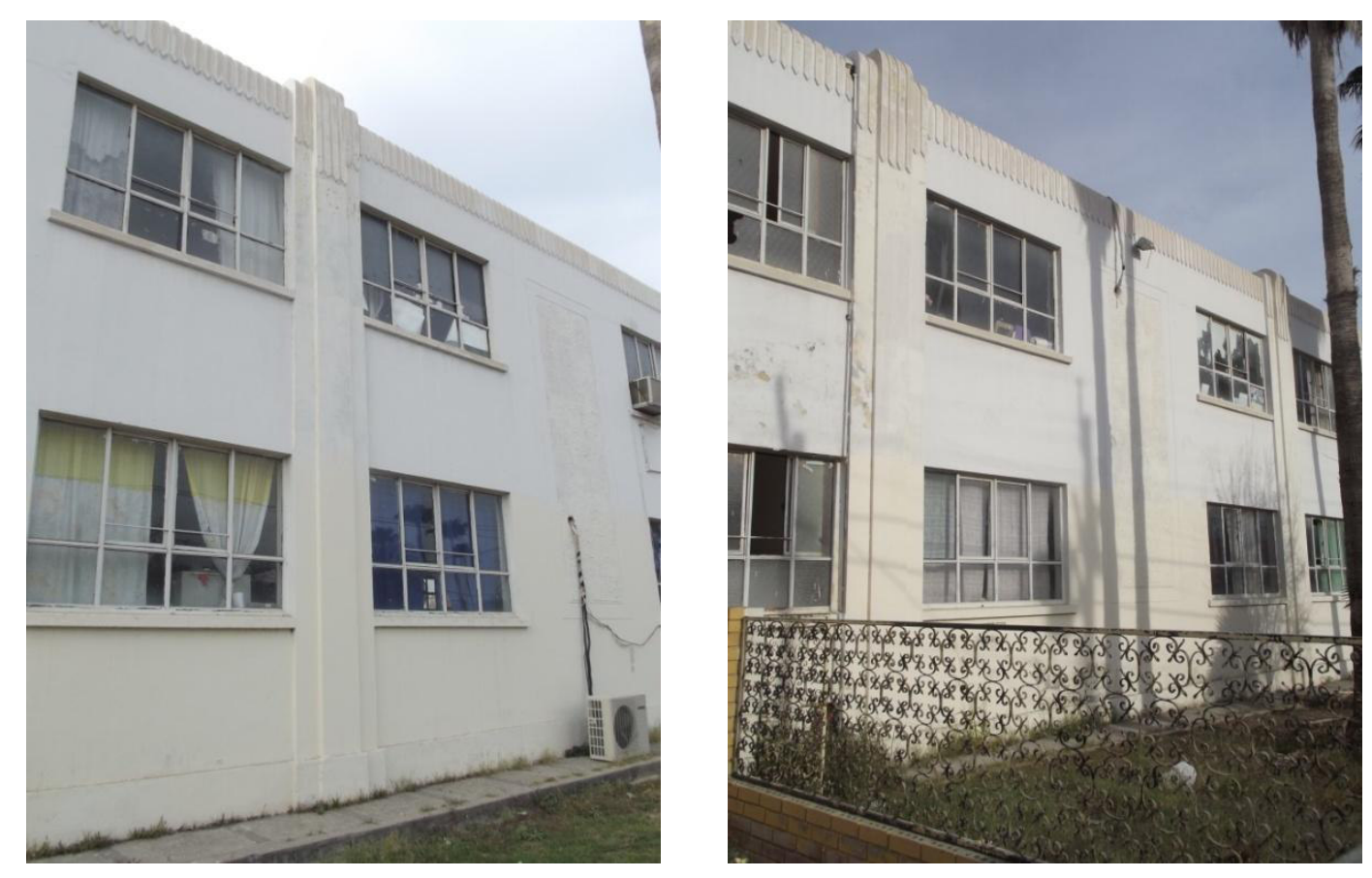

Detalle de las fachadas de la calle Hidalgo, la primera, y de la calle Juárez, la segunda. Se aprecia la composición de las pilastras con bandas superpuestas y de las decoraciones por medio de lengüetas tanto de las pilastras como del remate de los muros.

Del interior no se conserva ningún tipo de ornamento Art Déco y como se pude apreciar por las imágenes, el edificio en general se encuentra en mal estado de conservación: se han puesto luminarias exteriores con cableado por encima de las pilastras y de los recuadros de las fachadas laterales, así como al final del muro lateral izquierdo que da a la calle Juárez se abrió una puerta para la entrada de automóviles al patio trasero. Todo esto sin el menor tiento de afectar al edificio en su decoración original.

Este inmueble comparte las dos principales variantes del Art Déco: el Streamline se aprecia en la fachada principal que como anotamos anteriormente, con el ábaco y la disposición hacia las fachadas laterales que asemeja a un diseño aeronáutico; el Zigzag está 
claramente expuesto en las lengüetas de las pilastras y los remates, que a pesar de ser una decoración que se utilizó en la década de los treinta, aquí todavía aparece claramente en la siguiente década, lo que denota cómo en el país, el Art Déco siguió utilizándose en los años cuarenta del pasado siglo, cuando otros lenguajes arquitectónicos ya se habían impuesto de moda. Además su composición la inscribe dentro de la Tendencia Geometrista.

A pesar de la buena calidad del edificio como un digno ejemplo de Art Déco en el estado de Nuevo León, es curioso que no haya sido catalogado en el Catálogo Nacional de Monumentos Históricos Inmuebles de Nuevo León del INAH y más aún en la reciente Guía de Patrimonio Arquitectónico de Nuevo León del CONARTE. 


\subsection{EL ART DÉCO EN COAHUILA}

En el estado de Coahuila las producciones Art Déco se centran en las ciudades de Saltillo, por ser la capital, y en Torreón, una urbe cuyo desarrollo se da en el siglo XX.

En Saltillo, como en muchas ciudades del país, después de la Revolución se dio un auge en la construcción de escuelas, especialmente para la educación básica, por lo que hay cinco centros educativos públicos que fueron edificados con los parámetros estilísticos del Art Déco. Y la iglesia por su parte, también entro en la tarea de la renovación de sus espacios, por lo que la Diócesis de Saltillo manda a construir el nuevo seminario, que a pesar de ser una obra de finales de los años cuarenta del siglo XX, aún comparte elementos estilísticos Art Déco. El esparcimiento a través del cine tiene todavía en pie un digno ejemplo en Saltillo, así como un pequeño inmueble comercial en el centro de la ciudad. Podríamos decir que poco se construyó bajo el lenguaje del Art Déco, pero aunque escaso es de muy buena calidad.

Torreón tuvo su punto de lanzamiento comercial después del Revolución. Esto provocó la necesidad de levantar nuevos espacios públicos y privados para el comercio, esparcimiento y los servicios. Muchos se ha derrumbado, poco se ha conservado y dentro de esto último, algunos edificios prácticamente han perdido sus características Art Déco.

Hay un caso más que incluimos y es en el lejano pueblo de Nueva Rosita, donde se edificó una escuela en una zona poca poblada, pero con los lineamientos de la modernidad de lo Déco.

\subsubsection{EL DESARROLLO URBANO DE SALTILLO Y SU ARQUITECTURA ART DÉCO}

Cuando se inicia la transformación hacia el México Moderno después de la Revolución, Saltillo como muchas ciudades de la República, vivían en una situación urbana que más bien aún parecía rural. Salvo el centro de la ciudad donde los edificios porfirianos

y las grandes casonas de la elite presumían de una arquitectura y urbanismo citadinos, el resto de la ciudad era más bien un pueblo en condiciones rurales. 
En el año de 1927 la ciudad tiene una modernización al pavimentarse con asfalto las primeras calles del centro, así como la carretera a Monterrey. El Palacio de Gobierno tuvo reformas en su interior para albergar más oficinas que atendieran las nuevas necesidades de los servicios ofrecidos tanto por el gobierno estatal como federal. ${ }^{216}$ También se instalaron a finales de los años veinte las primeras líneas de autobuses foráneos y urbanos, una vez que se iba pacificando el país y la región, pues todavía en la misma ciudad de Saltillo se veían los efectos de los levantamientos militares ante el descontento por quienes manipulaban el poder.

La vida agrícola de la ciudad que era lo que empujaba su economía, pronto fue transformada hacia una economía industrial, a pesar de que en 1923 se funda la Escuela de Agricultura de Coahuila Antonio Narro en la Hacienda Buena Vista, en las afueras de la ciudad, y que vivirá como independiente hasta 1938 cuando pasa a ser parte del estado y ahora es la Universidad Autónoma Agraria Antonio Narro.

Ya desde 1916 se inician las operaciones comerciales del Grupo Industrial Saltillo (GIS), que en 1928 se llamaba Isidro López y Hermanos cuando empezaron con los trabajos de fundición con CIFUNSA (Compañía Fundidora del Norte Sociedad Anónima) y en 1932 crean CINSA (Compañía Industrial del Norte Sociedad Anónima), empresa dedicada a la fabricación de utensilios de cocina, calentadores, refacciones de estufas y artículos de aluminio, convirtiéndose en la empresa de su giro más fuerte del país.

En la misma época, la fábrica de ropa Éxito confeccionaba uniformes industriales, escolares, así como indumentaria de vestir cotidiana.

Los Molinos el Fénix, empresa fundada desde 1885, había sufrido el incendio de sus instalaciones en 1920, pues la mayoría estaba construida con madera. Se reconstruye y en 1940 se estrena el local que está en la calle Allende, construido ya con ladrillo y cemento, ampliando sus instalaciones. La molienda del trigo y el maíz la hacía ser la fábrica más grande el noreste de México.

Estas fábricas requirieron de la mano de mano de obra, por lo que muchos campesinos dejaron sus trabajos agrícolas para convertirse en obreros y muchos más

\footnotetext{
${ }^{216}$ Pablo Cuéllar Valdés, Historia del Estado de Coahuila, Saltillo, Coahuila, Universidad Autónoma de Coahuila, 1979, p. 234.
} 
migraron de los pueblos cercanos a Saltillo, así como gente del estado de San Luis Potosí que llegó a la capital de Coahuila.

Ante esta situación, también se hacía necesario fortalecer la educación básica y media, primicia del gobierno postrevolucionario entre otras tantas acciones. Y a la vez, el hecho de que algunos personajes de la Revolución eran coahuilenses, la solicitud de apoyo federal para emprender la tarea educativa se vio como una prerrogativa a cumplir: Francisco I. Madero (1873-1913), quien logra derrocar a la dictadura porfirista y luego se convierte en mártir de la democracia nació en Parras; Venustiano Carranza (1859-1920), "el Constitucionalista" era oriundo de Cuatro Ciénegas; los presidentes de cortos periodos en plena contienda revolucionaria, Eulalio Gutiérrez Ortiz (1881-1939) nacido en Ramos Arizpe y Roque González Garza (1885-1962) saltillense. Ya no era tiempo de ver las diferencias ideológicas y del próximo pasado revolucionario, sino de echar marcha hacia delante para modernizar la ciudad.

Los planteles educativos que se erigieron entre las décadas de 1930 y 1940 que tienen el lenguaje del Art Déco fueron la Escuela Coahuila, la Escuela Álvaro Obregón, la Escuela Margarita Maza de Juárez, la Escuela Constituyentes de 1917 y el Ateneo Fuente. Todas fueron diseñadas y construidas por Zeferino Domínguez Villarreal (1894-f?), cuyo genio creador a pesar de tener una formación autodidacta, supo imponer en sus obras la estilística de vanguardia del Art Déco, tanto Clásico, Zigzag y Streamline. Dentro de estos centros educativos, el Ateneo Fuente que estrena su nuevo campus, fue el más grande e importante de su época que sólo vino a ser superado cuando se construye Ciudad Universitario en la ciudad de México en 1950. A la vez que se construía el Ateneo, también se desplegaba la ciudad hacia el norte, por lo que se traza el boulevard Venustiano Carranza que conectaba con la carretera a Monterrey y se crearon nuevas colonias habitacionales para la clase media y acomodada.

Como Zeferino Domínguez construía lo que se le pedía, también hay un pequeño comercio en el centro de la ciudad llamado Casa Joch, edificio que resguarda todavía parte de su decorado Art Déco.

Pero también la iglesia católica pide los servicios de Zeferino Domínguez y le encargan el Seminario del Sagrado Corazón, erigido en el sur de la ciudad, en una zona de escasos recursos y por donde se extendía la calle Manuel Acuña para convertirse en la 
calzada Antonio Narro. Aunque el seminario se construye a finales de los años cuarenta y se pone en funciones en la siguiente década, aún exhibe algunos diseños Art Déco dentro de un edificio en su mayoría funcionalista.

La obra de Zeferino Domínguez Villarreal ha sido descrita en un libro dedicado a su obra por el arquitecto Jesús Ramírez Rodríguez, catedrático investigador de la Universidad Autónoma de Coahuila, sin embargo, los trabajos de Domínguez Villarreal donde aplicó los lenguajes del Art Déco no han sido tratados como tales, es por eso que lo dedicado a estudiar en Saltillo en su mayoría corresponde a este constructor y por esta razón es que aquí especificamos cuáles son los inmuebles de su autoría.

Un cine fue erigido con la estilística del Art Déco en el centro de la ciudad, como era la moda de ese tiempo tener modernos y amplios espacios para el esparcimiento a través de la pantalla grande, donde se exhibían las cintas de la Época de Oro de nuestro cine nacional y las grandes producciones hollywoodenses.

Para la descripción de estos edificios usaremos las variantes Art Déco aplicadas a la arquitectura descritas en el capítulo 1, así como las Tendencias de Enrique X., de Anda expuestas en el capítulo 2. 


\subsubsection{ARQUITECTIURA ESCOLAR}

\section{a. Escuela Coahuila}

La Escuela Coahuila se localiza en la calle Juan Antonio de la Fuente 401, en el centro de Saltillo, aunque la entrada y fachada principal es por la calle Matamoros frente al jardín del mismo nombre con orientación hacia el poniente.

Es de doble planta rectangular, pues tiene dos patios, sin embargo la parte principal es la que corresponde al primer patio. Los materiales que fueron utilizados son una combinación de sillar, ladrillo y cemento. Las obras se iniciaron a mediados de 1930 y se inauguró el inmueble un 16 de septiembre de 1931, para conmemorar el aniversario de las fiestas de la Independencia. Fue idea del gobernador Nazario S. Ortiz Garza (1893-1991), quien buscaba cubrir las necesidades de la educación básica, al construir un nuevo edificio escolar y para esto invitaron a Zeferino Domínguez Villarreal (1894-f?). Una placa colocada en el pequeño vestíbulo evoca la fecha de la apertura del inmueble.

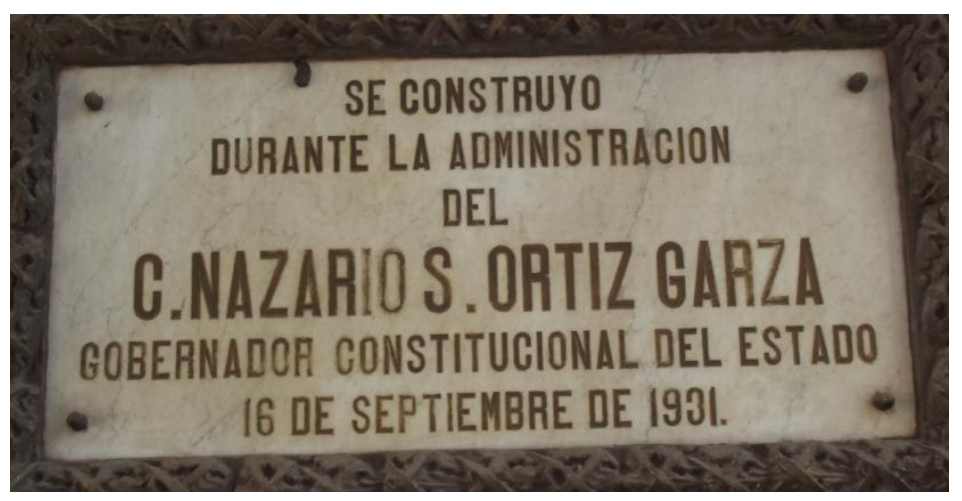

Placa en el vestíbulo de entrada.

Es interesante cómo el constructor mezcló los materiales como el adobe para los muros, con concreto armado para columnas y trabes. Desafortunadamente el detrimento que han sufrido los muros por la humedad no se ha atendido como debería ser y la escuela demuestra bastante deterioro.

La construcción tiene dos lenguajes que se usaban y estaban de moda en esos años: el Neocolonial y el Art Déco. Aquí Domínguez Villarreal mezcló hábilmente las dos 
corrientes estilísticas, teniendo en su estructura un edificio tipo siglo XVIII, con dos plantas, patio central principal, patio trasero, escalera de acceso a la planta alta y varios motivos decorativos. Así pues, los elementos neocoloniales los dejaremos de lado, sólo los mencionaremos, ya que lo que nos interés es avocarnos al Art Déco. Sobre este asunto de la diversidad estilística de la Escuela Coahuila en el libro Arquitectura Escolar SEP 90 Años, dice: “...es otro caso de difícil clasificación debido a la variedad de la ornamentación empleada en todos sus elementos constructivos". 217

En la fachada principal destaca el vano de acceso de doble altura formado por un arco abocinado de doble arcada, elemento muy común en la arquitectura Déco, tal como lo explica Enrique X. de Anda al referir a los elementos distintivos del Art Déco en México. El primer arco va flanqueado por molduras, mientras que el segundo está biselado hacia el interior. Algo que utiliza Zeferino Domínguez es el azulejo de talavera para darle un toque nacionalista, lo mismo en las cuatro placas verticales decorativas con guirnaldas que caen verticalmente rodeando a la puerta, dos rehundidas y dos realzadas, donde las de la parte superior su contorno tiene una caída en forma de triple escapulario, llevado un orientación de composición geométrica. Estas guirnaldas usadas en la decoración de la arquitectura ecléctica de transición entre los siglo XIX y XX, aquí se les da un sentido más rectilíneo que curvo, por lo que su diseño bien puede ser un Neoclásico Moderno. En la parte superior está enmarcado el nombre de la escuela con letras típicamente Déco, de una fuerte innovación geométrica, tanto en el diseño de las grafías como en el acomodo de las mismas.

Por lo que respecta a las ventanas neocoloniales, llevan decoraciones en azulejos que también serían del Neoclásico Moderno, pues las de abajo en la parte superior lucen una guirnalda al estilo clásico, pero con formas geometrizadas y las de arriba en la parte baja con azulejos en tono azul forman tres "us" onduladas a manera de una abstracción de un adorno vegetal.

El pretil ondulado y que se eleva en la parte central, las bandas que dividen cada tramo, así como las almenas estilizadas, son elementos neocoloniales. El escudo en el remate en azulejo es una serpiente y un medio sol.

\footnotetext{
${ }^{217}$ Axel Arañó (editor), Arquitectura Escolar SEP 90 años, México, Secretaría de Educación Pública, Consejo Nacional para la Cultura y las Artes, 2011, p. 129.
} 
Las lámparas que están colocadas en ambos lados de la jambas, tratan de imitar una composición de luminarias neogóticas, en donde se denota ese afán de incluir varias modalidades de estilos por parte de Zeferino Domínguez, pero predominando la modernidad del Art Déco.

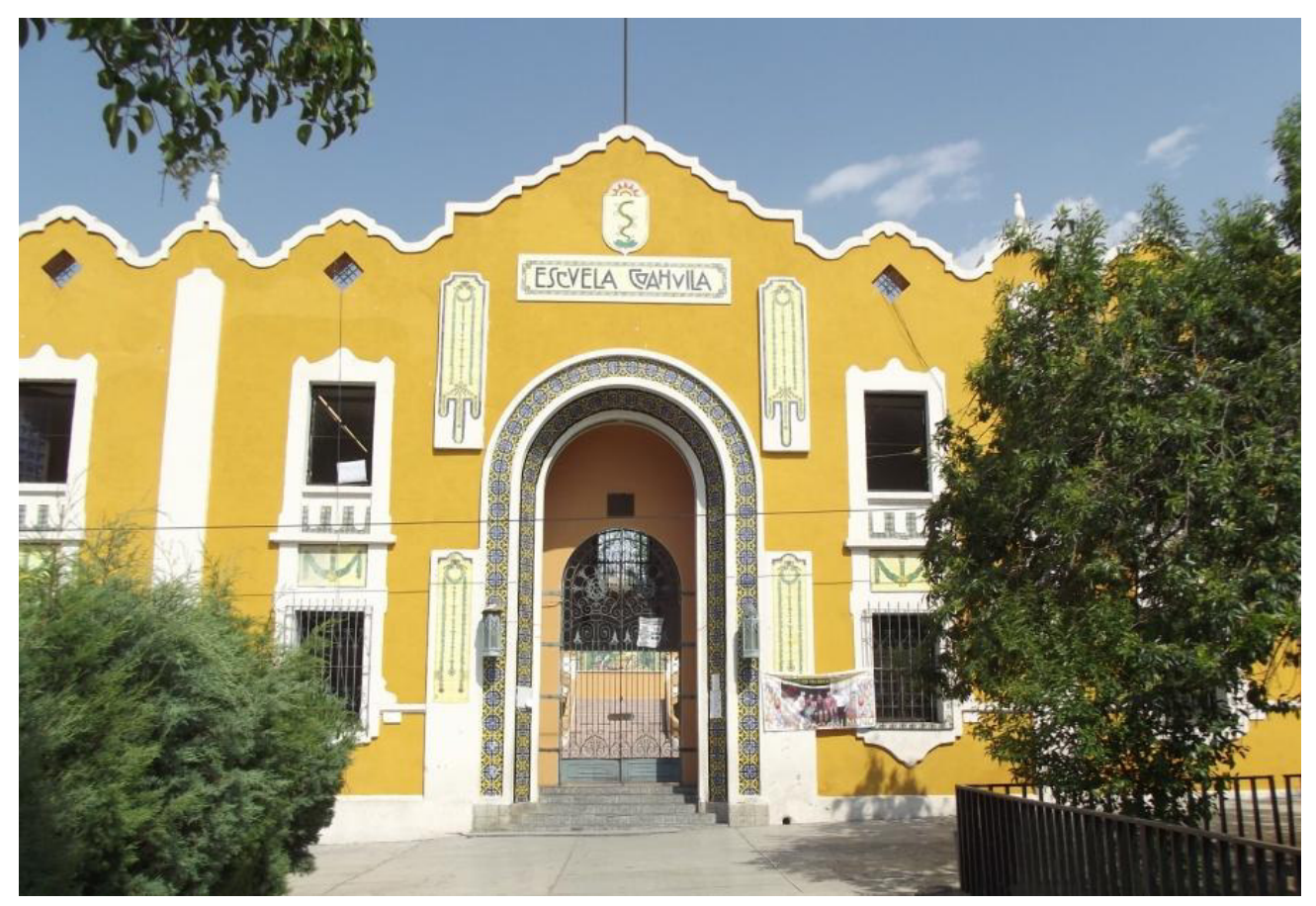

Fachada principal por la plaza Matamoros.

La fachada norte que da a la calle Juan Antonio de la Fuente y que es la que tiene la dirección oficial, lleva la misma disposición y decoración de las ventanas. En la entrada la puerta es rectangular y en el segundo piso sale un balcón decorado con talavera formando un conjunto de "us" rectangulares. Se repiten las mimas placas de la fachada principal a los lados de la puerta, lo mismo que el letrero y el escudo.

Cuando se cruza la reja de entrada al patio principal, después de un segundo vano de menor dimensión, la Escuela Coahuila ofrece un espectáculo visual extraordinario de un Art Déco de magnífica calidad: primero es el patio principal, con un llamativo piso como a manera de un gran damero con losetas en blanco y negro, desplazándose alrededor un corredor techado donde se distribuyen las aulas y oficinas. Las columnas que sostienen la techumbre del corredor son cuadradas, biseladas en cada arista, con zócalo y capitel toscano en color dorado con borlas en cada esquina. Los arcos son deprimidos y levemente 
apuntados, lo que permite más entrada de luz a los corredores, cuyo piso está forrado con mosaicos en color gris y rojo que van armando juegos geométricos de zigzags.

Una amplia escalera central con un mural en el descanso lleva al segundo piso, cuyos corredores son abiertos.

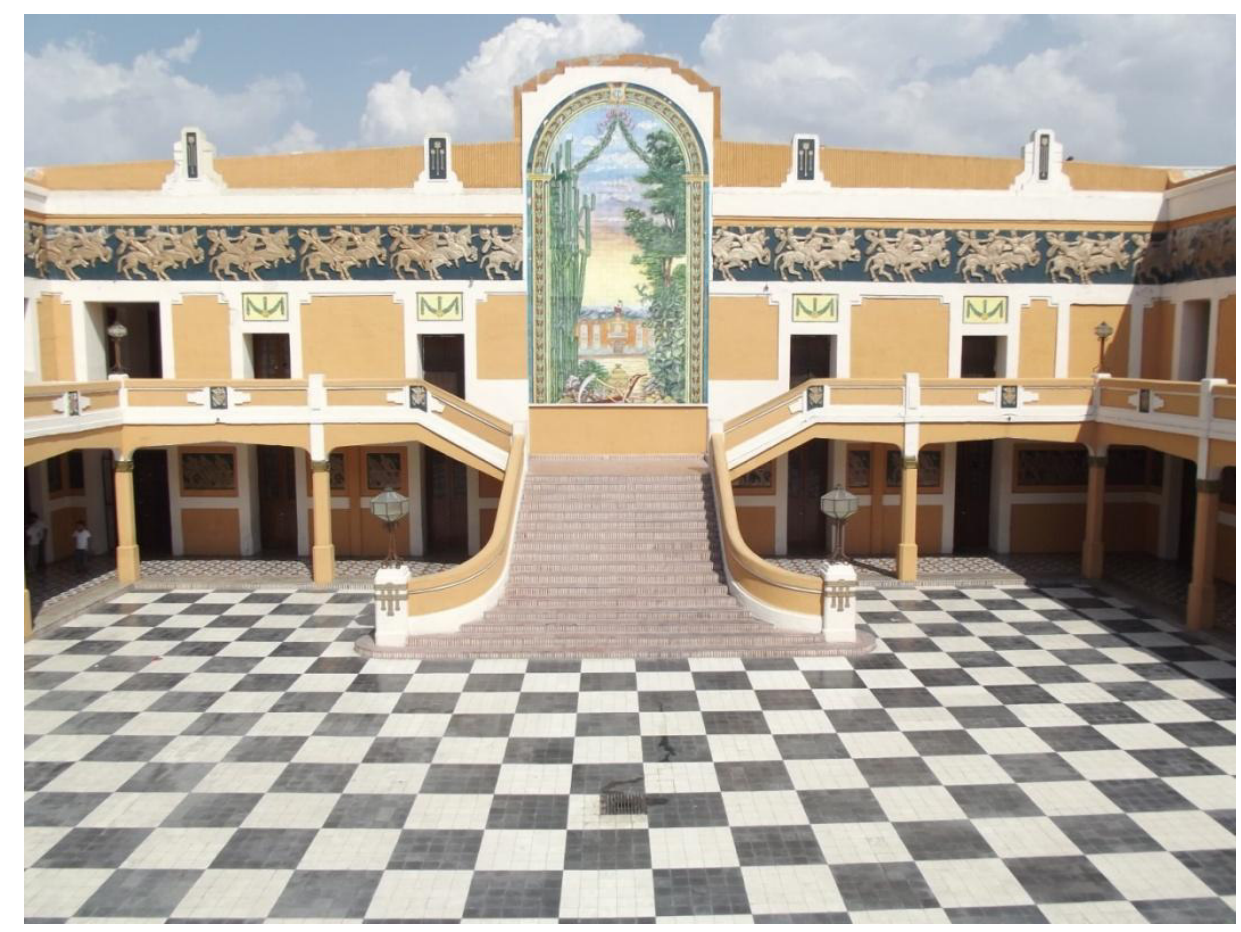

Patio principal con el mural de Salvador Tarazona al centro.

En las paredes de las aulas y oficinas del primer piso unos relieves en estuco encuadrados por gruesas molduras representan a pescadores en sus faenas cotidianas, obra atribuida a Salvador Tarazona Pérez (f?-1955 ó 1961). Algunos son más grandes que otros, ya que unos incluyen a ocho personajes y otros solamente a cuatro, tres y dos. Coloreados en dorado y con fondo azul, su figura se inclina hacia la izquierda para representar la fuerza ejercida al jalar las redes. Es una analogía entre el pescador y el maestro, pues el primero extrae del mar a los peces para el sustento, mientras que el pedagogo saca de la ignorancia a sus alumnos, según la interpretación de la profesora Ana María Delgado Ibarra. ${ }^{218}$

¿Qué tanto estaría informado visualmente Tarazona sobre la Exposición Internacional de París de 1925 que dichos relieves tiene una fuerte influencia de los del

\footnotetext{
${ }^{218}$ Jesús Ramírez, Op. Cit., p. 27.
} 
Pabellón de una Embajada trabajados por Max-Blondat (1872-1925)? En el de La llegada del Embajador unas mujeres desnudas en diversas posiciones cargan una guirnalda, como si estuvieran dentro del mar con todo y peces con las burbujas formadas por su respiración; ellas están inclinadas hacia la derecha. En el de Tarazona, son hombres robustos semidesnudos, posicionados hacia la izquierda, como ya lo mencionamos, unos de frente y otros de espalda, mirando hacia uno y otro lado, arrastrando las redes, entre olas, cangrejos, la rosa náutica y la luna en cuarto creciente. Es un trabajo que refleja hondamente la decoración Déco utilizada en los años treinta del siglo XX, con la intención de dinamismo, dentro de la rigidez de los trazos anatómicos, que con pocas líneas trasmiten la fuerza física, la musculatura y la ardua tarea del trabajo en el mar.

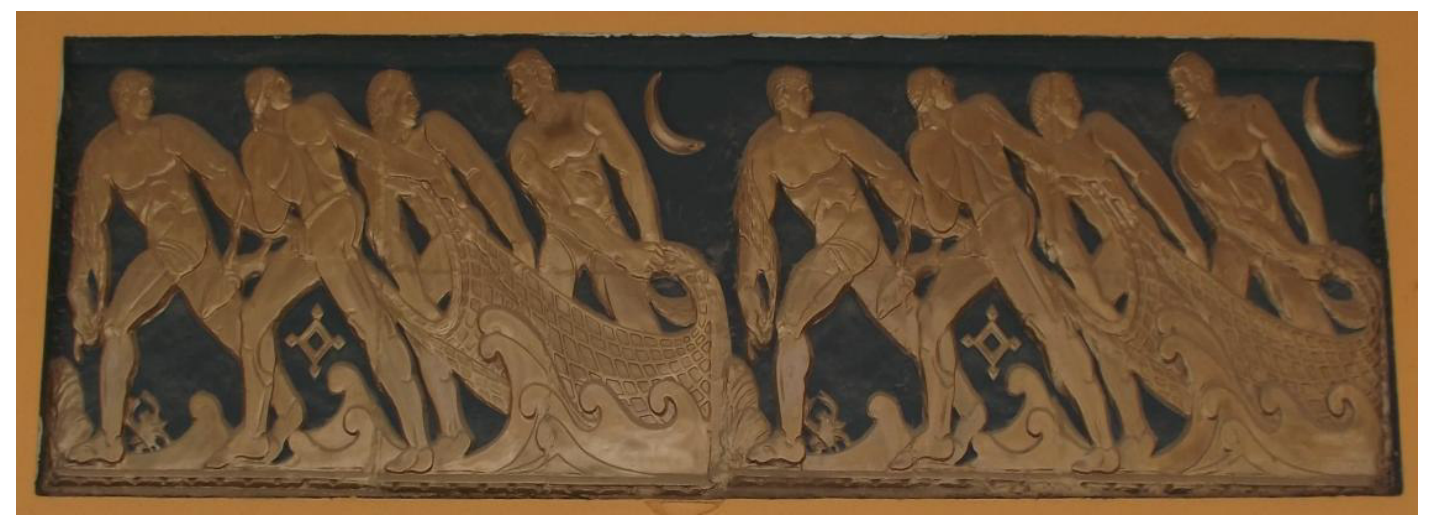

Relieve de los pescadores en el muro norte del primer piso.

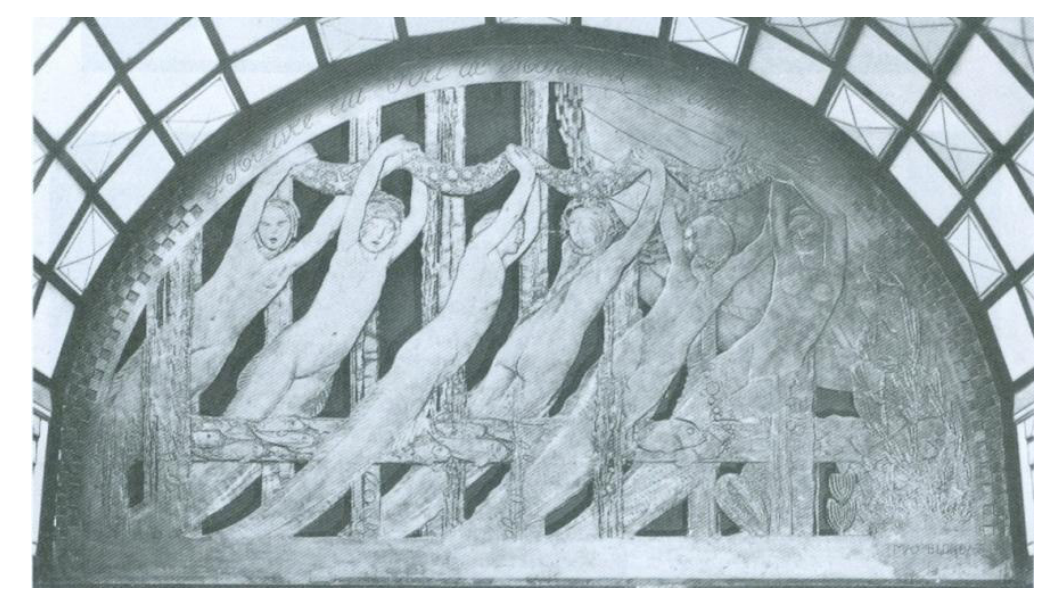

Relieve en el Pabellón de un Embajador, obra de Max-Blondat, 1925.219

\footnotetext{
${ }^{219}$ Theodore Menten, The Art Deco Style in Household Objects Architecture Sculpture Graphics Jewelry, New York, Dover Publications, 1972, p. 171.
} 
Para ascender al segundo piso hay una amplia escalera cuyos peldaños llevan mosaico con decoración a base de líneas verticales. El pasamos es curvo y arranca desde unos zócalos escalonados en la parte superior que sostienen unas octagonales lámparas con base de hierro con roleos geometrizados. Los zócalos están decorados con dos bandas horizontales y tres verticales a manera de ínfulas en color dorado. Todo el conjunto contiene un geometrismo poliédrico característico de los diseños Déco. En el descanso de la escalera un grandioso y llamativo mural en azulejos obra de Tarazona, representa el paisaje coahuilense, el trabajo agrario por los instrumentos de labranza y en el fondo la misma Escuela Coahuila. Es un aporte a difundir el nacionalismo, en este caso regional, que estaba en boga en los años de la postrevolución.

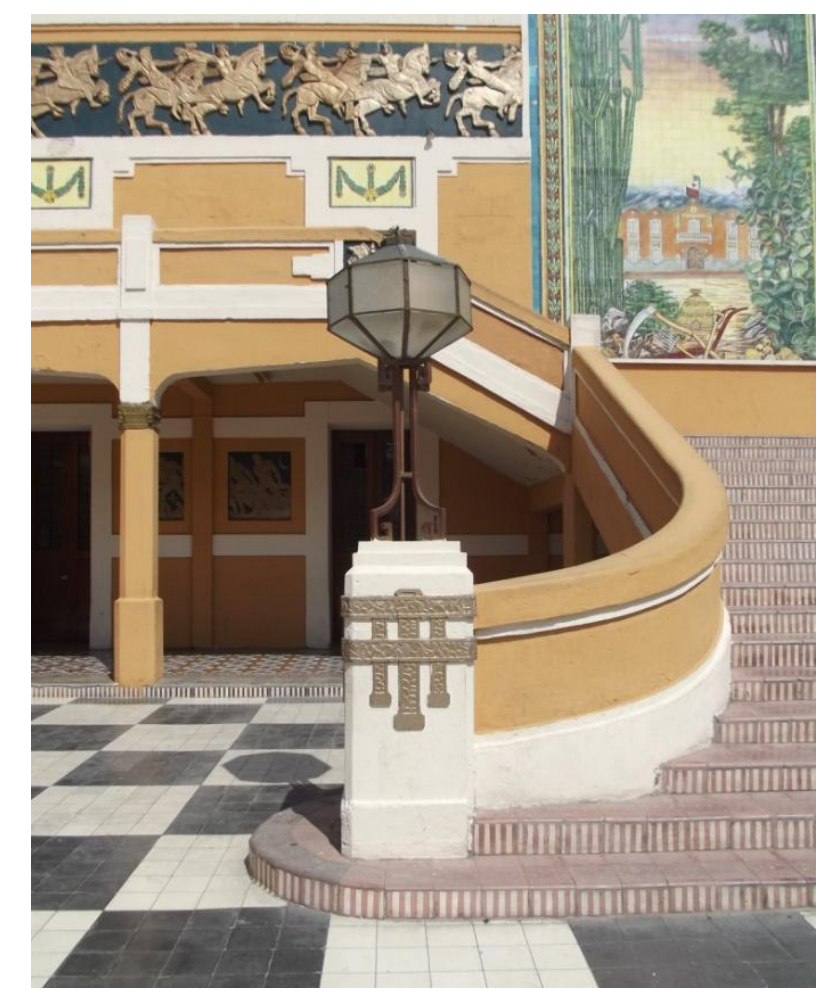

Detalle del zócalo del pasamanos y de la lámpara.

El segundo piso está descubierto. El antepecho que resguarda los pasillos se encuentra ornado con una banda horizontal que lo recorre todo. En cada esquina están colocadas unas lámparas como las del arranque de la escalera. Como si fuera una prolongación de la columna del primer piso, un dado divide cada tramo y en medio un 
relieve en dorado con fondo azul está acompañado en cada lado por un par de rectángulos, uno mayor y otro menor. El relieve es como un escudo con trazos geometrizados. Todos estos elementos conjugan la idea de la decoración a través de la geometría, rasgo distintivo del Art Déco.

Las puertas de las aulas están decoradas con acodamientos dobles en las esquinas, que más que un rasgo Déco es una reminiscencia colonial y las guiñarlas en azulejos como las de las fachadas exteriores, es un detalle decorativo de tipo clásico, que como anotamos en párrafos anteriores por su rígida composición bien podría ser un elemento del Neoclásico Moderno.

Por encima de las puertas corre un friso ininterrumpido, salvo en la zona del mural, también atribuido a Tarazona que con los mismos colores de los relieves del primer piso encarna a unos guerreros de tipo clásico griego que se pasan una antorcha, símbolo de la trasmisión de la luz del conocimiento, como es el quehacer de una escuela, interpretación dada por Ignacio Quiroz Martínez. ${ }^{220}$

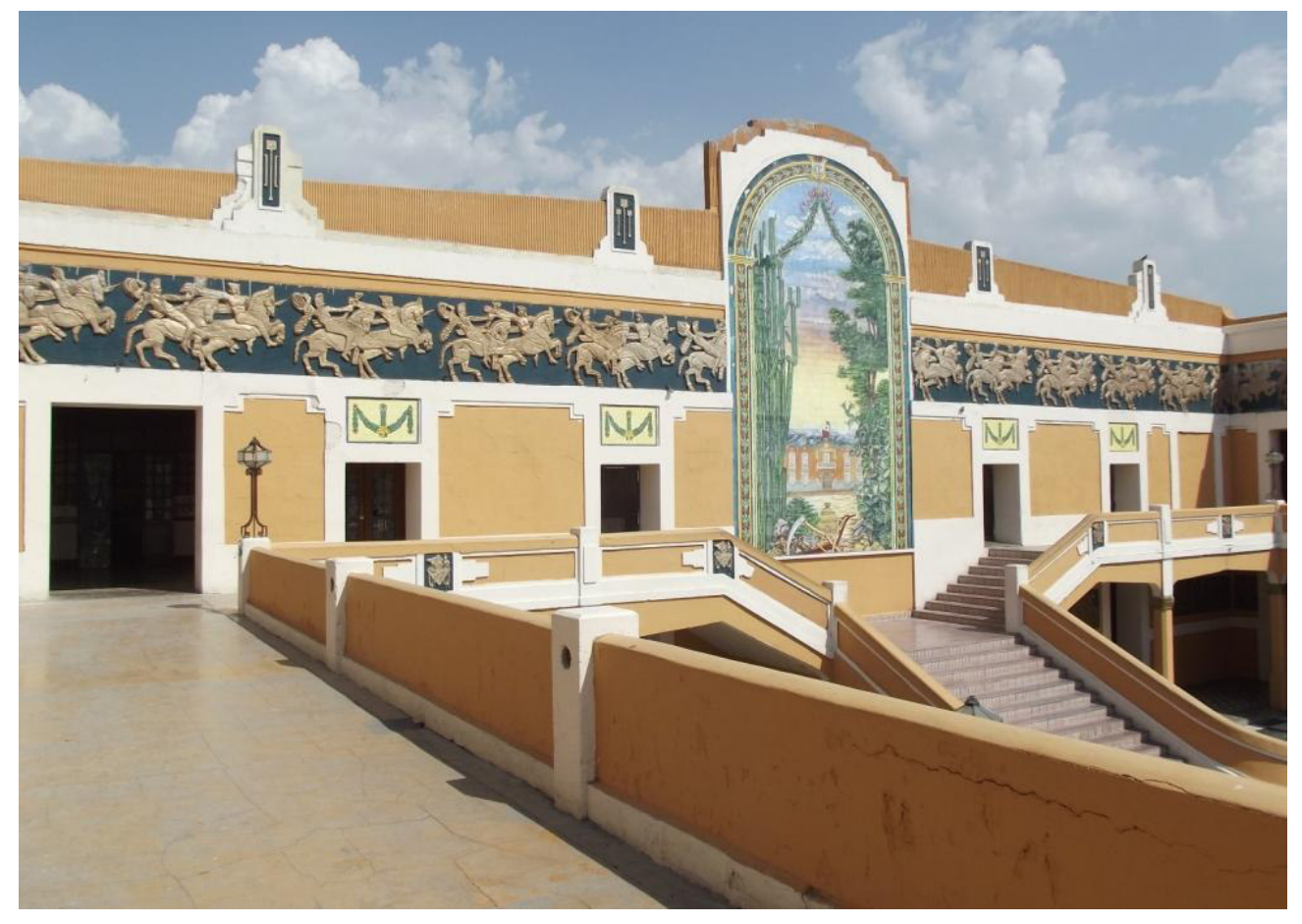

Segundo piso, muro oriente.

\footnotetext{
${ }^{220}$ Jesús Ramírez, Op. Cit., p. 27.
} 
Los milicios montados a caballo, éstos en pleno galope, uno está con la cuatro patas en el piso y el otro sólo con dos. La pose de los caballeros también inclinada hacia la izquierda, se hermana con los otros relieves. La tirantez de los brazos en el momento de entregar la tea denota la conexión de la horizontalidad con las líneas oblicuas de la pose de los personajes y de las extremidades de los equinos, lo que resalta el geometrismo anguloso del Art Déco tipo Zigzag.

El remate del muro oriente del segundo piso es de forma ascendente y como si estuviera tapizado, líneas verticales muy esbeltas lo cubren, además de tener decoraciones insertas: en los extremos muestra unas palas con cuchara cuadrada y a los lados unas molduras; están empotradas en unos diseños a manera de una caja de reloj tipo Luis XV, pero geometrizada. Otras decoraciones cercanas al mural son tres palas, una mayor y dos menores, también con cuchara cuadrada. Estos ornamentos intensifican el sentido de la geometría de la línea recta vertical, la oblicua y el cuadrado, enfatizando la estilística Art Déco.

Los otros muros llevan en la parte superior un ábaco central de mayor tamaño con remate curvilíneo y otros dos ábacos rectangulares. Resguardan decoraciones alusivas a la enseñanza, como en el caso del muro norte que tiene al centro un libro con antorchas y a los lados, un tintero y unas plumas. Una moldura que se recorta en los ábacos recorre los otros tres muros, norte, sur y poniente, con lo que le da una intensa expresión de linealidad.

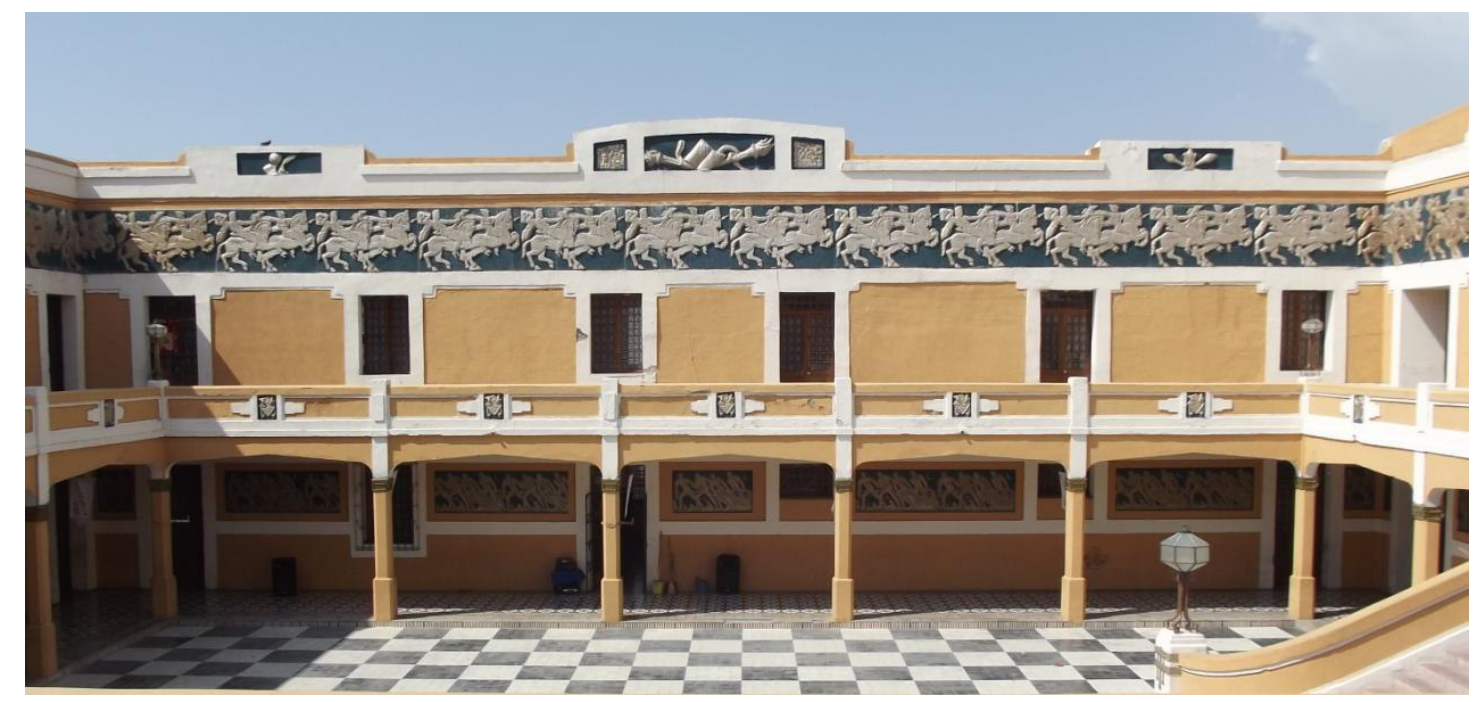

Lado norte. En los ábacos del segundo piso están al centro un libro con antorchas, a la izquierda un tintero con una pluma y a la derecha dos plumas entrecruzadas. 
Para concluir sobre este magno edificio y sus elementos Art Déco, hay una parte que destaca ampliamente, además de formar un contraste cromático. Es el piso de primer patio. Formado con mosaicos blancos y negros, a su vez arman una combinación de cuadrados a manera de un tablero de damas españolas, con lo que resalta la geometría de todo el edifico, pues invita a retener visualmente la configuración de lo geométrico. La alternancia cromática del blanco y negro, contrasta con los colores del edificio, que son blanco y melón para los muros y molduras y dorado y verde en los relieves. Simplemente, Zeferino Domínguez juega con las tonalidades con el sólo hecho de resaltar lo geométrico y estar dentro de la moda constructiva de esos años, recordando las pinturas de Piet Mondrian y la estética de De Stijl o los fundamentos compositivos de Paul Klee impartidos en la Bauhaus e inclusive las propuestas de Malevich para el Constructivismo soviético, todo esto enalteciendo la geometría de lo cuadrado ligado íntimamente a la estética del Art Déco.

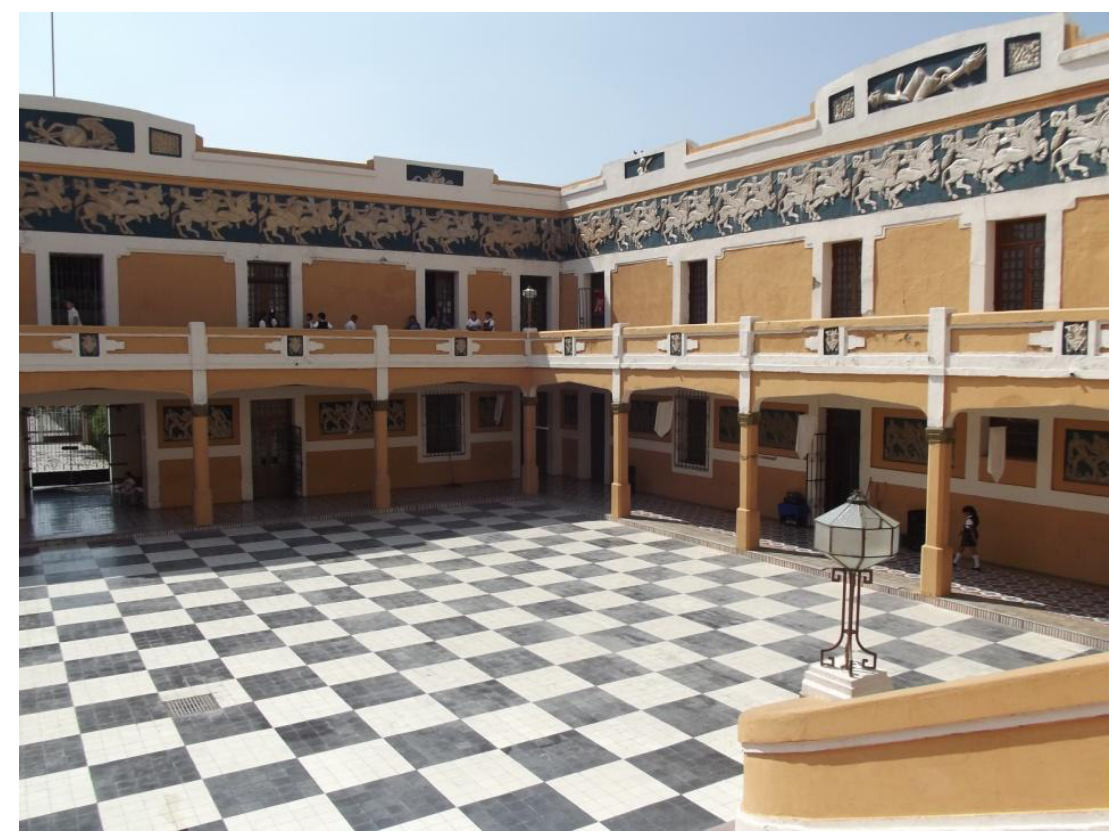

Piso del patio.

Con los elementos de Art Déco que posee la Escuela Coahuila, vemos que ostenta tanto parte compositivas como decorativas de tipo Déco Zigzag, pues la geometrización cuadrada, rectangular, de líneas oblicuas en los relieves son las que predominan es esta variante estilística. Sin embargo, como comentamos que hay elementos de tipo clásico, como son las guirnaldas de las fachadas exteriores, o los relieves que están tratados con 
temas clásicos, forman parte de un Neoclásico Moderno. Estos dos lenguajes están armonizados e integrados en el edificio con los componentes neocoloniales, obteniendo como resultado un edificio moderno, lujoso, amplio y llamativo que cumplía con las grandes expectativas que se deseaban para la educación básica del país. Y esto aunado a la decoración, la escuela también es un edificio representativo de la Tendencia Decorativista.
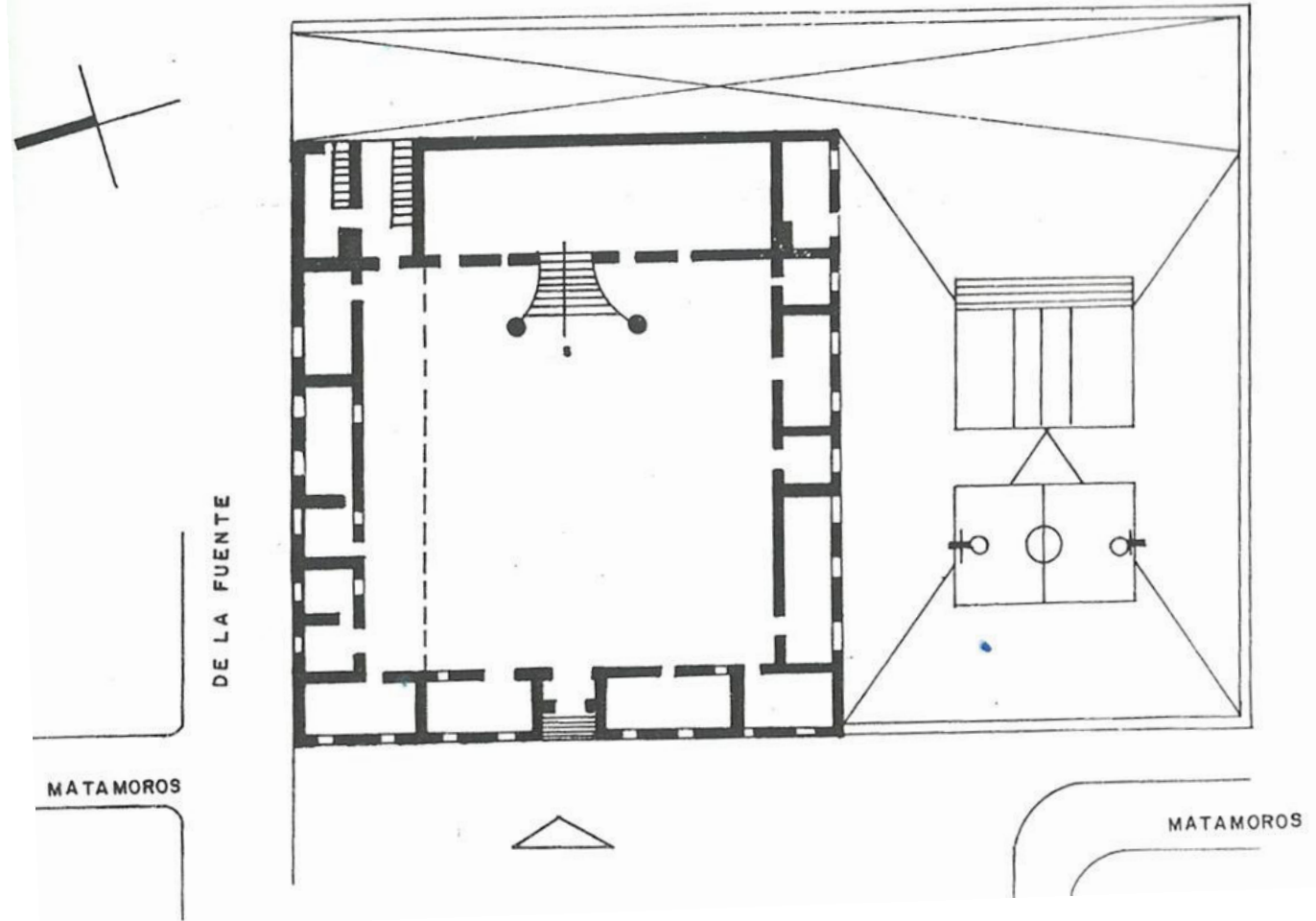

Plano de la Escuela Coahuila.

INAH, Catálogo Nacional de Monumentos Históricos Inmuebles. Coahuila, Tomo 3, México, SEP, INAH, Programa Cultural de las Fronteras, Gobierno del Estado de Coahuila, 1986, p. 1189. 


\section{b. Ateneo Fuente}

El magnánimo edificio de este recinto educativo se ubica en Avenida Venustiano Carranza, esquina con Avenida Universidad, s/n., en la colonia República. La fachada principal está orientada hacia poniente.

El origen de esta institución se remonta al tiempo del juarismo, cuando en la época de la Invasión Francesa, el afamado jurisconsulto coahuilense, el licenciado Juan Antonio de la Fuente (1814-1867), madura la idea de fundar un importante centro de estudios que funcionara a manera de un ateneo. Una vez que se reinstalan las instituciones republicanas con la salida de los franceses, durante el segundo periodo de gobierno estatal republicano de Andrés S. Viesca (1827-1908), el 11 de julio de 1867 al expedir la Ley de Institución Pública del Estado de Coahuila se crea el Ateneo Fuente, el cual fue instalado en el centro de la ciudad en lo que fuera el exconvento de San Francisco. Ateneo, porque además de funcionar como tal desde el punto de vista educativo, se decía que Saltillo era como la Atenas de México por el gran número de personajes del saber nacidos y/o desarrollados ahí y Fuente, por el apellido de su fundador. Ahí subsistió por muchos años, hasta que en la época de la reconstrucción nacional postrevolucionaria, el gobernador Nazario S.Ortiz Garza, quien dirigió el poder estatal de 1929 a 1933, con el apoyo de empresarios y de recursos estatales consigue un monto necesario para emprender la edificación de un nuevo inmueble de grandes proporciones y con miras a un crecimiento futuro. El gobierno estatal adquirió un terreno de diez hectáreas en las afueras de la ciudad en lo que se conocía como las goteras, lugar donde posteriormente se desarrollo la colonia República, la cual se convirtió en la zona de la clase acomodada saltillense de esa época.

Sobre la importancia del edificio e institución que alberga la Preparatoria de la Universidad Autónoma de Coahuila, el historiador Vito Alessio Robles en 1934, a un año de la inauguración, escribió lo siguiente: "Alguien dijo que en la ciudad de Saltillo los mejores edificios estaban destinados a escuelas y expresó una gran verdad. Otro afirmó quizá hiperbólicamente, que Saltillo era la Atenas de México. La verdad es que pocas ciudades de la república han producido en igual proporción que Saltillo un grupo tan numeroso de literatos notables, de hombre de ciencia, de pintores de renombre y de 
músicos afamados. El alma mater de esta espléndida floración ha sido el glorioso Ateneo Fuente".221

Para el proyecto se invito a Zeferino Domínguez Villarreal, quien diseñó un magno edificio con planta en forma de una $\mathrm{H}$. El nuevo plantel tendría veinte salones para clases con cuatro anexos, dos talleres de dibujo, cuatro laboratorios, una gran biblioteca, un museo, una pinacoteca con salón de estudios, un paraninfo con capacidad para quinientas butacas, oficinas administrativas, un observador meteorológico, más las áreas de servicios sanitarios. Se utilizó ladrillo industrializado en los muros y en las estructuras concreto armado con cemento, el material moderno del Art Déco, fabricado en Monterrey.

La primera piedra se colocó el 25 de abril de 1932 y para agosto del siguiente año se concluían las obras. El edificio fue inaugurado hasta septiembre para aprovechar las fiestas patrias del 15 y 16 de 1933, para lo cual estuvieron presentes funcionarios federales y estatales. Fue todo un grandioso acontecimiento, pues se convertía en un espacio educativo de nivel medio superior de la más alta dimensión a nivel nacional, pues no había en ninguna ciudad de la República algún inmueble educativo que se le pareciera en calidad constructiva y espacialidad, que sólo vino a ser superado cuando se construyó Ciudad Universitaria en la ciudad de México en 1950.

Siempre se ha manejado como el autor de la obra al arquitecto autodidacta Zeferino Domínguez, tal como lo confirma el arquitecto investigador Jesús Ramírez Rodríguez en su libro sobre la obra de Domínguez Villarreal; ${ }^{222}$ sin embargo, algunos investigadores han revelado que más bien fue Antonio Blas Cortinas (1890-1959) el creador del Ateneo Fuente, como es el caso del arquitecto Jesús Martín López López, maestro del la Universidad Autónoma de Coahuila, quien en su libro Arquitectura y escuelas en Saltillo, Coah., comenta lo siguiente: "Según el desaparecido ateneísta Miguel Santana, el concepto formal del edificio es posiblemente diseño original de Abel Blas Cortina, definido y construido por Zeferino Domínguez". 223

En una investigación reciente el arquitecto Mario Alberto Mojaraz de León también afirma que fue el ingeniero autodidacta Antonio Blas "el Chato" Cortinas, quien realmente

\footnotetext{
${ }^{221}$ Vito Alessio Robles, Saltillo en la historia y la leyenda, México, A. del Bosque Impresor, 1934, p. 238.

${ }^{222}$ Jesús Ramírez Rodríguez, La obra de Zeferino Domínguez Villarreal en el siglo XX, Saltillo, Coah., Gobierno del Estado de Coahuila, Instituto Coahuilense de Cultura, 2007, pp. 29-40.

${ }^{223}$ Jesús Martín López López, Arquitectura y escuelas en Saltillo, Coah., Saltillo, Coah., Universidad Autónoma de Coahuila, 2007, p. 104.
} 
diseñó y construyó el edificio, teniendo como asistente al propio Zeferino Domínguez. ${ }^{224}$ La poca información que hay sobre Blas Cortinas, quien tenía el puesto de Director de Obras del Gobierno de Coahuila durante el gobierno de Nazario Ortiz Garza, es la razón por la cual se le ha atribuido la obra a Domínguez Villarreal.

El edificio se encuentra en muy buen estado de conservación, habiendo tenido dos restauraciones e intervenciones: en 1967 donde se ampliaron aulas y laboratorios; y otra en 2005 que se enfocó a pintura, decoración interior y jardinería. En marzo de 1987 el último piso donde se resguardaba la biblioteca del gran escritor saltillense Artemio del Valle Arizpe (1884-1961), sufrió un incendio que acabó casi con la totalidad de los más de dos mil volúmenes, afectándose solamente esa parte del inmueble.

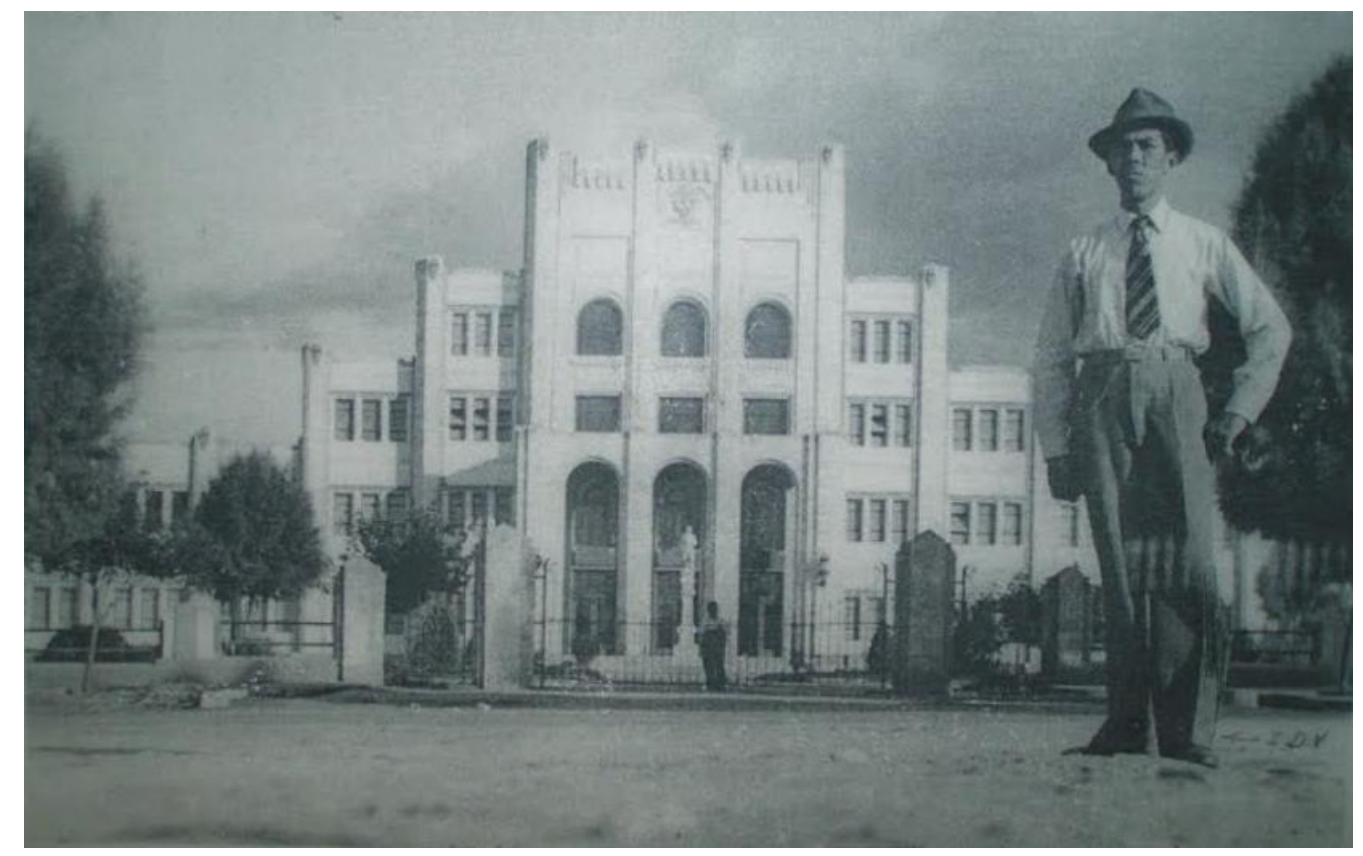

El Ateneo recién concluido y Zeferino Domínguez.225

El cuerpo central donde está la entrada es un elevado cubo donde la primera parte que se desplaza hacia el frente, la componen tres elevados arcos de medio punto cuyos intradoses se encuentran biselados y abarcan el primer y segundo nivel; los arcos se

\footnotetext{
${ }^{224}$ El Diario de Coahuila, "El Ateneo Fuente y la historia oculta de Antonio Blas Cortinas", El Diario de Coahuila, Saltillo, Coah., sábado 13 de agosto de 2011, www.eldiariodecoahuila.com.mx/notas/2011/8/13/ateneo-fuente-historia-oculta-antonio-blas-cortinas248134.asp

${ }^{225}$ Foto en: Jesús Ramírez Rodríguez, Op. Cit., portada.
} 
separan por pilastras rectangulares terminadas en punta de flecha y las de los lados se adosan sobre otra pilastra de mayor tamaño provocando el efecto geométrico de ángulos superpuestos. Después de una escalinata de cinco peldaños, un nártex preambula la entrada al edificio, donde se disponen tres puertas rectangulares y tres arcos de medio punto.

El tercer nivel lo conforman tres ventanales rectangulares, más la terraza que se forma con los arcos de la entrada. En el cuarto piso los tres ventanales son de arco de medio punto; la unión con la parte superior del tercer nivel y la parte baja del cuarto se hace por medio de tres rectángulos tablereados en posición horizontal, distribuidos unos sobre otros de menor a mayor; en la parte baja de las ventanas del cuarto nivel hay una ornamentación con dentados y en la parte superior las curvaturas de los arcos se remarcan con una doble superposición a manera de dosel.

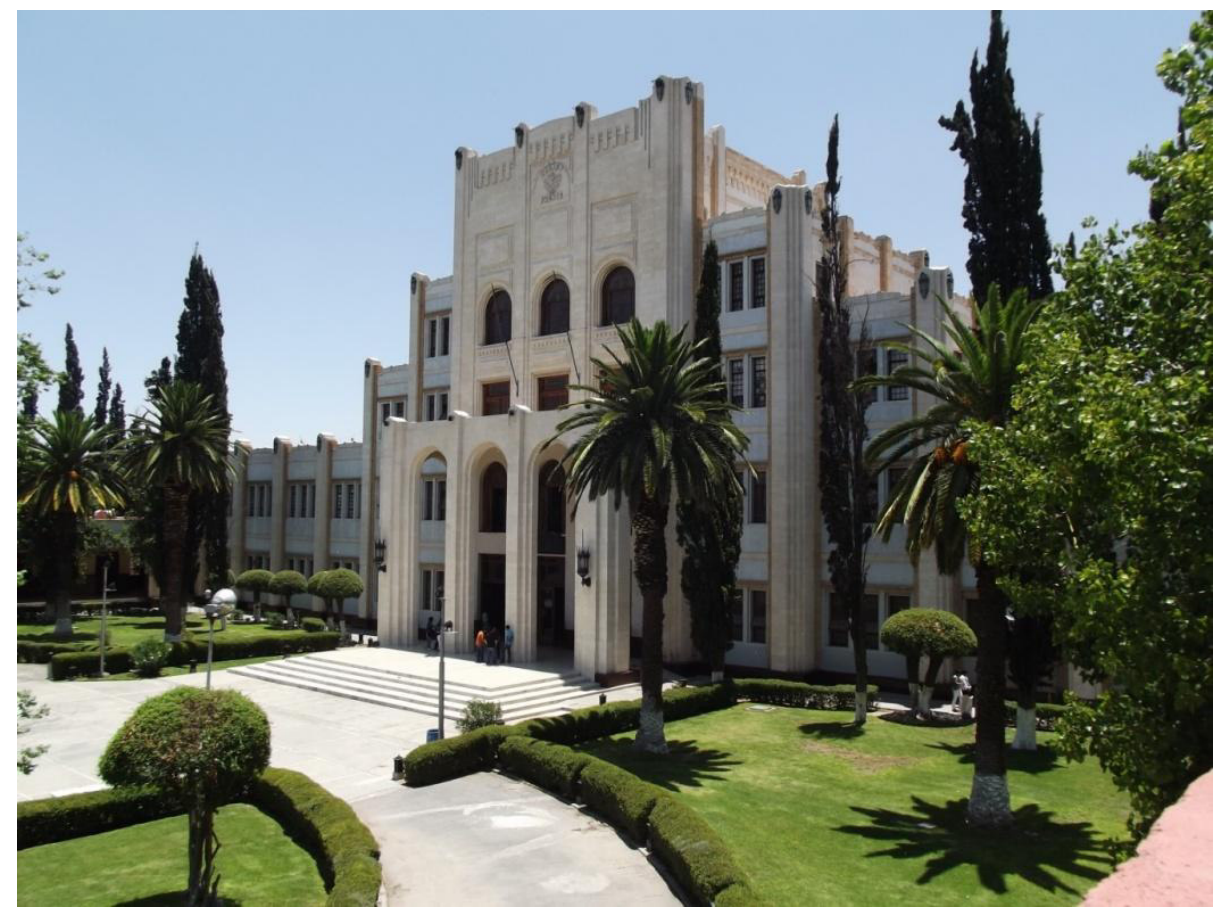

Fachada principal con el nártex formado por los tres arcos.

El último nivel lleva un muro ciego que se orna con rectángulos también superpuestos en grupos de tres. Al centro el escudo de la institución y en los remates unas decoraciones con colgaduras rectangulares y flores intercaladas armonizan en su geometricidad con las estrías escalonadas de las partes laterales, a la vez que se conjugan 
con la elevación de la calle central que termina en forma angular. Las pilastras que se elevan desde el tercer nivel terminan de la misma manera que las del los arcos de la entrada en forma de punta de flecha, teniendo las de los extremos dos perfiles angulares adosados que permiten el ensamble de las pilastras de los cuerpos laterales norte y sur, los cuales son más bajos. Éstos tienen una pilastra de la misma altura que la frontales, pero trabajada en sillar, más otras tres menores, escalonadas y terminadas en punta de flecha, también confeccionadas en ladrillo. Llevan por ornato muy Déco, un dentando sobrepuesto e intercalado por unas bandas colgantes intercaladas también en sillar, con lo que se vigoriza aún más, la estética del Art Déco, a través de un cinetismo geométrico.

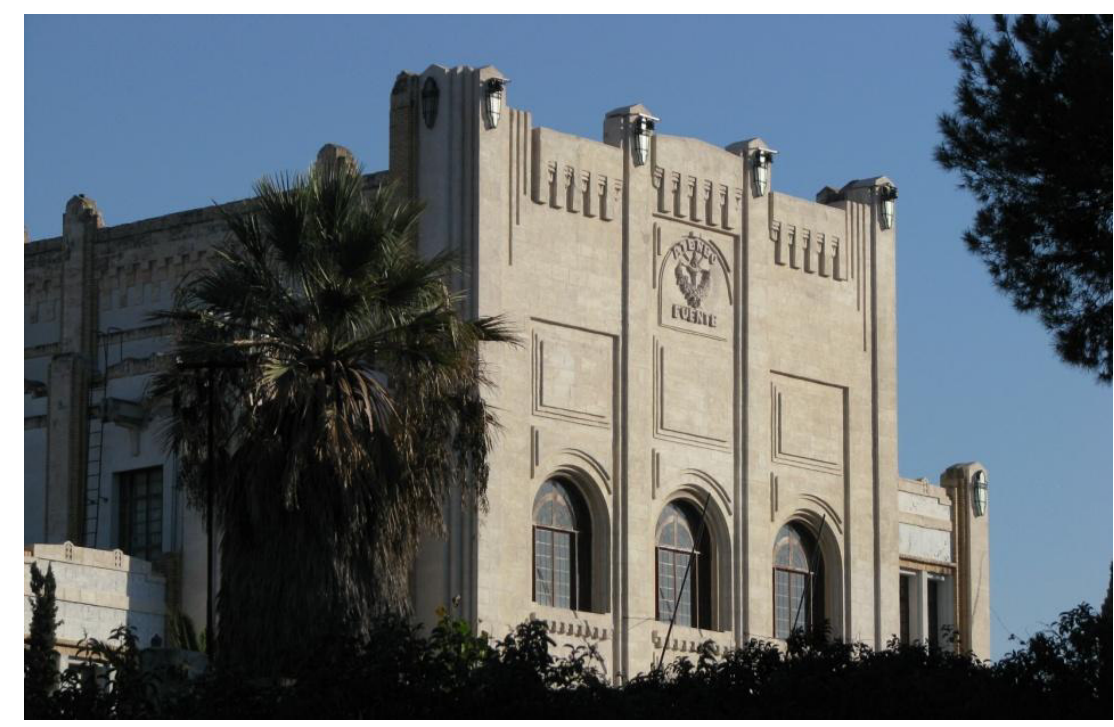

Quinto piso del cuerpo central con las decoraciones de las colgaduras, estrías, escudo y las pilastras terminadas en punta de flecha.

Este cuerpo central que es el eje de todo el conjunto con sus cinco niveles alcanza los veintisiete metros y está forrado con piedra de sillar. Su decoración a base de los elementos geométricos, de las pilastras cuadradas y del remate final le proporciona un sentido de elevación y armonía entre las líneas rectas y rectángulos, con lo que la presencia del Art Déco Zigzag es ineludible.

A cada lado del cuerpo central se van adosando hacia atrás las otras partes del eje central del edifico. Primero son cuatro pisos con tres ventanas rectangulares en cada nivel; en los extrememos se repite el modelo de la pilastra terminada en punta de flecha que se eleva por encima de la altura del remate y que se yuxtapone con una pilastra que mira hacia 
la parte lateral por medio de un par de perfiles angulares. Por arriba de las ventanas del cuarto nivel, unos ábacos recortados de manera escalonada llevan un par de pequeñas elevaciones que se ornan con tres cuadrados superpuestos. Esta idéntica decoración se repite en las partes laterales, utilizando el ladrillo en las pilastras.

Continúan ahora desplantándose hacia el fondo, unos cuerpos de tres niveles levemente más anchos, pero llevando la misma composición que los anteriores. Y finalmente, unos lienzos de cuatro tramos, abarcando dos niveles, con ventanales también de tres en tres. Los tramos se separan de igual forma con pilastras cuadradas y rematando con el mismo tipo de ábaco utilizado en los otros cuerpos descritos. En los últimos tramos y en el segundo nivel, estos cuerpos se ensamblan con las aulas dispuestas de oriente a poniente mediante un tramo con puerta rectangular. Pasando las aulas, se adosan unos cuerpos laterales con corredor de tres tramos que conducen a un aula de cada lado colocadas de manera transversal; en cada esquina, llevan las pilastras con la misma composición que las del resto del edificio.
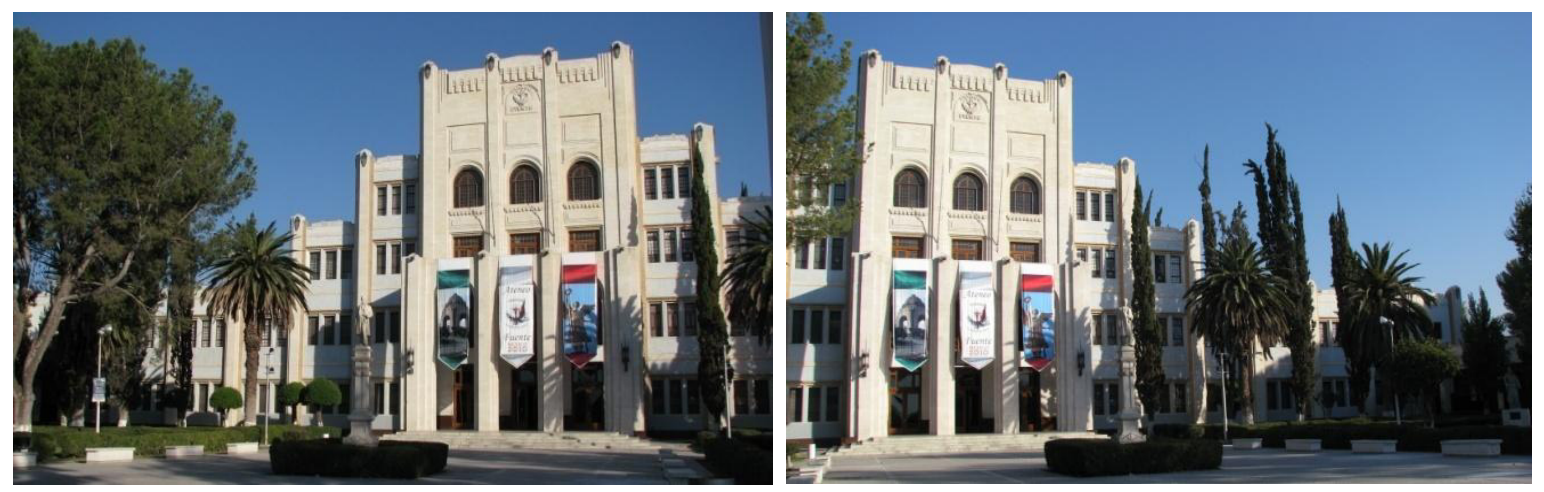

Los cuerpos laterales que se adosan al cubo central forman un juego de cubos ensamblados.

De una gran calidad constructiva es esa forma de fusionar los cuerpos cúbicos del eje central, empezando por los arcos de doble altura, luego el cubo central, los cuerpos laterales de cuatro y tres niveles, para concluir con los de dos pisos, además de la repetición de los siguientes motivos en los cuerpos adosados al central: la unión hacia la parte interior de todos los tramos es por medio de perfiles afanados en ladrillo, con lo que se adquiere un cromatismo dual entre lo anaranjado de este material y lo claro de la cantera; por lo que respecta a los ventanales llevan una doble moldura, donde la de la parte superior es en 
ladrillo, lo mismo que una banda que corre horizontalmente por debajo de cada grupo de ventanas.

Todo lo anterior sumado al escalonamiento ascendente y la composición poliédrica de los cuerpos es de una suprema calidad del ensamble de todas sus partes, que aunado a la intrínseca decoración de líneas rectas, rectángulos, cuadrados, instituyen un formidable conjunto de geometrización Art Déco del periodo Zigzag.

El grupo de aulas que se encuentran hacia el frente sobre los ejes oriente-poniente tienen la planta en forma de L; llevan un corredor techado con cuatro vanos sostenidos por pilastras y en la parte frontal tres ventanales tripartitos están divididos a través de pilastras de ladrillo terminadas en punta de flecha y las de los extremos forradas con mortero rematan escalonadamente; en la parte lateral hay un solo ventanal también tripartito, con pilastras análogas a las anteriores.

Algo que sobresale son las pilastras en ladrillos adosadas en los ángulos de unión de los muros, ya que destacan tres estrías sobresaltadas y ascendentes que combinan su elevación con la de las otras pilastras, exaltando uno de los principales motivos decorativos emanados de la Exposición Internacional de París de 1925 y que se uso recurrente en el periodo Zigzag del Déco.

Para culminar todavía más con la geometrización, unos ábacos acodados cierran los muros, resaltado su límite a través de una moldura que al mismo tiempo resalta a tres cuartas partes de la altura de los lienzos.

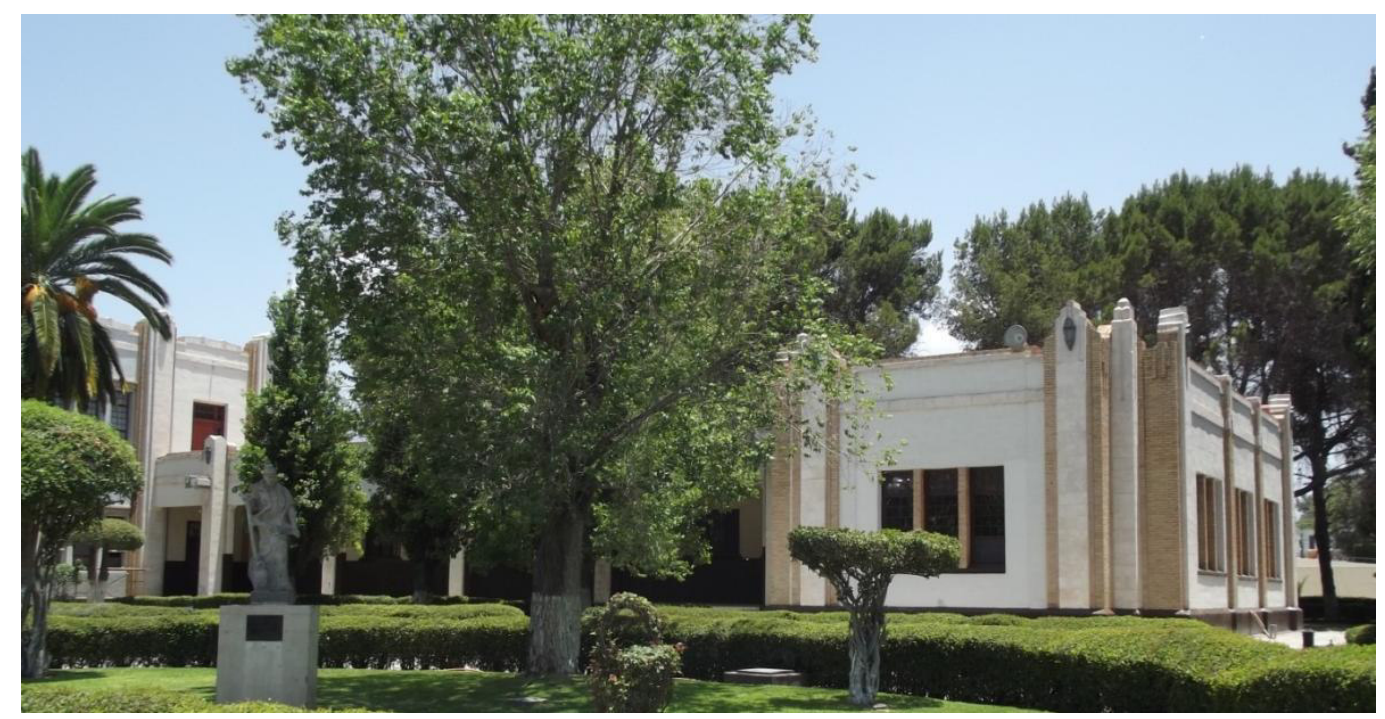

Aulas del lado sur hacia la parte frontal del conjunto. 
Pasando hacia la parte de atrás del edificio, adjunto al cuerpo central se abren unos corredores de cada lado conformados por seis vanos, los cuales llevan en la parte interior unas pilastras planas que en la intersección con la trabe recortan el ángulo por medio de unas pequeñas zapatas, lográndose con esto un cerramiento ochavado. Este tipo de vanos se repetirán en varias secciones del edificio. Las pilastras que sostienen la techumbre son de sillar y van acompañadas de perfiles en ladrillo que sobrepasan la altura de la elevación del techo, terminando en punta de diamante. Lo que visto de frente sería un ábaco acodado en los extremos, se convierte a la vez en el antepecho de una larga balconada del segundo piso del cuerpo central en su fachada trasera y equivalente a segundo nivel que se desplaza de norte a sur.

Una moldura rectangular y en dirección horizontal recorre la parte superior a manera de entablamento y en cada tramo se insertan unos cúbicos botaguas sostenidos por angulares zapatas. Los muros de las aulas van separados por pilastras en ladrillo con dobles perfiles adosados y se prolongan hasta el segundo piso de lo que es la cara posterior de los cuerpos adyacentes al cuerpo central, donde se repiten la moldura y los ábacos.

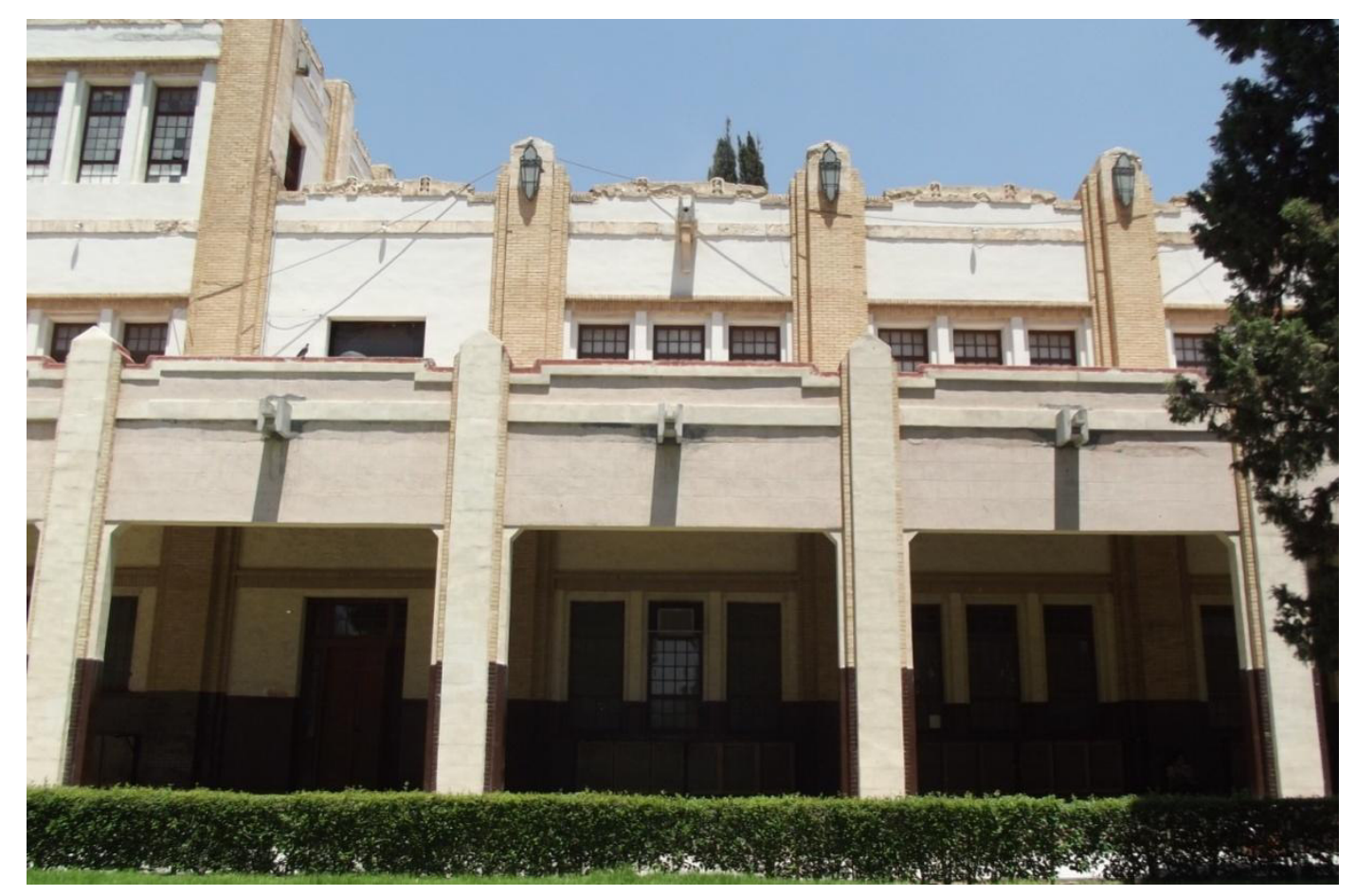

Corredor y aulas de la parte trasera adosada al cuerpo central. Se aprecia la moldura horizontal, los botaguas cúbicos y las pilastras del muro que se prolonga hacia el segundo piso. Los ábacos de segundo nivel están bastante deteriorados. 
El ritmo de profundidad de los cubos espaciales, de las líneas horizontales de moldura y ábaco, de las líneas verticales de las pilastras y los leves remetimientos escalonados de los perfiles, enlazan la semántica zigzagueante y geométrica de la arquitectura Art Déco Zigzag.

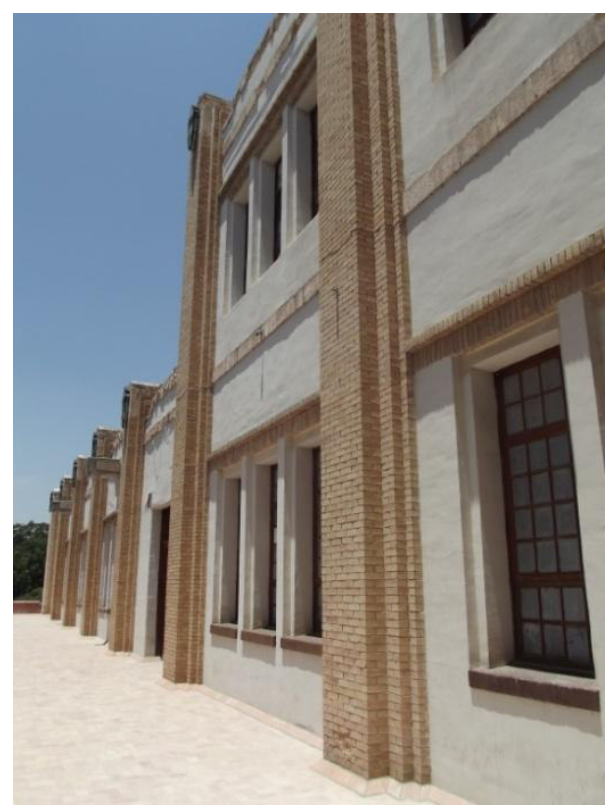

Segundo y tercer piso vistos por la parte posterior.

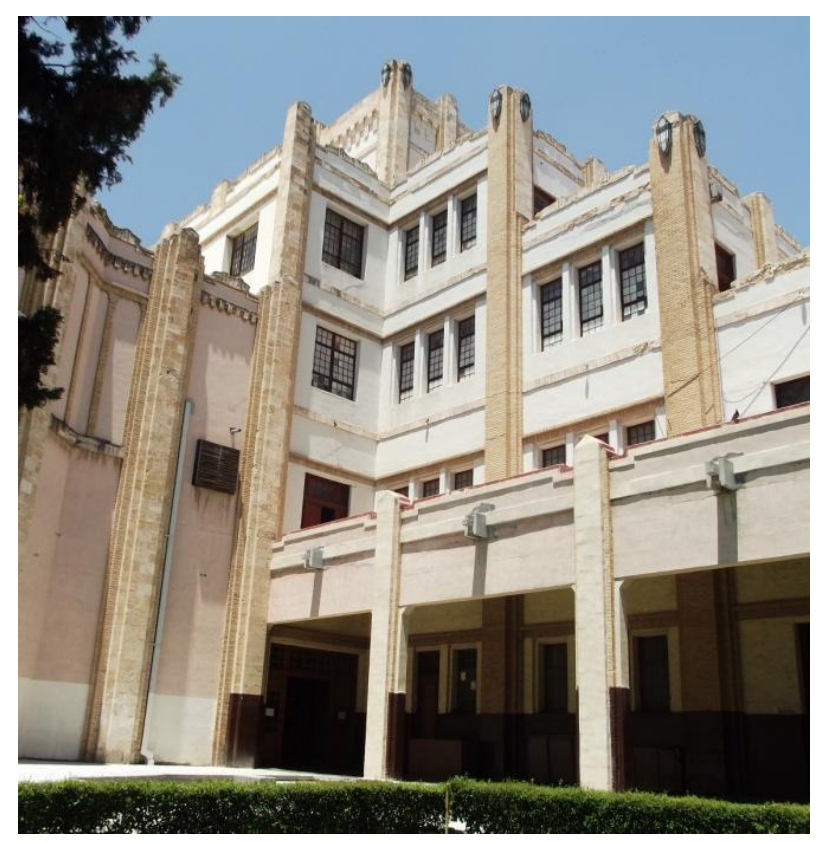

Corredor de la parte trasera y el cuerpo central. 
Las aulas que se disponen hacia la parte trasera del conjunto en la zona oriente y de cada lado mirando al norte y sur, contienen planta en forma rectangular, la cual se ensancha hacia los extremos justo a la mitad. Este segmento del edificio se compone de un largo corredor de diez vanos sostenidos por pilastras que en los muros exteriores llevan pilastras trabajadas con ladrillos y forradas con aplanado en la parte frontal con la misma composición de las que se distribuyen en la parte delantera que terminan en punta de flecha. También presentan la banda horizontal a todo lo largo y el mismo tipo de botaguas, con los ábacos acodados en las esquinas. Se conservan la mayoría de las lámparas originales de formas geométricas, simulando un escudo.

El hecho de que estos dos corredores y sus diez vanos sean de un solo piso, permite que la atención visual del cuerpo central no se pierda, ya que como va descendiendo en proporción de un nivel, esta parte trasera del edificio es una extensión de menor escala, pero de mayor tamaño que proyecta alargadamente el armazón de cubos de manera sutil y delicada.

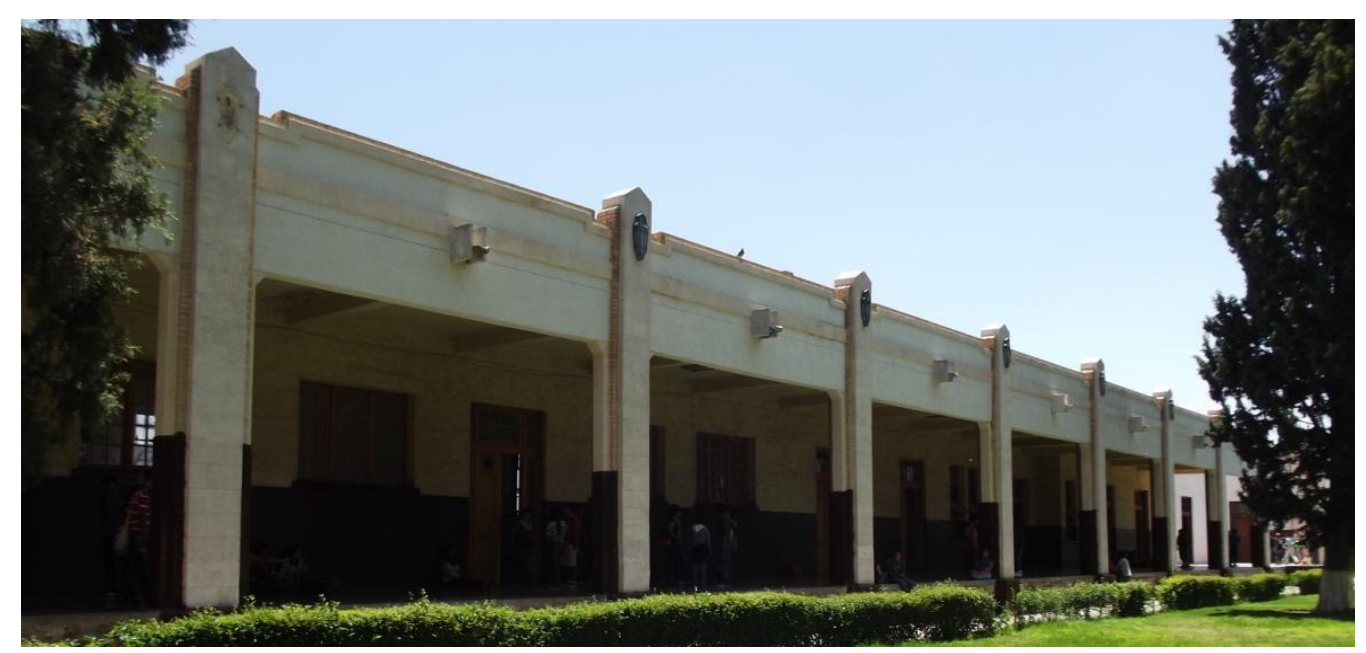

Corredor y aulas de la parte trasera de la zona oriente del edificio que miran hacia el norte.

Al finalizar estás aulas, un pequeño salón se ubica después de un espacio; llevan dos puertas de entrada y con el mismo uso de las pilastras en ladrillo terminadas en punta de flecha. Cabe comentar que para reforzar los juegos geométricos que hay en todo el inmueble, la planta de estos salones se recorta en las esquinas de la parte trasera de los 
mismos, con lo que vistos desde ese lado, el muro se remete, llevando pilastras en cada ángulo, forjando un enfoque de ritmo zigzagueante típicamente Déco.

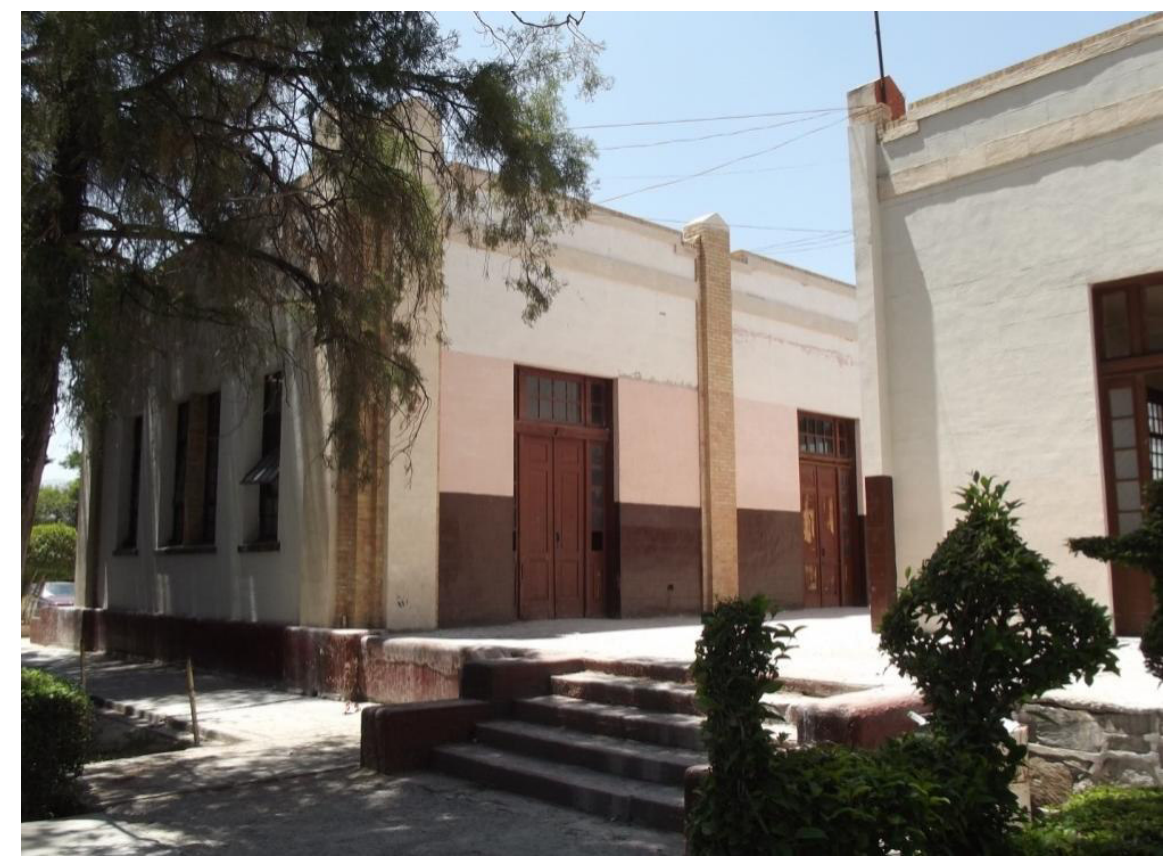

Salón de la parte final de las aulas traseras. Éste corresponde al que mira hacia el sur.

Adosado al cuerpo central pero por la parte trasera, está el Paraninfo. Los muros laterales son curvos, pues corresponden a la sala y la parte final es rectangular que es donde va el escenario. En las paredes curvas cuatro ventanales alargados con arcos de medio punto van en un primer nivel y arriba de éste, grupos de tres arcos ciegos deprimidos se forman con ladrillos, con la diferencia que en lugar de ser curvo en las esquinas, se compone de tres leves acodamientos escalonados. Ventanales y arcos van separados por medio de pilastras terminadas en punta de flecha, cuya cara frontal es de sillar y tres perfiles angulares de cada lado se van adosando al muro de manera descendente. Un dentando como el que se usa prácticamente en todo el edificio exorna la parte superior de los muros, para rematar con unas pequeñas coronillas con dos leves elevaciones triangulares.

Lo que corresponde al escenario, en los muros laterales se abren unas pequeñas puertas rectangulares de cada lado; pero lo que destaca es que en los tres muros, los dos laterales, norte y sur, y el de atrás que mira hacia el oriente, de la misma manera que los 
muros curvos, entre pilastras de sillar y ladrillos, se distribuyen cuatro arcos ciegos con doble moldura; después de un espacio se abren unos tableros con estrías rehundidas, los cuales prácticamente ya no se pueden apreciar debido a que fue agregado en 1967 un cuarto de utilería al escenario.

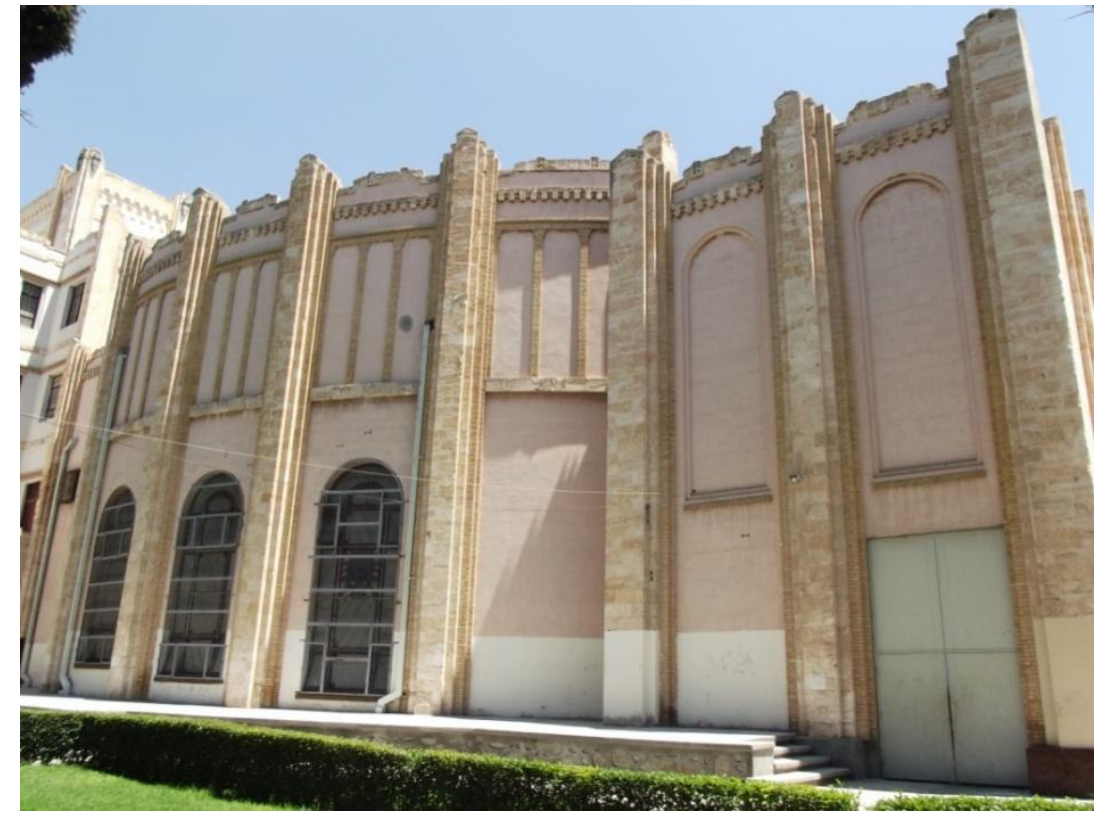

Muros exteriores del paraninfo.

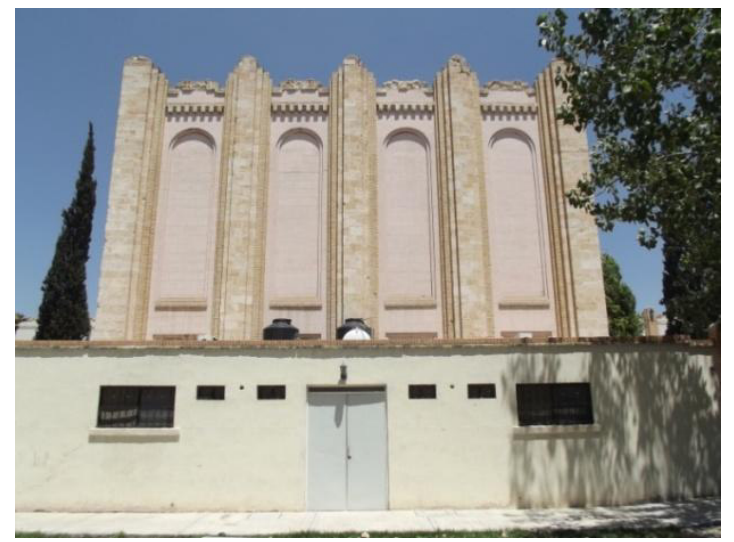

Muro trasero del escenario con el agregado de 1967 que estropeó la visibilidad.

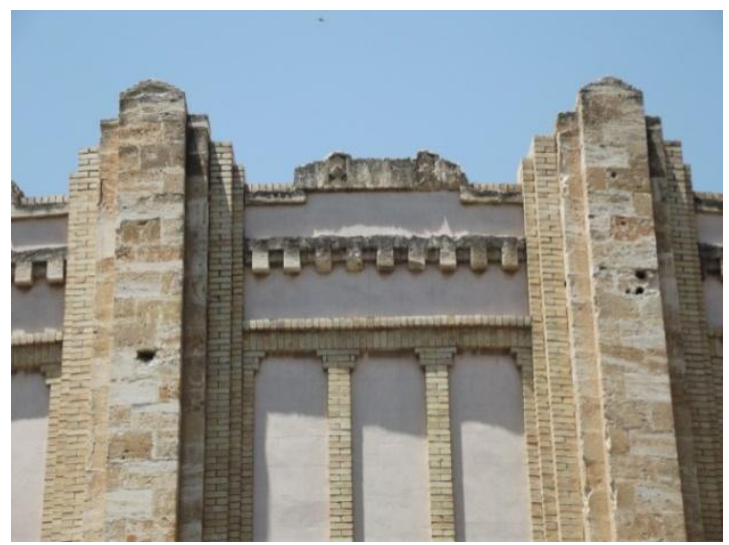

Detalle del dentado y del ábaco del muro lateral del Paraninfo.

El aderezo decorativo que se adquiere con pilastras, arcos de medio punto, deprimidos, escalonamientos, estrías, perfiles de esta parte exterior del paraninfo, van en la misma orientación de remarcar el ornamento geométrico del Art Déco Zigzag, que si bien 
es la constante que se quiso enaltecer para denotar la modernidad del edificio, no se descuidó en ninguna parte, por lo que llama la atención que hasta en los muros exteriores del paraninfo donde se podría pensar que no era necesario poner los atavíos decorativos, éstos no se dejaron de lado.

Dos construcciones más cierran en la parte posterior y al centro todo lo que era el campus original del Ateneo Fuente.

La primera se trata de una unidad sustentada sobre un zócalo a la que se accede a través de una escalinata y que lleva el nombre de "Salón de Deportes". La planta es ochavada y al frente tiene un pequeño pórtico cúbico, el cual está sustentado por dos pilastras de doble cara, con perfiles adosados de ladrillo y terminando en puntas de flecha que le dan un fuerte sentido de geometricidad. Este tipo de pilastras se repiten en los muros tres, cinco y siete, mientras que en los lados dos, cuatro, seis y ocho donde van las ventanas, el muro se desplaza hacia delante del nivel de la superficie. Octágono, con cuadrado, cubo con prisma, fórmula de figuras geométricas Art Déco. De la misma manera que las aulas descritas anteriormente, este salón lleva la moldura horizontal en piedra de sillar que la recorre alrededor, el ábaco acodado en la parte frontal y lateral, con la divergencia que en la parte de atrás un cubo de dos niveles se eleva con la misma decoración de las pilastras usadas en la entrada.

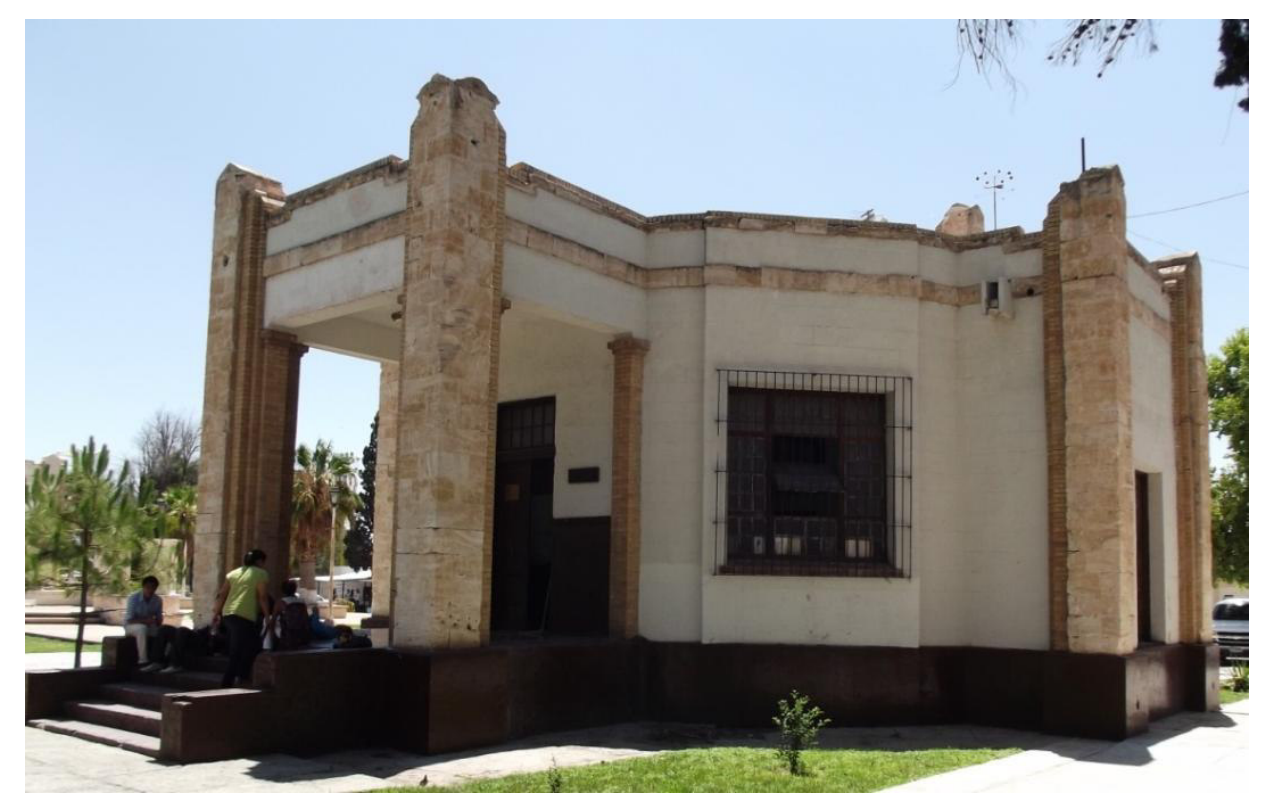

Salón de deportes. 
La otra construcción de la parte posterior es un cuarto de planta rectangular donde se establecieron los "Laboratorios". Se ubica después de un espacio ajardinado a un lado del "Salón de Deportes", su tamaño es más grande y de la misma manera todo el cuarto está apoyado sobre un zócalo. La entrada igualmente es un pórtico cuadrado con escalinata de cuatro peldaños y alfarda escalonada, con lo que le da el sentido de geometrización. Como las paredes de los corredores de la parte oriente, también aquí el salón de los "Laboratorios" tiene la moldura rectangular en sillar que recorre todo el edificio y el remate superior lleva ábacos recortados en las esquinas, con lo cual se remarca el sentido de geometría del Déco Zigzag.

Las pilastras son iguales a las del "Salón de Deportes", de doble cara, hechas con ladrillo y terminadas en punta de flecha, que se repiten en cada esquina. A cada lado de la entrada hay un ventanal tripartito con cornisa hecha en ladrillo, que armoniza con la decoración que lleva a la misma altura y con el mismo material el vano de acceso. En el interior no hay ningún tipo de decoración ni elementos Déco.

Como se ha podido apreciar en la parte exterior de las diferentes unidades del inmueble, la constante decorativa se refrenda, con algunos pequeños cambios, pero que al final de cuentas, todo gira en torno al Art Déco Zigzag.

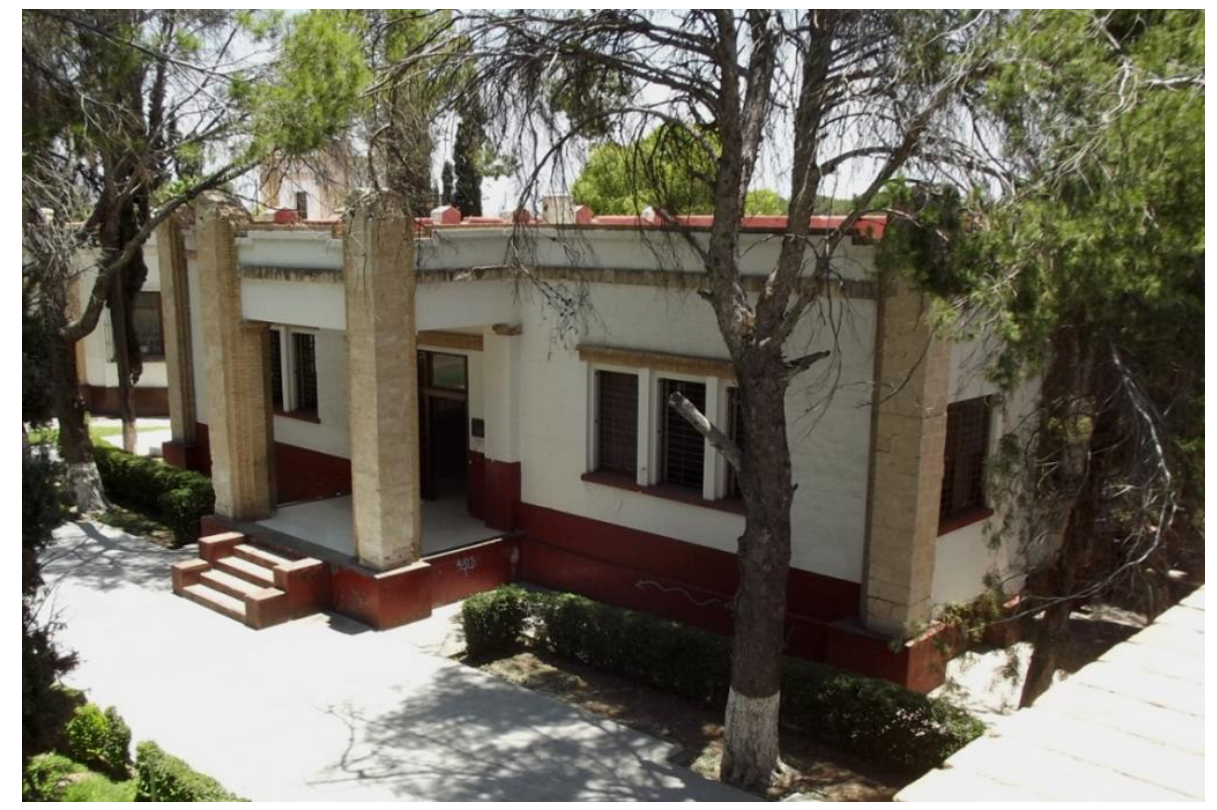

Laboratorios. 
Para ingresar al vestíbulo del Ateneo Fuente, con los arcos de entrada se forma un nártex. En la puerta central nos da la bienvenida un relieve rectangular con recortes escalonados manufacturado en yeso y pintado en color obscuro. Sobre un bajo relieve resalta el rostro de una mujer de duras facciones. El contorno de las cejas se une a la nariz de amplias fosas nasales; pómulos y mentón están remarcados y las orejas se acomodan angularmente, mientras que las pupilas de los ojos están levemente marcadas. La solución que se aplica en este rostro remite a lo que se hacía con los artistas de la época, como lo hiciera el mismo Diego Rivera, que con contornos poco definidos se le da la figuración a las formas anatómicas. El pelo peinado hacia atrás se acomoda con gruesos cabellos que caen en rizos, pero con una redondez que apunta hacia lo cuadrado, tal como lo han explicado Jean Paul Bouillon y Xavier Esqueda sobre la presencia de lo geométrico en el Art Déco. Los cuellos de un vestido nos permite imaginar una vestimenta a través una túnica o traje tipo hábito. Hacia los lados y en un plano hacia atrás, un rayado amorfo rellena todo el espacio.

Este relieve se refiere a la representación de las diosa Atenea, en su simbología de la sabiduría, protegiendo como madre el imponente edifico del Ateneo Fuente, con una estética de sencillez figurativa, que apunta hacia las composiciones que remiten a las máscaras primitivas de las Vanguardias o a esas combinaciones de los popular con lo prehispánico del México postrevolucionarios, ambas, utilizados en los tiempos del Déco.

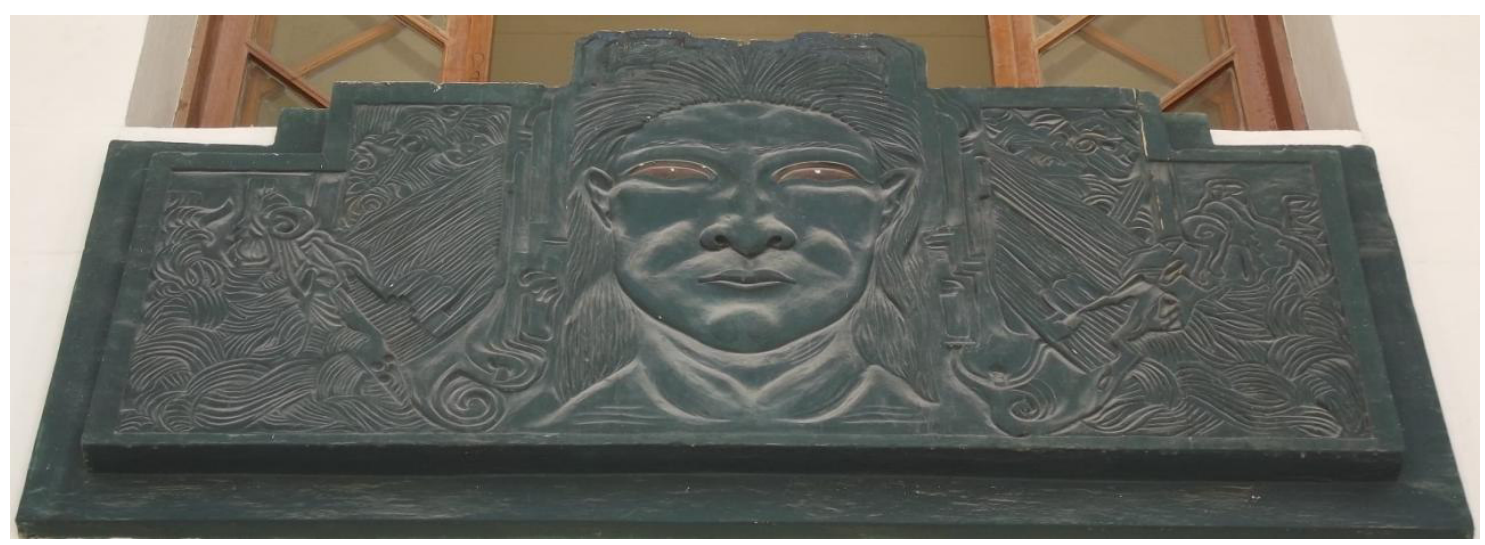

Relieve en la puerta principal.

El posible autor tal vez sea Salvador Tarazona Pérez (f?-1955 ó 1961), aquel desconocido y olvidado artista valenciano que deambuló por Estados Unidos, México y 
Venezuela, cuya vida está actualmente desempolvada por varios autores en una publicación reciente de la Secretaría de Cultura del Estado de Coahuila. ${ }^{226}$

El vestíbulo es rectangular. Flamantemente se elevan cuatro pisos que le otorgan una espacialidad ascendente y bien iluminada. En el primero, las columnas de tipo clásico llevan las bases circulares, los capiteles en color dorado y los fustes con anillo toscano son de un color obscuro que imita mármol negro con vetas plateadas, lo mismo que las trabes. El capitel es una mezcla entre el dórico con la combinación de unas espirales cuadriculadas que cuelgan en cada esquina con lo que se armonizan con gran magistralidad elementos del Neoclásico Moderno con la geometricidad del Déco Zigzag. En cada esquina del vestíbulo las columnas van en grupo de tres, una de ellas desplazada hacia atrás con la diferencia de tener forma cuadrada en la base, fuste y capitel.

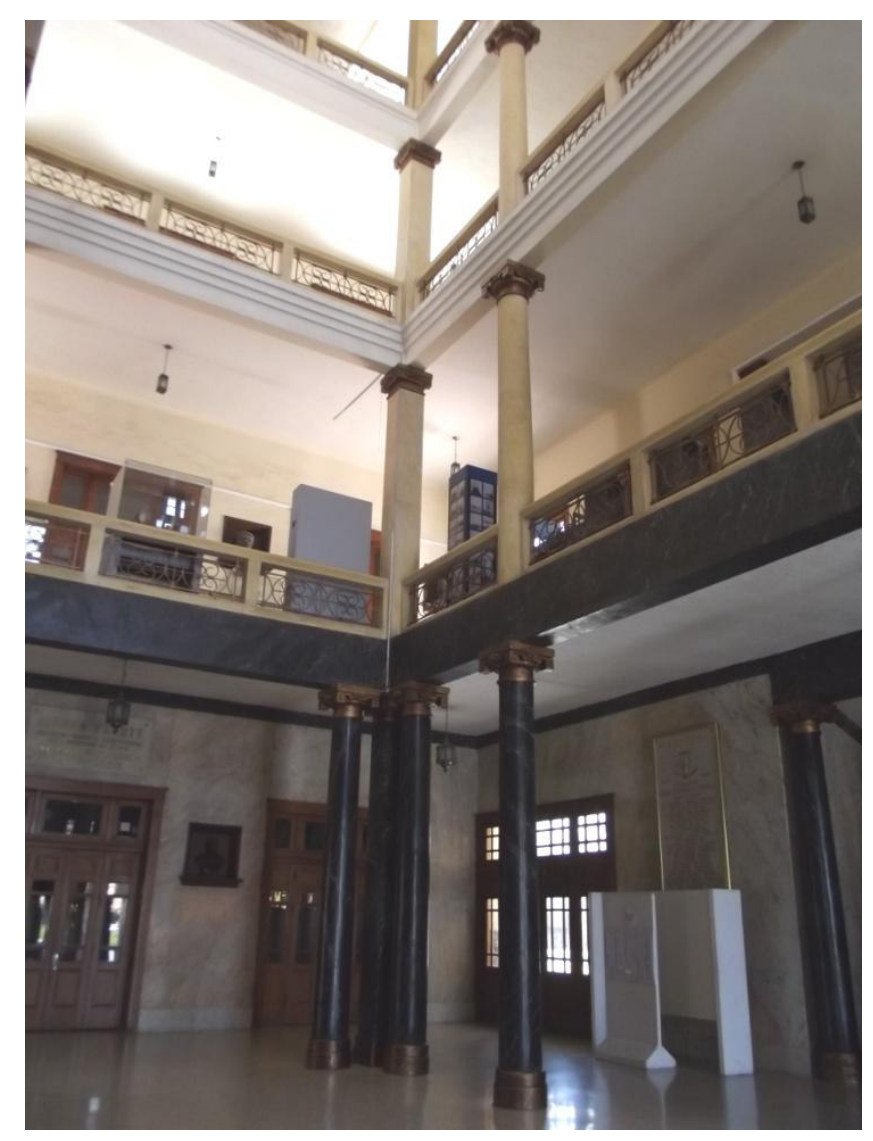

Interior donde se aprecian los cuatro pisos y las herrerías de los barandales.

\footnotetext{
${ }^{226}$ VV.AA. Tarazona. Presencia en Coahuila y el mundo. Saltillo, Secretaría de Cultura de Coahuila, 2012, Colección Patrimonio Coahuilense No. 1. Este libro no lo incluimos en la Bibliografía, ya que sólo sabemos que fue publicado, pero no fue una obra de consulta.
} 
Los demás pisos tienen las columnas con el mismo diseño que las del primero, pero los fustes son de color blanco y con la diferencia de que en las esquinas van pilastras cuadradas. Las trabes del segundo piso se ajustan con cuatro molduras horizontales a manera de tablones, mientras que los barandales llevan herrerías con formas orgánicas elípticas con roleos en la sección interior, pero con la directriz de estar geometrizadas.

En las esquinas de las techumbres y principalmente en el último piso se insertan unas zapatas pintadas en color dorado que aunque de diseño clásico, ostentan unas figuras en forma de rombos que se amalgaman en la parte interior, con lo cual se forma un juego tipo Déco Zigzag. Tanto en la parte suprior como inferior llevan recortes angulares escalonados y las borlas que cuelgan tienen la composición de pirámides truncadas, todo dentro de un lenguaje geometrizante, combinando el Neoclásico Moderno con la variante Zigzag.

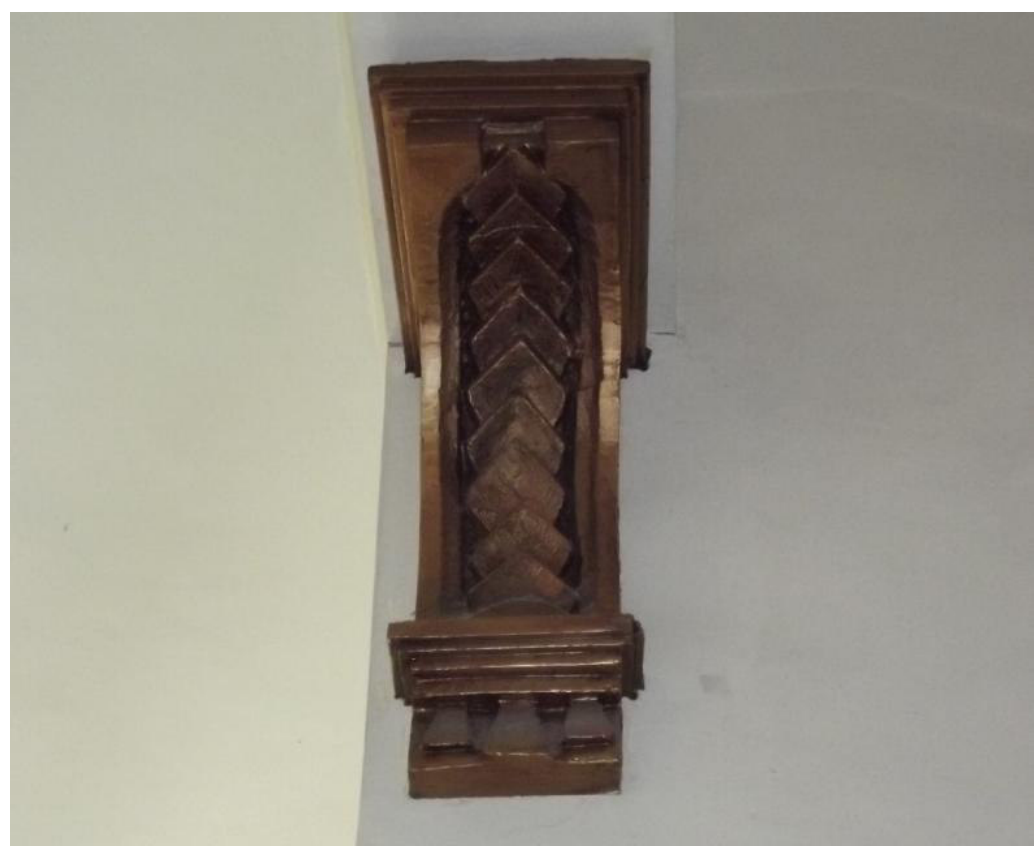

Zapata en el segundo piso.

En el último piso el techo tiene un tragaluz que está formado por doce pequeños casetones perforados, con lo que le da una grácil iluminación, pero suficiente, la cual se combina con la de los ventanales frontales que se van alternando en forma cuadrada en los pisos primero y tercero, y con arco de de medio punto en los pisos segundo y cuarto que para el caso de los del segundo nivel sus partes están acomodadas con líneas 
perpendiculares en el arco y en el tímpano que miran hacia el centro, con lo que se refuerza aún más el sentido decorativo de tipo Art Déco Zigzag junto con las "X" del espacio equivalente a las jambas.

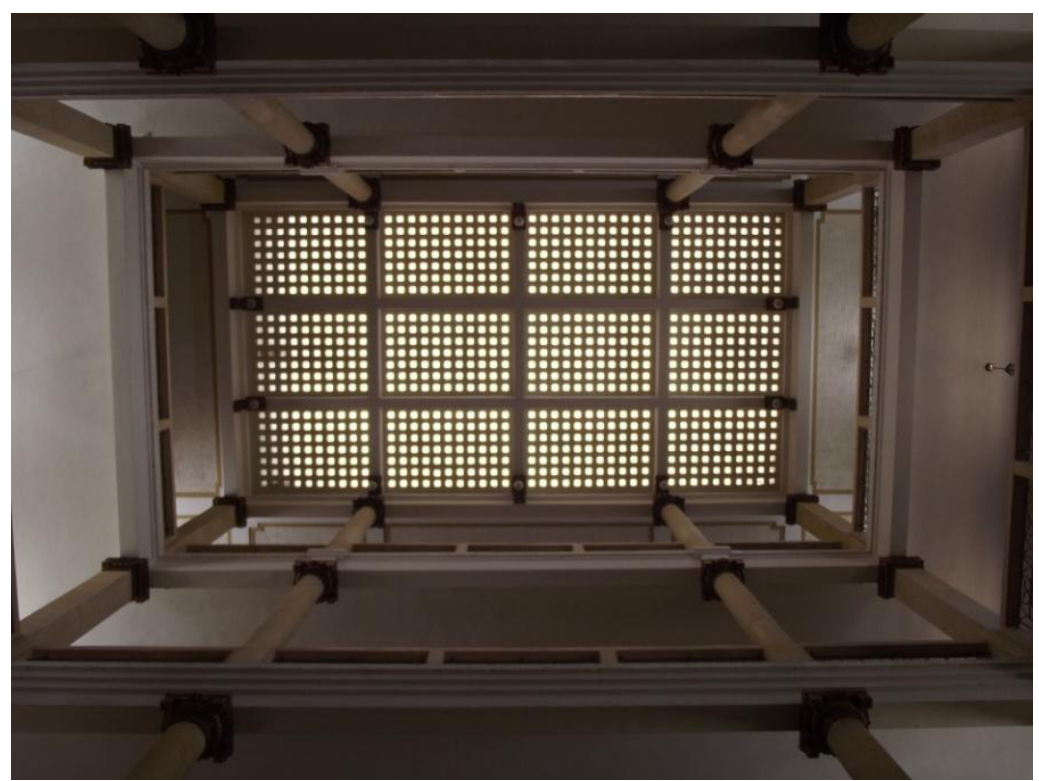

Tragaluz en el vestíbulo.

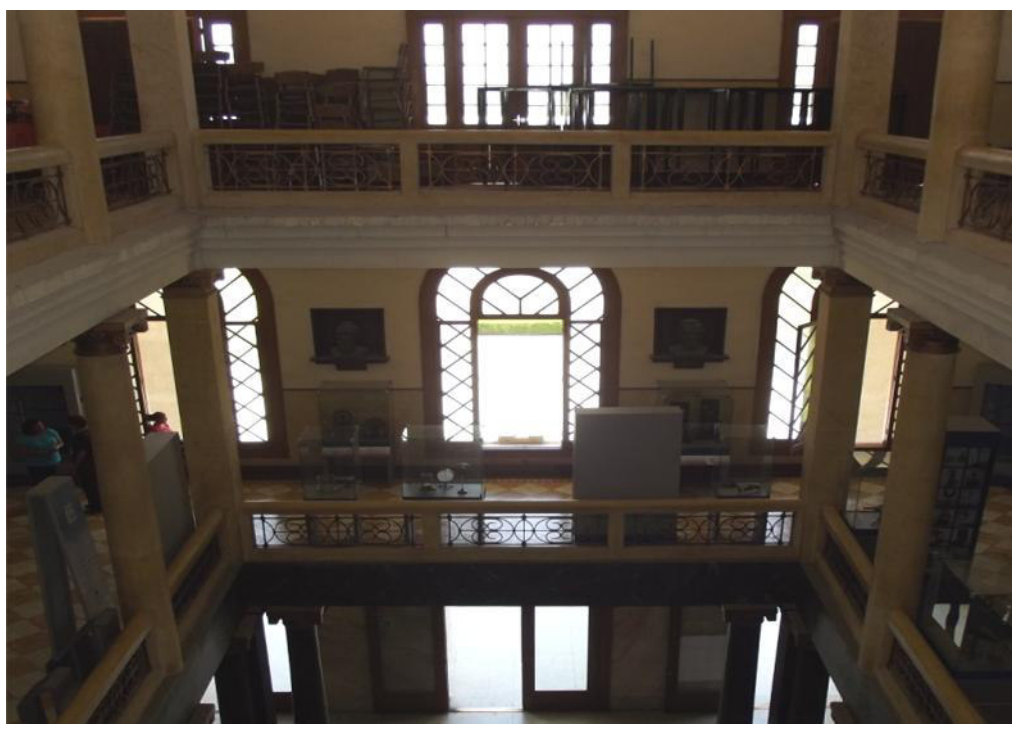

Ventanales frontales. En el segundo piso las líneas perpendiculares acentúan el sentido Déco Zigzag.

El Paraninfo se encontraba conectado directamente con el vestíbulo, pero en 1967 cuando hubo una intervención y ampliación del inmueble, se le colocó el muro de entrada y 
la hisóptica del interior. Aparte, en 2005, ante otra intervención de rescate decorativo y de pintura, se rehicieron algunos de los ornamentos, por lo que aunque se intentó dejar lo más parecido al original, si hubo algunas leves modificaciones. La planta es elíptica, aunque achatada en los extremos. En los muros laterales curvos lleva ocho grandes ventanales con arcos rebajados, con lo que se ilumina bastante bien el espacio. Si tomamos en cuenta que en los teatros normalmente no hay este tipo de iluminación, el origen del Paraninfo fue concebido como un salón de actos académicos y no de espectáculo, de ahí la razón de por qué se buscó que tuviera tanta luminosidad.

El proscenio de arco escarzano descansa sobre columnas de tipo dórico. Pares de columnas con capitel también dórico se recargaban en zócalos, los cuales ahora están integrados a toda una base circundante después de las intervención de 1967.

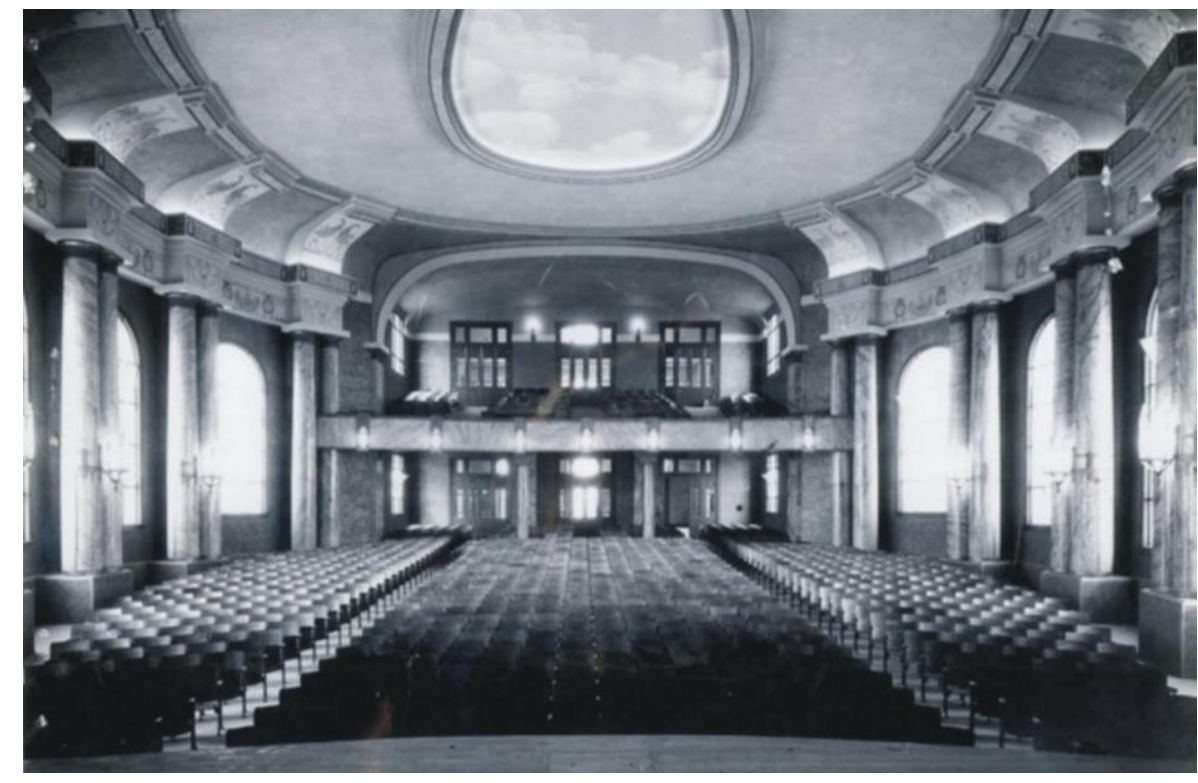

Paraninfo en la década de los años cuarenta con los zócalos de las columnas.227

Estas columnas acomodadas por pares imitan a un mármol blanco con vetas rosadas, sostienen unos frisos decorados y cornisas, ambos elementos resaltados, que se van alternando con la trabe del muro, para luego a su vez cargar unas estilizadas ménsulas que se despliegan hacia el cielo y ensamblarse a una banda circular con el despunte de unos rectángulos cúbicos. Geometría engalanada menudamente de formas ondulantes sutiles que

\footnotetext{
${ }^{227}$ www.saltillodelrecuerdo.blogspot.com
} 
recuerda a los diseños adecuados hacia lo palaciego y grandilocuente de los espacios destinados al espectáculo.

Las lámparas en latón que se encuentran en las columnas fueron acertadamente restauradas para dejarlas en su forma original; son hexagonales, con perfiles dorados que presentan horadaciones de formas geométricas y con tres vidrios recortados con diseños góticos en la parte superior. La parte baja de las lámparas terminan a manera de punta de diamante, conservando así toda su semántica decorativa de tipo Déco Zigzag.

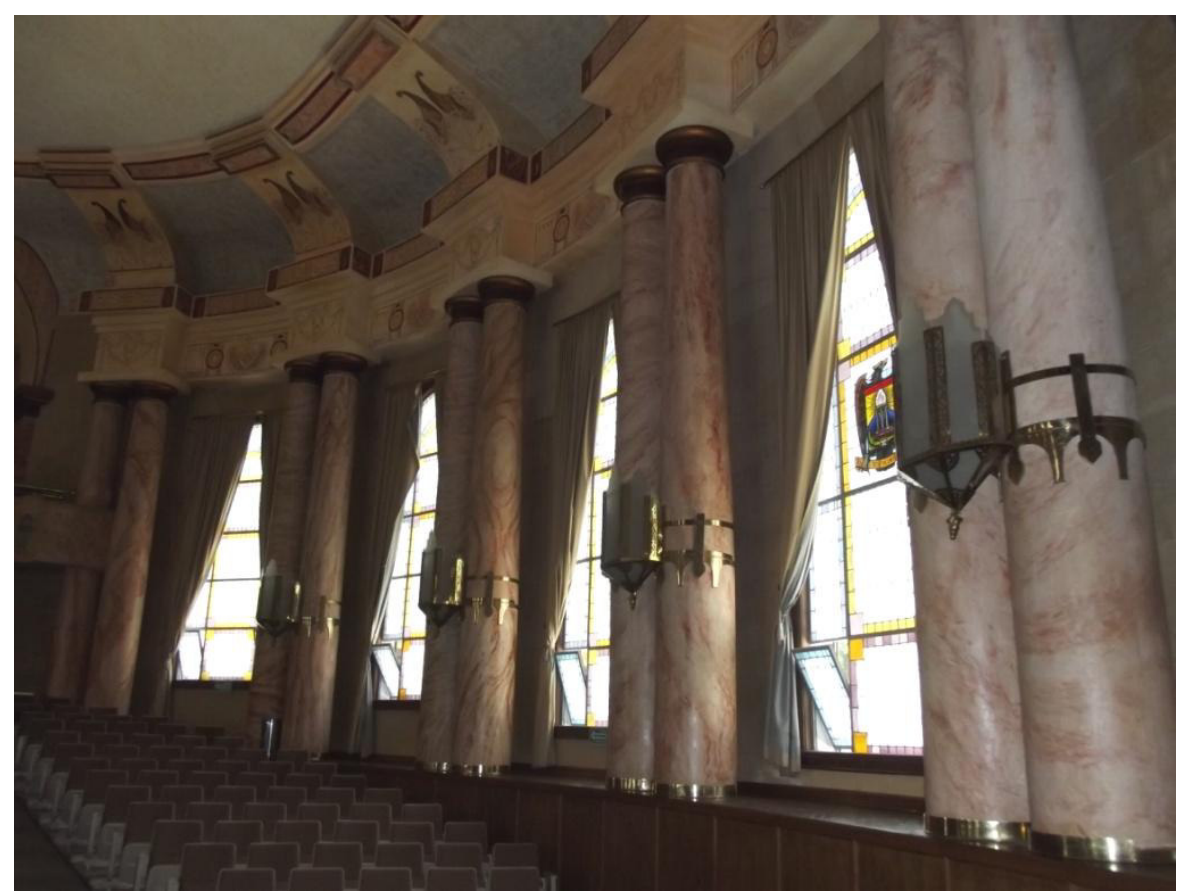

Pares de columnas insertas en la base circundante con las lámparas insertas muy del estilo Art Déco Zigzag.

En dichas ménsulas se han conservado las decoraciones realizadas por Salvador Tarazona, las cuales representan a unos pares de leones alados muy estilizados, que de inmediato nos remiten a esa fauna emanada de los diseños de los años veinte y treinta del pasado siglo, con esos bestiarios imaginados o reales, de un mundo exótico que viene de lo egipcio, mesopotámico o del mundo antiguo griego y romano que emperifolla los espacios de la convivencia social de una clase emergente que busca el glamur y la elegancia, dentro de un espacio educativo como sucede tanto en el Paraninfo, como en todo el conjunto del Ateneo Fuente. 


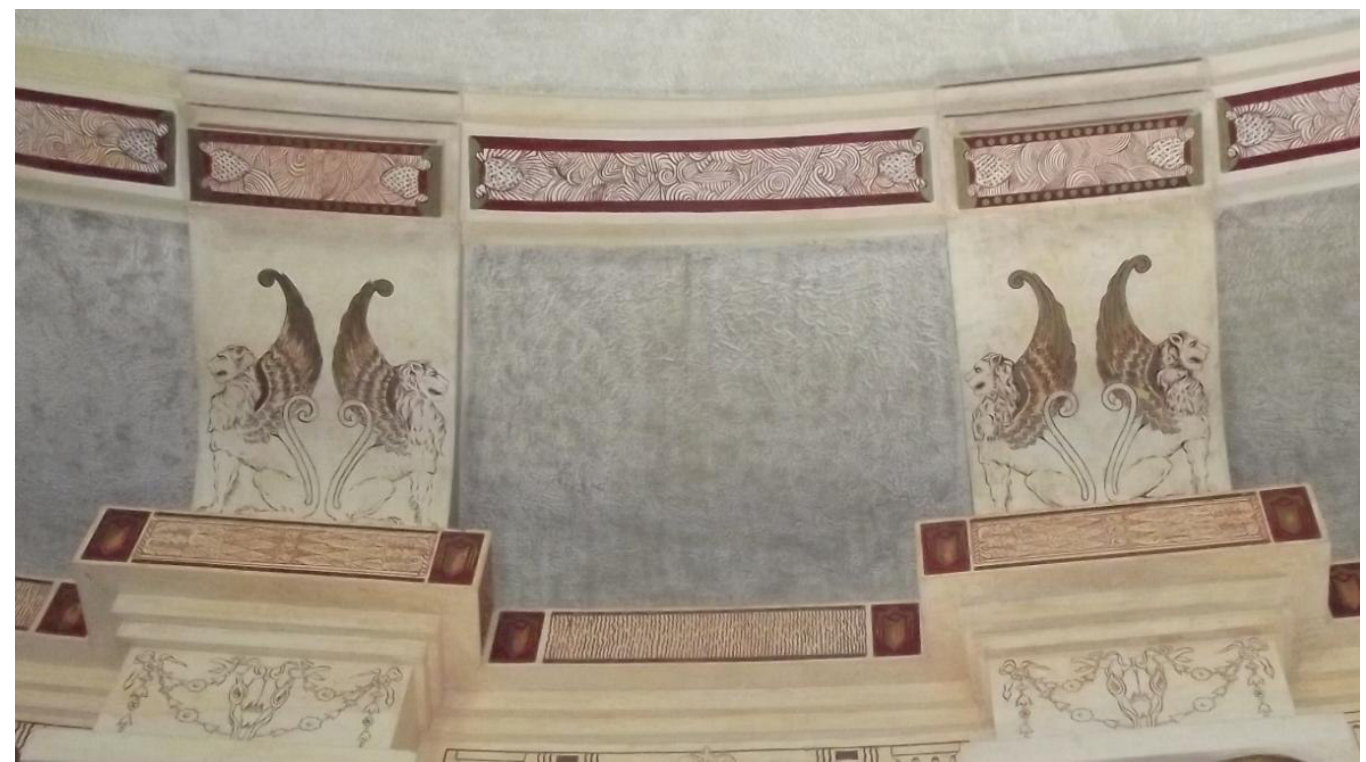

Detalle de las ménsulas con los leones alados y las decoraciones en las bandas superiores y en las bases de las ménsulas.

Con la restauración de 2005 se descubrió que había unas decoraciones en las bandas que corren por encima de las ménsulas. Consisten en trazados geométricos intrincados entre sí, similares a los de la placa de la entrada principal. En cada extremo una forma vegetal, tal vez una granada, acompaña a cada dibujo. Son definitivamente, diseños muy Art Déco Zigzag, como los que se usaban en muchas de los ornamentos de los años 30. A la vez, en lo que serían las bases de las ménsulas, los dibujos de unas hojas en forma de dagas en grupos de tres y frente a frente forman también diseños del tipo Zigzag. Estos trabajos han sido atribuidos a Salvador Tarazona, ya que era el artista pintor encargado de las decoraciones en los tiempos de la construcción del inmueble. Fue el artista Jesús Reyes Siller, encargado de las reparaciones, quien dio dicha atribución, basándose en los rastros que iban encontrando en el momento de limpiar columnas, muros y el techo, así como las pinturas que se encuentran a cada lado del escenario. ${ }^{228}$

Si en las últimas décadas del siglo XIX y la primera el XX bajo el régimen porfirista se habían construido inmuebles públicos para el espectáculo cultural bajo los dictados estilísticos del Beaux-Arts, del Historicismo, del Eclecticismo así como del Art Nouveau y estaban dirigidos para una elite, ahora era también en las escuelas para estudiantes de cualquier clase y sector social donde se instalaban auditorios, muchas veces bajo la estética

\footnotetext{
${ }^{228}$ Jesús Ramírez Rodríguez, Op. Cit, p. 37.
} 
del Art Déco, como sucedió en el señorial Ateneo Fuente con su Paraninfo, hoy utilizado para diversas actividades académicas y culturales.

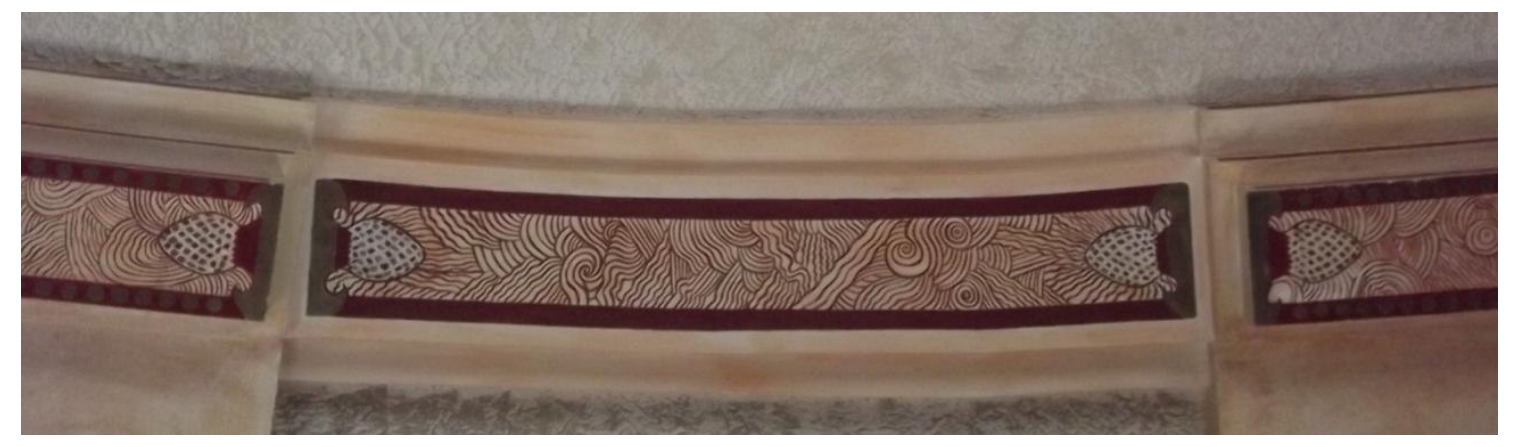

Decoración de las bandas colocadas arriba de las ménsulas.

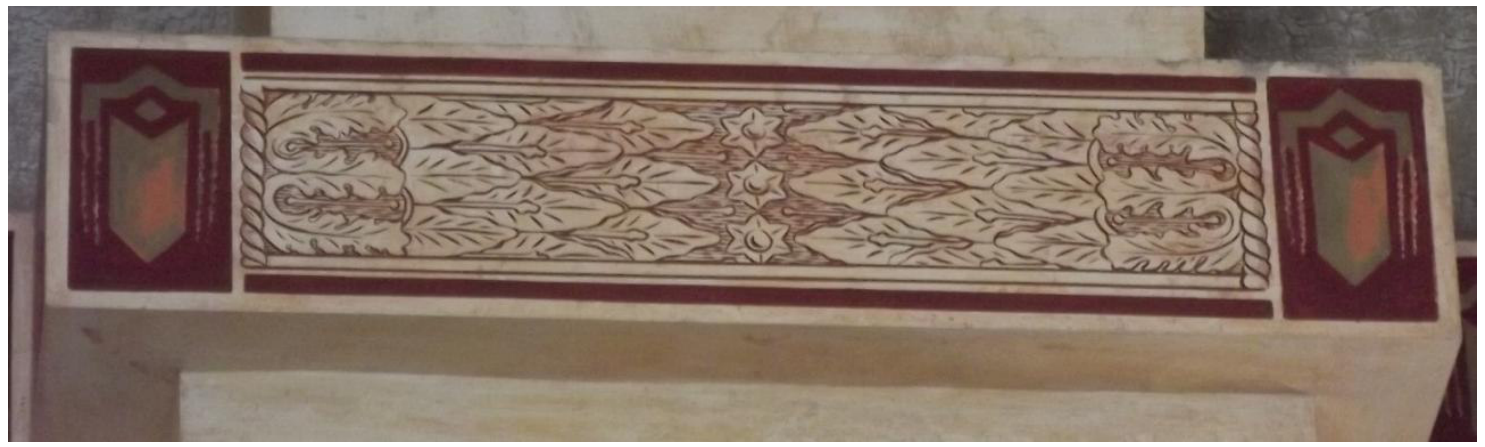

Detalle de la decoración de la base de las ménsulas.

En el techo del Paraninfo está una pintura de un cielo nublado que la circunda una moldura decorada; lo interesante es que los motivos del ornamento son como los de las de las bandas superiores de las ménsulas, es decir, formas geométricas superpuestas entre sí que le dan un fuerte dinamismo muy Art Déco.

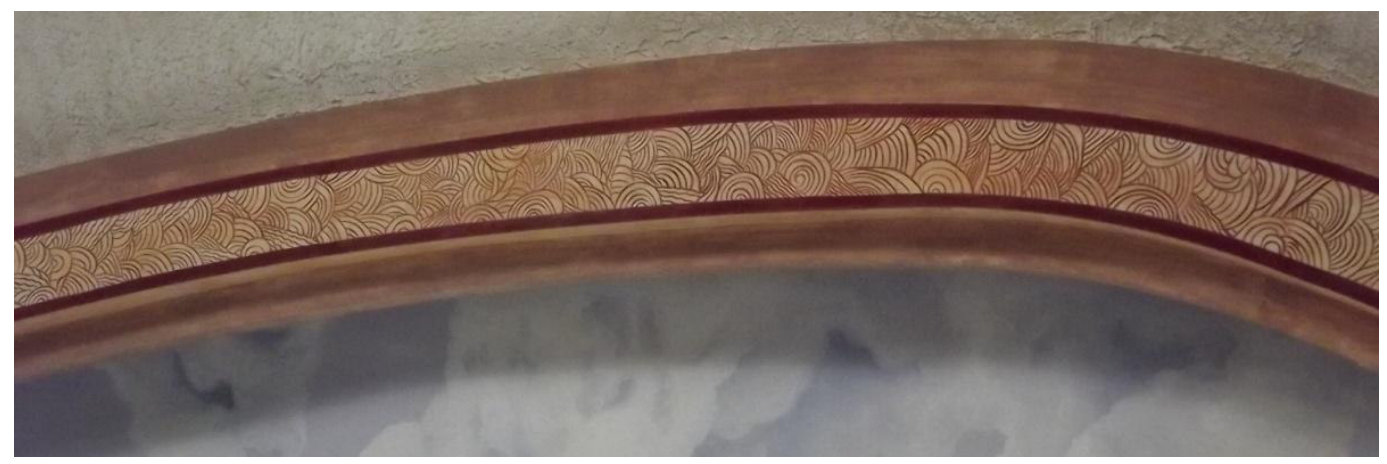

Detalle de los decorados de la moldura circúndate de la pintura del techo. 


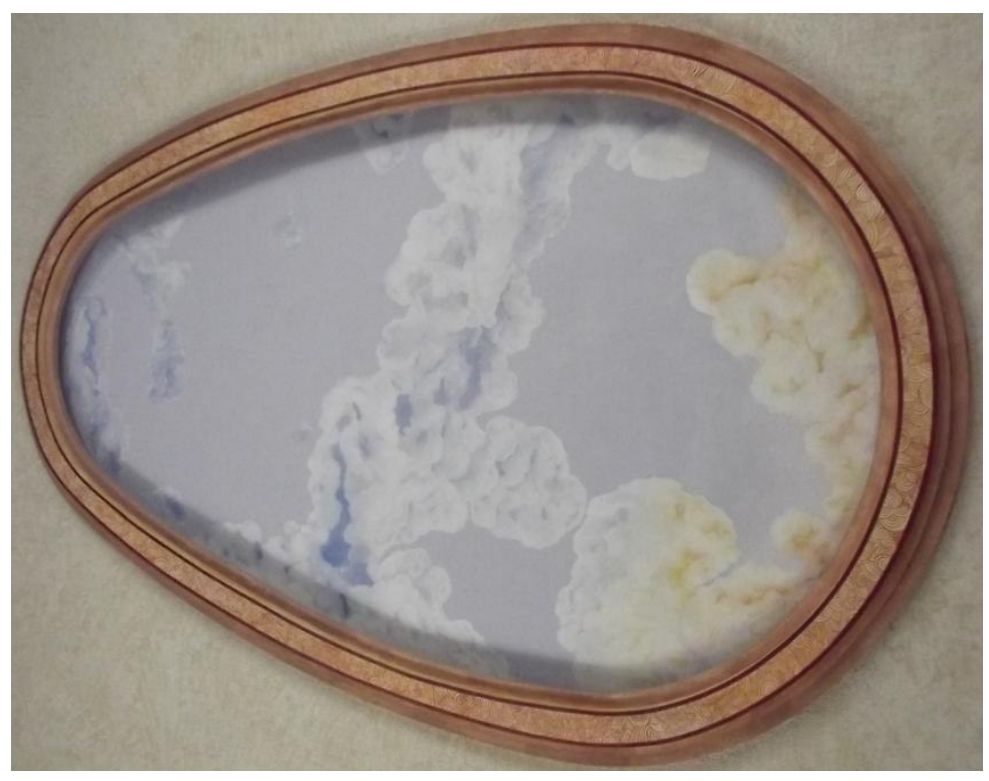

Pintura en el techo del Paraninfo.

En la galería del Paraninfo, un barandal ondulado está ornado en su parte frontal por siete lámparas colocadas sobre un par de bandas superpuestas que se introducen hacia la parte interior, típico elemento decorativo de la arquitectura Déco del periodo Zigzag. Las lámparas son cerradas y están trabajadas en latón con vidrio opaco, llevan formas geométricas, terminando tanto en la parte superior como inferior en forma de flecha angostándose en la parte baja, lo cual hace que se relacionen con las pilastras exteriores de todo el edificio, reforzando así los juegos geométricos del tipo Déco Zigzag.

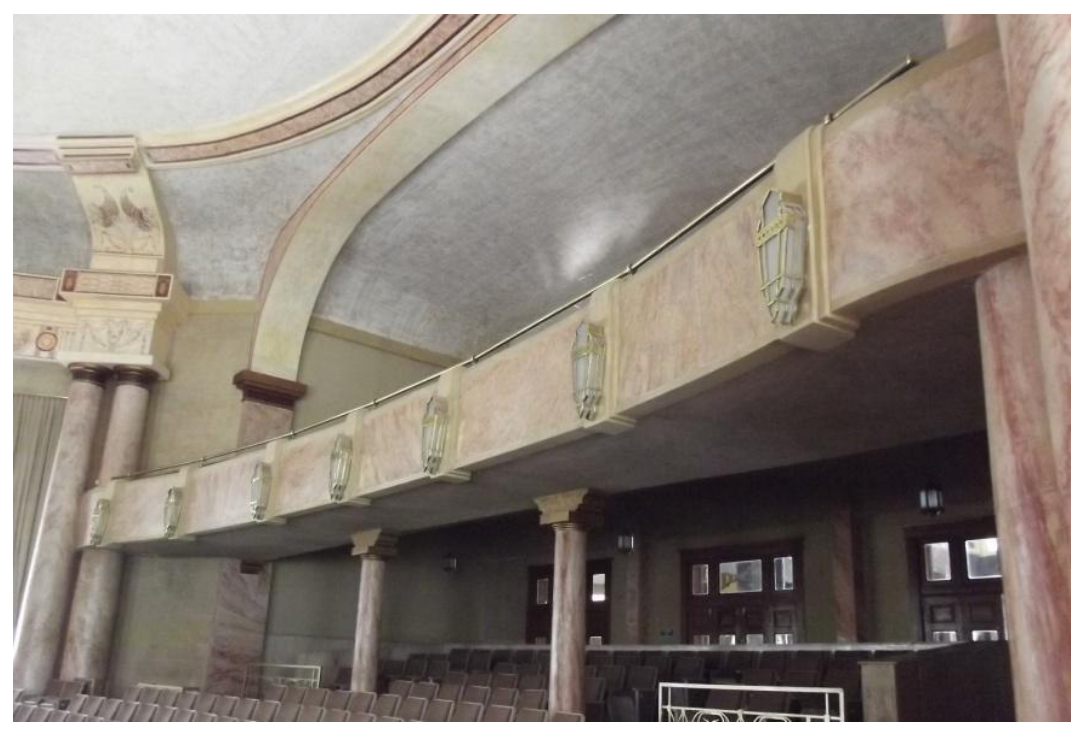

Barandal de la galería con las lámparas colocadas sobre las bandas. 
Hemos descrito en el Ateneo Fuente los elementos distintivos del Art Déco, que como hemos visto son del tipo Zigzag porque la geometría que se consigue con las formas geométricas de exterior, así como las del interior resaltan la conjunción de líneas rectas, ángulos, rectángulos, cubos, con las decoraciones descritas del Paraninfo, compartiendo las Tendencias Geometrista y Decorativista.

Jesús Ramírez Rodríguez en el libro sobre Zeferino Domínguez al afirmar sobre la influencia del Art Déco en el Ateneo Fuente dice: “Así, para arquitectos, ingenieros y diseñadores, dicho estilo se convirtió en la expresión plástica de vanguardia que emplearon en los proyectos más importantes, con el fin de modernizar el contexto urbano de las ciudades. Esta influencia en México tenía sus vasos comunicantes más próximos con Estados Unidos, ya que en sus ciudades más importantes se estaban construyendo los primeros rascacielos bajo el manto del Art Déco... La fiebre edilicia por este estilo encuentra en el Ateneo Fuente su máximo exponente en Saltillo". ${ }^{229}$

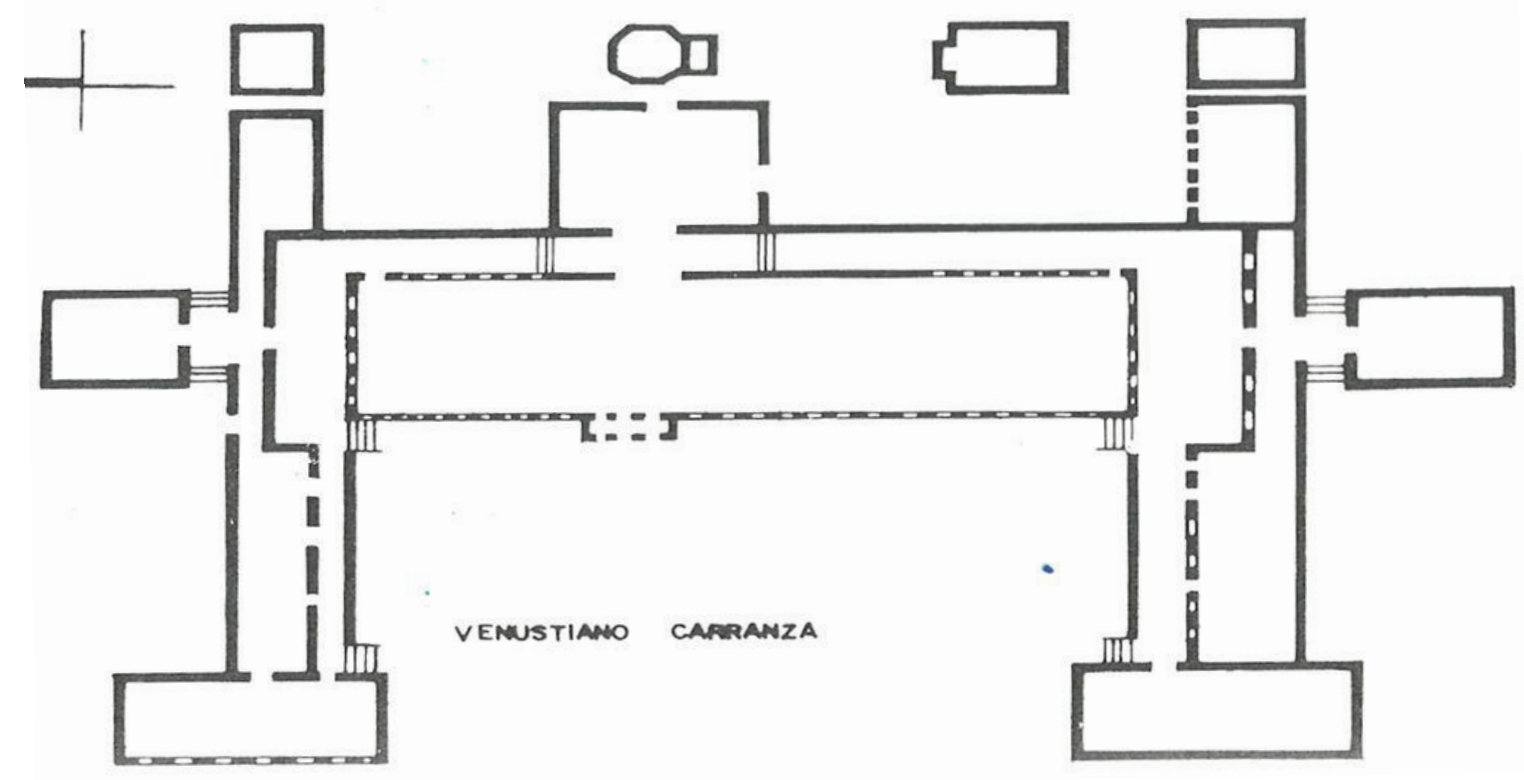

Plano del Ateneo Fuente.

INAH, Catálogo Nacional de Monumentos Históricos Inmuebles. Coahuila, Tomo 3, México, SEP, INAH, Programa Cultural de las Fronteras, Gobierno del Estado de Coahuila, 1986, p. 1547.

${ }^{229}$ Jesús Ramírez Domínguez, Op. Cit., pp. 35-36. 


\section{c. Escuela Álvaro Obregón}

En la calle del mismo nombre con el número 717 sur, con orientación hacia el poniente, está ubicada la Escuela Álvaro Obregón. Formó parte de las escuelas edificadas durante la gestión de Nazario S. Ortiz Garza como gobernador del estado, siendo ésta la última de su administración pues se construyó de abril a noviembre de 1933. A la vez, también fue una más de las obras de Zeferino Domínguez Villarreal, de quien podríamos decir que fue el constructor oficial de Ortiz Garza. La planta del edificio es en "U", con dos patios rectangulares, uno central y otro trasero. Al frente tiene un pequeño jardín lo que hace que el edificio no esté al límite con la banqueta y cuenta con dos pasillos laterales.

De un solo nivel, salvo en las oficinas donde hay dos plantas, el material utilizado fue el ladrillo, con revestimiento de aplanados. Lleva una barda frontal de mediana altura que se compone de un conjunto en forma de letras $U$, terminando sus pilastras en recortes biselados muy típicos Art Déco. En la entrada principal un par de pilastras se unen en la parte superior por medio de unas copas unidas que forman una celosía geométrica del tipo Déco Zigzag. Tras pasar la barda se accede al edificio por medio de una escalinata de seis peldaños curvos en sus extremos y un barandal que mira hacia la entrada, el cual lleva recorte en forma de pétalos trebolados.

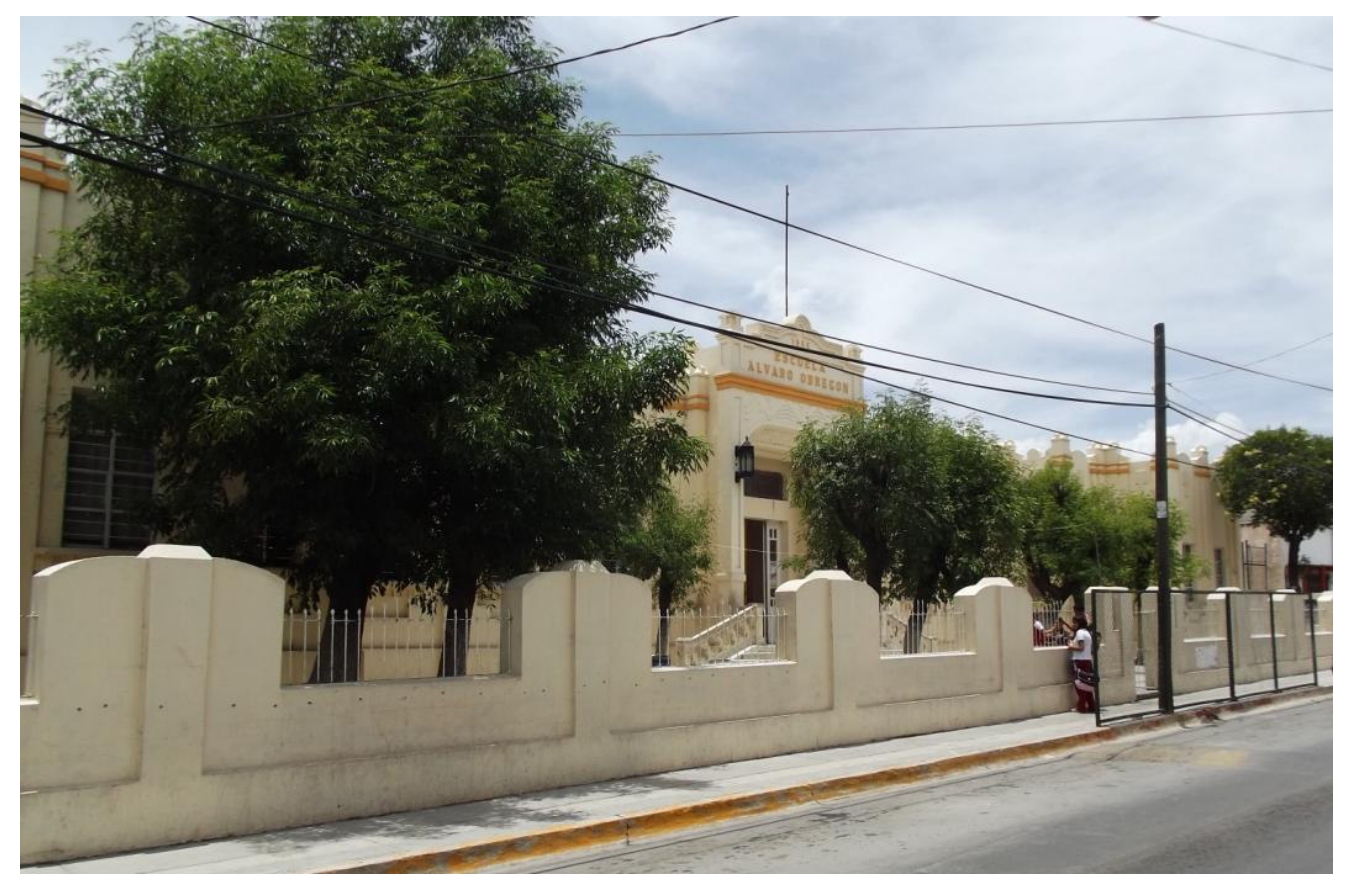

Barda frontal de la escuela. 
La puerta, uno de los elementos más Art Déco del edificio, se conforma con tres arcos deprimidos abocinados que descansan en un zócalo de tres caras. En el primer arco una decoración de ángulos colocados hacia abajo con líneas ondulantes horizontales, remarca los motivos ornamentales del periodo Déco Zigzag, lo mismo que el espacio entre los arcos y el ábaco, el cual es de zigzags entre líneas ondulantes que resalta este tipo de ornato que se desarrolló ampliamente en esa época y que es típicamente Art Déco. En los extremos molduras resaltan unos tablereados, donde se empotran unas lámparas de tipo neogótico. El nombre de la escuela va dentro de un ábaco, el cual también en los extremos lleva espacios tablereados y en la parte superior, en el piñón recubierto con molduras ondulantes y acodadas está el año de construcción: 1933. Como todas las escuelas de la época, lleva astabanderas, elemento utilizado en edificios de tipo Art Déco.

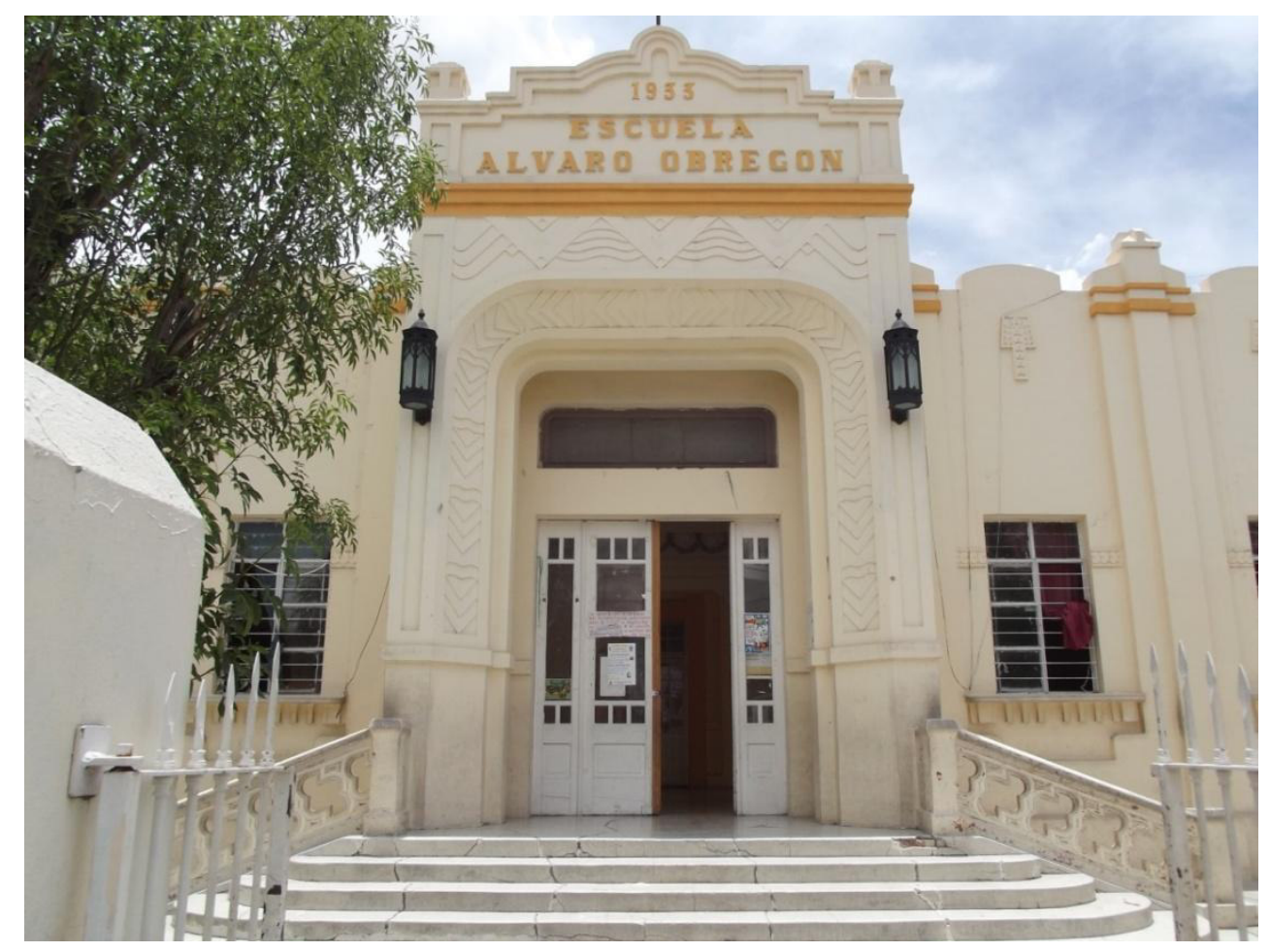

Acceso de la escuela. Se parecían los peldaños curvos, el barandal con las celosías en forma de pétalos trebolados. En la puerta destacan las decoraciones de tipo Art Déco Zigzag.

El muro frontal de la fachada está divido en tramos en donde se empotran las ventanas de forma rectangular. Cada tramo se divide por medio de tres pilastras adosadas, destacando la central. A la altura de lo que fuera un capitel, dos molduras, una más gruesa 
que otra, limitan y aderezan la elevación de las pilastras; las laterales se recortan oblicuamente y la central con más elevación remata en una forma como de llave o grifo con cuatro tramos, abstracción industrial de las emanadas de los diseños de la Exposición Internacional de París de 1925. Por su parte, los tramos terminan con un remate curvo.

Las ventanas en la parte baja llevan una saliente que está sostenida por pequeñas ménsulas rectangulares, a manera de un dentado espaciado, que a la vez se inserta dentro de un recorte rehundido geometrizado. A las tres cuartas parte de altura de las ventanas, en ambos lados, unas decoraciones de bandas a manera de "chalchihuites" 230 con una punta de maguey inserta le otorgan un sentido de prehispanismo, ya que como anotamos en el capítulo II, muchos de los elementos indígenas de la época prehispánica sirvieron de adorno para las construcciones Art Déco. El "chalchihuite" símbolo de la belleza espiritual y la espina de maguey utilizada para el autosacrificio fueron elementos que se plasmaron en las decoraciones de objetos suntuarios, templos y palacios de los mexicas y que aquí, aunque no con la misa connotación, sirven para ornar tanto como componentes nacionalistas, como modernos.

Otra decoración de tipo prehispánico es la que va en la parte superior de cada tramo que divide al muro. Un trapecio con mango encuadrado, como si fuera una pala, combina los motivos decorativos del "chalchihuite" con las puntas de maguey, además de incluir unas tiras de rombos recortados sobrepuestos. Todo este elemento es una lección de geometrismo decorativo de tipo Déco Zigzag.

En los extremos del muro de la fachada, dos tramos de desplazan hacia el frente, con lo que además se intensifica la geometrización tanto de la planta del edificio como de las decoraciones, en donde Zeferino Domínguez adquiere con este trazo, una conjugación de elementos típicos Art Déco, con el triunfo de la geometría.

Los muros norte y sur que dan a ambos pasillos, se dividen de la misma manera con las pilastras y las decoraciones descritas.

\footnotetext{
${ }^{230}$ El chalchihuite de origen náhuatl es un elemento decorativo de origen prehispánico que desde los tiempos del periodo clásico ( 0 a 900 d.C.) ya es utilizado por algunas culturas, pero especialmente con los mexicas es donde tuvo un mayor uso. Consiste en una pequeña dona plana que simboliza la belleza pura de tipo espiritual.
} 

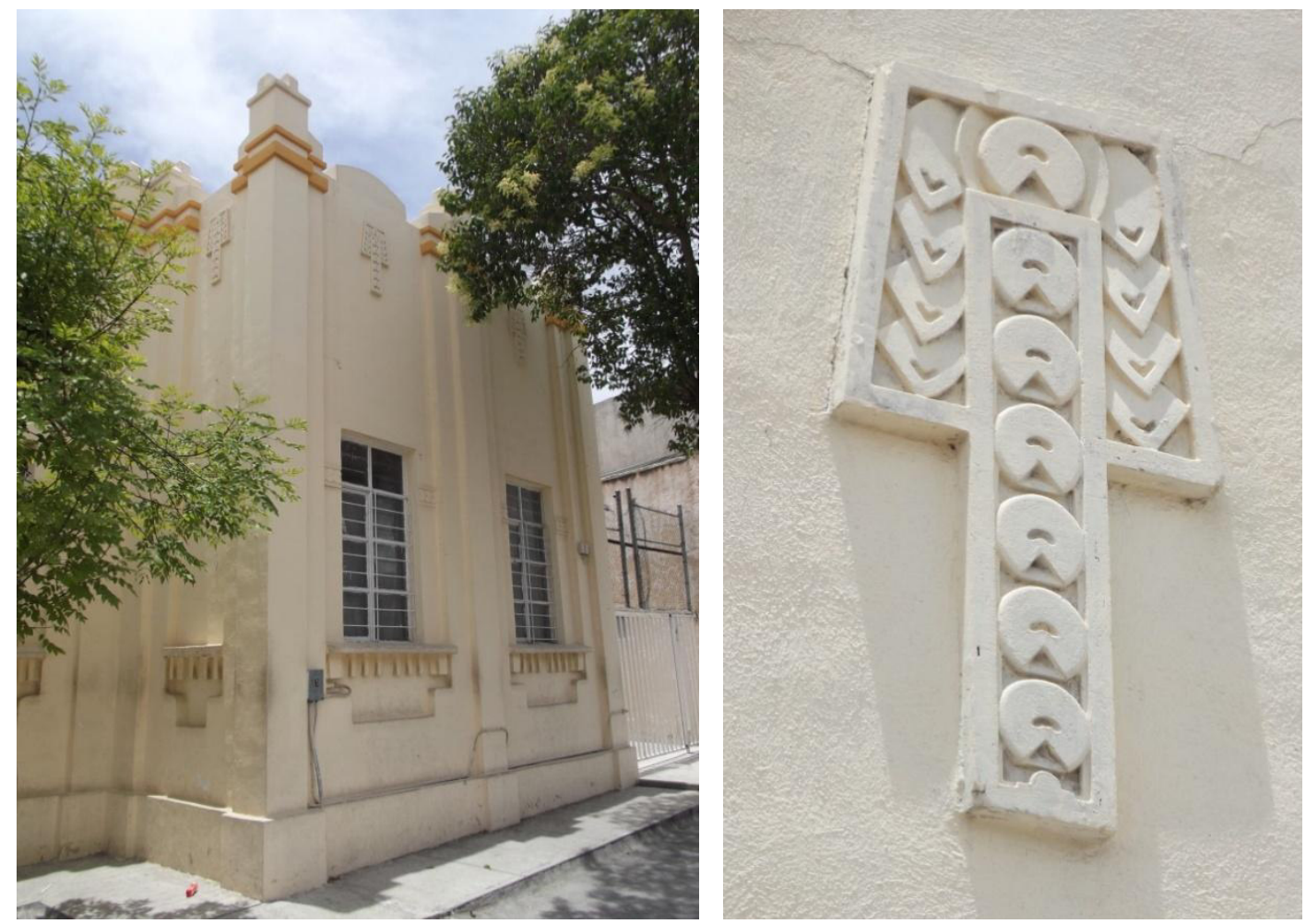

Extremo derecho de la fachada donde se desplaza hacia el frente en dos tramos y detalle decorativo de la parte superior. Se aprecian los chalchihuites en cuya parte baja se insertan las espinas de maguey.

Hay unos relieves empotrados en la parte lateral de los muros de la entrada principal que representan a hombres con atuendos indigenistas. Aunque se dice que son de tipo maya, más bien son como muchas obras de aquellos años que intentaban recalcar el mundo indígena. Son dos los relieves, uno a cada lado, con la figura humana de un indígena con taparrabo terminado en punta de flecha, que se sostiene desde un atuendo que pasa por detrás de la espalda; el torso lo lleva desnudo y las manos elevadas sostienen un platón con pepitas de cacao, alimento y moneda a la vez que usaban los mexicas. El personaje está parado sobre una ménsula con decoraciones de zigzag, misma que se repiten pero con más amplitud en el borde del plato. El fondo lleva unas líneas corrugadas y en la parte superior unos ornatos nuevamente en forma de zigzag. Atribuidos a Salvador Tarazona, es la fusión del mundo indígena con los motivos decorativos del Arte Déco Zigzag, dándole así a la comunidad escolar el mensaje del indigenismo, pero con un lenguaje moderno de la época, por lo que serían una muestra de la Tendencia Nacionalista Prehispanista. Estos relieves que se encuentran remetidos del nivel del muro, en la parte baja hay un rehundido en forma 
de $\mathrm{T}$, con un dentado alternado de tres-dos-tres, con lo que le da más impulso al sentido de lo geométrico.
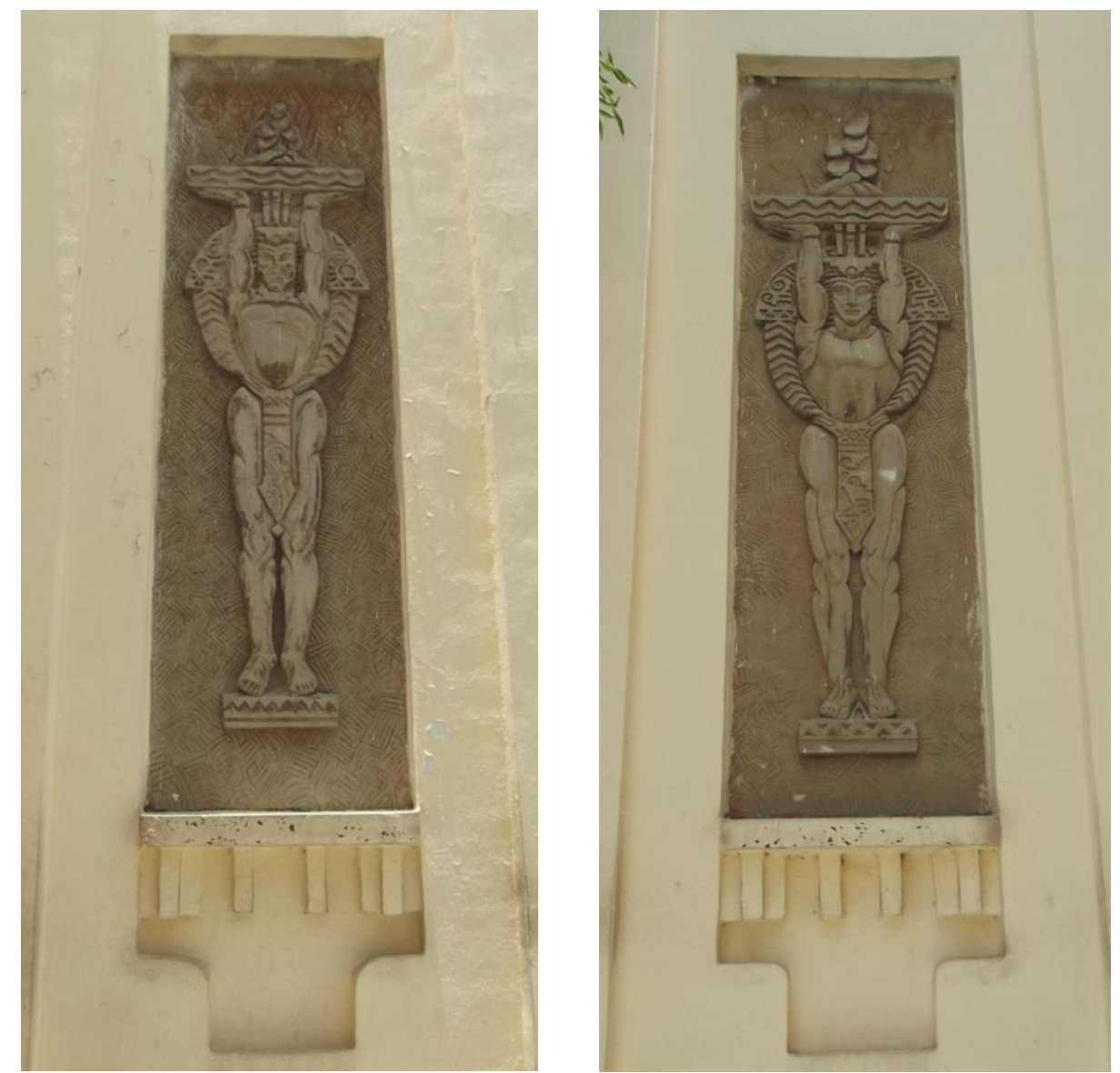

Relieves con personajes indígenas. Se aprecia que son diferentes entre sí en los rasgos físicos y en algunos detalles como las pepitas de cacao o los decorados en zigzag de las ménsulas.

Al entrar al inmueble en un pequeño vestíbulo está la placa conmemorativa del edificio con la fecha de inauguración: 29 de noviembre de 1933, con el nombre de Zeferino Domínguez autor del proyecto y encargado de la dirección constructiva, además de otros personajes como el alcalde, los regidores y los síndicos.

El techo está compuesto por una retícula de vidrio block enmarcada por perfiles biselados, lo cual nos rememora a la cubierta del lobby del Ateneo Fuente, que de la misma manera inyecta una tenue luz al vestíbulo, pero suficiente para este espacio. Es evidente el uso similar de la iluminación que quiso darle Zeferino Domínguez a ambos edificios. 


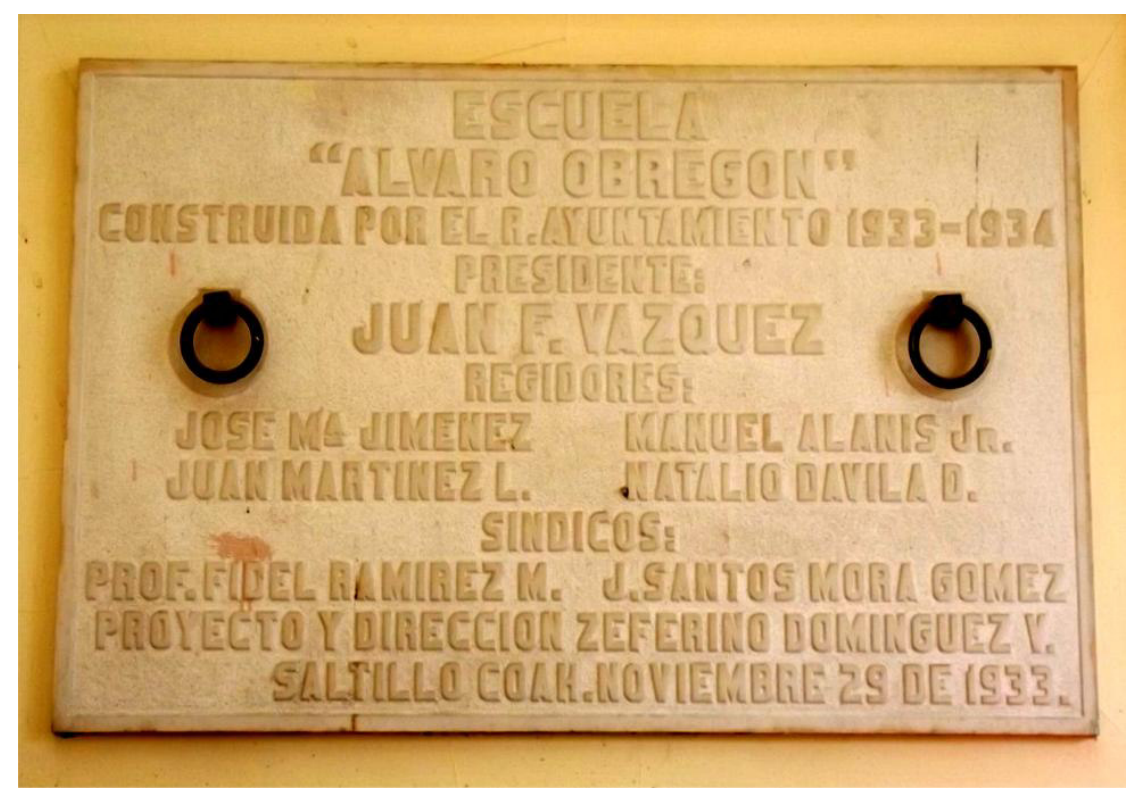

Placa en el vestíbulo. En el penúltimo renglón está el nombre de Zeferino Domínguez.

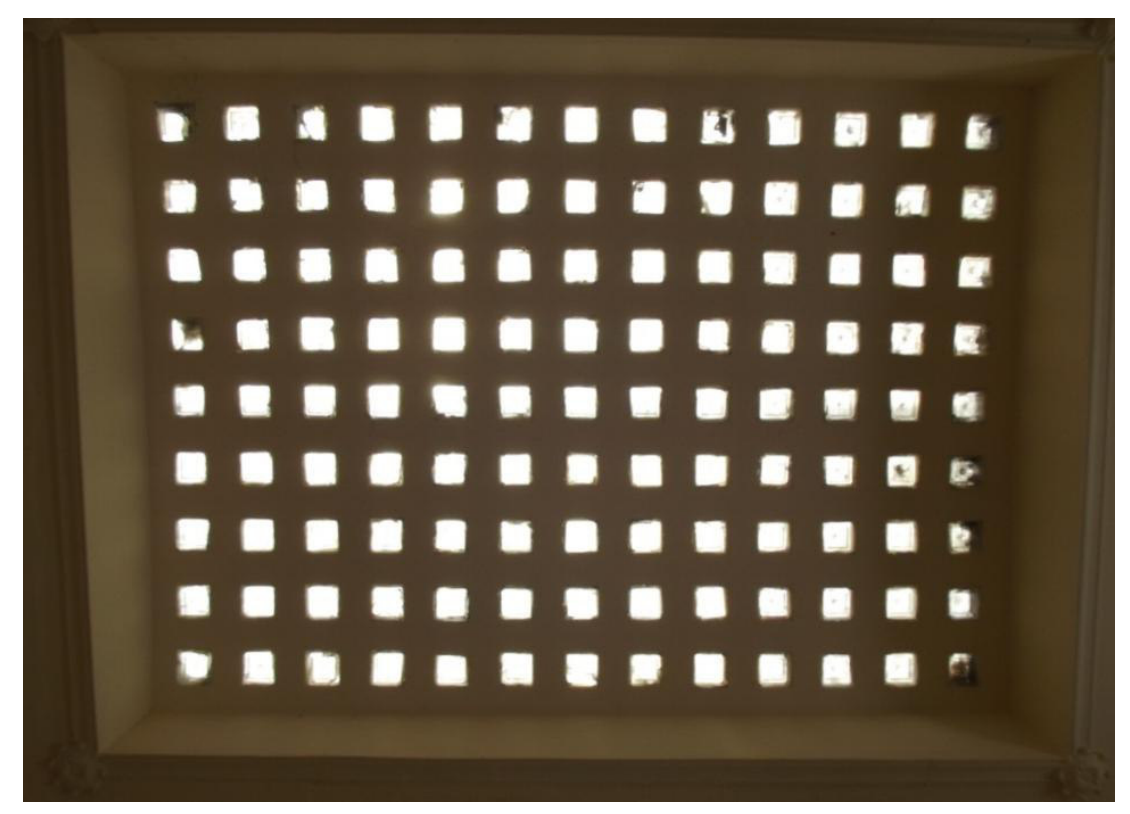

Techo con casetones de vidrio block del vestíbulo.

En la parte del interior se conservan algunas bases de lámparas manufacturadas con cemento seguramente hechas en moldes. Tiene una forma de la mitad de un prisma reto hexagonal que de arriba hacia abajo se va recortando. Inicia con una moldura circular y luego se continúa con un dentado plano y curvo que se introduce hacia la superficie. Dentro 
de los tres recortes que continúan hacia abajo, en la parte frontal lleva en rehundido un adorno como si fuera una artesanía mexicana, como los aventadores de aire que se utilizan para avivar el fuego. Lleva insertos elementos geométricos como es en la parte superior un rombo y en la inferior un triángulo; cinco semicírculos geometrizados van en la parte central y el contorno está decorado con líneas encontradas, tal como son los fondos de los relieves de los personajes indígenas del exterior, trabajos muy dentro del estilo de Tarazona. En las caras laterales, también aparecen rombos y bandas de líneas rectas descendentes. Termina en la parte baja con una ménsula con la misma composición del todo el objeto.

El geometrismo de este elemento tiene una fuerte similitud en la composición con las figuras humanas del exterior y a la vez el geometrismo imperante de su diseño lleva una semántica de objeto tipo Art Déco Zigzag y de componentes que intentan resaltar lo mexicano indigenista.

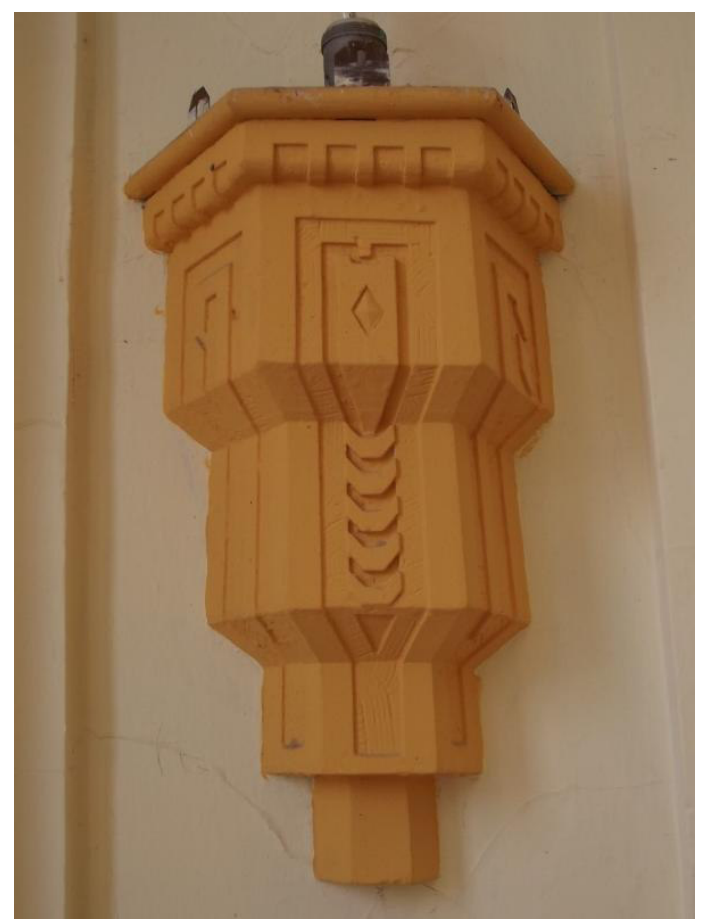

Base de lámpara del interior.

Lo que corresponde a las oficinas son dos niveles que están ubicados en el centro de la parte frontal del edificio. Tienen una distribución de un rectángulo y un ochavo alargado. Los muros que dan hacia el patio, los del primer piso llevan ventanales y debajo de éstos, 
unos rehundidos rectangulares destacan la geometría; en la planta alta resaltan unas pilastras adosadas en grupo de dos y de tres con doble vista en las esquinas. Se elevan por arriba del límite del muro, destacándose en elevación unas más que otras, haciendo juego con los remates superiores que tienen formas geométricas, simulando un coronamiento de esa parte del edificio. Las pilastras llevan unas molduras en la parte baja y alta que armonizan con la banda que divide los dos pisos.

Esta parte de la Escuela Álvaro Obregón es todo un armazón de formas cúbicas, así como de líneas verticales y horizontales, utilizando el lenguaje que estaba en boga del Art Déco de la variante Zigzag.

A los lados de las oficinas se abren corredores techados de dos vanos que luego se continúan perpendicularmente a cada lado con cinco vanos. En dichos pasillos se distribuyen las aulas. Los vanos son rectangulares y se separan por pilastras que se elevan por arriba del nivel de los muros y terminan redondeadas. Llevan molduras en la parte superior para simular que tienen capitel. Los remates entre cada pilastra son ábacos escalonados y con formas curvas como el del muro central del cuerpo de las oficinas.

Se restauraron unas lámparas que están colocadas debajo de las molduras de las pilastras que contienen la misma forma de las decoraciones exteriores en forma de trapecio con mango, con lo que se conservó el estilo Art Déco de estas luminarias.

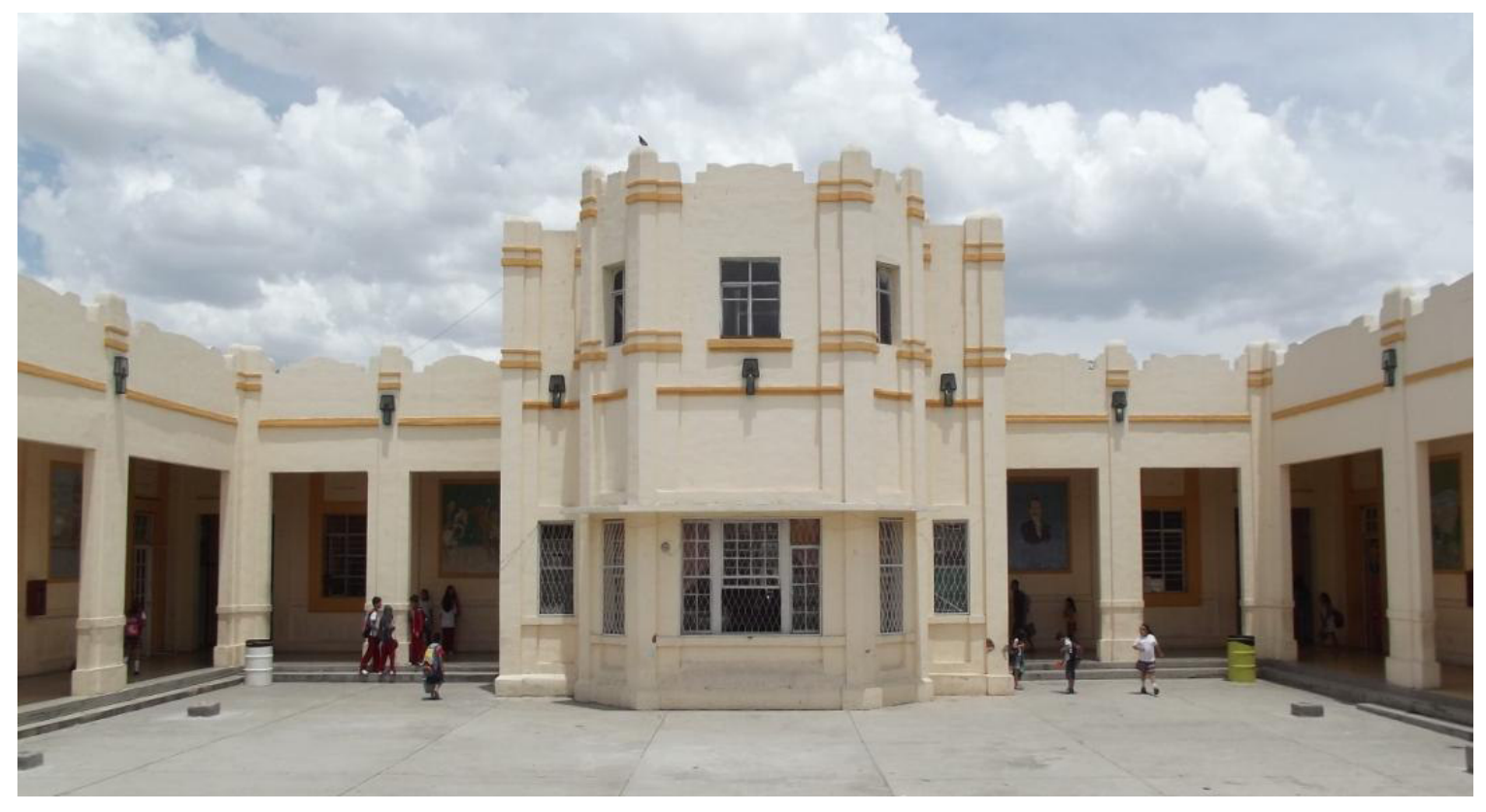

Oficinas que dan hacia el patio y corredores con las aulas. 


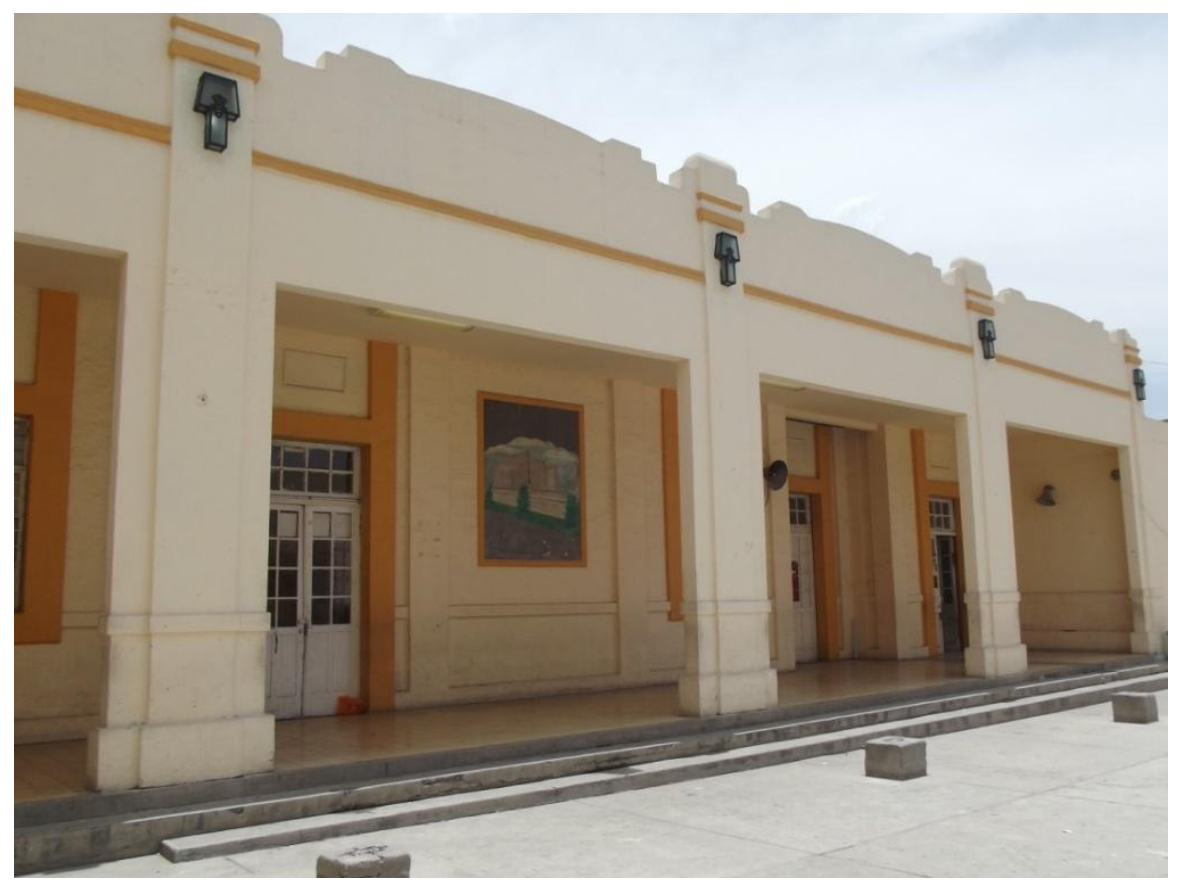

Detalle del corredor norte. En cada pilastra están colocadas las lámparas restauradas.

Como era usual en esos años y atendiendo al programa educativo de fomentar los actos cívicos al aire libre, en muchos planteles educativos se colocaron teatros en los patios. El de la Escuela Álvaro Obregón tiene una plataforma que en su parte frontal es semicircular con peldaños por el frente y forma ochavada en los extremos. Muros laterales en forma de ochavo se elevan siguiendo la composición de la plataforma, llevando pares y tríos de respiraderas verticales alargadas, que además de cumplir con su función de ventilación, a la vez desempeñan un papel decorativo geométrico. En la parte posterior de estos muros unas pequeñas columnas con doble moldura sirven de contrafuertes y juegan el papel de recortar la altura, con lo que se remarca aún más el sentido de elevación de los muros. Cercano al escenario, unos contrafuertes envuelven al conjunto, posicionándose por arriba de la techumbre, como si fueran unos cinturones. Las formas geometrizadas y tripartitas de estos contrafuertes, al mismo tiempo presentan delicadas estrías, solución para acentuar el ornato Art Déco Zigzag. Un par de molduras recorre toda la parte superior que por su disposición horizontal contrastan con la verticalidad de los demás elementos.

El remate del teatro se compone de un entablamento con formas angulares muy del tipo Déco Zigzag, para terminar con un par de molduras que resguardan un espacio rehundido. Al centro entre dos pequeños contrafuertes como los mayores, hay un ábaco 
acodado y curvo. La conjunción de los ángulos del entablamento con las molduras horizontales le otorgan a esta parte del teatro una idea de cinetismo, como si fueran partes industriales de una banda que recorre algún instrumento fabril. El vano del escenario es rectangular y en el interior la concha está decorada con cuatro gajos levemente rehundidos y separados por molduras que remarcan el contorno geometrizado.

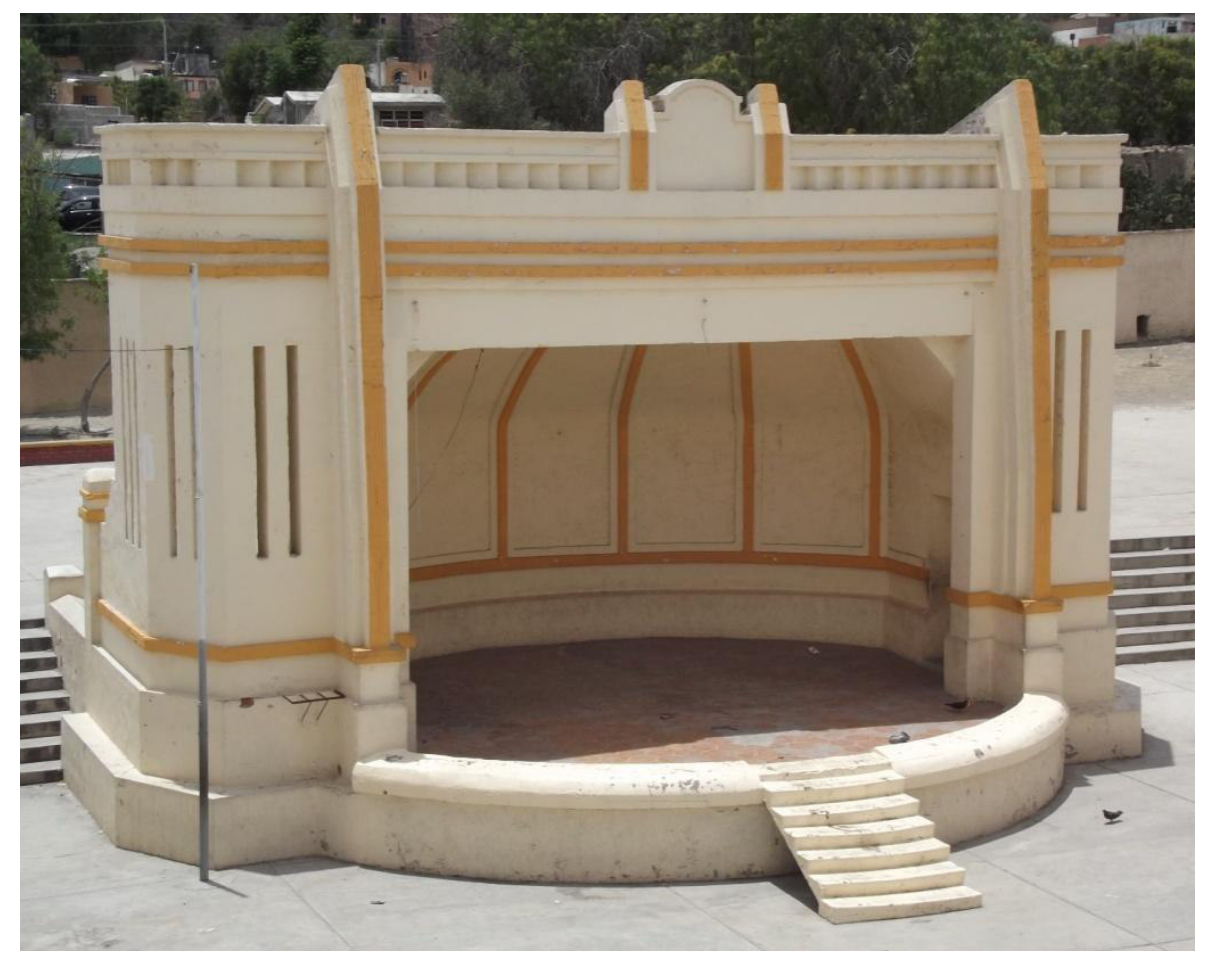

Teatro al aire libre en el patio central.

Esta escuela luce la fusión del estilo Art Déco Zigzag, como analizamos en varios elementos decorativos y compositivos, con un sentido nacionalista y con las Tendencias Decorativista y Nacionalista Prehispanista. Por eso Jesús Martín López afirma que: "Dentro de un estilo que se puede considerar como Déco, conlleva la mezcla del nacionalismo imperante, el cual se presenta de manera significativa en los relieves homorfos de su fachada principal". 231

A pesar de ser una obra tan importante para la misma ciudad de Saltillo por lo que significó su aporte a la educación en esos años y además de haber sido diseña y construida por Zeferino Domínguez, la Escuela Álvaro Obregón sufre un fuerte deterioro y al parecer

\footnotetext{
231 Jesús Martín López, Op. Cit., p. 100.
} 
no hay la intención por ser remozada. Por eso dice con mucha nostalgia el articulista Alfredo Velázquez Valle: "Sería una decisión afortunada el que las autoridades volvieran los ojos a este edificio emblemático de la educación básica de la ciudad y le dieran la imagen original que en sus inicios tuvo: ventanas de madera, retiro de los techos actuales por otros acordes con la arquitectura original, remozamiento del hall con la restauración del portón de entrada y sus vidrios biselados con sus grabados; rescate del techo del foro, restauración de las originales escaleras de madera que conducen a la planta alta, recuperación de las salidas laterales y recuperación, también, de los detalles de iluminación molduras en muros y pretiles, entre otros, serían los aspectos que devolverían a dicha escuela su grandeza arquitectónica propia del tiempo del art decó". ${ }^{232}$

\section{d. Escuela Margarita Maza de Juárez}

En la misma avenida Carranza, donde se encuentra el Ateneo Fuente, en el número 1544 se ubica la Escuela Margarita Maza de Juárez, cuya orientación es al poniente.

Los orígenes de esta institución son muy peculiares, pues se funda en 1942 como una Escuela de Corte y Confección de Ropa y para el año siguiente ya cambiaba su nombre por el de Escuela Industrial Femenil. En eso años aún la mujer en México seguía siendo relegada de los estudios profesionales, pero es interesante que se abriera una institución educativa por parte del estado para que las damas pudieran obtener una educación escolarizada, - más allá de pequeñas academias, conventos o en clases particulares - donde además también podían adquirir conocimientos sobre repostería, panadería, concina y belleza. Debido al cambio de giro en la educación con los pasos de los años, la escasez de alumnas y la incorporación de la mujer a la educación profesional, en el año de 1972 a la Escuela Industrial Femenil se le dio el nombre que lleva actualmente, además de cambiarle de giro para convertirla en una escuela secundaria, ya que el presidente de ese entonces Luis Echeverría Álvarez (1922) declaró a ese año como Benito Juárez por el centenario de la muerte de dicho personaje, por lo tanto se renombraron muchos colegios, calles, avenidas

\footnotetext{
${ }^{232}$ Alfredo Velázquez Valle, "Escuela Primaria Gral. Álvaro Obregón”, El Periódico de Saltillo, Saltillo, Coahuila, abril de 2012, edición 278, http://www.elperiodicodesaltillo.com/2012\%20abril/escuela.html
} 
y municipios por todo el país, incluyendo también el nombre de su cónyuge, Margarita Maza de Juárez, en instituciones cuya origen o vocación tuviera que ver con la mujer.

El gobernador Benecio López Padilla (1888-1969) concibe la idea de levantar un propio edifico para esta escuela que sesionaba en la Escuela Centenario. Así pues, en lo que ya eran las orillas de la ciudad, se le encarga el proyecto nuevamente a Zeferino Domínguez Villarreal en 1945, siendo inaugurado el 20 de noviembre de ese año. Con una planta en forma de "E" acostada y dos niveles, los materiales utilizados fueron el ladrillo y el concreto armado.

Por toda la parte frontal hay un patio y jardín que antecede al edifico. Está protegido por rejas, conservándose de las originales solamente la de la entrada. Entre dos pilares, la reja muestra motivos decorativos geométricos de ovoides y líneas oblicuas en la parte baja, luego cruzamientos de dos letras " $\mathrm{X}$ " que forman unos zigzags, mismos que se repiten en la parte superior y pequeños círculos al centro, todos unidos por líneas verticales. A pesar de ser ya de los años cuarenta, estos magníficos motivos geométricos son acendradamente de tipo Art Déco Zigzag, porque en el remate de la reja las líneas horizontales que se van acortando, forman un escalonamiento que se curvea en los extremos, lo cual manifiesta un decorado de clara raigambre Streamline, aparte de que se emparenta con el remate de la fachada principal.

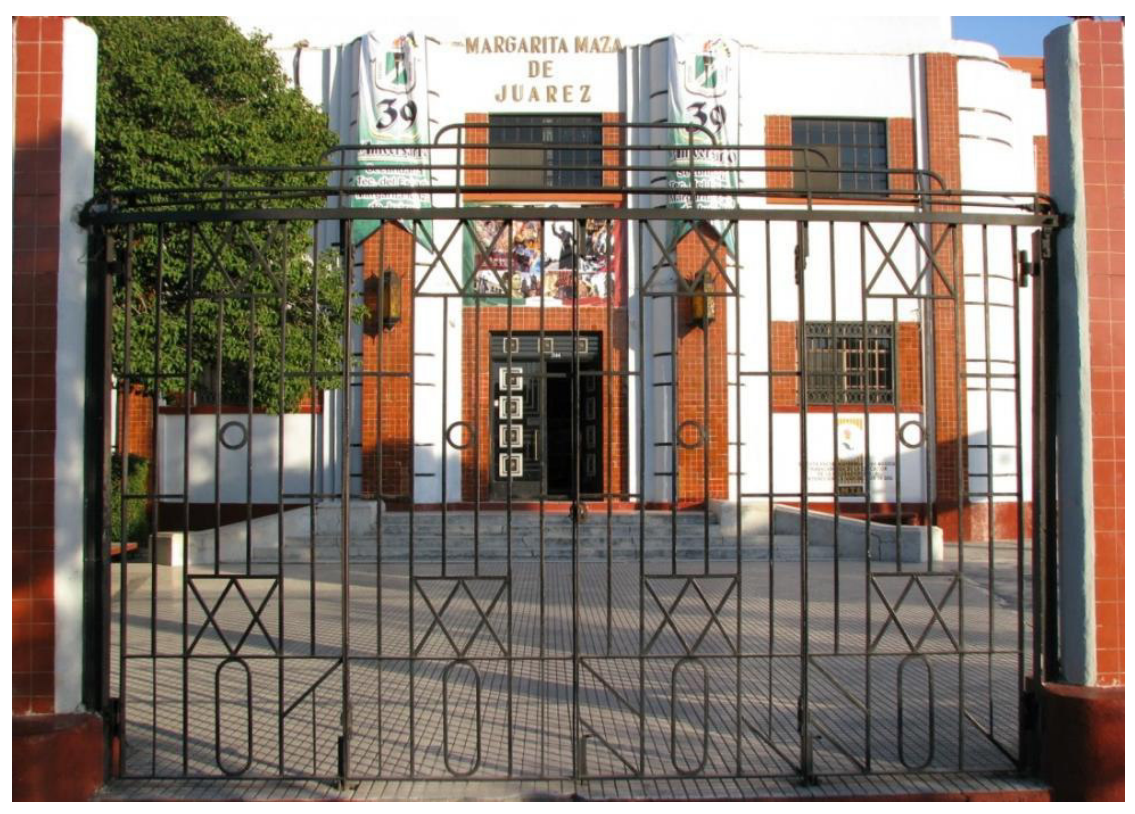

Reja de la entrada con los motivos decorativos Zigzag y Streamline. 
Para acceder al edificio una escalera con cuatro peldaños conduce a la puerta; los peldaños están protegidos por un barandal de poca altura que se abre con una leve curvatura a cada lado que inicia con unos zócalos cuadrados, terminando de la misma manera con zócalos rectangulares. El barandal en la superficie lleva un doble recorte en los extremos con lo que se da un efecto de dos bandas superpuestas; esto le quita pesadez a la vez que expone un elemento decorativo de los que mucho se utilizaban en las fachadas en el Déco Zigzag, a pesar de ser ya una edificación de los años cuarenta.

Uno de los elementos más Art Déco de este inmueble están en el cuerpo central de la fachada principal. Primero son los medios cilindros achatados que bordean la entrada y que alcanzan el doble nivel, plegándose al muro a través de dobles perfiles angulares. A manera de grandes columnas, estos elementos llevan cinco pares de bandas horizontales en color dorado, como si fueran cintos que pliegan estos componentes a la pared y por el frente se sobreponen unas bandas verticales cubiertas de azulejos rojizos, donde se empotran unas lámparas octogonales; además de la curva de los medios cilindros que se resalta del nivel de la superficie del acceso, con las líneas horizontales se refuerza el sentido de dinamismo.

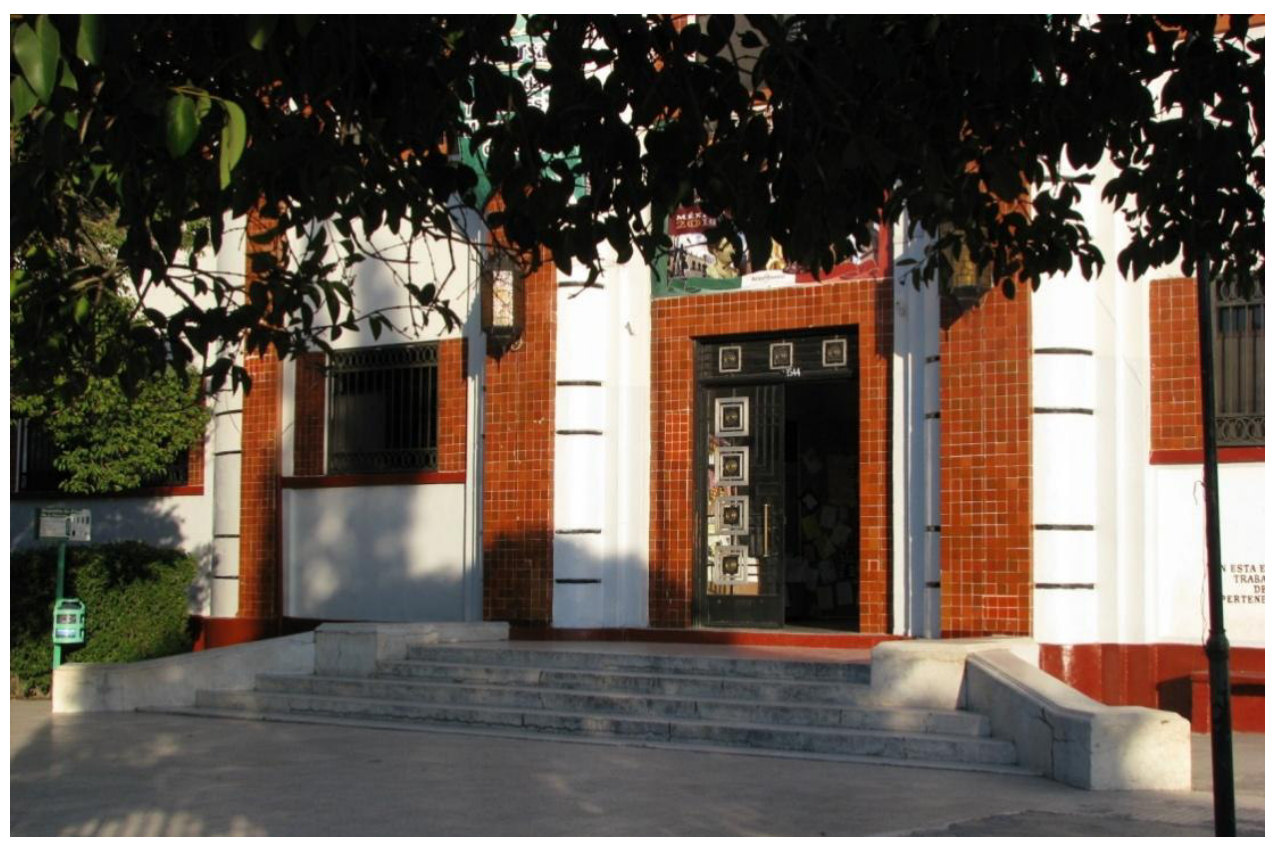

Escalera y puerta de entrada. En los barandales se aprecia el recorte en los extremos que simula dos bandas sobrepuestas. 
Otro elemento Déco es el vano de acceso rectangular que está cubierto de azulejos rojizos. La puerta lleva en los lienzos unos recuadros en plateado con círculos dorados al centro, así como líneas en grupo de tres en disposición de ángulo recto y tres líneas horizontales que se entrecruzan; en la parte superior los recuadros son más ligeros y descansan sobre cuatro barras en posición horizontal, donde toda esta mixtura de elementos acentuadamente geométricos son de la variante Art Déco Streamline. En el segundo nivel sólo hay una ventana rectangular, cuyos extremos están forrados con el mismo tipo de azulejos rojizos y luego más arriba el letrero de la institución con letras que no son Art Déco, pues fueron colocadas en 1972. En la parte superior, en el remate, un pretil escalonado con recortes curvos va de mayor a menor, terminando con la astabandera de tres niveles, componente que hoy sirve de base para unas luminarias y que está en concordancia con la parte superior de la reja de entrada. Al destacar la conjunción de los componentes curvos con las bandas horizontales, Zeferino Domínguez le otorga a esta parte del edifico una estilística distintiva del Déco Streamline.

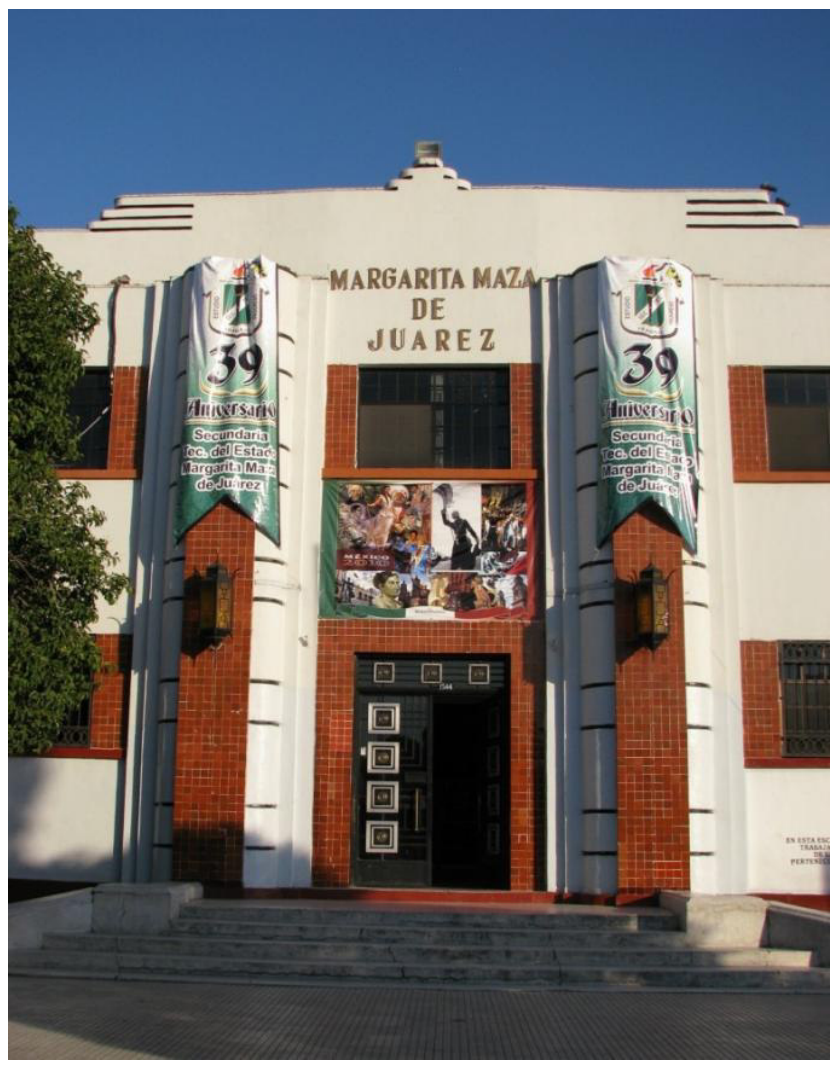

Parte central de la fachada principal. 
A los lados de los medios cilindros y después de dos biseles angulares escalonados hacia dentro, se rehúnde levemente el muro que lleva en los dos niveles el mismo tipo de ventanas rectangulares, para continuar con un perfil angular y una pilastra plana revestida de azulejos que simulan bandas superpuestas. La armazón de elementos geométricos continúa con un tercio de los cilindros con todo y pares de bandas que unen a esta parte central con los muros a través, nuevamente, de dobles perfiles angulares. El muro rehundido y los cuartos de cilindros prolongan la distribución de componentes de tipo Déco Streamline.

Todo este segmento del edificio está colocado hacia delante del resto de las paredes de la fachada, con lo que se enfatiza más aún como cuerpo principal. También es importante mencionar que en muchas partes tales como la puerta, pilastras y ventanas que están recubiertas por los azulejos en color rojizo, fue con el objetivo de buscar una cromática de contraste a través de colores suaves.

Después de los cuartos de cilindros de este cuerpo del edificio que está colocado hacia adelante, los muros que continúan formando la fachada principal, se desplazan hacia atrás, llevando cuatro grupos de ventanas dobles, para terminar con el último cuerpo de la fachada que está colocado hacia delante al mismo nivel del cuerpo central. Esta última parte llevan dos ventanas en el primer piso y en el segundo un recuadro hundido va tapiado.

Las fachadas laterales norte y sur exponen cuatro tramos en una distribución de grupos de ventanas de cuatro en cuatro en ambos niveles, donde Zeferino Domínguez utiliza un lenguaje de la arquitectura funcionalista.

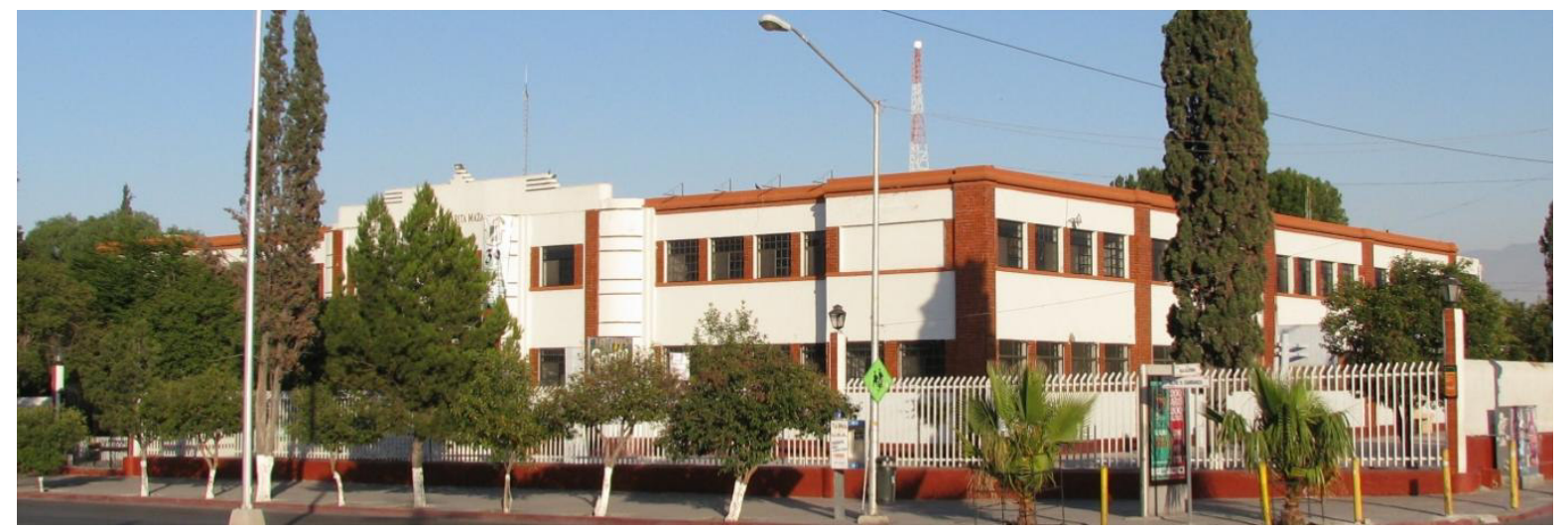

Vista del lado derecho de la fachada principal, con el muro rehundido y la última parte desplazada hacia el frente. Las fachadas laterales tienen un sentido funcionalista, como se aprecia aquí en la fachada sur. 
En el interior, el vestíbulo es un espacio hexagonal que conduce a varias áreas del edificio. Está constituido por seis columnas que sostienen el mismo número de trabes, las cuales llevan un par de molduras. Las columnas son octagonales, teniendo cuatro de los lados más angostos. En la parte baja llevan una decoración muy Déco tipo Zigzag que consiste en unas estrías sobrepuestas la cuales terminan en punta de flecha. Tres anillos moldurados forman el capitel, haciendo Zeferino Domínguez algo sumamente original y aunque sea la construcción del año 1945, aún estas decoraciones nos remiten al Déco Zigzag. En la pared lateral derecha del vestíbulo está la placa de la entrega de la Escuela Industrial Femenil a la mujer coahuilense, un 20 de noviembre de 1945.

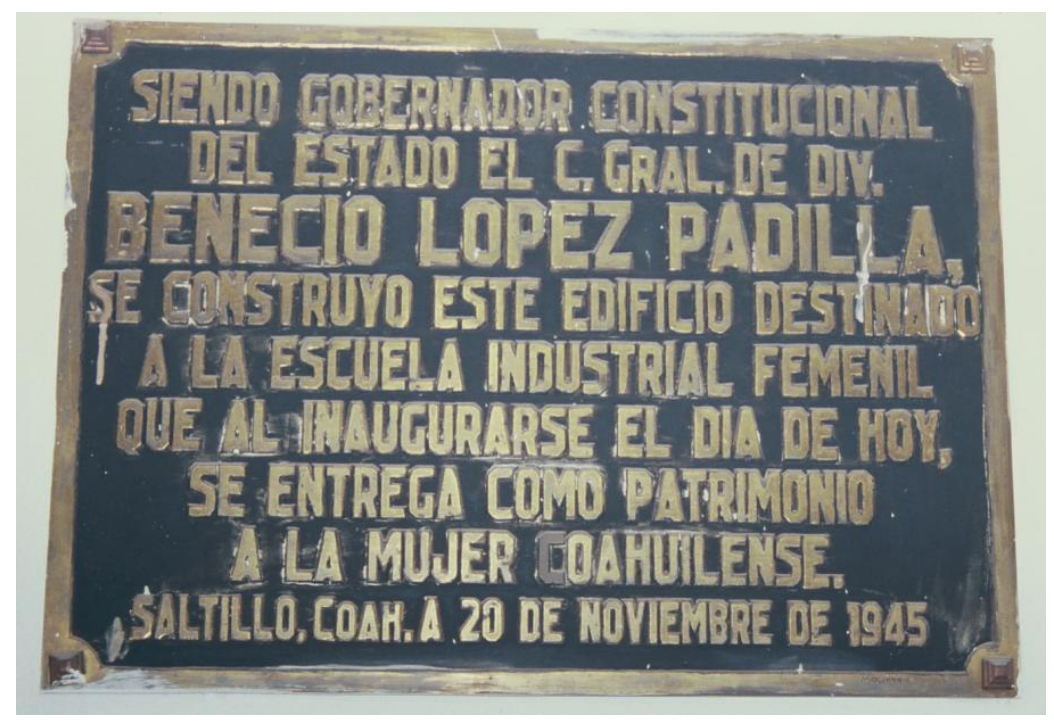

Placa en el vestíbulo.

El piso está forrado con mosaicos que integran el hexágono con líneas negras que resguardan cuadrados rojos y verdes. Al centro, un círculo envuelve a una estrella de seis picos que a su vez circunda a otra más pequeña con la misma composición, todo esto con un fondo amarillo. Este ejercicio cromático a su vez lo es de formas geométricas que nuevamente nos llevan hacia los ornatos utilizados por el Art Déco Zigzag, como son las formas angulosas de las estrellas, además de estar dentro del lenguaje de las vanguardias como el De Stijl. En la parte del vestíbulo donde termina el hexágono, a ambos lados arrancan escaleras, cuyos peldaños están forrados de mosaicos cafés, lo mismo que los pisos tanto de la planta baja, como del segundo nivel. El pasamanos principia con una curva 
para darle más apertura; lleva dos bandas superpuestas, similar a la escalera de entrada al edificio. Entre los anillos de las columnas, las molduras de las trabes y los perfiles que se forman con las bandas superpuestas del pasamanos de la escalera, le da al vestíbulo un ritmo horizontal de delicadas líneas en movimiento.

Pasando el espacio del hexágono, hay otra área cuadrada que antecede a la entrada del auditorio. El piso está compuesto de pequeños cuadros blancos y negros que nos recuerda al piso de la monumental Escuela Coahuila, ya que ambos llevan una composición a manera de tablero de damas españolas. Entonces la combinación de los diversos elementos geométricos, círculos, triángulos, rectas, cuadrados del piso de todo el vestíbulo, es nuevamente el enaltecimiento de las formas geométricas, emanadas de las vanguardias artísticas que van a constituirse como elementos del Art Déco en sus diversas etapas.

La puerta de acceso al auditorio es de vidrio. Las hojas de entrada no son las originales, pero sí la decoración que corresponde a unos rombos y triángulos isósceles a los lados, que se hermanan con otros triángulos de la parte superior donde se forma un zigzag. Estas figuras geométricas se complementan con las del piso, componiendo un ensamble de diversas figuras geométricas en diferentes ritmos y colores.

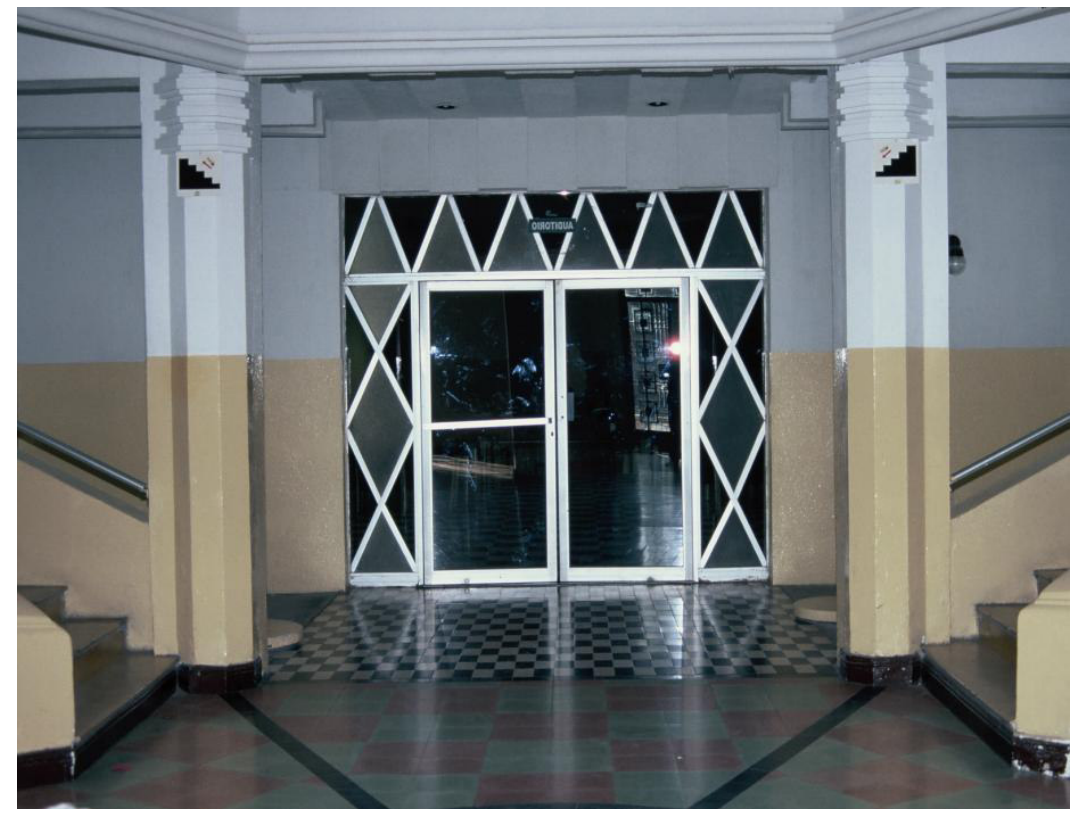

Vestíbulo. Se aprecian los anillos que forman el capitel de las columnas, las trabes con sus molduras, los pasamanos de la escalera y las figuras geométricas del piso y de la puerta del auditorio. 
En lo que corresponde a los espacios laterales de ambos lados se distribuyen oficinas y salones. Lo interesante en estas áreas es que se forman también hexágonos, pero en este caso son irregulares, ya que las trabes sólo son cuatro, dos de menor tamaño, y en lo que corresponde a los muros no las hay, pero el espacio de todos modos se constituye hexagonalmente. Los arquitrabes llevan ahora el par de molduras en la parte superior cercanas al techo y se sostienen con un par de columnas, también octogonales y con los tres anillos moldurados a manera de capitel como las del vestíbulo, pero sin las decoraciones de las estrías en relieve en la parte baja.

Como nos podemos dar cuenta, el interior del edificio de la Escuela Margarita Maza de Juárez es una conjunción de formas geométricas, donde Zeferino Domínguez aprovecha el uso de los materiales modernos como son los arquitrabes en concreto para concertar polígonos irregulares hexagonales.

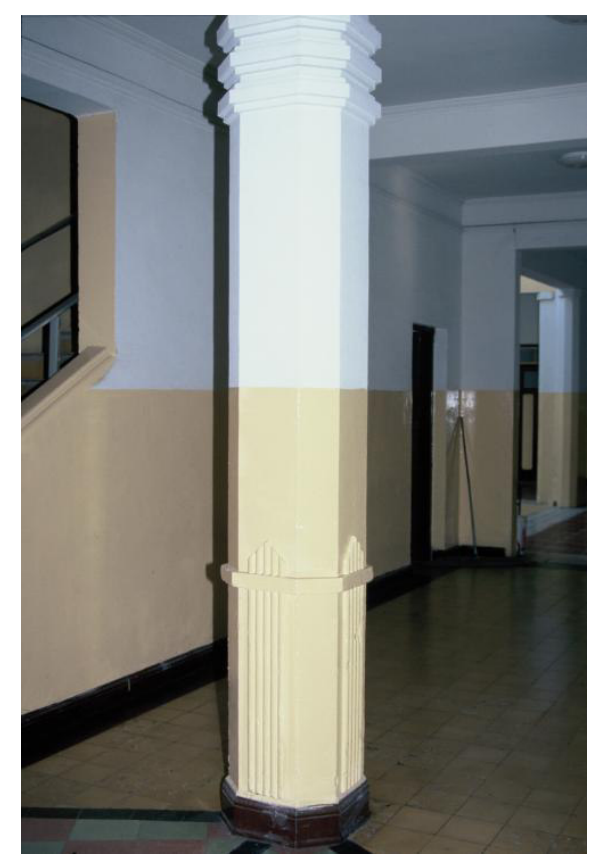

Columna octogonal en el pasillo interior derecho. En la parte baja las estrías y en la alta el capitel formado con anillos.

A pesar de haber sido construido en 1945, este edificio luce muchos elementos de Art Déco tipo Zigzag como vimos con los componentes geométricos por lo que comparte al mismo tiempo la Tendencia Geometrista, sin embargo a la vez también ostenta un Déco de 
la variante Streamline como es en la reja de entrada, en el remate de la fachada principal y en las trabes del interior. Un inmueble donde Zeferino Domínguez buscó amalgamar los aún vivientes ornatos del Art Déco, con la entrada del Funcionalismo. Una combinación de lenguajes arquitectónicos y estilísticos, pero integrados adecuadamente.

\section{e. Escuela Constituyentes de 1917}

En la zona sur de lo que es el centro de Saltillo y en uno de los barrios de origen tlaxcalteca, es donde se ubica la Escuela Constituyentes de 1917 en la calle Moctezuma s/n esquina con Luis Gutiérrez con orientación hacia el poniente.

Fue construida en 1945 bajo el mandato del general Benecio López Padilla, quien gobernó Coahuila de 1941 a 1945, distinguiéndose su periodo por la construcción de carreteras y de varios planteles educativos. Obra también de Zeferino Domínguez Villarreal, la planta del inmueble es en forma de "L". Debido a un desnivel del terreno por la topografía del lugar, Zeferino Domínguez primero tuvo que nivelar el suelo, para lo cual

distribuyó una plataforma realizada con concreto. El edificio es de dos plantas y los materiales utilizados son el concreto y ladrillo.

Si bien los elementos Art Déco son pocos, ya que el edificio más bien es una transición hacia los nuevos lenguajes modernos como el funcionalismo, además por la fecha en que fue levantado, vale la pena resalar sus componentes Déco de tipo Streamline.

Para acceder al edificio hay una escalinata que conduce a la entrada principal, la cual está remetida hacia adentro del nivel de los muros y protegida en la parte superior por una marquesina. El segundo piso tiene tres ventanas cuadradas y una pequeña marquesina y remata en la parte central para resaltar el geometrismo con un ábaco escalonado que funciona de base para la astabandera, elemento muy típico del Déco tanto del Zigzag como del Streamline.

De lado izquierdo adosado al cuerpo central, un gran cilindro con tres ventanales verticales está colocado hacia delante, con lo que se consigue el efecto de acoplamiento de poliedros, conformado por el cubo central y el cilindro, resaltando la geometría y el volumen. En la parte superior una doble moldura decora delicadamente a esta parte del edificio. Atrás de este cuerpo, yendo más atrás del nivel del cuerpo central, un prisma 
rectangular sobresale por la fachada norte que da a la calle Luis Gutiérrez, remarcando el ensamblaje de cuerpos poliédricos.

Del lado derecho de la entrada principal, sobresaliendo hacia el frente $\mathrm{y}$ hermanándose con el límite del cuerpo cilíndrico, un gran prisma rectangular colocado horizontalmente se adosa al conjunto; lleva una pequeña cornisa en el segundo nivel, como la del cuerpo central, con lo que la mínima decoración lineal se consigue con este efecto de geometrismo entre horizontales, verticales y curvas.

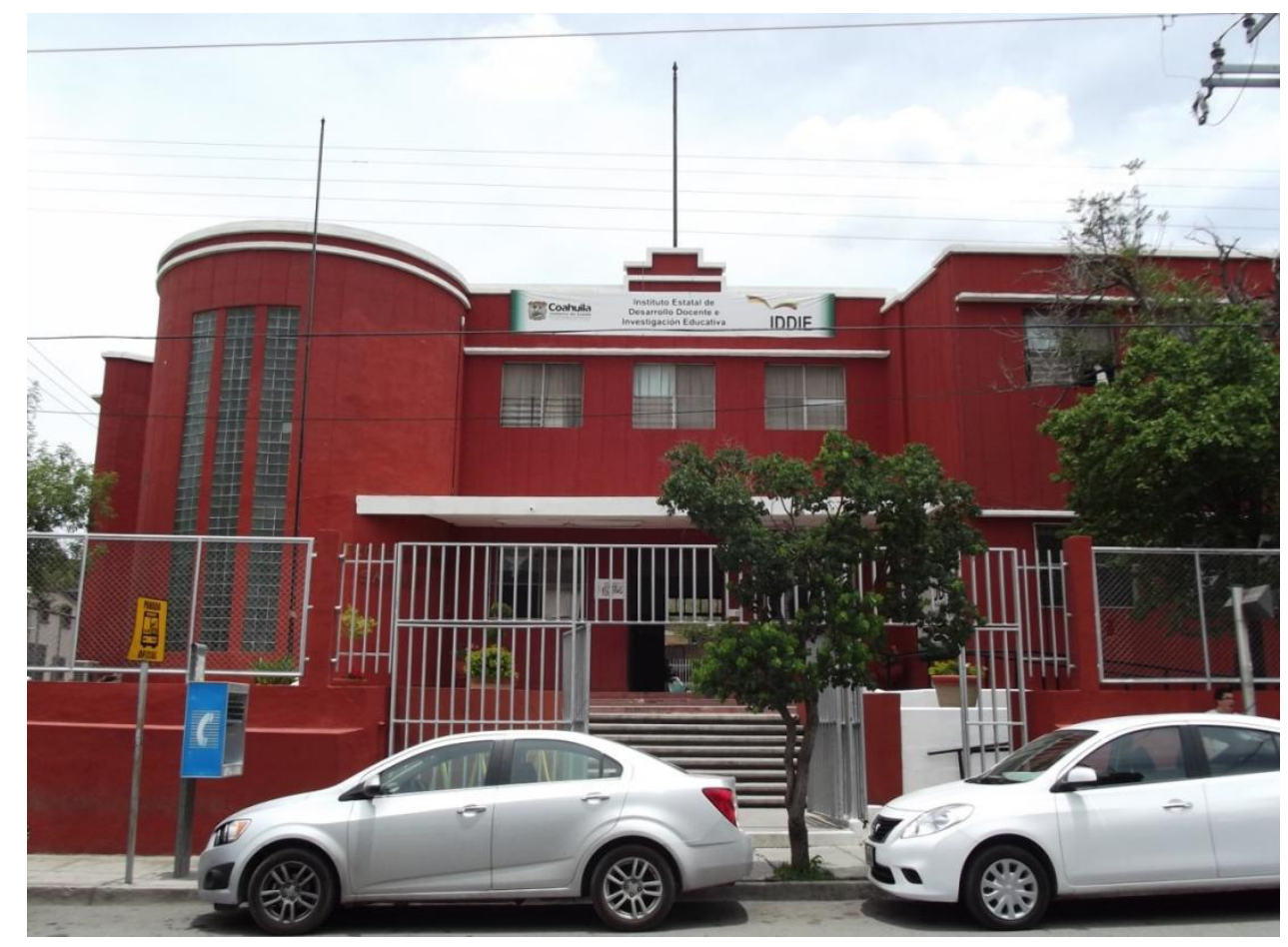

Vista frontal donde se aprecia el cuerpo cilíndrico y el prisma rectangular sobre la fachada norte. A la derecha del cuerpo central, el prisma rectangular horizontal con el muro que mira al norte rehundido en la parte central.

La Escuela Constituyentes de 1917 a pesar de tener pocos elementos decorativos, Zeferino Domínguez buscó integrar algún ornato ya dentro de una arquitectura moderna que tendía hacia la eliminación de los atavíos, como sucedía con las propuestas del Funcionalismo. Así púes, en el cuerpo derecho, en el muro que mira hacia el norte, el constructor rehúnde la parte central de la pared, como si fuera una de aquellas bandas que sobresalen en edificios Déco Zigzag, pero que ahora en sentido inverso la pared se recorta hacia dentro para dar la idea de movimiento y conducción hacia el geometrismo. 
Y si al inseparable el maridaje de los cuerpos poliédricos le aunamos la conexión que hay en la parte superior a través de la moldura que envuelve a todo el edificio, tenemos por resultado una construcción de tipo Déco Streamline, donde se desarrolla una semántica de lo mecánico de la mano de lo industrial por medio de los diseños arquitectónicos que a la vez son una abstracción de lo maquinaria interior de algún aparato electrodoméstico o de comunicación, o bien de un motor de transporte aéreo, marítimo o terrestre e inclusive el diseño de una edificación fabril con los influjos del Bauhaus o del Constructivismo soviético.
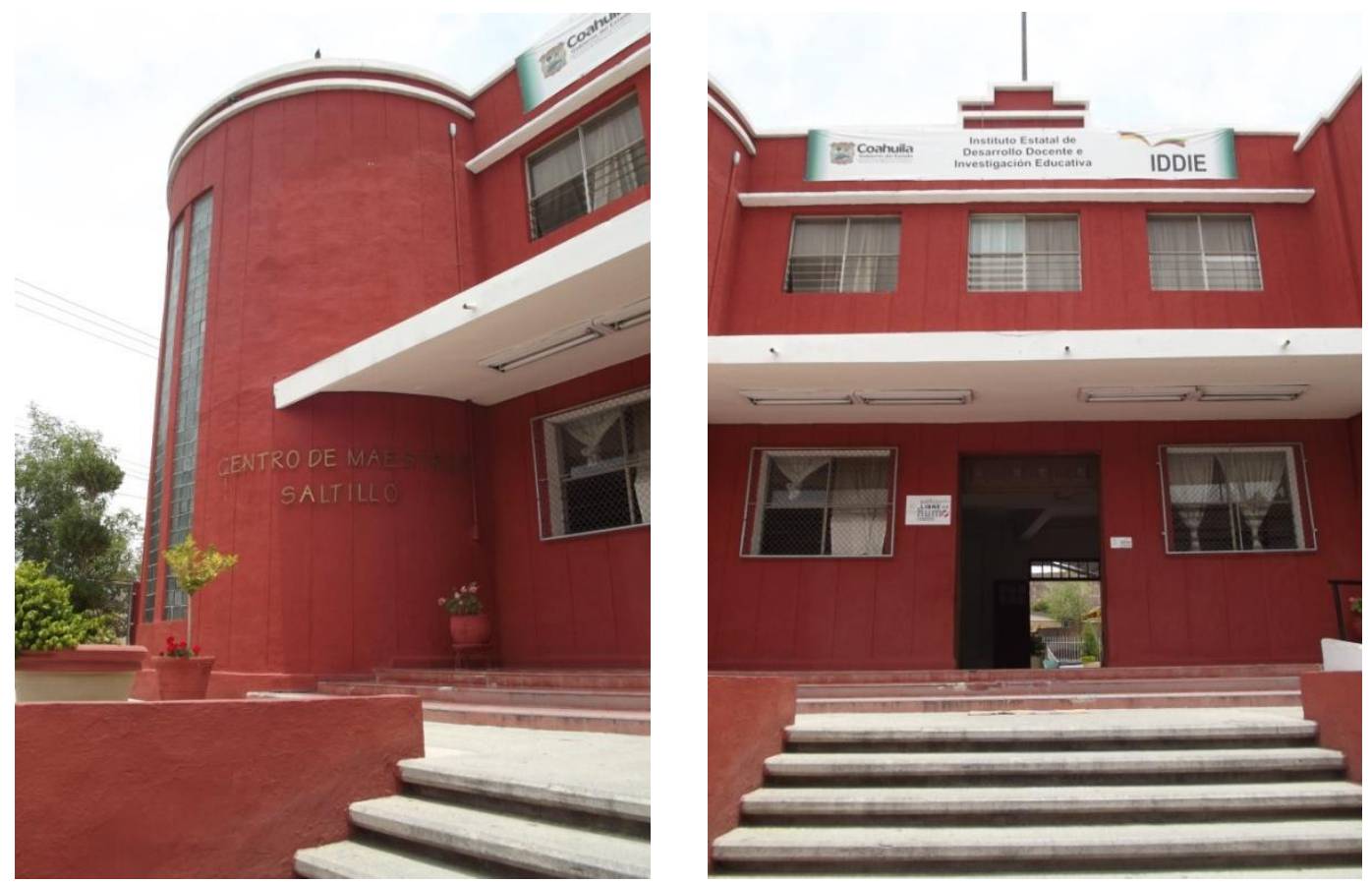

El cuerpo cilíndrico y el central de la escuela. Destacan como ornato la doble moldura, las cornisas,

En la entrada del vestíbulo, a mano derecha se encuentra la placa con la fecha de apertura, pero sólo aparece el año de 1946, que fue el año que inició labores cuando el gobernador López Padilla ya había dejado el cargo.

Ningún tipo de decoración se conserva en el interior. Lo que si nos remite al Art Déco Streamline es la escalera curva que conduce al segundo piso con los tres ventanales verticales de vidrio-block, los cuales ofrecen una buena iluminación; la curvatura interior de dicha escalera está resguardada por el cilindro exterior, por lo que si bien nos recuerda a 
los diseños de la Bauhaus, a la vez fueron utilizados en los años treinta y todavía cuarenta del siglo XX, como es el caso de muchas construcciones en México, dentro del lenguaje del Art Déco.

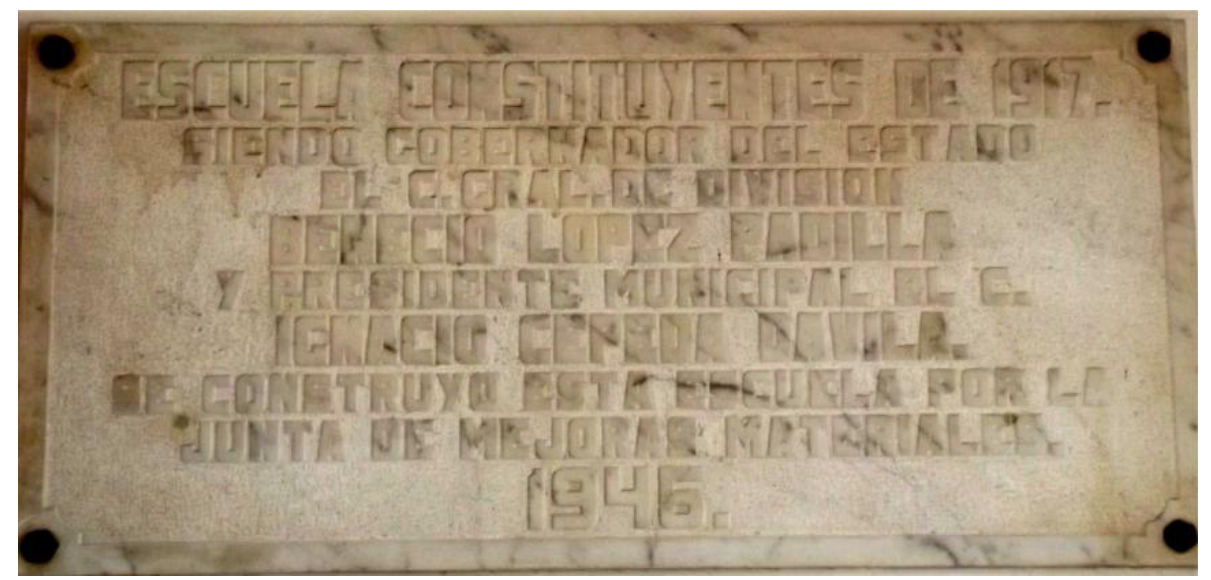

Placa en el vestíbulo con la fecha de 1946.

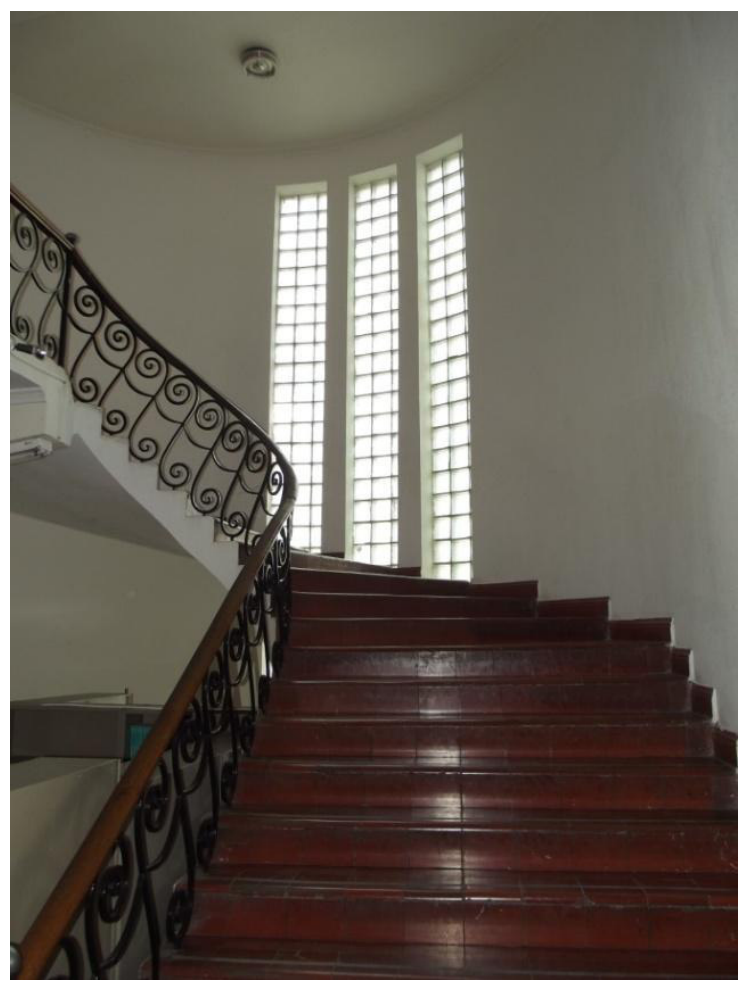

Escalera curva con los tres ventanales de tipo Streamline de donde se obtiene una buena iluminación. 
El inmueble que se encuentra en buen estado de conservación, actualmente aloja al Instituto Estatal de Desarrollo Docente e Investigación Educativa, dejando su antigua vocación de escuela de enseñanza primaria y secundaria. A pesar de tener pocos elementos distintivos del Art Déco, por el cerramiento de los planos es un buen ejemplo de la Tendencias Plasticista y sobre todo de las construcciones que abrazaron el Déco Streamline como una propuesta de seguir modernizando al país y que conducía hacia la internacionalización, a través de los diseños aerodinámicos e industriales, de los cuales México aún estaba bastante distante, pero que al forjarlos en las construcciones de diversa índole, se iba construyendo el ideal del "México Moderno" postrevolucionario. 


\subsubsection{ARQUITECTURA DEL OCIO}

\section{a. Cinema Palacio}

El Cinema Palacio se ubica en el corazón de la ciudad, en la calle Guadalupe Victoria esquina con Acuña, cuya fachada principal en ochavo tiene una orientación hacia el noroeste.

Fue mandado a construir por su fundador, el señor Gabriel Ochoa Aguirre y se inauguró el 1 de diciembre de 1941, estando presente en su primer día de funciones el gobernador, General Benecio López Padilla. Es de planta rectangular, sin embargo el frente se recorta en ochavo y con un cuarto de círculo. Sobre el autor un solo dato que dice: "Pero Gabriel Ochoa fue un hombre visionario y mandó construir, con un arquitecto regiomontano, este clásico cine que todavía sigue en pie". ${ }^{233} \mathrm{El}$ edificio tiene capacidad para 1.600 espectadores, distribuidas las butacas en dos plantas, en la luneta baja y la luneta alta.

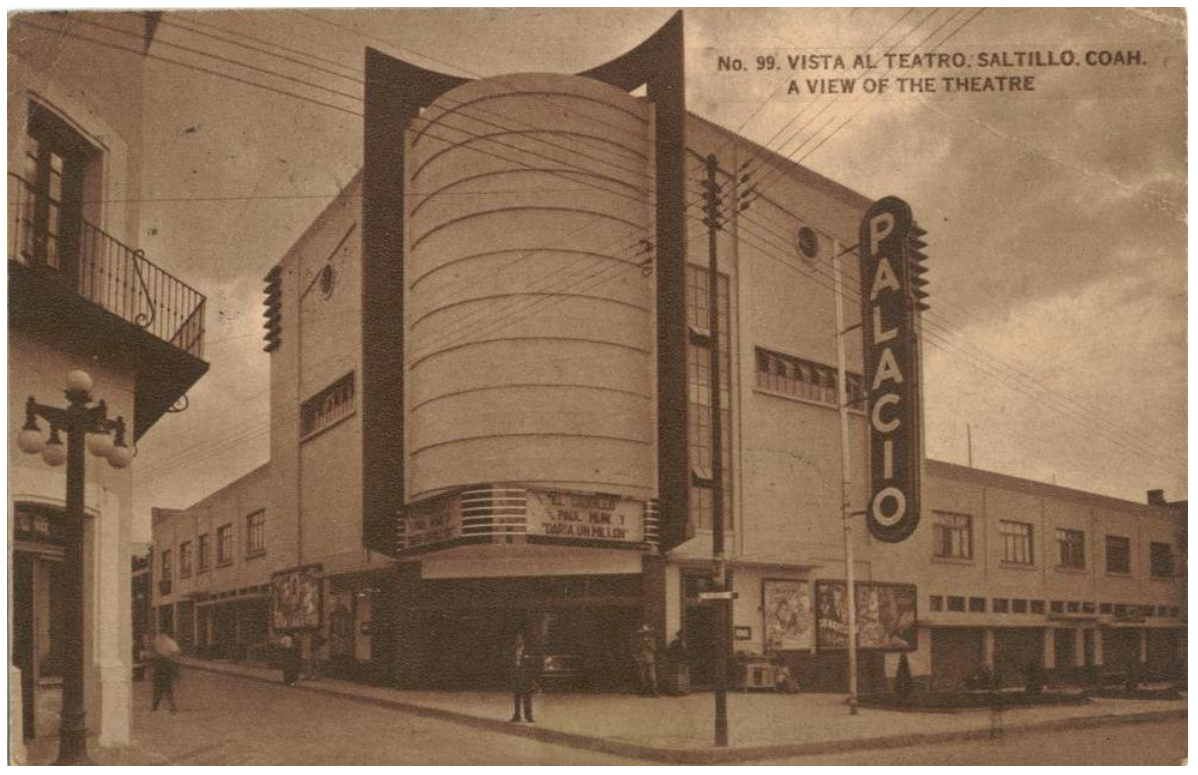

Cinema Palacio en la década de $1960 .^{234}$

\footnotetext{
${ }^{233}$ Eugenia Flores Soria, "Una historia viviente", Zócalo Saltillo, Saltillo, Coahuila, jueves 25 de julio de 2013, http://www.zocalo.com.mx/seccion/articulo/una-historia-viviente-1374704196

En Entrevista el día miércoles 13 de noviembre de 2013 con el señor Augusto César Morelos Ochoa, nieto del fundador y actual propietario, tampoco tenía el dato del arquitecto constructor.

${ }^{234}$ http://www.skyscrapercity.com/showthread.php?t=873612\&page=8
} 
El exterior llama la atención por su cerramiento de los muros, pues aparenta ser una gran mole de concreto, descansando sobre un pequeño pedestal. La entrada al vestíbulo es pequeña en relación con el resto del edifico; se compone de cuatro puertas de doble hoja de madera con vidrio. Encima está actualmente el letrero que no formaba parte del diseño original, como se puede ver en la foto antigua, pues la cartelera se anunciaba en placas blancas traslúcidas iluminadas por luces interiores, como era la usanza de esos tiempos y se disponían mirando hacia las calles Victoria y Acuña. Jambas con base forradas con granito negro enmarcan el vano de la entrada. Unas charolas en latón de donde salía proyectada la luz hacia arriba, aún se conservan a la mitad de las jambas.

Pon encima de la entrada se proyecta una marquesina en forma triangular, redondeada en la punta. En cada lado de las calles Acuña así como Victoria, hay unas puertas rectangulares con el perfil forrado de granito gris, material que también lleva el rodapié; en la parte superior de las puertas igualmente llevan marquesinas, pero estriadas, de forma rectangular y redondeadas en las esquinas. El conjunto de las tres marquesinas proporcionan una directriz de diseño Déco Streamline.

En la fachada principal por arriba del letrero, un cuarto de cilindro con diez bandas llama la atención por su fuerza expresiva. Es inmediata su relación con lo industrial, pues pareciera un émbolo o un pistón mecánico, elementos que se parodiaban en las construcciones Art Déco de la variante Streamline. Y para vigorizar aún más la composición de la fachada, una banda inserta perpendicularmente, envuelve al cuerpo cilíndrico. En el arranque a la altura de las marquesinas la banda se recorta angularmente y en la parte superior se curvea de manera cóncava. Esta intersección entre la banda y el cilindro es un ejercicio de geometría descriptiva, con la conjunción de la línea recta y curva, determinantes de las estructuras Art Déco, en este caso del tipo Streamline.

Por las calles Victoria y Acuña, en las fachadas norte y poniente, lo que corresponde al segundo cuerpo que está por arriba del nivel de las marquesinas, un vano rectangular encuadrado por una moldura plana y pequeñas ventanas cuadradas, da luz hacia el interior de la luneta alta. Entre dos bandas, una que arranca al nivel de la marquesina y la otra que inicia desde el rodapié, enmarcan a un vano rectangular de pequeño tamaño en posición horizontal, también remarcado por una moldura, el cual está situado a la mitad de la pared y a tres cuartas partes de la altura del otro vano; en el ángulo inferior, derecho, para la 
fachada de la calle Victoria, e izquierdo para la calle Acuña, está colocada una pequeña ventana cuadrada con repisón. Para continuar con los elementos geométricos en la parte superior y al centro, un óculo moldurado remata las fachadas. Es muy importante resaltar cómo el arquitecto insertó dos bandas que confinan estas fachadas: una horizontal en la parte baja inmediatamente arriba de la marquesina y la otra diagonal en el segmento superior. Ésta última corta con el eje horizontal de toda la pared.

Finalmente, el muro se extiende más allá de la segunda banda vertical, para rematar con seis molduras angulares que parecieran un radiador o unas aletas, lo que denota su estilo Déco Streamline.

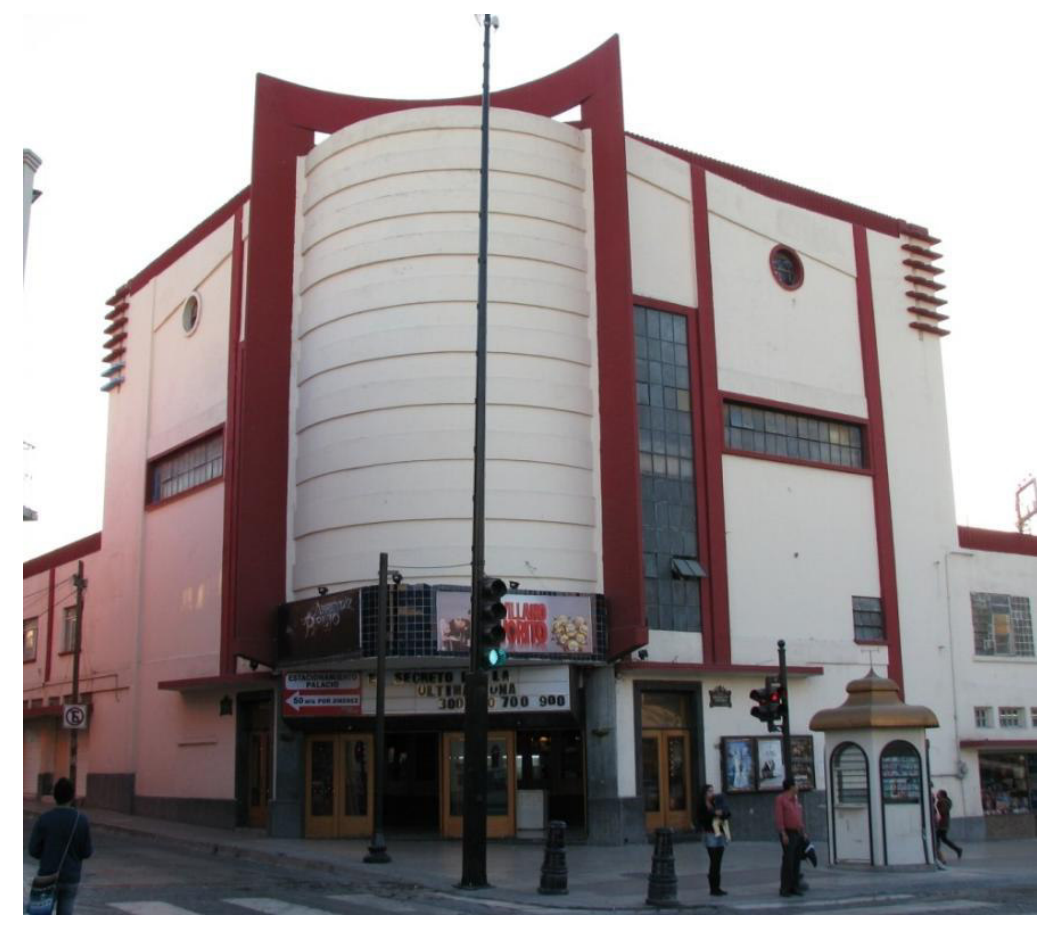

Vista exterior.

Toda la semántica manifestada en el exterior de este inmueble es una exhibición de algunos lenguajes de vanguardia que convergieron en el Art Déco, tales como De Stijl, Bauhaus o el Constructivismo y que le trasmiten a través de los componentes geométricos su carácter Déco Streamline, ya que el cilindro frontal pareciera flotar, mientras los resguarda la moldura que lo circunda; las ventanas como si fueran unas escotillas de barco o aeroplano más las aletas de los extremos superiores, le dan una figuración industrial 
aerodinámica a toda la fachada, por lo que el Cinema Palacio en el exterior es un claro ejemplo de Art Déco Streamline.

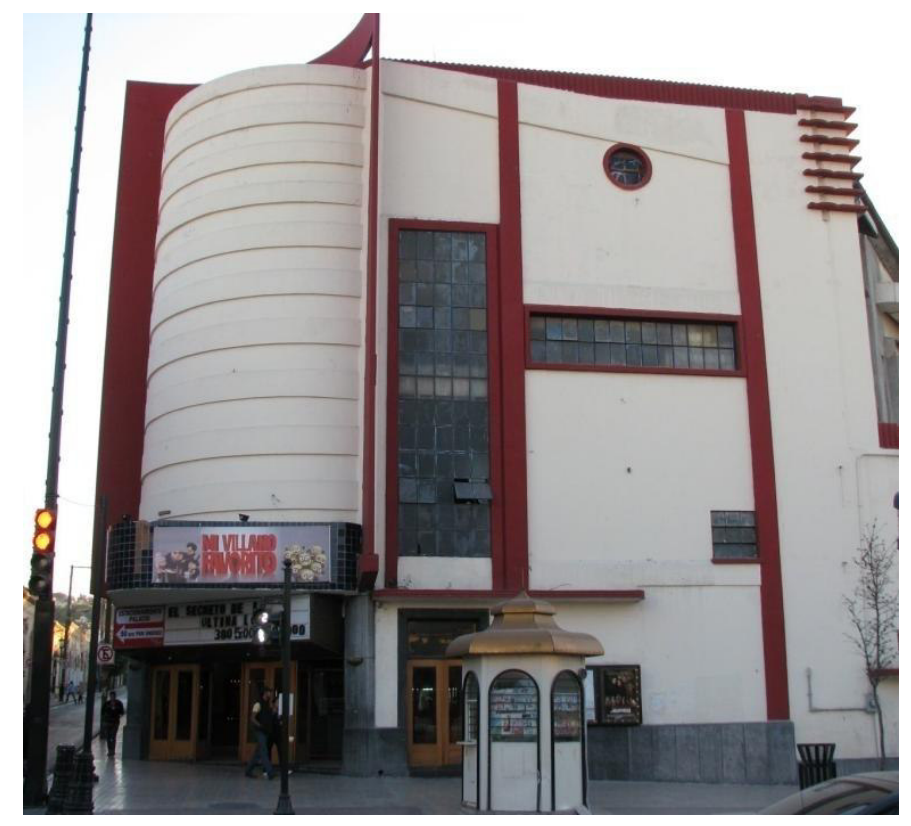

Fachada lateral poniente por la calle Victoria.

Un dato anecdótico sumamente atrayente es que en su segunda estancia por Saltillo en 1946, el artista norteamericano Edward Hopper (1882-1967) pintó algunos lugares de esta ciudad, entre ellas al Cinema Palacio. La obra es una acuarela titulada "El Palacio", del año 1946, y se conserva en el Whitney Museum of American Art de Nueva York. La vista es desde la azotea del Hotel Arizpe Sainz y se aprecia la parte superior del cine con la estructura que lo circunda pintada de color verde, así como el letrero que daba a la calle Victoria. Al fondo se ven los cerros, el cielo azul con nubes alargadas y un pasaje arbolado que seguramente es el referente a la alameda. En aquel entonces, el más monumental y moderno cine de la ciudad, fue un contraste para el artista entre las casas antiguas y la nueva sala cinematográfica. Contrariamente a lo que se suponía, Hopper molesto y desilusionado con el carácter de la gente y el clima intenso del verano, abandona la ciudad. Obvio, un norteamericano de agreste carácter en una pequeña ciudad, más con sabor a pueblo donde escaseaban las necesidades de una pareja acostumbrada a las usanzas del “American Way of Live”, aunque renegaran hipotéticamente de eso, retornan a su país natal. 
Esta imagen nos presenta cómo eran los colores del cine: lo que hoy son rojos, entonces eran verdes, como la grande banda que rodea al cilindro, o las molduras resaltadas de las fachadas laterales. Taciturno, solitario y siempre acompañado de su inseparable esposa Josephine, Hopper, quien visitó tres veces Saltillo, inmortalizó al Palacio, como, se le conoce popularmente al cine hasta la fecha.

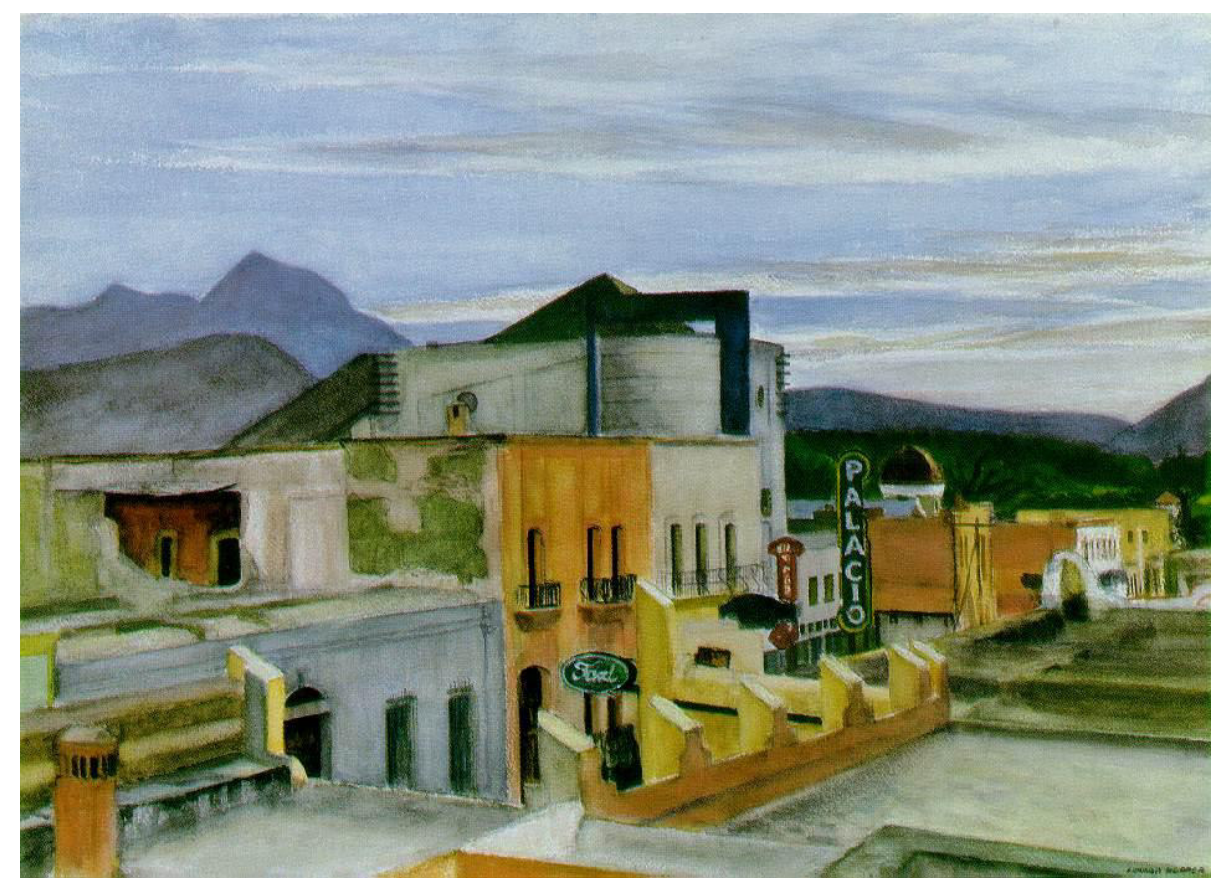

Palacio, 1946.

Edward Hopper.

Whitney Museum of American Art, Nueva York. ${ }^{235}$

En las cuatro puertas de doble hoja de la entrada que están confeccionadas con marco de madera y vidrio, conservan en su mayoría unas decoraciones Déco Zigzag realizadas con cinta adhesiva para vidrio, que con el paso del tiempo se han borrado algunas partes. Los ornatos consisten, de arriba para abajo, en tres escudos en forma de flor de lis, para luego continuar con unos recuadros acomodados en líneas quebradas unidas en forma de "M" invertida, que por las perspectivas juegan ópticamente con el espectador; después dos líneas horizontales, nuevamente escudos en forma de flor de lis, pero acomodados de manera adversa en pares superpuestos, para culminar los atavíos con un

\footnotetext{
${ }^{235}$ WikiArt, "Edward Hopper. El Palacio", www.wikiart.org/en/edward-hopper/el-palacio
} 
zigzag compuesto por tres líneas y finalmente con tres círculos recortados. En las hojas cuatro y cinco de las puertas, se alcanza a percibir letreros que dicen "Cinema Teatro Palacio". Estas puertas llevan la característica decoración del periodo Déco Zigzag, aunque ya esté realizado en los años cuarenta, que infortunadamente algunos tramos se están cayendo por la falta de mantenimiento.

Por las fachadas laterales oriente y poniente, correspondientes a las calles Victoria y Acuña, también hay unas puertas de hojas dobles con la misma decoración descrita.

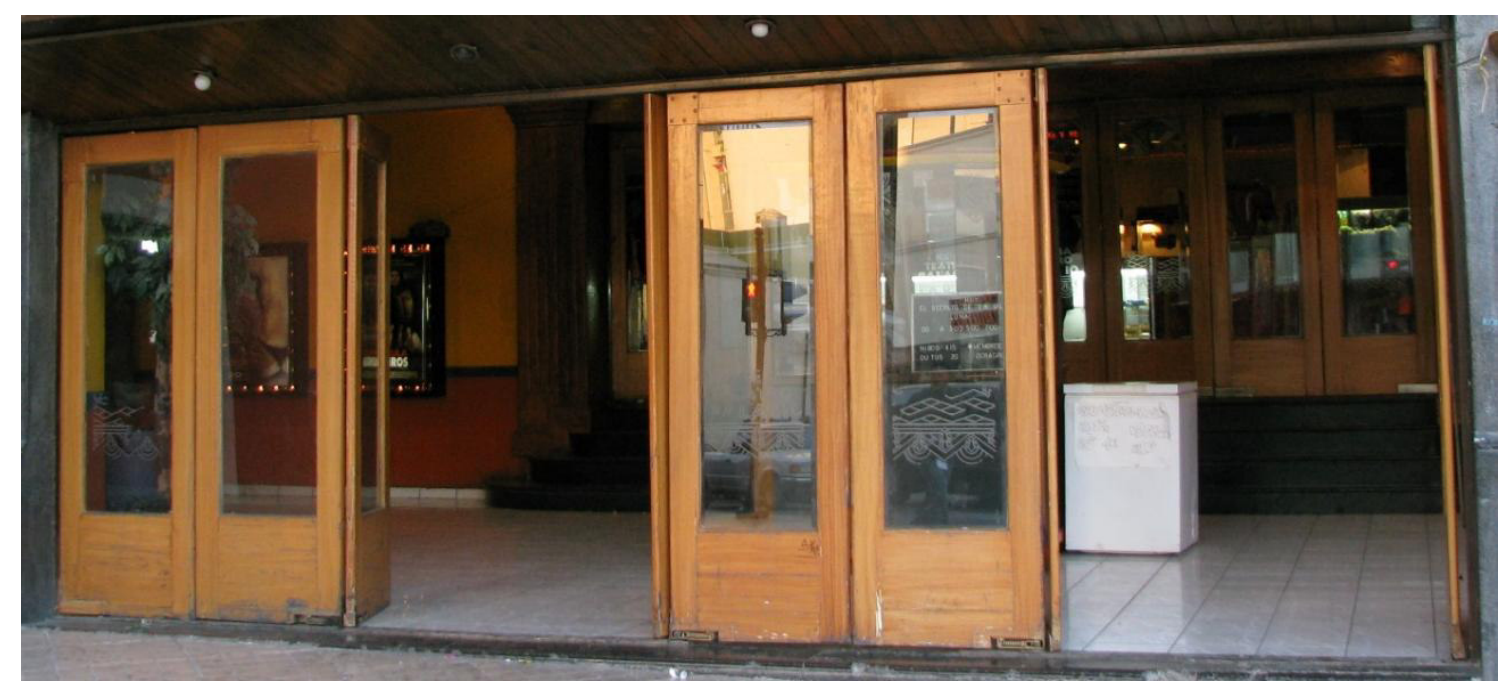

Puertas del acceso principal.

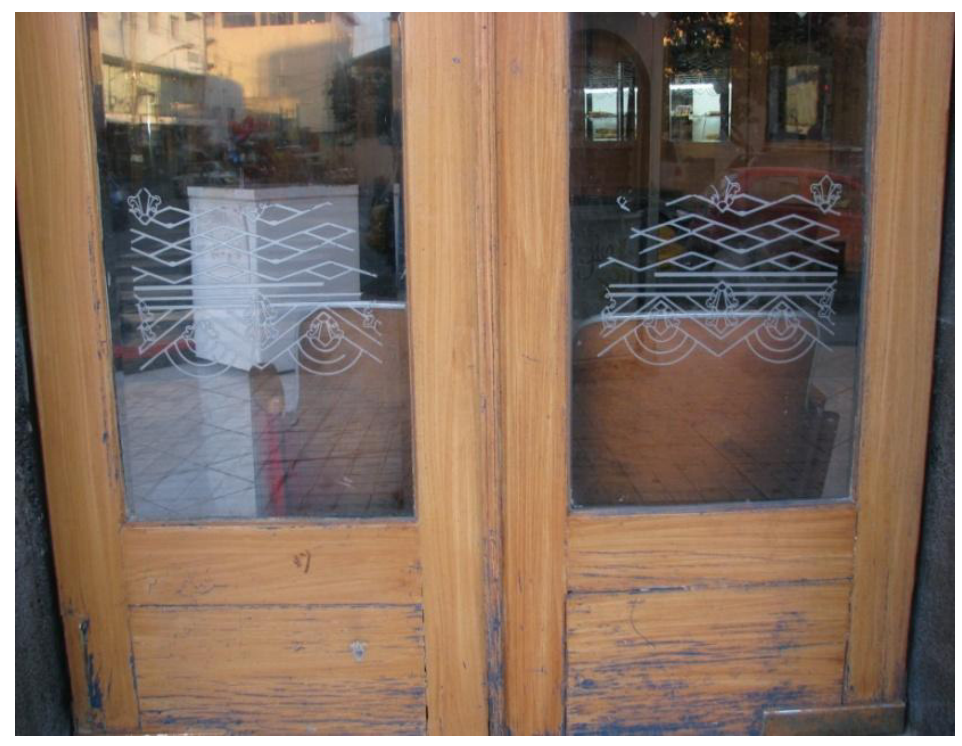

Puertas de la fachada poniente con detalles de ornatos Zigzag. 
El cine cuenta con un nártex en el cual hay una amplia escalera de tres peldaños con los extremos curveados; están forrados de granito negro, material muy utilizado en los años del desarrollo del Art Déco, y dan paso al lobby, el cual también todavía luce losetas de granito negro. De la misma manera que la puerta principal, cuatro puertas de doble hoja ostentan idéntica decoración con los diseños zigzag y los semicírculos concéntricos, la cual gracias a que se encuentran en la parte interior se han conservado de mejor modo, lo mismo que los letreros de "Cinema Teatro Palacio".

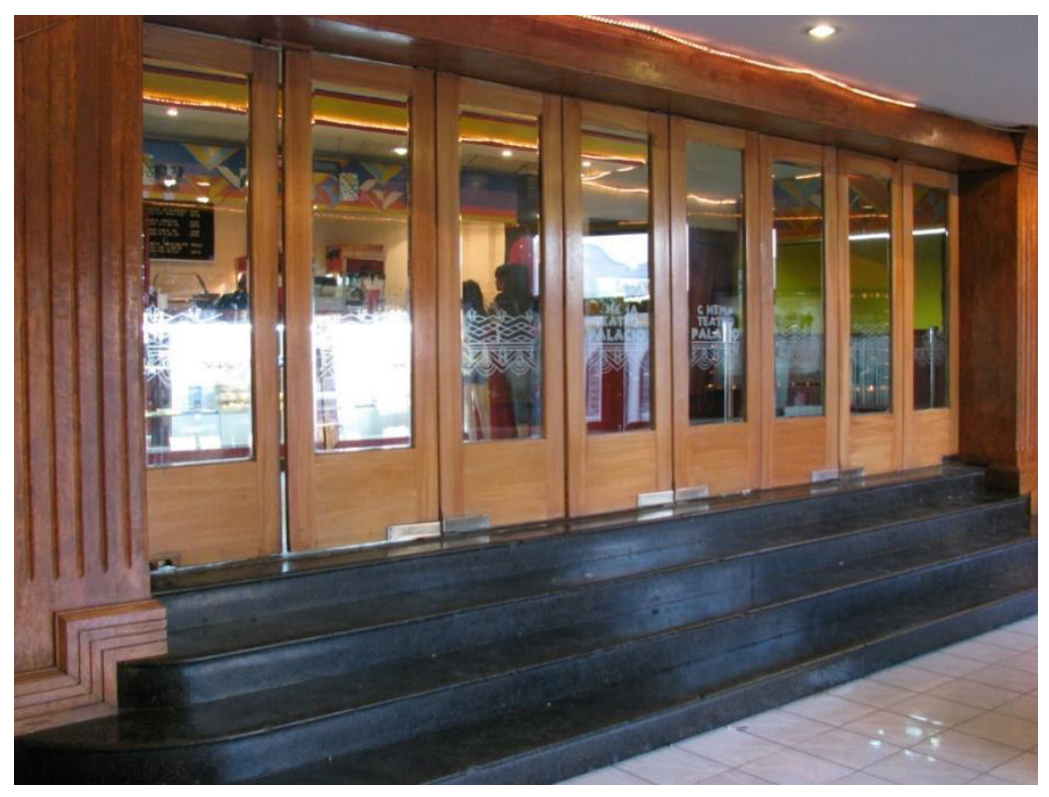

Puerta de entrada al "lobby".

En el interior no conserva ningún atuendo Art Déco, aunque en la dulcería del lobby le pintaron unas decoraciones en vivos colores con adornos tipo zigzag, pero que no son originales.

Rentado por muchos años y nuevamente manejado por sus propietarios, el Cinema Palacio es un extraordinario ejemplo de la modernidad arquitectónica que se gestó en los años cuarenta del siglo XX y que gracias a su buena conservación sigue exhibiendo su diseño Art Déco Streamline y una combinación de las Tendencias Geometrista y Plasticista. 


\subsubsection{ARQUITECTURA COMERCIAL}

\section{a. Casa Joch}

La Casa Joch es un pequeño comercio y departamentos habitacionales que se ubica en el entrecruce de las calles Juan Aldama y Zaragoza en el centro de la ciudad. Su fachada principal está en ochavo orientada hacia el sureste. Tiene dos fachadas: sobre la calle Aldama con orientación al sur y la de la calle Zaragoza con visa hacia el oriente.

Zeferino Domínguez Villarreal fue el autor de este comercio, sin embargo no se tiene la fecha exacta de su construcción, pero por los estilos arquitectónicos pudo haberse construido en la segunda mitad de la década de 1940. Es de planta rectangular y de dos niveles. Está construida con concreto y aplanados de cemento. En la planta baja donde están instalados comercios no se conserva nada de lo original y sólo es en el segundo piso en la fachada principal donde aún sobreviven elementos compositivos tipo Art Déco.

La fachada sur sobre la calle Aldama es más grande, abarcando en la planta baja dos comercios más la puerta de acceso hacia los departamentos del segundo nivel y cuatro ventanales en la planta alta, mientras la fachada oriente en la calle Zaragoza sólo incluye un comercio en la planta baja y dos ventanales en el piso superior.

Por arriba de una marquesina que circunda el inmueble, en la fachada principal y en el segundo nivel, unas jambas encuadran al muro, las cuales están formadas con cinco placas remedando el almohadillado, que se extienden hacia las fachadas laterales. Tienen un color verde jaspeado imitando al mármol, pero están hechas de cemento aplanado; las vetas son de color blanco y rosa y aunque con un trazo lineal quebradizo, están acomodadas a manera de zigzag. El remate es escalonado, levemente dispuesto hacia atrás y con las vetas en posición oblicua hacia la izquierda y la derecha, respectivamente de cada lado, parodiando caídas de rayos, motivo decorativo del Déco Zigzag relacionado con la fuerza intensa de la energía eléctrica; al centro del remate se empotra una placa rectangular trabajada en el mismo material, donde están colocadas dos molduras curveadas en color rosa que envuelven el remate, característica distintiva del Art Déco de la variante Zigzag. Donde descansa la placa, lo que equivale a la trabe, una parte está rehundida y otra 
resaltada, dando por resultado un juego de las superficies, transponiendo la visión de un muro plano, por uno de proyección cinética.

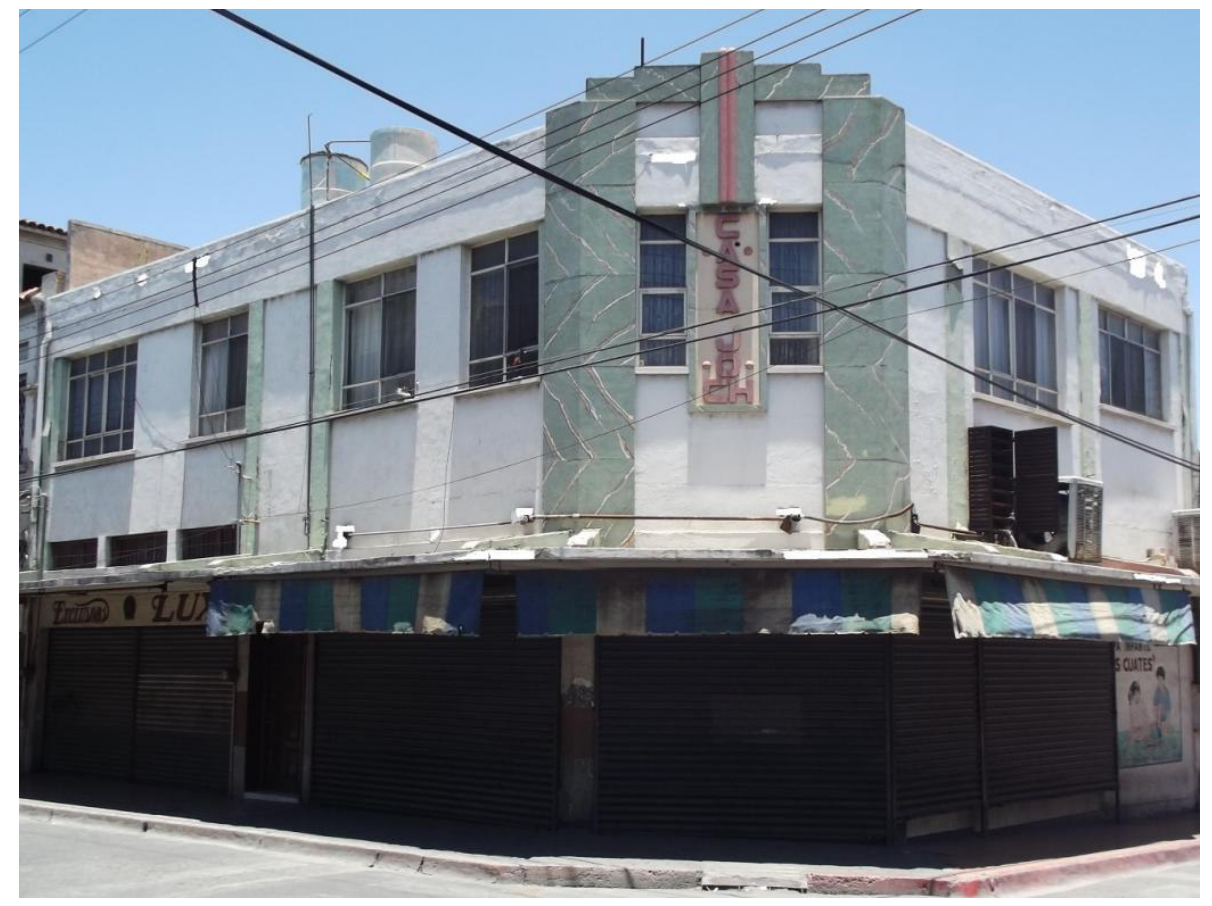

Vista general.

Debajo de la placa con el par de molduras y posicionada hacia atrás está el nombre del comercio enmarcado por el mismo ingrediente de cemento, imitación de mármol verde con las vetas rosas y blancas. Sobre fondo color crema resaltan las grafías manufacturadas con granito rosa, material que en los inmuebles Art Déco es utilizado en pisos, escaleras, lambrines, rodapiés, arcos, pero raramente en letreros, por lo tanto es un caso particular, idea insólita de Zeferino Domínguez.

La posición de las letras es en vertical, sin embargo en la palabra Joch, la "C" y la “H” están en horizontal, otorgándole una originalidad más al letrero. Por ornato lleva dos botones a cada lado de la letra "A" y de la letra "O".

La Casa Joch, que como podemos observar en las imágenes, se encuentra en mal estado de conservación, sobreviviendo ante la embestida de comercios y el tráfico vehicular. Debido a que su constructor fue el genial Zeferino Domínguez Villarreal y que está registrada aunque sea con un corto texto en el libro de Jesús Ramírez Rodríguez, aunado a que su ubicación es en el centro de la ciudad donde se han rescatado edificios 
históricos y que conserva los componentes de Art Déco Zigzag y de la Tendencia Decorativista, esperamos que no vaya a ser derrumbada o transformada totalmente.

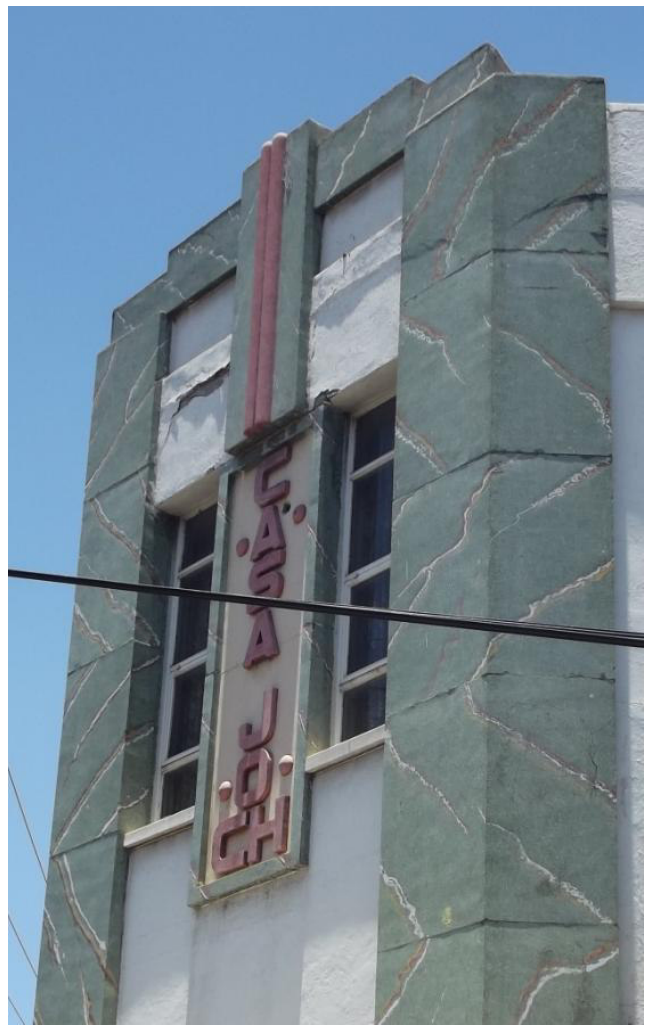

Detalle del remate escalonado, la placa con las molduras y el letrero. 


\subsubsection{ARQUITECTURA RELIGIOSA}

\section{a. Seminario Diocesano del Sagrado Corazón}

El Seminario Diocesano del Sagrado Corazón se encuentra en la calzada Antonio Narro 1450, en la zona sur del centro de la ciudad, con orientación al norte.

Sus orígenes están vinculados a Monseñor Jesús María Echavarría y Aguirre (18581954), quien desde que fue nombrado Obispo de la Diócesis de Saltillo soñaba con tener un seminario propio. Después de los difíciles años de la Revolución, de la Guerra Cristera y de la persecución religiosa en la década de los años treinta del siglo pasado, en 1938 se colocó la primera piedra del futuro seminario, recibiendo la ayuda del Obispo coadjutor Monseñor Luis Guízar Barragán (1895-1981), en un terreno hacia el sur de la ciudad y en lo que entonces eran las afueras del tejido urbano. En 1942 cuando se planeaba cómo podría ser el edificio, los Obispos Guízar y Echavarría dialogan sobre dónde debería estar la capilla, para lo cual acordaron que debía quedar en el centro del edificio en un patio cuadrado a manera de claustro. Para las obras se invitó a Zeferino Domínguez, quien siguió las indicaciones de los prelados, aunque la construcción tardó muchos años y el seminario fue inaugurado el 7 de febrero de 1957, sin que Monseñor Echavarría viera su sueño realizado.

La planta es un cuadrado y tiene dos pisos. En la parte baja están las oficinas, comedor, cocina y salones. En el segundo nivel los cuartos y baños. La capilla está situada en el centro del patio con una orientación de norte a sur. Para la construcción se utilizaron el concreto armado y el ladrillo, más el granito de la capilla, material típicamente de uso en el Art Déco. Debido a que las obras se iniciaron en 1943 y fueron interrumpidas en varias ocasiones, es la razón por la que el seminario tiene elementos Art Déco, pues en sí el edificio lleva un lenguaje funcionalista, además de haber sido retocado en varias ocasiones, por lo que perdió su composición original.

El inmueble se encuentra separado de la calzada Antonio Narro por medio de la calle Lic. Miguel Cárdenas que conduce hacia la entrada del estacionamiento. Está metido más de cincuenta metros, con el fin de lograr un ambiente de recogimiento y de asilamiento del ruido citadino, aunque con la expansión de la ciudad ya quedó envuelto por la mancha urbana. 
De los elemento Art Déco que posee el edificio está la fachada principal, aunque en sí toda es de una sencillez de estilo funcionalista, pero en la entrada donde se abre un pórtico y un balcón sostenido por pilastras cuadradas forradas con ladrillo, en el remate superior hay dos aleros, el de abajo más grande que el de arriba, los cuales están unidos por pequeños cilindros, denotando elementos del Déco Streamline, por su sentido aerodinámico.

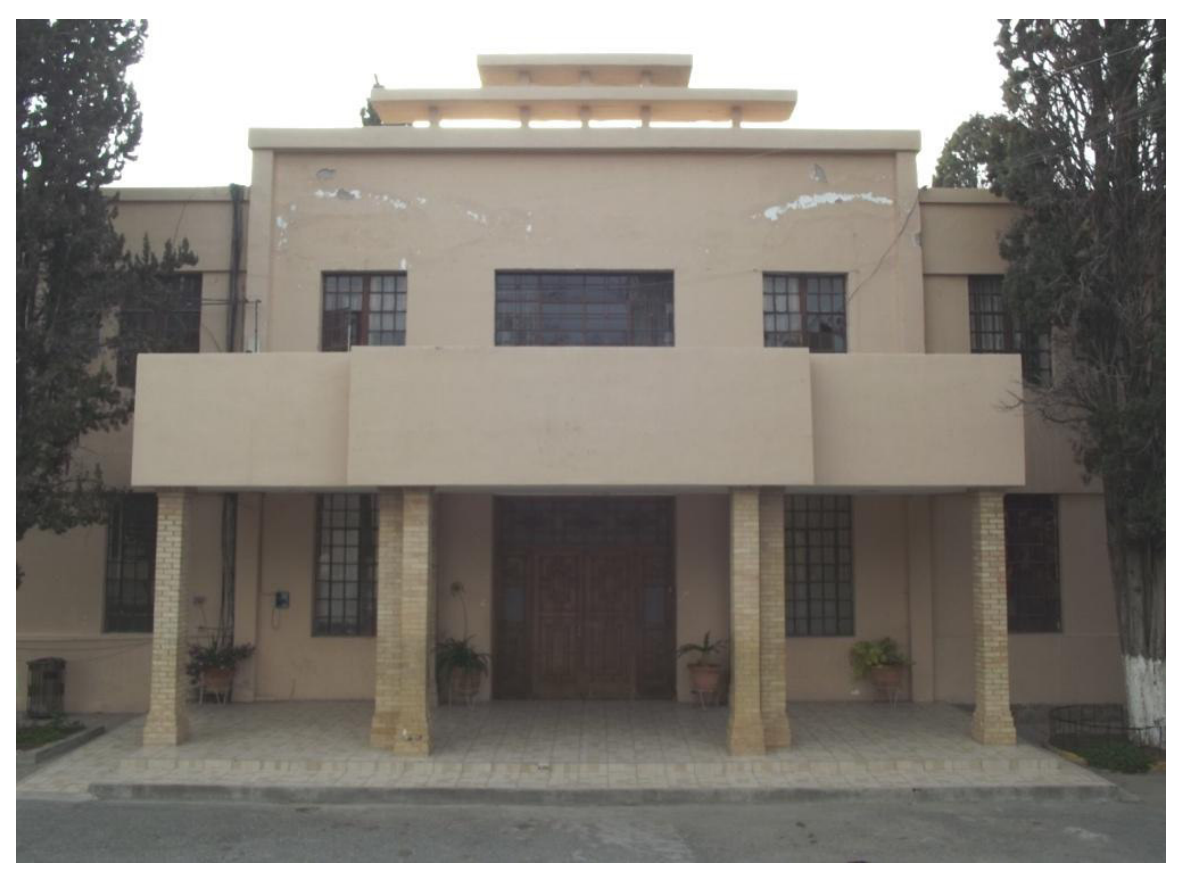

Fachada principal.

En el interior, un patio cuadrado hace las veces de claustro con corredores en ambos pisos ya acusan el estilo funcionalista, pero de la mano con el regionalismo de la arquitectura vernácula de la zona, al utilizar el ladrillo como material decorativo. En la intersección de las cuatro esquinas y en el centro de los cuerpos oriente, poniente y sur del segundo piso, los remates son de forma escalonada, estando forrados con ladrillos que armonizan con las pilastras de capitel dórico revestidas del mismo material que se encuentran en los dos pisos. Dichos remates son de los utilizados desde la época del Art Déco Zigzag y que a la vez servían de asta banderas, que en este caso en el espacio que se forma a manera de tímpano en los muros oriente, poniente y sur fueron colocados unos escudos de forma poligonal irregular de seis lados que exponen motivos religiosos. 
Cabe aclarar que los pretiles del segundo piso también fueron recubiertos con ladrillos en forma de petatillo durante unas reparaciones en la década de los años setenta del pasado siglo.

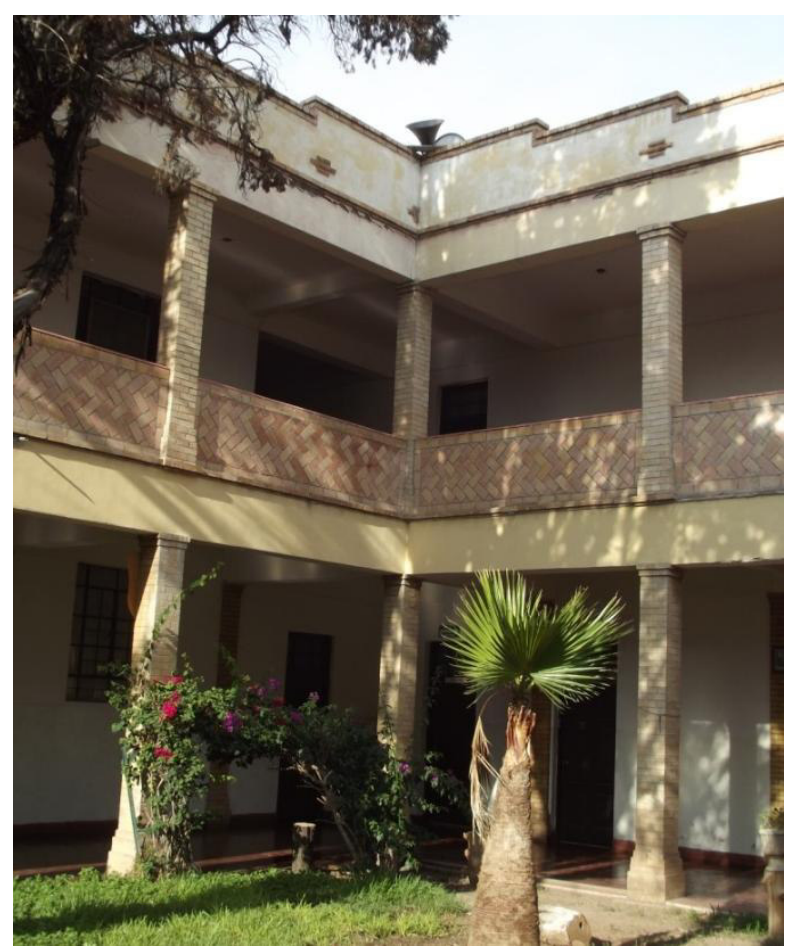

Remate escalonado en la intersección de los pasillos.

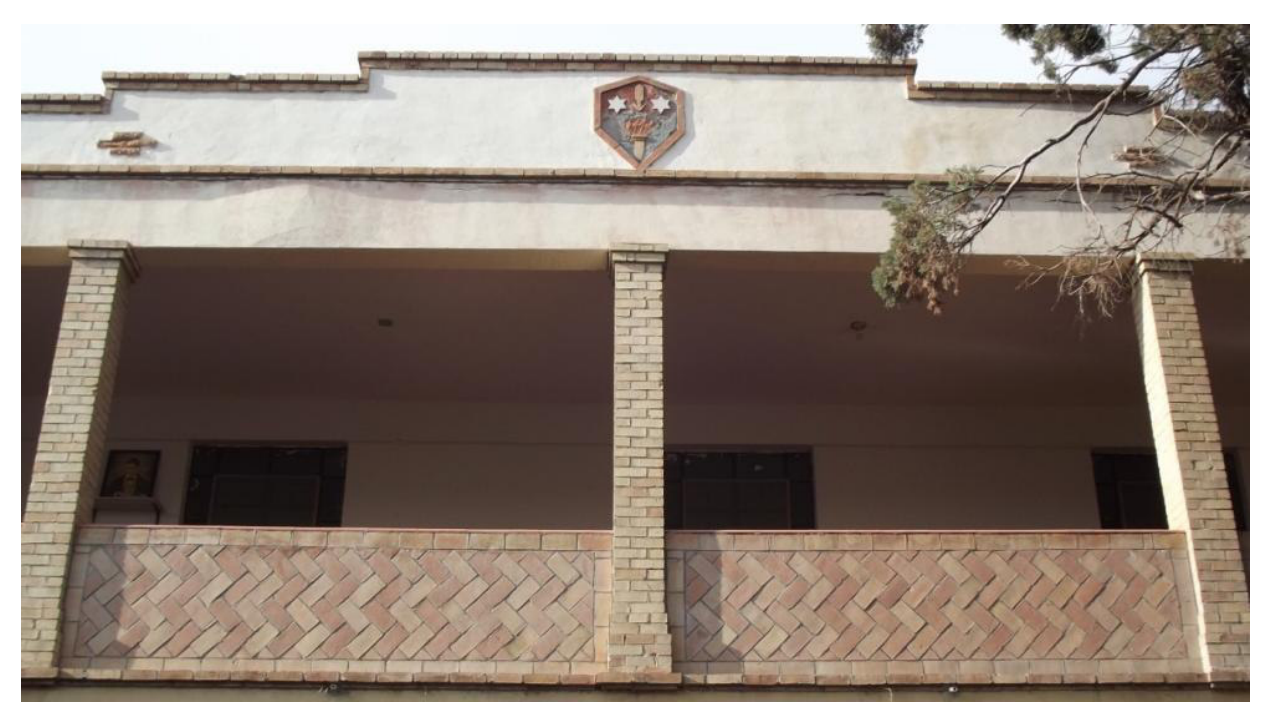

Remate escalonado en el muro poniente. 
Los tres escudos tienen un diseño en base a una composición poliédrica de seis lados, donde libremente se acomodan los motivos iconográficos con su contenido teológico. Son de un recalcado geometrismo, los cuales denotan todavía las directrices que Zeferino Domínguez utilizaba en base a las variantes del Art Déco Zigzag y Streamline, en plena invasión de la corriente funcionalista.

En el muro oriente el escudo lleva del lado izquierdo al Sagrado Corazón de Jesús con la corona de espinas y cuatro llamas sobre fondo dorado, pues es a quien está dedicado el seminario, simbolizando el color la divinidad de Dios, que en este caso es la del Hijo; al centro una espiga de trigo en alusión tanto al pan como al cuerpo de Cristo consagrado; en seguida del lado derecho con base en rojo, color que refiere a la sangre de los mártires, una estrella blanca de seis picos como símbolo de la letanía lauretana “Stella Maris”, estrella de la mañana para referirse a la Virgen María. Abajo, la paloma del Espíritu Santo sobre fondo azul, el cual es el color del cielo. ${ }^{236}$

Los motivos están confeccionados con formas acentuadamente geométricas: en el caso del corazón las cuatro llamas están bastante rígidas, un fuego más industrial que natural, como se representa en los diseños Art Déco; el trigo lleva dos hojas en la parte de abajo a manera de triángulos escalenos, mientras que las espigas son representadas con ligeras líneas oblicuas y la estrella de seis picos se forma con dos triángulos equiláteros.

Pero sobre todo es la paloma la que más llama la atención, por su diseño y por estar realizada con piezas de ladrillo: la cabeza con un triángulo mayor y uno más pequeño para la oreja, las alas con líneas horizontales escalonadas de arriba hacia abajo, el cuerpo es un rombo que en la parte superior se incrusta un triángulo y en la inferior un cuadrado; las patas son unos triángulos con una leve incisión vertical en el centro y la cola con dos triángulos escalenos y en rehundido un rectángulo con terminación en punta de flecha.

Los componentes de este escudo son de un Art Déco que van desde las figuras geométricas angulares y triangulares del Zigzag de las flamas, del trigo, de la estrella, del cuerpo de la paloma, hasta las concepciones aerodinámicas del Streamline de las alas de la paloma.

\footnotetext{
${ }^{236}$ Las interpretaciones iconográficas de algunos de los motivos y de los colores fueron tomadas de José Antonio Pérez-Rioja, Diccionario de Símbolos y Mitos, Madrid, Tecnos, 2008 y de Udo Becker, Enciclopedia de los Símbolos, México, Océano, 1996.
} 


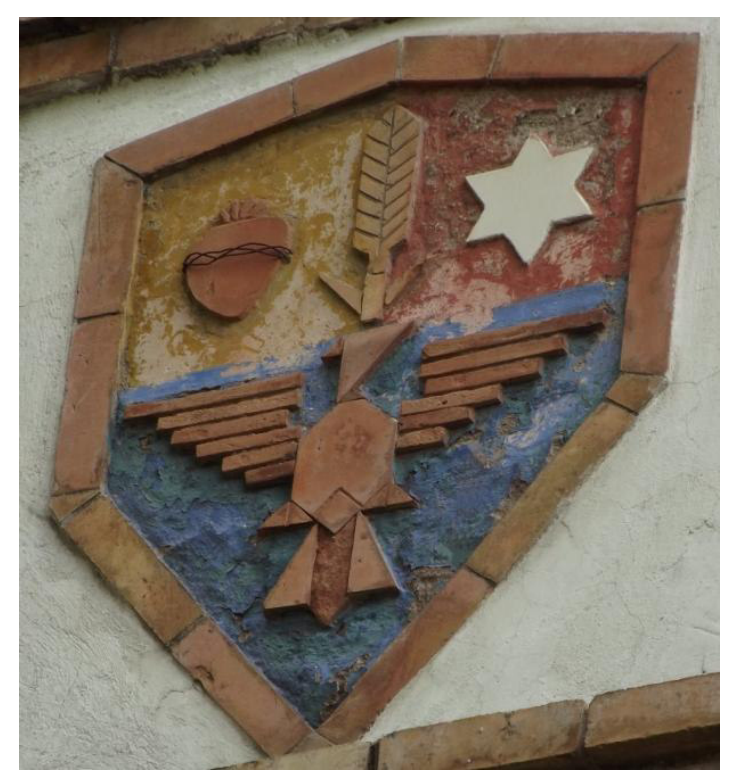

Escudo en el muro oriente.

En el muro poniente el escudo presenta en la parte baja sobre fondo azul una antorcha, la cual significa a uno de los emblemas de la pasión de Cristo, pues se asocia con la noche cuando fue apresado. ${ }^{237}$ Arriba, sobre fondo rojo, dos estrellas blancas: la ya referida a la Virgen María y la otra a San José, que de acuerdo a los evangelios apócrifos el Protoevangelio de Santiago y La Historia de José el Carpintero, mencionan a José como descendiente de la casa de David, ${ }^{238}$ cuyo símbolo es la estrella de seis picos; de aquí que la representación de ambas estrellas se refieran a los padres de Jesús, mismo que está simbolizado en la antorcha.

Los elementos Art Déco están presentes en el mango formado por un triángulo isósceles truncado y un rectángulo, mientras que en la parte superior se ensamblan dos molduras escalonadas de menor a mayor. En lo que corresponde a la flama de la antorcha cinco triángulos escalenos sobrepuestos de izquierda a derecha y orientados hacia la diestra consuman la geometricidad del objeto. Nuevamente se repite, como en el escudo anterior, el mismo diseño del trigo, así como de las estrellas de seis picos, con lo cual en este escudo se arma un esquema de Déco Zigzag, ya que se resaltan las composiciones geométricas, angulosas y ritmadas.

\footnotetext{
${ }^{237}$ Jose Antonio Pérez-Rioja, Op. Cit.

${ }^{238}$ Louis Réau, Iconografía del arte cristiano, Barcelona, Ediciones del Serbal, 1997, Tomo 2, Vol. 4, p. 162.
} 


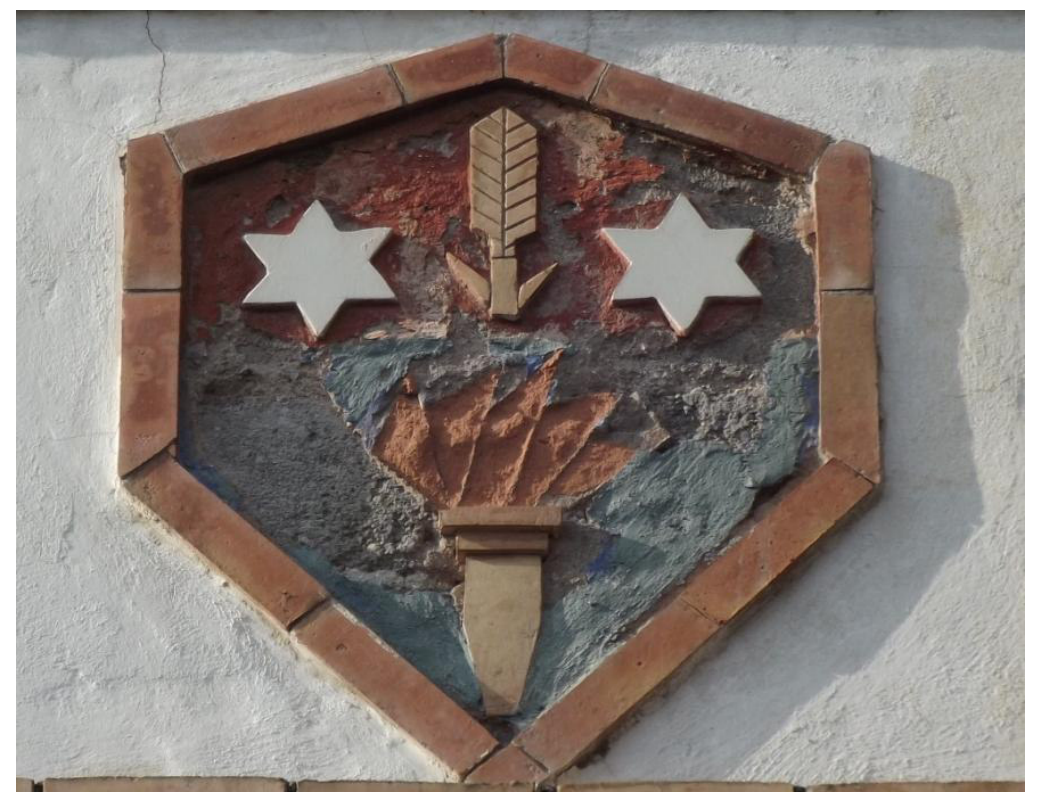

Escudo en el muro poniente.

El escudo del muro sur en la parte baja exhibe una cruz que a un cuarto del madero central, en la parte baja, se le adhieren de cada lado unos triángulos escalenos; en el centro de la intersección de las barras, un poliedro en forma de tetraedro invertido que el corazón de Jesús, porta los tres clavos de la crucifixión de Cristo; este elemento se empotra sobre un fondo triangular de la cruz y que extendiéndose en el segmento horizontal, termina a cada lado con triángulos escalenos colocados hacia abajo. En la parte superior, donde iría el letrero, éste se abstrae con un triángulo truncado. Al centro, con letras rojas el anagrama mariano de "María Virgen" con la "V" invertida. En la fracción superior, nuevamente la estrella blanca de seis picos es una alusión a la Virgen María. Desafortunadamente el fondo azul, símbolo de lo celestial, se encuentra bastante deteriorado. El geometrismo de la cruz es extraordinario, ya que reúne formas triangulares planas y con volumen, como es el caso del poliedro, integrando un producto de tipo Art Déco Zigzag, pero que a su vez podría ser también Streamline, pues precisamente pareciera el diseño en planta de una aeronave. Por lo que concierne al anagrama mariano, con " $\mathrm{M}$ " más la "V" invertida incrustada en el centro disponen un diseño de clara raigambre Déco Zigzag, reforzándolo con las puntas de la estrella. 


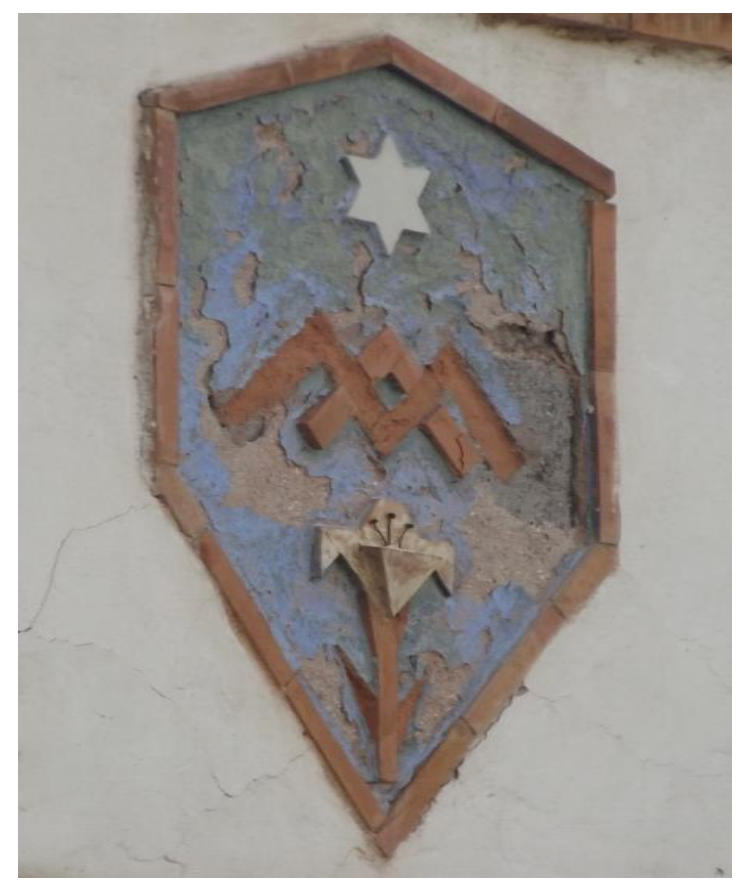

Escudo en el muro sur.

Algo muy visiblemente Art Déco en el Seminario Diocesano del Sagrado Corazón es la puerta de la capilla, la cual se ubica al centro del patio. Este acceso está compuesto por un vano abocinado con tres arcos de medio punto, redondeados, que van de mayor a menor, para terminar en un arco más donde se empotra la puerta de madera de dos hojas. El color de los arcos es crema y la base a manera de rodapié está levemente resaltada, la cual es de color rosa, lo mismo que las pilastras que enmarcan el vano, todo trabajado en granito bruñido. El piso de la entrada, también de granito, está veteado con clores rojos y blanco.

El conjunto de los componentes de esta puerta es de una calidad excepcional, aunado el pulido de los materiales que otorgan una sensación de suavidad. Esta puerta es como las que describe Enrique X. de Anda al clasificar el Art Déco hecho en la ciudad de México y que anotamos en el capítulo 2, perteneciendo a la "Tendencia Decorativista, Elementos Exteriores, Vanos de Acceso". Visualmente nos invita a entrar al lugar, pues al ir acortándose el espacio de los arcos e ir retrocediendo de adelante hacia atrás es una manera de proyectar la sensación de acogimiento, que como dice De Anda: “...cada determinada distancia aparece materialmente el perfil del vano cada vez de menor 
dimensión, con lo que se obtiene el clásico juego de líneas ritmadas tan entrañable al estilo Déco". 239

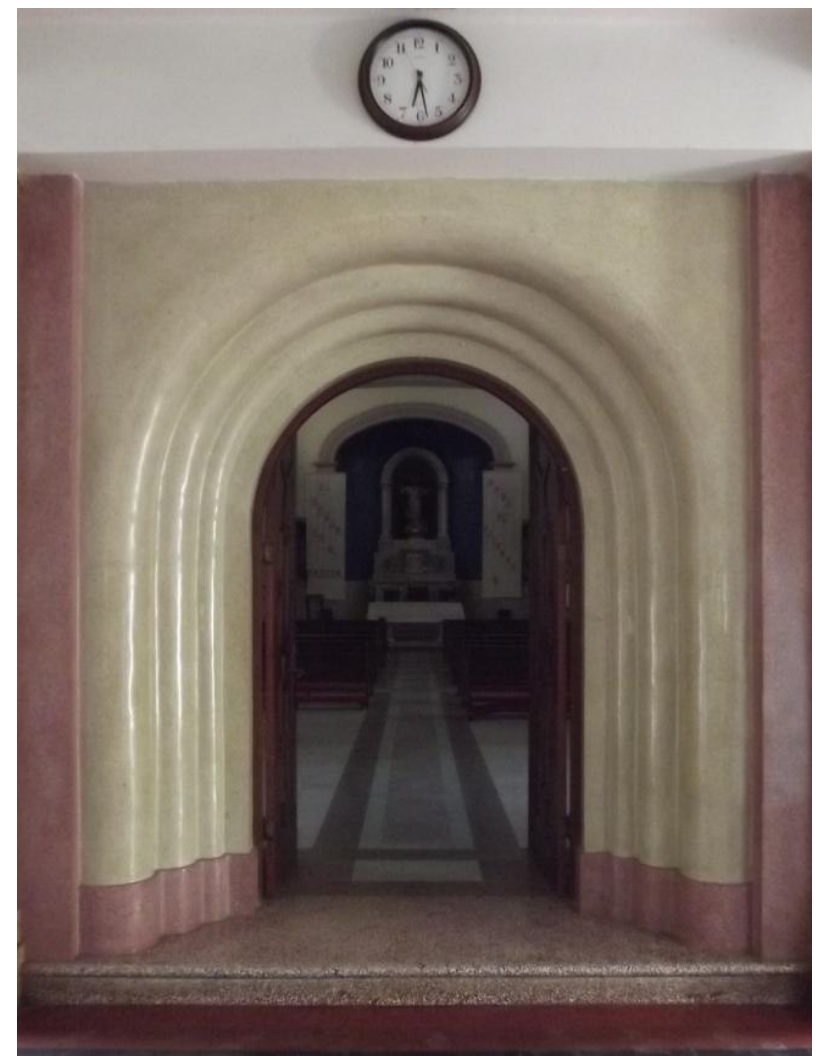

Puerta de la capilla.

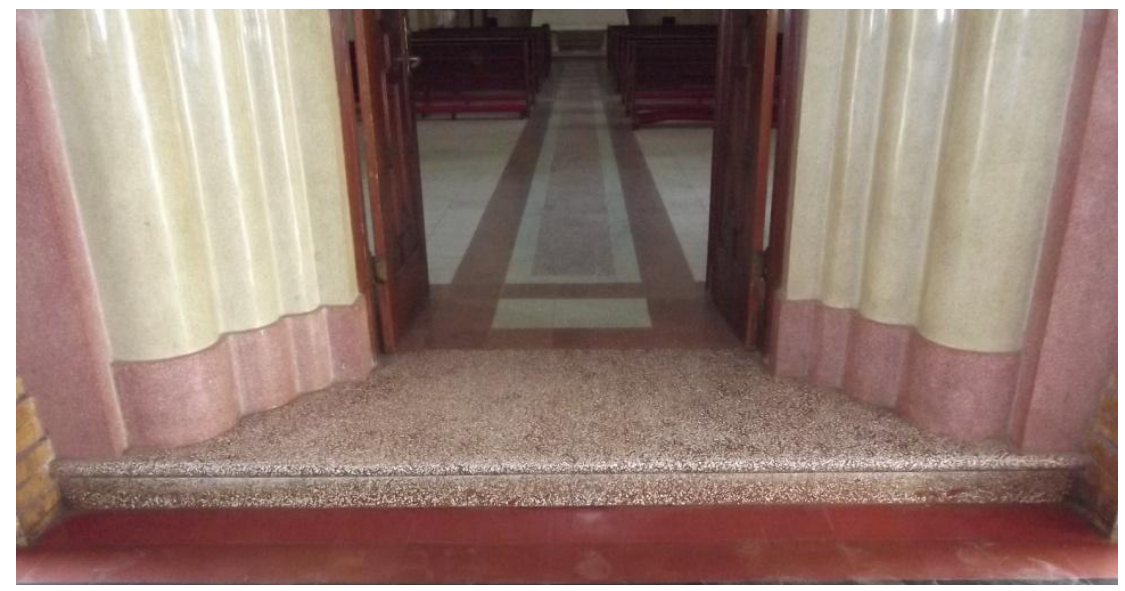

Detalle de la parte baja del piso y del arco.

${ }^{239}$ Enrique X., de Anda Alanís, La Arquitectura de la Revolución Mexicana. Corrientes y estilo de la década de los veintes, México, IIE, UNAM, 1990, p.148. 
Este tipo de accesos se realizaron más en los años veinte y la primera mitad de los treinta en la época en que se desarrolló el Déco Zigzag en México, pero aquí vemos su vigencia a finales de la década de los cuarenta, con todos sus elementos típicamente Art Déco.

De las obras que ejecutó Zeferino Domínguez en Saltillo dentro del lenguaje Art Déco, el Seminario Diocesano del Sagrado Corazón fue la última, pues ya la influencia del Funcionalismo, así como la integración y búsqueda de otros estilos en boga, era obvio que trabajara en otras direcciones, sin embargo, encontramos que el edificio combina tano el Déco Zigzag con el Streamline, así como la Tendencia Decorativista. 


\section{$\begin{array}{lllllll}\text { 3.3.2. TORREÓN, UNA CIUDAD DEL SIGLO } & \text { XX } & \text { Y } & \text { SUS }\end{array}$ MANIFESTACIONES ART DÉCO}

La historia de Torreón se inicia en 1848 con la compra de la Hacienda de San Lorenzo de la Laguna por lo señores Leonardo Zuloaga y Juan Ignacio Jiménez, lugar que más tarde se llamará Hacienda del Torreón cuando el mismo señor Zuloaga construye una presa y un torreón de vigía. Así pues, pasando los años cincuenta del siglo XIX se crearon una serie de rancherías y haciendas dedicadas a la agricultura y a la siembra del algodón, gracias a la bonanza del agua por las trece lagunas que existían en la zona, alimentadas por los ríos Nazas y Aguanaval, de ahí el apelativo de la Región de La Laguna.

Para 1883 ya pasaba el ferrocarril, especialmente para recoger la carga de las pacas de algodón, sin embargo la población era eminentemente rural. Pero unos años más tarde, en 1887 el señor Andrés Guillermo Eppen Aschernborn (1840-1909), oriundo de la ciudad de México y de origen prusiano, compra varias rancherías junto al "torreón" del ferrocarril y con el ingeniero Federico Wulff, norteamericano de ascendencia alemana, se inicia el trazo de varias manzanas para la venta de terrenos habitacionales y así en 1888 se inicia lo que es la ciudad de Torreón, que alcanzó el rango de "Villa" el 24 de febrero de 1893.

Algo que detonó el desarrollo de la ciudad, junto con el ferrocarril, fue que en 1889 el Gobierno del estado de Coahuila decretó una exención de impuestos, tanto a nivel municipal, como estatal, a los habitantes del "Torreón del Ferrocarril", con que se dio la llegada de familias de extranjeros, entre ellos europeos y chinos, para dedicarse al comercio y las acciones financieras por lo que se crearon varias instituciones bancarias e industrias entre 1893 y 1907, de las cuales ya no existen en su mayoría. Algunas de estas empresas fueron La Constancia, creada en 1890 por Alfonso Aymes para la fabricación de hilados y tejidos, y al finalizar el siglo, otra factoría llamada Compañía Industrial de Hilados y Tejidos $\mathrm{La}$ Fe, fundada por Joaquín Serrano en $1898 .{ }^{240}$

Debido a un incendio en las antiguas instalaciones de una jabonera, en 1900 nace La Unión, Compañía Jabonera de Torreón, creada en por el señor Joaquín Serrano. Entre 1900 y 1901, los señores Ernesto Madero, Carlos González Montes de Oca y Joaquín

\footnotetext{
${ }^{240}$ Jose León Robles de la Torre, Torreón en las Letras Nacionales, Torreón Coahuila, Editorial del Norte Mexicano, 1986, p. 84.
} 
Serrano organizaron la Compañía Fundidora Metalúrgica de Torreón, ${ }^{241}$ lo que vino a dar más empuje a la industria de la villa de Torreón.

En 1907, el 17 de junio, se le otorga el rango de ciudad a la villa de Torreón, debido a su crecimiento poblacional que ya alcanzaba los cuarenta mil habitantes y a su destacado desarrollo comercial e industrial. Es por esto que se dice que Torreón es una urbe del siglo $\mathrm{XX}$, más por los acontecimiento que le tocó vivir en sus inicios como ciudad.

¿Pero qué le pasó entonces a la incipiente ciudad que se estancaría su próspero y acelerado desarrollo? Pues que en los años de la Revolución fue tomada tres veces: en 1911 por las fuerzas maderistas con el terrible genocidio de 303 chinos comerciantes y banqueros; en 1913 por la fuerzas de Francisco Villa y la de 1916 por el propio Pancho Villa. La ciudad vivió el terror del saqueo, la muerte, el hambre y la incertidumbre, por lo que muchas familias emigraron de la ciudad.

Fue hasta finales de los años veinte y principios de los treinta cuando la ciudad toma su rumbo, cuando bajo la administración gubernamental de Nazario Ortiz Garza (1893-1991), durante sus tres años de gobierno comprendidos entre 1929 a 1933, emprende obras de desarrollo urbano en Torreón como la creación de la Alameda Carranza, la escuela del mismo nombre, el Estadio de beisbol de la Revolución, así como la remodelación, ampliación, arreglo y apertura de vías de comunicación como fue el boulevard Revolución. Una obra de suma importancia fue la pavimentación de la carretera a Saltillo y la mejora de las comunicaciones hacia las ciudades vecinas de La Laguna en el estado de Durango como son Ciudad Lerdo y Gómez Palacio. La ciudad de Torreón recobra la paz y el desarrollo tanto de la industria como del comercio vuelve a coger fuerza, aunado a la llegada de migrantes árabes de origen libanes y españoles exiliados de la guerra civil, quienes emprendieron diversos tipos de negocios de abarrotes, mercerías, hospedaje y alimentos.

Ante la necesidad de renovar la arquitectura pública y privada como en muchas partes del país, se levantó un nuevo mercado, el Juárez, el Edificio Eléctrico, algunos hoteles como el Galicia y el majestuoso Estadio de la Revolución, obra de Zeferino

\footnotetext{
${ }^{241}$ Beatriz González Montemayor, Efemérides del Municipio de Torreón Coah. 1848-1948, Torreón, Coahuila, Ayuntamiento de Torreón, 1999, p. 12.
} 
Domínguez, edificios que exhiben estructuras y decoraciones con las características distintivas del Art Déco.

Como la renovación de la ciudad coincide con los años del Art Déco, mucho se levantó bajo este estilo en sus diversas manifestaciones y algunos edificios siguen en pie, pero con la pérdida de sus diseños originales o algunos más que están en un grado superlativo de deterioro, por lo que no consideramos incluirlos, ya que prácticamente no conservan elementos Déco.

De la misma manera que en los edificios de Saltillo, utilizaremos para las descripciones las características de la arquitectura Art Déco del señaladas en el capítulo 1 y las Tendencias de Enrique X, de Anda incluidas en el capítulo 2. 


\subsubsection{ARQUITECTURA DE SERVICIOS}

\section{a. Mercado Juárez}

En una manzana que abarca la avenida Juárez y las calles Blanco, Hidalgo y Acuña, se encuentra el Mercado Juárez, con orientación al norte en la entrada de la avenida que lleva su nombre y que se considera como la principal. Tiene planta cuadrada y sólo conserva sus cuatro entradas en cantera, ya que el resto fue remodelado tanto en el interior como en el exterior.

Originalmente este centro comercial se levantó en 1906, pero un incendio lo destruyó en 1929. En 1930 se iniciaron los planes para levantar un mercado completamente nuevo, asignándose las obras a la compañía del ingeniero José Bracho, para terminar con la construcción e inaugurarla en $1932 .^{242}$

Las cuatro portadas son bastante similares y sólo se diferencian por algunos detalles decorativos o por los productos del campo que se representan, por lo que primero las describiremos generalmente y luego daremos detalles específicos de cada una.

Las entradas son cuadrangulares, recortadas en las intersecciones superiores formando un ochavo. En el friso llevan el letrero del centro comercial con letras mayúsculas y a los lados en las enjutas dentro de un trapecio rectángulo invertido, emergen frutos y verduras. Como vimos en los capítulos anteriores, las entradas ochavadas son algo típicamente Déco, especialmente del periodo Zigzag, que en este caso se conjuntan con las decoraciones orgánicas dentro de la figura trapezoidal, diseño característico del Art Déco en general. A los lados de la entrada unas gruesas jambas se componen de dos cuerpos rectangulares ensamblados y desplazados hacia el frente, destacando el primero de ellos, el cual lleva una ancha moldura rectangular enmarcando decoraciones de frutos y adornos geometrizados. En la parte baja, tanto las entradas, como las jambas se resaltan a manera de zócalo, que en la zona central de la jamba se prologa levemente hacia arriba.

Las jambas principales rematan recortadas, con lo que hacen juego con los ochavos de las entradas. En la parte superior, una base con moldura concluye la altura con una

\footnotetext{
${ }^{242}$ Carlos Castañón Cuadros, “Arquitectura Art Déco. Un estilo internacional en Torreón”, Museo Arocena, Torreón, Coahuila, México, 2013, www.museoarocena.com/exhibiciones/actuales/artdeco/
} 
pirámide truncada. El sentido de elevación a manera de plataformas piramidales es lo que denota esta composición, prototípica del Art Déco Zigzag, que además remite a las influencias indigenistas en el Art Déco mexicano.

En los extremos, los contrafuertes estás formados de tres partes: primero, un contrafuerte mayor está recortado oblicuamente en la parte superior; lleva una incisión que sigue la forma del contorno para terminar en una greca; segundo, dos pilastras de menor tamaño y acopladas una detrás de otra concluyen con la ordenación de cubos superpuestos que refuerzan la estética del Déco Zigzag.

La iluminación es bastante original pues brota de la parte superior de las jambas. Unos doseles geométricos ochavados están armados de tres partes, la cuales van de menor a mayor de arriba hacia abajo, siendo la parte menor igual al remate de la jamba, diseños que aparentan la forma de una plataforma piramidal prehispánica de tablero y talud. Las lámparas cuelgan de los doseles pero su forma es hexagonal, terminando a manera de punta de diamante, que con los ensambles de sus partes dan la idea los recortes que se le hacen a la piedra preciosa. Con esto apreciamos como la composición de las portadas sobresalen aún más del límite de la superficie con la proyección hacia delante de las luminarias, además de enfatizar el sentido geométrico del ensamblaje de cubos y poliedros. Las imágenes fueron difíciles de captar debido tanto al tráfico vehicular, como al peatonal y al establecimiento de puestos sobre las banquetas, mismo que invaden la visibilidad de las portadas. Además, las portadas se encuentran en un lamentable estado de conservación, demostrando que no se les da mantenimiento, ni la gente tiene conciencia de la importancia artística de las mismas.

La que se considera como la portada principal es la de la avenida Juárez con orientación hacia el norte. En el friso está el letrero con letras mayúsculas. En la enjuta izquierda delante de unas bandas recortadas desigualmente y curveadas aparecen granadas, peras así como limones con sus ramas, mientras que de una espiral que se conecta con unas bandas seccionadas geométricamente cuelga una penca de plátanos. En la enjuta del lado derecho hay gruesas bandas curvas, triángulos irregulares, líneas quebradas, una espiral, formas geométricas que acompañan a calabazas, peras, uvas, piñas, berenjenas y dentro de una banda en forma de "U", unos tomates completan la exhibición de productos. 


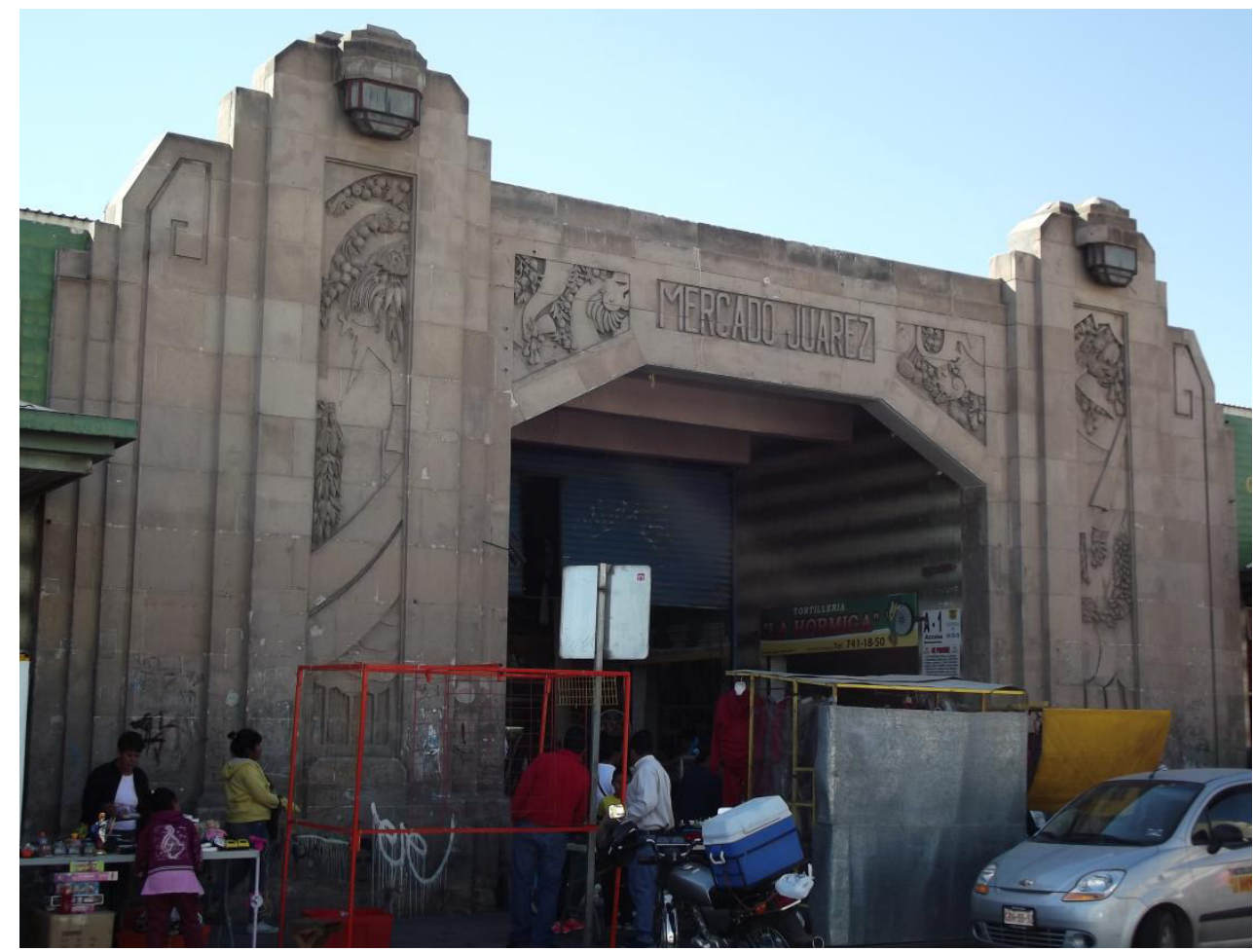

Portada de la avenida Juárez con orientación al norte.
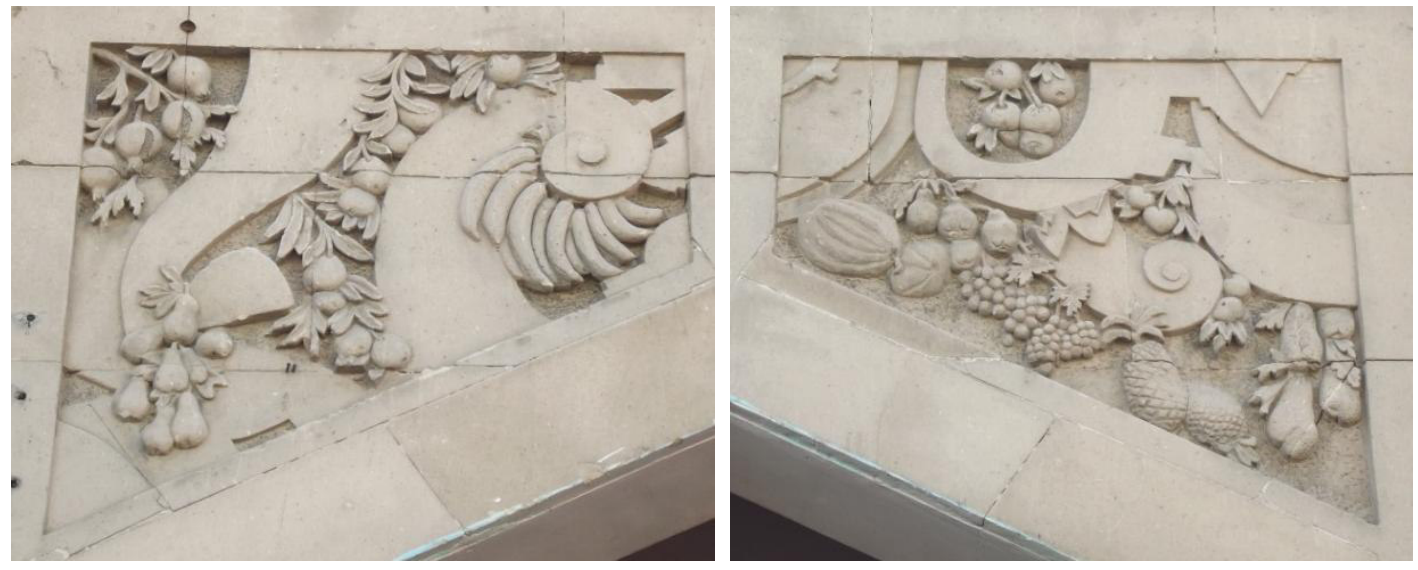

Enjutas de la portada de la avenida Juárez con los diseños geométricos de fondo. La de lado izquierdo porta granadas, peras, limones y plátanos. La del lado derecho calabazas, peras, uvas, piñas, berenjenas y tomates.

La jamba izquierda arranca con unas nubes y cuatro hileras que representan el agua, para luego pasar a dos bandas curvas. De unas mazorcas cuelgan los maíces de lado izquierdo, representan la dieta nacional mexicana con lo que se quiere enfatizar el 
nacionalismo. Más arriba delante de unos trapecios y rayos, se acomodan zanahorias, betabeles y hasta arriba limones. La jamba derecha inicia con unas bandas curvas en posición horizontal. A la mitad cuelgan racimos de rábanos, cebollines, cebollas y ajos delante de unas bandas zigzagueantes; más arriba tomates, calabacitas, calabazas y limones en la parte superior, en donde se cierra la decoración con recortes de tipo angular, rectangular y curvo.

Las luminarias que rematan las jambas se encuentran en buen estado de conservación.
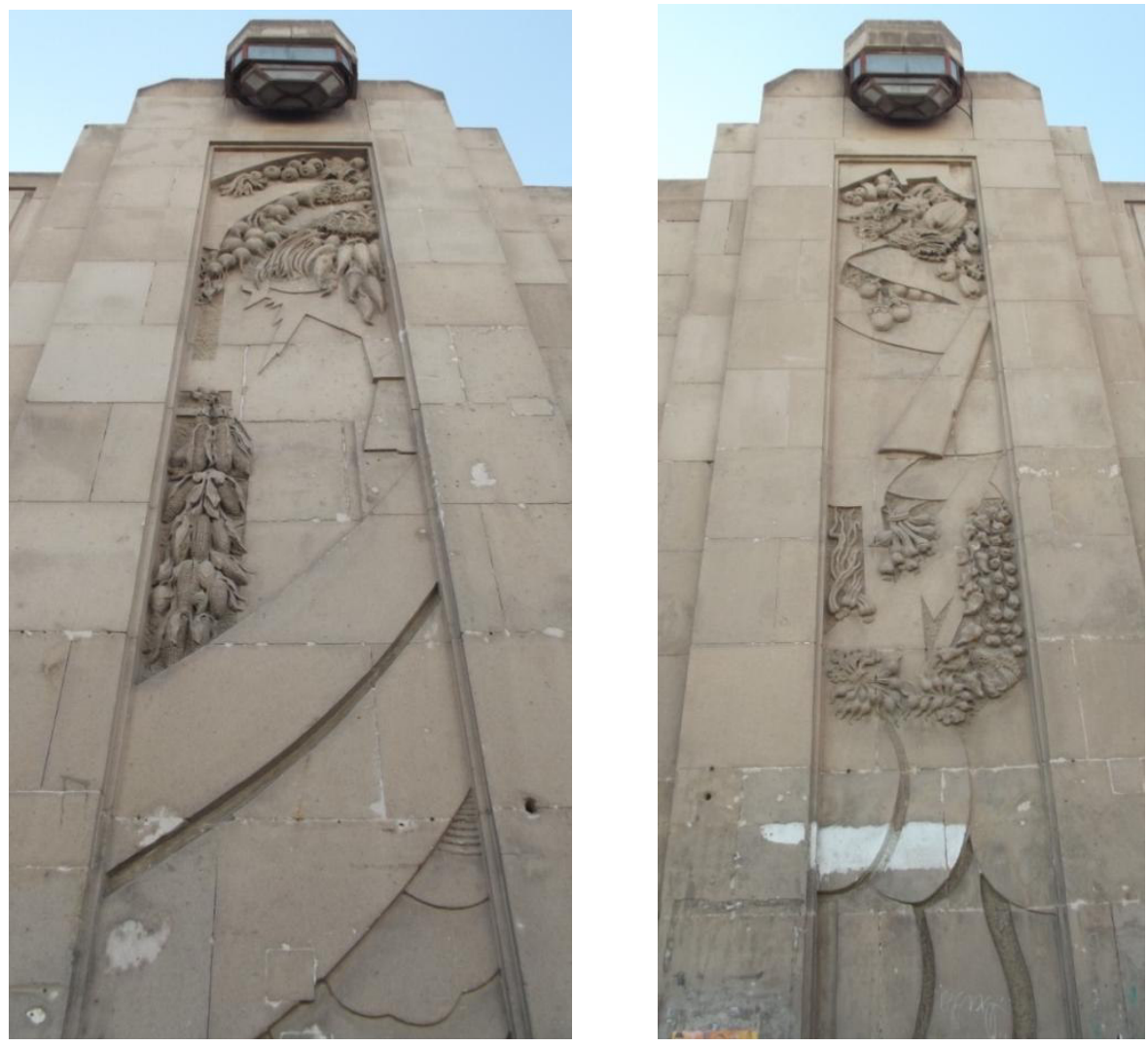

Jambas de la portada de la avenida Juárez. En la izquierda se aprecian las mazorcas del maíz, rábanos, betabeles y limones, mientras que en la derecha cebollas, cebollines y ajos están colocados en la parte central y arriba

Con dirección al oriente está la portada de la calle Blanco, cuyo letrero en el friso se encuentra en malas condiciones, ya que las letras han sufrido bastante erosión. En la enjuta izquierda del friso, entre una espiral, bandas serpentinas, triángulos curveados, líneas quebradas desemejantes tipo zigzags se distribuyen berenjenas, naranjas, piñas, uvas 
peras, así como calabazas, mientras que dentro de un diseño alabeado penden unos tomates. La enjuta derecha se encuentra algo deteriorada; unos plátanos se adaptan a la curvatura de una espiral, mientras que de una banda sinuosa y diseños curvos, limones, peras así como granadas se acomodan entre los espacios resultantes.

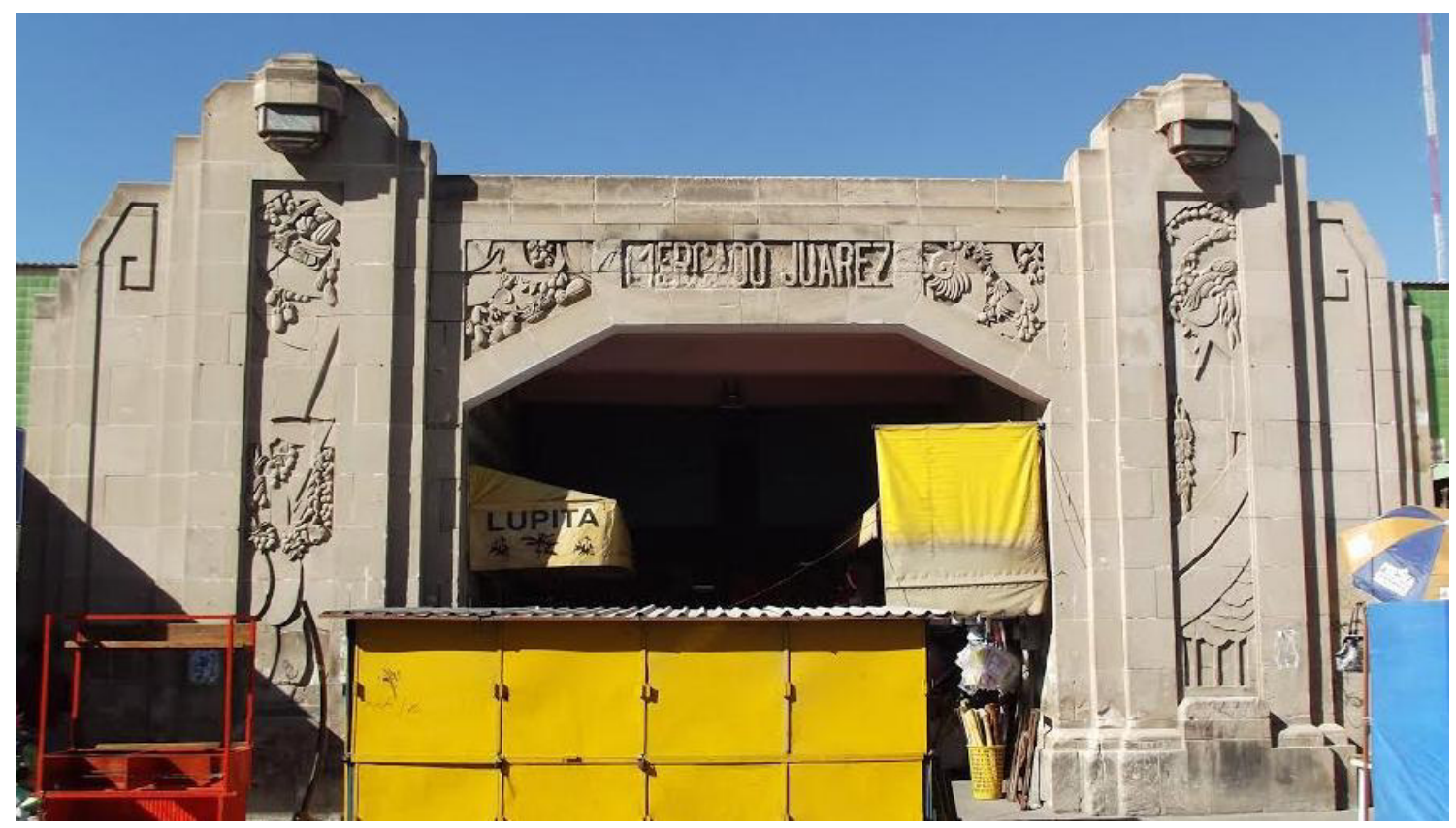

Portada de la calle Blanco con dirección al oriente.
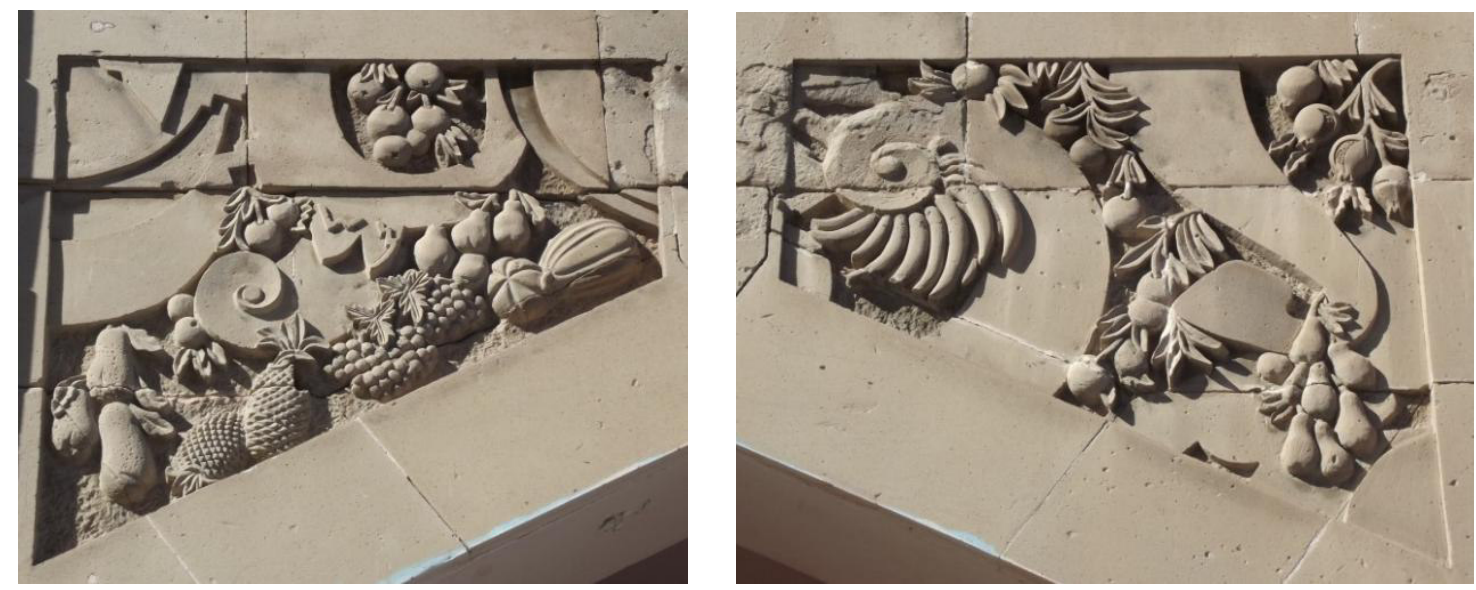

Enjutas de la calle Blanco con berenjenas, limones, piñas, uvas, calabazas, peras y tomates en la de la izquierda y en la de la derecha, plátanos, limones, peras y granadas. 
Las jambas presentan decoraciones de diseños geométricos con frutos y verduras. La de la izquierda inicia con un par de bandas curvas y luego tres elipses superpuestas; a la mitad rábanos, cebollas, un repollo, pimientos, ajos y betabeles sobresalen entre bajorrelieves angulosos en forma de zigzags, para terminar con bandas curvas en la parte superior donde hay papas, calabazas, hojas de maíz atadas y limones. En la jamba derecha se repite el mismo motivo de la parte baja de la jamba izquierda de la avenida Juárez: tres líneas verticales que salen de unas nubes, denotando el agua; a la mitad mazorcas de maíz y después de unos diseños zigzags heterogéneos zanahorias, lechugas, un repollo y acoplándose a dos bandas curvas, cebollas, otro repollo y limones en la parte superior.
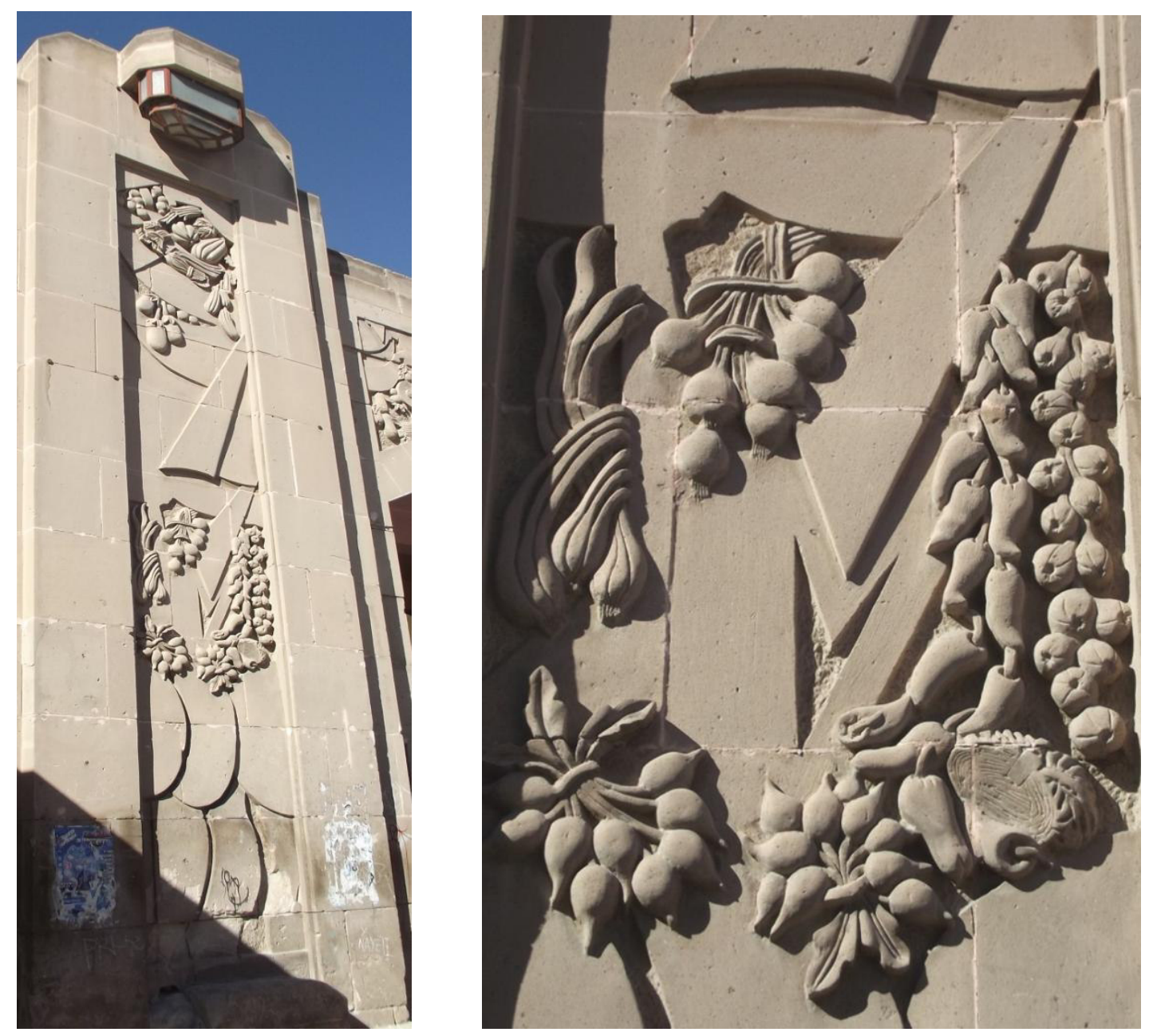

Jamba izquierda de la portada de la calle Blanco. En el detalle se aprecian los rábanos, la lechuga, los pimientos, cebollas y betabeles con los selectos diseños zigzags. 

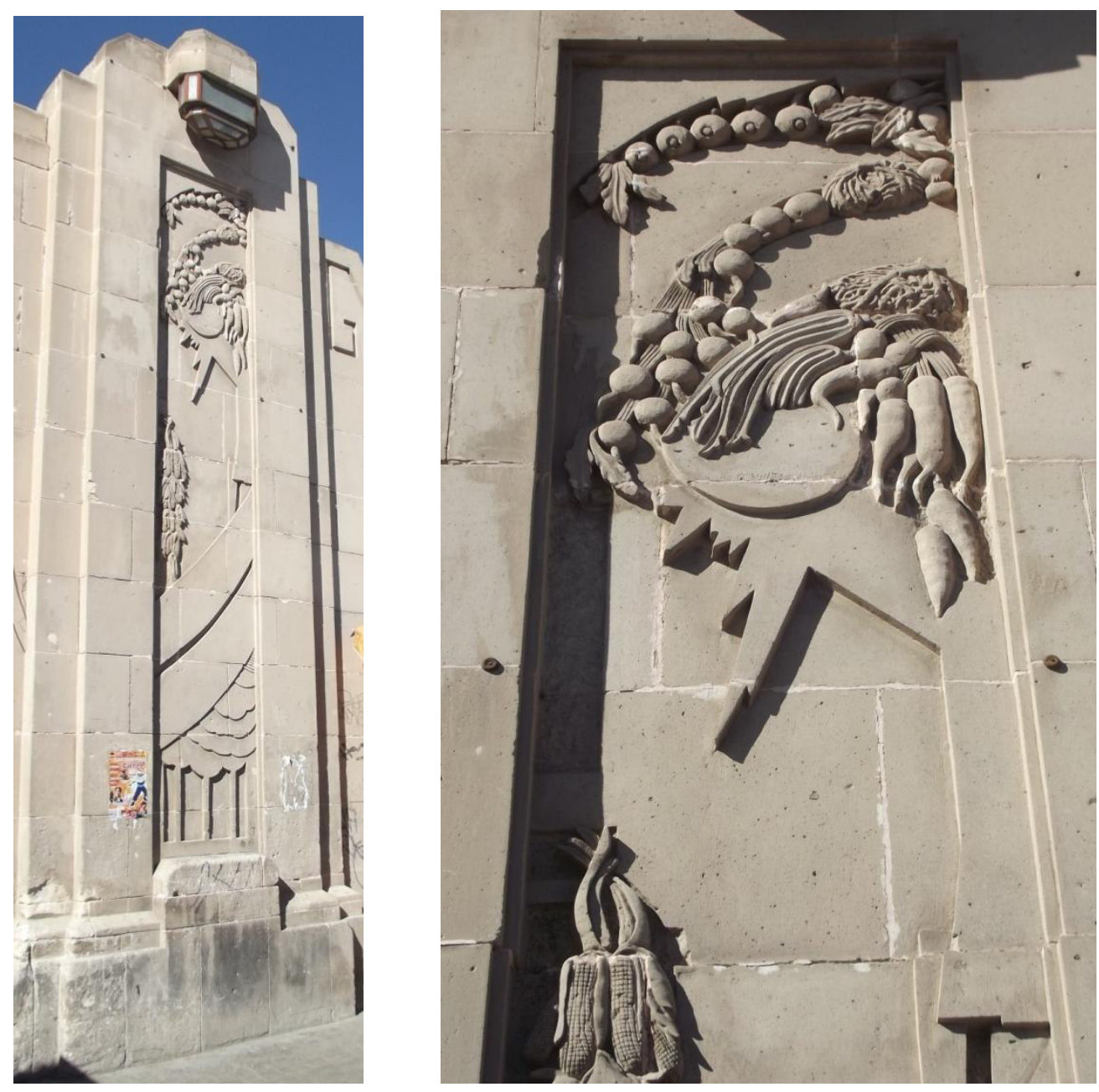

Jamba derecha de la calle Blanco con el detalle de la parte superior con los bajorrelieves zigzagueantes con formas angulosas a manera de rayos disímiles. Se alcanzan a ver parte de las mazorcas de maíz y después los rábanos, betabeles, lechugas, repollos y los limones.

La portada de la calle Hidalgo tiene orientación hacia el sur. En el friso se aprecia una ligera desunión de las lajas de cantera donde va el letrero. Las enjutas repiten los motivos decorativos de las portadas anteriores, coincidiendo con las de la avenida Juárez. Lo mismo sucede con las jambas que al estar en posición paralela con la portada de la avenida Juárez, llevan la misma distribución tanto en la jamba izquierda como en la derecha, con la diferencia que la izquierda carece de la luminaria, donde solamente queda el dosel. Por la invasión de puestos sobre la banqueta es complicado poder captar esta portada. 


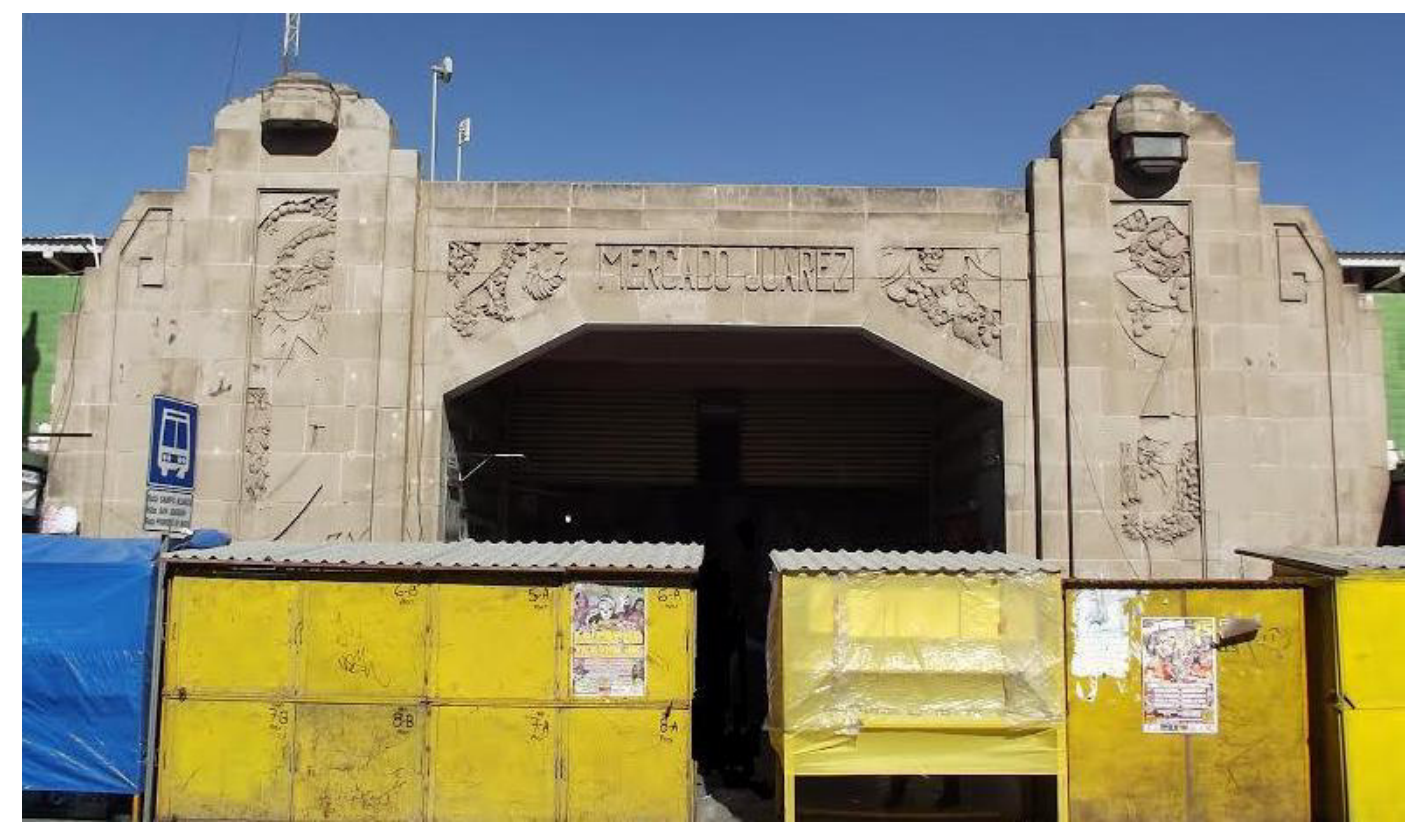

Portada de la calle Hidalgo con orientación al sur.
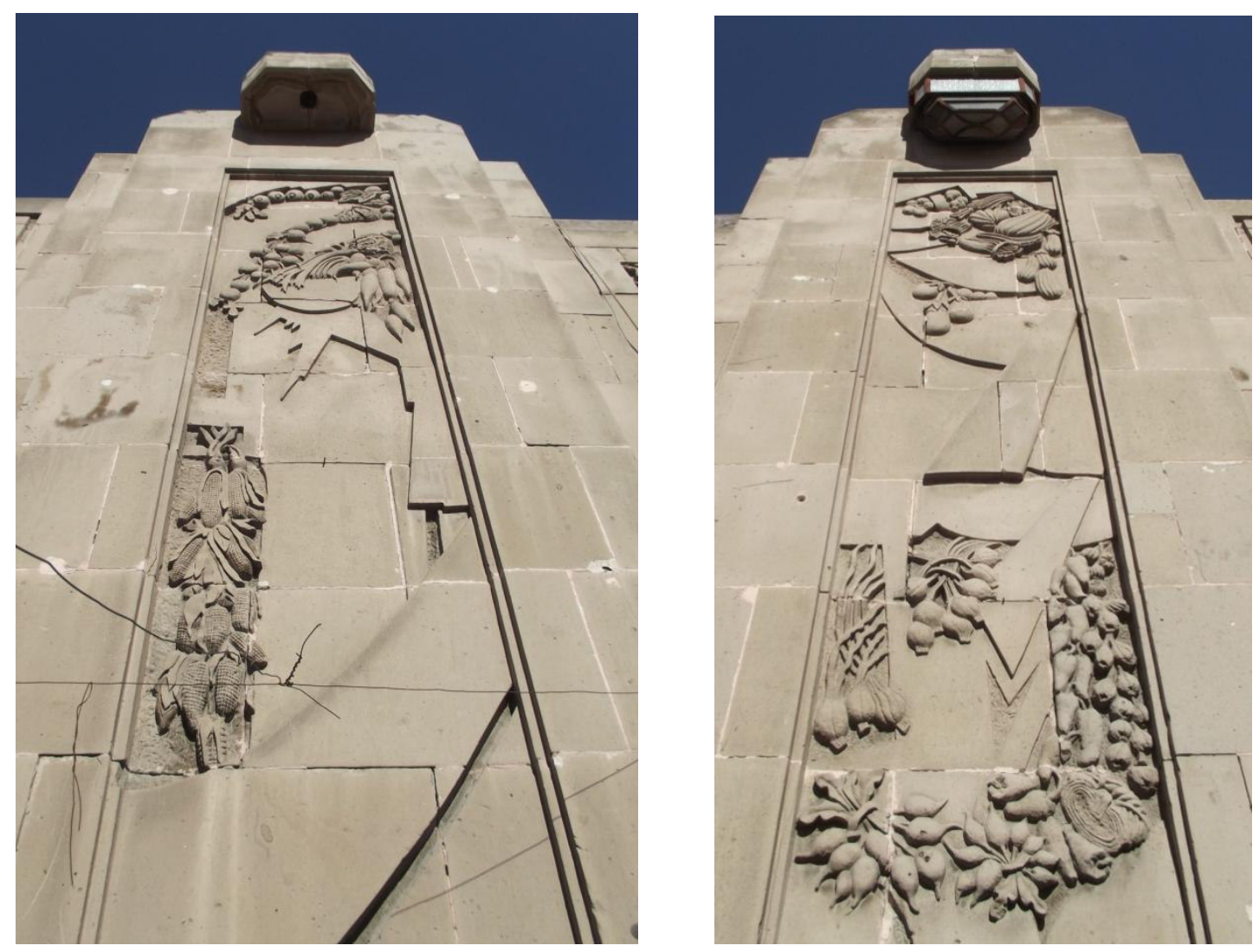

Jambas de la calle Hidalgo. 


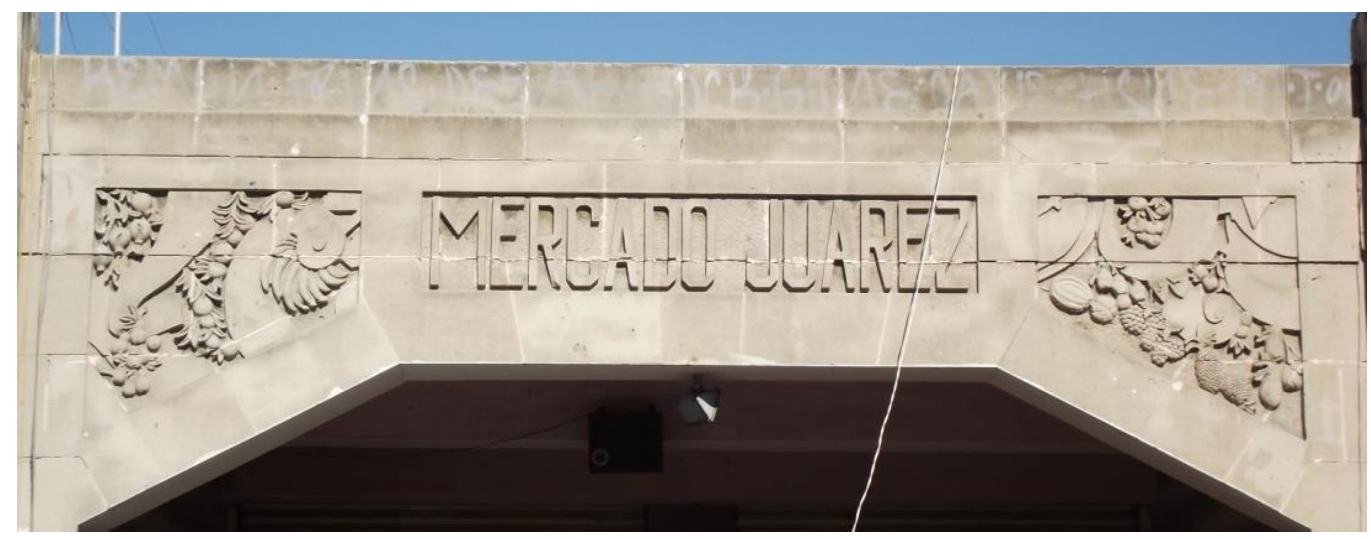

Friso de la portada de la calle Hidalgo. Las enjutas llevan la misma decoración como las de la avenida Juárez.

La portada de la calle Acuña tiene su orientación hacia el poniente. En el friso hay algunas lajas que se están desprendiendo, por lo que el letrero está tenuemente descuadrado. Al estar en relación con la posición de la portada de la calle Blanco, ostenta las mismas decoraciones tanto de enjutas como de jambas. Igual que la portada de la calle Hidalgo, la jamba izquierda carece de la lámpara.

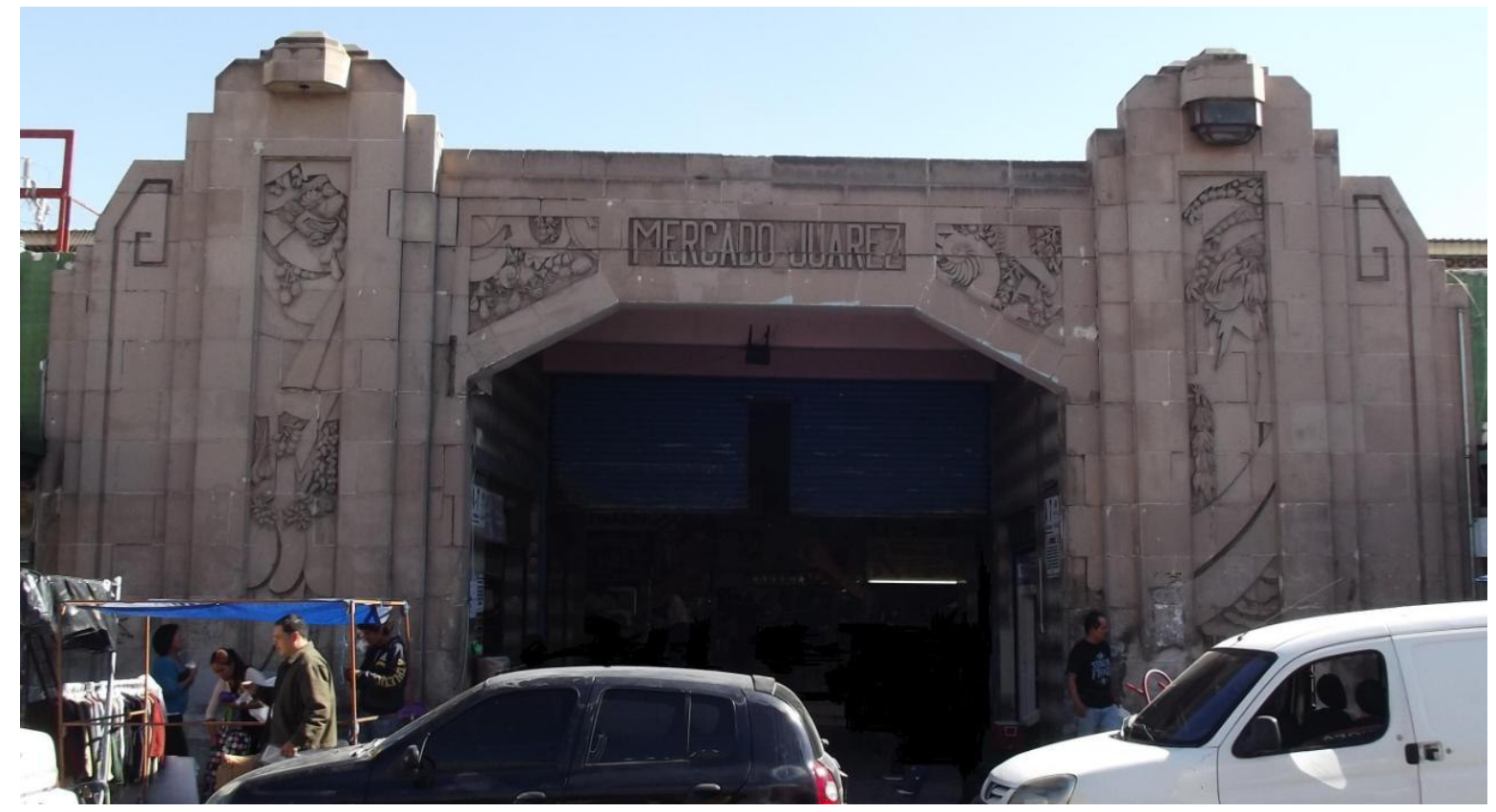

Portada de la calle Acuña con dirección al poniente. 

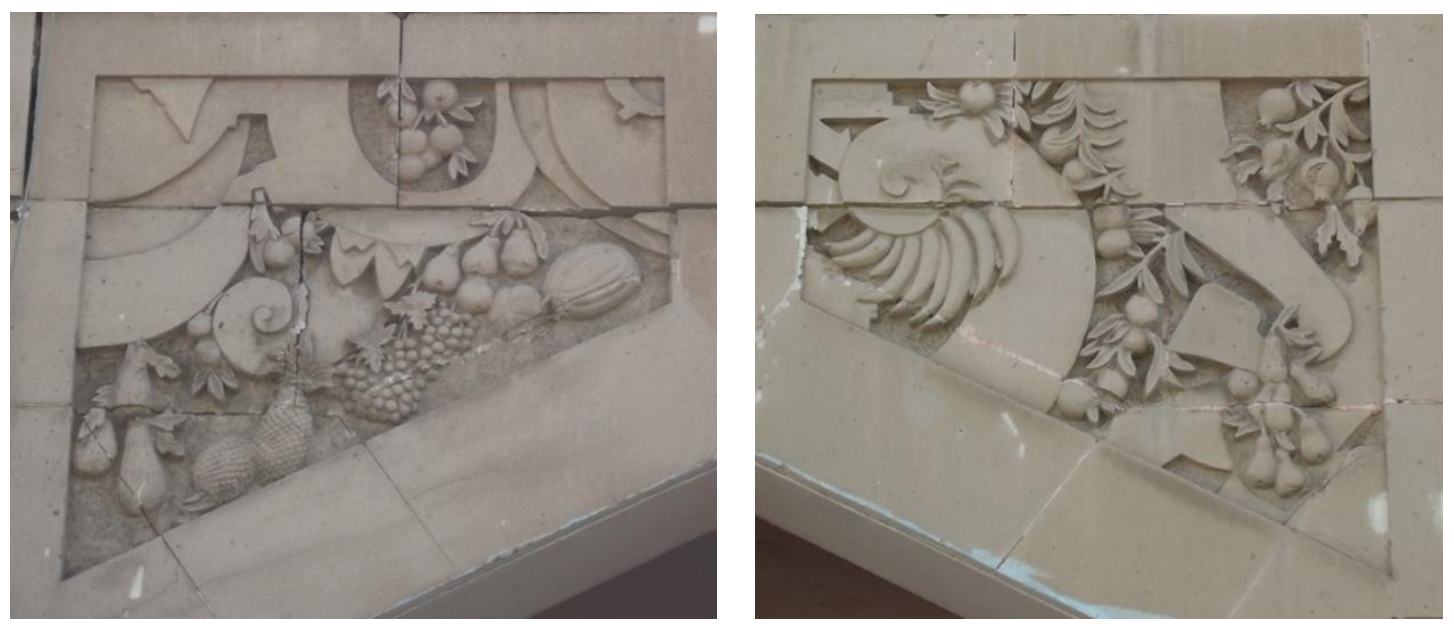

Enjutas de la calle Acuña.
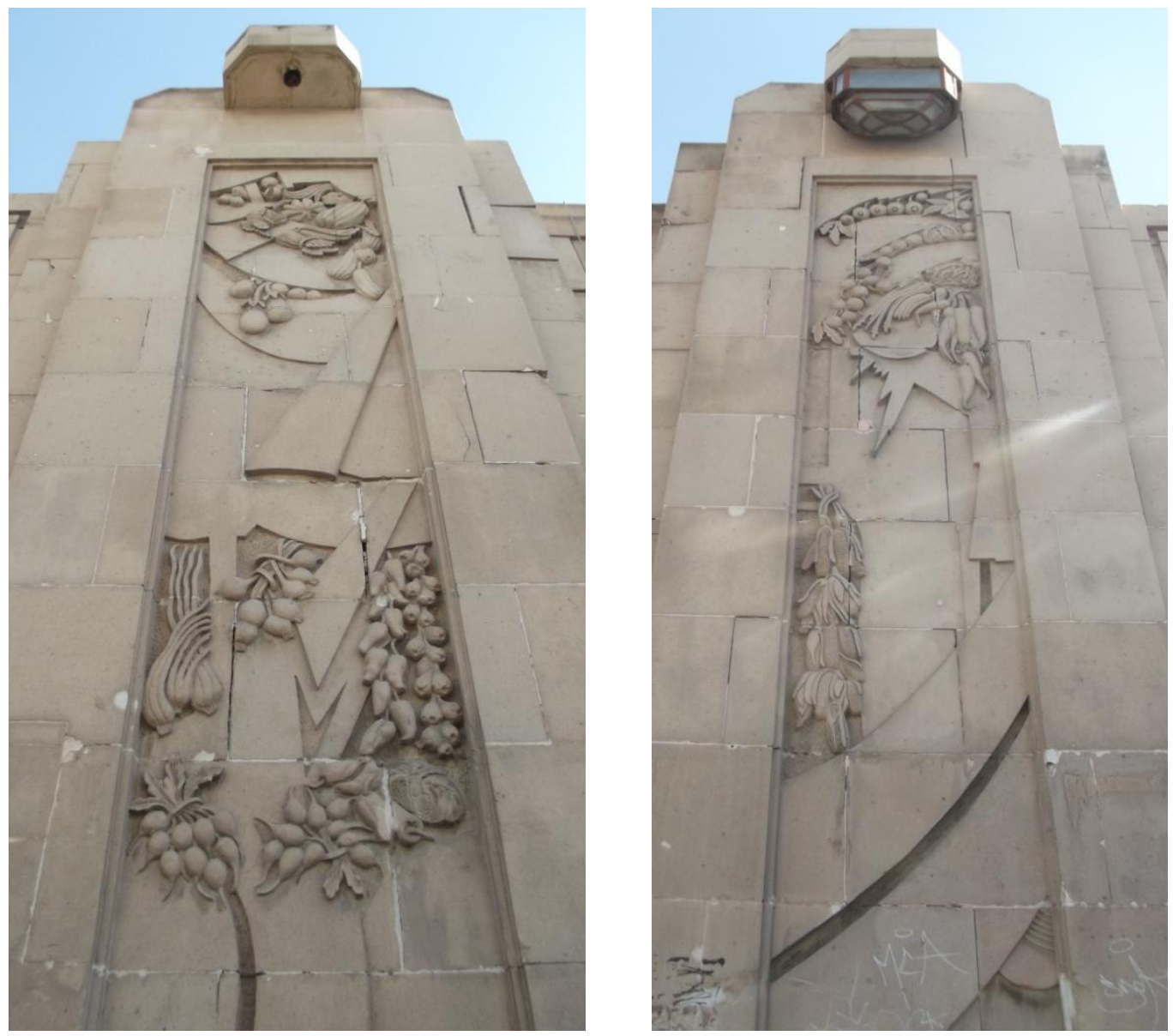

Jambas de la calle Acuña.

El Mercado Juárez de Torreón es un caso único en México, hasta donde tenemos información, de un centro comercial con este tipo de decoraciones. Es una lástima que esté 
condiciones de deterioro, pero esperemos que gracias a la investigación que está realizando el Museo Arocena se pueda llevar a cabo una restauración de las portadas.

El gran conjunto de decoraciones geométricas y de tipo zigzag, combinadas con las frutas y verduras constituyen una auténtica muestra de Art Déco Zigzag, en donde se encuadran los elementos orgánicos, exponiendo una modernidad de la época, tal como se estaban dando los dictados ornamentales del Déco, que dentro de las Tendencias de Art Déco mexicano el Mercado Juárez es un exponente de la Geometrista y por supuesto de la Decorativista.

\section{b. Edificio Eléctrico}

El Edifico Eléctrico se ubica en el centro de Torreón, a un lado de la Plaza de Armas, en la esquina conformada por las calles Av. Juárez y Valdés Carrillo, cuya fachada principal se encuentra sobre la calle Valdés Carrillo, con dirección al oriente.

La construcción data del año de $1930^{243}$ y fue levantada para las oficinas de atención al público de la The American and Foreing Power Company, empresa que se encargaba de la generación y distribución de la energía eléctrica en la región de La Laguna. Desafortunadamente no conseguimos el dato del arquitecto y/o constructora de este pequeño edifico de planta en forma de L, de dos pisos, erigido con concreto y estructuras de hierro; en la parte exterior fue forrado con cantera de color rosa. En el año de 1992 fue declarado edificio con valor histórico por el Municipio de la ciudad de Torreón.

El inmueble ha sufrido muchas modificaciones y adaptaciones, por lo que en el interior no conserva nada de elementos Art Déco. En el exterior han sido cambiadas las ventanas y agregado el letrero de "CFE (Comisión Federal de Electricidad)", después de la nacionalización de la industria eléctrica, llevada a cabo en 1960. Lo que corresponde al primer piso, la altura abarca los vanos que limitan al nivel de una marquesina que rodea al edificio, pero alcanza un nivel medio más que se denota con unas pequeñas ventanas rectangulares, para luego continuar con el segundo piso. Esta disposición permite una buena iluminación del primer piso donde están las oficinas de atención al público, ya que en el segundo nivel se encuentran oficinas administrativas.

\footnotetext{
${ }^{243}$ Carlos Castañón Cuadros, Op. Cit., sin página.
} 


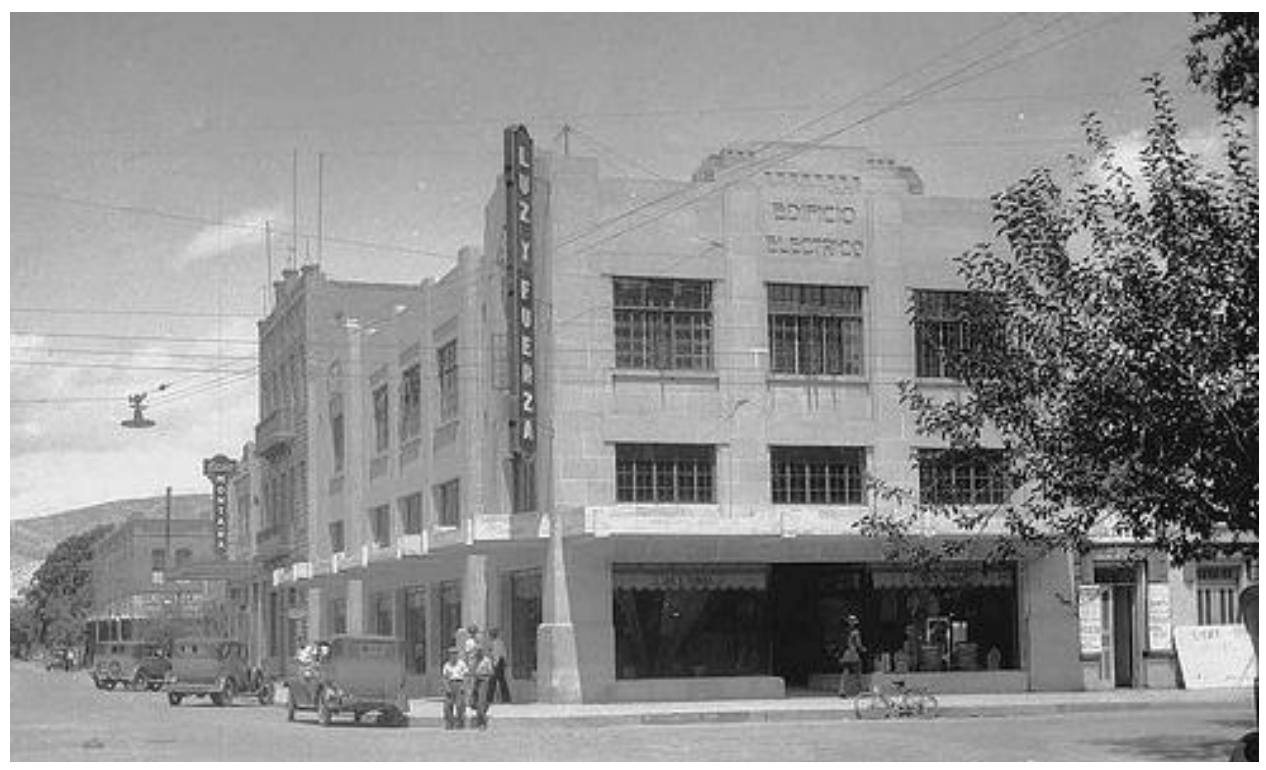

Edificio eléctrico recién inaugurado. ${ }^{244}$

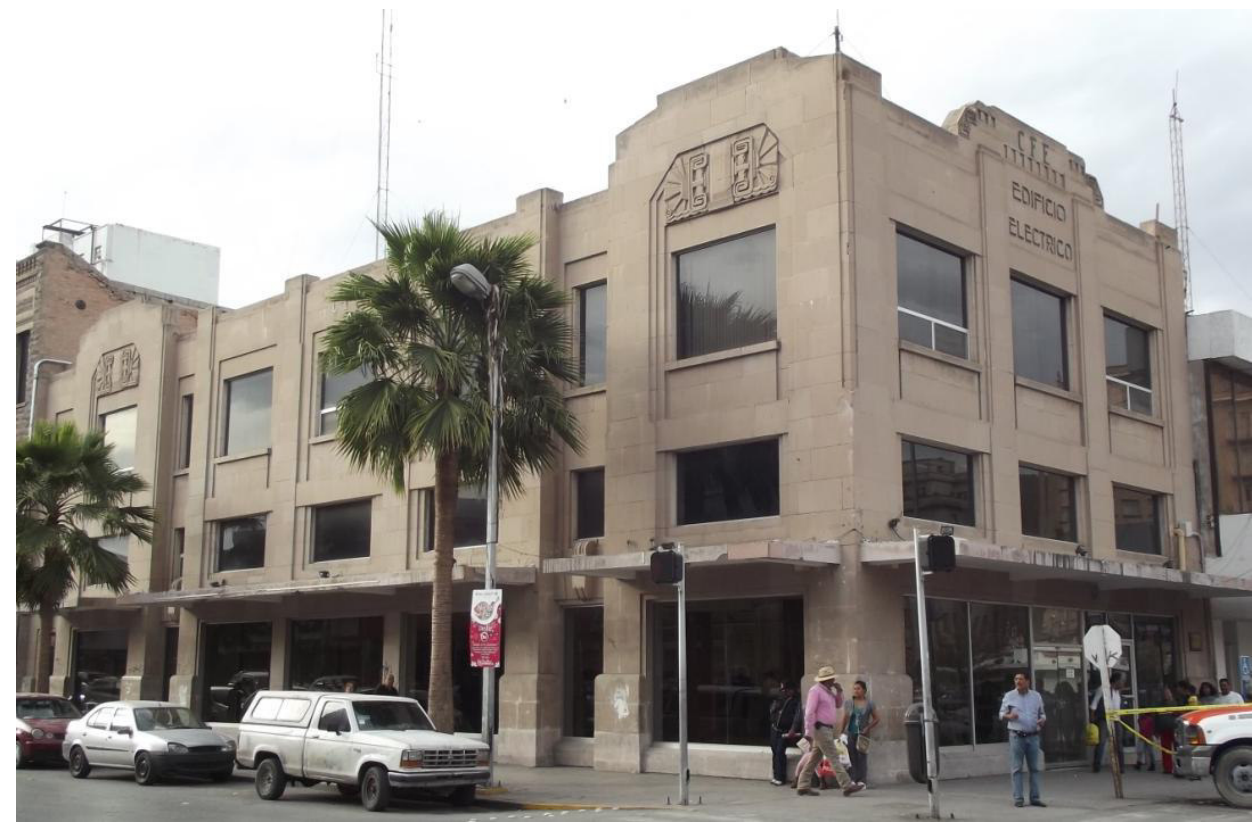

Vista general.

Es en el exterior donde se conservan elementos y decoraciones Art Déco. En la fachada principal que da hacia la calle Valdés Carrillo, un gran ventanal abarca prácticamente todo el vano, soportado por un largo zócalo con bisel, recortado en la puerta de entrada. El contorno del ventanal está recortado con un perfil angular hacia el interior

\footnotetext{
${ }^{244}$ http://foros.elsiglodetorreon.com.mx/cultura/567864-torre\%C3\%B3n+de+anta\%C3\%B1o.html
} 
del muro. En los extremos, a manera de rodapié, se resalta el nivel y se recorta a la altura promedio de una persona de $1.60 \mathrm{~m}$., de estatura. Después de la marquesina, un grupo de tres ventanas rectangulares en posición horizontal están rehundidas por medio de un doble enmarcamiento y de un recurso muy utilizado en los años del Art Déco que consiste en cuatro pares de bandas superpuestas que se prolongan hacia arriba, marcando el límite de los tres espacios. Debajo del repisón de las ventanas del segundo nivel se forman unos recuadros tablereados, que se repiten en la parte superior de las ventanas del segundo piso. En el recuadro central está el letrero de "EDIFICIO ELECTRICO" (sic), trazado con grafías estilizadamente geométricas, muy típicas del Déco de la etapa Zigzag.

En el remate de esta fachada, la elevación de las cuatro bandas se recorta perfiladamente de manera ascendente una sobre otra; en las de los extremos continúan con la prolongación del nivel a través de un poliedro rectangular, para de esta manera componer un juego de elevaciones cúbicas recortadas, consumándose con un piñón instalado en la sección central.

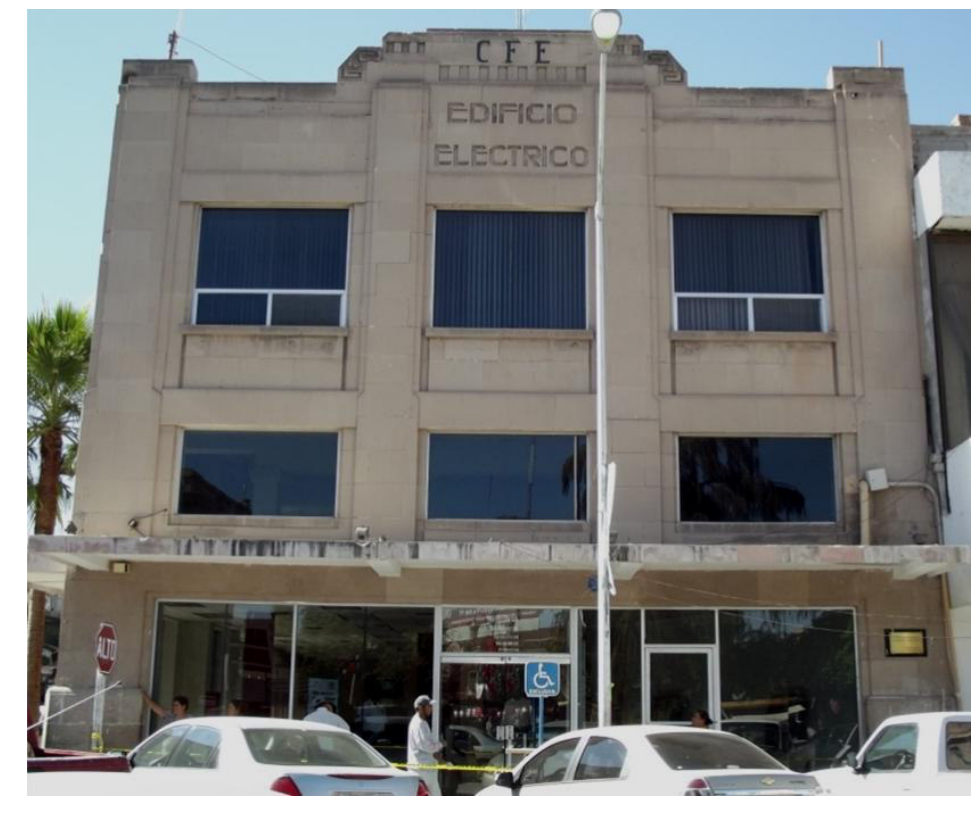

Fachada principal sobre la calle Valdés Carrillo.

El piñón se eleva escalonadamente en dos niveles con recortes de líneas oblicuas. En el primer nivel, en los extremos, hay unas decoraciones de grecas encontradas ornadas con filamentos y que envuelven a un elemento vegetal. Las decoraciones florales 
resguardadas por contornos geométricos son uno de los muchos componentes del Art Déco Zigzag, lo mismo que los recuadros rehundidos situados por encima del letrero y que hacen juego con los dos recuadros del segundo nivel colocados en los extremos. Finalmente para darle todavía más elevación al piñón, una pequeña prominencia rectangular plana está remetida del nivel de la pared, con lo cual se consigue prolongar la altura y reforzar la geometricidad de todo el remate.

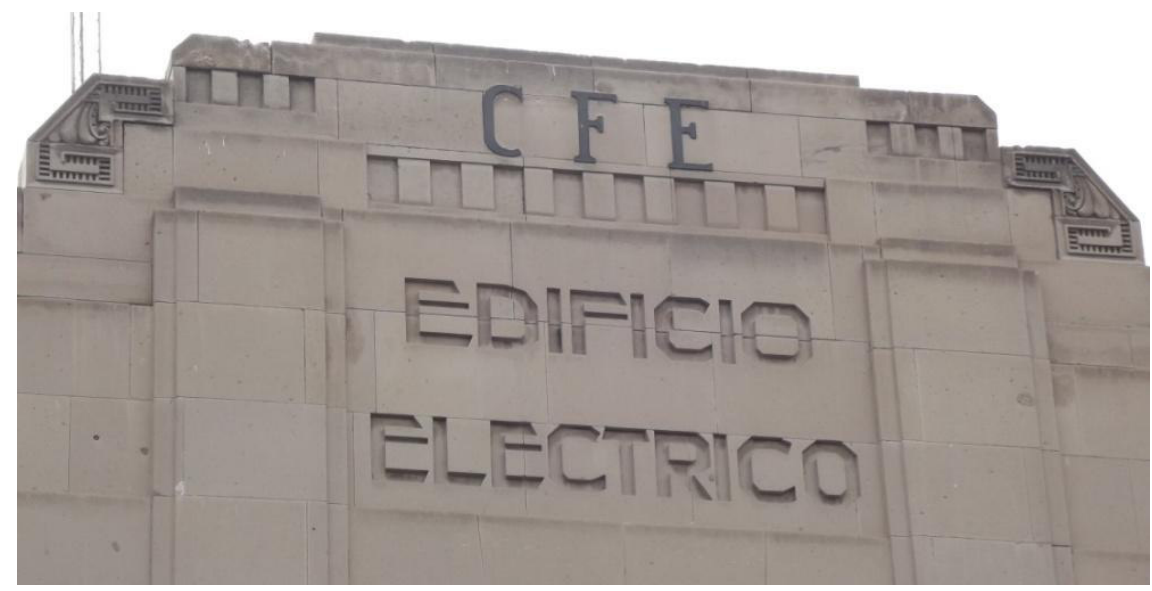

Detalle del piñón de la fachada principal.

La fachada lateral sur que da a la avenida Juárez se compone de ocho tramos que a su vez conforman tres portadas, interesante solución que describiremos de izquierda a derecha.

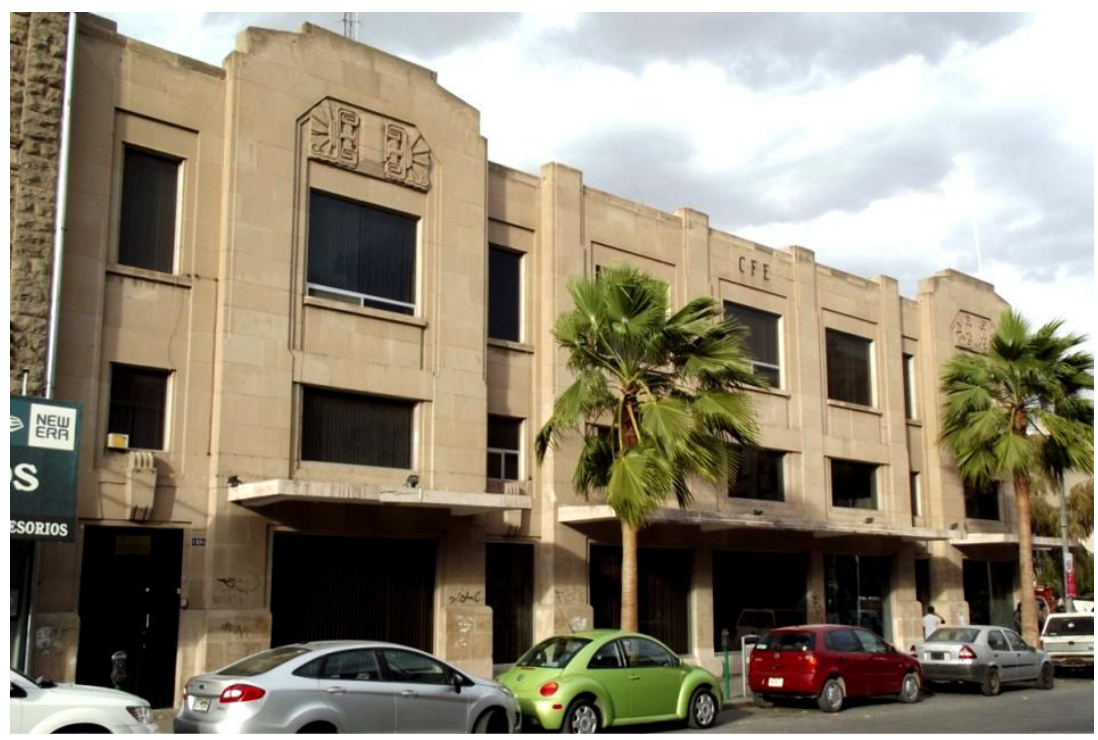

Fachada lateral sur que da a la avenida Juárez con sus tres portadas. 
Tres partes forman la primera portada. En el primer nivel se encuentran dos accesos, ya que el de la izquierda sigue siendo entrada para las oficinas del segundo piso y el de la derecha está convertido en ventana. Al centro un gran vano para ventana. Los tres vanos están recortados con perfiles angulares y de la misma manera que en la fachada oriente, los muros se resaltan a manera de rodapié. En los cuerpos laterales por arriba de los vanos se empotran unos elementos decorativos en forma de clave. Son unos maravillosos poliedros recortados que descansan sobre un recorte de un trapecio invertido sobre la trabe; en la parte baja llevan un par de delicadas escisiones y en la alta cuatro delicadas bandas curvas. El ejercicio compositivo que hizo con estos adornos el autor de este edificio es de una marcada estética Art Déco del periodo Zigzag, ya que conjuga los elementos geométricos con recortes e inclusión de líneas rectas y curvas, creando un objeto suntuoso, cuya función es solamente la decorar y enfatizar la elegancia geométrica del inmueble. Las pequeñas ventanas intermedias y las del segundo nivel de los cuerpo laterales, se resguardan por el marco seccionado angularmente hacia adentro; en la parte del remate superior de estos cuerpos laterales, la elevación se recorta hacia adentro, pero en el izquierdo un cubo continúa con el sentido ascensional y escalonado del edificio. El cuerpo central de esta portada está levemente adelantado del nivel de la superficie de los cuerpos laterales, con lo que se obtiene un juego de planos alternados; por encima del ventanal central hay una marquesina y arriba de ésta una ventana rectangular en posición horizontal con el recuadro con perfiles angulares incisos, proyectan aún más el movimiento de planos, para continuarlo con las jambas que se recortan de manera oblicuamente y se prolongan para bordear de forma ochavada a la ventana del segundo piso. Tres recortes de filamentos enmarcan a esta ventana, intensificando el geometrismo de planos y superficies.

En un segmento por encima de la ventana hay un relieve al centro que figura a una columna sobre base y con un suave recuadro en la parte frontal; de los lados salen unas presillas que se unen a unas letras "E" (con la particularidad que la del lado derecho está en posición inversa), conformadas por unas grecas molduradas de donde emanan desde la parte central unos zigzags sobre unas bandas, los cuales representan a los rayos de la energía eléctrica, ya que las letras "E" significan Edificio Eléctrico. A los extremos unos dobles rayos de luz brotan de la estilización de unas pirámides truncadas sobre base colocadas en posición vertical, representación de la luz eléctrica que se expande y alumbra 
a la región; y abajo unas dobles volutas con ondulaciones, simbolización del agua de las hidroeléctricas que producen la energía eléctrica que provee la luminosidad.

El relieve es un fenomenal diseño de elementos del Art Déco Zigzag, con toda la semántica de la geometría, las líneas quebradas, los zigzags, los rayos de luz abiertos en su acomodo, así como las grecas que bien podrían ser de influencia prehispánica. Además, es la era de las grandes transformaciones tecnológicas en el país y exactamente la energía eléctrica que iba de la mano con el progreso de la época, se representaba con esas líneas quebradas, parodiando a los rayos de las fuerzas de la naturaleza. Relieve del más fino Art Déco Zigzag que no sólo representa a este arte en el Noreste de México, sino en todo el país.

El remate superior es un piñón que sobrepasa el nivel de la altura y se eleva escalonadamente, formando la abstracción de un moño cayendo en tres partes, composición también inconfundiblemente Déco Zigzag.

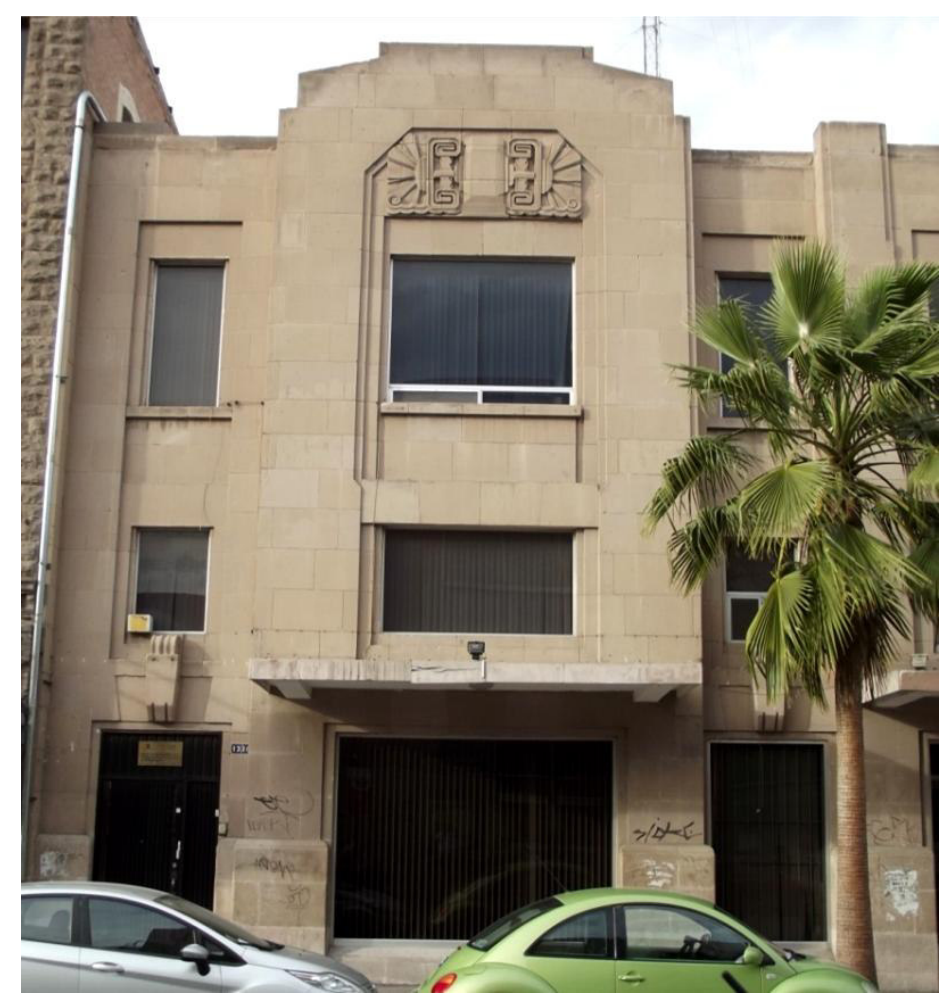

Primera portada de la fachada sur. Por arriba de los vanos laterales del primer piso se encuentran las claves trabajadas en un depurado Déco Zigzag. 


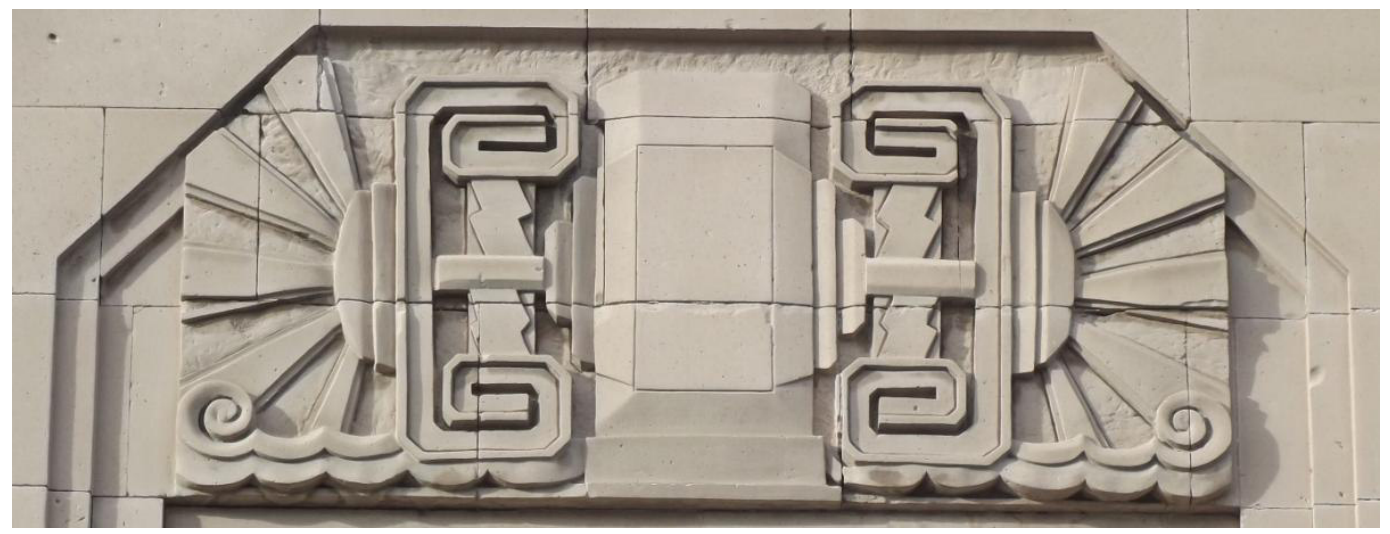

Relieve del segundo piso de la primera portada de la fachada sur.

La segunda portada está desplazada levemente más hacia el frente, pero menos que las otras dos. Al igual que la fachada principal y la primera portada de la fachada sur, hay una parte del primer nivel resaltada a manera de rodapié. Tres ventanales cuadrados están recargados sobre zócalos biselados. Una marquesina abarca los tres tramos y divide los dos pisos. De la misma forma que la portada anteriormente descrita, las ventanas que se localizan por arriba de la marquesina son rectangulares colocadas en posición horizontal y el contorno está recortado con perfiles angulares. Las tres ventanas del segundo piso llevan marcos seccionados y debajo del repisón se repite el mismo recuadro tablereado.

Lo interesante de esta portada es cómo el arquitecto resuelve las cuatro pilastras que se elevan por arriba del nivel de la techumbre; a la altura de la trabe de las ventanas que están por arriba de la marquesina, las pilastras de los extremos se recortan mínimamente, pero las cuatro a tres cuartas partes de la altura, también se seccionan con un perfil angular, con lo que induce a elevar la representación de linealidad ascendente.

Con tres bases colocadas tenuemente hacia el interior del nivel de la superficie, más la altura de las pilastras, se adquiere un dinamismo de cubos que suben y bajan, los cuales conjuntamente con los recuadros y perfiles de los vanos, conciertan un dibujo perfecto de líneas verticales, horizontales, rectángulos y cuadrados de la más exquisita Tendencia Geometrista y del Art Déco de la variante Zigzag.

Las letras “CFE” (Comisión Federal de Electricidad) que están en el arquitrabe de la ventana central, fueron puestas después de 1960 cuando se nacionalizó la industria eléctrica. 


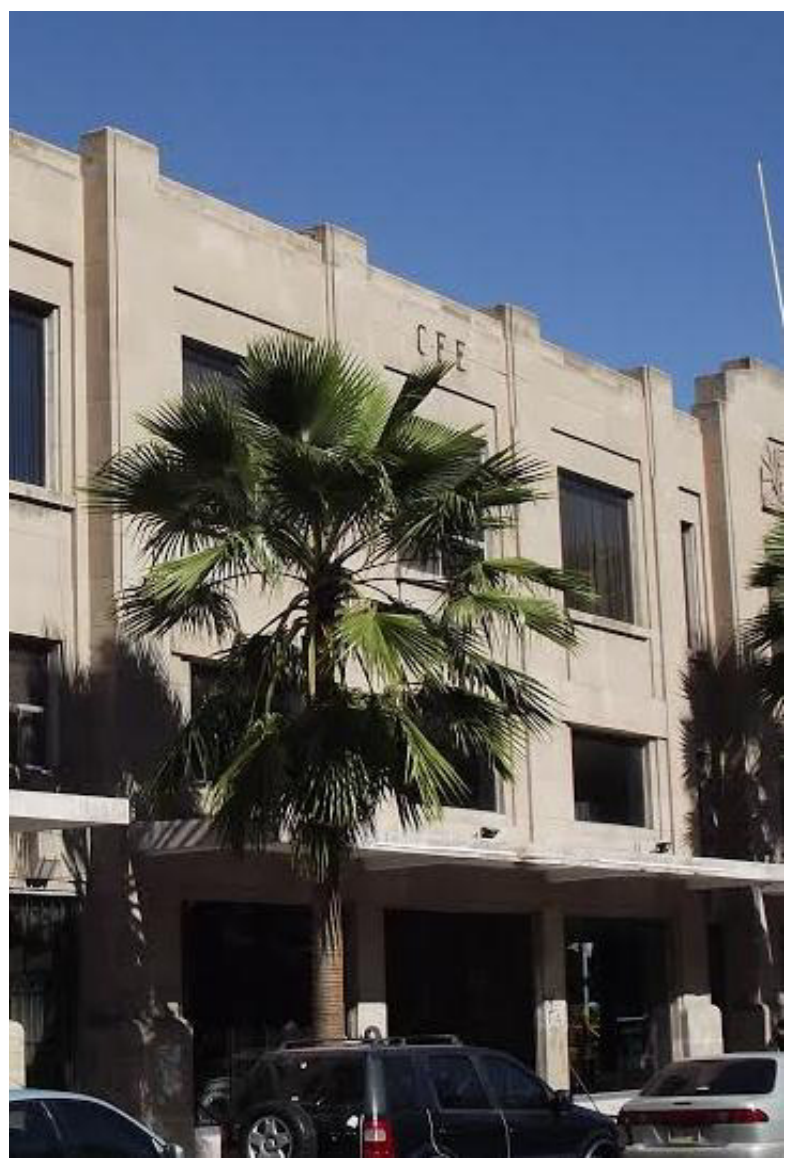

Segunda portada de la fachada sur que se compone de tres tramos.

La última portada luce el mismo diseño que la primera, a excepción que sólo tiene dos tramos: el izquierdo y el del centro. Así como fue descrita la primera portada, el tramo lateral izquierdo de esta tercera portada es análogo a los laterales de la primera, así como el central que ostenta fielmente los mismos elementos, incluyendo el sorprendente relieve y el remate en forma escalonada. Toda esta portada también lleva la marquesina que divide a los dos pisos. En el segundo nivel del cuerpo central, el ángulo de intersección con la fachada principal presenta una incisión que arranca en forma de punta de flecha y mira hacia ambas partes en el segundo piso, por lo que esta unión se distingue y se ajusta a los perfiles angulares y recortes lineales de todo el conjunto. 


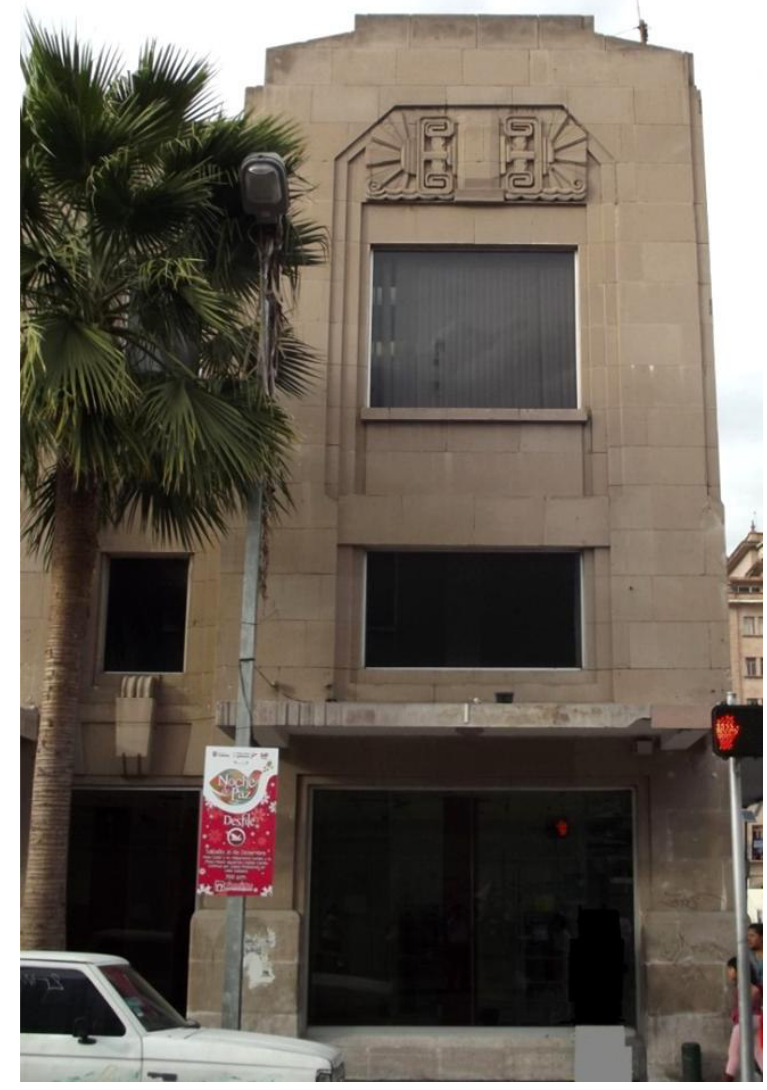

Tercera portada de la fachada sur que solamente abraca dos tramos.

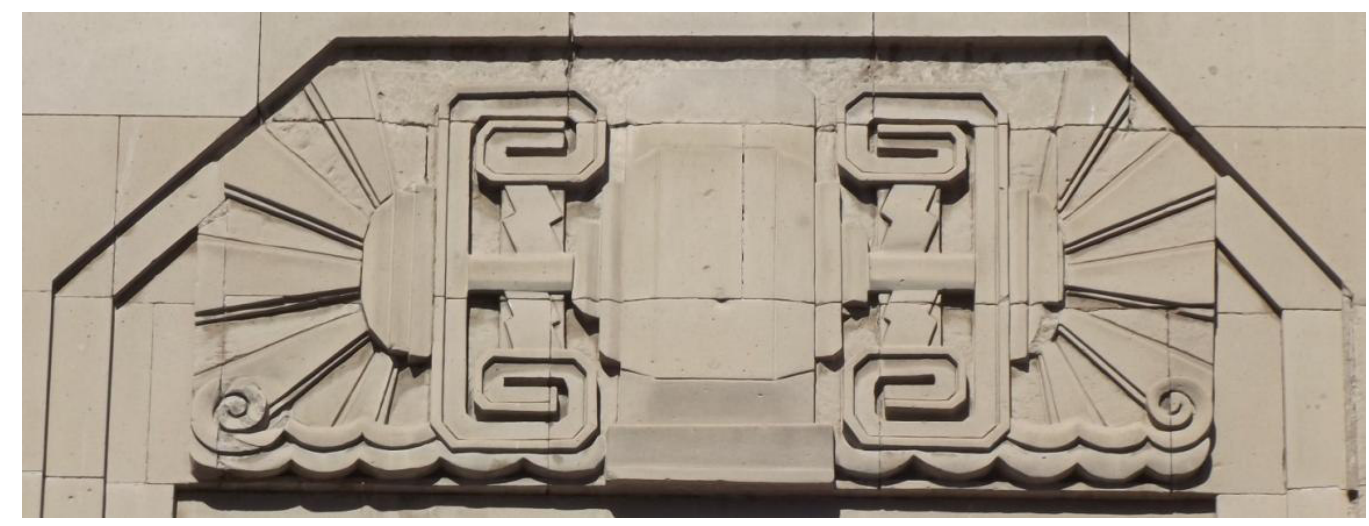

Relieve de la parte superior de la tercera portada de la fachada sur.

Este edificio es toda una armazón de cuadrados, rectángulos, cubos, líneas rectas, quebradas y oblicuas; juego de planos y superficies, así como de relieves geometrizados. Categóricamente, un claro ejemplo de Art Déco Zigzag, dentro de la Tendencia Geometrista, pues es un triunfo más un homenaje a la correlación de elementos 
compositivos con formas geométricas, que al miso tiempo se desempeñan como decoración y ornato.

Gracias a que el uso del Edificio Eléctrico ha sido ininterrumpido desde su inauguración, se ha mantenido en buenas condiciones de conservación, aunado a que haya sido declarado patrimonio arquitectónico de la ciudad.

\section{c. Hotel Galicia}

Este hotel se ubica en el centro de la ciudad entre la avenida Juárez y la calle Cepeda, donde se encuentra la fachada principal con dirección al poniente y enfrente de la plaza principal. Aunque no se tiene el dato preciso de su construcción, fue en los años treinta del siglo XX cuando se erige, que por sus componentes decorativos bien pudo haber sido durante los primeros años de dicha década. Fue mandado a edificar por un agricultor español de nombre Fernando Rodríguez, avecindado en la ciudad y construido por el contratista Cesáreo Lumbreras, ${ }^{245}$ utilizando materiales como la cantera y el concreto armado. Es evidente que el señor Rodríguez quiso darle un toque español con referencias neomudéjares, recuerdos del Modernismo o Art Nouveau, pero a la vez con la inserción de detalles de la modernidad de la época en que se edifica y de ahí que también lleve ornatos del Art Déco.

El edificio tiene una planta cuadrangular, aunque en la intersección de las calles se forma una pequeña fachada en ochavo. Es de dos plantas y aún sigue funcionado como hotel, pese a su mal estado de conservación. En 1992 fue declarado por el gobierno municipal como monumento histórico de la ciudad.

Este inmueble posee una amalgama de estilos, donde se combina una intención del Colonial Californiano, el Neomudéjar, resabios de Art Nouveau y elementos de Art Déco "en su fachada como el zig-zag en el balcón principal", ${ }^{246}$ por lo que éstos últimos serán los que describiremos. La parte exterior es la que ostenta la decoración, ya que en la parte interior sólo se conserva en la estancia un vitral con ornatos florales. En síntesis, es un edificio bastante ecléctico que a la vez combina acertadamente sus ornamentos.

\footnotetext{
${ }^{245}$ Carlos Castañón Cuadros, Op. Cit., sin página.

246 Ídem.
} 


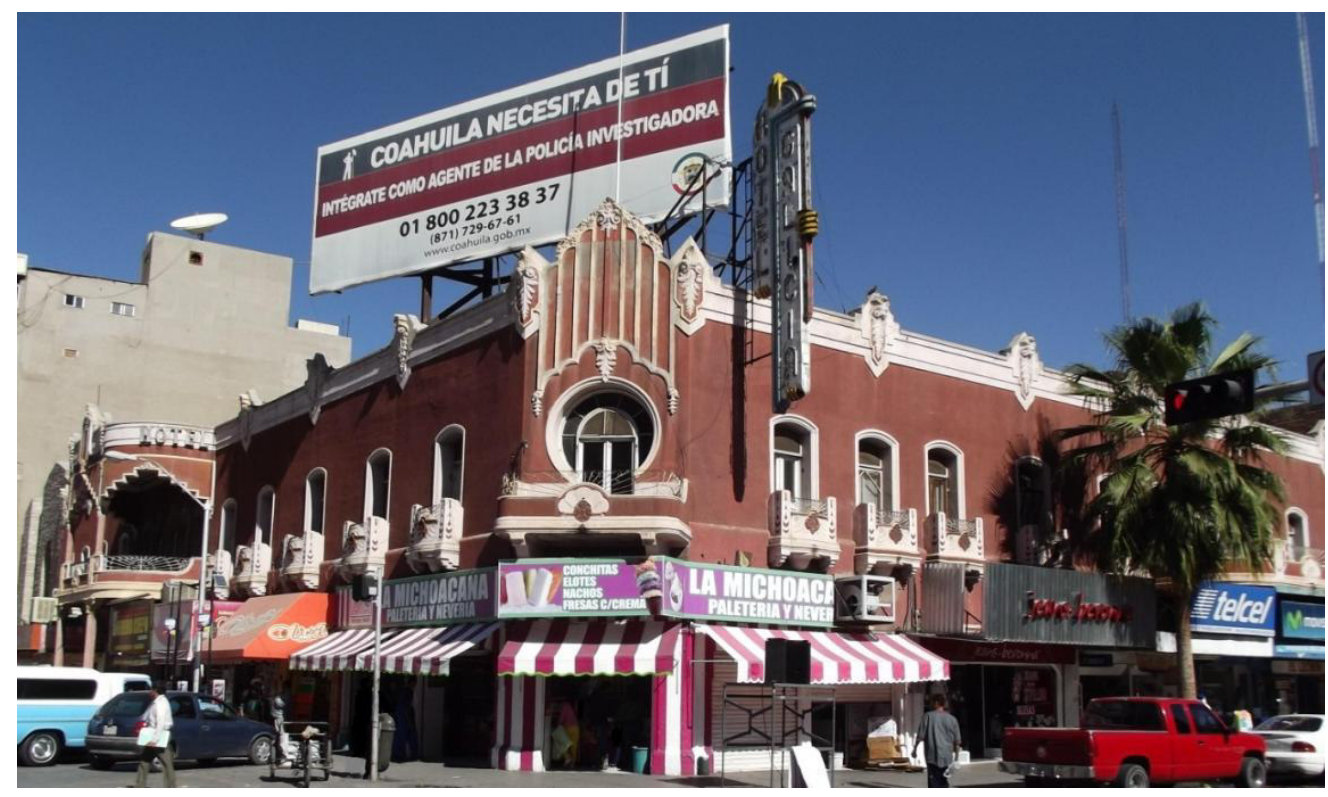

Vista general.

Por la calle Cepeda está el acceso al hotel. Tiene un pórtico y balcón que se desplazan hacia el frente. Del lado izquierdo de la puerta se conservan dos ventanales originales; en medio de los dos hay una moldura floreada de donde cae un adorno conformado por tres líneas verticales, siendo la central de mayor tamaño. En la parte superior de un ventanal cuadrado se dibujan un ángulo recto y luego unos trapecios que dan la idea de resaltar un dintel, donde el trapecio envuelve a un ornato floral. Estos detalles decorativos eran muy usuales dentro de la estética del Déco Zigzag de los años treinta.

El balcón redondeado en las esquinas, entre los diversos elementos decorativos que ostenta, destacan como Art Déco los zócalos de las columnas, los cuales llevan una moldura rectangular y acodada en la parte central superior que resguarda a ornatos a manera de telas curvilíneas sobrepuestas y tres formas puntiagudas y redondeadas compuestas por pequeños cuadrados. Típicos elementos decorativos del Déco Zigzag que remiten a la formas orgánicas geometrizadas. A los lados de los zócalos, salen tres líneas curvas terminando en pequeños roleos, que si bien pueden venir del Nouveau, son bastante rígidas por lo cual forman parte también de Déco; igualmente sucede con la reja del barandal, que con la disposición radial remite a las composiciones que denotaban la fuerza de la energía o las luces espectaculares de Hollywood, pero a la vez con los adornos de 
dobles roleos nos lleva a pensar en ornatos del estilo Florale, la variante italiana del Art Nouveau.

Lo que sí es netamente Déco Zigzag es la parte superior del balcón, donde por medio de unos escalonamientos moldurados ascendentes y descendentes van componiendo un magnifico zigzag que en las columnas se une a través de un ángulo agudo articulado con una moldura floral. Este fastuoso zigzag un elemento muy destacable Art Déco que resalta la decoración geométrica del edificio, en medio del eclecticismo decorativo que presenta la construcción.

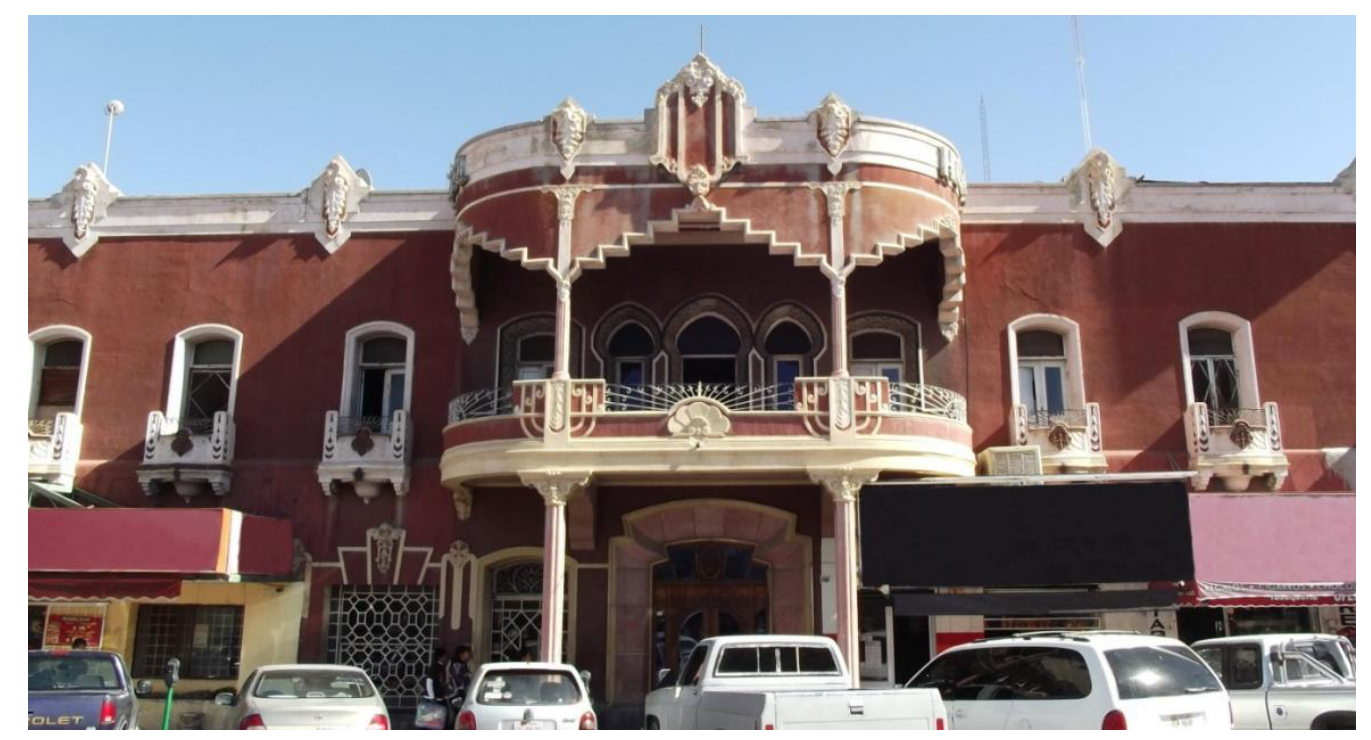

Acceso de la calle Cepeda. Del lado izquierdo de la puerta se miran los adornos Déco Zigzag.

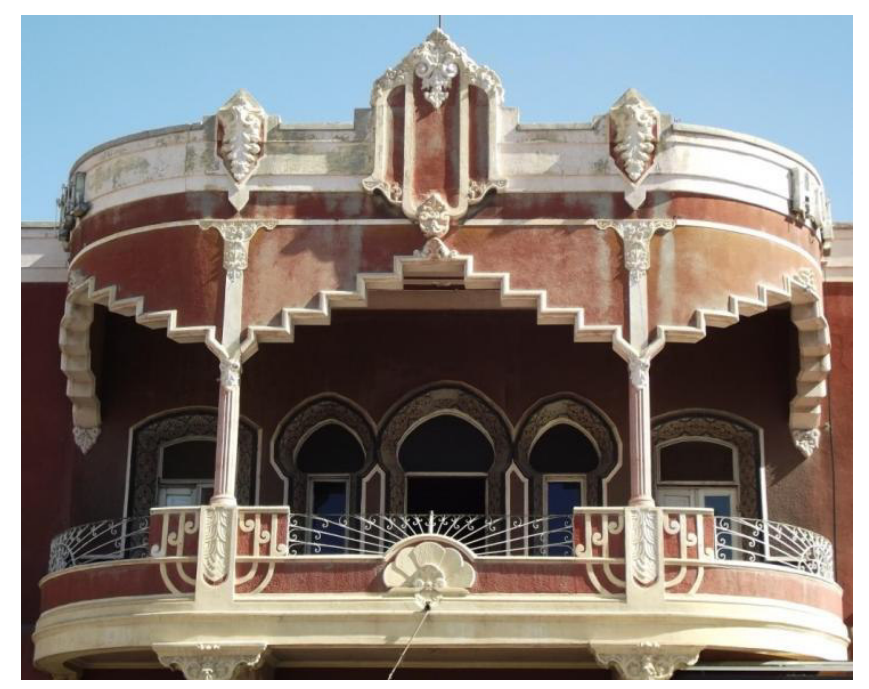

Balcón principal de la calle Cepeda. 


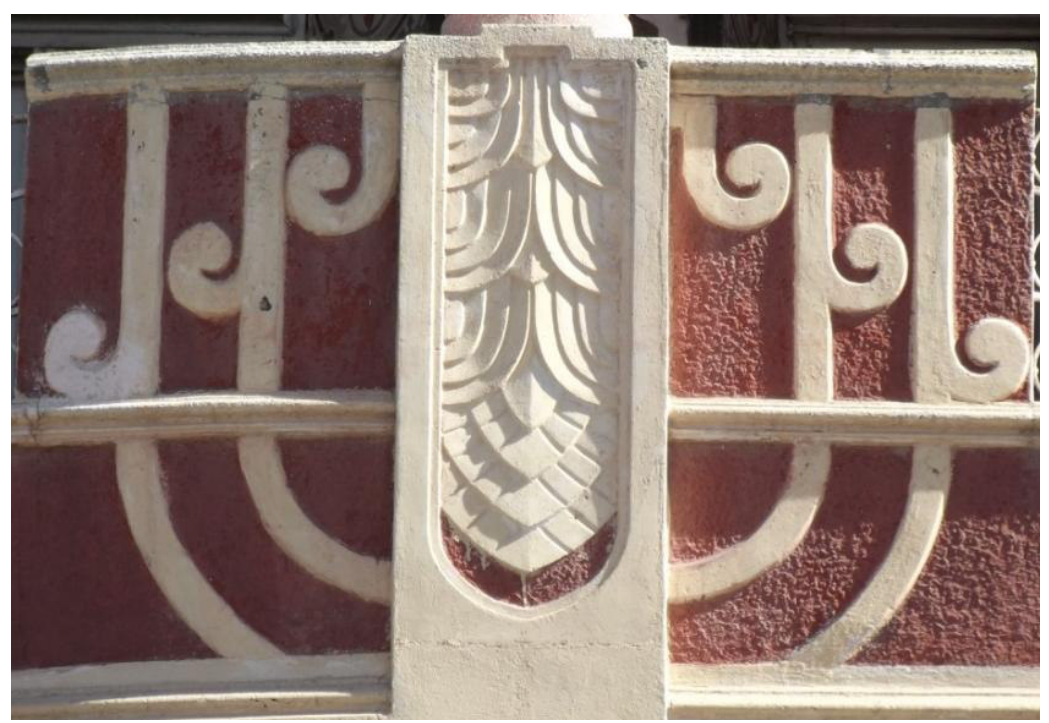

Detalle decorativo del zócalo de las columnas del balcón principal de la calle Cepeda.

En el segundo piso de las fachadas tanto de la calle Cepeda como de la avenida Juárez hay unos balcones que llevan también decoraciones Déco. Las zapatas que sostienen los balcones van en pares, una mayor y otra menor, y se conforman de tres elementos escalonados. Los antepechos llevan rejería como el balcón de la calle Cepeda, con forman radiales y volutas; al centro hay una adorno floral y de las esquinan emanan unos abanicos que van creciendo de menor a mayor, propagando la sensación de cinetismo de la mano con la geometricidad. Las pequeñas pilastras de los lados están elevadas en la parte superior y una moldura sigue la misma forma, enmarcando una decoración que asemeja hojas de palmera pero en posición inversa, que termina con dos ángulos curveados y una luna en cuarto creciente.

Estos ornatos de los balcones del Hotel Galicia reflejan dos variantes del Déco: por un lado, las zapatas, el antepecho y la composición de las pilastras son del tipo Art Déco Zigzag y, por otro, los adornos orgánicos de palmeras son del Tropical Déco, pues la cercanía con el sur de los Estados Unidos y la temperatura cálida de la zona donde se ubica Torreón, aunque sin playa, son determinantes geográficos para la influencia de esta variante de Art Déco. 


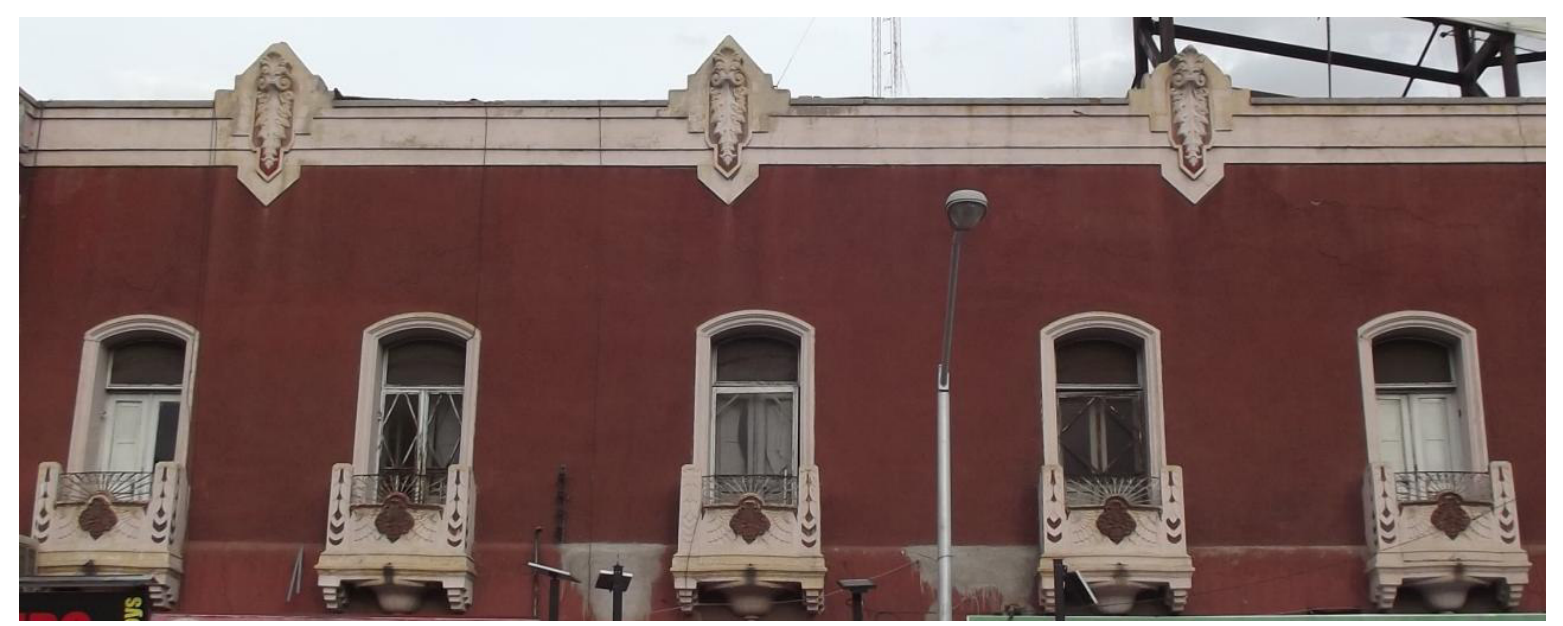

Balcones de la calle Cepeda.

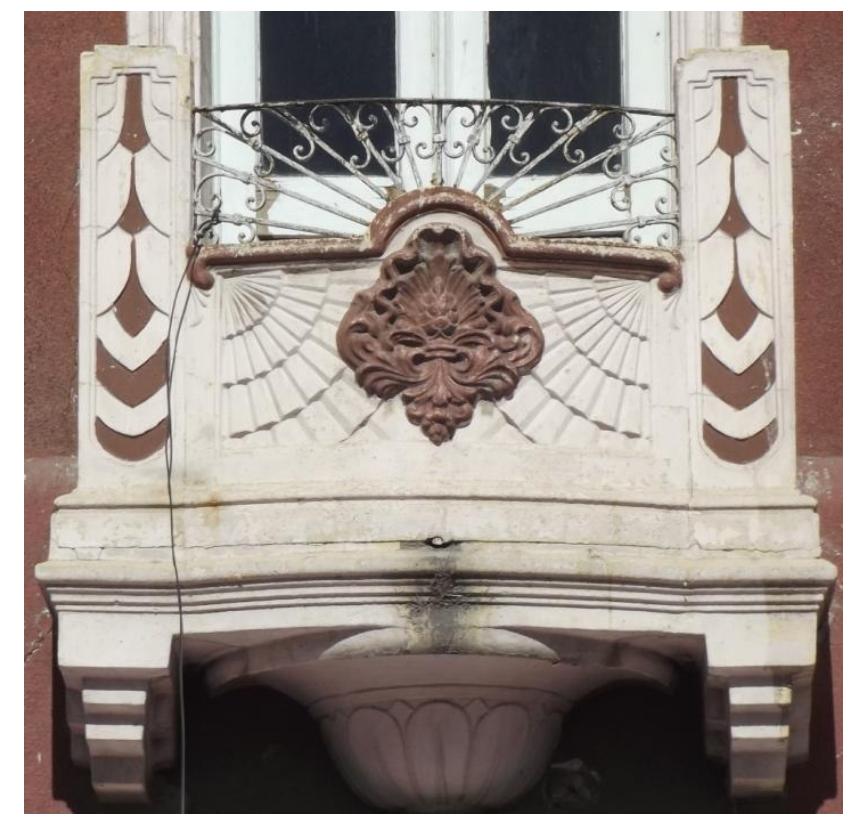

Detalle de las decoraciones de un balcón de la calle Cepeda.

En la avenida Juárez, además de los balcones mencionados, ya casi para terminar la fachada hay un balcón semicircular que tiene en la rejería la misma composición del balcón de la calle Cepeda. Tiene un par de pilastras con la misma decoración del mencionado balcón, con la diferencia de que las líneas curvas que están a los lados de las pequeñas pilastras, solamente son dos en lugar de tres. 


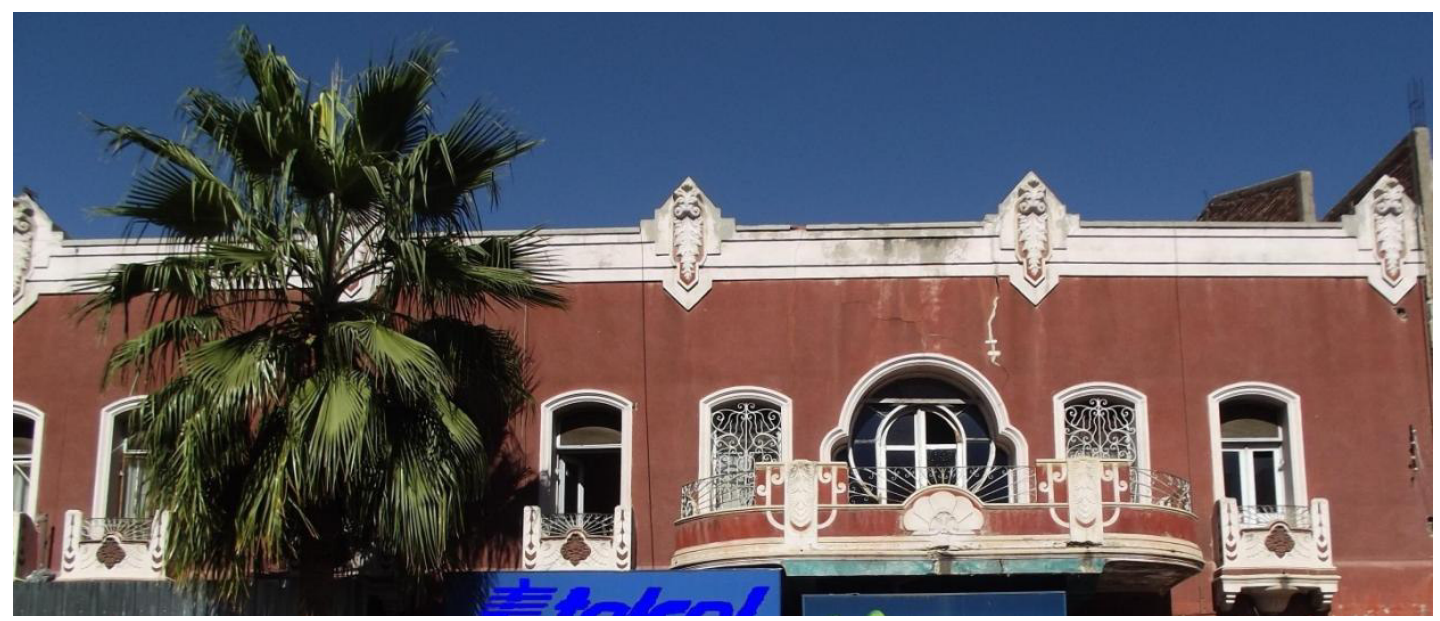

Balcones de la avenida Juárez y el balcón de forma semicircular.

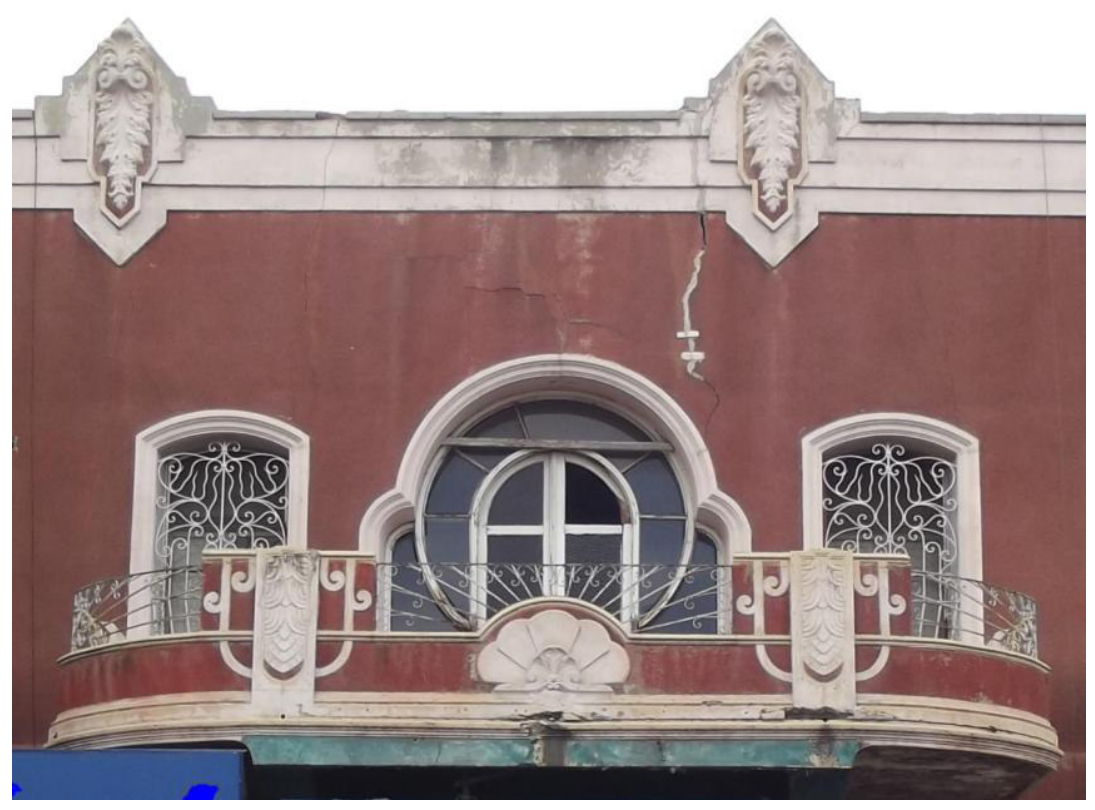

Detalle del balcón de la avenida Juárez.

El letrero original en lámina aún sobrevive. En un aparatoso deterioro, todavía conserva las luces de las letras que en algún tiempo le dieron el hechizo deslumbrante de la modernidad eléctrica. Como aquellos letreros de los cines que llamaban al espectador, así el letrero del Hotel Galicia se empotra verticalmente al muro, pero dejando espacio entre ambos. Está formado por dos partes que se ensamblan por medio de un elemento central que sobresale. La parte superior es curva; lleva una crestería redonda de tres partes, siendo de mayor altura la central. A la mitad y viendo hacia la calle, cuatro molduras curvas se instalan en el letrero como si fueran broches. $\mathrm{Y}$ en cada parte baja se incrustan tres 
pequeños elementos a manera de pinzas. Todas estas molduras están pintadas en color amarillo. La parte donde va la palabra "Hotel" es más pequeña que la que dice "Galicia"; tienen forma rectangular y están separadas por una doble moldura en color azul; una se extiende levemente en tamaño más que la otra en la parte inferior. A la altura de donde inicia la curva las dos molduras envuelven al letrero, continuando su deslizamiento por la otra cara del letrero, para así mirar en ambas direcciones. Este letrero es un caso donde el diseño y los colores remiten al De Stijl y definitivamente es un objeto decorativo del tipo Art Déco Streamline, ya que proyecta elementos tipo aerodinámicos, a la vez que la volatilidad de su colocación.
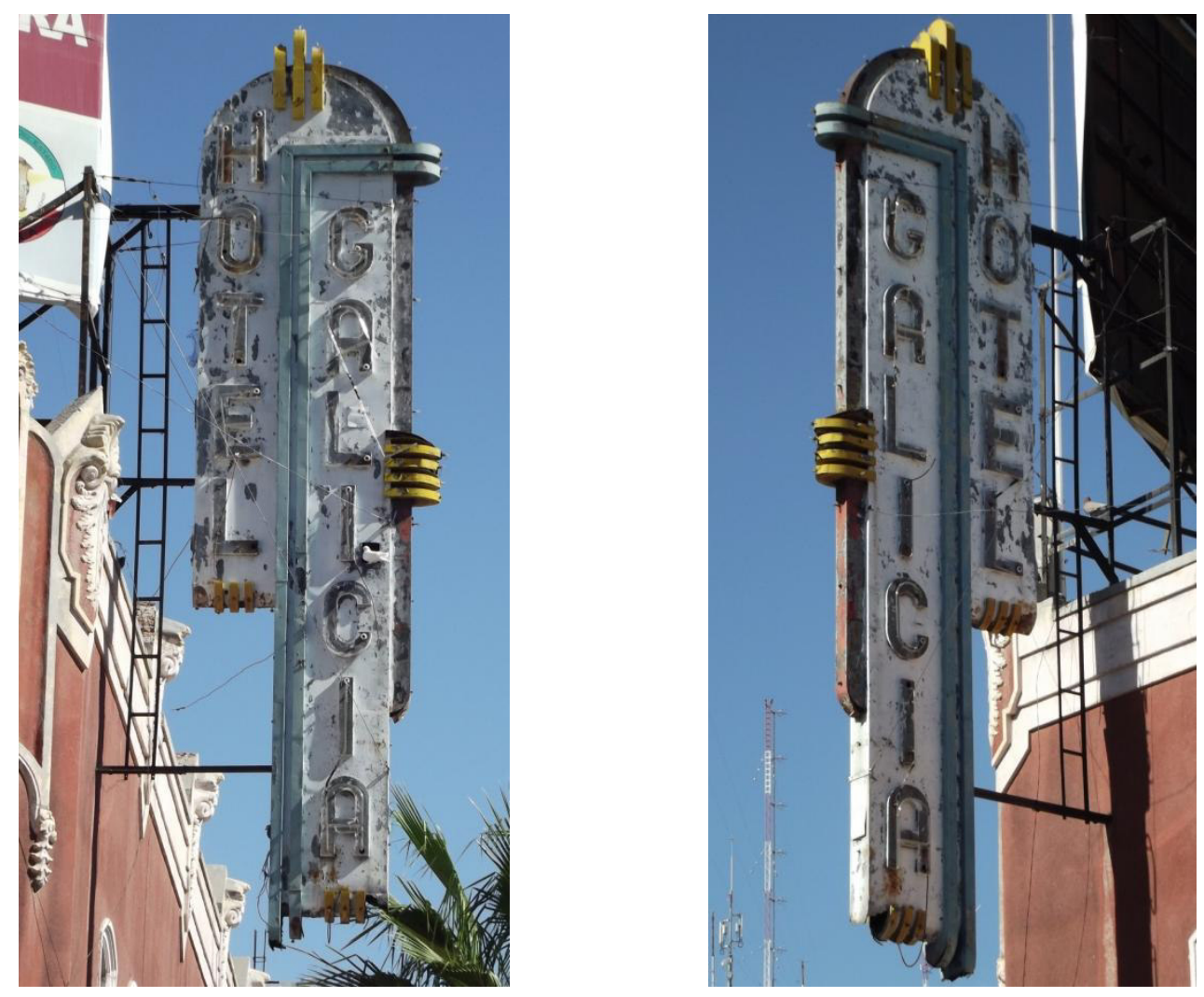

Letrero. Del lado izquierdo con orientación al poniente y del derecho mirando hacia el oriente.

El Hotel Galicia es un interesante caso de Arte Déco Zigzag, Tropical Déco y Streamline, además de ser un claro ejemplo de la Tendencia Decorativista, pues son justamente los adornos Déco, insertos dentro de eclecticismo decorativo, lo que distinguen a este inmueble, que a pesar de su lamentable estado de preservación, sigue mostrando sus llamativos ornatos. 


\subsubsection{ARQUITECTURA DEL OCIO}

\section{a. Estadio de la Revolución}

En una amplia manzana comprendida entre las avenidas Juárez y Allende y las calles Rosendo Guerrero y Juan Gutenberg, en la colonia Luis Echeverría, Sector Oriente, se ubica el majestuoso Estadio de la Revolución, cuya entrada principal está dirigida hacia el sur sobre la avenida Juárez.

La obra fue costeada por el gobierno del Estado, bajo la administración de Nazario S. Ortiz Garza. Para la construcción fue contratado al ya citado arquitecto autodidacta Zeferino Domínguez Villarreal, quien diseñó y dirigió las obras de construcción. Los trabajos se iniciaron en 1931 y fue inaugurado el 15 de septiembre de 1932, para celebrar el aniversario del inicio de las guerras de Independencia. Fue una gran fiesta a la que asistió el propio gobernador, el general Manuel Pérez Treviño (1890-1945), líder del Partido Nacional Revolucionario y toda la plana mayor del poder político y económico de la ciudad y del estado de Coahuila.

La inauguración fue todo un acontecimiento para la ciudad. En el periódico El Siglo de Torreón del viernes 16 de septiembre, en la primera plana se refirió el pomposo acto con emotivos encabezados y subencabezados, tales como:

“EL ESTADIO DE LA REVOLUCIÓN FUE INAUGUIRADO SOLEMNEMENTE. El desfile de los atletas y soldados

ALGO BELLO

Fueron los números de escolares y dragones

A las 10 horas 55 minutos hizo la declaración respectiva el general Manuel Pérez Treviño

COMO FUE LA CEREMONIA

El estadio presentó imponente e impresionante espectáculo. En el ambiente todo era emoción"247

El material utilizado fue el concreto armado aparente y la gradería tiene una capacidad para 8.500 personas. El recinto fue concebido originalmente como un estadio olímpico para competencias de atletismo y futbol, pero más tarde fue adaptado para beisbol, ya que en la zona era el deporte más degustado y practicado en esa época.

${ }^{247}$ El Siglo de Torreón, Torreón, Coahuila, viernes 16 de septiembre de 1932, p. 1. 


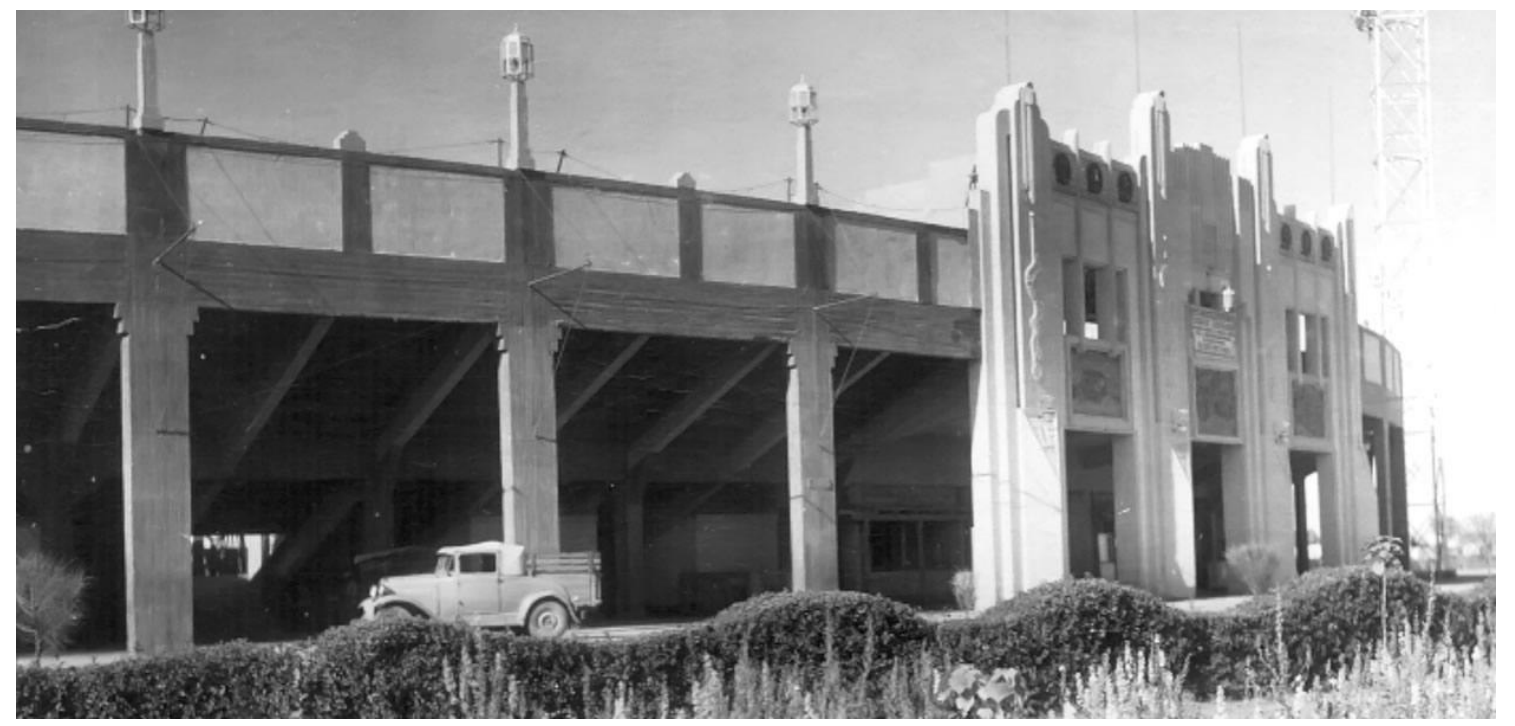

El Estadio recién construido en $1932 .{ }^{248}$

La entrada es una vistosa concepción artística Art Déco. Se compone de tres tramos flanqueados por cuatro columnas. El acceso es a través de tres vanos rectangulares de la misma altura, separados por cuatro contrafuertes recortados que presentan una decoración dentro de un triángulo isósceles invertido. Se trata de unas composiciones geométricas de líneas estriadas dentro de un recorte escalonado y diseños florales rectilíneos.

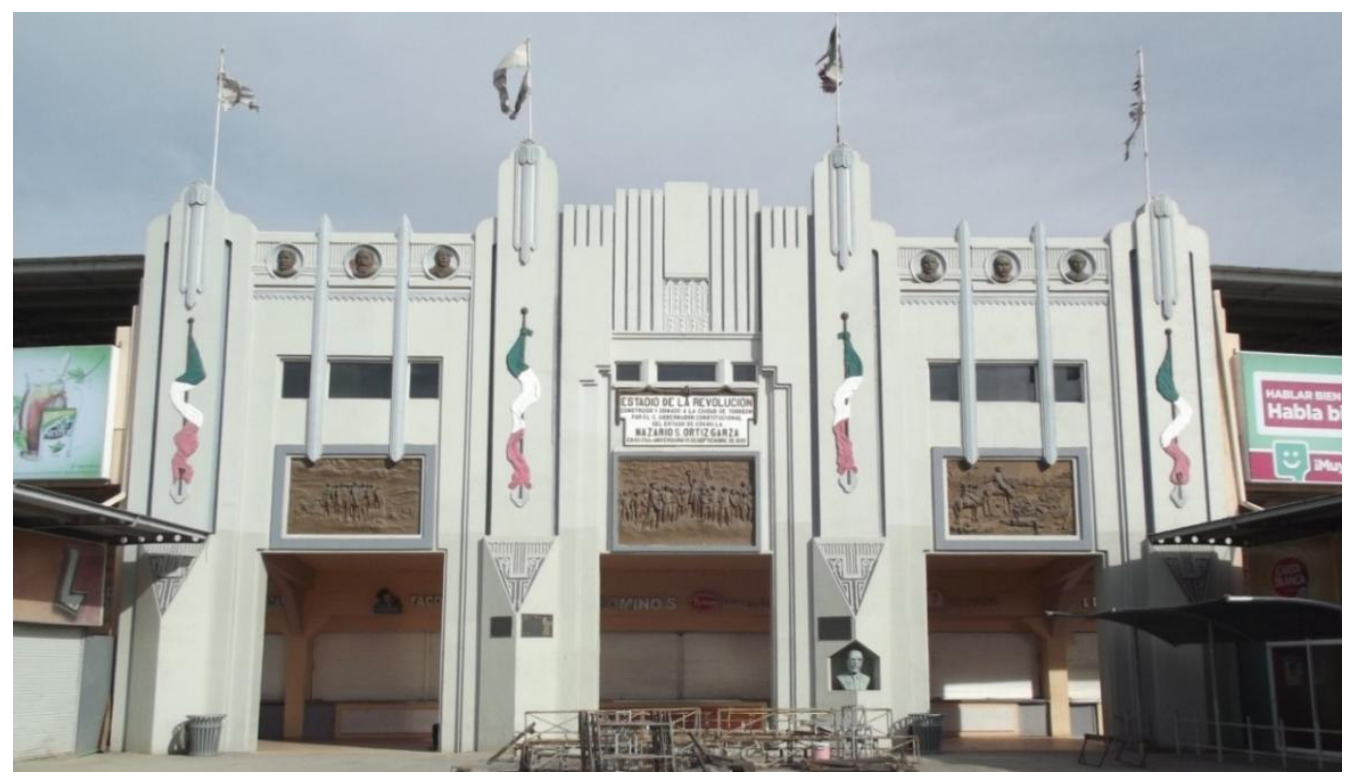

Fachada principal del estadio.

${ }^{248}$ www.metrolaguna.com/estadio-de-beisbol-revolución.html 


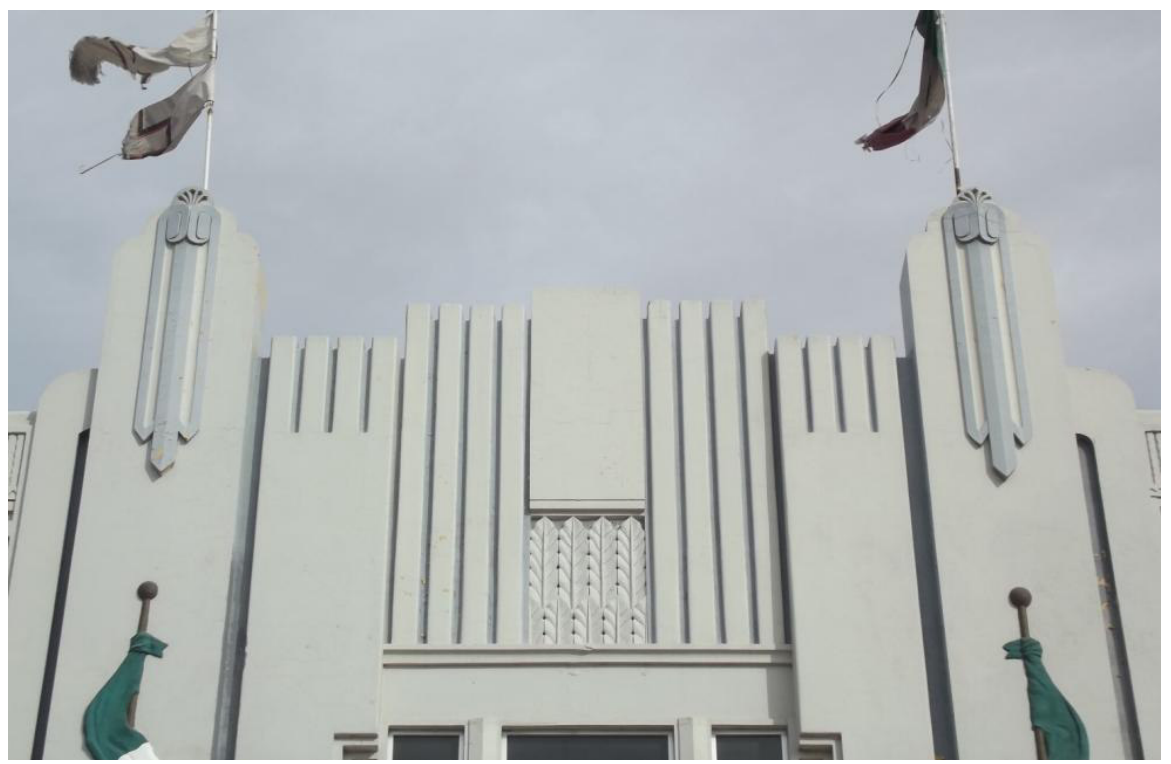

Detalle de la parte superior del cuerpo central

Arriba de los accesos hay tres relieves que tratan temas revolucionarios del Estado de Coahuila, pues es en alusión al nombre del inmueble. Aunque no son Art Déco en su composición, en la parte superior del enmarcamiento del primer y tercer relieve nacen un par de molduras terminadas en punta de flecha que son Déco Zigzag. El primero de izquierda a derecha se refiere al ejército constitucionalista comandado por Venustiano Carranza (1859-1920); el segundo narra la entrada de Francisco I. Madero (1873-1913) a la ciudad de México después del triunfo de las elecciones federales de octubre de 1911, símbolo del triunfo de la Revolución en contra de la dictadura de Porfirio Díaz (18301915); y en el tercero el General Calixto Contreras (1867-1918), destacado militar de las fuerzas villistas, defiende a Torreón contra las fuerzas federales en la batalla de septiembre de 1913.

Estos ensalzamientos de los acontecimientos revolucionarios servían para reforzar el nacionalismo político emanado de las ideologías del Partido Nacional Revolucionario en pleno "Maximato", además de enarbolar las figuras de Madero y Carranza quienes eran coahuilenses, un orgullo para el Estado. Curiosamente, Jesús Ramírez en el libro sobre Zeferino Domínguez dice que los relieves narran la historia del deporte. ${ }^{249}$

\footnotetext{
${ }^{249}$ Jesús Ramírez Rodríguez, Op. Cit., p. 40.
} 


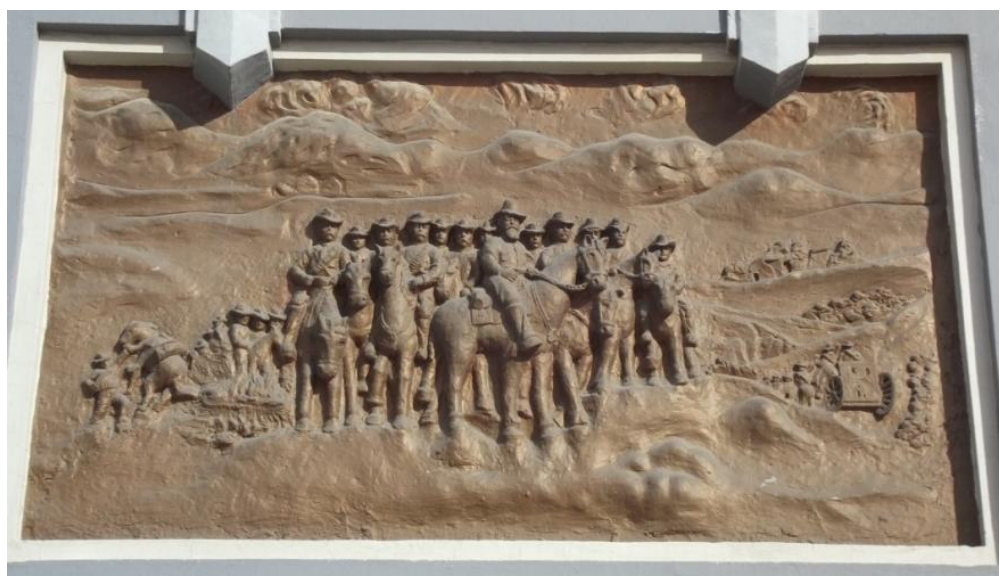

Primer relieve: Venustiano Carranza y su ejército constitucionalista.

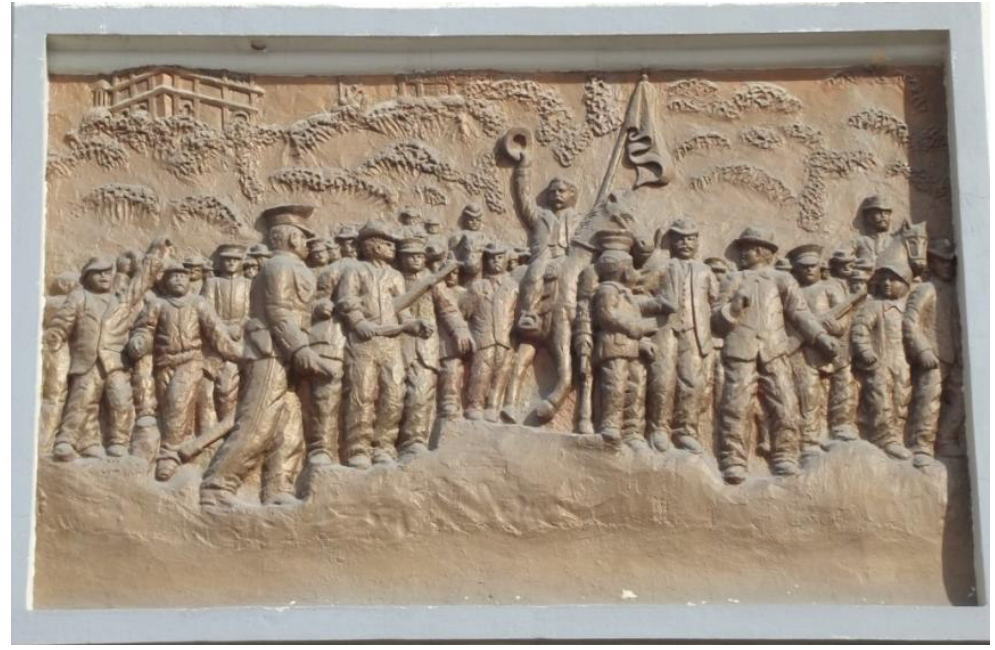

Relieve central: Francisco I. Madero entra a la ciudad de México.

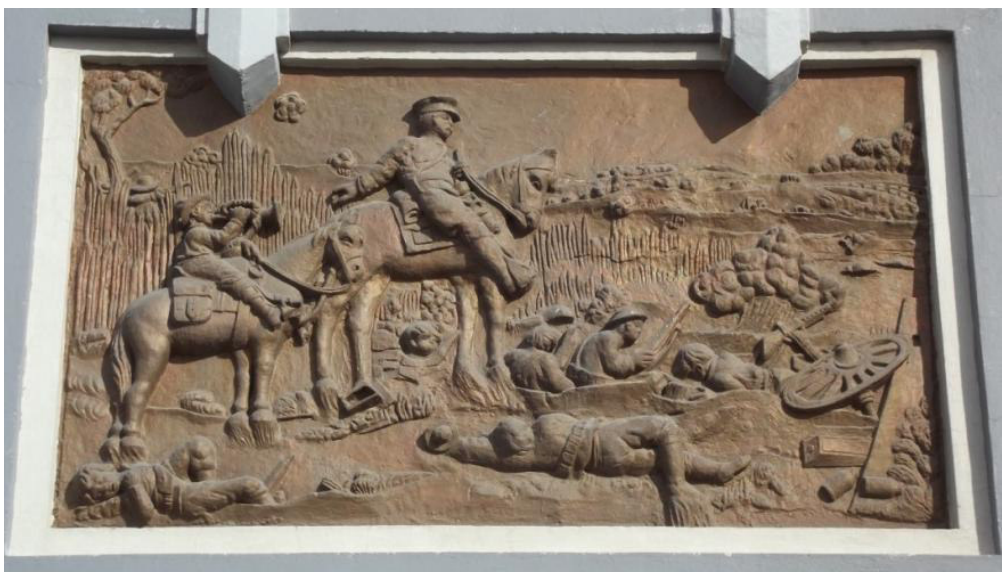

Tercer relieve: el general Calixto Contreras en la defensa de Torreón en septiembre de 1913. 
Arriba del relieve central está una placa con los datos de la edificación del inmueble. La cartela rectangular está recortada en la parte baja y lleva por adorno en la parte superior una colgadura de olivo. El texto dice:

\author{
"ESTADIO DE LA REVOLUCION \\ CONSTRUIDO Y DONADO A LA CIUDAD DE TORREON \\ POR EL C. GOBERNADOR CONSITUCIONAL \\ DEL ESTADO DE COAHUILA \\ NAZARIO S. ORTIZ GARZA \\ EN SU 25/o ANIVERSARIO 15 DE SEPTIEMBRE DE 1932”
}

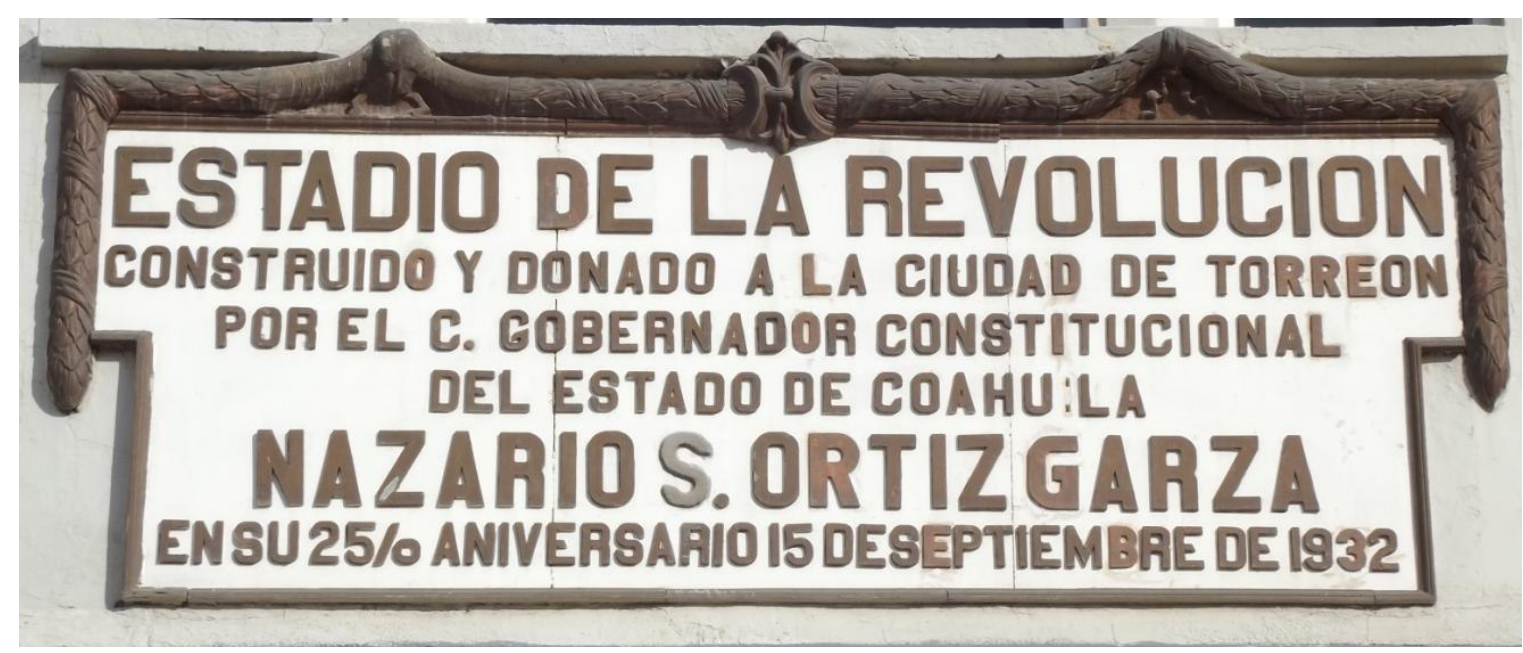

Placa con el nombre del gobernador y la fecha de inauguración.

Lo que aquí desconcierta es a qué aniversario se refiere la placa, pues no es ni del gobierno de Ortiz Garza, ni de la fundación de la ciudad, ni de la Revolución.

A los lados donde se encuentran el relieve central y la placa, el nivel de la superficie se rehúnde doblemente y pares de perfiles angulares siguen una línea escalonada, resaltando el sentido de geometricidad. Por arriba de la placa tres ventanas rectangulares van separadas por molduras con volumen angular. Desde abajo arrancan las jambas de las puertas que se seccionan y se proyectan hacia arriba, terminando en cuatro recortes a manera de bandas que a la vez asemejan unos cactus, elemento utilizado por la variante Pueblo Déco de sur de los Estados Unidos y con fuerte influencia en la región noreste de México, además de que la zona donde se ubica Torreón es bastante árida y se dan ese tipo de plantas. En el centro, el remate se prolonga con mayor altura y va acompañado con cuatro bandas de cada lado, mientras que en la parte central hay un 
adorno de típica raigambre Art Déco: primero tres hojas y la mitad de cada una a los lados, para después colocarse cuatro hojas de mayor tamaño. El diseño inmediatamente nos remite a los elementos fitomorfos de los trabajos de los artistas mencionados en el primer capítulo, tales como Edgar Brandt, Paul Follot o René Lalique. Toda esta parte superior con los adornos de las bandas y del remate central expresan el gusto y conocimiento que Zeferino Domínguez tenía del Art Déco de la época del Zigzag.

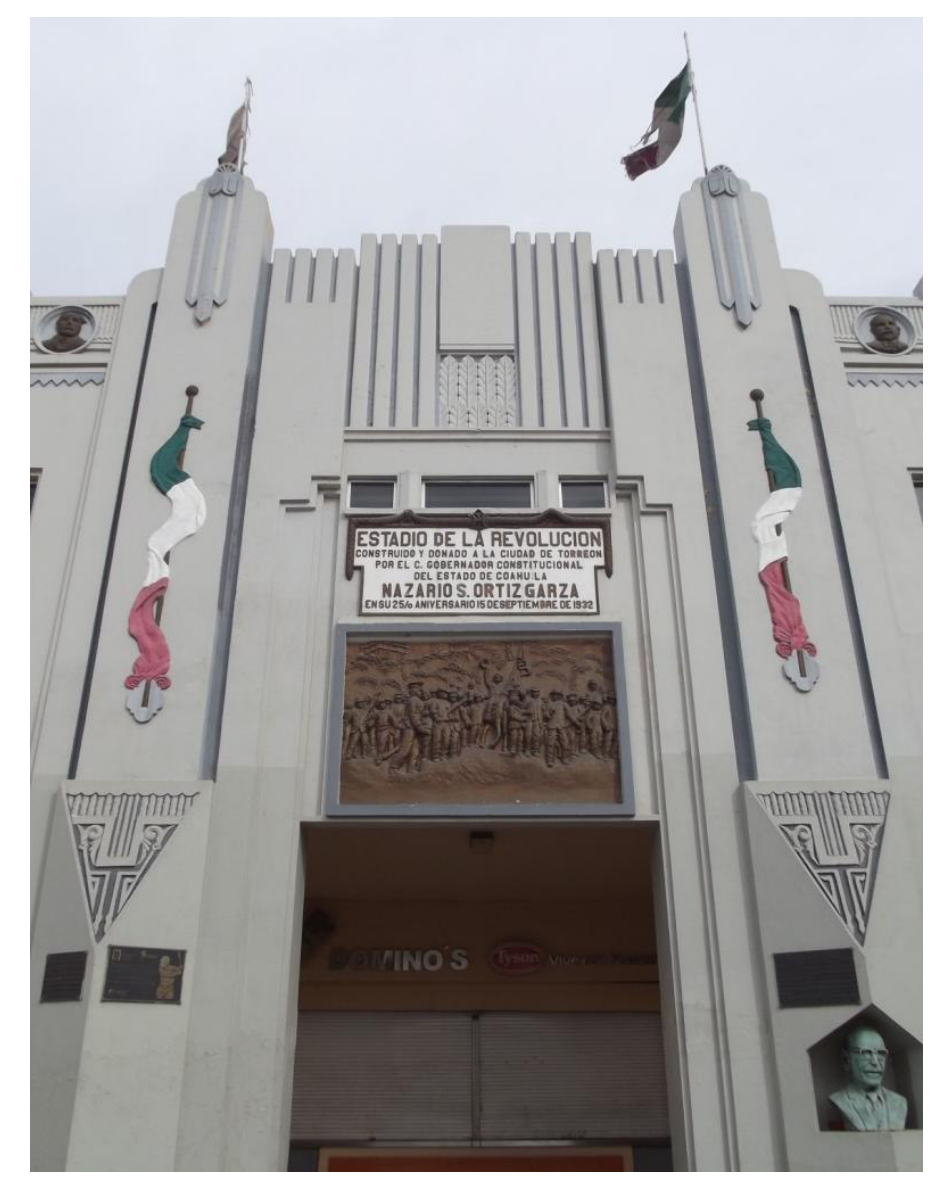

Perfiles rehundidos a los lados del relieve central y la placa. En la parte superior el adorno central fitomorfo con las estrías a los lados.

En las entradas laterales y arriba de los relieves, pares de molduras se elevan por arriba del remate, atravesando unos ventanales rectangulares. Un friso con tres medallones va adornado con unos dentados de triángulos, uno debajo del friso y otro por atrás de los medallones; esto es una muestra más del agrado por el encanto decorativo a través de zigzags que a la vez ilustran un cinetismo decorativo. Los medallones están colocados en 
metopas las cuales llevan una decoración conformada por estrías levemente abultadas, con lo que se aumenta la idea de movimiento. Nuevamente el Déco de tipo Zigzag hace su presencia.
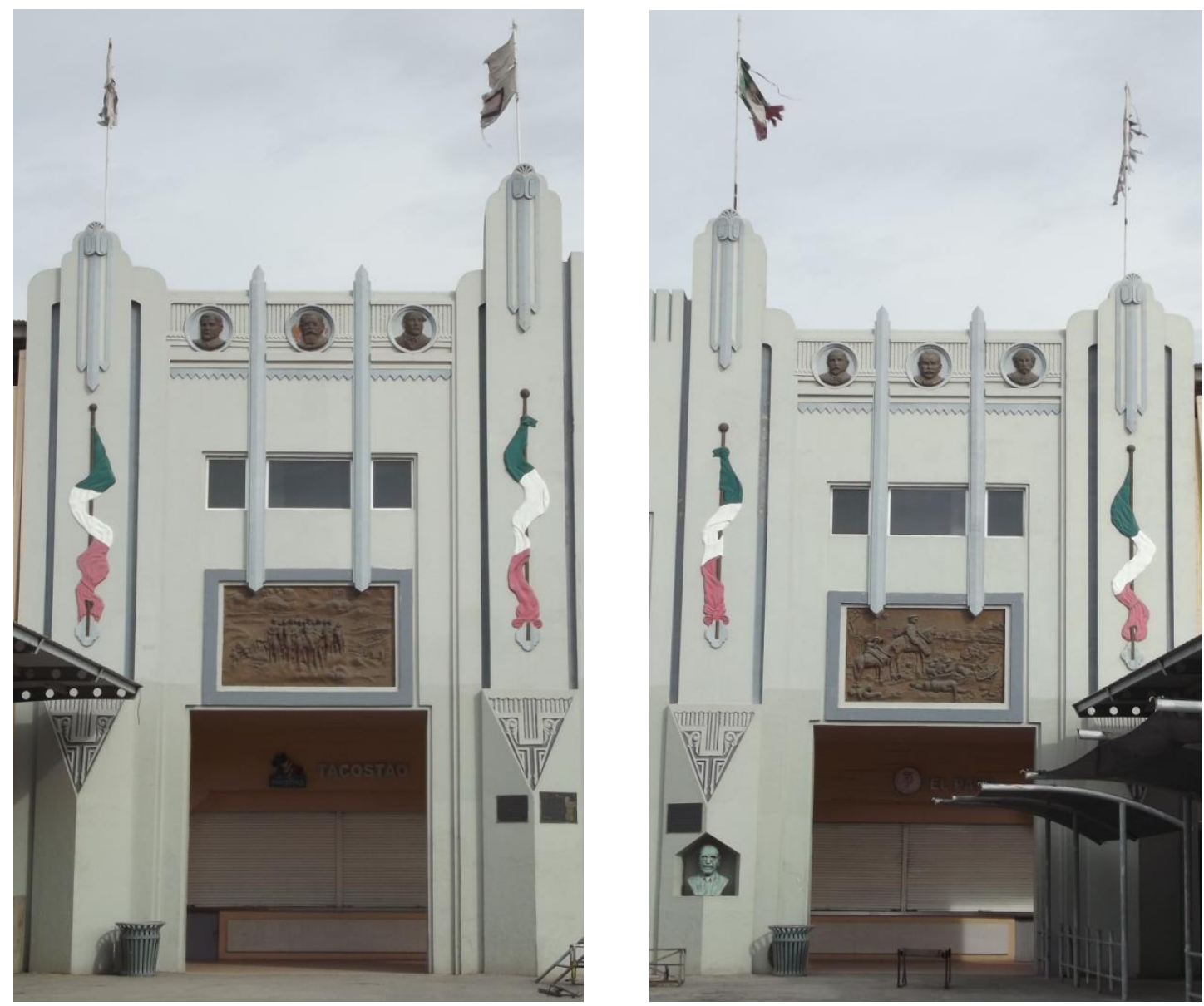

Puertas laterales. Arriba de los relieves las molduras atravesando los ventanales y los frisos.

Con el fin de inculcar y resaltar el nacionalismo político postrevolucionario, en los seis medallones se retratan a personajes de la Revolución.

Del lado izquierdo y de izquierda a derecha están: nada menos y nada más que Plutarco Elías Calles (1877-1945), el “Jefe Máximo de la Revolución”, personaje que conducía los destinos de la nación detrás del trono y líder moral del Partido Nacional Revolucionario; Venustiano Carranza, coahuilense que nació en Cuatro Ciénegas, gobernador de Coahuila y creador del Ejército Constitucionalista para atacar al "Chacal" Victoriano Huerta (1850-1916) asesino de Madero, además de ser Presidente de 1914 a 
1919 en convulsionadas situaciones y creador de la Constitución de 1917; finalmente, el General Manuel Pérez Treviño, nacido en Guerrero Coahuila, fundador con Elías Calles del Partido Nacional Revolucionario (PNR) y en el año de la inauguración del estadio líder del PNR.

En los tres medallones del lado derecho y en el mismo orden aparecen: Francisco I. Madero, otro coahuilense nacido en Parras, Presidente de la República de 1911 a 1913, quien se reveló contra la dictadura de Porfirio Díaz (1830-1915) y fuera asesinado por Huerta, con lo que la Revolución se amplió más y por eso es conocido como el "Mártir de la Democracia”; Álvaro Obregón (1880-1928), Presidente de México de 1920 a 1924 una vez terminada la fase armada, cruel político y militar que mandó matar a todos aquellos que pudieran estorbarle, incluyendo a Venustiano Carranza y que luego de ser reelegido para Presidente es asesinado en 1928; Aquiles Serdán (1876-1910), quien fuera uno de los conspiradores contra Díaz y muere en su casa por los mando militares, por lo que es considerado también como un mártir de la Revolución y que con su muerte se inicia como tal la rebelión contra Díaz.

Sin embargo, ¿por qué están en el mismo lugar Obregón y Carranza, si el primero mandó matar al segundo para quedarse con el poder absoluto de la Revolución? Pues como afirma Abelardo Villegas al hablar del nacionalismo político que se desarrolló bajo los dictados del gobierno postrevolucionario y unipartidista: “...la historia los describe como enemigos todos entre sí, como había ocurrido antes en la Independencia: Zapata contra Madero, Villa y Zapata contra Carranza, Carranza contra Obregón, Calles contra el obregonismo, Cárdenas contra Calles...Pero la ideología nacionalista sostiene que a través de estas diferencias personales se consiguió la unidad nacional, entonces se les tributa homenajes en sus correspondientes efemérides y a los principales se le ha reinhumado en el monumento a la Revolución". 250

Lo desconcertante, es que pese a las vidas negras de la mayoría de los protagonistas honrados por su participación en la Revolución, son tratados como héroes por parte del gobierno priista.

250 Abelardo Villegas, "El sustento ideológico del nacionalismo mexicano", El Nacionalismo y el Arte Mexicano (IX Coloquio de Historia del Arte), México, UNAM, 1986, p. 397. 


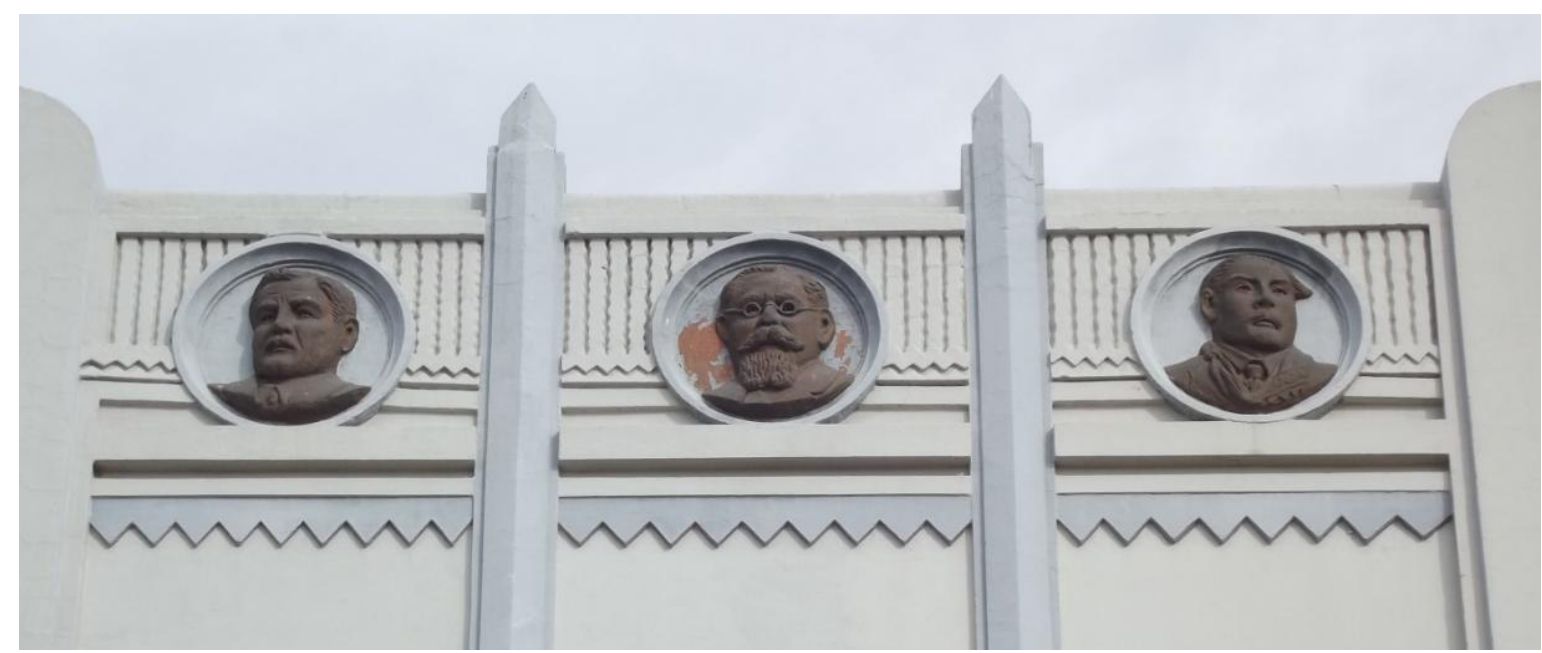

Personajes del lado izquierdo: Plutarco Elías Calles, Venustiano Carranza y Manuel Pérez Treviño. Se aprecia la decoración de los dentados zigzgas, así como las estrías levemente abultadas.

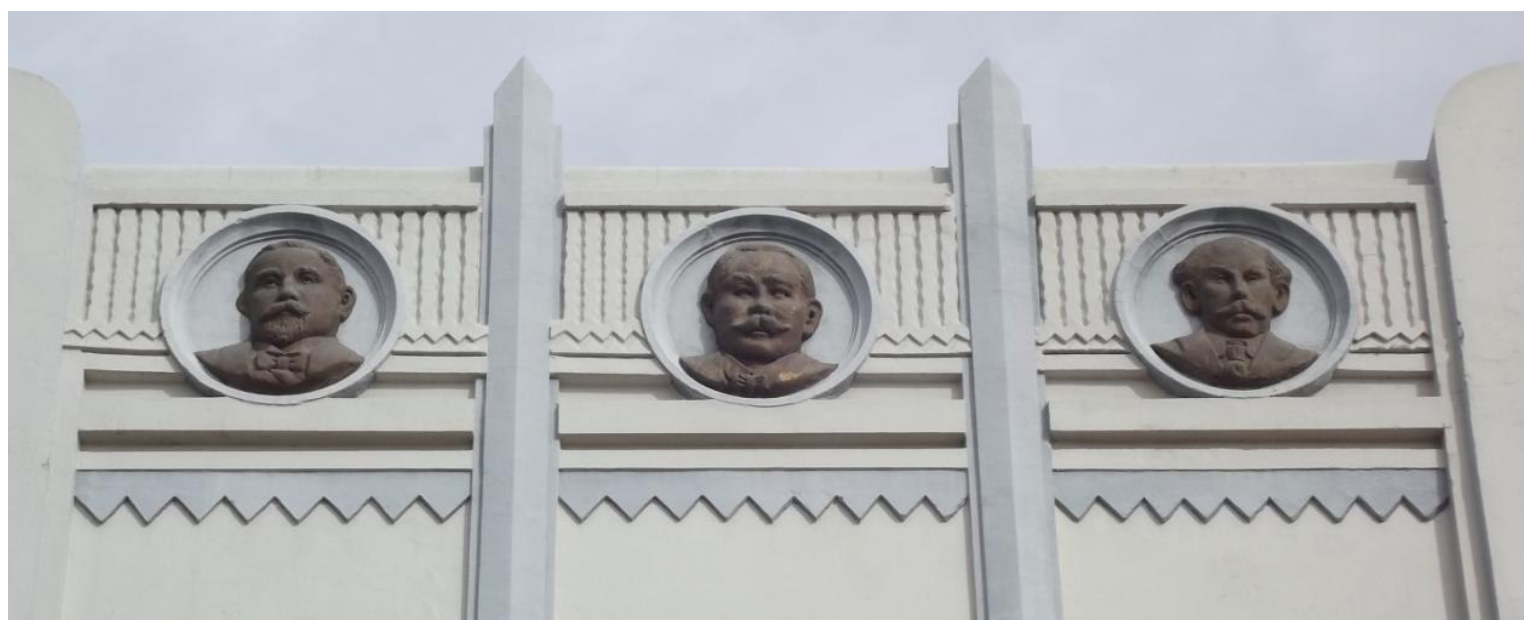

Personajes del lado derecho: Francisco I. Madero, Álvaro Obregón y Aquiles Serdán.

Para continuar con la exaltación del nacionalismo, las cuatro columnas llevan banderas mexicanas enrolladas, como si estuvieran en movimiento, cada una con diferente envolvimiento en el tubo, pero no lleva el escudo nacional del águila y la serpiente. Las columnas centrales se adosan a los cuerpos adyacentes mediante unas bandas curvas que se ensamblan lateralmente, dejando un canal rehundido; sobrepasando el nivel del remate, las columnas se elevan en forma trilobulada, adornadas con un atavío compuesto por líneas verticales que caen de unos roleos que forman un moño, en cuya parte superior va aderezado con un elemento floral. Las otras dos columnas laterales llevan una doble banda 
a los lados; se elevan menos que las centrales y a la vez portan el mismo decorado de las columnas centrales. Espléndido adorno que con su deslizada y estilizada geometría engalana las cuatro columnas dentro de una estética Art Déco del periodo Zigzag de los años treinta.

Las cuatro columnas soportan asta banderas, como pasaba en la gran mayoría de los edificios Déco del periodo de entreguerras, en los cuales se enaltecía el patriotismo que en este caso para México, como ya anotamos anteriormente, era el nacionalismo político procreado por el partido en el poder.

La elevación que se consigue en todo el remate de la fachada a través de las columnas, molduras, así como la parte central con las estrías, es un fantástico juego de prominencias, tanto de líneas rectas, curvas, triángulos, que le dan esa altivez geométrica típicamente Art Déco.
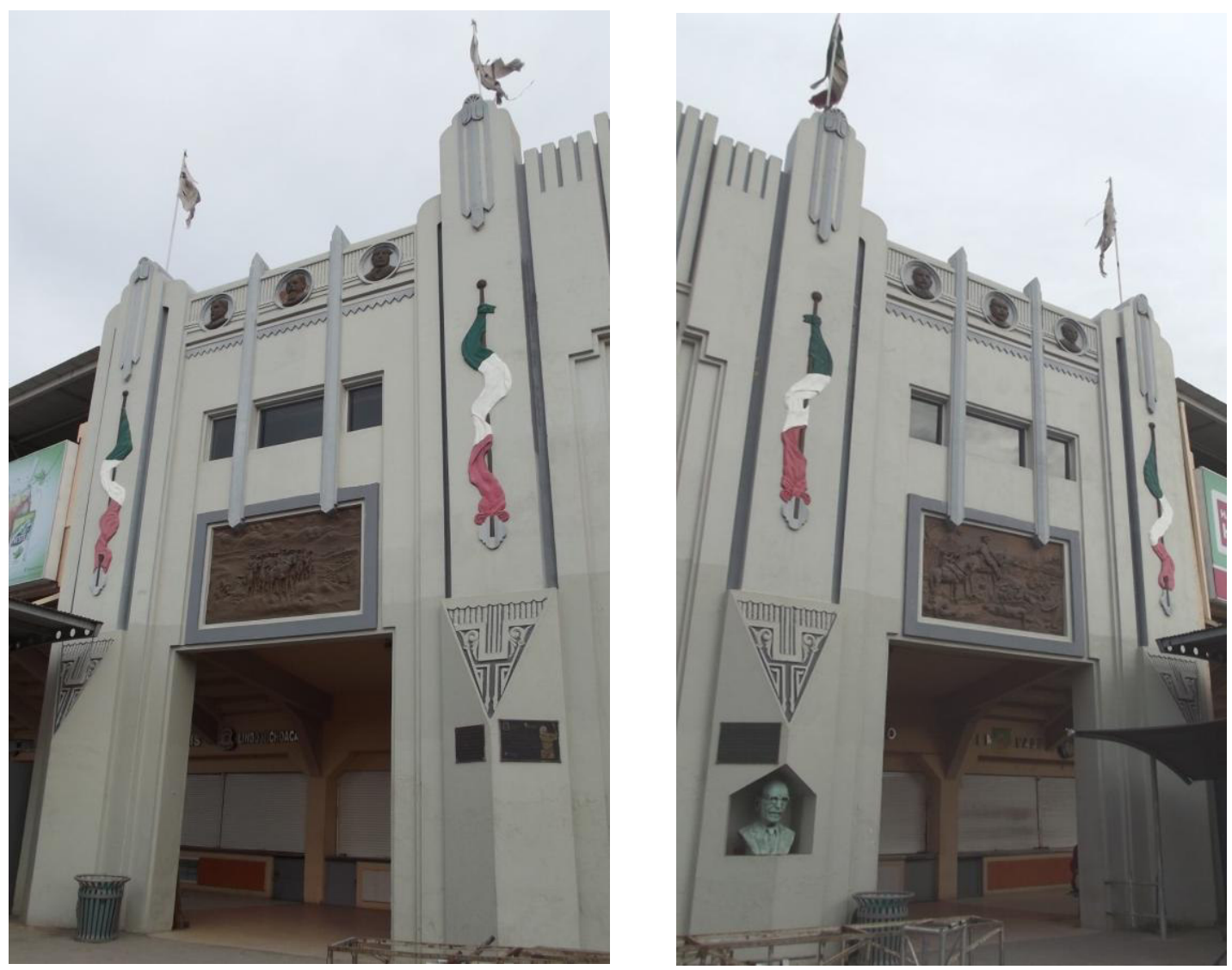

Las cuatro columnas con las bases y los adornos de banderas y moños. Las placas así como el busto de Nazario Ortiz Garza son de años posteriores. 


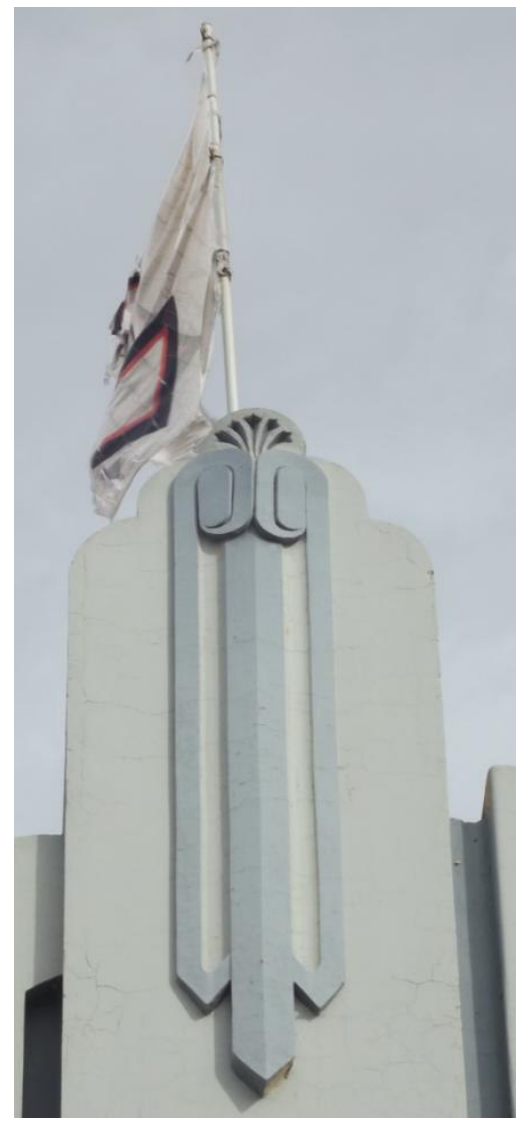

Detalle de un adorno de la parte superior de las cuatro columnas.

Pasando la entrada principal por debajo de la gradería y a mano derecha el nombre de Zeferino Domínguez está inscrito en una placa.

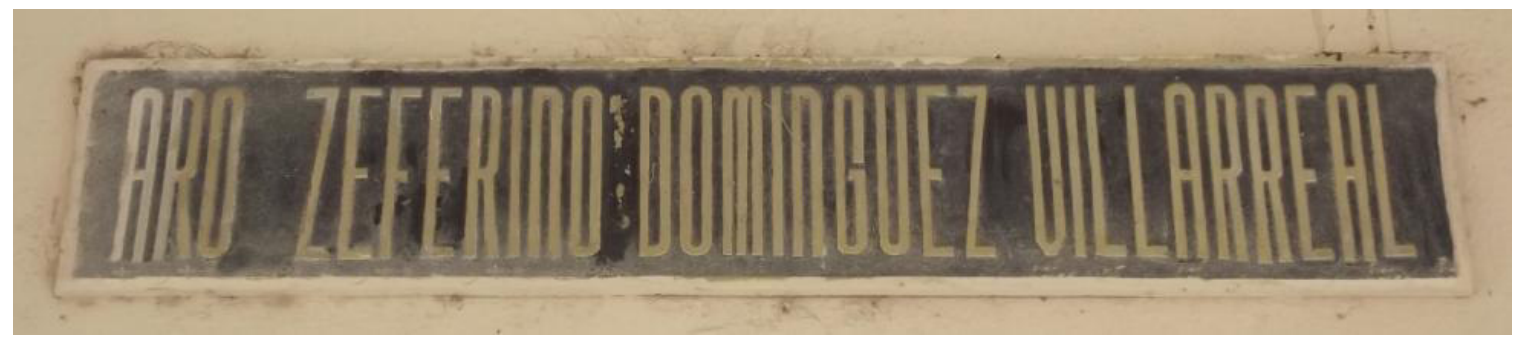

Placa con el nombre de Zeferino Domínguez.

El estadio conserva algunas de sus luminarias originales, ya que despuésde estar abandonado por varios años, fue rehabilitado, restaurado y puesto en funciones nuevamente en marzo de 2003. Las lámparas parecieran inspiradas en el Pabellón Studium-Louvre de la gran exposición parisina de 1925, obra de Albert Laprade, citado en 
el capítulo 1. Son octagonales y en la parte superior se cierran amanera de una techumbre tipo pagoda de ocho partes también. Los cristales que están adornados con esgrafiados de hojas, tal como se usaban las decoraciones de plantas geometrizadas, llevan en la parte central un reforzamiento con un diseño escalonado que recorre toda la lámpara. Estan colocadas sobre unas pilastras triaungulares de concreto, atrás de la nueva techumbre de lámina. Son típicamnente Déco Zigzag, pero desafortudamanete se conservan en malas condiciones.
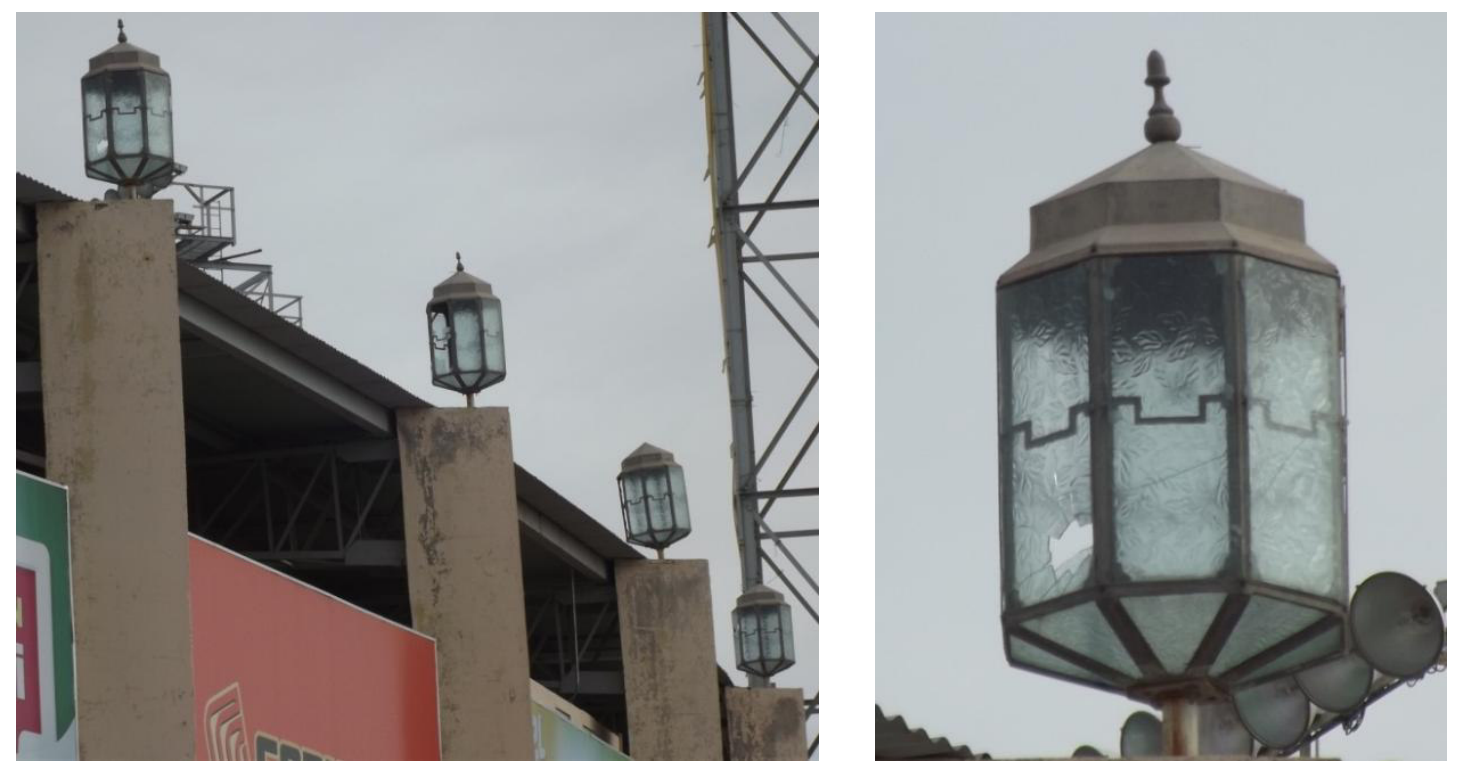

Lámparas originales y el detalle de una de ellas donde se nota el deterioro.

En México hay pocos estadios que se conservan de la época de los años treinta del siglo XX. Y los que aún están en pie o en funciones, ninguno tiene la calidad artística como los es el Estadio de la Revolución de Torreón. Zeferino Domínguez no sólo concibió el espacio deportivo, sino que supo darle un distintivo toque decorativo en su fachada con esos magistrales diseños Art Déco, únicos en el país, hablando de un centro deportivo. Una fachada enlucida concertando las ornamentaciones de Déco con los componentes del nacionalismo, ambos combinados con el uso del material moderno, el cemento, utilizado tanto para su estructura como para el ornato.

Claro ejemplar del Art Déco Zigzag, además de mezclar las Tendencias tanto Geometrista como Decorativista. 


\section{b. Parque del Estadio de la Revolución}

En la parte posterior del Estadio de la Revolución, hacia el lado norte y colindando con la avenida Allende, se ubica un parque donde se encuentran unas estructuras que funcionaron como escenario de un teatro al aire libre. También fueron construidas por Zeferino Domínguez Villarreal en el mismo año que el estadio en 1932. El material utilizado fue el concreto y el ladrillo forrado de cemento.

Se trata de un cuerpo central conformado por dos vanos rectangulares más unas paredes adosadas y dos columnas laterales aisladas a una distancia de siete metros del cuerpo central. Como ahí fueron instaladas canchas de basquetbol, bancas de hierro, juegos, bebederos y un área techada con lámina para eventos, actualmente es difícil captar el conjunto con todos sus elementos.

El cuerpo central exalta el geometrismo de una manera intensa. Consiste en dos vanos rectangulares de gran altura, tres columnas, un arquitrabe y tres componentes superiores. A los lados de las columnas se adjuntan unos lienzos con pilastras.

Las tres columnas sin base constituyen prismas pentagonales, considerando los cinco cuerpos planos que se unen en el fuste; los capiteles son tripartitos por cada lado, es decir llevan tres partes por el lado norte y tres por el lado sur, y están formados por cuatro recortes moldurados y escalonados de menor a mayor, proyectados hacia el frente, los cuales se enlazan con cuatro perfiles angulares del arquitrabe de los dos vanos.

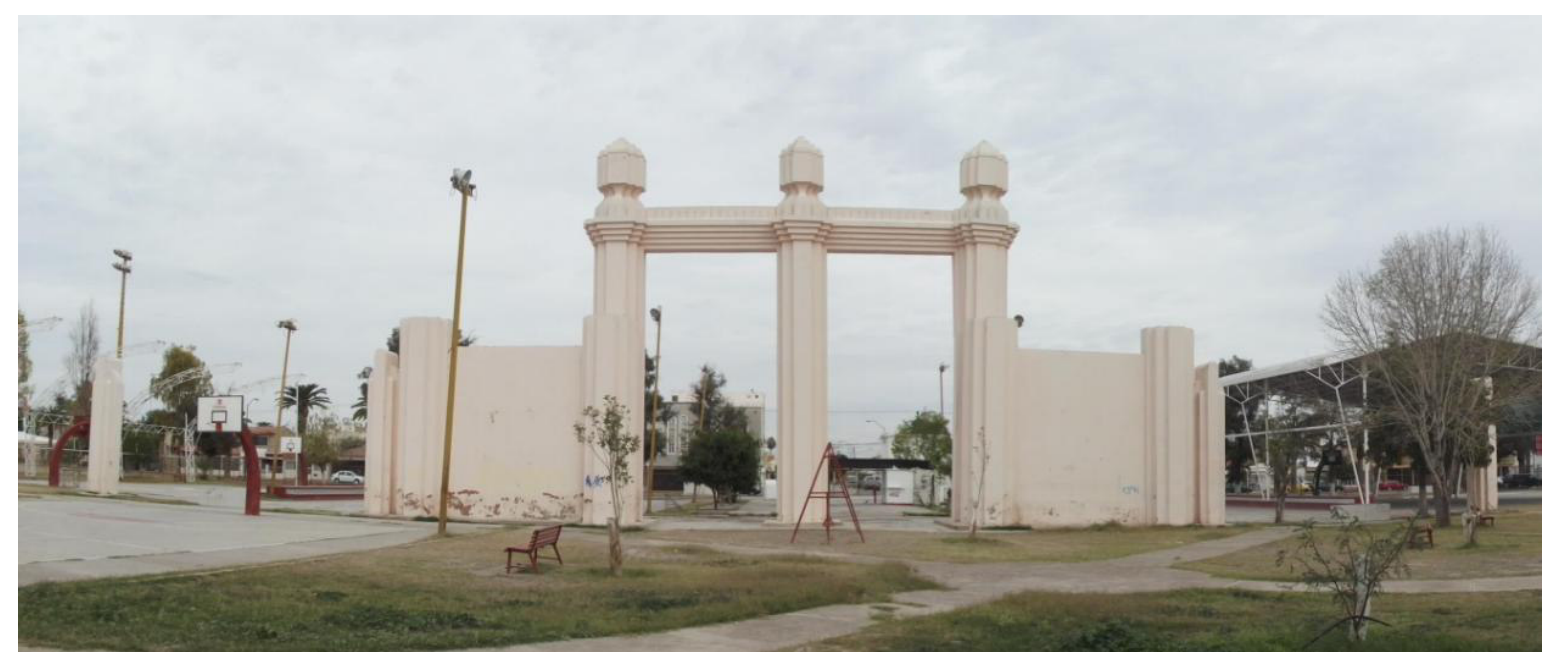

Estructura del escenario del teatro al aire libre visto de sur a norte con las dos columnas laterales. Del lado derecho detrás del árbol se alcanza a percibir una de ellas. 
La linealidad y la geometría de este cuerpo central apuntan a concertar un Art Déco Zigzag que se divisa desde cualquier ángulo, ponderando el acoplamiento geométrico de las partes.

Por arriba del arquitrabe, un largo zócalo que sirve de base a los tres poliedros que rematan la estructura, sigue el ritmo dilatado de los capiteles; está adornado con un dentado cuya parte superior se cierra curvilíneamente. Luego continúa la base de los poliedros que se recortan cóncavamente, sosteniendo cinco prismas rectangulares adheridos que constituyen un solo cuerpo poliédrico, el cual en la parte superior presenta un recorte rehundido y una moldura saliente que rodea a la figura, para terminar con unas caídas ondulantes provenientes de la parte superior a manera de agua congelada.

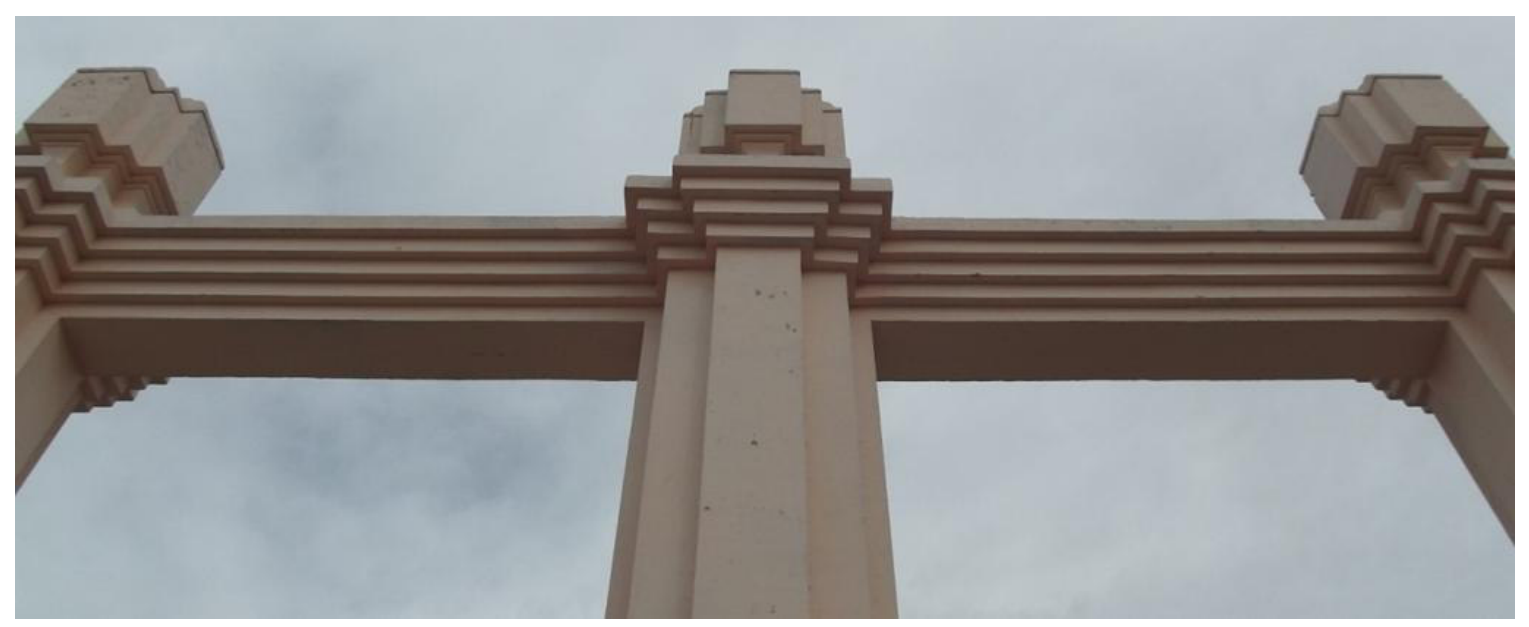

Detalle de las molduras de los capiteles y del arquitrabe formando un zigzag escalonado.

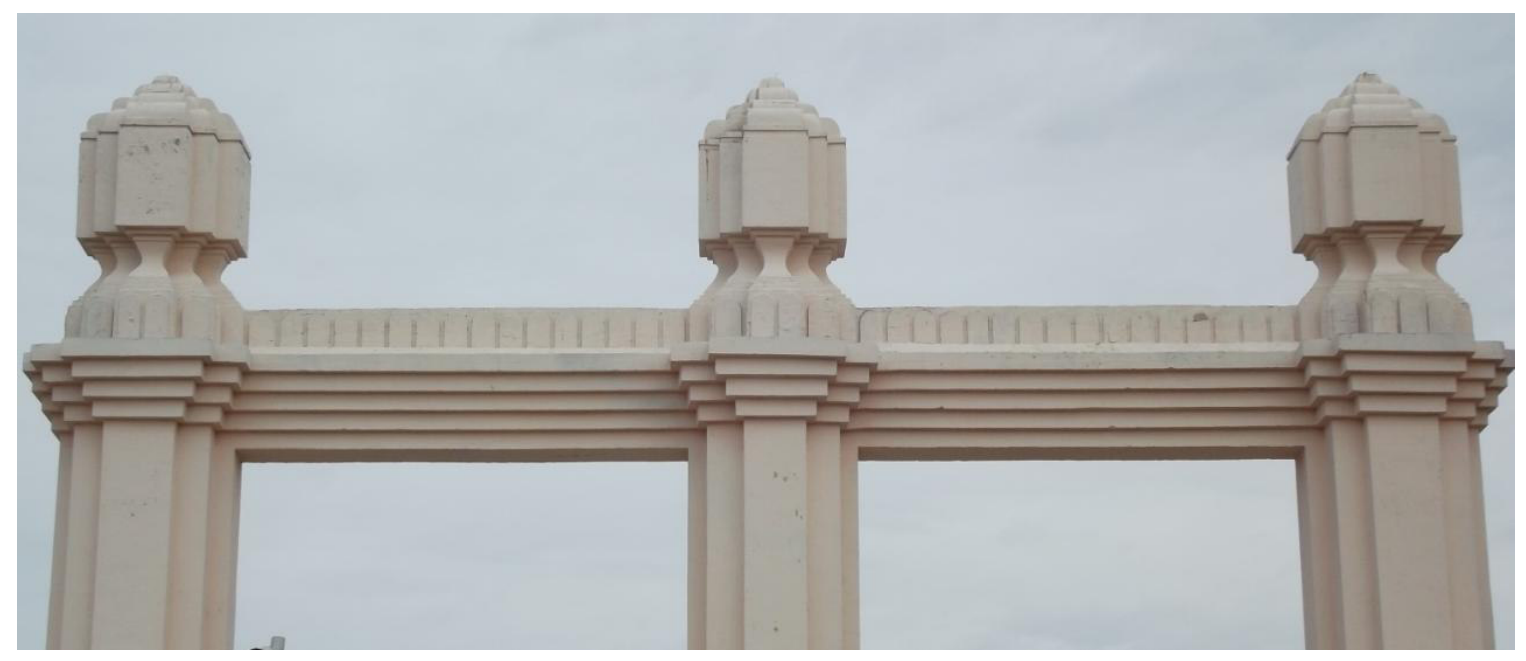

Detalle de la parte superior del cuerpo central con la base y los tres poliedros. 
A los lados de las columnas laterales se acoplan unos prismas de cinco cuerpos rectangulares de mayor grosor, cuya elevación no alcanza las tres cuartas partes del fuste de las columnas. De ahí salen los muros de menor altura, para repetirse en los lados oriente y poniente el mismo tipo de prisma. Finalmente, en los extremos, se yuxtaponen unos prismas de menor tamaño, cuyo cuerpo central es un delgado rectángulo que termina de forma curva, más dos bandas incrustadas de cada lado que se recortan en forma redondeada y cuatro perfiles angulares que terminan piramidalmente. Esta parte de la estructura está desplazada hacia el frente del nivel de la superficie de las columnas.

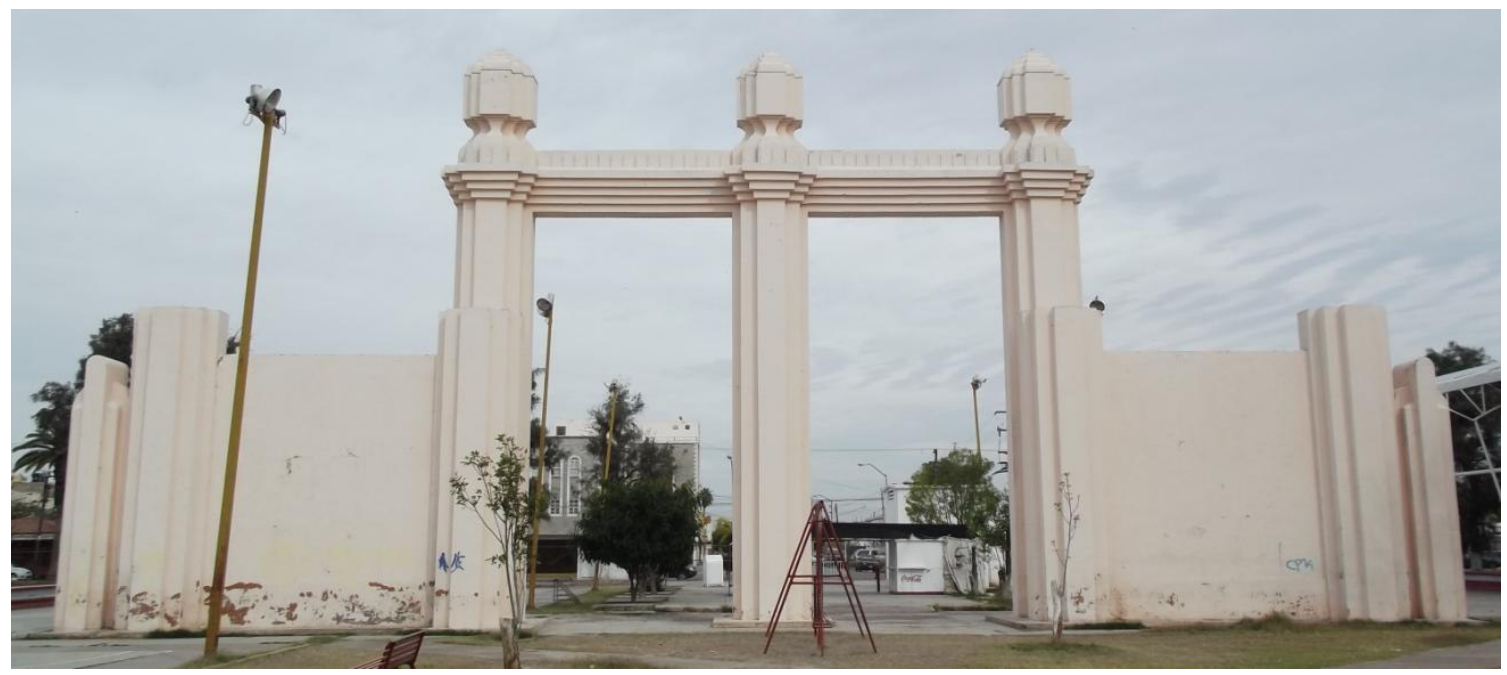

La estructura principal vista de sur a norte con los prismas adosados a las columnas laterales y los muros.

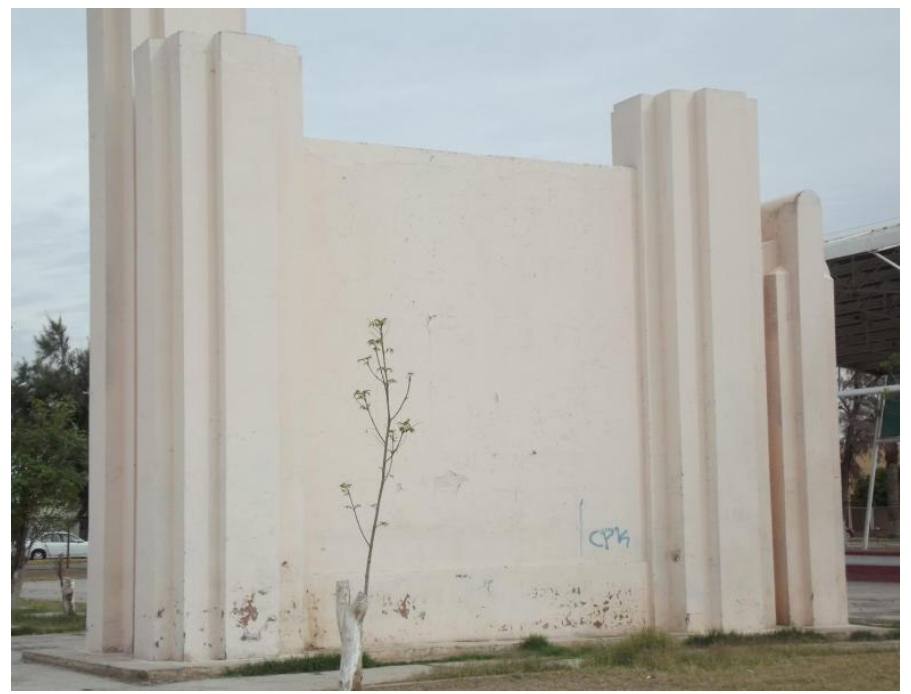

Muro derecho donde se aprecia la última parte con el prisma yuxtapuesto por el lado oriente. 
Definitivamente, de nueva cuenta, los esquemas de la exposición parisina de 1925 están presentes, preponderando los diseños que se convirtieron en modelo del Art Déco.

A una distancia de siete metros y en la misma línea de la estructura central, hay tanto en el lado oriente como en el poniente unos prismas exentos con la misma composición que los yuxtapuestos en los extremos. De cinco cuerpos, donde el central termina curvilíneamente y se acoplan cuatro perfiles angulares, son de la misma altura y forma como sus semejantes.
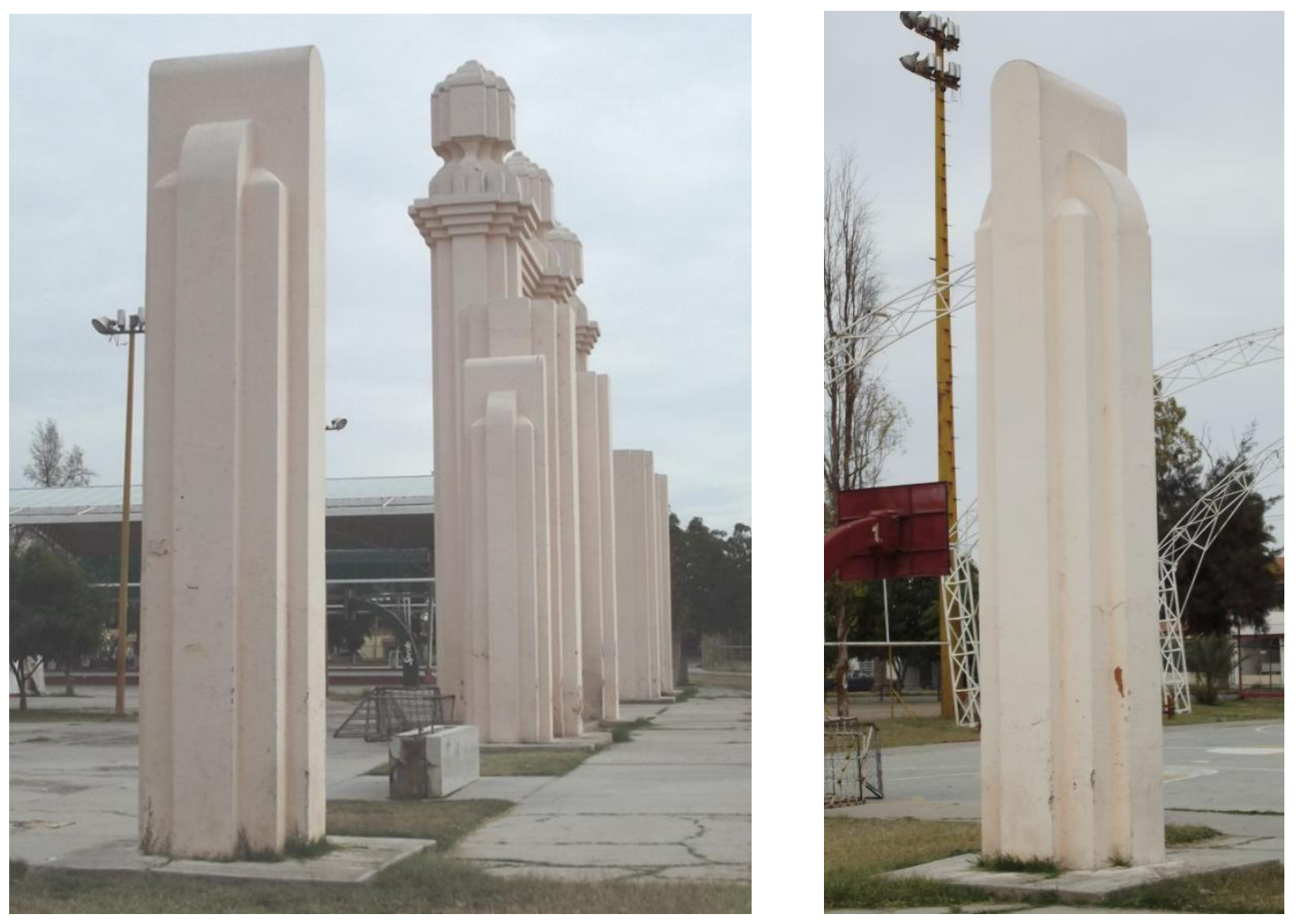

Prisma exento del lado poniente y detalle del mismo.

El conjunto de este escenario exhibe una geometricidad con mucha calidad compositiva, donde la recta predomina, pero ésta a la vez se ensambla con la curva en los prismas laterales, todo conjugado formidablemente con la linealidad, lo rectangular y lo cúbico que forma una estructura de Art Déco Zigzag y de las Tendencia Geometrista y Plasticista. 


\subsubsection{Nueva Rosita}

El origen de Nueva Rosita se remonta a 1869 cuando después de la Intervención Francesa se funda San Juan de Sabinas, precisamente a un lado del rió Sabinas, enclavado en el centro del estado de Coahuila, en la región carbonífera más grande del país. Durante el porfiriano y al desarrollarse la minería del carbón mineral, se crearon pequeños poblados entre los que estaba la villa de Nueva Rosita y así en 1906 se crea el municipio de Sabinas, en donde queda situado Nueva Rosita.

Después de la Revolución, Nueva Rosita se desarrolla más en cuanto a población y trabajo minero, por lo que se construye un pabellón de procesamiento para el mineral con una alta torre que data de 1929, que ahora es el símbolo de la ciudad.

Su economía y forma de vida está en un $90 \%$ alrededor de la extracción, procesamiento y distribución del carbón mineral. Con el incremento de migrantes de pueblos y rancherías para el trabajo minero, más el crecimiento poblacional, se vio la necesidad de establecer una escuela de nivel secundaria y fue así como se creó y abrió sus puertas la Secundaria Federal B-27 en el año de 1946, que hoy lleva el nombre de Fortunato Gutiérrez Cruz, la cual tiene entre sus componentes constructivos decoraciones Art Déco.

El 5 de mayo de 1979, Nueva Rosita es elevada al rango de ciudad y cabecera del municipio de San Juan de Sabinas.

\subsubsection{ARQUITECTURA ESCOLAR}

\section{a. Escuela Fortunato Gutiérrez Cruz}

La Escuela Fortunato Gutiérrez Cruz se ubica en las afueras de la ciudad sobre la avenida Adolfo López Mateos s/n, esquina con el boulevard Simón Bolívar. Su orientación es hacia el sur.

Ante la necesidad de tener una escuela de nivel secundaria, se iniciaron labores de este nivel en 1944 en una casa de la sociedad Antigua Mutualista Benemérito de las Américas, creándose un comité para conseguir fondos, tanto a nivel local, estatal y federal. 
Al poco tiempo, la ayuda federal llegó y se iniciaron las obras para una nueva escuela, todavía en la administración del general Benecio López Padilla, quien se distinguió como un gobernador del estado de 1941 a 1945 que impulsó la obra pública, razón por la cual la placa que lleva la fachada de la escuela dice 1945, aunque el inmueble fue inaugurado el 16 de septiembre de 1946 con el nombre de Secundaria Federal B.27. El acontecimiento fue tan grande para la región carbonífera y para la villa de Nueva Rosita, que para la inauguración estuvo nada menos que el Secretario de Educación Pública del país, el maestro, intelectual y diplomático Jaime Torres Bodet (1902-1974). Fue designado como director de la escuela el profesor Fortunato Gutiérrez cruz (1905-f?), quien se había distinguido por su labor docente y su formación académica en pedagogía. Debido al fuerte impulso que dio a la Secundaria B.27 durante su gestión, ahora la escuela lleva su nombre.

El inmueble es monumental y más para la ciudad en su tiempo de construcción. Tiene planta en forma de "E", con unas pequeñas prolongaciones oblicuas en los extremos. El cuerpo central es de dos plantas y de una en el resto del edificio. Está hecho con cemento, con un estilo rústico y Art Déco en el exterior frontal, mientras que en el interior ya presenta una estética funcionalista. No encontramos el dato del autor y/o constructora.

Debido a que en el amplio patio frontal que antecede a la entrada están plantados árboles y palmeras, es bastante complicado captar la fachada principal, por lo que utilizaremos también imágenes históricas para describir esa parte del plantel.

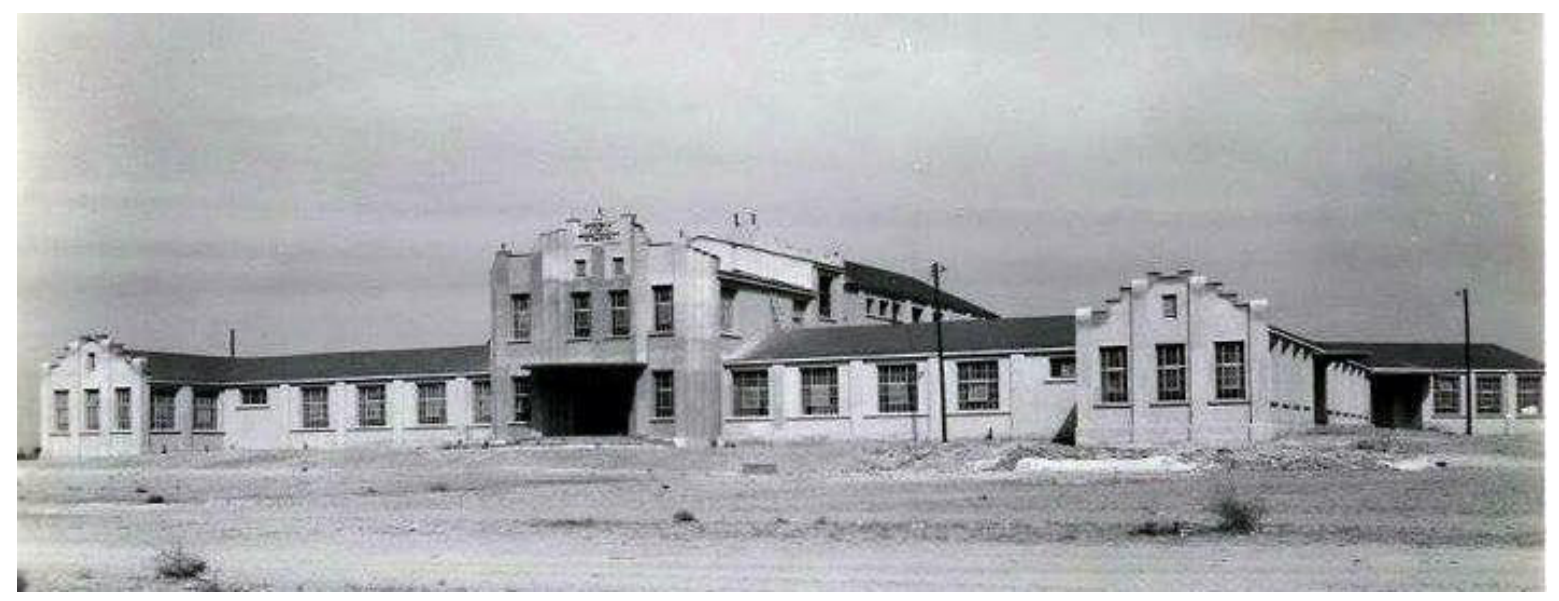

La escuela terminada en julio de 1946.251

${ }^{251}$ www.facebook.com/pages/Nueva-Rosita-Coah/ 


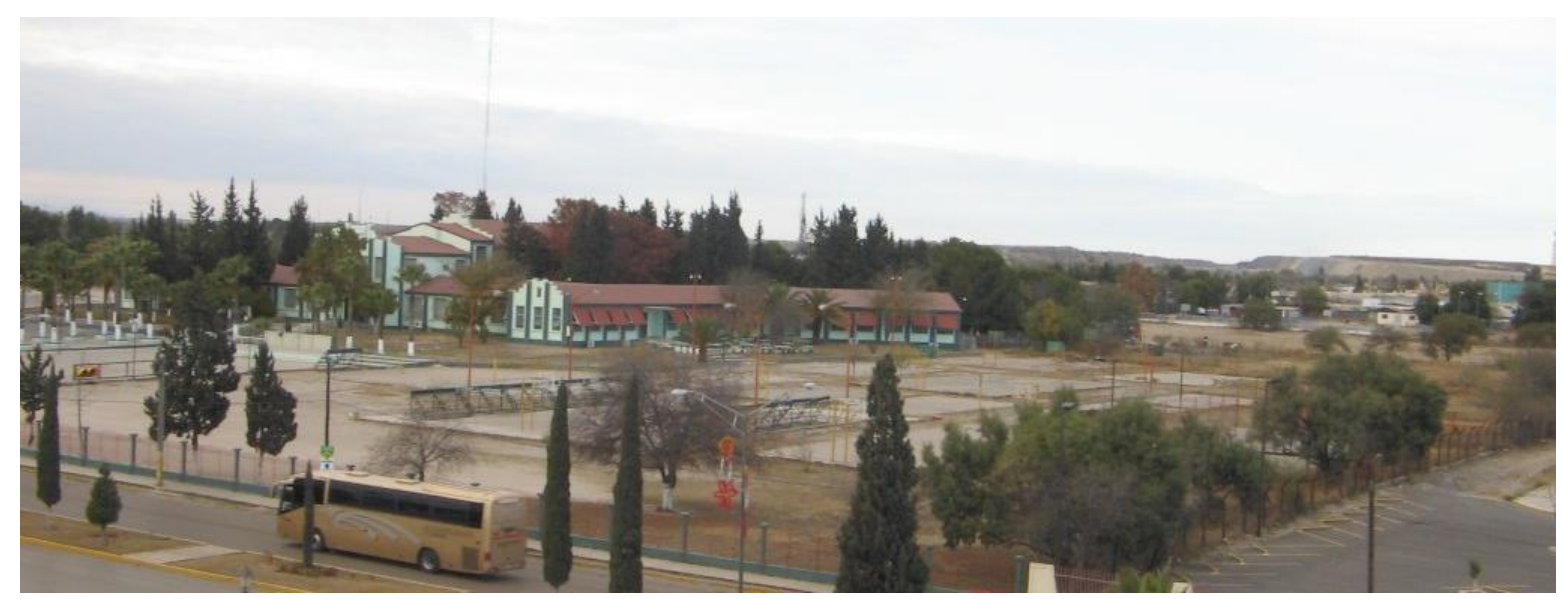

Vista general con los jardines y espacios deportivos. ${ }^{252}$

En la fachada principal en el cuerpo central de la misma originalmente tres peldaños circulares, ahora recortados, llevan hasta la puerta de acceso que se forma con un vano rectangular con tres medias muestras que van de mayor a menor, las cuales se unen con tres trabes en la misma disposición, lográndose así una entrada abocinada. Una marquesina circular que hace juego con la escalinata está sostenida por unas extendidas zapatas en forma de cuñas piramidales; el filo frontal está cubierto con mosaicos en color verde. A los lados del vano se encuentran unas pilastras estriadas que se prolongan hasta el límite del segundo nivel. Por arriba de la marquesina, en lo correspondiente al segundo piso, al centro una pilastra estriada que se eleva hasta el límite del letrero, hace juego con las dos laterales; a cada lado de la pilastra hay unos ventanales rectangulares y por encima de éstos, unos más pequeños ayudan a darle sentido de elevación al muro central. A cada lado, nuevamente las tres medias muestras y como si fueran continuación de las del primer piso, se elevan ahora de menor a mayor por encima del límite del techo, recortadas oblicuamente y con una moldura. Una figura triangular con acodamientos funciona como un pequeño contrafuerte de las medias muestras. Al centro y para cerrar el muro central está el letrero que dice: "1945 S.E.P. SECUNDARIA FEDERAL".

El día de la inauguración se sobrepuso un letrero colgante con el año de 1946 y las mismas palabras de Secundaria Federal, pues la idea era inaugurarlo dentro del gobierno de Benecio López, quien entregó el poder el 30 de noviembre de 1945. El letrero es un rectángulo enmarcado por una moldura, que se cierra con un escalonamiento con forma de

\footnotetext{
${ }^{252}$ Foto: Luis Enrique Reséndiz.
} 
trapecio, el cual sirve de base para la astabandera. A los lados, el cerramiento del muro se eleva con unos cuadrados que están a la altura de la prominencia trapezoidal.

A los lados del vano de acceso hay unos ventanales rectangulares que se repiten en el segundo piso con el mismo tamaño y forma que los centrales que se colocaron arriba de la marquesina. Unas pilastras estriadas recorren ambos pisos terminando curvadamente, para luego finalizar con medias muestras que ahora van de manera escalonada de adelante hacia atrás, en sentido inverso a las del cuerpo central, que se recortan hacia abajo y con la misma moldura en la parte superior.

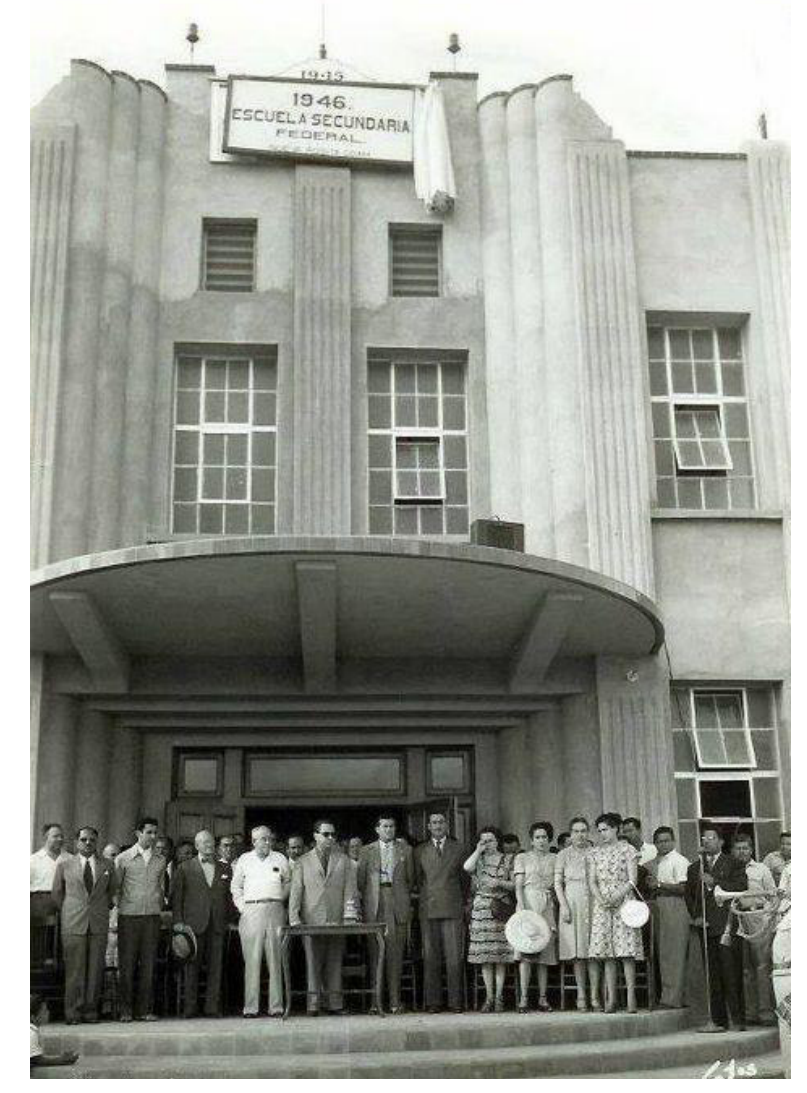

Ceremonia de apertura del 20 de septiembre de 1946. Además del cuerpo central, todavía alcanza a verse una de las pilastras de los extremos. ${ }^{253}$

El ligado geométrico de cilindros, líneas rectas, círculos, así como todo el remate superior con formas ascendentes y descendentes, consigue una estética Art Déco Zigzag de

\footnotetext{
${ }^{253}$ Nueva Rosita, Ibídem.
} 
considerable elegancia y modernidad, realizada muchos años después de cuando estuvo en boga, con las salvedad de la muy buena ejecución, cuando inclusive el Déco ya iba de salida en su etapa Streamline. Esto nos demuestra como en plenos años cuarenta, el Art Déco para la nación seguía siendo una estilística que simbolizaba la modernización del país.
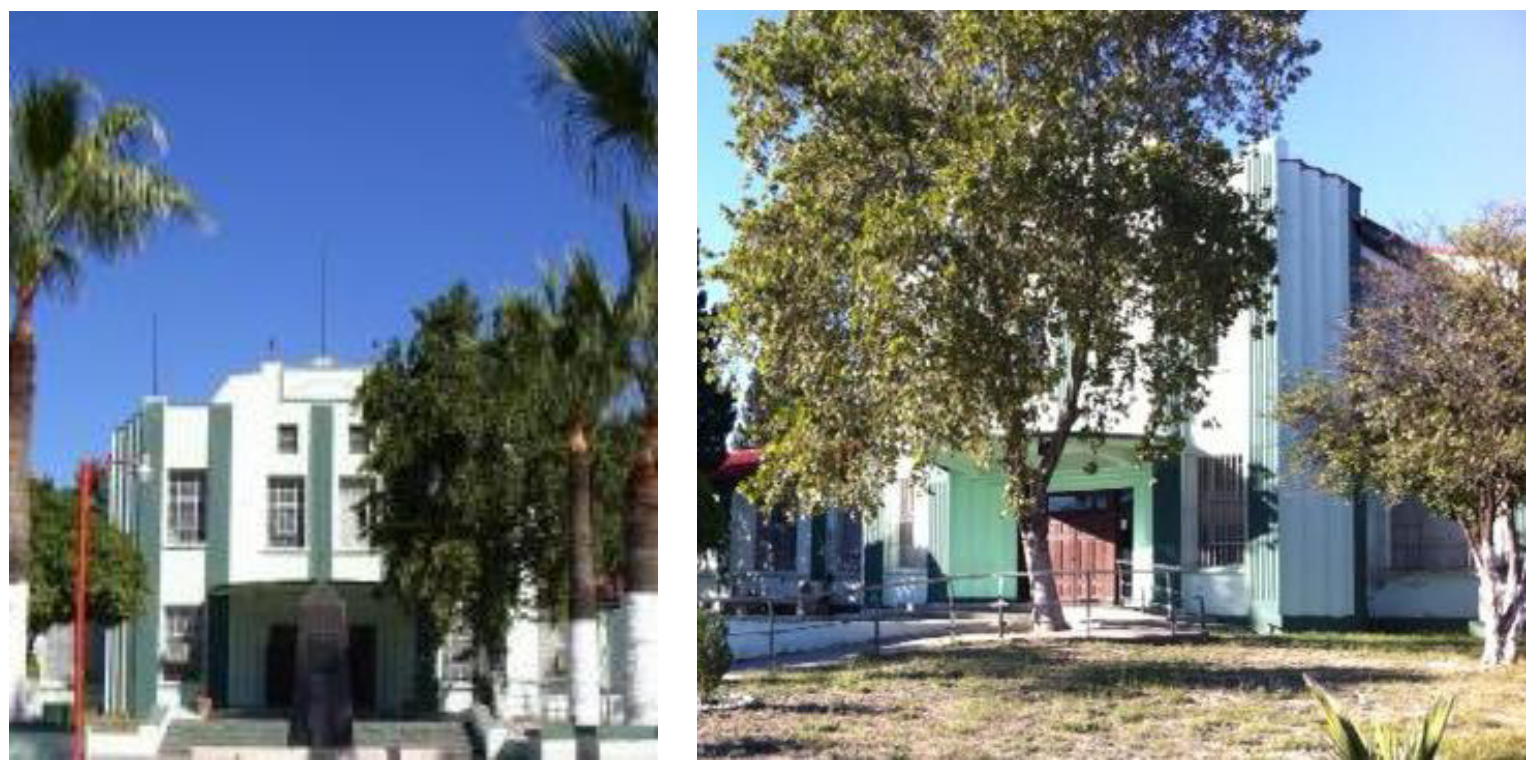

Detalles del cuerpo central de la fachada principal con orientación hacia el sur.

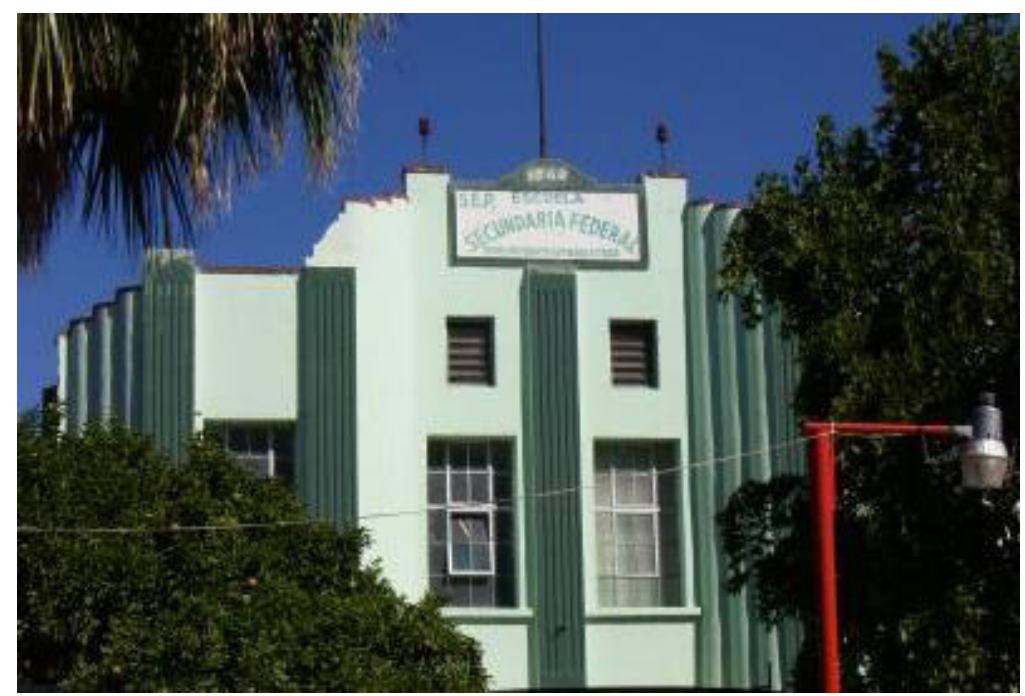

Detalle del segundo cuerpo de la fachada principal con el letrero. 
Adosados la fachada principal y colocados hacia atrás están unos cuerpos laterales de salones con ventanas rectangulares y techos de doble agua. Al final de estos cuerpos se ensamblan perpendicularmente y a nivel de la fachada principal los cuerpos extremos del edificio en los lados oriente y poniente, donde también se distribuyen salones de clase. Las fachadas se componen de base, tres ventanales rectangulares, cuatro pilastras estriadas que envuelve al muro en la parte superior, detalle distintivo Art Déco, siendo las del centro de mayor tamaño que las de los extremos. En el centro, arriba de la ventana, se ubica una más pequeña para cerrar esta parte del muro en el remate con un recorte rectangular. En los lados el cerramiento de los muros en la parte superior es escalonado en tres niveles, donde se enlaza lo rústico de la arquitectura vernácula de la zona con el techo en dos aguas y lo moderno de la geometricidad Art Déco, en este caso de la variante Zigzag. Infortunadamente en la fachada del cuerpo poniente se colocó una estructura para colocar tanques de agua, lo cual le quita visibilidad.
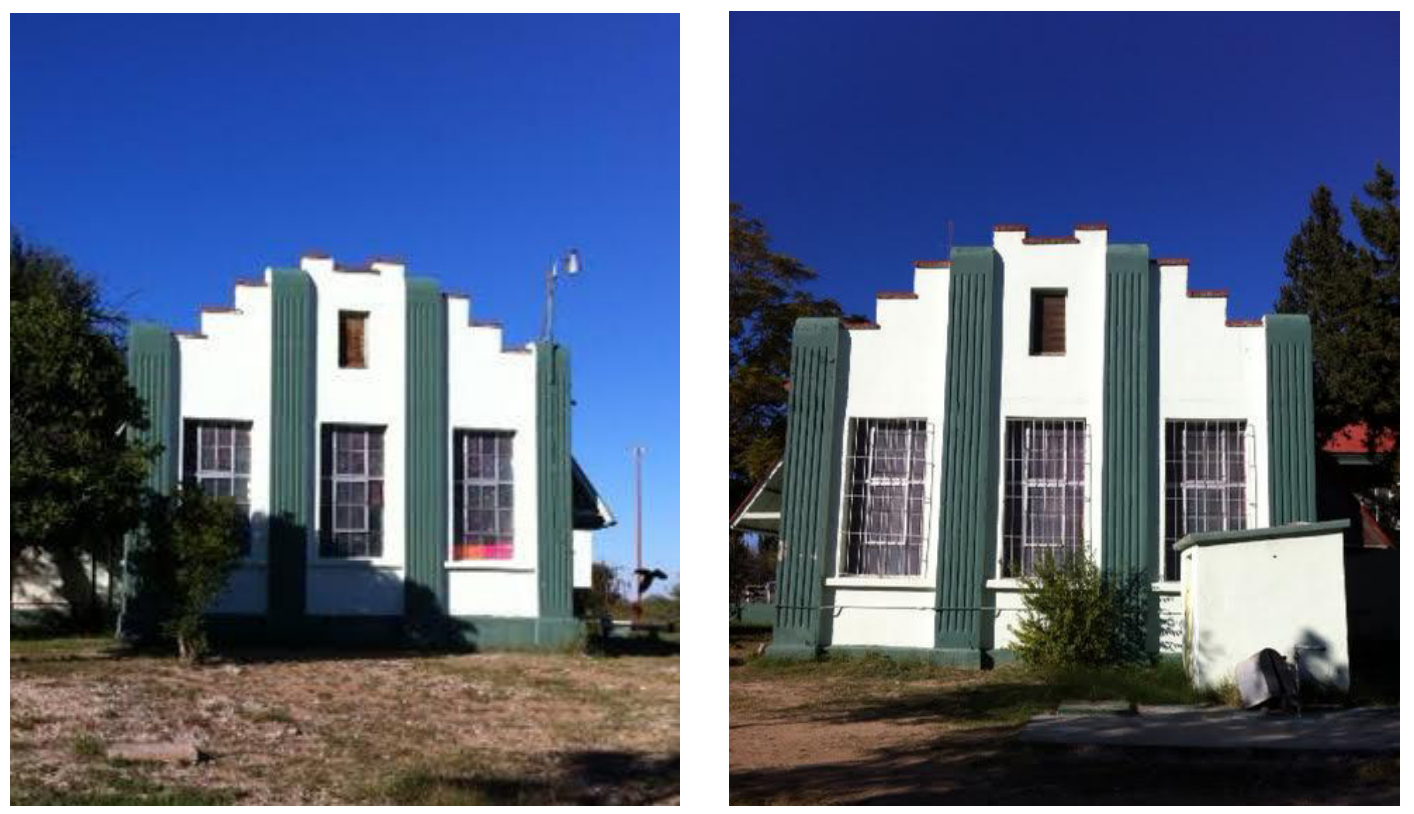

Fachadas de los cuerpo laterales oriente y poniente.

Estos cuerpos oriente y poniente justo a la mitad tienen entradas consideradas como las laterales que dan salida hacia las zonas deportivas. La del lado oriente aún mantiene sus escalinatas circulares de tres peldaños como los tenía la entrada principal. El vano de acceso es rectangular y abocinado con tres perfiles; tiene marquesina circular sostenida por 
dos zapatas en forma de cuñas. El diseño de estas entradas es tipo Art Déco Zigzag, aunque en el caso de las marquesinas, al igual que la fachada principal, bien podrían ser Streamline por su símil con aleros aeronáuticos.
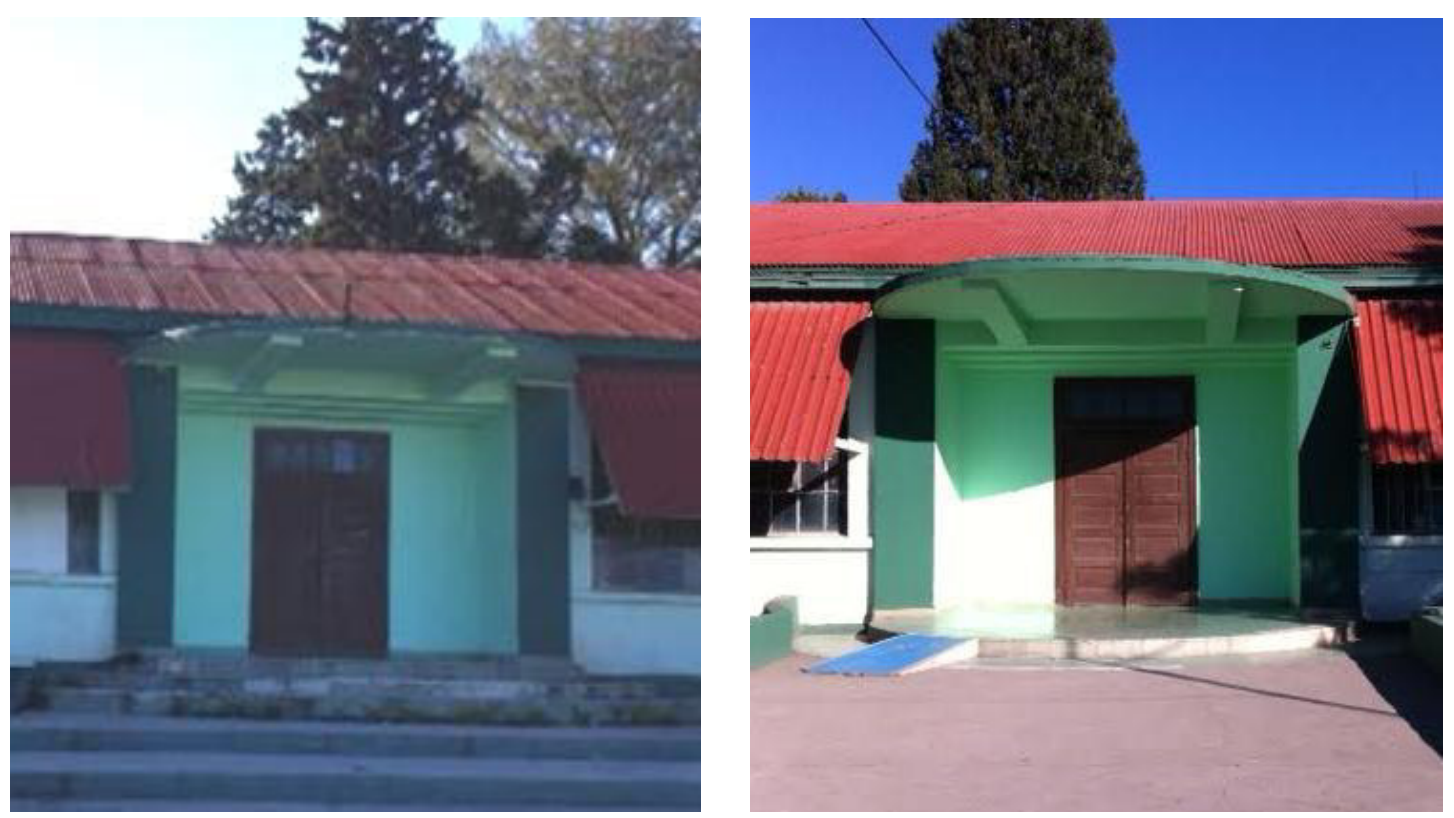

Puertas laterales oriente y poniente. La del lado oriente aún con los tres peldaños originales.

Caso singular y aislado, en la lejanía de la zona carbonífera, la Escuela Fortunato Gutiérrez Cruz es una obra colosal tanto en su época de inicios como hasta ahora, que sigue llamando la atención por novedad constructiva que exhibe en el exterior elementos del Art Déco Zigzag y en menor parte Streamline. 


\section{CONCLUSIONES}

Como es sabido el Art Déco no fue un movimiento estético desarrollado por un específico grupo de artistas a partir de manifiestos más o menos concretos, sino la forma de expresión artística que, durante las décadas de los años veinte y treinta del siglo pasado, caracterizó a buena parte de las artes plásticas; preferentemente aquellas dedicadas al mundo de la decoración, el cartelismo, el diseño gráfico o la moda. De tal manera que en la formulación del Art Déco adquirieron un importante protagonismo no sólo determinadas corrientes y fenómenos artísticos, sino, sobre todo, las escuelas y talleres de decoración.

La denominación, Art Déco, comenzó a utilizarse a raíz de la exposición Les Annés 25 que realizó el Musée des Arts Décoratifs de París en 1966. En aquel momento, se empleó la expresión Art Déco para referirse a la Exposition Internationale des Arts Décoratifs et Industriels Modernes de 1925 y conceptualizar estilísticamente la producción artística francesa junto a la de determinados países participantes en la muestra. Progresivamente, bajo la denominación Art Déco fue catalogándose también buena parte de la producción artística de los años treinta, de manera especial aquellas obras que seguían los lineamientos estéticos de la exposición del 25.

En los años setenta toma fuerza el estudio de las realizaciones artísticas bajo el nombre de Art Déco y fue Paul Maenz quien en su libro Art Déco: 1920-1940 le llama "un estilo de entreguerras" denominando a la creaciones "los décos", al referirse a la diversidad de producciones, pero que comparten cánones estéticos similares. Por eso, otras exposiciones en la misma Francia o cruzando el Atlántico en los Estados Unidos, que continuaron, ampliaron y extendieron los preceptos de la exposición de 1925, son estudiadas también como Art Déco.

En el punto de partida del Art Déco, la Exposition Internationale des Arts Décoratifs et Industriels Modernes de 1925, destacaron los grandes pabellones parisinos y franceses, así como los de otros países, llamando la atención los de la Europa del Este de Polonia y la Unión Soviética. La elegancia, el donaire decorativo de la exposición, las producciones emanadas de ella tomaban un rumbo basado en la geometría, las culturas

vernáculas, los novedosos materiales y las vanguardias artísticas, todo mezclado para ofertar a una nueva alternativa artística. 
Como consecuencia de la exposición parisina de 1925, lo decorativo será una constante durante los años del Art Déco, especialmente a través del mobiliario con el uso de materiales exóticos y novedosos como sucedió en Francia, modelo a seguir por varios países. Al mismo tiempo, la moda detonaba para transformar principalmente la vestimenta femenina, revolucionando con formas y colores novedosos, de la mano con las corrientes de vanguardia artística de la época que coadyuvaron a la conformación del Art Déco.

Más allá de la exposición parisina de 1925, otras dos magnas muestras en la década de los treinta también favorecieron a la expansión del Déco: Exposition Coloniale Internationale de 1931 y la Exposition Internationale des Arts et Techniques de 1937. Y cruzando el Atlántico en los Estados Unidos las exposiciones Century of Progress Exposition, celebrada en Chicago en el año de 1933, Golden Gate International Exposition de 1939 en San Francisco y la de New York World's Fair de 1939 en Nueva York, dan lecciones al mundo del progreso tecnológico y hacen suyo el Art Déco para difundirlo mundialmente.

Los antecedentes del Art Déco se inician con el Art Nouveau a finales del siglo XIX y principios del XX, pues de la silueta de la línea curva, sinuosa y serpenteante posteriormente se pasará a la recta, quebrada y oblicua. En los países como Reino Unido, Bélgica, Francia, Holanda, España, tuvieron propios arquitectos y diseñadores del Art Nouveau y sus diferentes acepciones según cada nación. El Art Nouveau también tuvo sus representantes en Estados Unidos y en México dejó su presencia con obras en la capital e inclusive en Monterrey.

Posteriormente, el camino hacia la geometría, con la recta y el cubo como primicias irán tomando fuerza en los diversos movimientos artísticos en la última década del siglo XIX como fue la Escuela de Glasgow y al inicio del XX con la Secesión de Viena y el Taller Vienés de donde emana lo que se considera como el primer monumento integral Art Déco que es el Palais Stoclet de Bruselas. Durante la segunda y tercera década del siglo pasado varios movimientos artísticos de vanguardia, escuelas y talleres como el Cubismo en Francia, el Abstraccionismo Ruso a través del Suprematismo y el Constructivismo, la Deutscher Werkbund y la Bauhaus en Alemania, el De Stijl en Holanda, tuvieron en sus cánones ideológicos el uso de la geometría, con formas puras, el uso del color para algunos, 
los productos en serie y hasta el diseño industrial, con lo que contribuyeron a conformar los que conocemos como el Art Déco.

Aunque tuvo su participación como manufacturera de muebles, la Compagnie des Arts Francaise, a la vez engalanaba cualquier objeto que se les proponía ornar: tiendas, casas, oficinas, barcos, relojes, objetos decorativos. Su aporte a la constitución del Art Déco a través de diseños geometrizados de la flor, la fauna animal o las evocaciones de estilos pasados fue sumamente significativa y substancial. Y de la lejana Rusia llegarán a Francia Les Ballets Russes con un grupo de artistas que se verá nutrido con los artistas en boga y que durante casi veinte años crearon coreografías, música, escenografías y vestuario, viajando por Europa, compartiendo con las vanguardias la máxima modernidad del arte y dejando influencias dentro del Art Déco.

En esa época de "entreguerras", un nuevo sector de la sociedad occidental quiere tener acceso a los novedosos productos procedentes de los grandes almacenes, confeccionados con nuevos materiales. Los motivos decorativos de culturas lejanas a Occidente se ponen en boga, después de las incursiones en Egipto, Perú, México y la revaloración de los grupos indios del sur de los Estados Unidos. Al mismo tiempo, es la época de la consagración de la maquina, de los “Años Locos”, del Jazz, que son algunos de los aspectos culturales de los años del Art Déco.

Para comprender el Art Déco, varios autores han dado características distintivas, donde coinciden la línea recta, el zigzag, la geometría, la ornamentación y se han distinguido dos principales variantes: el Zigzag y el Streamline, con un antecedente que es el Neoclásico Moderno. Sin embargo, para Estados Unidos y que tuvieron su influencia en México están el Pueblo Déco y el Tropical Déco. El Zigzag tuvo su principal auge en la década de los veinte, durante la cual se destaca lo geométrico, las líneas quebradas, las curvas suavizadas, los zigzags y mucha ornamentación. El Streamline se desarrolló en la década de los treinta exaltando lo aerodinámico e industrial, incorporando una decoración que simbolice la fuerza del maquinismo. El Neoclásico Moderno aunque su iniciación fue anterior a la gran exposición del 25, incorpora elementos de la Antiguiedad Clásica, Renacimiento y Neoclásico, pero su presencia la podemos encontrar durante todos los años del Déco. El Pueblo Déco y el Tropical Déco están más presentes en la década de los 
treinta, incluyendo elementos decorativos de los indios del sur de los Estados Unidos, para el primero, y de las playas de Miami, para el segundo.

En general, como algunas de las más importantes características distintivas del Art Déco están: geometría del cubo, líneas quebradas, zigzags, esferas, círculos, hexágonos y octágonos; soles radiantes, fluidos acuáticos, fuentes congeladas; gacelas, panteras, águilas en referencia a la velocidad; elementos fitomorfos geometrizados y enmarcados; nuevos y exóticos materiales industriales y naturales son utilizados en los diversos objetos como el cromo, la baquelita, la piel de zapa, el galuchat o maderas exóticas. Los motivos decorativos de las culturas prehispánicas de América, de Egipto, de Mesopotamia de los grupos aborígenes europeos son apropiados para la decoración. La máquina, la velocidad, los aparatos electrodomésticos, la energía eléctrica, son símbolos del progreso y del triunfo industrial. Y finalmente, la figura humana de hombres atléticos, fuertes, o elegantes, junto a damas con nuevas modas y actitudes sociales antes no vistas, como fumar, asistir en cocteles, piscinas, o conduciendo un auto.

Si decimos que el Art Déco lo podemos distinguir en diversas manifestaciones, nosotros opinamos que es en la arquitectura donde su presencia es más visible, ya que para el caso de las ciudades de Europa Occidental donde se modernizó mucho de la arquitectura, sobre todo después de la I Guerra Mundial, se edificaron inmuebles bajo este estilo. Siguiendo los lineamientos de las variantes que tuvo el Déco, hubieron muchos edificios previos que iban apuntando hacia la estética del Art Déco y que luego se manifestaron abiertamente en las tres variantes del Neoclásico Moderno, el Zigzag y el Streamline, más las variantes del Pueblo Déco y el Tropical Déco en los Estados Unidos. Aparte, los crecidos rascacielos estadounidenses contribuyeron con una arquitectura de grandes proporciones, donde todo se combinaba desde la decoración, los modernos materiales, hasta la colosal altura cúbica. Así como en las principales ciudades de Europa Occidental y de Estados Unidos mucho abundó el Art Déco, en las capitales y ciudades importantes de algunos de los países de América Latina se construyeron dignos ejemplos de Art Déco como fue en Buenos Aires, La Plata, Montevideo, Santiago de Chile, Bogotá, La Habana y por supuesto la ciudad de México.

En México los inicios del estudio del Art Déco datan de 1977 cuando se organizó una exposición en la ciudad de México en el Instituto Norteamericano de Relaciones 
Culturales denominada Art Déco en México, con textos de varios autores y por primera vez se trataba el tema por arquitectos e investigadores quienes participaron en el catálogo. La segunda vez fue tan sólo tres años después, en el verano de 1980 y en el Noreste de México: el Museo Pape de Monclova fue sede de la muestra que llevó el título de Art Nouveau. Art Deco, exposición que consistió en la exhibición de objetos de colecciones particulares. Pero para el mismo año de 1980, de agosto a octubre, en la ciudad de México se llevó a cabo la exposición Una puerta al Art Deco, en la Galería Aristos de la UNAM, en la que se mostraban fotografías de una catalogación de edificios Déco en la ciudad de México. El texto de Xavier Esqueda, aunque breve, es una buena explicación de lo que es el Art Déco y su presencia en la arquitectura.

En 1986 se publicará por la UNAM el libro Art Deco. Retatro de una época, de Xavier Esqueda, verdadera "Biblia" del estilo para México y referencia obligada para las investigaciones que sobre el tema se han realizado en el país. Enrique X., de Anda, en 1990 publica también con la UNAM el libro La Arquitectura de la Revolución Mexicana. Corrientes y estilos de la década de los veintes, cuyo contenido de ocho capítulos, en el sexto analiza la arquitectura Art Déco en la ciudad de México. El último trabajo que estudia y analiza al Art Déco en la nación fue el egregio catálogo de la exposición Art Déco. Un país nacionalista. Un México cosmopolita, llevada a cabo en la capital de la república en el Museo Nacional de Arte de noviembre de 1997 a abril de 1998, suntuosa exhibición de gráficos, fotografías, pinturas, esculturas, objetos decorativos, mostrando la rica producción Déco en la ciudad de México y algunas obras en otras ciudades del país, cuyos amplios e ilustrativos textos fueron escritos por Enrique X., de Anda.

Los años en que el Art Déco llegó a México, la Revolución concluía su fase armada para entrar en una época de caudillaje, cuando se inician grandes obras por la cultura y el arte como fue el Muralismo. Más tarde con el Maximato y ya en la década de los treinta con el Cardenismo y una relativa paz social, México vivía una transformación de sus estructuras políticas, económicas, sociales y culturales. Ante una evolución hacia el México Moderno postrevolucionario, el Art Déco significaba una alternativa de modernidad, por lo tanto mucho se construyó para modernizar al país con este estilo. Con ilustraciones de revistas principalmente provenientes de Estados Unidos, con la llegada e importación de artículos decorativos y domésticos, más una recuperación económica, el Art Déco llegó a 
México, obviamente con destino principal la capital del país, pero a su vez tocó otras ciudades del interior de la república. El cemento era sinónimo de modernidad, pues substituía a materiales como la piedra, el adobe, la madera, para revelar su durabilidad, sus capacidades constructivas e inclusive escultóricas y decorativas.

El mundo prehispánico fue una vital fuente de inspiración para el Art Déco en México, ya que por un lado era parte del nacionalismo etnológico indigenista que fomentaba el Estado y por otro, cuadraba muy bien con la estética del Déco por el uso de la geometría. Obras de artistas mexicanos tomaron como tema el ideario indigenista, sobre todo durante los treinta años del porfiriato. Muchos exploradores ingleses, franceses, norteamericanos durante la segunda mitad del siglo XIX viajaron a México para explorar las ruinas mayas, especialmente, o de otras culturas. Después de la Revolución en la década de los veinte y de los treinta se iniciaron las exploraciones y conservación de sitios arqueológicos por parte del gobierno. Pero curiosamente, en Estados Unidos en la zona de California, Texas y hasta en New York, los motivos prehispánicos iban de la mano en muchas construcciones y de allá llegaron las influencias prehispánicas al país. También a través del Muralismo mucho se difundió lo prehispánico bajo los esquema del Art Déco como fue el caso de considerables murales de Diego Rivera.

Después del contexto de los años del Art Déco en México, las características distintivas tienen algunas variantes para el caso de la arquitectura. Las primarias aportaciones de Israel Katzman en la década de los sesenta, luego las de Alberto Yarza en los setenta, convergen las de Esqueda en los años ochenta que son las más definitorias, para luego llegar a los trabajos de Enrique X., de Anda, quien aporta cuatro tendencias, aunque aplicadas a los edificios de la ciudad de México: Geometrista, Plasticista, EclécticoMayista y Decorativista. Surgen los nombres de grandes arquitectos del Art Déco con sus obras en México como fueron: Vicente Mendiola, Manuel Cortina García, Leonardo Noriega, Joaquín Capilla, Carlos Obregón Santacilia, Ernesto Ignacio y José María Buenrostro, Juan Segura, Manuel Ortiz Monasterio, Federico Mariscal, Francisco José Serrano, todos ellos con trabajos en la ciudad de México, por lo que aún falta mucho por investigar en otras ciudades del país como lo han hecho Olga Clarisa Becerra Mercado en Guadalajara, Javier Guerrero Romero en Durango, Rogelio Sánchez Mena en León, Cristina Silva Angón en Puebla y Enrique Urzaiz Lares en Mérida. 
Para el caso de la escultura poco se ha teorizado al respecto, salvo lo propuesto por Esqueda. Nosotros proponemos que hubo tres tipos de esculturas Art Déco: las monumentales y de gran tamaño, los relieves y las de pequeño formato. Tanto dentro de la ciudad de México como fuera de ella, las esculturas pulularon, pues el nacionalismo postrevolucionario conmemoró a través de las esculturas públicas personajes o acontecimientos. Trabajos de Ignacio Asúnsolo, Oliverio Martínez, Manuel Centurión, Guillermo Ruiz, Fidias Elizondo, son algunos de los escultores que se destacaron por su obras Art Déco de gran formato. Un hallazgo nuestro es que el monumento a la Nao de China (págs. 354 y ss.) en el Puerto de Acapulco, obra extraordinaria de Manuel Centurión, no haya sido estudiada por nadie y nosotros la incluimos aquí, por ser una escultura Art Déco de mucha calidad. Aún hace falta estudiar la escultura Déco en México, especialmente las obra de pequeño formato de autores como Rómulo Rozo, Luis Ortiz Monasterio, Carlos Bracho o Ernesto Tamariz.

Y si bien la pintura Art Déco se ha estudiado por Esqueda y por De Anda, hay mucho por indagar en la pintura muralista más allá de Diego Rivera y Roberto Montenegro, lo mismo que la obra de caballete de Jorge González Camarena o Fermín Revueltas, artista que según Esqueda fue quien más trabajó el Art Déco. Lo mismo ocurre con la obra gráfica, todavía faltaría mucho que investigar, porque si bien la abundante producción de Ernesto "Chango" García Cabral o Miguel Covarrubias ha sido tomada en cuenta, sin embrago hay bastantes dibujantes y artistas que están en el abandono histórico.

Un fuerte nacionalismo se dio en todos los ámbitos culturales en los años del desenvolvimiento del Art Déco en México. Las artesanías, la literatura de la Revolución, ni se diga el cine con idílicos temas sobra la idiosincrasia nacional. De la mano con el cine, la radio se convirtió en la gran difusora de las ideas tanto del nacionalismo como de la identidad, sobre todo a través de las canciones del folclor y en este proceso de la radiodifusión Monterrey tuvo mucha aportación. También la música clásica tomó el camino del nacionalismo, pues los compositores egresados de los conservatorios escribieron partituras inspirándose en las piezas de tradición popular para contribuir con la concientización de lo nacional.

Sobre los principales aportes de investigación de este trabajo del Art Déco en los estados de Nuevo León y Coahuila en la Región Noreste de México, encontramos que en 
Monterrey, capital de Nuevo León, tiene muchas obras arquitectónicas Art Déco, ya que la ciudad se convirtió en un polo de desarrollo industrial, el más importante del país.

La "Arquitectura Escolar" en Monterrey comparte tres características: primero, que son escuelas públicas, segundo fueron construidas por FYUSA (Fomento y Urbanización S.A.), empresa de la ciudad de México que hizo mucha obra para el estado y, tercero que se desconocen los autores de los edificios, pero al ser de FYUSA la constructora, seguramente fueron Manuel Muriel y Antonio Lamosa, ya que eran quienes se encargaban de todos los proyectos. Encontramos que las tres variantes del Déco están presentes en estos planteles educativos: el Neoclásico Moderno en la Fernández de Lizardi (págs. 413 y ss.) y en el interior de la Presidente Calles (págs. 468 y ss.), el Zigzag en la Industrial Álvaro Obregón (págs. 423 y ss.) y la Presidente Calles, y el Streamline en la Nuevo León (págs. 457 y ss.) y en la Monterrey (págs. 462 y ss.). La subvariante Tropical Déco la comparten las escuelas Nuevo León y Monterrey. La Tendencia Geometrista está presente en las cinco edificaciones y la Tendencia Decorativista se aprecia en la Fernández de Lizardi y en la Presidente Calles. A pesar de que estas escuelas han sido referidas o mencionadas en escritos sobre la arquitectura en la ciudad, se indica de paso que son Art Déco, pero sin dar sus características estilísticas, los mismo que el magnánimo vitral de la Escuela Industrial Álvaro Obregón, obra de Roberto Montenegro, que aunque ya se hizo una publicación sobre el tema, tampoco se describe desde la perspectiva del Art Déco. Un aporte muy significativo es el haber descubierto las firmas de Manuel Centurión en las dos esculturas del exterior de la Escuela Presidente Calles, pues ningún autor que ha tratado la escultura moderna en el México como lo es Lily Kassner lo menciona, lo mismo sucede con los que han estudiado la arquitectura y el arte del siglo XX en Monterrey, aparte que estas esculturas son del mismo autor del Monumento a la Nao de China que citamos en el capítulo 2 y que tampoco es mencionada en los libros de arte mexicano.

El único edificio analizado en la "Arquitectura Gubernamental” es el Palacio Federal (págs. 487 y ss.), también construido por FYUSA y que se ha estudiado y descrito por varios tratadistas, sin embargo no se había hecho un estudio exhaustivo de sus elementos compositivos Art Déco y tampoco se había llevado a cabo una descripción del panel escultórico de lo que era la fachada principal o sur, relieve impar en México y que dentro de su temática sobre el trabajo agrícola e industrial de la región, se retomará en los 
murales de la Catedral. Es un edificio de lo más excelso del Déco Zigzag, no sólo a nivel nacional, sino también internacional, aparte de tener la Tendencia Nacionalista Prehispanista que nosotros proponemos en lugar de la Tendencia Ecléctico-Mayista, al presentar en las portadas laterales oriente y poniente, cabezas de Quetzalcóatl que bien pueden ser teotihuacanas, toltecas-mayas o mexicas y no solamente mayistas.

En la "Arquitectura de Servicios", en el abandonado Mercado del Norte (págs. 506 y ss.) encontramos que coincide en inicio de construcción con las Escuelas Fernández de Lizardi, Industrial Álvaro Obregón y el Palacio Federal, lo que indica el fuerte empuje por modernizar la ciudad por parte del gobierno; entró en funciones en el mismo año de las escuelas mencionadas y ya se tiene el nombre de un constructor, el arquitecto español Cipriano J. González Bringas, quien utilizó el Déco Zigzag y las Tendencias Geometrista y Plasticista. El Edificio La Nacional (págs. 512 y ss.) se levanta varios años después que el mercado y además es privado, pero fue construido por FYUSA, la empresa que le daba servicio al gobierno y que construyó las escuelas citadas arriba y el Palacio Federal; igual que su edificio "hermano" en la ciudad de México, el Edificio La Nacional está diseñado con la estética del Art Déco Zigzag y la Tendencia Geometrista. Recientemente estos inmuebles fueron catalogados por su importancia arquitectónica del siglo XX y se les etiquetó como Déco, pero sin dar los elementos compositivos de dicho estilo como lo hacemos en nuestra tesis.

Para el caso de la “Arquitectura Asistencial”, el portentoso Hospital Civil (págs. 519 y ss.) tuvo varias etapas de construcción y participaron varias personalidades locales de la construcción como fueron Leopoldo Quijano, Eduardo Belden, Antonio Sava. Ostenta ante todo una Art Déco Zigzag, con la Tendencia Geometrista, pero aún conserva la puerta de la entrada un Déco de Tendencia Nacionalista Prehispanista y es el único edificio público de la ciudad que todavía resguarda unas lámparas Déco originales. Como otros edificios mencionados como Art Déco, tampoco se habían dado las características distintivas para catalogarlo dentro de este estilo.

Los cuatro cines que analizamos en la "Arquitectura del Ocio", el Lírico (págs. 529 y ss.) y el Encanto (págs. 532 y ss.) fueron construidos en el mismo bienio, pero con lenguajes diferentes: el primero, construido por Arturo Oliverio Cedeño, es un Neoclásico Moderno, aunque distinto al de la Escuela Fernández de Lizardi y al interior del vestíbulo 
de la Presidente Calles; el segundo, tiene como autor a Luis Fernando Flores, es un claro ejemplar del Streamline y de la Tendencia Plasticista. Los cines "hermanos", el Monterrey (págs. 537 y ss.) y el desaparecido Reforma (págs. 545 y ss.), ostentaban el Streamline en los últimos años en que se construía bajo el lenguaje del Art Déco y tienen al mismo arquitecto, Lisando Peña Jr., participando en el Reforma Arturo Oliverio, pero ahora bajo la variante Streamline. En el caso de la Sociedad Recreativa Acero (págs. 551 y ss.) coincide que fue inaugurada el mismo día que las escuelas Fernández de Lizardi e Industrial Álvaro Obregón, ya que fue construida también por FYUSA. Un trascendental aporte sobre este edificio es que a pesar de estar en el Parque Fundidora, no se mencione por ninguna parte su importancia decorativa Art Déco a través de los relieves que son de magnífica calidad.

La Iglesia de Cristo Rey (págs. 559 y ss.) que fue analizada en la tipología de “Arquitectura Religiosa", fue diseñada por Eduardo. D. Belden y como es sabido está inspirada en la iglesia de Notre Dame de Raincy. Concluida ya muy tardíamente a finales de la década de los cuarenta, sin embargo en la torre campanario hecha con cemento aparente, encontramos un Art Déco Streamline. En el interior está el altar a la Virgen de Guadalupe con un medallón cuyos motivos decorativos son de Art Déco Zigzag, lo cual nunca antes se habían mencionado.

Caso muy peculiar es La Esquina Famosa (págs. 565 y ss.) referida en la “Arquitectura Comercial”, pues es un pequeño inmueble comercial de autor desconocido de estructura Streamline, pero que posee un adorno en cemento con un diseño súper aerodinámico bastante original, con lo que se refuerza en el edificio su estirpe Déco Streamline.

Víctima de la ignorancia fue la Plaza General Treviño o del Chorro (págs. 570 y ss.) que analizamos en la tipología "Urbanismo y Renovación”, anónimo, único y estupendo ejemplo de Art Déco Zigzag, pero que fue despojado en una errónea restauración de sus elementos Pueblo Déco.

En el subcapítulo dedicado a "Las Artes Plásticas y las Artes Decorativas" en Monterrey, tenemos tres casos de murales. Los analizados primeramente son los de Ángel Zárraga en la Catedral (págs. 578 y ss.), los cuales a pesar de su extraordinaria calidad han estado relegados de la historia del Muralismo por la razón de tener una temática religiosa. Además de darles una lectura iconográfica, estos murales tienen muchísimos elementos Art 
Déco Zigzag a pesar de estar trabajados en la primera mitad de los años cuarenta, pero creemos que dicha influencia en el artista fue por su larga estancia en París y que de ahí haya quedado prendado con el Déco de los años veinte. Si de alguna manera estos murales son mencionados en el estudio de la obra de Zárraga, jamás se les había dado una interpretación desde la estética Déco, por lo que consideramos que nuestro trabajo es una buena aportación tanto para la historia del Art Déco en México, como para el estudio del pintor. En segunda instancia, en la Casa del Campesino están los murales de Crescenciano Garza Rivera (págs. 594 y ss.) pintados unos pocos años antes que los de la Catedral, de los cuales el principal en la cabecera de la sala, conlleva un lenguaje Art Déco tanto Zigzag como Streamline, de lo que nunca antes se había dicho, aparte de que poco se ha escrito sobre ellos y su calidad artística es un tanto cuanto menor. El tercer mural es de Fermín Revueltas, Alegoría de la Producción (págs. 604 y ss.), aunque originalmente no era para esta ciudad, sin embrago permanecerá por veinticinco años, por lo cual lo incluimos en este estudio. Su magnífica calidad artística va de la mano con sus elementos Art Déco, de los cuales se ha dicho que contienen dicha estética, pero no se dice el porqué, mas como anotamos en el capítulo 3, es el mural más abierta y decididamente Art Déco de México. El segundo y tercer mural llevan la coincidencia de tratar temas nacionales del México Moderno, pero en calidad distan mucho uno de otro.

Las esculturas de Adolf Laubner de la iglesia de La Purísima (págs. 615 y ss.) presentan diseños a base de cilindros, esferas y formas curvas recortadas, con lo cual denotan un Art Déco Streamline. La obra de Laubner no se ha estudiado en su cabalidad y mucho menos se ha dicho de sus diseños en base a los componentes Art Déco. Para el Monumento a Mariano Escobedo de Guillermo Ruiz (págs. 623 y ss.), el escultor utilizó una vaciado realista para el militar y su caballo, sin embargo le imprime algunos componentes Art Déco Zigzag, tomando en cuenta que Ruiz es uno de los escultores que más produjo efigies Déco, como lo comentamos en el Capítulo 2. Con dos años de distancia entre las piezas de Laubner y de Ruiz, son bastante diferentes entre sí, pues Laubner avanza hacia la abstracción y Ruiz se queda con la figuración.

Para cerrar el subcapítulo "Las Artes Plásticas y las Artes Decorativas” examinamos estilísticamente bajo la perspectiva del Déco los vitrales de Roberto Montenegro en el Colegio Civil (págs. 628 y ss.), los cuales ya han sido estudiados, pero sólo 
descriptivamente. Realizados casi al mismo tiempo que los de la Escuela Industrial Álvaro Obregón, fueron diseñados con motivos Art Déco Zigzag y están bastante ligados con los de la escuela industrial, sobre todo en las poses de los protagonistas para el caso de los de la escalera y con el del plafón por la rueca industrial. Estos vitrales de Montenegro han estado relegados de las publicaciones del arte mexicano, empero su extraordinaria calidad, por lo que creemos que esta disertación pueda servir a través de la relectura ofrecida para difundirlos más e insertarlos dentro de los estudios del Art Déco que se hagan en México.

Fuera del área metropolitana de Monterrey, en algunos municipios encontramos varios ejemplos Art Déco que no se han estudiado. El primero de ellos es Anáhuac, que al ser fundado en 1933 tiene muchas construcciones Déco, pero algunas son demasiado pobres en su calidad tanto constructiva como decorativa, por lo que solamente incluimos dentro la "Arquitectura Gubernamental" el Palacio Municipal (págs. 649 y ss.) y el Edificio Agrario (págs. 652 y ss.); el primero con fuertes tintes nacionalistas en la portada, coincide con el segundo en que ambos son Déco Zigzag y exponentes de la Tendencia Geometrista, con lo que coincide la Escuela Cuauhtémoc (págs. 654 y ss.), analizada dentro de la “Arquitectura Escolar”. La Fuente del Obelisco (págs. 656 y ss.), examinada como monumento Art Déco dentro de la tipología "Urbanismo y Renovación", es un caso del Déco Zigzag. Aunque no encontramos dato alguno sobre las construcciones de Anáhuac, todo se le atribuye al ingeniero Pedro Pedrero, pero este municipio bien merece un estudio sobre su arquitectura original de su fundación, pues hasta la fecha no se ha escrito nada de sus construcciones.

Linares tiene al menos dos de las cuatro construcciones analizadas, que sí se han mencionado en otros trabajos. Dentro de la "Arquitectura Comercial" primero nos detenemos en una Gasolinería (págs. 659 y ss.) sin nombre que fue incluida en el Catálogo de Monumentos del INAH y en el de Patrimonio Arquitectónico del CONARTE (donde se alude de paso que es Art Déco), ya que lleva la fecha de construcción y es un claro ejemplo de Art Déco Zigzag, por lo que gracias a estas acciones de las instituciones culturales no fue derribada y sólo se conserva parte de la misma. El otro inmueble que también se menciona en el catálogo del INAH, pero sin especificar su estilística Déco, es un comercio que llevó el nombre de Melesio Elizondo (págs. 662 y ss.), el cual además de tener elementos del Art Déco Zigzag, conlleva características de la Tendencia Decorativista. Dentro de la misma 
tipología incluimos la Botica Morelos (págs. 665 y ss.) que si bien es un atractivo visual del municipio, es un prototipo del Déco Zigzag en que se resalta de manera excesiva la Tendencia Nacionalista Prehispanista, así como la Tendencia Geometrista y por supuesto la Decorativista. Se le considera a su propietario y fundador, el señor Pedro Salce Arredondo, como el autor del inmueble, ya que él personalmente hacía los diseños y dirigía las obras tanto de construcción como de decoración. A pesar de haber tenido hasta reportajes televisivos, a este singular inmueble no se le ha dado su lugar como una construcción Neoindigenista, con sus componentes Art Déco. Bajo la "Arquitectura del Ocio", Linares conserva en desuso y abandono un gran cine que llevó el nombre de Teatro Benitez (págs. 683 y ss.), del cual no se sabe su autor; es un digno espécimen del Art Déco Streamline en su admirable fachada, pero nuevamente con la situación de no haberse estudiado antes.

En el municipio de Sabinas Hidalgo, sólo analizamos un edificio en la "Arquitectura del Ocio”. Se trata del pequeño Cine Olimpia (págs. 688 y ss.), una construcción anónima típicamente Art Déco de la variante Zigzag y de la Tendencia Geometrista, que subsiste y sigue en funcionamiento, aunque olvidada de los estudios de los historiadores de la arquitectura regional y que en este trabajo por primera vez es tomada en cuenta.

De la misma manera que en el municipio anterior, solamente encontramos un inmueble en Salinas Victoria, que al tratarse de un plantel educativo lo clasificamos dentro de la “Arquitectura Escolar”. Se trata del Colegio Dr. Lucas Lazcano (págs. 692 y ss.), un edificio realizado por Marcelo Quintero que combina los elementos Art Déco Zigzag con el Streamline, más la Tendencia Geometrista, de buena calidad constructiva y que tampoco se ha indizado en los catálogos ni en los trabajos sobre la arquitectura regional.

En el estado de Coahuila los lugares donde encontramos Art Déco fueron Saltillo, Torreón y Nueva Rosita. Saltillo, capital del estado, como muchas capitales de los estados de la república, tuvo una fuerte actividad constructiva principalmente con centros educativos. Para esto, la obra que realizó el autodidacta Zeferino Domínguez Villarreal en los planteles escolares fue analizada y publicada por el arquitecto Jesús Ramírez Rodríguez, sin embargo, la descripción de la aportación al Art Déco sólo se menciona de paso, sin dar las características específicas de por qué las edificaciones poseen dicho estilo. Dentro de la “Arquitectura Escolar”, la Escuela Coahuila (págs. 703 y ss.), un portento de decoración 
Déco Neoclásico Moderno, Zigzag y de la Tendencia Decorativista, inicia la lista de cinco construcciones de Domínguez Villarreal dedicadas a la educación. Luego siguió el espléndido y magnánimo Ateneo Fuente (págs.713 y ss.), con sus modernas, amplísimas y lujosas instalaciones que lo hacía el centro educativo más grande de México, destellando con sus componentes y decoraciones Zigzag, así como luciendo las Tendencias Geometrista y Decorativista. La Escuela Álvaro Obregón (págs. 737 y ss.) que en el exterior lleva unos personajes ataviados con indumentarias indígenas denotan la Tendencia Nacionalista Prehispanista, sin embargo el edifico lleva el lenguaje del Art Déco Zigzag y de la Tendencia Decorativista. Años más tarde cuando Zeferino Domínguez fue contratado para levantar la Escuela Margarita Maza de Juárez (págs. 747 y ss.), ya emplea el lenguaje del Funcionalismo, pero con la presencia del Déco Zigzag combinado con el Streamline y la Tendencia Geometrista. Domínguez cierra su etapa Déco con la Escuela Constituyentes de 1917 (págs. 755 y ss.), ejemplo tardío del Déco Streamline y de la Tendencia Plasticista.

Otros dos edificios Déco están descritos en el libro de Jesús Ramírez que de igual manera que los edificios escolares muy por encima se dice que son Art Déco: la Casa Joch (págs. 767 y ss.) y el Seminario del Sagrado Corazón (págs. 770 y ss.). El primero que lo analizamos como "Arquitectura Comercial” se trata de una pequeña construcción que tanto es comercio como departamentos habitacionales, donde el Déco Zigzag con la Tendencia Decorativista están presentes a pesar de ser un inmueble tardío para este estilo. El segundo que es el seminario analizado bajo la tipología de "Arquitectura Religiosa", se trata de un grande inmueble que en su mayoría exhibe el Funcionalismo, pues tuvo varias etapas constructivas y fue concluido cuando el Art Déco ya había pasado de moda, pero Domínguez le imprime capitalmente Streamline y en segunda instancia el Zigzag junto con la Tendencia Decorativista.

Zeferino Domínguez Villarreal trató muchos lenguajes arquitectónicos y como pudimos ver estudió, conoció, manejo y combino las variantes del Art Déco. Si bien Jesús Ramírez ya hizo un merecido homenaje a Zeferino Domínguez, aún faltaba analizar sus obras Déco detenidamente, con la descripción de las características formales como lo ofrecemos en este estudio.

Un edificio más encontramos en Saltillo, el Cinema Palacio (págs. 760 y ss.). Inserto en la "Arquitectura del Ocio", sin hallar el autor, es un caso de Art Déco Streamline 
en su estructura arquitectónica, pero que exhibe todavía sus decoraciones Zigzag en las puertas de acceso. Relegado por los historiadores de la arquitectura coahuilense, a pesar de la fama que adquirió en Estados Unidos al ser pintado por Edward Hopper, esta sala de cine que vuelve a estar en funciones, esperemos sea valorada y catalogada como un importante edifico Art Déco.

Torreón es una ciudad que prácticamente se desarrolla en la postrevolución, por lo tanto algunas de sus edificaciones se levantaron con la estilística del Art Déco. En la “Arquitectura de Servicios” analizamos el Mercado Juárez (págs. 782 y ss.), un descuidado céntrico comercio construido por el ingeniero José Bracho, con unas excelentes portadas Déco Zigzag ricas en decoración, edificio que fue mencionado en el catálogo de la exposición del Art Déco en México del Museo Nacional de Arte y que después se quedó en la omisión de todo el arte mexicano. Otro inmueble de servicios del que no encontramos la autoría de su construcción es el Edificio Eléctrico (págs. 792 y ss.), hermanado con el Mercado Juárez en materiales como la cantera y sobre todo en formas compositivas, compartiendo la variante Déco Zigzag y la Tendencia Geometrista, por lo que podemos inferir que haya sido obra del mismo autor del Mercado Juárez. Y un caso más es el Hotel Galicia (págs. 801 y ss.), construido por Cesáreo Lumbreras bajo los lineamientos del propietario Fernando Rodríguez, quien quiso transmitir sus orígenes hispanos en una construcción ecléctica, en la cual aflora el Art Déco Zigzag, el Tropical Déco y hasta el Streamline del letrero, con una fuerte presencia de la Tendencia Decorativista. Estos edificios rescatados de la indiferencia al ser declarados patrimonio de la ciudad, ahora están siendo valorados gracias a la catalogación del Museo Arocena y esperemos que aún sea más el interés por conservarlos a través del análisis e información aportados por nuestra tesis doctoral.

De nueva cuenta sale a relucir la figura de Zeferino Domínguez, autor del majestuoso Estadio de la Revolución (págs. 808 y ss.), dedicado al beisbol. Óptimos elementos decorativos Déco Zigzag exornan la fachada, con una acentuación del nacionalismo postrevolucionario. Aún sobreviven las luminarias, dignos objetos Art Déco de la misma variante Zigzag. Recinto con presencia de las Tendencias Geometrista y Decorativista mencionado por Jesús Ramírez, casi nada dice de sus bellos adornos Art Déco y más aún de los relieves, de los cuales incluso Ramírez expone que están dedicados 
al deporte. Significativo aporte ofrecemos al describir este estadio desde la perspectiva estilística del Déco y más aún la identificación de los personajes de los medallones y las escenas de los relieves. Junto al estadio, la estructura al aire libre del Parque anexo (págs. 820 y ss.), obra también de Domínguez, de acentuado geometrismo, muestra un Art Déco Zigzag, combinado con las Tendencias Geometrista y Plasticista. El genio de Zeferino Domínguez está presente en Torreón con el legado de estas dos espléndidas construcciones, ahora ya analizadas y descritas en este tratado bajo la óptica estilista del Art Déco.

Por último y para cerrar, en el lejano poblado de Nueva Rosita, un aislada muestra de la "Arquitectura Escolar", la Escuela Fortunato Gutiérrez (págs. 824 y ss.), que con una combinación de elementos Déco Zigzag y Streamline, pues fue edificada tardíamente dentro de los tiempos del desarrollo del Art Déco, sólo es mencionada por los lugareños como su centro de educación media, pero su grandeza estilística no se había descrito antes.

Sabemos que hay muchas más cosas por estudiar del Art Déco en la Región Noreste de México en los estados de Nuevo León y Coahuila, pero consideramos que las expectativas de llevar a cabo un estudio sobre ejemplares destacados del Déco, la hemos realizado de la mejor manera posible, con las limitantes de no existir la información deseada en los archivos o en las publicaciones bibliográficas, periódicas y electrónicas. Somos conscientes que una vez finalizada esta investigación podamos optar por abrir nuevos estudios, dirigidos a completar el conocimiento a cerca de la autoría de las obras y a extender nuestro radio de acción a unos escenarios más amplios que la Región Noreste de México. También confiamos que nuestro trabajo sirva de base a futuros investigadores del Art Déco en México, por lo que no podemos dejar de considerar la necesidad de afrontar, de manera inmediata, la publicación de nuestro estudio.

En todo caso, nuestro empeño e interés, al acometer la realización de la presente tesis doctoral, ha estado dirigido y centrado en el conocimiento, estudio, catalogación y análisis estilístico de las obras más relevantes de un específico contexto regional del Art Déco mexicano, con el objetivo de valorar y dar a conocer su extraordinaria riqueza. En este sentido, hemos trabajado para aportar ejemplos inéditos, en mayor número en Nuevo León que Coahuila, y, sobre todo, para vincular las características formales de las obras analizadas a la estética Déco. De tal manera que este conjunto de obras puedan incorporarse 
y enriquecer, en un futuro, al importante movimiento artístico internacional que hoy conocemos con el nombre de Art Déco. 


\section{BIBLIOGRAFÍA}

ALFARO, Francisco H.; OCHOA, Alejandro.

La República de los cines. México, Clío, 1998.

ALESSIO ROBLES, Vito.

Saltillo en la historia y la leyenda. México, A. del Bosque Impresor, 1934.

AMÁBILIS, Manuel.

El pabellón de México en la exposición ibero-americana de Sevilla. México, Talleres Gráficos de la Nación, 1929.

ARAÑó, Axel (editor).

Arquitectura escolar SEP 90 años. México, Secretaría de Educación Pública, Consejo Nacional para la Cultura y las Artes, 2011.

ARNALDO, Javier.

Las vanguardias históricas (1). Madrid, Historia 16, 1993, colecc. Historia del Arte, No. 45.

ARWAS, Victor.

Art Deco, New York, Abrams, 2000.

BARBOSA ALANÍS, Héctor Javier.

Monterrey. Descubra el ayer de nuestra ciudad. Monterrey, N.L., Agencia Promotora de Publicaciones, 2010.

Recuerdos de Monterrey. Monterrey, N.L., s/ed., 1993.

BARRIENTOS CLAUDIO, Francisco Javier.

"La educación preparatoria y tecnológica". La Enciclopedia de Monterrey. Tomo III Nuevo León: visión al futuro, Monterrey, N.L., Milenio, Multimedios, 2008, 2a . , edición.

BAYER, Patricia.

Art Deco, Barcelona, Océano, 1997.

BECKER, Udo.

Enciclopedia de los símbolos. México, Océano, 1996. 
BELTRANDO-PATIER, Marie-Claire.

Historia de la Música. Madrid, ESPASA, 2001.

BENÉVOLO, Leonardo.

Historia de la arquitectura moderna. Barcelona, Gustavo, Gili, 1982, $5^{\text {a }}$ edición.

BENTON, Charlotte; BENTON, Tim; WOOD, Ghislaine (eds.)

Art Deco 1910-1939. London, V\&A Publications, 2003.

BOSSAGLIA, Rossana.

L'Art Déco. Roma, Laterza, 1984.

BOUCHER, Francois.

20,000 years of fashion. The History of Costume and Personal Adornment. New York, Harry N. Abrams, 1987.

BOUILLON, Jean Paul.

Diario del ART DÉCO. Barcelona, Destino, 1989.

BRAOJOS GARRIDO, Alfonso; GRACIANO GARCÍA, Amparo.

El pabellón de México en la Sevilla de 1929: evocaciones históricas y artísticas. Sevilla, Universidad de Sevilla, 1998.

BREEZE, Carla.

American ART DECO architecture and regionalism. New York, W.W. Norton \& Company, 2003.

BRÖHAN, Torsten; BERG, Thomas.

Avantgarde Design 1880-1930. Köln, Benedikt Taschen, 1994.

BURIAN, Edward R. (ed.)

Modernidad y arquitectura en México. México, Gustavo Gili, 1998.

CAMACHO CERVANTES, Hortencia.

“Anáhuac. Puerta de entrada a Nuevo León". VV.AA. Nuevo León a través de sus municipios. Vol. I. Monterrey, N.L., Milenio, Multimedios, 2010.

Desde el El Salado hasta el Bravo símbolos de identidad municipal. Anáhuac, N.L., DIF Municipal de Anáhuac, 1997. 
CANTÚ SILVA, Marcos; MARROQUíN CAVAZOS, Susana; LOREDO MACÍAS, Sergio.

Escuela Industrial y Preparatoria Técnica Álvaro Obregón 75 Aniversario. Monterrey, N.L., UANL, 2005.

CÁRDENAS HEIRAS, Sergio; BENAVIDES, Héctor.

"Los medios, voces de libertad". La Enciclopedia de Monterrey. Nuevo León: visión al futuro. Tomo III. Monterrey, N.L., Milenio, Multimedios, 2008, 2ª edición.

CASA BAYER.

Rincones Mexicanos por García Cabral. México, Casa Bayer, S.A., s/f.

CASAS GARCÍA, Juan Manuel.

Documento de recomendaciones para una ciudad en su $401^{\circ}$ aniversario. Monterrey, N.L., Tesis de Licenciatura en Arquitectura, Universidad Autónoma de Nuevo León, 1997.

CASAS GARCÍA, Juan Manuel; COVARRUBIAS MIJARES, Rosana; PEZA RAMÍREZ, Edna Mayela.

Concreto y efímero. Catálogo de arquitectura civil de Monterrey. 1920-1960. Monterrey, N.L., CONARTE, 2012.

CASASÚS, Fernando Rafael.

Monterrey 414 trozos de su historia. Monterrey, N.L., Creatividad Editorial, 2010, $3^{\text {a }}$, edición.

CAVAZOS GARZA, Israel.

Breve historia de Nuevo León. México, El Colegio de México, Fideicomiso Historia de las Américas, Fondo de Cultura Económica, 1994.

Diccionario Biográfico de Nuevo León. Monterrey, N.L., Universidad Autónoma de Nuevo León, 1984.

"Páginas para una historia de Monterrey". VV.AA. La Enciclopedia de Monterrey. Una ciudad con memoria. Tomo I. Monterrey, N.L., Milenio, Multimedios, 2008, $2^{\mathrm{a}}$ edición.

CAVAZOS GARZA, Israel; ORTEGA RIDAURA, Isabel.

"Monterrey. Capital de Nuevo León". VV. AA. Nuevo León a través de sus municipios. Tomo III. Monterrey, N.L., Milenio, Multimedios, 2010. 
CAVAZOS GARZA, Israel; GONZÁLEZ, Homero; TAMEZ, Santiago; MACÍAS, Armando; VÁZQUEZ David.

1930-1980. 50 aniversario de la Escuela Industrial y Preparatoria Técnica "Álvaro Obregón”. Reseña Histórica. Monterrey, N.L., 1980.

CERRILLO RUBIO, Lourdes.

"Cartografía de una fascinación: Diaghilev, los Ballets Rusos y España” en: Miguel Cortés Arrese y Juan Agustín Mancebo Roca (Eds.), El viaje a Rusia, Murcia, Nausícaä, 2008.

La moda moderna. Génesis de un arte nuevo. Madrid, Siruela, 2010.

"Significados del estilo Chanel". Estudios de Historia del Arte. Homenaje al Profesor De La Plaza Santiago, Valladolid, Universidad de Valladolid, Diputación de Valladolid, 2009.

CHALUMEAU, Jean-Luc.

Cubismo. Barcelona, Poligrafía, 1996.

CIRICI, Alexandre.

"Modernismo". Historia del Arte. México, Salvat Mexicana de Ediciones, 1979, Tomo 10.

CIRLOT, Lourdes. (ed)

Primeras Vanguardias Artísticas. Textos y Documentos. Barcelona, Labor, 1995.

COHEN, Jean-Louis

Le Corbusier. Köln, Taschen, 2013.

CONSEJO PARA LA CULTURA Y LAS ARTES DE NUEVO LEÓN.

Fermín Revueltas y la modernidad, de lo rural a lo urbano. Monterrey, N.L., Consejo para la Cultura y las Artes de Nuevo León, 2004.

Nuevo León imágenes de nuestra memoria. Monterrey, N.L., Consejo para la Cultura y las Artes de Nuevo León, 2003.

COSTANTINO, María.

Art Nouveau. Madrid, LISBSA, 1993. 
COVARRUBIAS, Miguel.

El Sur de México. México, D.F., Instituto Nacional Indigenista, 1980.

Island of BALI, Jakarta, Periplus Editions, 1973.

CRUZ, J.A. (ed.)

ALBUM DE ANIVERSARIO DE LA FUNDACIÓN DE LA CIUDAD DE MONTERREY, N.L. 159620 DE SEPTIEMBRE DE 1946. Monterrey, N.L., s/ed., 1946.

CUÉLLAR VALDÉS, Pablo.

Historia del Estado de Coahuila. Saltillo, Coahuila, Universidad Autónoma de Coahuila, 1979.

DE ANDA ALANÍS, Enrique X.

Historia de la Arquitectura Mexicana. México, Gustavo Gili, 2013, $3^{\text {a }}$, edición.

La Arquitectura de la Revolución Mexicana. Corrientes y Estilos de la década de los veinte. México, IIE, UNAM, 1990.

“La Arquitectura Mexicana entre 1921 y 1933”. "La Arquitectura Mexicana entre 1934 y 1945". Historia del Arte Mexicano. Arte Contemporáneo I. México, SEP, Salvat, 1986, $2^{\mathrm{a}}$ edición.

DE FEO, Vittorio.

La arquitectura en la U.R.S.S., 1917-1936. Madrid, Alianza Editorial, 1979.

DE LA MAZA, Francisco.

Del neoclásico al art nouveau y Primer viaje a Europa. México, Secretaría de Educación Pública, 1974.

DE LA PLAZA, Francisco Javier.

"El Art Déco". Conferencia dictada en la Universidad de Monterrey, miércoles 19 de marzo de 1997.

DE MICHELI, Mario.

Las vanguardias artísticas del siglo XX. Madrid, Alianza Editorial, 1981, $2^{\mathrm{a}}$ edición. 
DROSTE, Magdalena.

Bauhaus, 1919-1933. Köln, Taschen, 1993.

DUARTE ORTEGA, Nicolás.

"Cuando los inspectores sí inspeccionaban", en: El Norte, Monterrey 400: Una historia de progreso. Monterrey, N.L., El Norte-Castillo, 1996.

DUNCAN, Alastair.

American Art Deco. Nueva York, Thames and Hudson, 1999.

MUEBLES ART DÉCO. Barcelona, Stylos, 1986.

DUNCAN, Alastair. (ed)

Encyclopedia of Art Deco. Londres, Quantum Books, 1988.

DUNHAM, Judith.

Details of Frank Lloyd Wright. The California Work, 1909-1974. San Francisco, Chronicle Book, 1994.

EDER, Rita.

"Las imágenes de los prehispánico y su significación en el debate del nacionalismo cultural". El nacionalismo y el Arte Mexicano (IX Coloquio de Historia del Arte). México, UNAM, Instituto de Investigaciones Estéticas, 1986.

\section{EL NORTE.}

Monterrey 400: Una Historia de Progreso. Monterrey, N.L., El Norte-Castillo, 1996.

ELIZONDO FERRARA, Aurelia; MARTÍNEZ GUTIÉRREZ, Juan Manuel.

El Mural de la Casa del Campesino, San Pedro Garza García, N.L., Universidad de Monterrey, Tesis de Maestría en Humanidades, 1995.

ESQUEDA, Xavier.

Catálogo de la Exposición Una puerta al Art Deco. México, UNAM, Centro de Investigación y Servicios Museológicos, 1980.

El Art Deco. Retrato de una época. México, UNAM, Centro de Investigación y Servicios Museológicos, 1986. 
ETTINEGR McENULTY, Catherine Rose.

"La presencia del siglo XX en el tejido del centro histórico de Morelia expresiones de integración", en: Carlos Montero Pantoja y María Silvina Mayer Medel (coordinadores). Estudios de Arquitectura y Urbanismo del siglo XX. Memorias del Tercer Encuentro Nacional de Arquitectura del Silgo XX del ICOMOS Mexicano A.C. Puebla, Instituto de Ciencias Sociales y Humanidades "Alfonso Vélez Pliego", Benemérita Universidad Autónoma de Puebla, ICOMOS MEXICANO, A.C., 2007.

FAGIUOLI, Martino.

La Habana Deco. Bolonia, CV Export, 2003.

FERNÁNDEZ, Justino.

Arte Contemporáneo de México. México, UNAM, 1994, $2^{a}$., edición.

El Arte del siglo XIX en México. México, UNAM, 1967, 2ª, edición.

FERNÁNDEZ POLANCO, Aurora.

Fin de siglo: Simbolismo y Art Nouveau. Madrid, Historia 16, 1989, colecc. Historia del Arte No. 42.

FIELL, Charlotte \& Peter.

Diseño del siglo XX. Köln, Taschen, 2012.

FLORES GARCÍA, Marisol.

Guía de recorridos urbanos de la colonia Hipódromo. México, INBA, Universidad Iberoamericana, 2002.

FONDO EDITORIAL DE LA PLÁSTICA MEXICANA.

La Pintura Mural de la Revolución Mexicana 1921-1960. México, Banco Nacional de Comercio Exterior, S.A., 1960.

FORNÉS BONAVÍA, Leopoldo.

Cuba, cronología: cinco siglos de historia, política y cultura. Madrid, Verbum, 2003.

FRAMPTON, Kenneth.

American Masterworks. New York, Rizzoli, 1995. 
FRANCO, Enrique; ARTEAGA, Agustín.

"Lo nacional como vanguardia: escultura, identidad e historia", en: Magdalena Zavala y Alejandrina Escudero (Coordinación editorial). Escultura Mexicana. De la Academia a la instalación. México, INBA, Landucci Editores, 2001, 2a ., edición.

\section{FUNDACIÓN "LA CAIXA".}

Catálogo de la exposición Los Ballets Rusos de Diaghilev 1909/1929. Cuando el arte baila con la música. Barcelona-Madrid, Fundación "la Caixa", TURNER, 2011.

GARCÍA FELGUERA, María Santos.

Las vanguardias históricas (y 2). Madrid, Historia 16, 1993, colecc. Historia del Arte No. 46.

GARCÍA MOLL, Roberto; BALI WUEST, Jaime.

México arqueológico, México, Salvat, 1988.

GARCÍA RIERA, Emilio.

Historia del Cine Mexicano. México, SEP, 1986.

GARCÍA RIERA, Emilio; MACOTELA, Fernando.

La Guía del Cine Mexicano de la pantalla grande a la televisión 1919-1984. México, Patria, 1984.

GARZA USABIAGA, Daniel.

"Arquitectura en México después de la Revolución", en: Luz María Sepúlveda (coordinadora). Las artes plásticas y visuales en los siglos XIX y XX. El Patrimonio Histórico y Cultural de México (1810-2010). Tomo VI. México, Dirección General de Publicaciones del CONACULTA, 2013.

GOLDIN, John.

El Cubismo. Una historia y un análisis. Madrid, Alianza Editorial, 1993.

GONZÁLEZ DE MONTEMAYOR, Beatriz.

Efemérides del Municipio de Torreón Coah. 1848-1948. Torreón, Coahuila, Ayuntamiento de Torreón, 1999.

GONZÁLEZ GORTÁZAR, Fernando. (ed.)

La arquitectura mexicana del siglo XX. México, CONACULTA, 1996, Lecturas Mexicanas, Cuarta serie. 
GÖSSEL, Peter; LEUTHÁSER, Gabriele.

Arquitectura del Siglo XX. Köln, Taschen, 2012.

GRAVELOT, Huber; COCHIN, Nicolás.

Iconología. México, Universidad Iberoamericana, 1994.

GÜELL, Xavier.

Gaudí. Barcelona, Gustavo Gili, 1991, colección Guías de Arquitectura.

HABASQUE, Guy.

"Cubismo". Historia del Arte. México, Salvat Mexicana de Ediciones, 1979, Tomo 11.

HATJE, Ursula.

Historia de los Estilos Artísticos. Madrid, Ediciones Itsmo, 1971.

HAYES, Joy Elizabeth.

Radio Nation: Communication, popular Culture, and Nationalism in Mexico. Tucson, University Arizona Press, 2000.

HIESINGER, Kathryn B.; MARCUS, George H..

Landmarks of Twentieth-Century Desing. New York, Abbeville Press, 1993.

HILLIER, Bevis; ESCRITT, Stephen.

Art Deco Style. London, Phaidon Press Ltd, 1977.

INAH; SEP.

Catálogo Nacional de Monumentos Históricos Inmuebles. Coahuila. Tomos III y IV. México, SEP, INAH, Programa Cultural de las Fronteras, Gobierno del Estado de Coahuila, 1986.

Catálogo Nacional de Monumentos Históricos Inmuebles. Nuevo León. Tomos III y $I V$. México, SEP, INAH, Programa Cultural de las Fronteras, Gobierno del Estado de Nuevo León, 1984.

INSTITUTO MEXICANO NORTEAMERICANO DE RELACIONES CULTURALES. Catálogo de la exposición El Art Deco en México. México, Instituto Mexicano Norteamericano de Relaciones Culturales, A. C., 1977. 


\section{INSTITUTO NACIONAL DE BELLAS ARTES.}

Catálogo de la exposición Art Déco. Un país nacionalista, un México cosmopolita. México, Instituto Nacional de Bellas Artes, 1997, 1ª edición, $19981^{a}$ reimpresión.

La construcción del Palacio de Bellas. México, Instituto Nacional de Bellas Artes, 1984.

JAFFÉ, L.C.

"Abstracción geométrica". Historia del Arte. México, Salvat Mexicana de Ediciones, 1979, Tomo 11.

JIMÉNEZ, Jorge H.

"Las condiciones materiales de realización de la arquitectura del art-déco", en: Fernando González Gortázar. (ed.) La arquitectura mexicana del siglo XX. México, CONACULTA, 1996, Lecturas Mexicanas, Cuarta serie.

KASSNER, Lily.

Diccionario de escultores mexicanos del siglo XX. México, CONACULTA, 1997.

"Escultura nacionalista". Historia del Arte Mexicano. Arte Contemporáneo II. México, SEP, Salvat, 1986, 2ª edición.

KATZMAN, Israel.

Arquitectura Contemporánea Mexicana. México, INAH, 1964.

KULTERMANN, Udo.

"Arquitectura del siglo XX". Historia del Arte. México, Salvat Mexicana de Ediciones, 1979, Tomo 12.

LACLOTE, Michel.

Diccionario Larousse de la Pintura. Barcelona, Planeta de Agostini, 1987.

LAMBERT, Rosemary.

El siglo XX. Barcelona, Gustavo Gili, 1989, $3^{\text {a }}$., edición.

LAMPUGNANI, Vittorio Magnano. (ed.)

Enciclopedia GG de la arquitectura del siglo XX. Barcelona, Gustavo Gili, 1989. 
LANDUCCI LERDO DE TEJADA, Sandro.

Los Murales del Palacio de Bellas Artes. México, Américo Arte Editores, Instituto Nacional de Bellas Artes, 1995.

LEAL RÍOS, Armando.

“Linares. Primera sede episcopal de Nuevo León”. VV. AA. Nuevo León a través de sus municipios. Tomo III, Monterrey, N.L., Milenio, Multimedios, 2010.

LEHNERT, Gertrud.

Histoire de la mode au XXe siécle. París, Könemann, 2000.

LIST ARZUBIDE, Germán.

El movimiento estridentista. México, Secretaría de Educación Pública, 1987.

LÓPEZ LÓPEZ, Jesús Martín.

Arquitectura y escuelas en Saltillo, Coah. Saltillo, Coah., Universidad Autónoma de Coahuila, 2007.

LORENTE, Juan F. Esteban.

Tratado de Iconografía, Madrid, Istmo, 2002.

LUSSIER, Suzanne.

Art Deco Fashion. Londres, Bulfinch Press, 2003.

MAENZ, Paul.

Art Déco: 1920-1940. Barcelona, Gustavo Gili, 1974, colecc. Comunicación Visual.

MAGAÑA FAJARDO, Carolina.

El Art Déco en la ciudad de México. Retrospectiva de un movimiento arquitectónico, México, UNAM, Tesis de Doctorado en Arquitectura, 2007.

McCARTER, Robert.

Frank Lloyd Wright. London, Phaidon, 1999.

MALDONADO CERVANTES, Enrique.

"Salinas Victoria Centro histórico del valle de las Salinas". VV. AA. Nuevo León a través de sus municipios. Tomo IV. Monterrey, N.L., Milenio, Multimedios, 2010. 
MANRIQUE, Jorge Alberto.

“Tres décadas en la escultura 1920-1950", en: Escultura Mexicana. De la Academia a la instalación. México, INBA, Landucci Editores, 2001.

MAPLES ARCE, Manuel.

Poemas Interdictos. Jalapa, Ver., Ediciones de Horizonte, 1927.

Urbe: súper-poema bolchevique es 5 cantos. México, Botas e Hijos, 1924.

MARTÍNEZ, Oscar Eduardo.

"Monterrey, ciudad vieja, ciudad nueva. Su arquitectura y urbanismo". La Enciclopedia de Monterrey. Tomo II. La capital industrial de México. Monterrey, N.L., Milenio, Multimedios, 2008, $2^{\mathrm{a}}$ edición.

MAYER-SERRA, Otto.

Músicos y Música de Latinoamérica. México, Atlante, 1947.

MEDELLÍN, María Luisa.

"El amor a la patria tenía un '10"'. Monterrey 400. Una historia de progreso. Monterrey, N.L., El Norte-Castillo, 1996.

MEGGS, Philip B.; PURVIS, Alston W.

Historia del diseño gráfico. Barcelona, RM VERLAG, 2009.

MÉNDEZ-VIGATÁ, Antonio E.

"Política y lenguaje arquitectónico. Los regímenes posrevolucionarios en México y su influencia en la arquitectura pública", en: Eduard R. Burian. (ed.) Modernidad y arquitectura en México. México, Gustavo Gili, 1998.

MENDIRICHAGA, José Roberto.

Patrimonio Plástico de la UANL. San Nicolás de los Garza, N.L., Universidad Autónoma de Nuevo León, 1991.

MENDIRICHAGA, Rodrigo.

"Industria: crecimiento de un gigante". La Enciclopedia de Monterrey. Tomo I1. La capital industrial de México. Monterrey, N.L., Milenio, Multimedios, Grijalbo, 2008, $2^{\mathrm{a}}$., edición.

Los cuatro tiempos de un pueblo. Nuevo León en la historia. Monterrey, N.L., Instituto Tecnológico y de Estudios Superiores de Monterrey, 1985. 
MENDIRICHAGA, Tomás y Xavier.

La Catedral de Monterrey, Monterrey, EMEDICIONES, 1990, 2ª , edición.

MENTEN, Theodore.

The Art Deco Style in Household Objects Architecture Sculpture Graphics Jewelry. New York, Dover Publications, 1972.

MINNAERT, Jean-Baptiste.

Henri Sauvage ou l'exercice du renouvellement. Paris, Norma, 2002.

MONSIVÁIS, Carlos.

"Notas sobre la cultura mexicana en el siglo XX". Historia General de México. Tomo 2. México, El Colegio de México, 1981.

MONTEMAYOR, Andrés.

Historia de Monterrey. México, Asociación de Editores y Libreros de Monterrey, 1971.

MORGAN, Sarah.

Art Deco: the european style. Greenwich, CT, Dorset Press, 1990.

MOYSSÉN LECHUGA, Xavier (ed).

Artes Plásticas de Nuevo León 100 Años de Historia Siglo XX. Monterrey, N.L., Museo de Monterrey, 2000.

MUSACCHIO, Humberto.

Diccionario Enciclopédico de México. México, Andrés León Editor, 1995, $1^{\text {a }}$ edición, $10^{\mathrm{a}}$ reimpresión.

MUSEO BILIOTECA PAPE.

Catálogo de la exposición ART NOUVEAU. ART DECO. Monclova, Coahuila, Museo Biblioteca Pape, 1980.

NÉRET, Gilles.

Klimt. Köln, Taschen, 1993.

Lempicka. Köln, Taschen, 1993. 
NOELLE, Louise.

Arquitectos contemporáneos de México. México, Trillas, 1993, 2ª edición.

NOELLE, Louise; TEJEDA, Carlos.

Catálogo Guía de Arquitectura Contemporánea. Ciudad de México. México, Fomento Cultural Banamex, 1993.

OBRA SOCIAL "la Caixa".

Los Ballets Rusos de Diaguilev 1909/1929 cuando el arte baila con la música. Barcelona, Fundación "la Caixa"/TURNER, 2011.

ORTA VELÁZQUEZ, Guillermo.

100 Biografías en la Historia de la Música. México, Olimpo, 1970.

ORTEGA-COCA, Teresa.

Eduardo García Benito y el Art-Déco. Valladolid, Ayuntamiento de Valladolid, Fundación Municipal de Cultura y Diputación de Valladolid, 1999.

ORTIZ GAITÁN, Julieta.

Entre dos mundos: los murales de Roberto Montenegro. México, UNAM, Instituto de Investigaciones Estéticas, 1994.

Roberto Montenegro: Producción Mural (1919-1966). México, D.F., Tesis de Maestría en Historia del Arte, UNAM, 1989.

PEEL, Lucy; POWELL, Polly; GARRETT, Alexander.

Introducción a la Arquitectura del siglo XX. Barcelona, CEAC, 1990.

PEVSNER, Nikolaus.

Historia de las tipologías arquitectónicas. Barcelona, Gustavo Gili, 1979.

PÉREZ-RIOJA, José Antonio.

Diccionario de Símbolos y Mitos, Madrid, Tecnos, 2008, $8^{\text {a }}$, edición.

PÉREZ ROJAS, Javier.

Art Deco en España. Madrid. Cátedra, 1990.

PILDAS, Ave.

Movie Palaces. New York, Calrkson N. Potter, Inc., 1980 
POLETTI, Therese.

Art Deco San Francisco. The Architecture of Timothy Pflueger. New York, Princeton Architectural Press, 2008.

POMAR, María Teresa.

"Presentación", en: Dr. Atl. Las Artes Populares en México. México, Instituto Nacional Indigenista, 1980, Serie Artes y Tradiciones Populares, No. 1.

PORTILLO VALADEZ, José Antonio.

La Purísima Concepción en Monterrey. Templo e imágenes más antiguas. Monterrey, N.L., s/e., 2006.

PRIETO GONZÁLEZ, José Manuel.

Guía de Patrimonio Arquitectónico de Nuevo León. Monterrey, N.L., Consejo para la Cultura y las Artes de Nuevo León, 2009.

RAMÍREZ, Fausto.

"La visión europea de la América Tropical: los artistas viajeros", Historia del Arte Mexicano, México, SEP, Salvat, 1986, 2ª, edición, vol. 10.

RAMÍREZ, Juan Antonio.

La arquitectura en el cine Hollywood, la Edad de Oro. Madrid, Alianza Editorial, 1995.

RAMÍREZ RODRÍGUEZ, Jesús.

La obra de Zeferino Domínguez Villarreal en el siglo XX. Saltillo, Coah., Gobierno del Estado de Coahuila, Instituto Coahuilense de Cultura, 2007.

RÉAU, Louis.

Iconografía del arte cristiano. Barcelona, Ediciones del Serbal, 1997.

RIEDL, Peter Anselm.

"Wassily Kandinsky", Cinco Grandes de la Pintura Moderna, México, PROMEXA, 1980.

ROBLES DE LA TORRE, José León.

Torreón en las Letras Nacionales. Torreón, Coahuila, Editorial del Norte Mexicano, 1986. 
RODRÍGUEZ RUIZ, Delfín.

La arquitectura del siglo XX. Madrid, Historia 16, 1993, colecc. Historia del Arte, No. 47.

ROEL, Santiago.

Nuevo León, Apuntes históricos. Monterrey, s/e., 1963, $11^{\text {a }}$ edición.

ROMÁN, J. Miguel.

Colores del Alma. Los vitrales de Roberto Montenegro en la Universidad Autónoma de Nuevo León; una revisión histórica e iconográfica. Monterrey, N.L., Universidad Autónoma de Nuevo León, 2008.

ROMERO KEITH, Delmari.

"Otras figuras del muralismo". Historia del Arte Mexicano. Arte Contemporáneo II. México, SEP, Salvat, 1986, 2ª edición.

RUBIO Y RUBIO, Alfonso.

“Adolfo Laubner". Universidad Mexicana del Noreste. Educadores de Nuevo León. Monterrey, N.L., Universidad Mexicana del Noreste, 1996.

S/A.

Art Déco, mobiliario y metalistería. Madrid, Edimat, 1999.

S/A.

Art Déco, pintura y diseño. Madrid, Edimat, 1999.

S/A.

Catálogo de Monumentos del Estado de Nuevo León. Monterrey, N.L., Secretaría de Educación y Cultura, 1984.

S/A.

El mueble del siglo XX. Art Déco. Barcelona, Planeta-Agostini, 1989.

S/A.

Giorgio de Chirico. Barcelona, Poligrafía, 1995.

SALAZAR, Horacio.

"La entrada al nuevo siglo", en: Moyssén, Xavier (ed). Artes Plásticas de Nuevo León 100 Años de Historia Siglo XX. Monterrey, N.L., Museo de Monterrey, 2000. 
SALAZAR GIL, Fernanda.

Un acercamiento a las ilustraciones de tipo decadentista de Crescenciano Garza Rivera en el periódico El Universal entre 1921 y 1925. México, Instituto de Investigaciones Estéticas, UNAM, Tesina de La Especialidad en Historia del Arte, 2004.

SALDAÑA, José P.

¿Y Qué Hicimos?... Monterrey en el siglo XX. Monterrey, N.L., Al Voleo-El Troquel, 1988.

SALINAS FLORES, Oscar.

Historia del Diseño Industrial. México, Trillas, 1992.

SÁNCHEZ MENA, Rogelio.

El Art Decó en León, Guanajuato. México, Instituto Nacional de Antropología e Historia, 1995.

SCHNEIDER, Luis Mario.

El Estridentismo: México 1921-1927. México, UNAM, 1985.

SELLE, Gert.

Ideología y utopía del diseño. Barcelona, Gustavo Gili, 1975.

SEMBACH, Kalus-Jürgen.

Modernismo. Köln, Taschen, 2007.

SEP.

Diego Rivera. Catálogo General de Obra Mural y Fotografía Personal, México, Instituto Nacional de Bellas Artes, 1998.

SEPÚLVEDA, Nazario.

"El cine en Monterrey". La Enciclopedia de Monterrey. Tomo I. Una ciudad con memoria. Monterrey, N.L., Milenio, Multimedios, 2008, 2ª., edición.

SILVA ANGÓN, María Cristina Rocío.

"La Arquitectura Art Deco en Puebla. Su valoración y conservación", V Encuentro Internacional Ciudad Imagen y Memoria, Forum UNNESCOUniversidad de Oriente, Facultad de Construcciones, Santiago de Cuba, 2007.

STERNAU, Susan A.

ART DECO. Flights of artistic fancy. Nueva York, Smithmark, 1997. 
STERNER, Gabriele.

Modernismos. Barcelona, Labor, 1982, $1^{\text {a }}$., reimpresión.

TAFURI, Manfredo; DAL CO, Francesco.

Arquitectura contemporánea. Aguilar, Madrid, 1978, 1ª reimpresión 1980.

TAPIA MÉNDEZ, Aureliano.

La Purísima. Historia de una imagen y su templo. Monterrey, N.L., Al Voleo-El Troquel, 1989.

La Virgen Chiquita. Historia de una imagen y sus templos. Monterrey, N.L., Al Voleo-El Troquel, 2003.

TENORIO TRILLO, Mauricio.

Artilugio de la nación moderna. México en las exposiciones universales. 18801930. México, Fondo de Cultura Económica, 1998.

TOCA FERNÁNDEZ, Antonio.

"Evolución crítica de la arquitectura en México: 1900-1990", en: Fernando González Gortázar. (ed.) La arquitectura mexicana del siglo XX. México, CONACULTA, 1996, Lecturas Mexicanas, Cuarta serie.

TREVIÑO VILLARREAL, Héctor Jaime.

"Sabinas Hidalgo capital del norte nuevoleonés". VV. AA. Nuevo León a través de sus municipios. Tomo IV, Monterrey, N.L., Milenio, Multimedios, 2010.

TRIADÓ TUR, Juan Ramón.

Historia del Arte, Barcelona, Editorial Norma, 1998.

\section{UNIVERSIDAD AUTÓNOMA DE NUEVO LEÓN.}

1933-1993: una historia compartida. Monterrey, N.L., Universidad Autónoma de Nuevo León, 1994.

Universidad de Nuevo León: testimonio de fundación, UANL, 60 aniversario 19331993. San Nicolás de los Garza, N. L., Universidad Autónoma de Nuevo León, 1994.

URIBE, Eloísa.

"Los ciudadanos libran su historia. Escultura 1843-1877". Historia del Arte Mexicano, México, SEP, Salvat, 1986, 2ª, edición, vol. 10. 


\section{URZAIZ LARES, Enrique.}

"Arquitectura de la modernidad posrevolucionaria en Mérida, Yucatán: el equipamiento urbano", en: Carlos Montero Pantoja y María Silvina Mayer Medel (coordinadores). Estudios de Arquitectura y Urbanismo del siglo XX. Memorias del Tercer Encuentro Nacional de Arquitectura del Siglo XX del ICOMOS Mexicano A.C. Puebla, Instituto de Ciencias Sociales y Humanidades "Alfonso Vélez Pliego", Benemérita Universidad Autónoma de Puebla, ICOMOS MEXICANO, A.C., 2007.

Arquitectura en Tránsito: Patrimonio Arquitectónico de la Primera Mitad del Siglo XX en la Ciudad de Mérida. Mérida. Universidad de Yucatán, 1997.

VASCONCELOS, José.

La Tormenta. México, Jus, 1958.

VICENS, Francesc.

Arte Abstracto Arte Figurativo. Barcelona, Salvat, 1979.

VILAR, María José.

Estética y tiranía de la moda. Barcelona, Planeta, 1975.

VILLEGAS, Abelardo.

"El sustento ideológico del nacionalismo mexicano". El Nacionalismo y el Arte Mexicano (IX Coloquio de Historia del Arte), México, UNAM, IIE, 1986.

VV.AA.

Historia del Arte. Madrid, Espasa Calpe, 1999.

La Enciclopedia de Monterrey. Monterrey, N.L., Milenio, Multimedios, 2008, 2ª edición.

Nuevo León a través de sus municipios. Monterrey, N.L., Milenio, Multimedios, 2010.

WARNCKE, Carsten-Peter.

DE STIJL. 1917-1931. Köln, Taschen, 1993.

WEBER, Eva.

Art Deco. Madrid, Lisba, 1993. 
ZEVI, Bruno.

Historia de la arquitectura moderna. Barcelona, Poseidón, 1980.

ZIMMERMANN, Claire.

Mies van der Rohe, Köln, Taschen, 2009.

ZURIÁN, Carla.

Fermín Revueltas. Constructor de Espacios. México, INBA, Museo Mural Diego Rivera, Editorial MR, 2002. 


\section{Publicaciones periódicas}

ANAYA RODRÍGUEZ, Edgard.

"Herencia Déco por los rumbos de La Villa". MÉXICO en el tiempo. México, Editorial Jilguero/INAH, Año 3, No. 18, mayo/junio 1997, pp. 35-41.

BARRAGÁN, Juan Ignacio; DÍAZ DÍAZ, Enrique.

"Arquitectos del Noreste". Del Noreste, Monterrey, N.L., Edición Especial, Nos. 10-11-12, Urbis Internacional, 1992.

BARRANCO CHAVARRÍA, Alberto.

"Ciudad de la Nostalgia. La Mano de Obregón”. Reforma. México, D.F., domingo 11 de junio de 2000, secc. B, Ciudad y Metrópoli, p. 9 B.

BARRERA, Yolanda.

"Invierten 100 millones en monumentos". El Norte. Monterrey, N.L., martes 6 de octubre de 1987, secc. Cultural, p. 1.

BAUTISTA, Virginia.

"Restauran el Edificio San Martín. Invitan a habitar una 'obra de arte' ". Reforma.

México, D.F., viernes 16 de junio de 2000, secc. C, Cultura, p. 1 C.

CABRAL PÉREZ, Ignacio.

"Arquitectura Art Déco en la ciudad de Puebla". Snob, Puebla, Pue., Año. 1, número 3, diciembre de 1982, p. 12.

CERRILLO RUBIO, Lourdes.

"El nuevo decorado en los ballets rusos de Serge Diaghilev". Revista de Investigación, Colegio Universitario de Soria, Tomo VI, No. 1-2, 1982, pp. 33-52.

"Paul Poiret y el Art Déco". Anales de Historia del Arte, Madrid, Universidad Complutense, Volumen Extraordinario, 2008, pp. 513-525.

CHAUVIN, Marianne (coordinadora).

Vitrales. México, D.F., Artes de México, Número 94, junio 2009. 
CUÉ, Concha; NORIEGA Inés, RODRÍGUEZ BARRÓN, Daniel.

"EL Centro Histórico; origen, esplendor y gloria del Art Déco mexicano". Centro.

Guía para caminantes. México, Centro Editores, Año 3, núm. 15, febrero de 2005, pp. 30-61.

DE MATTOS ÁLVAREZ, Dulce María.

"Del Art Nouveau al Art Deco". Casa del Tiempo, México, Universidad Autónoma Metropolitana, Vol. IV, Época III, Número 46, Noviembre 2002, pp. 46-53.

DERBEZ GARCÍA, Edmundo.

"Escuela Industrial y Preparatoria Álvaro Obregón”. Memoria Universitaria, Monterrey, N.L., Universidad Autónoma de Nuevo León, Año I, Núm. 9, octubre de 2010, pp. 6-11.

El PORVENIR.

"Declara el Secretario de Gobierno en el asunto del pintor Vicario Román", El Porvenir, Monterrey, N.L., domingo 11 de julio de 1937, p. 4

El artista Garza Rivera da principio a la decoración de la Casa Agrarista", El Porvenir, Monterrey, N.L., viernes 14 de agosto de 1937, p.4

"El primero de noviembre empezarán a trabajar los talleres de la Escuela Industrial". El Porvenir, Monterrey, N.L., domingo 26 de octubre de 1930, p. 4.

"La exposición de Bellas Artes se instalará en la escuela Industrial". El Porvenir, Monterrey, N.L., lunes 29 de septiembre de 1930, p. 5.

Los murales del Auditorium Emiliano Zapata se concluyen con rapidez", El Porvenir, Monterrey, N.L., viernes 25 de febrero de 1938, p.4

"Para en cuatro de octubre vendrá a Monterrey el Presidente de la República, Ing. Ortiz Rubio”. El Porvenir, Monterrey, N.L., domingo 3 de agosto de 1930, p. 4.

"Verdaderos maestros en su oficio, técnicos y prácticos atenderán a la escuela Industrial de Nuevo León”. El Porvenir, Monterrey, N.L., viernes 29 de agosto de 1930 , p. 4.

\section{EL SIGLO DE TORREÓN.}

"El Estadio de la Revolución fue inaugurado solemnemente". El Siglo de Torreón, Torreón, Coahuila, viernes 16 de septiembre de 1932, p. 1. 
FLORES Y ESCALANTE, Jesús; DUEÑAS, Pablo.

"El Art Déco y la radiodifusión: forma de vida urbana". Relatos e Historias en México. México, Editorial Raíces, Año II, Número 22, junio 2010, pp. 54-60.

GÁLVEZ, Felipe.

"Voz jinete del aire". México en el Tiempo. México, D.F., Año 3, No. 23, marzo/abril 1998, pp. 10-17.

GONZÁLEZ, Deyanira.

"Evitan que Monterrey pierda Memoria”. El Norte. Monterrey, N.L., domingo 8 de octubre del 2000, secc. Bienes Raíces, p. 1.

GUERRERO, Vicente.

“Quedarán protegidos edificios del Siglo 20”. El Norte. Monterrey, N.L., lunes 12 de junio del 2000, secc. Vida, p. 1.

GUERRERO, Rocío; DELGADO, Cecilia.

"El Art Déco. Una nueva alternativa cultural". México en el tiempo. México, México Desconocido, Año 3, No. 23, marzo/abril 1998, pp. 26-29.

HERRERA GARCÍA, Emma Leticia; MC PHAIL FANGER, Elsie; SALAZAR TORRES, Citlali. "El monumento a Álvaro Obregón, arte y política. Una obra y un héroe mutilados". Argumentos. México, Universidad Autónoma MetropolitanaXochimilco, Vol. 22, No. 61, septiembre-diciembre 2009, pp. 193-219.

JIMÉNEZ, Víctor.

"El Palacio de Bellas Artes en 1930: viejas piedras, nuevas ideas". México en el Tiempo, México, México Desconocido, Año 3, Núm, 23, marzo-abril 1998, pp. 1825.

"El Siglo del México Contemporáneo en la Arquitectura". México en el Tiempo, México, México Desconocido, Año 5, Núm, 33, 1999, pp. 34-41.

JUEVES DE EXCÉLSIOR.

“Edición Especial Pro Monterrey”. Excélsior. México, D.F., noviembre de 1929.

LAVISTA, Mauricio.

“Decó. La geométrica ciudad”. México Desconocido, México, Jilguero, No. 140, octubre de 1988, pp. 23-34. 
MAC MASTERS, Merry.

"Enrique X., de Anda presentó su libro. Desprotegida, la arquitectura mexicana moderna”. El Nacional. México, D.F., sábado 6 de marzo de 1993, secc. Cultura, p. 20.

MARTÍNEZ CELIS, Eduardo (ed).

"Monterrey 400. Los Forjadores de su Progreso: Lorenzo H. Zambrano Gutiérrez". El Diario de Monterrey, Suplemento especial, La Enciclopedia de Monterrey, Monterrey, N.L., 29 de octubre de 1995, pp. 10, 15 y 17.

MENDOZA LEMUS, Gustavo.

"Pide revivir el acervo de Crescenciano Garza Rivera", Milenio, Monterrey, N.L., martes 6 de abril de 2010, p. 36.

MOYSSÉN ECHEVERRÍA, Xavier.

"El Nacionalismo y la Arquitectura". Anales del Instituto de Investigaciones Estéticas. México, UNAM, Vol, 14, No. 55, 1986, pp.111-131.

"Un dibujante erótico: Crescenciano Garza Rivera". Anales del Instituto de Investigaciones Estéticas. México, UNAM, Vol. XVI, No. 63, 1992, pp. 137-147

OLIVO, Oscar.

"Las bellas artes del palacio", Artes Plásticas, Nos. 1 y 2, octubre 1984 - enero 1985, pp. 25-31.

PRADO, Mario.

"Preparan catálogo de inmuebles de NL". El Porvenir. Monterrey, N.L., martes 26 de septiembre del 2000, secc. Cultura, p. 1.

PRIETO GONZÁLEZ, José Manuel.

"Monterrey como Estridentópolis: vigencia del ideal urbano de la vanguardia histórica mexicana", Palapa, Colima, México, Universidad de Colima, vol. IV, núm. I, enero-junio, 2009, pp.17-31.

RIELLO, José.

"Paul Klee en la Bauhaus" Descubrir el Arte, Madrid, Año XIV, n' 169, marzo 2013, pp. 74-83.

S/A.

"CUBISMO. Cómo nació". Saber Ver. México, Fundación Cultural Televisa, No. 6, septiembre-octubre 1992, pp. 38-59. 
S/A.

"La Secesión de Viena". Saber Ver. México, Fundación Cultural Televisa, No. 7, noviembre-diciembre 1992, pp. 24-61.

S/A.

“Les années 20”. Art \& Décoration. Paris, No. 351, juin 1997, pp.66, 68 y 70.

S/A.

"Viajeros en el Usumacinta". Arqueología Mexicana. México, Editorial Raíces, INAH, vol. IV, No. 22, noviembre-diciembre de 1996, pp. 30-35.

SILVA ANGÓN, María Cristina Rocío.

"EL Art Deco en Puebla". bulevar, Puebla, Pue., Año XXV, No. 160, julio/agosto de 2014, pp. 4-6.

TAVARES LÓPEZ, Edgar.

"El edificio de la Compañía de Seguros La Mutua". Relatos e historias de México. México, Editorial Raíces, Año III, No. 32, abril 2011, pp. 10-11.

UNIVERSIDAD AUTÓNOMA DE NUEVO LEÓN.

Memoria Universitaria No. 1, enero de 1933. Monterrey, N.L., Universidad Autónoma de Nuevo León, 2013.

URÍAS, Patricia: RUIZ, Andrés.

"Arquitectura Mexicana. El Arte de los Espacios". Memoria de Papel. México, CONACULTA, Año 3, No. 6, junio de 1993, pp. 53-65.

URZAIZ LARES, Enrique.

“Arquitectura Neoindigenista del siglo XX en Yucatán”. México en el Tiempo, México, México Desconocido, septiembre/octubre 1997, No, 20, pp. 19-25.

VÁZQUEZ, Abraham.

"Destacan en catálogo su valor arquitectónico". El Norte, Monterrey, N.L., domingo 21 de enero de 2007, secc. Vida, p. 3.

VELÁZQUEZ, Adriana.

"Eric Thompson: “QQuién soy entre el pueblo de los putunes?”. Arqueología Mexicana. México, Editorial Raíces, INAH, vol. II, No. 11, enero-febrero de 1995, pp. 50-54. 


\section{Webgrafía de Textos}

ALVARADO GINESI, Eduardo.

"El Cine Olimpia en Sabinas Hidalgo". Reportajes de Alvarado. Televisa Monterrey, viernes 4 de noviembre de 2011.

http://www.veengle.com/s/cine\%20olimpia.html

AMADOR TELLO, Judith.

"Monumento a Obregón, en el abandono". Proceso.com.mx, México, D.F., viernes 17 de diciembre de 2010.

www.proceso.com.mx/rv/modHome/pdfdetalleExclusiva/86493

CASTAÑÓN CUADROS, Carlos.

"Arquitectura Art Déco. Un estilo internacional en Torreón”. Museo Arocena, Torreón, Coahuila, México, 2013.

www.museoarocena.com/exhibiciones/actuales/artdeco/

DEBROISE, Olivier.

“Ángel Zárraga: aspectos de un muralismo olvidado". La Cultura en México, México, D.F., 18 de julio de 1979.

www.arte-mexico,com/critica/od69.htm

EL DIARIO DE COAHUILA.

"El Ateneo Fuente y la Historia oculta de Antonio Blas Cortinas". El Diario de Coahuila, Saltillo, Coah., sábado 13 de agosto de 2011. www.eldiariodecoahuila.com.mx/notas/2011/8/13/ateneo-fuente-historia-ocultaantonio-blas-cortinas-248134.asp

FLORES SORIA, Eugenia.

"Una historia viviente". Zócalo Saltillo, jueves 25 de julio de 2013. http://www.zocalo.com.mx/seccion/articulo/una-historia-viviente-1374704196

GOBIERNO MUNICIPAL DE LINARES NUEVO LEÓN.

“Teatro Benítez". Linares Nuevo León, Hualahuises Nuevo León, Instalación y Primera Sesión del Comité Pueblo Mágico. Linares, N.L., jueves 5 de septiembre de 2013.

http://pueblomagicolinares-hualahuises.com/pdf/1sesion.pdf 
GUADARRAMA PEÑA, Guillermina.

"Hacia una legislación para la defensa del patrimonio y el muralismo". discurso visual. Revista digital del Cenidiap. México, Centro de Investigación, Documentación e Información de Artes Plásticas, No. 10, enero-marzo 2004. http://disucrsovisual.cebart.gob.mx/anteriores/dvweb10/index.html

IVANOVNA PAVLIUKÓVA, Larisa.

"Murales de Máximo Pacheco en la Escuela Primaria Domingo Faustino Sarmiento: sobreviviendo al olvido". Crónicas. El Muralismo, Producto de la Revolución Mexicana, en América. México, UNAM, IIE, No. 1, 1998. www.ojs.unam.mx/index.php/cronicas/issue/view/1384/showToc

MALLET, Victoria.

“Parque San Martín”, México, D.F., 1 de septiembre de 2011. Art Decó México. http://www.artdecomexico.com/parquesanmartin/

MENDOZA LEMUS, Gustavo.

“Trabajan sobre techado del Lírico". El Porvenir, Monterrey, N.L., miércoles 27 de junio de 2007.

http://www.elporvenir.com.mx/notas.asp?nota_id=142084

NUEVA ROSITA, COAHUILA.

"Escuela Fortunato Gutiérrez Cruz".

www.facebook.com/pages/Nueva-Rosita-Coah/

S/A.

"Anáhuac". Enciclopedia de los Municipios de México. Nuevo León. México, Instituto Nacional para el Federalismo y el Desarrollo Municipal, Gobierno del Estado de Nuevo Léon, 2005.

www.elocal.gob.mx/work/templates/enciclo/nuevoleon/municipios/19005a.htm

S/A.

"Galería de la Historia. México a través del acero". horno 3 ciencia y tecnología al rojo vivo, Monterrey, N.L.

http://www.horno3.org/new_index.html

S/A.

"La evolución del cine a través de los años". Perfil, Monterrey, N.L., Prepa Tec Campus Valle Alto, marzo 2006

http://prepatec.mty.itesm.mx/perfil_online 
SÁNCHEZ, René

"Cines del ayer: Cine Reforma".

http://cineramaonline.blogspot.mx/2007/05/cines-del-ayer-cine-reforma.html

SÁNCHEZ REYNA, Ramón.

"El Art Déco, una tendencia en la vida cotidiana". Cultura y Arte. Morelia,

Michoacán, Año 3, No. 18, septiembre-octubre de 1998, pp. 1-8.

http://www.umich.mx/univ/publica/contacto/sep98/ramon1.html

VELÁZQUEZ VALLE, Alfredo.

"Escuela Primaria Gral. Álvaro Obregón". El Periódico de Saltillo, Saltillo,

Coahuila, abril de 2012, edición 278.

http://www.elperiodicodesaltillo.com/2012\%20abril/escuela.html

VICTORIA AND ALBERT MUSEUM.

ART DECO 1910-1939. London, Victoria and Albert Museum, 27 March-20 July 2003.

http://www.vam.ac.uk/vastatic/microsites/1157/_art_deco/virtual/

ZAPATA PACHECO, Juan.

"Reconstruirán fachada del Cine Reforma". El Porvenir, Monterrey, N.L., jueves 3 de abril de 2008, secc. Cultural.

http://www.elporvenir.com.mx/notas.asp?nota_id=206088 


\section{Webgrafía de Imágenes \\ En orden de aparición en Capítulos y subcapítulos}

\section{Capítulo 1}

\section{2.}

Edgar Brand, El Oasis, p. 31:

Lynn Byrne, 2DESIGNER WHO'S WHO: Edgar Brandt", Décor Arts, Now. http://www.decorartsnow.com/2013/11/08/designer-whos-who-edgar-brandt/

Maurice Dufréne, Aparador, p. 34:

1stdibs, "MAURICE DUFRENE documented exceptional buffet in carved mahogany with a marble top".

http://www.1stdibs.com/furniture/storage-case-pieces/buffets/maurice-dufrenedocumented-exceptional-buffet-carved-mahogany/id-f_725364/

\section{3.}

Cartel París 1937, p. 46:

“L’Exposition Internationale Arts et Techniques á Paris 1937”. http://lartnouveau.com/art_deco/expo_internationale_1937.htm

Pabellón del Aire, p. 47:

Playin in the Wolrd Game, "Hall the Aeronautic-Paris 1937". https://playingintheworldgame.wordpress.com/tag/1937/

\subsection{1.}

John Ruskin, Las Siete Lámparas de la Arquitectura, p. 50:

George P. Landow, "Ruskin". http://www.victorianweb.org/espanol/autores/ruskin/pm/intro.html 
Tienda L'Art Nouveau, p. 56:

Boutique de Siegfried ("Samuel") Bing (1839-1905) 22, rue Chauchat Paris ouverture en décembre 1895.

http://lartnouveau.com/documents/boutique_bing_art_nouveau.htm

Otto Wagner, Karlplatz, p. 59:

"Otto Wagner Pavilion, Karlsplatz".

http://www.aviewoncities.com/gallery/showpicture.htm?key=kveat0358

Luis Doménech, Palau de la Música Catalana, p. 61:

Arquiscopio, "El Palau de la Música Catalana".

http://arquiscopio.com/el-palau-de-la-musica-mas-arquitectura-del-momento/

Louis Sullivan, Auditorium Building, p. 63:

Alargos, Arte e Historia,"La escuela de Chicago. El origen de los Rascacielos". http://algargosarte.lacoctelera.net/post/2011/06/01/la-escuela-chicago-origen-losrascacielos

\subsection{2.}

Charles Rennie Mackintosh, School of Arts, p. 68:

michellegoetz, "Innovation-Art Nouveau".

http://michellegoetz.wordpress.com/2011/08/22/innovation-art-nouveau/

\subsection{5.}

Kasimir Malevich, Architektone, p. 101:

The Charnel House. From Bahaus to Beinhaus, "Architektons". http://thecharnelhouse.org/tag/architektons/

Alexander Rodchenko, Construcción Espacial No. 12, p. 107:

MoMA, "The Collection. Alexander Rodchenko". http://www.moma.org/collection/object.php?object_id=81043 
Vladimir Tatlin, Letatlin, p. 109:

José Jiménez, “Exposición Vladimir Tatlin”, Cuerpo y Tiempo, lunes 9 de julio de 2012. http://josejimenezcuerpoytiempo.blogspot.mx/2012/07/exposicion-vladimir-tatlin.html

\subsection{7.}

Bart van der Leck, Composición, p. 122:

TATE, "Bart van der Leck. Composition 1918".

http://www.tate.org.uk/art/artworks/leck-composition-t00896

\subsubsection{0.}

Léon Bakst, Cléopatre, p. 153:

“Cléopatre 1909".

http://theatrex.net/Ida/cleopatra.htm

Mikhail Larionov, Le Soleil de Nuit, p. 154:

De Young/ Legion of Honor Fines Arts Museums of San Francisco, "Mikhail Feodorovich Larionov, Courtain deisgn for the dance performance, Le Soleil de Nuit".

http://art.famsf.org/mikhail-feodorovich-larionov/curtain-design-dance-performance-lesoleil-de-nuit-midnight-sun

Nikolai Roerich, El beso de la tierra, p. 155:

Matthew McDonald, 'Forever Young? 'The Rite of Spring' approaches 100, Boston Syphony Orchesta.

http://www.bso.org/brands/bso/features/forever-young.aspx

\subsection{1.}

Aspiradora Electrolux, p. 173:

Ignacio Urbina Polo, "Vacuum_electrolux_1930", di-conexiones.

http://www.di-conexiones.com/navibot-s-aspiradoras-inteligentes-o-mascotaselectronicas/vacuum_electrolux_1930/ 


\subsection{2.}

Val Myers, BBC Broadcasting House, p. 187:

Movehut, "BBC Staff Complain About Noise at New Broadcasting House". http://www.movehut.co.uk/news/bbc-staff-complain-about-noise-at-new-broadcasting$\underline{\text { house-10915/ }}$

Bertram Goodhue, Nebraska State Capitol, p. 188:

OpenBuildings, "Nebraska Sate Capitol".

http://openbuildings.com/buildings/nebraska-state-capitol-profile-2839\#

Raymond Hood, Rocekefeller Center, p. 195:

"Rockefeller Center". http://diegomolinasobradillo.blogspot.mx/2010/10/new-yorkd.html

Lee Lawrie, Atlas, p. 196:

New York Daily Photo, "Atlas".

http://newyorkdailyphoto.com/nydppress/?p=266

Isamu Noguchi, News, p. 196:

"Noguchi-Associated Pres bas-relief,1938-1940.

https://www.flickr.com/photos/raimist/318310011/

John Bird Illes, Julian Rudolph Leathart y W.F., Grainger, Margate Cinema, p. 198:

Picture Ville, "Margate's Dreamland revival is on the move", Weddesday, 22 August 2012. http://www.pictureville.net/2012/08/margates-dreamland-revival-is-on-move.html

Charles Holdes, Arnos Grove Station, p. 198:

Ian Jones, "The London Underground's most beautiful stations", The Telegraph, Tuesday 15 July 2014.

http://www.telegraph.co.uk/travel/picturegalleries/9778235/The-London-Undergroundsmost-beautiful-stations.html 
Charlee Lee, Academy Theatre, p. 199:

"Academy Theatre 1938 by architect S. Charlee Lee".

http://www.you-are-here.com/theatre/academy.html

Carl Henrich Boller, KiMo Theatre, p. 200:

KiMo Alburquerque".

http://commons.wikimedia.org/wiki/File:KiMo_Albuquerque.jpg

Vestíbulo del KiMo Theatre, p. 201:

"KiMo Theatre".

http://www.mu-43.com/showthread.php?t=24326\&page=10

\section{Capítulo 2}

\section{4.}

Teotihuacán, p. 262:

"Teotihuacán". http://www.historiacultural.com/2010/10/cultura-teotihuacana.html

Templo Mayor, p. 263:

Universes in Universi, "México Art Destinations. Mexico/Culturas Antiguas/Templo Mayor".

http://universes-in-universe.org/esp/art_destinations/mexico/tour/templo_mayor/01

Palenque, p. 264:

Destinos Turísticos de México, "Palenque, Chiapas".

http://www.mexplora.com/destinos_mexico/destino.php?id=2600

Tula, p. 265:

Maravillas Arquitectónicas, "México". http://perso.wanadoo.es/berethor07/mexico.htm 
Raymon Hood y André Fouilhoux, McGraw-Hill Building, p. 270:

Docomo_us, "McGraw-Hill Building".

http://www.docomomo-us.org/register/fiche/mcgrawhill_building

Robert Stacy-Judd, Aztec Hotel, p. 274:

"Aztec Hotel 1924 architec Robert Stacy-Judd.

http://www.you-are-here.com/building/aztec_hotel.html

Robert Stacy-Judd, First Baptist Church, p. 275:

"Art Deco Church".

https://www.flickr.com/photos/intherough/9467036691/

Octavius Morgan, John A. Walls, Stiles Oliver Clements, Mayan Theatre, p. 276:

"Mayan Theatre".

http://www.publicartinla.com/art_buildings/mayan1.html

Alfred Charles Bossom, Petroleum Building, p. 277:

Arch-ive.com, "Great Southwest Life Building".

http://arch-ive.org/archive/great-southwest/

Diego Rivera, Xochipilli y la Adoradoras, p. 280:

Xochipilli, "Xoxhipilli".

http://ojosdesconocidos.blogspot.mx/2010/12/dinamica-expansiva-oo.html

Diego Rivera, México Prehispánico, p. 281:

Brenton LeMesurier,"Diego Rivera Murals, Palacio Nacional”.

http://brentonlemesurier.wordpress.com/2012/10/27/diego-river-murals-palacio-nacional/ 


\subsection{1.}

Juan Segura, Edificio Ermita, pp. 313 y 314:

Panoramio, "Edificio Ermita".

http://www.panoramio.com/photo/51237081

Palacio de Bellas Artes, vestíbulo, p. 322:

http://www.skyscrapercity.com/showthread.php?t=381315\&page=3

Palacio de Bellas Artes, Cara de Chaac, p. 322:

Chocolate Fish Fotos, "Image of Chaac on a light panel inside the Palacio de Bellas Artes". http://www.chocolate-fish.net/img_-9295_lang_spanish

Palacio de Bellas Artes, taquilla y hoja del escenario, pp. 322 y 323:

Mariangel Coghlan, "Espacios Musicales. Palacio de Bellas Artes".

http://mariangelcoghlan.blogspot.mx/2013/07/espacios-musicales.html

Palacio de Bellas Artes, balcones de la sala de espectáculos, p. 323:

"Palacio de Bellas Artes".

http://www.skyscrapercity.com/showthread.php?t=381315\&page=3

Fidias Elizondo, Cristo Rey, p. 352:

Zona Turística, "Cerro del Cubilete".

http://www.zonaturistica.com/tips-en/281/cerro-del-cubilete-guanajuato.html

\subsection{3.}

Roberto Montenegro, Iberoamérica, p. 367.

El Universal, "Los murales de Roberto Montenegro".

http://fotos.eluniversal.com.mx/coleccion/muestra_fotogaleria.html?idgal=11864 
Diego Rivera, La Creación, p. 369.

"Diego Rivera. La Creación, 1992".

http://www.sanildefonso.org.mx/mural_anfiteatro.php?iframe=true\&width $=810 \&$ height $=10$ $\underline{0 \%}$

\section{Capítulo 3}

\subsubsection{1.}

Escuela Fernández de Lizardi, p. 415:

http://cdigital.dgb.uanl.mx/la/1080074131/1080074131.html

\subsubsection{4.}

Hospital Civil, vista aérea, p. 522:

http://www.medicina.uanl.mx/hu/acerca-de/historia/

\subsubsection{8.}

Plaza General Treviño, p. 570:

www.mexicoenfotos.com

\subsubsection{1.}

Ateneo Fuente, Paraninfo, p. 731:

www.saltillodelrecuerdo.blogspot.com

\subsubsection{2.}

Cinema Palacio, p. 756:

http://www.skyscrapercity.com/showthread.php?t=873612\&page $=8$ 
Edward Hopper, Palacio, p. 760:

WikiArt, "Edward Hopper. El Palacio".

www.wikiart.org/en/edward-hopper/el-palacio

3.3.2.1.

Edificio Eléctrico, p. 793.

http://foros.elsiglodetorreon.com.mx/cultura/567864-

torre\%C3\%B3n+de+anta\%C3\%B1o.html

\subsubsection{2.}

Estadio de la Revolución, p. 809:

www.metrolaguna.com/estadio-de-beisbol-revolución.html

\subsubsection{1.}

Escuela Fortunato Gutiérrez Cruz, p. 825.

www.facebook.com/pages/Nueva-Rosita-Coah/

Escuela Fortunato Gutiérrez Cruz, ceremonia de apertura, p. 827:

www.facebook.com/pages/Nueva-Rosita-Coah/ 


\title{
CENTROS DE DOCUMENTACIÓN ESPECIALIZADOS CONSULTADOS
}

\author{
Nuevo León: \\ Archivo General del Estado de Nuevo León. Monterrey, N.L. \\ Capilla Alfonsina, Sección Historia, Universidad Autónoma de Nuevo León. \\ Monterrey, N.L. \\ Colección Xavier Moyssén, Biblioteca, Universidad de Monterrey. San Pedro \\ Garza García, N.L. \\ Hemeroteca, Biblioteca General, Universidad Autónoma de Nuevo León. \\ Monterrey, N.L. \\ Sala Ignacio Bernal, Biblioteca, Instituto Tecnológico de Estudios Superiores de \\ Monterrey. Monterrey, N.L.
}

\section{Coahuila:}

Instituto Cultural de Coahuila. Saltillo, Coah.

Museo Arocena. Torreón, Coah. 